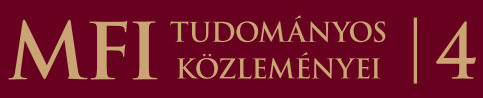

SZERKESZTETTE:

NAGY ZOLTÁN - HORVÁTH ATTILA

A KÜLÖNLEGES JOGREND

ÉS NEMZETI SZABÁLYOZÁSI

MODELLJEI

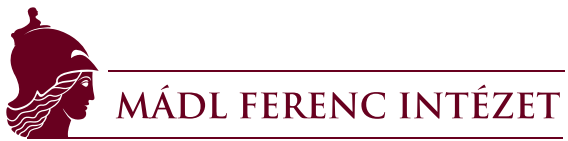




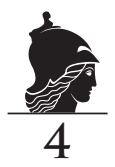




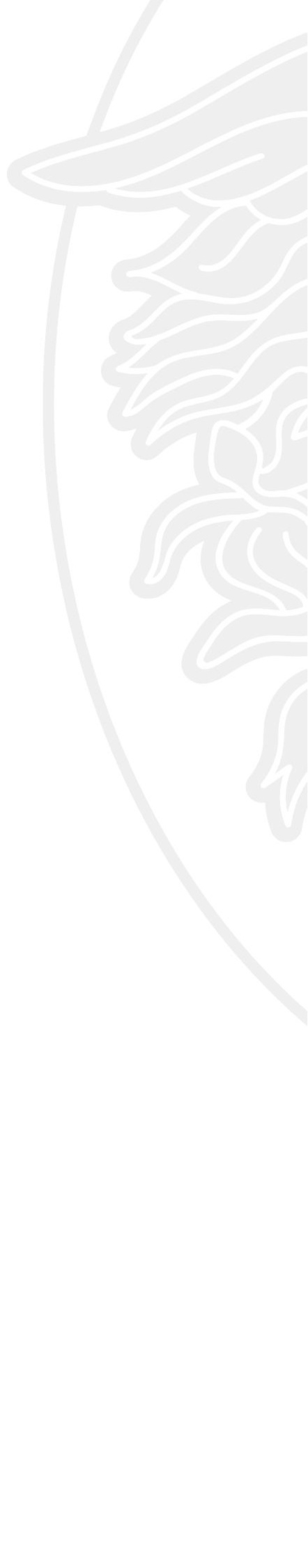


SZERKESZTETTE:

NAGY ZOLTÁN - HORVÁTH ATTILA

\section{A KÜLÖNLEGES \\ JOGREND \\ ÉS NEMZETI \\ SZABÁLYOZÁSI \\ MODELLJEI}

\section{MFI ToraninNos $\mid 4$}

MÁDL FERENC ÖSSZEHASONLÍTÓ JOGI INTÉZET

Budapest $\cdot 2021$ 
A különleges jogrend és nemzeti szabályozási modelljei

ISBN 978-615-01-1492-7

ISBN 978-615-01-1493-4 (e-könyv)

DOI: 10.47079/2021.nzha.kulon.4

Szerkesztők:

\section{Prof. Dr. Nagy Zoltán}

Dr. Horváth Attila

\section{Szakmai lektorok:}

Dr. Kádár Pál, PhD dandártábornok, Nemzeti Közszolgálati Egyetem

Dr. Raisz Anikó, PhD egyetemi docens, Miskolci Egyetem

Dr. Till Szabolcs, PhD ezredes, Nemzeti Közszolgálati Egyetem

\section{Olvasószerkesztő:}

Pokorádi Zsófia

Mádl Ferenc Intézet Tudományos Közleményei

ISSN 2732-3242

Sorozatszerkesztő: Szilágyi János Ede

A kézirat lezárva: 2020. december 31.

Nyomdai előkészítés, tördelés és borítóterv:

Idea Plus (Kolozsvár)

Nyomdai kivitelezés: AK Nyomda Kft.

Felelős vezetô: Káldor Gábor

Martonvásár, 2021

Korrektúra:

Szenkovics Enikő 


\section{Szerzők:}

Dr. Béres Nóra, PhD, LLM (2. és 26. fejezet)

kutató (Mádl Ferenc Összehasonlító Jogi Intézet)

tanársegéd (Miskolci Egyetem Állam- és Jogtudományi Kar,

Európai és Nemzetközi Jogi Intézet)

Csemáné Dr. Váradi Erika, PhD, LLM (8. és 20. fejezet)

vezető kutató (Mádl Ferenc Összehasonlító Jogi Intézet)

egyetemi docens (Miskolci Egyetem Állam- és Jogtudományi Kar,

Bünügyi Tudományok Intézete)

Dr. De Negri Laura, LLM (19. fejezet)

kutató (Mádl Ferenc Összehasonlító Jogi Intézet)

PhD-hallgató (Andrássy Egyetem, Interdiszciplináris Doktori Iskola)

Dr. Domaniczky Endre, PhD (4. és 11. fejezet)

vezető kutató (Mádl Ferenc Összehasonlító Jogi Intézet)

Dr. Dornfeld László (12., 13. és 27. fejezet)

kutató (Mádl Ferenc Összehasonlító Jogi Intézet)

Dr. Hojnyák Dávid (9. és 28. fejezet)

kutató (Mádl Ferenc Összehasonlító Jogi Intézet)

PhD-hallgató (Miskolci Egyetem, Deák Ferenc Állam- és Jogtudományi Doktori Iskola)

Dr. Horváth Attila, PhD (5., 6. és 29. fejezet)

vezető kutató (Mádl Ferenc Összehasonlító Jogi Intézet)

adjunktus (Nemzeti Közszolgálati Egyetem Államtudományi és Nemzetközi Tanulmányok

Kar, Alkotmányjogi és Összehasonlító Közjogi Tanszék)

Dr. Marinkás György, PhD (3. és 15. fejezet)

kutató (Mádl Ferenc Összehasonlító Jogi Intézet)

adjunktus (Miskolci Egyetem Állam- és Jogtudományi Kar,

Európai és Nemzetközi Jogi Intézet) 
Prof. Dr. Nagy Zoltán, PhD (Bevezető, 7. fejezet) főosztályvezető (Mádl Ferenc Összehasonlító Jogi Intézet)

egyetemi tanár (Miskolci Egyetem Állam- és Jogtudományi Kar, Államtudományi Intézet, Pénzügyi Jogi Tanszék)

Dr. Németh Zoltán, LLM (10., 16. és 25. fejezet) kutató (Mádl Ferenc Összehasonlító Jogi Intézet)

Stollsteiner Gabriel (14. fejezet)

PhD-hallgató, tanársegéd (Université Paris-Est Créteil)

kutató (Mádl Ferenc Összehasonlító Jogi Intézet)

Dr. Szentpáli-Gavallér Pál (18. és 22. fejezet)

kutató (Mádl Ferenc Összehasonlító Jogi Intézet

PhD-hallgató (Miskolci Egyetem, Deák Ferenc Állam- és Jogtudományi Doktori Iskola)

Dr. Szinek Csütörtöki Hajnalka (9. és 24. fejezet)

kutató (Mádl Ferenc Összehasonlító Jogi Intézet)

PhD-hallgató (Miskolci Egyetem, Deák Ferenc Állam- és Jogtudományi Doktori Iskola)

Dr. Szinek János (24. fejezet)

kutató (Mádl Ferenc Összehasonlító Jogi Intézet)

PhD-hallgató (Miskolci Egyetem, Deák Ferenc Állam- és Jogtudományi Doktori Iskola)

Dr. Szőke Péter (17. fejezet)

kutató (Mádl Ferenc Összehasonlító Jogi Intézet)

Prof. Dr. Trócsányi László, CSc (1. fejezet)

egyetemi tanár (Károli Gáspár Református Egyetem Állam- és Jogtudományi Kar, Alkotmányjogi Tanszék; Szegedi Tudományegyetem Állam- és Jogtudományi Kar, Nemzetközi és Regionális Tanulmányok Intézete)

tiszteletbeli elnök (Mádl Ferenc Összehasonlító Jogi Intézet)

Dr. Ungvári Álmos (21., 23. és 28. fejezet)

kutató (Mádl Ferenc Összehasonlító Jogi Intézet)

PhD-hallgató (Pázmány Péter Katolikus Egyetem, Jog- és Államtudományi Doktori Iskola) 


\section{Rövid tartalom}

Előszó

Bevezető

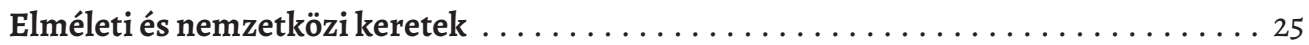

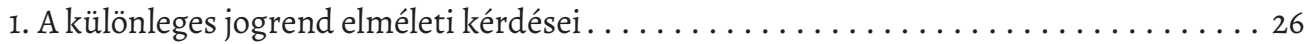

2. A különleges jogrend nemzetközi jogi dimenziói az emberi jogok

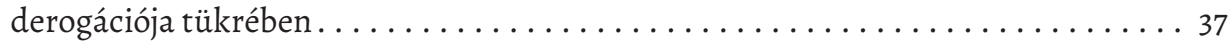

3. A Covid-járvány uniós szintû́ kezelése - A hatáskörök hálójának elmélete . . . . . . 52

A különleges jogrend hazai vonatkozásai $\ldots \ldots \ldots \ldots \ldots \ldots \ldots \ldots \ldots \ldots$

4. A különleges jogrend magyar szabályozásának történeti fejlődése

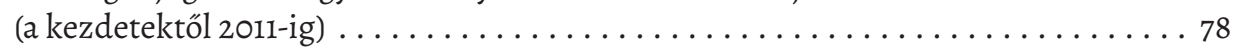

5. A különleges jogrend fejlődése Magyarországon a kilencedik Alaptörvény-módosítás

tükrében. ................................. 122

6. A 2020-as Covid-veszélyhelyzet alkotmányjogi szemmel . . . . . . . . . . . . . . . . 149

7. Fiskális és monetáris eszközök a járványügyi veszélyhelyzet

gazdasági hatásainak mérséklésére

A különleges jogrend Európában és Európán kívül . . . . . . . . . . . . . . . . . . . 193

8. Ausztria: 150 éves gyökerek, 21. századi megoldások . . . . . . . . . . . . . . . . . . . . 194

9. A különleges jogrend alkotmányos és törvényi szintű szabályozása Csehországban . . 217

10. Különleges jogrend különleges intézkedésekkel Dániában . . . . . . . . . . . 241

11. A különleges jogrend az Egyesült Királyságban . . . . . . . . . . . . . . . 252

12. Fokozatosság elve és átfogó védelem: a különleges jogrend Észtországban . . . . . . . 277

13. Amikor az alkotmány hallgat: Finnország különleges jogrendje . . . . . . . . . 301

14. Franciaország: folyamatosan különleges jogrend, a koronavírus idején is . . . . . 322

15. Különleges felhatalmazás különleges jogrend kihirdetése nélkül,

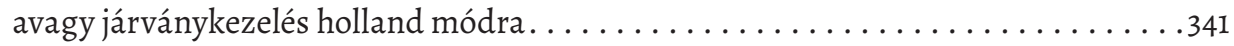

16. Különleges jogrendi szabályok Lengyelországban . . . . . . . . . . . . . 358

17. Lettország készen állt: egy könnyúszerkezetes jogrendszer példája . . . . . . . . . . . 376 . . . . . . 398

18. A különleges jogrendi esetkörök szabályozása Litvániában . . . . . . . . . . . . . . 398

19. Németország, a többszintû válságkezelés iskolapéldája . . . . . . . . . . . . 414

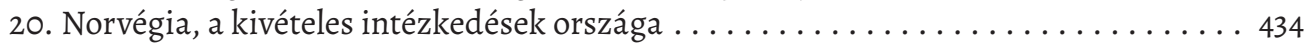

21. A különleges jogrendi szabályozás Olaszországban: a hadiállapot

és a kivételes hatalomgyakorlás egyéb esetkörei. . . . . . . . . . . . . 457

22. A prezidenciális jelleg hangsúlyossága a különleges jogrend

romániai szabályozásában. ...................... 480

23. A kivételes állapot alkotmányos és törvényi szintű szabályozása Svédországban . . . 504

24. A különleges jogrendi esetkörök alkotmányos és törvényi szintû szabályozása

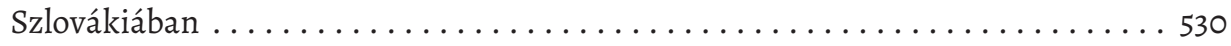

25. Spanyolország, ahol a különleges jogrend valóban különleges. . . . . . . . . . . . . . 549 
26. Ahol a különleges jogrend egyáltalán nem is különleges: az amerikai modell. . . . . .563

27. A korlátlan államhatalom sajátos korlátja: a különleges jogrend Kínában . . . . . . . 592

Konklúziók. . . . . . . . . . . . . . . . . . . . . . . . . . . . 609

28. Összegzés - A koronavírus-járvány kezelésének tapasztalatai

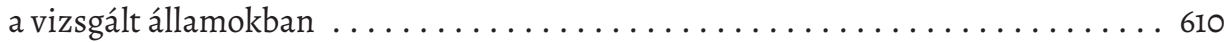

29. Összegzés - A különleges jogrend az alkotmányokban . . . . . . . . . . 624 


\section{Részletes tartalomjegyzék}

Előszó

Bevezető

Elméleti és nemzetközi keretek ............................... 25

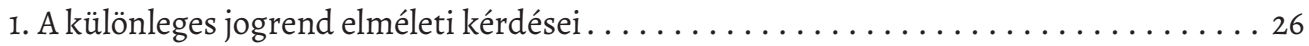

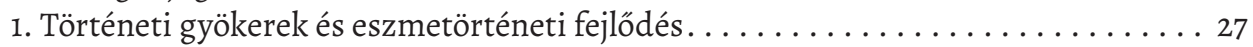

2. A különleges jogrend meghatározása és alkalmazhatósága . . . . . . . . . . 31

3. A különleges jogrend igazolhatósága és az abban védett értékek . . . . . . . . . . . . . . . . . . . . . .

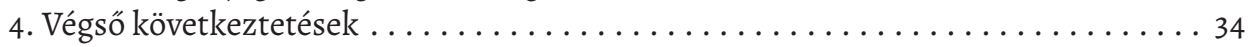

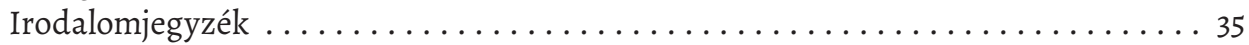

2. A különleges jogrend nemzetközi jogi dimenziói az emberi jogok

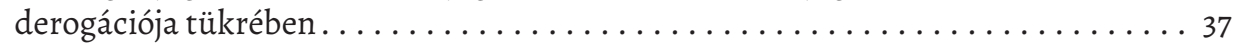

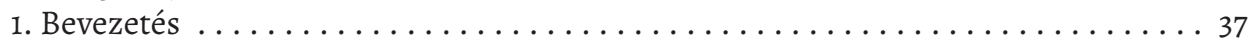

2. A Polgári és Politikai Jogok Nemzetközi Egyezségokmányának 4. cikke . . . . . . 39

3. Az Emberi Jogok Európai Egyezményének 15. cikke . . . . . . . . . . . 44

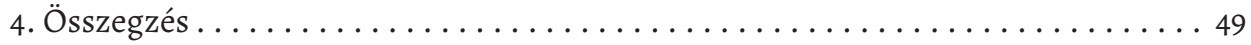

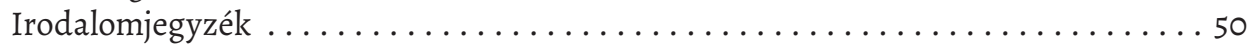

3. A Covid-járvány uniós szintû́ kezelése - A hatáskörölk hálójának elmélete . . . . . . . 52

1. Az EU különleges jogrendi szabályozásra vonatkozó szabályainak áttekintése . . . 52

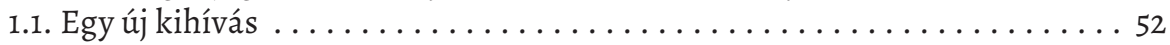

1.2. A különleges jogrend szabályozására vonatkozó uniós hatáskörök hiánya. . 53

1.3. Az alapjogok korlátozhatóságának kérdése rendkívüli helyzetekben

az Európai Unió Bíróságának ítélkezési gyakorlata nyomán . . . . . . . 54

1.4. A különleges jogrend jogállamisági kontextusba kerülése -

az Európai Bizottság megnyilvánulásai . . . . . . . . . . . . . . 59

2. A különleges jogrendre tekintettel bevezetett, a belső piaci szabadságokat érintő tagállami korlátozások kapcsán az Európai Bizottság részleges fellépése,

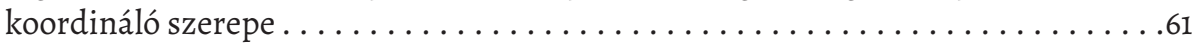

2.1. Az EU fellépése járványügyi kérdésekben ...............61

2.2. Az áruk szabad mozgásának korlátozása . . . . . . . . . . . . . 64

2.3. A személyek szabad mozgásának korlátozása: tagállami határzárak, egészségügyi karantén elrendelése új belépőknek,

ingázó munkavállalókra vonatkozó kivételek . . . . . . . . . . . . 66

2.4. Könnyítések a szolgáltatások szabad mozgásának biztosítása érdekében . . 68

3. Az uniós intézmények eljárási szempontú igazodása a megváltozott

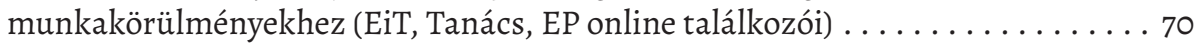

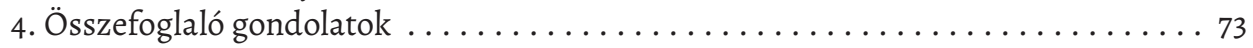

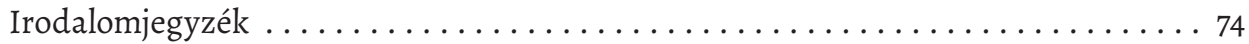


4. A különleges jogrend magyar szabályozásának történeti fejlődése

(a kezdetektől 2011-ig) . ................................ 78

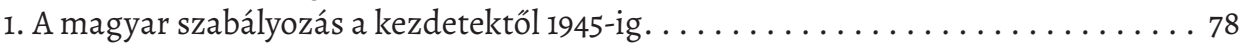

1.1. Korai szabályozás a magyar és az európai jogrendszerekben $\ldots \ldots \ldots \ldots 78$

1.1.1. A kivételes hatalom és a különleges jogrend fogalmi keretei . . . . 78

1.1.2. A kivételes hatalom megjelenése az európai országok jogában . . . 79

1.1.3. A kivételes hatalom megjelenése a magyar jogban.......... 81

1.1.4. Kitekintés: az osztrák különleges jogrend érvényesülése

Magyarországon (1848-1865) . . . . . . . . . . . . . . 8 82

1.1.5. Kivételes hatalom a dualizmus korában .............. 83

1.2. A különleges jogrend első átfogó magyar szabályozása:

a kivételes hatalomról szóló 1912. évi LXIII. törvénycikk ......... 83

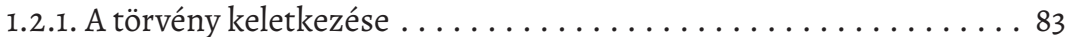

1.2.2. A kivételes hatalom korlátai . . . . . . . . . . . . . . 84

1.2.3. A kormánybiztosok hatásköre . . . . . . . . . . . . 85

1.2.4. A kivételes hatalom által érintett jogágak, jogszabályok . . . . . 86

1.2.5. A törvény a gyakorlatban: a kivételes hatalom alkalmazása

és kiterjesztése (1914-1918) . . . . . . . . . . . . . . . . . 8 89

1.2.6. Kitekintés: a különleges jogrend szabályozása

az Osztrák-Magyar Monarchia másik felében (1867-1918) . . . . . 90

1.3. A különleges jogrend továbbélése a két háború korában . . . . . . . . . 91

1.3.1. Biztos pont a válságban (1918-1922) ............... 91

1.3.2. A kivételes hatalom állandósulása (1923-1939) . .......... 92

1.3.3. A különleges jogrend újabb szabályozása: a honvédelemről

szóló 1939. évi II. törvény . . . . . . . . . . . . . . . . 93

1.4. A kivételes hatalom a II. világháború alatt (1939-1945) . . . . . . . . . 95

2. A kivételes hatalom a Rákosi-rendszerben $(1945-1956) \ldots \ldots \ldots \ldots \ldots \ldots \ldots$

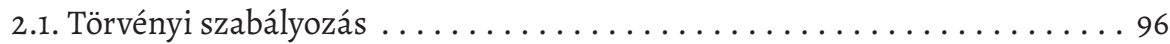

2.2. Alkotmányi szabályozás. ........................... 97

2.2.1. Az első chartális alkotmány . .................. 98

2.2.2. A kivételes hatalom szabályozása az 1949-es alkotmányban. . . . 99

2.2.3. A kivételes hatalom szabályozásának hasonlóságai

és különbségei az 1919-es és az 1949-es alkotmányokban. . . . . . . . 101

3. A kivételes hatalom szabályozása a Kádár-rendszerben (1956-1989) . . . . . . . . 102

3.1. Törvényi szabályozás . .............................. 102

3.1.1. Az 1960-as honvédelmi törvény. ................. 102

3.1.2. Az 1976-os honvédelmi törvény .................. 104

3.2. Alkotmányi szabályozás........................... 106

3.3. A kivételes hatalom jogi rezsimjének változásai a 20. század

második felében............................... 107

4. A kivételes hatalom szabályozása a rendszerváltást követő

évtizedekben (1989-2010) . . . . . . . . . . . . . . . . . . . . . 108

4.1. Alkotmányi szabályozás . . . . . . . . . . . . . . . . . . . . . . 108

4.2. Törvényi szabályozás .............................. 109 
4.2.1. A rendkívüli intézkedések szabályozása (különleges jogrend) . . . .110

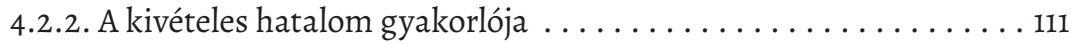

4.3. A kivételes hatalom kodifikálásának tanulságai az 1989-2011

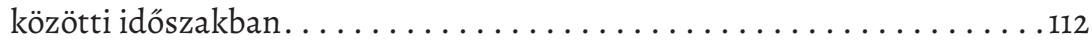

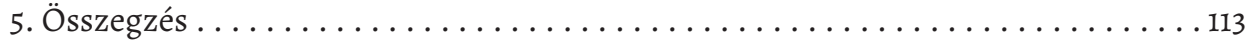

5.1. Az ,alkotmányszegény" ország. . . . . . . . . . . . . . . 113

5.2. A kivételes hatalom jogszabálybokrai és többszintû normaszerkezetei . . . 114

5.3. Kivételesből általános jellegû́ keretszabályozás . . . . . . . . . . . . . . . . . . . . . . . . .

5.4. Politikai rendszereken átívelő szabályozási tárgy . . . . . . . . . . . . 115

5.5. Dinamikus és statikus periódusok a kivételes hatalom kodifikációja során . 116

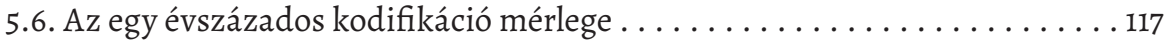

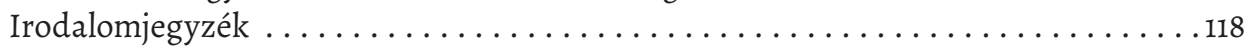

5. A különleges jogrend fejlődése Magyarországon a kilencedik Alaptörvény-módosítás tükrében. . . ............................... 122

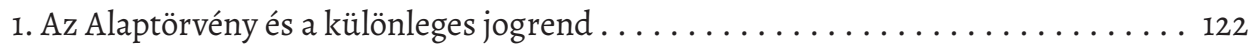

1.1. Az Alaptörvény formai és szerkezeti újításai . . . . . . . . . . . . . . . . . . . . . . . . .

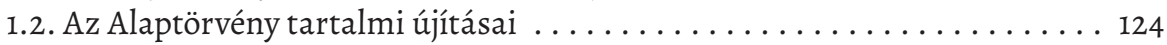

1.3. A terrorveszélyhelyzet mint új különleges jogrendi kategória . . . . . . . . . 128

2. A különleges jogrend átfogó reformja: az Alaptörvény kilencedik módosítása. . . . 130

2.1. A (régi-)új különleges jogrendek: hadiállapot, szükségállapot,

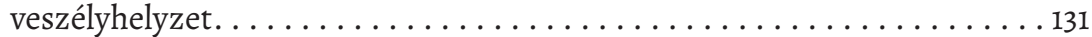

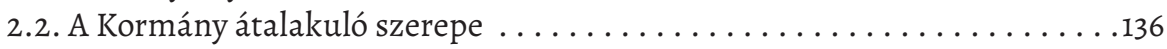

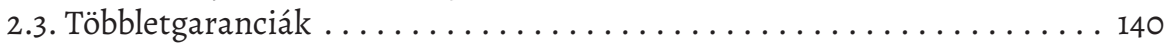

3. Összegzés - A különleges jogrend rendszerváltás utáni evolúciója . . . . . . . . . 142

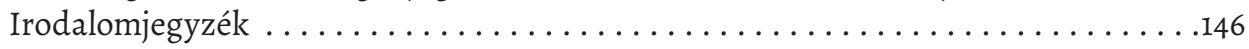

6. A 2020-as Covid-veszélyhelyzet alkotmányjogi szemmel . . . . . . . . . . . . . . . . .149

1. A Covid-19 előtti veszélyhelyzetek . . . . . . . . . . . . . . . . . . . . . . . . . 149

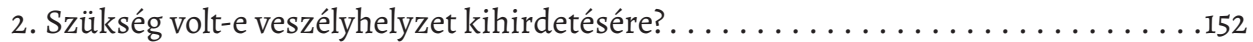

3. Veszélyhelyzet vs. járvány: az Alaptörvény és a katasztrófavédelmi törvény

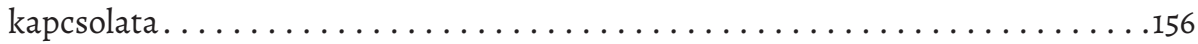

4. A veszélyhelyzetet kihirdető rendeletek . . . . . . . . . . . . . . . . . . . . 159

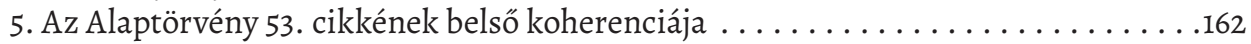

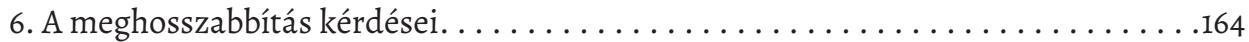

7. Összegzés . . . . . . . . . . . . . . . . . . . . . . . . . . . . 170

8. A veszélyhelyzet korrekciója: az Alaptörvény kilencedik módosítása . . . . . . . 171

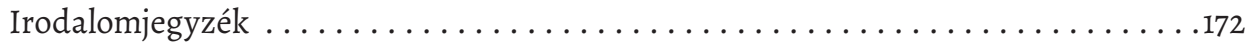

7. Fiskális és monetáris eszközök a járványügyi veszélyhelyzet

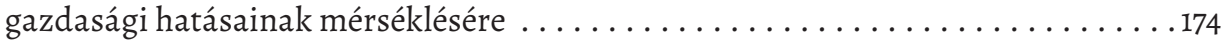

1. Bevezető gondolatok. . . . . . . . . . . . . . . . . . . . . . . . . . . 174

2. A magyar fiskális politika a járványügyi veszélyhelyzetben . . . . . . . . . . . . . 177

3. Monetáris politika a járványügyi veszélyhelyzet okozta gazdasági válságban . . . .186

Irodalomjegyzék . . . . . . . . . . . . . . . . . . . . . . . . . 189 
8. Ausztria: 150 éves gyökerek, 21. századi megoldások. . . . . . . . . . . . . . . . . . . . 194

1. A különleges jogrend alkotmányos és törvényi szintú szabályozása . . . . . . . . . . 194

2. Az alapjogok korlátozására vonatkozó szabályok különleges jogrend idején . . . . 198

3. A különleges jogrend kihirdetésének gyakorlati esetei . . . . . . . . . . . . 207

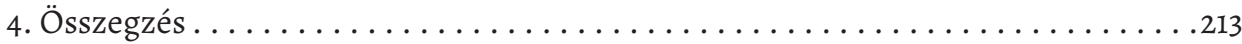

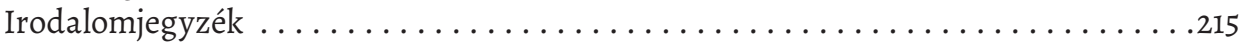

9. A különleges jogrend alkotmányos és törvényi szintû́ szabályozása Csehországban . . .217

1. A különleges jogrend alkotmányos és törvényi szintű szabályozása . . . . . . . . 217

1.1. A különleges jogrendi tényállásokra vonatkozó közös szabályok. . . . . . . 221

1.2. A veszélyhelyzet mint különleges jogrendnek nem minősülő rendkívüli felhatalmazás esetköre . . . . . . . . . . . . . . 222

1.3. A különleges jogrendre való felkészülést segítő békeidejű szabályok, valamint a válságkezelésre vonatkozó szabályok . . . . . . . . . . . 223

2. Az alapjogok korlátozására vonatkozó szabályok különleges jogrend idején . . . . 228

3. A különleges jogrend kihirdetésének gyakorlati esetei . . . . . . . . . . 230

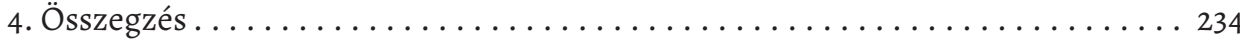

Irodalomjegyzék . . . . . . . . . . . . . . . . . . . . . . . . . . . . 239

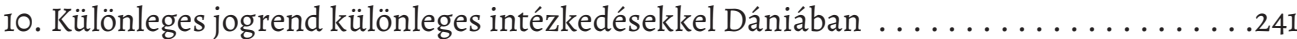

1. A különleges jogrend alkotmányos és törvényi szintű szabályozása,

valamint a különleges jogrend és esetkörei . . . . . . . . . . . . . . . 241

2. Az alapjogok korlátozásával kapcsolatos kérdések . . . . . . . . . . . . 242

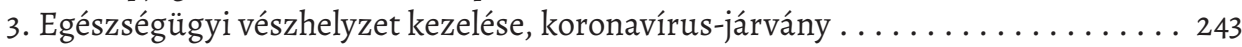

3. 1. A koronavírus-járvány első hulláma Dániában . . . . . . . . . . . . . 243

3.2. A második hullám intézkedései . . . . . . . . . . . . . . . . . 249

4. Különleges jogrend, járványügyi vészhelyzet kihirdetésével kapcsolatos

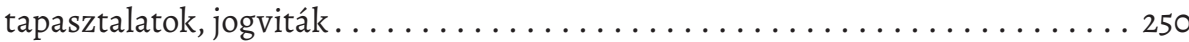

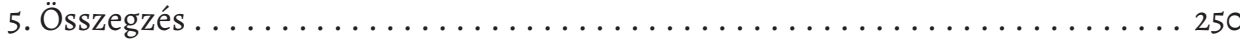

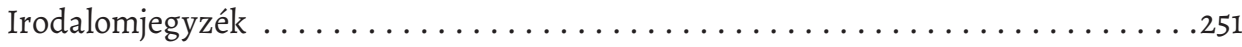

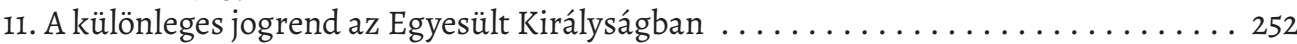

1. A különleges jogrend alkotmányos és törvényi szintû szabályozása . . . . . . . 252

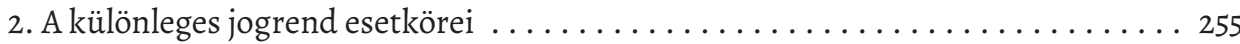

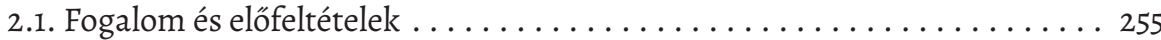

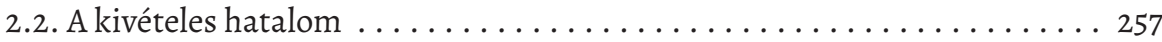

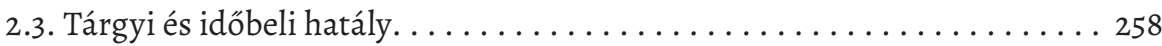

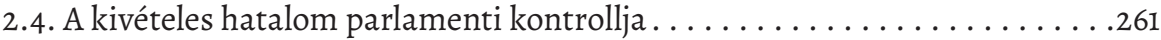

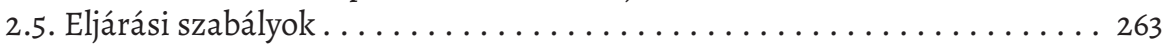

3. Az alapjog-korlátozással kapcsolatos kérdések . . . . . . . . . . . . . . 264

4. Egészségügyi vészhelyzet kezelése, koronavírus-járvány . . . . . . . . . 265

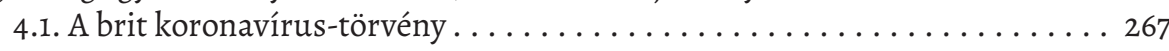

4.2. Az ország lezárása (national lockdown és local lockdown) . . . . . . . . . . 269

5. A különleges jogrenddel és a járványügyi veszélyhelyzet kihirdetésével

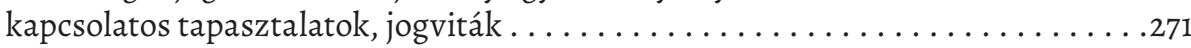

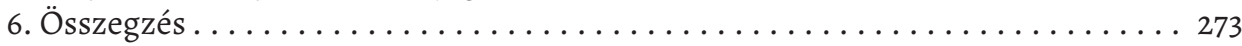

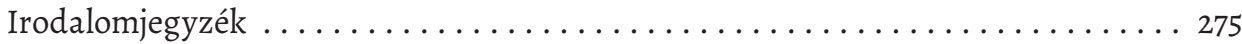


12. Fokozatosság elve és átfogó védelem: a különleges jogrend Észtországban . . . . . . . 277 1. A különleges jogrend alkotmányos és törvényi szintű szabályozása és esetkörei . . 277 1.1. A különleges jogrendre való felkészülést segítő békeidejû szabályok

és a kapcsolódó szervezetrendszer . . . . . . . . . . . . . 283

1.2. A válságkezelésre vonatkozó szabályok . . . . . . . . . . . . . . 287

2. Az alapjogok korlátozására vonatkozó szabályok különleges jogrend idején . . . . 290

3. A koronavírus-járványra adott állami reakció . . . . . . . . . . . . . . . . 292

4. A különleges jogrend a gyakorlatban: viták és kihívások. . . . . . . . . . . . . . 294

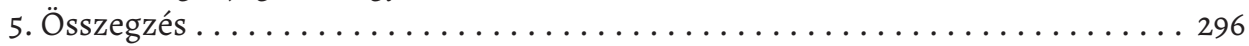

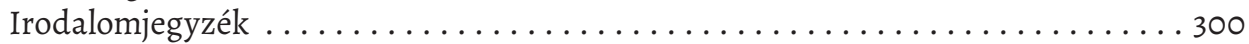

13. Amikor az alkotmány hallgat: Finnország különleges jogrendje . . . . . . . . . . 301

1. A különleges jogrend alkotmányos és törvényi szintû́ szabályozása,

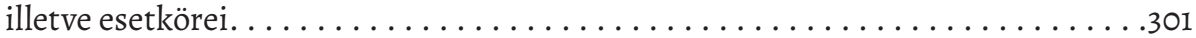

1.1. A különleges jogrendre való felkészülést segítő békeidejû szabályok

és a kapcsolódó szervezetrendszer . . . . . . . . . . . . . . . . 305

1.2. A válságkezelésre vonatkozó szabályok . . . . . . . . . . . . . . . . . 307

2. Az alapjogok korlátozására vonatkozó szabályok különleges jogrend idején . . . . 309

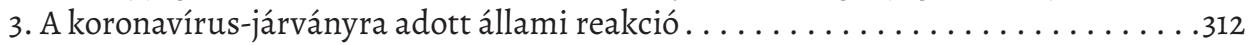

4. A különleges jogrend a gyakorlatban, viták és kihívások . . . . . . . . . . 315

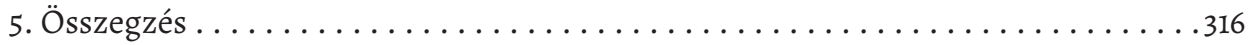

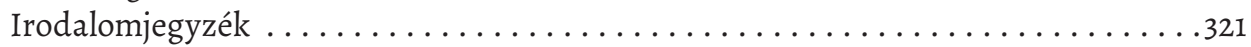

14. Franciaország: folyamatosan különleges jogrend, a koronavírus idején is . . . . . 322

1. A különleges jogrend szabályozása és esetkörei . . . . . . . . . . . . . . . . . . . . . . 322

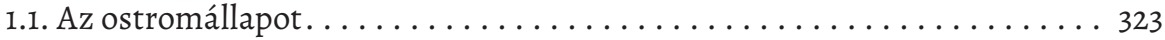

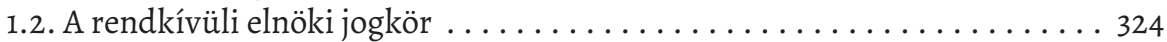

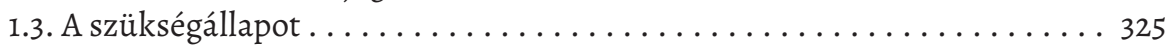

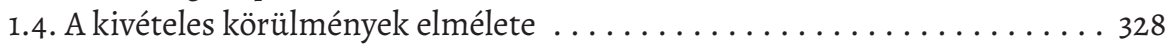

2. Az alapjogok korlátozására vonatkozó szabályok különleges jogrend idején . . . . 329

3. A koronavírus-járvány miatt bevezetett különleges jogrend Franciaországban . . 330

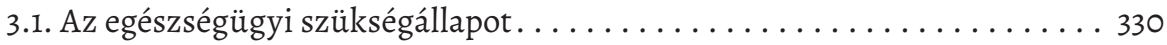

3.2. A koronavírus-járvány okozta rendkívüli állapot leküzdése érdekében

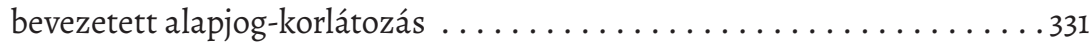

4. A különleges jogrend kihirdetésének gyakorlati esetei . . . . . . . . . . . . . 334

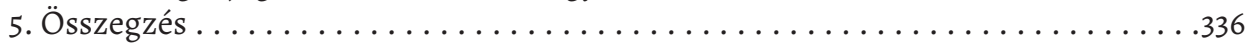

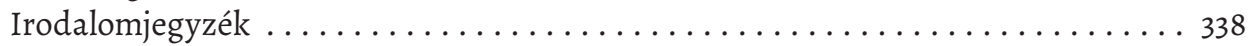

15. Különleges felhatalmazás különleges jogrend kihirdetése nélkül,

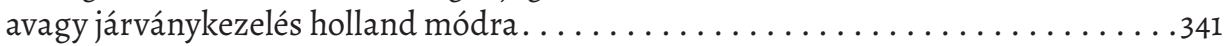

1. A különleges jogrend alkotmányos és törvényi szintû szabályozása . . . . . . . . . 341

2. Az alapjogok korlátozására vonatkozó szabályok

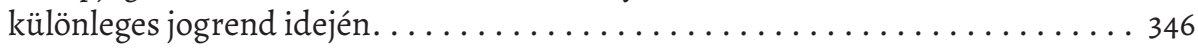

3. A koronavírus-járvány miatt bevezetett különleges intézkedések

és az alapjogok korlátozásának alkotmányossága . . . . . . . . . . . . . . . . 347 . . . . . . . . . . . . .

3.1. A 2020 tavaszán bevezetett intézkedések. . . . . . . . . . . . . . . . 347

3.2. A bevezetett intézkedések értékelése a jogállamiság

és a demokratikus elszámoltathatóság szempontjából . . . . . . . . . . . . 349 
3.3. A törvényi reform

4. A különleges jogrend kihirdetésének gyakorlati esetei

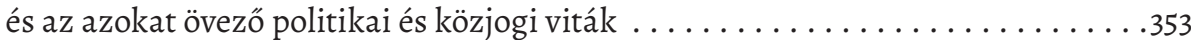

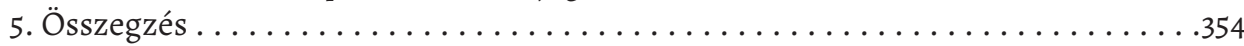

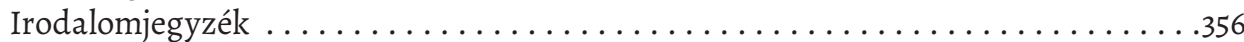

16. Különleges jogrendi szabályok Lengyelországban . . . . . . . . . . . . 358

1. A különleges jogrend alkotmányos és törvényi szintű szabályozása,

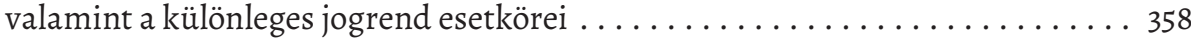

2. Az alapjogok korlátozásával kapcsolatos kérdések . . . . . . . . . . . . . 361

3. Az egészségügyi válsághelyzet kezelése és a koronavírus-járvány . . . . . . . . . . . . . . . . . . . . 364

3.1. A koronavírus-járvány első hulláma Lengyelországban. . . . . . . . . . 366

3.2. A koronavírus-járvány második hulláma Lengyelországban . . . . . . 368

4. A különleges jogrend és a járványhelyzet kihirdetésével kapcsolatos

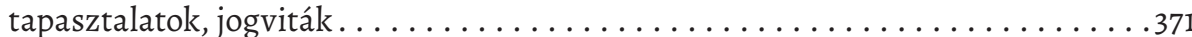

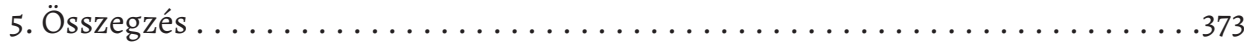

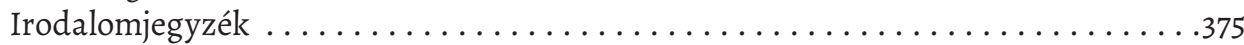

17. Lettország készen állt: egy könnyúszerkezetes jogrendszer példája . . . . . . . . . . . 376

1. A különleges jogrend alkotmányos és törvényi szintû szabályozása és esetkörei . . . 376

2. Az alapjogok korlátozására vonatkozó szabályok különleges jogrend idején . . . . 381

3. A koronavírus-járvány miatt bevezetett különleges jogrend Lettországban. . . . . 386

4. A különleges jogrend kihirdetésének gyakorlati esetei . . . . . . . . . . . . . . . . . . . . . . . . . . . . . . . . . . . . . .

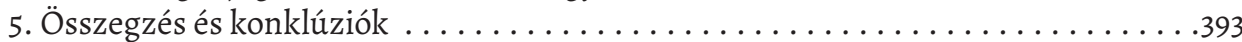

Irodalomjegyzék . . . . . . . . . . . . . . . . . . . . . 397

18. A különleges jogrendi esetkörök szabályozása Litvániában . . . . . . . . . . . . . . 398

1. A különleges jogrend alkotmányos és törvényi szintű szabályozása, esetkörei. . . . 398

2. Az alapjogok korlátozásával kapcsolatos kérdések . . . . . . . . . . . 401

3. A koronavírus-járvány és az egészségügyi vészhelyzet kezelése . . . . . . . 403

4. Összegzés . . . . . . . . . . . . . . . . . . . . . . . . . . . . 409

Irodalomjegyzék . . . . . . . . . . . . . . . . . . . . . . . . . . . . . .

19. Németország, a többszintû́ válságkezelés iskolapéldája . . . . . . . . . . .414

1. A különleges jogrend alkotmányos és törvényi szintû szabályozása és esetkörei . . .414

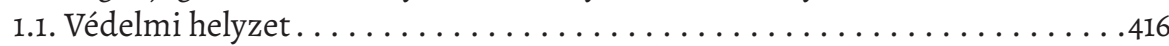

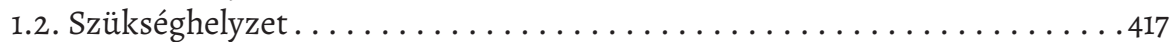

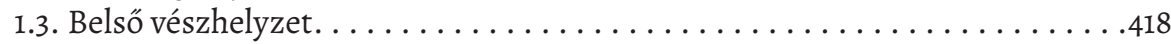

1.4. Katasztrófahelyzet . . . . . . . . . . . . . . . . . . . . . 419

2. Az alapjogok korlátozása különleges jogrend keretében . . . . . . . . . . 420

3. Az egészségügyi vészhelyzet kezelése és a koronavírus-járvány . . . . . . . . . . . . . . . . . 423

4. A járványügyi vészhelyzet kihirdetésével kapcsolatos jogviták . . . . . . . . 426

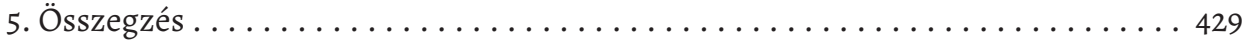

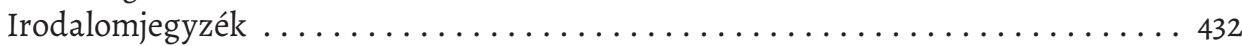

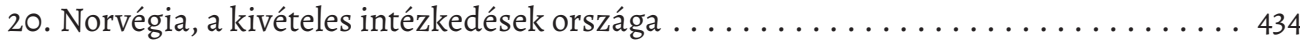

1. A különleges jogrend alkotmányos és törvényi szintú szabályozása . . . . . . . . . 434

2. Az alapjogok korlátozására vonatkozó szabályok különleges jogrend idején . . . . 439

3. A különleges jogrend kihirdetésének gyakorlati esetei . . . . . . . . . . 445

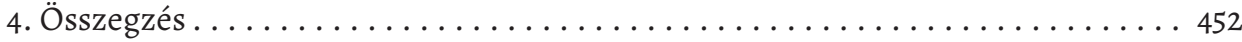


Irodalomjegyzék

21. A különleges jogrendi szabályozás Olaszországban: a hadiállapot

és a kivételes hatalomgyakorlás egyéb esetkörei.

1. A különleges jogrend alkotmányos és törvényi szintú szabályozása . . . . . . . . . . 457

1.1. Hadiállapot . . . . . . . . . . . . . . . . . . . . . . . . . . . . 459

1.2. Sürgősségi rendeleti kormányzás $\ldots \ldots \ldots \ldots \ldots \ldots \ldots \ldots \ldots \ldots \ldots \ldots \ldots$

1.3. Központi hatáskörelvonás.......................... 463

2. Az alapjogok korlátozására vonatkozó szabályok a különleges jogrend idején . . . . 466

3. A koronavírus-járvány olaszországi kezelése . . . . . . . . . . . . . 467

4. A különleges jogrend bevezetésével és a járványügyi szükségállapot

kihirdetésével kapcsolatos tapasztalatok, jogviták . . . . . . . . . . . 470

5. Összegzés . . . . . . . . . . . . . . . . . . . . . . . . . . . . . . . . 474

Irodalomjegyzék $\ldots \ldots \ldots \ldots \ldots \ldots \ldots \ldots \ldots \ldots \ldots \ldots \ldots \ldots \ldots \ldots \ldots$

22. A prezidenciális jelleg hangsúlyossága a különleges jogrend romániai szabályozásában. ......................... 480

1. A különleges jogrend alkotmányos és törvényi szintú szabályozása, esetkörei. . . . 480

2. Az alapjogok korlátozásával kapcsolatos kérdések ............... 488

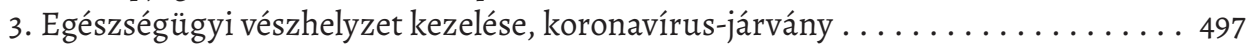

4. Összegzés . . . . . . . . . . . . . . . . . . . . . . . . . . . . . . . . . 499

Irodalomjegyzék ................................. 503

23. A kivételes állapot alkotmányos és törvényi szintú szabályozása Svédországban . . . 504

1. A különleges jogrend alkotmányos és törvényi szintủ szabályozása . . . . . . . . . 504

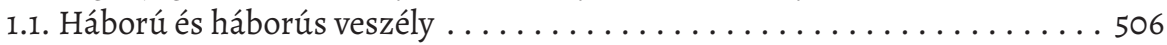

1.2. Békeidejú kivételes szituációk . .................... 510

2. Az alapjogok korlátozására vonatkozó szabályok különleges jogrend idején . . . . . .515

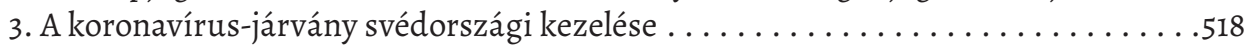

4. A különleges jogrend bevezetésével és a járványhelyzet

kezelésével kapcsolatos tapasztalatok, jogviták. . . . . . . . . . . . 523

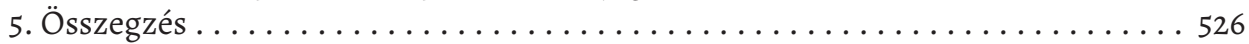

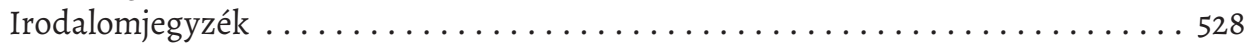

24. A különleges jogrendi esetkörök alkotmányos és törvényi szintú szabályozása

Szlovákiában .................................. 530

1. A különleges jogrend alkotmányos és törvényi szintú szabályozása . . . . . . . 530

1.1. Az alkotmányos szervek bemutatása és a különleges jogrendi

tényállásokra vonatkozó közös szabályok ................ 534

1.2. A válsághelyzet és a rendkívüli helyzet mint a különleges

jogrendnek nem minősülő rendkívüli felhatalmazás esetkörei ...... 536

1.3. A különleges jogrendre való felkészülést segítő békeidejú szabályok, valamint a válságkezelésre vonatkozó szabályok ..............557

2. Az alapjogok korlátozására vonatkozó szabályok különleges jogrend idején .... 538

3. A különleges jogrend kihirdetésének gyakorlati esetei . . . . . . . . . . . . 540

4. Összegzés . . . . . . . . . . . . . . . . . . . . . . . . . . . . . . . . 543

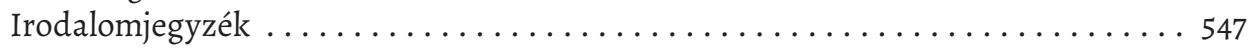


25. Spanyolország, ahol a különleges jogrend valóban különleges. . . . . . . . . . . . 549

1. A különleges jogrend alkotmányos és törvényi szintû szabályozása

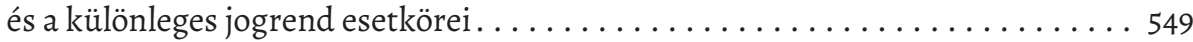

2. Alapjog korlátozásával kapcsolatos kérdések . . . . . . . . . . . . . 553

3. Az egészségügyi vészhelyzet kezelése, koronavírus-járvány . . . . . . . . . .556

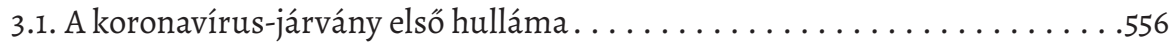

3.2. A koronavírus-járvány második hulláma. . . . . . . . . . . . . 558

4. A különleges jogrend és a járványügyi vészhelyzet kihirdetésével

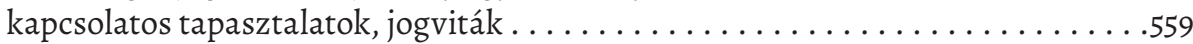

5. Összegzés . . . . . . . . . . . . . . . . . . . . . . . . . . . 561

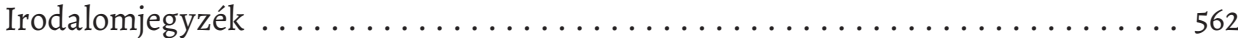

26. Ahol a különleges jogrend egyáltalán nem is különleges: az amerikai modell . . . . . . . .563

1. A különleges jogrend alkotmányos és törvényi szintű szabályozása, esetkörei. . . . .563

1.1. A közegészségügyi szolgáltatásokról szóló 1944. évi törvény

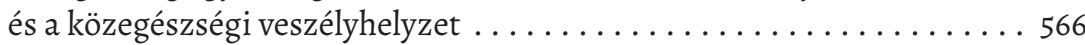

1.2. Az Egyesült Államok Kódexe: külkapcsolatok és az előre nem látható veszélyhelyzet. . . . . . . . . . . . . . . . . . . . . . . . . . . . 567

1.3. Az országos veszélyhelyzetról szóló 1976. évi törvény és az országos veszélyhelyzet. . . . . . . . . . . . . . . . . . . . . . . . . 568

1.4. A Stafford-törvény és a veszélyhelyzet, az elemi katasztrófa, valamint a veszélyhelyzeti készültség . . . . . . . . . . . . . . . . . . . . 569

1.5. A 2002. évi belbiztonsági törvény és az elemi katasztrófa, valamint a terrorhelyzet. . . . . . . . . . . . . . . . 571

1.6. A 2006. évi Katrina hurrikán utáni veszélyhelyzet-kezelési reformról szóló törvény és a katasztrofális esetek. . . . . . . . . . . . 572

2. Az alapjogok korlátozására vonatkozó szabályok különleges jogrend idején . . . .573

3. A koronavírus-járvány miatt bevezetett különleges jogrend

az Egyesült Államokban és a járványkezelésre adott szövetségi,

tagállami és helyi szintû́ válaszok . . . . . . . . . . . . . . . . 576

4. A különleges jogrend kihirdetésével kapcsolatos jogviták. . . . . . . . . . 583

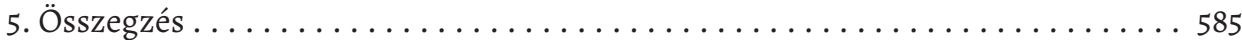

Irodalomjegyzék . . . . . . . . . . . . . . . . . . . . . 590

27. A korlátlan államhatalom sajátos korlátja: a különleges jogrend Kínában . . . . . . . 592

1. A különleges jogrend alkotmányos és törvényi szintű szabályozása és esetkörei . . 592

1.1. A különleges jogrendre való felkészülést segítő békeidejű szabályok

és a kapcsolódó szervezetrendszer . . . . . . . . . . . . . . . . 596

1.2. A válságkezelésre vonatkozó szabályok . . . . . . . . . . . . . . . 597

2. Az alapjogok korlátozására vonatkozó szabályok különleges jogrend idején . . . . 599

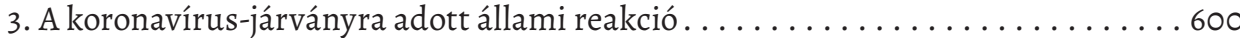

4. A különleges jogrend a gyakorlatban, viták és kihívások . . . . . . . . . . 602

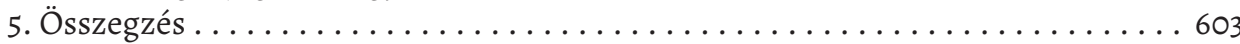

Irodalomjegyzék . . . . . . . . . . . . . . . . . . . . . . . . . . . 607 
Konklúziók. 609

28. Összegzés - A koronavírus-járvány kezelésének tapasztalatai

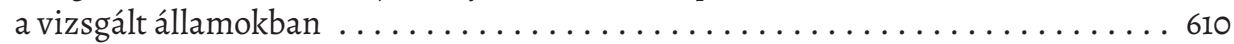

1. Különleges jogrend bevezetése a koronavírus-járvány kezelése érdekében $\ldots \ldots 6611$

2. A koronavírus-járvány kezelése érdekében megvalósuló rendeleti kormányzás, és a parlament kontrollfunkciója. .........................615

3. A koronavírus-járvány kezelése során bevezetett alapjog-korlátozás, valamint a járványkezeléssel összefüggésben felmerült közjogi-politikai viták . . .618

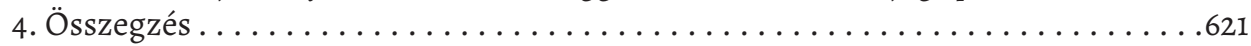

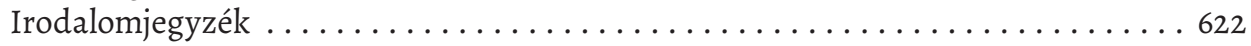

29. Összegzés - A különleges jogrend az alkotmányokban . . . . . . . . . . . . . 624

1. Az alkotmányos szabályozás mélysége. ..................... 626

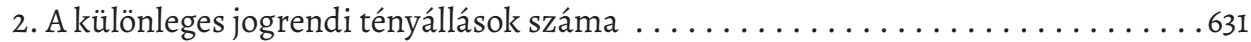

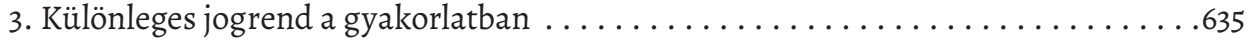

4. A magyar különleges jogrend a külföldi megoldások tükrében . . . . . . . . 639

Irodalomjegyzék ..................................... 642 



\section{Előszó}

„Midôn ezt írtam, tiszta volt az ég” - mennyivel mást jelentenek ma ezek a sorok ebben a több mint egy éve húzódó járványhelyzetben, amikor nem tudunk személyesen kapcsolatot tartani, nem tudunk utazni, és a nemzetközi kapcsolataink is a videokonferenciákra redukálódnak. Repülők immár több mint egy éve nem, vagy csak igen korlátozottan szelik át az eget, kondenzcsíkjaik nem festenek fehér sávokat az ég tiszta kékjére. Szerencsére azonban más értelemben is tisztul az ég, és az oltási program és a Kormány intézkedéseinek hatására már látszanak jelei annak, hogy fokozatosan visszatérhetünk a régi életünkhöz.

Egy éve ilyenkor azonban más volt a helyzet. A világ összes országának vezetői azon fáradoztak, hogy a lehető legtöbb emberéletet megmenthessék, és elegendő számú orvosi eszközt biztosíthassanak saját állampolgáraiknak. Az Európai Unió válságkezelése kudarcba fulladt, a nemzetállamok átvették a kezdeményező szerepet, és igyekeztek menteni a menthetôt. Földünk, „e nagy egyetem” országainak többsége és az Európai Unió összes tagállama különleges intézkedéseket, illetve jogrendet léptetett életbe. Jelen könyv a magyaron kívül 16 uniós tagállam, valamint a brit, a norvég, az amerikai és a kínai szabályozást vizsgálja. Az alkotmányokba, illetve az alsóbb szintû normákba foglalt különleges jogrendek általános ismertetésen túl kitér a COVID-19-járvány leküzdése érdekében bevezetett konkrét intézkedésekre, ismerteti az egyes országokban felmerült jogvitákat, valamint összehasonlítást nyújt a hazai szabályozással is.

A kötetet elolvasva nemcsak a különleges jogrend nemzeti, nemzetközi és európai uniós szintû szabályozását ismerjük meg, de átfogó képet kaphatunk annak történeti-filozófiai, jogirodalmi hátteréről, bevezetésének okairól, valamint arról, hogy egyes országok hogyan építették be az alkotmányos rendszereikbe.

Alkotmányos hagyományaiknak és a járványügyi helyzetnek megfelelően valamennyi tagállam speciális intézkedéseket léptetett életbe. Egy részük a járványhelyzet alatt alkotmányban rögzített rendkívüli jogrendet vezetett be, míg mások egészségügyi vagy katasztrófavédelmi szabályozás által biztosított különleges felhatalmazással éltek.

Bizonyára jóval könnyebb dolga lett volna a jogalkotónak, ha egy évvel ezelótt is rendelkezésünkre állt volna egy ehhez hasonló hiánypótló mư. Akkor azonban még csak annyit láttunk, hogy „a nagy egyetem megszünt forogni egy pillanatig”. Ebben a teljesen újszerủ kihívásban pedig azt a felhatalmazást, amellyel Magyarországon a Kormány kezelni és csökkenteni tudta a vészt, a különleges jogrend biztosította. Gyors és hathatós felhatalmazásra volt szükségünk, hogy időben cselekedni tudjunk és emberéleteket menthessünk.

I Vörösmarty Mihály Előszó c. verse. 
2019 decemberében jelentették az első új típusú koronavírusos beteget a kínai Vuhanban, a magyar kormány pedig Orbán Viktor miniszterelnök úr vezetésével rendkívül korán, már 2020. január 31-én létrehozta az Operatív Törzset a járványügyi intézkedések felügyeletére. Február 2-án hazaszállították a Vuhanban élő magyar állampolgárok közül azokat, akik éltek ezzel a lehetőséggel. Az első hazai megbetegedésről 2020. március 4-én kaptunk hírt. Az Egészségügyi Világszervezet (WHO) rövidesen, március 11-én kelt közleményében a COVID-19-fertőzést világjárvánnyá nyilvánította.

Magyarország Kormánya 2020. március 11-ével az egészség és az élet megóvása, valamint a nemzetgazdaság stabilitásának biztosítása érdekében országos veszélyhelyzetet hirdetett ki. A veszélyhelyzet hazánk esetében az Alaptörvényben szabályozott rendkívüli jogrend egyik formája. Mivel a Kormány veszélyhelyzeti jogalkotása a vonatkozó normák értelmében csak tizenöt napig maradhat hatályban, ezért azt a Parlament mint a legfóbb népképviseleti szerv felhatalmazása alapján meg kellett hosszabbítani. Az Országgyúlés ezt a felhatalmazást a koronavírus elleni védekezésről szóló 2020. évi XII. törvény elfogadásával március 30-án megadta.

Ebben a példátlan helyzetben a tagállamoknak jogában állt, egyben kötelességük is volt rendkívüli intézkedéseket hozni állampolgáraik védelme és a válság felszámolása érdekében. Alapvető követelmény, hogy a rendkívüli intézkedéseknek ideiglenesnek, szükségesnek és arányosnak kellett lenniük, valamint biztosítani kellett ezek rendszeres felülvizsgálatát. A magyar intézkedések ezeknek az alapelveknek maradéktalanul megfeleltek. Az Alkotmánybíróság és a bíróságok továbbra is múködtek, tevékenységüket a helyzetnek megfelelő eljárási szabályok könnyítették meg. Az állami szervek alkotmányos és jogszerű múködésének felügyelete mindvégig biztosított volt, és a mai napig biztosított.

A Kormány intézkedései központjában kezdetektől fogva a védekezés és a gazdaság életben tartása állt. Így a mozgást korlátozó intézkedések mellett az elsők között vezettük be a hitelmoratóriumot, terjesztettük ki a szociális és családtámogatási juttatásokat, könnyítettük meg az egészségügyi ellátás online formáit és szabályoztuk a távoktatást.

Mint ahogyan azt maga a könyv is helyesen állapítja meg, az Európai Uniónak nincs kapcsolódó hatásköre kötelező erejű döntések meghozatalára, hiszen a különleges jogrendre vonatkozó alkotmányos és törvényi szabályok meghozatala kizárólagos tagállami hatáskörbe tartozik. Ugyan a pandémia kitörése után nem sokkal a Bizottság azt ígérte, hogy öszszehasonlító tanulmányban fogja részletesen elemezni az egyes tagállamok veszélyhelyzeti intézkedéseit, ezzel a mai napig adós maradt. Mi, az Igazságügyi Minisztériumban megelőlegezve jelen kötetet, elvégeztünk egy uniós összevetést, és kimutattuk, hogy a magyar intézkedések között egyetlen olyan sincs, amelyre ne lenne példa más európai államban. Ezenfelül sokszor enyhébb intézkedésekkel értük el azt az eredményt, amelyhez más tagállamban drasztikusabb eszközök kellettek - gondoljunk csak az intézkedésekkel szembeni tüntetők és a rendőrség összecsapásaira Belgiumban és Németországban, vagy a drasztikus olaszországi intézkedésekre. Természetesen a magyar emberek józan belátása, türelme, jogkövető 
magatartása és példamutató együttmúködése is kellett ahhoz, hogy szembeszállhassunk a világjárvánnyal.

Míg Magyarország esetében a különleges jogrend alkotmányos felhatalmazáson és az Alaptörvényünkben lefektetett részletes szabályokon alapult, addig több tagállamban úgy vezettek be különleges jogrendet, hogy azt semmilyen jogszabályi felhatalmazás nem alapozta meg. A járvány intenzitásának csökkenésével összhangban Magyarország az elsők között szüntette meg a különleges jogrendet. 2020. május 26-án a Kormány törvényjavaslatot nyújtott be az Országgyúlésnek, amelyben indítványozta a különleges jogrend megszüntetését. A veszélyhelyzet így bevezetése után néhány hónappal, június 18-án megszúnt, a koronavírus elleni védekezésről szóló törvény pedig hatályát vesztette.

Ezzel egyidejûleg bevezettük az úgynevezett járványügyi készültséget, hiszen az oltások kifejlesztéséig nem lehetett könnyíteni a korlátozásokon. A rendes alkotmányos rend részeként ez idő alatt a kormánynak sokkal korlátozottabb volt a jogköre, mint a különleges jogrendben. A járványt azonban vakcinák híján nem lehetett megállítani, ezért a vírus második hullámának megfékezése érdekében kénytelenek voltunk 2020. november 4-tôl visszaállítani a különleges jogrendet - ezúttal jóval mérsékeltebb nemzetközi kritikát kiváltva, ám továbbra is folyamatos ellenzéki támadások kereszttüzében.

Bár jelen kutatás fókusza nem terjedt ki a 2021-es fejleményekre, kijelenthetjük, hogy a jelen könyv hasábjain részletesen bemutatandó jogszabályok és intézkedések segítették leküzdeni a járvány első hullámát, igyekeztek megfékezni a másodikat, és reményeink szerint az oltásokkal végleg eltüntetik a harmadik hullámot, megengedve a társadalomnak, hogy visszatérhessen normális életéhez.

Budapest, 2021 májusa

Dr. Varga Judit

igazságügyi miniszter 



\section{Bevezető}

A Mádl Ferenc Összehasonlító Jogi Intézet Közjogi Kutatási Főosztályának kutatói által írt könyv egy fiatal, 2019-ben alakult intézet egyik nagyszabású tudományos munkája. A téma feldolgozását több hónap kutatómunka előzte meg, de a járványügyi veszélyhelyzet a könyv elkészítése után is fennáll, így a kutatás folyamatos volt az elkészítés alatt is. A kutatást azonban 2020 decemberében lezártuk, így a 2021-es jogszabályi változásokat e kiadvány már nem tartalmazza.

A könyv célja, hogy bemutassa a különleges jogrendi szabályozás elméletét és a járványügyi veszélyhelyzet miatt bevezetett szabályozási megoldásokat. A jogi megoldások öszszehasonlító jogi elemzése és bemutatása rendkívüli jelentőséggel bír a jövőre nézve, hiszen olyan helyzettel szembesültek a modern kori demokráciák, amely jövőbeli előfordulása sem zárható ki. A tapasztalatok és a következtetések fontos támpontot adhatnak a jogtudomány és a jövőbeli jogalkotás számára egyaránt.

A téma tanulmányozásához fontosnak tartottuk az elméleti alapok meghatározását, a különleges jogrendi szabályozás jogelméleti és alkotmányjogi kontextusba helyezését. A jogintézmények megértéséhez szükségesnek ítéltük meg a nemzetközi és európai uniós jogi tudományterület feldolgozását a téma szempontjából.

A kötet alapvetôen Európára, ezen belül is fóként az Európai Unió tagállamaira fókuszál. A vizsgálandó országok kiválasztása során nem a teljességre törekedtünk, hanem arra, hogy a kontinens valamennyi régióját érintsük a kutatásunk során. Ennek megfelelően a nagy, meghatározó uniós tagállamok (Németország, Franciaország, Olaszország és - immár múlt időben - az Egyesült Királyság) mellett vizsgálunk számos közép-európai országot, de a skandináv és a balti államok sem maradnak ki az elemzésünkből. Az országok kiválasztása során törekedtünk arra, hogy egy sok országot felölelő, sokszínú képet mutassunk be Európából az olvasó számára. Ezt indokolta az eltérő jogi szabályozás, illetve az eltérő járványkezelés egyaránt.

Az Európán kívüli országok közül a könyv az Egyesült Államok és Kína szabályozását dolgozza fel. Erre a két államra azért esett a választásunk, mert fontos szerepet töltenek be az Európai Unió mellett a világpolitikában és a világgazdaságban egyaránt, továbbá a két államnak fontos szerep jutott a járványügyi veszélyhelyzetben. A Covid-19 Kínából indult, de gyors intézkedések révén végül sikeresen kezelték a vírushelyzetet, és a gazdaságot sem érte olyan megrázkódtatás, mint ahogy az európai államokban érezhetó. Az USA-ban viszont a legtöbb áldozatot szedte a járvány, még 2021-ben is súlyos pandémiás válsággal kell szá-

Prof. Dr. Nagy Zoltán, PhD

zoltan.nagy@mfi.gov.hu

főosztályvezető (Mádl Ferenc Összehasonlító Jogi Intézet)

egyetemi tanár (Miskolci Egyetem Állam- és Jogtudományi Kar, Államtudományi Intézet, Pénzügyi Jogi Tanszék) 
molnia az országnak. Súlyosak továbbá a társadalmi és gazdasági következmények, amelyek az új elnöki adminisztrációnak jelentenek kihívást az elkövetkező években.

Az egyes országfejezeteken belül bemutatásra és elemzésre kerülnek a különleges jogrend alkotmányos és törvényi szintú szabályai és a különleges jogrend esetkörei. Hangsúlyosnak gondoltuk az alapjog-korlátozással kapcsolatos kérdéseket, mivel ezen a területen vetődtek fel a legjelentősebb problémák. A Covid-19-járvány következtében az egyes országok lezárták határaikat, korlátozták a szabad mozgást, kijárási tilalmat rendeltek el. Az államok hol gyorsan, hol kevésbé gyorsan reagáltak a pandémiás kihívásokra, és ezek sok esetben érintették az alkotmányos szabályokat. A járványhelyzet kapcsán felmerül a kérdés, hogy mit tehet meg az állam ilyen veszélyhelyzetben, jó-e, hogy olyan felhatalmazással rendelkezik, amely gyors intézkedést tesz lehetôvé. Megoldás-e a törvényhozási kontroll, vagy jobb, ha teljes felhatalmazást kap a kormány, és csak utólag számol be a parlamentnek. Ebben a helyzetben a gyors döntések biztosították a megfelelő védekezést. A jog által felállított alkotmányos korlátok fontosak, hiszen a kormányok a korlátlan felhatalmazással visszaélhetnek, de a társadalmi és gazdasági érdekek egyaránt előnyt kell hogy élvezzenek. A nagyobb szabadságot biztosító svéd modell a kezdeti pozitív helyzet után egészségügyi tragédiát okozott a skandináv országban. Mindezekre tekintettel a kutatókat foglalkoztatták azok a kérdések, amelyek az egészségügyi veszélyhelyzet kezelésével kapcsolatosak. Feldolgozásra kerültek jogviták, amelyek szintén rámutattak arra, hogy a szabályozásnak milyen problémákkal kell szembenéznie.

Az országfejezeteken belül kiemelten kezeltük a magyar szabályozást, hiszen ez képezte az összehasonlítás alapját is. A könyv célja tehát nemcsak az, hogy bemutassa az egyes országok szabályozását, hanem az is, hogy összehasonlítsa a magyar szabályozást az egyes országok jogi megoldásaival. Az összehasonlításra sor kerül az egyes országok elemzésénél, illetve az öszszegző fejezetben egyaránt. A magyar rész a legrészletesebb a könyvben, mivel ezt tekintettük viszonyítási pontnak a többi országgal való összevetésnél. Az összehasonlító elemzés érdekében a magyar résznél kifejtésre kerül a különleges jogrend történeti fejlődése, valamint a járványügyi veszélyhelyzet és a járványügyi veszélyhelyzet miatt kialakult gazdasági válság kezelésének módszerei. A gazdasági válságkezelést a többi ország esetében nem elemezzük a terjedelmi korlátok miatt, de a magyar fejezetnél látható, hogy a gazdasági válságnak milyen jelentős társadalmi hatásai vannak, és ezek szorosan összefüggenek a járványhelyzet kezelésével. A tiltó szabályok, korlátozások elősegítették a járvány kezelését, viszont a gazdasági és társadalmi következmények sok esetben hasonló károkat okozhatnak egy társadalomban, mint maga a járvány. Ennek mérlegelése óriási feladatokat ró az egyes kormányokra.

A téma kutatása nem fejezhető be, csak lezárható, hiszen a különleges jogrend a könyv befejezését követően is fennáll. Reméljük, hogy a munkánk elősegíti a további kutatásokat, vitákat generál a témával kapcsolatban, hiszen a tudomány és a joggyakorlat fejlődését a viták és a levont következtetések, tapasztalatok viszik előre.

Budapest, 2021. január 5.

Prof. Dr. Nagy Zoltán 


\section{ELMÉLETI ÉS \\ NEMZETKÖZI \\ KERETEK}




\section{A különleges jogrend elméleti kérdései}

\section{TRÓCSÁNYI LÁSZLÓ}

A koronavírus okozta járvány kitörése és gyors elterjedése szükségessé tette a világ sok táján jó ideje leginkább csak az egyetemi előadások elméleti és a hétköznapi élet valóságától távoli kérdéseként ismert kivételes hatalomgyakorlás és különleges jogrend intézményének gyakorlatban történő alkalmazását. Számos ország vezetője a járványt leginkább háborúval, annak közegészségügyi következményeit pedig egy háború által okozott csapással tartotta öszszevethetônek. Bár nemzetközi jogi értelemben a hasonlat nyilvánvalóan sántít, ugyanakkor mégis jól rávilágít a járvánnyal szembeni védekezés azon sajátosságára, hogy a veszély sikeres elhárítására és orvoslására az államszervezeti struktúra és az állami múködés hagyományos rendje nem alkalmas. A járványügyi védekezés, különösen pedig az egészségügyi ellátórendszerek túlterheltségének megfékezése, de közben a gazdaság müködőképességének lehetőség

I A járvány által előidézett veszélyt hadiállapothoz hasonlította többek között a kínai elnök és kommunista pártfötitkár Xi Jinping (www.xinhuanet.com/english/2020-02/11/c_138771934.htm, letöltve: 2020. december 15.), Emmanuel Macron francia elnök (www.reuters.com/article/us-health-coronavirus-macron-restriction/ we-are-at-war-france-imposes-lockdown-to-combat-virus-idUSKBN2133G5, letöltve: 2020. december 15.), valamint az amerikai elnök, Donald Trump is (www.whitehouse.gov/briefings-statements/remarks-presidenttrump-vice-president-pence-members-coronavirus-task-force-press-briefing-5/, letöltve: 2020. december 15.). Ilyen nyilatkozatot tett a magyar miniszterelnök, Orbán Viktor is 2020 őszén (http://abouthungary.hu/ blog/pm-orban-in-an-exclusive-interview-our-war-plan-against-the-coronavirus-is-about-ensuring-thathungary-continues-to-function/, letöltve: 2020. december 15.).

Prof. Dr. Trócsányi László, CSc

laszlo.trocsanyi@mfi.gov.hu

egyetemi tanár (Károli Gáspár Református Egyetem Állam- és Jogtudományi Kar, Alkotmányjogi Tanszék; Szege-

di Tudományegyetem Állam- és Jogtudományi Kar, Nemzetközi és Regionális Tanulmányok Intézete)

tiszteletbeli elnök (Mádl Ferenc Összehasonlító Jogi Intézet)

Trócsányi, L. (2021) 'A különleges jogrend elméleti kérdései’ in Nagy, Z., Horváth, A. (szerk.) A különleges jogrend és nemzeti szabályozási modelljei, 26-36. o. Budapest: Mádl Ferenc Összehasonlító Jogi Intézet.

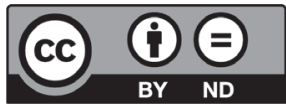

https://doi.org/10.47079/2021.nzha.kulon.4_1 
szerint való megőrzése ${ }^{2}$ a hagyományos, békeidőszaktól eltérő államhatalmi szervezeti rend és múködés bevezetését indokolta. ${ }^{3} \mathrm{~A}$ különleges jogrend jó pár évtizede elméleti jogászkodásra ítélt kérdései így váltak az európai és Európán kívüli országok mindennapjainak részévé 2020ban, a kitört Covid-19-járvány időszakában. A jelen kötet ezen apropóból tekinti át a közjó érdekében alkalmazott, normálistól eltérő, kivételes állami müködést.

A különleges jogrend átfogó jellegú tárgyalására vállalkozó összehasonlító jogi kötet megkerülhetetlen része azonban a magát a különleges jogrendet övezőáltalános elméleti kérdések megismerése és bemutatása. A különleges jogrend alkotmányos rendszerben betöltött helyének bemutatására és tárgyalására már csak azért is nagy szükség mutatkozik, mert a rendszerváltoztatást megelőző hazai történelemben számos rossz emlék is tapad - az alkotmányos hagyományoktól elszakadt - kivételes hatalomgyakorlás intézményéhez. Ezért az egyes európai és Európán kívüli országok rendkívüli állapotot és különleges jogrendet szabályozó tételes jogi szabályozásainak vizsgálatát megelőzően érdemes a különleges jogrend legalapvetőbb elméleti kérdéseit bevezető jelleggel felvázolni. Melyek a kivételes hatalomgyakorlás történelmi gyökerei, és miért válhat ilyen hatalomgyakorlás szükségessé az alkotmányos rendszerekben? Mikor jelent meg az alkotmányjogi szabályozásuk, és mikor váltak az alkotmányjog részévé? Mi igazolhatja bevezetését, és melyek az alkalmazásának alapvető feltételei? Mi a funkciója, és milyen érdekeket vagy értékeket véd? Ezek azok az alapvető kérdések, amelyeket a tanulmány törekszik megvizsgálni. A különleges jogrend eredetének, államelméleti hátterének és igazolhatóságának feltárása és tárgyalása ahhoz kíván hozzájárulni, hogy a kötet összehasonlító jogi részei érthetőbbé válhassanak. Ennek érdekében jelen tanulmány elsőként górcső alá veszi a különleges jogrend történelmi gyökereit (1), majd ezt követően megvizsgálja meghatározásának és alkalmazhatóságának elméleti kérdéseit (2). Kísérletet tesz a különleges jogrend igazolására, illetve számba veszi az abban védett értékeket (3), majd végül összegzést nyújt (4).

\section{Történeti gyökerek és eszmetörténeti fejlődés}

A valamely külső vagy belső ok miatt felborult állami múködés és döntéshozatali rend helyébe lépő kivételes hatalomgyakorlás ideiglenes lehetősége nem új keletû jelenség az államelmélet történetében. A hatalom természetét és a hatalomgyakorlás funkcióit már az ókori görögök az athéni demokráciákban is vizsgálták. ${ }^{4} \mathrm{Az}$ arisztotelészi államformatan

2 Horkay Hörcher Ferenc a Politikafilozófia járványidején címú írásában mutat rá arra, hogy a politikai hatalomnak Szkülla és Kharübdisz, két véglet között kell hajóznia, és a legkisebb rosszat kell megtalálnia (Horkay Hörcher, 2020).

3 Az egyes európai országok koronavírus-járvány miatt bevezetett különleges jogrend összehasonlító vizsgálatáról lásd például: Ungvári-Hojnyák, 2020.

4 Trócsányi, 2014, 33. 0. 
vizsgálta a hatalomgyakorlás döntési aspektusait, és arra a következtetésre jutott, hogy a veszélyek elhárítása hatékonyabb, ha egyetlen vagy csak néhány személy kezében összpontosul a hatalom, ugyanis így a demokratikus hatalomgyakorláshoz képest egyszerúbb a jogkorlátozó döntések meghozatala.

Az athéni demokrácia mellett az ókori Róma államszervezetében az állandó magisztrátus mellett ismert volt a főhatalmat koncentráló rendkívüli magisztrátus (magistratus extraordinarii) intézménye. A rendkívüli magisztrátus a tisztségét kinevezéssel nyerte el megszabott időtartamra és meghatározott feladat elvégzése céljából. Ilyen rendkívüli magisztrátus volt a szükséghelyzetekben az egyik consul által a szenátus egyetértésével kinevezett - korábban consuli tisztséget viselt - dictator, aki legfeljebb hat hónapig gyakorolhatta a főhatalom teljességét. ${ }^{5}$

Az ókori görög és római előzményeket követően az államtörténelem azon szakaszaiban, amikor az állami múködés jog általi korlátozottsága csak viszonylagos volt, illetve amikor az abszolút szuverenitás teóriájára épült, nem merült fel a kivételes hatalomgyakorlás vagy a különleges jogrend megteremtésének az igénye. Ezekben a korszakokban ugyanis a fóhatalom gyakorlása nem volt olyan korlátozott, hogy kivételes helyzetek rögzítését igényelte volna. A kivételes hatalom és a különleges jogrend szabályozása a hatalommegosztás, a törvényeknek alávetett állami múködés elvével, az alapjogok elismerésével és a jogforrási hierarchia érvényesítésével nyert ismét értelmet. ${ }^{6}$ Ennek megfelelően a kivételes hatalomgyakorlás kérdései az újkori polgári államisághoz kapcsolódó alkotmányelméletekben jelentek meg. John Locke felfogása szerint a különleges helyzetekben a szuverenitásból fakadó főhatalom a közösség javára és a közjó megóvása érdekében akár a jog ellenében is gyakorolható. Ebben az értelmezésben tehát a kivételes hatalomgyakorlás összeforr a közjó érvényesítésével.7 Ezzel összhangban a polgári átalakulást követő modern kori államteóriák két nagyobb csoportba sorolhatók. Az első csoportba tartozók azt vallják, hogy a kivételes hatalomgyakorlás jogon kívüli jelenség, míg a második csoporthoz tartozók szerint a jog (alkotmány) uralma a kivételes hatalomgyakorlás során is érvényesül.

Carl Schmitt, az első csoporthoz tartozók híres képviselője azt vallja, hogy a kivételes hatalomgyakorlást igénylő különleges helyzetek nem láthatók előre, következésképpen pedig a jog nem is képes ezeket meghatározni. ${ }^{8}$ Hasonlóan vélekedik Friedrich Koja is, aki szerint a különleges állapot az, amely nem vagy nem hatékonyan kezelhető a jog eszközeivel. ${ }^{9}$ Schmitt olvasatában az alkotmányok funkciója legfeljebb az lehet, hogy meghatározzák azt, aki a kivételes hatalmat a különleges helyzetekben gyakorolhatja. Ez pedig nem (lehet) más, mint a szuverén,

5 Földi-Hamza, 1996, 19-23. o.

6 Farkas, 2020a, 324-325. o.

7 Locke, 1999.

8 Carl Schmitt úgy fogalmaz, hogy „a kivételes állapot nem határozható meg az érvényes jogrend keretein belül, nem írható körül tényállásként, legfeljebb a végszükség állapotaként, az állam létének veszélyhelyzeteként stb. jellemezhető" (Schmitt, 1992, 1-2. o.).

9 Koja, 2003, 797. 0. 
aki egyfelől a különleges helyzet megállapításáról dönthet, másfelől pedig a kivételes hatalmat is gyakorolhatja a veszélyeztető vagy fenyegető helyzet elhárítása, valamint a „normális” állapot helyreállítása érdekében. Ezt a két különböző döntést a szuverenitás gyakorlója jogosult meghozni, a hatáskörének feltételeit és tartalmát a jog nem köti. Schmitt értelmezése szerint tehát a szuverenitás letéteményese a jog által nem kötött és nem is származtatott jellegú politikai eredetú hatalom. ${ }^{10}$ Ezt a tételt azzal igazolja, hogy a szuverénnek áll hatalmában felfüggeszteni a pozitív jogot, vagyis a kivételes hatalomgyakorlás elszakad a jogtól. ${ }^{11}$

Ezzel ellentétes álláspontot fogalmaz meg például az angolszász jogfelfogást képviselő Albert V. Dicey, aki szerint a kivételes hatalomgyakorlás része a jognak, és ennek megfelelóen utólagos bírói megítélés tárgyát képezi. ${ }^{12}$ Ennek megfelelően a főhatalom kizárólag a jog uralmával összhangban gyakorolható. ${ }^{13}$ Ehhez hasonló álláspontra helyezkedik Schmitt kortárs kritikusa, Hans Kelsen is, aki tagadja a jogon kívül álló szuverén létezését. Álláspontja értelmében az állam és a jog nem válik el egymástól, mert az állami jogrendben a hierarchikusan felépülő jogi normák szükségszerûen egymástól, végső soron pedig az alapnormától nyerhetik el érvényességüket. Következésképpen, az olvasata szerint, ez a hierarchikusan felépülő jogrendet megkerülő hatalomgyakorlás érvénytelen..$^{14}$

Az első világháború időszakában Robert Hoerni a szükséghelyzet jogát (droit de nécessité) a lausanne-i föderális bíróság 1915. december 14-i döntésére alapozta, amely szerint a kormány a kivételes, rendkívüli körülmények (circonstances exceptionnelles) következtében nincs kötve az alkotmányhoz. A rendkívüli körülmények előre nem határozhatók meg, így az alkotmányi szabályozás sem lehetséges. Az állam jogos önvédelme a természetjogon alapszik. ${ }^{15}$ Ezzel szemben foglalt állást Duguit, aki úgy vélte, hogy a szükséghelyzetre alapított hatalomgyakorlás illegális. ${ }^{16}$ Mindazonáltal az alábbi feltételekkel el tudta fogadni a törvényhozás helyetti rendeleti jogalkotást:

- háború, fegyveres konfliktus, a köztisztviselók általános sztrájkja;

— a parlament nem tud összeülni, illetve összehívása jelentős késedelemmel járna;

- a rendeleti jogalkotást a parlament utólagosan jóváhagyja, amint arra lehetősége van. ${ }^{17}$

Németországban Jellinek a kormány kivételes hatalomgyakorlását szintén azzal a feltétellel tudta elfogadni, amennyiben a parlament utólagosan legitimálja a rendkívüli helyzetben elfogadott intézkedését. Carré de Melberg szerint az alkotmány tól való eltérés illegális,

10 Schmitt, 1992.

$11 \mathrm{Az}$ állam ezekben a helyzetekben lényegében elhagyja az általános rendet, és egy sajátos új rendet tételez, egyfajta alternatív jogrendet hoz létre. Erről lásd bővebben: Kelemen, 2020a, 189-190. 0.

12 Dicey, 1902.

13 Mészáros, 2017, 36-38. o.

14 Kelsen, 2001.

15 Hoerni, 1917.

16 Duguit, 1923.

17 Saint-Bonnet, 2001. 
abban az esetben, amennyiben ez a rendkívüli helyzetre tekintettel megtörténne, az az alkotmány tacitus módosításával lenne egyenértékúu. ${ }^{18}$

Az államelméleti vitákon túl a gyakorlatban a polgári átalakulás eredményeként megalkotott alkotmányokban kellett választ nyújtani a védelmi és biztonsági kihívásokat jelentő különleges helyzetek kezelésére. Ez elsősorban azért jelentett kihívást a korábbi korszakokhoz képest, mert a jogforrási hierarchia érvényesülése, a hatalmi ágak elválasztása és az egymást ellenőrző garanciális funkciója folytán az államszerkezet összetettebbé, az állami müködés és döntéshozatal pedig nehézkesebbé és időigényesebbé vált. A kivételes hatalomgyakorlásra, valamint a rendes múködéstôl eltérő állammúködésre a közjó és a közérdek védelme érdekében lehetőséget biztosító különleges jogrend gyakorlati megvalósulása és alkotmányjogi fogalma ezért a kartális alkotmányok 19. századi elfogadásához kapcsolódik. A hatalmi ágak elkülönítésével, a végrehajtó hatalom joghoz kötésével és ellenőrzésével a kivételes hatalomgyakorlás az alkotmányos rend szerves részévé vált. Ekkor gyökeresedtek meg a hatalomgyakorlás angolszász és kontinentális (német és osztrák) modelljei, amelyek között kell számon tartani a Magyar Királyság területén is érvényesülő kivételes hatalomról szóló 1869-es törvényt. ${ }^{19}$ Hosszú előkészítő munkát követően ezek az előzmények ágyaztak meg az első hazai kivételes hatalmi törvény 1912-es elfogadása előtt is. Az „állami létérdeket” szem előtt tartó szabályozást a garanciális jellege és körültekintő igényessége miatt olyan neves jogtudósok méltatták, mint Angyal Pál, Edvi Illés Károly és Búza László jogászprofesszorok. ${ }^{20}$

A 20. század második felétől kezdődően az alkotmányos rendszerekben a különleges jogrend kihirdetésére az alkotmányban meghatározott feltételek fennállása esetén - az embereket, az államot és az alkotmányos rendet veszélyeztető körülmény elhárítása érdekében nyílik lehetôség akkor, ha az állami múkködés hagyományos rendje és rendes jog eszközei nem bizonyulnak elégségesnek a veszély elhárításához. ${ }^{21}$ Kitapintható, hogy ez az „alkotmányközpontú" felfogás a különleges jogrendre az alkotmányosság részeként tekint, szemben az úgynevezett „államközpontú” felfogással, amely a szuverenitást előtérbe helyezve vallja, hogy a pozitív jog nem korlátozhatja az állami múködés rendkívüli helyzetben való cselekvését. ${ }^{22}$ $\mathrm{Az}$ „alkotmányközpontú” felfogás elfogadásával és térnyerésével a különleges jogrend keretei között megvalósuló kivételes hatalomgyakorlás - hasonlóan az alapjogokhoz vagy a bírói fe-

18 Saint-Bonnet, 2001.

19 Erről részletesen lásd: Kelemen, 2020b, 43-76. o.

20 Részletesen lásd: Kelemen, 2020c, 96-106. o.

21 Többek között Csink Lóránt jut arra a következtetésre, hogy a különleges jogrend bevezetését és az abban meghatározott állami múködést nem a jelenség, vagyis a különleges helyzet, hanem a veszély indokolja (Csink, 2017, 8-9.). Hasonlóan lásd: Chowdhury, 1989.

22 Jakab András és Till Szabolcs különbséget tesz az „alkotmányközpontú” és „államközpontú” felfogás között a hatalomgyakorlás joghoz kötöttsége szempontjából (Trócsányi-Schanda, 2014, 470-471. o.). 
lülvizsgálat intézményéhez - egyfajta alkotmányjogi garanciaként is szolgál a kormányzás során. ${ }^{23}$ Egyszerre jelent szélesebb kormányzási felhatalmazást és alkotmányjogi garanciát. ${ }^{24}$

A nemzeti alkotmányok nem mindegyike ismeri a kivételes hatalomgyakorlást, mindazonáltal az alkotmányos szokásjog alapján számos országban a jogrend részének tekintik. ${ }^{25}$

\section{A különleges jogrend meghatározása és alkalmazhatósága}

A kivételes hatalomgyakorlás és a különleges jogrend bevezetése mindig feltételez valamilyen különleges helyzetet. A különleges helyzet lehet valamilyen erőszakos jelenség, mint például külső és belső fegyveres konfliktus vagy akár kibertámadás; természeti csapás és ipari szerencsétlenség, mint például egy árvíz vagy járvány; valamint gazdasági és társadalmi válság is. A különleges helyzetek sajátossága, hogy bár tipizálhatók, de kimerítő módon semmiképpen sem határozhatók meg, ugyanis az idők során folyamatosan bővülnek újabb és újabb jelenségekkel, míg eközben a korábban súlyos veszéllyel járó jelenségek a tudomány és technológia fejlődésének köszönhetően már nem vagy jóval kevésbé jelentenek fenyegetést. ${ }^{26} \mathrm{~A}$ különleges helyzetek közös jellemzője ugyanakkor, hogy azonnali és gyors állami beavatkozást - válságkezelést - igényelnek. A különleges jogrenddel összefüggő egyik legjelentősebb kérdés ugyanakkor az, hogy milyen különleges helyzet indokolhatja a különleges jogrend bevezetését, illetve ki jogosult erról dönteni.

A különleges helyzet és a különleges jogrend kapcsolatát, illetve a különleges jogrend természetét övezően a hazai jogirodalom számos különböző elméleti felfogást ismer. Az egyik népszerú felfogás kiindulópontját a szabadság és a biztonság dichotómiája jelenti, amely szerint a különleges jogrend a társadalom múködésének az az állapota, amelynél fogva a biztonság súlyos mértékben fenyegetett. Az állam a különleges jogrend keretei között megalkotott speciális szabályok segítségével garantálja a biztonságot, jelentősebb mértékú alapjog-korlátozás az ára, vagyis többet kell áldozni a szabadságból. ${ }^{27} \mathrm{Ez}$ a fenyegetettség jelenik meg abban a meghatározásban, amelynek értelmében kivételes hatalom akkor gyakorolható, ha az „ország rendkívüli helyzetben van külső vagy belső fenyegetettség okán”. ${ }^{28}$ Más felfogások szerint a különleges jogrend bevezetésére az úgynevezett „alkotmányveszélyeztető helyzetek" adnak okot, míg a különleges jogrend olyan szabályok megalkotását teszi lehetôvé,

23 E körben érdemes felidézni Friedrich Koja szavait, aki szerint „a szülkségállapot egy alkotmányos állapot és nem az alkotmánynélküliség állapota" (Koja, 2003, 799. o.).

24 Ezzel összhangban mutat rá Varga Zs. András arra, hogy jelenleg az állami hatalomgyakorlással szemben alkotmányjogi és nemzetközi jogi elvárás, hogy a jogban legyen szabályozott, a hatalomgyakorlás joghoz kötöttsége „mára előíróvá (normatívvá, perspektívvé) vált” (Varga Zs., 2015, 11-12. o.).

25 Svájcban például sikertelen törekvések voltak a kivételes jogrend alkotmányi szintû szabályozására, mindezek ellenére a kivételes hatalomgyakorlást meghatározott esetekben a jogrend részének tekintik (Kley, 2020).

26 Részletesebben lásd: Csink, 2017.

27 Csink, 2017, 8-9. o.

28 Bódi, 2016, 45. o. 
„amelyek egyrészt a cselekvés alkotmányos kötelezettségeit lazítják (hatékonyság), másrészt viszont védelmet is biztosítanak az e lazításokkal való esetleges visszaélésekkel szemben". ${ }^{29}$ Ezt a kiindulópontot veszi alapul az az álláspont, amely szerint a különleges jogrend „alapvetően az állam rendkívüli helyzetekben való múködőképességének, az állami szuverenitás, az alkotmányos rend, az állampolgárok élet- és vagyonbiztonságának fenntartását biztosító jogi szabályozási keret létrehozása volt". ${ }^{30}$ Ehhez képest a funkcionális megközelítés talaján álló álláspontok érdeklődésének terében az rejlik, hogy a különleges jogrend mennyiben támogatja az állam múködését és védelmi erőfeszítéseit. ${ }^{31}$ Ennek megfelelően a különleges jogrendet a válságkezelés eszközének tekinti, „a válságkezelés dinamikus folyamatának egy közjogi döntésekkel meghatározott szakaszát jelenti, amikor a válság normál jogrend keretei között eredményesen már nem kezelhetô". ${ }^{32}$

Ezeket a jogirodalmi álláspontokat alapul véve a különleges jogrend leginkább egyfajta „immunreakcióként" jellemezhetô, amelyben a rendhagyó állami mưködés nyújt orvoslást olyan válságra vagy veszélyre, amelyet a nehézkesebb és időigényesebb hagyományos állami múködés keretei között már nem lehet kezelni. Ennek figyelembevételével a különleges jogrend jellegadó sajátosságai közé tartozik egyfelől az időbeli korlátozottság,,33 másfelől pedig, a védelmi jellegéből fakadóan az, hogy a hagyományos állami múködés mielőbbi visszaállítására törekszik. Ennek megfelelően a különleges jogrend nemcsak rendhagyó állami múködést jelöl, hanem az állam (ön)védelmi eszköztárának utolsó eleme. ${ }^{34}$ A neves jogtudós, Concha Győző a rendkívüli állapotot és a kivételes hatalomgyakorlást természetszerú igénynek, az államiság szükségszerü részének tartotta, szavai szerint a kivételes állapot az állam vagy a társadalom megvédéséhez és a közrend fenntartásához szükséges eszköz. ${ }^{35}$ Olvasatában a kivételes hatalomgyakorlásra a folyamatosan megjelenő fenyegetések elhárítása érdekében a világ valamennyi táján nélkülözhetetlen szükség mutatkozik. Az egyes nemzeti szabályozások csupán abban különböznek, hogy ki jogosult a kivételes hatalomgyakorlás és a különleges jogrend kihirdetésére, és milyen terjedelmú felhatalmazás birtokában járhat el a kivételes hatalmat gyakorló. ${ }^{36}$

Ezek figyelembevétele alapján a különleges jogrend alkalmazásának előfeltételeként és egyben garanciális korlátjaként vehető számba, hogy a leküzdendő veszély vagy válság

29 Jakab-Till, 2014, 466. o.

30 Lakatos, 2014.

31 Kádár Pál véleménye szerint a különleges jogrend lényege, hogy a „normál békeidőszaki múködéshez képest egyes állami szervek vagy személyek kiegészítő jogosítványokat kapnak, míg más személyek vagy szervek jogai korlátozásra kerülnek a válsághelyzet megoldása érdekében” (Kádár, 2014, 6. o.).

32 Keszely, 2017.

33 Ezzel áll összhangban Tomcsányi Móric találó megfogalmazása, amely szerint: „A kivételes hatalom mindig átmeneti jellegú s ennyiben is kivételes. A törvényhozás a rendkívüli viszonyok hatása alatt csak ideiglenesen e szükséghelyzet tartamára és persze a megjelölt alkotmányi határok között engedi át saját rendelkező hatalmának gyakorlását a kormánynak, s a rendkívüli viszonyok megszúntével e kivételes rendeletek érvénye is megszúnik. Ez az átmeneti jelleg is egyik ismertető vonása a kivételes hatalomnak [...]." Idézi: Farkas, 2020a, 329-330. o.

34 Farkas, 2020b, 26-28. o.

35 Concha, 1905, 386. o.

36 Farkas, 2020a, 329-330. o. 
a közösség valamilyen - alkotmányban is kifejezésre jutó - értékét fenyegeti. Ezen túl a fenyegetettség elhárításához állami beavatkozás szükséges, ugyanakkor az állami múködés hagyományos rendje ehhez nem elégséges, vagyis ultima ratióként szolgál a veszély vagy a válság leküzdéséhez. ${ }^{37}$ Végül pedig a különleges jogrend alkalmazásának korlátozottságát kiegészítő további ismérv - mint ahogyan azt a hatalomgyakorlás kivételessége is tükrözi az intézmény átmenetisége, vagyis időleges jellege.

\section{A különleges jogrend igazolhatósága és az abban védett értékek}

Mint ahogyan az előző rész kitért rá, a jogállamokban a különleges jogrend egyik kulcsfontosságú alkotmányjogi kérdése, hogy mely különleges helyzetek igazolhatnak kivételes hatalomgyakorlást. Ebből a szempontból figyelemre méltó a különleges jogrend kétarcúsága. Egyfelől a politikai döntéshozatal és a jogalkotási folyamat koncentrálásán, illetve a jogforrási hierarchia szigorú érvényesítésének részleges feloldásán keresztül az állami múködés hatékonyságát és időszerüségét erősíti, másfelől pedig szélesebb teret nyit bizonyos alapvető jogok korlátozása előtt.

E körben ugyanakkor szükséges hangsúlyozni, hogy míg az előbbi a különleges jogrend bevezetésének oka, addig az utóbbi legfeljebb csak elkerülhetetlen velejárója lehet. Másként fogalmazva: a kivételes hatalomgyakorlás olyan - kimerítő jelleggel előre nem meghatározható vagy felsorolható - válsághelyzetek elhárítását vagy kezelését szolgálja, amelyek az összetett, nehézkes, vitákkal terhes és időigényes hagyományos állami múködés rendjében már egyáltalán nem vagy nem kellően orvosolhatók, ${ }^{38}$ és annál hatékonyabb védelmi intézkedéseket, azonnali döntéshozatalt, illetve gyorsabb állami beavatkozást igényelnek. ${ }^{39}$ Ez a gyors állami múködés pedig feltételezi a hatalommegosztás és a jogforrási hierarchia hatalomkorlátozásának lazítását. Ennek megfelelően találó az a hasonlat, amely a különleges jogrendet - utalva annak ultima ratio jellegére - a jogállam vagy az alkotmányosság jogos védelmi helyzeteként aposztrofálja. ${ }^{40} \mathrm{~A}$ kivételes hatalomgyakorlásra és a különleges jogrend bevezetésére ugyanis az államiság, az alkotmányos rend vagy a társadalom fennmaradását veszélyeztető, súlyos fenyegetés teremthet lehetőséget. Ennek során a hagyományos állami múködés a fenyegetés mértékéhez igazodóan és annak eredményes elhárításáig felfüggeszthető. Emellett azonban a kivételes hatalomgyakorlás - a jogos védelem intézményéhez hasonlóan - nem jelenthet egy jogon (vagy alkotmányon) kívüli állapotot, hanem maga is

37 Farkas, 2020a, 323, 339. o. Hasonló elvet fogad el az Emberi Jogok Európai Bíróságának gyakorlata is, erről lásd: Mészáros, 2016, 208. o.

38 Ennek megfelelően Magyary Zoltán álláspontja szerint a parlamentáris rendszer csak a békés viszonyok között alkalmas kormányzásra, míg fenyegető helyzet idején hatékonyabb döntéshozatalra kell törekedni (Magyary, 1942, 206. o.).

39 A válság és a különleges jogrendi időszak kapcsolatáról részletesen lásd: Keszely, 2017.

40 Erről lásd: Farkas, 2020a, 338. o. 
korlátos, ugyanis bizonyos alkotmányjogi garanciák, mint például a célhoz kötöttség vagy az alkotmánybírósági kontroll ezen idők során továbbra is érvényesek maradnak.

Erre figyelemmel bizonyos alapvető jogok korlátozása a különleges jogrendnek önmagában nem lehet célja, hanem a fenyegetés elhárításának csak szükséges eszköze és ezáltal velejárója. A különleges jogrend konstituálásának kiváltó oka ugyanis nem az alapvető jogok korlátozása, hanem olyan különleges helyzet, amely gyors és hatékony állami beavatkozást igényel. Sót, a jogos védelmi helyzet analógiája alapján, amennyiben a különleges jogrend bevezetésére okot adó fenyegetés az alkotmányt vagy az abban kifejezésre jutó értéket veszélyezteti, úgy a kivételes hatalomgyakorlás közvetlen és közvetett jogot védő funkcióval rendelkezik. A különleges jogrend közvetlen jogot védő funkciója abban nyilvánul meg, hogy a közösség számára becsesebb vagy korlátozást nem engedő jogok javára és erősebb védelme érdekében más jogok korlátozásának tiszteletben tartását követeli meg; bizonyos, alkotmányban elismert jogok védelmét előrébb sorolja. Így például a járvány idején - a vírus gyors terjedésének lassításán vagy megakadályozásán keresztül - az emberi élet és egészség fokozottabb védelme érdekében rendeli el a gyülekezés jogának, a vallás vagy a mozgás szabadságának korlátozásait. Ugyanakkor a kivételes hatalomgyakorlás és a különleges jogrend emellett közvetett módon is rendelkezik jogot védő funkcióval, amennyiben a kivételes közhatalmi intézkedéseknek a fenyegetés elhárítására és a hagyományos alkotmányos rend - beleértve az abban elismert alapvetô jogok és szabadságok teljes érvényesülése - mihamarabbi visszaállítására kell irányulniuk. Másként fogalmazva, a különleges jogrend átmenetisége az alkotmányos jogok teljes spektrumának érvényesülését szolgálja.

Látható tehát, hogy az alkotmány részeként szabályozott különleges jogrendnek az alkotmányos rendszerekben nélkülözhetetlen védelmi szerepköre van. Az államiságot, az alkotmányos rendet és a társadalmat veszélyeztető fenyegetések elhárításával ugyanis végső soron az alkotmányban kifejezett értékek megóvására irányul. Ez a szükségszerú értékvédő funkciója jelenti a kivételes hatalomgyakorlás és a különleges jogrend legfontosabb jelenkori igazolását.

\section{Végső következtetések}

A tanulmány felvázolta a kivételes hatalomgyakorlás és a különleges jogrend történelmi gyökereit, eszmetörténeti alapvonalait, valamint újkori megjelenését, funkcióját és igazolhatóságát. Ez utóbbi körben érdemes felidézni Deák Ferencet, aki egykoron úgy fogalmazott, hogy „az ostromállapot szomorú kényszerúség; Isten mentse a hazát, hogy rá szükség legyen; de az ostromállapotnál még súlyosabb állapot az, ha nincs törvény, mely azt szabályozza, és ha az ostromállapoti törvény helyett önkény lép a sorompóba". ${ }^{41}$ E veretes szavakkal összhangban a tanulmány egyik fontos elméleti következtetése, hogy a régmúltra visszatekintő és a jelenkori

41 Idézet Deák Ferencnek a katonai bíróságok hatásköréről szóló 1868. évi vitában december 6-án elhangzott felszólalásából. Lásd: Greguss, 1868, 380. o. Idézi: Farkas, 2020a, 328-329. o. 
alkotmányos kultúrákban egyetemesen érvényesülő különleges jogrend olyan alkotmányjogi vívmány, amely garanciális jelentőségú a nemzeti alkotmányos értékek megóvásához.

\section{Irodalomjegyzék}

BóDI, S. (2016) 'A civilizációk összecsapása? A tömeges bevándorlás által életre hívott migrációs válsághelyzet elemzése és a különleges jogrend', Hadtudomány, 26(1-2), 41-51. o.

CHOwdhurY, S. R. (1989) Rule of Law in a State of Emergency: The Paris Minimum Standards of Human Rights Norms in a State of Emergency. 1. kiadás. London: Pinter Publishers

ConchA, Gy. (1905) Politika II. Közigazgatástan. 1. kiadás. Budapest: Grill Károly Könyvkiadóvállalata

Csınk, L. (2017) 'Mikor legyen a jogrend különleges?', Iustum Aequum Salutare, 13(4), 7-16. o.

DiCEY, A. V. (1902) Bevezetés az angol alkotmányjogba. 1. kiadás. Budapest: Magyar Tudományos Akadémia

Duguit, L. (1923) Traité de droit constitutionnel. 1. kiadás. Paris: Tome

FARKAS, Á (2020b) 'Bevezetés a különleges jogrend témakörének fontosabb alapkérdéseibe' in Farkas, Á., Kelemen, R. (szerk.) Szkülla és Kharübdisz között - Tanulmányok a különleges jogrend elméleti és pragmatikus kérdéseiról, valamint nemzetközi megoldásairól. 1. kiadás. Budapest: Magyar Katonai Jogi és Hadijogi Társaság

FARKAS, Á. (2020a) 'Gondolatok a különleges jogrend természetéről a modern államiságban' in Farkas, Á., Kelemen, R. (szerk.) Szkülla és Kharübdisz között - Tanulmányok a különleges jogrend elméleti és pragmatikus kérdéseiről, valamint nemzetközi megoldásairól. 1. kiadás. Budapest: Magyar Katonai Jogi és Hadijogi Társaság

FöLDI, A., HAMzA, G. (1996) A Római Jog története és institúciói. 1. kiadás. Budapest: Nemzeti Tankönyvkiadó

GREGUSS, Á. (szerk.) (1868) Az 1865-dik évi deczember 10-dikére hirdetett Országgyülés képviselöházának naplója-tizenegyedik kötet. Pest: Athenaeum

HoERnI, R. (1917) De l'état de névessité en droit public fédérale suisse: étude juridique sur les pleins pouvoirs. 1. kiadás. Geneve: Société Générale d'Imprimerie

HORKAY HÖRCHER, F. (2020) Politikafilozófia járványidején [Online]. Elérhető: https://orszagut. com/nyomtatott_cikk/politikafilozofia-jarvany-idejen (Letöltve: 2020. december 15.)

JAKAB, A., Till, Sz. (2014) 'A különleges jogrend' in Trócsányi, L., Schanda, B. (szerk.) Bevezetés az alkotmányjogba. Az Alaptörvény és Magyarország alkotmányos intézményei. 1. kiadás. Budapest: HVG-ORAC

KÁDÁR, P. (2014) 'A kivételes hatalomtól a különleges jogrend idején bevezethető intézkedésekig', Katonai Jogiés Hadijogi Szemle, 2(1), 5-46. o.

Kelemen, R. (2020a) 'A különleges jogrend, mint jogrendi fogalom jellemzői' in Farkas, Á., Kelemen, R. (szerk.) Szkülla és Kharübdisz között-Tanulmányok a különleges jogrend elméleti 
és pragmatikus kérdéseiról, valamint nemzetközi megoldásairól. 1. kiadás. Budapest: Magyar Katonai Jogi és Hadijogi Társaság

KELEMEN, R. (2020b) 'A különleges jogrend történeti modelljeinek kialakulása és fejlődése a 20. század második évtizedének végéig' in Farkas, Á., Kelemen, R. (szerk.) Szkülla és Kharübdisz között - Tanulmányok a különleges jogrend elméleti és pragmatikus kérdéseirōl, valamint nemzetközi megoldásairól. 1. kiadás. Budapest: Magyar Katonai Jogi és Hadijogi Társaság

KELEMEN, R. (2020c) 'Az 1912-es kivételes hatalmi törvény születése és rendszere' in Farkas, Á., Kelemen, R. (szerk.) Szkülla és Kharübdisz között - Tanulmányok a különleges jogrend elméleti és pragmatikus kérdéseirōl, valamint nemzetközi megoldásairól. 1. kiadás. Budapest: Magyar Katonai Jogi és Hadijogi Társaság

Kelsen, H. (2001) Tiszta jogtan. 1. kiadás. Budapest: Rejtjel

KeszelY, L. (2017) 'A különleges jogrend a védelmi igazgatás gyakorlati jogalkalmazói szemszögből', Iustum Aequum Salutare, 13(4), 77-89. o.

KLEY, A. (2020) Pleins pouvoirs [Online]. Elérhetô: https://hls-dhs-dss.ch/fr/articles/010094/ 2020-10-06/ (Letöltve: 2020. december 15.)

KojA, F. (2003) 'Állami szükségállapot és a szükségállapotra vonatkozó jog' in Takács, P. (szerk.): Államtan - Írások a XX. századi általános államtudomány köréből. 1. kiadás. Budapest: Szent István Társulat

LAKaTos, L. (2014) 'A különleges jogrend és a honvédelem szabályzása', MTA Law Working Papers, 2014/49. [Online]. Elérhető: https://jog.tk.hu/mtalwp/a-kulonleges-jogrend-es-ahonvedelem-szabalyzasa (Letöltve: 2020. december 8.)

LOCKE, J. (1999) Másodikértekezés a polgári kormányzatról. 1. kiadás. Budapest: Polis

Magyary, Z. (1942) Magyar közigazgatás. 1. kiadás. Budapest: Királyi Magyar Egyetemi Nyomda

MÉszÁros, G. (2016) 'Alapjogi bíráskodás különleges helyzetekben: a strasbourgi bíróság releváns esetjoga', Pro Futuro, 6(2), 200-218. o.

MÉszÁros, G. (2017) 'Uralhatja-e a jog a kivételes állapotot? A kivételes állapot elmélete a két rivális álláspont alapján', Iustum Aequum Salutare, 13(4), 31-41. o.

SAINT-Bonnet, F. (2001) L'état d'exception. 1. kiadás. Paris: Presses Universitaires de France SCHмIтT, C. (1992) A politikai teológia. 1. kiadás. Budapest: ELTE ÁJK

TrócsánYi, L. (2014) 'Alaptanok' in Trócsányi, L., Schanda, B. (szerk.) Bevezetés az alkotmányjogba. Az Alaptörvény és Magyarország alkotmányos intézményei. 1. kiadás. Budapest: HVG-ORAC

UngVÁRI, Á., HoJnYÁk, D. (2020) 'Az Európai Unió egyes tagállamainak koronavírusjárványra adott válasza, különös tekintettel a vizsgált államok által bevezetett különleges jogrendi szabályozásra', Miskolci Jogi Szemle, 15(1), 122-138. o.

VARGA Zs., A. (2015) Eszménybőllbálvány? Ajoguralom dogmatikája. 1. kiadás. Budapest: Századvég 


\section{A különleges jogrend nemzetközi jogi dimenziói az emberi jogok derogációja tükrében}

\section{BÉRES NÓRA}

\section{Bevezetés}

Noha a különleges jogrendre vonatkozó szabályok főként az államok belső jogában lelhetők fel, valamint az is a nemzeti jogalkotó által választott alkotmányjogi megoldások függvénye, hogy egy adott állam a különleges jogrend melyik modelljét alkalmazza, ${ }^{1}$ az ilyenkor elsődleges kérdésként felmerülő alapjog-korlátozás a nemzetközi emberi jogi szerződések alkalmazásával, illetve azok hatályának felfüggesztésével szorosan összefügg.

Így jelen fejezet témájának lehatárolása érdekében már rögtön e ponton szükséges bevezetni egy fogalmi különbségtételt, ez pedig nem más, mint az emberi jogok korlátozása és az emberi jogok alkalmazásának felfüggesztése közötti disztinkció. Általában véve elmondható, hogy az emberi jogokat tartalmazó nemzetközi szerződések kettős terminológiát alkalmaznak, és meghatározzák, hogy békeidôben milyen feltételek mellett lehetséges korlátozások alkalmazása. A korlátozások lehetőségének elsődleges oka az, hogy a legtöbb emberi

I Így például míg a kontinentális jogcsaládba tartozó európai államok a dichotóm modellt alkalmazzák, addig az Amerikai Egyesült Államok a monista modellt követi (bővebben lásd az Egyesült Államokról szóló 26. fejezetet).

Dr. Béres Nóra, PhD, LLM

nora.beres@mfi.gov.hu

kutató (Mádl Ferenc Összehasonlító Jogi Intézet)

tanársegéd (Miskolci Egyetem Állam- és Jogtudományi Kar, Európai és Nemzetközi Jogi Intézet)

Béres, N. (2021) 'A különleges jogrend nemzetközi jogi dimenziói az emberi jogok derogációja tükrében' in Nagy, Z., Horváth, A. (szerk.) A különleges jogrend és nemzeti szabályozási modelljei, 37-51. o. Budapest: Mádl Ferenc Összehasonlító Jogi Intézet.

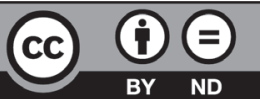


jog nem abszolút, hanem sokkal inkább az egyén és a közösség érdeke közötti érzékeny balansz megtestesítője. ${ }^{2}$ Ezzel párhuzamosan ugyanakkor az is jellemző, hogy e szerződések rögzítik a jogok nem garantálásának, azaz az eltérés jogának, a derogációnak a lehetőségét is. ${ }^{3} \mathrm{Az}$ alapjog-korlátozás és a derogáció fogalma közé tehát nem tehetünk egyenlőségjelet: az eltérés joga azt jelenti, hogy az e szerződésekben részes államok számára szigorúan meghatározott anyagi jogi és eljárásjogi feltételek betartása mellett lehetőségük nyílik rá, hogy különleges jogrend idején bizonyos nemzetközi emberi jogi kötelezettségvállalásaik alól ideiglenesen mentesüljenek. Ennek pedig az a legfontosabb gyakorlati következménye, hogy az eltérés jogával élő államot a derogációval érintett szerződéses cikkek megsértéséért később nem lehet felelősségre vonni. ${ }^{4} \mathrm{~A}$ derogációval kapcsolatban fontos továbbá megjegyezni, hogy az abszolút jogok ${ }^{5}$ alkalmazásától különleges jogrend idején sem lehet eltérni, azaz az ilyen jogok nem derogálhatók.

E fejezet konkrét tárgyát két derogációs klauzula vizsgálata képezi, amelyek a Polgári és Politikai Jogok Nemzetközi Egyezségokmányának ${ }^{6}$ (a továbbiakban: PPJNE vagy Egyezségokmány) 4. cikke, ${ }^{7}$ valamint az Emberi Jogok Európai Egyezményének ${ }^{8}$ (a továbbiakban: EJEE vagy Egyezmény) 15. cikke.9 Utóbbiak kiválasztásának egyértelmú oka az volt, hogy

2 Daes, 1983, 183. o.

3 Gárdos-Orosz, 2018, 29-30. o.

$4 \mathrm{Az}$ persze már más kérdés, hogy ha az eltérés jogát biztosító szerződéses cikket sérti meg a részes állam, például úgy, hogy a különleges jogrend kihirdetésének feltételei nem állnak fenn. E kérdésről részletesebben lásd késóbb e fejezetet.

5 Ilyenek például az élethez való jog, a kínzás tilalma, a rabszolgaság és szolgaság tilalma vagy a visszaható hatály alkalmazása a büntetőjogban.

6 1976. évi 8. törvényerejü rendelet az Egyesült Nemzetek Közgyülése XXI. ülésszakán, 1966. december 16-án elfogadott Polgári és Politikai Jogok Nemzetközi Egyezségokmánya kihirdetéséről.

7 PPJNE 4. cikk (1) A nemzet létét fenyegető és hivatalosan kihirdetett szükségállapot idején az Egyezségokmányban részes államok az adott helyzet által szigorúan megkövetelt mértékben tehetnek olyan intézkedéseket, amelyek eltérnek az Egyezségokmányban vállalt kötelezettségeiktől, feltéve, hogy az ilyen intézkedések nem állnak ellentétben egyéb nemzetközi jogi kötelezettségeikkel, és nem jelentenek kizárólag faj, szín, nem, nyelv, vallás vagy társadalmi származás alapján történő megkülönböztetést.

(2) E rendelkezés alapján nem lehet eltérni a 6., 7., 8. (1. és 2. bekezdés), 11., 15., 16. és 18. cikktől.

(3) Az Egyezségokmányban részes minden állam, amely él az eltérés jogával, az Egyesült Nemzetek fótitkára útján haladéktalanul tájékoztatni köteles az Egyezségokmányban részes többi államot azokról az intézkedésekről, amelyektől eltért, és azokról az okokról, amelyek erre késztették. További tájékoztatást kell adni ugyanezen az úton arról az időpontról, amikor az állam az ilyen eltéréseknek véget vet.

8 1993. évi XXXI. törvény az emberi jogok és az alapvető szabadságok védelméről szóló, Rómában, 1950. november 4-én kelt Egyezmény és az ahhoz tartozó nyolc kiegészítő jegyzőkönyv kihirdetéséről.

9 EJEE 15. cikk (1) Háború vagy a nemzet létét fenyegető más rendkívüli állapot esetén bármely Magas Szerződő Fél a jelen Egyezményben meghatározott kötelezettségeitől eltérő intézkedéseket tehet a helyzet szükségessége által feltétlenül megkívánt mértékben, feltéve, hogy az ilyen intézkedések nem ellentétesek egyéb nemzetközi jogi kötelezettségeivel.

(2) E rendelkezés alapján nem lehet eltérni a 2. cikk rendelkezéseitől, kivéve a jogszerú háborús cselekmények következtében okozott haláleseteket, vagy a 3. cikk, 4. cikk (1. bekezdés), valamint a 7. cikk rendelkezéseitől. (3) Az eltérés jogával élő Magas Szerződő Fél az Európa Tanács főtitkárának teljes körű tájékoztatást ad az általa tett intézkedésekről és azok okairól. Ugyancsak tájékoztatja az Európa Tanács fótitkárát, amikor az ilyen intézkedések hatályukat vesztették, és az Egyezmény rendelkezéseit ismét teljes mértékben végrehajtják. 
Magyarország - és az e könyvben bemutatott legtöbb ország - mindkét szerződésnek részes állama, így az ezekben foglalt rendelkezések hazánkat - és persze a többi országot is kötik..$^{10}$

Továbbá megjegyzendő, hogy napjainkban a derogációs klauzulák alkalmazása a koronavírus-járvánnyal kapcsolatban a világ számos országában bevezetett különleges jogrend miatt mind a PPJNE, mind az EJEE vonatkozásában ${ }^{11}$ különös jelentőséggel bír, tekintve, hogy az államok is a szokásosnál jóval gyakrabban kívántak az eltérés jogával élni. Az Európa Tanács nyilvántartása szerint például idáig tíz állam (Albánia, Észak-Macedónia, Észtország, Grúzia, Lettország, Moldova, Örményország, Románia, San Marino és Szerbia) nyújtott be az EJEE 15. cikk (3) bekezdése szerinti nyilatkozatot az Európa Tanács fốtitkárához. ${ }^{12}$ Mindemellett persze megjegyzendő, hogy az EJEE 15. cikkére való hivatkozás előtt, illetve a notifikáció elmaradása esetén az alapjogok korlátozása a szükségesség/arányosság tesztje alapján is alátámasztható a nem abszolút jogok esetén. ${ }^{13}$

\section{A Polgári és Politikai Jogok Nemzetközi Egyezségokmányának 4. cikke}

A PPJNE egyfajta primus inter pares szerepet tölt be az univerzális nemzetközi emberi jogi szerződések között. Részes államainak száma 2020. december 15-én 173, ${ }^{14}$ amely a nemzetközi közösség egészét tekintve tekintélyes számnak mondható. Ebből is adódik, hogy az Egyezségokmányban foglalt kötelezettségek univerzális természetúek, azon kevés állam számára pedig, amelyek nem részes felei a PPJNE-nek, a szokásjog és a múvelt nemzetek által elismert jogelvek bizonyítékaként szolgálnak.

10 A PPJNE és az EJEE mellett az Emberi Jogok Amerikai Egyezménye (27. cikk) és az Európai Szociális Charta (30. cikk) tartalmaz még derogációs klauzulát. Lásd: American Convention on Human Rights, opened for signature Nov. 22, 1969, 1144 U.N.T.S. 123, entered into force July 18, 1978; 1999. évi C. törvény az Európai Szociális Charta kihirdetéséről.

11 Az eltérés jogával élő államok naprakész listái megtalálhatók a United Nations Treaty Collections, valamint a Treaty Office of the Council of Europe honlapján: https://treaties.un.org/Pages/ViewDetails. aspx?chapter=4\&clang=_en\&mtdsg_no=IV-4\&src=IND; www.coe.int/en/web/conventions/full-list/-/conventions/webContent/62111354 (Letöltve: 2020 . december 15.).

12 Lásd bővebben: Istrefi, 2020.

13 Till, 2020, 41-52. o. European Court of Human Rights, Guide on Article 15 of the European Convention on Human Rights, Derogation in Time of Emergency. Elérhető: www.echr.coe.int/Documents/Guide_Art_15_ENG.pdf (Letöltve: 2020 . december 15.).

14 United Nations Treaty Collections, International Covenant on Civil and Political Rights. Elérhető: https:// treaties.un.org/Pages/ViewDetails.aspx?src=TREATY\&mtdsg_no=IV-4\&chapter=4\&clang=_en (Letöltve: 2020. december 15.). 
A PPJNE kontrollmechanizmusát ${ }^{15}$ háromféle eljárás keretében látja el az Emberi Jogok Bizottsága (a továbbiakban: Bizottság). ${ }^{16} \mathrm{Az}$ első a részes államok periodikus írásbeli jelentéseinek vizsgálata az Egyezségokmány átültetéséről, amelyek keretében a Bizottság egyfajta konstruktív párbeszédet folytat az állammal, és erről jelentést küld az ENSZ Közgyúlésének. Ez a Bizottság egyik legfontosabb feladata, azaz a tagállamok belső jogának monitoringja, így többek között a 4. cikk megfelelő átültetésének vizsgálata is. ${ }^{17} \mathrm{Az}$ államok a Bizottságnak megküldött periodikus jelentésekben kötelesek tájékoztatást nyújtani az esetlegesen kihirdetett különleges jogrend idején történő jogalkotásról és jogalkalmazásról, ami eredményében egyfajta összehasonlító analízis kialakulásához vezet. Ilyen vizsgálatra példaként a Bizottság egyik 2001. évi jelentése hozható, amelyben a Bizottság aggodalmát fejezte ki Horvátország alkotmányának különleges jogrendre vonatkozó 17. cikke miatt, mert az nem felelt meg az Egyezségokmány 4. cikkében foglaltaknak: a különleges jogrend kihirdetése nem csak a „nemzet létét fenyegető szükségállapot idején” és az Egyezségokmány által meghatározott „szigorúan megkövetelt mértékben” történhetett, továbbá Horvátország alkotmánya az abszolút jogok között a PPJNE 8. cikk (1)-(2) bekezdését, 11. cikkét és 16. cikkét nem szerepeltette. ${ }^{18}$ Ugyanabban az évben a Bizottság ${ }^{19}$ a guetamalai helyzet miatt is aggodalmának adott hangot, mivel az ország alkotmányos szabályai a PPJNE-ben foglalt kötelezettségek hatálybaléptetésének gátat szabtak, tekintve, hogy a személyi elven alapuló joghatóság-gyakorlást csak a hadsereg tagjai felett alkalmazták, illetőleg nem ismerték el az őslakosok egyes jogait.

A második eljárástípus az egyéni panasz kivizsgálása abban az esetben, ha az állam ratifikálta a PPJNE Első Kiegészítő Jegyzőkönyvét is ${ }^{20}$ - ilyenkor az eljárás nem kötelező állásfoglalással zárul. A kontrollmechanizmus harmadik típusú eljárása az állam kontra állam panaszok kivizsgálása akkor, ha az állam a PPJNE 41. cikke ${ }^{21}$ szerinti nyilatkozattal ehhez külön hozzájárult, ám mivel a Bizottság a PPJNE 4. cikkének értelmezésével az első kettő eljárási formában foglalkozott, a harmadik eljárástípust a továbbiakban nem vizsgáljuk.

15 Lamm, 2018, 225-231. o.; Kovács, 2016, 373. o.; Joseph-Castan, 2013, 622-633. o.

16 A magyar nyelvû szakirodalom a Human Rights Committee-t néhol Emberi Jogi Bizottságnak, néhol Emberi Jogok Bizottságának fordítja. E fejezetben a PPJNE 28. cikkét alapul véve az Emberi Jogok Bizottsága terminológiát alkalmazzuk. Lásd még: Kovács, 2016, 373. 0.

17 UN Doc. A/46/40, \$\$ 56-58, 99.

18 UN Doc. A/56/40, Vol. I, \$80(9).

19 UN Doc. A/56/40, Vol. I, \$ 85(10)-(11).

$20 \mathrm{Az}$ Első Kiegészítő jegyzőkönyvnek 2020. december 15-én 116 részes állama van. Lásd: uo.

21 PPJNE 41. cikk (1) Az Egyezségokmányban részes bármelyik állam e cikk alapján bármikor kijelentheti, hogy elismeri a Bizottság arra vonatkozó illetékességét, hogy az átvegyen és megvizsgáljon olyan bejelentéseket, amelyekben valamely részes állam azt állítja, hogy egy másik részes állam nem teljesíti az Egyezségokmányban foglalt kötelezettségeit. Az ennek a cikknek az alapján történő bejelentéseket csak az esetben lehet elfogadni és megtárgyalni, ha azok olyan részes államtól származnak, amely kijelentette, hogy saját magára nézve elismeri a Bizottság illetékességét. A Bizottság nem vesz át olyan bejelentést, amelyben olyan részes állam érdekelt, amely nem tett ilyen kijelentést. 
A 4. cikk a PPJNE kulcsfontosságú rendelkezése, amelynek tárgyi hatálya minden bizonnyal az emberi jogokat leginkább kihívás elé állító helyzetekre terjed ki. ${ }^{22} \mathrm{E}$ cikkel kapcsolatban elsőként tehát azt érdemes tisztáznunk, hogy pontosan milyen esetkörökre vonatkozik. A PPJNE úgy fogalmaz, hogy a nemzet létét fenyegetô szükségállapot ${ }^{23}$ a 4 . cikk alkalmazásának szükségszerú előfeltétele. Jóllehet a Bizottság a szükséghelyzet egzakt definícióját nem alkotta meg, annyit leszögezett, hogy „nem minden zavargás vagy katasztrófa minősül a nemzet létét fenyegető szükségállapotnak a 4. cikk (1) bekezdés alapján”. ${ }^{24}$ Továbbá példálózó jellegû felsorolást is olvashatunk a 4. cikk 2001. évi általános kommentárjában, amely szerint a nemzetközi és a nem nemzetközi fegyveres konfliktusok, a természeti katasztrófák, a tömeges és erőszakos tüntetések vagy a súlyos ipari katasztrófák ilyennek minősülhetnek. ${ }^{25}$ Így például 1989-ben Kanada pusztító erdőtüzek miatt hivatkozott az Egyezségokmányban definiált nemzet létét fenyegető szükségállapotra, ${ }^{26}$ míg Spanyolország terrorveszéllyel indokolva. ${ }^{27} \mathrm{~A}$ háború, amely értelemszerủen tartalmilag szintén beletartozik a nemzet létét fenyegető szükségállapot kategóriájába, az EJEE 15. cikkétől eltérően nincs önállóan nevesítve a PPJNE 4. cikke alatt. E terminológiát per se ugyanis az Egyezségokmány szándékosan kerüli, minthogy az ENSZ felállításának egyik eredendő célja a béke fenntartása és a háborúk megelőzése volt, s emiatt jobbnak látták az alapító tagállamok, hogy a háború kifejezést az ENSZ-dokumentumokban még az említés szintjéról is számúzik. ${ }^{28} \mathrm{~A}$ háborútól eltérően a gazdasági válság önmagában nem szolgáltathat okot a nemzet létét fenyegető szükségállapotra, ám következményei már megállhatják a helyüket. Erre jó példa Ecuador, ahol 2001-ben az országot sújtó gazdasági válság következtében kialakult belsô zavargások vezettek egy hétig tartó különleges jogrend bevezetéséhez. ${ }^{29}$

Továbbá a 4. cikk (1) bekezdése alapján az is a szükségállapot fennállásának követelménye, hogy ez a helyzet a nemzet létét veszélyeztesse, amely kitétel egyértelmúen a részes államok hatalommal való visszaélésének kiiktatását célozza meg. E ponton érdekességként megjegyzendő, hogy az EJEE 15. cikke szó szerint ugyanezt a terminológiát alkalmazza, amelynek értelmezésére az Emberi Jogok Európai Bíróságának (a továbbiakban: EJEB vagy Bíróság) a Lawless kontra Irország ügyben hozott ítéletét tekinthetjük irányadónak. Eszerint

22 Nowak, 2005, 72-93. o.

23 Itt kívánjuk megjegyezni, hogy a PPJNE 4. cikkének hiteles magyar nyelvú fordításában a public emergency kifejezés szükségállapotként szerepel, ezzel szemben az EJEE 15. cikkének szintén hiteles magyar nyelvú fordításában a rendkívüli állapotot nevesíti. Lásd az Egyesült Nemzetek Közgyúlése XXI. ülésszakán, 1966. december 16-án elfogadott Polgári és Politikai Jogok Nemzetközi Egyezségokmánya kihirdetéséről szóló 1976. évi 8. törvényerejû́ rendeletet, valamint az emberi jogok és az alapvető szabadságok védelméről szóló, Rómában, 1950. november 4-én kelt Egyezmény és az ahhoz tartozó nyolc kiegészítő jegyzőkönyv kihirdetéséről szóló 1993. évi XXXI. törvényt.

24 UN Doc. A/56/40, Vol. I, 202, \$3.

25 UN Doc. A/56/40, Vol. I, 202, \$3, 5.

26 UN Doc. A/46/40, \$59.

27 UN Doc. A/46/40, \$150-152.

28 UN Doc. A/2929, \$ 39.

29 UN Doc. A/56/40, Vol. I, \$ 33. 
a nemzet létét veszélyeztető szükségállapot olyan, „az egész lakosságot érintő krízishelyzet vagy szükségállapot, mely az államalkotó közösség szervezett életét veszélyezteti”. ${ }^{30} \mathrm{~A}$ szervezett élet veszélyeztetése mind a lakosság, mind a területi integritás, mind pedig az államszervek kitettségében megnyilvánulhat. Az elsőre példaként hozható fel, hogy 2001-ben Guatemala azért folyamodott derogációhoz, mert 27 különösen veszélyesnek nyilvánított fogvatartott megszökött egy büntetés-végrehajtási intézetből, akiknek a bírósági tárgyalása során tanúként sok embert hallgattak ki, és az ő életüket féltve a nemzet létét veszélyeztető szükségállapot kihirdetése mellett döntöttek. ${ }^{31}$ Ami a területi integritást illeti, szintén 2001-ben Szudán „az egyes régiókban uralkodó kivételes körülményekre” hivatkozva hirdetett különleges jogrendet, mivel a humanitárius katasztrófába torkolló etnikai ellenségeskedések $^{32}$ az ország stabilitását és biztonságát veszélyeztették. ${ }^{33}$

A belső jogi terminológia ugyanakkor nem lényeges a 4. cikk (1) bekezdés alkalmazása szempontjából, azaz nem szükséges, hogy a különleges jogrend szükségállapotként kerüljön kihirdetésre. A PPJNE 4. cikke szerint megállja a helyét az is, ha ostromállapotot (Argentína, Bolívia, Kolumbia), ${ }^{34}$ riasztást (Spanyolország), ${ }^{35}$ gazdasági szükségállapotot (Nicaragua), ${ }^{36}$ hadiállapotot (Finnország) ${ }^{37}$ vagy nemzeti szükségállapotot (Madagaszkár) ${ }^{38}$ hirdetnek ki, a lényeg sokkal inkább a tartalomban rejlik: az elnevezés helyett lényegesebb, hogy a derogáció kivételes és ideiglenes természetû legyen, ${ }^{39}$ tehát az, hogy amint a nemzet léte már nincs veszélyben, haladéktalanul vissza kell térni a „békebeli” szabályozáshoz.

Az Egyezségokmányban biztosított eltérés jogának az is előfeltétele, hogy a szükségállapotot hivatalosan is ki kell hirdetni. E kritérium egyértelmúen a törvényesség és jogállamiság elveinek erősítésére hivatott azokban az időkben, amikor arra éppen a leginkább szükség van. A kihirdetés az átláthatóság elsődleges eszköze, az önkényes derogáció és a de facto különleges jogrend garanciális ellensúlya. Bár szintén az EJEB esetjogából való merítésről van szó, anélkül, hogy előre kívánnánk szaladni, a Branningan \& MacBride kontra Egyesült Királyság ${ }^{40}$ ügyet már e ponton is érdemes megemlíteni. Az eset tényállása szerint a panaszosok beadványukban azt sérelmezték, hogy az Egyesült Királyság soha nem hirdetett ki hivatalosan szükségállapotot az észak-írországi terrorveszéllyel összefüggésben, amivel szemben az alperes állam azzal védekezett, hogy a belügyminiszter a képviselőházban formálisan

30 Lawless v. Ireland, ECtHR, (Ser. A) No. 3 (1961), \$ 28.

31 UN Doc. A/56/40, Vol. I, \$34.

32 Lásd bővebben: Béres, 2020, 59-65. o.

33 UN Doc. A/57/40, Vol. I, \$ 32 .

34 UN Doc. A/45/40, Vol. I, \$ 219; UN Doc. A/57/40, Vol. I, \$34 (Argentína); UN Doc. A/52/40, Vol. I, \$204 (Bolívia);

UN Doc. CCPR/C/SR.222, \$3 (Kolumbia).

35 UN Doc. CCPR/C/SR.142, \$5.

36 UN Doc. CCPR/C/SR.442, \$7.

37 UN Doc. CCPR/C/SR.170, \$84.

38 UN Doc. CCPR/C/SR.83, \$27; UN Doc. CCPR/C/SR.84, \$11.

39 UN Doc. A/56/40, \$2.

40 Branningan \& MacBride v. United Kingdom, ECtHR, (Ser. A) No. 539 (1993), § 17. 
bejelentette a különleges jogrendet. A Bíróság ezen érvelésnek helyt adott, a panaszosok beadványát pedig elutasította, mert a belügyminiszter parlamentben tett szóbeli nyilatkozatát elég hivatalosnak és nyilvánosnak találta, az EJEE 15. cikkében foglalt derogáció jogszerüségéhez szükséges mértékủnek..$^{41}$ Azt sem az EJEE, sem a PPJNE nem határozza meg, hogy a hivatalos kihirdetésre melyik állami szervnek van hatásköre. Ez utóbbi a gyakorlatban az állam alkotmányos berendezkedésének függvénye. Mindazonáltal kétséges lehet, hogy erre egyetlen személynek, például az uralkodónak, az elnöknek, a miniszterelnöknek vagy a haderő fôparancsnokának juttatott hatáskör elegendő garanciát nyújt-e. ${ }^{42}$

Az Egyezségokmány 28. cikk (1) bekezdése által felállított Bizottság a 4. cikkel az Első Kiegészítő Jegyzőkönyv által biztosított egyéni panaszeljárás keretében foglalkozott a legtöbbet, például Uruguay kapcsán az 1970-es és az 1980-as években. Így például a Ramirez kontra Uruguay ${ }^{43}$ ügyben kimondta, hogy hivatalból vizsgálhatja a 4. cikk alkalmazhatóságát akkor is, ha a részes állam konkrétan nem hivatkozott rá. Emellett a Bizottság a Silva kontra Uruguay $^{44}$ ügyben hozott állásfoglalásában azt is javasolta, hogy ha egy részes állam a derogációt az Egyezségokmány 4. cikk (1)-(2) bekezdései alapján igazolni tudja, akkor az, hogy a 4. cikk (3) bekezdése szerinti tájékoztatási kötelezettségének nem tett eleget, még nem zárja ki, hogy a derogáció alátámasztásához érvényes kimentési okot szolgáltasson. A derogáció Egyezségokmányban meghatározott feltételeinek bizonyítása az egyéni panaszeljárásokban a részes államot terheli. Noha a Bizottság az államok szuverén jogát a szükségállapot kihirdetésére elismeri, kontrollmechanizmusként funkcionál a nemzeti mérlegelés jogszerúsége felett. ${ }^{45}$ Ez a megközelítés ugyanakkor némileg elsiklik az EJEB joggyakorlata mellett, amely az Írország kontra Egyesült Királyság ${ }^{46}$ ügyben úgy foglalt állást, hogy elsősorban a részes államok mérlegelési szabadságába esik a szükségállapot nemzet létét veszélyeztetô jellegének meghatározása, és ha e szükségállapot elrendelésre került, akkor utána az is, hogy az ultima ratióként alkalmazott jogrendben bevezetett eszközökkel meddig lehet elmenni a szükségállapot leküzdése érdekében.

A PPJNE azt is lehetővé teszi részes államai számára, hogy az emberi jogok korlátozásával válaszoljanak különleges helyzetekre derogáció helyett, ${ }^{47}$ ráadásul a korlátozásra és a derogációra vonatkozó alapelvek között átfedések lehetnek, úgymint például a szükségesség, az arányosság, a diszkrimináció tilalma vagy egyéb nemzetközi jogi kötelezettségek tiszteletben tartása [az arányosság és a diszkrimináció tilalma a PPJNE 4. cikk (1) bekezdé-

41 Uo. $\$ \$ 72-73$.

42 McGoldrick, 2003, 380-429. o.

43 UN Doc. A/35/40, \$121.

44 UN Doc. A/36/40, \$130.

45 Maroufidou v. Sweden, UN Doc. A/36/40, 160, \$\$ 10.1-10.2; Aumeeruddy-Cziffra v. Mauritius, UN Doc. A/36/40, 134, \$ 9.2(b)2(ii)3; Hammel v. Madagascar, UN Doc. A/42/40, 130, \$ 20; V.R.M.B. v. Canada, UN Doc. $\mathrm{A} / 43 / 40,258, \$ 6.3$.

46 Republic of Ireland v. United Kingdom, ECtHR, (Ser. A) No. 25, (1978), \$ 207.

47 Kiss, 1980, 290. o. 
sének szövegéből egyenesen következik]. Az államok pedig sok esetben veszélyhelyzet esetén sem élnek a derogáció lehetőségével, hanem a jogkorlátozás keretein belül maradva próbálnak meg reagálni a különleges helyzetek által előidézett kihívásokra. A PPJNE úgyszintén ezt a logikát sugallja: amennyiben lehet, inkább jogkorlátozásra kerüljön sor, semmint derogációra. A gyakorlat is ezt támasztja alá, például Ciprus, Suriname, Mexikó vagy Irak ${ }^{48}$ a jogkorlátozás adta eszközökkel válaszolt az államban kialakult különleges helyzetekre.

Összegzésképpen tehát megállapíthatjuk: a PPJNE 4. cikke expressis verbis elismeri, hogy előfordulhat olyan szükséghelyzet, amikor az Egyezségokmányban foglalt jogok derogációja jogszerû. Amennyiben viszont a PPJNE részes állama erre a cikkre hivatkozik - mivel az Egyezségokmány ezen rendelkezése a részes felekre egyszersmind elsődleges kötelezettséget ró -, az állami felelősség által kínált kimentési okokra (például jogos önvédelemre vagy szükséghelyzetre) párhuzamosan már nem lehet hivatkozni. ${ }^{49}$ Hasonlóképpen, az is a 4 . cikk alkalmazásának egyik rendhagyó következménye, hogy a nemzetközi szerződések jogának főszabályára - miszerint egyetlen részes fél sem hivatkozhat belső jogának rendelkezéseire annak igazolásául, hogy elmulasztotta a szerződést teljesíteni (1969. évi Bécsi Egyezmény 27. cikk) $)^{50}$ - egyidejúleg nem lehet hivatkozni.

\section{Az Emberi Jogok Európai Egyezményének 15. cikke}

A PPJNE-hez hasonlóan az EJEE-nek is van derogációs klauzulája, mi több, e két derogációs klauzula szövegében nagyon hasonlít egymásra, néhány fordulata szó szerint megegyezik. Utóbbi okára az Egyezségokmány előkészítő anyagai (travaux préparatoires) egyértelmú válasszal szolgálnak, amelyekből megtudhatjuk, hogy noha a PPJNE csak 1966-ban került elfogadásra, a 4. cikk tervezetét már 1949-ben véglegesítették, s később ez a szövegváltozat került bele a 17 évvel késóbb aláírásra megnyitott dokumentumba. ${ }^{51} \mathrm{Az}$ 1950-ben elfogadott Egyezmény derogációs klauzuláját tehát a PPJNE 4. cikkének ezen 1949-es verziója ihlette, illetve később az Emberi Jogok Amerikai Egyezményének 27. cikkét is. ${ }^{52}$

A belső joghoz hasonlóan, a különleges jogrend definíciójának megalkotása a nemzetközi szerződésekben sem könnyú, sốt talán a magas számú állami konszenzusért kiáltó dokumentumokban e folyamat még sokkal nehezebb is. A szerződések megkötésének folyamatát gyakorta jellemző diplomáciai zsákutcákba szorulás mellett a derogációs klauzulák esetén

48 Ciprus UN Doc. A/34/40, \$383 (1979), Suriname UN Doc. A/35/40, \$2 297 (1980), Mexikó UN Doc. A/54/40, Vol. I, $\$ 324$, Irak UN Doc. A/46/40, \$\$ 618-56.

49 Crawford, 2002, 160-189. o.

50 Vienna Convention on the Law of Treaties, art. 27, May 23, 1969, 1155 U.N.T.S. 331, entered into force Jan. 27, 1980; 1987. évi 12. törvényerejű rendelet a szerződések jogáról szóló, Bécsben, az 1969. évi május hó 23. napján kelt szerződés kihirdetéséről.

51 El Zeidy, 2003, 279. o.

52 Lásd bővebben: Raisz, 2009. 
az is különösen nehéz, hogy a tervezett szöveg ne legyen túlzottan kiterjesztő, azaz ne adjon zöld utat az esetleges állami visszaéléseknek, mindazonáltal ne legyen túlzottan megszorító se, azaz képes legyen arra, hogy a különleges jogrendre okot szolgáltató helyzetek széles skáláját lefedje. Jobb híján a különleges jogrend definiálása egyfajta jogalkotó 'zsonglőrködésének' tekinthetô, ám itt a tét kétségkívül jelentős: olyan helyzetekre kell egy elasztikus fogalmat rászabni, amelyek egyáltalán nem láthatók előre, egyáltalán nem kiszámíthatók. ${ }^{53}$

Az Emberi Jogok Európai Bizottsága a nemzet létét fenyegető más rendkívüli állapot fogalmát először 1959-ben definiálta a már említett Lawless kontra Írország ügyben, miszerint: „olyan kivételes és közvetlen veszélyhelyzet vagy az egész lakosságot - nem pedig elkülönült csoportokat - sújtó válság, ami veszélyt jelent az államalkotó közösség szervezett életére". ${ }^{54}$ Végül azonban, mint ahogyan azt már fentebb is láthattuk, a Bíróság az ügyben meghozott ítéletében e fogalmat némileg árnyalta, és arra jutott, hogy a 15. cikk terminológiája alatt az államalkotó közösség szervezett életét veszélyeztető, az egész népességet érintő krízishelyzetet vagy szükségállapotot kell érteni. Tulajdonképpen ez utóbbi megállapítás lett az EJEB további esetjogának kiindulási alapja, amelynek eredeti, francia nyelvú szövegében nemcsak a „kivételes”, hanem a „közvetlen” jelző is szerepelt, ${ }^{55}$ így ezek jelentését fejlesztette később tovább az Emberi Jogok Európai Bizottsága az úgynevezett görög ügyekben. ${ }^{56}$

Az EJEE 15. cikke lehetővé teszi részes államainak, hogy számos, az Egyezményben szereplő emberi jog alkalmazásának hatályát felfüggesszék, ám ez utóbbi nyilván nem olyan egyszerû: a derogációs klauzulát csak pontosan meghatározott rendkívüli esetekben, szigorú standardok és konkrét eljárási lépések betartása mellett lehet „múködésbe hozni". ${ }^{57}$ A 15. cikk olvasata alapján megállapíthatjuk, hogy alkalmazása három együttes előfeltételhez kötött: háború vagy a nemzet létét fenyegető más rendkívüli állapot fennállása; a derogációnak a helyzet szükségessége által feltétlenül megkívánt mértéke; továbbá az így meghozott intézkedések a részes állam egyéb nemzetközi jogi kötelezettségeivel való összeegyeztethetősége.

Az EJEE 15. cikk alkalmazásának első kritériuma tehát a háború vagy a nemzet létét fenyegető más rendkívüli állapot fennállása. A PPJNE 4. cikk (1) bekezdésével ellentétben az EJEE 15. cikk (1) bekezdésében megjelenik a háború is a nemzet létét fenyegető más rendkívüli állapot ${ }^{58}$ mellett, lényegében véve a nemzet létét fenyegetô rendkívüli állapotok egyik

53 Hamilton, 1960, 153. o.

54 Lawless v. Ireland, 1 ECtHR (Ser. B), [1960-61] \$ 82.

55 Lawless v. Ireland, $\$ 28$.

56 3321/67 (Denmark v. Greece), 3322/67 (Norway v. Greece), 3323/67 (Sweden v. Greece), 3344/67 (Netherlands v. Greece).

57 El Zeidy, 2003, 282. o.

58 Érdekességként megjegyzendő, hogy míg a PPJNE 4. cikk (1) bekezdése szükségállapotot említ, addig az EJEE 15. cikk (1) bekezdésének magyar nyelvú fordításában rendkívüli állapot szerepel. Ez a terminológiai kettősség azonban az angol nyelvû szerződésekben nincs jelen, mindkét jogszabályhelyen az emergency kifejezést használták. 
eseteként. Az Emberi Jogok Európai Bizottsága a Lawless kontra Írország $g^{59}$ ügyben kimondta, hogy a háború e helyütt nem kell hogy a totális háborút jelentse, kevésbé átfogó jellegű fegyveres konfliktusok is idetartozhatnak, amennyiben a nemzet létét veszélyeztetik. ${ }^{60}$ Továbbá a görög ügyekben az Emberi Jogok Európai Bizottsága arra a következtetésre jutott, hogy az Egyezmény 15. cikk (1) bekezdése szerinti rendkívüli állapotnak ténylegesnek és közvetlennek kell lennie, az egész nemzet létét és a közösség szervezett életét kell veszélyeztetnie, továbbá szükséges, hogy az EJEE által biztosított rendes intézkedések és korlátozások többé már nem elegendőek a közbiztonság, a közegészség és a közrend fenntartásához. A ténylegesség és a közvetlenség ebben az esetben azt jelenti, hogy általános preventív jelleggel nem lehet a 15. cikkre hivatkozni, azaz a rendelkezés csak akkor hívható fel, ha a rendkívüli állapot már bekövetkezett, vagy haladéktalanul be fog következni.

Noha a Lawless kontra Írország ügyben alkalmazott értelmezés azt sugallta, hogy a rendkívüli állapotnak az egész nemzet életét kell veszélyeztetnie, e standardot későbbi esetjogában a Bíróság félretette. Ehelyett utóbb az Irország kontra Egyesült Királyság ügynek köszönhetően inkább az az álláspont vált elfogadottá, hogy az államterületnek csak egy részét sújtó események is veszélyeztethetik az egész nemzet létét, és ilyen esetekben a derogációt csupán ezen érintett területre kell alkalmazni. Tehát a rendkívüli állapot által előidézett veszélynek az egész nemzet létét kell érintenie, emellett ugyanakkor a veszélyforrásnak elegendő csak bizonyos területeken jelen lennie. ${ }^{61}$

A nemzet létét fenyegető más rendkívüli állapot fogalmának értelmezése során a Bíróság az A és mások kontra Egyesült Királyság ${ }^{62}$ ügyben hangsúlyozta az államok mérlegelési szabadságát a különleges jogrend kihirdetése vonatkozásában, és helyben hagyta a brit kormány arra irányuló érveit, hogy a 2001. szeptember 11-i terrortámadások után - noha akkoriban az Egyesült Királyságban semmiféle terrorcselekmény nem történt - különleges jogrendet hirdettek ki az Egyesült Államokkal való szoros kapcsolatra hivatkozva. Az EJEB ebben a döntésében az állam szabad mérlegelésének olyannyira teret engedett, hogy bár az Egyesült Királyságon kívül egyetlen részes állam sem jelezte derogációs szándékát a globális terrorveszélyre hivatkozva, jogszerűnek ítélte meg az Egyezménytől való eltérés alkalmazását. ${ }^{63}$

Az EJEE 15. cikk alkalmazásának második előfeltétele a derogációnak a helyzet szükségessége által feltétlenül megkívánt mértéke, ami talán a legjobban tükrözi a derogációs klauzula esszenciáját. A megkívánt mérték vizsgálatakor három tényezőt kell figyelembe venni: a derogáció szükségességét, az alkalmazott intézkedések arányosságát és a derogáció időtartamát - jóllehet később a Brannigan \& McBride kontra Egyesült Királyság64 ügyben az EJEB

59 Lawless v. Ireland, $\$ \$ 81-82$.

60 Svensson-Mccarthy, 1998, 295. o.

61 Questiaux, 1982, 15. o.

62 A and Others v. United Kingdom, Application no. 3455/05, Council of Europe: European Court of Human

Rights, 19 February 2009.

63 Harris-O'Boyle-Bates-Buckley, 2018, 831. o.

64 Brannigan \& McBride v. United Kingdom, [1993] Eur. Ct. H.R. (ser. A) No. 258-B. 
további tényezők számbavételét is szükségesnek ítélte meg, úgymint a derogációval érintett jogok természete és a derogációhoz vezetô események vizsgálata.

Az Egyezmény derogációs klauzulája alkalmazásának harmadik előfeltétele a részes állam egyéb nemzetközi jogi kötelezettségeivel való összeegyeztethetősége. A konzisztencia elve már a PPJNE 4. cikkének kezdeti, 1949. évi szövegváltozatában is fellelhető volt ${ }^{65}$ amely lényegében véve úgy értelmezhetô, hogy az egyéb nemzetközi jogi kötelezettségekkel való összeegyeztethetetlenség a derogációs klauzula tárgyi hatályán túlnyúlik, és nem fér bele a helyzet szükségessége által feltétlenül megkívánt mérték kategóriájába. Ezen túl egyetlen részes állam sem hivatkozhat az EJEE 15. cikkére abból a célból, hogy egyéb nemzetközi jogi kötelezettségei alól így szabaduljon, amit egyébként az Egyezmény 53. cikke is kimond. ${ }^{66}$ Arra, hogy konkrétan melyik nemzetközi jogi kötelezettségek tartoznak a 15. cikkben megemlített kötelezettségek hatálya alá, sehol sem találhatunk utalást. Az 1949. évi genfi egyezmények és az 1977. évi Első és Második Kiegészítő Jegyzőkönyveik ${ }^{67}$ minden bizonnyal idetartoznak, valamint a nemzetközi szokásjog és a civilizált nemzetek által elismert általános jogelvek, s különösképpen a nemzetközi jog jus cogens normái. E helyütt érdekességként érdemes lehet felvillantani, hogy a Ciprus kontra Törökország68 ügyben Ciprus azzal érvelt, hogy Törökország nem hivatkozhat az Egyezmény 15. cikkére, mivel a Cipruson véghezvitt katonai mûveletei agresszív háborúnak minősülnek, s mint olyanok, az ENSZ Alapokmányába ${ }^{69}$ ütköznek. Vagy például a Brannigan \& McBride kontra Egyesült Királyság ügyben a panaszosok éppen azzal érveltek, hogy az Egyesült Királyság a PPJNE 4. cikkét mint egyéb nemzetközi jogi kötelezettségét sértette meg azzal, hogy nem hirdette ki hivatalosan a szükségállapotot. Ez utóbbival azonban az EJEB nem értett egyet, mint ahogyan arra már fentebb is utaltunk a belügyminiszter képviselőházban tett nyilatkozatának megítélése kapcsán.

Fontos továbbá megjegyezni, hogy az Egyezmény négy abszolút jogot tartalmaz, amelyekkel szemben nem lehet különleges jogrend idején sem eltérést alkalmazni. Ezek az élethez való jog (2. cikk); a kínzás, embertelen, megalázó bánásmód vagy büntetés tilalma (3. cikk); a rabszolgaság és szolgaságban tartás tilalma [4. cikk (1) bekezdés] és a büntetés

65 El Zeidy, 2003, 291. o.

66 EJEE 53. cikk. Az Egyezmény egy ellenrendelkezését sem lehet úgy értelmezni, hogy az korlátozza vagy csorbítja azokat az emberi jogokat és alapvető szabadságokat, amelyeket bármely Magas Szerződő Fél joga vagy az olyan egyezmény biztosít, melynek ez a Magas Szerződő Fél részese.

67 Geneva Convention for the Amelioration of the Condition of the Wounded and Sick in Armed Forces in the Field, Aug. 12, 1949, 6 U.S.T. 3114, 75 U.N.T.S. 31; Geneva Convention for the Amelioration of the Condition of Wounded, Sick and Shipwrecked Members of Armed Forces at Sea, Aug. 12, 1949, 6 U.S.T. 3217, 75 U.N.T.S. 85; Geneva Convention Relative to the Treatment of Prisoners of War, Aug. 12, 1949, 6 U.S.T. 3316, 75 U.N.T.S. 135; Geneva Convention Relative to the Protection of Civilian Persons in Time of War, Aug. 12, 1949, 6 U.S.T. 3516, 75 U.N.T.S. 287; Protocol Additional to the Geneva Conventions of 12 August 1949, and Relating to the Protection of Victims of International Armed Conflicts, opened for signature Dec. 12, 1977, 1125 U.N.T.S. 3; Protocol Additional to the Geneva Conventions of 12 August 1949, and Relating to the Protection of Victims of Non-International Armed Conflicts, opened for signature Dec. 12, 1977, 1125 U.N.T.S. 609.

68 Cyprus v. Turkey, [1976] 4 Eur. H.R. Rep. 482, 553 (Commission report).

69 1956. évi I. törvény az Egyesült Nemzetek Alapokmányának törvénybe iktatásáról. 
kiszabásának tilalma törvényi rendelkezés nélkül [7. cikk (1) bekezdés]; és bár szövegszerü utalást nem találhatunk rá, valószínúsíthetően a megkülönböztetés tilalma (14. cikk) is a fel nem függeszthető jogok körébe tartozik, továbbá a Hatodik Kiegészítő Jegyzőkönyv 3. cikke és a Tizenharmadik Kiegészítő Jegyzőkönyv 2. cikke is a halálbüntetés eltörléséről, valamint a Hetedik Kiegészítő Jegyzőkönyv 4. cikke a kétszeres eljárás tilalmáról..$^{70}$

Az Egyezmény 15. cikk (3) bekezdése kimondja, hogy az eltérés jogával élni kívánó részes állam az Európa Tanács foótitkárának teljes körü tájékoztatást köteles adni az általa tett intézkedésekről és azok okairól. A tájékoztatási kötelezettség elő́ŕrása az EJEE-nek alapvető garanciális eleme, mivel a többi részes állam a 15. cikk alkalmazásáról a főtitkár tájékoztatása révén szerez hivatalosan tudomást, és e tájékoztatás birtokában nyílik lehetőségük arra is, hogy később esetlegesen eljárást indítsanak az eltérés jogával élő részes féllel szemben. ${ }^{71}$

A tájékoztatás szempontjából két tényezőnek van jelentősége: az időnek és a felfüggesztő nyilatkozat tartalmának. Noha az EJEE 15. cikke - a PPJNE 4. cikkéhez és az Emberi Jogok Amerikai Egyezménye 27. cikkéhez hasonlóan - szövegszerú utalást nem tartalmaz a tájékoztatás haladéktalan jellegére nézve, az esetjog arra enged következtetni, hogy e tájékoztatásnak elkerülhetô késedelem nélkül meg kell történnie. ${ }^{72}$ Ezzel párhuzamosan felmerül a kérdés, hogy vajon a tájékoztatásnak a különleges jogrend kihirdetését meg kell-e előznie. A választ ugyancsak a Lawless kontra Írország ügyben lelhetjük meg, amelyben a Bíróság jogszerûnek találta, hogy Írország a különleges jogrend bevezetése után 12 nappal nyújtotta be nyilatkozatát a főtitkárhoz. ${ }^{73} \mathrm{Az}$ Írország kontra Egyesült Királyság ügyben sem találta az EJEB egyezménysértőnek a brit kormány által 11 nappal a különleges jogrend kihirdetése után benyújtott nyilatkozatot. Ezzel szemben a görög ügyekben az Emberi Jogok Európai Bizottsága úgy látta, hogy a négy hónapos késedelem jogszerűsége már nem támasztható alá, és a görög kormány nyilatkozatának benyújtása előtt hozott intézkedéseire a 15. cikk nem szolgáltathat kimentési okot. ${ }^{74}$

Ami a felfüggesztő nyilatkozat tartalmát illeti, először is azt kell az EJEE részes államának meghatároznia, hogy az Egyezmény mely cikkeitől akar eltérni. Ezzel kapcsolatban az vethet fel további kérdéseket, hogy ha az állam az EJEE valamely cikkét a felfüggesztő nyilatkozatban nem jelöli meg, mégis később a gyakorlatban el kíván térni tőle. Az Írország kontra Egyesült Királyság ügy tényállása szerint Írország pontosan azzal érvelt, hogy az Egyesült Királyság az EJEE 14. cikkétől75 (megkülönböztetés tilalma) nem térhet el, tekintve, hogy

70 El Zeidy, 2003, 294. o.

71 El Zeidy, 2003, 295. o.

72 Oraá, 1992, 58. o.

73 Lawless v. Ireland, \$223.

74 El Zeidy, 2003, 296. o.

75 EJEE 14. cikk. A jelen Egyezményben meghatározott jogok és szabadságok élvezetét minden megkülönböztetés, például nem, faj, szín, nyelv, vallás, politikai vagy egyéb vélemény, nemzeti vagy társadalmi származás, nemzeti kisebbséghez tartozás, vagyoni helyzet, születés szerinti vagy egyéb helyzet alapján történő megkülönböztetés nélkül kell biztosítani. 
az Európa Tanács fôtitkárához benyújtott nyilatkozatában korábban e rendelkezést nem jelölte meg, ám az Emberi Jogok Európai Bizottsága a 14. cikk felől közelített az esethez, és mivel úgy találta, hogy a brit kormány nem valósított meg hátrányos megkülönböztetést, a 15. cikk esetleges sérelmét már nem vizsgálta. Ezzel szemben a testület a görög ügyekben ténylegesen is állást foglalt e kérdésben, és kimondta, hogy az EJEE 15. cikk (3) bekezdése nem ró arra irányuló abszolút kötelezettséget az államokra, hogy valamennyi, később derogációval érintett szerződéses cikket tételesen felsoroljanak. ${ }^{76} \mathrm{Az}$ Egyezmény 15. cikk (3) bekezdése a fentiek mellett arra is utal, hogy az Európa Tanács főtitkárát az eltérés keretében meghozott intézkedésekről is részletesen tájékoztatni kell: a görög kormányt részben pont emiatt marasztalták el, amikor nem nyújtott megfelelő tájékoztatást az 1968. évi alkotmány alapján megtett lépésekről. ${ }^{77} \mathrm{~A} 15$. cikk (3) bekezdése értelmében az államnak arról kell még számot adnia, hogy a derogációval milyen okból kíván élni, végül pedig arról is értesítenie kell az Európa Tanács foótitkárát, ha az elállás jogával többé már nem kíván élni, és visszatér az EJEE „békeidejứ” alkalmazásához.

\section{4. Összegzés}

A különleges jogrend jogának legfontosabb nemzetközi jogi vetülete az emberi jogi egyezmények alkalmazásának ideiglenes felfüggesztési lehetősége. Utóbbi állítás az e könyvben bemutatásra kerülő országokra különösen igaz, minthogy az európai államok esetében nemcsak a PPJNE 4. cikke, hanem az EJEE 5. cikke is lehetőséget kínál a derogációra.

Az eltérés joga, mint ahogyan az alapjogok korlátozása a belső jogban, a nemzetközi jogban is kivételes kell legyen, sőt még inkább az: egyfajta ultima ratio a szerződő államok kezében. Jóllehet a PPJNE végrehajtási mechanizmusát megtestesítő Emberi Jogok Bizottsága kötelező erejű határozatokat nem hozhat, az Emberi Jogok Európai Bíróságához hasonlóan számottevő szerepet töltött be a derogációs klauzulák értelmezésében. A két testület esetjogát sok esetben praktikus együttesen szemlélni, minthogy a PPJNE 4. cikke és az EJEE 15. cikke tartalmában - és néhol fogalomhasználatában is - nagyon hasonló, vagy éppen megegyezik. S bár a PPJNE hivatalos magyar fordítása a szükségállapot, az EJEE pedig a rendkívüli állapot terminológiáját alkalmazza, ezek tartalmilag voltaképpen azonos kategóriákat fednek le.

Egyúttal az is látható, hogy e két cikk esetjoga gyakorlati példákban nem bővelkedik legalábbis az Egyezségokmány és az Egyezmény más cikkeivel összevetve. Ennek nemcsak a vizsgált rendelkezések végsőeszköz-jellege az oka, hanem az is, hogy az egyébként különleges jogrendet kihirdető államok sokszor nem jelentik be az eltérés szándékát az ENSZ és 
az Európa Tanács fốtitkáraihoz. Ennek akkor nincs is különösebb következménye - a gyakorlati szintézisben való megjelenésen túl -, ha az állam ellen az illetékes nemzetközi fórumokhoz nem érkezik be panasz jogsértés miatt. Ellenben abban az esetben, ha a különleges jogrend kihirdetését hivatalos tájékoztatás nem előzi meg vagy haladéktalanul nem követte - és persze a panaszban foglalt egyéb feltételek is fennállnak -, az állam megsérti a PPJNE 4. vagy az EJEE 15. cikkét.

\section{Irodalomjegyzék}

BÉREs, N. (2020) A Biztonsági Tanács által a Nemzetközi Büntetóbiróság elé utalt helyzetek legfontosabb jogi problémái (PhD-értekezés). Miskolc: Miskolci Egyetem Deák Ferenc Állam- és Jogtudományi Doktori Iskola

CRAWFORD, J. (2002) The International Law Commission's Articles on State Responsibility [Online]. Elérhető: http://assets.cambridge.org/97805218/13532/sample/9780521813532ws.pdf (Letöltve: 2020. december 15.)

DAEs, E. (1983) The Individual's Duties to the Community and the Limitations on Human Rights and Freedoms under Article 29 of the U.D.H.R., UN Doc. E/CN.4/Sub.2/432/Rev.2 (1983) [Online]. Elérhető: https://digitallibrary.un.org/record/52410?ln=en (Letöltve: 2020 . december 15.)

El ZEIDY, M. (2003) 'The ECHR and States of Emergency: Article 15 - A Domestic Power of Derogation from Human Rights Obligations', San Diego International Law Journal, 4(1), 277-318. o.

GÁRdos-Orosz, F. (2018) 'Alapvető jogok korlátozása' in Lamm, V. (szerk.) Emberi Jogi Enciklopédia. 1. kiadás. Budapest: HVG-ORAC

Hamilton, A. (1961) ‘The Federalist’ in Rossiter, C. (szerk.) The Federalist Papers. 1. kiadás. New York: Penguin

Harris, D., O'Boyle, M., Bates, C. Buckley (2018) Law of the European Convention on Human Rights. 1. kiadás. Oxford: Oxford University Press

IstREFI, K. (2020) To Notify or Not to Notify: Derogations from Human Rights Treaties [Online]. Elérhető: http://opiniojuris.org/2020/04/18/to-notify-or-not-to-notify-derogations-fromhuman-rights-treaties/ (Letöltve: 2020. december 15.)

JOSEPH, S., CASTAN, M. (2013) The International Covenant on Civil and Political Rights. 1. kiadás. Oxford: Oxford University Press

KIss, A. (1980) 'Permissible Limitations on Rights' in Henkin, L. (szerk.) The International Bill of Rights: The Covenant on Civil and Political Rights. 1. kiadás. New York: Columbia University Press

Kovács, P. (2016) Nemzetközi közjog. 3. kiadás. Budapest: Osiris

LAMM, V. (2018) 'ENSZ Emberi Jogi Szerződési Bizottságok' in Lamm, V. (szerk.) Emberi Jogi Enciklopédia. 1. kiadás. Budapest: HVG-ORAC 
MCGoldrick, D. (2004) 'The Interface Between Public Emergency Powers and International Law', Oxford University Press and New York University School of Law, 2(2), 380-429. o.

NowAK, M. (2005) UN Covenant on Civil and Political Rights. 1. kiadás. Kehl am Rhein: Engel

OraÁ, J. (1992) Human Rights in States of Emergency in International Law. 1. kiadás. Oxford: Oxford University Press

Questiaux, N. (1982) Question of the Human Rights of Persons Subjected to any Form of Detention or Imprisonment: Study of the Implications for Human Rights Recent Developments Concerning Situations Known as States of Siege or Emergency, U.N. Doc. E/CN.41Sub.2/1982/15 [Online]. Elérhető: www.refworld.org/docid/3boofo8960.html (Letöltve: 2020. december 15.)

RAIsz, A. (2009) Az Emberi Jogok Európai és Amerikaközi Bíróságának egymásra hatása (PhDértekezés). Miskolc: Miskolci Egyetem Deák Ferenc Állam- és Jogtudományi Doktori Iskola SvensSON-MCCARTHy, A. (1998) The International Law of Human Rights and States of Exception. 1. kiadás. Leiden: Brill

Till, Sz. P. (2020) Freedom of European National Constitutions to Regulate Emergencies. (Comparative Study on the Hungarian Structure of Special Legal Orders). Budapest: Hungarian Society for Military Law and Law of War 


\title{
3. A Covid-járvány uniós szintú kezelése - A hatáskörök hálójának elmélete
}

\author{
MARINKÁS GYÖRGY
}

\section{Az EU különleges jogrendi szabályozásra vonatkozó szabályainak áttelkintése}

\subsection{Egyújkihívás}

2020 tavaszán világossá vált, hogy az új típusú koronavírus-járvány kezelése - amely január óta mind a közvéleményt, mind a tagállami és uniós döntéshozókat is foglalkoztatja nem korlátozódik kizárólag járványügyi kérdésekre, azaz egy olyan területre, amelyben az EU gyakorlatilag semmilyen kompetenciával nem rendelkezik kötelező erejû döntések meghozatalára. A járvány ugyanis a lakosság egészsége mellett komolyan veszélyezteti az állami költségvetések egyensúlyát és a gazdaság müködőképességét, ${ }^{1}$ ily módon az egy-

I Egyrészről az állami költségvetésekben komoly összeget szükséges átcsoportosítani a védekezés közvetlen költségeire - egészségügyi és védőfelszerelések -, másrészről közvetetten a gazdasági szereplők állami szubszidiálást igényelnek annak érdekében, hogy elkerülhető legyen a gazdaság teljes összeomlása és a munkanélküliségi ráta egekbe szökkenése. Mindezt egy olyan helyzetben, amikor az államnak a gazdasági szereplők elmaradt jövedelmei miatt magának is elmaradó adóbevételekkel kell számolnia (részletesen lásd az IMF elemzését: Deb et al., 2020).

Dr. Marinkás György, PhD

gyorgy.marinkas@mfi.gov.hu

kutató (Mádl Ferenc Összehasonlító Jogi Intézet)

adjunktus (Miskolci Egyetem Állam- és Jogtudományi Kar, Európai és Nemzetközi Jogi Intézet)

Marinkás, Gy. (2021) 'A Covid-járvány uniós szintű kezelése - A hatáskörök hálójának elmélete’ in Nagy, Z., Horváth, A. (szerk.) A különleges jogrend és nemzeti szabályozási modelljei, 52-76. o. Budapest: Mádl Ferenc Összehasonlító Jogi Intézet.

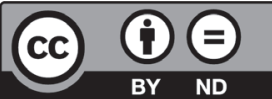


séges belső piac múködését is fenyegeti. Ennek megfelelően az Európai Unió intézményei - az Európai Bizottsággal az élen - az alapító szerződések által lehetővé tett keretek között fellépve különböző akciótervekkel és javaslatokkal álltak elő a belső piac múködőképességének fenntartása érdekében, ideértve a személyek szabad mozgásának korlátozása esetén alkalmazandó egységes szempontokat. A jelen fejezet ennek megfelelően arra koncentrál, hogy megvizsgálja, milyen alapító szerződésbeli - eredeti rendeltetésük szerint az egységes belső piac múködését biztosítani hivatott - rendelkezések állnak az uniós intézmények rendelkezésére a koronavírus-járvány okozta problémák leküzdésére. Az Európai Bizottság ezzel egyidejűleg jogállamisági szempontból ellenőrizte a tagállami kormányok által bevezetett válságkezelő intézkedéseket, ideértve az egyes államokban kihirdetett különleges jogrendi állapotot. Ily módon a koronavírus-járvány egyes országok esetében egy régóta zajló vitát is újból feltüzelt, amelyre azonban e helyütt nem kívánunk kitérni. Végül, de nem utolsósorban a járvány olyan folyamatokat is felgyorsított, mint a különböző digitális technológiák alkalmazása a döntéshozatali eljárásokban. Ahogyan a tavasz során a magyar oktatási rendszernek is villámgyorsan kellett átállnia a digitális oktatásra, úgy az EU intézményeinek is adaptálódniuk kellett az új helyzethez. Az e téren hozott rendelkezések és azok eredményessége szintén bemutatásra kerül.

\subsection{A különleges jogrend szabályozására vonatkozó uniós hatáskörök hiánya}

Az alapító szerződések ${ }^{2}$ alapján a különleges jogrendre vonatkozó alkotmányos és törvényi szabályok meghozatala kizárólagos tagállami hatáskörbe tartozik. Az Európai Uniónak és intézményeinek nincs hatásköre ${ }^{3}$ kötelező erejü döntések meghozatalára e téren. Árnyalja ugyanakkor a képet, hogy egyrészről annak ellenére megfigyelhetők bizonyos szabályozási tendenciák ${ }^{4}$ a különleges jogrendi szabályozás terén, hogy az uniós jog nem fogalmaz meg elốrást arra nézve, hogy a szabályozásnak alkotmányos vagy törvényi szinten kell-e rögzí-

2 Az Európai Unióról szóló szerződés (EUSZ) egységes szerkezetbe foglalt változata (HL C 326, 2012. 10. 26. 13-390. o.); Az Európai Unió működéséről szóló szerződés (EUMSZ) egységes szerkezetbe foglalt változata (HL C 326, 2012. 10. 26., 47-390. o.).

3 Érdemes megemlíteni az Egymillió aláirás a szolidáris Európáért nevú, európai polgári kezdeményezésre irányuló javaslatot, tekintve, hogy a kezdeményezés egy uniós szintû szükségállapot-fogalom bevezetésére irányult. Jóllehet az a különleges jogrend elrendelésére alapot adó okok közül csak egy szúk körre - jelesül az euróövezeti válsághoz kapcsolódó államcsőd esetére - korlátozódott volna. Lásd: Az Európai Unió Bíróságának 93/17. sz. sajtóközleménye a C-589/15. P. sz. Alexios Anagnostakis kontra Bizottság ügyben hozott ítélet kapcsán (Luxembourg, 2017. szeptember 12.).

4 Ilyen tendencia, hogy a legtöbb államban a parlament feladata dönteni a szükségállapot elrendeléséről. Kivételt képeznek ez alól azon államok, amelyek - az operativitás szempontját előtérbe helyezve - az államfőt ruházzák fel e jogkörrel. Emellett több államnál is megjelenik a kormányfő mint a különleges jogrend bevezetésének jogával felruházott alkotmányos tényező (Till, 2019; Ságvári, 2016; Kelemen, 2019, 9-34. 0.). 
tettnek lennie. ${ }^{5}$ Másrészről a terror elleni háború jegyében hozott uniós intézkedések tagállami végrehajtása során - amely adott esetben alapjogi korlátozást követelhet meg - a tagállamoknak figyelemmel kell lenniük egyes, az uniós jogban garantált alapjogokra, illetve a vonatkozó bírósági gyakorlatra.

\subsection{Az alapjogok korlátozhatóságának kérdése rendkivüli helyzetekben az Európai Unió Bíróságának itélkezési gyakorlata nyomán}

Tekintve, hogy az Európai Unió elődje - az Európai Gazdasági Közösség - elsősorban gazdasági jellegú szervezetként jött létre, az Európai Gazdasági Közösséget létrehozó szerződés ${ }^{6}$ nem tartalmazott utalást az emberi vagy alapvetô jogokra, ${ }^{7}$ az alapjogok védelme az Európai Unió Bíróságának (EuB) - korábbi nevén Európai Közösségek Bírósága - joggyakorlatában jött létre. ${ }^{8} \mathrm{Az}$ alapjogokra való első utalást a maastrichti szerződés ${ }^{9}$ tartalmazta, amelyet az amszterdami szerződés finomított. Az alapító szerződésbeli rendelkezések értelmében az Európai Unió a közösségi jog általános elveként tiszteletben tartja az alapvető jogokat, ahogyan azokat az Emberi Jogok Európai Egyezménye ${ }^{10}$ (EJEE) tartalmazza; továbbá ahogyan azok a tagállamok közös alkotmányos hagyományaiból következnek.

Hiányzott ugyanakkor egy írott alapjogi katalógus, amely végül az Európai Unió Alapjogi Chartája ${ }^{11}$ (a továbbiakban: Charta) formájában öltött testet. A fogadtatása azonban nem volt egyöntetúen pozitívnak nevezhetô: egyrészt nem kevesen ellenezték a Charta jogi erôvel történő felruházását, ${ }^{12}$ másrészt egészen 2006 -ig az EuB is tartózkodott attól, hogy hivatkozzék rá. ${ }^{13} \mathrm{~A}$ Chartát végül a lisszaboni szerződés ${ }^{14} 6$. cikke ruházta fel jogi kötőerôvel, és nyilvánította az uniós jogrend szerves részévé. A Charta által garantált jogok nagyrészt átfedésben vannak az EJEE által garantált jogokkal, figyelembe véve ugyanakkor a közösségi jog speciális jellemzőit, példának okáért az európai polgársághoz kapcsolódó jogokat. Megálla-

5 Érdemes megjegyezni, hogy az EU-ból azóta már kilépett Egyesült Királyság esetében az alkotmányos szintú szabályozás megkövetelése - tekintve, hogy az ország nem rendelkezik írott alkotmánnyal - egyenesen értelmezhetetlen lett volna.

6 Az Európai Gazdasági Közösséget létrehozó szerződés (Róma, 1957. március 25.).

7 Voltak ugyan rendelkezései, amelyek elsőre akár emberi jogi indíttatásúaknak túnhetnek - mint például a férfi és női munkavállalók közti különbségtételt tiltó „egyenlő munkáért egyenlő bért” elvének deklarálása, valamint a munkavállalók szabad mozgása és a diszkrimináció tilalma -, e rendelkezések ugyanakkor gazdasági érdekekről, mintsem önzetlen humánus megfontolásokról szóltak.

8 Részletesen lásd: Kiss, 2010.

9 Maastrichti szerződés (HL C 191, 1992. 07. 29., 1-112. 0.).

10 Emberi Jogok Európai Egyezménye (Róma, 1950. november 4.) ETS No.005.

11 Az Európai Unió Alapjogi Chartája (HL C 326, 2012. 10. 26., 391-407. o.).

12 Defeis, 2012, 1211. o.

13 Első említésére a C-540/03. számú, az Európai Parlament kontra Európai Unió Bizottsága ügyben 2006. június 27-én hozott ítélet 4. és 31. pontjában került sor.

14 Lisszaboni szerződés az Európai Unióról szóló szerződés és az Európai Közösséget létrehozó szerződés módosításáról (HL C 306, 2007. 12. 17., 1-271. 0.). 
pítható ugyanakkor, hogy a Charta egyes általa garantált jogok tekintetében túlszárnyalja az EJEE által garantált jogvédelmet..$^{15}$

A Charta 51. cikk (1) bekezdése értelmében: „E Charta rendelkezéseinek címzettjei - a szubszidiaritás elvének megfelelő figyelembevétele mellett - az Unió intézményei, szervei és hivatalai, valamint a tagállamok annyiban, amennyiben az Unió jogát hajtják végre.” A (2) bekezdés értelmében: „[A] Charta az uniós jog alkalmazási körét nem terjeszti ki az Unió hatáskörein túl, továbbá nem hoz létre új hatásköröket vagy feladatokat az Unió számára, és nem módosítja a Szerződésekben meghatározott hatásköröket és feladatokat." Tekintve, hogy az alapító szerződésekben nincs rendelkezés a rendkívüli jogrendet illetően, a Charta által garantált jogok legfeljebb akkor hívhatók fel rendkívüli jogrend kihirdetése idején, amennyiben a rendkívüli jogrend azért került bevezetésre, mert a tagállam valamely uniós jog végrehajtásának kikényszerítése érdekében azt szükségesnek látta. Példának okáért a terrorizmus elleni harc során.

A koronavírus-járvány kapcsán kettő, a Charta által rögzített alapjog, a gyülekezési jog - ideértve az egyébként békés tüntetések elleni aránytalan rendőri fellépéseket -, illetve a véleménynyilvánítás szabadságának korlátozása körül folyt különösen élénk társadalmi, politikai és jogi vita.

A gyülekezéshez való jogot a Charta 12. cikke garantálja. A járvány európai megjelenését követően mind a 27 EU-tagállam korlátozásokat vezetett be a gyülekezési jog vonatkozásában. A tagállami korlátozások szigorúságukat tekintve széles skálán mozogtak. Jóllehet egészségügyi szempontból a korlátozások léte kétségkívül indokolható, ${ }^{16}$ azok mértéke, illetve az egészségügyi megfontolások és a gyülekezés szabadságának egymással szembeni súlyozása megfontolt mérlegelést igényel. ${ }^{17} \mathrm{~A}$ társadalmi távolságtartás szabályainak biankó csekként - a gyülekezési jog korlátozásának megkérdőjelezhetetlen indokául - történő alkalmazása nyilvánvalóan nem felel meg az arányosság követelményének. A tagállamok közül mindössze három vezetett be differenciált szabályozást: Dánia, Csehország és Hollandia. Utóbbi 2020. április 28-án azonban megszüntette a differenciált szabályozást, és a többi tagállamhoz hasonlóan általános, a differenciálást nélkülöző tilalmat vezetett be. A tilalmak több országban is alkotmánybírósági - vagy más felsőbb bíróság általi - felülvizsgálat tárgyát képezték. A német alkotmánybíróság - az állandó joggyakorlatának megfelelően ${ }^{18}$ - a 2020. április 15-i döntésében ${ }^{19}$ leszögezte, hogy a közegészségügyi megfontolások

15 Marinkás, 2013, 103. o.

16 ECDC, Guidelines for the Implementation of Nonpharmaceutical Interventions against COVID-19

24 September 2020. Elérhető: www.ecdc.europa.eu/sites/default/files/documents/Covid-19-guidelines-nonpharmaceutical-interventions-september-2020.pdf (Letöltve: 2020. október 31.).

17 Civil Liberties Union for Europe and Greenpeace European Unit: Locking Down Critical Voices. How Governments' Responses to the Covid-19 Pandemic Are Unduly Restricting Civic Space and Freedoms Across the EU Civil (September 2020), 11-14. 0 .

18 Kommers, 2007.

19 BVerfG, Beschluss der 1. Kammer des Ersten Senats vom 15 April 2020. - 1 BvR 828/20. 
nem szolgálhatnak mindent felülíró érvként a gyülekezéshez való jog korlátozása kapcsán. Hasonlóképpen, Franciaország kvázi alkotmánybírósága, az Államtanács a gyülekezési jog aránytalan korlátozásának minősítette a tíz fónél több ember részvételével megtartott demonstrációk tilalmát. ${ }^{20}$ A szlovén alkotmánybíróság a 2020. augusztusi döntésében a szükségesség és az arányosság szempontjából a különleges intézkedések elrendelésére alapot adó indokok heti rendszerességgel történő felülvizsgálatát látta szükségszerűnek. ${ }^{21}$ Jóllehet bírósági ügy nem származott belőle, a felülvizsgálat elmaradása Belgium esetében is problémaként merült fel: míg az esetszámok csökkenésével a boltokra vonatkozó szabályok már májusban felülvizsgálatra kerültek, a bárok és az éttermek pedig júniusban újra kinyithattak, addig a gyülekezési jog felülvizsgálatára csak júliusban került sor. ${ }^{22}$

A gyülekezési jog korlátozása kapcsán azonban nemcsak a jogalkotás, hanem a jogalkalmazás vonatkozásában is felmerültek problémák, ami egyrészt a jogalkotó által kijelölt keretek bizonytalanságából adódott, másrészt a jogalkalmazó következetlenségéből. A jogalkotó által kijelölt keretek bizonytalan voltára kiváló példa a ciprusi szabályozás, amely a tömegrendezvények betiltásának feltételéül a „nagyszámú gyülekező” kifejezést használta, illetve az ír és a holland szabályozás, amely gyakorlatilag a rendőrség diszkrecionális jogkörébe utalta annak előzetes megbecsülését, hogy a résztvevők milyen valószínúséggel sértik majd meg a hatályos járványügyi szabályokat. Utóbbira - azaz a jogalkalmazónak a jogbiztonságot nem szolgáló következetlenségére - példa a francia rendőrség, amely bejelentette, hogy az akkor hatályos szabályokkal ellentétes voltuk ellenére nem fog fellépni a Black Lives Matter mozgalom által szervezett demonstrációkkal szemben, majd ezt követően rendszeresen karhatalmi erő igénybevételével történő tömegoszlatás révén vetett véget a tüntetéseknek, amelyek nem egy esetben a tüntetők és a rendőrök közötti összecsapásban végződtek. A rendőri erők által alkalmazott erőszak aránytalan volta a svéd rendőrség vonatkozásában ${ }^{23}$ is felmerült. ${ }^{24}$

A véleménynyilvánítás és a tájékozódás szabadsága szintén az Alapjogi Chartában garantált jog. A jog magában foglalja, hogy a tömegtájékoztatás sokszínûségét - és a szabadságot, amely e sokszínûséget lehetôvé teszi - tiszteletben kell tartani. A véleménynyilvánításhoz valójog kurtítása nyomós indokot feltételez. Ilyen nyomós indok lehet a dezinformációk terjesztésének visszaszorítása vagy megakadályozása. A dezinformációk ugyanis Josep Borrell közös kül-és biztonságpolitikai főképviselő megfogalmazásában „a koronavírus-világjárvány idején életeket olthatnak ki”. ${ }^{25}$ A koronavírus kapcsán, főleg a kezdeti hónapokban olyan mér-

20 Conseil d'État, statuant au contentieux, Nos. 440846, 440856, 441015 (13/06/2020).

21 Ustavno sodišče Republike Slovenije, U-I-83/20 (27.08.2020).

22 Civil Liberties Union for Europe and Greenpeace European Unit, 2020, 7. o.

23 Civil Liberties Union for Europe and Greenpeace European Unit, 2020, 14-15. o.

24 A rendőri erők alkalmazhatóságának elméleti kérdéseit lásd: Lee, 2020, 247. o.

25 Európai Bizottság: Koronavírus: Az EU megerôsiti a dezinformációval szembenifellépést (Sajtóközlemény, Brüsszel, 2020. június 10.) Elérhető: https://ec.europa.eu/commission/presscorner/detail/hu/ip_20_1006 (Letöltve: 2020. október 17.). 
téket öltött a dezinformációk, áltudományos állítások és pletykák terjedése, hogy a WHO külön nevet adott a jelenségnek: infodemic. ${ }^{26} \mathrm{~A}$ dezinformációk ilyen mértékú áramlását két tényező segítette elő: $:{ }^{27}$ egyrészrôl az, hogy a koronavírus teljesen új betegségként jelent meg, amely érthető módon pánikot keltett a lakosság körében, másrészról az, hogy a tudományos világ maga is megosztott volt azt illetően, hogy pontosan mivel is áll szemben az emberiség. Utóbbiból következően a járvány megjelenését követő első hónapokban a fals információkat nehéz volt megkülönböztetni a valós tényeken alapuló információktól. A kormányoknak azzal kellett szembesülniük, hogy a dezinformációk aláássák a lakosság bizalmát és együttmúködő készségét, megnehezítve vagy lehetetlenné téve a védekezést. A dezinformációk visszaszorítása tehát mindenképpen szükségessé vált, a tagállami szabályozások azonban egyes esetekben a szólásszabadsághoz való jog aránytalan és szükségtelen korlátozását valósították meg. A jelenségre az Európai Bizottság is felfigyelt, és véleményt bocsátott ki A Covid-19-cel kapcsolatos dezinformáció kezelése - lássuk a valós tényeket címen, ${ }^{28}$ amelyben a 2018-ban kiadott, A dezinformációval szembeni cselekvési tervre ${ }^{29}$ építve látja el tanácsokkal a tagállamokat azt illetően, hogy miként lépjenek fel a dezinformációk terjedésével szemben oly módon, hogy az hatásos legyen, miközben a szükségesség és arányosság tesztjét is kiállja. A feloldandó jogi probléma az egyén egészséghez való jogának védelme és általában véve a közegészségügyi megfontolások érvényre juttatása, valamint a szólásszabadsághoz való jog összeegyeztetése. Különösen nehézzé teszi e feladatot, hogy - amint az Európai Bizottság írja - az álhírek, áltudományos tézisek és félrevezető egészségügyi információk terjesztése önmagában nem feltétlenül jogsértô. ${ }^{30} \mathrm{E}$ jelenség legtöbb esetben inkább tudatlanságból és az információ mennyiségéből adódó zavarodottságból ered. Az ilyen típusú dezinformációkkal szemben az Európai Bizottság szerint a legjobb védekezés egy hatékony tájékoztató kampány megszervezése. Más a helyzet az összeesküvés-elméletekkel és a gyúlöletbeszéddel, ${ }^{31}$ amelyek veszélyeztethetik az emberi egészséget, károsíthatják a társadalom kohézióját, nyilvános erőszakhoz és társadalmi zavargáshoz vezethetnek. Hasonlóképpen káros a fogyasztók csodaszerek ígéretével történő megtévesztése, valamint a koronavírussal kapcsolatos információkat csaliként használó kiberbúnözés. Végül, de nem utolsósorban komoly károkat okoznak a jellemzően

26 WHO: Working Together to Tackle the "Infodemic" (29.06.2020.) Elérhető: www.euro.who.int/en/healthtopics/Health-systems/digital-health/news/news/2020/6/working-together-to-tackle-the-infodemic (Letöltve: 2020. október 31.).

27 Azonkívül természetesen, hogy a közösségi média soha nem tapasztalt lehetőséget adott az átlagember számára a gondolatai minél szélesebb körben való terjesztésére.

28 Európai Bizottság: A COVID-19-cel kapcsolatos dezinformáció kezelése-lássuk a valós tényeket. Brüsszel, 2020. 06. 10. JOIN (2020) 8 final.

29 Európai Bizottság: Cselekvési terv a félretájékoztatással szemben. Brüsszel, 2018. 12. 05. JOIN (2018) 36 final.

30 Amennyiben az lenne, a Facebook- felhasználók egy jelentős részét hatósági eljárás alá lehetne vonni [a Szerző megjegyzése].

31 A járvány kezdeti szakaszában egyértelmúen megfigyelhető volt a kínai származású személyekkel szembeni ellenséges attitúd: FRA, 2020, 33-35. o. 
harmadik országok kormánya által pénzelt dezinformációs kampányok, ${ }^{32}$ amelyek célja az Európai Unió lakosságában már így is megfigyelhetô polarizáció tovább növelése, valamint saját maguk jobb színben történő feltüntetése. ${ }^{33}$

A fentieket összefoglalva tehát az Európai Bizottság szerint először is különbséget kell tenni a jogszabály által meghatározott jogellenes tartalom és a káros, ám nem jogellenes tartalom között. Másodszor meg kell határozni, hogy fennáll-e a megtévesztés vagy a közérdeknek való károkozás, illetve a gazdasági haszonszerzés szándéka. Ilyen szándék hiányában - például amikor a polgárok tudtukon kívül, jóhiszemúen osztanak meg hamis információkat barátaikkal és családjukkal - az érintett tartalom mindössze félretájékoztatásnak tekinthető. A szándék megléte esetében azonban bûncselekményről beszélhetünk. Egyes tagállamokban e cselekmények már a járványt megelőzően is büncselekménynek számítottak, míg más tagállamokban - például Magyarországon ${ }^{34}$ - a járvány hatására vezettek be az e cselekményeket kriminalizáló szabályokat. „A Bizottság álláspontja szerint azok a jogszabályok, amelyek túl tágan határozzák meg ezeket a büncselekményeket és aránytalan büntetéseket szabnak ki rájuk [...] különösen aggályos[ak] a véleménynyilvánítás szabadsága szempontjából." ${ }^{35}$ Habár itt az Európai Bizottság külön kiemeli Magyarországot - illetve a Bizottság a 2020. évi jogállamisági jelentéséhez füzött munkadokumentumban is hangsúlyozta aggályait ${ }^{36}$ - a magyar Büntetô törvénykönyv új rendelkezései kapcsán, érdemes megjegyezni, hogy a társadalom egészének védelme és az alapjogok közötti kellő egyensúlyt több más tagállamnak sem sikerült megtalálnia, amint azt a Civil Liberties Union for Europe and Greenpeace European Unit jelentése is tanúsítja. A dokumentum szerint a legaránytalanabb intézkedést a román kormány hozta, amely saját magának adott felhatalmazást az internetes tartalmak cenzúrázására. A jelentés alapján továbbá több tagállam kormánya - nyugat- és kelet-közép-európai kormányokat is ideértve - korlátozta az újságírók kérdezéshez való jogát a sajtótájékoztatókon úgynevezett előzetes szứrők alkalmazása révén. Azonban pozitív példákat is találni, például a francia és a lengyel kormány hatékony együttmúkködést alakított ki az internetes keresőmotorokat múködtető vállalkozásokkal a dezinformációk visszaszorítása érdekében. ${ }^{37}$

32 A dezinformációs múveletek tipikusan a hibrid hadviselés eszköztárába tartoznak (Resperger, 2018).

33 Lásd a következő alfejezetben a Kína és Oroszország által küldött felajánlásokkal kapcsolatos európai uniós állásfoglalásokat.

34 A 2012. évi C. törvény (Btk.) 337. \$ (2) bekezdését a koronavírus elleni védekezésről szóló 2020. évi XII. törvény iktatta be.

35 COM JOIN (2020) 8 final, 3-4., 12-14. o.

36 Bizottsági Szolgálati Munkadokumentum: 2020. évi jogállamisági jelentés. Országfejezet - A jogállamiság helyzete Magyarországon, amely a következő dokumentumot kíséri [...] 2020. évi jogállamisági jelentés: A jogállamiság helyzete az Európai Unióban. Brüsszel, 2020. 09. 30. SWD (2020) 316 final, 18. o.

37 Civil Liberties Union for Europe and Greenpeace European Unit, 2020, 19-22. o. 


\subsection{A különleges jogrend jogállamisági kontextusba kerülése- az Európai Bizottság megnyilvánulásai}

Amint a bevezető gondolatok között említettük, a tagállamok által bevezetett intézkedéseket az Európai Bizottság jogállamisági szempontból is megvizsgálta. E téren kizárólag a koronavírus-járvány kapcsán bevezetett kormányzati intézkedések Bizottság általi vizsgálatára szorítkozunk, és - bár ez meglehetősen nehéz vállalkozás - tudatosan távol tartjuk magunkat a magyar és a lengyel jogállamisági helyzet körül évek óta tartó vita elemzésétől.

Kora tavasztól kezdve az EU-tagállamok mindegyike jogszabályi válaszlépéseket vezetett be a koronavírus-járvány teremtette helyzetre való tekintettel..$^{38}$ Két EU-tagállam - Románia és Litvánia - az EJEE 15. cikke által garantált lehetőséggel élve még az egyezmény egyes cikkeinek hatályát is felfüggesztette a szükséghelyzetre hivatkozva. ${ }^{39} \mathrm{~A}$ különleges jogrendi helyzetek bevezetésének indokoltsága több országban politikai kontextusba került. Magyarország esetén például a fent említett, a szerző által kerülni kívánt jogállamisági vita kontextusába. A Bizottság márciusban kijelentette, hogy vizsgálni fogja a magyar különleges jogrendi szabályokat. Egy hónappal később Věra Jourová, az Európai Bizottság értékekért és átláthatóságért felelős alelnöke azt nyilatkozta, hogy a tavasszal bevezetett magyar különleges jogrendi intézkedések nem sértik az uniós jogot. ${ }^{40} \mathrm{E}$ tekintetben említést érdemel, hogy a 2020. évi jogállamisági jelentésekhez füzött munkadokumentumokban ${ }^{41}$ az Európai Bizottság számos más ország kapcsán is talált kifogásolnivalót. Romániában ${ }^{42}$ az alkotmánybíróság alkotmányellenesnek nyilvánította a karanténszabályokat megszegókre kirótt magas bírságokat, mivel „a bírságok alapjául szolgáló szabályok az állampolgárok és az alapvető állami intézmények alapjogait és szabadságait korlátozták vagy befolyásolták, ezért azokat hivatalosan csak a parlament fogadhatja el, e célra soron kívüli kormányrendelet nem alkalmazható". ${ }^{33} \mathrm{~A}$ cseh bírósági rendszer meglehetősen aktív volt a kormány, az egészségügyért felelös minisztérium és az egyéb állami szervek által elrendelt intézkedések törvényességi

38 Cipruson példának okáért a kormány felhatalmazást kapott, hogy intézkedéseket fogadjon el a Covid-19-világjárvány leküzdésére. Ugyan nem került sor az alkotmányban szereplő szükséghelyzet kihirdetésére, de a kormány alkalmazta a járványok ellenőrzéséről szóló törvényt. Lásd: Bizottsági Szolgálati Munkadokumentum: 2020. évi jogállamisági jelentés. Országfejezet - A jogállamiság helyzete Cipruson [...] Brüsszel, 2020. 09. 30. SWD (2020) 312 final, 11. o.; lásd továbbá: Ungvári-Hojnyák, 2020.

39 Council of Europe: Notifications under Article 15 of the Convention in the Context of the COVID-19 Pandemic. Elérhető: www.coe.int/en/web/conventions/full-list///conventions/webContent/62111354 (Letöltve: 2020. november 8.).

40 Wanat-Eder, 2020; Kirst, 2020.

41 Bizottsági Szolgálati Munkadokumentum: 2020. évi jogállamisági jelentés. Országfejezet - A jogállamiság helyzete Máltán [...] Brüsszel, 2020. 09. 30. SWD (2020) 317 final; Bizottsági Szolgálati Munkadokumentum, 2020. évi jogállamisági jelentés. Országfejezet - A jogállamiság helyzete Belgiumban [...] Brüsszel, 2020. 09. 30. SWD (2020) 300 final.

42 Bizottsági Szolgálati Munkadokumentum, 2020. évi jogállamisági jelentés. Országfejezet - A jogállamiság helyzete Romániában [...] Brüsszel, 2020. 09. 30. SWD (2020) 322 final.

43 152/2020. sz., 2020. május 6-i határozat. 
és alkotmányossági felülvizsgálatában, több intézkedést is hatályon kívül helyezve, ${ }^{44}$ jóllehet a szükséghelyzetet elrendelő kormányhatározat kiállta a próbát. Akad pozitív példa is a helyzet kezelésére: Írországban az Európai Bizottság szerint „a Covid-19-világjárvány kezelésére irányuló jogszabályi intézkedések elfogadása a rendes jogalkotási eljárás keretein belül, célirányos megbeszélések folytatásával történt". ${ }^{45}$

A különleges jogrendi helyzetek fenntartásának indokoltsága a tagállamok túlnyomó többségében jellemzően júniusban került felülvizsgálatra, és a megszúnésük kihirdetése is ezen időpontra datálható. Több tagállam azonban továbbra is a készültség magasabb fokát tartotta fenn: Magyarország például járványügyi készültséget vezetett be 2020 . június 18 -án. ${ }^{46} \mathrm{~A}$ bevezetett enyhébb intézkedésekkel kapcsolatosan felmerült leggyakoribb kritika az volt, hogy azok nem szolgálják a jogbiztonságot, illetve bújtatott módon továbbra is lehetôvé teszik a rendeleti úton történő kormányzást. E kritikát a francia, a holland és a magyar szabályozás is megkapta. A luxemburgi szabályozás a koronavírus tüneteit mutató személyek kényszergyógykezelését lehetôvé tevő szabály miatt járta meg a legfelsőbb bírói fórumot. ${ }^{47}$

Az enyhítéseket az ősz folyamán újabb szigorítások követték: egyre több tagállam vezette vissza a különleges jogrendi szabályokat, hazánk kormánya 2020. november 4-én $n^{48}$ ezúttal kevesebb kritikát kiváltva, mint tavasszal.

$\mathrm{Az}$ EuB elé 2020. május 28-án nyújtották be az első, a tagállamok által elrendelt különleges jogrendi helyzet EU-konform jellegét firtató előzetes döntéshozatal iránti kérelmet. ${ }^{49}$ Az előterjesztő tagállami bíróság lényegében azt kérdezte az EuB-tól, hogy a nemzeti szükségállapotot kihirdető olasz törvényerejû rendelet és az annak hatályát meghosszabbító jogi aktus, amelyek gyakorlatilag az igazságszolgáltatás leállását - és ezzel együtt az alapeljárásban történő ítélethozatal meghiúsulását - eredményezték, sértik-e a kérdést előterjesztő bíróság függetlenségét és a tisztességes eljárás elvét. Továbbá, ezekhez kapcsolódóan sértik-e az egyén méltósághoz, szabadsághoz és a biztonsághoz, a törvény előtti egyenlőséghez, a megkülönböztetésmentességhez, a méltányos és megfelelő munkakörülményekhez, a társadalombiztosítási ellátásokhoz való hozzáféréshez, valamint a szabad mozgáshoz és tartózkodáshoz füződő jogait, amint azokat az Alapjogi Charta garantálja? A 2020. december 10-i végzésében ${ }^{50}$ az $\mathrm{EuB}$ a keresetet - amint az az ítélkezési gyakorlata ${ }^{51}$ alapján várható volt - elutasította, arra hivatkozva, hogy az alapeljárás tényállásának - egy közlekedési bal-

44 Bizottsági Szolgálati Munkadokumentum: 2020. évi jogállamisági jelentés. Országfejezet - A jogállamiság helyzete Csehországban [...] Brüsszel, 2020. 09. 30. SWD (2020) 302 final.

45 Bizottsági Szolgálati Munkadokumentum: 2020. évi jogállamisági jelentés. Országfejezet - A jogállamiság helyzete Îrországban [...] Brüsszel, 2020. 09. 30. SWD (2020) 306 final.

46 283/2020. (VI. 17.) Korm. rendelet a járványügyi készültség bevezetéséről.

47 FRA, 2020, 16. o.

48 478/2020. (XI. 3.) Korm. rendelet a veszélyhelyzet kihirdetéséről.

49 C-220/20. sz. XX kontra OO ügy (a beadvány beérkezett: 2020. május 28-án).

$50 \mathrm{C}-220 / 20$. sz. XX kontra OO ügy, a Bíróság végzése, 2020. december 10.

51 Somssich, 2018. 
esetnek - nincsenek határon átnyúló elemei, és az uniós jog alkalmazására sem került sor. Utóbbi tekintetében az EuB nem találta meggyőzőnek a tagállami bíróság azon érvelését, hogy az érintett olasz jog uniós irányelveket hajt végre.

\section{A különleges jogrendre tekintettel bevezetett, a belső piaci szabadságokat érintő tagállami korlátozások kapcsán az Európai Bizottság részleges fellépése, koordináló szerepe}

\subsection{Az EU fellépése járványügyi kérdésekben}

Az EU kezdeti fellépését a koronavírus-járvány kezelésében számos kritika és vád érte, kiábrándítónak bélyegezve azt. Egyes vélemények egyenesen azzal vádolták az Európai Uniót, hogy cserbenhagyta a tagállamait;52 ellentétben Kínával és Oroszországgal, ahonnan a válság kezdetén a tagállamok segítséget remélhettek és kaptak. ${ }^{53}$ Olaszország esetében - ismerve a 2020 első hónapjaiban ott kialakult helyzetet - egyáltalán nem meglepő, hogy növekedett az euroszkeptikusok tábora. ${ }^{54} \mathrm{~A}$ francia és a német lakosság körében is nőtt az euroszkepticizmus, jóllehet kisebb mértékben. ${ }^{55}$

A tisztánlátást akadályozó indulatokat hátrahagyva fel kell ismerni azonban, hogy az EU intézményeinek kezét kötötték az alapító szerződések rendelkezései. Azoknak a kialakult helyzetre tekintettel való értelmezése - adott esetben újraértelmezése - idôt vett igénybe. Az alapító szerződések vonatkozó rendelkezései - többek között a hatáskör-átruházás elvét rögzítő EUSZ 5. cikk (1)-(2) bekezdése, valamint az EU-t „az emberi egészség védelme és javítása terén" támogató, összehangoló vagy kiegészítő intézkedések elfogadására felhatalmazó EUMSZ 6. cikk - értelmében az EU cselekvési lehetőségei meglehetősen korlátozottak: főszabályként kötelező erejü döntéseket nem hozhat járványügyi kérdésekben. Az egészségügy terén meglévő hatásköreit az EUMSZ 168. cikke (Népegészségügy), valamint az 1082/2013/EU határozat ${ }^{56}$ rögzítik. Az EUMSZ 168. cikk (1) bekezdése értelmében „[...] az Unió fellépése [...] kiegészíti a nemzeti politikákat [...]”. A (7) bekezdés pedig egyértelmúen rögzíti, hogy az egészségügyi szolgáltatások és az orvosi ellátás megszervezése

52 Wojtyczka, 2020.

53 Ismerve a világ müködését, a millió dolláros kérdés, hogy e segítség mennyire volt önzetlen. Lásd az Európai Bizottság által kiadott, A Covid-19-cel kapcsolatos dezinformáció kezelése - lássuk a valós tényeket címú dokumentumot, illetve az Európai Parlament Kutatószolgálatának tájékoztatóját (Bentzen, 2020).

54 Scazzieri, 2020.

55 Tidey, 2020.

$56 \mathrm{Az}$ Európai Parlament és a Tanács 1082/2013/EU határozata (2013. október 22.) a határokon átterjedő súlyos egészségügyi veszélyekrôl és a 2119/98/EK határozat hatályon kívül helyezéséről. EGT-vonatkozású szöveg (HL L 293, 2013. 11. 05., 1-15 0.) - amely a korábbi 2119/98/EK határozatot (HL L 268, 1998. 10. 03., 1-7. o.) váltotta fel. 
tagállami hatáskörben van. Mindez az Alapjogi Charta 35. cikkében is megerősítésre kerül a „nemzeti jogszabályokban és gyakorlatban megállapított feltételek mellett” kitétel révén. Az említett 1082/2013/EU határozat elősegíti a tapasztalatok és jó gyakorlatok megosztását a tagállamok között; továbbá segíti a különféle egészségügyi fenyegetések kivédését célzó nemzeti stratégiák kidolgozását és azok interoperabilitását. ${ }^{57}$

A fentiek alapján jól látható tehát, hogy a járványügyi védekezés az alapító szerződésekben rögzítettek szerint főszabályként a tagállamok feladata, az EU-nak sem hatásköre, sem erőforrásai nincsenek az egészségügyi szolgáltatások és az orvosi ellátás megszervezésére. Ugyanakkor az EU intézményeinek a kezdeti hezitálást felváltó határozott fellépése - és az azokat elemző Purnhagen és szerzőtársai által jegyzett tanulmány ${ }^{58}$ is - bizonyítja, együtt, mintegy hálóként szemlélve a hatásköröket megállapítható, hogy az EU meglehetősen széles körû hatáskörökkel rendelkezik, ${ }^{59}$ jóllehet e hatásköröket az egészségügyi területen kívül kell keresni. ${ }^{60}$ Ennek megfelelően az EU támogató, összehangoló vagy kiegészítő intézkedéseit - amelyek „az emberi egészség védelmét és javítását” célozzák - az egységes belső piac múködése szempontjából érdemes megközelíteni. Az EUMSZ 114. cikk (1) bekezdése alapján az EU a kereskedelmet akadályozó vagy a versenyt torzító tényezők felszámolását célzó intézkedéseket fogadhat el. Ezen intézkedések közvetlenül vagy közvetetten szolgálhatják az emberi egészség védelmét és javítását: ${ }^{61}$ az EUMSZ 114. cikk (3) bekezdése értelmében az EU egységes belső piacot érintő rendelkezéseinek kifejezetten védelemben kell részesíteniük az emberi egészséget, vagy javítaniuk kell azt. Ennek keretében, amenynyiben új tudományos tények nyernek bizonyítást, az EU kötelezettsége a harmonizált intézkedéseinek kiigazítása. ${ }^{62}$ Példának okáért, amennyiben bármilyen új bizonyíték merülne fel a koronavírus ételcsomagolás útján történő terjedéséről, az EU intézményeinek ki kell igazítaniuk az ételek csomagolására vonatkozó egészségügyi szabályozást. Az EU-nak ezenfelül lehetősége van ösztönző intézkedéseket elfogadni, a jelenlegi helyzetben például a Covid-19 elleni küzdelemben elért bizonyos eredményekhez kötni a plusz uniós források lehívását. Purnhagen és szerzőtársai ezenfelül - az első ránézésre - határokon átnyúló elemet nélkülöző tagállami intézkedések - amilyenek az iskolabezárások és a kijárási korlátozások esetén is megállapíthatónak tartják az EU hatásköreit, többek között a Dassonville-63 és a Carpenter-64 ügyekre hivatkozva. Álláspontjukat arra alapozzák, hogy a kijárási korlátozás

57 A részleteket lásd az Európai Bizottság honlapján: https:/ec.europa.eu/health/security/overview_hu (Letöltve: 2020. október 17.).

58 Purnhagen, 2020.

59 Purnhagen, 2020, 303. o.

60 Purnhagen, 2020, 303. o.

61 Lásd: C-376/98. sz. Németországi Szövetségi Köztársaság kontra Európai Parlamentés az Európai Unió Tanácsa (dohánytermékek reklámja) ügy, ítélet, 2000. október 5.

62 Lásd még a C-491/01. sz. British American Tobacco-ügyet.

63 C-8/74. sz. Dassonville-ügy, ítélet, 1974. július 11.

64 C-60/00. sz. Carpenter-ügy, ítélet, 2002. július 11. 
példának okáért akadályozhatja a határokon keresztül ingázó munkavállalókat abban, hogy elérjenek a munkahelyükre.

Purnhagen és szerzőtársai további példákat sorolnak fel az EU koordináló szerepére, amelyeket az eltelt időben a gyakorlat is igazolt.

Először is, a 2019/98/EK határozat ${ }^{65}$ óta az EU több esetben koordinálta a tagállamok

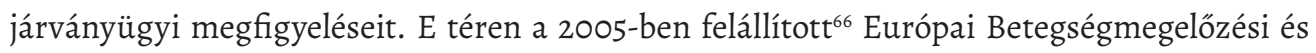
Járványvédelmi Központ, ${ }^{67}$ valamint az Európai Bizottságból és az egyes tagállamok illetékes közegészségügyi hatóságaiból álló Korai Figyelmeztető és Gyorsreagáló Rendszer ${ }^{68}$ is jól vizsgázott a szakirodalom megítélése szerint. ${ }^{69} \mathrm{~A}$ tagállamok az utóbbi keretében hangolták össze az intenzív ellátási férőhelyeket és a megfelelően képzett egészségügyi személyzetet érintő igényeket és felajánlásokat. ${ }^{70} \mathrm{Az}$ Európai Bizottság a 2020. április 3-án közzétett iránymutatásaiban ${ }^{71}$ részletezte a határokon átnyúló egészségügyi segítségnyújtás koordinálása kapcsán figyelembe veendő szabályokat. Többek között arra buzdította a tagállamokat, hogy tekintsenek el egyes, a területet szabályozó uniós jogi aktusok ${ }^{72}$ bizonyos rendelkezéseinek alkalmazásától: „A Bizottság felszólítja a tagállamokat, hogy pragmatikus megközelítéssel kezeljék a sürgős ellátást igénylő betegek esetét [...]."73

Másodsorban az EU több esetben bátorította a tagállamokat az együttmúködésre annak érdekében, hogy azok egységes utasszúrő intézkedéseket fogadjanak el, ideértve az utasok testhőmérsékletének szưrésére vonatkozó szabályok egységessé tételét. A jogalapot az EUMSZ 168. és 100. cikk (2) bekezdése, illetve az ezek alapján elfogadott, a polgári légi közlekedés védelmének közös szabályairól szóló európai parlamenti és tanácsi rendelet ${ }^{74}$

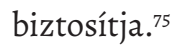

65 Az Európai Parlament és a Tanács 2119/98/EK határozata (1998. szeptember 24.) a Közösségben a fertőző betegségek járványügyi felügyeleti és ellenőrzési hálózatának létrehozásáról (HL L 268, 1998. 10. 03. 1-7. o.) (hatályon kívül).

66 Az Európai Parlament és a Tanács 851/2004/EK rendelete (2004. április 21.) az Európai Betegségmegelőzési és Járványvédelmi Központ létrehozásáról (HL L 142., 2004. 04. 30., 1-11. 0.).

67 European Centre for Disease Prevention and Control (ECDC).

68 Early Warning and Response System (EWRS).

69 Townend et al., 2020.

70 Lásd a német Külügyminisztérium honlapját az intenzív ellátásra szoruló olasz és holland betegek átvételéről. - German Federal Foreign Office, How Germany is Helping Europe in the Covid-19 Crisis (24. 03. 2020) [Onine]. Elérhető: www.auswaertiges-amt.de/en/aussenpolitik/europa/maas-corona-europe/2328352 (Letöltve: 2020. október 29.).

71 Európai Bizottság: Iránymutatások a COVID-19-válság összefüggésében folytatott, határokon átnyúló egészségügyi együttmüködésre irányuló uniós sürgősségi segítségnyújtásról (COM 2020/C 111 I/O1, 2020. 04. 03.).

72 Az Európai Parlament és a Tanács 883/2004/EK rendelete (2004. április 29.) a szociális biztonsági rendszerek koordinálásáról (HL L 166., 2004. 04. 30., 1. o.); Az Európai Parlament és a Tanács 2011/24/EU irányelve (2011. március 9.) a határon átnyúló egészségügyi ellátásra vonatkozó betegjogok érvényesítéséről (HL L 88., 2011. 04. 04., 45-65. о.).

73 COM 2020/C 111 I/O1, para. 4.

74 Az Európai Parlament és a Tanács 300/2008/EK rendelete (2008. március 11.) a polgári légi közlekedés védelmének közös szabályairól és a 2320/2002/EK rendelet hatályon kívül helyezéséről (HL L 97, 2008. 04. 09., 72-84. 0.).

75 A légi közlekedés szabályairól részletesen lásd: Angyal, 2011. 
Harmadrészt az EU-nak lehetősége van pénzügyi finanszírozást nyújtani - többek között a strukturális alapokon keresztül -, annak ellenére is, hogy az EU költségvetése arányaiban meglehetősen korlátozott. ${ }^{76} \mathrm{E}$ körben kiemelendő, hogy az EUMSZ 180. és 181. cikkei alapján az EU hatáskörrel rendelkezik orvosi kutatások finanszírozására, ideértve a vakcinafejlesztést. Purnhagen és szerzőtársai e téren is helyesen „jósolták meg” az EU hatásköreit: az Európai Unió Bizottsága 2020. október 15-én adta ki a Felkészülés a Covid-19-oltási stratégiákra és az oltóanyagok alkalmazására címú közleményét,77 amelyben a 2020 tavasza óta tartó tárgyalások eredményeit összegzi. Az Európai Bizottság a Szükséghelyzeti Támogatási Eszköz finanszírozásával ${ }^{78}$ három szerződést írt alá - az AstraZeneca, a Sanofi-GSK és a Johnson\&Johnson vállalatokkal -, más vakcinagyártókkal ${ }^{79}$ pedig hasonló megállapodásokról folytat tárgyalásokat. Az Európai Bizottság célja a széles vakcinaportfólió kialakítása, tekintve, hogy előre lehetetlen eldönteni, hogy a potenciális oltóanyagok közül melyik fogja sikerrel zárni a fejlesztési és engedélyezési eljárást - ami az uniós piacon való forgalomba hozatal előfeltétele -, illetve melyik bizonyul hatékonynak. A változatos portfólió révén maximalizálható az európai polgárok számára a vakcinához való minél gyorsabb hozzáférés lehetősége. ${ }^{80}$

Negyedrészt, az EUMSZ 122. cikk (1) bekezdése értelmében a Tanácsnak a Bizottság javaslata alapján módjában áll határozni a gazdasági helyzetnek megfelelő intézkedésekről, különösen, ha egyes termékek esetén súlyos ellátási gondok merülnek fel. A (2) bekezdés értelmében pedig a Tanács uniós pénzügyi támogatást nyújthat annak a tagállamnak, amely általa nem befolyásolható rendkívüli eseményekből eredő nehézséggel küzd, illetve ahol e nehézségek veszélye áll fenn.

Végül, de nem utolsósorban az Európai Bizottságnak módjában áll az állami támogatások tilalma alól kivételeket biztosítani.

\subsection{Azáruk szabad mozgásának korlátozása}

Az influenza-védőoltásokra kivetett tagállami exporttilalmakra is tekintettel ${ }^{81}$ érdemesnek tartjuk in medias res az egészségügyi felszerelések és gyógyszerek kivitelére a tag-

76 Marinkás, 2020; Marinkás, 2018.

77 Európai Bizottság: Felkészülés a COVID-19 oltási stratégiákra és az oltóanyagok alkalmazására. Brüsszel, 2020. 10. 15. COM (2020) 680 final.

78 A Tanács (EU) 2016/369 rendelete (2016. március 15.) az Unión belül szükséghelyzeti támogatás nyújtásáról (HL L 70., 2016. 03. 16., 1-6. o.).

79 CureVac, Moderna és Pfizer-BioNTech.

$80 \operatorname{COM}(2020) 680$ final, 3. o.

81 Tekintve, hogy 2020 őszén megugrott az igény az influenzaoltásra, a többletkészletekkel még rendelkező országok - többek között Németország és Belgium - exporttilalmat vezetett be a védőoltásokra. Lásd: Portfolio.hu: Magyarország egyelőre nem kap több influenza elleni vakcinát. 2020. október 29. Elérhető: www.portfolio. hu/gazdasag/20201029/magyarorszag-egyelore-nem-kap-tobb-influenza-elleni-vakcinat-454966 (Letöltve: 2020. november 28.). 
államok által bevezetett korlátozásokkal kezdeni a kérdés tárgyalását annak érdekében, hogy érzékelhető legyen, az egységes belső piac szabályai milyen mértékben hatják át az élet minden területét. E helyütt érdemes emlékeztetni, hogy az előző pontban írottaknak megfelelően járványügyi intézkedések terén az EU nem rendelkezik jogosultsággal kötelező erejú döntések meghozatalára. Amint azonban az Európai Bizottság a 2020. március 13-án kelt, A Covid-19-járvány nyomán hozott koordinált gazdasági válaszintézkedések címú kommünikéjében ${ }^{82}$ emlékeztetett, a fent említett egészségügyi felszerelések és gyógyszerek árunak számítanak, következésképpen alkalmazandók rájuk az áruk szabad mozgásának szabályai. Továbbá az Európai Bizottság álláspontja szerint a tagállami korlátozások nem veszik figyelembe az ellátási lánc integrált voltát, és azzal a veszéllyel fenyegetnek, hogy e javak nem jutnak el azon helyekre, ahol az adott pillanatban a legnagyobb szükség van rájuk. Az Európai Bizottság álláspontja szerint az egészségügyi felszerelésekre bevezetett exportkorlátozások az arányosság elvével ellentétesek, és ennek megfelelóen fogja azokat kezelni. ${ }^{83}$ Purnhagen és szerzôtársai ennek kapcsán jegyzik meg, hogy itt tulajdonképpen az alapszabadságok és az azok alóli kivételek hagyományos megközelítésének megfordításáról van szó: ahelyett, hogy a tagállamok az EUMSZ 36. cikkén alapuló jogukat gyakorolva korlátoznák az alapszabadságok érvényesülését - azaz egészségügyi okokból korlátoznák az áruk szabad mozgását -, az EU korlátozza a tagállamokat az alapító szerződésből eredő joguk gyakorlásában, annak érdekében, hogy érvényt szerezzen a tagállamok közötti szolidaritásnak, ${ }^{84}$ illetve biztosítsa az egészségügyi felszerelés eljutását a megfelelő célországokba.

A fuvarozási és ellátási láncok sérülékenysége egyebekben rövid úton világossá vált: 2020 áprilisára a közúti fuvarok száma az előző évi adatokhoz viszonyítva több mint 50\%-kal esett vissza Spanyolországban, 46\%-kal Franciaországban és 37\%-kal Olaszországban, súlyos károkat okozva a gazdaságban..$^{85} \mathrm{~A}$ visszaesésnek két alapvető oka volt: egyrészről a nem létfontosságú iparágak leállása miatt a kereslet drasztikusan megcsappant, másrészről a kínálatban is hiány állt be. Utóbbi amiatt következett be, hogy a külföldön dolgozó közúti fuvarozók egy része otthagyta a munkáját, és elindult haza, mielött a lezárások és a további szigorítások miatt egy idegen országban ragadna a megélhetés lehetősége nélkül. Jóllehet a kereslet és a kínálat idôvel egyensúlyba került azáltal, hogy a közúti fuvarozás átorientálódott azon iparágak irányába, ahol igény mutatkozott rá, erre jellemzően csak a nagyobb vállalkozások voltak képesek, amelyek általában széles ügyfélkörrel dolgoznak, így egy-egy ügyfél kiesése nem sodorja válságba a vállalatot. A kisebb ügyfélkörrel rendelkező vállalko-

82 Európai Bizottság: A COVID-19-járvány nyomán hozott koordinált gazdasági válaszintézkedések. Brüsszel, 2020. 03. 13. COM (2020) 112 final.

83 COM (2020) 112, para. 3.1.

84 Purnhagen, 2020, 304. o.; lásd még COM (2020) 112.

$85 \mathrm{Ez}$ a jelen fejezet szerzőjének értelmezésében bizonyította az alapító atyák azon elképzelését, hogy a gazdasági érdekek összefonódása menthetetlenül együttmüködésre kényszeríti az integrációban részt vevő államokat. Szerencse a szerencsétlenségben, hogy ennek bizonyításához nem volt szükség háborúra - elég volt egy vírus. 
zások nem minden esetben voltak képesek ilyen rugalmasan reagálni. ${ }^{86} \mathrm{~A}$ gazdasági károk komolyak voltak: 2020. júniusi becslések ${ }^{87}$ szerint az ágazat helyreállításához hozzávetőlegesen 75 milliárd € összegú támogatásra lenne szükség.

Az Európai Bizottság az egészség védelmét, valamint az áruk és alapvető szolgáltatások rendelkezésre állását biztosító határigazgatási intézkedésekre vonatkozó iránymutatáshoz ${ }^{88}$ kapcsolódva március 23-án elfogadta a zöld sávok végrehajtásáról szóló közleményt. ${ }^{89} \mathrm{~A}$ közlemény alapkoncepciója az ellátási láncok folyamatos múködésének biztosítása az egységes piacon, valamint az esetleges hiányok elkerülése. Az Európai Bizottság amellett, hogy intézkedéseket javasolt az áruszállításban dolgozók egészségének védelme érdekében, a tagállamokat a szállító jármúvek határon való, fölösleges intézkedések nélküli átengedésére szólította fel. A Bizottság álláspontja szerint az áruszállító járműveket érintő várakozási idő összességében nem haladhatja meg a 15 percet, tekintet nélkül az általuk szállított árukra. ${ }^{90}$

E zöld sávok továbbfejlesztésével kapcsolatban az Európai Bizottság október 28-án adott ki újabb közleményt a járvány újbóli felerősödésére való tekintettel. ${ }^{91} \mathrm{~A}$ Bizottság a dokumentumban megerősítette a korábban kitűzött célok érvényességét, valamint az adminisztráció és az ellenőrzések elektronikus úton történő végrehajtására ösztönözte a tagállamokat. Amint az Európai Bizottság megjegyezte, a tagállamok egy része ezt már sikeresen meg is tette az első hullám idején. A Tanács 2020 . október 13-i ajánlása92 19. pontjának b) alpontjára utalva emlékeztette a tagállamokat, hogy a szállítószemélyzetet minden tagállami hatóságnak kulcsfontosságú munkavállalókként és szolgáltatókként kell megjelölnie és elismernie, és az ilyen munkavállalók nem kötelezhetők karanténra, amennyiben e kulcsfontosságú feladatukat látják el.

\subsection{A személyek szabad mozgásának korlátozása: tagállami határzárak, egészségügyi karantén elrendelése új belépőknek, ingázó munkavállalókra vonatkozó kivételek}

A személyek szabad mozgása - lánykori nevén a munkavállalók szabad mozgása - az egységes belső piac múködésének másik kiemelt fontossággal bíró alapköve, amelyet számos

86 The State of Europe's Road Freight Market - 4 Key Insights from Sixfold's Covid-19 Map by Transport Intelligence, May 5 , 2020. Elérhető: www.ti-insight.com/briefs/the-state-of-europes-road-freight-market-4-key-insights-fromsixfolds-Covid-19-map/ (Letöltve: 2020. november 14.).

87 Marle, 2020.

88 Európai Bizottság: COVID-19-Az egészség védelmét, valamint az árukés alapvetô szolgáltatások rendelkezésre állását biztosító határigazgatási intézkedésekre vonatkozó iránymutatások. Brüsszel, 2020. 03. 16. C (2020) 1753 final.

89 European Commission: Coronavirus: Commission Presents Practical Guidance to Ensure Continuous Flow of Goods across EU via Green Lanes. Brussels, 23 March 2020 IP/20/510.

90 Mindez utólag meglehetősen ambiciózus célkitûzésnek hat, tekintve, hogy márciusban a 10-15km hosszú sorok sem voltak ritkák az egyes határátkelőknél.

91 Európai Bizottság: A gazdaság müködőképességének a COVID-19-világjárvány újbóli felerősödése során történő fenntartása érdekében a közlekedési zöld sávokfejlesztéséről. Brüsszel, 2020. 10. 28. COM (2020) 685 final.

92 A Tanács (EU) 2020/1475 ajánlása (2020. október 13.) a szabad mozgásnak a COVID-19-világjárvány miatti korlátozására vonatkozó koordinált megközelítéséről, HL L 337., 2020. 10. 14., 3. o. 
alapító szerződésbeli és egyéb elsődleges jogforrásnak tekinthető rendelkezés - EUMSZ 45. cikk (1) bekezdése, a „schengeni vívmányok"93 -, valamint számos másodlagos uniós jogforrás - köztük a 2004/38/EK irányelv ${ }^{94}$ - garantál. A tagállamok ezen alapszabadság tekintetében is fenntartották azon jogukat, hogy közrendi, közbiztonsági vagy közegészségügyi okokból - mint amilyen egy fertőző betegség - korlátozhassák azt, és ideiglenes jelleggel visszaállítsák a határellenőrzést. Amint azt Purnhagen és szerzőtársai áprilisban „megjósolták", az EU e téren is rendelkezik a szükséges hatáskörökkel annak érdekében, hogy hatékonyan hangolja össze a tagállami intézkedéseket. A cikkben felvázoltak az ősz folyamán realizálódtak, amikor az EU egységes szabályozást vezetett be az országok besorolására, az utazási korlátozások bevezetésére és a határok lezárására.

Az áruk szabad mozgása kapcsán a 2020. március 16- i, a határigazgatási intézkedésekre vonatkozó bizottsági iránymutatásban az Európai Bizottság emlékezteti a tagállamokat, hogy bár a schengeni határellenőrzési kódex ${ }^{95} 25$. cikk (1) bekezdése értelmében a tagállamoknak jogukban áll ideiglenesen visszaállítani a belső határellenőrzéseket,96 az egészségügyi ellenőrzések (például testhőmérséklet-mérés) és egyéb intézkedések nem feltétlenül követelnek ilyen drasztikus korlátozásokat. Sőt, a határellenőrzés visszaállítása felesleges torlódásokat okozhat a határokon, ami felgyorsíthatja a vírus terjedését, ${ }^{97}$ valamint fokozza a gazdasági károkat. ${ }^{98}$ Amennyiben a tagállamok mégis a határellenőrzések ideiglenes bevezetése mellett döntenek, úgy biztosítaniuk kell, hogy a kulcságazatokban dolgozó, napi szinten ingázó személyek számára a határok továbbra is átjárhatók maradjanak. ${ }^{99}$ A tagállamoknak továbbá ügyelniük kell arra, hogy a bevezetett korlátozó intézkedéseket - a Gebhard-ügyben ${ }^{100}$ lefektetett szabályoknak megfelelően - egyrészt megkülönböztetés nélkül alkalmazzák; másrészt a bevezetésüket közérdekú kényszerítô indokok tegyék szükségessé; harmadrészt alkalmasak legyenek az általuk elérni kívánt cél megvalósításának biztosítására; végezetül pedig ne lépjenek túl az annak megvalósításához szükséges mértéken.

A járványhelyzet enyhülésével az Európai Bizottság 2020. május 13-án adta ki az iránymutatásait ${ }^{101}$ a turisták, az utazók és a vállalkozások számára, amelyben részletezi, hogy a tagállamok milyen egészségügyi óvintézkedések tiszteletben tartása mellett oldhatják fel

93 Schengeni megállapodás (1985. június 14.); schengeni egyezmény (1990. június 19.).

94 Az Európai Parlament és a Tanács 2004/38/EK irányelve (2004. április 29.) az Unió polgárainak és családtagjaiknak a tagállamok területén történő szabad mozgáshoz és tartózkodáshoz való jogáról [...] (HL L 158, 2004. 04. 30., 77-123. o.)

$95 \mathrm{Az}$ Európai Parlament és a Tanács (EU) 2016/399 rendelete (2016. március 9.) a személyek határátlépésére irányadó szabályok uniós kódexéről (HL L 77., 2016. 03. 23., 1-52. o.).

96 Amelyrôl a kódex (2016/399/EU rendelet) 27. cikke által elő́rtak szerint elôzetesen értesíteniük kell a többi tagállamot és az Európai Bizottságot.

97 C (2020) 1753 final, paras. 18-25.

98 Meninno-Wolff, 2020.

99 C (2020) 1753 final, paras. 18-25.

100 Lásd: C-55/94. sz. Gebhard-ügy, ítélet, 1995. november 30., para. 37.

101 Európai Bizottság: Turizmusés közlekedés: a Bizottság iránymutatása arról, hogy miként lehet a biztonságot szem elött tartva újra utazni, és beindítani az európai turizmust 2020-ban és azon túl. Brüsszel, 2020. május 13. (IP/20/854). 
az utazási korlátozásokat. A turisztikai cégek tevékenységének újraindítása céljából pedig június 15-én elindította a Re-open Europe platformot ${ }^{102}$ annak érdekében, hogy elősegítse az utazás és idegenforgalom biztonságos újraindítását, illetve biztosítsa az utazni kívánó közönség tájékoztatását. Problémaként merült fel ugyanakkor, hogy a tagállamok által bevezetett eltérő intézkedések - például a kötelező karantén időtartamára vonatkozóan -, illetve az eltérô szempontok alapján alkalmazott zöld, narancssárga és piros besorolás, valamint a tagállamok által saját hatáskörben elrendelt határzárak ${ }^{103}$ koordinálatlansága potenciálisan veszélyeztették a személyek szabad mozgását. A problémák elhárítására az Európai Bizottság 2020. szeptember 4-i javaslatában ${ }^{104}$ egy tanácsi ajánlás meghozatalát kezdeményezte, amely végül 2020. október 13-án került kibocsátásra A szabad mozgásnak a Covid-19-világjárvány miatti korlátozására vonatkozó koordinált megközelitésról címen. Jóllehet a határzárak elrendelésének joga az alapító szerződésekben foglaltaknak megfelelően továbbra is tagállami hatáskörben maradt, az ajánlás a 8-12. pontjaiban meghatározza azokat a kritériumokat, amelyeket a tagállamoknak figyelembe kell venniük a korlátozások bevezetésekor - jelesül: az új esetek száma, pozitív teszteredmények aránya, tesztelési arány -, illetve a tagállamok adatszolgáltatási kötelezettségét, amely alapján az Európai Betegségmegelőzési és Járványvédelmi Központ meghatározza az egyes országok besorolását. A 14-16. pontok rögzítik a tagállamok azon kötelezettségét, hogy az általuk tervezett korlátozó intézkedésekről a többi tagállamot és az Európai Bizottságot tájékoztassák, valamint hogy előzetesen koordinálják a bevezetendő intézkedéseket.

\subsection{Könnyítések a szolgáltatások szabad mozgásának biztosítása érdekében}

A szolgáltatások nyújtásának szabadságát az EUMSZ 56. cikke garantálja, a definícióját az 57. cikke rögzíti. Az 58. cikk értelmében a közlekedés területén a szolgáltatásnyújtás szabadságára a közlekedésre vonatkozó cím (EUMSZ VI. cím) rendelkezései az irányadók. A közlekedés területén azonban értelemszerủen az EUMSZ 169. cikk (1) bekezdésében az EU számára garantált hatásköröket is megfelelően figyelembe kell venni. A (2) bekezdés értelmében az EU az EUMSZ 114. cikke alapján a következő módokon járul hozzá az EUMSZ 169. cikk (1) bekezdésében rögzítettek megvalósulásához: a belső piac megvalósításával öszszefüggésben elfogadott intézkedések, illetve a tagállami politikákat támogató, kiegészítő és figyelemmel kíséró intézkedések révén.

Tekintve, hogy a modern gazdaságokban a GDP hozzávetôleg kétharmadát a szolgáltatóipar adja - és ezen belül is a járvány által leginkább sújtott turizmus, közlekedési ágazat, szállóvendég-fogadás, éttermi szolgáltatások, szabadidős tevékenységek, illetve

102 https://reopen.europa.eu/hu (Letöltve: 2020 . november 14.).

103 Nicolás, 2020.

104 Európai Bizottság: Javaslat a COVID-19-világjárványra való reagálás keretében a szabad mozgás korlátozására vonatkozó összehangolt megközelitésről. Brüsszel, 2020. 09. 04. COM (2020) 499 final. 
kultúra az EU GDP-jének közel 10\%-át teszi ki ${ }^{105}$-, az Európai Bizottság e téren is megfogalmazta ajánlásait a koordinált fellépés érdekében. A fentebb már említett, 2020. május 13-i iránymutatásaiban a Bizottság tehát a turizmus mellett az ahhoz szükséges közlekedés kérdésével is foglalkozott. Az uniós szabályozás értelmében a menetjegyek (repülőgép, vonat, busz, komp), illetve az utazási csomagok törlése esetén az utazóknak jogukban áll választani a visszatérítés módját illetően, amely történhet készpénzben vagy utalvány formájában. Tekintve, hogy a válság az utazásszervezőket is komoly pénzügyi nehézségek elé állította, az Európai Bizottság a fogyasztó pénzvisszatérítéshez való jogának megerősítésén kívül az utalványos rendszer népszerúsítése mellett tette le a voksát, amely mindkét fél - azaz a szolgáltató és a szolgáltatást igénybe vevő - számára megfelelő kompromisszumot jelenthet. A Bizottság meghatározta az utalványokkal kapcsolatos fogyasztóvédelmi szabályokat. ${ }^{106}$

Jóllehet az Európai Bizottság javaslatai alkalmasak voltak a károk mérséklésére, hosszú távon minden bizonyosság szerint tartós reformokra lesz szükség az eseti jellegú tũzoltás helyett. Az Európai Unió Tanácsának soros elnöki tisztét ellátó Németország elnökségi programjának első helyén a koronavírus okozta válság következményeinek hosszú távú kezelése, valamint a gazdasági és társadalmi talpra állás szerepel. Ezzel összhangban a jelenlegi trojka a 2020. október 12-én kiadott közös közleményében ${ }^{107}$ a hatályos fogyasztóvédelmi szabályoknak a koronavírus-járvány alapján leszû́rt tanulságok fényében történő felülvizsgálatát és megreformálását irányozta elő.

A Bizottság és a Tanács mellett az unió ügynökségei is iránymutatásokkal, tanácsokkal látták el a gazdasági szereplőket és az uniós polgárokat. A biztonságos légi utazás feltételeit illetően az Európai Repülésbiztonsági Ügynökség fogalmazta meg iránymutatásait. ${ }^{108}$ Az Európai Fogyasztói Központok Hálózata ${ }^{109}$ pedig a fogyasztók és kereskedők számára adott tanácsokat ${ }^{110}$ a koronavírus-járvánnyal kapcsolatosan egyre elterjedtebb, online platformon végrehajtott megtévesztésekkel szembeni védekezésről. ${ }^{111} \mathrm{Az}$ ajánlásokban a csalók által használt kifejezések és módszerek ismertetése révén készítik fel az átlagfogyasztót

$105 \mathrm{IP} / 20 / 854$.

106 Jelesül: védelmet kell biztosítani a kibocsátó fizetésképtelenné válásának esetére; az utalványok érvényességi idejét legalább 12 hónapban kell megállapítani, és visszatéríthetônek kell lenniük; lehetővé kell tenni, hogy az utas bármely, az utazási iroda által kínált utazást választhassa - természetesen a különbözet elszámolásával -, valamint az utalvány másik utasra való átruházhatóságát. Lásd: IP/20/854.

107 Joint Paper of the Trio Partners Germany, Portugal and Slovenia. Consumer Protection in Europe Lessons Learned from the COVID-19-pandemic (12.10.2020). Elérhető: www.bmjv.de/SharedDocs/Downloads/DE/News/PM/ 161020_Joint_Trio_Paper.pdf;jsessionid=EoB61E2E3B831A3CAD5DB88467CB37A2.2_cid334?_blob=publicationFile\&v=1 (Letöltve: 2020 . november 14.).

108 European Union Aviation Safety Agency (EASA) (2020).

109 European Consumer Centre (ECC).

110 A kérdéssel az Európai Bizottság a szólásszabadság korlátozása kapcsán már foglalkozott a vonatkozó fejezetben már elemzett JOIN (2020) 8 final jelû́ dokumentumban.

111 Dornfeld, 2020. 
a csalárd szándékú eladók kiszűrésére. ${ }^{112}$ Továbbá 2020 márciusában ${ }^{113}$ és áprilisában ${ }^{114}$ Didier Reynders, a jogérvényesülésért és a fogyasztópolitikáért felelős biztos - a fogyasztóvédelmi együttmúködési hálózat ${ }^{115}$ közös álláspontjával összhangban - levélben fordult több internetes platformhoz, közösségimédia-vállalkozáshoz, keresőportálhoz és webáruházhoz, amelyben az együttműködésüket kéri a felületeiken közzétett hamis és csalárd információk eltávolítása érdekében.

\section{Az uniós intézmények eljárási szempontú igazodása a megváltozott munkakörülményekhez (EiT, Tanács, EP online talállkozói)}

Az EU intézményrendszerét a 2020 kora tavaszán gyors mértékben eszkalálódó vírushelyzet komoly kihívás elé állította. ${ }^{116} \mathrm{Az}$ Európai Központi Bank (EKB) és az Európai Számvevőszék belső szabályzata már a Covid-19-járvány előtt lehetôvé tette a távmeghallgatásokat és az írásbeli döntéshozatalt, így a munka a válsághelyzet során is viszonylag zökkenőmentesen folytatódhatott. A másik öt intézmény múködéséről mindez nem mondható el. A legsúlyosabb csapás az Európai Parlamentet (EP) érte: a kialakult helyzet a vélemények minél szélesebb körben történő ütköztetését - az intézmény működésének lényegi elemét - szorította vissza a lehető legminimálisabb szintre. Egyrészről a döntéseket sürgôsen kellett meghozni, másrészről az elektronikus úton történő megbeszélések több száz képviselő jelenléte esetén kaotikus, elhúzódó jelleget öltöttek. Ennek megfelelően korlátozták az ülések hosszát, és a hozzászólásokat is igyekeztek röviden és tömören intézni. ${ }^{117}$ Ily módon a döntéshozatal demokratikussága mellett egyebekben az EUMSZ 15. cikkében rögzített nyilvánosság elve is nyilvánvalóan sérült. Végül, de nem utolsósorban a szavazás során - amely főszabályként kézfeltartással történik - nehézségeket okozott a megfelelő helyettesítő módszer megtalálása. ${ }^{118}$

112 Csalások a COVID-19 kapcsán. A fogyasztóvédelmi együttműködési (CPC-) hálózat fellépése a tisztességtelen kereskedőkkel szemben a koronavírus-járvány okozta válsághelyzetben. Elérhető: https://ec.europa.eu/info/departments/ justice-and-consumers/justice-and-consumers-funding-tenders/funding-areas/consumer-programme-cp/ enforcement-consumer-protection/scams-related-Covid-19_hu (Letöltve: 2020. november 14.).

113 Covid 19-Scams - Letter to Platforms (March 2020).

114 Covid 19-Scams - Letter to Platforms (April 2020).

115 Consumer Protection Cooperation Network (CPCN).

116 Herszenhorn-Wheaton, 2020.

117 Bodson, 2020, 2. 0.

118 Az Európai Parlament eljárási szabályzata 2019-2024 (9. ciklus), 25. cikk (9. pont), 178. cikk, 187. cikk (1. pont), 237. cikk (2. pont). Elérhető: www.europarl.europa.eu/doceo/document/RULES-9-2020-02-03_HU.pdf (Letöltve: 2020 . október 20.). 
Az Európai Unió Tanácsa (Tanács) szintén nem volt felkészülve a virtuális térben történő döntéshozatalra. Jóllehet az eljárási szabályzatának ${ }^{119} 12$. cikke sürgős kérdésekben vagy rendkívüli körülmények fennállta esetén lehetővé teszi az írásbeli szavazást, ahhoz azonban - minden egyes döntés elött - a Tanács vagy a COREPER egyhangú hozzájárulására van szükség. Az elnök kivételes körülmény fennállta esetén szintén javasolhatja ezen eljárás alkalmazását; ilyen esetekben az írásbeli szavazás akkor alkalmazható, ha a Tanács valamennyi tagja beleegyezik az eljárás alkalmazásába. Tekintve, hogy az utazási korlátozások miatt egyedül az állandó képviselók és helyetteseik voltak abban a helyzetben, hogy személyesen is találkozhassanak Brüsszelben, a Tanács arra a döntésre jutott, hogy 2020. március 23-tól'120 egy hónapos - meghosszabbítható - időtartamra szünetelteti a személyes jelenléttel történő ülésezést, és a COREPER szintjére delegálja a döntéshozatalt. E megállapodást hosszas vita elôzte meg, tekintve, hogy egyes álláspontok szerint - még akkor is, ha csak ideiglenesen - a közösségi döntéshozatal újabb térnyerését hozta a kormányközi döntéshozatallal szemben. Másképpen fogalmazva, a kérdés a szuverenitás kontextusába kerülve jogi vita helyett politikai vitává alakult arról, hogy hol legyen a válságkezelés centruma, Brüszszelben vagy a 27 fóvárosban. A tagállami kormányok a döntéshozatal jogának fenntartása érdekében egyrészről garanciális szabályként rögzítették, hogy a döntések meghozatala előtt az illetékes miniszterek informális videokonferencián egyeztetik az álláspontjaikat, másrészről a magyar, a lengyel és szlovén kormányok nyilatkozatot ${ }^{121}$ füztek a döntéshez, hangsúlyozva annak átmeneti jellegét. ${ }^{122}$

Az Európai Tanács (EiT) nem módosította az eljárási szabályzatát,, ${ }^{123}$ amelynek 7. cikke az írásbeli szavazást csak korlátozott körben teszi lehetôvé, a szabályzat módosítása nélkül pedig a 4. cikk nyelvtani értelmezéséből adódóan a tárgyalások lefolytatása és az európai tanácsi következtetések kiadása csak az állam- és kormányfók személyes jelenlétével tartott tárgyalásokat követően lehetséges. Így áthidaló megoldásként az állam- és kormányfők infor-

119 A Tanács eljárási szabályzata (HL L 325, 2009. 12. 11.), 36-61. 0.

120 A Tanács (EU) 2020/430 határozata (2020. március 23.) a Tanács eljárási szabályzatától a COVID-19-világjárvány által az Unióban okozott utazási nehézségekre tekintettel való ideiglenes eltérésről (HL L 88I., 2020.03. 24., 1-2. 0.).

121 Kérdésként merült fel továbbá, hogy milyen esetekben lehetséges ezen eljárást alkalmazni. A Tanács Jogi Szolgálata arra az álláspontra helyezkedett, hogy azt a rendes jogalkotási eljárásra, valamint az atipikus jogalkotási eljárások közül egyes tanácsi következtetések elfogadásához lehetséges használni. Lásd: Council of the European Union: “Summary Record - Permanent Representatives Committee - 20 and 22 April 2020", 7709/20 CRS CRP 20. Brussels, 7 May 2020, 2. o.

122 Álláspontunk szerint mind Benjamin Bodson eufóriája, mind a tagállami kormányok aggodalma felesleges volt e téren: az állandó képviselők és a helyettesek nemzetközi jogi szempontból nagyköveti rangban tevékenykedő diplomatának minősülnek, következésképpen a küldő állam kormányának bármikor lehetősége van őket - akár indokolás nélkül - visszahívni, amennyiben megítélése szerint nem képviseli maradéktalanul a küldő ország kormánya által képviselt álláspontot. Részletesen lásd: Az Európai Unió Tanácsának Főtitkársága: A Tanács eljárási szabályzata, illetve megjegyzések a Tanács eljárási szabályzatához (2016), 125 o. Elérhető: www.consilium.europa.eu/media/29811/qc0415692hun.pdf (Letöltve: 2020. október 20.).

123 Az Európai Tanács eljárási szabályzata (HL L 315, 2009. 12. 02., 52. o. és HL L 325, 2009. 12. 11., 36. 0., corrigendum, HL L 55, 2010. 03. 05., 83. o.). 
mális videómegbeszéléseket tartottak, az európai tanácsi következtetések helyett pedig az Európai Tanács elnökének következtetései kerültek kiadásra. Ez az új helyzet az EiT aktuális elnökének ${ }^{124}$ olyan mozgásteret biztosított, amelyet az állam- és a kormányfők bizonyosan nem kívántak: az elnök a következtetéseit ugyanis a saját nevében adta ki, elkerülve az európai tanácsi következtetések kiadását rendszeresen megelőző, a szöveg szavaival és a mondanivaló hangsúlyával kapcsolatos hosszas egyeztetéseket. ${ }^{125}$ Habár európai tanácsi következtetések nem kerültek kiadásra, az állam- és a kormányfők március 26-án kiadtak egy együttes nyilatkozatot, ${ }^{126}$ amelyben vázolták a koronavírus-járvány elleni fellépés fóbb pontjait.

Jóllehet az Európai Bizottság esetében már a 2010-es eljárási szabályzatának elfogadásakor felmerült a technológia és a távközlés fejlődése nyújtotta új lehetőségek kiaknázásának gondolata, erre csak a Bizottság eljárási szabályzatának 2020. április 22-i módosításának elfogadása révén került sor. ${ }^{127}$ Habár az írásbeli szavazás - bizonyos feltételek teljesülése esetén - már korábban is megengedett volt, a biztosok telekommunikációs eszköz révén történő becsatlakozása újdonságnak számít.

Jóllehet az EuB e-Curia rendszere, amely egyes iratok elektronikus benyújtását teszi lehetővé, ${ }^{128}$ már 2018-ban bevezetésre került, ${ }^{129}$ azonban a Bíróság és a Törvényszék a tárgyalásokat továbbra sem tarthatja online, ami a lezárások idején az EuB munkájának akadályoztatásához vezetett: a főtanácsnoki indítványok és ítéletek kihirdetését elhalasztották. Az EuB Alapokmányának ${ }^{130} 31$. és 53. cikkei, valamint a Bíróság eljárási szabályzatának ${ }^{131} 79 ., 88$., 200. cikkei és a Törvényszék eljárási szabályzatának ${ }^{132}$ 109., 118. cikkei értelmében ugyanis a fentebb említett eseményeknek főszabály szerint nyilvánosan kell történniük. Tekintve, hogy az eljárási szabályzat nem szól az elektronikus távközlési eszköz révén biztosított nyilvánosságról, az csak hagyományos formában biztosítható. Hasonlóképpen nyilvánosan kell esküt tenniük az újonnan kinevezett bíráknak és főtanácsnokoknak. Ennek megfelelően a Bíróság új fötanácsnokának 2020. március 23-án elektronikus távközlési eszköz útján tett

124 Charles Michael (hivatalban 2019. december 1-től).

125 Herszenhorn-Wheaton, 2020.

$126 \mathrm{Az}$ Európai Tanács tagjainak együttes nyilatkozata. Brüsszel, 2020. március 26. Elérhető: www.consilium. europa.eu/media/43087/26-vc-euco-statement-hu.pdf (Letöltve: 2020. október 18.).

127 A Bizottság (EU, Euratom) 2020/555 határozata (2020. április 22.) eljárási szabályzatának módosításáról C/2020/3000 (HL L 127I., 2020. 04. 22., 1-2. 0.).

$128 \mathrm{Az}$ e-Curia az Európai Unió Bírósága által múködtetett alkalmazás, amely a Bíróság és a Törvényszék elé kerülő ügyekben lehetôvé teszi a felek képviselői, valamint a Bíróság elé kerülő előzetes döntéshozatal iránti kérelmek keretében a nemzeti bíróságok számára, hogy az eljárási iratváltásokat a hivatalokkal kizárólag elektronikus úton bonyolítsák le.

129 A bíróság határozata (2018. október 16.) az eljárási iratoknak az e-Curia alkalmazáson keresztül történő benyújtásáról és kézbesítéséről; A Törvényszék határozata (2018. július 11.) az eljárási iratoknak az e-Curia alkalmazáson keresztül történő benyújtásáról és kézbesítéséről.

130 Az Európai Unió múködéséről szóló szerződés egységes szerkezetbe foglalt változata (3.), Jegyzőkönyv az Európai Unió Bíróságának Alapokmányáról (HL C 202., 2016. 06. 07., 210-229. o.).

131 A Bíróság eljárási szabályzata (HL L 265., 2012. 09. 29., 1-42. 0.).

132 A Törvényszék eljárási szabályzata (HL 2015. L 105., 2015. 03. 04., 1. o.). 
eskütétele ${ }^{133}$ felvetett bizonyos aggályokat: az ugyanis mind a Bíróság alapszabályzatával, mind a Bíróság eljárási szabályzatának 4. cikkével ellentétes módon történt. ${ }^{134}$

\section{4. Összefoglaló gondolatok}

Jelen fejezetben bemutatásra került, hogy bár az EU főszabály szerint nem rendelkezik hatáskörökkel az egészségügyi válságkezeléssel és a különleges jogrendi helyzettel kapcsolatosan - az elsősorban a tagállamok hatáskörébe tartozik az alapító szerződések alapján -, a koronavírus-járvány új megközelítésbe helyezte e szerződések rendelkezéseit. Az EU intézményei és szervei a kezdeti hezitálást követően ráébredtek, hogy a koronavírus-járvány okozta problémákat az egységes belső piac felől közelítve, illetve a hatásköröket hálóként szemlélve az EU-nak számtalan eszköz áll a rendelkezésére, hogy segítse a tagállamait annak érdekében, hogy a szükséges egészségügyi felszerelések eljussanak oda, ahol éppen a legnagyobb szükség van rá, valamint hogy a tagállamok megvédhessék a gazdaságukat az öszszeomlástól. E cél az áruk, a személyek és a szolgáltatások szabad mozgásának uniós szintû́ összehangolása - és adott esetben a tagállamoknak az alapszabadságok korlátozásához való jogainak megnyirbálása - révén érhetô el. A zöld sávok rendszerének létrehozása, a fuvarozásban dolgozó munkavállalók kulcsfontosságúként történő elismerése és a mozgásuk lehető legkevesebb korlátozás mellett történő lehetővé tétele, valamint az egyes országok egységes színkód alapján történő besorolása mind e cél elérését segíti elő.

A fejezetben bemutatásra került továbbá az egyes alapjogok - azon belül is kiemelten az Alapjogi Charta által is garantált gyülekezési és a szólásszabadság - korlátozásának kérdése. A jogkorlátozásokkal kapcsolatban a mérlegelés tárgyát a közösség - az egészséghez fúződő jogból eredeztethető - érdekei és az egyéni szabadságjogok közötti egyensúly megtalálása képezte. E körben az Európai Bizottság jogállamisági jelentései, az egyes tagállamok alkotmánybíróságainak gyakorlata, valamint egyes NGO-k jelentései is ismertetésre kerültek. Általánosságban elmondható, hogy kevés uniós országnak sikerült megtalálnia a kelló egyensúlyt a fenti érdekek között, jellemzően megállapításra került egyik vagy másik jog korlátozásának aránytalan volta. A kutatás alapján a két leggyakoribb problémát az egészségügyi megfontolások „biankó csekként” való, a gyülekezési jog teljes körû, differenciálatlan korlátozását eredményező használata, valamint a szólásszabadsághoz és az információhoz való jog aránytalan - a legtöbb esetben a dezinformációk elleni fellépéssel indokolt - korlátozása jelentette.

133 Court of Justice of the European Union: Press Release $N^{\circ} 34 / 20$ : "Entry into office of a new Advocate General at the Court of Justice”. Luxembourg, 23 March 2020. Elérhető: https:/curia.europa.eu/jcms/upload/docs/ application/pdf/2020-03/cp200034en.pdf (Letöltve: 2020. november 29.).

134 Alemanno-Stefan, 2014. 
Végül, de nem utolsósorban bemutatásra került az uniós intézmények alkalmazkodása a koronavírus-járvány által teremtett helyzethez, jelesül az eljárási szabályzataik oly módon történő módosítása révén, hogy az lehetôvé tegye az elektronikus távközlési eszközök útján történő tárgyalást és döntéshozatalt. Az alkalmazkodás a vizsgált intézmények közül csak az EKB és a Számvevőszék esetén ment zökkenőmentesen, e két intézmény eljárási szabályzata ugyanis már a koronavírus-járványt megelőzően tartalmazott rendelkezéseket a szóban forgó eszközök igénybevételére. Az intézmények többségét az átállás azonban komoly kihívás elé állította mind jogi szempontból - nem egy esetben politikai vitát generálva, mint a Tanács esetében -, illetve a döntéshozatal demokratikusságának szempontjából, mint az EP esetén. E kérdések megnyugtató rendezése még várat magára.

Összefoglalva a fent írtakat elmondható, hogy az EU intézményei a kezdeti hezitálásuk után megtalálták a módját annak, hogy az alapító szerződések értelmezése és esetenként újraértelmezése révén hatékonyan reagáljanak a válság okozta kihívásokra, és segítsék a tagállami intézkedéseket. Hasonlóképpen, az elektronikus eszközök használatára való áttérést is megvalósították - jóllehet ez utóbbi téren akadtak hiányosságok.

\section{Irodalomjegyzék}

Alemanno, A., Stefan, O. A. (2014) 'Openness at the Court of Justice of the European Union: Toppling a Taboo', Common Market Law Review, 51(1), 1-47. o.

ANGYAL, Z. (2011) Légiközlekedési jog az Európai Unióban. Budapest: HVG-ORAC

BentZen, N. (2020) COVID-19 Foreign Influence Campaigns Europe and the Global Battle of Narratives. EPRS, PE 649.367 - April 2020 [Online]. Elérhető: www.europarl.europa.eu/ RegData/etudes/BRIE/2020/649367/EPRS_BRI(2020)649367_EN.pdf (Letöltve: 2020. október 20.)

Bodson, B. (2020) Rethinking EUInstitutions' Rules ofProcedureafterCOVID-19(European Policy Brief, No. 62, July 2020) [Online]. Elérhetô: www.egmontinstitute.be/content/uploads/2020/07/ epb-62-benjamin-bodson-final.pdf?type=pdf (Letöltve: 2020 . október 20.)

Deb, P., Furceri, D., Ostry, J. D., TAWK, N. (2020) 'The Economic Effects of COVID-19 Containment Measures', IMF Working Papers, No. 20/158, 1-44. o.

DEFEIS, E. (2012) 'Human Rights, The European Union, and the Treaty Route: from Maastricht to Lisbon', Fordham International Law Journal, 35(5), 1207-1230. o.

DoRNFELD, L. (2020) 'A koronavírus-járvány hatása a kiberbúnözésre', In Medias Res, 2020/2, 193-204. o.

European Union Aviation Safety Agency (EASA) (2020) COVID-19 Aviation Health Safety Protocol Operational Guidelines for the Management of Air Passengers and Aviation Personnel in Relation to the COVID-19 Pandemic. Issue No. 02 (Issue date:30/06/2020) [Online]. Elérhető:www.easa. 
europa.eu/sites/default/files/dfu/EASA-ECDC_COVID-19_Operational\%2oguidelines\%20 for\%20management\%20of\%2opassengers_v2.pdf (Letöltve: 2020 . november 14.)

FRA (2020) Coronavirus Pandemic in the EU - Fundamental Rights Implications. Bulletin \#4 (30 June 2020) [Online]. Elérhető: https://fra.europa.eu/sites/default/files/fra_uploads/fra2020-coronavirus-pandemic-eu-bulletin-july_en.pdf (Letöltve: 2020. november 8.)

HerszenhoRn, D. M., Wheaton, S. (2020) How Europe Failed the Coronavirus Test: Contagion's Spread Is a Story of Complacency, Overconfidence and Lack of Preparation [Online]. Elérhető: www.politico.eu/article/coronavirus-europe-failed-the-test/ (Letöltve: 2020. október 20.)

KELEMEN, R. (2019) 'A különleges jogrend szabályozása az egyes alkotmányokban I. Általános alapvetés, fogalmi elhatárolás', Vélemények a Katonai Jog Világából, 2019/1, 1-12. o.

KELEMEN, R. (2019) 'Az Alaptörvény szükségállapot-szabályozásának kritikai áttekintése az egyes európai uniós tagállamok alkotmányainak figyelembevételével - Különös tekintettel a visegrádi államok alkotmányaira' in Bartkó, R. (szerk.) A terrorizmus elleni küzdelem aktuális kérdései a XXI. században. 1. kiadás. Budapest: Gondolat

KiRst, N. (2020) How a Public Health Crisis Became an Aggravation of the Rule of Law Crisis in the European Union [Online]. Elérhetö: http://dcubrexitinstitute.eu/2020/04/how-a-publichealth-crisis-became-an-aggravation-of-the-rule-of-law-crisis-in-the-european-union/ (Letöltve: 2020. november 8.)

Kiss, B. (2010) 'Az alapjogok korlátozása az Európai Unió nemzeti alkotmányaiban', Acta Universitatis Szegediensis: Acta Juridica et Politica, 73, 455-465. o.

Kommers, D. (2007) 'Germany: Balancing Rights and Duties' in Goldsworthy, J. (szerk.) Interpreting Constitutions: A Comparative Study. 1st Edition. Oxford: Oxford University Press, 370. o.

LEE, J. (2020) 'Note on COVID-19 and the Police Powers Doctrine: Assessing the Allowable Scope of Regulatory Measures During a Pandemic', Contemporary Asia Arbitration Journal, 13(1), 229-248. o.

MARINKÁs, Gy. (2018) 'How Not to Build a Monetary Union? - The Structural Weaknesses of the EMU in the Light of the 2008 Crisis and the Institutional Reforms for Their Correction', Hungarian Yearbook of International Law and European Law, 6, 437-471. o.

MARINKÁs, Gy. (2013) 'Az emberi jogok védelmének fejlődése az Európai Unióban: az Unió csatlakozása az Emberi Jogok Európai Egyezményéhez, valamint a joggyakorlat fejlesztése a bíróságok részéről', Miskolci Jogi Szemle, 8(1), 97-120. o.

MARINKÁs, Gy. (2020) 'What If a New Crisis Comes? - In Other Words, Is the EMU Prepared for Another Possible Financial Crisis?' in Blažo, O., Mokrá, L., Máčaj, A. (szerk.) Právne výzvy pre novú Európsku komisiu. Zborník z vedeckej konferencie organizovanej Univerzitou Komenského $v$ Bratislave, Právnickou fakultou dňa 6 a 7. februára 2020 v priestoroch Univerzity Komenskéhov Bratislave. 1. kiadás. Bratislava: Univerzita Komenského 
MARLE, G. VAN (2020) Road Freight Industry Needs €75bn from the EU to Recover from Pandemic [Online]. Elérhető: https://theloadstar.com/road-freight-industry-needs-e75bn-fromthe-ec-to-recover-from-pandemic/ (Letöltve: 2020. november 14.)

Meninno, R., Wolff, G. (2020) As the Coronavirus Spreads, Can the EU Afford to Close Its Borders? [Online]. Elérhető: https://voxeu.org/content/coronavirus-spreads-can-eu-afford-closeits-borders (Letöltve: 2020. december 13.)

Nicolás, E. S. (2020) EU Warning after Hungary Unilaterally Shuts Borders [Online]. Elérhető: https://euobserver.com/coronavirus/149282 (Letöltve: 2020. november 14.)

Purnhagen, K. P., Flear, M. L., Hervey, T., Herwig, A., De Ruijter, A. (2020) 'More Competences than You Knew? The Web of Health Competence for European Union Action in Response to the COVID-19 Outbreak', European Journal of Risk Regulation, 11(2), 297-306. o. RESPERgER, I. (2018) A válságkezelés és a hibrid hadviselés. 1. kiadás. Budapest: Dialóg Campus Kiadó

SÁGVÁRI, Á. (2016) Különleges jogrenddel a terror ellen - kitekintés az európai gyakorlatra [Online]. Elérhető: https://jog.tk.mta.hu/blog/2016/o2/kulonleges-jogrenddel-aterror-ellen (Letöltve: 2019. december 9.)

SCAZZIERI, L. (2020) The EU Needs to Counter Italy's Coronavirus-induced Euroscepticism [Online]. Elérhető: www.cer.eu/in-the-press/eu-needs-counter-italys-coronavirusinduced-euroscepticism (Letöltve: 2020. október 20.)

SOMSSICH RÉKA (2018) 'Az előzetes döntéshozatali eljárás közel hat évtized távlatából', Iustum Aequum Salutare, 14(2), 39-55. o.

TIDEY, A. (2020) COVID-19 Has 'Weakened' the Case for the EU, Say Germans, French and Italians [Online]. Elérhető: www.euronews.com/2020/05/26/Covid-19-has-weakened-the-casefor-the-eu-say-germans-french-and-italians (Letöltve: 2020. október 20.)

TILL, Sz. (2019) 'Különleges jogrend' in Jakab, A., Fekete, B. (szerk.) Internetes Jogtudományi Enciklopédia. Elérhető: http://ijoten.hu/szocikk/kulonleges-jogrend (Letöltve: 2020. december 13.)

Townend, D., van de Pas, R., Bongers, L., Haque, S., Wouters, B., Pilot, E., Stahl, N., SCHRÖDER-B̈̈CK, P., SHAW, D., KRAFFT, T. (2020) 'What is the Role of the European Union in the COVID-19 Pandemic?', Medicine and Law, 39(2), 249-268. o.

UNGVÁRI, Á., HoJNYÁK, D. (2020) 'Az Európai Unió egyes tagállamainak koronavírusjárványra adott válasza, különös tekintettel a vizsgált államok által bevezetett különleges jogrendi szabályozásra', Miskolci Jogi Szemle, 15(1), 122-138. o.

WANAT, Z., Eder, F. (2020) Jourová: Brussels 'Concerned' by Polish, Hungarian Coronavirus Measures [Online]. Elérhető: www.politico.eu/article/jourova-brussels-concerned-bypolish-hungarian-coronavirus-measures/ (Letöltve: 2020. november 8.)

Wojtyczka, I. (2020) Professor Tomasz Grzegorz Grosse Interviewed by Izabela Wojtyczka: The Virus Will Change the EU, but Not How We Might Expect [Online]. Elérhető: https:// warsawinstitute.review/issue-2020/the-virus-will-change-the-eu-but-not-how-wemight-expect/ (Letöltve: 2020. október 21.) 


\section{A KÜLÖNLEGES JOGREND HAZAI VONATKOZÁSAI}




\title{
4. A különleges jogrend magyar szabályozásának történeti fejlődése (a kezdetektől 2011-ig)
}

\author{
DOMANICZKY ENDRE
}

\section{A magyar szabályozás a kezdetektől 1945-ig}

\subsection{Korai szabályozás a magyar és az európai jogrendszerekben}

\subsubsection{A kivételes hatalom és a különleges jogrend fogalmi keretei}

A kivételes hatalom és a különleges jogrend nem új keletû́ intézmények a magyar közjogban. A kivételes hatalom nem más, mint a végrehajtó hatalom számára az alkotmányos rend felfüggesztése révén biztosított túlhatalom. A különleges jogrend pedig a kivételes hatalom időszakában fennálló jogrend, amelynél a különleges szó az állami múködés megszokott rendjétől való eltérésre utal. ${ }^{1}$

A kivételes hatalom fogalmának lényegi elemei: az alkotmányos rend, a felfüggesztés és a túlhatalom. Az alkotmányos rend egy stabil, többszereplős államszervezetet feltételez,

I A különleges szó akár a különös szinonimájaként is felfogható, hiszen az általánostól eltérő, speciális jogi rezsimre alkalmazzák.

Dr. Domaniczky Endre, PhD

endre.domaniczky@mfi.gov.hu

vezető kutató (Mádl Ferenc Összehasonlító Jogi Intézet)

Domaniczky, E. (2021) ‘A különleges jogrend magyar szabályozásának történeti fejlődése (a kezdetektől 2011-ig)' in Nagy, Z., Horváth, A. (szerk.) A különleges jogrend és nemzeti szabályozási modelljei, 78-121. o. Budapest: Mádl Ferenc Összehasonlító Jogi Intézet.

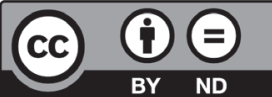


ez az európai államoknál általában az újkorban alakult ki. Alkotmányos rend alatt gyakran az írott alkotmány meglétére gondolunk, ám ezek csak a 18. század végétől kezdenek elterjedni. Alkotmányos rend azonban írott alkotmány hiányában is létezhet, ezt éppen a kivételes hatalommal kapcsolatos korai magyar példák igazolják (1.1.3. pont). A felfüggesztés az alkotmányos rend kikapcsolásának időleges, korlátozott voltára utal. A kivételes hatalom gyakorlása tehát csak bizonyos célok elérése érdekében lehetséges, a végrehajtó hatalmat a többi alkotmányos tényező korlátozásával e célok miatt ruházzák fel - a normál alkotmányos keretek között elfogadott szabályok által - többletjogosítványokkal. A túlhatalom kifejezés a többletjogosítványok tartalmát magyarázza. Normál esetben a végrehajtó hatalom intézkedései más hatalmi ágak által kontrolláltak. A túlhatalom ehhez képest tesz lehetôvé bizonyos intézkedéseket, eljárásokat, amelyeket az elérendő célok kivételessége, rendkívülisége indokol.

Bár a fogalom lényegi elemei között nem szerepelt a kiemelt állami vagy társadalmi cél meghatározása, érdemes erről is néhány szót ejteni. A kivételes hatalom átfogó szabályozásának igénye a polgári államok kiteljesedését követően, a 19. század második felében jelentkezett. A mai jogállamfogalom több eleme, előfeltétele ekkor már létezett a közjogban. ${ }^{2}$ Ezek időleges korlátozásának, kiiktatásának lehetôsége révén nyerte el a kivételes hatalom és a különleges jogrend a mai jelentéstartalmát. E közjogi garanciák felfüggesztésével csak kiemelten fontos állami, társadalmi érdek, afféle állami végszükséghelyzet állitható szembe. ${ }^{3}$ Ilyenek lehetnek a mai szóval a közrend, a nemzetbiztonság, a közegészség és a nemzetgazdaság védelmének esetkörei, amelyek nagyrészt a 20. századi államokat és közösségeket egyaránt fenyegetô eseményekre reflektálva kristályosodtak ki és épültek be - sztenderdként a jogállam fogalmának ismérvei közé (a 20. század második felében). A kivételes hatalom ugyanis egy korlátozott eszköz, ahogy a jogállamban „maga a közhatalom sem korlátlan”. ${ }^{4}$

Összegezve a fogalmi elemeket látható, hogy a kivételes hatalom és a különleges jogrend fogalmak a polgári államok kialakulásával fokozatosan nyerték el mai jelentéstartalmukat. Mindez nem jelenti azt, hogy e jogintézménynek ne lettek volna korábbi jogtörténeti előzményei. Az alábbiakban vázlatosan ezek szabályozását követjük nyomon elsősorban Magyarországon, de kitekintéssel egyes európai államokra is.

\subsubsection{A kivételes hatalom megjelenése az európai országok jogában}

A rendi keretek között kivételes hatalommal elsősorban büntetőjogi vagy katonai szempontból találkozhatunk. ${ }^{5} \mathrm{~A}$ kivételes hatalom szabályozásának egységesülését, a jogállamfo-

2 Így például a hatalommegosztás elve, a polgári szabadságjogok egy része, a parlament szuverenitásának elmélete.

3 Lásd még: Polner, 1916, 86-87. o.

4 Lásd a 11/1992. (III. 5.) AB határozatot (Alkotmányos elvek és esetek, 1996, 538. o.).

5 Lásd bővebben: Mezey, 2015, 25-32. o. 
galommal párhuzamos fejlődését a 18. század végén bekövetkező amerikai és francia forradalom alkotmánytörténeti folyamatai segítették elő.

Az Egyesült Államok alkotmánya (1787) már biztosította - szúk körben - az elnök számára a kivételes hatalom lehetőségét, ${ }^{6}$ egyúttal a későbbi alkotmányozási folyamatoknál a hatalommegosztás tekintetében hivatkozási alappá vált. Az Emberi és Polgári Jogok Nyilatkozata (1789) pedig felsorolta azokat a jogokat, amelyek lassanként egyetemes emberi jogokká válva lehetôvé tették „az egyéni szabadság megalapozását és biztosítékokkal való körülbástyázását"? ${ }^{7}$

Nem véletlen, hogy Franciaországban viszonylag korán, már az 1799-es alkotmányban meghatározták az alkotmány felfüggesztésének esetköreit, ${ }^{8}$ hiszen a hatalmi ágak (együtt) múködését e szabályozás nagymértékben megkönnyítette. Napóleon 1815-ös alkotmánytörvénye ugyancsak foglalkozott a különleges jogrend kérdésével, amikor kimondta, hogy az ostromállapot csak külhatalom támadása, illetve belső zavargások esetén vezethető be. ${ }^{9}$ A 19. század nagy részében azonban a kérdést alkotmányi felhatalmazás alapján törvényi szinten szabályozták. ${ }^{10}$

Németországban a kivételes hatalom egyik korai szabályozása az 1851-es porosz alkotmányban található, amely miután felsorolja az állampolgári jogokat, háború vagy belső zavargások esetére ezek felfüggesztését is lehetővé teszi. ${ }^{11} \mathrm{~A}$ kérdést az alkotmány felhatalmazása alapján 1851-ben külön törvény bontotta ki, amelyet azért kell megemlíteni, mert az 1871-es német birodalmi alkotmány kivételes hatalomról szóló szabályozása e törvényre épült. ${ }^{12}$ Hasonló az 1912-es bajor törvény által alkalmazott megoldás is. ${ }^{13}$

Oroszországban, ahol „egészen a XX. század elejéig a cári hatalom teljességét jogi értelemben semmiféle formális norma vagy intézmény nem korlátozta", ${ }^{14}$ az 1906-os alkotmány megemlítette a háborús helyzetet, illetve a kivételes állapotot, mint a különleges jogrend alá tartozó kategóriákat, és az uralkodó jogkörébe utalta az alkalmazási terület meghatározását. ${ }^{15} \mathrm{Az}$ alkotmány egyúttal rögzítette, hogy a részletszabályokat törvényi szinten kell rendezni, de ez a törvény az I. világháború kitöréséig nem készült el, az alkotmányt pedig 1917

6 Vö.: Art. II., Sec 3, Cl 3. - ez ma is létezik (lásd: Jánosi, 1867, II. 60-61. o.). A kivételes hatalom egyesült államokbeli szabályozásának jellegzetességeire lásd bővebben: Mészáros, 2016.

7 Polner, 1917, 25. o.

8 92. \$. Elérhető: https://en.wikisource.org/wiki/Constitution_of_the_Year_VIII (Letöltve: 2020 . június 10.).

9 Lásd a 66. pontot: www.napoleon-series.org/research/government/legislation/c_additional.html (Letöltve: 2020. június 10.).

10 Vö.: Polner, 1917. A francia szabályozás alkotmánytörténeti fejlődésére lásd még: Ságvári, 2017.

11 Lásd: 36. cikk. Elérhető: https://en.wikisource.org/wiki/Constitution_of_the_Kingdom_of_Prussia (Letöltve: 2020. június 10.).

12 Lásd: 66. cikk. Elérhető: https://en.wikisource.org/wiki/Constitution_of_the_German_Empire (Letöltve: 2020. június 10.). Lásd még: Tóth, 1967.

13 Buza, 1915 és Buza, 1917. A későbbi német szabályozásra lásd még: Szabó, 2017.

14 Sz. Bíró, 2017, 137. o.

15 Lásd: 15. és 83. pont. Elérhető: https://tinyurl.com/h8z4V7x8 (Letöltve: 2020. június 5.). 
végén hatályon kívül helyezték. ${ }^{16}$ Jogtörténeti érdekességként említendő, hogy a szovjet államra a végrehajtó hatalom túlsúlya volt jellemző, függetlenül a különböző alkotmányokban rögzített államberendezkedéstől.

Végezetül itt kell röviden megemlékezni a brit szabályozás jellegzetességeiről is. Nagy-Britannia (1801-től Egyesült Királyság) kivételes jogrend tekintetében az eddig felsorolt országoktól némiképp eltérő utat követett. Maga az alapdokumentum is más, mint a kontinentális országokban. Az angol történeti (íratlan) alkotmány ${ }^{17}$ ugyanis nem egyetlen írott jogszabály, hanem századokon keresztül létrejött, organikus konstrukció, amelynek tartalmát folyamatos jogértelmezés révén határozzák meg. ${ }^{18} \mathrm{~A}$ brit kivételes hatalommal kapcsolatos szabályozás gyökerei a közép- és a kora újkorra nyúlnak vissza ${ }^{19}$ (míg a fenti példáknál általában újkori eredetûek). Fontos különbség az is, hogy a kivételes hatalmat lehetôvé tévő jogszabályok már a 18. század második felében is léteztek, évtizedekkel megelőzve a többi ország hasonló megoldásait. ${ }^{20}$

Magyarország a 19. században az Osztrák Császárság, majd az Osztrák-Magyar Monarchia része volt. A kivételes hatalom korai osztrák szabályozásának jellemzőit ezért a következő pontban, a magyar kodifikációs kísérletekhez kapcsolódva mutatjuk be.

\subsubsection{A kivételes hatalom megjelenése a magyar jogban}

A kivételes hatalomra vonatkozó általános szabályozás csak a 20. század elején készült, ám a törvényhozás egyes konkrét esetekben már jóval korábban lehetővé tette az ügyek kivé-

16 Oroszországban egy 1881-es törvény meghatározta a fokozott védelem és a rendkívüli védelem állapotát, és a kormányzókat feljogosította egyes állampolgári jogok korlátozására. 1892-ben ezen túlmenően megjelent a hadiállapot fogalma is, amely a kormányzók számára a belső rend helyreállítása érdekében bármilyen intézkedést lehetôvé tett. Az 1906-os alkotmányban említett külön törvény hiányában a gyakorlatban az említett 1881-es törvényt alkalmazták. Bővebben lásd: Tóth, 1967, 10-11. o.; Búza, 1915.

17 „Angliában ugyanis az alkotmány nem egy törvénynek vagy egyes fötörvényeknek egyenes teremtménye, hanem az összes, évszázadokon keresztül alkotott parlamenti végzemények, a százados nemzeti közszokás visszfénye, melynek helyes visszatükröztetése azért nehéz, mert az egyes főszervek múködése, melyekből az alkotmány áll, inkább mint időleges irány, sem mint élesen megvont hatalmi kör jelentkezik." (Concha, 1888, II. 177. o.).

$18 \mathrm{Az}$ angol jog az alapvető emberi jogok katalógusszerủ felsorolásától ezért is idegenkedik, azok elsődleges forrása ugyanis a common law (bírói jog), bár tartalmukra egyes jogi aktusok (Magna Charta, Petition of Rights, Bill of Rights, Habeas Corpus Act) is jelentős hatással bírtak. Az eltérő eredet talán a legfontosabb oka annak, hogy a 18-19. században az angol és a kontinentális „alapjogi katalógus” némiképp eltért egymástól (például a levéltitok, a tanszabadság, a vallásszabadság és a sajtószabadság kérdésében). Lásd még: Concha, 1888, II. 14-172. o.

19 E tekintetben talán a legfontosabb különbség a kontinentális országokhoz képest, hogy a törvény előtti egyenlőség, amely a kontinensen a polgárosodás egyik fô célkitüzése volt, a szigetországban már a középkor folyamán elismerést nyert. „[...] az angol társadalom századok óta a törvény előtti egyenlőség elvén nyugszik. Az angol egyéni szabadság bástyái, a Magna Charta óta, a szegényt és gazdagot, a hatalmas fơurat s az egyszerú parasztot egyaránt védelmezik, a törvény előtti jogegyenlőség az alkotmány alapvonása." (Concha, 1888, 121. о.).

20 Lásd: Coercion Acts. Elérhető: www.oxfordreference.com/view/10.1093/oi/authority.20110803095621949 (Letöltve:2020. június 10.). Az angol jogfelfogás szerint a kivételes hatalom gyakorlásának feltétele a Habeas Corpus Act (a törvényes eljáráshoz való jog) felfüggesztése volt. Az intézményről bővebben lásd: Concha, 1888, II. 172-174. o. 
teles eljárásban történő kezelését. ${ }^{21} \mathrm{~A}$ leggyakrabban ${ }^{22}$ idesorolt jogszabályok a 18. századból származnak, a legkorábbi ezek közül az alapvető törvényhozási hatásköröket érintő, a felkelésrôl és az adózásról szóló 1715. évi VIII. törvény, amely váratlan háborús helyzet esetén lehetôvé tette és szabályozta az uralkodó fenti tárgyakban való eljárását.

A kivételes hatalom szabályozásának ügye az 1848-49-es forradalom és szabadságharc időszakában vált központi témává, amikor mind az osztrák, mind a magyar kézben lévő területeken kivételes állapot bevezetésére került sor. Magyar részről az első kivételes hatalomról szóló törvényjavaslatok (egy képviselői indítványként, egy pedig a Deák Ferenc vezetésével múködő Igazságügyi Minisztérium által jegyzett előterjesztésként) is ekkor készültek. Mindkét - az 1848 júliusában benyújtott - javaslat a kivételes hatalom (korabeli elnevezéssel: az ostromállapot) átfogó szabályozását célozta. Általános szabályozás helyett azonban végül csak az igazságszolgáltatás területén a rögtönítélő bíráskodás törvényi szabályozására került sor 1849 elején. ${ }^{23}$ Bár törvényi szabályozása elmaradt, a rendkívüli helyzetek kezelése a gyakorlatban kormánybiztosok ${ }^{24}$ kiküldése útján történt.

\subsubsection{Kitekintés: az osztrák különleges jogrend érvényesülése Magyarországon (1848-1865)}

1848 októberében az osztrák-magyar ellentétek kiéleződésével az uralkodó királyi leirattal feloszlatta a magyar országgyúlést, egyúttal teljhatalmú királyi biztost nevezett ki a Magyar Királyság teljes területére, és deklarálta, hogy „Magyarország hadi törvények alá vettetik". ${ }^{25}$ A királyi biztos (báró Jellasics) kiűzését követően, 1848 novemberében herceg Windischgrätz kapott teljhatalmat, amit decemberben az új uralkodó, Ferenc József is megerősített. Windischgrätz 1848 decemberétől a - katonai igazgatásnak alárendelt - közigazgatás megszervezésére királyi biztosokat nevezett ki. Az alkotmányos szintú felhatalmazást majd csak az olmützi alkotmány biztosította 1849 tavaszán, ${ }^{26}$ amely a birodalmi gyúlés akadályoztatása esetén felhatalmazta a császárt ideiglenes szabályok megalkotására.

21 Összefoglalóan lásd: Tóth, 1982.

22 A 19. századi jogtudósok véleménye megoszlott az e körbe tartozó jogszabályokról, azok tartalmáról, egyáltalán a kivételes hatalom fennállásáról. Érdemes itt még megemlékezni Molnár Kálmán jogászprofesszor Kormányrendeletek címú monográfiájáról (1911) is, amely szintén foglalkozik a kérdéssel.

23 Lásd: 1849. évi I. törvénycikk a rögtönitélő hadi s polgári vegyes biróságok felállitása, szerkezete, eljárása, s itéletek alá tartozó esetek meghatározása tárgyában. Lásd még: Mezey, 2003.

24 A végrehajtó hatalom szervei és a törvényhozás elsősorban a különböző szervek közötti koordináció elősegítésére vagy rendkívüli helyzetek kezelésére gyakran biztosokat küldtek ki, akikre vélhetôen a korábbi királyi biztosok elnevezésének mintájára általában kormánybiztosként hivatkoztak. Az első biztosok kiküldésére még 1848 márciusában sor került. A kormánybiztosok 1848-49-es szabályozására és múködésére lásd Csizmadia Andor és Hermann Róbert munkáit.

25 Idézi: Tóth, 1982, 17. o.

26 Vö.: olmützi alkotmány 87. \$. Elérhető: www.verfassungen.at/at-18/verfassung49-i.htm (Letöltve: 2020. június 10.). 
Bár az olmützi alkotmányt 1851-ben hatályon kívül helyezték, ${ }^{27}$ az ostromállapot (katonai igazgatás) a gyakorlatban csak 1856 elején szűnt meg Magyarországon. Az 1860-61-es, a magyar alkotmányosság helyreállítását célzó kísérletek kedvezőtlen fogadtatását követően azonban az uralkodó újra a különleges jogrend bevezetése mellett döntött. Bár az 1861 októbere és 1865 júniusa között létező provizórium a korábbi ostromállapotnál enyhébb szabályozást eredményezett, a különleges jogrend egyik esetköreként kell számításba vennünk. ${ }^{28}$

\subsubsection{Kivételes hatalom a dualizmus korában}

A kiegyezést követően az Osztrák-Magyar Monarchia mindkét felében felmerült a kivételes hatalom szabályozásának igénye. ${ }^{29}$ Magyarországon azonban hosszú idő keresztül csupán eseti jelleggel, egyes törvényekhez kapcsolódva biztosították a kivételes hatalom lehetőségét, ugyanis „[...] törvényhozásunk egész szelleme tanúsítja, hogy hazánkban a szükségrendeleteknek csak igen szúk mérvben lehet jogilag helye". ${ }^{30} \mathrm{Az}$ elméletben szúk körünek tartott kivételek azonban a honvédelem és a közigazgatás területére estek, ${ }^{31}$ és a gyakorlatban akár jelentős mértékủ beavatkozást is lehetôvé tettek volna. ${ }^{32}$

\subsection{A különleges jogrend első átfogó magyar szabályozása: a kivételes hatalomról szóló 1912. évi LXIII. törvénycikk}

\subsubsection{A törvény keletkezése}

A századfordulón, a nagyhatalmak közti feszültségek növekedésével elsősorban katonai, hadügyi kérdésként került előtérbe a kivételes hatalom ügye. ${ }^{33} \mathrm{~A}$ kiegyezési törvény alapján ez úgynevezett közös ügynek számított, ${ }^{34}$ ezért a közös hadügyminisztérium megkeresései

27 Hatályon kívül helyezték 1851. 12. 31-én (Magyarországot illető Törvény- és Kormánylap 1852, 1. kötet 1. szám). 28 Lásd bővebben: Tóth, 1982, 33-34. 0.

29 Az osztrák szabályozást lásd lentebb. Magyarországon 1868-ban egy egyesületi és gyülekezési törvényjavaslat (a továbbiakban: Javaslat) készült, amely e jogok felfüggesztéséről is rendelkezett. A Javaslat - háború vagy belforrongás, illetve az egyesülési vagy gyülekezési jog nem rendeltetésszerủ használata esetén - az eljárásra az országgyưlés tájékoztatása mellett a belügyminisztert jogosította volna fel. A Javaslatra bővebben: Domaniczky, 2010.

30 Lásd: Kiss, 1886, 20. o.

31 A honvédelem területén a honvédség, illetve a népfelkelés határokon kívül történő felhasználása, közigazgatás területén pedig a kormány határozatainak végrehajtása volt az a kiemelt cél, amely a kivételes hatalom biztosítását indokolta. Vö.: 1868. évi XLI. tv., 1886. évi XX. tv., valamint 1870. évi XLII. és 1886. évi XXI. tv., illetve Kiss, 1886, 20. o. és Moskovitz, 1906, 25-27. o.

32 Például az 1905-1906-os válság idején, amikor a kormány egyébként is „[k]ivételes állapot kihirdetését javasolta..." (Katus, 2012, 562. o.).

33 Lásd bővebben: Mezey, 2016, 11-18. o.

34 Lásd: a magyar korona országai és az Ô Felsége uralkodása alatt álló többi országok között fennforgó közös érdekú viszonyokról, s ezek elintézésének módjáról szóló 1867. évi XII. törvénycikk. 
egy önálló magyar tervezet elkészítésének irányába hatottak. ${ }^{35}$ A kormány koncepciójának egyik legfontosabb eleme az volt, hogy a kivételes hatalom gyakorlását Magyarországon a katonai helyett polgári hatóságra kell bízni. ${ }^{36}$

A háború esetére vonatkozó kivételes intézkedésekről szóló 1912. évi LXIII. törvénycikket (a továbbiakban: Kit.) - mint arra már a cím is utalt - eredetileg a háború vagy arra történő előkészület időszakában szükséges rendkívüli intézkedések megalkotása céljából ${ }^{37}$ fogadta el a magyar országgyưlés. A tárgyi hatály - összevetve a Monarchia ciszlajtán részében létező szabályozással - kifejezetten szúk volt, csak a legszükségesebb területre (a háborús helyzetre és arra való felkészülésre) szorítkozott..$^{38}$ Azon belül viszont egy szigorúan korlátozott, valóban kivételes hatáskört konstituált: ez volt a kivételes hatalom.

\subsubsection{A kivételes hatalom korlátai}

A Kit. szerint tehát a kivételes hatalom: (a) háború vagy háborús előkészület ${ }^{39}$ időszakában; (b) kormányzati döntést követően; (c) a Kit. alapján; (d) a szükséges mértékben vehető igénybe. A kivételes hatalom létezése időben korlátozott: legkésőbb a háború befejezésével megszúnik. Ekkor a Kit. alapján tett intézkedések is hatályukat vesztik, azaz a már folyamatban lévő ügyekre nézve is azonnal a rendes törvényes állapot áll helyre. ${ }^{40} \mathrm{~A}$ kivételes hatalom alapján hozott intézkedések időbeli hatálya korlátozott és feltételes: ha a háború nem törne ki, legfeljebb négy hónapig maradhatnak hatályban, hacsak az országgyuulés ${ }^{41}$ jóvá nem hagyja öket. ${ }^{42}$

A kivételes hatalom alapján hozott intézkedések tárgyát, hatályát és a hatálybalépés időpontját a kormány állapítja meg, de ezeket az intézkedéseket a legszélesebb körben ismertetni kell: egyrészt az állampolgárokkal a hivatalos lapban való közzététel útján, illetve minden érintett községben a helyben szokásos módon; másrészt utólag az országgyưléssel,

$35 \mathrm{Az}$ 1912-es törvény megszületése tehát elsősorban nem organikus jogfejlődés eredményeként, hanem egy adott közjogi problémára adott válaszként értelmezhető. A szabályozás időszerúsége vitán felül állt, viszont a saját javaslat megalkotása a magyar szuverenitást demonstrálta. Az egyeztetési folyamat állomásaira és a magyar álláspont alakulására lásd: Galántai, 1981, 196-197. o. Továbbá lásd még: Kelemen, 2016.

36 Részletesen lásd: Galántai, 1981, 196-197. o.

37 Kit. 1. \$ (1) bekezdés.

38 „Az 1912:63. tc. világos intencióval megkonstruált törvényünk s különösen abból a szempontból méltányolható, hogy mint lehet a posszibilis garanciák szoros védőfala között is biztosítani a kormányhatalomnak azt a szabad kezet, azt a rugalmas postestast, mely háborús viszonyok között eminens érdekünk." (Felszeghy, 1914, 474. o.; Polner, 1914).

39 A Kit. törvényjavaslatának indokolása szerint a katonai elókészület az az időszak, „[...] a midőn a helyzet komolysága általánosan és kétségbevonhatlanul megállapitható" (Részletes indokolás az 1. \$-hoz).

40 Vö.: Kit. 1. \$ (2) bekezdés és 3. \$.

41 E tekintetben a kormány államérdekre hivatkozással kérheti a vita mellőzését (vagyis a gyorsított országgyưlési döntéshozatalt). Lásd: Kit. 4. \$(4) bekezdés.

42 Lásd: Kit. 1. \$ (3) bekezdés. 
amelynek a „kivételes hatalom igénybevételét, valamint azt, hogy a kivételes hatalomból folyó intézkedések mely területre terjednek ki [...] a legközelebbi ülésben be kell jelenteni”.43

\subsubsection{A kormánybiztosok hatásköre}

Az 1848-49-ben a gyakorlatban bevált kormánybiztosi intézmény Kit.-be történő beépítése jelzi, hogy a sietség ellenére az elôterjesztő a magyar jogi hagyományoknak is megfelelő tervezet készítésére törekedett. A kormánybiztos itt már egyértelmú feladat- és hatáskörökkel rendelkezett, ugyanakkor teljhatalmát a jogalkotó több eszközzel - így például az intézkedései ellen biztosított jogorvoslati joggal - korlátok közé szorította.

A Kit.-ben rögzített felhatalmazáson alapuló közigazgatási feladatok végrehajtására Magyarországon a kormány, Horvát-Szlavónországokban a bán kormánybiztosokat ${ }^{44}$ nevezhet ki. ${ }^{45}$ Kormánybiztosok „csak magyar honos polgári egyének” lehetnek. ${ }^{46} \mathrm{~A}$ kormánybiztosok a kormánynak közvetlenül alárendelve múködnek, de az illetékes katonai parancsnokokkal összhangban kötelesek eljárni. A kormánybiztosok illetékességi területét a kormány állapítja meg: állandó székhely esetén egy vagy több törvényhatóság területére terjed ki, a katonai parancsnok mellé kirendelt kormánybiztos illetékessége viszont a katonai parancsnok teljes múködési területére is kiterjedhet. ${ }^{47}$

Feladatuk általánosságban, hogy „szükség esetén a közrend és a közbiztonság fenntartásáról gondoskodjanak, és hogy azokat a rendes közigazgatási intézkedéseket is megtegyék, amelyek a hadviselés sikere érdekében szükségesek". ${ }^{48}$ Ennek érdekében közvetlenül utasíthatják a törvényhatósági alkalmazottakat, az állami erdészet személyzetét, a rendfenntartó erők (csendőrség és rendőrség), valamint a pénzügy- és a határőrség alkalmazottait, akik a kormánybiztostól a Kit. alapján kapott feladatokat soron kívül kötelesek végrehajtani. E közegek az illetékes miniszter jóváhagyásával hatáskörükön kívüli feladatokra is igénybe vehetők. ${ }^{49} \mathrm{~A}$ kormánybiztos intézkedései azonnal végrehajtandók, viszont velük szemben

43 Lásd: Kit. 2. \$, valamint Részletes indokolás a 2. \$-hoz. Bár a Kit. csak az állampolgárok esetében írja elő a kormány tájékoztatási kötelezettségét, „ha intézkedéseit kiterjeszti, korlátolja vagy hatályukat megszünteti”, a törvénycikk és a törvényjavaslat indokolásából a jogalkotónak a legszélesebb nyilvánosság biztosítását célzó szándéka olvasható ki, vagyis ez esetben is szükséges az országgyûlés utólagos tájékoztatása.

44 A kormánybiztosi intézménynek komoly hagyományai voltak a magyar történelemben, illetve a közjogban. Az 1848-49-es szabadságharc alatti múködésükre lásd bővebben: Hermann, 1998.

45 Vö.: Kit. 4. \$ (1) és (12) bekezdés.

46 Vagyis a Magyar Királyság állampolgárai, akik nem tagjai a hadseregnek.

47 Kit. 4 . $\$(3)-(4)$ bekezdés.

48 Vö.: Kit. 4 . $\$(2)$ bekezdés.

49 A késlekedő, nem engedelmeskedő alkalmazottat a kormánybiztos felfüggeszthette, másokkal helyettesíthette, a feladat ellátására alkalmatlannak vélt személyt pedig rendelkezési állományba helyezhette. Ezen intézkedések hatálya a rendkívüli állapot megszúnéséig tartott, de a vétkes magatartása miatt felfüggesztett alkalmazott ellen hivatalból fegyelmi eljárást is kellett indítania (az erre egyébként általában hatáskörrel rendelkező személyeknek). Vö.: Kit. 4. \$(5)-(10) bekezdés. 
a Kit. jogorvoslati jogot biztosított az illetékes miniszterhez. A megtámadott döntés ellen annak meghozatalától számított 15 napon belül lehetett fellebbezéssel élni. ${ }^{50}$

\subsubsection{A kivételes hatalom által érintett jogágak, jogszabályok}

A Kit. érdemi része mai jogi szakszóval nevezve alapjogi korlátozások lehetőségét teremti meg (5-12. \$), illetve egyes cselekmények vagy mulasztások szankcionálását vagy azok általában szokásos büntetési tételének megemelését teszi lehetővé (15., 18-30. \$). ${ }^{51}$

A Kit. által lehetôvé tett alapjogi korlátozásokat az alábbi táblázat szemlélteti.

\begin{tabular}{|c|l|}
\hline $\begin{array}{c}\text { Helyi } \\
\text { önkormányzáshoz } \\
\text { való jog }\end{array}$ & $\begin{array}{l}\text { (a) A kormány rendelettel ideiglenesen hatályon kívül helyezheti az ön- } \\
\text { kormányzati szabályrendeletek rendőri természetú rendelkezéseit, ezek } \\
\text { helyére belügyminiszteri vagy kormánybiztosi rendelettel ideiglenes sza- } \\
\text { bályozás alkotható; (b) a belügyminiszter a törvényhatósági bizottság vagy } \\
\text { a községi (rendezett tanácsú városi) képviselő-testület minden határozatát, } \\
\text { amely hadviselési érdeket sért vagy a közrend és a közbiztonság fenntar- } \\
\text { tását veszélyezteti, hivatalból megsemmisítheti, és „amennyiben a fenti } \\
\text { szempontból intézkedésre szükség van, ezt saját hatáskörében megteheti” } \\
\text { [Kit. 5. \$ (2)-(3) bekezdés]. }\end{array}$ \\
\hline $\begin{array}{c}\text { Jogorvoslathoz } \\
\text { való jog }\end{array}$ & $\begin{array}{l}\text { A helyi önkormányzatok szabályalkotási jogának elvonásával kapcsolatos } \\
\text { rendelkezések és intézkedések ellen jogorvoslatnak nincs helye [Kit. 5. \$ } \\
\text { (3) bekezdés]. }\end{array}$ \\
\hline $\begin{array}{c}\text { Külföldre utazáshoz } \\
\text { való jog }\end{array}$ & $\begin{array}{l}\text { A kormány az útlevél-kiállítás jogát az állam egész területén vagy egy } \\
\text { részén a törvény szerint eljáró hatóságok hatásköréból kiveheti, és Magyar- } \\
\text { országon a belügyminiszter, Horvát-Szlavónországokban a bán hatás- } \\
\text { körébe utalhatja [Kit. 6. \$ (1) bekezdés]. }\end{array}$ \\
\hline
\end{tabular}

50 Vö.: Kit. 4. \$ (11) bekezdés, valamint Részletes indokolás a 4. \$-hoz. A két szöveg összevetéséből következően fellebbezéssel az érintett élhetett.

51 A törvény biztosítja továbbá a rendkívüli állapot kezeléséhez szükséges pénzügyi mozgásteret (a hadviseléshez szükséges költségek megelőlegezését) is a kormány számára, amíg az országgyưlés azokat meg nem állapítja. Lásd: Kit. 17. \$. 


\begin{tabular}{|c|c|}
\hline $\begin{array}{l}\text { Szabad mozgás } \\
\text { és tartózkodási } \\
\text { hely szabad } \\
\text { megválasztása }\end{array}$ & 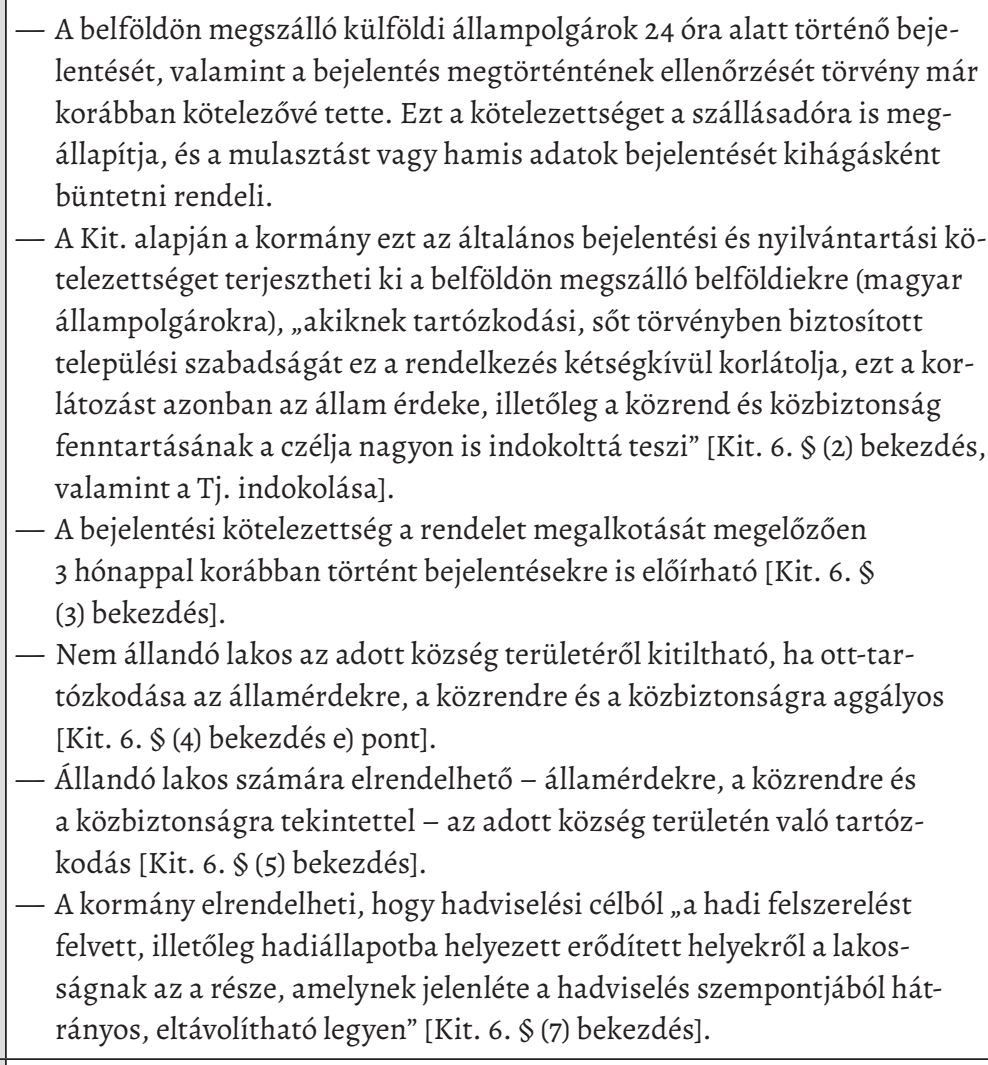 \\
\hline Tulajdonhoz való jog & $\begin{array}{l}\text { A kormány korlátozhatja vagy megtilthatja olyan tárgyak birtoklását } \\
\text { vagy használatát, amelyek a hadviselés érdekeinek vagy a közrendnek } \\
\text { és a közbiztonságnak veszélyeztetésére használhatók (fegyverek, lőszer, } \\
\text { lôpor, robbantó anyagok stb.), és az ily tárgyak beszolgáltatását elrendelheti } \\
\text { [Kit. 7. § (1) bekezdés]. }\end{array}$ \\
\hline $\begin{array}{l}\text { Vállalkozáshoz való } \\
\text { jog }\end{array}$ & $\begin{array}{l}\text { Ha tartani lehet attól, hogy egyes fogyasztási cikkek ára a katonaság be- } \\
\text { vonulása, elvonulása, katonai elókészületek vagy háború nyomán arányta- } \\
\text { lanul és indokolatlanul emelkedni fog, a kormány hatósági árat rendelhet el } \\
\text { [Kit. 7. \$ (4)-(5) bekezdés]. }\end{array}$ \\
\hline $\begin{array}{c}\text { Személyi } \\
\text { szabadsághoz } \\
\text { való jog }\end{array}$ & $\begin{array}{l}\text { Ha az a gyanú merül fel, hogy valaki a hadviselés érdekeinek vagy a köz- } \\
\text { rendnek és a közbiztonságnak veszélyeztetésére használható tárgyat (fegy- } \\
\text { verek, lőszer, lópor, robbantó anyagok stb.) jogosulatlanul tart birtokában, } \\
\text { ennek megállapítása végett nála személymotozás és házkutatás tartható. } \\
\text { A jogosulatlanul birtokolt tárgyakat el kell kobozni [Kit. 7. \$ } \\
\text { (2)-(3) bekezdés]. }\end{array}$ \\
\hline
\end{tabular}




\begin{tabular}{|c|c|}
\hline $\begin{array}{l}\text { Magántitok védel- } \\
\text { méhez való jog }\end{array}$ & $\begin{array}{l}\text { A kormány a nemzetközi egyezmények korlátai közt megteheti mindazokat } \\
\text { az intézkedéseket, amelyek szükségesek avégből, hogy a postai, távirdai } \\
\text { és távbeszélő-forgalom és -érintkezés a hadviselés érdekeinek megóvása } \\
\text { céljából ellenőrzés alá vétessék [Kit. 8. \$ (1) bekezdés]. }\end{array}$ \\
\hline $\begin{array}{l}\text { Szabad vélemény- } \\
\text { nyilvánítás joga }\end{array}$ & $\begin{array}{l}\text { — A kormány elrendelheti, hogy az időszaki lapoknak és más sajtótermé- } \\
\text { keknek a sajtöügyi közvádlóhoz benyújtandó sajtórendészeti köteles- } \\
\text { példányait a szétküldés előtt kell a legközelebbi ügyészségnek, illetve } \\
\text { rendőrségnek kézbesíteni, és hogy a szétküldés, amennyiben korábban } \\
\text { meg nem engedik, időszaki lapoknál csak a sajtórendészeti kötelespéldány } \\
\text { kézbesítésétől számított három óra múlva, más sajtótermékeknél a kézbe- } \\
\text { sítés napjától számított egy hét múlva veheti kezdetét. } \\
\text { — Ha az illetékes ügyészség vagy rendôrség arról győződik meg, hogy } \\
\text { valamely sajtótermékkel a hadviselés érdekeit érintô búncselekmény va- } \\
\text { lósul meg, a sajtótermék szétküldését megtilthatja, ám ezzel egyidejûleg } \\
\text { köteles a tilalom megszegésének a 25. \$-ban megállapított (büntetőjogi) } \\
\text { következményeit a sajtótermék elóállítójával közölni. } \\
\text { — A kormány egyes belföldi időszaki lapok megjelenését és ter- } \\
\text { jesztését - amennyiben közleményeik a hadviselés érdekeit } \\
\text { veszélyeztetik - betilthatja. } \\
\text { — A kormány a külföldről érkező sajtótermékeket rendeltetési helyülkre } \\
\text { érkezésük előtt ellenőrizheti, és amennyiben tartalmuk a hadviselés } \\
\text { érdekeire veszélyes, azokat lefoglaltathatja. } \\
\text { — Külföldi időszaki lapok behozatala és terjesztése egészen is eltiltható } \\
\text { [Kit. 11. \$ (1)-(5) bekezdés]. }\end{array}$ \\
\hline Egyesülési jog & $\begin{array}{l}\text { Ha az „állam biztonsága szempontjából szükséges”: } \\
\text { — új egyesületek vagy fiókegyesületek alakítása megtiltható; } \\
\text { — már meglevő egyesületek vagy fiókegyesületek gyúlése ellenőrizhető, } \\
\text { múködésük korlátozható vagy felfüggeszthető; } \\
\text { — a hatósági ellenőrzés alatt nem álló kereskedelmi társaságok vagy más } \\
\text { társulatok, pénztárak rendőri ellenőrzés alá vonhatók, ha az a gyanú } \\
\text { merül fel, hogy múködésük jogszabályba vagy alapszabályukba ütközik, } \\
\text { avagy államellenes irányzatot vesz. A gyanú beigazolódása esetén gyú- } \\
\text { léseik betilthatók vagy feloszlathatók, jogellenes határozataik végre- } \\
\text { hajtása pedig megtiltható [Kit. 9. \$ (1) bekezdés]. }\end{array}$ \\
\hline Gyülekezési jog & $\begin{array}{l}\text { Ha az állam biztonsága érdekében szülsséges, a kormány politikai jellegû } \\
\text { népgyuulések, felvonulások, körmenetek stb. tartását megtilthatja, és } \\
\text { - a közigazgatási hatóságok gyưléseinek kivételével - egyéb gyúlések } \\
\text { tartását hatósági engedélytől teheti függővé, tekintet nélkül arra, hogy } \\
\text { bejelentésük rendes körülmények között kötelező-e, vagy sem [Kit. 10. § } \\
\text { (1) bekezdés]. }\end{array}$ \\
\hline
\end{tabular}




\begin{tabular}{|c|l|}
\hline $\begin{array}{c}\text { Polgári eljárásjogi } \\
\text { garanciák }\end{array}$ & $\begin{array}{l}\text { A kormány a magánjogi követelések érvényesítése tekintetében - ideértve } \\
\text { a váltókövetelések érvényesítését is -, továbbá a polgári peres és nem peres } \\
\text { eljárás és általában a polgári igazságszolgáltatás, végül a jegybank ügyvitele } \\
\text { tekintetében rendkívüli intézkedéseket tehet, és evégból a fennálló törvé- } \\
\text { nyektôl eltérő rendelkezéseket is állapíthat meg [Kit. 16. \$]. }\end{array}$ \\
\hline $\begin{array}{c}\text { Büntetőjogi } \\
\text { garanciák }\end{array}$ & $\begin{array}{l}\text { Kit. alapján: (a) egyes büntetőeljárási szabályok kormány- vagy miniszteri } \\
\text { rendelettel is megalkothatók; (b) egyes búncselekmények a búnvádi per- } \\
\text { rendtartástól (Bp.) eltérố szabályok alapján is elbírálhatók; (c) „a polgári } \\
\text { büntetố bíróságok akkor is eljárhassanak, ha a Bp. szerint illetékes- } \\
\text { séggel nem is bírnak” [Kit. 12. \$1-4. pontok, 31. \$ és Részletes indokolás } \\
\text { a 12. \$-hoz és a 31. \$-hoz]. }\end{array}$ \\
\hline
\end{tabular}
1. táblázat
Alapjog-korlátozások a Kit.-ben
Forrás: a szerző saját összeállítása a Kit. alapján

A Kit. által bevezetett szankciók alapvetően háromirányúak voltak: kihágási (szabálysértési) tényállások szigorítása, bővítése; büntetőjogi szigorítások létező tényállások kiegészítése, új tényállások megalkotása révén; rendes eljárások statáriális körbe vonása.

A kihágási tényállások egy része az alapjogi korlátozásokhoz kapcsolódik (6-7., 9-11. \$), de a Kit. tartalmaz egy generális klauzulát is a kormánybiztos intézkedéseinek nyomatékosítása érdekében [15. \$ (1) bekezdés]. A büntetőjogi szigorítások célja az állam érdekeinek háború idején történő „hathatós büntetőjogi védelme”, ${ }^{52}$ ennek érdekében a törvény több helyen szigorítja és pontosítja a büntető- (1878. évi V. törvény) és a kihágási (1879. évi XL. törvény) törvényeket. A rendes eljárások statáriális körbe vonása körében a Kit. anyagi és alaki szabályoktól való eltéréseket is engedett a kormány számára, amikor lehetővé tette, hogy egyes büncselekményekre a rögtönítélő bíráskodás szabályait alkalmazzák, ${ }^{53}$ másrészt e szabályokat a szokásostól eltérôen rendeleti úton is megalkothassák. ${ }^{54}$

\subsubsection{A törvény a gyakorlatban: a kivételes hatalom alkalmazása és kiterjesztése (1914-1918)}

A szarajevói merényletet követő válsághelyzet eszkalálódásával az Osztrák-Magyar Monarchia a háborús előkészület (1.2.2. pont) szakaszába lépett. A jogforrások alapján

52 Lásd: Kit. Részletes indokolás a II. fejezethez.

53 Lásd: Kit. 12. \$4 pont és Részletes indokolás a 12. \$-hoz.

54 Lásd: Kit. 31. \$ és Részletes indokolás a 31. \$-hoz, valamint a polgári büntetőbíráskodás alá tartozó egyéneknek a honvéd büntetőbíráskodás alá helyezéséről szóló 5491/1914. ME rendelet [Rendeletek Tára (a továbbiakban: RT) 1914. 1990.] és a gyorsított búnvádi eljárás szabályairól szóló 12002/1914. IM rendelet (RT 1914. 1976-1989.), továbbá a gyorsított bưnvádi eljárás életbeléptetéséról szóló 5488/1914. ME rendelet (RT 1914. 1434-1437.). 
a Kit. alkalmazására először az 1914. július 26-i rendeletcsomag kapcsán került sor. ${ }^{55}$ E rendeletcsomag egyes elemeinek hatályát aztán 1914. augusztus 1-jével kiterjesztették,, ${ }^{56}$ és ezzel megkezdődött a Kit. felhatalmazása alapján készült rendeletek kiadása. A háború állandósulásával a Kit. és „rendeletbokrai” a hétköznapi élet egyre több területét fonták át. ${ }^{57}$ A törvény szinte állandó hivatkozási alappá vált, ${ }^{58}$ ezért a szövegét a gyakorlati tapasztalatok alapján és az újonnan felmerülő helyzetek kezelése érdekében a háború ideje alatt többször is módosították. ${ }^{59}$

\subsubsection{Kitekintés: a különleges jogrend szabályozása az Osztrák-Magyar Monarchia másikfelében (1867-1918)}

Amíg Magyarországon a kivételes hatalom átfogó szabályozására csak a dualizmus utolsó évtizedében, akkor is csak a honvédelem érdekeihez kapcsolódóan került sor, Ausztriában a kiegyezést követően kibocsátott alaptörvények már általános jellegú szabályokat tartalmaztak a különleges jogrendre. ${ }^{60} \mathrm{~A}$ máig hatályos, a polgárok alapvetó jogairól szóló törvény ${ }^{61}$ az egyes jogok korlátozásával kapcsolatban a részletszabályok kidolgozását külön törvényre bízta, amely 1869-ben el is készült. ${ }^{62}$

A törvény egészen a világháború végéig hatályban volt, ${ }^{63} 1914$ májusa és 1917 eleje között ez alapján kormányozták a Monarchia osztrák felét. ${ }^{64}$

55 Lásd: RT 1914. 1410-1413.

56 Lásd: RT 1914. 1448-1450.

57 Vö. például a házasságkötésre vonatkozó kivételes intézkedésekről szóló 647/1915. ME rendelet (RT 1915. 7072.), illetve az Élesztőipari Bizottság alakításáról szóló 119/1918. ME rendelet (RT 1918. 3-6.).

58 Lásd például a háború fogalmát az 1915. évi XIX. törvényben.

59 Vö.: 1914. évi L. tv., 1915. évi XIII. tc., 1916. évi IV. tv., 1917. évi VII. tv.

60 Lásd: az 1861. február 26-i alaptörvényt módosító államalaptörvény 14. \$ (korabeli magyar fordítását lásd: Pesti Napló 1867. 12. 28. 96.).

61 Korabeli magyar fordítását lásd: Pesti Napló 1867. 12. 29. 99., valamint Deák, 2001.

62 Ez volt az 1869. május 5-i törvény, eredeti szövegét lásd: Reichsgesetzblatt 1869/31. 303-306., magyar nyelvú összefoglalását Polner, 1917, 38-40. o., valamint Tóth, 1967.

63 A magyar fél részére tehát viszonylag korán rendelkezésre állt volna egy szabályozási minta, amelynek alkalmazása azonban az alapjogok törvény általi szabályozását is szükségessé tette volna, amellyel azonban a törvényhozás az egész korszakban adós maradt. Az alapjogi szabályozással - amely tehát a kivételes hatalom szabályozásának előfeltétele is lett volna - kapcsolatos osztrák és magyar felfogás különbözőségét jól demonstrálja Eöttevényi, é. n. Az egyesülési és gyülekezési jog tekintetében lásd még: Domaniczky, 2010; Domaniczky, 2012.

64 Lásd bővebben: Szinai, 1986; Murber, 2018. 


\subsection{A különleges jogrend továbbélése a két háború korában}

\subsubsection{Biztos pont a válságban (1918-1922)}

A háború végén a Károlyi-kormány a Kit.-et - az 1918. november 16-i néphatározatnak megfelelően - kétféleképpen használta. ${ }^{65}$ Egyrészt megkezdte a szabadságjogokkal kapcsolatban bevezetett korlátozások (például egyesülési, gyülekezési jog, sajtószabadság) feloldását, ${ }^{66}$ másrészt viszont továbbra is élt a Kit. által biztosított felhatalmazásokkal a már létező szabályozások fenntartásához. ${ }^{67}$ A szabadságjogokra vonatkozó korlátozásokat a Friedrich-kormány visszaállította. ${ }^{68}$

A Kit. és a hozzá kapcsolódó joganyag rendeltetése szerint a háború végéig maradt volna hatályban, de a békeszerződés megkötéséhez közeledve a hatályát meghosszabbították. Az erről szóló 1920. évi VI. törvény ${ }^{69}$ a meghosszabbítás lehetséges időtartamát a „békeszerződés megerősítésétől” számított egy évben határozta meg, amely három hónappal még meghosszabbítható volt. ${ }^{70} \mathrm{~A}$ békeszerződés becikkelyezésére azonban csak az 1921. évi XXXIII. törvénnyel került sor, amely 1921. július 26 -án lépett hatályba, ${ }^{71}$ tehát az 1920-as törvény alapján a Kit.-féle joganyag legkésőbb 1922 júliusának végéig maradhatott volna hatályban.

Fontos megjegyezni, hogy a kivételes hatalom alapján keletkezett joganyag hatályának fenntartását csak részben indokolta a békébe történő átmenet zökkenőmentessége. Sokkal inkább arról volt szó, hogy a különleges jogrend a számtalan nehézséggel küzdő ország újraszervezését könnyítette meg. Erre utalt az 1920. évi VI. törvény, amikor a kivételes hatalom fenntartásának alapjául szolgáló érdeket a belső rend, a közbiztonság és a külpolitikai érdekek biztosításában határozta meg. ${ }^{72}$ Fontos szemléletbeli változásnak számít az is, hogy a jogalkotó felismerte, hogy egyes jogviszonyok a háború időszakában (vagy azt követően)

65 Fontos kiemelni, hogy a Károlyi-kormány és a Nemzeti Tanács megvizsgálta, hogy a régi rend által alkotott jogforrásokra mennyiben támaszkodhat. Károlyi maga a „tiszta jogalap” álláspontjára helyezkedett, ennek köszönhetően fennállása alatt folyamatosan élt a Kit. által biztosított felhatalmazásokkal. Lásd bővebben: Schönwald, 1969, 233-234. o.

66 Vö.: 4802/1918. ME rendelet (RT 1918. 2198-2199.), 4969/1918. ME rendelet (RT 1918. 2199-2200.), 4970/1918. $\mathrm{ME}$ rendelet ( $\mathrm{RT}$ 1918. 2200.).

67 Vö. például a burgonya, tengeri és árpa szesztermeléshez való felhasználásának eltiltásáról szóló 4878/1918. ME rendeletet vagy a fa- és faszénkészletek bejelentésére és nyilvántartására, valamint felhasználásuk és forgalomba hozataluk szabályozására vonatkozó 1851/1917. ME számú és 2086/1917. ME számú rendeletek egyes intézkedéseinek módosításáról szóló 5034/1918 ME rendeletet (RT 1918. 2197, 2201.).

68 Vö.: 5499/1919. ME rendelet (RT 1919. 874-875.), 5084/1919. ME rendelet (RT 1919. 729-730.).

69 Hatályba lépett: 1920. május 13.

70 Lásd: a háború esetére szóló kivételes hatalom meghosszabbításáról szóló 1920. évi VI. törvény 1. \$.

71 Lásd: a trianoni békeszerződés életbeléptetéséről szóló 7200/1921. ME rendelet (RT 1921. 241-242.).

72 Lásd: 1920. évi VI. törvény $1 . \$$ (2) bekezdés. 
oly mértékben változtak meg, hogy az eredeti állapot visszaállítása (az összes Kit.-tel kapcsolatos jogszabály hatályon kívül helyezése) már nem lehetséges. ${ }^{73}$

\subsubsection{A kivételes hatalom állandósulása (1923-1939)}

Az 1920. évi VI. törvényből is kiolvashatóan a Bethlen-kormánynak szüksége volt a kivételes hatalomra, még a törvényben biztosított határidő után is, ezért végül egy költségvetési törvénybe beépítve tette lehetővé a különleges jogrendre épült szabályozás fenntartását. ${ }^{74}$ Az 1922 augusztusában hatályba lépő, az 1922/23. költségvetési év első hat hónapjában viselendő közterhekről és fedezendő állami kiadásokról szóló 1922. évi XVII. törvény 6. \$-a egyszerre írta elő - szoros határidőhöz kötve - a Kit.-féle joganyag deregulációját, ${ }^{75}$ illetve adott idôbeli korlát nélküli, ám a Kit.-re épülő rendeletalkotási jogot a kormánynak a „békeszerződés végrehajtása vagy a békeszerződés rendelkezései következtében előállott helyzet rendezése céljából". ${ }^{76}$

A Kit.-féle joganyag első deregulációja ezt követően 1923-ban megtörtént, ${ }^{77}$ de a korszak végén, az 1939-es honvédelmi törvény ${ }^{78}$ hatálybalépéséhez kapcsolódva még egy deregulációs hullám következett, és a kormány végül számos (közel száz), Kit. alapján hozott rendeletet továbbra is hatályban tartott. ${ }^{79}$ Ezekre nézve a Hvt. 1939 megengedte, hogy a kormány tetszőlegesen módosítsa és kiegészítse azokat. ${ }^{80}$

Meg kell jegyezni, hogy a gazdasági világválság kezelésére - a „gazdasági és hitelélet rendjének megóvása" érdekében - a kormány törvénnyel egy, a Kit.-hez képest szúkebb körû́ felhatalmazást is kapott 1931-ben. ${ }^{81}$

73 Vö.: 1920. évi VI. tv. 2. \$. A háborús joganyag hatályon kívül helyezése vagy hatályban tartása valamennyi hadviselő államban problémát okozott. A kérdésre országonként eltérő válaszok születtek (például Magyarország és Új-Zéland a hatályban tartás, Ausztrália a hatályon kívül helyezés mellett döntött).

74 Lásd még: Takács, 1973.

75 Lásd: 1922. évi XVII. tv. 1. \$(1)-(2) bekezdés.

76 Lásd:1922. évi XVII. tv. 1. \$(3) bekezdés.

77 Lásd: a kivételes hatalom alapján kibocsátott egyes rendeletek hatályának megszúnéséről szóló 960/1923. ME rendelet (RT 1923. 29-38.). Az 1939-es dereguláció alkalmával a jogalkotó utalt arra, hogy a 6976/1922. ME rendelet készítésekor a jogszabályok listájába hiba csúszott, ezt 1939-ben próbálták korrigálni (vö.: RT 1939. 282. 2-3. \$).

78 A honvédelemról szóló 1939. évi II. törvény (a továbbiakban: Hvt. 1939).

79 Lásd: a háború esetére szóló kivételes intézkedésekről alkotott törvények, valamint a kivételes hatalom meghosszabbításáról és kiterjesztéséről szóló törvényi rendelkezések alapján kibocsátott, illetőleg fenntartott rendeletek közzétételéról szóló 8270/1939. ME rendelet (RT 1939. 1281-1355.).

80 Lásd: Hvt. 1939232 . \$ (3) bekezdés.

81 Lásd: a gazdasági és hitelélet rendjének, továbbá az államháztartás egyensúlyának biztosításáról szóló 1931. évi XXVI. törvény, amelyet egészen 1944. december 31-ig időről időre folyamatosan meghosszabbítottak (utoljára: 1944. évi IV. tv.). 


\subsubsection{A különleges jogrend újabb szabályozása: a honvédelemröl szóló 1939. évi II. törvény}

Az újabb konfliktushelyzet kapujában került sor a honvédelemról szóló 1939. évi törvény megalkotására, amely végül a Kit.-et és az azt módosító valamennyi törvényt, továbbá a Kit. hatályát fenntartó törvényi rendelkezéseket is hatályon kívül helyezte. ${ }^{82}$ A Hvt. 1939 ugyanakkor lehetôvé tette a Kit. alapján létrejött jogszabályok további hatályban tartását is, a Teleki-kormány deregulációs rendelete e felhatalmazás alapján készült (1.3.2. pont). ${ }^{83}$

A Hvt. 1939 egyúttal újrakodifikálta a kivételes hatalom intézményét. ${ }^{84} \mathrm{~A}$ kivételes hatalomnak a honvédelmi törvénybe való inkorporálása rendszerektől függetlenül hosszan tartó hagyományt teremtett. ${ }^{85} \mathrm{~A}$ Hvt. 1939 - a Kit. alkalmazása során, több mint két évtized alatt összegyưlt tapasztalatokra építve ${ }^{86}$ - a korábbinál jóval tágabb körben vonta meg a kivételes hatalom korlátait.

Alapesetben a Hvt. 1939 szerint a kormány kivételes hatalommal élhet: háború vagy az országot közvetlenül fenyegetô háborús veszély idején; a törvényhozás további rendelkezéséig; a szükséges mértékben, de a Hvt. 1939-ben meghatározott rendelkezések révén. ${ }^{87}$ Ez alól kivételként, „ha a késedelemben veszély van”, a Hvt. 1939 egy tág felhatalmazást is biztosít a kormány részére: a honvédelem érdekében; a közigazgatási, magánjogi, eljárási és a törvényhozás hatáskörébe tartozó egyéb intézkedések meghozatalára. ${ }^{88} \mathrm{E}$ tág felhatalmazással szemben a Hvt. 1939 egy tárgyi ${ }^{89}$ és eljárási ${ }^{90}$ korlátot állapít meg. A kivételes hatalom általános korlátjaként a Hvt. 1939 rögzíti, hogy elrendelése négy hónapra szólhat, és azt csak az országgyúlés hozzájárulásával lehet alkalmanként négy hónappal meghosszabbítani.91 A Hvt. 1939 ugyancsak a Kit.-re épülő jogszabálybokrok tapasztalataiból okulva törvényi felhatalmazást biztosít a kormány részére a háborút követő átmeneti időszak intézkedéseinek megtételére.92 A Hvt. 1939 fenntartotta továbbá a kivételes hatalommal kapcsolatos büntetőjogi szabályozásra vonatkozó igényét, bár ezek a rendelke-

82 Lásd: Hvt. 1939 231. \$ (2) bekezdés.

83 Hvt. 1939 232. \$, valamint 8270/1939. ME rendelet (RT 1939. 1281-1355.).

84 Hvt. 1939141-170. \$.

85 Vö.: a honvédelemről szóló 1960. évi IV. tv., 1976. évi I. tv., 1993. évi CX. tv., 2004. évi CV. tv., 2011. évi CXIII. tv. 86 A tapasztalatok beépítését - számos esetben a konkrét jogszabályi helyek megjelölése mellett - egyébként a Hvt. 1939 javaslatához készült indokolás is hangsúlyozza. Lásd bővebben: Hvt. 1939 javaslatának Részletes indokolása (a 141-170. \$-hoz).

87 Hvt. 1939141. \$ (1) bekezdés.

88 Hvt. 1939141. $\$(2)$ bekezdés.

89 A Hvt. 1939141. \$ (3) bekezdése szerint az állami főhatalom szervezetét és múködését érintő, a törvényhatósági és községi önkormányzat rendszerét módosító vagy megszüntető rendelkezéseket kibocsátani, továbbá az egyébként fennálló törvényi felhatalmazásokon túlmenően anyagi büntetőjogi szabályokat megállapítani nem lehet.

90 A Hvt. 1939141. \$ (3) bekezdése szerint a (2) bekezdés alapján kibocsátott rendeleteket haladéktalanul be kell mutatni az alábbi rendelkezések értelmében az országgyúlés mindkét házából alakítandó országos bizottságnak, amelynek összehívása iránt elnökei nyolc napon belül intézkednek.

91 Hvt. 1939141. $\$(8)$ bekezdés.

92 Hvt. 1939141. $\$(9)$ bekezdés. 
zések a Kit.-tel ellentétben a törvényen belül nem különülnek el.93 A Hvt. 1939 szankciórendszerrel kapcsolatos legfontosabb újítása a kormánybiztos kihágási jogkörrel történő felruházása volt.94

A Hvt. 1939 által meghatározott, kivételes hatalom révén szabályozható területeket terjedelmi okok miatt táblázatos formában tekintjük át.

\begin{tabular}{|c|c|c|c|c|}
\hline $\begin{array}{c}\text { Közigazgatással } \\
\text { kapcsolatos } \\
\text { hatáskörölk }\end{array}$ & $\begin{array}{l}\text { Rendészeti } \\
\text { hatáskörök }\end{array}$ & $\begin{array}{c}\text { Pénzügyi } \\
\text { hatáskörölk }\end{array}$ & $\begin{array}{l}\text { Igazságszolgálta- } \\
\text { tással kapcsolatos } \\
\text { hatáskörök }\end{array}$ & $\begin{array}{l}\text { Egyéb kivételes } \\
\text { hatáskörök }\end{array}$ \\
\hline $\begin{array}{l}\text { közigazgatási } \\
\text { szervezet } \\
\text { módosítása } \\
\text { (Hvt. 142.\$) }\end{array}$ & $\begin{array}{l}\text { útlevéllel } \\
\text { kapcsolatos } \\
\text { jogkörök } \\
\text { (Hvt. 146. \$) }\end{array}$ & $\begin{array}{c}\text { államháztartási } \\
\text { hitelmúveletek } \\
\text { (Hvt.155.\$) }\end{array}$ & $\begin{array}{c}\text { polgári jogi igaz- } \\
\text { ságszolgáltatás } \\
\text { (Hvt. 159.\$) }\end{array}$ & $\begin{array}{c}\text { határidők elmulasz- } \\
\text { tásából vagy meg nem } \\
\text { tartásából származó } \\
\text { jogkövetkezmények } \\
\text { elhárítása és enyhítése } \\
\text { (Hvt. 162. \$) }\end{array}$ \\
\hline $\begin{array}{c}\text { közig. határozatok } \\
\text { megsemmisítése, } \\
\text { illetve intézkedési } \\
\text { jogkör } \\
\text { (Hvt.143.\$) }\end{array}$ & $\begin{array}{l}\text { egyesülési jog } \\
\text { korlátozása } \\
\text { (Hvt. 148. §) }\end{array}$ & $\begin{array}{l}\text { pénzforgalom } \\
\text { szabályozása és } \\
\text { korlátozása } \\
\text { (Hvt. 156. \$) }\end{array}$ & $\begin{array}{l}\text { büntető eljárásjogi } \\
\text { szabályok kiegé- } \\
\text { szítése és módo- } \\
\text { sítása, büntető } \\
\text { eljárásjogi ga- } \\
\text { ranciák (törvényes } \\
\text { bíróhoz való jog) } \\
\text { korlátozása } \\
\text { (Hvt. 160. \$) }\end{array}$ & $\begin{array}{c}\text { közegészségügyi } \\
\text { intézkedések } \\
\text { (Hvt. 163.\$) }\end{array}$ \\
\hline $\begin{array}{c}\text { kormánybiztos } \\
\text { utasítási és } \\
\text { rendelkezési joga } \\
\text { (Hvt. 144. \$) }\end{array}$ & $\begin{array}{l}\text { gyülekezési jog } \\
\text { korlátozása } \\
\text { (Hvt. 149. \$) }\end{array}$ & $\begin{array}{c}\text { közszolgáltatá- } \\
\text { sokkal kapcso- } \\
\text { latos jogkörök } \\
\text { (Hvt. 157. \$) }\end{array}$ & $\begin{array}{l}\text { bírók bele- } \\
\text { egyezés nélküli } \\
\text { áthelyezése } \\
\text { (Hvt.161. } \$)\end{array}$ & $\begin{array}{l}\text { temetőkkel kapcso- } \\
\text { latos intézkedések } \\
\text { (Hvt. 164. §) }\end{array}$ \\
\hline $\begin{array}{c}\text { kormánybiztos } \\
\text { kihágási jogköre } \\
\text { (Hvt. 145. \$) }\end{array}$ & $\begin{array}{c}\text { kiürítés } \\
\text { (Hvt. 147. \$) }\end{array}$ & $\begin{array}{c}\text { nemzeti } \\
\text { hitelintézetek } \\
\text { müködésével } \\
\text { kapcsolatos } \\
\text { jogkörök } \\
\text { (Hvt. 158. \$) }\end{array}$ & & $\begin{array}{c}\text { kötelező biztosítá- } \\
\text { sokkal kapcsolatos } \\
\text { intézkedések } \\
\text { (Hvt. 165. \$) }\end{array}$ \\
\hline
\end{tabular}

93 A szankciórendszerrel kapcsolatban fontos megjegyezni, hogy a Kit. mellett már az 1920-as évektől több külön törvényt is elfogadtak, ezek egymáshoz való viszonyának bemutatása jelen tanulmányban nem lehetséges. Bővebben vö. a Hvt. 1939 tervezetéhez készült részletes indokolással.

94 Hvt. 1939145. \$. 


\begin{tabular}{|c|c|c|c|c|}
\hline $\begin{array}{c}\text { Közigazgatással } \\
\text { kapcsolatos } \\
\text { hatáskörök }\end{array}$ & $\begin{array}{l}\text { Rendészeti } \\
\text { hatáskörölk }\end{array}$ & $\begin{array}{c}\text { Pénzügyi } \\
\text { hatáskörök }\end{array}$ & $\begin{array}{l}\text { Igazságszolgálta- } \\
\text { tással kapcsolatos } \\
\text { hatásköröl }\end{array}$ & $\begin{array}{c}\text { Egyéb kivételes } \\
\text { hatáskörök }\end{array}$ \\
\hline & $\begin{array}{l}\text { kitiltás, fel- } \\
\text { ügyelet, ôrizet } \\
\text { (Hvt. 150. \$) }\end{array}$ & & & $\begin{array}{c}\text { érdekképviseleti szer- } \\
\text { vekkel kapcsolatos } \\
\text { jogkörök } \\
\text { (Hvt. 166. \$) }\end{array}$ \\
\hline & $\begin{array}{l}\text { sajtóellenőrzés } \\
\text { (Hvt. 151. \$) }\end{array}$ & & & $\begin{array}{l}\text { kereskedelmi társa- } \\
\text { ságokkal és kereske- } \\
\text { dőkkel kapcsolatos } \\
\text { jogkörök (Hvt. 167. \$) }\end{array}$ \\
\hline & $\begin{array}{l}\text { posta-, távíró-, } \\
\text { távbeszélő- } \\
\text { forgalom, } \\
\text { valamint a rádió } \\
\text { ellenőrzése } \\
\text { (Hvt. 152.\$) } \\
\end{array}$ & & & $\begin{array}{c}\text { tanintézetek tanul- } \\
\text { mányi és vizsga- } \\
\text { rendjével, valamint } \\
\text { a képesítő vizsgákkal } \\
\text { kapcsolatos jogkörök } \\
\text { (Hvt. 168. \$) }\end{array}$ \\
\hline & $\begin{array}{c}\text { fegyverekre, } \\
\text { lőszerekre, } \\
\text { robbanószerekre } \\
\text { és más veszélyes } \\
\text { tárgyakra } \\
\text { vonatkozó } \\
\text { korlátozás } \\
\text { (Hvt.153. } \$ \text { ) }\end{array}$ & & & $\begin{array}{c}\text { ipari és gazdasági } \\
\text { foglalkozások gya- } \\
\text { korlásához szükséges } \\
\text { előfeltételektől való } \\
\text { eltérést biztosító } \\
\text { jogkörök } \\
\text { (Hvt. 169. \$) }\end{array}$ \\
\hline & $\begin{array}{c}\text { szeszes italok } \\
\text { kiszolgálásának } \\
\text { korlátozása } \\
\text { (Hvt.154.\$) }\end{array}$ & & & $\begin{array}{c}\text { vagyontárgyak biz- } \\
\text { tonságba helyezésével } \\
\text { kapcsolatos jogkörök } \\
\text { (Hvt. 170. \$) }\end{array}$ \\
\hline
\end{tabular}

2. táblázat

Kivételes hatalom révén szabályozható területek a Hvt. 1939-ben

Forrás: a szerzô saját összeállitása a Hvt. alapján

\subsection{A kivételes hatalom a II. világháború alatt (1939-1945)}

A Hvt. 1939 kivételes hatalomról szóló rendelkezéseire hivatkozással a világháború időszakában folyamatosan készültek rendeletek. Ezek egyik része általában a kivételes hatalom 
igénybevétele érdekében, ${ }^{95}$ másik része pedig az egyes konkrét felhatalmazási szakaszok (142-170. §) alapján került kiadásra. A Hvt. 1939 kivételes hatalomról szóló rendelkezéseire 1945-ben még az Ideiglenes Nemzeti Kormány is hivatkozott, ${ }^{96}$ de ezek a hivatkozások rövid időn belül elmaradtak. ${ }^{97}$ A Hvt. 1939-et majd csak az 1960. évi honvédelmi törvény helyezte hatályon kívül.98

\section{A kivételes hatalom a Rákosi-rendszerben ${ }^{99}(1945-1956)$}

\subsection{Törvényi szabályozás}

Az Ideiglenes Nemzetgyúlés (a továbbiakban: INGY) 1944. december 21-tôl az 1945-ös választást követően létrejött Nemzetgyưlés 1945. november 29-i alakuló üléséig volt a szuverenitás legfőbb letéteményese, ${ }^{100}$ ám ebből eredő jogosítványait csak korlátozottan gyakorolta. ${ }^{101}$ Bár a rendkívüli körülmények között a kivételes hatalomra az új államhatalomnak is égető szüksége lett volna, ezzel kapcsolatos törvénykezésre csak 1946-ban került sor. Miután a születőben lévő államhatalom nem a jogfolytonosságra épült, a Hvt. 1939 felhatalmazására való hivatkozás sem jelentett megoldást. Az egyetlen járható útnak egy sui generis gyakorlat kialakítása túnhetett; végül ezt szentesítették az 1946 és 1949 közötti törvények.

A kivételes hatalom gyakorlása kezdetben azon alapult, hogy „[a]z Ideiglenes Nemzetgyűlés felhatalmazta az Ideiglenes Nemzeti Kormányt az ország ügyeinek vezetésére. Ez a felhatalmazás 1945. szeptemberig szolgált a kormány rendeletalkotó és -kibocsátó tevékeny-

95 Hvt. 1939141. \$, vö.: 8100/1939. ME rendelet (RT 1939. 1266-1267.), 11710/1939. ME rendelet (RT 1939. 2348.), 3650/1940. ME rendelet (RT 1940. 926.), 6090/1940. ME rendelet (RT 1940. 1881.), 9420/1940. ME rendelet (RT 1940. 3344.), 3130/1941. ME rendelet (RT 1941. 1112.), 6320/1941. ME rendelet (RT 1941. 2119.). Lásd még: Vargyai, 1979.

96 Vö.: a közalkalmazottak igazolásáról szóló 15/1945. ME rendelet (MK 1945/1. 3.), a közszolgálatban álló tisztviselők és egyéb alkalmazottak illetményei, továbbá a nyugdíjasok, özvegyek és árvák ellátási díjai tárgyában 800/1945. ME rendelet (MK 1945/22. 1.).

97 1944. december 21-től a szuverenitás kizárólagos letéteményese - így a kivételes hatalom szabályozására jogosult szerv - az Ideiglenes Nemzetgyuulés volt (MK 1945/1. 1.). A jogfolytonosság kérdése nemcsak 1945-ben, hanem már 1918-1920-ban is felmerült. Terjedelmi okok miatt itt csupán említés szintjén hivatkozom Molnár Kálmán munkáira, valamint újonnan megjelent életrajzára (Schweitzer, 2018), továbbá Polner Ödön egyik tanulmányára (Polner, 1931).

98 1960. évi IV. tv. 127. \$.

99 A korszakolásra lásd: Gyarmati, 2011; Palasik, 2000; újabban pedig: Palasik, 2017.

100 A változást az 1945. december 16-án hatályba lépett 1945. évi XI. törvény szentesítette [1. \$ (1) bekezdés].

101 Így például nem alkotott törvényeket. Föglein Gizella megfogalmazásában: az „Ideiglenes Nemzetgyúlés - a háborús körülményekből adódóan, önmagát korlátozva - még nem hozott legmagasabb szintủ jogszabályokat, vagyis törvényeket, csak határozatokat; mivel a budapesti és a dunántúli képviselők, azaz a teljesség híján még »csonka« volt. Így törvényalkotásra tulajdonképpen nem is volt jogosult, pontosabban nem jogosította fel önmagát." (Föglein, 1992, 5. o.). Bővebben az INGY-re: Feitl, 1995. 
ségének alapjául [...] 1945 szeptemberében a kormány újabb felhatalmazást kapott azzal a kiegészítéssel, amely a gyakorlatban már korábban is múködött, hogy a rendelettervezeteket előzetes jóváhagyásra be kell mutatni az INGY Politikai Bizottságának."102

A kivételes hatalomról szóló törvény megalkotására (vagyis a már létező gyakorlat törvénybe foglalására) - az állam gazdasági, pénzügyi és közigazgatási rendjének biztosítása érdekében - az 1946. évi VI. törvénnyel ${ }^{103}$ (a továbbiakban: Kht.) került sor. A Kht.-nek az 1912-es és az 1939-es szabályozással való összevetése révén látható, hogy 1946-ban elsősorban egy ideiglenes, az állami és nemzetgazdasági érdekek megvalósítását lehetővé tevő felhatalmazás készült.

A törvényben meghatározott időbeli és tárgyi hatály csak látszólag szoros, ugyanis a kivételes hatalom időben akár több mint öt hónapig vehető igénybe, és a kibocsátott rendeletekhez csupán a Nemzetgyúlés (a valóságban az INGY, majd az Országgyúlés Politikai Bizottsága) utólagos jóváhagyására volt szükség. ${ }^{104}$

A tárgyi hatály tekintetében a kivételes hatalom alapján csak az államháztartás egyensúlyának helyreállítása érdekében; a Nemzetgyưlés által alkotott törvények kivételével bármely magánjogi, büntetőjogi, közigazgatási és a törvényhozás hatáskörébe tartozó egyéb rendelkezéstől eltérő; a közjogi természetû rendelkezéseket nem érintő szabályozás megalkotására nyílik lehetőség. ${ }^{105}$

A Kht. által biztosított kivételes hatalom a gyakorlatban hasznosnak bizonyult, erre tekintettel lejárta után újabb törvény készült, ${ }^{106}$ amelynek hatályát több alkalommal is - utoljára 1949. december 31-ig - meghosszabbították. ${ }^{107}$

\subsection{Alkotmányi szabályozás}

A Magyar Népköztársaság Alkotmányáról (a továbbiakban: NKA) szóló 1949. évi XX. törvény 1949. augusztus 20 -án lépett hatályba. ${ }^{108}$ Megalkotása az addig de facto monista ala-

102 Palasik, 2000, 36-37. és 47-48. o.

103 A nemzeti kormány részére rendeletek kibocsátására adott felhatalmazásról szóló 1946. évi VI. törvény (a továbbiakban: Kht.).

104 Kht. 1. \$ (2)-(3) bekezdés, illetve 1947. évi XXVI. tv. 2. \$. Ez az ellenőrzési jogkör az 1940-es évek második felében többször változott. Palasik 1944. december és 1945. szeptember között a kormány rendelettervezeteinek előzetes jóváhagyásáról írt (Palasik, 2000, 47-48. o.). A Kht.-ben negyedévenkénti utólagos jóváhagyást kodifikáltak. Az 1947. évi XVI. tv. viszont - a rendeletek elfogadásától számítva - 15 napos határidőt írt elő a kormány számára, hogy a jóváhagyást megkérje.

105 Kht. 1. \$ (1) bekezdés.

106 Lásd: 1946. évi XVI. tv.

107 A Kht.-val (1946. évi VI. tv.) kapcsolatos szabályozás tartalmán azonban az élesedő politikai harcok egyre látványosabb nyomot hagytak. Vö.: 1946. évi XVI. tv., 1946. évi XXVIII. tv., 1947. évi VIII. tv., 1947. évi XXVI. tv., 1948. évi XXIV. tv., 1948. évi LVI. tv., 1949. évi XVII. tv.

108 Az 1949-es alkotmány a Politikai Bizottságot voltaképpen felszámolta, ezáltal a kivételes hatalomról szóló szabályozás a korábban rögzített időtartamnál három hónappal korábban gyakorlatilag hatályát vesztette (lásd bővebben: Mezey, 2003, 254. o.). Vö. még: 1.5.1. pont, valamint 1946. évi XVI. tv. 
pokon álló magyar szabályozást duálissá változtatta, hiszen a törvényi mellett innentől kezdve megjelent az alkotmányi szint is. Kérdéses azonban, hogy a kivételes hatalom szabályozása esetében már 1949-tôl duális szabályozásról beszélhetünk-e, és ha nem, akkor egyáltalán mikor jelenik meg először e jogintézmény az alkotmányban.

\subsubsection{Az első chartális alkotmány}

A kérdés megválaszolásához vissza kell kanyarodni az 1919-es Tanácsköztársasághoz, ugyanis az első magyar írott alkotmány megalkotása e politikai rendszerhez köthető, még akkor is, ha a Magyarországi Szocialista Szövetséges Tanácsköztársaság alkotmánya (a továbbiakban: TKA) ${ }^{109}$ csak rövid ideig maradt hatályban. ${ }^{110}$

A TKA konkrét rendelkezést nem tartalmazott sem a kivételes hatalomról, sem a különleges jogrendről, azonban rendelkezéseinek egybevetése révén kirajzolódnak az ilyen esetben eljárásra jogosult szerv(ek) feladat- és hatáskörei. A TKA alapján a legfőbb hatalmat a Szövetséges Tanácsok Országos Gyúlése gyakorolja. ${ }^{111}$ A TKA szerint ennek hatáskörébe tartozik „minden nagyfontosságú állami ügy”, amelyeket az alkotmány példálódzva, tizennyolc pontban fel is sorol. ${ }^{112}$ E felsorolásból három esetkör ${ }^{113}$ a Szövetséges Tanácsok Országos Gyúlésének kizárólagos hatáskörébe tartozik, de ezek közül csupán a háború és béke kérdésköre kapcsolódhat a kivételes hatalom gyakorlásához is. ${ }^{114} \mathrm{~A}$ többi esetben - amennyiben a Szövetséges Tanácsok Országos Gyúlése nem ülésezik - a Szövetséges Központi Intézőbizottság is eljárhat, ${ }^{115}$ ugyanis ez a szerv ilyenkor „legfőbb intézője az ország ügyeinek: a legfóbb törvényhozói, végrehajtói és bírói hatalmat gyakorolja". ${ }^{116}$ Létezik azonban egy ennél szúkebb körû grémium is, a Kormányzótanács, amelynek tagjait és elnökét a Szövetséges Központi Intézőbizottság választja meg. ${ }^{117}$

A Kormányzótanács alapvető feladata a Tanácsköztársaság ügyeinek - a Szövetséges Tanácsok Országos Gyủlése, valamint a Szövetséges Központi Intézőbizottság utasításainak

109 Lásd: Belügyi Közlöny (a továbbiakban: BK) 1919. 07. 06. 1078-1093.

$110 \mathrm{Az}$ első írott alkotmány az 1919. április 2-án megjelent ideiglenes alkotmány volt (a Forradalmi Kormányzótanács XXVI. sz. rendelete, BK 1919. 04. 06. 705-708.), elemzését lásd: Mezey, 2003, 373-374. o., valamint Bihari, 1979.

111 TKA 15. \$.

112 TKA 16. \$.

113 Ezek a következők: a) az alkotmány megállapítása és megváltoztatása; b) a hadüzenet és békekötés; c) az ország határainak megállapítása. Lásd:TKA 16. \$ harmadik szakasz.

114 Elsősorban oly módon, hogy a békekötés és a hadüzenet időpontja befolyással lehet a kivételes hatalom kezdő és befejező időpontjára, ahogy ez fentebb, a Kit. és Hvt. 1939 kapcsán már részletesen bemutatásra került (1.2. és 1.3. pontok).

115 Vö.: TKA 16. \$ második szakasz és 20. \$.

116 TKA 20. \$ első szakasz. A szövetséges központi intéző bizottság feladat- és hatásköreit lásd még: TKA 20. \$ második szakasz és 21 . \$.

117 TKA 24. \$. 
megfelelő - vezetése. ${ }^{118}$ Ennek során „[á]ltalában megteheti mindazt, ami az állami teendők gyors elintézéséhez szükséges", ${ }^{11}$ azonban rendeleteiről, határozatairól s fontos ügyekben tett intézkedéseirôl haladéktalanul értesíteni ${ }^{120}$ kell a Szövetséges Központi Intézőbizottságot, ${ }^{121}$ amely ezek felett reformatórius jogkörrel rendelkezik, vagyis a Kormányzótanács rendeleteit, határozatait és intézkedéseit megváltoztathatja. ${ }^{122}$ Egyetlen speciális esetben azonban a Kormányzótanács a Szövetséges Központi Intézőbizottság értesítése nélkül is intézkedhet: ez a „rendkívüli sürgősség” esete. ${ }^{123} \mathrm{Ez}$ a megfogalmazás elég tág keretet biztosított (volna) egy olyan helyzetben, amikor a kivételes hatalom gyakorlása általában felmerülhetett.

A TKA fenti rendelkezéseinek összevetése során az első magyar chartális alkotmánynak a kivételes hatalommal kapcsolatos rendelkezéseiről a következő megállapításokat tehetjük:

- a kivételes hatalmat igényló esetek legnagyobb részében a Szövetséges Központi Intézőbizottság lett volna jogosult intézkedni, kivéve, ha a Szövetséges Tanácsok Országos Gyúlése éppen ülésezik;

- egy szúkebb körben azonban, amikor a „rendkívüli sürgősség” megkívánja, a Kormányzótanács a Szövetséges Központi Intézőbizottság bevonása nélkül is eljárhatott volna.

A TKA szövegezése természetesen sok kívánnivalót hagyott maga után, amit valószínúleg már a kodifikátorok is éreztek. A hatásköri összeütközések elkerülése érdekében ezért biztosíthattak szabályozási elsőbbséget a Szövetséges Tanácsok Országos Gyúlésének. ${ }^{124}$ Ez a kivételes hatalom szabályozása tekintetében hosszabb távon az alkotmány módosítása nélkül is megnyitotta volna egy részletes jogszabály elkészítése előtt az utat.

\subsubsection{A kivételes hatalom szabályozása az 1949-es alkotmányban}

Az NKA deklarálja, hogy az Országgyủlés „a Magyar Népköztársaság legfelsőbb államhatalmi szerve”, ${ }^{125}$ amely „gyakorolja a népszuverénitásból folyó összes jogokat, meghatározza a kormányzás szervezetét, irányát és feltételeit" ${ }^{126} \mathrm{E}$ jogkörében az Országgyưlés dönt

118 TKA 26. $\$$.

119 TKA 27. $\$$.

120 A TKA 28. és 30. \$-ának összevetéséből egyértelmúen következik, hogy az értesítésnek előzetesnek kell lennie, és amennyiben a Kormányzótanács mégsem a Szövetséges Központi Intézôbizottság útmutatásai szerint járna el, akkor intézkedései és az általa kibocsátott jogszabályok megváltoztathatók. Vagyis a TKA lényegében egyetértési jogot biztosít a Kormányzótanács tekintetében a Szövetséges Központi Intézőbizottság számára.

121 TKA 28. \$.

122 TKA 29. \$.

123 TKA 30. $\$$ A rendkívüli sürgősség esetkörének kimunkálására nem hagyott időt a történelem, de tipikusan ilyen eset lehet egy természeti katasztrófa vagy hadüzenet nélküli háború esetén a védekező hadműveletek megindítása.

124 TKA 16. \$ második szakasz.

125 NKA 10. \$ (1) bekezdés.

126 NKA 10. $\$(2)$ bekezdés. 
- többek között - a háború és béke kérdésében. ${ }^{127} \mathrm{Az}$ alkotmány egy másik rendelkezése szerint pedig „, [h]áború vagy egyéb rendkívüli körülmények esetén az Országgyűlés megbízatásának meghatározott időre való meghosszabbítását is kimondhatja". ${ }^{128} \mathrm{~A}$ feloszlatott Országgyúlés pedig - háború vagy egyéb rendkívüli körülmények esetén - ismét összehívható; az összehívásra a Népköztársaság Elnöki Tanácsa jogosult. ${ }^{129}$

A Népköztársaság Elnöki Tanácsa (a továbbiakban: NET) az NKA szovjet alkotmányból átvett újítása volt, egyfajta kollektív államfó, amelynek legfontosabb feladata az alig ülésező Országgyúlés helyettesítése volt. ${ }^{130}$ Hatáskörével kapcsolatban két jogszabályhelyet kell itt megemlíteni. A NET egyrészt eljárhat mindazon ügyekben, amelyet törvény a hatáskörébe utal, ${ }^{131}$ másrészt amikor az Országgyuulés nem ülésezik, „jogkörét a Népköztársaság Elnöki Tanácsa gyakorolja; az Alkotmányt azonban nem változtathatja meg”. ${ }^{132}$ A minisztertanács az új alkotmányban egyszerú végrehajtó szervvé vált,, ${ }^{133}$ és mint ilyen, a kivételes hatalom gyakorlása szempontjából nem jött számításba.

Az NKA alapján tehát a kivételes hatalom gyakorlója az Országgyúlés és a NET lehetett, bár láthattuk, hogy egyértelmú szabályozás helyett a jogalkotó megelégedett csupán az „egyéb rendkívüli körülmények” fordulat elhelyezésével - amelybe természetesen a kivételes hatalom gyakorlását kiváltó események is beleérthetôk. Nehezebb azonban az ilyen esetben eljárásra jogosult szerv egyértelmú meghatározása, ugyanis az NKA látszólag csupán az alkotmánymódosítást tartja fenn kizárólagos hatáskörként az Országgyúlés részére, valójában azonban az NKA 18. \$-ban az Országgyúlés megbízásának saját hatáskörben történő meghosszabbítása arra utal, hogy a „háború és egyéb rendkívüli körülmények” esetköre fontossága miatt elsősorban az Országgyưlés intézkedését igényelné. Miután az egyéb rendkívüli körülmények a NET hatáskörei között nem kerültek tételes felsorolásra, és a kérdést külön törvényben sem rendezték, mind az Országgyưlés, mind a NET elsőbbsége mellett több érvet is fel lehetett sorakoztatni, ami - ha nem kirakatalkotmányról lett volna szó - egy kritikus helyzetben könnyen koherenciazavart idézhetett volna eló.

A jogalkotó maga is érzékelte a szöveg hiányosságait, de a kivételes hatalom ügyében a szükséges alkotmánymódosítás már csak a Kádár-rendszerben készült el (3.2. pont).

127 NKA 10. $\$(3)$ bekezdés $g$ ) pont.

128 NKA 18. $\$(2)$ bekezdés.

129 NKA 18. $\$(3)$ bekezdés.

130 Lásd bővebben: Mezey, 2003, 396-398. o.

131 NKA 20. \$ (1) $k$ ) pont.

132 NKA 20. $\$$ (4) bekezdés.

133 NKA 22-28. \$. 


\subsubsection{A kivételes hatalom szabályozásának hasonlóságai és különbségei} az 1919-es és az 1949-es alkotmányokban

Bár az 1949-es alkotmány már preambulumában visszautalt az 1919-es Tanácsköztársaságra, hidat létesítve ezáltal a két jogi rezsim között is, érdemes megvizsgálnunk, hogy vajon a kivételes hatalom szabályozásában voltak-e hasonlóságok a két alkotmány, a TKA és az NKA között.

Ahogy az 1919. és 1949. évi történelmi helyzet, úgy a két alkotmány keletkezési körülményei is eltérnek egymástól. Bár a TKA-t a hatályos szovjet alkotmány ${ }^{134}$ ismeretében szövegezték, a szövegszerú egyezések ellenére is számos egyedi jellegzetességgel bírt. ${ }^{135}$ Az NKA viszont „jórészt az 1936-os szovjet alkotmány mintájára készült. A szerkesztőknek csak [...] az eltéréseket kellett indokolniuk." ${ }^{136}$

Bár a kivételes hatalomra mindkét alkotmány szövegében csupán utalások találhatók, amelyek megnehezítik a jogalkotói szándék kiderítését, az egyértelmúen megállapítható, hogy a kivételes hatalom gyakorlására jogosultak körében jelentős eltérések vannak. A TKA alapján - mint láthattuk - a Kormányzótanácsnak az esetek nagy részében lehetősége nyílik, hogy rendkívüli körülmények között eljárhasson. Az NKA szerint viszont a Minisztertanácsnak semmilyen ehhez hasonló jogosítványa nem maradt. A kormány (Minisztertanács) jogosítványainak eltúnése, amely egyébként szöges ellentétben állt a magyar jogfejlődési tendenciákkal, ${ }^{137}$ egyértelmúen a NET szovjet alkotmányból a magyar jogrendszerbe való beültetésével magyarázható. Míg az 1919-es szabályozás alapján elképzelhető volt némi szervezeti összjáték egy rendkívüli állapot kezelése esetén, addig 1949-ben a jogalkotói cél egyértelmúen egy, az államigazgatás teljes vertikumát uraló és azt szabályozni képes - egyébként az állampárttal összefonódó - intézmény megalkotása volt. Ennek megfelelően az NKA kapcsán fentebb feltett kérdések többsége is egyértelmúen megválaszolható, hiszen az 1949-es alkotmány szerkezetéből egyértelmúen a NET-nek a kivételes hatalommal való felruházása következett volna, viszont e kérdés egyértelmú rendezése az NKA szövegében elmaradt. ${ }^{138}$

$134 \mathrm{Az}$ 1918. július 10-i alkotmány szövegét lásd: http://constitution.garant.ru/science-work/modern/3988990/ chapter/b89690251be5277812a78962f6302560 (Letöltve: 2020. december 10.).

135 Lásd bővebben: Bihari, 1979, 200-202. o.

136 Mezey, 2003, 388. o.

137 Vö. jelen könyvfejezet 1.2. és 1.3.3. pontjait.

138 A szabályozás hiányos volta már a kortársaknak is feltûnt, lásd például Ádám Antalnak a NET hatásköreiről szóló kétrészes tanulmányát. Ádám, 1967a; Ádám, 1967b. 


\section{A kivételes hatalom szabályozása a Kádár-rendszerben $(1956-1989)^{139}$}

\subsection{Törvényi szabályozás}

\subsubsection{Az 1960-as honvédelmi törvény}

Az 1956-os forradalom és szabadságharc után még néhány évnek kellett eltelnie, mire egy új honvédelmi törvény tervezete az Országgyûlés elé került. Az 1960-as honvédelmi törvény ${ }^{140}$ megalkotásának indoka kettős volt: egyrészt a haderőfejlesztést kívánta elősegíteni, másrészt a hatályos joganyagnak az NKA-val való harmonizációját kívánta megvalósítani egy hosszabb távú jogalkotási program részeként. ${ }^{141}$ Ez utóbbi cél: a jogharmonizáció nem volt mentes az ideológiai töltettől, hiszen a szocialista Magyarországon pontosan a kivételes hatalom és annak a Hvt. 1939-ben a II. világháború kezdetén kiteljesedő szabályozása jelképezte „az akkori uralkodó osztálynak a totális fasiszta diktatúrára, a rablóháborúban való részvételre és nem utolsósorban a munkásmozgalom, illetôleg az antifasiszta mozgalom teljes megsemmisítésére irányuló törekvését". ${ }^{142}$

A Hvt. 1939 kivételes hatalomról szóló része viszont egy több évtizedes jogfejlesztés eredményeként került 1939-ben kodifikálásra. Az új hatalom ezzel a „kodifikációs bravúrral” minden ideológiai viszolygása ellenére is élni akart, ${ }^{143}$ ezért a korábbi szabályozás több elemét is átemelte a Hvt. 1960-ba. Maga a kivételes hatalom jogi rezsimje Rendkívüli intézke-

139 A kérdésre lásd még: Szentpáli-Gavallér, 2020. Az 1956-os forradalom időszakának a téma szempontjából releváns, jogtörténeti szempontú vizsgálatát terjedelmi okok miatt mellőztük.

140 A honvédelemről szóló 1960. évi IV. törvény (a továbbiakban: Hvt. 1960).

141 Czinege Lajos honvédelmi miniszter expozéjában külön ki is emelte, hogy „Alkotmányunk keletkezése óta, a benne lefektetett alapelveknek megfelelően - a szocializmus építése során - gyökeres átalakuláson ment át és mélyrehatóan megváltozott államunk egész rendje, gazdasági, társadalmi és politikai szerkezete, kialakult tehát az új alap, amely szükségszerúen maga után vonja a felépítmény megváltoztatását is. Az új jogi felépítmény ennek a fejlődésnek a menetében nem egy csapásra, hanem a jogi szabályozás különböző területeinek fokozatos átalakítását célzó új szocialista jellegú törvények megalkotása útján jön létre. Az egységes és teljes szocialista jogrendszer kiépítésének jegyében születtek meg a korábbi években az alkotmány elvi tételeit részletes jogi szabályozásban realizáló legfontosabb törvényeink [...] Készülő́ben van más fontos jogterületek újszerủ szabályozása is [...] A szocializmus építése során kialakult új gazdasági és társadalmi viszonyok így érlelték törvényhozásunk időszerű feladatával az alkotmányos honvédelmi kötelezettség tartalmának és a honvédelmi igazgatás rendjének szabályozásáról szóló új honvédelmi törvény megalkotását is." [Országgyúlési Napló (a továbbiakban: OGYN) 1960. 12. O1-jei ülésnap, 758. o.].

142 Vö.: általános indokolás az 1960. évi IV. törvény tervezetéhez. Hasonlóan nyilatkozott egyébként a törvényjavaslat elfogadásakor az előterjesztő honvédelmi miniszter is (OGYN 1960. 12. 01-jei ülésnap, 759. o).

143 Ez egyébként az 1960. évi IV. törvény tervezetéhez készített indokolásból is kiderül, vö.: általános indokolás és részletes indokolás a XXI. fejezethez. 
dések háború idején cím alatt került kodifikálásra. ${ }^{144} \mathrm{Nem}$ külön törvényben, mint ez egyébként az NKA 10. \$ (3) bekezdés a) pontja, valamint a 20 . $\$$ (1) bekezdés $k$ ) pontja alapján kézenfekvő lett volna, hanem - az 1939-es szabályozás szellemének megfelelően - újra a honvédelmi törvényben.

A Hvt. 1960 XXI. fejezete lényegében részben az 1939-es szabályozás egyes elemeinek átvételével, ${ }^{145}$ részben azok átfogalmazásával ${ }^{146}$ és kiegészítésével készült. Az egyik leglátványosabb jogalkotói döntésnek a kormánybiztos intézményének megőrzése számított, még akkor is, ha múködése kizárólag háború idejére korlátozódott; ${ }^{147}$ és még ekkor sem vonta „maga után az államhatalom helyi szervei, illetőleg a tanácsi végrehajtó bizottságok múködésének még csak ideiglenes szünetelését sem". ${ }^{148}$

Pontosító jellegû́ volt, hogy a Hvt. 1939 által következetesen használt kártérítés helyére a Hvt. 1960-ban mindenütt kártalanítás lépett, ugyanis az előterjesztő a szóhasználattal azt kívánta kifejezésre juttatni, hogy „nem jogellenes, hanem jogos, törvényen alapuló intézkedésekből eredő hátrányról van szó [...]” ${ }^{149}$

A Hvt. 1960 XXI. fejezetében a leglényegesebb újítás a Hvt. 1939-hez képest a személyi tulajdonban álló gépjármúvek használatának honvédelmi célból történő megtiltása vagy korlátozása mint önálló pont beiktatása volt - ezt azonban elsősorban a gépjármúvek rohamos elterjedése indokolhatta. ${ }^{150}$

Végül, ha a fentiekből nem vált volna nyilvánvalóvá a Hvt. 1939 és a Hvt. 1960 közötti erős átfedés, akkor érdemes egy pillantást vetni a Hvt. 1960 XXI. fejezetének végén [123. \$ (1) bekezdés] elhelyezett felhatalmazásra, amely szerint „,[a] jelen fejezetben meghatározott rendkívüli intézkedéseket a Minisztertanács rendeli el". Valóban, ez volt a Hvt. 1939, valamint az 1912-es Kit. alapkoncepciója is, viszont a Minisztertanács kivételes hatalommal való fel-

144 A Hvt. 1960 által használt „rendkívüli intézkedések” fogalom, ha nem is illeszkedett tökéletesen az NKA által alkalmazott „rendkívüli körülmények” fogalmához, de nyilvánvalóvá tette a két szabályozás kapcsolatát.

145 Érdemes összevetni a Hvt. 1960 XXI. fejezetének szakaszait (115-122. \$) a Hvt. 1939 rendelkezéseivel, és az átfedések azonnal láthatóvá válnak. Nézzük meg a Hvt. 1960 paragrafusait úgy, hogy mögéjük helyezzük (zárójelben) a korábbi törvény, a Hvt. 1939 kapcsolódó szakaszait: 115. $\$$ (1) bekezdés - (140. \$), 115. \$ (2) bekezdés - (140. \$), 116. $\$-(149 . \$), 117 . \$-[151 . \$(1)-(4)$ bekezdés], 118. $\$(1)-(2)$ bekezdés - [147. $\$(1),(3)$ bekezdés], 119. $\$$ (1)-(2) bekezdés - [170. $\$(1),(3)$ bekezdés], 120. $\$-[163 . \$(1)-(3)$ bekezdés], 121. $\$(1),(3)$ bekezdés $-[170 . \$(1)$, (3) bekezdés], 121. $\$(2)-(3)$ bekezdés - $(152 . \$), 122 . \$(1)$ bekezdés - [142. $\$ d)$ pont], 122. $\$(2)$ bekezdés $-[142 . \$$ e) pont].

146 Lásd például a Hvt. 1960117. \$-át, amely a Hvt. 1939151. \$ (1)-(4) bekezdéseinek összevonásával és pontatlanabb megszövegezésével készült. A Hvt. 1960115. \$ (1)-(2) bekezdése látszólag jogfejlesztést tartalmaz, ha csak a Hvt. 1939-cel vetjük össze, de ha vizsgálódásunkba a Kit.-et is bevonjuk, egyértelmúvé válik, hogy egy precízebb normaszöveget sikerült kevésbé szabatos formába átfogalmazni. Pozitív ellenpélda is akadt azonban, lásd például: Hvt. 1960120 . \$, ahol a normaszöveg egyszerúsödött, viszont a rendelkezés céljában lényegi változás nem történt.

147 Vö.: Hvt. 1960122. \$ (1) bekezdés.

148 Vö.: Indokolás az 1960. évi IV. törvény tervezetéhez, részletes indokolás a 114-123. \$-hoz.

149 Vö.: Indokolás az 1960. évi IV. törvény tervezetéhez, részletes indokolás a 114-123. \$-hoz.

150 Ugyanis a Hvt. 1939170. \$-ának generális felhatalmazása alá egyébként a személyi tulajdonban álló gépjármúvek is befértek volna. 
ruházása - ahogy fentebb láthattuk (2.2.2. pont) - éles ellentétben állt az NKA koncepciójával, ahol a kormány puszta végrehajtó szerv, és a hatáskörök szinte kizárólagos birtokosa a NET volt. Az a NET, amely a Hvt. 1960 többi részében egyébként további felhatalmazásokat kapott, köztük olyanokat is, amelyek a Hvt. 1939-ben még a Minisztertanácsot illették. ${ }^{151}$ A Minisztertanács és a NET hatásköreinek Hvt. 1960-ban történt összemosása tehát éppen a jogalkotó egyik fô célkitúzését, az NKA-nak megfelelő joganyag elkészítését hiúsította meg (ráadásul egy jogállamban súlyos koherenciazavarhoz is vezethetett volna egy rendkívüli állapot bevezetése esetén). ${ }^{152}$

\subsubsection{Az 1976-os honvédelmi törvény}

A honvédelemról szóló 1976. évi I. törvény (a továbbiakban: Hvt. 1976) preambuluma szerint a törvény megalkotására elsősorban a védelmi képesség növelése, a honvédelem szervezetrendszerének szabályozása, illetve a honvédelmi kötelezettséget teljesíto állampolgárok jogainak és kötelezettségeinek rögzítése miatt volt szükség. ${ }^{153}$

A Hvt. 1976 szövege és a törvényjavaslat indokolása egyaránt terjengős, és a Hvt. 1960 ellentmondásainak kiküszöbölése helyett a többszintûvé váló szabályozással ${ }^{154}$ csupán állandósította az értelmezési nehézségeket. ${ }^{155}$

A kivételes hatalom szabályozása tekintetében a Hvt. 1976-nak voltak előremutató kezdeményezései, mint például a rendkívüli helyzet esetköreinek elkülönítése, az egyes helyzetekhez feladat- és hatáskörök hozzárendelése vagy a Hvt. 1939 kivételes hatalomról szóló feladat- és hatásköri kataszterének újraszabályozása. Ezek miatt még akkor is sikeres kodifikációs kísérletről beszélhetünk, ha az újszerủ szabályozási koncepciót nem sikerült végigvezetni az egész törvényen, és a kivételes hatalomról szóló Negyedik rész szövegezése számos helyen nehézkes és ellentmondásokkal terhelt. ${ }^{156}$

151 Vö.: Hvt. 1939141. \$ (7) és Hvt. 1960 8. \$ (3) bekezdés. Ami 1939-ben minisztertanácsi hatáskör, ott 1960-ban már a NET járhat el!

152 Illetve hiúsíthatta volna meg, ha a szocialista jogrendben a jogszabályi hierarchia vagy a normaszövegek tartalma következetesen érvényesült volna. A korabeli jogszabályok relatív voltának rekonstruálhatóságára lásd: Germuska, 2011.

153 Lásd még: Indokolás az 1976. évi I. törvény tervezetéhez, általános indokolás.

154 Alkotmány, törvény, végrehajtási rendeletek (MT rendelet és HM rendelet is), törvényjavaslat indokolása.

155 Vagyis a Hvt. 1976 magán viselte a korszak valamennyi kodifikációs jellegzetességét. A „szocialista jogrendszerben a jogállamiság követelményével szemben az úgynevezett többszintú szabályozás vált uralkodóvá. [...] Az alacsony szintú jogszabályok tekintetében a jogi túlszabályozás vált általánossá" - foglalta össze az egyik jogtörténeti tankönyv (Mezey, 2003, 395. o.).

156 İgy például a Hvt. 1976 54. \$ (1) bekezdése szerint „[h]áború idején a szükséghez képest el lehet rendelni a XVIII. és XIX. fejezetben meghatározott, valamint egyéb rendkívüli intézkedéseket". Ez utóbbi fogalom részben valószínúleg utalás a XIX. fejezet címére (a gazdálkodást érintő és egyéb rendkívüli intézkedések), amit azonban az idézett törvényhely külön is megemlített. Az „egyéb rendkívüli intézkedések” így voltaképpen definíció és rendszertani elhelyezkedés nélkül maradtak, ami egy intézkedést igénylő helyzetben akár súlyos hibákat is előidézhet(ett volna). Súlyosabb jogalkotási problémára utal, hogy ez a rendelkezés a Hvt. 1976 1994es hatályon kívül helyezéséig változatlanul fennmaradt. 
Ennél nagyobb probléma azonban, hogy a Hvt. 1976 - miközben a Hvt. 1939-ből átemelte és újraszabályozta a Honvédelmi Tanács intézményét ${ }^{157}$ - a szabályozás szintjén ${ }^{158}$ (elméletileg) lehetővé tette, hogy a kivételes hatalom gyakorlása kikerüljön a polgári hatóságok kezéből. ${ }^{159}$

Terjedelmi okok miatt itt csupán röviden vehetjük sorra a Hvt. 1976 kivételes hatalommal kapcsolatos szabályait:

- A Hvt. 1976 elődjéhez hasonlóan jelentős mértékben támaszkodott a Hvt. 1939 szabályozására, azonban a releváns szabályok egy részét a Rendkivüli intézkedések elnevezésû́ Negyedik részen kívül helyezte el (XIV-XVI. fejezetek). Maga a Negyedik rész három fejezetből (XVII-XIX. fejezetek) áll, de egyes, a kivételes hatalom gyakorlásához kapcsolódó rendelkezések (például honvédelmi szabálysértések és honvédelmi kötelezettségszegés miatt kiszabott szankciók) a záró rendelkezéseket tartalmazó Ötödik részben találhatók.

— A Hvt. 1976 egyik fó újítása a Hvt. 1960-hoz képest a decentralizáció volt. Míg a Hvt. 1960 koncepciója szerint a kivételes hatalom birtokosa elsősorban a Minisztertanács (kormány) volt, a Hvt. 1976 szerint viszont a rendkívüli intézkedéseket a NET vagy a Minisztertanács (kormány), illetve a Minisztertanács (kormány) felhatalmazása alapján az illetékes miniszter vagy a megyei honvédelmi bizottság, valamint múveleti területen a katonai parancsnok is elrendelhette. ${ }^{160} \mathrm{~A}$ kormánybiztos intézménye eltûnt a rendszerből.

- A Hvt. 1976 - felismerve, hogy kivételes hatalmat igénylő helyzetek nem csak háború esetén állhatnak elő - megkísérelte a rendkívüli helyzetek csoportosítását. Négy esetkört különített el: háború, ${ }^{161}$ az állam biztonságát fenyegető veszély; ${ }^{162}$ a közrend

157 A Honvédelmi Tanács 1972 óta szerepelt az alkotmányban. A Hvt. 1976 egyik feladata az alkotmányi szabályozással való összhang megteremtése volt, amint ezt Czinege Lajos honvédelmi miniszter a törvényjavaslat vitája során hangsúlyozta is: „Az alkotmány rendelkezéseivel összhangban rögzíti az Országgyúlésnek és az Elnöki Tanácsnak az ország védelmével összefüggő jogkörét. Külön említést érdemel az a rendelkezés, amely a rendkívüli hatáskörrel felruházott Honvédelmi Tanács létrehozásáról és feladatairól szól. Az alkotmány szerint az Elnöki Tanács rendkívüli viszonyok esetén Honvédelmi Tanácsot hozhat létre. Jogállásának és feladatai meghatározásának törvényi szabályozása - a felkészülés érdekében - azonban már most indokolt, szükséges" (OGYN 1976. 03. 18-i ülésnap, 406. o.).

158 Vö.: a Hvt. 1976 9. \$ (3) és (4) bekezdését, amely szerint „[a]z Elnöki Tanács állapítja meg a Honvédelmi Tanács összetételét, választja meg elnökét, titkárát és tagjait”, illetve „[a] Honvédelmi Tanács elnöke a fegyveres erők és fegyveres testületek főparancsnoka". Ez a rendelkezés egészen 1989 decemberéig hatályban maradt.

159 A normaszöveg és a törvényjavaslat indokolásának összevetéséből az tủnik legvalószínúbbnek, hogy a megfogalmazással a jogalkotó a lehető legtágabb hatáskört kívánta biztosítani a NET számára a rendkívüli helyzetben történő eljáráshoz (vagyis a látszattal ellentétben itt egy alapvetően pozitív előjelû́ kodifikációról van szó). A kivételes hatalom polgári hatóságok alá rendelése - kvázi alapelvként - 1912 és 1976 között politikai rendszertől függetlenül valamennyi szabályozásban szerepelt.

160 Hvt. 197654 . $\$(3)-(5)$ bekezdés.

161 Hvt. 19764 . $\$(1)$ bekezdés.

162 Hvt. 1976 54. \$ (2) bekezdés, azonban a törvény elején [Hvt. 1976 4. \$ (2) bekezdés] a fogalmat a jogalkotó az állam biztonságát súlyosan fenyegető veszélyként kodifikálta. 
és közbiztonság védelme; ${ }^{163}$ elemi csapás elhárítása, illetőleg következményeinek csökkentés ${ }^{164}$ érdekében elrendelt rendkívüli intézkedések, de ezek dogmatikai hátterének kidolgozásával adós maradt. ${ }^{165}$

- Maguk a rendkívüli intézkedések többségükben azonosak a Hvt. 1939-ben és a Hvt. 1960-ban szereplőkkel. Az új rendelkezéseket részben a technikai fejlődés, ${ }^{166}$ részben a szocialista államrendszer kiépülése ${ }^{167}$ indokolta, de átfogó rendszerezésük a törvény 1994-es hatályon kívül helyezéséig sem történt meg.

\subsection{Alkotmányi szabályozás}

A kivételes hatalom alkotmányi szabályozásának keretei egészen 1972-ig változatlanok maradtak az NKA-ban. A korszak legfontosabb változását, a Honvédelmi Tanács (a továbbiakban:HT) kodifikációját az 1949. évi XX. törvény módosításáról és a Magyar Népköztársaság Alkotmányának egységes szövegéről szóló 1972. évi I. törvény valósította meg. ${ }^{168}$ A HT mint jogintézmény valószínűleg a Hvt. 1939-ből került át az NKA-ba, ${ }^{169}$ de a jogalkotó ezzel egyidejủleg az alkotmányi szabályozáshoz kapcsolódó részletszabályok megalkotását - a Hvt. 1960 módosításával - nem végezte el. Erre csupán négy évvel később, a Hvt. 1976 elfogadásával került sor. E törvény megalkotásával ugyanis a jogalkotó egyik kiemelt célja az NKA és a Hvt. 1960 összhangjának megteremtése volt, többek között a HT hatásköreire vonatkozóan. ${ }^{170}$

163 Hvt. 1976 54. \$ (2) bekezdés.

164 Hvt. 1976 54. $\$(2)$ bekezdés.

165 Az előterjesztő erre csupán a Hvt. 1976 javaslatának indokolása során tett egy halvány kísérletet (részletes indokolás az 1-5. \$-hoz, valamint az 55-56. \$-hoz). A dogmatikai háttér hiánya különösen annak fényében szembetűnő, hogy az időleges munkakötelezettségről szóló 1967. évi 27. tvr. már a mai katasztrófavédelmi szabályozás alapjait fektette le, amikor „elemi csapás, valamint az ország érdekét fenyegető egyéb veszély elhárítása érdekében" lehetővé tette az állampolgárok békeidőben történő ideiglenes munkára kötelezését. Lásd még: az 1967. évi 27. tvr. végrehajtásáról szóló 50/1970. (XII. 20.) Kormányrendeletet is. A jogintézmény szabályozási előzményei egyébként a Hvt. 1939-re vezetők vissza (vö.: Hvt. 1939 92. \$). Az elméleti háttérre lásd: Székely, 1964; Czank, 1978.

166 Lásd: radioaktív, nukleáris, sugárzó anyagokra és a músorvevő készülékekre vonatkozó szabályok [Hvt. 1976. 55. $\$(6)$ bekezdés].

167 Vö.: tervgazdálkodás bevezetése [Hvt. 1976 56. \$ (2) bekezdés], szövetkezetek közvetlen állami felügyelet alá vonása [Hvt. 1976 56. \$ (3) bekezdés], múvelődési intézmények múködésének korlátozása vagy beszüntetése [Hvt. 1976 56. $\$(7)$ bekezdés].

168 A törvényjavaslat vitájakor elhangzott, hogy az alkotmánymódosítás egyik célja a Magyar Népköztársaság biztonságának növelése. Ezt „szolgálja az az új rendelkezés, amely szerint háború, vagy az állam biztonságát súlyosan fenyegető veszély esetére az Elnöki Tanács rendkívüli hatáskörrel felruházott honvédelmi tanácsot hozhat létre, továbbá az állam biztonságát súlyosan fenyegető veszélyt, illetve annak megszüntetését az Elnöki Tanács állapítja meg és hirdeti ki" (Kállai Gyula expozéja, OGYN 1972. 04. 19-i ülésnap, 560. o.).

169 Vö.: Hvt. 1939 3. \$ (Legfelső Honvédelmi Tanács). Ugyanakkor meg kell jegyezni, hogy a látszólagos szabályozási hasonlóság nem jelent intézményi vagy tartalmi azonosságot, mint ez Kelemen Roland tanulmányából egyértelmúen kiderül (Kelemen, 2018).

170 Vö.: Czinege Lajos honvédelmi miniszter expozéja (OGYN 1976. 03. 18-i ülésnap, 406. o.). 


\subsection{A kivételes hatalom jogi rezsimjének változásai a 20. század másodikfelében}

Az 1944 és 1994 közötti fél évszázad során több, különböző mélységû́ rendszerváltás zajlott le Magyarországon. Az 1944 és 1989 közötti politikai rendszerek egyik legfontosabb közös jellemzője az állami szuverenitás korlátozott voltában jelölhetô meg. Az ideológiai eltérések mellett valószínúleg ez a korlátozott szuverenitás az oka annak, hogy a kivételes hatalom szabályozása és a jogintézmény használata az 1912-1944 közötti időszakhoz képest háttérbe szorult.

Bár a korszakban több honvédelmi törvény is készült, ezek egyaránt az 1944 előtti szabályozásból merítkeztek, ahogy 1956 után az alkotmány is. Maga a jogintézmény kodifikációja nem élvezett elsőbbséget a honvédelmi jogharmonizáció során, sőt - mint láthattuk - még a különböző, alkotmányi és törvényi szintû szabályozások összhangjának megteremtésére sem törekedtek. A kivételes hatalom fogalmához a szocialista időszakban egyértelmúen negatív politikai jelentéstartalom társult, de pusztán az ideológiai megfontolások nem akadályozták meg, hogy a jogalkotó rendszeresen visszanyúljon az 1939-es szabályokhoz. A jogintézményen a szovjet megszállás időszakában (1944-1989 között) tulajdonképpen csak a legfontosabb technikai jellegú jogfejlesztéseket végezték el, ${ }^{171}$ de az átfogó, koncepcionális újrakodifikálás mindvégig elmaradt. A két jelentős kivétel közül negatív előjellel említhető a HT katonai vezetés alá rendelése, ami egyértelmú szakítást jelentett a magyar jogi hagyományokkal, de még a HT esetében sem beszélhetünk világos koncepció kialakításáról. Az egyetlen jelentős, pozitív jellegú kivétel a jogalkotó azon felismeréséből ered, hogy az alapvetően háborús célokra kifejlesztett jogi rezsim más kivételes esetekben is használható. A kivételes hatalmat igénylő helyzetek kategorizálására a Hvt. 1976-ban került sor, de egységes koncepciót ebben az esetben sem sikerült felmutatni.

Mindezek ismeretében a kivételes hatalommal kapcsolatos szabályozás 20. századi története két nagy szakaszra bontható. ${ }^{172}$ 1912-1944 között, a világháborús erőfeszítések, majd a függetlenné váló magyar állam újjászervezése érdekében végzett küzdelem időszakában egy dinamikus szabályozási szakasz látható, amelynek kodifikációs csúcsteljesítménye a Hvt. 1939 kivételes hatalomról szóló része. Az 1944-1989 közötti időszak ezzel szemben egy statikus, minimális jogfejlesztéssel járó időszak, amelyben a jogalkotó - bár felismeri a szabályozási igényt - minimális érdeklódést mutat egy saját koncepció kidolgozása iránt, inkább megelégszik a Hvt. 1939 vonatkozó szabályozásának újrahasznosításával.

171 Lásd például: a nukleáris energia fogalmának megjelenése, személygépkocsi kisajátításának szabályozása.

172 Korszakolás szempontjából a századokat a szigorú kronológiai kötöttségek helyett didaktikai okokból a magyar szempontból kiemelkedő korszakhatárokhoz kötve értelmezem, így jelen írásban a „rövid huszadik század" történettudományban gyakran használt fogalmára (1914-1989) támaszkodtam (vö. például: Lukacs, 2020, 5-14. o.), mert ez a kivételes hatalom kodifikációjának tárgyalását is megkönnyíti. 


\section{A kivételes hatalom szabályozása a rendszerváltást követő évtizedekben (1989-2010)}

\subsection{Alkotmányi szabályozás}

Az 1989-es „törvényes forradalom”173 során politikai alkuk révén és jogi eszközök segítségével rövid idő alatt lezajlott a piacgazdaságba történő átmenet. A rendszerváltás egyik fontos aktusa, az alkotmányrevízió megtörténte után az alsóbb szintű joganyag újrakodifikálása több évig elhúzódott.

A kivételes hatalom esetében az alkotmányi szabályok megváltoztatása az alkotmány módosításáról szóló 1989. évi XXXI. törvénnyel 1989. október 23-án megtörtént. Az alkotmányrevízió a vizsgált jogintézmény tekintetében minőségi változással járt. ${ }^{174} \mathrm{~A}$ módosított alkotmány (a továbbiakban: MKA) elvégezte a kivételes hatalmat igénylő esetkörök Hvt. 1976 által félbehagyott tipizálását. Az MKA - a jogforrási hierarchia legfelső szintjén - három esetkört konstituált: ${ }^{175}$ hadiállapot, rendkívüli állapot, szükségállapot. ${ }^{176} \mathrm{Ez}$ a csoport 1993-ban a váratlan támadás, ${ }^{177}$ 2004-ben a megelőző védelmi helyzet ${ }^{178}$ esetköreivel bővült. ${ }^{179} \mathrm{~A}$ jogalkotó egyúttal - valószínúleg érzékelve a túl tág megfogalmazásban rejlő veszélyeket - újrakodifikálta a Honvédelmi Tanács intézményét is, és a HT elnökévé civil döntéshozót, a köztársasági elnököt tette meg. ${ }^{180}$ Ugyancsak jogalkotói döntés nyomán a részletszabályok kidolgozása törvényi - illetve kisebb részben rendeleti - szinten történt meg a rendszerváltás utáni években.

Itt kell továbbá megemlíteni, ${ }^{181}$ hogy 2004-ben a hadkötelezettség katonai szolgálati kötelezettségének megszüntetése kapcsán az alkotmányban rögzítették a rendkívüli állapot idején vagy megelőző védelmi helyzetben a hadkötelezettséggel, valamint a rendkívüli állapot idején a honvédelmi munkakötelezettséggel kapcsolatos szabályokat. ${ }^{182}$

173 A Deák István által az 1848-as forradalomra használt kifejezés 1989-re is használhatónak tûnik, mert ahogy ott az áprilisi törvényekhez (1848. 04. 11.), itt egy teljes alkotmányrevízióhoz (1989. 10. 23.) mint szimbolikus eseményhez kapcsolható a rendszerváltás megindulása (amely azonban, 1848-hoz hasonlóan, inkább egy többlépcsős, hosszabb folyamatként képzelhető el). A fogalom használatát lásd bővebben: Deák, 1983.

174 A kivételes hatalom gyakorlását lehetővé tévő esetkörök tartalma, alkalmazásának feltételei az 1989. évi XXXI. törvény, valamint a törvényjavaslat miniszteri indokolása alapján egyértelmúen elkülöníthetők.

175 Lásd még: Petrétei, 2006.

176 MKA 19/A-19/D. \$.

177 MKA 19/E. \$, beiktatta az Alkotmány módosításáról szóló 1993. évi CVII. törvény, hatályos 1994. 01. 01-től.

178 MKA 19. \$ (3) bekezdés $n$ ) pontja, beiktatta az Alkotmány módosításáról szóló 2004. évi CIV. törvény, hatályos 2005. 01. 01-tól.

179 Till, 2019.

180 MKA 19/B \$ (2) bekezdés. Ezzel egyidejúleg a HT korábbi, törvényi szintú szabályozása [Hvt. 1976 9. \$ (2)-(4) bekezdés] hatályát veszítette.

181 Lásd még: Szentpáli-Gavallér, 2020, 10. o.; Farkas-Kádár, 2016.

182 A Magyar Köztársaság Alkotmányáról szóló 1949. évi XX. törvény módosításáról szóló 2004. évi CIV. törvény, hatályos: 2005. 01. 01-jétől. 


\subsection{Törvényi szabályozás}

A rendszerváltást követően a Hvt. 1976 még évekig hatályban maradt, és csak 1994 elejétól váltotta le a honvédelemről szóló 1993. évi CX. törvény (a továbbiakban: Hvt. 1993). Ez egészen 2005-ig funkcionált, amikor a honvédelemről és a Magyar Honvédségről szóló 2004. évi CV. törvény (a továbbiakban: Hvt. 2004) lépett a helyére. A Hvt. 2004-et a tárgyidőszakban végig alkalmazták, és csak az Alaptörvény hatálybalépésével egyidejűleg helyezték hatályon kívül. ${ }^{183}$

A Hvt. 1976 rendszerváltáson átívelő hatálya valószínúleg elősegítette struktúrájának és rendelkezéseinek továbbélését. A kivételes hatalommal kapcsolatos szabályok jelentős része a korszak mindkét honvédelmi törvényében erős átfedést mutat a Hvt. 1976 szövegével. A Hvt. 1976 megalkotását követően kialakult duális szabályozási koncepció ugyancsak megszilárdult. Amíg azonban az alapvetô szabályokat a korszakban mindvégig az MKA tartalmazta, a Hvt. 1993, majd a Hvt. 2004 egyre terjengősebbé váló fejezetei lassanként elvesztek a részletekben. ${ }^{184} \mathrm{~A}$ honvédelmi törvény túlterheltté válása - ahogy az a Hvt. 1976 esetében is történt - a szabályozás egy részét rendeleti szintre tolta tovább. ${ }^{185} \mathrm{Az}$ így létrejövő „többszintû́ normaszerkezetek" végül a szabályozás alá vont jogintézmény eredeti céljának megvalósulását is veszélyeztették.

A kivételes hatalom lényege ugyanis - mint azt a Kit. 1912-es elfogadásakor az előterjesztő ki is emelte - birtokosának kivételes helyzetben kivételes intézkedésekre való feljogosítása. A Hvt. 1976-tól kezdve törvényenként egyre gyarapodó számú részletszabály viszont nem segítette, hanem akadályozhatta a kivételes hatalom birtokosának eljárását, aki gyors cselekvés helyett könnyen elveszhetett (volna) a formai eloórásokban. ${ }^{186} \mathrm{~A}$ jogalkotó azonban sem 1976-ban, sem később (1993-ban vagy 2004-ben) nem fogadta meg ${ }^{187}$ az 1912-es törvényja-

183 Hatályon kívül helyezte a honvédelemről és a Magyar Honvédségről, valamint a különleges jogrendben bevezethető intézkedésekről szóló 2011. évi CXIII. törvény (a továbbiakban Hvt. 2011), amely már az Alaptörvény felhatalmazása alapján került megalkotásra.

184 Itt fontos megemlíteni, hogy az 1990-es évek végén az alkotmánytervezet előkészítéséhez kapcsolódóan történt kísérlet a minősített időszakok rendszerének alkotmányos újragondolására (Somogyvári, 1998, 11081111. o.). Az Alaptörvény tervezetének előkészítésével kapcsolatban a különleges jogrendi esetkörök számának csökkentésére lásd az új Alkotmány elfogadásának előkészítéséről szóló 9/2011. (III. 9.) OGY határozatot, illetve ennek elemzésére: Till, 2017a, 46-47.

185 Vö.: Hvt. 1976 és a végrehajtására kiadott 6/1976. (III. 31.) MT rendelet; Hvt. 1993 és a végrehajtására kiadott 178/1993. (XII. 27.) Kormányrendelet; Hvt. 2004 és a végrehajtására kiadott 71/2006. (IV. 03.) Kormányrendelet.

186 Ami a szocializmus időszakában, az ország látszólagos szuverenitása mellett amúgy csak formaságnak számított, az az 1989 után visszanyert önrendelkezési jog birtokában komoly hatásköri összeütközések okozója lehetett volna.

187 A jogalkotó döntését természetesen számos körülmény befolyásolhatta. Jelen fejezetben terjedelmi okok miatt nem lehetséges a témához kapcsolódó legfontosabb alkotmánybírósági határozatok elemzése, amelyek a jogalkotó döntési helyzetének határait nagymértékben befolyásolták [lásd különösen a 2/1998. (II. 4.) AB határozatot, az 50/2001. (XI. 29.) AB határozatot, valamint a 102/E/1998. AB határozatot]. 
vaslat kodifikátorainak intelmét, akik a kivételes hatalom minél absztraktabb és egyszerúbb szabályozása mellett érveltek. ${ }^{188}$

A korszak két honvédelmi törvényének a kivételes hatalom birtokában meghozható intézkedésekről, valamint a kivételes hatalom gyakorlására feljogosítottak köréről szóló részeit az alábbiakban tekinthetjük át.

\subsubsection{A rendkivüli intézkedések szabályozása (különleges jogrend)}

A szocializmus korának honvédelmi törvényei a Hvt. 1939 által átmeneti intézkedéseknek $^{189}$ nevezett jogalkotási felhatalmazásokat rendkívüli intézkedések elnevezés alatt tartalmazták. Ez a fogalom, amely 2011 óta a különleges jogrend idején foganatosítható intézkedéseket jelöli a joganyagban, a rendszerváltást követően továbbélt; a Hvt. 1993 és a Hvt. 2004 egyaránt ezt használta.

Láthattuk, hogy a Hvt. 1939 kivételeshatalom-fogalmához tartozó intézkedések egy része a Hvt. 1976-ban már a Rendkivuüli intézkedések fejezeten kívül került elhelyezésre. Ezek a szabályok a rendszerváltást követően sem tértek vissza a Kivételes hatalom fejezetbe, hanem kötelezettségekként előbb a rendkívüli intézkedésekhez kapcsolódva (Hvt. 1993 VIII. fejezet), majd attól rendszertanilag is távol kerülve (Hvt. 2004 II. fejezet) kerültek kodifikálásra.

A rendkívüli intézkedések (Hvt. 1993 IX. fejezet, Hvt. 2004 XIV. fejezet) tagolása csak kismértékben változott a tárgyidőszakban. Az általános rendelkezések mellett a rendkívüli intézkedések négy csoportját ${ }^{190}$ különítette el a jogalkotó: a honvédelmi igazgatásra vonatkozó intézkedések; a közigazgatásra, közrendre, közbiztonságra vonatkozó intézkedések; az igazságszolgáltatásra vonatkozó intézkedések; a gazdasági és anyagi szolgáltatási kötelezettségre vonatkozó intézkedések. A Hvt. 2004-ben ehhez egy külön cím, A megelőző védelmi helyzettel kapcsolatos szabályok és intézkedések kapcsolódtak.

A korszak honvédelmi törvényei a honvédelmi igazgatásra vonatkozó intézkedések cím alatt a rendkívüli szolgálat szabályait helyezték el. ${ }^{191} \mathrm{Az}$ igazságszolgáltatásra vonatkozó in-

188 „A törvényjavaslat [...] felhatalmazza a minisztériumot [értsd: a kormányt - D. E.] arra, hogy a [...] kivételes hatalmat a szükség mértékéhez képest igénybe vehesse, vagyis hogy bizonyos kivételes intézkedéseket a következő szakaszokban felállított korlátok közt a szükség mértékéhez képest megtehessen. Lehetetlen ugyanis pontosan előre látni, hogy az egyes adott esetekben mily kivételes intézkedések megtétele lesz szükséges. Ez okból bízza a törvényjavaslat ennek megítélését és megállapítását a további szakaszok által vont korlátok közt a kormányra, de e széles körủ felhatalmazás korlátozásául szolgál a törvényszakasznak az a rendelkezése is, hogy a kormány a kivételes hatalmat csakis a szükség mértékéhez képest veheti igénybe, tehát a törvényjavaslat következő szakaszaiban részletezett kivételes hatalomból mindenkor csakis annyit alkalmazhat, a mennyit az adott esetben a fennforgó viszonyok és körülmények okvetlenül szükségessé tesznek." Indokolás az 1912. évi LXIII. törvénycikk tervezetéhez (részletes indokolás az 1. \$-hoz).

189 Hvt. 1939141. \$ (9) bekezdés.

190 A Hvt. 1976-ban még csak két csoport szerepelt a rendkívüli intézkedések cím alatt:állam- és közbiztonsággal kapcsolatos intézkedések; gazdálkodást érintő és egyéb intézkedések (Hvt. 1976 55-56. \$).

191 Vö.: Hvt. 1993 202-206. \$ és a Hvt. 2004153-158. \$. 
tézkedések körében vegyes, az igazságszolgáltatás szervezetét, ${ }^{192}$ illetve múködését ${ }^{193}$ érintő szabályok kerültek kodifikálásra. ${ }^{194}$ A rendkívüli intézkedések ezen csoportja egyébként a Hvt. 1976 egy rövid, a statáriális bíráskodás elrendelését lehetôvé tevő bekezdéséből vált önálló címmé a Hvt. 1993-ban. ${ }^{195}$

A két, már a Hvt. 1976-ban is létező cím közül a közigazgatásra, közrendre, közbiztonságra vonatkozó intézkedések a rendkívüli intézkedések legrégebbi, már az 1912-ben elfogadott Kit. óta folyamatosan bővülő csoportját ölelték fel. Hagyományosan itt kerültek elhelyezésre az egyesülési, a gyülekezési joggal, az utazással (ki- és beutazási tilalom) és a mozgásszabadsággal (például kijárási tilalom) kapcsolatos korlátozások, a sajtóellenőrzés (cenzúra) szabályai. A Hvt. 1993 ehhez - a hatalommegosztás elvét érvényesítve - eljárásra jogosult vagy kötelezett személyeket, valamint feladat- és hatásköröket rendelt hozzá, amiket a Hvt. 2004 is átvett, illetve pontosított. ${ }^{196}$

A Hvt. 1976-ban kodifikált gazdasági rendkívüli intézkedések több okból sem illeszkedtek hézagmentesen a törvény szövegébe. Egyrészt a fogalmak meghatározása nem volt egyértelmú, másrészt a Hvt. 1939, amelynek mintájára a cím készült, egy tôkés gazdasági rendszerben fogant, amelynek gazdálkodási részre vonatkozó intézkedései csak nehezen voltak beleilleszthetők a szocialista jogrendbe. A rendszerváltást követő gazdasági változások kedvezően hatottak e cím újraszabályozására. A Hvt. 1993 által kidolgozott anyagi szolgáltatási kötelezettségre vonatkozó intézkedések körében egyrészt kötelezettségek, ${ }^{197}$ másrészt korlátozó rendelkezések, ${ }^{198}$ harmadrészt rendkívüli eltérést lehetôvé tévő szabályok kerültek elhelyezésre. ${ }^{199} \mathrm{Ez}$ a cím is tartalmazott eljárási szabályokat, feladat- és hatásköri elő́rásokat. A Hvt. 1993 rendelkezéseinek többségét a Hvt. 2004 is átvette. ${ }^{200}$

\subsubsection{A kivételes hatalom gyakorlója}

A Hvt. 1976 fontos újítása volt, hogy a HT szabályozásával megteremtette az alkotmányi és törvényi rendelkezések összhangját. A HT-re vonatkozó szabályozás azonban minimális és - láthattuk - a magyar jogi hagyományoktól eltérő volt. A rendszerváltást követően az MKA - a hatalommegosztás elvének megfelelően - a kivételes hatalom gyakorlására több

192 Például bíróságok és ügyészségek létesítése, bírói és ügyészségi önkormányzati szervek múködésének felfüggesztése, bírák ideiglenes kirendelése.

193 Például a rögtönbíráskodás szabályainak alkalmazása, eljárások felfüggesztése, a holtnak nyilvánítás szabályainak módosítása.

194 Vö.: Hvt. 1993224-232. \$ és a Hvt. 2004176-184. \$.

195 Lásd: Hvt. 1976 55. \$ (8) bekezdés.

196 Vö.: Hvt. $1993207-223$. \$ és a Hvt. 2004159-175. \$.

197 Például szerződéskötési kötelezettség, devizaérték vagy nemesfém kötelező vételre felajánlása.

198 Például kötött munkaerő-gazdálkodás, közlekedési infrastruktúra használatának korlátozása, jegy- vagy utalványrendszer bevezetése.

199 Például adók és illetékek mértékének módosítása, fejezeti előirányzatok módosítása.

200 Vö.: Hvt. 1993 223-248. \$ és a Hvt. 2004185-200. \$. 
szervet, illetve személyt is feljogosított. A kivételes hatalom gyakorlására jogosult a tárgyidőszakban az adott kivételes helyzettől függően a Honvédelmi Tanács, a köztársasági elnök vagy a kormány lehetett. Az országgyưlés ellenőrzési jogának alapvető szabályait szintén az MKA rögzítette.

A Hvt. 1993 egyik jelentős érdeme a korábban hiányzó, HT-re vonatkozó részletes szabályozás megalkotása és rendszerbe foglalása volt, amely egyébként a legtöbb esetben az egyes hatáskörgyakorlók együttmúködésére épülő alkotmányi koncepció más szereplőire vonatkozóan is tartalmazott kiegészítő szabályokat. ${ }^{201} \mathrm{~A}$ kivételes hatalom gyakorlójára vonatkozó rendelkezéseket - szerkezetileg részben más helyre iktatva - a Hvt. 2004 is megőrizte. ${ }^{202}$

A Hvt. 1993 HT-ről szóló fejezete két címre tagolódik: a) hatásköri szabályok ${ }^{203}$ és b) a HT múködése. ${ }^{204} \mathrm{Az}$ elsô cím alatt a feladat- és hatáskörök mellett a mentelmi jog, a HT megalakításához és mûködéséhez szükséges helyettesítési sorrendek találhatók. A második cím az ügyrend megalkotásával, a döntéshozatallal, az érvényességi kellékekkel és a döntések közlésével kapcsolatos szabályokat tartalmazza. Egyes értelmező rendelkezéseket külön cím alatt (Általános rendelkezések), a rendkívüli intézkedésekról szóló fejezetben helyezte el a jogalkotó. ${ }^{205}$

\subsection{A kivételes hatalom kodifikálásának tanulságai az 1989-2011 közötti időszakban}

A kivételes hatalommal kapcsolatos joganyag rögtön az 1989-es alkotmányrevízióval minőségi változáson ment keresztül, a korábban a Hvt. 1976-ban található, de egységes koncepcióba nem foglalt esetköröket alkotmányi szinten rögzítették. Az esetkörök az elkövetkező másfél évtizedben gyarapodásnak indultak, számuk háromról ötre növekedett. A kivételes hatalom gyakorlására jogosultak körét - ugyancsak 1989-ben - alkotmányi szinten újra meghatározták. Ennek részeként a HT egyértelmú szabályozást nyert.

A részletszabályokat a korszak legjelentősebb ágazati törvénye, a Hvt. 1993 tartalmazta, amely azonban szerkezetében jelentős mértékben támaszkodott elődje, a Hvt. 1976 megoldásaira. A Hvt. 1993 kivételes hatalomra vonatkozó szabályozása talán éppen ezért sikeredett felemásra. Egyes részek, mint a HT hatásköreire és működésére vonatkozó rendelkezések előremutatók, mások, mint például a különleges jogrendre vonatkozó szabályok már-már a jogszabály használhatóságát veszélyeztető mértékben terjengősek. ${ }^{206}$ A Hvt. 1993 téma szempontjából kiemelt rendelkezéseit a Hvt. 2004 szinte változtatás nélkül vette át, sôt még

201 Lásd például a Hvt. 1993 X. fejezet általános rendelkezések címét.

202 Vö.: Hvt. 1993 X. fejezet és a Hvt. 2004 V. fejezet.

203 Hvt. 1993249-251. \$.

204 Hvt. 1993252-256. \$.

205 Hvt. 1993199-201. \$.

206 Itt érdemes megemlíteni, hogy például 1997-ben azért nem született minősített időszaki törvény, mert a 200 szakasz terjedelmú tervezetet az akkori igazságügyi tárca nem találta elég részletesnek. (Köszönet Till Szabolcs lektornak a kiegészítésért!). 
a Hvt. 2011 is erôteljesen támaszkodott arra a struktúrára, amely a 2010-es évekből visszatekintve nemzeti szabályozásnak tûnt, de valójában a Hvt. 1976 egyre halványabban kirajzolódó kontúrját képezte le.

Mindezeket figyelembe véve a kivételes hatalom 1989 utáni kodifikációjának mérlege felemásra sikeredett: jelentős eredmények ${ }^{207}$ mellett a kivételes hatalom jogintézményét nem sikerült megtisztítani a túlterjeszkedő, az esetleges használatot akadályozó szabályoktól. ${ }^{208}$ Ha a jogintézmény egy teljes évszázadot (1912-2011) átívelő kodifikációs kísérletein végigtekintünk, akkor a Hvt. 2011 egy hosszú idő után jó irányba tett lépésnek túnik. ${ }^{209}$

\section{5. Összegzés}

\subsection{Az „alkotmányszegény” ország}

A kivételes hatalommal kapcsolatos korai szabályozás részben alkotmányokhoz kötődött. A több tekintetben példaértékûvé váló francia szabályozás például számos francia alkotmányban is megjelent. Magyarország alkotmánytörténetének egyik jellegzetessége, hogy különböző alkotmánytervezetek ${ }^{210}$ kidolgozása ellenére tartós írott alkotmányt csak a 20. század közepére sikerült létrehozni (2.2. pont). ${ }^{211}$

A kivételes hatalommal kapcsolatos szabályozás így kezdetben a történeti alkotmányban foglalt szabályozás részeként jelent meg, ${ }^{212}$ az első kodifikációs kísérlete, valamint a gyakorlati alkalmazás is katonai érdekek mentén valósult meg a 19. század közepén. Az első részletes szabályozásra viszonylag későn, ${ }^{213}$ ugyancsak katonai érdekből és törvénnyel került sor.

A jogintézmény már túljutott kodifikációs „csúcspontján” (Hvt. 1939), mire 1972-ben egyértelmú szabályozást kapott az alkotmányban. Innentől kezdve beszélhetünk a kivételes hatalom tekintetében valódi duális szabályozásról, amelynek egyes elemei azonban csak aZ 1989-es alkotmányrevíziót követően foglalták el végleges helyüket.

207 Például az 1989-ben kidolgozott alkotmányi szabályozás vagy a Hvt. 1993 HT-re vonatkozó rendelkezései.

208 E tekintetben csak a Hvt. 2011 hozott minőségi javulást, amikor a jogalkotó a már létező joganyagot teljes egészében felülvizsgálta, és nem riadt vissza a fogalmak évtizedek óta elmaradt tisztázásától sem (lásd például: a különleges jogrend megjelenése a Hvt. 2011 címében). A fogalomhasználat eltéréseinél elegendô csak utalni arra, hogy az alkotmány módosításáról szóló 1989. évi XXXI. tv. javaslatához készült indokolás a „különleges hatalom" (Részletes indokolás az 5. \$-hoz), a módosított alkotmányi rendelkezéseket elemző tudományos írás a „rendkívüli hatalom" (Újfalvi, 1990) kifejezést használta, miközben a Kit. [1. \$ (1) bekezdés] és a Hvt. 1939 [141. \$ (1) bekezdés] egyértelműen kivételes hatalomról beszélt.

209 Újabb előremutató jogfejlesztés csak a járvány időszakában szerzett gyakorlati tapasztalatok nyomán várható. Vö.: az Alaptörvény kilencedik módosításának vonatkozó részeit (T13647. számú törvényjavaslat, 2020. 11. 30., illetve annak egységes szerkezetbe foglalt, 13647/15. számú változatát, 2020. 12. 14.).

210 Átfogóan lásd: Horváth, 2012.

211 Lásd még: Domaniczky, 2009.

212 Vö.: Virozsil, 1861, 132-133. o.

213 Ehhez képest lásd a nemzetközi példákat az 1.1.2. pontban. 


\subsection{A kivételes hatalom jogszabálybokrai és többszintü normaszerkezetei}

Az 1912-ben garanciákkal szilárdan körülbástyázott Kit. az I. világháború alatt gyorsan általános kodifikációs hivatkozási alappá vált. Az összeomlást követően pedig kiderült, hogy felhatalmazása, illetve az ennek alapján már létrejött „jogszabálybokrok” alkalmazása nélkülözhetetlen az államszervezet és a nemzetgazdaság újjászervezéséhez, erre tekintettel hatályát folyamatosan meghosszabbították. Rövidesen azonban az is nyilvánvalóvá vált, hogy a Kit. felhatalmazása alapján kibocsátott rendelettömeg önálló életre kelt, szinte minden passzusából különböző, többször módosított rendeletbokrok nőttek ki. Ezek deregulációjával az 1920-as és az 1930-as években is megpróbálkoztak, de még a Rákosi-rendszerben is előfordult, hogy egyes, a Kit.-re tekintettel kibocsátott jogszabályokat külön hatályon kívül kellett helyezni. ${ }^{214}$

Az 1930-as években a Kit. utódjául szolgáló Hvt. 1939-ben a jogszabályi hierarchia biztosítása érdekében már külön beépítettek az átmeneti időszakra, illetve a kivételes hatalom alapján kibocsátott joganyag további sorsára vonatkozó szabályokat. ${ }^{215}$

A Hvt. 1939 alapján a II. világháború időszakában szintén jelentős mennyiségú joganyag keletkezett, ám ezek hatályon kívül helyezését a jogalkotó helyett végül a történelmi helyzet oldotta meg. Az 1945-ben megalakult Nemzetgyúlés viszonylag korán szabályozás alá vonta a kivételes hatalom intézményét, ${ }^{216}$ ám a Kht.-t eredetileg is csak átmeneti jellegú jogszabálynak szánhatták.

A korlátozott szuverenitással rendelkező országban a kivételes hatalom elvesztette a korábbi jelentôségét, hiszen az állammal összenôtt párt enélkül is szabad kezet kapott elképzelései megvalósításához. Az 1949-1989 közötti időszak honvédelmi törvényei azonban - nyilvánvalóan a Hvt. 1939 koncepciójának hatása alatt - kétszer is újrakodifikálták a jogintézményt. A korábbi feszes, célhoz kötött szabályozás azonban egyre terjengősebbé, esetenként többszintűvé vált („többszintû normaszerkezetek”), ami - ha szükség lett volna rá a kivételes hatalom felhasználását jelentős mértékben megnehezíthette volna.

\subsection{Kivételesből általános jellegü keretszabályozás}

A Kit. megalkotásakor a kormány és a jogalkotók nagy része is egy adott háborús helyzet kezelésére készült, amelynek végeztével a kivételes hatalom időszaka is véget ér. Sajnos már a háború első hónapjaiban rá kellett döbbenniük, hogy a kivételes hatalomra és az általa biztosított eszközrendszerre - a közösség érdekében - hosszabb ideig is szükségük lehet; ez a felismerés jelenik meg a törvény 1914-es módosításában. ${ }^{217}$

214 Vö. például: az egyesülési jogról szóló 1955. évi 18. tvr. 16. \$.

215 Lásd: Hvt. 1939141. \$(9) bekezdés.

216 1946. évi VI. törvény.

217 A háború esetére szóló kivételes intézkedésekről alkotott 1912:LXIII. törvénycikknek és a hadiszolgáltatásokról szóló 1912:LXVIII. törvénycikknek kiegészítéséről szóló 1914. évi L. törvénycikk. 
A háború végén pedig a teljes szuverenitását visszanyert ország döntéshozói újabb és újabb - elôre nem látott - rendkívüli helyzetekkel találkoztak: háborús megszállás, államterület és -határok rapid változása, polgárháború, gazdasági válság. Ezek kezelése évekig eltartott, és mindegyikük a korábban látott és megszokott módszerektől eltérô megközelítést, gyors reagálást és újfajta eszközrendszert igényelt. A kivételes hatalomról szóló törvény és az azon alapuló alacsonyabb szintú jogszabályok egy része önmagától is elvesztette aktualitását, ${ }^{218}$ más részük azonban a világháború után is hatályban maradt, hosszabb távon is állandósítva a kivételes helyzetet.

A két világháború korának (1918-1939) időszakában a kivételes hatalom jelentőségét a kivételes helyzet állandósulása adta, ami lehetôvé tette az eredetileg háborúra tervezett rezsim békeidejú felhasználását. Addig, amíg a jogalkotó is felismerte, hogy a háborús szabályozás békeidejû́ alkalmazásában számos, korábban kihasználatlan lehetôség rejlik, még évtizedek teltek el. A kivételes helyzetek három esetkörének Hvt. 1976-ban történt kodifikálása viszont egy újabb, a kivételes hatalom háborús és békeidejư felhasználásának egyaránt új irányokat szabó időszak (1976-2011) nyitányát jelentette. Az ez irányú jogfejlesztés az Alaptörvény, illetve a Hvt. 2011-es elfogadásában csúcsosodott ki.

\subsection{Politikai rendszereken átívelő szabályozási tárgy}

A kivételes hatalom és a Kit. felhatalmazása alapján létrejött különleges jogrend - láthattuk - még a folyamatos rendszerváltásoktól terhelt 20. századi magyar történelemben is állandónak bizonyult. A jogintézmény megjelenési formája, a jogforrás időről időre változott, de 1912 és 1949 között szinte folyamatosan használták, és - mint a kormányzás nélkülözhetetlen eszközét - rendszereken átívelően fejlesztették.

Az 1912-es alapjogszabály hatályát 1914 és 1918 között többször is kiterjesztették. A Károlyi-kormány kivonta a hatálya alól az alapjogok egy részét, amely - ha a korlátozásukat lex specialisként külön rendezik, mint az például az 1867-es osztrák törvényben történt - akár egy új jogfejlesztési iránnyá is válhatott volna, ha néhány hónapon belül zárójelbe nem teszik.

Az 1920-as években a háború alatt megszilárdult jogkört gyakorolták, a Hvt.-ben pedig a két évtizedes gyakorlatot rendszerbe foglalva újraszabályozták. Az 1940-es évek második felében - elsősorban az 1930-as években bevezetett gazdasági jellegủ kivételes hatalom mintájára - egy ideiglenes szabályozást fejlesztettek ki, majd kodifikáltak.

218 Ahogy az 1920. évi VI. törvény javaslatának indokolása megfogalmazta: „Ezek az intézkedések nagyrészben olyan természetúek ugyan, hogy a háború megszúntével céljukat vesztették és vagy máris hatálytalanoknak tekinthetők, vagy nehézség nélkül hatályon kívül helyezhetők; mindazáltal nagy számmal vannak közöttük olyanok is, amelyek a háború által teremtett rendkívüli helyzet kényszerítő hatása alatt olyan viszonyokat szabályoztak, amelyek a háború következtében újonnan keletkeztek vagy a lényegesen átalakult körülmények miatt új szabályozást kívántak, s amelyekre nézve a kivételes hatalom alapján alkotott szabályoknak egyszerú és rögtönös megszüntetése zavarok és bonyodalmak felidézése nélkül egyáltalában nem lehetséges." Vö.: 1920. évi VI. törvény 1. \$ (3) bekezdés. 
Az 1949-es alkotmány ezt a kérdést megkerülte, ${ }^{219}$ helyette a kivételes hatalom az 1960-as honvédelmi törvényben kapott helyet, ahol - bár az 1939-es Hvt. rendszerét tükrözi - a szabályozás jelentős mértékủ visszalépéssel járt a korábbi Hvt. koncepciójához képest. Ez a negatív irányú jogfejlődés elsősorban a kivételes hatalom elértéktelenedésére utalhat. A pártállam látszólagos jogrendjében ugyanis a kérdés elvesztette jelentőségét. Nem kellett szabályozni, mert a hatalommegosztás csak papíron létezett, és a gyakorlását sem kellett korlátozni, mert a párt minden szervben és intézményben korlátlan hatalommal rendelkezett. ${ }^{220}$

Az 1989-es rendszerváltás egy újabb dinamikus kodifikációs szakasz nyitányának tekinthető. A téma alkotmányi és törvényi szinten is új szabályozást nyert, egyrészt a némileg túlszabályozott szocialista joganyagra építkezve (rendkívüli intézkedések köre), másrészt viszont annak külföldi minták segítségével történő továbbgondolása révén (a kivételes helyzetek esetkörei, a kivételes hatalom gyakorlására jogosítottak személyi köre). Ami a korszakban (1989-2011) fájó hiányosság maradt, az a magyar jogi hagyományoknak a legújabb külföldi jogfejlődés eredményeivel való összevetése és ötvözése. Erre csak a tárgyidőszak végén, 2011-ben történt kísérlet.

\subsection{Dinamikus és statikus periódusok a kivételes hatalom kodifikációja során}

A kivételes hatalom szabályozásának történetét kísértük figyelemmel a kezdetektől egészen 2011-ig. Látható volt, hogy Magyarországon - bár több nemzetközi (köztük 1867-től az osztrák) példa is rendelkezésre állt - a szabályozás késôn és honvédelmi kérdésként jelentkezett. A kérdéshez a tárgyalt időszakban mindvégig az államérdek oldaláról közelítettek, az emberi jogokkal való összekapcsolódás - mint például 1867-ben Ausztriában - itthon (egy rövid kivételtől eltekintve) nem történt meg (erre majd csak 1989 után ${ }^{221}$ került sor).

Bár a kivételes hatalom szabályozási koncepciója 1912 és 1939 között folyamatosan változott, és közben egyre részletesebbé vált, a kivételes hatalom polgári irányítás (kormány) alá rendelésének elve állandósult. A törvény megalkotásának célja kezdetben az állam múködtetésének megkönnyítése volt, ám a II. világháború alatt fokozatosan az államszervezet totális irányítását lehetővé tevő eszközzé vált. A kivételes hatalom 1946-1949 közötti ideiglenes szabályozása ugyancsak az államhatalom megszerzésének eszközéül szolgált.

Ezt követően a jogintézmény egészen 1989-ig nem állt a figyelem középpontjában. Szabályozását - elsősorban a korábbi szabályozás mintájára - fontosnak tartották, de a jogfejlesztés több részletben, egységes koncepciót nélkülözve zajlott. Erre tekintettel, összevetve

219 Pontosabban a Kht. szabályozása az Elnöki Tanács hatásköreinek megvonásánál szolgálhatott mintaként. Vö.: 1949. évi XX. tv. 20. \$ (4)-(5) bekezdés.

220 Bővebben lásd: Bihari, 2005.

221 Egyrészt az MKA módosítása révén, amelynek XII. fejezete részletesen felsorolta az alapvető jogokat és kötelességeket, miközben előírta, hogy az alkotmány alkalmazása rendkívüli állapot idején sem függeszthető fel. Másrészt Magyarország 1993-ban jogrendje részévé tette az Emberi Jogok Európai Egyezményét (1993. évi XXXI. tv.), amelynek 15. szakasza szükséghelyzet idején lehetôvé teszi egyes emberi jogok korlátozását. 
az 1912-1949 közötti dinamikus szakasszal, 1949-1989 között egy alapvetően statikus kodifikációs időszakról beszélhetünk. A kivételes hatalom szabályozása 1989-ben került újra előtérbe, de a periódus (1989-2011) egészét - néhány év (1989-1993) kivételével - inkább az átmeneti, mint dinamikus jelzővel lehetne jellemezni.

\subsection{Az egyévszázados kodifikáció mérlege}

A kivételes hatalom modern szabályozása egy nehézkesen induló kodifikáció során került a magyar joganyagba. A jogalkotó a korban már létező generális szabályozás (például a korabeli osztrák törvény) átvétele helyett kifejezetten a háborús helyzet kezelését kívánta megkönnyíteni egy saját fejlesztésû́ törvénnyel. A szabályozást később analógiával a válságokkal terhelt békeidőre is alkalmazhatóvá tették, de a konkrét békeidejû rendelkezések kidolgozása egészen 1976-ig elmaradt.

A kivételes hatalom szabályozása az elmúlt évszázad nagyobbik részében döntően monista volt. Az alkotmányi és törvényi szint duális szerkezethez szükséges összhangját csak 1972-ben tudta megteremteni a jogalkotó. Azóta a szabályozás többnyire mindkét szinten egy időben vagy közel egy időben valósul meg. A joganyag két szint közötti eloszlását a korszakban legutóbb 2011-ben, előtte 1989-ben vizsgálták felül.

A jogintézményt érintő rendelkezések száma a tárgyidőszakban fokozatosan növekedett. A Hvt. 1939 különböző jogtechnikai megoldásokkal próbálta a szabályok és a szabályozók számát csökkenteni. Ennek részeként magát a jogintézményt is újrakodifikálta. Ilyen jellegû, tudatos, egységes koncepció mentén zajló kodifikáció a kivételes hatalommal kapcsolatos szabályokat legközelebb csak 1989-ben érintette. Kodifikáció természetesen a tárgyidőszak többi (1939-1989 és 1989-2011) részében is történt, de e változások többsége elsősorban kismértékủ és deskriptív jellegú volt.

Láthattuk, a szabályozási tárgy politikai rendszerváltozásoktól függetlenül mindvégig létezett, e 20. századi magyar történelemre oly jellemző rendszerváltozások egyik legfontosabb hatása talán a kivételes hatalomra vonatkozó koncepcionális jogfejlesztés elmaradásában jelölhető meg. Az újabb tervezetek elsősorban az akkor hatályos szabályozásra támaszkodtak, és - talán ideológiai okokból is - mind az 1912-es, mind az 1939-es törvény szerkezetének, jelentőségének felmérése és értékelése hosszú ideig váratott magára, és csak az I. világháború centenáriumához kapcsolódva kezdődött meg a jogintézmény korai történetének vizsgálata.

E tudományos igényú, jogtörténeti jellegú vizsgálat jelen esetben elsősorban nem az elmélet, hanem a gyakorlat számára járna haszonnal. Az 1989-2011 közötti jogfejlesztés ugyanis - láthattuk - nagymértékben épített a szocialista időszak joganyagára, illetve annak egy részére, ahelyett, hogy a jogintézmény hazai szabályozásának jellegzetességeire, a korábbi koncepciók hol ciklikus, hol hektikus változásaira koncentrált volna. Márpedig a magyar szabályozási előzmények ismerete nélkül az esetek nagy részében a külföldi minták adaptá- 
ciója sem lehet sikeres. Azonban esetünkben ez utóbbi - a külföldi minták - feldolgozása és bemutatása is későn indult meg.

A jogalkotónak a kivételes hatalom újraszabályozására vonatkozó igénye fentiek miatt 2010-ben egyrészt időszerû, másrészt viszont - az összehasonlító jogi vizsgálatok elmaradása miatt - talán idő előtti volt. A következő évtizedben előbb a téma elméleti, ${ }^{222}$ majd 2020-ban gyakorlati oldalának előtérbe kerülése talán egy újabb, átfogó kodifikáció nyitányának tekinthető, amely során az elméleti eredmények, a külföldi minták és a saját gyakorlati tapasztalatok előnyösen ötvözhetôk.

\section{Irodalomjegyzék}

Alkotmányos elvek és esetek (1996). 1. kiadás. Budapest: Colpi

ÁDÁm, A. (1967a) 'Az Elnöki Tanács hatáskörének fejlődése I.', Állam és Igazgatás, 17(4), 310322. 0.

ÁDÁm, A. (1967b) 'Az Elnöki Tanács hatáskörének fejlődése II.', Állam és Igazgatás, 17(5), 424435. 0.

BIHARI, M. (2005) Magyar politika 1944-2004. Politikaiés hatalmi viszonyok. 1. kiadás. Budapest: Osiris.

BIHARI, O. (1979) 'Alkotmányok és alkotmányozás a Magyar Tanácsköztársaságban', Állam és Igazgatás, 29(3), 193-202. o.

BuzA, L. (1915) 'Az államjogi kivételes állapot', Jogtudományi Közlöny, 50(27), 305-306. o.; (28), 313-314. o.; (32), 350-351. o.; (33), 361-362. o.; (36), 386-387. o.

Concha, Gy. (1888) Újkorialkotmányok. 1. kiadás. Budapest: MTA

CzANK, L. (1978) 'A honvédelmi munkakötelezettségről az új honvédelmi törvény tükrében', Honvédelem, 19(8), 94-104. o.

DEÁk, Á. (2001) 'Az 1867. decemberi ausztriai törvénycikkek a közös ügyekról és azok kezelési módjáról', Aetas, 16(3), 238-243. o.

DEÁK, I. (1983) Kossuth Lajos és a magyarok 1848-49-ben. 1. kiadás. Budapest: Gondolat

DomANiczKy, E. (2009) A jogállam és a civil szektor Magyarországon, különös tekintettel a helyi önkormányzatokra. 1. kiadás. Budapest: Publikon

DomanıczKY, E. (2010) 'Az első magyar egyesülési törvényjavaslat', Közjogi Szemle, 3(2), 26-34. o.

222 Elméleti és gyakorlati szempontból is kifejezetten előremutató volt a Pázmány Péter Katolikus Egyetem, az MTA TK JTI és a Magyar Katonai Jogi és Hadijogi Társaság által 2017-ben közösen szervezett, $A$ különleges jogrend címú konferencia, ahol az elhangzott előadások összegezték az addigi „nemzetközi jogi, hazai és külföldi alkotmányjogi, közigazgatási jogi, büntetőjogi, jogelméleti és jogtörténeti, valamint politikatudományi kutatásokat" (Jakab, 2017, 1. o.; Till, 2017b; Tóth, J., 2017). Lásd még továbbá: Lakatos, 2014; Till, 2014; Kádár, 2014. 
Domaniczky, E. (2012) 'Adalékok a magyar egyesülési jog szabályozásához a dualizmus korában', Jogtörténeti Szemle, 14(1), 1-17. o.

EÖTtevÉNyi Nagy, O. (é. n.) Ausztria nemzetiségi politikája [Online]. Elérhetô: http://mtda.hu/ ADATTAR/cikktar/e_cikk/eottevenyi_nagy_oliver_ausztria_nemzetisegi_politikaja.pdf (Letöltve: 2020. június 7.)

FARKAS, Á., KÁDÁR, P. (szerk.) (2016) Magyarország katonai védelmének közjogi alapjai. 1. kiadás. Budapest: HM Zrínyi Térképészeti és Kommunikációs Szolgáltató Közhasznú Nonprofit $\mathrm{Kft}$.

Feitl, I. (szerk.) (1995) Az Ideiglenes Nemzetgyúlés és az Ideiglenes Nemzeti Kormány 1944-1945. 1. kiadás. Budapest: Politikatörténeti Alapítvány.

Felszeghy, B. (1914) 'A belső igazgatást érdeklő kivételes intézkedések', Közigazgatási Szemle, I(I), 473-485. o.

FöGLEIN, G. (1992) 'Az államföi jogkör ideiglenes szabályozása és gyakorlása Magyarországon 1944-1946 között', Jogtörténeti Szemle, 4(5), 3-15. o.

GalántaI, J. (1981) 'A háborús állam. A „kivételes hatalom” kodifikálása és alkalmazása 1914-1916-ban' in Pölöskei, F., Ránki, Gy. (szerk.) A magyarországi polgári államrendszerek. 1. kiadás. Budapest: Tankönyvkiadó

Germuska, P. (2011) A Honvédelmi Tanács és a Honvédelmi Bizottság Magyarországon, 1952-1980 [Online]. Elérhetô: www.nationaler-verteidigungsrat.de/downloads/germuska_ht_hb.pdf (Letöltve: 2020. december 1.)

GyARMATI, Gy. (2011) A Rákosi-korszak. 1. kiadás. Budapest: ÁBTL-Rubicon

HERMANN, R. (1998) 'A kormánybiztosi rendszer 1848-1849-ben', Hadtörténeti Közlemények, 111(1), 28-77. 0.

HermanN, R. (1999) 'A kormánybiztosi rendszer 1848-1849-ben' in Bessenyei, J., Fügedi, M., Ö. Kovács, J., Ringer, Á., Schimert, P. (szerk.) Történelmi tanulmányok. A Miskolci Egyetem történettudományi tanszékeinekévkönyve 1999. 1. kiadás. Miskolc: Miskolci Egyetem BTK

HoRváth, A. (2012) 'Alkotmányjogi javaslatok és reformok, 1790-1949' in Jakab, A., Körösényi, A. (szerk.) Alkotmányozás Magyarországon és máshol: politikatudományi és alkotmányjogi megközelitések. 1. kiadás. Budapest: Új Mandátum Kiadó - MTA TK PTI

JAKAB, A. (2017) 'Előszó', Iustum Aequum Salutare, (13)4, 1. o.

JÁNosi, F. (1867) Alkotmányok gyüjteménye. 1. kiadás. Pest: Pfeifer.

KÁDÁR, P. (2014) 'Sarkalatos átalakulások: A kétharmados/sarkalatos törvények változásai a honvédelem területén 2010-2014', MTA Law Working Papers, 2014/36. [Online]. Elérhetô: https://jog.tk.hu/mtalwp/sarkalatos-atalakulasok-a-ketharmadossarkalatostorvenyek-valtozasai-a-honvedelem-teruleten-2010-2014?download=pdf (Letöltve: 2020 . december 10.)

Katus, L. (2012) A modern Magyarország születése. 1. kiadás. Pécs: PTKE-Kronosz

Kelemen, R. (2016) 'A háború esetére szóló kivételes intézkedéseket tartalmazó 1912. évi LXIII. törvény országgyúlési vitája és sajtóvisszhangja', Parlamenti Szemle, 1(1), 70-91. o. 
Kelemen, R. (szerk.) (2017) Források a kivételes hatalom szabályozásának magyarországi geneziséról. 1. kiadás. Budapest: Magyar Katonai Jogi és Hadijogi Társaság

KELEMEN, R. (2018) 'A Honvédelmi Tanács. Szerves fejlődés vagy elnevezésbeli hasonlóságok a magyar jogtörténetben? (Honvédelmi Bizottmány - Legfelső Honvédelmi Tanács Honvédelmi Tanács szabályozása, jellege)', Katonai és Hadijogi Szemle, 2018/1, 63-94. o.

KIss, I. (1886) Magyar államjog. 1. kiadás. Eger: Lyceum Könyvnyomda

LAKaTos, L. (2014) 'A különleges jogrend és a honvédelem szabályzása' MTA Law Working Papers, 2014/49. [Online]. Elérhető: https://jog.tk.hu/mtalwp/a-kulonleges-jogrend-es-ahonvedelem-szabalyzasa (Letöltve: 2020 . december 8.)

LuKACs, J. (2020) A huszadik század rövid története. 1. kiadás. Budapest: Európa

MEZEy, B. (2016) 'Az első világháború jogi törvényhozói előkészítése: a kivételes hatalomról szóló 1912. évi 63. törvénycikk' in Kónya, P. (szerk.) Elsô világháború a Kárpátokban. 1. kiadás. Eperjes: Eperjesi Egyetem

Mezey, B. (szerk.) (2003) Magyar alkotmánytörténet. 1. kiadás. Budapest: Osiris

Mezey, B. (2015) 'A kivételes hatalom jogi természete', Jogtörténeti Szemle, 17(4), 25-32. o.

Moskovitz, I. (1906) 'A kormánybiztos', Jog, 25(4), 25-27. o.

MURBeR, I. (2018) 'Az osztrák és a magyar válságkezelés 1918-1920. Hasonlóságok és különbségek a közös birodalom összeomlását követően', Századok, 152(6), 1293-1320. o.

PALASIK, M. (2000) A jogállamiság megteremtése és kudarca Magyarországon 1944-1949. 1. kiadás. Budapest: Napvilág

Palasik, M. (2017) Parlamentarizmustól a diktatúráig (1944-1949). 1. kiadás. Budapest: Országház Kiadó

Petrétei, J. (2006) 'A minősített időszakokra vonatkozó alkotmányi (törvényi) szabályozás sajátosságai' in Ádám, A., Cseresnyés, F., Kajtár, I. (szerk.): Tanulmányok az 1956. évi forradalom és szabadságharc 50. évfordulójára. 1. kiadás. Pécs: PTE ÁJK

Polner, Ö. (1914) 'A háború okából tett kivételes intézkedések', Jogállam, 7(7-8), 489-512. o.

POLNER, Ö. (1931) 'Jogfolytonosság és ideiglenes alkotmány', Jogállam, 30(3-4), 144-151. o.

POLNER, Ö. (1916) [Polner Ödön előadása a Magyar Jogászegyletben]. Jogtudományi Közlöny, 51(9), 86-87. O.

POLNER, Ö. (1917) 'A háború esetére szóló kivételes hatalom alkotmányjogi jelentősége', Jogállam, 16(1-2), 25-42. 0.; (3-4), 129-150. o.

SÁGVÁRI, Á. (2017) 'Különleges jogrend a francia jogban', Iustum Aequum Salutare, 13(4), 179188. o.

SCHÖNWALD, P. (1969) A magyarországi 1918-1919-es polgári demokratikus forradalom állam-és jogtörténeti kérdései. 1. kiadás Budapest: Akadémiai Kiadó

SCHWeItzer, G. (2018) „A tisztességes jogtanár”-Molnár Kálmán pályaképe. 1. kiadás. Budapest: MTA TK JTI

SOMOGYVÁRI, I. (szerk.) (1998) Az Országgyülés Alkotmány-elókészítő munkájának dokumentumai 1994-1998. (2. kötet) 1. kiadás. Budapest: Parlamenti Módszertani Iroda 
Sz. Bíró, Z. (2017) Az elmaradt alkotmányozás. 1. kiadás. Budapest: Osiris

SzABó, I. (2017) 'Különleges jogrend a weimari alkotmányban', Iustum Aequum Salutare, 13(4), 127-141. 0.

SzÉKELY, S. (1964) 'A honvédelmi munkakötelezettségról', Honvédelem, (15)10, 46-54. o.

SzINAI, M. (1986) 'A parlamenten kívüli kormányzás Ausztriában és Magyarországon az első világháború után', Századok, 120(4), 802-805. o.

TAKÁcs, Gy. (1973) 'A sajtó és a kivételes hatalom', Jogtudományi Közlöny, 28(7-8), 407-411. o.

TILL, Sz. (2014) 'Tézisek az Alaptörvény és a honvédelem sarkalatos törvényi szintjének összefüggéseiről', MTA Law Working Papers, 2014/42. [Online]. Elérhető: https://jog. tk.hu/mtalwp/tezisek-az-alaptorveny-es-a-honvedelem-sarkalatos-torvenyi-szintjenekosszefuggeseirol?download=pdf (Letöltve: 2020 . december 15.)

Till, Sz. (2017a) A honvédelmi alkotmányosság 30 éve Magyarországon 1988-2017. 1. kiadás. Budapest: Zrínyi Kiadó

TiLL, Sz. (2017b) 'A különleges jogrendi kategóriarendszer egyszerúsítésének jövőbeli esélyei', Iustum Aequum Salutare, (13)4, 55-75. o.

TiLL, Sz. (2019): 'Különleges jogrend' in Jakab, A., Fekete, B. (szerk.) Internetes Jogtudományi Enciklopédia [Online]. Elérhető: http://ijoten.hu/szocikk/kulonleges-jogrend (Letöltve: 2020. november 16.)

То́тн, Á. (1967) 'A kivételes állapot intézményének kialakulása néhány burzsoá állam jogrendszerében', Acta Juridica et Politica, 14(8), 1-19. o.

Tóтн, Á. (1982) 'A statárium és az ostromállapot szabályozása 1848-tól a kiegyezésig', Acta Juridica et Politica, 29(5), 1-37. o.

Tóтн, J. Z. (2017) 'A rögtönbíráskodás története Magyarországon a XIX-XX. században', Iustum Aequum Salutare, (13)4, 143-177. o.

ÚjFALVI, A. (1990) '„Szükség törvényt bont” avagy a rendkívüli jogrend szabályozása a Negyedik Köztársaságban', Magyar Közigazgatás, (40)7, 614-625. o.

VARGYAI, Gy. (1979) 'A kivételes hatalom és az államszervezet militarizálásának néhány kérdése Magyarországon a második világháború előestéjén', Jogtudományi Közlöny, 34(11), 756-764. o.

VIROzsIL, A. (1861) Magyarország nyilván- vagy közjoga mint az alkotmánya eredetétól 1847/8-ig fennállott. Buda: Magyar Kir. Egyetemi Nyomda 


\section{A különleges jogrend fejlődése Magyarországon a kilencedik Alaptörvény-módosítás tükrében}

\section{HORVÁTH ATTILA}

\section{Az Alaptörvény és a különleges jogrend}

A 2012. január 1-jén hatályba lépő Alaptörvény egyik legmarkánsabb újítása a különleges jogrend újraszabályozása volt. A tárgykör új alapokra helyezése - formai szempontból - egyrészt terminológiai változásokat hozott, másrészt érintette a különleges jogrendi szabályok alaptörvényi elhelyezkedését, harmadrészt pedig jelentősen módosult ezen rendelkezések súlya. Az Alaptörvény természetesen tartalmi változásokat is hozott, bár ezek közel sem voltak olyan látványosak, mint a formai újítások. ${ }^{1}$ A következókben ezeket a módosításokat vesszük számba. (Tekintve, hogy a különleges jogrendre irányuló alkotmányos szabályozás számos korábbi elemzés tárgya volt már, nem az egyes különleges jogrendek átfogó bemutatására vállalkozunk, hanem a változásokat kívánjuk felvázolni.)

I Az Alkotmány és az Alaptörvény különleges jogrendi rendelkezéseinek összevetésére lásd például: László, 2018.

Dr. Horváth Attila, $\mathrm{PhD}$

attila.horvath@mfi.gov.hu

vezetô kutató (Mádl Ferenc Összehasonlító Jogi Intézet)

adjunktus (Nemzeti Közszolgálati Egyetem Âllamtudományi és Nemzetközi Tanulmányok Kar, Alkotmányjogi és Összehasonlító Közjogi Tanszék)

Horváth, A. (2021) 'A különleges jogrend fejlődése Magyarországon a kilencedik Alaptörvény-módosítás tükrében' in Nagy, Z., Horváth, A. (szerk.) A különleges jogrend és nemzeti szabályozási modelljei, 122-148. o. Budapest: Mádl Ferenc Összehasonlító Jogi Intézet.

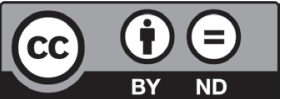




\subsection{Az Alaptörvény formai és szerkezeti újításai}

Az Alkotmányhoz képest az Alaptörvény különleges jogrendi szabályozása formai és szerkezeti szempontból három újdonságot hozott: megváltozott az elnevezés, az elhelyezkedés és a terjedelem.

Ami az elnevezést illeti, az Alaptörvény egy kicsi, de jogértelmezési-dogmatikai szempontól fontos adósságot törlesztett azzal, hogy bevezette a különleges jogrend kifejezést, ezzel egységes terminológiai keretet adva a szabályozási tárgykörnek. Az Alaptörvény előtt ugyanis nem volt egy jogszabályilag definiált összefoglaló elnevezése ezeknek a helyzeteknek. A minősitett időszak terminus technicust ugyan az Alkotmány nem tartalmazta, a jogirodalom és a jogszabályok egy része is használta - és részben ma is használja - ezt a kifejezést. ${ }^{2}$ (Az, hogy mintegy 20 hatályos jogszabályban ${ }^{3}$ a mai napig megtalálható ez a fordulat, abból a szempontból problémás, hogy álláspontunk szerint nem egyértelmú, hogy a kifejezés alatt pontosan mely különleges jogrendi kategóriákat kell érteni - ti. az összeset, vagy csak az Alkotmány által anno elismert kategóriákat.) A különleges jogrend elnevezéssel kapcsolatban a 2020-as tapasztalatok alapján kijelenthető, hogy a kifejezés nem igazán ment át a köztudatba/köznyelvbe, és nemcsak a média, de még a hivatalos állami kommunikáció is valamiért a rendkivüli jogrend kifejezést részesíti előnyben. ${ }^{4}$ Ennek talán az lehet az oka, hogy az utóbbi összetétel kifejezőbb, azaz a laikusok számára is beszédesebb, ugyanis a jelenkori helyzetet jobban megvilágítja a rendkivüli jelző, mint a - teljesen más köznapi jelentéssel bíró - különleges jelző. ${ }^{5}$

Alapvetően változott meg a különleges jogrendi szabályok elhelyezkedése is. Amint az előző fejezetben láttuk, az Alkotmány kissé esetleges módon, szétszórtan, az Ország-

2 A minősitett időszak kifejezésen kívül előfordultak még a következők is: rendkívüli jogrend, különleges állapotok, minősített helyzetek (Szilvásy, 2019, 105. o.). A következőkben az Alkotmány szabályozásának értékelése során is a különleges jogrend kifejezést használjuk.

3 Lásd például:

— a földmérési és térképészeti tevékenységről szóló 2012. évi XLVI. törvény 6. \$ (15) bekezdését;

— az elektronikus hírközlésről szóló 2003. évi C. törvény 86. \$ (1) bekezdés d) pontját; a 92. \$ (9)-(10) bekezdését;

— a nemzeti vérkészlettel való gazdálkodás szabályairól szóló 439/2015. (XII. 28.) Korm. rendelet 8. \$-át;

- az elektronikus hírközlés veszélyhelyzeti és minősített időszaki felkészítésének rendszeréről, az államigazgatási szervek feladatairól, múködésük feltételeinek biztosításáról szóló 100/2004. (IV. 27.) Korm. rendelet egészét.

Az is megjegyzendő, hogy a minősített időszak kifejezést kimondottan ritkán definiálták a jogszabályok. Így például a postáról szóló - már hatálytalan - 2003. évi CI. törvény 3. \$15. pontja értelmében „[m]inősített időszak: az az időszak, amely az Alkotmány alapján rendkívüli állapotnak, szükségállapotnak vagy veszélyhelyzetnek minősül". Ezt az értelmező rendelkezést az Alaptörvény hatálybalépését követően módosították, azonban a minősitett időszak kifejezés továbbra is megmaradt a törvényben.

4 Beszédes tény, hogy a Google internetes kereső a különleges jogrend kifejezésre 32 ezer, a rendkívüli jogrendre pedig több mint háromszor ennyi, 141 ezer találatot ad.

5 Ugyanakkor itt arra is kell utalni, hogy a hipotetikus rendkivüli jogrend kifejezés könnyen összekeverhető (lenne) a rendkivüli állapot kifejezéssel. 
gyưlésrôl (rendkívüli állapot, szükségállapot, váratlan támadás), illetve a Kormányról szóló fejezetben (veszélyhelyzet) szabályozta az egyes különleges jogrendi állapotokat. A rendelkezések nagyobb része - több alkotmánymódosítás nyomán - az Országgyűlés jogköreiről és az országgyűlési képviselőkről szóló szakaszok közé ékelődött be, egyfajta idegen testként funkcionálva, ugyanis az egyes különleges jogrendi időszakok túlmutattak az Országgyứlésen. A szabályozás áttekinthetőségét az is rontotta, hogy az ugyanazon különleges jogrendre vonatkozó rendelkezések sem egy helyen kerültek szabályozásra. ${ }^{6}$ Az Alkotmány nem túl szerencsés szerkezeti megoldásával szemben az Alaptörvény egy különálló részt - tehát nem csak fejezetet! - szentel a különleges jogrendnek, ami annak fényében különösen beszédes, hogy az Alaptörvény - a Nemzeti hitvalláson és a Záró rendelkezéseken kívül - mindössze négy részből áll. Ezzel kapcsolatban Kádár Pál „profiltisztítást” említ, hozzátéve, hogy „[a]z 1949. évi XX. törvény a rendszerváltást követően kialakított minősített időszakokra vonatkozó rendelkezéseit az Alaptörvény immár »fajtatiszta« különleges jogrendi rendelkezésekké nemesítette".?

Rátérve a terjedelemre, az Alkotmányhoz képest az Alaptörvényben a különleges jogrend nagyobb súlyt kapott: az alkotmányozó a korábbinál közel másfélszer nagyobb terjedelemben kodifikálta ezen rendelkezéseket, ezzel az Alaptörvényben a különleges jogrendi szabályok abszolút és relatív súlya is nőtt.

\subsection{Az Alaptörvény tartalmi újításai}

Bár a fenti formai és szerkezeti újítások kétségkívül látványosak, az Alaptörvény tartalmi szempontból nem hozott fundamentális változásokat. Egyrészt az öt különleges jogrend mindegyike megtalálható volt az Alkotmányban (noha - amint arra később visszatérünk - a váratlan támadás nem volt nevesítve), ${ }^{8}$ másrészt a kihirdetések feltételeiben és az egyes szereplők kompetenciájában sem történt igazán jelentős változás.

A rendkívüli állapotra vonatkozó szabályozás minimális mértékben módosult. Az Alaptörvény egyrészt pontosította a kihirdetés egyik feltételét: az Alkotmány hadiállapot esetén tette lehetővé a rendkívüli állapot kihirdetését, ${ }^{9}$ míg az Alaptörvényben már a „, hadiállapot kinyilvánítása" kifejezés szerepel..$^{10}$ Másrészt pontosításra kerültek az Országgyülés megbíza-

6 Így például a megelőző védelmi helyzet meghatározására az Országgyủlés jogköreiről szóló felsorolásban került sor $[19 . \$(3)$ bekezdés $n$ ) pont], de a Kormány cselekvési lehetőségét a Kormányról szóló rendelkezések között találtuk [35. $\$$ (1) bekezdés $m$ ) pont, illetve (3) bekezdés].

7 Kádár, 2014, 1. o.

8 Vö.: Alaptörvény záró és vegyes rendelkezéseinek 23. pontja. Az eredetileg a Magyarország Alaptörvényének átmeneti rendelkezései 25. cikkében megjelenő rendelkezések arra szolgáltak, hogy tisztázzák az Alkotmány egyes különleges jogrendjeinek a „jogutódlását” abban a - nem túl valószínủ - esetben, ha az Alaptörvény hatálybalépése úgy következne be, hogy valamelyik különleges jogrend már korábban ki lett hirdetve.

9 Alkotmány 19. $\$(3)$ bekezdés $h$ ) pont.

10 Alaptörvény 48. cikk (1) bekezdés $a$ ) pont. 
tásával összefüggő rendelkezések. ${ }^{11}$ Ezzel kapcsolatban az Alaptörvénybe az is bekerült, hogy a feloszlott vagy feloszlatott Országgyúlést rendkívüli állapot idején a Honvédelmi Tanács is összehívhatja. ${ }^{12}$ (Az Alkotmány ezt a jogot csak a köztársasági elnöknek adta meg. ${ }^{13}$ )

Ennél fontosabb fejlemény volt, hogy az Alaptörvény pontosabban elhatárolta egymástól a szükségállapot és a veszélyhelyzet kihirdetésének feltételeit. Erre azért volt szükség, mert a két különleges jogrend részben átfedésben volt egymással. ${ }^{14} \mathrm{Az}$ Alkotmány - többek között „az élet- és vagyonbiztonságot tömeges méretekben veszélyeztető [...] elemi csapás vagy ipari szerencsétlenség" esetén tette lehetôvé a szükségállapot kihirdetését, ${ }^{15}$ míg a veszélyhelyzet bevezetésének célja „az élet- és vagyonbiztonságot veszélyeztető elemi csapás, illetőleg következményeinek az elhárítása" volt. ${ }^{16} \mathrm{~A}$ két meghatározás mindegyike utal az (élet- és vagyonbiztonságot veszélyeztető) elemi csapásra, és ebből a szempontból az elhatárolás alapja - elvileg - az lehetett, hogy az élet- és vagyonbiztonságot tömeges méretekben veszélyezteti-e a kialakult helyzet. ${ }^{17} \mathrm{Az}$ Alaptörvény annyiban tisztább szabályozást teremtett, hogy az elemi csapást és az ipari szerencsétlenséget mint tényállási elemeket kivette a szükségállapotból, és ezek immár a veszélyhelyzetről szóló cikkben kerültek szabályozásra. További változás, hogy a Magyar Honvédség felhasználhatósága rendelkezés ${ }^{18}$ átkerült a Magyar Honvédségre vonatkozó rendelkezések közül a szükségállapot szabályai közéi azzal a kiegészítéssel, hogy a „ha a rendőrség alkalmazása nem elegendő" fordulat helyébe a „ha a rendőrség és a nemzetbiztonsági szolgálatok alkalmazása nem elegendő" szövegrész lépett. Az értelmezési problémákat elkerülendő, az Alaptörvény már nem használja a szükséghelyzet kifejezést. Az Alkotmány ezzel a kifejezéssel a szükségállapot kihirdetését megalapozó körülményeket illette (ti. szükséghelyzetben kellett szükségállapotot kihirdetni), ${ }^{20}$ azonban álláspontunk

11 Alkotmány 28/A. $\$(1)-(2)$ bekezdés vs. Alaptörvény 48. cikk (7) bekezdés.

12 Alaptörvény 48. cikk (8) bekezdés.

13 Alkotmány 28/A. \$ (3) bekezdés.

14 Kádár, 2014, 1. o.

15 Alkotmány 19. $\$(3)$ bekezdés i) pont.

16 Alkotmány 35. \$(1) bekezdés i) pont.

17 A helyzetet némileg árnyalta, hogy az Alkotmány idején hatályos, a polgári védelemről szóló 1996. évi XXXVII. törvény a veszélyhelyzetet a következóképp definiálta: „a szükséghelyzetet [Alkotmány 19. \$ (3) bek. i) pont] el nem érő mértékü, az élet- és vagyonbiztonságot vagy a környezetet veszélyeztető természeti csapás, illetőleg ipari baleset okozta állapot, amelyet különösen a következő események válthatnak ki: [...]”. Tehát a törvény - szemben az Alkotmánnyal - ipari baleset esetén is lehetővé tette veszélyhelyzet bevezetését. Ezzel magyarázható, hogy a 2010. októberi kolontári vörösiszap-katasztrófát követően „csak” veszélyhelyzet kihirdetésére került sor. Ezzel összefüggésben egyes szerzők olyan politikai gyakorlatról írnak, amely „a kihirdethető korabeli minősített időszakok közül az enyhébbek bevezetésére törekedett akár egyes tényállási elemek alkotmányos hiányában is” (Farkas-Till, 2016,65 . o.). Kissé sarkosabb az a vélemény, amely szerint a vörösiszap-katasztrófa kezelése „az Alkotmány szövegszerủ követelményétől eltérve" zajlott le a veszélyhelyzet szabályai szerint [Till, 2019, (23)]. Utóbbi meglátással kapcsolatban kiemelendő, hogy az ipari szerencsétlenség fordulat az Alkotmány akkor hatályos szövegében csak a szükségállapotnál [19. \$(3) bekezdés i) pont] szerepelt, a veszélyhelyzetnél [35. \$ (1) bekezdés i) pont] nem.

18 Alkotmány 40/A. $\$(2)$ bekezdés.

19 Alaptörvény 50. cikk (1) bekezdés.

20 Alkotmány 19. $\$(3)$ bekezdés i) pont. 
szerint ez indokolatlan fogalmi túlbonyolítás volt. ${ }^{21} \mathrm{~A}$ szükségállapotra vonatkozó szabályok közül az Alaptörvény törölte a rendkívüli állapot szubszidiárius jellegére utaló rendelkezést: „A szükségállapotra egyébként a rendkívüli állapotra vonatkozó szabályokat kell alkalmazni." ${ }^{\prime 2}$ Ehelyett külön cikkben foglalta össze a rendkívüli állapotra és a szükségállapotra vonatkozó közös szabályokat, ${ }^{23}$ megkönnyítve ezzel a jogértelmezést.

A megelőző védelmi helyzetre vonatkozó szabályozás egy szempontból került kiegészítésre: az alkotmányozó rögzítette, hogy a Kormány rendelete a megelőző védelmi helyzet megszúnésével hatályát veszti. ${ }^{24}$

A váratlan támadásnál formai szempontból fontos újítás, hogy az Alaptörvény adott egy egzakt megnevezést ennek a helyzetnek, ugyanis az Alkotmány nem tartalmazta a váratlan támadás kifejezést, noha az ezt az állapotot szabályozó rendelkezése ${ }^{25}$ tartalmilag lényegében egybeesett az Alaptörvény későbbi rendelkezésével. ${ }^{26}$ Ahogyan a megelőző védelmi helyzetnél, úgy az Alaptörvény itt is tisztázta, hogy a Kormány rendelete a váratlan támadás megszúnésével hatályát veszti. ${ }^{27}$ Ezen túl kisebb jelentőségú változás, hogy míg az Alkotmány a Kormány intézkedési kötelezettségét kifejezetten a köztársasági elnök által jóváhagyott védelmi terv keretében tette lehetővé, ${ }^{28}$ addig az Alaptörvény úgy fogalmaz, hogy a Kormány „szükség esetén a köztársasági elnök által jóváhagyott fegyveres védelmi terv szerint" teszi meg ezeket az intézkedéseket. ${ }^{29}$

A veszélyhelyzetet illetően - amint arra fentebb utaltunk - fontos változás volt a szükségállapottól való pontosabb elhatárolás, amely eredményeként az elemi csapás és az ipari szerencsétlenség már egyértelmủen a veszélyhelyzet kihirdetését alapozhatja meg. Az Alkotmány a Kormány veszélyhelyzeti intézkedéseivel kapcsolatban még hivatkozott a közrend és a közbiztonság védelmére, azonban az Alaptörvényben már csak a következmények elhárítására utal. A közrend és a közbiztonság védelmére történő utalás tehát kikerült, ami öszszefügghet a szükségállapot és veszélyhelyzet - már említett - „finomhangolásával”, amely

21 Annyiban azonban van létjogosultsága a szükséghelyzet/szükségállapot megkülönböztetésnek, hogy az előbbi a különleges jogrendet megalapozó körülményekre, az utóbbi pedig már a kihirdetett különleges jogrendre vonatkozik. Ezzel kapcsolatban Till úgy vélekedik, hogy „[e]gy ideális szabályozási rend elkülönítené a helyzeteket - amelyek a kiváltó okok tényállásszerú megvalósulásai - az állapotoktól, amelyek a feljogosított állami szerv döntésétől kezdődően a különleges jogrendi időszakra vonatkozó szabályok érvényesítései” [Till, 2019, (13)].

22 Alkotmány 19/C. $\$(5)$ bekezdés.

23 Alaptörvény 48. cikk.

24 Alaptörvény 51. cikk (5) bekezdés.

25 Alkotmány 19/E. \$. Az, hogy az Alkotmány nem adott nevet ennek a különleges jogrendnek, ahhoz a meglehetôsen suta megoldáshoz vezetett, hogy a tulajdonképpeni váratlan támadást a jogszabályok „az Alkotmány 19/E. \$-a szerinti eset"-ként emlegették.

26 Alaptörvény 52 . cikk.

27 Alaptörvény 52. $\$$ (4) bekezdés.

28 Alkotmány 19/E. $\$(1)$ bekezdés.

29 Alaptörvény 52. \$ (1) bekezdés. Megjegyzendő, hogy 2023. július 1-től az Alaptörvény már nem utal a fegyveres védelmi tervre. 
következtében a veszélyhelyzet esetköre a katasztrófa típusú helyzetekre korlátozódott. ${ }^{30}$ (De úgy is lehet érvelni, hogy a következmények elhárításába beleértendő a közrend és a közbiztonság védelme is. (31 $^{31}$ A Alkotmány nem szabályozta a Kormány veszélyhelyzeti rendeleteinek a sorsát; ${ }^{32}$ a hiányosságot pótolandó az Alaptörvény kimondja, hogy ezek a rendeletek 15 napig maradnak hatályban, kivéve, ha a Kormány - az Országgyűlés felhatalmazása alapján - a rendelet hatályát meghosszabbítja..$^{33}$ Ezenfelül az Alaptörvénybe az is bekerült, hogy a Kormány rendelete a veszélyhelyzet megszúnésével hatályát veszti. ${ }^{34}$

Az egyes különleges jogrendek szabályozási változását követően arra is rá kell mutatni, hogy az Alkotmányhoz képest az Alaptörvény jóval szúkebben vonta meg azon alapvető jogok körét, amelyek különleges jogrend idején sem függeszthetők fel vagy korlátozhatók. Az Alkotmány mintegy tucat alapjogot részesített ilyen fokú védelemben, többek között a vallásszabadságot és a szociális biztonsághoz való jogot is. ${ }^{35}$ Az Alaptörvény értelmében viszont ez a feltétel nélküli védelem csak az élethez és emberi méltósághoz való jogot, az emberi méltósághoz való joghoz kapcsolódó nevesített tilalmakat (kínzás, embertelen, megalázó bánásmód és büntetés tilalma stb.), valamint a tisztességes eljáráshoz való jog egyes garanciáit (ártatlanság vélelme, védelemhez való jog, nullum crimen/nulla poena sine lege elve, ne bis in idem elve) illeti meg. ${ }^{66}$ Álláspontunk szerint az Alaptörvény szabályozása észszerűbbnek tûnik, hiszen az Alkotmány olyan alapjogokat is feltétlen védelemben részesített, amelyek korlátozása reális lehetőség lehet egyes különleges jogrendi időszakokban (mint például a személyi szabadság vagy a vallási szertartások megtartása mint a vallásszabadság egyik részjogosítványa). Másrészt arra is rá kell mutatni, hogy az Alkotmány nem az összes különleges jogrend esetén tette lehetôvé az alapjogok korlátozását, hanem csak rendkívüli állapotban, szükségállapotban és veszélyhelyzetben. Az Alaptörvény megoldása ebből a szempontból is logikusabbnak túnik, ugyanis adott esetben például a megelőző védelmi helyzet is szükségessé teheti az alapvetô jogok korlátozását vagy felfüggesztését. ${ }^{37}$

Az Alaptörvény az Alkotmányhoz képest néhány többletgaranciát is tartalmaz a különleges jogrendi rendelkezései között. Az Alkotmány csak a rendkívüli állapot vonatkozásában írta elő, hogy a Honvédelmi Tanács sem jogosult az Alkotmány alkalmazásának felfüggesz-

30 László, 2018, 381-382. 0.

31 Különösen, ha figyelembe vesszük, hogy a katasztrófavédelemről és a hozzá kapcsolódó egyes törvények módosításáról szóló 2011. évi CXXVIII. törvény (Kat.) V. fejezete több olyan intézkedést tesz lehetővé a Kormány számára, amelyeknek van közrend- és közbiztonság-védelmi vonatkozása is (például kijárási tilalom, gyülekezési tilalom, szabad mozgás korlátozása).

32 Így például a kolontári vörösiszap-katasztrófa miatt kihirdetett veszélyhelyzet - ahogyan az a következő fejezetből is kiderül - 267 napig volt hatályban.

33 Alaptörvény 53. \$(3) bekezdés.

34 Alaptörvény 53. \$(4) bekezdés.

35 Jakab, 2011, 301. o.

36 Alaptörvény 54. cikk (1) bekezdés.

37 Vö.: Jakab, 2011, 301. o. 
tésére, ${ }^{38}$ valamint hogy az Alkotmánybíróság múködése nem korlátozható. ${ }^{39}$ (Bár ehhez hozzátehetjük, hogy - amint már utaltam rá - a szükségállapotra egyébként a rendkívüli állapotra vonatkozó szabályokat is alkalmazni kellett, így az előbbi elốrások a szükségállapotra is vonatkoztak.) Az Alaptörvény ezeket a tilalmakat valamennyi különleges jogrendre kiterjeszti. ${ }^{40} \mathrm{Azt}$ is meg kell jegyezni, hogy míg az Alkotmány nem tartalmazott rendelkezéseket a különleges jogrend megszüntetéséról, addig az Alaptörvény kifejezetten kimondja, hogy a különleges jogrendet a különleges jogrend bevezetésére jogosult szerv megszünteti, ha kihirdetésének feltételei már nem állnak fenn. ${ }^{41}$

Összességében tehát elmondható, hogy az Alaptörvény a formai-szerkezeti újítások mellett jobbára valóban csak az Alkotmány szabályozásának rendszerezési és dogmatikai pontosítási igényú újraalkotására vállalkozott. ${ }^{42}$

\subsection{A terrorveszélyhelyzet mint új különleges jogrendi kategória}

Az igazi „innovációt” a 2016-os hatodik Alaptörvény-módosítással beiktatott terrorveszélyhelyzet jelentette, amely a hatodik különleges jogrendként került az Alaptörvénybe.43 Az alkotmányozó olyan új típusú biztonsági kihívásokra hivatkozott, „amelyek a korábbi klasszikus államközi fenyegetésekre adott különleges jogrendi válaszokkal hatékonyan és a szükségesség-arányosság követelményeit betartva megfelelően nem kezelhetők" ${ }^{44} \mathrm{Mindez}$ tehát azt jelentette, hogy - legalábbis az alkotmányozó álláspontja szerint - a terrorizmus nem volt beilleszthető a meglevő különleges jogrendi rendszerbe, így szükség volt egy új különleges jogrendi kategória bevezetésére. A terrorveszélyhelyzet alkotmányos rangra emelésének indokoltságával kapcsolatban eltérnek egymástól a szakmai álláspontok. ${ }^{45}$ Simicskó István úgy érvel, hogy a terrorveszélyhelyzet alaptörvényi beiktatása egy szükséges lépés volt, hiszen egyik különleges jogrendi kategória sem volt alkalmas a terrorveszély kezelé-

38 Alkotmány 19/B. \$ (4) bekezdés.

39 Alkotmány 19/B. $\$(6)$ bekezdés.

40 Alaptörvény 54. $\$(2)$ bekezdés.

41 Alaptörvény 54. cikk (3) bekezdés.

42 Jakab-Till, 2019, 435. o.

43 Alaptörvény 51/A. cikk.

$44 \mathrm{Az}$ Alaptörvény hatodik módosításához füzött indokolás.

45 Megjegyzendő, hogy az ellenzék részéről volt egy alaptörvény-módosítási javaslat, amely a terrorveszély kezelését újabb különleges jogrend bevezetése nélkül kívánta megoldani. A javaslat a Magyar Honvédségre vonatkozó alaptörvényi rendelkezéseket kiegészítette volna azzal, hogy „[a] Magyar Honvédség közreműködhet a rendőrségnek a terrorcselekmény megelőzése, félbeszakítása, következményeinek elhárítása és az elkövetők elfogása érdekében végrehajtott, sarkalatos törvényben meghatározott kiemelt biztonsági intézkedések végrehajtásában". A javaslat indokolása szerint indokolatlan egy újabb különleges jogrendi kategória bevezetése (T/11024. sz. iromány). Elérhető: www.parlament.hu/irom40/11024/11024.pdf (Letöltve: 2020. december 3.). A kormánypárti és az ellenzéki javaslatok összevetésére lásd: Till, 2016, 33-40. o. 
sére..$^{46} \mathrm{Amint}$ kifejti, a rendkívüli állapot a hagyományos, államok közötti háborúra irányuló kategória, ráadásul az állampolgárok jogainak korlátozását terrorveszély esetén a biztonsági helyzethez képest túlzott mértékben tenné lehetővé. ${ }^{47} \mathrm{~A}$ szerző a szükségállapot alkalmazhatóságával szemben öt ellenvetést tesz. Egyrészt a szükségállapot tényállásának a releváns fordulatából („az élet- és vagyonbiztonságot tömeges méretekben veszélyeztető, fegyveresen vagy felfegyverkezve elkövetett súlyos, erőszakos cselekmények") hiányzik a közvetlen fenyegetés megelőzésének különleges jogrendi lehetősége (ti. az előbbi súlyos, erőszakos cselekmények veszélye még nem alapozhatja meg a szükségállapot kihirdetését). A második kifogás a „tömeges méretekben” kitételre irányul, ugyanis álláspontja szerint ez csak a megtörtént és jelentős áldozatokat követelő eseményekre vonatkoztatható. Harmadrészt a szerző arra is utal, hogy „demokratikus deficit vádja merülhetne fel, amennyiben a köztársasági elnök egyszemélyi rendeleti államirányítása jönne létre a terrortámadás elhárítása okán". ${ }^{48}$ A negyedik ellenérvet - a rendkívüli állapothoz hasonlóan - az állampolgárok indokolatlan mértékû́ jogkorlátozása képezi. ${ }^{49}$ Végezetül az írás azt is hangsúlyozza, hogy a szükségállapot protokollja nem alkalmas a gyors reagálásra. ${ }^{50}$ Simicskóhoz hasonlóan Farkas Ádám is úgy vélekedik, hogy a terrorveszélyhelyzet a 2016-ban meglévő esetkörök egyikébe sem volt maradéktalanul beilleszthető. A szerző úgy jellemzi a terrorveszélyhelyzetet, mint a szükségállapot „előszoba-tényállását”, és ami ennélfogva a normál jogrend és a szükségállapot koordináta-rendszerében egy köztes megoldási lehetőség a hathatósabb állami fellépésre. ${ }^{51}$ Till Szabolcs a terrorveszélyhelyzet szükségességével kapcsolatban összességében szintén elfogadó álláspontot vesz fel egy 2016-os írásában..$^{52}$

A fenti megközelítésekkel szemben Mészáros Gábor úgy véli, hogy terrortámadás esetén is alkalmazható lenne a szükségállapot második fordulata, hiszen egy ilyen eseményt is minősíthetnénk úgy, mint az élet- és vagyonbiztonságot tömeges méretekben veszélyeztető, fegyveresen vagy felfegyverkezve elkövetett súlyos, erőszakos cselekmény, vagyis ez alapján - szól az érvelés - nem indokolt a szükségállapothoz képesti önálló szabályozás. ${ }^{53} \mathrm{~A}$ szerző

46 Simicskó, 2016. Az, hogy a megelőző védelmi helyzet, a váratlan támadás, valamint a veszélyhelyzet miért nem alkalmas a terrorveszély kezelésére, álláspontunk szerint egyértelmú, így a szerző ez irányú fejtegetéseinek bemutatásától eltekintünk.

47 Simicskó, 2016, 105. o.

48 Simicskó, 2016, 106. o. Ezzel kapcsolatban viszont adódik a kérdés: ha például egy puccskísérlet miatt kerül bevezetésre a szükségállapot, akkor ez az ellenérv ugyanúgy megállná-e a helyét?

49 Simicskó, 2016, 106. o.

50 Simicskó, 2016, 106. o.

51 Farkas, 2016a, 184. o.

52 Till, 2016.

53 Mészáros, 2017, 128-129. o. Megjegyzendő, hogy a szerző itt nem veszi figyelembe, hogy a jogszabályok megfogalmazása alapvetően egyes számban történik, viszont az Alaptörvény 48. cikk (1) bekezdés b) pontja következetesen többes számban fogalmaz („cselekmények”), azaz a szükségállapot kihirdetéséhez események sorozatára van szükség. Till a terrorveszélyhelyzettel kapcsolatban arra mutat rá, hogy a terrortámadás esetén „a megvalósult támadás felételének pedig egyszeri akció is eleget tehet, szemben a szükségállapoti tényállás többes számú megfogalmazásával" (Till, 2017, 66. o.). 
ezenfelül aggályosnak találja, hogy a terrorveszélyhelyzet alaptörvényi szabályozása alapján nem határozható meg pontosan, hogy mi minősül terrortámadásnak, illetve terrortámadás jelentős és közvetlen veszélyének, így fennáll annak a veszélye, hogy a Kormány visszaélésszerúen használhatja ki a szabályozás hiányosságait. ${ }^{54}$ Ósze Áron szintén a terrorveszélyhelyzet bevezetésének feleslegességét hangsúlyozza, és egyúttal úgy vélekedik, hogy a szükségállapot tényállásának bővitésével (a jelentős és közvetlen veszélyre történő utalás beemelésével) utóbbi különleges jogrend keretében is kezelhető lenne a terrorizmus fenyegetése. ${ }^{55}$ Ságvári Bence számos európai ország alkotmányának vizsgálatát követően arra a következtetésre jutott, hogy „a különleges jogrend kifejezetten terrorizmusra szabása nem európai gyakorlat", és egy újabb különleges jogrend hazánkban sem feltétlenül indokolt..

\section{A különleges jogrend átfogó reformja: az Alaptörvény kilencedik módosítása}

Az Alaptörvény 2020. decemberben elfogadott kilencedik módosítása (a továbbiakban: Módosítás) gyökeresen átalakította a különleges jogrendre vonatkozó szabályozást. A Módosítás általános indokolása védelmi és biztonsági reformról szól, és leszögezi, hogy a módosítás célja „a korszerúbb, a változó biztonsági környezethez jobban alkalmazkodó és az elmúlt évek válságkezeléseinek tapasztalataira építő, hatékony rendszer" kialakítása, hozzátéve, hogy az Alaptörvénybe többletgaranciákat is beépítenek. A részletes indokolás ezen túl megemlíti még az átláthatóságot és a fokozatosság elvét, mint a módosító javaslat során szem előtt tartott elveket. A különleges jogrendi rész rövidülésével járó reform ${ }^{57}$ legfontosabb elemeként a korábbi hat különleges jogrendi állapot helyett a Módosítás nyomán csak három kategória lesz megkülönböztetve: a hadiállapot, a szükségállapot és a veszélyhelyzet. ${ }^{58} \mathrm{Meg}$ ítélésünk szerint az átláthatóságot javítja, hogy a Módosítás - szemben a most hatályos szövegváltozattal - először végigveszi az egyes különleges jogrendeket, majd csak ezt követően tárgyalja a közös szabályokat. ${ }^{59}$

54 Mészáros, 2017, 129-130. o.

55 Ôsze, 2018, 40-41. o. Megjegyzendő ugyanakkor, hogy a terrorveszélyhelyzettel kapcsolatos ellenvélemények kevésbé veszik figyelembe, hogy a terrorveszélyhelyzetben más a rendkívüli jogosítványok címzettje, mint szükségállapotban, illetve az Alaptörvény azonnali intézkedéseket is lehetővé tesz a terrorveszélyhelyzet kezdeményezését követően, míg a szükségállapotnál ilyen lehetőség nincs.

56 Ságvári, 2016.

$57 \mathrm{Az}$ új különleges jogrendi rész terjedelme a jelenleginek mintegy háromnegyede.

58 Alaptörvény új 48. cikk.

59 Jelenleg a különleges jogrend tárgyalása a rendkívüli állapotra és a szükségállapotra vonatkozó közös szabályokkal indul (48. cikk), és ezt követően következik a rendkívüli állapot és a szükségállapot részletesebb tárgyalása. Ennek a megoldásnak az a hátránya, hogy pont a rendkívüli állapot címet viselő 49. cikkből nem derül ki a rendkívüli állapot lényege, hogy ti. mikor és ki által kerül sor ennek kihirdetésére. 
A következőkben először az egyes különleges jogrendekre vonatkozó szabályozás újdonságait mutatjuk be, majd a Kormány különleges jogrendi szerepének átalakulását tárgyaljuk, végül pedig a Módosítás által bevezetett többletgaranciákat vesszük számba. A változások ismertetése és értékelése előtt le kell szögezni, hogy az új különleges jogrendi rendelkezések meglehetősen soká, 2023. július 1-jén lépnek majd hatályba, ${ }^{60}$ így a - remélhetőleg minél kisebb számú válsághelyzeteket egy jó darabig még a hatályos szabályozás keretei között kell kezelni.

\subsection{A (régi-)új különleges jogrendek: hadiállapot, szükségállapot, veszélyhelyzet}

Az újonnan kialakított hadiállapot voltaképpen a katonai típusú különleges jogrendeket öleli fel, ${ }^{61}$ és - amint az indokolás rámutat - alapvetően a rendkívüli állapot elemeit ötvözi a megelőző védelmi helyzet egyes szabályaival. ${ }^{62} \mathrm{~A}$ következő ábra a rendkívüli állapot/hadiállapot kihirdetésére okot adó körülmények változását foglalja össze:

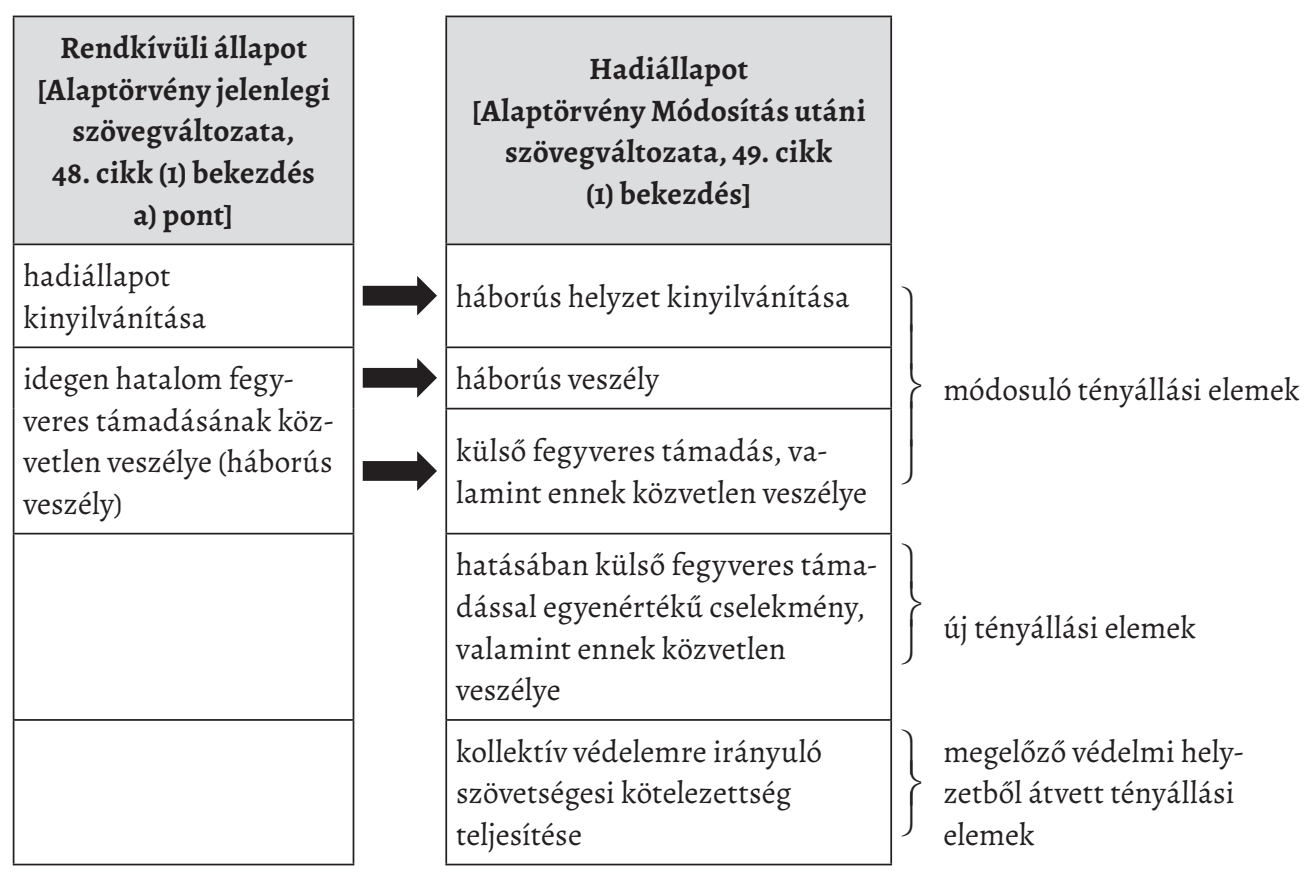

1. ábra

A rendkivüli állapotés a hadiállapot tényállási elemeinek változása az Alaptörvényben

Forrás: a szerzô saját összeállitása

60 Módosítás 12. cikk (2) bekezdés.

61 Alaptörvény új 49. cikk.

62 A Módosítás 11. cikkéhez füzött indokolás. 
Amint látható, a hadiállapot kifejezés fontos jelentésváltozáson esett át: míg az Alaptörvény jelenleg hatályos szövegében a hadiállapot (pontosabban annak kinyilvánítása) idézheti elő a rendkívüli állapotot, ${ }^{63}$ addig a Módosításban a hadiállapot már maga a különleges jogrend. Amint az indokolás kiemeli, a jelenlegi „hadiállapot kinyilvánítása” fordulat megegyezik az új „háborús helyzet kinyilvánítása” fordulattal. ${ }^{64} \mathrm{~A}$ második változást az jelenti, hogy az ,idegen hatalom fegyveres támadásának közvetlen veszélye (háborús veszély)" tényállás helyébe voltaképpen két fordulat lép. Az egyik a háborús veszély, ami abból a szempontból érdekes, hogy a jelenlegi szöveg is tartalmazza ezt a kifejezést, és a zárójeles feltüntetés arra utal, hogy a háborús veszély az idegen hatalom fegyveres támadásának közvetlen veszélyét jelenti. A Módosítás nyomán a háborús veszély fordulat "lecsupaszítva” megmarad - értve ez alatt azt, hogy ez a fogalom immár nem kerül kibontásra. A másik új fordulat a „külső fegyveres támadás, valamint ennek közvetlen veszélye”. Ez két szempontból is újdonságot hoz: egyrészt az „idegen hatalom fegyveres támadása” helyett az új szövegváltozat „külső fegyveres támadás”-ra utal, másrészt immár nemcsak ennek a közvetlen veszélye alapozhatja meg a hadiállapot kihirdetését, hanem maga a támadás is. ${ }^{65} \mathrm{Mindez}$ azt jelenti, hogy a hadiállapot - bár erre az indokolás nem utal - álláspontunk szerint magába olvasztja a jelenleg váratlan támadásnak nevezett különleges jogrendet is. A váratlan támadás kiváltó alapja az Alaptörvény hatályos szövegváltozatában a "külső fegyveres csoportoknak Magyarország területére történő váratlan betörése”; a hadiállapot „külső fegyveres támadás, valamint ennek közvetlen veszélye meghatározása" fordulata viszont kellően inkluzív ahhoz, hogy a külső fegyveres csoportok (például gerillacsoportok) ${ }^{66}$ betörésének kezelésére is alkalmas legyen. Míg tehát a rendkívüli állapot a reguláris hadviseléssel áll összefüggésben, addig a hadiállapot nemcsak a háborús helyzetet (veszélyt) öleli fel, hanem minden egyéb külső fegyveres támadást.

A harmadik változást az jelenti, hogy immár nemcsak a fegyveres támadás (illetve ennek közvetlen veszélye ${ }^{67}$ ) válthatja ki ezt a típusú különleges jogrendet, hanem - új

63 Vö.: Petrétei, 2015, 29-30. o. Amint Till kiemeli, jelenleg a hadiállapot nem jelent sui generis különleges jogrendi alakzatot [Till, 2019 (15)].

64 A Módosítás 5. cikkéhez füzött indokolás.

65 Bár ezzel kapcsolatban megjegyzendő, hogy ha a veszélyre való reagálás lehetséges, akkor - logikus módon a bekövetkezett támadásra is lehet reagálni.

66 A gerillacsoport mint példa elsőként az Alkotmány módosításáról szóló - a váratlan támadást beiktató 1993. évi CVII. törvény indokolásában jelent meg, és azóta több alkotmánykommentár is átvette.

67 A rendkívüli állapot jelenlegi „idegen hatalom fegyveres támadásának közvetlen veszélye” fordulatát Kelemen két szempontból is bírálja: ez a tényállási elem - álláspontja szerint - egyrészt szembehelyezkedik az Alaptörvény által elfogadott nemzetközi jogi szabályanyag fogalmaival (ti. „azt sugallja, hogy az önvédelmi cselekmények megvalósítását már preemptív megkezdheti a magyar állam, ami pedig sérti a nemzetközi jogi dogmatikát”), másrészt pedig „kizárja az állam szuverenitását veszélyeztető kisebb súlyú, de mégis fenyegető külső támadások hatékony kezelhetőségét (Kelemen, 2017, 52-54. o.). A szerző által jelzett problémák közül a másodikat véleményünk szerint megoldja a Módosítás, ugyanis immár mindenfajta külső fegyveres támadás megalapozhatja a rendkívüli állapot kihirdetését. 
elemként - a „hatásában külső fegyveres támadással egyenértékủ cselekmény” is. ${ }^{68}$ Ezen utóbbi kifejezés az indokolás szerint lehet akár a kibertérből érkező olyan rendkívüli erejû́ és átfogó támadás is, amely Magyarország szuverenitása szempontjából hasonló súlyúnak tekinthetô, mint egy fegyveres támadás. ${ }^{69}$ Végezetül a megelőző védelmi helyzet „beolvasztása” abban nyilvánul meg, hogy „kollektív védelemre irányuló szövetségesi kötelezettség teljesítése" esetén is hadiállapotot kell hirdetni. ${ }^{70}$ Mindez egyben azt is jelenti, hogy a kollektív védelmi kötelezettségen kívüli szövetségesi együttmúködés főszabály szerint normál jogrendi válságkezelés keretében kerül szabályozásra..$^{71}$

Az indokolás nemcsak a váratlan támadás „sorsát” nem említi, hanem a jelenlegi terrorveszélyhelyzet jövőjére sem tér ki. ${ }^{72}$ Míg a váratlan támadásról - a jelenleg hatályos szöveg és a módosítás egybevetését követően - kijelenthető, hogy a Módosítás nyomán a hadiállapotba fog betagolódni, addig a terrorveszélyhelyzetnél már valamivel nehezebb annak megítélése, hogy az ilyen típusú helyzetet a jövőben melyik különleges jogrendi kategóriában lehet majd kezelni. Ha abból indulunk ki, hogy a terrortámadás is egyfajta támadás, úgy azt - a hadiállapot második fordulata alapján - külső fegyveres támadásnak (vagy akár ezzel egyenértékú cselekménynek) is nevezhetjük. Amennyiben viszont a terrorra mint veszélyre helyezzük a hangsúlyt, úgy a szükségállapot második fordulata - az életés vagyonbiztonságot tömeges mértékben veszélyeztetô súlyos, jogellenes cselekmény - is alkalmazhatónak tûnik, ugyanis ezek az attribútumok a terrorcselekményre is igazak. ${ }^{73}$ Összességében úgy véljük, hogy az alkotmányozó tisztább helyzetet teremtett volna, ha legalább az indokolásban utal arra, hogy a sui generis különleges jogrendi kategóriaként megszûnő váratlan támadás és a terrorveszélyhelyzet a jövőben hogyan kerül majd kezelésre. ${ }^{74}$

A szükségállapot kihirdetésére okot adó körülmények kisebb változáson estek át, ${ }^{75}$ ezeket a következő ábra foglalja össze:

68 Alaptörvény új 49. cikk (1) bekezdés b) pont.

69 A Módosítás 11. cikkéhez füzött indokolás.

70 Alaptörvény új 49. cikk (1) bekezdés c) pont.

71 A 11. Módosítás cikkéhez füzött indokolás.

72 Természetesen az is elképzelhető, hogy a terrorveszélyre vagy a terrortámadásra történő reakció a későbbiekben törvényi szinten kerül szabályozásra.

73 Vö.: Mészáros, 2017, 128. o.; Kelemen, 2017, 60. o. Utóbbi szerző úgy vélekedik, hogy a terrorveszélyhelyzet a szükségállapot egy speciálisnak nevezhető formája.

74 A másik megoldás az lett volna, ha az Alaptörvény kilencedik módosításához is készül egy olyan „fordítókulcs", amely világosan szabályozza, hogy egy esetlegesen már kihirdetett különleges jogrendre a módosított Alaptörvény mely rendelkezéseit kell alkalmazni.

75 Alaptörvény új 50. cikk (1) bekezdés. 


\begin{tabular}{|c|c|}
\hline $\begin{array}{c}\text { Szülkségállapot } \\
\text { [Alaptörvény jelenlegi szövegváltozata, } \\
\text { 48. cikk (1) bekezdés b) pont] }\end{array}$ & $\begin{array}{c}\text { Szükségállapot } \\
\text { [Alaptörvény Módosítás utáni szövegvál- } \\
\text { tozata, 50. cikk (1) bekezdés] }\end{array}$ \\
\hline $\begin{array}{c}\text { a törvényes rend megdöntésére vagy a ha- } \\
\text { talom kizárólagos megszerzésére irányuló } \\
\text { fegyveres cselekmények }\end{array}$ & $\begin{array}{c}\text { az alkotmányos rend megdöntésére, } \\
\text { felforgatására vagy a hatalom kizárólagos } \\
\text { megszerzésére irányuló cselekmény }\end{array}$ \\
\hline $\begin{array}{c}\text { az élet- és vagyonbiztonságot tömeges } \\
\text { méretekben veszélyeztetó, fegyveresen vagy } \\
\text { felfegyverkezve elkövetett súlyos, erószakos } \\
\text { cselekmények }\end{array}$ & $\begin{array}{c}\text { az élet- és vagyonbiztonságot tömeges } \\
\text { mértékben veszélyeztető súlyos, jogellenes } \\
\text { cselekmény }\end{array}$ \\
\hline
\end{tabular}

2. ábra

A szükségállapot tényállási elemeinek változása az Alaptörvényben

Forrás: a szerző sajátösszeállítása

Összességében megállapítható, hogy a Módosítás következtében valamelyest lazultak a szükségállapot kihirdetésének feltételei:

— immár nemcsak az alkotmányos (korábbi kifejezéssel: törvényes) rend megdöntésére, hanem annak „csak” a felforgatására irányuló cselekmény is megalapozhatja a szükségállapot kihirdetését;

— a tényállási elemek közül kikerültek a „fegyveres(en)”/,felfegyverkezve” kifejezések;

- az élet- és vagyonbiztonságot tömeges méretekben veszélyeztető, súlyos, erőszakos cselekménynek immár nem kell erőszakosnak, „csak” jogellenesnek lennie;

- míg az Alaptörvény hatályos változata a diszpozícióban - a jogszabályszerkesztési elôírásokra figyelemmel kissé szokatlan módon - többes számban beszél fegyveres, illetve erőszakos cselekményekról, ${ }^{76}$ addig a Módosítás - talán éppen a terrorveszélyhelyzet beolvasztása érdekében - egyes számra vált, amely arra utal, hogy akár egyetlen ilyen cselekmény is megalapozhatja a szükségállapot kihirdetését.

A szükségállapotot megalapozó körülmények tágításának az indokolás szerint az az oka, hogy az alkotmányozó fel kíván készülni a létfontosságú infrastruktúrák, illetve az információs technológia felforgató, ártó, támadó célra való alkalmazhatóságára. ${ }^{77}$

Fontos változás, hogy a szükségállapot a jövőben csak 30 napra lesz kihirdethető, de ezt az Országgyưlés a képviselők kétharmadának szavazatával 30 nappal meghosszabbíthatja, ha a kihirdetésére okot adó körülmény továbbra is fennáll. ${ }^{78}$ Ezenfelül további újítás, hogy

76 Till, 2016, 36-37. o.; Till, 2019, [21]. Az előbbi írásában a szerző szerint „[k]érdéses ugyanis, hogy például egy nagyobb horderejü, de elszigetelt [tehát egyetlen - H. A.] merénylet önmagában alkalmas-e a szükségállapot megalapozására". A Módosítás nyomán erre a kérdésre elvileg már egyértelmúen igenlő választ lehet adni. 77 A Módosítás 11. cikkéhez fúzött indokolás.

78 Alaptörvény új 50. cikk (3) bekezdés. 
a Módosítás nyomán kikerül az Alaptörvényből a Magyar Honvédség szükségállapot idején történő felhasználását lehetővé tevő rendelkezés. ${ }^{79}$

A veszélyhelyzet kihirdetésére okot adó körülmények szintén kisebb mértékben módosultak.

\begin{tabular}{|c|}
\hline $\begin{array}{c}\text { Veszélyhelyzet } \\
\text { [Alaptörvény jelenlegi szövegváltozata, } \\
\text { 53. cikk (1) bekezdés] }\end{array}$ \\
\hline $\begin{array}{c}\text { az élet- és vagyonbiztonságot veszélyeztető } \\
\text { elemi csapás vagy ipari szerencsétlenség } \\
\text { esetén }\end{array}$ \\
\hline
\end{tabular}

3. ábra

A veszélyhelyzet tényállási elemeinek változása az Alaptörvényben

Forrás: a szerző saját összeállítása

A Módosítás nyomán az elemi csapás és az ipari szerencsétlenség csak példálózó módon jelenik meg, azaz egyéb, az élet- és vagyonbiztonságot veszélyeztető súlyos esemény esetén is lehetőség nyílik veszélyhelyzet kihirdetésére. ${ }^{80}$ (Ezzel a szövegpontosítással tehát elhárulnak az Alaptörvény és a katasztrófavédelmi törvény ütközésére hivatkozó - a következő fejezetben részletesen is bemutatott - aggályok.)

Részben valószínúleg a 2020. tavaszi jogértelmezési dilemmákra is reagálva ${ }^{81}$ a Módosítás konkrét időbeli keretet szab, amikor kimondja, hogy a veszélyhelyzet - a szükségállapothoz hasonlóan - 30 napra hirdethetô ki. ${ }^{82}$ Amint az közismert, a jelenleg hatályos alaptörvényi szabályozás értelmében a veszélyhelyzet addig tart, amíg a Kormány meg nem szünteti - viszont a veszélyhelyzeti rendeletek csak 15 napig maradnak hatályban (kivéve, ha a Kormány - az Országgyưlés felhatalmazása alapján - a rendelet hatályát meghosszabbítja). A Módosítás hatálybalépését követően ez a kettősség megszúnik, és mind a veszélyhelyzet - 30 napon túli - időtartama, mind pedig a veszélyhelyzeti kormányrendeletek hatálya az Országgyưlés döntésétől függ. Ez egyrészt azt jelenti, hogy a veszélyhelyzet 30 napon túl csak akkor tartható fenn, ha az Országgyúlés felhatalmazza a Kormányt a meghosszabbítására, ${ }^{83}$ másrészt viszont a veszélyhelyzeti kormányrendeletek hatályának meghosszabbítására nem lesz szükség, ugyanis ezek egészen addig hatályban maradnak, amíg az Országgyúlés hatályon kívül nem helyezi ôket (erre bármikor lehetősége van a törvényhozásnak), vagy meg nem szünik a veszélyhelyzet. Röviden tehát: eddig a veszélyhelyzeti kormányrendeletek hatályának meghosszabbításához kellett

79 Alaptörvény 50. cikk (1) bekezdés. A változás oka nem derül ki a Módosítás indokolásából. Elképzelhető, hogy a jövőben törvényi szinten kerül majd rögzítésre egy hasonló tartalmú rendelkezés.

80 Alaptörvény új 51. cikk (1) bekezdés.

81 Erről lásd a 6. fejezet 6. pontját.

82 Alaptörvény új 51. cikk (2) bekezdés.

83 Alaptörvény új 51. cikk (3) bekezdés. 
az Országgyưlés, ezentúl viszont a veszélyhelyzet időtartamának meghosszabbításához lesz szükség a parlamenti felhatalmazásra. Álláspontunk szerint ez az újitás abból a szempontból kétségtelenül szerencsés, hogy egyszerre egyszerüsíti a Kormány helyzetét (ti. nem lesz szükség a veszélyhelyzeti rendeletek hosszabbítgatására) és növeli a parlamenti kontrollt (ti. az Országgyû́lés bármelyik veszélyhelyzeti rendeletet bármikor hatályon kívül helyezheti). ${ }^{84}$

A Módosítás veszélyhelyzetre vonatkozó rendelkezései egy további pontosító jellegú kiegészítést tesznek azzal, hogy rögzítik, hogy a veszélyhelyzet meghosszabbításához adott felhatalmazásához az Országgyûlés a jelen lévő országgyưlési képviselők kétharmadának szavazatával dönt. A hatályos szabályozás nem utal a kétharmados többségre a veszélyhelyzeti rendeletek hatályának meghosszabbítása vonatkozásában, amiből az következik, hogy ehhez elegendő az abszolút többség. ${ }^{85}$

Végezetül egy további, mindhárom különleges jogrendet érintő - az indokolásban nem említett - változásra hívjuk fel a figyelmet: a tényállások körülírását követően az egyértelmú kötelezésre utaló hirdet igét a hirdethet kifejezés váltotta fel, vagyis az Országgyúlés/Kormány ezekben a helyzetekben „csak” kihirdetheti az adott különleges jogrendet. A -het képző beszúrásából az következik, hogy az Országgyúlésnek/Kormánynak - elvileg - mérlegelési joga van a kihirdetést illetően. ${ }^{86}$

\subsection{A Kormány átalakuló szerepe}

Az Alaptörvény kilencedik módosítása nyomán különleges jogrendben a Kormánynak rendkívüli módon megnő a szerepe, és egyben a felelőssége is. A különleges jogrendi rendeletalkotás címzettje immár minden esetben a Kormány, azaz a Módosítás általános jelleggel, mindhárom különleges jogrendi helyzetre kiterjedően mondja ki, hogy a Kormány rendeletet alkothat. ${ }^{87}$ (A rendeletek jellemzői - ti. hogy abban a Kormány sarkalatos törvényben meghatározottak szerint egyes törvények alkalmazását felfüggesztheti, törvényi rendelkezésektől eltérhet, valamint egyéb rendkívüli intézkedéseket hozhat - változatlanok maradnak.) A Kormány súlyának növekedését az indokolás azzal magyarázza, hogy „a különleges jogrend kihirdetését kö-

84 Amint a 6. fejezetből kiderül, a veszélyhelyzeti kormányrendeletek meghosszabbítása több szempontból is problémásnak minősült 2020 tavaszán.

85 Annak, hogy a koronavírus elleni védekezésről szóló 2020. évi XII. törvény (a továbbiakban: Kevtv.) sarkalatosnak minősült, azaz kétharmados többséget igényelt, az volt az oka, hogy - amint a sarkalatossági záradékból (9. \$) kiderül - a törvény több olyan tárgykört [például az Alkotmánybíróság múködése (5. \$)] szabályozott, amelyek csak kétharmados többséggel módosíthatók. Azt is itt kell megjegyezni, hogy a meghosszabbítás egyáltalán nem igényel törvényi formát, hiszen az országgyúlési határozat keretében is megadható (erről lásd a 6. fejezet 6. pontját).

86 Mindez különösen azokban az esetekben bírhat relevanciával, amikor valamely különleges jogrend kihirdetéséhez szükséges körülmények mintegy objektív módon, egyértelmúen eldönthetők - például beáll a háborús helyzet. Kérdés, hogy ilyenkor az Országgyủlésnek van-e tényleges mérlegelési joga.

87 Alaptörvény új 53. cikk (1) bekezdés. Megjegyzendő, hogy a szakirodalomban már korábban is volt olyan javaslat, amely szerint minden esetben a Kormánynak kellene lennie a felhatalmazás címzettjének és a felelősség viselőjének (Farkas, 2020a, 369. o.). 
vetően gyors, operatív és mind politikai, mind jogi értelemben felelős döntéshozatal biztosítása szükséges, amire a magyar alkotmányos rendszerben a Kormány mutatkozik alkalmasnak". Mindez azt jelenti, hogy az alkotmányozó egyrészt felszámolja a mintegy 170 éves elóképpel rendelkező Honvédelmi Tanácsot, ${ }^{88}$ másrészt megszünteti a köztársasági elnök rendeletalkotási jogát. A Honvédelmi Tanács jelenlegi szerepét lényegében a Kormány fogja betölteni azzal, hogy a köztársasági elnök jogkörét a Kormány ilyenkor sem veszi át (bár megjegyzendő, hogy a köztársasági elnök jogosult a hadiállapot kihirdetésére, a szükségállapot kihirdetésére és meghoszszabbítására, valamint arra, hogy felhatalmazza a kormányt a veszélyhelyzet meghosszabbítására, ha az Országgyúlés e döntések meghozatalában akadályoztatva van). ${ }^{89}$

A Módosítás világosabb keretet teremt a kormányrendeletek parlamenti kontrollja vonatkozásában is, ugyanis általános érvénnyel, valamennyi különleges jogrendre kiterjedően rögzítésre kerül, hogy az Országgyưlés a Kormány által különleges jogrend idején a különleges jogrendre vonatkozó szabályok szerint alkotott rendeletet hatályon kívül helyezheti. ${ }^{90} \mathrm{Az}$ Alaptörvény ezt a kontrollszerepet jelenleg komplikáltabban, különleges jogrendenként eltérően szabályozza. ${ }^{91}$ A Módosítás másrészt - egy potenciális „kiskaput” bezárva - azt is tisztázza, hogy az Országgyưlés által hatályon kívül helyezett rendeletet a Kormány azonos tartalommal nem alkothatja meg újra, kivéve ha azt a körülmények jelentős változása indokolja..$^{92}$

A Módosítás azt is lehetôvé teszi a Kormánynak, hogy bizonyos esetekben már a különleges jogrend kihirdetése elött megkezdje a válsághelyzet kezelését. Erre akkor kerülhet sor, ha a Kormány már kezdeményezte a hadiállapot vagy a szükségállapot parlamenti kihirdetését, azonban még nem született meg az Országgyúlés erre vonatkozó döntése. Ezekben a - nevezzük így - előzetes rendeletekben a Kormány pontosan ugyanazokat teheti meg, mint a különleges jogrendi rendeletekben (ti. - sarkalatos törvényben meghatározottak szerint - a kihirdetésre okot adó körülmény azonnali kezeléséhez szükséges mértékben egyes törvények alkalmazását felfüggesztheti, törvényi rendelkezésektől eltérhet, valamint egyéb rendkívüli intézkedéseket hozhat). ${ }^{93} \mathrm{Az}$ előzetes rendeletek hatálya a hadiállapot vagy a szükségállapot kihirdetésére vonatkozó döntésig, de legfeljebb a kihirdetés Kormány általi kezdeményezésétől számított 60 napig, hadiállapot vagy szükségállapot kihirdetése esetén legfeljebb a hadiállapot vagy a szükségállapot megszűnéséig tart. ${ }^{94}$ Erre a kezdeményezés és a döntés közötti időszakra is vonatkoznak a - későbbiekben ismertetendő - garanciák (az Országgyuulés és az Alkotmánybíróság folyamatos múködésének szavatolása), valamint a már említett azonos tartalmú jogalkotás tilalma. ${ }^{95}$ További újítást jelent, hogy a módosítás azt a helyzetet is rendezi, amikor

88 A honvédelmi jellegú, (többnyire) kivételes hatalmi szervek bemutatására lásd: Kelemen, 2020. A szerző egyúttal arra is felhívja a figyelmet, hogy ezek a szervek csak korlátozottan tekinthetők egymás elődjeinek/utódjainak.

89 Alaptörvény új 56. cikk (1) bekezdés.

90 Alaptörvény új 53. cikk (3) bekezdés.

91 Alaptörvény 48. cikk (6) bekezdés, 50. cikk (4)-(5) bekezdés, 51/A. cikk (3) bekezdés, 53. cikk (3) bekezdés.

92 Alaptörvény új 53. cikk (3) bekezdés.

93 Alaptörvény új 54. cikk (1) bekezdés.

94 Alaptörvény új 54. cikk (3) bekezdés.

95 Alaptörvény új 54. cikk (5)-(7) bekezdés. 
a Kormány hozott ugyan előzetes rendeleteket, azonban a hadiállapot vagy a szükségállapot kihirdetésére végül nem kerül sor. Ekkor az Országgyúlés törvényt alkot a kormányrendeletekben hozott rendkívüli intézkedésekkel összefüggő szabályozási átmenetről. ${ }^{96}$

Arra is rá kell mutatni, hogy a Módosítás tisztázza azt a kérdést, hogy a különleges jogrend megszúnésekor pontosan mely kormányrendeletek vesztik hatályukat. Az Alaptörvény jelenleg a terrorveszélyhelyzet, a váratlan támadás, valamint a veszélyhelyzet esetén is úgy fogalmaz, hogy „[a] Kormány rendelete a veszélyhelyzet megszünésével hatályát veszti”. ${ }^{97} \mathrm{Ez}$ a megfogalmazás - különösen a határozott névelő miatt - azért nem szerencsés, mert nem derül ki belőle egyértelmúen, hogy a hatályvesztés valamennyi, a különleges jogrend keretében meghozott rendeletre vonatkozik (tehát azokra is, amelyeket a kormány normál jogrendben is meghozhatott volna), vagy csak azokra, amelyeket a különleges jogrendi felhatalmazás alapján hozott meg.98 A módosítás úgy tisztázza ezt a kérdést, hogy leszögezi: „A Kormány által különleges jogrend idején a különleges jogrendre vonatkozó szabályok szerint alkotott rendelet a különleges jogrend megszúnésekor hatályát veszti". ${ }^{99}$ A különleges jogrendre vonatkozó szabályok szerint alkotott rendelet kitétel egyértelmúen az utóbbi értelmezést teszi irányadóvá.

A fenti módosítások értékelését értelemszerủen megnehezíti az a tény, hogy - szerencsére - sem a Honvédelmi Tanács, sem pedig az államfó rendeletalkotásáról nincsenek tapasztalataink, vagyis az Alaptörvény módosítása csak elméletben létező, de a gyakorlatban soha nem múködő intézményeket számolt fel. Ennek megfelelően a változások értékelése során a tapasztalatok értelemszerúen nem szolgálhatnak kiindulópontul, vagyis jobbára csak elméleti síkon lehet megközelíteni ezen kérdéseket.

Ami a köztársasági elnök rendeletalkotási jogkörét illeti, kevés érv hozható fel amellett, hogy az államfő pont szükségállapot idején - azaz egy kiélezett, az állam létét fenyegető helyzetben - kapjon „válságmenedzselő” szerepet. Szente Zoltán szerint a „Magyarországon immár hagyományosan gyenge és funkciótlan államfő kiemelt szerepe már a rendkívüli és a szükségállapot tekintetében is indokolatlan - csupán szimbolikus jellegú, illetve tradíción alapul - [...]". ${ }^{100}$ A hatályos szabályozás szerint komoly államfói jogosítvány, hogy szükségállapot idején az Országgyưlés akadályoztatása esetén a köztársasági elnök dönt a Magyar Honvédség felhasználásáról, ha a rendőrség és a nem-

96 Alaptörvény új 54. cikk (4) bekezdés.

97 Alaptörvény 51/A. cikk (6) bekezdés; 52 . cikk (4) bekezdés; 53. cikk (4) bekezdés.

98 A kérdés némileg más kontextusban a 2020. tavaszi veszélyhelyzetben is felmerült. Ebben az esetben az volt a kérdés, hogy a 15 nap utáni hatályvesztés azokra a rendelkezésekre is vonatkozik-e, amelyeket a Kormány nem veszélyhelyzeti jogszabályként, hanem törvényi felhatalmazás alapján alkotott meg. Ilyen volt például a határellenőrzés visszaállítása [az élet- és vagyonbiztonságot veszélyeztető tömeges megbetegedést okozó humánjárvány megelőzése, illetve következményeinek elhárítása, a magyar állampolgárok egészségének és életének megóvása érdekében elrendelt veszélyhelyzet során teendő intézkedésekről szóló 41/2020. (III. 11.) Korm. rendelet 1. \$], amely az államhatárról szóló 2007. évi LXXXIX. törvény 16. \$ (4) bekezdés c) pontjában kapott felhatalmazáson alapult. A problémáról bővebben lásd: Salgó, 2020, 15. o.

99 Alaptörvény új 53. cikk (5) bekezdés.

100 Szente, 2020, 126. o. 
zetbiztonsági szolgálatok alkalmazása nem elegendő. ${ }^{101}$ Emellett szükségállapotban a köztársasági elnöknek kellene a honvédelmi törvényben ${ }^{102}$ meghatározott rendkívüli intézkedéseket bevezetni. ${ }^{103}$ Ezek nagyrészt olyan döntések (mint például a média korlátozása, forgalmi és utazási korlátozások, az igazságszolgáltatásra vonatkozó rendkívüli intézkedések), amelyek álláspontunk szerint egyrészt teljességgel idegenek a hazai köztársasági elnöki tisztségtől, és kétséges, hogy a napi igazgatási feladatoktól távolságot tartó, kis létszámú apparátussal rendelkező, jogi és politikai felelősséget nem viselő államfó mennyiben lenne képes adekvát döntéseket hozni szükségállapot idején (még akkor is, ha ilyen helyzetben valószínúleg folyamatos lenne a konzultáció a köztársasági elnök és a Kormány között). ${ }^{104}$ Másrészt az Alaptörvény alapján az sem világos, hogy szükségállapot idején a Kormány miért szorul háttérbe, hiszen az előbbi rendkívüli intézkedéseket a Kormány is meg tudná hozni. (Az államfó előtérbe helyezésének esetleg az lehet az oka, hogy a szükségállapotot kiváltó „belső” veszély esetén szimbolikus erôvel bír, hogy a nemzet egységét megtestesítő köztársasági elnök lesz a válságkezelés „arca”.) A köztársasági elnöknek jelenleg a rendkívüli állapot esetén is van szerepe, hiszen az ilyenkor megalakuló Honvédelmi Tanácsnak az elnöke, azonban itt egy olyan hibrid testületról van szó, amely átfogja a törvényhozó és a végrehajtó hatalmat is, ${ }^{105}$ de összességében a Kormány (tagjai) van(nak) benne többségben, ${ }^{106}$ vagyis itt közel sem lenne olyan meghatározó az államfó szerepe, mint szükségállapot idején. ${ }^{107}$

101 Alaptörvény 50. cikk (2) bekezdés.

102 A honvédelemről és a Magyar Honvédségről, valamint a különleges jogrendben bevezethetô intézkedésekről szóló 2011. évi CXIII. törvény (a továbbiakban: Hvt.).

103 Hvt. 64. \$ (3) bekezdés. Mészáros úgy fogalmaz, hogy „[b]ár a rendkívüli intézkedések megtételére a köztársasági elnök jogosult, valójában az Országgyưlés kétharmados többsége által elfogadott sarkalatos törvényben meghatározott intézkedések rendeleti úton történő elrendelésére korlátozódik a jogköre" (Mészáros, 2017, 120.). Ez a megközelítés inkább az államfő mozgásterének korlátaira helyezi a hangsúlyt, azonban arra is rá kell mutatni, hogy a Hvt. előbb hivatkozott rendelkezése számos rendkívüli intézkedés bevezetését teszi lehetővé a köztársasági elnök részére, azaz álláspontunk szerint az államfőnek meglehetősen nagy a mozgástere abban, hogy a több tucat intézkedés közül melyeket és hogyan vezeti be.

104 Vö.: Kelemen, 2017. 65. o. A szerző szerint „[a]z államfő ilyetén jogokkal való felruházása visszavezethető a polgári kori magyar jogi hagyományokra, ahol elóbb a király, majd a kormányzó birtokolt hasonló jogköröket, azonban ezen korszakban mindkettőnek erős jogi kapcsolata volt a végrehajtó hatalommal, sőt több tekintetben annak részeként fungált".

105 Vö.: Farkas-Kádár, 2016, 306. o.; Petrétei, 2015, 34-44. o.

106 Vö.: Till. 2019 [37]. Egyúttal arra is rá kell mutatni, hogy a Honvédelmi Tanácsban a tagok többsége mellett a Kormány mintegy „feloldódik”: mivel a testület ellátja a Kormány feladatait is, végső soron nemcsak a törvényeket rontanák le a Honvédelmi Tanács rendeletei, hanem egy esetleges korrekció esetén a kormányrendeleteket is „fel kellene húzni” erre a szintre.

107 Ugyanakkor a Honvédelmi Tanáccsal szemben is megfogalmazható kritika: Till szerint aggályos, hogy „éppen az állami múködés legnagyobb veszélyeztetését hivatott egy olyan állami intézmény kezelni, amelynek nincs alkalma a múködési gyakorlat megszerzésére" [Till, 2019, (37)]. Kovács további anomáliákat fogalmaz meg a Honvédelmi Tanáccsal kapcsolatban, rámutatva, hogy nem világosak a felelősségi viszonyok és a múködési kérdések (Kovács, 2015, 141-142. o.). 
Összességében megállapítható, hogy a Kormány súlya és felelőssége valóban megnő a Módosítás nyomán, és ezzel együtt a köztársasági elnök szerepe visszaszorul. Utóbbi a szükségállapot során játszott központi szerep megszüntetésében nyilvánul meg, viszont néhány területen megmaradnak az államfő jogosítványai. Így a köztársasági elnök jogosult a hadiállapot kihirdetésére, a szükségállapot kihirdetésére és - új jogkörként - meghoszszabbítására, valamint arra, hogy felhatalmazza a Kormányt a veszélyhelyzet meghosszabbítására, ha az Országgyúlés e döntések meghozatalában akadályoztatva van. ${ }^{108}$ Ezenfelül a Kormányt az államfő irányában is tájékoztatási kötelezettség terheli a különleges jogrendre vonatkozó szabályok szerint alkotott rendeletekről.

\subsection{Többletgaranciák}

Amint fentebb már utaltunk rá, a módosítás az Alaptörvénybe többletgaranciákat is beépít. Az egyik újdonság az Országgyúlésre vonatkozik: „A Kormány különleges jogrend idején köteles minden olyan intézkedést megtenni, amely az Országgyưlés folyamatos mứködését szavatolja.”109 (Sőt, a módosítás később úgy fogalmaz, hogy a Kormány már a hadiállapot vagy a szükségállapot kihirdetésének kezdeményezését követően köteles az Országgyuulés folyamatos múködését szavatoló intézkedést megtenni. ${ }^{1{ }^{10}}$ )

Az Országgyưlés folyamatos múködésével kapcsolatban 2020 tavaszán is merültek fel kérdőjelek, és a koronavírus elleni védekezésről szóló törvény által a Kormánynak biztosított általános (ellenzéki olvasatban „biankó”) felhatalmazás egyik indoka az volt, hogy „Magyarország Kormánya abban az esetben is megalkothassa és hatályában fenntarthassa a rendkívüli rendelkezéseket tartalmazó rendeleteit, ha az Országgyúlés bármely, a Covid-19-fertőzés okozta tömeges megbetegedést okozó, 2020. évben bekövetkezett humánjárvánnyal összefüggő okból nem ülésezik". ${ }^{111}$ Sőt, a törvény preambuluma is utalt arra, hogy a jogalkotó kifejezetten számol azzal a lehetőséggel, hogy az Országgyúlés ülésezése a humánjárvány következtében szünetelhet. A módosítás nyomán adott a kérdés: a Kormány vajon hogyan tudja szavatolni az Országgyúlés folyamatos múködését? Tekintve, hogy a Kormánynak közjogi szempontból lényegében nincs szerepe vagy ráhatása az Országgyưlés múködésére, itt valószínúleg az infrastruktúra biztosítására kell gondolni. A járványveszélyhelyzet rávilágított, hogy a jelenlegi jogi szabályozás abból a szempontból kétségtelenül rugalmatlan, hogy az Országgyưlés csak jelenléti módon tud múködni. ${ }^{112}$ (A Kormány számára mindez egyben

108 Alaptörvény új 56. cikk (1) bekezdés.

109 Alaptörvény új 52. cikk (3) bekezdés.

110 Alaptörvény új 54. cikk (5) bekezdés.

111 A Kevtv. általános indokolása.

112 Egy 2020 tavaszán végzett, 159 ország parlamentjének járványveszélyhelyzeti múködését vizsgáló kutatás azt vizsgálta, hogy az egyes országok mennyiben tették lehetôvé az infokommunikációs eszközök használatát a parlamentben. Az eredmények alapján a vizsgált parlamentek kb. 45\%-a engedett kisebb-nagyobb teret az elektronikus múködésnek; a többi ország (köztük Magyarország is) viszont semmilyen technológiai újítást nem vezetett be (Bar-Siman-Tov et al., 2021, 120.). 
hivatkozási alapot jelentett az Országgyuulés elektronikus szavazását és távolléti múködését szorgalmazó álláspontokkal szemben, megvédve egyúttal a Kevtv. általános felhatalmazási rendelkezését. ${ }^{113} \mathrm{~A}$ fentiek alapján tehát elképzelhető, hogy a jövőben megteremtődik az alaptörvényi/jogszabályi alapja annak, hogy az Országgyúlés ne csak jelenléti módon ülésezhessen és szavazhasson. ${ }^{114}$

A másik többletgarancia az Alkotmánybíróságot érinti: azt ugyan a jelenleg hatályos szöveg is rögzíti, hogy az Alkotmánybíróság múködése különleges jogrend esetén sem korlátozható, ${ }^{115}$ azonban a módosítás ezt kiegészíti azzal, hogy „[a] Kormány különleges jogrendben köteles minden olyan intézkedést megtenni, amely az Alkotmánybíróság folyamatos múködését szavatolja". ${ }^{116}$ A Kormány ezen kötelezettsége már a hadiállapot vagy a szükségállapot kihirdetésének kezdeményezését követően él. ${ }^{117}$ (Itt kell megjegyezni, hogy az elektronikus kommunikációs eszköz igénybevételével történő ülésezést már a Kevtv. is lehetôvé tette a testületnek. $)^{118}$

Kisebb, inkább csak szimbolikus jelentőségú az a módosítás, amelyik valamennyi különleges jogrendre vonatkozóan előírja a Kormány tájékoztatási kötelezettségét. A Kormánynak tehát a különleges jogrendre vonatkozó szabályok szerint alkotott rendeletről - beleértve a veszélyhelyzeti rendeleteket, valamint az előzetes rendeleteket is - folyamatosan tájékoztatnia kell a köztársasági elnököt, az Országgyuúlés elnökét és az Országgyưlés tárgykör szerint feladat- és hatáskörrel rendelkező állandó bizottságát. ${ }^{119}$ (A Kormánynak jelenleg csak megelőző védelmi helyzetben, ${ }^{120}$ terrorveszélyhelyzetben ${ }^{121}$ és váratlan támadás esetén ${ }^{122}$ van ilyen tájékoztatási kötelezettsége, de az első kettőben a címzettek között nem szerepel az Országgyúlés [csak az Országgyưlés tárgykör szerint feladat- és hatáskörrel rendelkező állandó bizottsága]).

113 „S még egyszer: a parlament ülésezésével kapcsolatban korábban az elektronikus szavazás és egyéb ötletek is elhangzottak. Az Alaptörvény csak arról rendelkezik, hogy a jelen lévő képviselők szavazatával hozza meg az Országgyưlés döntéseit. Van ugyan utalás arra, hogy más helyszínen is ülésezhet az Országgyưlés, de nyilván nem a virtuális térre alkotódott ez a fogalom" - mutatott rá Völner Pál, az Igazságügyi Minisztérium parlamenti államtitkára a Kevtv. országgyúlési vitája során. Elérhető: https://tinyurl.com/1bdow7nf (Letöltve: 2020 . december 1.).

114 A témakörben 2020. novemberben már született egy ellenzéki javaslat az Alaptörvény módosítására, amelynek értelmében Az Alaptörvény 53. cikke a következő (3a) bekezdéssel egészülne ki:

„(3a) Az Országgyúlés elnöke gondoskodik az Országgyúlés veszélyhelyzet ideje alatti múködéséhez és ülésezéséhez szükséges intézkedésekről. A határozatképességhez szükséges jelenlét elektronikus kommunikációs eszköz igénybevételével is biztosítható." Elérhetô: www.parlament.hu/irom41/13656/13656.pdf (Letöltve: 2020. december 1.).

115 Alaptörvény 54. cikk (2) bekezdés.

116 Alaptörvény új 52. cikk (4) bekezdés.

117 Alaptörvény új 54. cikk (7) bekezdés.

118 Kevtv. 5. \$ (2) bekezdés.

119 Alaptörvény új 53. cikk (2) bekezdés.

120 Alaptörvény 51. cikk (3) bekezdés.

121 Alaptörvény 51/A. cikk (3) bekezdés.

122 Alaptörvény 52. cikk (2) bekezdés. 
Végezetül megjegyzendő, hogy az újonnan bevezetendő garanciák sorát gyarapítja az a - fentebb már hivatkozott - rendelkezés, miszerint az Országgyúlés által hatályon kívül helyezett rendeletet a Kormány azonos tartalommal nem alkothatja meg újra (kivéve, ha azt a körülmények jelentős változása indokolja).

\section{3. Összegzés - A különleges jogrend rendszerváltás utáni evolúciója}

Amint arra a tanulmány címe is utal, a különleges jogrendre vonatkozó alkotmányos szabályozás egy sajátos utat járt be a rendszerváltás óta eltelt három évtizedben. A 4. ábra összefoglaló jelleggel illusztrálja a különleges jogrend fejlődését, rávilágítva, hogy a három kezdeti kategória előbb fokozatosan hatra emelkedett, majd a kilencedik Alaptörvény-módosítás - legalábbis mennyiségileg - visszatérést jelent a „kiinduló" 1989-es állapotokhoz.

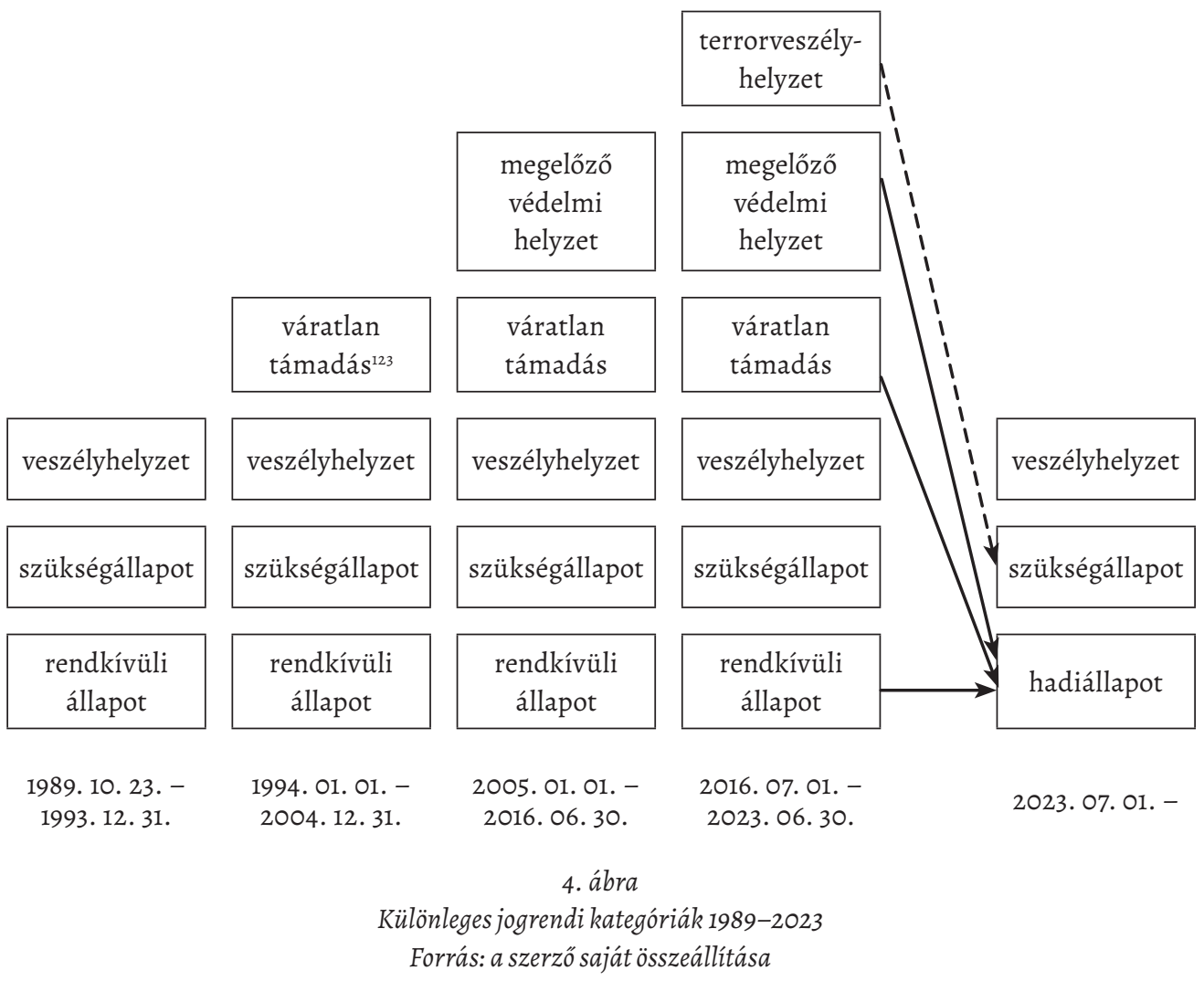

123 Itt ismét felhívjuk a figyelmet arra, hogy az Alkotmány 19/E. \$-a ugyan nem használta a „váratlan támadás” kifejezést, de az egyszerűség kedvéért az ábrában a 2012 előtti szabályozásra is ezt a kifejezést használjuk, ugyanis az Alkotmány 19/E. \$ (1) bekezdése, valamint az Alaptörvény 52. cikk (1) bekezdése lényegét tekintve megegyezik egymással. 
Az 1989-es és a 2023-ra előirányzott szabályozás nemcsak a különleges jogrendi kategóriák számában egyezik meg, hanem abban is, hogy ezek a kategóriák az alapvetố rendeltetésüket tekintve megegyeznek egymással: a rendkívüli állapot/hadiállapot a külső fegyveres (háborús), az állam szuverenitása ellen irányuló támadások elhárítására szolgál; a szükségállapot a belső eredetú veszélyek kezelését teszi lehetôvé, a veszélyhelyzet pedig az ipari-természeti jellegú katasztrófák esetén kerülhet kihirdetésre. A fentiekből azonban az is világossá vált, hogy ez a megfeleltetés egyáltalán nem jelenti azt, hogy a Módosítás tartalmi szempontból is visszatérést jelentene az 1989-es alkotmányszöveghez, hiszen a három kategória - különösen a rendkívüli állapot/hadiállapot - jelentős tartalmi változáson ment át. A fejezetből az is kiderült, hogy nemcsak az egyes tényállások módosultak, hanem az egyes szervek jogkörei is jelentősen átalakultak. Ennek megfelelően a tanulmány összegzése során ezt a két szempontot, vagyis a különleges jogrendi kategóriák számának alakulását, valamint a hatalmi centrumok kérdését járjuk körül.

Ami a különleges jogrendi kategóriák számát jelenti, a Mádl Ferenc Összehasonlító Jogi Intézet 2019-es, 19 külföldi államra kiterjedő kutatása visszaigazolta - és a jelen kötet utolsó fejezete bővebben is tárgyalja - azt a közvélekedést, hogy Magyarország valószínúleg „világrekorder" azzal, hogy alkotmányos szinten hat különböző különleges jogrendet intézményesített. ${ }^{124}$ Amint az előző fejezetben láttuk, a kiinduló három különleges jogrend az újabb és újabb típusú fenyegetések és biztonságpolitikai kihívások nyomán emelkedett hatra. Áttekintve az utólag beiktatott három különleges jogrendet, az alkotmányozó valamennyi esetben arra hivatkozott, hogy az Alkotmány/Alaptörvény aktuális rendelkezései nem alkalmasak egy adott helyzet kezelésére, és így a bevezetni kívánt új különleges jogrend voltaképpen egy „hézagot” töm be. ${ }^{125}$ A különleges jogrendi kategóriák eddigi szaporodásának fényében hogyan értékelhető tehát a Módosítás? Itt érdemes felidézni Tordai Csabának egy közelmúltban született írását: „Mára világosan kiderült, hogy olyan újabb és újabb kihívá-

124 Kádár pedig úgy fogalmaz, hogy nemzetközi összevetésben „az öt különleges jogrendi időszak meglehetősen tagoltnak tekinthetô" (Kádár, 2014, 9. o.).

$125 \mathrm{Az}$ alkotmányozó indokolása így szólt az egyes kategóriák beiktatásakor:

Váratlan támadás: „Nem rendelkezik az Alkotmány azonban idegen hatalom fegyveres támadásának nem minősülő külső fegyveres csoportok (például gerillacsoportok) váratlan betörése, vagy az ország légterének szándékos megsértése, illetve váratlan légitámadás esetén a támadás elhárítása érdekében a fegyveres erők korlátozott mérvú igénybevételéről." (Az Alkotmány módosításáról szóló 1993. évi CVII. törvényhez füzött indokolás).

Megelőző védelmi helyzet: „A minősített időszakok jelenlegi alkotmányi szabályozása hézagos, mivel nem ad lehetőséget az olyan, a megváltozott biztonságpolitikai környezetben esetlegesen felmerülő helyzetek kellő gyorsasággal történő kezelésére, amelyek a rendkívüli állapot szintjét el nem érő biztonsági fenyegetéssel járnak" (A Magyar Köztársaság Alkotmányáról szóló 1949. évi XX. törvény módosításáról szóló 2004. évi CIV. törvényhez füzött általános indokolás 3. pontja).

Terrorveszélyhelyzet: „A kialakult biztonsági környezetre figyelemmel a módosítás az Alaptörvény különleges jogrendi szabályainak kiegészítését szolgálja a terrorizmus új típusú biztonsági kihívásainak megelőzése és kezelése érdekében, [...]." (Magyarország Alaptörvényének hatodik módosításához füzött általános indokolás). 
sokkal szembesülünk időről időre, hogy ismeretelméletileg nagyon nehéz pontos definíciót adni a kihívásokra - mivel pedig maguk a kihívások nem pontosan ismertek előre, lényegében lehetetlen előre pontos tényállással meghatározni, hogy milyen rendkívüli intézkedésekre lehet szükség.” Majd arra figyelmeztetett, hogy „középtávon a minősített időszakokra vonatkozó egész alkotmányos konstrukciónkat - más alkotmányos demokráciák példájához igazodva - újra kell gondolni”. ${ }^{126}$ Kelemen Roland is a túlszabályozottságra hivatkozik, és „fogalmilag kusza alkotmányos helyzet"-ről ír, mihamarabbi felülvizsgálatot sürgetve. ${ }^{127}$ Farkas Ádám a különleges jogrendi kategóriák bővüléséről úgy vélekedik, hogy „[e]z a fajta bővítő megközelítés annak ellenére, hogy esetről esetre elvett a szabályozási rendszer konzisztenciájából és a szabályozás átláthatóságából és ezáltal az alkalmazhatóságából, értelemszerûnek mutatkozott évtizedeken keresztül a sajátos történelmi és biztonsági helyzet miatt”. ${ }^{128}$ Ugyanő egy másik munkájában pedig arra mutat rá, hogy a jogalkotó „az 1989-es rendszerváltozás óta inkább a szabályozással való kontrollálás és állami önkorlátozás módszerét választotta a rugalmas, de megfelelő ellensúlyokkal és intézményi kontrollokkal operáló megoldás helyett. Ennek a szabályozási szemléletmódnak a megnyilatkozása az a végletekig feszített kazuisztika a védelmi és biztonsági szabályozásban [...]". ${ }^{129}$

A Módosítás - ebből a szempontból - annyiban biztosan előrelépést jelent, hogy a tényállások inkluzívabbá váltak (különösen a hadiállapot esetén, és kisebb mértékben a szükséghelyzetnél és a veszélyhelyzetnél). ${ }^{130} \mathrm{Az}$ alkotmányozó által kitűzött átláthatóság egyértelmúen javult azzal, hogy a három katonai típusú különleges jogrend összevonásra került, és az új tényállásokat álláspontunk szerint sikerült úgy megfogalmazni, hogy a jövőben a három korábbi helyzet mindegyike kezelhető legyen az új alaptörvényi szabályozás keretében. (Bizonytalanság - amint fentebb utaltunk rá - egyedül a terrorveszélyhelyzet ,jogutódlása" kapcsán merülhet fel.) Szintén tanulságos Csink Lóránt meglátása, amely szerint „[a] különleges jogrendre okot adó jelenségek változékonysága nem teszi lehetôvé olyan szabályozás kialakítását, amely egyszerre részletes és stabil". ${ }^{131} \mathrm{Az}$, hogy a Módosítás nyomán kevésbé részletessé vált-e a szabályozás, részben értelmezés kérdése (hiszen a részletesség nem kizárólag a kategóriák számától függ), de talán okkal bízhatunk abban, hogy a most kialakított rendszer időtállóbb lesz, mint az 1989-es vagy a 2011-es struktúra. Az új különleges rendi rész kétségtelenül letisztultabb, áttekinthetőbb és logikusabb lett, kevesebb ismétlődő rendelkezéssel. A hadiállapot és a szükségállapot a kezelését tekintve közelebb került egymáshoz, ami elsősorban a Honvédelmi Tanács kiiktatásával és a köztársasági elnök szükségállapoti szerepének jelentős csökkentésével valósult meg.

126 Tordai, 2020.

127 Kelemen, 2017, 68. o.

128 Farkas, 2020a, 352-353. o.

129 Farkas, 2020b, 15. o.

130 Vö.: Farkas Ádám javaslatával (Farkas, 2020a, 369. o.).

131 Csink, 2017, 15. o. 
Egyúttal azonban arra is rá kell mutatni, hogy aligha határozható meg egzakt módon az - alkotmányos szinten szabályozandó - különleges jogrendek „ideális” száma. A több különleges jogrendi kategória mellett elsősorban az az érv szól, hogy minél több a kategória, a kormányzat, - elvileg - annál inkább tudja érvényesíteni az arányosság követelményét, vagyis azt az elvárást, hogy az adott válság kezelésére alkalmas különleges jogrendek közül a lehetô legenyhébb kerüljön bevezetésre. ${ }^{132}$ Ezzel párhuzamosan egy tagoltabb rendszer nagyobb fokú adaptációt tesz lehetővé. ${ }^{133}$ A különleges jogrendi helyzetek nagy száma ugyanakkor értelemszerúen bonyolultabb szabályozással jár együtt, ami - ahogyan fentebb utaltunk rá - szintén kifogás tárgya lehet. Álláspontunk szerint a Módosítás által végrehajtott kategóriacsökkentés sem jelenti okvetlenül az arányosság követelményének sérelmét, hiszen a törvényi szabályozás módosításával megfelelő garanciákat lehet a rendszerbe építeni.

Az elmúlt évtized különleges jogrendi szabályozásának a másik értékelési szempontja a jogkörök elosztása lehet. E helyütt érdemes felidézni Kukorelli István gondolatát: „Visszaemlékezve a háromszögletû́ Nemzeti Kerekasztal tárgyalásaira, igenis ki kell mondanunk, hogy a fegyveres erő tekintetében ott és akkor az operativitás számunkra nem bírt jelentőséggel a hatalommegosztás és az alkotmányos korlátozás követelményei mellett." ${ }^{134}$ Ennek megfelelően a rendszerváltás idejének bizonytalansága, a „túlbiztosításra” való hajlam a különleges jogrendi szabályozáson is rajta hagyta a lenyomatát. Mindez főként a végrehajtó hatalommal (a Kormánnyal) szembeni bizalmatlanságban nyilvánult meg, ${ }^{135}$ hiszen pontosan a két legsúlyosabb különleges jogrend, vagyis a rendkívüli állapot és a szükségállapot szabályozása lett úgy kialakítva, hogy a Kormány látványosan háttérbe szorult. Az „ideiglenes történelmi szituáció indulatai által generált szabályok ${ }^{{ }^{136}}$ aztán évtizedeken át nem módosultak érdemben, bár az kétségtelen, hogy a később felállított különleges jogrendek a Kormány súlyának növekedését és mozgásterének bővülését hozták magukkal. Till Szabolcs ezzel kapcsolatban teszi fel a kérdést, miszerint a különleges jogrendi hatalomgyakorlás hatékonysága szempontjából mennyiben védhetô a döntéshozatali centrumok váltakozása. ${ }^{137}$

132 Vö.: Jakab, 2009, 635. o. Így például a Módosítás nyomán a jövőben akkor is hadiállapotot kell/lehet majd kihirdetni, amikor a jelenlegi helyzet alapján elegendő lenne a megelőző védelmi helyzet bevezetése. Egy esetleges terrortámadás esetén pedig szükségállapotot vagy hadiállapotot kellene kihirdetni, amelyek jóval nagyobb hatalomkoncentrációval és jogkorlátozással járnak, mint a mostani terrorveszélyhelyzet (vö.: Petrétei, 2015, 30. o.).

133 Ezzel kapcsolatban Till - a hazai különleges jogrendi szabályozás összetettségét elemezve - arra mutat rá, hogy „az alapvetően megváltozott biztonságpolitikai környezethez képest a rendszer adaptálhatóságának foka már meghaladja a rendszer elemeinek mennyiségi csökkentéséből önmagából nyerhető előnyöket" (Till, 2017, 73. o.). A szerző egyúttal arra is figyelmeztet, hogy az alkotmányos rendszer kialakítása során a jogi érvelések szerepe nem lehet kizárólagos.

134 Kukorelli István 2015-ös szóbeli közlését idézi: Farkas, 2015, 6. o.

135 Farkas-Kádár, 2016, 305-306. o. Farkas szerint visszatérő probléma, hogy a viták során a mindenkori kormánnyal szembeni bizalmatlanság erősebb, mint a fegyveres védelem kérdéseinek érdemi vonatkozásai (Farkas, 2016b, 174. o.).

136 Farkas, 2016a, 29. o.

137 Till, 2019, 23. sz. jegyzet. 
Amint fentebb kifejtettük, a Módosítás szakít a hatalmi ágak közti határokat összemosó hibrid megoldásokkal, ${ }^{138}$ vagyis a hatalmi centrumok hármasságával (Honvédelmi Tanács köztársasági elnök - Kormány), és - a gyorsasági, az operativitási, valamint a politikai és jogi felelősségi szempontok alapján - mindhárom különleges jogrend idején a Kormányra osztja ki a „válságmenedzser” szerepét.

Zárásként két további szempontot kívánunk hangsúlyozni. Egyrészt a különleges jogrend az alkotmányos rendszerünknek egy egyedülállóan sajátos eleme abból a szempontból, hogy - szerencsére - meglehetősen kevés gyakorlati tapasztalat áll rendelkezésünkre, hiszen a hat meglevő kategóriából egyedül a veszélyhelyzet került már kihirdetésre. Ennek megfelelően talán azt sem túlzás állítani, hogy a fentebb elemzett, a kategóriák „optimális" száma, valamint az egyes szereplők kompetenciája körül forgó viták és dilemmák túlságosan elméleti jellegúek (másik kifejezéssel éve: spekulatívak), hiszen a vizsgálat tárgya egy olyan szabályozás, amely túlnyomórészt eddig csak „papíron” létezett, és így a „Beváltotta-e a Honvédelmi Tanács a hozzá füzött reményeket?" jellegú kérdések nyilvánvalóan értelmetlenek. Másrészt arra is rá kívánunk mutatni, hogy a különleges jogrendről, illetve az ebben bekövetkező változásokról kizárólag az Alaptörvény szövegét alapul véve csak egy korlátozott képet lehet kapni. Jelen kötet kéziratának véglegesítésekor vált ismertté, hogy az Alaptörvény kilencedik módosítása egy átfogó védelmi-biztonsági reform nyitányaként szolgál..$^{139}$

\section{Irodalomjegyzék}

Csink, L. (2017) 'Mikor legyen a jogrend különleges?', Iustum Aequum Salutare, 13(4), 7-16. o. FARKAS, Á. (2015) 'Az állam fegyveres védelmi rendszerének kérdései a kortárs fenyegetések tükrében', Katonai Jogi és Hadijogi Szemle, 3(1), 5-51. o.

138 Farkas, 2020b, 16. o.

139 Jelen kötet már a szakmai lektoráláson is átesett, amikor a Kormány - 2021. május 11-én - az Országgyúlés részére benyújtotta a védelmi és biztonsági tevékenységek összehangolásáról szóló T/16221. sz. törvényjavaslatot. Elérhetô: www.parlament.hu/irom41/16221/16221.pdf (Letöltve: 2021. május 15.). Amint a javaslat általános indokolása a következőképp fogalmaz: „Az Alaptörvény kilencedik módosításának, a 21. századra jellemző új típusú válságok, hibrid fenyegetések hatékony kezelésének és az alapvető jogok minél szélesebb körú védelmének hármas feltételrendszere szükségessé tette a védelmi és biztonsági feladatok és a különleges jogrend idején bevezethető intézkedések jogi szabályozásának megújítását. A jelen törvény e három szempontnak egyszerre kíván eleget tenni. Elfogadása egyedülálló módon járulna hozzá az egyéni és az össztársadalmi biztonságtudat erősítéséhez, a biztonságérzet fokozásához, és végső soron a tényleges biztonság minél nagyobb mértékủ szavatolásához." A javaslat célja többek között az, hogy a különleges jogrend kihirdetését közvetlenül megelőző intézkedések körét, illetve a hadiállapot vagy a szükségállapot kihirdetésének kezdeményezését követôen, továbbá különleges jogrendben bevezethetô intézkedéseket újraszabályozza. 
FARKAS, Á. (2016a) 'Magyarország katonai védelmének polgári evolúciója és alkotmányos alapvonalai' in Farkas, Á., Kádár, P. (szerk.) Magyarország katonai védelmének közjogi alapjai. 1. kiadás. Budapest: Zrínyi Kiadó

FARKAS, Á. (2016b) ‘Gondolatok a terrorveszélyhelyzetről', Szakmai Szemle, 2016/3, 174-189. o.

FARKAS, Á. (2020a) 'Egy lehetséges narratíva a védelemszabályozási szemléletünk megúításához' in Farkas, Á., Kelemen, R. (szerk.) Szkülla és Kharübdisz között-Tanulmányok a különleges jogrend elméleti és pragmatikus kérdéseiról, valamint nemzetközi megoldásairól. 1. kiadás. Budapest: Magyar Katonai Jogi és Hadijogi Társaság

FARKAS, Á. (2020b) ‘Gondolatok a koronavírus-járvány és a védelmi, biztonsági szabályozás kölcsönhatásairól', Belügyi Szemle, (68)5, 9-22. o.

FARKAS, Á., KÁDÁR, P. (2016) 'A különleges jogrendi szabályozás fejlődése és katonai védelmi vonatkozásai' in Farkas, Á., Kádár, P. (szerk.) Magyarország katonai védelmének közjogi alapjai. 1. kiadás. Budapest: Zrínyi Kiadó

FARKAS, Á., Till Sz. (2016) 'A honvédelmi alkotmány és alkotmányosság alapkérdései Magyarországon’ in Farkas Á., Kádár P. (szerk.) Magyarország katonai védelmének közjogi alapjai. 1. kiadás. Budapest: Zrínyi Kiadó

JAKAB, A. (2009) 'Az Országgyứlés akadályoztatása különleges állapotokban' in Jakab, A. (szerk.) Az Alkotmány kommentárja I. 1. kiadás. Budapest: Századvég

JAKAB, A. (2011) Az új Alaptörvény keletkezése és gyakorlati következményei. 1. kiadás. Budapest: HVG-ORAC

JAKAB, A., TilL, Sz. (2019): 'A különleges jogrend' in Trócsányi, L., Schanda, B., Csink, L. (szerk.) Bevezetés az alkotmányjogba. Az Alaptörvényés Magyarország alkotmányos intézményei. 6. kiadás. Budapest: HVG-ORAC

KÁDÁR, P. (2014) 'Sarkalatos átalakulások: A kétharmados/sarkalatos törvények változásai a honvédelem területén 2010-2014', MTA Law Working Papers, 2014/36. [Online]. Elérhetô: https://jog.tk.hu/mtalwp/sarkalatos-atalakulasok-a-ketharmadossarkalatos-torvenyekvaltozasai-a-honvedelem-teruleten-2010-2014?download=pdf (Letöltve: 2020 . december 10.)

KELEMEN, R. (2017) 'Az Alaptörvény különleges jogrendi rendszerének egyes dogmatikai problémái - kitekintéssel a visegrádi államok alkotmányának kivételes hatalmi szabályaira', Katonai Jogi és Hadijogi Szemle, 2017/1-2, 37-68. o.

Kelemen, R. (2020) 'A mítoszokon túl - önképú kivételes hatalmi szervek a magyar alkotmánytörténetben (A Honvédelmi Bizottmánytól a Honvédelmi Tanácsig)' in Farkas, Á., Kelemen, R. (szerk.) Szkülla és Kharübdisz között-Tanulmányok a különleges jogrend elméleti és pragmatikus kérdéseirōl, valamint nemzetközi megoldásairól. 1. kiadás. Budapest: Magyar Katonai Jogi és Hadijogi Társaság

KovÁcs, I. (2015) 'A békeidőszaki válságok fegyveres kezelésének közjogi aspektusa', Katonai Jogi és Hadijogi Szemle, 2015/1, 115-147. o. 
LÁszLó, V. (2018) 'Az Alaptörvény hatálybalépését követő és közvetlenül azt megelőző időszaki különleges jogrend hazai szabályozásának összehasonlító elemzése', Hadtudományi Szemle, 11(4), 366-385. o.

MÉszÁros, G. (2017) ‘,Alkotmány, válságban” - a különleges helyzetek kezelésének dimenziói az Alaptörvény elfogadásától napjainkig', Jura, 2017/2, 118-133. o.

Ősze, Á. (2018) 'Analízis a magyar különleges jogrendi szabályozás hatékonyságáról', Diskurzus, $8(2), 33-44.0$.

Petrétei, J. (2015) A köztársasági elnök rendkívüli állapottal összefüggő feladat- és hatáskörei, Állam-és Jogtudomány, 56(4), 24-44. o.

Bar-Siman-Tov, I., Rozenberg, O., BenoÏt, C., Waismel-Manor, I., Levanon, A. (2021) 'Measuring Legislative Activity during the Covid-19 Pandemic: Introducing the ParlAct and ParlTech Indexes', International Journal of Parliamentary Studies, 1(1), 109-126. o.

SÁGVÁRI, Á. (2016) Különleges jogrenddel a terror ellen - kitekintés az európai gyakorlatra [Online]. Elérhető: https://jog.tk.hu/blog/2016/o2/kulonleges-jogrenddel-a-terror-ellen (Letöltve: 2020. november 10.)

SALGó, L. P. (2020) 'A hazai veszélyhelyzeti jogalkotás a kodifikátor szemével', Fontes Iuris, 6(2), 8-18. o.

SimicsKó, I. (2016) 'A terrorizmus elleni védelem fokozása a különleges jogrendi kategóriák bővítésével', Hadtudomány, 2016/3-4, 100-113. o.

SZENTE, Z. (2020) 'A 2020. március 11-én kihirdetett veszélyhelyzet alkotmányossági problémái', Állam-és Jogtudomány, 61(3), 115-139. o.

SzILVÁsy, Gy. P. (2019) 'A különleges jogrend és a rendeletalkotás', Katonai Jogi és Hadijogi Szemle, 2019/1, 105-131. o.

TiLL, Sz. (2016) 'Alkotmányos változatok migránsokra és terrorra', Katonai Jogi és Hadijogi Szemle, 2016/1-2, 7-63. o.

TiLL, Sz. (2017) 'A különleges jogrendi kategóriarendszer egyszerúsítésének jövőbeli esélyei', Iustum Aequum Salutare, 13(4), 55-75. o.

TiLL, Sz. (2019): 'Különleges jogrend' in Jakab, A., Fekete, B. (szerk.) Internetes Jogtudományi Enciklopédia [Online]. Elérhetô: http://ijoten.hu/szocikk/kulonleges-jogrend (Letöltve: 2020. november 16.)

TORDAI, Cs. (2020) A közjog határai a járványveszély idején [Online]. Elérhető: https:// igyirnankmi.atlatszo.hu/2020/03/16/a-kozjog-hatarai-a-jarvanyveszely-idejen/ (Letöltve: 2020. október 5.) 


\section{A 2020-as Covid-veszélyhelyzet alkotmányjogi szemmel ${ }^{1}$}

\section{HORVÁTH ATTILA}

\section{A Covid-19 elötti veszélyhelyzetek}

Bár az Alaptörvény jelenleg hat különböző különleges jogrendi tényállást ismer, ezek közül - hozzátehetjük: szerencsére - egyedül a veszélyhelyzet hatályosult. ${ }^{2}$ A 2020. március 11-én kihirdetett veszélyhelyzet nem az első volt Magyarországon - annyira nem, hogy a Kormány a rendszerváltás óta nem kevesebb mint 16 alkalommal hozott már ilyen döntést. Amint a 3. táblázatból kitúnik, a veszélyhelyzetre okot adó körülmény 15 alkalommal az árvíz és a belvíz volt, ${ }^{3}$ egyszer pedig - a 2010-es kolontári iszapkatasztrófa nyomán - ipari baleset miatt kellett veszélyhelyzetet hirdetni.

1 Jelen fejezet a szerző A veszélyhelyzet közjogi és jogalkotási dilemmái-mérlegen az Alaptörvény 53. cikke címû, a Közjogi Szemle 2020/4. számában megjelent tanulmányának bővített és aktualizált változata.

2 Till, 2019, [14].

3 A 15 ár-/belvizes veszélyhelyzet valójában kevesebb, hét időszakra vonatkozik, azonban a Kormány egyes esetekben - akár néhány nap különbséggel - több veszélyhelyzetet kihirdető rendeletet is kiadott, többnyire eltérő területi hatállyal.

Dr. Horváth Attila, PhD

attila.horvath@mfi.gov.hu

vezető kutató (Mádl Ferenc Összehasonlító Jogi Intézet)

adjunktus (Nemzeti Közszolgálati Egyetem Államtudományi és Nemzetközi Tanulmányok Kar, Alkotmányjogi és Összehasonlító Közjogi Tanszék)

Horváth, A. (2021) 'A 2020-as Covid-veszélyhelyzet alkotmányjogi szemmel' in Nagy, Z., Horváth, A. (szerk.) A különleges jogrend és nemzeti szabályozási modelljei, 149-173. o. Budapest: Mádl Ferenc Összehasonlító Jogi Intézet.

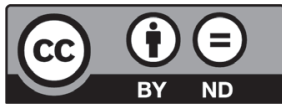




\begin{tabular}{|c|c|c|c|c|}
\hline & $\begin{array}{l}\text { Veszélyhelyzetet kihirdető } \\
\text { kormányrendelet }\end{array}$ & $\begin{array}{l}\text { Veszélyhely- } \\
\text { zetre okot adó } \\
\text { körülmény }\end{array}$ & Területi hatály ${ }^{4}$ & $\begin{array}{c}\text { Hatály } \\
\text { idótartama }\end{array}$ \\
\hline 1. & 47/2000. (IV. 10.) Korm. rendelet & árvíz & 9 megye & 32 nap \\
\hline 2. & 40/2001. (III. 6.) Korm. rendelet & árvíz & 1 megye & n. a..$^{5}$ \\
\hline 3. & 176/2002. (VIII. 15.) Korm. rendelet & árvíz & 3 megye és a fôváros & 6 nap $^{6}$ \\
\hline 4. & 76/2006. (IV. 3.) Korm. rendelet & árvíz & Duna és Ipoly egyes szakaszai & 7 nap $^{7}$ \\
\hline 5. & 87/2006. (IV. 14.) Korm. rendelet & árvíz & Tisza egyes szakaszai & 11 nap \\
\hline 6. & 101/2006. (IV. 25.) Korm. rendelet & árvíz & Tisza egyes szakaszai & 14 nap \\
\hline 7. & 183/2010. (V. 17.) Korm. rendelet & árvíz & 1 megye & 8 nap \\
\hline 8. & 186/2010. (VI. 2.) Korm. rendelet & árvíz és belvíz & 1 megye & 15 nap \\
\hline 9. & 187/2010. (VI. 2.) Korm. rendelet & árvíz & 1 megye & 7 nap \\
\hline 10. & 188/2010. (VI. 3.) Korm. rendelet & árvíz és belvíz & 2 megye & 14 nap \\
\hline 11. & 189/2010. (VI. 4.) Korm. rendelet & árvíz és belvíz & 8 megye & 13 nap \\
\hline 12. & 245/2010. (X. 6.) Korm. rendelet & ipari baleset & 3 megye & 267 nap \\
\hline 13. & 1/2011. (I. 12.) Korm. rendelet & árvíz & 1 megye & 43 nap \\
\hline 14. & 15/2011. (II. 24.) Korm. rendelet & árvíz & 1 megye & n. a $^{8}$ \\
\hline 15. & 177/2013. (VI. 4.) Korm. rendelet & árvíz & 3 megye és a fôváros & 46 nap \\
\hline 16. & 191/2013. (VI. 10.) Korm. rendelet ${ }^{9}$ & árvíz & 5 megye & 40 nap \\
\hline
\end{tabular}

3. táblázat

A 2020 elött kihirdetett veszélyhelyzetek jellemzöi

Forrás: a szerző saját összeállítása

4 A területi hatály csak hozzávetőlegesen, egyszerűsítve került feltüntetve a táblázatban (a járási szintủ megjelölést mellőztük).

5 A 40/2001. (III. 6.) Korm. rendeletet formálisan csak 2004. május 1-jével - egy átfogó deregulációs jogszabály [105/2004. (IV. 27.) Korm. rendelet] keretében - helyezték hatályon kívül, de a veszélyhelyzet értelemszerủen nem állt fenn több mint három éven át. (A jogalkotó tehát egyszerúen csak „megfeledkezett” a veszélyhelyzetet kihirdető kormányrendelet hatályon kívül helyezéséről.)

6 A veszélyhelyzetet a 179/2002. (VIII. 21.) Korm. rendelet ugyan 2002. augusztus 21-i hatállyal feloldotta, azonban a veszélyhelyzetet kihirdető kormányrendeletet csak az előbbi lábjegyzetben említett deregulációs kormányrendelet helyezte hatályon kívül.

7 A veszélyhelyzetet a 85/2006. (IV. 10.) Korm. rendelet ugyan 2006. április 10-i hatállyal feloldotta, azonban a veszélyhelyzetet kihirdető kormányrendeletet csak a 118/2008. (V. 8.) Korm. rendelet helyezte hatályon kívül.

8 A 15/2011. (II. 24.) Korm. rendeletet formálisan csak 2014. szeptember 5-ével - egy átfogó deregulációs jogszabály [222/2014. (IX. 4.) Korm. rendelet] keretében - helyezték hatályon kívül, de a veszélyhelyzet természetesen ezúttal sem állt fenn három és fél éven át.

9 A kormányrendelet formailag egy módosító jogszabály volt, azonban egyúttal veszélyhelyzetet is hirdetett. 
Annak, hogy a médiában - és esetenként a szakirodalomban is ${ }^{10}$ - találkozhattunk olyan állításokkal, hogy ez volt az első kihirdetett veszélyhelyzet - vagy általában különleges jogrend -, valószínűleg az lehet az oka, hogy a Covid-19 miatti veszélyhelyzet a jelentőségét, a következményeit és nem utolsósorban az általa kiváltott közjogi-politikai vitákat tekintve eddig egyedülálló fejleménynek bizonyult hazánkban, és természetesen gyökeresen különbözik a korábbiaktól.

Egyrészt a 2020 előtti veszélyhelyzetek területi hatálya minden esetben egy-egy körülhatárolt földrajzi egységre (többnyire egy vagy több megyére vagy járásra) terjedt ki, azonban a Covid-19 miatti veszélyhelyzet országos hatállyal került kihirdetésre, azaz egyfajta „általános veszélyhelyzet ${ }^{{ }^{11}}$ volt. Másrészt a korábbi veszélyhelyzetek - a kolontári iszapkatasztrófa kivételével - jóval rövidebb idôtartamra korlátozódtak, míg a járvány miatti veszélyhelyzet 99 napig tartott. A harmadik - és a legfontosabb - különbség a veszélyhelyzettel járó intézkedésekhez kötődik. A korábbi kihirdető rendeletek által bevezetett rendkívüli intézkedések értelemszerúen az árvíz-/belvízveszéllyel szembeni védekezéshez - mint egy lokális problémához - kapcsolódó rendelkezések voltak (így például a közlekedés korlátozása, kitelepítés, közterületi rendezvény vagy nyilvános gyưlés megtiltása, szabad mozgás korlátozása), amelyek ugyan mutatnak részbeni átfedést a 2020-as rendkívüli intézkedésekkel, azonban a lakosságnak egy viszonylag szúk körét érintették. A vírus miatti veszélyhelyzet viszont az állampolgárok széles körének mindennapjait, az állam és a gazdaság múködését alapvetően befolyásoló, hosszú távú hatásokkal járó időszaknak bizonyult - és bizonyul napjainkban is.

A veszélyhelyzet és annak életünk szinte minden szegmensére kiható következményei természetesen rövidesen tudományos vizsgálatok tárgyává is váltak. A veszélyhelyzet értelemszerúen ezer szállal kötődik a joghoz, így a jogtudomány múvelői is látványosan növekvő érdeklődést tanúsítanak a korábban talán némileg elhanyagolt témakör iránt. ${ }^{12}$ Ebben a fejezetben a 2020. márciustól decemberig tartó időszak közjogi és jogalkotási dilemmáira fókuszálunk, különös tekintettel az Alaptörvény veszélyhelyzetet szabályozó 53. cikkére. (A veszélyhelyzet bevezetésének és a veszélyhelyzeti jogalkotásnak jóval több alkotmányjogi problémája van, mint amennyire ki fogunk térni, így a fejezet természetesen nem minősül teljes körü áttekintésnek.)

A következőkben elsőként azt a kérdést járjuk körül, hogy egyáltalán szükség volt-e veszélyhelyzet kihirdetésére. Ezt követôen az Alaptörvény, valamint a katasztrófavédelemról és a hozzá kapcsolódó egyes törvények módosításáról szóló 2011. évi CXXVIII. törvény (Kat.) kapcsolatát és valószínűsíthetô ütközését tárgyaljuk; majd a veszélyhelyzeteket kihirdető rendeleteket vizsgáljuk. A fejezet 5. pontja az Alaptörvény veszélyhelyzetet szabályozó 53. cikkének belső koherenciáját elemzi, majd a veszélyhelyzet(i kormányrendeletek) meghoszszabbításával kapcsolatban felmerülő értelmezési problémákat vázoljuk fel. Az összegzést

10 Így például Mészáros „a rendszerváltás utáni Magyarországon először bevezetett különleges jogrend”-ről ír (Mészáros, 2019, 69. o.).

11 Balázs-Hoffman, 2020, 1. o.

12 Lásd például a Glossa Iuridica folyóirat Jog és erkölcs címü különszámát vagy a Társadalomtudományi Kutatóközpont Jogtudományi Intézet Epidemiológia és jogtudomány című kutatási projektjét. 
követően röviden kitérünk az Alaptörvény kilencedik módosítására is, amelyet a jelen kötet kéziratának lezárásakor fogadott el az Országgyưlés, és amely gyökeresen átalakítja a különleges jogrendre vonatkozó szabályozást, és egyben - amint látni fogjuk - a tanulmány által felvetett problémák egy részére is megoldást kínál.

\section{Szükség volt-e veszélyhelyzet kihirdetésére?}

A veszélyhelyzet 2020. március 11-i bevezetését követően rövidesen megjelentek azok a szakmai álláspontok, amelyek szerint a járványra hivatkozva egyrészt szükségtelen és indokolatlan a különleges jogrend kihirdetéséhez folyamodni, másrészt pedig a Kormánynak eleve nem is lett volna jogi lehetősége a különleges jogrend kihirdetésére, ugyanis a járvány nem alapozhatja meg a veszélyhelyzet bevezetését. A következőkben az előbbi ellenérvet vizsgáljuk meg, majd a 3. pontban az utóbbi álláspontot tárgyaljuk.

A veszélyhelyzet bevezetését szükségtelennek és indokolatlannak tartó álláspontok ${ }^{13}$ arra hivatkoztak, hogy a járvány normál jogrendi körülmények között is kezelhetô lett volna, ugyanis ehhez az egészségügyi törvényben ${ }^{14}$ megtalálhatók a megfelelố rendelkezések. Az Eütv. a népegészségügyi fejezetben egyrészt külön alcím alatt foglalkozik a járványüggyel, ${ }_{15}^{15}$ másrészt pedig a törvény 2012. január 1-je óta szabályozza az úgynevezett egészségügyi válsághelyzetet és az egészségügyi veszélyhelyzeti ellátást. ${ }^{16} \mathrm{Ami}$ az Eütv. járványügyi rendelkezéseit illeti, kétségtelen, hogy a jogszabály számos korlátozásra ad lehetőséget, ráadásul - mutat rá a kommentár - „[a] hatályos magyar közrendi jellegú járványügyi szabályozás hagyományosan és európai összehasonlításban is meglehetősen szigorú. A szabályozás imperativitását tekintve nemcsak a már kialakult járványügyi veszélyhelyzet esetében, hanem a preventív ellátások igénybevételére kötelezés területén is kifejezetten »aktivista «. ${ }^{{ }_{17} 7} \mathrm{Az}$ Eütv. értelmében a járványügyi tevékenység célja - többek között a fertőző megbetegedések, a járványok megelőzése és leküzdése, ${ }^{18}$ és ennek érdekében a következő jogosítványok állnak a hatóságok rendelkezésére (a felsorolás nem teljes körü)::19

— az egyén személyes szabadsághoz való jogának korlátozása; ${ }^{20}$

- betegjogok korlátozása; ${ }^{21}$

13 Lásd például: Mészáros, 2019; Lattmann, 2020.

$14 \mathrm{Az}$ egészségügyről szóló 1997. évi CLIV. törvény (Eütv.).

15 Eütv. III. fejezet 6. cím.

16 Eütv. XIV. fejezet. 2012 előtt „katasztrófa-egészségügyi ellátás” elnevezéssel tartalmazott hasonló rendelkezéseket.

17 Dósa-Hanti-Kovácsy, 2016, 154. 0.

18 Eütv. 56. \$(1) bekezdés.

19 A következőkben az Eütv.-nek a veszélyhelyzet kihirdetésekor hatályos szövegváltozatát vesszük alapul, hiszen a 2020. márciusi jogi szabályozást vizsgáljuk. Az Eütv. 2020. júniusi módosítása a járványügyi rendelkezéseket is kiegészítette, bevezetve például a hatósági házi karantén intézményét (a veszélyhelyzet megszúnésével összefüggő átmeneti szabályokról és a járványügyi készültségről szóló 2020. évi LVIII. törvény 309. \$).

20 Eütv. 56. $\$(2)$ bekezdés $a$ ) pont $a a$ ) alpont.

21 Eütv. 56. $\$(2)$ bekezdés $a$ ) pont $a b$ ) alpont és $b$ ) pont. 
- a törvényben meghatározott intézkedések tűrésére, illetve megtételére kötelezés;22

- járványügyi elkülönítés; ${ }^{23}$

— járványügyi megfigyelés; ${ }^{24}$

- járványügyi zárlat; ${ }^{25}$

— járványügyi ellenőrzés; ${ }^{26}$

— személy felkutatása járványügyi intézkedés végrehajtása érdekében. ${ }^{27}$

Az Eütv. az Egyéb járványügyi intézkedések alcím alatt járvány esetén - többek között a következők korlátozását vagy megtiltását teszi lehetővé: ${ }^{28}$

- minden olyan intézmény múködése, illetve rendezvény és tevékenység, amely a járvány terjedését elősegítheti;

— az egyes területek közötti személyforgalom, élőállat- vagy áruszállítás;

- az egyes területek lakosainak más területek lakosaival való érintkezése;

- a fekvőbeteg-gyógyintézet látogatása;

— az egyes területek elhagyása.

A járványügyi rendelkezések mellett az Eütv.-ből az egészségügyi válsághelyzet érdemel alaposabb figyelmet. ${ }^{29}$ Hangsúlyozandó, hogy ez nem minősül különleges jogrendnek, hanem csupán egy speciális ellátási formának, ${ }^{30}$ amelynek a bevezetése akkor indokolt, „amikor valamilyen rendkívüli helyzetben az ellátási igények és lehetőségek diszkrepanciája miatt szükségképpen szúkebbek az ellátási opciók, nem teljesen érvényesülhetnek az ellátói és betegjogok, valamint kötelezettségek". ${ }^{31}$ A törvény értelmében egészségügyi válsághelyzetnek - többek között - a következő események minősültek:32

- minden - rendszerint váratlanul bekövetkező - esemény, amely a polgárok életét, testi épségét, egészségét vagy az egészségügyi szolgáltatók múködését veszélyezteti

22 Eütv. 56. $\$(2)$ bekezdés $a$ ) pont $a c$ ) alpont.

23 Eütv. 63-64. $\$$.

24 Eütv. 65-67. \$.

25 Eütv. 65-67. \$.

26 Eütv. 68-70. $\$$.

27 Eütv. 70/A. \$.

28 Eütv. 74. $\$(2)$ bekezdés $a)-e$ ) pont.

29 Itt ismét felhívjuk a figyelmet, hogy az Eütv. 2020. márciusi szövegváltozatát vizsgáljuk.

30 A különleges jogrend és az egészségügyi válsághelyzet viszonyát tisztázza az a rendelkezés, amely szerint különleges jogrend bevezetésekor az egészségügyi válsághelyzeti ellátásra vonatkozó rendelkezéseket kell alkalmazni az egész országra kiterjedően, azonban ez esetben nem szükséges az egészségügyi válsághelyzet kihirdetése [Eütv. 228. \$ (3) bekezdés]. Itt kell megjegyezni, hogy az Eütv. kapcsolódó (XIV.) fejezete az Egészségügyi válsághelyzeti és egészségügyi veszélyhelyzeti ellátás címet viseli, azonban a törvényben később nem fordul elő az egészségügyi veszélyhelyzeti ellátás kifejezés; helyette az egészségügyi válsághelyzeti ellátás kifejezést használja.

31 Dósa-Hanti-Kovácsy, 2016, 473-474. o.

32 Eütv. 228. $\$(2)$ bekezdés. 
vagy károsítja olyan mértékben, hogy az az egészségügyi ellátási szükségletek és a helyben rendelkezésre álló kapacitás közötti aránytalanság kialakulásához vezet;

— nemzetközi horderejû́ közegészségügyi-járványügyi szükséghelyzet (függetlenül attól, hogy erre különleges jogrend idején vagy azon kívül kerül sor).

Egészségügyi válsághelyzet esetén az általános szabályoktól több szempontból is el lehet térni33 - így például a betegjogok csak akkor és kizárólag olyan mértékben gyakorolhatók, amikor és amennyiben nem veszélyeztetik az egészségügyi válsághelyzet felszámolásának eredményességét; ${ }^{34}$ az egészségügyi ellátórendszerre, az egészségügyi szolgáltatás szakmai követelményeire, valamint az egészségügyi dolgozók jogaira és kötelezettségeire elő́rt rendelkezéseket pedig bizonyos eltérésekkel kell alkalmazni. ${ }^{35}$

Miután röviden felvázoltuk az Eütv. releváns rendelkezéseit, adott a kérdés: a fenti szabályozási keretek között valóban meg lehetett-e volna oldani a Covid-19 kezelését? Mészáros Gábor a 2020. március végén (tehát még a járványhelyzet igazi eszkalálódása elôtt) írt elemzésében - miután összefoglalta az Eütv. kapcsolódó szabályozását - erre összességében igenlő választ adott: „A fentiek alapján is látható, hogy az Eütv. megalkotásakor a jogalkotó készült a koronavírus okozta járványhoz hasonló helyzetekre; ez a jogszabály biztosítja a rendes jogi múködés keretében a helyzet kezelésének lehetőségét. A körülmények tehát nem feltétlenül teszik szükségessé különleges jogrend alkalmazását [...].”36 Amint az Igazságügyi Minisztérium jogszabály-előkészítés összehangolásáért és a közjogi jogalkotásért felelős helyettes államtitkárának tanulmányából kiderül, eleinte (2020. március elején) még valóban az egészségügyi válsághelyzet kihirdetése tûnt kézenfekvő megoldásnak, azonban március 9-én már egyértelmúvé vált, hogy ez „legfeljebb ideiglenesen tudna eszköztárat biztosítani a járvány hatásainak kezelésére, hosszabb távon a különleges jogrend intézményéhez, a veszélyhelyzethez kell nyúlni”. ${ }^{37}$

A fenti vitát utólagosan, mintegy 9 hónap távlatából nem lenne méltányos „eldönteni”, ráadásul jóval alaposabb elemzésre lenne szükség annak megítéléséhez, hogy a veszélyhelyzet alatt a Kormány által meghozott több száz intézkedés mindegyike „belefért” volna-e a normál jogrendi múködésbe. Az viszont egyértelmủen kijelenthető - és ez már 2020 . március végén látható volt -, hogy a Covid-19-járványra nem lehet(ett) kizárólag egészségügyi problémaként tekinteni, hiszen a pandémiás helyzetnek szinte felmérhetetlenül jelentősek a gazdasági, munkaerőpiaci, szociális stb. hatásai is. Másrészt az is kérdéses, hogy az Eütv. egyes - fentebb hivatkozott - rendelkezései vajon valóban jogalapot szolgáltathattak volna-e a Kormány által meghozott olyan intéz-

33 Megjegyzendő, hogy az ellátói válsághelyzet [Eütv. 228. \$ (2) bekezdés b) pont] az egyébként a válsághelyzeti ellátásra előírt rendkívüli szabályok közül számos nem alkalmazható (Eütv. 232/A. \$). Az egészségügyi válsághelyzeti ellátás részletes szabályait az egészségügyi válsághelyzeti ellátásról szóló 521/2013. (XII. 30.) Korm. rendelet tartalmazza.

34 Eütv. 229. \$ (1) bekezdés.

35 Eütv. 229. \$(2) bekezdés.

36 Mészáros, 2019, 67. o.

37 Salgó, 2020, 12-13. o. 
kedésekhez, mint például a látogatási tilalom elrendelése a felsőoktatási intézményekben vagy a kijárási korlátozás? Itt ismét fel kell idézni az Eütv.-nek azt a rendelkezését, amely első olvasatra rendkívül széles jogköröket biztosít az egészségügyi államigazgatási szerv (azaz ebben az esetben a járási hivatal) részére: „Járvány esetén korlátozható vagy megtiltható minden olyan intézmény múkködése, illetve rendezvény és tevékenység, amely a járvány terjedését elősegítheti. ${ }^{{ }^{38}}$ Mészáros ezen rendelkezésre hivatkozva úgy érvelt, hogy az Eütv. is lehetôvé tette volna az oktatási intézmények bezárását, a tömegrendezvények megtiltását, az ország területének elhagyását, valamint a személyforgalom korlátozását. ${ }^{39} \mathrm{~A}$ rendelkezés megfogalmazásából valóban az következik, hogy lényegében „minden” korlátozható vagy megtiltható, hiszen az intézmény-rendezvény-tevékenység hármas értelmezése tetszőlegesen széles lehet, ugyanis aligha van az életnek olyan szegmense, ami ne lenne besorolható a három fogalom valamelyikébe. (Az Eütv. hasonlóan tág jogköröket biztosít a személyforgalom, valamint egyes területek elhagyásának korlátozásával/megtiltásával

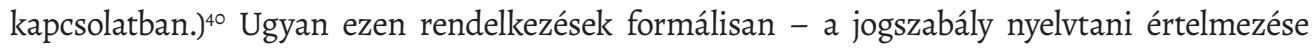
alapján - valóban lehetőséget adtak volna a különböző bezárásokra és a kijárási korlátozásokra is (hiszen például az egyetem is tekinthető intézménynek, márpedig akkor be is zárható), azonban két ellenvetés is tehetô. Egyrészt úgy véljük, hogy az Eütv. hivatkozott rendelkezéseinek kodifikálásakor aligha egy globális, így az egész országot hónapokra-évekre megbénító járvány lebegett a jogalkotó szeme előtt. Életszerütlennek és a törvény szellemiségével ellentétesnek tartanánk, ha az összes oktatási intézményre kiterjedő, hónapokon át tartó, a társadalom jelentős részét érintő bezárásáról egy Kormány alatti szakigazgatási hatóság döntene. (Nem igényel különösebb magyarázatot, hogy ez utóbbi más kategória, mint például egy általános iskola bezáratása egy hétre.) Másrészt arra is rá kell mutatni, hogy az országos tisztifőorvos - nem lévén jogalkotó - jogszabályban értelemszerúen nem rendelhette volna el ezeket a tiltásokat és korlátozásokat. Jogszabály híján marad az egyedi határozat, valamint a normatív utasítás, azonban egyik sem minősülhetett volna jogszerú megoldásnak. Az egyedi határozatnak nem lehet célja a jogalanyok magatartásának általános jelleggel való szabályozása, a normatív utasításban pedig csak a vezetése, az irányítása vagy a felügyelete alá tartozó szervek szervezetét és múködését, valamint tevékenységét szabályozhatja az országos tiszti fóorvos (mint a központi hivatal vezetője). ${ }^{41}$

A fentiek alapján összességében azon az állásponton vagyunk, hogy a veszélyhelyzet kihirdetése nélkül aligha lett volna kezelhető a Covid-19-járványhelyzet. (Mindez azonban távolról sem jelenti azt, hogy ne merültek volna fel jogi aggályok a különleges jogrend során, mint ahogy azt sem, hogy a hazai jogrendszer teljes egészében alkalmas lett volna a helyzet kezelésére.)

38 Eütv. 74. $\$(2)$ bekezdés $a)$ pont.

39 Mészáros, 2019, 68. o.

40 Eütv. 74. $\$(2)$ bekezdés b) és $d$ ) pont.

41 Vö.: a jogalkotásról szóló 2010. évi CXXX. törvény 23. \$ (4) bekezdés c) pont. 2020. március végén - a veszélyhelyzet kihirdetését követóen megalkotott kormányrendeletek hatályvesztése miatt - az országos tiszti fóorvos mégis rákényszerült, hogy határozatban „hosszabbítsa meg” egyes kormányrendeletek hatályát. Balázs és Hoffman meggyőzően bizonyítja, hogy ez a határozat - egyfajta „pszeudonorma” - semmilyen értelmezés alapján nem volt jogszerünek minősíthető. (Balázs-Hoffman, 2020, 3. o.). 


\section{Veszélyhelyzet vs. járvány: az Alaptörvény és a katasztrófavédelmi törvény kapcsolata}

A veszélyhelyzet kihirdetését követően megfogalmazódott kritikák azt is szóvá tették, hogy a Kormánynak a járványra hivatkozva nem lett volna lehetősége a különleges jogrend bevezetésére, ${ }^{42}$ ugyanis az Alaptörvény 53 . cikk (1) bekezdése csak két esetben teszi lehetôvvé a veszélyhelyzet kihirdetését: az egyik az élet- és vagyonbiztonságot veszélyeztető elemi csapás, a másik pedig - értelemszerúen az élet- és vagyonbiztonságot szintén veszélyeztető - ipari szerencsétlenség.

Az Alaptörvény és a Kat. kapcsolatát illusztrálja a következő ábra, amely mintegy összekapcsolja az alaptörvényi és a törvényi rendelkezéseket:

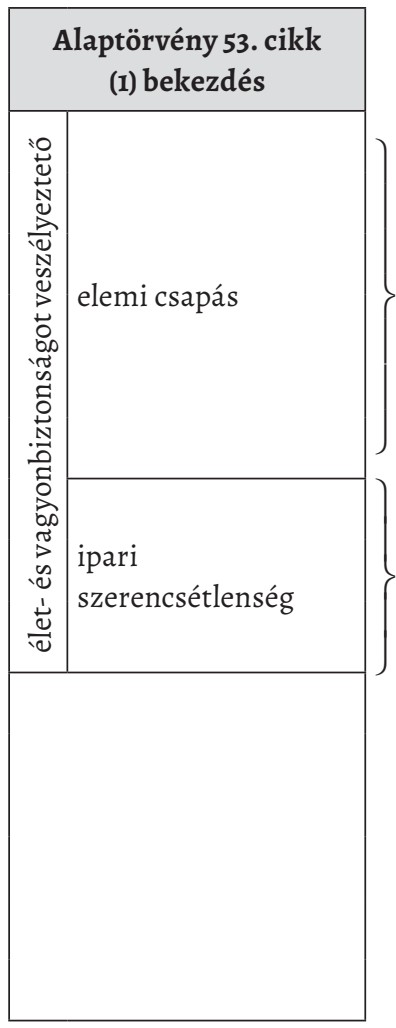

\begin{tabular}{|l|}
\hline \multicolumn{1}{|c|}{ Kat. 44. § } \\
\hline a) elemi csapások, természeti eredetû́ veszélyek, különösen \\
\hline aa) árvíz* \\
\hline ab) belvíz* \\
\hline ac) hóesés* \\
\hline ad) más szélsőséges idójárás* \\
\hline ae) földtani veszélyforrások \\
\hline b) ipari szerencsétlenség, civilizációs eredetú veszélyek, különösen \\
\hline ba) a veszélyes anyagok és hulladékok szabadba kerülése* \\
\hline bb) nem tervezett radioaktív kiszóródás és egyéb sugárterhelés* \\
\hline c) egyéb eredetú veszélyek, különösen \\
\hline $\begin{array}{l}\text { ca) tömeges megbetegedést okozó humánjárvány vagy járvány- } \\
\text { veszély, valamint állatjárvány }\end{array}$ \\
\hline cb) ivóvíz szennyeződése* \\
\hline cc) légszennyezettség* \\
\hline cd) kritikus infrastruktúrák múködési zavara* \\
\hline
\end{tabular}

$$
\text { 5. ábra }
$$

Az Alaptörvény és a Kat. kapcsolata

Forrás: a szerző saját összeállítása

(Megjegyzés: a csillaggal jelölt tényállások egyszerüsittett/röviditett formában kerültek feltüntetésre)

42 A publicisztikák közül lásd például: Lattmann, 2020; Schiffer, 2020; Tordai, 2020. A tudományos közlemények közül lásd például: Mészáros, 2019; Szente, 2020. 
A Kat. 44. \$-át alaposabban megvizsgálva két - egymással szorosan összefüggő aggály merülhet fel. Egyrészt a szakasz felvezető szövege a következő: „A veszélyhelyzet az Alaptörvény 53. cikkében meghatározott olyan helyzet, amelyet különösen a következő események válthatnak ki: [...]." A különösen kifejezés használata egyértelmúsíti, hogy a jogalkotó a 44. \$ három fố elemből [a)-c) pontok] álló felsorolását nem tekinti taxatívnak, noha az Alaptörvény 53. cikk (1) bekezdése kizárólag az elemi csapás és az ipari szerencsétlenség esetén teszi lehetővé a veszélyhelyzet kihirdetését. A különösen kitétel visszaköszön az a)-c) pontok mindegyikében, vagyis ezek a felsorolások sem taxatívak, hanem pusztán példálózó jellegúek. Ezen utóbbi megoldás azonban álláspontunk szerint nem kifogásolható, ugyanis célszerûtlen lenne elvárni a jogalkotótól, hogy például az elemi csapások összes lehetséges megnyilvánulási formáját számba vegye. [Egy hipotetikus - Magyarországon persze meglehetősen valószínútlen - példával megvilágítva: egy több megyére kiterjedô túzvész esetén az a) pont annak ellenére is alkalmazható lenne, hogy az alpontokban nincs megemlítve a tûzvész.]

A másik probléma a Kat. 44. \$c) pontja, amely az egyéb eredetú veszélyek kategóriáját megalkotva mintegy kiegészíti az Alaptörvény kapcsolódó rendelkezését. Ebben a pontban kapott helyet a veszélyhelyzet kihirdetését megalapozó ca) alpont is (tömeges megbetegedést okozó humánjárvány vagy járványveszély). Szente Zoltán szerint a c) pont „az Alaptörvény által a veszélyhelyzetre vonatkozó tényállások önkényes kiterjesztése, amelyre az Országgyúlésnek nem volt felhatalmazása”, és így „az alaptörvény-ellenes módon terjeszkedik túl az Alaptörvény szövegén". ${ }^{43}$ Hasonlóan érvel Mészáros, rámutatva egyúttal arra is, hogy a Kat.-nak eleve nem lenne feladata a veszélyhelyzetet előidéző körülmények pontos meghatározása, ugyanis az Alaptörvény 53. cikk (1) bekezdése értelmében a Kat.-nak csak a rendkívüli intézkedések törvényi meghatározására kellene szorítkoznia. ${ }^{44}$ Szemben az előbbi álláspontokkal, Balázs István és Hoffman István nem utalt az alaptörvény-ellenességre: a szerző́k mindenfajta értékelés nélkül rögzítették, hogy a Kat. 44. \$c) pontja „[a]z Alaptörvény szabályát tágan értelmezve, annak szó szerinti értelmezéséhez képest, azt bővítve" nevesíti a humánjárványt. ${ }^{45}$

A fentiek alapján két kérdést kell feltenni: egyrészt azt, hogy a járvány(veszély) megfeleltethető-e a két alaptörvényi kategória (elemi csapás/ipari szerencsétlenség) valamelyikének, másrészt pedig azt, hogy miként értékelhető a Kat. 44. \$-a az Alaptörvény 53. cikk (1) bekezdésének fényében.

43 Szente, 2020, 133. o.

44 Mészáros, 2020, 66. o. Ezzel szemben a Kat. 44. \$-a azt mondja ki, hogy „[a] veszélyhelyzet az Alaptörvény 53. cikkében meghatározott olyan helyzet, amelyet különösen a következő események válthatnak ki: [...]”. Ebből a fogalmazásmódból az következik, hogy a Kat. lényegében definiálni kívánja a veszélyhelyzetet, méghozzá a kiváltó körülmények felsorolásával.

45 Balázs-Hoffman, 2020, 2. o. 
Ami az első kérdést illeti, az ipari szerencsétlenség értelemszerủen kizárható, így a kérdés arra egyszerűsödik le, hogy elemi csapásnak minősíthető-e a járvány(veszély). A kérdés nyelvi-szemantikai és jogi síkon is vizsgálható. A szemantikai szempontot illetően kiemelendő, hogy a témakört érintő közjogi-politikai diskurzusban mindkét irányú érvelésre találunk példát. Orbán Balázs, a Miniszterelnökség miniszterhelyettese szerint - utalva a bibliai tíz csapásra is, amelyek közül legalább három tömeges kór formájában jelentkezett a koronavírus-járvány egyértelmúen elemi csapásnak minősül. ${ }^{46}$ Mások viszont arra hívják fel a figyelmet, hogy a mértékadó lexikonok értelmében az elemi csapás „a természet erőinek (elemeinek) müködése folytán szokott bekövetkezni", ${ }^{7}$ illetve a járványokat általában a nemzetközi szakirodalomban sem sorolják a természeti katasztrófák közé. ${ }^{48}$

A nyelvi szempontú vizsgálódásnál természetesen nagyobb relevanciával bír a jogi megközelítés, azaz hogy az Alaptörvény és a Kat. összevetése során elemi csapásnak minősül-e a járvány(veszély). Itt viszont az a helyzet, hogy a Kat. 44. \$-a a járvány(veszély)t kifejezetten kiveszi az elemi csapások közül, és külön kategóriába (egyéb eredetú veszélyek) sorolja, vagyis a Kat. a járvány(veszély)t egyértelmúen nem tekinti elemi csapásnak. Megjegyzendő, hogy - amint Szente rámutat - az Alaptörvényből nem következik, hogy a humánjárványt ne lehetne az elemi csapások fogalmi körébe vonni, ${ }^{49}$ ugyanis - tehetjük hozzá - egy szó köznapi és jogszabályban definiált jelentéstartalma nem kell hogy szükségszerúen egybeessen..$^{50}$

Lehetséges-e olyan értelmezés, amely szerint a járvány(veszély) mégiscsak az elemi csapások közé tartozik? Álláspontunk szerint ez csak úgy lenne lehetséges, ha úgy érvelünk, hogy a Kat. 44. \$-a voltaképpen kettébontja az Alaptörvény elemicsapás-fogalmát, azaz az a) és a c) pont egyaránt az elemi csapást definiálja (pontosabban az elemi csapáshoz tartozó esetköröket sorolja fel) - előbbi manifeszt módon, utóbbi pedig mintegy kiegészítőleg. Ez esetben arról lenne szó, hogy az elemi csapásnak van egy tágabb [Alaptörvény 53. cikk (1) bekezdés] és egy szúkebb [Kat. 44. $\$$ a) pont] meghatározása, és a járvány(veszély) ugyan a Kat. elemicsapás-definíciójának nem felel meg, de az Alaptörvény alapján mégis lehet elemi csapásnak minősíteni.

Rátérve a másik kérdésre: vajon miként értékelhető a Kat. 44. \$-a az Alaptörvény 53. cikk (1) bekezdése fényében? Amint láttuk, az egyik narratíva az lehet, hogy a Kat.

46 Orbán, 2020.

47 A Pallas Nagy Lexikona. VI. kötet, Budapest: Pallas, 1994. 14. o. Idézi Szente, 2020, 117. o. Megjegyzendő, hogy az Alaptörvény hivatalos angol fordítása az elemi csapásra a natural disaster kifejezést használja. A szintén mértékadó Merriam-Webster-szótár szerint: „a sudden and terrible event in nature (such as a hurricane, tornado, or flood) that usually results in serious damage and many deaths". Elérhetô: www.merriam-webster. com/dictionary/natural\%20disaster (Letöltve: 2020 . november 10.).

48 Szente, 2020, 132. o.

49 Szente, 2020, 133. o.

50 A jogszabályszerkesztésről szóló 61/2009. (XII. 14.) IRM rendelet (Jszr.) 67. \$ (2) bekezdése értelmében egy fogalom jelentése az adott jogszabály alkalmazásában eltérhet a köznyelvi jelentésétől, illetve a más jogszabályban meghatározott jelentésétől (ez esetben értelmező rendelkezést kell alkalmazni). 
alkotmányellenesen "beleír” az Alaptörvénybe azzal, hogy egy kvázi taxatív felsorolást (elemi csapás, ipari szerencsétlenség) egyrészt ténylegesen is kibővít [a c) ponttal], másrészt pedig a további bővítés előtt is nyitva hagyja a lehetőséget [a 44 . $\$$ nyitó szövegrészében a különösen szó arra utal, hogy nemcsak az a)-c) pontok válthatják ki a veszélyhelyzetet]. A másik lehetséges értelmezés az lehet, hogy a Kat. 44. \$-a voltaképpen csak értelmezi és kifejti, részletezi az „elemi csapás vagy ipari szerencsétlenség” kifejezést. Ebben az esetben tehát az „elemi csapás vagy ipari szerencsétlenség” kifejezésre nem mint egy felsorolásra (pláne nem egy taxatív felsorolásra) kell tekinteni, hanem mint egy olyan általános tényállási elemre, amely törvényi szintû́ konkretizálást igényel. Ezen álláspont védelmében felhozható, hogy az Alaptörvény számos rendelkezését a jogszabályok töltik meg tartalommal, és voltaképpen ez esetben is az történik, hogy a Kat. részletezi, konkretizálja a veszélyhelyzetet kiváltó körülményeket. Ehhez kapcsolódóan érdemes felidézni a Kat. indokolását: „Az új terminológia szerinti veszélyhelyzet meghatározásakor felülvizsgálatra és tudományos eredmények felhasználásával kiegészítésre, korszerúsítésre került a lehetséges veszélyek köre." A jogalkotó itt a veszélyhelyzet korábbi törvényi meghatározására ${ }^{51}$ utal vissza, amely abból a szempontból is érdekes számunkra, hogy a Pvt. definíciója részben hasonlított a mostanira: „veszélyhelyzet [...] az élet- és vagyonbiztonságot vagy a környezetet veszélyeztetô természeti csapás, illetőleg ipari baleset okozta állapot, amelyet különösen a következő események válthatnak ki: [...]”. Az ezt követő felsorolásban megtalálható volt a „súlyos, több embernél halálos lefolyású tömeges megbetegedést előidéző kórokozó megjelenése", illetve több olyan körülmény (például ivóvíz szenynyeződése), amelyeket a Kat. jelenleg az egyéb eredetú veszélyek közé sorol. Ez alapján tehát megállapítható, hogy a Pvt. a járványt (noha nem ezt a kifejezést használta) kétséget kizáróan a természeti csapások közé sorolta. ${ }^{52}$ Amennyiben a jogalkotó a későbbiekben a Kat. megalkotásakor - is ehhez a megoldáshoz tartotta volna magát [ti. a járványra és a másik három, c) pont alatti körülményre nem állít fel egy „egyéb” kategóriát], úgy a Kat. és az Alaptörvény ütközése valószínúleg fel sem merült volna.

\section{A veszélyhelyzetet kihirdető rendeletek}

A veszélyhelyzet kihirdetéséről szóló 40/2020. (III. 11.) Korm. rendelet (a továbbiakban: Kihirdető r.) bevezető része három fordulatra tagolható, amelyek közül az első kettő érdemel alaposabb figyelmet:

51 A polgári védelemről szóló 1996. évi XXXVII. törvény (a továbbiakban: Pvt.) 2. \$ (2) bekezdés.

52 Megjegyzendő ugyanakkor, hogy az Alkotmány 35. $\$$ (1) bekezdés i) pontja és a Pvt. 2. $\$$ (2) bekezdése sem okvetlenül volt összhangban egymással, ugyanis az előbbi rendelkezés csak „az élet- és vagyonbiztonságot veszélyeztető elemi csapás"-ra használta a veszélyhelyzet kifejezést, míg a Pvt. ezt kiegészítette az ipari balesettel is. 


\begin{tabular}{|c|c|c|}
\hline & $\begin{array}{c}\text { A Kihirdető r. bevezető } \\
\text { szövege }\end{array}$ & Az Alaptörvény érintett rendelkezései \\
\hline 1. & $\begin{array}{l}\text { az Alaptörvény 53. cikk } \\
\text { (1) bekezdésében } \\
\text { meghatározott hatáskörében, }\end{array}$ & $\begin{array}{l}53 . \text { cikk } \\
\text { (1) A Kormány az élet- és vagyonbiztonságot veszélyeztető } \\
\text { elemi csapás vagy ipari szerencsétlenség esetén, valamint ezek } \\
\text { következményeinek az elhárítása érdekében veszélyhelyzetet } \\
\text { hirdet ki, és sarkalatos törvényben meghatározott rendkívüli } \\
\text { intézkedéseket vezethet be. }\end{array}$ \\
\hline 2. & $\begin{array}{l}\text { a } 2 \text {. és } 3 . \$ \text { tekintetében } \\
\text { az Alaptörvény 53. cikk } \\
\text { (2) bekezdésében } \\
\text { meghatározott eredeti } \\
\text { jogalkotói hatáskörében, }\end{array}$ & $\begin{array}{l}\text { 53. cikk } \\
\text { (2) A Kormány a veszélyhelyzetben rendeletet alkothat, } \\
\text { amellyel - sarkalatos törvényben meghatározottak szerint - } \\
\text { egyes törvények alkalmazását felfüggesztheti, törvényi ren- } \\
\text { delkezésektől eltérhet, valamint egyéb rendkivüli intézkedéseket } \\
\text { hozhat. }\end{array}$ \\
\hline 3. & $\begin{array}{l}\text { az Alaptörvény 15. cikk } \\
\text { (1) bekezdésében meghatá- } \\
\text { rozott feladatkörében eljárva } \\
\text { a következőket rendeli el: }\end{array}$ & $\begin{array}{l}\text { 15. cikk } \\
\text { (1) A Kormány a végrehajtó hatalom általános szerve, amelynek } \\
\text { feladat- és hatásköre kiterjed mindarra, amit az Alaptörvény } \\
\text { vagy jogszabály kifejezetten nem utal más szerv feladat- és } \\
\text { hatáskörébe. [...] }\end{array}$ \\
\hline
\end{tabular}

4. táblázat

A Kihirdetőr r.és az Alaptörvény kapcsolata

Forrás: a szerző saját összeállítása

Az 1. fordulat a veszélyhelyzet kihirdetését lehetővé tevő alaptörvényi rendelkezésre utal, méghozzá úgy, hogy a fordulatban a „hatáskör” szó előtt nincs jelző. A Jogtár segítségével megállapítható, hogy ezzel a megoldással kizárólag a veszélyhelyzettel kapcsolatos kormányrendeletek esetén találkozhatunk. A 2. fordulat viszont már kifejezetten utal az (eredeti) jogalkotói hatáskörre, de csak a 2-3. \$ vonatkozásában. Jogalkotástani szempontból mindez tehát azt jelenti, hogy a veszélyhelyzet kihirdetése voltaképp nem egy eredeti jogalkotói hatáskörben meghozott aktusnak tekinthető. ${ }^{53}$

Ezt követően tanulságos közelebbről is megvizsgálni a Kihirdető r. 1. \$-át:

„1. \$ A Kormány az élet- és vagyonbiztonságot veszélyeztető tömeges megbetegedést okozó humánjárvány következményeinek elhárítása, a magyar állampolgárok

53 Itt érdemes feltenni azt a kérdést, hogy miként alakult volna a Kihirdető $r$. bevezetô része, ha a Kormány úgy döntött volna, hogy ebben a rendeletben kizárólag a veszélyhelyzet kihirdetéséről rendelkezik, és minden további (rendkívüli) intézkedést további rendeletekben hoz meg. Ebben az esetben a Kihirdető r. - elvileg egy olyan kormányrendelet lett volna, amelyet nem is eredeti, és nem is származékos jogalkotói jogkörében hozott volna meg a Kormány. 
egészségének és életének megóvása érdekében Magyarország egész területére veszélyhelyzetet hirdet ki."

Most pedig idézzünk fel egy korábbi, a dunai árvíz miatt veszélyhelyzetet kihirdető 2013-as kormányrendeletet: ${ }^{54}$

„1. \$ A Kormány Győr-Moson-Sopron megye és Komárom-Esztergom megye területére, [...] árvízi veszély miatt a katasztrófavédelemről és a hozzá kapcsolódó egyes törvények módosításáról szóló 2011. évi CXXVIII. törvény (a továbbiakban: Kat.) 44. \$a) pont aa) alpontja alapján veszélyhelyzetet hirdet ki."

A két szakaszt összevetve szembeötlő különbség, hogy a 2013-as rendelet kifejezetten (úgynevezett merev hivatkozással) utal a Kat. azon rendelkezésére, amely akkor lehetővé tette a veszélyhelyzet kihirdetését..$^{55}$ (Amennyiben a többi veszélyhelyzetet kihirdetô kormányrendeletet vizsgáljuk, ugyanezt tapasztaljuk.) Ezzel szemben a Kihirdető r. explicit módon nem hivatkozik a Kat.-ra, noha logikus lenne az az elvárás, hogy a különböző veszélyhelyzetek kihirdetésére hasonló formában kerüljön sor.

Figyelmet érdemel továbbá „az élet- és vagyonbiztonságot veszélyeztető tömeges megbetegedést okozó humánjárvány" fordulat, ami abból a szempontból érdekes, hogy mintegy ötvözi az Alaptörvény 53. cikk (1) bekezdésének kifejezését („élet- és vagyonbiztonságot veszélyeztető”) a Kat. 44. \$ ca) alpontjának kifejezésével („tömeges megbetegedést okozó humánjárvány”). Mészáros álláspontja szerint „[a] veszélyhelyzetet kihirdető kormányrendelet tehát nem az Alaptörvényre, hanem a Kat.-ra hivatkozással rendelte el a különleges jogrendet [...] ${ }^{56}$ Ez a meglátás azonban nem teljesen pontos, hiszen a Kihirdető r. formailag egyértelmúen az Alaptörvényre hivatkozik, viszont - és ennyiben egyet tudunk érteni a szerzővel - az 1. \$-ban megjelenik a Kat. kapcsolódó rendelkezése („tömeges megbetegedést okozó humánjárvány") is - ám mindez a Kat.-ra való hivatkozás nélkül. Összességében tehát megállapítható, hogy mintha a jogalkotó is igyekezett volna „elkenni” a veszélyhelyzet kihirdetésének alapjait, ugyanis abban utalt is, meg nem is a Kat.-ra. [Mindez akár azzal is összefügghet, hogy maga a jogalkotó is tudatában volt annak, hogy erősen aggályos a Kat. 44. \$c) pontja és az Alaptörvény 53. cikk (1) bekezdésének összhangja, és ezzel a felemás megoldással kívánta a helyzetet orvosolni.]

Ezek alapján egy újabb kérdés merül fel: vajon lehet-e úgy érvelni, hogy a Kormány voltaképpen közvetlenül az Alaptörvényből vezette le a veszélyhelyzet kihirdetésének lehetőségét,

54 Veszélyhelyzet kihirdetéséről és az ennek során teendő intézkedésekről szóló 177/2013. (VI. 4.) Korm. rendelet. 55 Kat. 44. \$a) pont aa) alpont: „árvízvédekezés során, ha az előrejelzések szerint az áradó víz az addig észlelt legmagasabb vízállást megközelíti és további jelentős áradás várható, vagy elháríthatatlan jégtorlasz keletkezett, vagy töltésszakadás veszélye fenyeget".

56 Mészáros, 2019, 66. o. 
és ez esetben nincs is szükség a Kat. 44. \$-ára? (Ebből a szempontból különösen érdekes Mészáros - fentebb már hivatkozott - felvetése, miszerint a Kat.-nak eleve nincs felhatalmazása a veszélyhelyzetet előidéző körülmények pontos meghatározására, ugyanis - állítja a szerző - a Kat. az Alaptörvény alapján „csak a rendkívüli intézkedések törvényi meghatározására szorítkozhat". $)^{57} \mathrm{~A}$ Kihirdetô r. bevezetô része alapján úgy túnik, mintha a jogalkotó formálisan kikapcsolta volna a Kat.-ot, és a járványt olyan, az élet- és vagyonbiztonságot veszélyeztetó elemi csapásnak tekintette, amely alapot ad a veszélyhelyzet kihirdetésére.

2020. novemberben ismételten veszélyhelyzetet hirdetett a Kormány. A veszélyhelyzet kihirdetésérôl szóló 478/2020. (XI. 3.) Korm. rendelet (a továbbiakban: 2 . Kihirdető r.) bevezető részének első fordulata kiegészült a „figyelemmel a katasztrófavédelemről és a hozzá kapcsolódó egyes törvények módosításáról szóló 2011. évi CXXVIII. törvény 51/A. \$-ára" szövegrésszel, ${ }^{58}$ azaz a jogalkotó immár formálisan is összekötötte a kormányrendeletet és a Kat.-ot. Csakhogy a Kat.-ra való hivatkozás továbbra sem problémamentes, ugyanis az nem a veszélyhelyzetet kiváltó okok valamelyikére [konkrétan a 44 . $\$ c$ ) pont ca) alpontjára] történik, hanem arra az 51/A. \$-ra, amely a humánjárvány miatt már kihirdetett veszélyhelyzetben meghozható rendkívüli intézkedéseket tartalmazza. Álláspontunk szerint a kihirdetés jogalapját illetôen sokkal tisztább helyzetet teremtettek a 2020 elôtti veszélyhelyzeteket bevezető rendeletek (mint például a fentebb hivatkozott 2013-as árvizes rendelet), azonban a jogalkotó a 2 . Kihirdető r. esetén nem (sem) ezt az utat választotta, ami összefügghet a Kat. 44. \$c) pontjának és az Alaptörvény 53. cikk (1) bekezdésének problémás kapcsolatával.

\section{Az Alaptörvény 53. cikkének belső koherenciája}

A következőkben az Alaptörvénynek a veszélyhelyzetet szabályozó 53. cikkét vesszük számba, és amellett érvelünk, hogy a rendelkezések szövegezése nem egyértelmú, és a cikk belső koherenciája is megkérdőjelezhető. Annak érdekében, hogy jobban kirajzolódjon a Kormány veszélyhelyzeti cselekvési jogosultsága, az 53. cikk (1)-(2) bekezdésében aláhúzással kiemeltük, és egyben $[A]-[D]$ betúkkel jelöltük, hogy az alaptörvényi rendelkezések milyen aktusokra adnak lehetőséget a Kormánynak:

„(1) A Kormány az élet- és vagyonbiztonságot veszélyeztető elemi csapás vagy ipari szerencsétlenség esetén, valamint ezek következményeinek az elhárítása érdekében [A] veszélyhelyzetet hirdet ki, és sarkalatos törvényben meghatározott $[B]$ rendkívüli intézkedéseket vezethet be.

57 Mészáros, 2019, 66. o. Vö.: Alaptörvény 54. cikk (4) bekezdés: „A különleges jogrendben alkalmazandó részletes szabályokat sarkalatos törvény határozza meg.".

58 A Kat. 2020. júniusban kiegészült egy új szakasszal (és egyben alcímmel: A Kormány rendkivüli intézkedései tömeges megbetegedést okozó humánjárvánnyal összefüggő veszélyhelyzetben). 
(2) A Kormány a veszélyhelyzetben [C] rendeletet alkothat, amellyel - sarkalatos törvényben meghatározottak szerint - egyes törvények alkalmazását felfüggesztheti, törvényi rendelkezésektől eltérhet, valamint $[D]$ egyéb rendkívüli intézkedéseket hozhat. ${ }^{.59}$

Az [A]-val jelölt aktus („veszélyhelyzetet hirdet ki”) magát a veszélyhelyzet kihirdetését jelenti. Amint Szente rámutat, az Alaptörvény szövege nem rendelkezik arról, hogy a veszélyhelyzetet a Kormánynak milyen formában kell kihirdetnie. ${ }^{60}$ Álláspontja szerint viszont az alkotmányossági és a joglogikai szempontok alapján is igazolható, hogy a rendeleti forma az adekvát. (Ehhez hozzátehetjük, hogy eddig valamennyi veszélyhelyzet kormányrendeletben került kihirdetésre.)

A [B]-vel jelölt aktus („rendkívüli intézkedéseket vezethet be”) két szempontból is problémásnak minősül. Egyrészt nem teljesen világos, hogy az ez alapján meghozott intézkedések csak a [C]-vel jelölt kormányrendelet(ek) keretében vezethetők-e be. Másrészt tisztázatlannak túnik a $[B]$ és a $[D]$ aktusok viszonya, hiszen meglehetősen hasonló kifejezésekről van szó („rendkívüli intézkedéseket vezethet be” vs. „rendkívüli intézkedéseket hozhat” - ráadásul a „sarkalatos törvényben meghatározottak szerint” kitétel mindkét aktusra vonatkozik).

A [D]-vel jelölt aktus („egyéb rendkívüli intézkedéseket hozhat”) esetén az okozhat értelmezési problémát, hogy erre a fordulatra is vonatkoztathatók-e a (2) bekezdésben körülírt rendelet attribútumai, vagyis az „egyéb rendkívüli intézkedéseket hozhat” csak a megalkotott rendelet keretén belül értelmezhető-e (ez esetben a fordulat illeszkedik az „amellyel” szót követő felsorolásba, annak egy elemét képezi). A másik interpretáció az lehetne, hogy a fordulat elválik a rendeletre utaló szövegrésztôl - ez esetben az értelmezés a következő lenne: „A Kormány a veszélyhelyzetben [...] egyéb rendkívüli intézkedéseket hozhat” (ti. rendeletalkotás nélkül is). Bár első látására is az első értelmezés túnik logikusnak, a Kat. 45. \$ (1) bekezdésére figyelemmel egyértelmú lesz a válasz: „Veszélyhelyzetben, a katasztrófa elhárításához szükséges mértékben és területen a Kormány rendeleti úton a 47-48. \$ szerinti rendkívüli intézkedéseket vezetheti be, illetve a 49-51. \$ szerinti rendkívüli intézkedések bevezetésével ezek végrehajtására adhat felhatalmazást." A Kat. tehát kifejezetten utal a rendeleti útra, vagyis a fentiek közül az első értelmezés a helyes. [Átláthatóbb lenne a helyzet, ha az 53. cikk (2) bekezdésében a felsorolás három elemét külön pontokba szedné az alkotmányozó. $]^{61}$ Mindezek alapján a [D] nem különálló aktus, hanem a [C] része, azaz a rendkívüli intézkedések meghozatala a rendeletalkotás révén lehetséges. (Mindez azt is jelenti, hogy az egyes törvények alkalmazásának felfüggesztése, valamint a törvényi rendelkezésektől

59 Megjegyzendő, hogy az 53. cikk (2) bekezdésében foglaltak lényegében változatlan formában megtalálhatók három másik különleges jogrendnél is \{megelőző védelmi helyzet [51. cikk (4) bekezdés]; terrorveszélyhelyzet [51/A. cikk (4) bekezdés]; váratlan támadás [52. cikk (3) bekezdés]\}.

60 Szente, 2020, 126. o.

61 Vö.: Jszr. 46. \$ (1) bekezdés. 
való eltérés is rendkívüli intézkedésnek minősülnek, de ezeken felül egyéb rendkívüli intézkedések is léteznek.)

Visszatérve a [B] és a [D] aktus elhatárolására, itt arról van szó, hogy ez a két fordulat voltaképpen ugyanazt az aktust jelenti-e, vagy sem. Az igenlő válasz mellett szól az a tény, hogy a [B] aktus is a sarkalatos törvényben meghatározott rendkívüli intézkedésnek minősül, akárcsak a [D] (már amennyiben „a [D] aktus a [C] aktus része” következtetésünk helyes). Viszont a $[B]=[D]$ következtetés erejét gyengíti, hogy az alkotmányozó valamilyen okból mégiscsak két külön bekezdésben említi ezeket, amelyek közül az (1) bekezdés a veszélyhelyzet kihirdetését szabályozza, a (2) pedig a veszélyhelyzet alatti rendeletalkotást. Vajon mi indokolta, hogy ugyanazon hatáskör (ti. a Kormány veszélyhelyzetben rendkívüli intézkedést vezethet be/hozhat) egymást követően kétszer - hasonló kontextusban, de némileg eltérő fogalmazásmóddal - is nevesítve legyen? Ha $[B] \neq[D]$, akkor viszont felmerül a kérdés, hogy létezik-e olyan - sarkalatos törvényben meghatározott - rendkívüli intézkedés, amelynek a bevezetése nem igényel rendeletalkotást. A Kormány a veszélyhelyzet kihirdetését követően számos - jogszabálynak értelemszerủen nem minősülő - kormányhatározatot is hozott a járvány kezelésével összefüggésben, azonban ezek csak közvetve köthetők össze a Kat.-tal mint irányadó sarkalatos törvénnyel. Ezenfelül - elméletileg - egy olyan értelmezés is elképzelhető, hogy a $[B]=[D]$, viszont a $[B]$-vel jelölt aktusokat a veszélyhelyzet kihirdetésével egyidejüleg vezetheti be a Kormány, és ezekre - lévén hogy nem a (2) bekezdés hatálya alá tartoznak - nem vonatkozik a 15 napos „élettartam”.

Összességében a legvalószínúbb - és egyben a leglogikusabb - értelmezés az, hogy $[B]=[D]$, csak éppen az alkotmányozó már az (1) bekezdésben jelezni kívánta, hogy veszélyhelyzetben a Kormány - sarkalatos törvényben meghatározott - rendkívüli intézkedéseket vezethet be. Ez azonban abból a szempontból felesleges - és egyben némileg félrevezetô is -, hogy a (2) bekezdés részletesebben is szabályozza a rendkívüli intézkedések meghozatalát.

\section{A meghosszabbítás kérdései}

Ahogyan maga a veszélyhelyzet, úgy annak meghosszabbítása sem példa nélküli a magyar közjogtörténetben. ${ }^{62}$ A 2020 előtt kihirdetett veszélyhelyzeteket tekintve megállapítható, hogy az Országgyưlés hét alkalommal járult hozzá ezek meghosszabbításához.63 A hozzájárulás mindegyik esetben országgyưlési határozat formájában történt, és határozott időre szólt (az árvíz miatti veszélyhelyzeteknél a hosszabbítás időtartama hozzávetőlegesen

62 A meghosszabbítás közjogi megoldásaira lásd: Ungvári-Hojnyák, 2020. Pontosításképp megjegyzendő, hogy ténylegesen nem magát a veszélyhelyzetet kell/lehet meghosszabbítani, hiszen a veszélyhelyzet időtartama a Kormány döntésétől függ; ehelyett a veszélyhelyzeti kormányrendeletek hatálya szorul meghosszabbításra.

63 Pontosításképp megjegyzendő, hogy az Alaptörvény hatálybalépése előtti veszélyhelyzetek esetén az Országgyúlés engedélyezte a veszélyhelyzet meghosszabbítását. 
40-50 nap volt, míg az iszapkatasztrófánál alkalmanként megközelítőleg 3 hónap). A járvány miatti veszélyhelyzet meghosszabbításának egyik újdonsága az volt, hogy az nem OGY határozatban, hanem törvényben történt (a koronavírus elleni védekezésről szóló 2020. évi XII. törvény - a továbbiakban: Kevtv.). Mivel sem a korábbi Alkotmány, sem az Alaptörvény nem határozta/határozza meg a meghosszabbítás formátumát, mindkét megoldás elfogadható, hiszen ahogyan a törvény, úgy az OGY határozat is normatív aktusnak tekinthető.

A következőkben azt járjuk körül, hogy milyen értelmezési problémák merül(het)tek fel a veszélyhelyzet - pontosabban a veszélyhelyzeti kormányrendeletek hatályának - meghoszszabbítása során. Kiindulópontként térjünk vissza a tanulmány előző pontjában alkalmazott [A]-[D] felosztáshoz. Álláspontom szerint az, hogy a [B] aktus ugyanaz-e, mint a [D], komoly relevanciával bír az adott intézkedés hatálya szempontjából. Az Alaptörvény 53. cikk (3) bekezdése ugyanis a következőképp rendelkezik: „A Kormány (2) bekezdés szerinti rendelete tizenöt napig marad hatályban, kivéve, ha a Kormány - az Országgyúlés felhatalmazása alapján - a rendelet hatályát meghosszabbítja." Ebből a rendelkezésből egyértelmúen az következik, hogy az $[A]$ és a $[B]$ aktusok hatályának meghosszabbításához nincs szükség az Országgyúlés felhatalmazására [hiszen azok nem minősülnek a (2) bekezdési rendeletnek], vagyis magának a kihirdetett veszélyhelyzetnek a meghosszabbításához nem szükséges az Országgyuulés felhatalmazása/hozzájárulása. Hasonló a helyzet a [B]-vel jelölt aktusoknál, azaz - elvileg - a sarkalatos törvényben meghatározott, már bevezetett rendkívüli intézkedések hatálya sem függ az Országgyúléstől.

A korábbi - de már Alaptörvény utáni - országgyưlési meghosszabbítások a következő fordulatot tartalmazták:64

„Az Országgyúlés az Alaptörvény 53. cikk (3) bekezdése alapján felhatalmazza a Kormányt, hogy a veszélyhelyzet kihirdetéséről és az ennek során teendő intézkedésekről szóló [...] Korm. rendelet hatályát legfeljebb [...]-ig meghosszabbítsa, [...]."

Ezzel szemben a Kevtv. így fogalmazott:

„3. \$ (1) Az Országgyúlés az Alaptörvény 53. cikk (3) bekezdése alapján felhatalmazza a Kormányt, hogy a veszélyhelyzetben az Alaptörvény 53. cikk (1) és (2) bekezdése szerinti kormányrendeletek hatályát a veszélyhelyzet megszűnéséig meghosszabbítsa.

$[\ldots]$

64 Lásd például: a 2013. június 4-én kihirdetett veszélyhelyzet meghosszabbításához történő hozzájárulásról szóló 44/2013. (VI. 12.) OGY határozat 1. a) pontját. 
(3) Az Országgyưlés a Rendelet hatálybalépését követően e törvény hatálybalépéséig megalkotott, (1) bekezdés szerinti kormányrendeleteket megerősíti."

Kérdéses, hogy miért volt szükség arra, hogy a felhatalmazás az 53. cikk (1) bekezdése szerinti - azaz a veszélyhelyzetet kihirdető, 40/2020. (III. 11.) számú - kormányrendeletre is kiterjedjen? Álláspontunk szerint ez két - egymással összefüggő - szempontból is felesleges: egyrészt ha a Kormány - az Alaptörvényben meghatározott körülmények esetén, de lényegében saját belátása alapján - dönthet a veszélyhelyzet kihirdetéséről, akkor ebből az következik, hogy a veszélyhelyzet megszüntetéséről is a Kormány dönt. Másrészt az Alaptörvény az 53. cikk (3) bekezdésében említett 15 napos szabályt csak a (2) bekezdés szerinti rendeletekre [C] vonatkoztatja, amiből az következik, hogy az (1) bekezdés szerinti rendelet [A] hatályát nem érinti a 15 nap lejárta.

Kiemelendő, hogy az Országgyúlés részére benyújtott T/9790. számú törvényjavaslat eredeti változata ${ }^{65}$ még így fogalmazott:

„3. \$ (1) Az Országgyûlés az Alaptörvény 53. cikk (3) bekezdése alapján felhatalmazza a Kormányt, hogy

a) a Rendelet [vagyis a Kihirdetô r. rendelet-H. A.] 2. \$-a és 3. \$-a, valamint

b) a veszélyhelyzetben az Alaptörvény 53. cikk (1) és (2) bekezdése szerinti kormányrendeletek hatályát a veszélyhelyzet megszűnéséig meghosszabbítsa."

Ez a szövegváltozat tehát a Kihirdető r.-et - pontosabban annak 2-3. \$-át - leválasztotta volna a többi veszélyhelyzeti rendeletről. De miért esett a 2-3. § „külön elbírálás” alá? Ennek megválaszolásához szükséges felidézni a Kihirdető r. szövegét:

„1. A veszélyhelyzet kihirdetése

1. \$A Kormány az élet- és vagyonbiztonságot veszélyeztető tömeges megbetegedést okozó humánjárvány következményeinek elhárítása, a magyar állampolgárok egészségének és életének megóvása érdekében Magyarország egész területére veszélyhelyzetet hirdet ki.

2. § (1) A Kormány a veszélyhelyzet elhárításáért felelős kormánytagként a miniszterelnököt jelöli ki.

(2) A miniszterelnököt az (1) bekezdés szerinti feladatának ellátásában Koronavírus-járvány Elleni Védekezésért Felelős Operatív Törzs segíti.

3. \$ (1) A veszélyhelyzettel kapcsolatos rendkívüli intézkedésekről külön kormányrendeletek rendelkeznek.

65 Elérhetô: www.parlament.hu/irom41/09790/09790.pdf(Letöltve: 2020. november 10.). 
(2) A Kormány a veszélyhelyzet fennállásának szükségességét folyamatosan felülvizsgálja.

(3) A Kormány az állampolgárok együttmủködését kéri a különleges jogrenddel járó intézkedések végrehajtásában.

2. Záró rendelkezések

4. \$ Ez a rendelet a kihirdetése napján 15 órakor lép hatályba."

Amint látható, az 1. $\$$ a veszélyhelyzet kihirdetésének tényét tartalmazta. Ez a rendelkezés volt az egész veszélyhelyzeti jogalkotás magja, hiszen ez a szakasz vezette be a különleges jogrendet. Ehhez képest a 2-3. \$ már "többletrendelkezéseket” tartalmazott, amelyek a $[B]$ vagy a $[D]$ szerinti aktusoknak minősülnek.

Ez a rendelet egyfajta hibrid rendeletnek minősül, hiszen egyszerre tartalmazta a veszélyhelyzet kihirdetésének tényét, valamint bizonyos további (rendkívüli?) intézkedések is ebben kerültek bevezetésre. ${ }^{66} \mathrm{~A}$ hibrid jelleg abból a szempontból érthető megoldás, hogy a jogalkotó a veszélyhelyzet kihirdetésével egyidejûleg bizonyos rendkívüli intézkedéseket is be kíván vezetni, hiszen önmagában a veszélyhelyzet deklarálása aligha alkalmas a probléma kezelésére. ${ }^{67}$ Bár bizonyos szempontból furcsa megoldásnak túnhet, de álláspontunk szerint dogmatikailag is tisztább helyzetet eredményezett volna, ha a Kormány egy külön rendeletet szentelt volna a veszélyhelyzet kihirdetésének, és ez a kihirdető jogszabály semmilyen további rendelkezést nem tartalmazott volna; a további (rendkívüli) intézkedések pedig külön kormányrendeletekbe kerültek volna. ${ }^{68}$

Úgy véljük, hogy a törvényjavaslat benyújtója maga is észlelte a Kihirdetô r. hibrid jellegét, és egyúttal annak is tudatában volt, hogy szabályozástechnikai szempontból nem szabad a rendeletet egységesként kezelni. A 2-3. \$ leválasztása azt szolgálta volna, hogy magának a veszélyhelyzetnek a meghosszabbításához ne kelljen az Országgyưlés hozzájárulását kérni. A Kevtv.-be végül ez a rendelkezés került:

„3. \$ (1) Az Országgyúlés az Alaptörvény 53. cikk (3) bekezdése alapján felhatalmazza a Kormányt, hogy a veszélyhelyzetben az Alaptörvény 53. cikk (1) és (2) bekezdése szerinti kormányrendeletek hatályát a veszélyhelyzet megszűnéséig meghosszabbítsa."

Ebben a rendelkezésben az Országgyưlés az 53. cikk (1) és (2) bekezdése szerinti kormányrendeletek hatályának meghosszabbításához adta meg a felhatalmazását. A (2) cikk szerinti

66 Vö.: Salgó, 2020, 14-15. o.

67 Megjegyzendő, hogy a 2. Kihirdető r. hibrid jellege már a formai tagolásban is érződik, ugyanis a jogalkotó immár külön-külön alcímet szentelt a veszélyhelyzet kihirdetésének, valamint A koronavírus-világjárvány következményeinek elhárításával összefüggő szabályoknak.

68 Ezzel ellentétes érvelésre lásd: Mészáros, 2019, 67. o. 
rendeletek - amelyek részben már korábban meg lettek alkotva, részben pedig késôbb kerültek megalkotásra - egyértelmúen korlátozott (15 napos) hatályú rendeletek.

Más a helyzet az (1) bekezdés szerinti rendeletekkel/rendelkezésekkel, ugyanis az már egyáltalán nem világos, hogy ezen rendelet(ek) esetén miként értelmezendő a meghosszabbítás. Amint fentebb láttuk, az 53. cikk (1) bekezdése két aktust foglal magába: a veszélyhelyzet kihirdetését $[A]$ és a rendkívüli intézkedések bevezetését [B]. Az előbbi biztosan nem igényel meghosszabbítást, hiszen - az Alaptörvény 54. cikk (3) bekezdése értelmében - a különleges jogrendet a különleges jogrend bevezetésére jogosult szerv megszünteti, ha kihirdetésének feltételei már nem állnak fenn - vagyis a 15 napos korlát magára a veszélyhelyzetre nem vonatkozik/vonatkozott. Annak, hogy a jogalkotó mégis szükségesnek érezte az (1) bekezdés szerinti rendeletek hatályának meghosszabbítását, az lehetett az oka, hogy a [B]-vel jelölt aktusok sorsát is figyelembe kívánta venni. Ezt alátámasztandó, nézzük meg a T/9790/15. számú összegző módosító javaslatot, ${ }^{69}$ amely változtatott a törvényjavaslat szövegén. Az iromány indokolása így szól:

„Tekintettel arra, hogy az ellenzéki pártok nem támogatták a határozati házszabályi rendelkezésektől való eltérésre vonatkozó kezdeményezést, így a törvényjavaslatot az Országgyuúlés 2020. március 24-én nem fogadhatta el. E tényre tekintettel a Kormánynak az emberek életének védelmében és a veszélyhelyzet negatív hatásainak mérséklése érdekében a járványügyi helyzetre tekintettel a törvényjavaslat hatálybalépését megelőzően hozott azon gyors és hatékony intézkedései, amelyek hatályát az Országgyưlés felhatalmazása hiányában a Kormány nem tudja meghosszabbítani, azok hatályukat vesztik. Emiatt a veszélyhelyzet kihirdetéséről szóló 40/2020. (III. 11.) Korm. rendelet 2. \$-a és 3 . \$-a is hatályát veszti a törvényjavaslat várható elfogadását és hatálybalépését megelőzően. Emiatt a törvényjavaslatban azokat a rendelkezéseket és szövegrészeket, amelyek a veszélyhelyzet kihirdetéséről szóló 40/2020. (III. 11.) Korm. rendelet 2. \$-ára és 3. \$-ára utalnak, el kell hagyni."

A jogalkotó tehát úgy vélte, hogy - az Országgyúlés meghosszabbításra való felhatalmazása hiányában - a Kihirdető r. 2-3. \$-a 15 nap után hatályát fogja veszíteni. Ez be is következett; a Jogtár a rendelet 2020. március 26-tól hatályos szövegváltozatában a következő megjegyzést füzi a 2-3. \$-hoz: „Hatályon kívül helyezve: Magyarország Alaptörvénye 53. cikk (3) bekezdése alapján. Hatálytalan: 2020. III. 26-án 15 órától."7o (Innentől kezdve csak a veszélyhelyzetet kihirdető 1 . \$ maradt hatályban.) Milyen következtetéseket lehet levonni a jogalkotó ezen gondolatmenetéből?

69 Elérhetô: www.parlament.hu/irom41/09790/09790-0015.pdf (Letöltve: 2020. november 10.).

70 Egyes álláspontok szerint ez volt az első eset, hogy egy jogszabály az Alaptörvény alapján automatikusan hatályát vesztette (Salgó, 2020, 14. o.). 
Egyrészt azt, hogy a jogalkotó mégiscsak különbséget tett a [B] és a $[D]$ aktusok között, hiszen ha a $[B]$ ugyanazt jelentené, amit a $[D]$, akkor a törvényben elegendő lett volna csak az 53. cikk (2) bekezdése szerinti kormányrendeletekre utalni. Viszont ha $[B] \neq[D]$, és azt az értelmezést követjük, hogy az Alaptörvény 53. cikk (1) bekezdése nemcsak a veszélyhelyzet kihirdetésére jogosítja fel a Kormányt, hanem egyúttal arra is, hogy sarkalatos törvényben meghatározott rendkívüli intézkedéseket vezessen be, akkor megint csak fel kell hívnunk a figyelmet arra, hogy az 53. cikk szerkezetéből - ahogyan arra már szintén utaltunk - az következik, hogy ezen utóbbi rendkívüli intézkedések 15 napon túli hatályának fenntartásához nem szükséges a meghosszabbítás. Kérdés, hogy a Kihirdető r. 2-3. \$-a ilyen sarkalatos törvényben meghatározott rendkívüli intézkedéseknek minősül-e.

Ami a 2. \$-t illeti, a Kat. a veszélyhelyzetre vonatkozó sajátos irányítási szabályok között nem tartalmaz kifejezett rendelkezést arra, hogy a veszélyhelyzet esetén annak elhárításáért felelős kormánytagot kell vagy lehet kijelölni, ${ }^{71}$ azonban a Kormánynak a veszélyhelyzetben játszott központi szerepére tekintettel teljességgel nyilvánvaló, hogy kijelölhető a veszélyhelyzet elhárításáért felelős kormánytag. A Koronavírus-járvány Elleni Védekezésért Felelős Operatív Törzs létrehozásával kapcsolatban kiemelendő, hogy azt nem a Kihirdető r. hozta létre, ugyanis a Törzs már több mint egy hónappal korábban felállításra került (méghozzá nem is kormányrendeleti, hanem - helyesen - "csak” kormányhatározati szinten). ${ }^{72} \mathrm{~A} 3 . \$$ (1) bekezdésében foglalt rendelkezésnek nincs különösebb normatív tartalma, és az abban foglaltak az Alaptörvény 53. $\$(2)$ bekezdése értelmében egyébként is magától értetődők. A (2) bekezdés szintén triviális rendelkezést tartalmaz, amely a rendeltetésszerú joggyakorlás elvéből is következik. A (3) bekezdés - már csak a fogalmazásmódja alapján is - szintén csak szimbolikus jellegû rendelkezésnek minősíthető.

A 2-3. \$ tartalmát elemezve tehát arra a következtetésre juthatunk, hogy ezek a rendelkezések nem minősülnek sarkalatos törvényben meghatározott rendkívüli intézkedéseknek. Egyrészt azért nem, mert a Kat. nem utal ilyen intézkedésekre, másrészt azért sem, mert ezek a rendelkezések/intézkedések korlátozott normatív hatállyal bírnak, és a rendkívüliségük is megkérdőjelezhető. Harmadrészt pedig pontosan az iménti rendelkezések egyike, a 3. \$ (1) bekezdése szögezi le, hogy a veszélyhelyzettel kapcsolatos rendkívüli intézkedésekről külön kormányrendeletek rendelkeznek - ez a megfogalmazás viszont arra enged következtetni, hogy a Kihirdetô r. nem ilyen rendkívüli intézkedéseket tartalmazó rendelet.

Összességében tehát nem látunk olyan érvet, amely amellett szólna, hogy ezen rendelkezések hatályának meghosszabbítására garanciális okokból szükség lett volna az Ország-

71 A Kat. veszélyhelyzetre vonatkozó sajátos irányítási szabályok között egyedül a miniszteri biztos kinevezését teszi lehetővé: „Amennyiben a veszélyhelyzet több megyét érint, vagy ha a katasztrófa elhárítása érdekében ez szükséges, a katasztrófák elleni védekezésért felelős miniszter - legfeljebb a veszélyhelyzet fennállásáig miniszteri biztost nevezhet ki." [46. $\$$ (1) bekezdés].

72 A Koronavírus-járvány Elleni Védekezésért Felelős Operatív Törzs felállításáról szóló 1012/2020. (I. 31.) Korm. határozat. 
gyưlésre. ${ }^{73}$ Ezek alapján úgy véljük, hogy a 15 napos határidő lejártának a Kihirdető r. 2-3. \$ hatályát nem kellett volna érintenie. ${ }^{74}$

\section{7. Összegzés}

Bár a fentiekben alapvetően kritikus módon, a problémákra rávilágítva vizsgáltuk a veszélyhelyzet közjogi és jogalkotási problémáit, természetesen azzal is tisztában vagyunk, hogy a kormányzatnak ezekben a helyzetekben napok vagy órák alatt kellett - esetenként példa nélküli - döntéseket hoznia, a jogalkotónak pedig ezeket a döntéseket meglehetősen gyors ütemben kellett jogi formába öntenie, aminek következtében bizonyos jogalkotási megfontolások szükségképpen háttérbe szorultak. A magunk részéról egyet tudunk érteni Tordai Csabával, aki szerint „rendkívüli helyzetekben a jog normativitása nem korlátozhatja az állam hatékony cselekvését: egyetlen emberélet sem kerülhet veszélybe rendkívüli jogrendre okot adó körülmények miatt csak azért, mert a normákat megfogalmazó jogalkotók nem látták előre az összes lehetséges veszélyt és szükséges intézkedést".75 Ebből a szempontból különösen figyelemre méltó az Igazságügyi Minisztérium jogszabály-előkészítés összehangolásáért és a közjogi jogalkotásért felelős helyettes államtitkárának az az (ön)kritikus megjegyzése, miszerint „a katasztrófavédelmi törvényben szereplő veszélyhelyzeti szabályokat nem járványhelyzet kezelésére írták", és a magyar jogrendszer nem volt felkészülve a koronavírus-járványból fakadó bizonytalan helyzet kezelésére. ${ }^{76}$

A 2020. őszi fejlemények nyomán megállapítható, hogy egyelőre még nem lehet múlt időben beszélni a veszélyhelyzetről, így a veszélyhelyzeti szabályozási rendszer múködésének teljes körủ kiértékelése is várat magára. Ugyanakkor az - már csak a fentebb hivatkozott helyettes államtitkári álláspont alapján is - vitathatatlan, hogy a szabályozás felülvizsgálatra szorul. ${ }^{77}$ Jelen fejezet a felmerült problémák közül csak a közjogi és jogalkotási kérdések közül érintett néhányat, és a fentiek alapján 2020. decemberben - még az Alaptörvény kilencedik módosítása előtt - a következő kiigazítások tûntek szükségesnek:

1. A jogalkotónak megnyugtató módon összhangba kell hoznia az Alaptörvényt és a Kat.-ot, ezzel elejét venni annak, hogy az Alkotmánybíróság egy esetleges erre irányuló indítvány esetén - akár csak részlegesen - megsemmisítse a Kat. 44. \$-át. Az ütközés feloldása

73 Ezzel ellentétes álláspontra és a jogalkotó részéről felmerülő értelmezési dilemmára lásd: Salgó, 2020, 15. o. A szerző szerint ellentétben állt egymással a nyelvtani és a jogdogmatikai értelmezés, és a jogalkotó az utóbbit követte. Az viszont nem derül ki a szerző gondolatmenetéből, hogy a 2-3. \$-ok miért minősülnének rendkívüli intézkedéseknek.

74 Hangsúlyozom, hogy a fenti megállapításaim nem általában vonják kétségbe a Kevtv.-t és az abban foglalt felhatalmazás létjogosultságát.

75 Tordai, 2020.

76 Salgó, 2020, 9. o.

77 A felülvizsgálat egyik eredménye a Kat. 2020. júniusi - a 21. jegyzetben említett - kiegészítése. 
során az alapkérdés az volt, hogy mit igazítunk mihez, hiszen a probléma mind a Kat., mind pedig az Alaptörvény módosításával kezelhető lenne. Álláspontunk szerint a Kat. tágabb (,inkluzívabb”) veszélyhelyzet-definíciója rugalmasabb reagálást tesz lehetôvé a kormányzat részére, így inkább az Alaptörvény 53. cikk (1) bekezdését lenne célszerủ módosítani.

2. Átgondolásra szorul az Alaptörvény 53. cikk (1)-(3) bekezdése, különösen a három bekezdés egymáshoz való viszonya. Az alkotmányozónak meg kell szüntetnie a Kormány sarkalatos törvényben meghatározott rendkívüli intézkedéseire való duplikált utalást.

3. A jövőben célszerủ lenne egyértelmủen elhatárolni egymástól a veszélyhelyzetet kihirdető, valamint a rendkívüli intézkedéseket bevezetô kormányrendeleteket, felszámolva ezzel a hibrid aktusokat. Mindez tisztább helyzetet teremtene a meghosszabbítás vonatkozásában is.

\section{A veszélyhelyzet korrekciója: az Alaptörvény kilencedik módosítása}

Amint a megelőző fejezetben bemutattuk, a jelen kötet kézirata lezárásának napján, 2020. december 15-én elfogadott kilencedik Alaptörvény-módosítás (a továbbiakban: Módosítás) gyökeresen átalakította az Alaptörvény különleges jogrendre vonatkozó szabályait. ${ }^{78}$ Tekintve, hogy a Módosítást az előző fejezetben részletesen elemeztük, e helyütt csak röviden reflektálunk a fentebb felvázolt javaslatok alkotmányozó általi „megfogadására”.

Elsőként azt kell leszögezni, hogy a veszélyhelyzet kihirdetésére okot adó körülmények a Módosítás nyomán immár nem kerülnek leszúkítésre az elemi csapásra és az ipari szerencsétlenségre, ugyanis ez a két eset csak példálózó módon jelenik meg: „A Kormány az élet- és vagyonbiztonságot veszélyeztető súlyos esemény - különösen elemi csapás vagy ipari szerencsétlenség - esetén, valamint ezek következményeinek az elhárítása érdekében veszélyhelyzetet hirdethet ki. ${ }^{79}$ Ezzel a Módosítás - mutat rá az indokolás - a veszélyhelyzet kihirdetését lehetővé teszi a jelenleg előre nem jelezhetô esetekben is. Ezzel a megoldással álláspontunk szerint elhárultak az Alaptörvény és a Kat. ütközésére hivatkozó aggályok.

Szintén megoldódik a veszélyhelyzet meghosszabbításával kapcsolatos problémák egy része, ugyanis a Módosítás értelmében magának a veszélyhelyzetnek a meghosszabbításához is szükség lesz az Országgyúlés felhatalmazására ${ }^{80}$ (a veszélyhelyzet maximális - meghosszabbítás nélküli - időtartama egyúttal 30 napra emelkedik). ${ }^{81}$ Fentebb utaltunk rá, hogy a jövőben célszerủ lenne egyértelmúen elhatárolni egymástól a veszélyhelyzetet kihirdető, valamint a rendkívüli intézkedéseket bevezető kormányrendeleteket, felszámolva

78 Magyarország Alaptörvényének kilencedik módosítása 11. cikk.

79 Új számozás szerinti 51. cikk (1) bekezdés.

80 Új számozás szerinti 51. cikk (3) bekezdés.

81 Új számozás szerinti 51. cikk (2) bekezdés. 
ezzel a hibrid aktusokat. A Módosítás tükrében ezen kifogás relevanciája csökkent, hiszen a jövőben már nem kizárólag a Kormánytól fog függeni, hogy meddig tart a veszélyhelyzet. Mindazonáltal fenntartjuk az álláspontunkat, hogy áttekinthetôbb és logikusabb lenne, ha a későbbiekben elkülönülnének egymástól a veszélyhelyzetet kihirdetô, illetve a további (rendkívüli) intézkedéseket tartalmazó kormányrendeletek.

Ami a Kormány rendkívüli intézkedéseire való duplikált utalást illeti, a fentebb kifejtett következetlenségek is megszúnnek, ugyanis a Módosításnak az Országgyưlés által elfogadott változata - szemben a javaslat eredeti szövegváltozatával ${ }^{82}$ - a veszélyhelyzetről szóló rendelkezések között - álláspontunk szerint helyesen - már nem tartalmazza, hogy a Kormány „sarkalatos törvényben meghatározott rendkívüli intézkedéseket vezethet be”. ${ }^{83}$ Ez felesleges is lenne, hiszen a Módosítás nyomán az Alaptörvény immár általános hatállyal, valamennyi különleges jogrendre vonatkozóan rögzíti, hogy „[a] Kormány különleges jogrendben rendeletet alkothat, amellyel - sarkalatos törvényben meghatározottak szerint egyes törvények alkalmazását felfüggesztheti, törvényi rendelkezésektől eltérhet, valamint egyéb rendkívüli intézkedéseket hozhat". ${ }^{84}$

Összességében tehát úgy véljük, hogy a veszélyhelyzetre vonatkozó alaptörvényi szabályozás korrekciói több szempontból is előrelépést jelentenek, azonban az is hangsúlyozandó, hogy a különleges jogrendi módosítások csak 2023. július 1-jén lépnek hatályba, így a fejezetben jelzett problémák a gyakorlatban továbbra is fennállnak.

\section{Irodalomjegyzék}

BALÁZs, I., HOFFMAN, I. (2020) 'Közigazgatás és koronavírus - a közigazgatási jog rezilienciája vagy annak bukása?', Közjogi Szemle, 13(3), 1-10. o.

DósA, Á., HANTI, P., KovÁCSY, Zs. (2016) Kommentár az egészségügyről szóló 1997. évi CLIV. törvényhez. 1. kiadás. Budapest: Wolters Kluwer

HojnYÁk, D., UngVáRI, Á. (2020) 'Az Európai Unió egyes tagállamainak koronavírusjárványra adott válasza, különös tekintettel a vizsgált államok által bevezetett különleges jogrendi szabályozásra', Miskolci Jogi Szemle, 15(1), 122-138. o.

82 Lásd a T/13647. számú törvényjavaslatot Magyarország Alaptörvényének kilencedik módosításáról. Elérhető: www.parlament.hu/irom41/13647/13647.pdf (Letöltve: 2020. november 10.). A törvényjavaslat 11. cikke értelmében az Alaptörvény 51. cikk (1) bekezdés helyébe a következő rendelkezés lépett volna: „A Kormány az életés vagyonbiztonságot veszélyeztető súlyos esemény - különösen elemi csapás vagy ipari szerencsétlenség esetén, valamint ezek következményeinek az elhárítása érdekében veszélyhelyzetet hirdethet ki, és sarkalatos törvényben meghatározott rendkivüli intézkedéseket vezethet be." (A kurzivált szövegrész a későbbiekben törlésre került.).

83 Új számozás szerinti 51 . cikk (1) bekezdés.

84 Új számozás szerinti 53. cikk (1) bekezdés. 
LatTmann, T. (2020) Vajon „elemi csapás” egy járvány, van-e alaptörvényi alapja a veszélyhelyzet kihirdetésének? [Online]. Elérhető: https:/lattmanntamas.hu/2020/03/11/vajon-elemicsapas-egy-jarvany-van-e-alaptorvenyi-alapja-a-veszelyhelyzet-kihirdetesenek/ (Letöltve: 2020. november 10.)

MÉszÁros, G. (2019) 'Indokolt-e a különleges jogrend koronavírus idején? Avagy a 40/2020. (III. 11.) Korm. rendelettel összefüggő alkotmányjogi kérdésekről', Fundamentum, 2019/3-4, 63-72. o.

ORBÁN, B. (2020) A járvány vége sajnos egyelóre nem látszik [Online]. Elérhető: https://index. $\mathrm{hu} /$ velemeny/2020/03/22/orban_balazs_miniszterelnokseg_velemeny_veszelyhelyzet_ meghosszabbitasa_felhatalmazas_orszaggyules/ (Letöltve: 2020. október 5.)

SALGó, L. P. (2020) 'A hazai veszélyhelyzeti jogalkotás a kodifikátor szemével', Fontes Iuris, $6(2), 8-18.0$.

SCHIFFER, A. (2020) Különleges jogbizonytalanság [Online]. Elérhető: https:/hvg.hu/itthon/ 20200313_schiffer_kulonleges_jogbizonytalansag_veszelyhelyzet_alkotmanyellenes (Letöltve: 2020. december 2.)

SZENTE, Z. (2020) 'A 2020. március 11-én kihirdetett veszélyhelyzet alkotmányossági problémái', Állam-és Jogtudomány, 61(3), 115-139. o.

TilL, Sz. (2019) 'Különleges jogrend' in Jakab, A., Fekete, B. (szerk.) Internetes Jogtudományi Enciklopédia [Online]. Elérhető: http://ijoten.hu/szocikk/kulonleges-jogrend (Letöltve: 2020. november 16.)

TORDAI, Cs. (2020) A közjog határai a járványveszély idején [Online]. Elérhető: https:// igyirnankmi.atlatszo.hu/2020/03/16/a-kozjog-hatarai-a-jarvanyveszely-idejen/ (Letöltve: 2020. október 5.) 


\title{
7. Fiskális és monetáris eszközök a járványügyi veszélyhelyzet gazdasági hatásainak mérséklésére
}

\author{
NAGY ZOLTÁN
}

\section{Bevezető gondolatok}

A vírusjárvány miatt bevezetett kormányzati intézkedések, illetve a járványtól való félelem komoly gazdasági kihívások elé állították a világgazdaságot, így a magyar gazdaságot is. A következmények csak kalkulálhatók, mivel a könyv és a fejezet elkészítése alatt még folyamatban van a különleges jogrend, a járványügyi intézkedések. A gazdasági válságok nem jelentenek újdonságot a kutatók számára, de a jelenlegi válság, annak kialakulása és ezzel összefüggő hatása újszerú a gazdaságtörténetben, talán a háborús helyzethez hasonlítható leginkább. ${ }^{1}$ A legnagyobb kihívást a helyzet kezelése jelenti, hiszen a járványügyi veszélyhelyzet komoly gazdasági és társadalmi károkat okoz. Tulajdonképpen nem lehet tökéletes döntést hozni, csak kevésbé rosszat. A különleges jogrendi korlátozó intézkedések csökkentik a vírus terjedését, az egészségügyi ellátórendszer terheltségét, de emellett komoly gazdasági károkat okoznak, és ennek is vannak társadalmi, egészségügyi hatásai. A gazdasági válság önmagában nem kezelhető különleges jogrendként, de a különleges jogrendi válságkeze-

1 Hasonló álláspontra lásd: Kádár, 2021.

Prof. Dr. Nagy Zoltán, PhD

zoltan.nagy@mfi.gov.hu

főosztályvezető (Mádl Ferenc Összehasonlító Jogi Intézet)

egyetemi tanár (Miskolci Egyetem Állam- és Jogtudományi Kar, Államtudományi Intézet, Pénzügyi Jogi Tanszék)

Nagy, Z. (2021) 'Fiskális és monetáris eszközök a járványügyi veszélyhelyzet gazdasági hatásainak mérséklésére' in Nagy, Z., Horváth, A. (szerk.) A különleges jogrend és nemzeti szabályozási modelljei, 174-191. o. Budapest: Mádl Ferenc Összehasonlító Jogi Intézet.

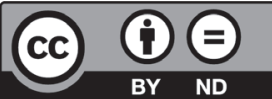


lésnek van gazdasági válságkezelési kimenete. ${ }^{2}$ Mindenesetre a kormányok politikájában kifejezésre jutott a gazdasági érvek mellett az emberi élet védelme, azaz a járvány esetén elsődleges a vírus elleni védekezés, és csak ezt követi a gazdasági hatások mérséklése, amit a fejlett országokban lehetôvé tesz a kiépített szociális háló. Azonban a fejlődő országokban a gazdasági válság emberéleteket követelhet. A szakirodalmi becslések alapján a válság miatt duplájára növekedhet az akut éhezéstől szenvedők száma. ${ }^{3}$

Miben tér el ez a válság a korábbi válságoktól? A gazdaság soha sincs nyugvó állapotban, hanem mindig változik, gazdasági növekedés vagy visszaesés ciklusában van. A konjunktúraciklus-elméletek szerint azonban a kiváltó okok eltérőek lehetnek, exogén és endogén magyarázatok jelentőségére egyaránt rámutat a közgazdaságtan. A jelenlegi válságot egyértelmủen külső, gazdaságon kívüli tényező váltotta ki, a koronavírus-járvány. ${ }^{4}$ Ez egyedi az eddigi modern gazdaságtörténetben, viszont magán hordozza a gazdasági válságok jó néhány közös jellemzőjét. A beruházások visszaesnek, a fogyasztási kiadásokat visszafogják, nő a munkanélküliség, csökken a kibocsátás, esik a GDP. ${ }^{5}$ Mindezek a hatások azonban eltérően érinthetik az egyes országokat attól függően, hogy milyen gazdasági, társadalmi állapotban vannak, mennyire sérülékeny a gazdaságuk, amire jó példaként hozható az előző, 2008-as gazdasági válság. ${ }^{6}$ Azonban a jelenlegi gazdasági válságnál a szakirodalom arra mutatott rá, hogy rövid távon ezek nem magyarázzák a krízis hatásait, és a válság kimenetelére sem adnak megoldást. ${ }^{7}$ Jól látható tehát, hogy ez a krízis más jellemzőkkel bír, így új kihívások eléállította a gazdaságpolitikát. A járvány miatt bevezetett kormányzati korlátozó intézkedések indították el a kereslet visszafogását, és egyben kínálati korlátozást is okoztak a gazdaságban. A keresleti és kínálati sokk együtt jelentkezett. A fogyasztás és a kibocsátás elé állított adminisztratív korlátok és a járvány miatt jelentkező óvatosság egyaránt éreztette hatását, ${ }^{8}$ azonban eltérő mértékben jelentkezett a gazdaság egyes területein. ${ }^{9}$ Azokban az országokban, ahol például a turizmus, az idegenforgalom a nemzetgazdaság jelentős

2 Vö.: Alaptörvény 36. cikk (6) bekezdés.

3 Botos, 2020, 385-388. o. A szerző rámutat arra, hogy a fejlődő országokban előfordulhat az a helyzet, hogy a válság okozta munkanélküliség miatt éhen is halhatnak az emberek. Erre vannak gazdaságtörténeti példák is, mint az 1930-as években a gazdasági válság idején. A jelenlegi válság kapcsán a becslések szerint $420-$ 580 millió ember kerülhet mélyszegénységbe.

4 Samuelson-Nordhaus, 2012, 389-391. o. A szerzők rámutatnak, hogy ilyen külső tényező lehet a háború, a forradalom, a népességmozgás és akár a tudományos innovációk is.

5 Samuelson-Nordhaus, 2012, 388-389. o.

6 Nagy, 2019, 5-6. o.

7 Czeczeli et al., 2020, 323. o.

8 Koppány, 2020, 449. 0.

9 Terták-Kovács, 2020, 369-370. o. A koronavírus-járvány okozta veszélyhelyzeti intézkedések eltérő mértékben sújtották az egyes ágazatokat. A szerzők rámutatnak arra, hogy a legnagyobb veszteséget a szállás, vendéglátás, szállítás és kiskereskedelem szenvedte el az ipar és a szabadidős, művészeti és egyéb szolgáltatások mellett. 
részét teszi ki, a válság erôteljesebb. ${ }^{10} \mathrm{~A}$ gazdaságpolitikának tehát a válságból való kilábalás megoldásait ennek megfelelően kell kiválasztania. ${ }^{11}$

A közgazdaság-tudomány különböző irányzatai között jelentős vita van a kormányzati beavatkozásról. ${ }^{12} \mathrm{~A}$ modern vegyes gazdaságban a kormányzati szektor szerepe jelentős, de ennek mértékéról, a piaci kudarcok orvoslásáról napjainkban is folyik a vita. A piaci kudarcok mellett a kormányzati beavatkozás kudarcát is ismeri a szakirodalom. ${ }^{13} \mathrm{~A} 2008$-as gazdasági válság megoldásában erőteljes szerepet játszottak a fiskális és monetáris politika eszközei, ami alapján a jelenlegi kormányok is megpróbálják ezt a válságkezelési módszert alkalmazni, nem várva meg a piac önszabályozó mechanizmusainak az érvényesülését. ${ }^{14}$

A 2008-as gazdasági válság jelentős kihívás volt a Gazdasági és Monetáris Unió akkor múködő mechanizmusaival szemben. Az uniós válságkezelésben egyrészt kiemelkedő szerepet töltöttek be az Európai Központi Bank likviditásnövelő, mennyiségi lazítást eredményező intézkedései, különösen az eszközvásárlási programok. Másrészt lényeges rövid távú, illetve tartós, rendszerszintú intézkedések történtek az európai gazdasági kormányzás rendszerében. Jellemzően kormányközi szerződések révén a makrogazdasági stabilitást előmozdító preventív és kiigazító mechanizmusok kerültek kiépítésre. ${ }^{15}$

Ugyanakkor az uniós költségvetés közvetlen válságkezelésre (stabilizációs funkció teljesítésére) alapvetó strukturális és funkcionális tényezők miatt volt képes. ${ }^{16} \mathrm{~A}$ közös költségvetés definitív módon kiegyensúlyozott, annyit költ az unió, amennyi bevétele van a tagállami és közös forrásokból. ${ }^{17}$ Ezért a fiskális politika területén a tagállamoknak elsősorban maguknak kellett szembenézniük a recesszióval. Az egyes tagállamok rendkívül eltérő államháztartási pozíciói eltérő fiskális impulzusokra adtak lehetőséget. Mindezek nagymértékben növelték az egyes tagállamok közötti diverzitásokat.

A jelenlegi helyzetben az Európai Unió tagállamai érzékelték a válság súlyosságát. Még nincsenek végleges számok, csak várható előrejelzések, de ezek súlyos gazdasági visszaesést

10 A gazdaság több területére a korlátozó szabályok sokkszerúen hatottak. A légitársaságok, az idegenforgalomhoz kapcsolódó vendéglátás és szállodaipar, a színházak, mozik, koncertek, rendezvények szervezése a teljes korlátozó szabályokkal szembesült. Ugyanakkor a gazdaság ilyen területeihez kapcsolódó szektoroknak egyaránt csökkenő kereslettel kellett számolniuk.

11 Muraközy, 2012, 21-44. o.

12 Muraközy, 2010, 794-795. o.

13 Stiglitz, 2000, 25-35. o.

14 Bessenyei, 2020, 181-185. o.

15 Szegedi, 2019, 101. o. Az Európai Unió a válságot követő évtizedben teljesen átalakította a pénzpiacok európai felügyeleti rendszerét, majd hozzákezdett az Európai Bankunió kialakításához, a szanálási mechanizmusok és a betétbiztosítási rendszer teljes reformjához. A válság közgazdasági kérdéseiről lásd bővebben: Halmai, 2014; Halmai, 2020a, 277-282. o.; Halmai, 2020b, 259-275. o.

16 Halmai, 2020a, 20-53. o.

17 Halász, 2018, 50-54. o., 149. o. A szerző kiemeli, hogy az uniós költségvetésben a bevételeknek és a kiadásoknak egyensúlyban kellett lenniük, így nem tervezhető hiány és többlet sem. Ha mégis felmerül hiány, annak kölcsönnel történő fedezésére költségvetési módosítást kell készíteni. A szabályozás szerint elkerülhetetlen, kivételes vagy előre nem látható körülmények felmerülése esetén terjeszthet elő az Európai Bizottság költségvetés-módosítást. 
jeleznek annak függvényében, hogy ezek az előrejelzések a júniusi járványhelyzet alapján készültek, és még nem számoltak a járványhelyzet második hullámával. ${ }^{18} \mathrm{~A}$ jelenlegi helyzetben azonban még a járvány terjedő narratíváival is számolni kell, amelyek hatással vannak a pandémia kezelése mellett a gazdasági eszközök hatékony érvényesülésére. ${ }^{19} \mathrm{~A}$ járványra az első azonnali reakció 2020-ban az elkerülhetetlen korlátozó intézkedések meghozatala volt. A rendkívüli jogrend bevezetése a bezárkózást hozta el a tagállamok számára, de globálisan is gyengítette a nemzetközi együttmúködést.

Költségvetési szempontból sajátos helyzet alakult ki, mivel az uniós költségvetési időszak végét jelenti 2020, így az uniós költségvetésből csak kisebb mértékű források állnak rendelkezésre. ${ }^{20} \mathrm{Az}$ első sokk után azonban már az EU is reagált a járvány gazdasági hatásainak mérséklésére. ${ }^{21} \mathrm{~A}$ legnagyobb lépést azonban az unió közös kötelezettségvállalása jelentette, amelynek keretében az EU vesz fel hitelt, és így biztosít forrást a tagállamok számára, amire eddig nem volt példa. ${ }^{22} \mathrm{Ez}$ a gazdasági integráció irányába tett lépésként is értékelhető, hiszen a tagállamok gazdasági szolidaritást vállalnak egymásért úgy, hogy közösen vesznek fel hitelt és vállalják annak visszafizetését. ${ }^{23}$

\section{A magyar fiskális politika a járványügyi veszélyhelyzetben}

A fiskális politika folyamataira hatással van a gazdasági válság, illetve a költségvetési politika is hatással van a válságra, így az állam gazdasági szabályozó szerepe felértékelődik. A gazdaságpolitika fontos célkitúzése az alacsony mértékú munkanélküliség, a gazdasági növekedés, a stabil, alacsony infláció. ${ }^{24}$ Ezeket a célokat szem elôtt tartva kezelik a kormányok a válság következményeit, illetve még folyamatában csökkentik a válság gazdaságra mért káros hatásait. A fiskális politika eszközrendszere a költségvetés szabályrendszeréhez

18 Jackson et al., 2020, 5-13. o. A kutatás az euróövezetben az OECD előrejelzése alapján 2020-ra 9,1\%-os, az IMF alapján 7,5\%-os, a Világbank alapján szintén 9,1\%-os gazdasági visszaesést vár a GDP-hez viszonyítva. Az Európai Bizottság az euróövezetre 7,7\%-os, a teljes EU-ra 7,4\%-os gazdasági visszaesést prognosztizál.

19 Shiller, 2020, 9-21. o. A narratív közgazdaságtan részletesen elemzi, hogy a közhiedelmek milyen szerepet játszanak a gazdasági eseményekben. A gazdasági válságok és maga a járvány is létrehoz történeteket, amelyek vírusként terjednek és befolyásolják a gazdasági döntéseket.

20 Szíjártó, 2020, 1-13. 0.

21 Balázs, 2020, 5-8. o. A szerző rámutat, hogy a válság gazdasági hatásainak mérséklésére feloldották a költségvetési hiányra és az állami támogatásokra vonatkozó korlátozó szabályokat, továbbá 37 milliárd eurót átcsoportosítottak a strukturális alapból a vírus elleni védekezésre. Az Európai Beruházási Bank 200 milliárd euró keretösszegben kínál beruházási hiteleket, az Európai Bizottság 100 milliárd eurós munkabért támogató alapot hozott létre a tavaszi időszakban.

22 Csürös, 2015, 122-155. o.

23 Botos, 2020, 392-395. o. Az Európai Unió 750 milliárd eurós keretet fogadott el, amelynek egy része támogatás formájában kerül folyósításra (390 milliárd euró), míg a másik része hitellehetőséget biztosít a tagállamok számára (360 milliárd euró).

24 Samuelson-Nordhaus, 2012, 570. o. 
kapcsolódva hat a gazdaságra. Az eszközöket többféle aspektusból lehet megközelíteni, beszélhetünk közvetett és közvetlen eszközökrőll25 vagy a költségvetés bevételeire és kiadásaira ható eszközökról egyaránt.

A gazdasági válság következtében a költségvetési politika kettős kihívás elé került mind a bevételi, mind a kiadási oldal tekintetében, így az ennek orvoslásához kapcsolódó eszközöket a két szegmens vizsgálatával kell bemutatni. A válság következtében a bevételi oldalon számolni kell többek között a csökkenő adóbevételekkel, a munkanélküliség növekedésével, a fogyasztás visszaesésével az elmaradó beruházások miatt. A kiadási oldalon a támogatások növelése miatt a kiadások növekedésével kell számolni. Ugyanakkor az átcsoportosítások, szerkezeti változások átstrukturálják a költségvetést, ami a költségvetési törvény módosításában ölt testet. A magyar fiskális politika 2008-tól kezdődően célként túzi ki a takarékos állami gazdálkodást és a felelős költségvetési politikát. A költségvetési politika alapvető célja lett az államadósság hosszú távon fenntartható szintjének az elérése, amit a költségvetési politika az egyensúlyközeli állapotának hosszú távú biztosítása révén kíván biztosítani, azaz a fiskális politika legfőbb meghatározója az államadósság stabilizálása volt. ${ }^{26} \mathrm{Az}$ államadóssággal pedig összefügg a költségvetési hiány, mivel főszabályként az államadósság a hiány finanszírozása révén keletkezik. ${ }^{27} \mathrm{~A}$ költségvetési fegyelem erősítése szükségszerü lépés volt, mert az államadósság szintje folyamatosan nőtt a jelentős mértékú államháztartási hiány miatt. ${ }^{28}$

A költségvetési hiány mértékét az uniós jog, a maastrichti szerződés a konvergenciakritériumok meghatározásával szabályozza. A fenntartható államháztartási gazdálkodás egyik fontos feltétele, hogy az államháztartás éves hiánya ne haladja meg a GDP 3\%-át. Ha egy uniós ország nem teljesíti a feltételeket, akkor túlzottdeficit-eljárás indul ellene. Magyarország az Európai Unióba való belépése, azaz 2004 óta túlzottdeficit-eljárás alatt állt 2013-ig, amely évben megszűnt az eljárás. Ennek alapját a két éven keresztül megvalósuló, illetve a további évekre is valószínúsített $3 \%$ alatti költségvetési hiány teremtette meg. ${ }^{29}$

Az államadósság rendszerbeli jelentőségét indokolja az alaptörvényi szabályozás, illetve a költségvetési eljárási rendben az adósságszabály érvényesülése, azaz a gazdálkodás egészét átfogja az a cél, hogy az államadósság folyamatosan csökkenjen, de legalább ne emelkedjen, és hosszabb távon az optimális adósságmérték elérhető legyen (GDP 50\%-a). Tehát a fiskális politika központi jogintézménye lett az államadósság-szabály. ${ }^{30} \mathrm{Az}$ államadósság-szabályra

25 Simon, 2019, 31-32. o. A szerző a közvetlen eszközök alatt a költségvetéshez kapcsolódó konkrét döntést jelent, míg a közvetett eszközök külön egyedi beavatkozás nélkül fejtik ki a hatásukat, mint például az adók.

26 A takarékos állami gazdálkodásról és a költségvetési felelősségről szóló 2008. évi LXXV. törvény. A törvény bevezető rendelkezései elvárásként fogalmazzák meg a fegyelmezett, átlátható és hosszú távon fenntartható költségvetési politika megteremtését és folytatását a hosszú távú gazdasági versenyképesség biztosítása mellett.

27 Vígvári, 2005, 175-178. o.

28 Sivák-Szemlér-Vígvári, 2013, 49-51. o. 2006-ban az államháztartási hiány mértéke a GDP 9,4\%-a volt.

29 Sivák-Szemlér-Vígvári, 2013, 61. o.

30 Kovács, 2016, 320-326. o. 
vonatkozó rendelkezéseket az Alaptörvény mellett a stabilitási törvény fejti ki részletesen. ${ }^{31}$ A szabály lényege, hogy a fenntartható államháztartási gazdálkodás és a jövő nemzedékekért vállalt felelősség érdekében az Országgyúlés olyan költségvetési törvényt fogadhat el, amelynek eredményeképpen az államadósság nem haladja meg a teljes hazai össztermék felét, azaz az Alaptörvény által meghatározott optimális államadósság mértékét. Ez általános alapelvnek is tekinthető. ${ }^{32} \mathrm{Az}$ alapelv azért tekinthetó általánosnak - ahogy az indokolás utal rá -, mivel az alapvető jogok érvényesülése, az állam hatékony múködése csak akkor garantálható, ha az ország társadalmi, gazdasági egyensúlyát államháztartási problémák nem veszélyeztetik. ${ }^{33}$ Ezért a költségvetési gazdálkodás, a költségvetési tervezés alapvető általános elve, hogy Magyarország a kiegyensúlyozott, átlátható és fenntartható költségvetési gazdálkodás elvét érvényesíti, amelyet az államháztartás mindkét alrendszerében múködő valamennyi szerv köteles tiszteletben tartani. A kiegyensúlyozottság a kiszámítható állami múködést, az átláthatóság a tájékozott és felelős polgárok részvételével zajló demokratikus közéletet, a fenntarthatóság a jövő nemzedékek sorsáért való felelősségvállalást hivatott szolgálni. ${ }^{34} \mathrm{~A}$ fenntartható államháztartási gazdálkodás többféle pénzügyi elvet ölel fel, de különös jelentősége a korábban említett államadósság-szabálynak van. ${ }^{35}$

Jelenleg azonban az államadósság ezt a mértéket jelentősen meghaladja, ezért az optimális államadósság eléréséig az Országgyûlésnek az államadósság csökkentésére irányuló költségvetést kell elfogadnia. ${ }^{36}$ Nyilvánvalóan az államháztartási gazdálkodásra ható tényezőkben olyan kivételes helyzetek, elháríthatatlan külső okból származó súlyos problémák keletkezhetnek, amelyek orvoslása kapcsán a szigorú szabályoktól eltérést enged az Alaptörvény (nemzetgazdaság tartós visszaesése, nemzetgazdasági egyensúly helyreállítása). A gazdasági válságra utaló szabályt a stabilitási törvény értelmezi kiterjesztő jelleggel, mivel kimondja, hogy a nemzetgazdaság tartós és jelentős visszaeséseként kell értelmezni minden olyan esetet, amikor az éves bruttó hazai termék reálértéke csökken. Ebben az esetben a stabilitási törvény megengedi, hogy a kormányzati szektor hiánya meghaladja a bruttó hazai termék 3\%-át, illetve azt, hogy az államadósság mutatója csökkenjen. ${ }^{37}$ A járvány következtében kialakult gazdasági válság tehát indokolja az államadósság-szabálytól való eltérést. Az államadósság növekedése a gazdasági válság esetén természetes folyamat, hiszen az állam túlköltekezése, a támogatások növelik a költségvetési hiányt. A hiány nagyságánál fontosabb a pluszforrások hasznosulása, hiszen ha a költségvetési pénzek elköltése haté-

31 Alaptörvény 36. cikk (4)-(5) bekezdés; Magyarország gazdasági stabilitásáról szóló 2011. évi CXCIV. törvény (a továbbiakban: Gst.) 2-10/F. \$.

32 Alaptörvény $\mathrm{N}$ ) cikk.

33 Nagy, 2014b, 5. o.

34 Drinóczi, 2012, 2-6. o.

35 Barcza, 2015, 444-447. o. A szerző rámutat arra, hogy a közgazdasági elméletek eltérően ítélik meg az optimális államadósság mértékét.

36 Nagy, 2014a, 12. o.

37 Gst. 7. \$. 
konyan történik, akkor az nemcsak a válságból való kilábalást alapozza meg, hanem a jövőbeni gazdasági növekedést is. ${ }^{38}$

A GDP jelentôs csökkenése és a nemzetgazdasági egyensúly helyreállítása egyaránt növelik az államadósságot, mivel az államadósság-mutató a GDP-hez van kötve, önmagában a GDP esése növeli az államadósság mértékét anélkül, hogy a költségvetési hiány változna. A költségvetést a válság érintheti a bevételi oldalról a bevételek elmaradása miatt, és érintheti kiadási oldalról a központi költségvetési támogatások növelése kapcsán.

A központi költségvetés kedvezőtlen alakulására az államháztartási törvény a rendkívüli intézkedések körében ad megoldást, amelynek célja az év közben meghozott kormányzati feladatok megvalósítása és a kiegyensúlyozott költségvetési gazdálkodás fenntartása. A korábbi szabályozást egészíti ki a jogalkotó az átmeneti intézkedésekkel, amelyek a veszélyhelyzettel vannak összefüggésben. A jogalkotó széles körú jogosítványokkal ruházza fel a Kormányt: a költségvetési törvényben nem szereplő költségvetési kiadásokat teljesíthet, illetve rendkívüli fizetési kötelezettséget írhat elő. A különleges jogrendre vonatkozó rendelkezés enyhíti a közterhek szabályozását, azaz el lehet térni a fizetési kötelezettségeket megállapító szigorú eljárási és anyagi jellegú szabályoktól, amelynek mértékét a gazdasági visszaesés és az egyensúly helyreállításához szükséges mértékben határozza meg a törvény. ${ }^{39}$ A szükséges mérték megitélése vitára adhat okot, mivel eddig még ismeretlen, az egész országot érintő veszélyhelyzetről van szó. A szakirodalmi álláspont is rámutat arra, hogy más szükségességi és arányossági mércét kell használni az eltérő gazdasági és élethelyzet miatt. A szükséges mérték megítélése nagyon nehéz, hiszen csak a válságot követően lehet megítélni, hogy a szabályoktól való eltérés szükséges volt-e. Kérdés tehát, hogy veszélyhelyzetben mit kell ez alatt érteni. ${ }^{40} \mathrm{~A}$ jogalkotó az Alaptörvény szabályozásában tekintettel van a veszélyhelyzetre, mivel kimondja, hogy különleges jogrendben az alapjogok a szükségesség és arányosság mértékét meghaladóan korlátozhatók. ${ }^{41}$ Minden válság más, ezért a megoldásokat nehéz a jog patikamérlegével adagolni. Ha a válság kezelése sikeres, akkor a választások során a kormány munkáját a választók ítélik meg, akik egyébként elszenvedik a válság negatív hatásait. A gazdasági eszközök túlzott törvényi mértékủ korlátozása akadályozhatja a kormányt a hatékony válságkezelésben. Erre mutat rá a koronavírus-járvány elleni véde-

38 Gazdasági válság 2020: A modern monetáris elmélet lesz a megoldás? Elérhető: https://elemzeskozpont.hu/ gazdasagi-valsag-2021-modern-monetaris-elmelet-lesz-megoldas (Letöltve: 2020. december 15.). A tanulmány rámutat arra, hogy van jó és rossz államadósság. Ha az állam a forrásokat beruházásra, gazdasági növekedésre vagy a jövőbeni gazdasági növekedés megalapozására költi, akkor ez nem okoz gondot az államháztartási gazdálkodás számára.

39 Gst. 38/A. \$.

40 Salgó, 2020, 15-16. o.

41 Alaptörvény 54.cikk (1) bekezdés: „Különleges jogrendben az alapvető jogok gyakorlása - a II. és a III. cikkben, valamint a XXVIII. cikk (2)-(6) bekezdésében megállapított alapvető jogok kivételével - felfüggeszthető vagy az I. cikk (3) bekezdése szerinti mértéken túl korlátozható." 
kezés céljából hozott törvény is, amely megerősítette és kiterjesztette átmenetileg a Kormány rendkívüli intézkedési jogát. ${ }^{42}$

A fiskális eszközöket feloszthatjuk a költségvetés bevételi oldalát érintő adójogi eszközökre és a kiadási összegeket érintő támogatási eszközökre. Az eszközök egy része már 2020 során bevezetésre került, míg mások csak 2021-tôl lépnek hatályba, és csak ettől kezdődően éreztetik a hatásukat. A hatásmechanizmus tekintetében a támogatási eszközök hatnak gyorsabban a gazdaságra, míg az adójogiak csak hosszabb távon éreztetik a hatásukat a gazdasági szereplőknél néhány kivételtől eltekintve, mint például az új adónem bevezetése. A válság okozta gazdasági problémák szükségessé tették a 2020-as költségvetés módosítását. ${ }^{43} \mathrm{~A}$ gazdaságvédelmi intézkedések keretében a jogalkotó több ezer milliárd forintos nagyságrendben csoportosított át költségvetési előirányzatokat, amelyből két külön alapot hozott létre a költségvetésben, amelyet továbbvisz a 2021-es költségvetési évre a járványügyi kiadásokra és a gazdaságvédelemre. ${ }^{44}$ Ezt indokolja, hogy 2020-ban a járványügyi veszélyhelyzet nem szúnik meg, tehát annak hatása lesz 2021-ben is a gazdaságra és a költségvetésre egyaránt. A gazdasági prognózisok jelentős pozitív változást jeleznek a 2021-es gazdasági növekedésben, de az előrejelzések teljesülése függ attól, hogy meddig tart 2021-ben a járványügyi veszélyhelyzet. ${ }^{45}$ Jelenleg úgy tûnik, hogy 2021 első félévében még a veszélyhelyzet fogja uralni a társadalmat és a gazdaságot.

A Járvány Elleni Védekezési Alap a járványhelyzet kezelése céljából jött létre, amelynek forrása az Országvédelmi Alap beolvasztásából keletkező előirányzatok, továbbá kiemelendő két új adónem, a gépjármúadó átcsoportosítása, illetve a pártok támogatási összegének az 50\%-a. A két új adónem illeszkedik az adópolitikába abból a szempontból, hogy a kormány nem általános, az adóalanyok széles körét érintő adónemet vezetett be vagy növelte az adóterheket, hanem speciális, szektorális különadókat. A korábbi válság gyakorlatát követve különadót állapított meg a hitelintézetekre. ${ }^{46} \mathrm{Az}$ új adónem összefüggésben van a pénzügyi szervezeteket terheló különadóval, amelyet még 2006-ban a központi költségvetési egyensúly javítása érdekében hoztak, a közteherviselésben érvényesítendő szolidaritás jegyében. ${ }^{47} \mathrm{Az}$ új adó szúkebb adózói kört határoz meg, mivel a 2006-os szabály a pénzügyi szervezetekre terjed ki, addig az új szabály csak a hitelintézeti szektort érinti.

42 A koronavírus elleni védekezésról szóló 2020. évi XII. törvény. A törvény 2. \$-a kimondja, hogy a nemzetgazdaság stabilitásának garantálása érdekében a Kormány rendeletével egyes törvények alkalmazását felfüggesztheti, törvényi rendelkezésektől eltérhet és egyéb rendkívüli intézkedéseket hozhat.

43 Magyarország 2020. évi központi költségvetésének a veszélyhelyzettel összefüggő eltérő szabályairól szóló 92/2020. (IV. 6.) Korm. rendelet (a továbbiakban: Költségvetési r.).

44 Magyarország 2021. évi központi költségvetéséről szóló 2020. évi XC. törvény (a továbbiakban: 2021-es költségvetési tv.).

45 Jackson et al., 2020, 5-13. o. A különféle előrejelzések (IMF, World Bank, OECD) 2,8\% és 5,2\% közé teszik a gazdasági növekedést 2021-ben.

46 A Gazdaságvédelmi Akcióterv végrehajtása érdekében a Járványügyi Alap feltöltését szolgáló, hitelintézetek járványügyi helyzettel összefüggő különadójáról szóló 108/2020. (IV. 14.) Korm. rendelet.

47 Az államháztartás egyensúlyát javító különadóról és járadékról szóló 2006. évi LIX. törvény. 
Továbbá az új hitelintézeti különadó ideiglenes, 2020. évre szól, és lehetőség van 5 év alatt egyenlő részletekben elszámolni a korábbi pénzügyi szervezetek különadójával szemben. A másik új adónem, amely az alap feltöltésére szolgál, a kiskereskedelmi adó. ${ }^{48} \mathrm{Az}$ adónem elsődlegesen a nagyobb árbevételủ adózókat sújtja jobban. Az adó szintén határozott időre bevezetett különadó, mivel a veszélyhelyzet megszűnését követő 30 napig áll fenn. Az alap harmadik adójogi forrása a gépjármúadó, amelyet az önkormányzati bevételek közül von el a Kormány. A gépjármúadó 40\%-a illette meg az önkormányzatokat a 2020-as költségvetés alapján, amely a módosítás során teljes összegben a központi költségvetéshez került, az alap feltöltésére. ${ }^{49}$

A különleges jogrenddel összefüggésben létrejött másik - költségvetési szempontból jelentősebb - alap a Gazdaságvédelmi Alap. Ebbe az alapba kerültek átcsoportosításra az egyes minisztériumok megtakarított forrásai, illetve ide olvadt be a Nemzeti Foglalkoztatási Alap..$^{50} \mathrm{Az}$ alapba sok program került, jelentős pénzügyi forrásokkal. Az alap finanszírozza többek között az egyedi és általános térségfejlesztési programokat (Magyar Falu Program, Modern Városok Program), a közlekedésfejlesztési és az energia- és klímapolitikai fejlesztéseket, a versenyképességet növelő fejlesztéseket (egészségipari fejlesztések), a nagyvállalati beruházásokat, a sport-, kulturális és turisztikai beruházásokat. Az alapon belül elkülönített részként múködik a Gazdaságvédelmi Foglalkoztatási Alap.

A központi költségvetés alrendszerét érintő átcsoportosítások mellett az önkormányzati alrendszert érintő jogszabályi módosításokra egyaránt sor került. A módosítás célja kettős volt: egyrészt forrásátcsoportosítás a központi költségvetés számára, mint a gépjármúadóból származó bevétel, másrészt az önkormányzati díj- és adócsökkentés, amivel a vállalkozók és magánszemélyek részére nyújt a Kormány közvetett támogatást.

A helyi önkormányzati autonómia elengedhetetlen feltétele a gazdasági önállóság, amit az alkotmányos rendelkezések egyaránt alátámasztanak, és a Helyi Önkormányzatok Európai Chartája is megerősít..$^{51} \mathrm{~A}$ forrásszabályozás pedig szorosan összefügg a közfeladat-

48 A Gazdaságvédelmi Akcióterv végrehajtása érdekében a Járványügyi Alap feltöltését szolgáló kiskereskedelmi adóról szóló 109/2020. (IV.14.) Korm. rendelet. 500 millió árbevételig $\% \%$ az adó, csak ennél magasabb árbevétel esetén merül fel a sávosan változó adófizetési kötelezettség.

49 2021-es költségvetési tv. Az alap a 2021-es költségvetésben már az Egészségbiztosítási Alappal együtt szerepel mint Egészségbiztosítási és Járvány Elleni Védekezési Alap, de két külön címre osztva és elkülönítve szerepeltetve a két alapot.

50 Magyarország konvergenciaprogramja 2020-2024. Elérhető: https://ec.europa.eu/info/sites/info/files/2020european-semester-convergence-programme-hungary_hu.pdf (Letöltve: 2020. december 15.); www. portfolio.hu/gazdasag/20201226/szep-csendben-hatalmasra-hizott-a-magyar-gazdasagvedelmimentocsomag-463178 (Letöltve: 2020. december 15.). A Gazdaságvédelmi Alapba 2020-ban mintegy 1300 milliárd forint volt előirányozva, de ez mintegy 4000 milliárd forintra növekedett az év végére, ami a GDP 9\%-át teszi ki. 2021-ben 2600 milliárd forint felett rendelkezik az alap a költségvetési előirányzatok alapján. Az alapba tartozik a Gazdaságvédelmi Foglalkoztatási Alap, amely a Nemzeti Foglalkoztatási Alap helyébe lép.

51 Lentner, 2017, 136-137. o. 
ellátással. ${ }^{52} \mathrm{Az}$ állam ugyan fokozatosan átvett feladatokat az önkormányzatoktól, tehát centralizáció indult el ezen a területen, de alapvető közszolgáltatások még maradtak az önkormányzatoknál, amelyek finanszírozásához az önkormányzati saját bevételek nélkülözhetetlenek..$^{53}$ A veszélyhelyzet azonban felülírta ezeket az elveket, az állam törekszik a források központosítására, és a veszélyhelyzeti védekezésre és a gazdaságvédelemre átcsoportosítani ezeket. Ennek következtében viszont nehéz helyzetbe kerülhetnek az önkormányzatok, mivel nem biztos, hogy megfelelő színvonalon tudják ellátni a településüzemeltetési feladatokat, illetve a válság következtében fellépő szociális problémákkal is szembe kell nézniük. A Kormány ezt úgy próbálja orvosolni, hogy a hiányzó forrásokat visszapótolja a kisebb települések esetében automatikusan, míg a nagyvárosok esetében diszkrecionálisan, egyedileg megvizsgálva az önkormányzatok forráshiányát. Ezzel a Kormány egyfajta kiegyenlítő mechanizmust érvényesít, a jobb gazdasági helyzetben lévő önkormányzatoktól forrást von el, míg a rosszabb helyzetben lévő önkormányzatok számára forrást biztosít. Az biztos, hogy a gazdasági válság mély nyomot fog hagyni az állam és az önkormányzatok gazdálkodásában egyaránt.

Három fôbb, az önkormányzati gazdálkodást jelentős mértékben befolyásoló rendelkezésre került sor:

- gépjármúadó elvonása;

- iparüzési adó módosítása;

- díjak korlátozása.

A gépjármúadó elvont része a járványügyi alapba kerül a korábban említettek szerint, aminek következtében ideiglenesen megszűnik ennek a központi adónak a megosztása a központi és az önkormányzati államháztartási alrendszer között. ${ }^{54} \mathrm{~A}$ megosztás egyébként egyedileg kerül szabályozásra a mindenkori költségvetési törvényekben, és az arány is folyamatosan változott több év távlatában, de az utóbbi években a 40\%-os arány állandósult. Az önkormányzatok számára ez fontos forrás lehetne a válságos időkben is, mivel ez nem változik lényeges mértékben a válság hatására.

Az iparüzési adó azonban lényegesen nagyobb mértékben érinti a nagyobb településeket, különösen azokat, ahol jelentős vállalkozási tevékenységet végeznek, és ezt arányaiban a kis- és középvállalkozások folytatják. A forráselvonás szintén az önkormányzatok pénzügyi autonómiáját szúkíti átmenetileg, a járványügyi veszélyhelyzet idejére. ${ }^{55} \mathrm{~A} 2021$-es adóévre vonatkozóan az iparúzési adó mértéke 1\%-ra csökken a kis- és középvállalkozások

\footnotetext{
52 Horváth M.-Péteri-Vécsei, 2014, 121-123. o.

53 Horváth M., 2014, 185-188. o.

54 A Költségvetési r. kimondja, hogy a 2020. évi költségvetési törvénytől eltérően állapítja meg a gépjárműadó megosztását, és 2020. január elsejétől visszamenőleg a beszedett gépjármúadó teljes összege a központi költségvetést illeti meg.

55 Kecső-Tombor, 2020, 22-30. 0.
} 
számára, kivéve, ha ettől alacsonyabb mértékben került megállapításra az adó. Ebben az esetben az alacsonyabb kulcs az irányadó. ${ }^{56} \mathrm{Az}$ iparúzési adót érinti továbbá a különleges gazdasági övezetek létrehozása, mivel az adómegállapítási jogkör a települési önkormányzattól a megyei önkormányzathoz kerül, a települési önkormányzat részére az illetékességi területén fennálló iparúzésiadó-kötelezettség megszűnik. A különleges gazdasági övezetbe jelentős vállalkozások tartozhatnak, magas adóerő-képességgel, így források allokációjára kerülhet sor a települési és a megyei önkormányzat között. Azonban a törvény korlátozza és feltételhez köti a Kormány jogát az ilyen övezetek kijelölésére, a bevezető rendelkezések által meghatározott keretek mellett is. Utal a jogalkotó arra, hogy kiemelt jelentőséggel bíró területek esetében munkahelyek megőrzése és gazdasági tevékenységek kedvező körülményeinek megteremtése érdekében van lehetősége a Kormánynak ilyen övezet kijelölésére a korlátozó feltételek mellett..$^{57}$

A harmadik, az önkormányzati alrendszer gazdálkodását jelentősen érintő szabály a díjak korlátozása. ${ }^{58} \mathrm{~A}$ Kormány a gazdaságvédelmi intézkedések keretében 2021 . december 31-ig az önkormányzat és az önkormányzat által fenntartott, alapított szervezetek, gazdálkodó szervezetek közszolgáltatásra megállapított díját maximálta, a díjemelést, új díj bevezetését, a díj új kötelezetti körre való kiterjesztését megtiltotta. A rendelkezés tehát mérsékli a vállalkozók és a lakosság terheit, de ugyanakkor az önkormányzatok forrásbővitését is korlátozza.

A fentieken túl általában a gazdasági válság kezelésével összefüggésben hozott szabályok és intézkedések több területre bonthatók: $:^{59}$

- munkahelymegőrzés és munkahelyteremtés;

— kiemelt ágazatok és hazai vállalkozások támogatása;

- családok támogatása;

- ellátásbiztonság fenntartása.

A munkahelyek megőrzése, illetve új munkahelyek teremtése kiemelt feladatként fogalmazódott meg a kormányprogramban. A keresletcsökkenés következtében a munkavállalók elbocsátásokra, illetve a munkaidő csökkentésére kényszerülnek. A Kormány támogatást vezetett be a rövidített munkaidő esetén a kieső munkaidőre eső nettó bérrész 70\%-áig. Továbbá a kiemelt ágazatokban nem kell munkáltatói járulékot fizetni, a munkavállalók járuléka csökken, így a nyugdíjárulék fizetésére sem kerül sor, az egészségbiztosítási díj pedig

56 639/2020. (XII. 22.) Korm. rendelet a koronavírus-világjárvány nemzetgazdaságot érintő hatásának enyhítése érdekében szükséges egyes intézkedésekről. A rendelet az 1990. évi C. törvény szerinti vállalkozót, adóalanyt érinti, amely a 2004. évi XXXIV. törvény szerint kis- és középvállakozásnak minősül, és a nettó árbevétele nem haladja meg a 4 milliárd forintot.

57 A gazdasági övezetről és a hozzá kapcsolódó egyes törvények módosításáról szóló 2020. évi LIX. törvény 1. \$.

58 Vígvári, 2002, 177. o.

59 Magyarország konvergenciaprogramja 2020-2024. Elérhető: https://ec.europa.eu/info/sites/info/files/2020european-semester-convergence-programme-hungary_hu.pdf(Letöltve: 2020. december 15.). 
a törvényi minimumra csökken. A szociális hozzájárulási adó 2\%-os csökkentése szintén a foglalkoztatást segíti elő, mint az adókönnyítések. Speciális fizetési könnyítések és adómérséklési lehetőségek állnak rendelkezésre a munkáltatók számára, mint például a munkaerőpiaci járulék átmeneti eltörlése. Egyes kiemelt ágazatokban tevékenykedő vállalkozók (többek között turizmus és vendéglátás, egészségipar, élelmiszeripar) számára adókönnyítéseket és adóelengedést alkalmaz a Kormány (a kisadózó vállalkozások és kisvállalati adó szerint adózók esetében). ${ }^{60} \mathrm{~A}$ munkahelyteremtés érdekében a beruházások és a technológiai fejlesztés támogatása került elótérbe. Kiemelt ágazat a környezetvédelem mellett a jövőbeni fejlődés előtt álló iparágak, mint például a mesterséges intelligencia, a kvantumtechnológia, de idesorolhatók azok az ágazatok is, amelyeket fokozottan érintett a gazdasági válság. A humánerőforrás biztosítása érdekében pedig az átképzéshez, továbbképzéshez biztosítanak támogatást az egyes programok. A családok számára a lakásberuházások támogatása mellett hiteltörlesztési moratórium biztosított, továbbá a lejáró gyes-, gyed-, gyet-ellátások meghosszabbításra kerülnek a veszélyhelyzet idejére.

A támogatáspolitika tehát a munkahelyek megtartására koncentrál rövid távon, de nem növeli a munkanélküliek ellátását. Ez az utóbbi évek gazdaságpolitikájának a következetes folytatása, amely a foglalkoztatás növelését tekinti fontos szempontnak, és kevésbé koncentrál az álláskeresőkre. Az utóbbi évek munkaerőhiánya ezt indokolta is, de a gazdasági válság okozta sokkhelyzetben célszerû́ lenne legalább átmeneti időre növelni a munkanélküli ellátások mértékét és idejét egyaránt.

A veszélyhelyzetben kiemelt jelentősége van a közszolgáltatások zökkenőmentes biztosításának, ső́t a társadalmi érdek érvényesítése során egyes gazdálkodó szervezetek múködése állami felügyelet alá vonható. Azoknál a közszolgáltatásoknál, amelyek állami vagy önkormányzati irányítás vagy közvetett tulajdon alatt állnak, könnyebben érvényesíthető a közérdek veszélyhelyzet esetén, mint a közszférától független vállalkozások esetén. Azonban ez utóbbi esetben is lehet olyan veszélyhelyzeti esemény, amely megköveteli a múködés állami felügyelet révén történő fenntartását, mint ahogy ez megtörtént 2020-ban a nemzetgazdasági szempontból jelentős vállalkozások esetében. ${ }^{61}$

60 A kisadózó vállalkozások tételes adójáról és a kisvállalati adóról szóló 2012. évi CXLVII. törvény.

61 Lentner-Cseh, 2020, 4. o. A szerzők rámutatnak arra, hogy Honvédelmi Irányító Törzs múködik 71, az ország szempontjából létfontosságú vállalatnál. Az állam közüzemi szektorbeli jelentőségére utaló további szakirodalom: Lentner-Molnár, 2020, 1-6. o.; Lentner, 2015, 763-783. o. 


\section{Monetáris politika a járványügyi veszélyhelyzet okozta gazdasági válságban}

A fiskális politika mellett a monetáris politika segíti a gazdaságpolitikai célkitúzéseket. ${ }^{62} \mathrm{~A}$ monetáris politika független a fiskális politikától, de mivel két összefüggő rendszerről van szó, a monetáris és fiskális politika sikerességének fontos alapköve a megfelelő koordináció. ${ }^{63} \mathrm{~A}$ magyar jegybanktörvény is utal arra, hogy a jegybank az elsődleges céljának veszélyeztetése nélkül támogatja a kormány gazdaságpolitikájátt. ${ }^{64} \mathrm{~A}$ monetáris politika megvalósítása érdekében széles körủ eszközrendszer áll a jegybank rendelkezésére, amelyek révén befolyásolhatja a pénz- és hitelkínálatot, valamint a pénz- és hitelkeresletet. ${ }^{65}$ Ezeket az eszközöket tekinthetjük hagyományos jegybanki eszközöknek. A korábbi gazdasági válság ${ }^{66}$ azonban már új trendeket hozott a világ vezető jegybankjainak monetáris politikájában. A szakirodalom rámutat arra, hogy a jegybanki eszköztár új elemekkel egészült ki, és a gazdasági válság kezelésében a jegybankok szerepe jelentősen felértékelődött. A konvencionális eszköznek számító kamatmérséklés a nulla kamatszint alatt már nem fejtette ki a hatását kellő mértékben. Így egyes jegybankok értékpapír-vásárlási programokat hirdettek, ezzel növelve a pénzpiaci likviditást. ${ }^{67} \mathrm{Az}$ Európai Központi Bank új eszközként a nagyvállalati hitelkövetelések fedezetként való elfogadását alkalmazta a 2008-as válságban, amely fontos eszközzé vált a válság után is az euróövezeti monetáris politikában. ${ }^{68}$

A jelenlegi válsággal kapcsolatos jegybanki eszközrendszer tovább bővült a korábbiakhoz képest, nem csak volumenében. Az Egyesült Államok jegybankja (FED) a gazdasági válság kapcsán gyorsan lépett fel, a kamatvágás mellett mennyiségi enyhítést jelentett be, keretösszeg nélkül. A FED az eszközvásárlásai keretében államkötvényt, ingatlanalapú jelzáloghitelt és vállalati kötvényeket egyaránt vásárolt. ${ }^{69} \mathrm{~A}$ magyar jegybank szintén változtatott a monetáris politikai eszköztárán a gazdasági válság hatásainak tompítása érdekében.

62 Nagy, 2006, 239-270. o.

63 Sivák-Vígvári, 2012, 204-205. o.

64 A Magyar Nemzeti Bankról szóló 2013. évi CXXXIX. törvény (a továbbiakban: MNBtv.) 3. \$. Az MNB elsődleges célja az árstabilitás elérése és megőrzése.

65 A monetáris politika eszközrendszerébe tartozik a betét elfogadása és hitel nyújtása, a nyílt piaci múveletek és visszavásárlási megállapodások, a saját értékpapírok kibocsátása, az árfolyam és kamatok meghatározása és befolyásolása, az értékpapír-leszámítolás és -visszleszámítolás, kötelező tartalék szabályozása.

66 Nagy, 2020, 85-88. o.

67 Lentner, 2019, 184-185. o.

68 A Magyar Nemzeti Bank monetáris politikai eszköztára a COVID-19-válság időszakában. Elérhető: www.mnb.hu/ letoltes/jegybanki-eszkoztar-2020-Covid19.pdf (Letöltve: 2020. december 15.).

69 Elérhető: https://elemzeskozpont.hu/gazdasagi-valsag-2021-modern-monetaris-elmelet-lesz-megoldas (Letöltve: 2020. december 15.). 
Az MNB a Covid-19-válságra vonatkozó összegzésében részletesen meghatározza a monetáris politika céljait és az ehhez rendelt eszközöket. ${ }^{70}$

Az MNB az eszközöket a célok alapján három területre bontotta:

- likviditás biztosítása;

— a rövid futamidejú hozamok rugalmasabb alakíthatósága;

— hosszú futamidejú hozamokra ható eszközök.

A likviditás növelése érdekében a jegybank új eszközöket alkalmaz. Az MNB a jegybankképes fedezetek körét bővítette a nagyvállalati hitelekkel, azaz a nagyvállalatokkal szembeni követelésekkel. Ennek következtében a magyar jog hatálya alá tartozó, egymilliárd forint feletti tőketartozások vonhatók be a jegybanki fedezetek körébe. Továbbá a jegybanki források elérhetôvé váltak a befektetési alapok számára, így részükre is lehetôvé vált a jegybanki hitelfelvétel a befektetési jegyek fedezete mellett (denominált értékpapír- és ingatlanalapok befektetési jegyei). Hosszú távú jegybanki hiteleszköz is bevezetésre került a pénzpiaci feszültség enyhítése érdekében. Így a pénzpiaci stabilitást hivatott biztosítani az MNB által nyújtott, maximálisan ötéves futamidejû, fix, legalább a jegybanki alapkamaton kamatozó, fedezett hitel. A tartalékkötelezettséget érintő rendelkezés szintén növelte a likviditást. A jegybank felfüggesztette a tartalékkötelezettséget, így az előírások nem teljesítése esetén nem alkalmaz jogkövetkezményt. ${ }^{71}$

A rövid futamidejủ hozamok rugalmassága érdekében a jegybank az egyhetes betét eszközét vezette be ismét, illetve a kamatfolyosót szimmetrikussá tette. A kamatfolyosó közepe lett a jegybanki alapkamat, míg a két széle az egynapos betéti kamat és az egynapos, egyhetes fedezett hitel kamata. Ez biztosítja a rugalmasságot a monetáris transzmisszió számára.

A hosszú futamidejú hozamokra ható eszközök bevezetése szintén a likviditás növelését szolgálja. A jegybank egyrészt átalakította a Növekedési Kötvényprogramot, másrészt új programként elindította a Növekedési Hitelprogram Hajrát, amellyel tovább bővülhet a hazai vállalkozások finanszírozása. Ez előnyös finanszírozást jelent, de nem biztos, hogy teljes mértékben új likviditást hoz, hiszen a korábbi hiteleiket kiválthatják ezzel a vállalkozások. ${ }^{72}$ A Növekedési Kötvényprogram ${ }^{73}$ módosításával enyhítette a feltételeket a jegybank,

70 Elérhető: www.mnb.hu/letoltes/jegybanki-eszkoztar-2020-Covid19.pdf (Letöltve: 2020. december 15.). A monetáris eszköztár elsősorban ez alapján kerül bemutatásra a továbbiakban.

71 MNBtv. 19-20. \$. Az MNB elnöke rendeletében elöírhatja, hogy a pénzügyi intézmények és a befektetési vállalkozások idegen forrásaik, egyes eszközeik és mérlegen kívüli tételeik meghatározott arányában tartalékot helyezzenek el az MNB-nél. Az MNB elnöke rendeletben szabályozza a tartalék kiszámítására, képzésének és elhelyezésének módjára, valamint a teljesítés elmaradása esetén alkalmazandó intézkedésekre vonatkozó elóírásokat.

72 Palócz-Matheika, 2020, 586. o.

73 A Növekedési Kötvényprogram a vállalati kötvénypiac likviditásának növelése érdekében indult 2019-ben. A program keretében az MNB 1150 milliárd forint keretösszegben nem pénzügyi vállalatok által kibocsátott kötvényeket vásárolt. Elérhetô: www.mnb.hu/monetaris-politika/novekedesi-kotvenyprogram-nkp (Letöltve: 2020 . december 15.). 
így az egy vállalatcsoporttal szembeni kitettsége 50 milliárd forintra növekedett, illetve a kötvények futamideje 20 évre változott. Idesorolható a már említett hosszú hiteleszközök bevezetése és az eszközvásárlási program. Az utóbbi keretében állampapír- és jelzáloglevél-vásárlási programokról döntött a jegybank. Az állampapír-vásárlások kerete nem meghatározott, a központi bank addig folytatja, ameddig ezt a gazdasági válság indokolja. A 2018-ban elindított, majd 2020-ban újraindított jelzáloglevél-vásárlási program keretében az MNB fix kamatozású, forintban kibocsátott jelzálogleveleket vásárol az elsődleges és másodlagos piacon, amelyeknek legalább egy év a hátralévő futamideje, és a Budapesti Értéktôzsdén nyilvános forgalomban vannak. A jegybank tehát a hagyományos monetáris politikai eszközök mellett olyan további eszközöket használ a likviditás bővítése érdekében, amelyeket a jelentős, a pénzpiacon meghatározó szerepet betöltő jegybankok is alkalmaznak.

A válság nem hagyja érintetlenül a bankrendszer múködését sem, hiszen a válsággal nő a pénzügyi intézmények kockázata. A szakirodalom rámutat viszont arra, hogy a jelenlegi válság felkészültebben érte a bankrendszereket, mivel a 2008-as válság után erőteljes reguláció következett be. ${ }^{74} \mathrm{~A}$ kockázatok azonban egyedi intézményi és rendszerszinten egyaránt jelentkezhetnek. A bankok múködési kockázata változott, új kockázati tényezők jelennek meg a világjárvány következtében. Fontos feladata a hitelintézeteknek, hogy a kockázatokból ne vagy csak kisebb veszteség keletkezzen. A szakirodalmi elemzés kiemeli azokat a kockázatokat, amelyek meghatározóvá váltak a járvány következtében, és az alábbiak szerint rámutat ezek jelentőségére. ${ }^{75}$

A geopolitikai kockázat jelentősége nőtt, a járványhelyzet miatt kialakult gazdasági válság kiterjed az egész világgazdaságra, és nehezen prognosztizálható a válságból történő kilábalás ideje és mértéke. Fontos kockázati elem a reziliencia, azaz a vállalkozás azon képessége, hogy egy esetleges válság után hogyan tudja helyreállítani a múködését. A tevékenységgel összefüggésben pedig az outsourcing kockázata lényeges, azaz hogy a külső partner fenn tudja-e tartani a múködését a munkaeró és az irodai feltételek kiesése esetén. A vírus miatt megnövekedett az otthoni munkavégzés, illetve a távoli munkavégzés, ami újabb kockázatokat hordoz, egyrészt a fegyelemcsökkenés, másrészt a gyors átállás miatt. Ebből adódóan nő a belső és külső csalások, illetve a kibertámadások száma. Az utóbbi esetben adatvesztés, adatlopás vagy rendszerleállás egyaránt előfordulhat. Ezek a kockázatok szorosan összefüggenek a munkavállalók egyéni kockázatával és az ezzel összefüggő szervezeti kockázattal. Ezek szintén nőttek a távoli munkavégzés következtében.

A bankok múködését szintén befolyásolja a Kormány által elrendelt hiteltörlesztési moratórium, amely a vállalkozások és a háztartások számára egyaránt lehetôvé teszi a hiteleik meghosszabbítását, ami szintén a likviditást növeli, segíti a vállalkozások múködését. A ház-

74 Terták-Kovács, 2020, 372-373. o.

75 Tamásné Völneki, 2020, 325-327. 0. 
tartások gazdálkodására szintén hatással van az előbbi mellett a fogyasztási hitelek teljes hiteldíjmutatójának maximalizálása. ${ }^{7}$

Mindezek a kockázatok egyben lehetőséget teremtenek a jogalkotó számára, hogy újraszabályozzon egyes területeket a tapasztalatokból kiindulva, hiszen nem biztos, hogy ez az utolsó ilyen járványügyi veszélyhelyzet. A tapasztalatok leszúrésére pedig kiváló lehetőséget teremt a tudományos kutatások folytatása.

\section{Irodalomjegyzék}

BALÁzs, P. (2020) 'A Covid-19-válság integrációs hatásai', Köz-gazdaság, 15(2), 5-12. o.

BARCZA, GY. (2015) 'Az államadósság szerepének változása a közgazdaságtanban és a magyar adósságkezelés alapelvei', Pénzügyi Szemle, 60(4), 444-457. o.

BESSENYEI, I. (2020) 'A fóáramú közgazdaságtan előrejelzése a koronavírus-járvány várható következményeiről', Tudásmenedzsment, 21(1), 181-185. o.

Вотоs, K. (2020) 'Élet és megélhetés. A gazdaságelmélet és a gyakorlat változásai a válság után', Pénzügyi Szemle, 65(3), 385-397. o.

Czeczeli, V., Kolozsi, P. P., Kutasi, G., Marton, Á. (2020) 'Gazdasági kitettség és válságállóság exogén sokk esetén', Pénzügyi Szemle, 65(3), 323-349. o.

Csû́Rös, G. (2015) Uniós pénzügyek. Az európai integráció fejlődésének pénzügyi jogi vizsgálata. 1. kiadás. Budapest: HVG-ORAC Kft.

CsÛ́Rös, G. (2018) 'Az állam (költségvetés) és a pénzügyi szektor közötti kapcsolat gyengítésére irányuló uniós intézkedések' in Árva, Zs., Szikora, V. (szerk.) A fogyasztók védelmének új irányai és kihivásai a XXI. században. 1. kiadás. Debrecen: Debreceni Egyetem Állam- és Jogtudományi Kar

CsÛ́RÖs, G. (2019) 'Erősebb stabilizáció az uniós közpénzügyekben?' in Halász, Zs. (szerk.) Magistra et Fautrix. Halustyik Anna emlékére. 1. kiadás. Budapest: Pázmány Péter Katolikus Egyetem Jog- és Államtudományi Kar

DRINóczI, T. (2012) 'Gazdasági alkotmány az Alaptörvényben', Pázmány Law Working Papers, 2012/33, 1-22. o.

HaLÁsz, Zs. (2018) Az Európai Unió költségvetésének szabályozása. 1. kiadás. Budapest: Pázmány Press

HaLmai, P. (2014) Krízis és növekedés az Európai Unióban. Európai modell, strukturális reformok. 1. kiadás. Budapest: Akadémiai Kiadó

HalmaI, P. (2020a) Európai gazdasági integráció. 1. kiadás. Budapest: Dialóg-Campus Kiadó

76 Magyarország konvergenciaprogramja 2020-2024. Elérhető: https://ec.europa.eu/info/sites/info/files/2020european-semester-convergence-programme-hungary_en.pdf(Letöltve: 2020. december 15.). 
HalmaI, P. (2020b) Mélyintegráció. A Gazdasági és Monetáris Unió ökonómiája. Budapest: Akadémiai Kiadó

HoRváth, M. T. (szerk.) (2014) Külön utak - Közfeladatok megoldásai. 1. kiadás. Budapest: Dialóg Campus

HoRVÁth, M. T., PÉTERI, G., VÉCSEI, P. (2014) 'A helyi forrásszabályozási rendszer magyarországi példája, 1990-2012', Közgazdasági Szemle, 61(2), 121-147. o.

Jackson, J. K., WeIss, M. A., SChWARzenberg, A. B., Nelson, R. M. (2020) ‘Global Economic Effects of COVID-19', Congressional Research Service [Online]. Elérhetô: www.wita.org/atpresearch/global-economic-effects-Covid/ (Letöltve: 2020. augusztus 12.)

KÁDÁR, P. (2021) 'A pandémia kezelése mint a nemzeti ellenálló képesség „tesztje”, Honvédségi Szemle, 149(2), 3-13. o.

KEcső, G. (2012) 'Adósságfékek az államháztartásban: költségvetési politika rövid pórázon', Jogi Tanulmányok, 2012/1, 417-430. o.

KECSő, G. (2018) 'Az Alaptörvény hatása az államháztartási jogra - különös tekintettel az eladósodás fékezésére', Közjogi Szemle, 11(3), 35-46. o.

Kecső, G., TомBoR, Cs. (2020) A helyi adók szabályozása és joggyakorlata Magyarországon külföldi kitekintéssel - különös figyelemmel az iparúzési adóra és a helyi vagyonadók arányosságára. 1. kiadás. Budapest: Nemzeti Közszolgálati Egyetem, Közigazgatási Továbbképzési Intézet KoppáNY, K. (2020) 'A kínai koronavírus és a magyar gazdaság kitettsége', Közgazdasági Szemle, 17(5), 433-455. o.

Kovács, Á. (2016) 'A Költségvetési Tanács a magyar Alaptörvényben’, Pénzügyi Szemle, 61(3), 320-337. 0.

LENTNER, Cs. (2015) 'A vállalkozás folytatása számviteli alapelvének érvényesülése közüzemi szolgáltatóknál és költségvetési rend szerint gazdálkodóknál - magyar, európai jogi és eszmetörténeti vonatkozásokkal' in Lentner, Cs. (szerk.) Adózási pénzü̈ytan és államháztartási gazdálkodás: Közpénzügyek és államháztartástan II. 1. kiadás. Budapest: Nemzeti Közszolgálati Egyetem és Tankönyvkiadó Zrt.

LENTNER, Cs. (2017) Közpénzügyi menedzsment. 1. kiadás. Budapest: Dialóg Campus

LENTNER, Cs. (2019) A magyar állampénzügyek fejlődéstörténete a dualizmus korától napjainkig. 1. kiadás. Budapest: L'Harmattan Kiadó.

LENTNER, Cs., CsEH, B. (2020) 'Állami tulajdonban lévő közüzemi vállalatok múködésfenntartásának egyes gazdasági és jogszabályi kérdései vészhelyzet esetén', Gazdaság és Jog, 28(5), 1-4. o.

LENTNER, Cs., MOLNÁR, P. (2020) 'Budapesti közüzemi szolgáltatások egyes szabályozási és hatékonysági kérdései a 2010-es állampénzügyi reform után', Pro Publico Bono: Magyar Közigazgatás, 8(1), 2-21. o.

MURAKÖZY, L. (2010) 'Válságok állama - államok válsága’, Közgazdasági Szemle, 57(8), 779-797. o. Muraközy, L. (2012) Államok kora. Az európai modell. 1. kiadás. Budapest: Akadémiai Kiadó NAGY, Z. (2006) 'A monetáris szervezet és tevékenység jogi szabályozása' in Károlyi, G. (szerk.) Gazdasági közjog. 1. kiadás. Debrecen: Debreceni Egyetem Kossuth Egyetemi Kiadó 
NAGY, Z. (2014a) Költségvetési gazdálkodás. Budapest: Nemzeti Közszolgálati Egyetem, Vezetőés Továbbképző Intézet [Online]. Elérhető: http://m.ludita.uni-nke.hu/repozitorium/ bitstream $/$ handle $/ 11410 / 10533 /$ Teljes\%20sz\%C3\%B6veg? sequence $=1 \&$ is Allowed $=y$ (Letöltve: 2020. december 15.)

NAGY, Z. (2014b) Költségvetési jog. Budapest: Nemzeti Közszolgálati Egyetem, Vezető- és Továbbképző Intézet [Online]. Elérhető: https://nkerepo.uni-nke.hu/xmlui/bitstream/ handle/123456789/10534/Teljes\%20sz\%F6veg;jsessionid=FE84558EA5EE5A6EBA3A7B20C4 490D90? sequence=2 (Letöltve: 2020 . december 15.)

NAGY, Z. (2019) 'A kriptopénzek helye és szerepe a pénzügyi rendszerben', Miskolci Jogi Szemle, 14(2), 5-14. o.

NAGY, Z. (2020) 'A pénzügyi rendszer problémái és kihívásai a jogi szabályozás számára', Miskolci Jogi Szemle, 15(2), 85-92. o.

Palócz, É., Matheika, Z. (2020) 'Dilemmák a Covid-19-válság magyarországi gazdasági hatásairól' in Kolosi, T., Szelényi, I., Tóth, I. Gy. (szerk.) Társadalmi Riport-2020. 1. kiadás. Budapest: TÁRKI

SALGó, L. P. (2020) 'A hazai veszélyhelyzeti jogalkotás a kodifikátor szemével', Fontes Iuris, 6(2), 8-18. O.

SAMUelson, P. A., NoRdhaus, W. D. (2012) Közgazdaságtan. 19. kiadás. Budapest: Akadémiai Kiadó

SHILLER, R. J. (2020) Narratív közgazdaságtan. 1. kiadás. Budapest: HVG

SIMON, I. (2019) Pénzügyi jog I. 1. kiadás. Budapest: ELTE Eötvös

SIVÁk, J., VÍGVÁRI, A. (2012) Rendhagyó bevezetés a közpénzügyek tanulmányozásába. 1. kiadás. Budapest: Complex

Sivák, J., Szemlér, T., VÍGVÁRI, A. (2013) A magyar államháztartás és az Európai Unió közpénzügyei. 1. kiadás. Budapest: Complex

STIGLITZ, J. E. (2000) A kormányzati szektor gazdaságtana. 1. kiadás. Budapest: KJK-KERSZÖV SzEGEDI, L. (2019) 'A Gazdasági és Monetáris Unió intézményrendszere' in Bóka, J., Gombos, K., Szegedi, L. (szerk.) Az Európai Unió intézményrendszere. 1. kiadás. Budapest: Dialóg Campus

SzijÁRTó, N. (2020) 'Az Európai Unió gazdasága és a koronavírus: Az Európai Bizottság útkeresése', Kihivások, 2020/236. Budapest: Világgazdasági Intézet, Közgazdaság- és Regionális Tudományi Kutatóközpont

TAMÁSNÉ VÖLNEKI, Zs. (2020) 'Krízismenedzsment és müködési kockázatkezelés a pénzügyi szektorban a Covid-19 árnyékában', Gazdaság és Pénzügy, 2020/3, 313-329. o.

TeRTÁk, E., KovÁcs, L. (2020) 'A szociális védelem és a társadalmi kohézió kihívásai válsághelyzetben a pénzügyi szférában', Pénzügyi Szemle, 65(3), 364-384. o.

VÍGVÁRI, A. (2002) Közpénzügyek, önkormányzatipénzügyek. 1. kiadás. Budapest: KJK-KERSZÖV VÍGVÁRI, A. (2005) Közpénzügyeink. 1. kiadás. Budapest: KJK-KERSZÖV 



$$
\begin{gathered}
\text { A KÜLÖNLEGES } \\
\text { JOGREND EURÓPÁBAN } \\
\text { ÉS EURÓPÁN KÍVÜL }
\end{gathered}
$$




\title{
8. Ausztria: 150 éves gyökerek, 21. századi megoldások
}

\author{
CSEMÁNÉ VÁRADI ERIKA
}

\section{A különleges jogrend alkotmányos és törvényi szintü szabályozása}

„A különleges jogrend az alkotmányos szabályozás különös része, a békétől eltérő időszakok joga. Maga a különleges jogrend elnevezés, mint az eltérő definíciós elemeket hordozó időszakok gyứjtőfogalma." ${ }^{1}$ Az osztrák alkotmány, a Bundes-Verfassungsgesetz ${ }^{2}$ a különleges jogrend fogalmát nem írja le, nem tartalmaz átfogó rendelkezéseket annak esetköreire, s nem ad kifejezett hatáskört a kormánynak, a szövetségi elnöknek vagy bármely más szervnek arra, hogy hivatalosan meghatározza a különleges jogrend alkalmazását megalapozó helyzet, így például a válság fennállását. Emellett speciális, a válságkezeléssel kapcsolatos eszközkészlet sem látszik megjelenni ezen a síkon, mint például kijárási tilalom elrendelésének lehetősége a krízisállapottal érintett földrajzi területre.

I Till, 2019, 2. o.

2 Szövetségi alkotmánytörvény (Bundes-Verfassungsgesetz, a továbbiakban: B-VG).

3 „A B-VG [...] nem tartalmaz a válsággal kapcsolatos konkrét eszközöket, például bizonyos érintett személyek számára kijárási tilalom bevezetésének lehetőségét egyes érintett területekre." (Reindl-Krauskopf et al., 2016, 149. o.).

Csemáné Dr. Váradi Erika, PhD, LLM judit.erika.varadi.csemane@mfi.gov.hu vezető kutató (Mádl Ferenc Összehasonlító Jogi Intézet) egyetemi docens (Miskolci Egyetem Állam- és Jogtudományi Kar, Bűnügyi Tudományok Intézete) elnök (Miskolci Egyetem Állam- és Jogtudományi Kar, Alternatív Konfliktuskezelési és Vitarendezési Interdiszciplináris Kutatóközpont)

Csemáné Váradi, E. (2021) 'Ausztria: 150 éves gyökerek, 21. századi megoldások' in Nagy, Z., Horváth, A. (szerk.) A különleges jogrend és nemzeti szabályozási modelljei, 194-216. o. Budapest: Mádl Ferenc Összehasonlító Jogi Intézet.




Az osztrák szabályozás hátterében részben a speciális esetkört érintő szabályozástörténeti előzmények, részben az Osztrák Köztársaság szövetségi államszervezete áll.

A különleges jogrendre az alkotmányban minimális utalást találunk. Abban az alkotmányban, amely ma is az 1920-as, alapjogi elemeiben az 1867-es alkotmányt, más vonatkozásokban az 1929-es alkotmánymódosítás elemeit és megoldásait foglalja magában. Az osztrák jogtörténetben megjelenő „kivételes hatalom” egy, az általánostól eltérő speciális helyzet által generált és csak annak fennálltáig múködő, az általánostól eltérő hatalomgyakorlási formát tett lehetővé. Ez azonban - a különleges jogrenddel megegyezően - az adott állam „normális", azaz mindennapi múködése mellett nem volt alkalmazható. Már az 1867-es osztrák állami alaptörvényből ${ }^{4}$ sem mellőzhető két szakasz kiemelése, ha a különleges jogrend hatályos szabályozást magyarázó korai forrásait vizsgáljuk. Ez egyrészt az StGG 14. cikke, amely lehetôvé tette, hogy - kivételes jelleggel, korlátozott esetkörben és mértékben, de - az osztrák birodalmi gyưlés (parlament) ülésezésének hiányában a kormány ideiglenesen törvényi erővel bíró rendeleteket adhasson ki. Másrészt az alaptörvény 20. cikkelye épp az alaptörvénnyel garantált jogok keretek közötti felfüggesztésére adott módot külön törvény (Suspensiongesetz) életre hívásának lehetővé tételével. ${ }^{5}$ Erre szigorú jogszabályi feltételek mellett, meghatározott helyen és időben kerülhetett sor, így például háború, háborús veszély („küszöbön álló háború”), belső nyugtalanság vagy alkotmányos szempontból „fenyegető jellegú tevékenység” esetén. Ezek fennállta mellett az állampolgárok alkotmányban ${ }^{7}$ rögzített jogai korlátozhatóvá, illetve felfüggeszthetővé válhattak (beleértve például az olyan alapjogokat, mint a gyülekezési, az egyesülési jog vagy a sajtószabadság). A 2. világháború után visszaállított 1920/1929-es alkotmány továbbvitelét és a szövetségi elnök kivételes hatalmát nem árnyékolta be az osztrák parlament 1933. márciusi felszámolását követő rendeleti kormányzás. Ennek indoka, hogy az autoriter állam múködésének nem az alkotmány 1929-es - a szövetségi elnök kivételes hatalmát lehetővé tevő - módosítása, hanem a mindvégig hatályban volt gazdasági felhatalmazásról szóló törvény ${ }^{8}$ jelentette a(z jog)elvi-törvényi alapját. "Az egykori alkotmányos jogrendet visszaállítva és a múlt alkotmányjogi vívmányaira építve, valamint az elismert jogtudósok, alkotmányjogászok politikai-alkotmányjogi kérdésekbe történő bevonásának köszönhetően létrejött a demokratikus alapokon múkködő és föderális szerkezetû Második Osztrák Köztársaság."ํㅜ Így a különleges jogrend

4 Staatsgrundgesetz (a továbbiakban: StGG): 1867. december 21-i állami alaptörvény a birodalmi tanácsban képviselt királyságok és országok állampolgárainak általános jogairól (RGBI. Nr. 142/1867).

5 Lásd erről részletesebben: Hinghofer-Szalkay, 2019.

6 Ez utóbbi felölelhette például azokat a nagy nyilvánosságot célzó megmozdulásokat, amelyek akár az állampolgárok személyes biztonságának sérülésével, akár javak elpusztításával fenyegettek.

7 StGG 8-10. és 12-13. cikk.

8 Kriegswirtschaftlichen Ermächtigungsgesetz (KWEG) [Gesetz vom 24. 7. 1917 (RGBl. Nummer 307)]. Bővebben lásd: Staudigl-Ciechowicz, 2018.

9 Lásd errôl részletesebben: Staudigl-Ciechowicz, 2018, 274-293. o.

10 Maróti, 2017, 392-406. o. 
fogalmának és eseteinek meghatározása sem az 1920-as - hatályába visszahelyezett - alkotmánynak, sem az azóta foganatosított módosító novelláknak nem volt tárgya.

Az alkotmány jelenlegi formájában is megőrzi tehát egyrészt azon sajátosságát, hogy számos, a különleges jogrend szempontjából meghatározó releváns kérdést (így például annak fogalmát, esetköreit, az azok kezelését lehetôvé tévő eszközkészletet) a kritikai megjegyzések ellenére nem - vagy nem teljeskörúen - szabályoz. Ugyanakkor a szövetségi elnök rendeleti kormányzását lehetôvé tevő kivételes hatalom megmaradt az alkotmányban. ${ }^{11}$

Nem változott a jogi felfogás a tekintetben sem, hogy a különleges jogrendet megalapozó szituációk jellegük, hatásaik, jelentőségük, kiterjedtségük stb. okán tipikusan - de nem kizárólagosan - szövetségi szinten kerülnek szabályozásra és végrehajtásra ('́gy az egészségüggyel kapcsolatos súlyos helyzetek kezelése), míg például természeti katasztrófák vagy túzvész esetén a tartományok is jogosultak döntést hozni és eljárni. Ugyanakkor az alaptörvényben nevesített válsághelyzetekben ${ }^{12}$ szövetségi szintre tartozik mind a jogalkotás, mind a végrehajtás, például katonai ügyekben vagy olyan intézkedéseknél, amelyek a háború során vagy annak eredményeként, a gazdaság egységes irányításának biztosításához szükségesnek tû́nnek (különös tekintettel a lakosság fogyasztási cikkekkel való ellátására).

Mindezen jog- és szabályozástörténeti előzményekből is eredően a jelenleg hatályos osztrák alkotmány sem tartalmaz rendelkezéseket a különleges jogrend fogalmát - egy kivételével -, esetköreit, reakcióeszközeit illetően. ${ }^{13}$ Ez azt eredményezi, hogy a szakirodalomban fellelhető elemzések szerint a különleges jogrendre vonatkozó normák rendszerezése és tartalma az osztrák jogelmélet oldaláról korántsem kritika nélküli. ${ }^{14}$

Az elméleti munkák ismerik az úgynevezett kvázi különleges jogrend fogalmát is. Ez alatt „olyan válsághelyzeteket értünk, amelyek esetében még nem kell/lehet kihirdetni a különleges jogrendet, azonban a normál jogrendtől eltérő megoldásokat kívánnak, amelyek során a gyakorlatban megvalósul egy-egy alapjog korlátozása, és amikor a kormányzat széles felhatalmazási jogkörökkel rendelkezik (lásd például menekültügyi válsághelyzet, egészségügyi válsághelyzet)". ${ }^{15}$ Minden állam célja a különleges jogrendet megalapozó helyzet kialakulásának megelőzése lenne, azonban ez nehézségbe ütközik: a közelmúlt több krízise is azt mutatta, hogy épp a prevencióra leginkább alkalmas eszkalációs szakaszban az „nem kapcsolható össze a különleges jogrenddel”. Ez Ausztria esetén is problémát jelent.

A szakirodalom szerint a válsághelyzet lehet belső vagy külső eredetú, szövetségi vagy tartományi szintû, katonai vagy civil területet érintő, s jellegét tekintve is igen különböző formát ölthet a zavargásoktól, terrortámadástól a katasztrófa- vagy egészségügyi válság-

11 B-VG 18 cikk (3)-(5) bekezdés.

12 B-VG 10. cikk (1) bekezdés 15. pont.

13 „Az osztrák alkotmány nem tartalmaz semmilyen kifejezett hatáskört a kormány, a szövetségi elnök vagy bármely más testület számára arra vonatkozóan, hogy hivatalosan - szövetségi szinten - meghatározza a válság fennállását." (Reindl-Krauskopf et al., 2016, 148. o.).

14 Koja, 1979.

15 Kelemen, 2019, 13. o. 
helyzeten át a kibertámadásig. Közös bennük, hogy bekövetkeztük esetén a lakosság nagyobb számát érintik, jelentősen veszélyeztetve az állam, a társadalom, az állampolgárok biztonságát. Mindez speciális intézkedéseket és különös múködési szabályokat igényel.

A modern európai alkotmányok már a kezdetektôl fogva ${ }^{16}$ ugyanazon négy nagy területét határozták meg a krízishelyzeteknek, amelyeket a mai legtöbb alkotmány is nevesít:

- a háború mint külső fenyegetettség;

- a belső biztonság fenyegetettsége felkelés vagy lázadás útján;

- természeti események vagy katasztrofális következményekkel járó vis maior esetek;

- egyéb gazdasági, társadalmi vagy humanitárius válságok, amelyek általában ellátási válságok is egyben.

Az osztrák jogelmélet - és így az alkotmányjog is - szintén négy olyan szituációt ismer, amely a különleges jogrendet megalapozó jellemzókkel rendelkezik.

A háborús helyzetre vonatkozóan az alkotmány kimondja, hogy az államvédelem katonai dimenziója mellett a szellemi, polgári és gazdasági értékek is védelmet élveznek. ${ }^{17}$ Továbbá az általános védelmi kötelezettség értelmében háború idején az osztrák állampolgárságú férfiak biztosítják a felfegyverzett polgárőrséget, azaz valamennyi osztrák állampolgár férfi hadköteles, az osztrák női állampolgárok pedig szabad akaratukból katonai szolgálatot teljesíthetnek a szövetségi hadseregben. ${ }^{18} \mathrm{Az}$ alkotmány szerint a szövetségi hadsereg fôparancsnoka a szövetségi elnök. ${ }^{19}$ Ezenkívül az alkotmány megköveteli, hogy a háborús helyzet fennállásáról szóló döntést a szövetségi gyưlés keretein belül hozzák meg - azaz a kormány egyedül nem határozhat erról.

Az állam rendje elleni második klasszikus fenyegetési formát a belső biztonságot támadó cselekmények testesítik meg. Ezeknek tradicionálisan két típusát különböztetik meg: az egyik a legfelsőbb szerv ellen elkövetett támadás, amely a hatalom átvételét célozza, a másik pedig a lázadás és a terror, amelyeknél a fenyegetés és a stabilitás felbomlasztása a cél.

A belső biztonságot fenyegető veszélyekre való reagálást érintő rendelkezés megtalálható az alkotmányban. Az alkotmányos intézményeket és múködésüket, illetve az állampolgárok demokratikus szabadságjogait, valamint a rend és a biztonság fenntartását a szövetségi hadsereg biztosítja. ${ }^{20} \mathrm{~A}$ krízishelyzetre vonatkozó részletes szabályozást a szövetségi had-

16 Az első modern európai alkotmány, az 1791-ben született lengyel alkotmány is a következő, különleges szabályokat igénylő helyzeteket ismerte: nemzetközi jogi kivételes helyzetek („különösen egy szomszédsági háborúban”), belső zavargások, „amelyek az országot [...] forradalommal fenyegetik”) az „általános éhínség nyilvánvaló veszélye”, a „szülőhaza elárvulása” a király betegsége vagy halála okán (Wißmann, 2015, 14. o.).

17 B-VG 9a. cikk (1) bekezdés.

18 B-VG 9a. cikk (3) bekezdés.

19 B-VG 80. cikk.

20 B-VG 79. cikk (2) bekezdés. 
seregről ${ }^{21}$ szóló törvény mellett a biztonsági rendőrségről, ${ }^{22}$ illetve a rendőrségi államvédelemről szóló törvény ${ }^{23}$ tartalmazza.

A harmadik kategóriát a "katasztrófa” elnevezés alá tartozó események képezik. Idesorolandók például a természeti katasztrófák, túzvész, illetve egyéb, az átlagosnál nagyobb méreteket öltő szerencsétlenségek. Ezen helyzetek kezelése túlnyomórészt a szövetségi tartományok hatáskörébe tartozik. Konkrét szabályanyaguk ugyan eltérhet egymástól, közös elem azonban, hogy a kialakult állapot megfékezéséhez bevonják a tủzoltókat, rendôrségi erőket, és ha szükséges, az állampolgárokat is. A szövetségi szint hatáskörébe tartozik a közlekedés és az egészségüggyel kapcsolatos súlyos helyzetek kezelése, valamint a járványok leküzdése is.

A negyedik csoport azon gazdasági, szociális és humanitárius természetú válsághelyzeteket öleli fel, amelyekben közös, hogy logisztikai jellegúek, és általuk az olyan alapvető javak, mint az élelmiszer-, víz- és energiaellátás veszélyeztetettek. E körben megemlítendő, hogy háborús helyzet kialakulása esetén - csakúgy, mint azokban a szituációkban, amikor a lakosság szükségleteit kell biztosítani - ezen intézkedéseket állami szinten kell megtenni. ${ }^{24}$

Noha a konkrét, a különleges jogrendet megalapozó esetek meghatározása az alkotmányban nem történik meg, és arra vonatkozóan is csak kivételesen találunk utalást, hogy az ezek fennálltában való döntés kinek az illetékességi körébe tartozik, ez - elsősorban az eljárásba beépített előzetes kontroll okán, a szakmai kritikák ellenére - sem jelent a gyakorlatban utóbb jogbiztonságot vagy alkotmányossági kritériumokat veszélyeztető elemet.

\section{Az alapjogok korlátozására vonatkozó szabályok különleges jogrend idején}

Az osztrák alkotmányjog két nagy csoportba sorolja azokat a vészhelyzeti elő́rásokat, amelyek a témakörben relevánsak, annak függvényében, hogy a vészhelyzeti előirások kompetenciabővitő jellegúek-e, vagy sem, illetve mennyiben korlátozhatják az alkotmányban garantált alapjogokat.

Az osztrák alkotmány két olyan rendelkezést ${ }^{25}$ tartalmaz, amely anélkül ad lehetóséget az állam és az állami szervek cselekvőképességének fenntartására, hogy ezzel együtt megadná a jogot azok speciális, bővített kompetenciakeretekkel történő kezelésére is.

Az 5. cikk rögzíti, hogy valamennyi legfelsőbb szintû szövetségi szervezet székhelye az osztrák szövetségi fơvaáros. Rendkívüli körülmények esetén azonban az osztrák szö-

\footnotetext{
21 Törvény a szövetségi hadseregről 2001 (Wehrgesetz 2001).

22 Törvény a biztonsági rendőrségről (Sicherheitspolizeigesetz).

23 A rendőrségi államvédelemről szóló törvény (Polizeiliches Staatsschutzgesetz).

24 B-VG 10. cikk (1) bekezdés 15. pont.

25 B-VG 5. és 79. cikk.
} 
vetségi elnök a szövetségi kormány kérésére - saját mérlegelést követően - ezt a szövetség területén más helyszínre áthelyezi. Nem kerül meghatározásra azonban a rendkívüli körülmény fogalma. Az alkotmány nevesítetten egy ilyen esetcsoportot jelöl meg, ${ }^{26}$ amely esetek közös jellemzője, hogy háborús vagy háború utáni állapotok. A szakirodalomban ${ }^{27}$ azonban erős az a megközelítés, hogy a rendkívüli körülmény tartalmilag nem szúkíthetô le erre a 15. pontra. Idesorolható a belső vagy jelentős nemzetközi politikai válság, széles körú társadalmi nyugtalanság, súlyos természeti katasztrófa csakúgy, mintha a helyváltoztatást a fơváros területi védelme kívánná meg.

A másik az alkotmány 79. cikke, amely a szövetségi hadsereg békeidejü tevékenységéről tartalmaz rendelkezéseket. ${ }^{28} \mathrm{~A}$ haza katonai védelmén túl a szervezet szerepet vállal a belső rend és biztonság, az alkotmányos intézmények és az állampolgárok demokratikus szabadságának védelmében, de közremúködik rendkívüli méretú elemi csapások és szerencsétlenségek esetén a segítségnyújtásban is. Erre azonban csak a törvényes polgári hatalmon keresztül kerülhet sor. Önálló katonai beavatkozás e tevékenységek keretében csak kivételesen és akkor lehetséges, ha az arra felhatalmazott szervet valamely magasabb hatalom képtelenné teszi a katonai beavatkozás foganatosítására, a további késedelem pedig például helyrehozhatatlan kárt okozna a társadalom tagjainak. ${ }^{29}$ Ilyen lehet a tényleges támadás visszaverése vagy a szövetségi hadsereg valamely egysége elleni erőszakos ellenállás felszámolása, a szabotázzsal vagy a terrorista cselekménnyel szembeni fellépés. A „valamely magasabb hatalom" fogalma nincs megadva, de vis maiornak minősülhet a szakirodalom szerint például, ha egy földrengés vagy lavina miatt az út- és vasúthálózat használhatatlanná válik, a telekommunikáció megsemmisül, s így a szövetségi hadsereg adott egységével az összeköttetés nem hozható létre. Hasonlóképpen az olyan belső felkelés is, amely megbénítja a törvényes polgári hatalom gyakorlását. A szövetségi hadsereg fennmaradó ereje ilyen esetekben sem maradhat tétlen, ha fellépésük egyéb alkotmányos feltételei fennállnak. Ekkor a döntés az adott katonai parancsnok kezében van. Amennyiben a törvényes polgári hatalom visszaszerzi „cselekvőképességét”, a fegyveres erők e jogosultsága megszúnik.

A kompetenciahatárokat kiterjesztő sürgősségi törvényi rendelkezések a szövetségi és tartományi alkotmányok, illetve egyéb releváns törvények azon rendelkezéseit ölelik fel, amelyek egy intézmény, illetve személy hatáskörét olyan területekre is kiterjesztik, amelyeket az általános szabályok más szervezethez vagy személyhez rendelnek. Ebbe a csoportba tartozik a szövetségi elnöknek, ${ }^{30}$ az adott tartomány kormányának, ${ }^{31}$ illetve kormányzójának ${ }^{32}$ sürgősségi rendeletalkotási joga csakúgy, mint a szövetségi kormány gazdaságirányítással

26 B-VG 10. cikk (1) bekezdés 15. pont.

27 Így például Wiesert hivatkozza Reindl-Krauskopf, 2016, 139. o.

28 B-VG 79. cikk (2) bekezdés.

29 B-VG 79. cikk (5) bekezdés.

30 B-VG 18. cikk (3)-(5) bekezdés.

31 B-VG 97. cikk (3)-(4) bekezdés.

32 B-VG 102. cikk (5) bekezdés. 
és az ellátásbiztonsággal kapcsolatos törvényhozási hatásköre. Noha több esetkör is ismert, Ausztriában nincs egységes alkotmányos szabályozás a sürgősségi törvényi felhatalmazások tekintetében, szemben néhány más európai országgal (például Svájc, Franciaország, Svédország).

Így például a tartományi kormányzó sürgősségi rendelet kiadására vonatkozó joga a törvényi feltételek mellett is csak a közvetlen szövetségi közigazgatás alá eső ügyekre korlátozódik - azaz nem teljes körrel járhat el a szövetségi közigazgatás legfelsőbb szervei helyett. Az alkotmány értelmében erre akkor kerülhet sor, ha az adott tartományban egy nyilvánvaló, a közösséget érintő, helyrehozhatatlan kár elhárításához lenne szükség az intézkedések azonnali megtételére, az erre hatáskörrel és illetékességgel rendelkező szövetségi közigazgatási legfelsőbb szervek azonban vis maior okán erre nem képesek („akadályozottak”).33 Ebben az esetben az intézkedések meghozatala nem lehetősége, hanem az alkotmány értelmében kötelessége a tartományfőnöknek. ${ }^{34} \mathrm{~A}$ szabályozás hátterében annak szándéka állt, hogy megelőzhető legyen a tartomány leállása abban az esetben, ha az ideiglenesen (például lavina, földomlás, rendkívüli időjárási viszonyok okán) elzáródik a szövetségi székhelyen található központi szervektől. ${ }^{35}$

Vészhelyzeti kompetencia illeti meg a tartományi kormányt is, amennyiben a vis maior helyzet fennállta okán a nyilvánvaló, a közösséget érintő helyrehozhatatlan kár elhárításához szükség lenne azonnali intézkedések foganatosítására, azonban a határozathozatalra jogosult tartományi gyưlés nem képes időben összeülni, vagy tevékenységében vis maior miatt akadályozott. Az alkotmány szerint a tartományi kormány - az arányos választás alapelvének megfelelően kinevezett tartományi gyúlési bizottság egyetértésével - ezt átmeneti törvénymódosító rendelettel megteheti ${ }^{36}$ Feltétele, hogy a tartományi alaptörvényt nem módosíthatja, de ezen túl nem vonhatja magával például a tartomány vagy a szövetség tartós anyagi megterhelését, nem keletkeztethet az állampolgárokra anyagi kötelezettséget, de nem jelentheti az állami vagyon elidegenítését sem. ${ }^{37} \mathrm{~A}$ sürgősségi rendeleteket a tartományi kormány haladéktalanul a szövetségi kormány tudomására kell hozza. Ezzel annak lehetősége is adott, hogy a szövetségi kormány azt alkotmányossági kontroll céljából közvetlenül az alkotmánybíróság elé terjessze. ${ }^{38}$ Bár a szabályozás struktúrájában és fóbb tételeiben visszatükrözi a szövetségi vészhelyzeti rendeletalkotási modellt, azonban itt - szemben a szövetségi szinttel - nincs szükség a bizottság „kifejezett hozzájárulására”.

Speciális szabályok kapcsolódnak a közvetlen gazdasági ellenőrzés területén illetékes szövetségi miniszterhez is. ${ }^{39} \mathrm{Az}$ időleges, kvázi vészhelyzeti kompetencia lényegileg egy,

33 B-VG 102. cikk (5) bekezdés.

34 A tartományfőnök a tartományi kormányzat vezetője, akit a tartományi parlament választ.

35 Peter Bußjägert és a Rill-Schäffer-kommentárt hivatkozza: Augustin, 2016, 67. o.

36 B-VG 97. cikk (3) bekezdés.

37 B-VG 97. cikk (4) bekezdés.

38 B-VG 139. cikk (1) bekezdés 6. pont.

39 B-VG 55. cikk (5) bekezdés. 
a szabad piacgazdaságba történő közvetlen beavatkozási lehetőséget biztosít az állam számára, ezért alkalmazhatóságára szigorú arányossági teszt mentén kerülhet sor. Az alkotmány értelmében az illetékes szövetségi miniszter a zavartalan termelést vagy a lakosság és más felhasználók fontos gazdasági és fogyasztási cikkekkel való ellátását célzó irányítási intézkedéseit tartalmazó rendeleteihez a Nemzeti Tanács főbizottságának jóváhagyására van szükség. (Sőt, a főbizottság határozatához tagjai legalább felének jelen kell lennie, és a leadott szavazatok kétharmadának támogató jellegúnek kell lennie.) Az érintett területek tipikusan az energiaszabályozás, olajkészletek, ellátásbiztonság, élelmiszer-gazdálkodás és árszabályozás. A szakirodalom értelmében ${ }^{40}$ fontos feltétel, hogy egy már bekövetkezett vagy legalábbis küszöbön álló azonnali ellátási zavar fenyegessen - kivéve, ha az piackompatibilis intézkedésekkel is kezelhetô.

Különleges jogrendi jogalkotási joggal (Notverordnungsrecht) - az alkotmány értelmében - a szövetségi elnök rendelkezik, ${ }^{41}$ amellyel háború, természeti katasztrófa és más vészhelyzetek esetében a kormány javaslatára élhet. Az alkotmányos szabályozás elméleti tételei itt is azonosak: amennyiben köztudomású, a nyilvánosság (közösség) számára jóvátehetetlen kár elhárítása érdekében a Nemzeti Tanács határozathozatalát igénylő intézkedések azonnali meghozatala olyan időpontban válik szükségessé, amikor a Nemzeti Tanács nem ülésezik, nem tud időben összeülni vagy tevékenységében felsőbb hatalom által akadályoztatott, a szövetségi elnök a szövetségi kormány javaslatára, saját vagy annak felelössége mellett megteheti a szükséges intézkedéseket ideiglenes, törvénymódosító rendeletek útján. Ezek érvényességéhez azonban szükség van - többek között - a szövetségi kormány ellenjegyzésére is. A szövetségi elnök vészhelyzeti kompetenciáinak több irányból is szigorú keretei és garanciális kontrollelemei vannak. Így például az alkotmány kizárja annak lehetôségét, ${ }^{42}$ hogy e jogi aktusok a szövetségi alkotmánytörvény rendelkezéseit módosítsák, mint ahogy nem keletkeztethetnek anyagi terhet sem a szövetség, sem a tartományok, sem az állampolgárok számára. Egyebekben az alkotmány azt is rögzíti, hogy a szövetségi kormány sürgősséggel hozott valamennyi rendeletét köteles haladéktalanul a Nemzeti Tanács elé terjeszteni, amelyet az előterjesztést követő 8 nap valamelyikére a szövetségi elnök hív össze, amennyiben a Tanács az adott időpontban nem ülésezik. ${ }^{43}$ Amennyiben igen, úgy annak elnökére hárul ez a feladat. Az előterjesztést követő négy héten belül a Tanács a rendelet helyére vagy egy megfelelő szövetségi törvényt hoz, vagy határozat útján követeli, hogy a szövetségi kormány azonnal helyezze hatályon kívül a rendeletet. Az utóbbi esetben a kormány köteles azonnal eleget tenni ennek a követelésnek. A Nemzeti Tanács időbeni határozathozatala céljából az elnök az elooterjesztést legkésőbb a négyhetes határidő utolsó előtti napján köteles szavazásra bocsátani; a részletes rendelkezéseket az ügyrend tartalmazza. Ameny- 
nyiben a rendeletet az előzőek alapján a szövetségi kormány hatályon kívül helyezi, ezzel egyidejúleg ismét hatályba lépnek azok a törvények, illetve szabályok, amelyeket a rendelet helyezett hatályon kívül.

Összességében rögzíthető, hogy Szabó István megállapításai a hatályos szabályozás kapcsán is irányadók: a szövetségi elnök „a szúkebb körbe tartozó kivételes hatalmat kapta meg, az alkotmány ugyanis pontosan rögzítette a kivételes hatalom körében alkalmazható eszközöket. Igazából nem is kell többes számban beszélnünk, mert egy eszköz volt, a törvényerővel bíró rendelet. Kivételes helyzetben eljárhatott a Nemzeti Tanács hatáskörében, de ezen túli rendkívüli hatalomgyakorlásra nem kapott felhatalmazást." ${ }^{{ }^{4} 4} \mathrm{Az}$ osztrák alkotmány ezen esetkör kapcsán sem teszi lehetôvé a tágabb kivételes hatalom lehetőségét. Ez esetben nemcsak olyan döntést hozhat egy államhatalmi szerv, amelyre nincs illetékessége, hanem olyan tartalmút is, amelyre egyébként az arra illetékes szerv sem lenne jogosult.

Az osztrák alkotmány szúk körben tartalmaz konkrét különleges jogrendi rendelkezéseket. Az alapjogok korlátozásával járó döntések alapját és kereteit speciális jogszabályokban - többek között a járvány(ügyi), ${ }^{45}$ a szövetségi biztonsági rendőrségről ${ }^{46}$ vagy a rendőrségi államvédelemról szólós7 törvényben - találhatjuk meg, amelyek meghatározott feltételek mellett komoly alapjogi korlátozásokat is megengednek a kormány, illetve az illetékes hatóságok számára. Így a biztonsági rendőrségről szóló hivatkozott törvény a szervezet hatáskörébe utalja számos olyan jogintézmény (például a kitiltás) alkalmazásának lehetőségét, amelyek - bár időben és térben korlátozottak - részben helyettesíthetik a kijárási tilalom elrendelhetőségét; egészségügyi indokoltság esetén ezt a Járványügyi tv. is lehetővé teszi. A rendészeti válságkezeléssel kapcsolatos szabályozás lehetséges területei közül például a közúti közlekedésről szóló rendelet ${ }^{48}$ felhatalmazást ad az illetékes hatóság számára, hogy forgalmi tilalmakat vagy korlátozásokat adjon ki, többek között a már bekövetkezett vagy közelgő természeti katasztrófák (például hegyomlás, lavina vagy annak veszélye) esetén. De hasonló tartalommal foganatosíthatnak intézkedéseket például a közúti felügyeletért felelős szervezetek rendkívüli - így az olyan alapvető javakkal, mint az élelmiszerrel, vízzel és energiával való ellátás, illetve a környezet veszélyeztetésével járó - helyzetek megelőzése, illetve kezelése esetén is. A forgalomkorlátozás, illetve -tiltás a gyakorlatban jól múködő, hatékony válságkezelési eszköz, légi, hajó- vagy vasúti forgalom felé történő kiterjesztése nem indokolt. ${ }^{49}$

Bár az egyes jogforrások nevesítik az alapjog-korlátozást is biztosító rendelkezések alkalmazására illetékes intézmények és személyek körét, két szervezet önálló kiemelése katasztrófa-, illetve krízishelyzetek kapcsán nem mellőzhető. Az Állami Válság- és Ka-

44 Szabó, 2010, 188. o.

45 Járvány(ügyi) törvény (Epidemiegesetz 1950) (a továbbiakban: Járványügyi tv.).

46 A szövetségi biztonsági rendőrségről szóló törvény (Sicherheitspolizeigesetz).

47 A rendőrségi államvédelemról szóló törvény (Polizeiliches Staatsschutzgesetz).

48 A közúti közlekedésről szóló rendelet (Straßenverkehrsordnung 1960).

49 Reindl-Krauskopf et al., 2016, 169. o. 
tasztrófavédelmi Menedzsment ${ }^{50}$ (SKKM) és a Nemzeti Biztonsági Tanács ${ }^{51}$ (NSR) szerepe meghatározó például zavargások, terrortámadás, katasztrófahelyzet, egészségügyi válsághelyzet vagy kibertámadás esetén is, függetlenül attól, hogy ezeket az alkotmány csak részben nevesíti, s erre vonatkozóan speciális szabályokat teljes körben nem tartalmaz.

2003 májusa óta a Szövetségi Belügyminisztérium felel az állami válság- és katasztrófavédelem kezeléséért, valamint a nemzetközi katasztrófaelhárítás koordinálásáért. Az SKKM-et 2004-ben szervezték újjá, ${ }^{52}$ létrehozva egy új koordinációs bizottságot, amelyet a közbiztonsági fóigazgató vezet. 2006-tól az Operatív és Koordinációs Központ53 (EKC) részét képezi a Szövetségi Figyelmeztetô Központ ${ }^{54}$ (BWZ), amely információs és állandó nemzeti kapcsolattartó pontként szolgál, közvetítve a tartományok, a szomszédos országok, az Európai Unió és az összes nemzetközi szervezet felé. A megelőzés előmozdítása mellett az SKKM lehetôvé teszi a hatékony katasztrófaelhárítást az összes felelős szövetségi ügynökség együttmúködésével, a tartományok katasztrófavédő hatóságai, a segély- és mentőszervezetek bevonásával válságok vagy katasztrófák esetén. ${ }^{55}$ Attól függően, hogy a fenyegetô veszély milyen horderejü és mekkora területet érint, a feladatok ellátásáért a járási főnökség, a polgármester, a tartományi kormány vagy a kifejezetten ilyen segítségnyújtásra létrehozott úgynevezett segélyszervezetek felelnek, amelyek az adott feladat ellátásáért felelős szerv alatt múködnek. ${ }^{56}$ Ilyenek például a tưzoltóság, a rendőrség vagy az osztrák fegyveres erők segítő csapatai. E körben megemlítendő, hogy a régiókon átnyúló fenyegetések szövetségi szinten kezelendők, ezzel szemben a válsághelyzet és katasztrófakezelés a helyi struktúrákban elsődlegesen az önsegély elvén alapul, azaz helyi szinten szükséges intézkedéseket foganatosítani. ${ }^{57} \mathrm{Az}$ átfogó biztonsági és katasztrófaelhárítási szolgáltatásokat segíti az önkéntes szervezetek közremúködése is a segítségnyújtási rendszerben. Katonai erők bevonásának lehetősége szövetségi szinten adott, a hatóságok és a polgári védelmi szervek révén pedig a lakosság is bekapcsolódik a reagálásba. Válsághelyzetben az illetékes szervek speciális felhatalmazással bírnak, ${ }^{58}$ így joguk (és egyben kötelezettségük is) a zavargás vagy felkelés jogi keretek közötti elnyomása, amelyhez egyéb jogszabályok (például a fegyverhasz-

50 Staatliches Krisen- und Katastrophenschutzmanagement (SKKM). Elérhető: www.bmi.gv.at/204/skkm/start.aspx (Letöltve: 2020. február 15.).

51 Nationaler Sicherheitsrat(NSR) Elérhető:www.bundeskanzleramt.gv.at/themen/sicherheitspolitik/nationalersicherheitsrat.html (Letöltve: 2020. február 15.).

52 Lásd a Belügyminisztérium feljegyzését: www.bmi.gv.at/204/SKKM/files/001_Ministerratsbeschluss.pdf (Letöltve: 2020. február 15.).

53 Einsatz- und Koordinationscenter (EKC). Elérhető: www.bmi.gv.at/103/Sektion_II/EKC/start.aspx (Letöltve: 2020. február 15.).

54 Bundeswarnzentrale (BWZ). Elérhető: www.bmi.gv.at/204/skkm/Bundeswarnzentrale.aspx (Letöltve: 2020. fenruár 15.).

55 Bundesministerium für Inneres, 2013.

56 Lásd erről: Jachs, 2011.

57 Lásd erre például Baden-Württemberg tartomány saját katasztrófavédelmi törvényét.

58 Reindl-Krauskopf et al., 2016, 177. o. 
nálati törvény ${ }^{59}$ további speciális felhatalmazást adnak, természetesen az arányosság követelményének szigorú figyelembevétele mellett.

A válságkezeléssel összefüggésben a másik - bár más körben pozicionált - kompetens szervezet a Nemzeti Biztonsági Tanács (NSR), amelyet az USA-t 2001. szeptember 11-én ért terrortámadások hatására állítottak fel. Az NSR két fő feladatköre a szövetségi kormány és egyes miniszterek számára történő tanácsadás, valamint a megfelelő intézkedések előkészítése a kül-, biztonság- és védelempolitika minden alapvető kérdésében, beleértve a válsághelyzeteket generáló szituációkat is. Tagjai részben meghatározott kormányzati pozícióban lévő személyek, részben a politikai pártok képviselői, elnöke a mindenkori osztrák kancellár.

A támadásokkal szembeni hatékony védelem szükségessé tette, hogy egyes válsághelyzetet generáló szituációk megelőzése kapcsán önálló szervezeti egységeket hozzanak létre. Ilyen a kibertámadásokkal szembeni fellépést koordináló Kiberbiztonsági Irányítócsoport, illetve az Alkotmányvédelmi és Terrorizmusellenes Szövetségi Hivata ${ }^{60}$ mint a rendőrség állami védelmet szolgáló hatósági egysége.

Az SKKM 2020-as stratégiája külön nevesíti a technikai innováción keresztül történő hatékonyságnövelés fontosságát. ${ }^{61} \mathrm{~A}$ stratégia a kibertér nem megfelelő müködésétől az állami és nem állami szereplők számítógépes rendszereinek közvetlen támadásáig minden aktivitást átfog, ahol a kibertér szolgál a különféle akciók terepeként, s amelyek nem állnak meg a nemzeti határokon. A Miniszterek Tanácsa 2012-ben hívta életre a Szövetségi Kancellária vezetésével a Kiberbiztonsági Irányítócsoportot, ${ }^{62}$ amelynek célja - többek között - a kiberbiztonsági intézkedések koordinálása, jelentéskészítés, tanácsadás és a Kiberbiztonság Megteremtését Célzó Osztrák Stratégia ${ }^{63}$ (ÖSCS) végrehajtásának figyelemmel kísérése. Az irányítócsoport állandó (például NSR-összekötő tisztviselők, kiberbiztonsági szakértők) és ideiglenes (más minisztériumok, szövetségi államok) tagokból, az állam képviselőiből és a kritikus infrastruktúrák üzemeltetőiből áll. A felelősség azonban megoszlik (az ország belső biztonságát veszélyeztető/fenyegetô támadás esetén a Szövetségi Belügyminisztérium, külső biztonság szempontjából releváns attaknál a Szövetségi Védelmi és Sportminisztérium kerül vezetố szerepbe; utóbbi esetén a katonai nemzetvédelem adja a tevékenység keretét).

59 Fegyverhasználati törvény (Waffengebrauchsgesetz).

60 Bundesamt für Verfassungsschutz und Terrorismusbekämpfung (BVT). Elérhető: www.bvt.gv.at/ (Letöltve: 2020. február 15.).

61 Lásd itt a 6. oldalt: www.kiras.at/fileadmin/_migrated/content_uploads/SKKM_Strategie_2020__Final_ Juli_09.pdf (Letöltve: 2020 . február 1.).

62 Cyber Sicherheit Steuerungsgruppe (További információ elérhető a Bundeskanzleramt [Strategie für Cyber-Sicherheit] honlapjáról: www.bundeskanzleramt.gv.at/themen/sicherheitspolitik/cyber-sicherheit.html [Letöltve: 2020. február 15.].

63 Elérhető: www.bundeskanzleramt.gv.at/dam/jcr:d785192e-8c9d-4c67-8af9-f292371de8c9/\%C3\%96sterreichis che\%20Strategie\%2of\%C3\%BCr\%20Cyber\%20Sicherheit.pdf(Letöltve: 2020. február 1.). 
A Digitális Ausztria információs és kommunikációs technológiabiztonság64 általános elvei korlátozás nélkül alkalmazandók a kiberbiztonság területére is; ezek a titoktartás, integritás, felelősség, hitelesség, elérhetőség, a privát szféra csakúgy, mint az adatok védelme. Ennek megteremtése, illetve biztosítása szintén a Kiberbiztonsági Irányítócsoport feladata.

A különleges jogrenddel és a különböző válsághelyzetek kezelésével kapcsolatban mindig is érzékenyen reagált az osztrák szakmai közeg, amit az újkori népvándorlások első hulláma során tapasztaltak csak tovább fokoztak. A kritika alá vetett rendelkezésekkel összefüggésben 2016-ra több javaslat ${ }^{65}$ is megfogalmazódott.

Az alkotmány értelmében meghatározott feltételek mellett kerülhet sor arra, hogy az alkotmánybíróság egy jogszabály jogellenességét megállapítsa. ${ }^{66}$ Így például szükséges egy olyan személy kérelme, aki azt állítja: a jogellenesség okán jogai közvetlen sérelmet szenvednek, ha az adott rendelet bírósági döntés vagy határozat elfogadása nélkül lép (ôt érintően) hatályba. ${ }^{67} \mathrm{Az}$ osztrák válságkabinet rendeleteinek alkotmánybírósági kontrollja kiemelt elvárás a szakirodalom tárgyalásában. Ezzel összefüggésben rögzítik például, hogy fontos lenne az alkotmánybíróság B-VG 139. cikkelye szerinti felülvizsgálati lehetőség biztosítása akkor is, ha annak időpontjában a vitatott rendelet (jogi norma) már nincs hatályban (lejárt). Ekkor ugyanis hiányzik az idézett törvényi feltétel: már nem áll fenn a kérelmező jogi szférájának közvetlen sérelme. Ilyen esetben lehetővé kellene tenni a norma jogellenességének „lejárat” utáni megállapíthatóságát is.

Ezzel összefüggésben rögzítik a rendeleti jogalkotás rendszeres alkotmánybírósági felülvizsgálatának hiányát azok rövid érvényességi időtartama miatt. Így fogalmazódott meg a gyorsított eljárás alkalmazhatóságának igénye.

Hasonló nehézséget jelent az alkotmányellenes rendelettel összefüggésben anyagi kártérítés fizetése. A jelenleg hatályos, a helyi hatóságok (önkormányzatok), az egyéb hatóságok és a közjogi intézmények felelősségéről szóló törvény ${ }^{68}$ több feltétel együttes fennállásához köti ${ }^{69}$ a kártérítés kifizetését, ezzel jelentősen leszúkítve annak gyakorlati alkalmazhatóságát. Ezért megfontolásra kínálta a szakirodalom a kompenzációs modell alkalmazását; így az anyagi kártérítés a rendelet jogellenességének utólagos megállapítása esetén külön jogi aktus nélkül is megilletné a sérelmet szenvedett felet.

64 'Sicherheit in der Informations- und Kommunikationstechnik (IKT)' E-Government in Österreich in Digitales Österreich. Elérhető: www.digitales.oesterreich.gv.at/sicherheit-in-der-ikt (Letöltve: 2020. február 1.).

65 Reindl-Krauskopf et al., 2016, 238-239. o.

66 B-VG 139. cikk.

67 B-VG 139. cikk (1) bekezdés.

68 Amtshaftungsgesetz (AHG).

69 Így például nem áll(hat) fenn kártérítési igény abban az esetben, ha a sérelmet szenvedett fél a kárt jogorvoslattal, a közigazgatási bírósághoz benyújtott panasszal vagy a közigazgatási törvényszéknél indítványozott felülvizsgálattal elháríthatta volna [AHG 2. \$ (2) bekezdés]. A kártérítési igény az alkotmánybíróság, a legfelsőbb bíróság vagy a közigazgatási bíróság határozatából automatikusan nem vezethető le [AHG 2. \$ (3) bekezdés). 
A gyakorlat és alkalmazhatóság oldaláról az osztrák jogrend által biztosítottak még azon sürgősségi jogi normák is, amelyek lehetôvé teszik az állami szervek kompetenciakeretének bővítését, megoldásaik okán azonban nem igazán veszik figyelembe a szükséghelyzetek által megkövetelt gyorsaságot, könnyú alkalmazhatóságot, valamint a felhatalmazás szükségességét. Igaz ez az alkotmányban rögzített különleges jogrendi rendelkezések, a szövetségi elnök sürgősségi rendeletalkotási jogára is. Bár a terrorizmus „európaizálódása”, illetve felerősödése - különösen 2001. szeptember 11. - után számos szervezeti változtatást foganatosított az állam, különösen a migrációs hullámmal kapcsolatos éles helyzet mutatott rá arra, hogy még további lépésekre van szükség. A menekültválsággal kapcsolatos negatív tapasztalatok tipikusan azzal összefüggésben merültek fel, hogy az illetékes hatóságok, illetve tisztviselók nem tudtak megfelelő gyorsasággal döntést hozni, illetve azok végrehajtása is túl nehézkes volt. Azaz egyértelmú eljárási és döntéshozatali struktúrákra s ezen keresztül egy új válságkezelési rendszerre volt szükség. ${ }^{70} \mathrm{~A}$ kritikák hatására bekövetkező aktivitások keretében létrehozott hattagú Biztonsági Kabinet feladata ${ }^{71}$ a katasztrófa- és válsághelyzeti koordináció. Tagjai a szövetségi kancellár, az alkancellár, valamint a védelmi, a külügy-, a pénzügy- és a belügyminiszter. Válsághelyzetben a szövetségi kormány kérésére 24 órán belül összeül, s üléseit ennek függvényében tartja, garantálva a gyors döntéshozatalt és a „hatékony biztonságirányítást”. A döntések megalapozottságát biztosítja, hogy azok meghozatala egyhangúlag történik - azaz a kancellárnak sincs utasításadási joga a testület felé. További változás, hogy a fegyveres erők feladatköre is bővült. Feladatuk a módosító rendelkezések hatására kiterjedt a kritikus infrastruktúrák védelmére, s jogot kaptak a határok átlépésére is, ha az a repülőgépek üldözése érdekében szükséges. Ennek foganatosításához számos további diplomáciai, jogi lépés szükséges (elsőként Svájc neve merült fel).

Alkotmányos módosítások a terrorizmussal szembeni hatékonyabb fellépés érdekében egyébként is indokoltnak tûntek, ${ }^{72}$ figyelemmel a kritikák hatására született azon tervekre, amelyek közt például a hatékonyabb terrormegelőzés érdekében a közterületek fokozott megfigyelésének kérdése szerepelt. Mindazonáltal a többségében 2016-ban realizálódott változásokat is érte már kritika. ${ }^{73}$ Egyrészt a tekintetben, hogy bár a Biztonsági Kabinet a múködési mechanizmusa okán megfelel a gyorsaság követelményének, valódi hatékonysága a szakirodalom szerint a parlamenthez való kapcsolata minőségétől függ. A kritikusok szerint valódi felhatalmazás és hatáskör nélkül nem tud eredményesen múködni a bizottság. Véleményük szerint ehhez akár a hatalomszétválasztás elvét is érintő széles körű intézkedési kompetenciákra van szükség. Az egyéb veszélyhelyzetekhez képest kevéssé súlyosnak értékelt mene-

70 Lásd a Wiener Zeitung 2016-os cikkét: www.wienerzeitung.at/nachrichten/politik/oesterreich/847111_ Bundesheer-erhaelt-mehr-Befugnisse.html (Letöltve: 2020 . november 11.).

71 Lásd a Belügyminisztérium 2017-es anyagának 51. oldalát: Mehr Freiheit. Mehr Sicherheit. Die Sicherheitsdoktrin des BMI für Österreich 2017-2020. Elérhető: www.bmi.gv.at/bmi_documents/1977.pdf (Letöltve: 2020. április 6.).

72 Seidl, 2016.

73 Augustin, 2016, 100-101. o. 
kültügyi válság kezelésének akadályozottsága azt is megmutatta, hogy az osztrák alkotmány különleges jogrendi szabályozásának felülvizsgálata és módosítása elkerülhetetlen lenne.

Áttekintve azokat az osztrák alkotmánybíróság, legfelsőbb bíróság, közigazgatási legfelsőbb bíróság által hozott döntéseket, ${ }^{74}$ amelyek - a pandémia kezelésétől eltekintve alapjog-korlátozásokkal összhangban születtek, megállapítható, hogy ezek döntő többsége különböző állampolgárságú (például szír, afgán, algériai, iráni, török) menekült személyeket érintő intézkedésekkel, menedékkérelmük elutasításával, illetve a belépő államba (például Olaszország) történő kitoloncolásuk elrendelésével vagy foganatosításával összefüggésben indult eljárásokban születtek. Ausztria nevével egyéb, alapjogsérelemmel kapcsolatos ügyben ritkán találkozni az Emberi Jogok Európai Bírósága előtt. Ilyen volt például a Schalk és Kopf kontra Ausztria ügyben 2010-ben született döntés. ${ }^{75}$

\section{A különleges jogrend kihirdetésének gyakorlati esetei}

Noha Ausztria újkori történetének legnagyobb krízishelyzete a Covid-19, amely a járványügyi rendelkezések eddig nem tapasztalt széles körú alkalmazását hozta, veszélyhelyzet idején alkalmazandó különleges jogrendi alkotmányos rendelkezések igénybevételére - figyelemmel a parlament mindkét kamarájának folyamatos ülésezésére - nem került sor. Ehelyett a Nemzeti Tanács átfogó jogszabályi csomagot ${ }^{76}$ készített 2020 márciusában, amely a Járványügyi tv. mellett a Covid-19 terjedésének lassítását célzó különféle intézkedések jogalkotási alapjául szolgált.

A számtalan korlátozó rendelkezés alkalmazásának keretét a különböző törvények célzott módosítása tette lehetôvé. E körből is kiemelkedik a Járványügyi tv., amelyet „egyszerư" jogtechnikai megoldással tettek jelen helyzetre is alkalmazhatóvá. A törvény nevesíti azokat a betegségeket (például lepra), amelyek esetén a jogszabály igen jelentős korlátozó intézkedései alkalmazhatók. ${ }^{77}$ Ez már tartalmazta a közel-keleti légzőszervi szindrómát (MERS-CoV), amely 2012-ben az Arab-félszigetről kiinduló, szintén koronavírus által okozott betegség. Ez került rövid kiegészítésre az új típusú koronavírus szerepeltetésével (neues Corona-Virus). A törvény - már kimondottan a Covid-19 vonatkozásában - többek között kimondja, hogy az elkülönítési intézkedéssel (karantén) érintett (beteg vagy potenciálisan fer-

74 European Union Agency for Fundamental Rights (FRA) Casa Law Darabase. Elérhető: https://fra.europa.eu/en/ case-law-database?field_fra_country\%5B0\%5D=995\&search_api_views_fulltext=\&sort_by=field_info_ decision_date\&sort_order=DESC\&page=1 (Letöltve: 2020 . április 6.).

75 Ilyen volt például a Schalk és Kopfkontra Ausztria ügyben 2010-ben született döntés. Michael Schalk és Johan Franz Kopf kérelmezők még 2004. augusztus 5-én azért fordultak a nemzetközi bírósághoz, mert hazájukban jogsérelem - és megkülönböztetés - érte őket, amennyiben azonos nemú párként az állam megtagadta tőlük a házasságkötés lehetőségét. Hiába éltek együtt, kapcsolatukat az állam nem ismerte el. [ECtHR/Application no. 30141/04/Judgement (Schalk and Kopfv. Austria)].

76 Lásd erről: Parlamentskorrespondenz Nr. 263 vom 15. Marz 2020.

77 Járványügyi tv. 1. \$. 
tőzött) személyek kapcsán a kerületi közigazgatási hatóság kap felhatalmazást arra, hogy a település polgármestere részére kiadja az intézkedés alá vont személy nevét és elérhetőségi adatait további ellátás, intézkedés stb. céljából. ${ }^{78}$

Az osztrák kormány jogszabályalkotói tevékenységének szakmai hátterét az úgynevezett Korona(vírus)-bizottság (Corona-Kommission) adja. A bizonyítékokon alapuló folyamatos kockázatértékelést végző tanácsadó testület a 9 tartomány képviselőin túl a szövetségi állam tudós szakértőiből, illetve a releváns szövetségi szintű hatóságok képviselőiből áll. A bizottság mind szövetségi, mind tartományi szinten rendelkezik minden szükséges információval, s összetételéből adódóan mind a tudományos, mind a gyakorlati megközelítés teret kap munkája során. Ennek eredményeként a járványügyi, gazdasági, társadalmi, szociális stb. kockázatok megállapításán túl azok csökkentési, mérséklési, megelőzési lehetőségeit is részletesen meghatározzák, arról közvetett módon, írásbeli összefoglalókkal folyamatosan tájékoztatva az egészségügyi minisztert is.

Az osztrák döntéshozók - ezen konklúziókra is figyelemmel - több törvényt is elfogadtak, amelyek széles körben tartalmaznak módosításokat ${ }^{79}$ a jogrendszer olyan alaptörvényeit érintően, mint például az állampolgársági, a közigazgatási bírósági vagy a telekommunikációs törvény. 2020. február 28-tól a különböző miniszteri rendeletek ${ }^{80}$ illetve Covid-19-törvények ${ }^{81}$ a pandémia megelőzési és kezelési igényének megfelelően rendelkeztek például a kereskedelmi vállalkozások múködésének korlátozásáról, illetve bezárásáról, a személyszállításról, a korona-segélyalapról, a válságkezelési alap (COVID-19-FondsG) létrehozataláról ${ }^{82}$ csakúgy, mint például a beutazásról vagy a korábbi korlátozó intézkedések enyhítéséről. A jogszabályok érintették az élet szinte minden területét - így például a gazdasági kamarákról szóló törvény módosítása elsősorban az akadálymentes múkködés feltételeit teremtette meg.

Szilárd határa a jogkorlátozó rendelkezéseknek, hogy azoknak szigorúan meg kell felelniük a járványhelyzet megelőzése és kezelése szempontjából vizsgált szükségesség és arányosság kritériumainak. Erre jó példát jelent a kijárási tilalom alakulása. Míg a járvány kezdetén országos kijárási tilalmat rendelt el a szövetségi kormány, amely szerint az állampolgárok az otthonukat csak élelmiszer-vásárlás, illetve a rászoruló emberek ellátása céljából hagyhatták el, az éttermek, bárok, kávézók és iskolák bezárásra, minden összejövetel, tömeges rendezvény betiltásra került, ez május elseje után megszúnt. Már nem állt fenn a két

78 Járványügyi tv. 3a. \$.

79 A jogszabályokat és azok gyakorlati kérdéseit tekinti át folyamatosan frissített tartalommal: Resch, 2020.

80 Így például a szövetségi szociális, egészségügyi, ápolási és fogyasztóvédelmi miniszter rendeletét az Ausztriába való belépésről a SARS-CoV-2 visszaszorításával kapcsolatban vagy a Covid-19 elterjedése elleni küzdelem érdekében hozott intézkedések enyhítéséről (részletesebben: FRA, 2020b).

81 2. COVID-19-Gesetz, 3. COVID-19-Gesetz, 5. COVID-19-Gesetz.

82 Bundesgesetz über die Errichtung des COVID-19-Krisenbewältigungsfonds (COVID-19-FondsG). Hasonlóképpen sikeres kezdeményezés volt a Korona rövid munkaidejú (Kurzarbeit) foglalkoztatást támogató program, lehetővé téve az eredeti nettó jövedelem 80-90\%-ának kézhezvételét csökkent munkaidő mellett is (FRA, 2020a, 25. o.). 
kritérium egy ilyen szintû alapjog-korlátozáshoz, hiszen a kis üzletek április közepi megnyitása nem vezetett a fertőzésszám megugrásához. Ezért ezt követően a mozgási szabadság korlátozásának a koronavírus-járvány megelőzése szempontjából szükséges és arányos mértéke az összejövetelek résztvevői számának maximum 10 fốben történő meghatározáaát vagy a minimális társadalmi távolság betartásának előirását indokolta. A második hullám újra indokolttá és arányossá tette a szigorúbb fellépést, így november 3-ával bevezették az éjszakai (20.00-06.00 óra) kijárási tilalmat, amely alól csak a rendeletben nevesített esetekben van kivétel.

Az alapjoggyakorlást szúkítő rendelkezések időbeli korláthoz kötöttek, amit tipikusan maguk a jogszabályok ${ }^{83}$ már hatálybalépésükkor tartalmaznak. Így például a Covid-19 terjedésének megakadályozását célzó ideiglenes intézkedésekről rendelkező szövetségi törvény 4. $\$$ (1) bekezdésében rögzíti, hogy a szövetségi törvény a kihirdetés napján lép hatályba, és 2020. december 31-én hatályát veszti. (Nem kizárt azonban a korlátozó intézkedések esetleges meghosszabbítása, mielőtt azok hatályukat vesztenék.)

A törvényességi kontroll számos formában fennáll, de az osztrák parlament nem gyakorol közvetlen ellenőrzést a Covid-19-törvény alapján a kormány által hozott egyedi intézkedések felett. ${ }^{84}$ Ennek hátterében az áll, hogy a rendeletekben rögzített alapjog-korlátozások bevezetéséért, végrehajtásáért, illetve megszüntetéséért továbbra is az adott jogterületért felelős szövetségi és tartományi minisztériumok (illetve áttételesen a végrehajtásban érintett egyéb hatóságok) felelnek. A parlament közvetett ellenőrzési joga azonban fennáll. Ez különösen arra fókuszál, hogy a kormány nem lépi-e túl részben a Covid-19-törvényben, részben a Járványügyi tv.-ben rögzített hatásköreit. Minthogy a demonstrációkat és más gyúléseket nevesítetten nem sorolta fel a Covid-19-intézkedésekről szóló rendelet egyik módosítása sem, így ezekre is a többi szabadtéri rendezvényre irányadó általános szabályok vonatkoznak. Ebből adódóan, amikor például 2020 őszén a koronavírus-tagadók (Corona Leugner) felvonulást szerveztek a korlátozó intézkedések ellen, Bécs rendőrfőnöke hiába kérte ${ }^{85}$ az egészségügyi hatóságokat annak betiltására, erre végül a magas járványügyi kockázatok ellenére sem került sor. A döntés értelmében ugyanis a tiltás jogi alapja nem állhatott fent, mert nem lehetett előzetesen tudni, hogy a demonstrálók betartják-e majd a maszkviselésre és a távolságtartásra vonatkozó előírásokat; azaz egészségük ténylegesen veszélyben lesz-e, vagy sem. ${ }^{86} \mathrm{~A}$ szükségesség és arányosság követelménye konkrét jogszabályi rendelkezések ${ }^{87}$ kapcsán is fennáll.

83 Például a Covid-19 védelmi intézkedésekről szóló rendelet (COVID-19-SchuMaV).

84 Atanassov et al., 2020, 3. o.

85 Lásd az ORF tudósítását: https://wien.orf.at/stories/3073612/ (Letöltve: 2020. november 10.).

86 A részt vevő körülbelül 1500 ember túlnyomó többsége egyébként sem a távolságtartásra, sem a maszkviselésre vonatkozó előírásokat nem tartotta be.

87 Így a Covid-19-korlátozásokat enyhítő rendelet (COVID-19-Lockerungsverordnung - COVID-19-LV) rendezvényeket érintő 10. \$ (13) bekezdése értelmében azon résztvevőkkel szembeni intézkedés alkalmazásától, akik megszegik a maszk viselésére vonatkozó szabályokat, tartózkodni kell, amennyiben a törvényes állapot enyhébb eszközökkel is helyreállítható, vagy ha az intézkedések aránytalanok lennének. 
Számos rendelkezés kapcsán a viták különösen erős politikai színezetet kapnak (például médiafinanszírozás), aminek hatására a Riporterek Határok Nélkül sajtószabadság-rangsorában két helyet visszaesett az ország..$^{88} \mathrm{~A}$ külföldi újságírók kormányzati sajtótájékoztatókon való részvételi lehetőségének korlátozása kapcsán az Európai Unió határozott rosszallása is megfogalmazódott. ${ }^{89}$ Sokan azt emelték ki, hogy a jelenlegi osztrák kormánynak „az üzenetek ellenőrzése" a legfontosabb prioritás, míg a „független és szabad média, amely kritikus jelentést készít és nyomon követi a kormány munkáját, természetesen nem kívánatos".

A pandémia által generált állami reakciókat ${ }^{90}$ érintő heves kritikák ${ }^{91}$ egyrészt a reagálás minőségét, másrészt a konkrét beavatkozási formákat, a döntéshozatal mikéntjét és annak tartalmi elemeit állították a középpontba.

Előbbire jó példa az osztrák sícentrumban, Ischgl településén kitört koronavírus-járvány kezelését vizsgáló, független szakértői bizottság megállapítása. A tiroli régiót mélyen megrázó történet elemzése kapcsán megállapítást nyert a hivatalnokok lassú reakciója, gyenge kommunikációja, „súlyos téves számításaik”, és az ebből adódó rossz kríziskezelési válaszok sora. ${ }^{92}$ Figyelemmel arra, hogy a településről pánikszerúen távozó külföldi turisták okán több ezer fertőzött személy árasztotta el Európát, ezért az osztrák ügyészség nyomozást folytat - gyanúsítottként - egy osztrák és három német személy ellen.

Számos negatív vélemény illeti a konkrét beavatkozási formákat. Így - miközben a nemzetek igyekeznek korlátozni ${ }^{93}$ a vírus terjedését - olyan technológiákhoz is folyamodnak (például az érintkezéseket nyomon követő applikációo ${ }^{94}$ lehetősége), amelyek jelentős adatvédelmi aggályokat ${ }^{95}$ vetnek fel. (De ezen túl is: például a Stopp-Corona-App megjelenésekor a közbeszédet a programot használni nem kívánókkal szembeni negatív attitűd uralta; gyakorlatilag előre megbélyegezték őket, mint olyan személyeket, akik semmit sem tesznek a vírus terjedésének megakadályozása érdekében.)

A döntéshozatal mikéntje és annak tartalmi elemei is a vizsgálatok részét képezték, függetlenül azok pozitív céljától. Az alapvető jogokat korlátozó intézkedések, valamint a jogalkotási eljárások egy-két nap alatt történő „felpörgetése”, ami nem igazán ad teret komoly parlamenti megfontolásnak, több negatív véleményt ${ }^{96}$ generált. Részben ezzel összefüg-

88 Lásd a Kurier cikkét:https://kurier.at/politik/inland/kritik-an-einschraenkungen-der-pressefreiheit-geradein-der-krise/400830557 (Letöltve: 2020 . november 11.).

89 „Nagyon aggasztó, hogy néhány országban a Covid-19-pandémiát ürügyként használják a sajtószabadság jogellenes korlátozásainak bevezetésére." (Lásd a DerStandard cikkét:www.derstandard.at/story/2000117254401/ eu-kommission-warnt-vor-beschraenkung-der-pressefreiheit [Letöltve: 2020 . november 1.].)

90 Bradley et al., 2020.

91 Lásd erről részletesebben: Bennoune, 2020.

92 Lásd a Deutsche Welle hírét: www.dw.com/en/commission-blames-austrian-government-for-poor-handlingof-ischgl-coronavirus-outbreak/a-55251063 (Letöltve: 2020. november 11.).

93 Bradley, et al., 2020, 576. o.

94 Wiese, 2020.

95 Lásd a Wiener Zeitung honlapját: www.wienerzeitung.at/verlagsbeilagen/digitale-republik/2057405-Ueberwachung-als-neue-Normalitaet.html (Letöltve: 2020 . november 11.).

96 Gamper, 2020. 
gésben az is megállapításra került, hogy Ausztriában hiányzik az alkotmánybíróságon keresztül megvalósuló ideiglenes jogi védelem. Azaz nincs olyan mechanizmus, amely lehetôvé tenné, hogy a tervezett törvényeket már a jogalkotási folyamat során ellenőrizze az alapvető jogoknak való megfelelés szempontjából.

Bár a Covid-19 lehetőséget kínálna az emberi jogok elérhetőségének szélesítésére, mélységének megerősítésére a társadalom marginalizálódott csoportjai (például szabadságvesztésüket töltők) számára is, ezek a jogszabályok úgynevezett „ad-hocizmusban” szenvednek - hiányzik belőlük a komplex látásmód, a rendszerben gondolkodás, így sokkal kevésbé képesek szolgálni ezen fokozottan kiszolgáltatott helyzetú személyek jogainak védelmét a pandémia idején. A veszély nagy, hiszen „mind a világjárvány, mind a kormány erre adott válaszai szinte minden nemzetközileg elismert emberi jogot fenyegetnek" ${ }^{97} \mathrm{Az}$ olyan, a járvány elterjedésének korlátozása céljából elengedhetetlen megoldások, mint a társadalmi távolságtartás, a maszkviselés és számos más tevékenység korlátozása, az emberi interakció szinte minden aspektusára kihatnak, ${ }^{98}$ és a figyelem középpontjába emelik a beavatkozás arányosságát, időlegességét, indokoltságát és utóbbi folyamatos igazolását. Így például a gyülekezési jog korlátozása a 2020 tavaszi „Vásárolni igen, tüntetni nem!” szlogen alapján komoly ellenérzést váltott ki. Ha a - nem vitathatóan - fontos gazdasági érdekek miatt megnyitott boltokban volt lehetőség vásárolni, akkor aligha volt magyarázható az összejövetelek mint a gyülekezési szabadság megtestesülései tilalma.99

A megfogalmazott aggályokat - függetlenül a Covid-jogszabályok megszületésének támadhatóságától - részben enyhíti a sunsetklauzulák alkalmazásával garantált és programozott „elmúlásuk”. Másrészt a transzparencia és az áttekinthetőség, indokoltság igazolhatósága érdekében életre hívták és elérhetővé tették ${ }^{100}$ az úgynevezett „korona-jelzőlámpát” (Corona-Ampel), a Korona(vírus)-bizottság kvalitatív és kvantitatív forrásokra támaszkodó területi epidemiológiai kockázatjelzését. A civil-, politikai, szakértői kontroll intenzitását mutatja, hogy például a Stop-Corona-App kapcsán az FPÖ politikusai azzal vádolták meg a kormányt, hogy "totalitárius kém- és megfigyelóállammá akarja építeni Ausztriát”. ${ }^{101}$ Az Osztrák Szövetségi Ügyvédi Kamara ${ }^{102}$ a koronapandémia miatt folyamatos és valós idejű

97 Lásd erről részletesebben: Neha, 2020.

98 Lásd erről részletesebben: Bennoune, 2020.

99 Lásd a Wiener Zeitung riportját: www.wienerzeitung.at/verlagsbeilagen/digitale-republik/2057986-Coronaund-Grundrechte-Shopping-ja-demonstrieren-nein.html (Letöltve: 2020. november 1.).

$100 \mathrm{Az}$ információk elérhetők a Corona-Ampel honlapról. Elérhető: https://corona-ampel.gv.at/karte-coronaampel/.

101 Lásd az APA-OTS beszámolóját: www.ots.at/presseaussendung/OTS_20200404_OTSo028/fpoe-kickl-sobotka-will-oesterreich-zum-totalitaeren-ueberwachungsstaat-umbauen (Letöltve: 2020. november 11.).

102 Az Osztrák Ügyvédi Kamarai Nap (ÖRAK) COVID-19-jogszabály-gyüjteménye a honlapjáról érhető el: www. rechtsanwaelte.at/Covid-19/gesetze-und-verordnungen/bundesgesetze/. 
online oldalt ${ }^{103}$ múködtet, kritikai támogatással. ${ }^{104} \mathrm{~A}$ szakmai folyóiratokban is intenzív a diszkusszió, ${ }^{105}$ például az oltások kötelezővé tételét érintően. ${ }^{106}$

A pandémia által generált helyzetet kísérő erős kritikai attitûd lecsapódik az osztrák alkotmánybíróság munkájában is. A beadványok száma jelentősen megnőtt a korábbi, migrációs krízis által uralt, hasonló kormányzati intézkedéseket kiváltó időszakhoz képest. Így a jogi felülvizsgálatok körében ${ }^{107}$ csak 2020-ban 38 döntés született (például a szolgálati jogról); ebből 13 érintett valamely Covid-19-jogszabályt. Az egyéni indítványra indult ügyek kezdetben inkább a visszatérés utáni karanténkötelezettség értelmezéséről, majd a létszáma távolságtartási, az utazási korlátozások jogalapjáról, illetve a jogkorlátozások arányosságáról, szükségességéről, újabb döntéseiben pedig azok indokoltságáról szóltak.

A határozatok egy része azzal kapcsolatban született, hogy az Ausztriába való visszatérés utáni karanténkötelezettség hogyan értelmezendő, a negatív Covid-teszt mennyiben váltja ki azt, és hogy ennek törvényi szintú eltérő szabályozása az alkotmányban rögzített alapjogokkal szembehelyezkedik-e. Ilyen például a V 432/2020-6 számú döntést megalapozó beadvány, amely a Szövetségi Szociális, Egészségügyi, Ápolási és Fogyasztóvédelmi Minisztérium a szomszédos országokból történő beutazással kapcsolatos intézkedéseket módosító miniszteri rendeletének ${ }^{108}$ alaptörvényben rögzített alapjogba való ütközését kérte kimondani, ${ }^{109}$ amit 2020. június 16-án az alkotmánybíróság elutasított. Más beadványok a szövetségi miniszter a Covid-19-hez kapcsolódó egyéb rendeletét ${ }^{110}$ támadták, többek között azon módosító tételt, amely szerint „egy kiscsoportban legfeljebb hat csapatjátékos, állandó személyi összetétellel [...] vehet részt”, illetve, hogy „a csapat játékosai, edzőnői és edzői, trénernői és trénerei között legalább két méter távolságot kell tartani”. Az indítványok - más okok miatt (például legitimáció) - itt is elutasításra kerültek. ${ }^{111}$ A létszámmal, illetve a távolságtartással kapcsolatos kérdéseken túl más beadvány az utazási korlátozásokat érintette. 2020. július 14-i határozatában elfogadta ugyanakkor az alkotmánybíróság ${ }^{112}$ annak az állampolgárnak a beadványát, s így a Covid-19-intézkedésekről szóló rendelet 1., 2., 4. és 6. \$-át

103 A Korona: Aktuális információk az igazságszolgáltatás és az ügyvédség számára címú tájékoztató oldal a Szövetségi Ügyvédi Kamara (BRAK) honlapján található.

104 Lásd a Szövetségi Ügyvédi Kamara honlapját: https://brak.de/zur-rechtspolitik/newsletter/nachrichten-ausberlin/2020/sondernewsletter-v-242020/ortung-von-mobiltelefonen-brak-aeussert-sich-kritisch/ (Letöltve: 2020. november 1.).

105 Fucik et al., 2020, 337. o.

106 Lásd erről részletesebben: Parlamentskorrespondenz Nr. 1378 vom 07. Dezember 2020.

107 Lásd erről az alkotmánybíróság honlapját. Kiválasztott döntések elérhetô: www.vfgh.gv.at/rechtsprechung/ Ausgewaehlte_Entscheidungen.de.html.

108 A szövetségi szociális, egészségügyi, gondozási és fogyasztóvédelmi miniszter rendelete a szomszédos országokból történő beutazással kapcsolatos intézkedéseiről szóló rendelet módosításáról (BGBl. II Nr. 195/2020)

109 Verfassungsgerichtshof V 432/2020-6 (16. Juni 2020.).

110 A szövetségi szociális, egészségügyi, gondozási és fogyasztóvédelmi miniszter rendelete a Covid-19-intézkedéscsomagról szóló törvény 2. \$1. cikkének megfelelően (BGBl. II Nr. 98/2020).

111 Verfassungsgerichthof V 401/2020-13, V 420/2020-9 döntései (15. Juni 2020).

112 Herzig, 2020. 
is hatályon kívül helyezte, aki grazi lakásából bécsi otthonába a korlátozó intézkedések miatt nem tudott tömegközlekedés használatával eljutni. Az alkotmánybíróság ez esetben a döntés alapját abban ragadta meg, hogy bár a Covid-19 terjedésének megakadályozása érdekében lehet alapjog-korlátozó intézkedést hozni, de az alkotmány által garantált mozgásszabadságot és egyéb polgári jogokat ennek meghatározása során a lehetőségekhez mérten, a legszélesebb körben tiszteletben kell tartani. A konkrét esetben ez hiányzott, azaz nem valósult meg az arányosság és indokoltság kritériuma. Az újabb, augusztusi rendeletmódosítás is fenn kívánta tartani a nyilvános helyekre való bejutás általános tilalmát - noha az alkotmánybíróság kifejezetten megjegyezte, hogy ilyen korlátozás csak megfelelő ideiglenes, személyes és objektív korlátozások mellett engedélyezhetô. Újabb döntéseiben ${ }^{113}$ az alkotmánybíróság követte nyári (2020. július 14-i) gyakorlatát, és számos rendelet alkotmányellenességét állapította meg - bár részben eltérő indokolással. Így jogellenes például több, 2020 tavaszán életbe lépett Covid-19-intézkedés, különösen az éttermekbe és a nem benzinkúthoz csatlakozó, önálló autómosókba való bejutás tilalma, a vendéglátóhelyek vendégszámának korlátozása, a távolságtartás elrendelése az éttermi szolgáltatást nyúitó szolgáltatók tekintetében. A döntések legkésőbb 2020. december 31-én lépnek hatályba. A jogellenesnek elismert rendelkezés esetében az alkotmánybíróság álláspontja szerint a benyújtott iratokból nem lehetett megállapítani, hogy az egészségügyi miniszter mely ténybeli körülmények alapján tartotta azokat szükségesnek és indokoltnak. Ez a tény azonban sérti a Covid-19-intézkedésekről szóló törvényben vagy a Járványügyi tv.-ben meghatározott alapelveket.

\section{4. Összegzés}

Az osztrák és a magyar különleges jogrendi szabályozás mind szellemiségében, mind jogtörténeti előzményeiben, mind jogtechnikai megoldásaiban jelentősen eltér egymástól. Ez annak ellenére igaz, hogy a két ország létének meghatározott időszakában azonos szövetségi rendszeren belül létezett - legyen az a Habsburg Birodalom, az Osztrák-Magyar Monarchia vagy épp az Európai Unió. Sikeres kommunikációs stratégiájának eredményeként a 2. világégés után, a Német Birodalomhoz való korábbi erős elköteleződési szándék ellenére az okkupációs elmélet került elfogadásra, lehetôvé téve ezzel az alkotmányos kontinuitást. A hatályos osztrák alkotmány így az 1920-as, alapjogi elemeiben az 1867-es alkotmányt, más vonatkozásokban az 1929-es alkotmánymódosítást foglalja magában, s továbbviszi a különleges jogrend sajátos megközelítését.

Noha mindkét ország jogrendszere eleget tesz az Európai Unió és egyéb nemzetközi dokumentumok elvárásainak mind garanciális, mind jogállamisági szempontból, a szabályozás szintjében és részletességében eltérő utat követnek. Ausztria alkotmányos szinten

113 Elérhető: www.vfgh.gv.at/medien/Entscheidungen_Oktober-Session.php (Letöltve: 2020. november 11.). 
(B-VG) nem szabályozza részletesen a különleges jogrendre vonatkozó ismérveket, s bár az elmélet a veszélyhelyzetek négy nagy csoportját ismeri - háborús helyzet, felkelés és lázadás, katasztrófák és ellátáshiány -, ezek közül az első kapcsán találhatunk részletesebb rendelkezést a $\mathrm{B}-\mathrm{VG}-$ ben. ${ }^{114} \mathrm{Az}$ alaptörvény nem rendel kifejezett hatáskört ${ }^{115}$ a kormánynak, a szövetségi elnöknek vagy bármely más szervnek arra, hogy hivatalosan meghatározza a válság, válsághelyzet fennállását. Különleges jogrendi jogalkotási joggal - az alkotmány értelmében - a szövetségi elnök rendelkezik, amellyel háború, természeti katasztrófa és más vészhelyzetek esetében a kormány javaslatára élhet. Ezen jog gyakorlását azonban komplex kritériumrendszer, azaz előzetes negatív (például a Nemzeti Tanács döntéshozatalának akadályozottsága), előzetes pozitív (például a szövetségi kormány ellenjegyzése), tartalmi szúkítő (például nem érintheti az alkotmányt) és utólagos (például haladéktalan beterjesztés a Nemzeti Tanács elé) feltétel bástyázza körbe, szigorú előzetes és utólagos kontrollt alkotva.

A szövetségi berendezkedésből adódóan a döntési és végrehajtó hatalom a szövetségi és tartományi hatóságok, illetve - történelmi okok miatt - az alkotmány és az egyéb törvények között megoszlik. A releváns alapjog-korlátozó rendelkezések elrendelhetőségének kritériumait az olyan jogszabályok tartalmazzák, mint például a biztonsági rendőrségről vagy a honvédelemről szóló törvény, megosztva a döntési jogokat az illetékes minisztériumok és a szövetségi kancellária között. A legélesebb szakmai kritikák ${ }^{116}$ logikailag következetlennek („logische Inkonsequenz”), a probléma gyökerénél való kezelését gátlónak („ein Notstand kaum an der Wurzel geheilt werden könnte") tekintik a vészhelyzeti szabályozás mikéntjét és formáját is. „[M]íg az alkotmány részleges és szétszórt intézkedéseket biztosít a szükséghelyzet kezelésére, Ausztria nem rendelkezik tényleges vészhelyzeti alkotmánnyal." ${ }^{{ }_{117}} \mathrm{Ez}$ - a példaértékủ krízisstratégia és intézményrendszer ellenére - különösen az egyéb veszélyhelyzetekhez képest kevéssé súlyosnak értékelt menekültügyi válság rendezésével összefüggő nehézségek okán erősödött fel, strukturális változtatásokat generálva (Biztonsági Kabinet).

Ezen elméleti megközelítést követi a koronavírus-járvány kezelése kapcsán is az osztrák állam. Figyelemmel arra, hogy az osztrák parlament mindvégig múködött, így nem került sor sem a különleges jogrendet érintő veszélyhelyzeti kormányzás, sem rendkívüli állapot kihirdetésére, sem sürgősségi rendeletek elfogadására. ${ }^{118}$ Élt ugyanakkor a kormány mindazokkal a jogszabályi felhatalmazásokkal, amelyek lehetővé tették alapjog-korlátozó rendelkezéseket megalkotását. Ezek kapcsán azonban fontos - akár az alkotmánybíróság döntését is kiváltó - kritérium a szükségesség, arányosság, indokoltság, hatékonyság és különösen

114 B-VG 9a. és 79. cikk.

115 Szemben például a német alaptörvény 80a. cikkében rögzített kétharmados szavazati kötelezettséggel.

116 Pernthaler és Ermacora gondolatait idézi Reindl-Krauskopf et al., 2016, 119. o.

117 Ermacora, 1998, 409. o.

118 European Training and Research Centre for Human Rights and Democracy: Coronavirus pandemic in the EU - Fundamental Rights Implications. Country: Austria. ETC Graz, 3 November 2020. European Union Agency. 
az időbeli korlátozottság megléte. Ez utóbbi konkrét időpontok (sunsetklauzulák) formájában kerül meghatározásra a Covid-19-rendeletekben, amelyek szükség esetén meghosszabbíthatók. A törvényességi kontroll tehát számos formában fennáll, de az osztrák parlament nem gyakorol közvetlen ellenőrzést a Covid-19-törvény alapján a kormány által hozott egyedi intézkedések felett. ${ }^{119}$

A szakmai források ${ }^{120}$ közül több ${ }^{121}$ szerint az alkotmányban rögzített különleges jogrendi rendelkezések, a szövetségi elnök sürgősségi rendeletalkotási joga kvázi „holt jognak” tekinthető, hiszen mind eljárási, mind tartalmi korlátozottsága okán (B-VG 18., 97. cikkelyei) célszerú alkalmazása szinte lehetetlen. Bár a terrorizmus nemzetköziesedése, illetve felerôsödése - különösen 9/11 - után számos szervezeti változtatást foganatosított az állam, különösen a migrációs válsággal kapcsolatos éles helyzet mutatta meg azt, hogy szükség van további lépésekre.

\section{Irodalomjegyzék}

Atanassov, N., Dalli, H., Dumbrava, C., Eckert, G., Jurviste, U., Radjenovic, A., Voronova, S. (2020) States of Emergency in Response to the Coronavirus Crisis: Situation in Certain Member States II. (European Parlament Briefing). Elérhető: www.europarl.europa. eu/RegData/etudes/BRIE/2020/651914/EPRS_BRI(2020)651914_EN.pdf (Letöltve: 2020. november 11.)

Augustin, J. (2016) Ausnahmezustand. Die österreichische Notstandsverfassung aufdem Prüfstand [Online]. Elérhető: www.publiclaw.at/pl/images/stories/schriftenreihe\%202-2016\%20 augustin.pdf (Letöltve: 2020 . november 11.)

Bennoune, K. (2020) '„Lest We Should Sleep”: COVID-19 and Human Rights', American Journal of International Law, 114(4), 666-676. o.

BRAdley, C. A., Helfer, L. R. (2020) 'Introduction to "The International Legal Order and the Global Pandemic"', The American Society of International Law, 114(4), 571-577. o.

Bundesministerium für Inneres (2013) Staatliches Krisen-und Katastrophenschutz-Management. Rechtliche und Organisatorische Grundlagen. 2. kiadás. Wien: BMI

ERMACORA, F. (1998) Österreichische Verfassungslehre. Taschenbuch. 1. kiadás. Wien: Verlag Österreich

FRA (2020a) Coronavirus Pandemic in the EU - Fundamental Rights Implications. Luxembourg: Publication Office of the EU

FRA (2020b) Coronavirus Pandemic in the EU - Fundamental Rights Implications. Country: Austria. European Training and Research Centre for Human Rights and Democracy.

119 Atanassov et al., 2020, 2-3. o.

120 Augustin, 2016, 100. 0.

121 Mathis Fister, Stefan L. Frank, Bernhard Raschauer gondolatait hivatkozza Augustin, 2016, 100. o. 
[Online]. Elérhetô: https://fra.europa.eu/sites/default/files/fra_uploads/austria-reportCovid-19-april-2020_en_0.pdf (Letöltve: 2020. november 11.)

Fucik, R., LeHofer, H. P. (2020) 'Die nächsten drei COVID-19-Gesetze', Österreichische Juristen Zeitung, 2020/8, 337-340. 0 .

GAMPER, A. (2020) Corona und Verfassung [Online]. Elérhető: www.uibk.ac.at/oeffentlichesrecht/100-jahre-b-vg/corona-und-verfassung.html (Letöltve: 2020 . november 11.)

JACHS, S. (2011) Einführung in das Katastrophenmanagement. 1. kiadás. Hamburg: Tedition HINGHOFER-SZALKAY, S. G. (2019) Verfassungsrechtsentwicklung aus rechtstatsächlicher Perspektive. 1. kiadás. Heidelberg: Springer

HeRzIG, R. (2020) Constitutional Court Overrules COVID19 Restrictions [Online]. Elérhető: www. internationallawoffice.com/Newsletters/Healthcare-Life-Sciences/Austria/PreslmayrAttorneys-at-Law/Constitutional-Court-overrules-COVID-19-restrictions (Letöltve: 2020. november 11.)

KeLEMEN, R. (2019) 'Az Alaptörvény szükségállapot-szabályozásának kritikai áttekintése az egyes európai uniós tagállamok alkotmányainak figyelembevételével' in Bartkó, R. (szerk.) A terrorizmus elleni küzdelem aktuális kérdései a XXI. században. 1. kiadás. Budapest: Gondolat Kiadó

KojA, F. (1979) Der Staatsnotstand als Rechtsbegriff. 1. kiadás. Wien: Pustet

Maróti, D. (2017) 'A Második Osztrák Köztársaság az átmeneti időszakban', Polgári Szemle, 13(1-3), 392-406. o.

NeHA, J. (2020) 'Pandemics as Rights-Generators', The American Society of International Law, 114(4), 677-686. o.

Reindl-Krauskopf, S., Salimi, F., Kraml, B., Schulev, E., Scharler, S-M., Pekler, J. (2016) Resilienz des Rechts in Krisenzeiten. 1. kiadás. Wien: Bundesministeriums für Inneres

Resch, R. (szerk.) (2020) Das Corona-Handbuch. Österreichs Rechtspraxis zur aktuellen Lage. 1. kiadás. Wien: Manz

SEIDL, C. (2016) Bundesheer wird gestärkt, der Bundeskanzler nicht [Online]. Elérhető: www. derstandard.at/story/2000045002069/bundesheer-wird-gestaerkt-der-bundeskanzlernicht (Letöltve: 2020. november 11.)

Staudigl-Ciechowicz, K. (2018) 'Das Kriegswirtschaftliche Ermächtigungsgesetz 1917', Beiträge zur Rechtsgeschichte Österreichs, 2018/2, 274-293. o.

SzABó, I. (2010) Ausztria államszervezete 1918-1955. 1. kiadás. Budapest: PPKE JÁK

Till, Sz. (2019) 'Különleges jogrend' in Jakab, A., Fekete, B. (szerk.) Internetes Jogtudományi Enciklopédia. Elérhető: http://ijoten.hu/szocikk/kulonleges-jogrend (Letöltve: 2020. december 13.)

Wiese, J. (2020) Bilanz nach einem halben Jahr „Stopp Corona“-App [Online]. Elérhető: https:// help.orf.at/stories/3202229/ (Letöltve: 2020. november 9.)

Wimmer, T., MülleR, N. (2018) Wirtschaftsrecht. 3. kiadás. Wien: Verlag Österreich

Wissmann, H. (szerk.) (2015) Europäische Verfassungen 1789-1990. 1. kiadás. Tübingen: Mohr Siebeck 


\title{
9. A különleges jogrend alkotmányos és törvényi szintú szabályozása Csehországban
}

\author{
HOJNYÁK DÁVID-SZINEK CSÜTÖRTÖKI HAJNALKA
}

\section{A különleges jogrend alkotmányos és törvényi szintü szabályozása}

A különleges jogrendre vonatkozó szabályozás a cseh jogrendben kizárólag alkotmányos szinten jelenik meg. A cseh alkotmányos szabályozás a hadiállapoton kívül eredetileg nem tartalmazott a különleges jogrendre vonatkozó rendelkezéseket, azonban az 1998-ban elfogadott, a cseh állam biztonságáról szóló alkotmánytörvény pótolta az alkotmányos szabályozás e hiányosságát. Az Állambiztonsági alk.tv. a különleges jogrendi tényállások taxatív felsorolását és átfogó szabályozását adja. A különleges jogrendre vonatkozó alapvetô szabályok mellett ugyanakkor ismertetésre kerülnek a különleges jogrendet megelőző, az arra való felkészülést szolgáló békeidejú szabályok, valamint a válságkezeléssel kapcsolatos jogi rendelkezések is.

1 Ústavní zákon č. 110/1998 Sb., o bezpečnosti České republiky (a továbbiakban:Állambiztonsági alk.tv.).

Dr. Hojnyák Dávid

david.hojnyak@mfi.gov.hu

kutató (Mádl Ferenc Összehasonlító Jogi Intézet)

PhD-hallgató (Miskolci Egyetem Deák Ferenc Állam- és Jogtudományi Doktori Iskola)

Dr. Szinek Csütörtöki Hajnalka

kutató (Mádl Ferenc Összehasonlító Jogi Intézet)

PhD-hallgató (Miskolci Egyetem, Deák Ferenc Állam- és Jogtudományi Doktori Iskola)

Hojnyák, D., Szinek Csütörtöki H. (2021) 'A különleges jogrend alkotmányos és törvényi szintû szabályozása Csehországban' in Nagy, Z., Horváth, A. (szerk.) A különleges jogrend és nemzeti szabályozási modelljei, 217-240. o. Budapest: Mádl Ferenc Összehasonlító Jogi Intézet.

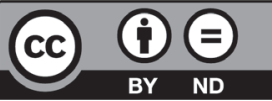


A cseh jogrend kapcsán ugyanakkor fontos megjegyezni, hogy a cseh alkotmány értelmében az alkotmánytörvények ${ }^{2}$ (más néven: alkotmányos törvények vagy alkotmányerejû́ törvények) a Cseh Köztársaság Alkotmányával, valamint az Alapjogok és Alapvető Szabadságok Chartájával együtt alkotják a Cseh Köztársaság alkotmányos rendjét. ${ }^{3} \mathrm{Az}$ alkotmány e rendelkezése alapján az alkotmánytörvények - így a fentebb említett Állambiztonsági alk. tv. is - a cseh alkotmányos rend részét képezik, így az ilyen jogszabályban foglaltak alkotmányos szintú szabályozásnak minősülnek. Míg a különleges jogrendre vonatkozó általános szabályok a cseh jogrendben alkotmányos szinten találhatók meg, addig a különleges jogrendet megelőző, az arra való felkészülést szolgáló békeidejú szabályok, valamint a válságkezelésre vonatkozó szabályok törvényi szinten kerültek rögzítésre.

A cseh jogrendben a különleges jogrend nevesített esetkörei a következők: szükségállapot (nouzový stav), ${ }^{4}$ államot fenyegető állapot (stav ohrožení státu) ${ }^{5}$ és hadiállapot (válečný stav). ${ }^{6}$

Az Állambiztonsági alk.tv. értelmében szükségállapot elrendelésére akkor van lehetőség, ha természeti, ökológiai vagy ipari katasztrófa, baleset vagy egyéb veszély következett be, amely az életet, az egészséget, a vagyonbiztonságot, a közrendet vagy a közbiztonságot jelentős mértékben veszélyezteti.7 Mint látható, ez a meghatározás nyitott, mivel tartalmazza az „egyéb veszély” kifejezést is. A kihirdetés konkrét okának nem kell egybeesnie az elôre rögzített események egyikével, azonban összehasonlíthatónak kell lennie a védett érték veszélyeztetésének alkalmasságával. ${ }^{8}$

Szükségállapot az ország egész területére, valamint annak egyes, meghatározott részei tekintetében is elrendelhetô. ${ }^{9}$ Szükségállapot esetén a kormány dönt annak elrendeléséről, azonban a kormánynak a kétkamarás törvényhozó hatalom ${ }^{10}$ alsóházát, a képviselőházat erről haladéktalanul tájékoztatnia kell, amely e döntést megsemmisítheti. ${ }^{11}$ Figyelni kell azonban arra, hogy az alkotmánytörvény szabályozása alapján a szükségállapot kihirdetésével egyidejúleg a kormány köteles meghatározni, hogy mely, külön törvényben lefektetett jogok

2 Az alkotmánytörvények elfogadásához az összes képviselő háromötödös többségének (minősített többség), valamint a jelen lévő szenátorok háromötödös többségének jóváhagyása szükséges [Cseh Köztársaság Alkotmánya (a továbbiakban: alkotmány) 39. cikk (4) bekezdés].

3 Alkotmány 112. cikk (1) bekezdés.

4 Az Állambiztonsági alk.tv. a nouzový stav kifejezést, míg az alkotmánytörvény hivatalos angol nyelvủ fordítása a state of emergency kifejezést használja.

5 Az Állambiztonsági alk.tv. a stav ohrožení státu kifejezést, míg az alkotmánytörvény hivatalos angol nyelvủ fordítása a condition of threat to the state kifejezést használja.

6 Az Állambiztonsági alk.tv. a válečný stav kifejezést, míg az alkotmánytörvény hivatalos angol nyelvú fordítása a state of war kifejezést használja.

7 Állambiztonsági alk.tv. 5. cikk (1) bekezdés.

8 A téma kapcsán lásd bővebben: Rychetský et al., 2015.

9 Állambiztonsági alk.tv. 2. cikk (2) bekezdés.

10 A cseh törvényhozó hatalom, a parlament kétkamarás, amelynek alsóháza a 200 főből álló képviselóház, felsőháza pedig a 81 szenátorból álló szenátus.

11 Állambiztonsági alk.tv. 5. cikk (4) bekezdés 
és milyen mértékben kerülnek korlátozásra. ${ }^{12}$ Minderre azonban kizárólag az Alapjogok és Alapvető Szabadságok Chartájával összhangban kerülhet sor, amely rögzíti az alapvető jogok és szabadságok korlátozhatóságának szabályait. Emellett a kormánynak meg kell határoznia azt is, hogy milyen kötelezettségeket és milyen mértékben ír elö. ${ }^{13} \mathrm{~A}$ szükségállapot legfeljebb 30 napig tarthat, amely azonban meghosszabbítható a képviselőház előzetes hozzájárulásával. ${ }^{14}$ Ugyanakkor a kormány vagy a képviselőház dönthet úgy is, hogy a meghatározott időtartam lejártát megelőzően megszünteti a szükségállapotot..$^{15}$ Fontos szabályként rögzíti továbbá az alkotmánytörvény, hogy szükségállapot nem rendelhető el olyan sztrájk esetében, amely jogok védelme vagy jogos gazdasági és társadalmi érdek védelme céljából szerveződött. ${ }^{16}$

E ponton rögzítendő, hogy a szükségállapot egy speciális, gyorsított eljárási formájának tekinthető a közvetlen veszélyhelyzet, amikor is a miniszterelnök maga rendelheti el a szükségállapotot, amennyiben a késedelem veszéllyel járna. A miniszterelnök intézkedését azonban 24 órán belül a kormánynak jóvá kell hagynia vagy meg kell semmisítenie. ${ }^{17}$ Erre az esetre is érvényes ugyanakkor az a szabály, hogy a képviselőház e döntést utólagosan megsemmisítheti.

Az alkotmánytörvény szabályozása alapján az államot fenyegetőállapot akkor rendelhető el, ha az állam szuverenitását, területi integritását vagy demokratikus alapjait külső hatalom közvetlenül fenyegeti ${ }^{18} \mathrm{~A}$ szükségállapottal ellentétben az államot fenyegető állapotnál a fenyegetés demonstratív felsorolása hiányzik, csak a "védelem tárgya” került szabályozásra. ${ }^{19}$ Az államot fenyegető állapot szabályozása kapcsán azonban hiányzik az alapjogok korlátozására-korlátozhatóságára való utalás. Ezzel kapcsolatban megjegyzendő, hogy a cseh alkotmányjogi szakirodalomban megjelenik olyan álláspont, amely az Állambiztonsági alk.tv. rendelkezéseit ${ }^{20}$ úgy értelmezi, hogy azok polgári kötelezettséget keletkeztetnek. Ez alapján az állampolgároknak részt kell venniük az állam biztonságának biztosításában, ami felfogható az alapvető jogokba való beavatkozás tolerálásának kötelezettségeként. ${ }^{21}$ E jogszabályi rendelkezés ilyen módon való értelmezése minden bizonnyal lehetséges, kérdéses azonban, hogy miért a legenyhébb különleges jogrendi tényállás, a fentebb ismertetett

12 Sládeček, 2020, 273. o.

13 Állambiztonsági alk.tv. 6. cikk (1) bekezdés. E jogszabályhely kapcsán ugyanakkor megjegyzendő, hogy a cseh szövegben rögzített zvláštní zákon kifejezés és az angol nyelvú fordításban megjelenő individual statutes kifejezés nem teljesen fedi egymást. Jelen munkában, a cseh szövegben rögzített kifejezést alapul véve a külön törvény kifejezést tekintjük irányadónak.

14 Állambiztonsági alk.tv. 6. cikk (2) bekezdés.

15 Állambiztonsági alk.tv. 6. cikk (3) bekezdés.

16 Állambiztonsági alk.tv. 5. cikk (2) bekezdés.

17 Állambiztonsági alk.tv. 5. cikk (3) bekezdés.

18 Állambiztonsági alk.tv. 7. cikk (1) bekezdés.

19 Lásd bővebben: Pavlíček et al., 2011.

20 Állambiztonsági alk.tv. 3. cikk (2) bekezdés.

21 Vaníček, 2001, 264. o. 
szükségállapot esetében tartalmaz a jogszabály kifejezett felhatalmazást az alapvető jogok korlátozása kapcsán. ${ }^{22}$

Az államot fenyegetô állapot a kormány indítványára kizárólag a képviselóház, valamint a szenátus abszolút többségének támogatása mellett rendelhetô el. ${ }^{23} \mathrm{Az}$ államot fenyegető állapot a szükségállapothoz hasonlóan az ország egész területére, valamint annak meghatározott részei tekintetében egyaránt elrendelhetô. ${ }^{24} \mathrm{Az}$ államot fenyegetó állapot idején a kormány kezdeményezheti, hogy a parlament sürgős eljárásban tárgyalja az általa benyújtott törvényjavaslatokat. A képviselőháznak az ilyen törvényjavaslatokról a benyújtástól számított 72 órán belül határoznia kell, majd azt a szenátusnak továbbítja, amely köteles a felterjesztéstôl számított 24 órán belül határozni a törvényjavaslatról. Amennyiben a szenátus ez idő alatt nem nyilvánít véleményt a törvényjavaslatról, akkor azt elfogadottnak kell tekinteni. ${ }^{25} \mathrm{Az}$ államot fenyegető állapot idején nem illeti meg a köztársasági elnököt az elfogadott törvények visszaküldésének joga (vétójog) az olyan törvények vonatkozásában, amelyeket sürgős eljárásban fogadott el a parlament. ${ }^{26} \mathrm{~A}$ kormány esetében pedig korlátként jelenik meg, hogy alkotmánytörvény megalkotására irányuló törvényjavaslatot nem kezdeményezhet sürgős eljárásban. ${ }^{27}$ Kiemelendő, hogy az alkotmánytörvény hallgat arról, hogy miként lehet az államot fenyegetó állapotot megszüntetni, kivételt jelent ez alól az az eset, ha a bejelentés konkrét határidőt tartalmaz. Az erre jogosult valószínúsíthetően az államot fenyegető állapotot kihirdetô állami szerv, tehát a parlament lesz. ${ }^{28}$

A hadiállapottal kapcsolatos szabályok részben az alkotmányban, részben az alkotmánytörvényben kerültek rögzítésre. A hadiállapot kinyilvánításáról a parlament határozhat, amennyiben a Cseh Köztársaságot megtámadják, vagy nemzetközi szerződés közös védelmi kötelezettséget ír elő az ország számára. ${ }^{29} \mathrm{~A}$ hadiállapot kinyilvánításáról szóló határozat elfogadásához a képviselők, valamint a szenátorok többségének szavazata szükséges. ${ }^{30}$ A cseh szabályozás hiányossága figyelhető meg ugyanakkor a tekintetben, hogy sem az alkotmány, sem az alkotmánytörvény nem határozza meg, hogy ki(k) vagy mely szerv(ek) kezdeményezhetik a hadiállapot elrendelését. Az alkotmánytörvény értelmében hadiállapot kizárólag az ország egész területére rendelhető el, ellentétben a már elemzett szükségállapot, valamint az államot fenyegető állapot kategóriákkal, amely tényállások kapcsán azt látjuk, hogy az ország egyes, meghatározott részei tekintetében is elrendelhetók. ${ }^{31} \mathrm{Az}$ alkotmánytörvény megfogalmazásából a hadiállapot ultima ratio jellegére következtethetünk, hiszen

22 Klíma, 2009, 877. o.

23 Állambiztonsági alk.tv. 7. cikk (1)-(2) bekezdés.

24 Állambiztonsági alk.tv. 2. cikk (2) bekezdés.

25 Állambiztonsági alk.tv. 8. cikk (1)-(2) bekezdés.

26 Állambiztonsági alk.tv. 8. cikk (3) bekezdés.

27 Állambiztonsági alk.tv. 8. cikk (4) bekezdés.

28 Stejskal, 2017, 34. 0.

29 Alkotmány 43. cikk (1) bekezdés.

30 Alkotmány 39. cikk (3) bekezdés.

31 Állambiztonsági alk.tv. 2. cikk (2) bekezdés. 
hadiállapot elrendelésére csak akkor van lehetőség, ha kevésbé intenzív intézkedések - tehát a szükségállapot vagy az államot fenyegető állapot elrendelése - nem megfelelőek vagy elégségesek a kívánt cél eléréséhez. ${ }^{32} \mathrm{~A}$ kormány az államot fenyegető állapot szabályaihoz hasonlóan a hadiállapot idején is kezdeményezheti, hogy a parlament sürgős eljárásban tárgyalja az általa benyújtott törvényjavaslatokat, míg a köztársasági elnököt ez esetben sem illeti meg az elfogadott törvények visszaküldésének joga az olyan törvények vonatkozásában, amelyeket sürgős eljárásban fogadott el a parlament.

\subsection{A különleges jogrendi tényállásokra vonatkozó közös szabályok}

Az Állambiztonsági alk.tv. rögzíti, hogy ha a fentebb említett három különleges jogrendi tényállás bármelyikének fennállása esetén az országban uralkodó körülmények nem teszik lehetővé a választások megtartását a rendes választási ciklusra előírt határidőn belül, e határidő törvény által legfeljebb 6 hónappal meghosszabbítható. ${ }^{33} \mathrm{Az}$ alkotmánytörvény továbbá rögzíti, hogy a képviselőház feloszlatása esetén a szenátus illetékes határozni a szükségállapot meghosszabbításáról vagy megszüntetéséról; a hadiállapot, valamint az államot fenyegető állapot kihirdetéséről, illetve dönteni Csehország részvételéről olyan nemzetközi szervezet védelmi rendszerében, amelynek az ország a tagja. ${ }^{34}$ Fontos szabályként jelenik meg továbbá, hogy mindhárom különleges jogrendi tényállás kihirdetéséról szóló határozatot a tömegtájékoztatás útján nyilvánosságra kell hozni, és a törvényekhez hasonlóan ki kell azokat hirdetni. ${ }^{35}$

Összességében elmondható, hogy az Állambiztonsági alk.tv. által rögzített szükségállapot, valamint az államot fenyegetố állapot esetében mindig a kormány kerül felhatalmazásra a szükséges intézkedések kidolgozására. ${ }^{36} \mathrm{Az}$ alkotmánytörvényben továbbá megjelenik a Nemzeti Biztonsági Tanács. ${ }^{37}$ Az NBT alapokmánya értelmében a testület 9 tagú, elnöke a miniszterelnök, míg alelnökei az első számú miniszterelnök-helyettes, valamint a belügyminiszter. ${ }^{38} \mathrm{Az}$ NBT tagja továbbá a védelmi miniszter, a külügyminiszter, a pénzügyminiszter, az ipari és kereskedelmi miniszter, a közlekedési miniszter, az egészségügyi

32 Állambiztonsági alk.tv. 2. cikk (1) bekezdés.

33 Állambiztonsági alk.tv. 10. cikk.

34 Állambiztonsági alk.tv. 11. cikk.

35 Állambiztonsági alk.tv. 12. cikk.

36 Állambiztonsági alk.tv. 5. és 7. cikk.

37 Bezpečnostní Rada Státu (a továbbiakban: NBT). Az NBT múködésével kapcsolatos részletszabályokat a testület alapokmánya rögzíti, amelyet az 544/2014. kormányhatározat (Usnesení vlády ČR ze dne 9. července 2014 č. 544) 1. számú melléklete tartalmaz. E kormányhatározat és a hozzá kapcsolódó melléklet - tehát maga az alapokmány - az utóbbi években többször is módosításra került, legutóbb a 692/2018. kormányhatározat által. A továbbiakban - az egyszerüség kedvéért - az NBT alapokmánya elnevezés alatt kerülnek hivatkozásra a kormányhatározat mellékletében rögzítettek.

38 NBT alapokmánya 3. cikk (1)-(3) bekezdés. E ponton megjegyzendő, hogy a jelenlegi cseh kormány első számú miniszterelnök-helyettese, valamint az ország belügyminisztere ugyanaz a személy, így a gyakorlatban az NBT elnöke, Andrej Babiš kormányfó munkáját alelnökként egy személy, a belügyi tárcát és az első számú miniszterelnöki pozíciót is betöltő Jan Hamáček látja el. 
miniszter, valamint a mezőgazdasági miniszter. ${ }^{39}$ Az NBT meghívására az üléseken jelen lehet a cseh törvényhozás alsóházának (képviselőház), valamint felsőházának (szenátus) elnöke, az NBT-ben nem állandó tag miniszter, valamint más közigazgatási hatóságok vezetôi, helyi és regionális önkormányzatok képviselői, illetve szakértők. ${ }^{40} \mathrm{E}$ szerv feladata a kormány által meghatározott mindazon javaslat elkészítése, amely az állam védelme érdekében szükséges. E rendelkezés kapcsán rögzíti az alkotmánytörvény, hogy a köztársasági elnöknek joga van részt venni az NBT ülésein; az NBT-től vagy annak tagjaitól jelentést kérni, valamint a döntéshozatali hatáskörébe tartozó bármely kérdést megvitatni e szervvel vagy annak tagjaival. ${ }^{41}$ Habár a köztársasági elnök az NBT vonatkozásában pluszjogosítványokat kap, alapvetően az államfő semleges, neutrális szerepköre figyelhető meg a különleges jogrendi tényállások tekintetében. A köztársasági elnök ugyan a fegyveres erők főparancsnoka, valamint kinevezi és előlépteti a tábornokokat, azonban a miniszterelnök vagy az általa megbízott kormánytag ellenjegyzése szükséges a határozatainak érvényességéhez. ${ }^{42}$

Azt látjuk tehát, hogy a különleges jogrendi kormányzás felhatalmazottja szükségállapot, valamint az államot fenyegető állapot esetén a kormány. A hadiállapot tekintetében pedig mind az alkotmány, mind az alkotmánytörvény hallgat arról, hogy ki vagy mely szerv jogosult a kormányzásra. ${ }^{43}$

\subsection{A veszélyhelyzet mint különleges jogrendnek nem minősülő rendkívülifelhatalmazás esetköre}

A klasszikus értelemben vett és fentebb elemzett különleges jogrendi tényállások mellett a cseh jogi szabályozásban megjelenik a veszélyhelyzet (stav nebezpečí) ${ }^{44}$ kategóriája is, amelyet a válságkezelésről szóló törvény ${ }^{45}$ nevesít. Fontosnak tartjuk azonban rögzíteni, hogy egyes szakirodalmi források a veszélyhelyzetet a különleges jogrendi esetkörök negyedik típusaként tartják számon. Ezt a megállapítást e szerzők egyrészt azzal indokolják, hogy az alkotmányos szabályozás a hadiállapot és az államot fenyegető állapot esetén meglehetősen hiányos vagy éppen nem egyértelmú, másrészt pedig az alkotmányos szabályozást nem tekintik kizárólagosnak e témakör vonatkozásában. ${ }^{46}$ Minderre tekintettel e ponton indokoltnak tartjuk rö-

39 NBT alapokmánya 3. cikk (4) bekezdés.

40 NBT alapokmánya 9. cikk (2) bekezdés.

41 Állambiztonsági alk.tv. 9. cikk.

42 Alkotmány 63. cikk (1) bekezdés c) és g) pont, valamint (3) bekezdés.

43 A cseh különleges jogrendi szabályozás kapcsán lásd még: Mareš-Novák, 2019; Kelemen, 2019, 9-35. o.; Kelemen, 2020, 207-234. o.; Jog-összehasonlító módszerrel elemzi az egyes európai országok különleges jogrendi szabályozását: Khakee, 2009, 32-40. 0.

44 A Válságkezelési tv. a stav nebezpečí kifejezést, míg e törvény hivatalos angol nyelvú fordítása a state of danger kifejezést használja.

45 Zákon č. 240/2000 Sb., o krizovém řízení a o změně některých zákonů (a továbbiakban: Válságkezelési tv.). 46 Ennek kapcsán lásd: Kudrna, 2017, 163. o. 
viden ismertetni ezt a kategóriát is, ugyanakkor jelen munka szerzői az alkotmánytörvény hármas felosztását tekintik irányadónak a különleges jogrend esetkörei kapcsán.

Veszélyhelyzetet sürgős intézkedésként akkor lehet elrendelni, ha az emberek élete, egészsége, vagyona, valamint a természeti környezet veszélyben van, azonban a fenyegetés intenzitása nem jelentős mértékú, és a közigazgatási hatóságoknak, a regionális és önkormányzati hatóságoknak, valamint az integrált mentőrendszer egységeinek a szokásos tevékenysége által nem hárítható el az adott fenyegetés. ${ }^{47}$ Veszélyhelyzet egy régión ${ }^{48}$ egész területére vagy annak egy meghatározott részére rendelhető el a regionális kormányzók, míg a foováros, Prága esetében a fốpolgármester által (a továbbiakban együtt: regionális kormányzók). A regionális kormányzóknak a veszélyhelyzet kihirdetését követően haladéktalanul tájékoztatniuk kell a kormányt, a Belügyminisztériumot, a szomszédos régiókat, illetve mindazon régiót, amelyre az adott fenyegetés hatással lehet. ${ }^{49} \mathrm{~A}$ veszélyhelyzet legfeljebb 30 napra rendelhető el, azonban a regionális kormányzók a kormány hozzájárulásával a veszélyhelyzet időtartamát meghosszabbíthatják. ${ }^{50} \mathrm{~A}$ veszélyhelyzetet kihirdetô határozatban rögzíteni kell a veszély elhárításához szükséges válságintézkedéseket, valamint azok hatályátt. ${ }^{51}$ Fontos szabályként rögzíti a törvény, hogy amennyiben nem lehetséges a veszély elhárítása, a regionális kormányzó haladéktalanul felkéri a kormányt, hogy hirdesse ki a szükségállapotot - mint különleges jogrendet - a már korábban rögzített szabályoknak megfelelően. A regionális biztosok által elrendelt válságintézkedések a szükségállapot kihirdetésének napján hatályukat vesztik, kivéve, ha a kormány másként határoz, ugyanakkor a hatályban maradt válságintézkedéseket a kormány intézkedéseinek kell tekinteni. ${ }^{52} \mathrm{~A}$ regionális kormányzó vagy a kormány dönthet úgy, hogy a meghatározott időtartam lejártát megelőzően megszünteti a veszélyhelyzetet, azonban a kormány akkor is megszüntetheti a veszélyhelyzetet, ha az ilyen állapotot kihirdető határozatban foglalt feltételek nem teljesülnek. ${ }^{53}$

\subsection{A különleges jogrendre való felkészülést segitô békeidejü szabályok, valamint a válságkezelésre vonatkozó szabályok}

Míg a különleges jogrendre vonatkozó alapvetô szabályok a cseh jogrendben alkotmányos szinten, a Cseh Köztársaság alkotmányában, valamint az Állambiztonsági alk. tv.-ben találhatók meg, addig a különleges jogrendet megelőző, az arra való felkészülést szolgáló békeidejú szabályok törvényi szinten kerültek rögzítésre. A téma szempontjából elsősorban az alábbi két törvény bír relevanciával: Csehország védelmének biztosításáról szóló

47 Válságkezelési tv. 3. \$ (1) bekezdés.

48 Csehország közigazgatásilag 13 régióra és a fôvárosra, Prágára tagolódik.

49 Válságkezelési tv. 3. \$(3) bekezdés.

50 Válságkezelési tv. 3. \$ (4) bekezdés.

51 Válságkezelési tv. 3. $\$(2)$ bekezdés.

52 Válságkezelési tv. 3. $\$(5)$ bekezdés.

53 Válságkezelési tv. 3. \$ (8) bekezdés. 
222/1999. törvény, ${ }^{54}$ valamint a Válságkezelési tv. Lényeges különbséget tenni a két törvény tárgyi hatálya között, hiszen míg az előbbi törvény a korábban rögzített különleges jogrendi tényállások közül az államot fenyegetô állapottal, valamint a hadiállapottal foglalkozik, addig a Válságkezelési tv. e két kategórián kívül eső különleges jogrendi esetkörökkel kapcsolatos szabályokat rögzít..$^{55}$ Mindkét törvény rendelkezik arról, hogy a különleges jogrendre való felkészülés tekintetében az egyes állami és önkormányzati szerveket milyen jogok illetik meg és milyen kötelezettségek terhelik.

A Védelmi tv. elsődlegesen a kormány hatáskörébe utalja a különleges jogrendre való felkészüléssel kapcsolatos feladatokat. ${ }^{56} \mathrm{~A}$ törvény szabályozása konzekvens a tekintetben, hogy kettéválasztja a kormánynak békeidőben, valamint a hadiállapot és az államot fenyegető állapot elrendelése esetén ellátandó feladatait. Ez alapján a kormány békeidőben különösen az alábbi, a különleges jogrendre való felkészülést szolgáló intézkedések megtételére jogosult, valamint kötelezett: ${ }^{57}$

- felméri azokat a kockázatokat, amelyek fegyveres konfliktusok okai lehetnek, és meghozza a szükséges döntéseket az ilyen kockázatok csökkentése vagy kiküszöbölése érdekében;

- felméri az állam készültségi szintjét a védelem biztosítása tekintetében, és ezzel összefüggésben jelentést nyújt be a köztársasági elnöknek és a parlament mindkét kamarájának a tényekről, valamint az állam védelmének megerősítésére irányuló javasolt intézkedésekről;

— jóváhagyja az állam védelmi stratégiáját; ${ }^{58}$

— dönt a fegyveres erők felépítésének, előkészítésének és felhasználásának alapvető irányairól, valamint a fegyveres erők mozgósításával kapcsolatos koncepcióról;

— jóváhagyja a polgári védelmi felkészítés koncepcióját;

- dönt az állam védelmének biztosításához szükséges egyéb, előre nem látható feladatokról;

- a köztársasági elnöknek és a parlamenti kamaráknak minden évben augusztus 31-ig (vagy kérelmükre bármikor) az állam védelméről szóló jelentést nyújt be. ${ }^{59}$

A törvény ugyanakkor nemcsak a kormány feladatait rögzíti, hanem meghatározza a többi minisztérium, az egyes régiók, az önkormányzatok, a közigazgatási szervek és a Cseh

54 Zákon č. 222/1999 Sb., o zajištování obrany České republiky (a továbbiakban: Védelmi tv.).

55 A két törvény tárgyi hatálya kapcsán lásd:Védelmi tv. 1. \$; Válságkezelési tv. 1. § (1) bekezdés.

56 Védelmi tv. 4 . $\$$.

57 A taxatív felsorolás kapcsán lásd:Védelmi tv. 5. \$(1) bekezdés a)-k) pont.

58 A cseh Védelmi Minisztérium honlapján elérhető a legfrissebb, 2017-ben elfogadott védelmi stratégia: www. army.cz/en/ministry-of-defence/strategy-and-doctrine/defence-strategy-of-the-czech-republic-135549/ (Letöltve: 2020 . december 15.).

59 Védelmi tv. 5 . \$ (3) bekezdés. 
Nemzeti Bank feladatait is a különleges jogrendre való felkészülés tekintetében. ${ }^{\circ}{ }^{\circ}$ Kiemelendő, hogy a törvény egészét áthatja az állami és önkormányzati szervek között fennálló együttmúködési és adatközlési kötelezettség - ezáltal is elősegítve a különleges jogrendre való felkészülést célzó intézkedések gyorsabb és hatékonyabb megvalósítását.

A Válságkezelési tv. szintén a kormány szerepének elsődlegességét hangsúlyozza a különleges jogrendre való felkészülés tekintetében. E törvény azonban nem szabályozza különálló módon azt, hogy a kormánynak békeidőben, valamint ettől elkülönülten, a különleges jogrend elrendelése esetén milyen ellátandó feladatai vannak, hanem e két kategóriát összevonja a szabályozás során. A Válságkezelési tv. által a kormány hatáskörébe utalt feladatok ${ }^{61}$ funkciójukat tekintve alapvetően megegyeznek a Védelmi tv.-ben rögzített kormányzati hatáskörökkel - értelemszerúen fegyveres erőkkel kapcsolatos rendelkezések a Válságkezelési tv.-ben nem kerültek rögzítésre. Új elemként jelenik meg ugyanakkor, hogy a kormány:

- feladatokat ruház(hat) a válságkezelő hatóságokra, valamint irányítja és ellenőrzi is e hatóságok tevékenységét; ${ }^{62}$

— jogosult valamely minisztériumot vagy más központi közigazgatási szervet kijelölni egy adott válsághelyzet megoldására való felkészülés összehangolására; ${ }^{63}$

- a válsághelyzetre való felkészülés során megvitatja a Cseh Nemzeti Bankkal a jegybank hatáskörébe tartozó intézkedéseket. ${ }^{64}$

A Cseh Köztársaság minisztériumainak és egyéb központi államigazgatási szerveinek létrehozásáról szóló, többször módosított 2/1969. törvény ${ }^{65}$ taxatív módon felsorolja az egyes minisztériumokhoz tartozó szakpolitikai területeket, és e területekhez kapcsolódóan meghatározza a különleges jogrendre való felkészülés során ellátandó feladatok körét. A téma szempontjából releváns rendelkezéseket - a már korábban rögzített, Védelmi Minisztériumra vonatkozó rendelkezéseken túl - csupán a Belügyminisztérium kapcsán találunk. A törvény rögzíti, hogy a Belügyminisztérium köteles ellátni a válságkezeléssel, a polgári vészhelyzeti tervezéssel, a lakosságvédelemmel, valamint az integrált mentőrendszerrel

60 Megjegyzendő, hogy a törvény a különleges jogrendre való felkészüléssel kapcsolatban a kormány mellett a védelmi minisztérium meghatározó szerepét emeli ki. A védelmi minisztérium által ellátandó feladatokról, azok taxatív felsorolásáról lásd: Védelmi tv. 6. \$ (1) bekezdés a)-i) pont. Megjegyzendő továbbá, hogy a Cseh Köztársaság minisztériumainak és egyéb központi államigazgatási szerveinek létrehozásáról szóló 2/1969. törvény taxatív módon meghatározza az egyes minisztériumok által ellátandó főbb feladatokat. E törvény a védelmi minisztérium feladatkörébe tulajdonképpen a Védelmi tv.-ben rögzítettekkel megegyező feladatokat utalja a különleges jogrendre való felkészülés tekintetében. Vö. az utóbbi törvény vonatkozó szakaszait az előbbi törvény 16. $\$$ (2) bekezdés a)-h) pontjával.

61 Válságkezelési tv. 4. \$.

62 Válságkezelési tv. 4. $\$$ (1) bekezdés a) pont.

63 Válságkezelési tv. 4. \$(1) bekezdés b) pont.

64 Válságkezelési tv. 4. $\$(2)$ bekezdés.

65 Zákon č. 2/1969 Sb., o zřízení ministerstev a jiných ústředních orgánů státní správy České republiky (a továbbiakban: Minisztériumi tv.). 
kapcsolatos feladatokat. ${ }^{66} \mathrm{Az}$ egyes minisztériumoknak a különleges jogrendre való felkészülésben betöltött szerepéről, békeidőben ellátandó feladataikról a már hivatkozott Védelmi tv., valamint a Válságkezelési tv. mellett az integrált mentőrendszerről szóló 239/2000. törvény ${ }^{67}$ rendelkezik. Figyelemmel ugyanakkor a terjedelmi korlátokra, jelen munkában nincs mód a vonatkozó jogszabályi rendelkezések bővebb ismertetésére.

A cseh szabályozás kapcsán elsőként az rögzítendő, hogy a válsághelyzet kategóriájába mely tényállások, élethelyzetek, fenyegetések sorolandók, hiszen ez alapján tudjuk a válságkezeléssel kapcsolatos jogi szabályozás kereteit meghatározni. A Válságkezelési tv. alapján a válsághelyzet egy gyưjitőfogalom, amely különböző rendkívüli események összességét jelöli. E törvény - a Mentőrendszer tv.-nyel összhangban - ilyen rendkívüli eseményként határozza meg egyrészről a klasszikus értelemben vett különleges jogrendi tényállásokat (így a hadiállapotot, az államot fenyegetố állapotot, valamint a szükségállapotot), másrészről pedig a kritikus infrastruktúra megzavarását eredményező rendkívüli eseményeket. ${ }^{68} \mathrm{~A}$ Válságkezelési tv. tárgyi hatálya ugyanakkor kizárólag azokra a rendkívüli eseményekre, helyzetekre terjed ki, amelyek nem kapcsolódnak az ország külső támadásokkal szembeni védelmének biztosításához. ${ }^{69}$ A gyakorlatban mindez tehát azt jelenti, hogy a hadiállapottal és az államot fenyegető állapottal kapcsolatos, az ilyen válsághelyzetek kezelésére vonatkozó szabályozás más törvény hatálya alá tartozik..$^{70}$ Mindezek alapján megállapítható, hogy a cseh jogi szabályozásban a válsághelyzetről és a válságkezelésről tágabb és szúkebb értelemben is beszélhetünk. Míg a tágabb értelmezés szerint a válsághelyzet kategóriája magába foglalja a különleges jogrendi esetköröket is, addig a szúkebb értelmezés alapján e kategóriába csak a különleges jogrendi tényállásokon kívül eső rendkívüli események tartoznak.

A válságkezeléssel kapcsolatos alapvető szabályok a már hivatkozott Válságkezelési tv.-ben kerültek rögzítésre. E törvény meghatározza, hogy a kormányt, a minisztériumokat, az egyes régiókat, az önkormányzatokat, a közigazgatási szerveket és a Cseh Nemzeti Bankot a válságkezelés során milyen jogok illetik meg és milyen kötelezettségek terhelik. A törvény elsődlegesen a kormány hatáskörébe utalja a válságkezeléssel összefüggő feladatok ellátását. Ez alapján a kormány által ellátandó legfontosabb feladatok a válságkezeléssel kapcsolatban a következők:

- feladatokat ruház(hat) a válságkezelő hatóságokra, valamint irányítja és ellenőrzi is e hatóságok válságkezeléssel kapcsolatos tevékenységét, ${ }^{71}$ ugyanakkor a törvény garanciális szabályként azt is rögzíti, hogy a válságkezelő hatóságok a válságkezelés

66 Minisztériumi tv. 12. \$(1) bekezdés m) pont.

67 Zákon č. 239/2000 Sb., o integrovaném záchranném systému a o změně některých zákonů (a továbbiakban: Mentőrendszer tv.).

68 Válságkezelési tv. 2 . \$ b) pont.

69 Válságkezelési tv. 1. $\$$ (1) bekezdés.

70 A hadiállapottal és az államot fenyegető állapottal kapcsolatos részletszabályokat az Állambiztonsági alk.tv., valamint a Védelmi tv. tartalmazza.

71 Válságkezelési tv. 4. \$ (1) bekezdés a) pont. 
során úgy kötelesek eljárni, hogy a személyek jogaiba történő beavatkozás ne haladja meg a szükséges mértéket; ${ }^{72}$

— jogosult valamely minisztériumot vagy más központi közigazgatási szervet kijelölni egy adott válsághelyzet megoldására való felkészülés összehangolására; ${ }^{73}$

— dönt a válsághelyzetek kezelésére szolgáló kormányzati munkacsoport, a Központi Válságstáb (Ústřední krizový štáb) felállításáról; ${ }^{74}$

- a válsághelyzetre való felkészülés során megvitatja a Cseh Nemzeti Bankkal a jegybank hatáskörébe tartozó intézkedéseket.75

A törvény rögzíti továbbá, hogy a válsághelyzetre történő felkészülés és a válságkezelés során a cseh jegybank köteles válságkezelő személyzetet felállítani, valamint a lehetséges kockázati forrásokról áttekintést készíteni, kockázatelemzéseket végezni, valamint kiküszöbölni azokat a hiányosságokat, amelyek válsághelyzethez vezethetnek. ${ }^{76} \mathrm{~A}$ Válságkezelési tv. a kormány mellett a minisztériumok meghatározó szerepét emeli ki a válságkezelés tekintetében, azonban a terjedelmi korlátokra tekintettel jelen munkában nincs lehetőség az ezzel kapcsolatos részletszabályok ismertetésére.

Fentebb már ismertetésre került, hogy a kormány a válsághelyzetek kezelése céljából felállíthatja a kormányzati munkacsoportként múködő Központi Válságstábot. ${ }^{77} \mathrm{~A}$ Központi Válságstáb a kormány nemzetbiztonsági és védelmi kérdésekkel foglalkozó testülete, az NBT szervezeti struktúrájába tagozódik, annak egyik szervezeti egységeként múködik. A Központi Válságstáb a szükségállapot, az államot fenyegető állapot, a hadiállapot esetén, valamint Csehország biztonságát más módon veszélyeztetô válsághelyzetben a miniszterelnök döntése alapján áll fel, és elsődleges feladata, hogy megoldási javaslatokat nyújtson be a válsághelyzet megoldására az NBT-nek vagy adott esetben közvetlenül a kormánynak. ${ }^{78} \mathrm{~A}$ Központi Válságstáb feladat- és hatáskörébe tartozik továbbá, hogy a válságkezelés tekintetében összehangolja az egyes minisztériumok és más központi közigazgatási szervek tevékenységét, valamint hogy biztosítsa az operatív együttmúködést a különböző nemzetközi szervezetek válságkezelô testületeivel. ${ }^{79} \mathrm{~A}$ testület 17 fóből áll, élén a miniszterelnök által kinevezett személlyel. Főszabályként a testület munkáját a belügyminiszter vezeti, azonban az államot fenyegető állapot, hadiállapot, valamint egyéb, az ország biztonságát veszélyeztető külső támadás esetén a Központi Válságstáb vezetője a védelmi miniszter lesz. ${ }^{80}$

72 Válságkezelési tv. 39c. \$.

73 Válságkezelési tv. 4. \$(1) bekezdés b) pont.

74 Válságkezelési tv. 4. \$ (1) bekezdés c) pont, valamint 24a. \$.

75 Válságkezelési tv. 4. $\$$ (2) bekezdés.

76 Válságkezelési tv. 13. \$(1) bekezdés a)-b) pont.

77 A Központi Válságstáb múködésével kapcsolatos részletszabályokat a testület alapokmánya rögzíti, amelyet az 1500/2008. kormányhatározat (Usnesení vlády ČR ze dne 24. listopadu 2008 č. 1500) tartalmaz.

78 Központi Válságstáb alapokmány 2. cikk 1. és 2. pont, valamint a 3. cikk.

79 Központi Válságstáb alapokmány 2. cikk 4. pont a) alpont.

80 Központi Válságstáb alapokmány 4. cikk. (1)-(2) bekezdés. 


\section{Az alapjogok korlátozására vonatkozó szabályok különleges jogrend idején}

A cseh alkotmány értelmében az alapvető jogok és szabadságok a bírói hatalom védelme alatt állnak, ${ }^{81}$ ezáltal a cseh jogrendszer a legmagasabb szintű védelmet garantálja az alapjogok érvényesülésének. E téma kapcsán a cseh alkotmányos rend részét képező Alapjogok és Alapvető Szabadságok Chartája ${ }^{82}$ bizonyul kulcsfontosságú jogforrásnak, hiszen abban kerülnek rögzítésre az alapjogok és alapvető szabadságok korlátozása esetén alkalmazandó általános szabályok. ${ }^{83}$ A charta deklarálja, hogy kötelezettségeket kizárólag törvény állapíthat meg, és e kötelezettségek csak az alapvető jogok és szabadságok tiszteletben tartása mellett rendelhetők el. ${ }^{84}$ Fontos kitételként jelenik meg továbbá, hogy az alapjogok korlátozására kizárólag az Alapjogok és Alapvető Szabadságok Chartájával összhangban kerülhet sor, valamint, hogy az alapjogok korlátainak meghatározásakor meg kell őrizni azok lényeges elemét, illetve a korlátozások nem használhatók fel más célok érdekében, mint amelyeket törvény meghatározott. ${ }^{85}$

A fentiekhez kapcsolódik, hogy több szakirodalmi álláspont ${ }^{86}$ alapján egy demokratikus jogállamban bármely rendkívüli intézkedés bevezetéséhez több feltétel együttes fennállása szükséges. Az általunk vizsgált szakirodalmi álláspont kapcsán a következők emelendők ki: kivételesség, törvényesség, arányosság, célzottság, az alkotmányos rend alapjainak sérthetetlensége, az ellenőrzési mechanizmusok megléte, illetve a nemzetközi jogból eredő kötelezettségek tiszteletben tartása. ${ }^{87}$

A különleges jogrendi esetköröket szabályozó Állambiztonsági alk.tv. az alapjogok korlátozása kapcsán rendkívül szûkszavú, hiszen csak a szükségállapot kapcsán rögzít rendelkezéseket. Ahogy az már fentebb rögzítésre került, a szükségállapot elrendeléséről a kormány dönt. Az Állambiztonsági alk.tv. szabályozása alapján a szükségállapot kihirdetésével egyidejûleg a kormány köteles meghatározni, hogy az egyes, külön törvényben lefektetett alapjogok milyen mértékben kerülnek korlátozásra. Mindemellett a kormány feladata annak meghatározása is, hogy az egyes szervek vagy személyek tekintetében milyen típusú, illetve mértékű kötelezettséget ír elő.

Az alapjogok különleges jogrend idején történő korlátozása kapcsán a legfontosabb jogszabálynak a Válságkezelési tv. tekinthető, amely részletesen taglalja az elrendelhető intézkedések egyes kategóriáit. Kiemelendő azonban, hogy a jogszabály kifejezetten csak a szükség-

81 Alkotmány 4. cikk.

82 A téma kapcsán lásd bővebben: Husseini et al., 2020.

83 Stejskal, 2017, 47. o.

84 Alapjogok és Alapvető Szabadságok Chartája 4. cikk (1) bekezdés.

85 Alapjogok és Alapvető Szabadságok Chartája 4. cikk (2) és (4) bekezdés. E kapcsán lásd bővebben: Orava, 2015, 54. 0.

86 Dienstbier, 2016, 26-30. o.; Klíma, 2012; Ramraj-Guruswamy, 2011, 91-95. o.; Scheppele, 2010, 178. o.

87 Dienstbier-Derka-Horák, 2020, 421. o. 
állapot, illetve az államot fenyegetô állapot ideje alatt bevezethető korlátozó intézkedéseket szabályozza. Ezen a ponton fontosnak tartjuk rögzíteni azt a tényt is, hogy a Válságkezelési tv. második, a Válságkezelő szervek címet viselő fejezetén belül nemcsak a kormány, hanem más szervek hatásköreit is szabályozza, különös tekintettel a Belügyminisztériumra, az Egészségügyi Minisztériumra, a Közlekedésügyi Minisztériumra, az Ipari és Kereskedelmi Minisztériumra, a községekre, a városokra, a kiterjesztett hatáskörú önkormányzatokra, valamint a Cseh Nemzeti Bankra. Mindemellett a Válságkezelési tv.-ben az NBT és a Központi Válságstáb hatáskörei is szabályozásra kerülnek. Tekintettel jelen munka terjedelmi korlátaira, e ponton nem kerül sor az összes válságkezelő szerv tevékenységének ismertetésére, csupán a kormány által elrendelhető legfontosabb intézkedéseket mutatjuk be az alapjog-korlátozással összefüggésben.

A törvényből kitưnik, hogy szükségállapot és az államot fenyegető állapot idején a szükséges időre és a szükséges mértékben kizárólag az alábbi alapjogok korlátozhatók:

- a személyi sérthetetlenséghez és a magánlakás sérthetetlenségéhez füződő jog;

- a természetes és jogi személyek tulajdonhoz való joga és a használati jogok;

- a szabad mozgáshoz és a lakhatáshoz való jog (a veszélyeztetett vagy a válsághelyzet által érintett területek tekintetében);

- a gyülekezési jog (a veszélyeztetett vagy a válsághelyzet által érintett területek tekintetében);

— az üzleti tevékenység végzéséhez való jog (olyan tevékenységekkel összefüggésben, amelyek veszélyeztethetik vagy megzavarhatják, esetleg ellehetetlenítenék a válságintézkedések hatékony végrehajtását);

- a sztrájkhoz való jog (amennyiben a sztrájkjog gyakorlása a mentési és likvidációs munkálatok megszakításához vagy ellehetetlenítéséhez vezetne). ${ }^{88}$

A törvényben taxatív módon felsorolásra kerültek a kormány által a szükségállapot ideje alatt elrendelhetô intézkedések is. Ebbe a kategóriába tartoznak különösen a következő korlátozó intézkedések: a személyek, illetve a vagyon meghatározott területről történő evakuálása; a személyek meghatározott területekre történő belépésének, tartózkodásának és mozgásának tilalma; a munkakötelezettség elrendelése ${ }^{89} \mathrm{~A}$ kormány a szükségállapot ideje alatt jogosult intézkedéseket hozni az államhatárok védelme, valamint a külföldiek vagy a hontalan személyek tartózkodásának biztosítása érdekében, illetve ezzel összefüggésben a válságintézkedések végrehajtásának biztosítása miatt elrendelheti a katonaság bevetését is. Ezenfelül a kormány a szükségállapot fennállásának ideje alatt tilalmakat vezethet be a pénzeszközök kezelése, valamint a fizetési forgalom tekintetében. ${ }^{90}$

88 Válságkezelési tv. 5 . \$.

89 Válságkezelési tv. 6. $\$$ (1) bekezdés.

90 Válságkezelési tv. 6. \$(3) bekezdés. 
A Válságkezelési tv. külön szakaszban rögzíti az államot fenyegető állapot különleges jogrendi tényállásának ideje alatt elrendelhető intézkedések körét. Ezek részben olyan intézkedések, amelyek a szükségállapot ideje alatt is elrendelhetők, ${ }^{91}$ azonban a törvény kiemeli, hogy a már említett intézkedések mellett a kormány az államot fenyegetó állapot idején korlátozhatja a Cseh Köztársaság területére történő beutazást olyan személyek vonatkozásában, akik más ország állampolgárai, emellett pedig korlátozhatja a lőfegyverek és looszerek birtoklását és viselését, valamint fokozottan ellenőrizheti a tárolt lőfegyverek, lőszerek, robbanóanyagok, nukleáris anyagok, ionizáló sugárforrások, veszélyes vegyi anyagok, biológiai anyagok és a géntechnológiával módosított organizmusok forgalmát. ${ }^{92}$

\section{A különleges jogrend kihirdetésének gyakorlati esetei}

A fent rögzített különleges jogrendi tényállások közül Csehországban a szükségállapot kihirdetésére találunk gyakorlati példákat, míg az államot fenyegető állapot, valamint a hadiállapot³ kihirdetésére ez idáig nem került sor. A gyakorlati példák körén belül azonban el kell különítenünk egymástól azokat az eseteket, amikor a szükségállapotot az ország egész területére, illetve annak csak egy meghatározott részére rendelték el.

Elsőként - a teljesség igénye nélkül - a szükségállapot kihirdetésének utóbbi kategóriába tartozó esetköreit emeljük ki:

A 2002. augusztusi áradások következtében az ország több régiójában árvízválság alakult ki, amely az érintett régiókban élő emberek életét, testi épségét és vagyonbiztonságát jelentős mértékben veszélyeztette, így Vladimír Špidla miniszterelnök 5 régióra kiterjedő szükségállapotot hirdetett ki. ${ }^{94}$

A 2006. áprilisi áradások következtében az ország több régiójában árvízválság alakult ki, amely az érintett régiókban élő emberek életét, testi épségét és vagyonbiztonságát jelentős mértékben veszélyeztette, így a kormány 7 régióra kiterjedő szükségállapotot hirdetett ki. 95

91 A Válságkezelési tv. ezen a ponton kifejezetten utal a szükségállapot idején elrendelhető intézkedésekre, melyeket a 6. \$ (1) és (3) bekezdésében, valamint a 7. \$-ban rögzít.

92 Lásd erről bővebben a Válságkezelési tv. 7. \$-át.

$93 \mathrm{Az}$ 1918-ben létrejött, majd 1993-ban Csehországra és Szlovákiára kettévált Csehszlovákia történetében egyetlen alkalommal, a második világháború során került sor formálisan hadiállapot kihirdetésére. 1941-ben Edvard Beneš, emigrációba vonult csehszlovák államelnök kijelentette, hogy Csehszlovákia hadban áll a náci Németországgal, valamint Magyarországgal, mivel e két ország megsértette a csehszlovák állam szuverenitását.

94 Rozhodnutí Předsedy vlády č. 373/2002 Sb. (373/2002. számú miniszterelnöki határozat). A szükségállapot 2002. augusztus 12 -től augusztus 22 -ig tartott.

95 Rozhodnutí vlády č. 121/2006 Sb. (121/2006. számú kormányhatározat). A szükségállapot 2006. április 2-tól április 19-ig tartott. 
A 2007. januári hurrikán következtében az ország több régiójában olyan súlyos válsághelyzet alakult ki, amely az ott élő emberek életét, testi épségét és vagyonbiztonságát jelentős mértékben veszélyeztette, így a kormány szükségállapotot hirdetett ki. ${ }^{96}$

A 2013. júniusi áradások következtében az ország több régiójában árvízválság alakult ki, amely az érintett régiókban élő emberek életét, testi épségét és vagyonbiztonságát jelentős mértékben veszélyeztette, így a kormány 6 régióra és a fơvárosra, Prágára kiterjedő szükségállapotot hirdetett ki.97

A hivatkozott esetek kapcsán láthatjuk, hogy szükségállapot elrendelésére kivétel nélkül természeti katasztrófa eredményeként elóálló válsághelyzet miatt került sor, amely válsághelyzet az érintett régiókban élő emberek életét, testi épségét és vagyonbiztonságát jelentős mértékben veszélyeztette. A szükségállapotot kihirdető kormány-, illetve miniszterelnöki határozatokban minden esetben rögzítésre kerül, hogy a válsághelyzettel összefüggésben mely alapjog milyen mértékben kerül korlátozásra. Így azt látjuk, hogy például a tulajdonhoz való jog a válsághelyzet kezeléséhez szükséges mértékben korlátozásra került; a szabad mozgás és tartózkodás joga, illetve a gyülekezési jog a veszélyeztetett vagy a válsághelyzet által érintett területeken korlátozásra került; a vállalkozáshoz, illetve az üzleti tevékenység végzéséhez fưződő jog szintén korlátozásra került, amennyiben e jog gyakorlója tevékenysége során veszélyeztette, megzavarta vagy megakadályozta a válságintézkedések végrehajtását. A szükségállapot kihirdetésével kapcsolatos közjogi vita vagy ehhez kapcsolódó bírósági ítélet és alkotmánybírósági döntés nem ismert a példaként hozott esetek vonatkozásában.

A modern kori Csehország történetében először 2020-ban, a koronavírus-járvánnyal összefüggésben került bevezetésre a szükségállapot az ország egész területére..$^{98} \mathrm{~A}$ koronavírus-járvány kezdeti szakaszában a cseh egészségügyi miniszter rendkívüli intézkedések (mimořádné opatření) bevezetése mellett döntött, amire a közegészség védelméről szóló 258/2000. törvény (a továbbiakban: Közeü.tv.) hatalmazta fel. ${ }^{99} \mathrm{~A}$ rendkívüli intézkedések bevezetését követően, 2020. március 12-én - egy nappal a veszélyhelyzet magyarországi elrendelését követően - a kormány a különleges jogrend bevezetését tartotta szükségesnek, ezért szükségállapotot hirdetett az ország egész területére. ${ }^{100} \mathrm{Az}$ Állambiztonsági alk.tv. értelmében - ahogy azt már fentebb is említettük - szükségállapot elrendelésére akkor van lehetőség, ha természeti, ökológiai vagy ipari katasztrófa következett be, vagy más olyan esemény, amely

96 Rozhodnutí vlády č. 11/2007 Sb. (11/2007. számú kormányhatározat). A szükségállapot 2007. január 25-től február 5 -ig tartott.

97 Rozhodnutí vlády č. 140/2013 Sb. (140/2013. számú kormányhatározat). A szükségállapot 2013. június 2-tól június 28-ig tartott.

98 Hojnyák-Ungvári, 2020, 125-128. o.

99 A törvény 80 . \$ (1) bekezdés g) pontja hatalmazza fel az egészségügyi minisztert a sürgősségi intézkedések megalkotására járványhelyzet idején, míg a 69. \$ (1) bekezdés nevesíti azokat az intézkedéstípusokat, amelyek járvány vagy annak bekövetkezésének veszélye esetén kerülhetnek elrendelésre.

100 Sova, 2020, 298. o. 
az életet, az egészséget, a vagyonbiztonságot, a közrendet vagy a közbiztonságot jelentős mértékben veszélyezteti. A szükségállapot során az állam a jogi eszközök három típusát alkalmazta a járvány kockázatának és következményeinek kezelésére: a törvényeket, a kormányzati válságintézkedéseket (amelyek kormányhatározatok formájában realizálódtak), valamint az egészségügyi miniszter által kibocsátott rendkívüli intézkedéseket.

Csehországban a szükségállapot elrendelése rendkívüli felhatalmazást biztosított a kormány számára a koronavírus-járvány kezeléséhez szükséges gyors és hatékony intézkedések meghozatalára, illetve az alapjogok korlátozására. ${ }^{101} \mathrm{Az}$ alapjogok korlátozása kapcsán elsődlegesen a Válságkezelési $\mathrm{tv}^{102}$ bír relevanciával, hiszen e jogszabály rögzíti, hogy a kormány - mint a rendeleti kormányzás felhatalmazottja - mely alapjogokat és milyen mértékben, illetve feltételek szerint jogosult korlátozni szükségállapot idején. A járvány jellegéből adódik, hogy a rendkívüli helyzet megfelelő kezelése érdekében Csehországban különösen az alábbi alapjogok kerültek korlátozásra: a szabad mozgáshoz való jog, a tartózkodási hely szabad megválasztásának joga, a gyülekezési jog, az oktatáshoz való jog, illetve a vállalkozás szabadsága. ${ }^{103}$

A szükségállapotot a különleges jogrendi állapotot szabályozó Állambiztonsági alk. tv. által megengedett leghosszabb időtartamra, 30 napra rendelték el. A szükségállapot végül - annak kétszeri meghosszabbítását követően - 66 nap után, 2020. május 17-én ért véget, a fokozott higiéniai és egészségügyi elóirások betartása azonban az elkövetkezendő időszakra is kötelező volt. A koronavírus-járvány második hullámát a szakértők októberre jósolták, azonban az a vártnál jóval korábban érkezett, és arra késztette a cseh kormányt, hogy ismét szükségállapotot hirdessen. A szükségállapot kihirdetésére 2020. október 5-én került sor, amely eredetileg 2020. november 3-ig volt érvényben, ugyanakkor a képviselőház e kézirat lezárásának időpontjáig három alkalommal, először november 20-ig, másodszor december 12-ig, legutóbb pedig december 23-ig meghosszabbította azt, tekintettel arra, hogy a kormány által hozott intézkedések érvényben tartása - a romló egészségügyi helyzet miatt - továbbra is indokolt.

E ponton szólni kívánunk azokról a közjogi-politikai vitákról is, amelyek a szükségállapot országos szintű kihirdetésével összefüggésben jelentkeztek. A szükségállapot kihirdetésével összefüggésben számos olyan, jogilag releváns eset vált ismertté, amely a cseh kormányzat feltételezett alkotmányellenes, valamint a jogállamiság kritériumait sértő intézkedéseit állította középpontba. Olyan alkotmányjogi panaszok és a közigazgatási bíróságokhoz benyújtott keresetek váltak ismertté a különleges jogrend bevezetésével összefüggésben, amelyek a kormány intézkedéseinek megsemmisítésére irányultak. E keresetek és alkotmányjogi panaszok elsősorban arra hivatkoznak, hogy a szükségállapot elrendelésére alkotmányellenes módon került sor, vagy hogy a kormány által a szükségállapottal összefüg-

101 Venice Commission, 2020, IV.D. 55. és 58. pont.

$102 \mathrm{Az}$ alapjogok korlátozása kapcsán e törvény 5 . \$a)-e) pontja, valamint a 6. \$ és 7. \$ bír kiemelt jelentőséggel. 103 A téma kapcsán lásd bővebben: Syllová, 2020, 19-21. 0. 
gésben kibocsátott jogszabályok alapjog-korlátozásra vonatkozó rendelkezései több esetben nem összeegyeztethetők a szükségesség-arányosság kritériumaival, illetve nem állnak összhangban az alkotmánytörvényben, valamint a Válságkezelési tv.-ben foglalt, alapjog-korlátozásra vonatkozó rendelkezésekkel. ${ }^{104} \mathrm{E}$ közjogi-politikai viták közül jelen munkában az alábbi konkrét eseteket kívánjuk röviden bemutatni.

David Zahumenský cseh ügyvéd 2020. március 26-án alkotmányos panaszt nyújtott be a cseh alkotmánybírósághoz. Panaszának jogalapját azzal indokolta, hogy véleménye szerint a szükségállapot kihirdetésére nem az alkotmányos renddel összhangban került sor, a szükségállapot kihirdetése nem tartja tiszteletben az alapvető emberi jogok védelmének követelményeit, továbbá kifogásolta a kormány egyes válságintézkedéseit, valamint az egészségügyi miniszter által kibocsátott intézkedéseket is, és kérte azok megsemmisítését. Az alkotmánybíróság a panaszt azonban több okból kifolyólag is elutasította: ${ }^{105}$

- a szükségállapot kihirdetéséről szóló kormányhatározat tekintetében azért, mert az alkotmánybíróság nem rendelkezik hatáskörrel annak alkotmányossága megítélése tekintetében;

- az egyes válságintézkedések kapcsán azért, mert a panaszt nyilvánvalóan nem az arra jogosult személy nyújtotta be;

- az egészségügyi miniszter intézkedései tekintetében pedig azért, mert a miniszter egyes intézkedéseit korábban már hatályon kívül helyezték.

Ezt követően Zahumenskýék az Emberi Jogok Európai Bíróságához fordultak jogorvoslatért.

Zahumenský felesége, Vendula Zahumenská a férje képviseletében még az alkotmányos panasz benyújtása előtti napokban, 2020. március 17-én egy keresettel ${ }^{106}$ fordult a Prágai Városi Bírósághoz, amelyben az egészségügyi miniszter által kibocsátott néhány intézkedést, a kormány egyes válságintézkedéseit, valamint a szükségállapot kihirdetéséről szóló kormányhatározatot kifogásolta, és kérte azok megsemmisítését. A bíróság a keresetet április 28-án elutasította. Ennek következtében Zahumenský és felesége panasszal fordultak a Legfelsőbb Közigazgatási Bírósághoz, kérelmezve a Prágai Városi Bíróság határozatának megsemmisítését. Kérelmüket a Legfelsőbb Közigazgatási Bíróság is elutasította. ${ }^{107}$

2020. április 23-án helyezte hatályon kívül a Prágai Városi Bíróság a cseh egészségügyi miniszternek a koronavírus-járvánnyal összefüggésben meghozott négy sürgősségi intézkedését, amelyek korlátozták az állampolgárok szabad mozgását, valamint üzleti-gazdasági tevékenységük végzését. ${ }^{108} \mathrm{~A}$ bíróság szerint az intézkedések törvényellenesek voltak, mert

104 Hojnyák-Ungvári, 2020, 134-136. o.

105 Például ÚS 8/20 sz. határozat.

106 Ügyiratszáma: 10 A 35/2020.

1072 As 141/2020 sz. ítélet.

108 Hejč, 2020, 185. o. 
meghozatalukra egy miniszternek sincs jogosultsága, ilyen döntéseket csak a kormány hozhat a Válságkezelési tv. alapján. ${ }^{109}$

Az alkotmánybíróság a koronavírus-járvány második hulláma alatt, novemberben, formai okokra hivatkozva két másik alkotmányos panaszt ${ }^{110}$ is elutasított, amelyeket a szükségállapot bevezetése és a korlátozó intézkedések kihirdetése miatt nyújtottak be. Az alkotmánybíróság hivatalos honlapján található tájékoztatás alapján a panaszokat nem az arra jogosult személyek nyújtották be, ezért kerültek elutasításra. ${ }^{111}$

\section{4. Összegzés}

Az alábbi táblázatban összefoglaljuk a cseh különleges jogrendi szabályozással kapcsolatos legfontosabb rendelkezéseket:

\begin{tabular}{|c|c|c|c|c|}
\hline & Szükségállapot & \begin{tabular}{|c} 
Közvetlen \\
veszélyhelyzet
\end{tabular} & $\begin{array}{c}\text { Államot fenyegető } \\
\text { állapot }\end{array}$ & Hadiállapot \\
\hline $\begin{array}{l}\text { Szabályozás } \\
\text { szintje }\end{array}$ & \multicolumn{3}{|c|}{ Alkotmányos (alkotmánytörvény) } & $\begin{array}{l}\text { Alkotmányos } \\
\text { (alkotmány és } \\
\text { alkotmánytörvény) }\end{array}$ \\
\hline Elrendelési okok & \multicolumn{2}{|c|}{$\begin{array}{l}\text { — Természeti, ökológiai, ipari } \\
\text { katasztrófa; } \\
\text { — más olyan esemény, amely } \\
\text { az életet, a vagyonbiztonságot, } \\
\text { a közrendet vagy a közbiz- } \\
\text { tonságot jelentős mértékben } \\
\text { veszélyezteti. }\end{array}$} & $\begin{array}{l}\text { Külső hatalom } \\
\text { az állam szuvere- } \\
\text { nitását, területi } \\
\text { integritását vagy } \\
\text { demokratikus } \\
\text { alapjait közvet- } \\
\text { lenül fenyegeti. }\end{array}$ & $\begin{array}{l}\text { — A Cseh Köz- } \\
\text { társaságot } \\
\text { megtámadják; } \\
\text { — nemzetközi } \\
\text { szerződés közös } \\
\text { védelmi kötele- } \\
\text { zettséget ír elő. } \\
\end{array}$ \\
\hline Elrendelés & $\begin{array}{l}\text { A kormány, } \\
\text { azonban a képvi- } \\
\text { selőház hatályon } \\
\text { kívül helyezheti. }\end{array}$ & $\begin{array}{l}\text { A miniszter- } \\
\text { elnök, de } 24 \\
\text { órán belül } \\
\text { a kormánynak } \\
\text { jóvá kell } \\
\text { hagynia, } \\
\text { azonban } \\
\text { a képviselőház } \\
\text { e döntést is } \\
\text { hatályon kívül } \\
\text { helyezheti. }\end{array}$ & $\begin{array}{l}\text { A kormány indít- } \\
\text { ványára a törvény- } \\
\text { hozás két házának } \\
\text { (képviselőház és } \\
\text { szenátus) abszolút } \\
\text { többsége. }\end{array}$ & $\begin{array}{l}\text { A törvényhozás két } \\
\text { házának (képvi- } \\
\text { selőház és szenátus) } \\
\text { abszolút többsége. }\end{array}$ \\
\hline
\end{tabular}

109 A téma kapcsán lásd bővebben: Rủžička, 2020, 549. o.

110 Például ÚS 99/20 és ÚS 100/20 sz. határozatok.

111 E kapcsán lásd a cseh alkotmánybíróság hivatalos honlapján szereplő közleményt: www.usoud.cz/aktualne/ ustavni-soud-odmitl-dve-stiznosti-proti-usnesenim-vlady-o-vyhlaseni-nouzoveho-stavu-a-o-prijetikrizoveho-opatreni (Letöltve: 2020. december 15.). 


\begin{tabular}{|c|c|c|c|c|}
\hline Felhatalmazott & Koükségállapot & $\begin{array}{c}\text { Közvetlen } \\
\text { veszélyhelyzet }\end{array}$ & $\begin{array}{c}\text { Államot fenyegetón } \\
\text { állapot }\end{array}$ & Hadiállapot \\
\hline Gyakorlati esetek & $\begin{array}{c}\text { Kormány, Nemzeti Biztonsági } \\
\text { Tanács }\end{array}$ & $\begin{array}{c}\text { Nem tartalmaz } \\
\text { bóvebbendelkezést. } \\
\text { lönleges jogrend kihirl } \\
\text { detésének gyakorlati } \\
\text { esetei címú részt. }\end{array}$ & Ez idáig nem került kihirdetésre. \\
\hline $\begin{array}{c}\text { Különleges jog- } \\
\text { rendnek nem } \\
\text { minősülő rend- } \\
\text { kívüli helyzet }\end{array}$ & \multicolumn{3}{|c|}{ Veszélyhelyzet (a Válságkezelési tv. alapján) } \\
\hline
\end{tabular}

\section{5. táblázat}

A Cseh Köztársaság különleges jogrendi szabályainak összegzése Forrás: a szerzők sajátösszeállítása

A különleges jogrendre vonatkozó alapvető szabályok a cseh jogrendben alkotmányos szinten, a Cseh Köztársaság Alkotmányában, valamint az Állambiztonsági alk.tv.-ben találhatók meg. A cseh szabályozás a különleges jogrendi esetkörök között három kategóriát nevesít: a szükségállapotot, az államot fenyegető állapotot, valamint a hadiállapotot, azonban külön rögzítendő a közvetlen veszélyhelyzet kategóriája, amely a szükségállapot egy speciális, gyorsított eljárási formájának tekinthető. Az egyes kategóriák kapcsán a cseh szabályozás korrekt módon rögzíti az elrendelésükre okot adó fenyegetéseket és élethelyzeteket. A klasszikus értelemben vett különleges jogrendi esetkörök mellett a cseh jogi szabályozásban megjelenik a veszélyhelyzet kategóriája is, amelyet egyes szakirodalmi források a különleges jogrendi esetkörök negyedik típusaként tartanak számon. A Válságkezelési tv. által nevesített veszélyhelyzet olyan esetkörként jelenik meg a cseh szabályozásban, amely elrendelése esetén - a törvény által az állami és önkormányzati szervek számára biztosított jogosítványoknál fogva - alkalmas lehet egy rendkívüli esemény következtében előálló válsághelyzet kezelésére, ilyenformán pedig szoros kapcsolatot mutat a különleges jogrendi tényállásokkal.

Az elvégzett kutatásból kitúnik, hogy a különleges jogrendi esetkörök elrendelése kapcsán a törvényhozó hatalom dominanciája érvényesül a cseh szabályozásban, hiszen az államot fenyegetó állapotot és a hadiállapotot a parlament rendeli el, míg a szükségállapot és a közvetlen veszélyhelyzet esetében a parlament utólagosan megsemmisítheti a kormánynak vagy a miniszterelnöknek a különleges jogrend elrendelésére vonatkozó döntését. A rendeleti kormányzás felhatalmazottja szükségállapot, valamint az államot fenyegető állapot esetén a kormány, azonban az utóbbi különleges jogrendi kategória esetében - mintegy 
döntés-elókészítő szervként - megjelenik az NBT is. Az NBT - amely a kormány állandó munkacsoportjaként mûkködik - a miniszterelnökből és a kormány által megbízott miniszterekből áll, és e szerv legfőbb feladata a kormány által meghatározott mindazon javaslat elkészítése, amely az állam védelme érdekében szükséges. A hadiállapot tekintetében azonban a cseh szabályozás hiányossága figyelhető meg, hiszen sem az alkotmány, sem pedig az alkotmánytörvény nem rögzíti, hogy ki vagy mely állami szerv van felhatalmazva a rendeleti kormányzásra. A különleges jogrendi tényállások vonatkozásában a köztársasági elnök szerepe neutrális, jogosítványai korlátozottak.

A különleges jogrendet megelőző, az arra való felkészülést szolgáló békeidejû szabályok ugyan több törvényben kerültek rögzítésre, azonban e törvények egymással szoros kapcsolatban állnak, és funkcionálisan kiegészítik egymást. E törvények a kormány, valamint a Védelmi Minisztérium meghatározó szerepét emelik ki a különleges jogrendre való felkészüléssel kapcsolatban. Ez a szabályozási megoldás mindenképpen hordozhat magában előnyöket, hiszen végső soron gyorsabbá és hatékonyabbá teheti a különleges jogrendre való felkészülés folyamatát. Kiemelendő, hogy e törvényekben nemcsak a kormány és a minisztériumok feladatai kerültek rögzítésre, hanem az egyes régiók, az önkormányzatok, a közigazgatási szervek és a Cseh Nemzeti Bank feladatai is meghatározásra kerültek.

A cseh alkotmányos szabályozás nem tartalmaz kifejezett rendelkezéseket a válságkezeléssel kapcsolatban, ide nem értve ugyanakkor a különleges jogrendre vonatkozó alkotmányos szabályokat. A válságkezeléssel kapcsolatos legfontosabb szabályok egy jogszabályban, a Válságkezelési tv.-ben kerültek rögzítésre. A válsághelyzetek gyors és hatékony kezeléséhez, a veszély elhárításához nagymértékben hozzájárulhat az, ha a válságkezeléssel kapcsolatos szabályok egységesen, egy jogszabályban kerülnek rögzítésre - e tekintetben pedig a cseh jogi szabályozás jó példaként szolgál. A Válságkezelési tv. meghatározza, hogy az egyes állami és önkormányzati szerveket milyen jogok illetik meg és milyen kötelezettségek terhelik a válságkezelés során. A téma szempontjából lényeges, hogy a kormány a válsághelyzetek kezelése céljából felállíthatja a kormányzati munkacsoportként múködő Központi Válságstábot, amely a kormány nemzetbiztonsági és védelmi kérdésekkel foglalkozó testülete, az NBT szervezeti struktúrájába tagozódik, annak egyik szervezeti egységeként múködik. A Központi Válságstáb különleges jogrend idején, valamint Csehország biztonságát más módon veszélyeztető válsághelyzetben a miniszterelnök döntése alapján áll fel, és elsődleges feladata, hogy megoldási javaslatokat nyújtson be az NBT-nek vagy adott esetben közvetlenül a kormánynak a válsághelyzet megoldására.

$\mathrm{Az}$ alapjogok különleges jogrend idején történő korlátozása kapcsán megjegyzendő, hogy arra kizárólag a cseh alkotmányos rend részét képező Alapjogok és Alapvető Szabadságok Chartájával összhangban kerülhet sor, amely jogszabály rögzíti az alapjogok korlátozásának általános szabályait. Az alapjog-korlátozás tekintetében részletesebb szabályokat határoz meg a Válságkezelési tv., amely ugyanakkor konkrétan csak két különleges jogrendi 
esetkör, a szükségállapot, valamint az államot fenyegető állapot vonatkozásában rögzíti a korlátozható alapjogok körét, illetve a korlátozás formáját és mértékét.

Ami a különleges jogrend kihirdetésének gyakorlati eseteit illeti, megállapítható, hogy az államot fenyegető állapot, valamint hadiállapot elrendelésére ez idáig nem került sor, azonban a szükségállapot kihirdetésére számos példát találunk. E gyakorlati példák közül kétségtelenül a koronavírus-járvány miatt a közelmúltban két alkalommal is kihirdetett országos szintû szükségállapot tekinthető a legjelentősebbnek. A különleges jogrend bevezetése kapcsán közjogi-politikai jellegú viták is értelemszerúen ezzel kapcsolatban merültek fel a közelmúltban.

A cseh és a magyar szabályozás összevetése kapcsán elsőként rögzítendő, hogy mindkét nemzeti szabályozás alkotmányos szinten rögzíti a különleges jogrenddel kapcsolatos legfontosabb szabályokat. Míg Csehországban a különleges jogrendi esetkörök hármas felosztása érvényesül (szükségállapot, államot fenyegető állapot, hadiállapot), addig a hatályos magyar szabályozás hat különleges jogrendi kategóriát nevesít (rendkívüli állapot, szükségállapot, megelőző védelmi helyzet, terrorveszélyhelyzet, váratlan támadás, veszélyhelyzet). E ponton fontosnak tartjuk rögzíteni, hogy az Alaptörvény kilencedik módosítása ${ }^{112}$ jelentősen átalakította a különleges jogrendre vonatkozó hazai szabályozást. A 2023. július 1-jén hatályba lépő változások következtében a korábbi hat különleges jogrendi kategóriát három váltja fel: a hadiállapot, a szükségállapot, valamint a veszélyhelyzet. Ilyenformán a magyar szabályozás - a cseh szabályozáshoz hasonlóan - a különleges jogrendi esetkörök hármas felosztását veszi át. A változások eredményeképpen a cseh és a magyar különleges jogrendi esetkörök tartalmilag is közelíteni fognak egymáshoz: a magyar veszélyhelyzet kategóriája a cseh szükségállapot kategóriájával, a magyar szükségállapot kategóriája pedig a cseh államot fenyegető állapottal mutat hasonlóságot, míg a háborús szituációhoz kapcsolódó rendkívüli helyzetek mind a cseh, mind a magyar jogrendben a hadiállapot kategóriája alatt kerülnek szabályozásra. További lényeges változás, hogy az Alaptörvény módosítása nyomán különleges jogrend idején a Kormány szerepe és felelőssége jelentősen megnő, hiszen mindhárom különleges jogrendi helyzet vonatkozásában a Kormány lesz a rendeleti kormányzás felhatalmazottja, mindez pedig szintén hasonlóságot mutat a hatályos cseh szabályozással. A különleges jogrendre való felkészülést segítô, valamint a válságkezelésre vonatkozó szabályozást illetően megállapítható, hogy míg Csehországban kifejezetten e kérdésekkel foglalkozó dedikált jogszabályok, addig Magyarországon különböző tárgyú - elsősorban honvédelemmel, valamint katasztrófavédelemmel foglalkozó - jogszabályok rendezik e területek jogi szabályozását.

Közös vonás, hogy a különleges jogrend kihirdetését követően a kormány meghatározó szerepe érvényesül, továbbá mindkét ország esetében elmondható, hogy a köztársasági elnök

112 Magyarország Alaptörvényének kilencedik módosításáról szóló T/13647. számú törvényjavaslat. Az Alaptörvény módosításáról szóló törvényt a kézirat lezárásáig nem hirdették ki a Magyar Közlönyben. 
szerepe többnyire neutrális, az államfők jogosítványai korlátozottak különleges jogrend idején. Habár a rendeleti kormányzás felhatalmazottja mindkét ország esetében a kormány, azonban mindez nem jelenti a törvényhozó hatalom teljes kiiktatását, hiszen a nemzeti parlamenteknek széles körủ jogosítványai vannak mind Csehországban, mind pedig Magyarországon a különleges jogrend kihirdetése, meghosszabbítása, valamint megszüntetése tekintetében. Megjegyzendő továbbá, hogy a - 2023. július 1-jétől megszúnő - magyar Honvédelmi Tanácshoz hasonló, rendkívüli állapotban az államfö, a parlament és a kormány szerepét is átvevő testületre nincs példa a cseh jogi szabályozásban, ugyanakkor az NBT - mint a cseh kormány nemzetbiztonsági és védelmi kérdésekkel foglalkozó testülete - funkcióját tekintve több elemében is hasonlóságot mutat a magyar jogintézménnyel. Habár a két testület összetétele és hatásköre különböző, de tevékenységük megegyezik a tekintetben, hogy a védelmi-nemzetbiztonsági koordinációban kiemelt szerepet játszanak különleges jogrend idején.

A cseh szabályozáshoz hasonlóan a magyar szabályozás is alkotmányos szinten rendelkezik az alapjog-korlátozás legfontosabb szabályairól. Az Alaptörvény is rögzít úgynevezett általános alapjog-korlátozási klauzulát [I. cikk (3) bekezdés], valamint számos alapvető jog esetén kifejezetten utal a korlátozás lehetőségére. Míg a cseh alkotmányos szabályozás rendkívül szúkszavú az alapjogok különleges jogrend idején történő korlátozásával kapcsolatban, addig az Alaptörvény rögzíti, hogy különleges jogrend idején az általános szabályozáshoz képest szélesebb körben van lehetőség az alapjogok korlátozására. A cseh és a magyar nemzeti szabályozás közös vonása továbbá az is, hogy a különleges jogrend során elrendelhető alapjog-korlátozás részletszabályai törvényi szinten kerültek rögzítésre. Míg Csehországban e tekintetben a Válságkezelési tv. tekinthető a legfontosabb jogszabálynak, addig Magyarországon - az úgynevezett honvédelmi tárgyú különleges jogrendi kategóriák esetén - a honvédelemről és a Magyar Honvédségről, valamint a különleges jogrendben bevezethető intézkedésekről szóló 2011. évi CXIII. törvény, valamint - a veszélyhelyzeti kategória vonatkozásában - a katasztrófavédelemről és a hozzá kapcsolódó egyes törvények módosításáról szóló 2011. évi CXXVIII. törvény.

Ahogyan az a fentebbi elemzésből is kitúnik, a meglehetősen túlszabályozott, struktúráját és fogalomrendszerét tekintve olykor nehezen átlátható és értelmezhető hatályos magyar szabályozáshoz képest a cseh különleges jogrendi szabályozás letisztultabb képet mutat. A cseh szabályozás korrekt módon rögzíti az egyes különleges jogrendi kategóriák elrendelésére okot adó fenyegetéseket, nem hagyva kétséget afelól, hogy az adott helyzetben melyik tényállás elrendelése szükséges és kívánatos. Ezt a megállapítást erôsíti az a tény is, hogy a különleges jogrendi tényállások tekintetében - a fennálló fenyegetés, veszély intenzitása alapján - a fokozatosság elve tisztán érvényesül. Megjegyzendő ugyanakkor, hogy pozitív elemei ellenére a cseh különleges jogrendi szabályok számos ponton hiányosak, elég, ha csak a hadiállapottal kapcsolatos, korábban már rögzített hiányosságokra gondolunk. 


\section{Irodalomjegyzék}

Belling, V. (2018) 'Výjimečný stav a hranice právního státu', Právník, 157(3), 200-220. o.

Dienstbier, J. (2016) 'Mimořádne situace a stavy v ústavní historii' in Wintr, J., Antoš, M. (szerk.) Vybrané problémyústavního práva v historické perspektivě. 1. kiadás. Praha: Univerzita Karlova, Právnická fakulta

Dienstbier, J., DeRKA, V., HorÁk, F. (2020) 'Ústavnost mimořádných opatření podle zákona o ochraně veřejného zdraví', Právník, 159(5), 417-432. o.

FARKAS, Á., KELEMEN, R. (szerk.) (2020) Szkülla és Kharübdisz között-Tanulmányok a különleges jogrend elméleti és pragmatikus kérdéseiről, valamint nemzetközi megoldásairól. 1. kiadás. Budapest: Magyar Katonai Jogi és Hadijogi Társaság

HEJČ, D. (2020) 'Nezákonnost mimořádných opatření Ministerstva zdravotnictví k onemocnění COVID-19 podle MS v Praze: Když obsah překračuje formu', Soudní rozhledy, 26(6), 185-190. o.

HoJNYÁK, D., UngVÁRI, Á. (2020) 'Az Európai Unió egyes tagállamainak koronavírusjárványra adott válasza, különös tekintettel a vizsgált államok által bevezetett különleges jogrendi szabályozásra', Miskolci Jogi Szemle, 15(1), 122-138. o.

HusseInI, F. ET AL. (2020) Listina základních práva svobod. Komentářr. 1. kiadás. Praha: C. H. Beck Kelemen, R. (2019) 'Az Alaptörvény szülkségállapot-szabályozásának kritikai áttekintése az egyes európai uniós tagállamok alkotmányainak figyelembevételével - Különös tekintettel a visegrádi államok alkotmányaira' in Bartkó, R. (szerk.) A terrorizmus elleni küzdelem aktuális kérdései a XXI. században. 1. kiadás. Budapest: Gondolat Kiadó

Khakee, A. (2009) Securing Democracy? A Comparative Analysis of Emergency Powers in Europe. Genf: Geneva Centre for the Democratic Control of Armed Forces [Online]. Elérhetô: www.files.ethz.ch/isn/99550/PP30_Anna_Khakee_Emergency_Powers.pdf (Letöltve: 2020. december 15.)

KLÍMA, K. ET AL. (2009) Komentářk Ústavěa Listině. 2. kiadás. Plzeň: Aleš Čeněk

KLíma, K. (2012) O právu ústavním. 1. kiadás. Praha: Wolters Kluwer

KUDRNA, J. (2017) 'Ústavní rámec zajištování bezpečnosti České republiky - zhodnocení současného stavu a úvahy de lege ferenda', Acta Universitatis Carolinae Iuridica, 63(4), 159174. 0 .

MAREš, M., NovÁK, D. (2019) Ústavní zákon o bezpečnosti České republiky (110/1998 Sb.). Komentář. 1. kiadás. Praha: Wolters Kluwer

Orava, V. (2015) Omezení základních práv při mimořádných situacích. 1. kiadás. Brno: Masarykova Univerzita, Právnická fakulta

Pavlíček, V., Gronský, J., HŘebejk, J., Jirásková, V., Mikule, V., PešKa, P., Sládeček, V., SUCHÁNEK, R., Syllová, J. (2011) Ústavní právo a státověda, II. díl. Ústavní právo České republiky. 1. kiadás. Praha: Leges

Ramraj, V. V., Guruswamy, M. (2011) 'Emergency Powers' in Ginsburg, T., Dixon, R. (szerk.) Comparative Constitutional Law. 1. kiadás. Cheltenham: Edward Elgar 
RŮŽIČKA, P. (2020) 'Právní režim nouzového stavu', Právní rozhledy, 28(15-16), 549-555. o.

Rychetský, P., LANGÁšEK, T., Herc, T., MLSNA, P., BARoš, J., JÄGER, P., MAJERČÍí, L', MATOUŠEK, L., Popovičová, L., Pospí̌̌ll, I., UHL, P. (2015) Ústava České republiky, Ústavní zákon o bezpečnosti ČR. Komentář. 1. kiadás. Praha: Wolters Kluwer

SCHEPpele, K. L. (2010) 'Legal and Extralegal Emergencies' in Whittington, K. E., Kelemen, R. D., Caldeira, G. A. (szerk.) The Oxford Handbook of Law and Politics. 1. kiadás. Oxford: Oxford University Press

SLÁDEČEK, V. (2020) 'Vláda a nouzový stav', Správní právo, 53(5-6), 266-281. o.

Sova, A. (2020) 'Přezkum opatření přijatých v době nouzového stavu', Správní právo, 53(5-6), 298-312. 0.

Stejskal, J. (2017) Mimořádné stavy v právním řádu ČR. 1. kiadás. Praha: Univerzita Karlova, Právnická fakulta

SYllová, J. (2020) 'K vyhlášení nouzového stavu v březnu 2020, opatřením vlády ministerstva zdravotnictví', Parlamentní institut, 2020/12 [Online]. Elérhető: www.psp.cz/sqw/text/ orig2.sqw?idd=171939 (Letöltve: 2020 . december 15.)

VANíčEK, J. (2001) ‘Činnost ústavních orgánů za krizových situací', Správní právo, 34(5), 257278. 0.

VENICE COMMISSION (2020) Interim Report on the Measures Taken in the EU Member States as a Result of the COVID-19 Crisis and Their Impact on Democracy, the Rule of Law and Fundamental Rights (Study No. 995/2020) [Online]. Elérhető: www.venice.coe.int/webforms/documents/?pdf=CDL-AD(2020)018-e (Letöltve: 2020 . december 15.)

WinTR, J. (2020) 'K ústavnosti a zákonnosti protiepidemických opatření na jaře 2020', Správní právo, 53(5-6), 282-297. o. 


\section{Különleges jogrend különleges intézkedésekkel Dániában}

NÉMETH ZOLTÁN

\section{A különleges jogrend alkotmányos és törvényi szintư szabályozása, valamint a különleges jogrend és esetkörei}

Dániában alkotmányos szinten a különleges jogrend területe lényegében szabályozatlan. ${ }^{1}$ A rendkívüli állapotra vonatkozóan az alkotmány 23. cikke² a következőt rögzíti: „Rendkívüli állapot esetén, amennyiben a parlament nem ülhet össze, a király ideiglenes jogszabályokat hozhat, amennyiben azok nem ellentétesek az alkotmánnyal; ezeket a parlament összehívásakor azonnal be kell terjeszteni megerősítésre vagy elutasításra."

Számos európai alkotmánnyal ellentétben ${ }^{3}$ tehát a dán alkotmány igen szúkszavú a különleges jogrenddel kapcsolatban - nincs általános alkotmányos rendelkezése a rendkívüli állapotnak, és csak egy külön cikk szól a szükségállapotról.

A dán hatóságok a koronavírus-járvány első hullámában azonnal reagáltak, és az alapvető jogokat korlátozták, különösen a gyülekezési szabadságot, valamint az alkotmányos polgári

1 Ságvári, 2016, 2. o.

2 Nemzeti Alkotmányok az Európai Unióban, 2016, 233. o.

3 Fallentin Nyborg et al., 2020, 1. o.

Dr. Németh Zoltán, LLM

zoltan.nemeth@mfi.gov.hu

kutató (Mádl Ferenc Összehasonlító Jogi Intézet)

Németh, Z. (2021) 'Különleges jogrend különleges intézkedésekkel Dániában' in Nagy, Z., Horváth, A. (szerk.) A különleges jogrend és nemzeti szabályozási modelljei, 241-251. o. Budapest: Mádl Ferenc Összehasonlító Jogi Intézet.

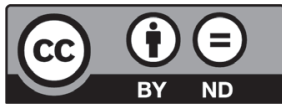


és politikai jogokat. Az alkotmányos szabályoknak kellően rugalmasnak kell lenniük, hogy ilyen rendkívüli helyzetekre is tudjanak reagálni, de Dánia történetében még csak hasonló sem fordult elő eddig, ezért a jogalkotó erre eddig nem tudott felkészülni. ${ }^{4}$

\section{Az alapjogok korlátozásával kapcsolatos kérdések}

A dán alkotmány részletesen foglalkozik az alapjogok kérdéskörével, és meghatározza azok körét a nyolcadik fejezetében. Az alkotmány azt a szabályozási rendszert követi, hogy alapvetően az általa felsorolt alapjogok korlátozását nem engedélyezi, kivéve, ha azokat külön törvényben vagy a köz érdekében korlátozni szükséges. Az alábbi táblázat összefoglalja az alkotmány alapjogi rendszerét és az alapjogok korlátozási lehetőségeit. ${ }^{5}$

\begin{tabular}{|c|c|c|c|}
\hline Alapjog & $\begin{array}{l}\text { Helye az alkot- } \\
\text { mányban }\end{array}$ & Az alapjog terjedelme & A korlátozás lehetősége \\
\hline Személyi szabadság & 71. cikk & Sérthetetlen & Törvény alapján \\
\hline Lakás & 72. cikk & Sérthetetlen & $\begin{array}{l}\text { Bírói rendelkezésre vagy } \\
\text { különleges törvényi } \\
\text { rendelkezés alapján }\end{array}$ \\
\hline Tulajdonjog & 73. cikk & Sérthetetlen & $\begin{array}{l}\text { Törvényben és teljes } \\
\text { kártalanítás mellett }\end{array}$ \\
\hline $\begin{array}{l}\text { Kereskedelemhez } \\
\text { való jog }\end{array}$ & 74. cikk & $\begin{array}{l}\text { Egyenlő és szabad } \\
\text { hozzáférhetőség }\end{array}$ & Kizárólag közérdeken alapulhat \\
\hline Munkához való jog & 75. cikk & Létfenntartás & Törvény szabályozza \\
\hline $\begin{array}{l}\text { Ingyenes általános } \\
\text { iskolai oktatás }\end{array}$ & 76. cikk & $\begin{array}{l}\text { Az iskoláskorú gyer- } \\
\text { mekek jogosultak rá }\end{array}$ & Törvény szabályozza \\
\hline $\begin{array}{l}\text { Szabad } \\
\text { véleménynyilvánítás }\end{array}$ & 77. cikk & $\begin{array}{l}\text { Korlátlan, de bírósági } \\
\text { felelősségvállalás mellett }\end{array}$ & Nem korlátozza törvény \\
\hline Egyesülési szabadság & 78. cikk & Előzetes engedély nélkül & Törvény szabályozza \\
\hline $\begin{array}{l}\text { Gyülekezési } \\
\text { szabadság }\end{array}$ & 79. cikk & Előzetes engedély nélkül & $\begin{array}{c}\text { Korlátozható, ha veszélyt jelent } \\
\text { a közrendre }\end{array}$ \\
\hline
\end{tabular}

6. táblázat

A dán alkotmány alapjogi rendszere

Forrás: a szerző saját összeállitása

4 Klinge et al., 2020, 131. o.

5 Nemzeti Alkotmányok az Európai Unióban, 2016, 239. o. 


\section{Egészségügyi vészhelyzet kezelése, koronavírus-járvány}

\section{1. A koronavírus-járvány első hulláma Dániában}

A parlament - amely a járványhelyzetben is folyamatosan ülésezett ${ }^{6}$ - a koronavírus-járvány első hullámának indulásakor, 2020 márciusában egyhangúlag elfogadta a dán járványügyi törvény ${ }^{7}$ módosítását, ${ }^{8}$ amely felhatalmazza az egészségügyi hatóságokat arra, hogy a rendőrség támogatásával vizsgálatokat folytassanak és intézkedéseket tegyenek. De jure értelemben Dánia nem vezetett be különleges jogrendet. ${ }^{9}$

A törvény képezi a Covid-19-járvány elleni küzdelem során szükséges legátfogóbb korlátozások alapját. ${ }^{10} \mathrm{~A}$ törvény több módosításában a parlament felhatalmazta a kormányt, hogy számos korlátozást, tilalmat vezessen be. Ez vonatkozik például az egyesületi, alapítványi közgyúlések tilalmára, az üzletek, éttermek bezárására, valamint a tömegközlekedés használatának korlátozására. Ezenkívül a kormány utasítást adhat ki magánszemélyeknek, és külön korlátozásokat szabhat a vállalkozásokra, például a közlekedési társaságokra az áruk és az orvosi felszerelések ellátásának biztosítása érdekében. A törvény számos alkotmányos jogot érint, beleértve a gyülekezés szabadságát és a tulajdonjogot.

A hatóságok által a Covid-19-cel kapcsolatban bevezetett intézkedések potenciális hatással vannak az alkotmányosan biztosított jogokra, például a személyi szabadság sérthetetlenségére, ${ }^{11}$ a gyülekezési szabadságra, ${ }^{12}$ valamint az Emberi Jogok Európai Egyezménye által biztosított jogokra, például a családi és magánélethez való jogra, a gyülekezési szabadságra, valamint a tulajdonhoz való jogra. ${ }^{13}$

A Covid-19-re vonatkozó szabályokat a Járványtv. módosításával vezették be. ${ }^{14} \mathrm{~A}$ törvény egyértelmúen olyan kerettörvény, amely a kormánynak, nevezetesen az egészségügyi miniszternek lehetőséget biztosít külön szabályok bevezetésére végrehajtási utasítások kiadásával. Ezek a szabályok később azonnal hatályba léphetnek. Nagyon fontos, hogy ezek a szabályok elsőbbséget élveznek minden más nemzeti jogszabály előtt (az alkotmány kivételével).

A korlátozásoknak azonban ideigleneseknek és arányosaknak kell lenniük, és meghatározott értékelések alapján meghatározott területekre korlátozódhatnak. A kormány több végrehajtási rendeletet adott ki, amelyek ilyen korlátozásokat írtak elő - ilyen volt többek

6 Venice Commission, 2020, 18. o.

7 Lov om foranstaltninger mod smitsomme og andre overførbare sygdomme (a továbbiakban: Járványtv.)

8 2020. 03. 17-i 208. számú törvény a fertőző betegségek és más fertőző betegségek elleni intézkedésekről szóló törvény módosításáról (Lov nr. 208 af 17-03-2020 lov om ændring af lov om foranstaltninger mod smitsomme og andre overførbare sygdomme).

9 Venice Commission, 2020, 14. 0.

10 Dittmer-Edelgaard, 2020.

11 Alkotmány 71. cikk.

12 Alkotmány 79. cikk.

13 European Union Agency for Fundamental Rights, 2020.

14 Járványtv. 27. \$. 
között a nagyobb gyülekezések tilalmáról, valamint az egyes létesítményekhez való hozzáférés tilalmáról és korlátozásáról szóló végrehajtási rendelet ${ }^{15}$ vagy a közlekedési ágazatban hozott intézkedésekről szóló végrehajtási rendelet. ${ }^{16} \mathrm{~A}$ végrehajtási rendelkezések 2020. március 18 -án 10 órakor léptek hatályba. E végrehajtási szabályozások legfontosabb rendelkezéseit az alábbiakban ismertetjük.

A Járványtv. további hatásköröket adhat a kormánynak, ideértve a 10 főnél kisebb létszámú gyưlések tilalmát is, amennyiben az egészségügyi hatóságok ajánlása alapján történik. 2020. április közepétől a kormány több intézkedést jelentett be Dánia fokozatos újranyitására számos korlátozás enyhítésével, amennyiben ezt az egészség szempontjából biztonságosnak tartják. A korlátozások fő része, például a gyülekezési tilalom tiltása eredetileg 2020. május 11-ig volt érvényben, azonban várhatóan az intézkedések nagy része hosszú ideig még érvényben marad. A nagygyúlések tilalma már 2020. szeptember 1-jéig volt érvényes.

A törvényt számos más törvény és szabály egészíti ki. Ez vonatkozik többek között a beutazási korlátozásokra és a határok lezárására, amelyeket a schengeni megállapodás alapján kezdetben 2020. április 13-ig kezdeményeztek. A kormány elkészített egy útmutatót a Covid19-járvány által érintett vállalkozások számára, ${ }^{17}$ valamint egy weboldalt a Covid-19-rôl dán nyelven. ${ }^{18}$

Az üzleti és ipari szempontból a legfontosabb rendelkezések között meg kell említeni, hogy a kormány megtilthatja vagy korlátozhatja azoknak a létesítményeknek a hozzáférését, amelyekkel az üzleti vállalkozások tulajdonosai rendelkeznek, és amelyekhez általános a nyilvánosság hozzáférése. A kormány szerint ezek lehetnek kompkikötők, repülöterek, állomások és találkozóhelyek, például fitneszközpontok, éttermek, koncerttermek, szoláriumok stb. A jogi keretben azonban nincsenek külön korlátozások, ezért a kormány elő́rhat bármilyen létesítménytípusra vonatkozó korlátozásokat.

A gyülekezési jog tilalmáról szóló végrehajtási rendelet ${ }^{19} 6$. szakasza szerint a következő létesítményeket le kell zárni a nyilvánosság előtt:

15 2020. 04. 17-i 442. számú végrehajtási rendelet a nagygyúlések tilalmáról, valamint az egyes létesítményekhez való hozzáférés tilalmáról és korlátozásáról (Bekendtgørelse om ændring af bekendtgørelse om forbud mod større forsamlinger og mod adgang til og restriktioner for lokaler i forbindelse med håndtering af Covid-19 - BEK nr 442 af 17/04/2020).

16 2020. 03. 17-i 22. számú végrehajtási rendelet a közlekedési ágazatban hozott intézkedésekről (Bekendtgørelse om foranstaltninger mod smitsomme og andre overførbare sygdomme på transportområdet - BEK nr 220 af 17/03/2020).

17 Elérhető: www.virksomhedsguiden.dk (Letöltve: 2020 . december 10.).

18 Elérhető: www.politi.dk/coronavirus-i-danmark (Letöltve: 2020. december 10.).

19 2020. évi 1971-es végrehajtási rendelet a nagygyưlések tilalmáról, valamint a helyiségekhez való hozzáférésről, illetve a COVID-19 kezelésével kapcsolatos korlátozásokról szóló végrehajtási rendelet módosításáról (BEK nr 1971 Bekendtgørelse om ændring af bekendtgørelse om forbud mod større forsamlinger og mod adgang til og restriktioner for lokaler og lokaliteter i forbindelse med håndtering af Covid-19) (A továbbiakban: Gyülekezési tilalom r.). 
- helyeket, ahol ételeket és italokat szolgálnak fel, vagy ahol az értékesítési helyen fogyasztandó dohányt értékesítik; élelmiszerek és italok elvitelként történő értékesítése azonban megengedett;

- bevásárlóközpontokat, játéktermeket és bazárokat, valamint az ezekben található üzleteket, kivéve, ha az üzletek közvetlenül az utcáról érhetők el, és az orvosi eszközöket árusító kisboltokat, gyógyszertárakat és szaküzleteket;

- helyeket, ahol sport- és szabadidős tevékenységeket gyakorolnak, beleértve a szerencsejáték-termeket, játszótereket és vízi parkokat, nyilvános uszodákat, fitneszközpontokat, színházakat és mozikat; a szükséges rehabilitációhoz használt létesítmények kivételével;

- tetováló- és piercingszalonokat, gyógyfürdőket, testápolási és szépségápolási klinikákat, masszázsklinikákat, fodrászatokat és más létesítményeket, amelyek olyan szolgáltatásokat kínálnak, amelyek szoros fizikai kapcsolatot jelentenek az ügyfelekkel, valamint a szoláriumokat.

A tilalom 2020. április 20-ig volt hatályban a személyes fizikai kontaktusban dolgozó kisvállalkozások, például a fodrászok, a szépségklinikák és a masszázsklinikák stb. számára. Ezeket az első hullám végén újra lehetett nyitni.

A kormány a Járványtv. alapján a fent említett tilalmak helyett a maximális kihasználtságra és más hasonló korlátozásokra vonatkozó szabályokat írhat elő, például a befogadóképességhez képest csak bizonyos számú ember tartózkodását engedélyezheti, vagy olyan követelményeket támaszthatnak, amelyek szerint az üzleti helyiségekben az embereknek bizonyos távolságot kell tartaniuk. Ezt például szupermarketekben, gyógyszertárakban és más kritikus vállalkozásokban lehet eloórni, ahol a tilalom nem kívánatos, de más korlátozásokra szükség van.

A Gyülekezési tilalom r. 7. szakaszában a kormány számos korlátozást vezetett be minden nyilvános hozzáféréssel rendelkező létesítménytulajdonosra. Ezek a korlátozások tehát nem csak bizonyos típusú létesítményekre vonatkoznak. A vállalkozás tulajdonosának meg kell győződnie arról, hogy ezek a követelmények teljesülnek:

- 4 négyzetméter alapterületen legfeljebb 1 fő engedélyezhető (az alapterületet faltól falig kell mérni, függetlenül a bútoroktól és a felszereléstől stb.);

- a létesítményeket a lehető legnagyobb mértékben úgy kell megszervezni, hogy minimalizálják a fertőzés kockázatát, többek között lehetővé téve az ügyfelek és a látogatók számára, hogy távolságot tartsanak egymás között;

- a létesítményekben vagy azok közelében tájékoztató anyagokat kell elhelyezni annak érdekében, hogy a Covid-19 tüneteivel küzdő emberek otthon maradjanak elszigetelten (az információs anyagnak meg kell felelnie a dán egészségügyi hatóság utasításainak); 
- biztosítani kell, hogy minden alkalmazott betartsa az egészségügyi hatóság jó higiéniára és megfelelő viselkedésre vonatkozó ajánlásait;

— a lehetőségekhez mérten kézfertôtlenítőt kell a látogatók részére biztosítani;

- a nem csomagolt élelmiszerek értékesítésekor az alkalmazottaknak kesztyút kell használniuk.

Ha a vállalkozások nem tartják be a fent említett korlátozásokat, a rendőrség elrendelheti a létesítmény bezárását egy meghatározott időszakra. ${ }^{20}$

A kormány el akarta kerülni azokat a nagy összejöveteleket, amelyek a betegség terjedésének nagy kockázatával járnak. A Járványtv. rendelkezései értelmében a kormány megkapja annak lehetőségét, hogy megtiltsa a nagygyưlések, egyeztetések, rendezvények stb. szervezését és az azokon történő részvételt. Ez magában foglalhatja beltéri, kültéri és nyilvános, valamint magángyưléseket (kivéve a magánlakásokban zajló eseményeket). A tiltások bármilyen típusú eseményre kiterjedhetnek, például koncertekre, sporteseményekre, partikra, közgyúlésekre és társaságokban vagy egyesületekben tartott találkozókra.

Először is, a kormány a Gyülekezési tilalom r. 1. szakaszában tiltást vezetett be, amely elözetesen 2020. május 11-ig volt hatályban. Másodszor, a kormány 2020. szeptember 1-ig megtiltotta a több mint 500 résztvevőből álló nagygyúléseket. A tilalom azt jelenti, hogy fesztiválok, koncertek, sportesemények stb. ebben az időszakban nagyrészt nem lesznek engedélyezettek.

E törvény értelmében a kormány felhatalmazást kapott arra, hogy általában megtiltsa a kevesebb mint 10 résztvevős gyülekezéseket is. Ehhez azonban meg kell követelni, hogy ez az egészségügyi hatóságok ajánlásain alapuljon, és csak akkor, ha a kevésbé radikális intézkedéseket nem tartják elégségesnek. A törvényjavaslat memoranduma feltételezi, hogy a tilalom nem vonatkozik az ugyanazon lakóhelyen lévő vagy közeli hozzátartozóikra. Ilyen tilalmat nem vezettek be, és várhatóan nem is alkalmazzák a későbbiekben sem.

A kormány megkapta annak lehetőségét, hogy bezárja azokat a meghatározott területeket, amelyekről úgy tartják, hogy különleges fertőzésveszélyt hordoznak. Ezenkívül a rendőrség lehetőséget kapott arra, hogy teljes mértékben megtiltsa bizonyos helyek látogatását, ahová a betegség terjedésének veszélye miatt a nyilvánosság általában hozzáfér. Ez vonatkozik például terekre, parkokra, utakra, strandokra, vidámparkokra, vasútállomásokra, repülőterekre, üzletekre és bevásárlóközpontokra. A tilalom látogatási tilalom volt, és nem kijárási korlátozás. ${ }^{21}$

A törvény értelmében a kormány utasíthat bárkit, aki fertőzött a Covid-19-cel, vagy bárkit, aki vélelmezhetően fertőzöttnek tekinthető, hogy vizsgáltassa meg magát, és vonuljon önkéntes karanténba. A hatóságok azonban a magánszemélyek lakóhelyeire nem mehettek be olyan bírósági végzés nélkül, amely figyelembe veszi az otthon sérthetetlenségének alkot-

20 Gyülekezési tilalom r. 8. cikk.

21 A korlátozás egy konkrét létesítményre vonatkozott, és nem általánosan mindenre egy meghatározott idősávon belül. 
mányos védelmét, vagyis az alkotmány 72 . szakaszát. ${ }^{22} \mathrm{~A}$ kormány megtilthatta a fertőzött személyeknek a tömegközlekedés használatát. Ez vonatkozik azokra a személyekre is, akik fertőzöttek lehetnek (például a nyilvánvaló tünetek alapján). Ez azt is jelenti, hogy kényszer alkalmazható azon utasokkal szemben, akik nem múködnek együtt.

A dán egészségügyi miniszter megtilthatta a közlekedési eszközökhöz való hozzáférést, és korlátozásokat állapított meg a maximális kihasználtságra vonatkozóan. Ez lehet például az a tilalom, hogy a szokásos befogadóképesség egynegyedénél több utast vegyenek fel, vagy ne legyen több utas, mint ahány férőhely van. A szabályok vonatokra, buszokra, villamosokra, metrókra, repülőgépekre és kompokra alkalmazhatók. A szabályok az állami és a magánszektorra egyaránt vonatkoztak. A kormány korlátozásokat vezetett be a távolsági buszok kihasználtságára, hogy azok maximálisan az utasok 50\%-ának megfelelő utast szállíthassanak. ${ }^{23}$

Az egészségügyi hatóságok 2020. április 4-i hatállyal előírhatják a vállalkozások számára, hogy egészségügyi információkat nyújtsanak be a betegség terjedésének megakadályozása érdekében. Fontos, hogy az információnak relevánsnak kell lennie.

A kormány egyedi szabályokat alkotott az áruellátás biztosítására. Ez magában foglalhatja a magánkereskedók által értékesített fontos javak kisajátítását. Kisajátítás esetén teljes kártérítést kell fizetni az alkotmány 73. szakasza alapján. ${ }^{24} \mathrm{~A}$ kormány külön végrehajtási rendeleteket adott ki az orvosi berendezésekról, ideértve a fertőtlenítőszer-ellátással kapcsolatos különleges intézkedéseket ${ }^{25}$ és a gyógyszer forgalmazásának korlátozását ${ }^{26}$ (a 2020. április 8-i 399. számú végrehajtási rendelet).

A közlekedési miniszter (a Járványtv.-tôl függetlenül) bizonyos sürgôsségi intézkedéseket hozott a szárazföldi szállítással történő áruellátás biztosítása érdekében, ideértve a képzési követelmények enyhítését és a pihenőidő szabályait. Ezen követelmények némelyikét a jármûvezetők kölcsönzésére vonatkozó tilalom ideiglenes hatályvesztéséről szóló végrehajtási rendelet határozza meg. ${ }^{27}$

22 Nemzeti Alkotmányok az Európai Unióban, 2016, 239. o.

23 2020. április 20-i 457. számú végrehajtási rendelet a távolsági buszok maximális megengedett kihasználtságáról (BEK nr 457 af 20/04/2020 Bekendtgørelse om maksimal tilladt belægning i fjernbusser som led i håndtering af Coronavirussygdom 2019 [COVID-19]).

24 Nemzeti Alkotmányok az Európai Unióban, 2016, 239. o.

25 2020. 03 25-i 277. számú végrehajtási rendelet az árucikkek szállítására vonatkozó különleges intézkedésekről (BEK nr 277 af 25/03/2020 Bekendtgørelse om særlige foranstaltninger vedrørende forsyning af desinfektionsmidler i forbindelse med håndtering af Coronavirussygdom 2019 [COVID19]).

26 2020. 04. 08-i 399. számú végrehajtási rendelet a gyógyszer forgalmazásának korlátozásairól (BEK nr 399 af 08/04/2020 Bekendtgørelse om ændring af bekendtgørelse om lægemiddelberedskabet i forbindelse med håndtering af Coronavirussygdom 2019 [COVID-19]).

27 2020. 03. 27-i 304. számú végrehajtási rendelet a sürgősségi intézkedésekről a szárazföldi szállítással történő áruellátás biztosítása érdekében, ideértve a képzési követelmények enyhítését és a pihenőidő szabályait (BEK nr 304 af 27/03/2020 Bekendtgørelse om ændring af bekendtgørelse om midlertidig ophævelse af forbud mod chaufførudlån og særlig forlængelse af kørekort, chaufføruddannelsesbevis, uddannelsesbevis og sikkerhedsrådgiverbevis til sikring af forsyningen af varer i forbindelse med håndtering af Coronavirussygdom 2019 [COVID-19]). 
A kormány hazánkhoz hasonlóan meghosszabbította a közgyúlések (például egyesületek esetén) tartásának és az éves jelentések benyújtásának határidejét. A kormány azonban meghatározta, hogy ez nem vonatkozik azokra a kötelezettségekre, amelyek magánszektorbeli szereplőknek a hatóságok vagy más magánszereplők irányába tett megállapodásain alapulnak. A megállapodásoktól függ, hogy a járvány miatt a felek milyen mértékben mentesülhetnek a megállapodások teljesítése alól.

A kormány az első hullám során bejelentette, hogy az egészségügyi miniszter feladata annak értékelése, hogy felhatalmazást kap-e a szükséges speciális szabályok kiadására. A kérdést végül bírósági felülvizsgálatnak vetik alá, így a vállalkozásoknak van lehetőségük panasszal élni minden felesleges vagy aránytalan intézkedéssel kapcsolatban. A kormány azonban azon az állásponton volt, hogy a vállalkozásoknak be kell tartaniuk a kormány utasításait, így a kormány felelôs a ténylegesen szükséges lépésekért.

A rendőrség és a hatóságok kiterjesztett hozzáférést kapnak a kényszerintézkedések bírósági végzés nélküli meghozatalához a törvény betartásának biztosítása érdekében. A kormány azonban visszavonta a kényszerintézkedések bírósági végzés nélküli végrehajtásának lehetőségét, figyelembe véve az alkotmánynak az otthon sérthetetlenségéről szóló 72. szakaszát.

A szabályok megsértése pénzbüntetéssel vagy súlyosabb esetben legfeljebb hat hónapos börtönnel büntethetô. Ami a vállalkozásokra kiszabott bírságokat illeti, figyelembe kell venni a vállalkozásban a búncselekmény idején alkalmazottak számát.

A kormány a törvényjavaslat memorandumában rögzítette az eredetileg rögzített bírságoknál magasabb ajánlott bírságszinteket. Az új szintek:

— a nagygyúlések tilalmának megsértése: 2500 DKK bírság első büncselekmény esetén; ${ }^{28}$

- a vállalkozások mulasztása esetén 10000 DKK bírság kisvállalkozásoknak (legfeljebb kilenc alkalmazott), 20000 DKK közepes méretú vállalkozásoknak (10-49 alkalmazott) és 40000 DKK nagyvállalkozásoknak (50 vagy annál több alkalmazott); a bírság 100\%-kal, illetve 150\%-kal emelhetô a második, illetve a harmadik búncselekmény esetén;

- ha a vállalkozások nem tartják be a bizonyos helyiségekre vonatkozó korlátozásokat, akkor alapesetben 3000 DKK bírság szabható ki.

A többi végrehajtási rendelet megsértése pénzbüntetéssel és legfeljebb hat hónapos börtönbüntetéssel büntethetô.

28 Gyülekezési tilalom r. 1. cikk. 


\subsection{A második hullám intézkedései}

2020. október 23-án a dán kormány úgy határozott, hogy új korlátozásokat vezet be, amelyek 2020. október 26. és 2021. január 2. között lesznek hatályosak. Az új korlátozások magukban foglalják azt a követelményt, hogy 2020. október 29-tôl a kiskereskedelmi üzletekben és bizonyos mértékig az oktatási intézményekben kötelező a maszk viselése. Korlátozásokat vezettek be az alkohol árusításában a szupermarketekben és a kioszkokban 22:00 óra után, és mindenkit arra biztattak, hogy korlátozza a társas kapcsolatok számát. Ezenkívül fokozták a határellenőrzést. Az összejövetelek létszámát 10 főben maximálták, kivéve a temetéseket, amelyeken 50 fő vehetett részt. Ezek a korlátozások 2020. december 13-ig érvényesek. ${ }^{29}$

A jelenleg, a koronavírus második hullámában hatályban lévő intézkedések:

- az összejövetelek résztvevőit 10 főben maximálták (hatályos 2020. október 26-tól 2020. december 13-ig);

- arcmaszk viselésének követelménye a kiskereskedelmi üzletekben és kioszkokban (hatályos 2020. október 29-tôl 2021. január 2-ig);

- arcmaszk viselésének követelménye - bizonyos mértékig - az oktatási intézményekben (hatályos 2020. október 29-tôl 2021. január 2-ig);

- az alkohol árusításának korlátozása a kiskereskedelmi üzletekben és kioszkokban 22:00 óra után (hatályos 2020. október 26-tól 2021. január 2-ig);

- bátorítás a társas kapcsolatok számának korlátozására (hatályos 2020. október 26-tól 2020. december 13-ig).

Fontos megemlíteni, hogy az egészségügyi hatóságok komoly erőfeszítéseket tesznek az ország lakosságának felvilágosításában, információval történő ellátásában, mivel ez lehet az egyik legjobb eszköz a járvány terjedésének érdemi lassítására, az úgynevezett járványgörbe ellaposítására. Ennek érdekében több tematikus honlap is múködik, amelyek információkkal látják el a lakosságot. Ezeken írásbeli anyagok, videók is megtalálhatók, amelyek például a maszkviselés helyes szabályaira is felhívják a figyelmet. ${ }^{30} \mathrm{~A}$ koronavírus-járvánnyal foglalkozó legjelentősebb az angol nyelven is elérhető honlap, ${ }^{31}$ amelyen minden aktuális információ megtalálható tematizált formában, így is közérthetőbbé téve a háttérjogszabályokat. ${ }^{32}$

29 Hivatalos tájékoztató honlap a koronavírusról: https://coronasmitte.dk/en/overview (Letöltve: 2020. november 26.).

30 Danish Healt Authority honlapja: www.sst.dk/en/English/publications (Letöltve: 2020. november 26.).

31 Elérhető: https://coronasmitte.dk/en (Letöltve: 2020 . november 26.).

32 A koronavírus hivatalos kormányzati honlapja: https://coronasmitte.dk/en (Letöltve: 2020. november 26.). 


\section{Különleges jogrend, járványügyi vészhelyzet kihirdetésével kapcsolatos tapasztalatok, jogviták}

A koronavírus-járvány során Dániában a vállalkozások tevékenységének korlátozása és az alkotmányban szabályozott kisajátítás kérdésköre körül alakult ki jogértelmezési dilemma. A kormány az első hullám során bejelentette, hogy az egészségügyi miniszter feladata annak értékelése, hogy felhatalmazást kap-e a szükséges speciális szabályok kiadására. A kérdést végül bírósági felülvizsgálatnak vetették alá, így a vállalkozásoknak van lehetőségük panasszal élni minden felesleges vagy aránytalan intézkedéssel kapcsolatban. A kormány azonban azon az állásponton volt, hogy a vállalkozásoknak be kell tartaniuk a kormány utasításait, így a kormány felelős a ténylegesen szükséges lépésekért.

A módosított törvény a Járványtv. - a vállalkozásoknak kompenzációt nyújtó - 27. szakaszát hatályon kívül helyezi. A kormány ezt azzal indokolta, hogy nem hiszi, hogy képesek lennének felmérni a korábbi rendelkezések gazdasági hatásait, ha aktiválnák őket. Ehelyett a kormány bejelentette, hogy az üzleti vállalkozásokkal és az iparral együttmúködve speciális kompenzációs rendszereket és egyéb mentőcsomagokat készít az intézkedések következményeinek „észszerú kompenzációja” biztosítása érdekében.

A kormány számos rendszert vezetett be a kereskedelem és az ipar támogatására: bérek és fizetések kompenzációs rendszere, a vállalkozások állandó költségeinek fedezésére szolgáló kompenzációs rendszer és a Dán Ipari Növekedési Alap keretében megvalósuló speciális garanciarendszerek formájában.

A kormány mentőcsomagjai nagyrészt kizárólag a költségeket fedezik, és nem az elveszett bevételeket. Ezért fontos, hogy a vállalkozások jogosultak legyenek „teljes kártérítésre”, ha az intézkedések az alkotmány 73. szakasza alapján kisajátításnak minősülnek. Eleinte ez az elveszített nettó nyereség megtérítésének igényét jelentheti. A legtöbb vállalkozás tekintetében azonban ez nem így lesz, ha az intézkedéseket általánosnak és nem konkrétnak tekintik, ami mellett szól, hogy ez kompenzációmentes szabályozás. Az intézkedések azonban annyira radikálisak lehetnek, hogy egyes vállalkozások esetében kisajátításnak tekinthetők, ami a tényleges átadás egyik formája. A kormány jelezte, hogy ez a helyzet állhat fenn, ha tilalmat írnak elô a lakosság vállalkozásai tulajdonához való hozzáférésére.

\section{5. Összegzés}

A dán szabályozás a különleges jogrenddel és az alapjogi korlátozásokkal összefüggésben a magyarhoz képest kevésbé részletes. Különösen a különleges jogrendi szabályokat érdemes megemlíteni, amelyről az alkotmány mindössze egy bekezdése rendelkezik. A dán történelmi hagyományok miatt a jogalkotók nem gondolkodtak ennél részletesebb szabályozáson, ezért a koronavírus-járvány kitörésekor szembesültek azzal, hogy a szabályozat- 
lanság miatt nagyon merev az alkotmány, ami nehezítheti a hatékony és gyors fellépést ilyen súlyos járványhelyzetben. A koronavírus egyes hullámainak kezelése szempontjából megállapítható, hogy a kormány időben előbb hozott intézkedéseket, de ott előbb is jelentkeztek a járványhelyzet negatív hatásai. Annyiban a dánok jó megoldást választottak, hogy az első hullámban hozott intézkedések hatályát egészen 2021 márciusáig kitolták, így nem volt szükség jogalkotói beavatkozásra a második hullámig, amikor viszont további, a magyar intézkedésekhez nagyon hasonló korlátozásokat vezettek be. A lakosság tájékoztatása szempontjából is mutatkozik hasonlóság a két ország között, mivel hazánkban és Dániában is informatív, áttekinthető tájékoztató honlap áll az érdeklődők rendelkezésére.

A két ország nehezen összehasonlítható, ha az alkotmányaikban található szabályokat vizsgáljuk, de az bizonyos, hogy a dán jogalkotó érzékenyebb az alapjogok korlátozása terén, és sokkal nehezebben hoz korlátozó intézkedéseket, ami a dán hagyományokra is visszavezethető.

\section{Irodalomjegyzék}

SÁGVÁRI, Á. (2016) Különleges jogrenddel a terror ellen - kitekintés az európai gyakorlatra [Online]. Elérhetô: https://jog.tk.mta.hu/blog/2016/o2/kulonleges-jogrenddel-a-terror-ellen (Letöltve: 2020. november 26.)

Nemzeti Alkotmányok az Európai Unióban (2016). Budapest: Wolters Kluwer

FAllentin Nyborg, A., Klinge, S., Krunke, H., RytTER, J. E. (2020) ‘Covid-19 and Emergency Laws in Denmark', Svensk Juristtidning, 10(20), 1098-1115. o.

Klinge, S., Krunke, H., FAllentin Nyborg, A., Rytter, J. E. (2020) 'Covid and Constitutional Law in Denmark' in Serna de la Garza, J. M. (szerk.) Covid-19 and Constitutional Law. Covid-19 et droit constitutionnel. 1. kiadás. México: Universidad Nacional Autónoma de México

Dittmer, M., Edelgaard, T. (2020) The Danish Epidemic Act [Online]. Elérhető: https:// gorrissenfederspiel.com/en/knowledge/news/Covid-19-the-danish-epidemic-act (Letöltve: 2020. november 26.)

European Union Agency for Fundamental Rights (2020) Coronavirus COVID-19 Outbreak in the EU. Fundamental Rights Implications [Online]. Elérhetô: https://fra.europa.eu/sites/default/files/ fra_uploads/denmark-report-Covid-19-april-2020_en.pdf (Letöltve: 2020. november 26.)

Venice Commission (2020) Interim Report on the Measures Taken in the EU Member States as a Result of the COVID-19 Crisis and Their Impact on Democracy, the Rule of Law and Fundamental Rights (Study No. 995/2020) [Online]. Elérhető: https://www.venice.coe.int/webforms/ documents/?pdf=CDL-AD(2020)018-e (Letöltve: 2020 . december 15.) 


\section{A különleges jogrend az Egyesült Királyságban}

DOMANICZKY ENDRE

\section{A különleges jogrend alkotmányos és törvényi szintú szabályozása}

Az Egyesült Királyságban a különleges jogrenddel kapcsolatos szabályok törvényi szinten kerültek megalkotásra. Maga a szabályozási igény történetileg korán, már a kora újkorban jelentkezett, de a hatályos joganyag közvetlen előzménye a 20. század eleji jogszabályok között lelhetô fel. ${ }^{1}$

Az Egyesült Királyság² krízismenedzsmentje alapvetően egyetlen jogszabályra épül, ez pedig a 2004-es, a nem katonai jellegú rendkívüli eseményekról szóló törvény. ${ }^{3}$ Ennek megalkotásával egyrészt a korábban különböző jogszabályokban szétszórtan található szabályok egységesítésre és modernizálásra kerültek, másrészt az egységes törvény elfogadása által számos, korábban a common law-ban található hatáskör került át az írott jog (statute law) területére. ${ }^{4}$

1 Vö. többek között: Defence of the Realm Act (1914), Emergency Powers Act (1920), Emergency Powers Act (Northern Ireland) (1926), Emergency Powers (Defence) Act (1939), Emergency Powers Act (1964). Lásd még: Bowman, 1916; Cotter 1953; Rosenfeld-Sajó, 2013.

2 A többi angolszász ország szabályozására lásd:Vikman, 2020, 259-279. o.

3 Civil Contingencies Act (a továbbiakban: CCA). (Megjegyzendő, hogy a hazai szakirodalom a jogszabályt többnyire polgári vészhelyzeti törvényként fordítja.).

4 UK Cabinet Manual 3.33-3.38. pontok. Elérhető: https:/assets.publishing.service.gov.uk/government/ uploads/system/uploads/attachment_data/file/60641/cabinet-manual.pdf (Letöltve: 2020. november 18.).

Dr. Domaniczky Endre, PhD

endre.domaniczky@mfi.gov.hu

vezető kutató (Mádl Ferenc Összehasonlító Jogi Intézet)

Domaniczky, E. (2021) 'A különleges jogrend az Egyesült Királyságban' in Nagy, Z., Horváth, A. (szerk.) A különleges jogrend és nemzeti szabályozási modelljei, 252-276. o. Budapest: Mádl Ferenc Összehasonlító Jogi Intézet.

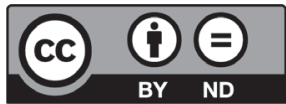


A törvény elnevezése furcsának tûnhet, de ha egy pillantást vetünk a hasonló európai jogszabályok kodifikációs megoldásaira, ${ }^{5}$ akkor egyértelmúvé válik az angol megoldás modellszerüsége. A kivételes hatalom a hatalom birtokosának oldaláról nézve katonai vagy polgári hatóságok által gyakorolt lehet. A 19. századi korai kodifikációk során az előbbi modell mellett döntött például a német vagy francia jogalkotó, az utóbbi mellett pedig a brit és a magyar. ACCA elnevezése - a nem katonai, vagyis polgári jellegú eseményekre vonatkozó szabályozás e jogtörténeti előzmények ismeretében válik egyértelmúvé, hiszen a törvény már a címében is utal rá, hogy az irányítás a rendkívüli helyzetben is a polgári hatóságok kezében marad.

A szerkezetileg három részre tagolt CCA egységes szabályozást biztosít a felkészülésre, a tervezésre, a védekezésre (első rész, 1-18. \$), valamint rögzíti a különleges jogrend bevezetésének feltételeit és korlátait (második rész, 19-31. \$). ${ }^{6}$ A törvény elsősorban keretszabályokat ír elö, az eljárási szabályokat rendeletek (regulations, illetve orders) tartalmazzák. ${ }^{7}$ Kiemelt szerepe van továbbá a körleveleknek, tájékoztatóknak, útmutatóknak és megállapodásoknak is, amelyek a felkészülésben segítik az egyes szervezeteket. Bár ez utóbbi szabályozóknak csak egy része rendelkezik jogi kötőerôvel, rendszeresen hivatkozzák őket. ${ }^{8}$

A CCA az eljárásra kötelezett szervezetek két fajtáját különbözteti meg, ezekre már békeidőben is különböző feladatok és kötelezettségek hárulnak. Az első és második kategóriás szervezetek körét a törvény mellékletei többnyire országrészekre (Anglia, Skócia, Wales, Észak-Írország) lebontva határozzák meg.

Első kategóriás szervezetek a helyi önkormányzatok, az egészségügyi szolgáltató szervek, a katasztrófavédelmi szervezet, egyéb, a törvény által megnevezett szervek. Második kategóriás szervezetek például a közszolgáltatók (víz, energia, szennyvíz) és a közlekedési szolgáltatók (busz- és vasúttársaságok, repülőterek, autópálya-ügynökségek, kikötői hatóságok). ${ }^{9}$ Az első körbe tartozó szervezetek legfontosabb feladata az elhárítás és védekezés területén való közremúködés. A második kategóriába tartozó szervezetek az úgynevezett együttmúködő szervezetek, amelyeket a tervezésbe kevésbé szükséges bevonni, viszont váratlan esemény bekövetkezése esetén könnyen érintetté válhatnak, ezért az együttmúködési és információáramlási csatornákat feléjük és közöttük ki kell építeni és fenn kell tartani.

A különleges jogrendet megelőző, az arra való felkészülést segítő békeidejú szabályok többsége az első kategóriás szervezetekre vonatkozik. Ezek legfontosabb feladata a veszélyhelyzeti tervek elkészítése, kockázatbecslés, veszélyhelyzeti tervek hatálybaléptetése,

5 Erről bővebben lásd jelen kötet 5. fejezetét.

6 A CCA harmadik része kiegészító és magyarázó rendelkezéseket tartalmaz (32-36. \$).

7 A legfontosabbak ezek közül: a Civil Contingencies Act (2004), (Contingency Planning) Regulations (2005), illetve két, 2011-es (Civil Contingencies Act 2004 [Contingency Planning] [Amendment] Regulations 2011) és 2012-es módosítása (Civil Contingencies Act 2004 [Contingency Planning] [Amendment] Regulations 2013), amelyek a vészhelyzeti tervezés részletszabályait tartalmazzák.

8 Ezek elsősorban a kormányzati oldalon találhatóak, lásd például: www.gov.uk/guidance/preparation-andplanning-for-emergencies-responsibilities-of-responder-agencies-and-others (Letöltve: 2020. január 13.).

9 Vö.: CCA 1. melléklet 3. rész 1. kategória, 19-28. pontok. 
a vállalkozások zavartalan múködéséhez szükséges intézkedések megtétele, a lakosság tájékoztatása érdekében szükséges teendők megtétele, a különböző helyi szervezetek közti információáramlás segítése a koordináció növelése érdekében, a vállalkozások tájékoztatása - és azok felkészítése - a vállalkozások múködésének biztosítását lehetôvé tevő tervről. ${ }^{10}$

A központi kormányzaton belüli koordinációs szerv ${ }^{11}$ a miniszterelnökségen belül található Civil Contingencies Secretariat, ${ }^{12}$ ide nemcsak vertikálisan, de horizontálisan, az ügygazda minisztériumoktól és ügynökségektôl is érkeznek információk..$^{13}$

A CCA-t a brit gyakorlat afféle végső eszköznek tekinti, alkalmazására 2004-es elfogadása óta még nem került sor. ${ }^{14} \mathrm{~A}$ legújabb jogfejlődési irány a CCA „végsőeszköz-jellegét” látszik megerősíteni, ugyanis 2020 elején a vírusjárvány kezeléséhez a jogszabály élesítése helyett külön speciális törvény (koronavírus-törvény, továbbiakban: $\mathrm{CVA})^{15}$ megalkotására került sor.

Bár a különböző méretû́ katasztrófák kezelése - azok jellege és súlyossága szerint - több törvény, így különösen a koronavírus-törvény és egyes ágazati törvények alkalmazásával is lehetséges, a különleges jogrend bevezetésére csak a CCA alapján kerülhet sor (a konkrét alkalmazási szabályokat lásd lentebb, a fejezet 2. pontjában).

Azt már nagyjából másfél évszázaddal korábban találóan megállapította Concha Győző, hogy „Angliában [...] az alkotmány nem egy törvénynek vagy egyes főtörvényeknek egyenes teremtménye, hanem az összes, évszázadokon keresztül alkotott parlamenti végzemények, a százados nemzeti közszokás visszfénye [...] ${ }^{16} \mathrm{Az}$ Egyesült Királyságban az alkotmányos alaptörvények listája nincs tehát kőbe vésve, viszont éppen a kivételes hatalommal való esetleges

10 Vö. például a kormányzati tájékoztató oldal anyagait. Elérhető: www.gov.uk/guidance/preparation-andplanning-for-emergencies-responsibilities-of-responder-agencies-and-others (Letöltve: 2020. január 13.).

11 Súlyosabb (2-3. szint) krízishelyzetben viszont a központi válságkezelő szerv a Kabinet Döntéshozó Irodái elnevezésú formáció, a szakszövegekben COBR-ként, a sajtóban viszont gyakran COBRA-ként hivatkozott Cabinet Office Briefing Rooms. Szerepére lásd: https://assets.publishing.service.gov.uk/government/uploads/ system/uploads/attachment_data/file/192425/CONOPs_incl_revised_chapter_24_Apr-13.pdf (különösen 2141. oldal). (Letöltve: 2020. január 13.) A krízishelyzetszinteket lásd: https://assets.publishing.service.gov.uk/ government/uploads/system/uploads/attachment_data/file/192425/CONOPs_incl_revised_chapter_24_Apr13.pdf, különösen 68. oldal. (Letöltve: 2020. január 13.).

12 Lásd a Civil Contingencies Secretariat (CCS) honlapját: www.gov.uk/government/emergency-preparationreponse-and-recovery. 2019 elején a részleg 94 fös személyzettel rendelkezett. Lásd még: https:// researchbriefings.parliament.uk/ResearchBriefing/Summary/LLN-2019-0034 (Letöltve: 2019. december 17.).

13 Központi szinten az elsődlegesen érintett kormányzati szervek a miniszterelnökség (Cabinet Office), a belügyminisztérium (Home Office), az önkormányzati minisztérium (Ministry of Housing, Communities and Local Governments), a védelmi minisztérium (Ministry of Defence), az egészségügyi és szociális minisztérium (Department of Health and Social Care). Elérhető: www.gov.uk/government/emergency-preparation-reponse-andrecovery\#guidance_and_regulation (Letöltve: 2020. január 13.).

$14 \mathrm{Ez}$ a megfontolt jogalkalmazási gyakorlat egyáltalán nem egyedülálló jelenség a brit jogtörténetben. A CCA előzményeként szolgáló 1920-as különleges jogrendi törvényt (Emergency Powers Act) 84 év alatt mindössze 12 alkalommal alkalmazták. Vö.: www.instituteforgovernment.org.uk/explainers/emergencypowers (Letöltve: 2020. június 19.).

15 Skóciában külön koronavírus-törvényt fogadtak el, ez a Coronavirus (Scotland) Act 2020 (a továbbiakban: CVAS).

16 Concha, 1888, II/177. o. 
visszaélés miatt a CCA tervezetének vitája során felmerült egy tételes lista meghatározása, és abban mind a különleges jogrendről szóló akkor hatályos, mind pedig az akkor tárgyalás alatt lévő, jelenleg hatályos törvény említésre került. ${ }^{17}$ Miután a CCA-t az elfogadása óta eltelt másfél évtizedben még nem alkalmazták, a probléma egyelőre csak elméleti szintű, de ez a közel két évtizedes vita jól jelzi a szabályozási tárgykör alkotmányos súlyát és helyzetét.

A téma szempontjából releváns törvények általában nem értelmezhetők önmagukban, a részletszabályokat különböző formában hozott rendeletek ${ }^{18}$ (statutory instruments) tartalmazzák. A CCA végrehajtási rendeletei tárgyuk szerint négy csoportba oszthatók:

- a CCA hatálybalépésével kapcsolatos végrehajtási rendeletek: a három rendelet a korábbi veszélyhelyzeti szabályozás és az új törvény harmonizációját végezte el, elsősorban a korábbi törvények hatályon kívül helyezésével;

- a veszélyhelyzetre való felkészülés (vészhelyzeti tervezés) részletszabályai és ezek módosításai: a vészhelyzeti tervezés szabályainak meghatározása az egyes országrészekre, egyes feladatoknál szabályozási jogkörök biztosítása, adatkezelési és adattovábbítási szabályok elöírása;

- a CCA első részéhez kapcsolódó első és második kategóriás szervezetek körének módosítása: a törvény ezen részei rendeleti úton módosíthatók;

- a törvény Skóciában való alkalmazását biztosító rendeletek: Skócia az Egyesült Királyság egyik, széles autonómiával bíró országrésze, ahol egyes szabályok önálló megalkotása vagy külön keretszabályozás kialakítása lehet szükséges. A CCA esetében eddig a törvény hatálybalépésének és a vészhelyzeti tervezésnek az ügyében készült önálló szabályozás.

\section{A különleges jogrend esetkörei}

\subsection{Fogalom és elöfeltételek}

A CCA-ban a szabályozási tárgyra vonatkozó egy évszázados kodifikációs tapasztalat sûrűsödik össze. A törvény második része - mint egy „míves lakat” - kiemelt védelemben

17 Vö.: Joint Committee on Draft Civil Contingencies Bill First Report 183. pont. Elérhető: https://publications. parliament.uk/pa/jt200203/jtselect/jtdcc/184/18407.htm\#a44, 183. pont (Letöltve: 2020. december 1.).

18 Ezek a következők: The Civil Contingencies Act 2004 (Commencement No.1) Order 2004; The Civil Contingencies Act 2004 (Commencement No.2) Order 2005; The Civil Contingencies Act 2004 (Commencement No.3) Order 2005; The Civil Contingencies Act 2004 (Contingency Planning) Regulations 2005; The Civil Contingencies Act 2004 (Contingency Planning) (Amendment) Regulations 2011; The Civil Contingencies Act 2004 (Contingency Planning) (Amendment) Regulations 2012; The Civil Contingencies Act 2004 (Amendment of List of Responders) Order 2005; The Civil Contingencies Act 2004 (Amendment of List of Responders) Order 2008; The Civil Contingencies Act 2004 (Commencement) (Scotland) Order 2005; The Civil Contingencies Act 2004 (Contingency Planning) (Scotland) Regulations 2005; The Civil Contingencies Act 2004 (Contingency Planning) (Scotland) Amendment Regulations 2013. Részletesen lásd: www.legislation.gov.uk. 
részesíti a különleges jogrend bevezetését lehetővé tevő kivételes hatalmat. A hatalom mindenkori birtokosai számára a CCA csak egy bonyolult feltételrendszer teljesülése esetén teszi lehetôvé a kivételes hatalom gyakorlását. Ahhoz, hogy a kodifikátori teljesítményt értékelni tudjuk, a legfontosabb rendelkezéseket előbb át kell tekintenünk.

A CCA egyetlen kivételes hatalom gyakorlását lehetővé tevő esetkörrel, a szükségállapottal (emergency) dolgozik, és egy hármas feltételrendszer teljesülése esetén teszi lehetővé a kivételes hatalom gyakorlását: ${ }^{19}$

— a szükségállapot bevezetését igénylő esemény megtörtént, éppen most történik vagy bekövetkezése várható;

- az esemény megelőzéséhez, kontrollálásához vagy hatásának enyhítéséhez szabályalkotás szükséges;

— a szabályalkotásra sürgősen van szükség.

Látszólag egyszerủ fogalomról és könnyen meghatározható előfeltételekről van szó, azonban a törvény több esetben ${ }^{20}$ - már az előfeltételeken belül is - él a többszörösen összetett definíciók alkalmazásának lehetőségével. Ennek megfelelően a fenti értelmező rendelkezésben szereplő szükségállapot fogalmát a CCA külön is - alapvetően tágan - megadja. ${ }^{21}$

Szükségállapotnak minősül:

— amely az Egyesült Királyság területén a közjólétet súlyosan károsító esemény vagy helyzet bekövetkezésével fenyeget;

— amely az Egyesült Királyság területén belül a környezetet súlyosan károsító esemény vagy helyzet bekövetkezésével fenyeget;

- háború, terrorcselekmény, amely az Egyesült Királyság biztonságának súlyos károsodásával fenyeget.

Ezen túlmenően a CCA a szükségállapot-fogalmon belüli egyes szavak értelmezésére is vállalkozik, ezzel azonban inkább bővíti, mint szúkíti a szükségállapot-fogalom alkalmazhatóságát. Így például a törvény szerint közjólétet károsító esemény vagy helyzet az, amely emberi élet kioltásával, emberi megbetegedéssel vagy sérüléssel, földönfutóvá válással, a tulajdon károsodásával; a pénz-, az élelem-, a víz-, az energia- vagy üzemanyag-szolgáltatás fennakadásával; a kommunikációs rendszer, a közlekedési lehetőségek, az egészségügyi szolgáltatások megszakadásával jár vagy járhat. ${ }^{22}$ Környezeti kár bekövetkezésével fenyegető esemény vagy helyzet pedig lehet a talaj, a víz, a levegó biológiai, kémiai, radioaktív anyaggal való szennyezése vagy annak előidézése, a növény- vagy állatvilág elpusztítása, illetőleg károsodásának előidézése. ${ }^{23}$

19 Vö.: CCA 21. \$ (2)-(4) bekezdés.

20 Vö.: CCA 19. $\$(2)$ bekezdés.

21 Vö.: CCA 1. \$ (1)-(3) bekezdés.

22 Vö.: CCA 19. \$ (2) bekezdés.

23 Vö.: CCA 19. \$ (3) bekezdés. 


\subsection{A kivételes hatalom}

Amennyiben az előfeltételek fennállnak, és a törvény hozzáférést enged a kivételes hatalomhoz, azonnal láthatóvá válik, hogy bár a hatalomgyakorlás normális menetéhez képest széles körü, és ezért kivételes hatalomról van szó, annak gyakorlása mégsem korlátlan. Sőt a CCA - a második részben - maga rögzíti a kivételes hatalom korlátait, korlátok közé szorítva ezáltal a kivételes hatalom gyakorlásán alapuló jogrend, a különleges jogrend jogforrásait is.

A kivételes hatalom korlátai a következők:

- korlátozott tárgyi hatály;

— korlátozott időbeli hatály;

- parlamenti kontroll.

Mielőtt azonban a korlátokat megvizsgálnánk, szót kell ejteni a végrehajtó hatalom mindenkori birtokosairól, akik a CCA alapján a kivételes hatalom gyakorlására jogosultak. A törvény a hatalomgyakorlók két csoportját ruházza fel - meghatározott sorrendben - a kivételes hatalom időszakában történő normaalkotásra. ${ }^{24}$ Mindenekelőtt az államfót, aki (szükség)rendeletet (Order-in-Council) ${ }^{25}$ alkothat, amennyiben a CCA 21. \$-ában leírt feltételek fennállnak. ${ }^{26}$ Másodsorban a miniszterek egy meghatározott körét, amennyiben a CCA 21. \$-ában leírt feltételek fennállnak, és a Queens-in-Council formában történő rendeletalkotás jelentős késedelemmel ${ }^{27}$ járna. A miniszterek meghatározott körét a CCA pontosan kibontja:

- a kincstár első lordja, vagyis a brit miniszterelnök;

- bármely államtitkár: ${ }^{28}$ a CCA tervezetéhez készült indokolás rávilágít a tág megfogalmazás keletkezési hátterére, ugyanis a jogalkotó lehetôvé kívánta tenni, hogy a kormányon belül az adott témában illetékes kormánytag minél gyorsabban kaphassa meg a rendeletalkotási felhatalmazást; ${ }^{29}$

- a kincstári megbízottak. ${ }^{30}$

24 Vö.: CCA 20. \$ (1)-(2) bekezdés.

25 A titkos tanácsban történő rendeletalkotásra lásd bővebben: https:/assets.publishing.service.gov.uk/government/ uploads/system/uploads/attachment_data/file/60641/cabinet-manual.pdf(1.14-1.18). (Letöltve:2020. november 19.).

26 A CCA tervezetéhez füzött magyarázatból egyértelmủen kitûnik, hogy a Queens-in-Council formában történő rendeletalkotás az államfő egyes kabinettagokkal történő közös jogalkotására vonatkozik, és ebben az esetben elsősorban a belügyminiszter lenne a jogszabálytervezet elöterjesztője. Vö. a CCA 20. \$ (1) bekezdéséhez füzött magyarázat 42 . pontjával.

27 A ,jelentős késedelem” jelentését a törvény külön meghatározza [CCA 20. \$ (4) bekezdés: „A jelentős késedelem ezen pont alkalmazásában az a késedelem, amely jelentős kárt okoz, vagy a megelőzést, ellenőrzést vagy a jelentős kár enyhítését jelentősen akadályozza."].

$28 \mathrm{Az}$ államtitkár itt miniszteri rangú tisztviselőt jelent. A pontos terminológiára lásd a CCA 20. \$ (3) bekezdés b) pontját és az Interpretation Act 1978 1. mellékletét.

29 Vö. még: a CCA 20. \$ (3) bekezdéséhez füzött magyarázat 43. pontja.

30 Vö. még: a CCA 20. $\$$ (3) bekezdéséhez füzött magyarázat 43. pontja. Elérhető: https://assets.publishing. service.gov.uk/government/uploads/system/uploads/attachment_data/file/60641/cabinet-manual.pdf (3.28-3.29., letöltve: 2020 . november 18.). 
Amennyiben sikerült a jogalkotó személyét meghatározni, e személynek a jogalkotói döntésért való felelősséget jogalkotói nyilatkozat tételével kell vállalnia (jogalkotói előzetes nyilatkozat, a továbbiakban: nyilatkozat). E nyilatkozat - mint az a szabályozásból kiolvasható - egyszerre tölti be a személyes felelősségvállalás, illetve az arányossági teszt szerepét. A nyilatkozat tartalma a következō: ${ }^{31}$

— az adott - szabályozással érintett - szükségállapot jellegének meghatározása;

- a jogalkotó nyilatkozata arra vonatkozóan, hogy:

— meggyőződött a kivételes hatalom gyakorlásához szükséges előfeltételek fennállásáról;

- meggyőződött arról, hogy a (szükség)rendeletek csak olyan rendelkezéseket tartalmaznak, amelyek alkalmasak az adott szükségállapot megelőzésére, ellenőrzésére vagy enyhítésére;

- meggyőződött arról, hogy a (szükség)rendeletek hatása kellően arányos a szükségállapot hatásával vagy jellegével;

— meggyőződött arról, hogy a szabályozás összeegyeztethető az Emberi Jogokról szóló Egyezményben foglalt jogokkal (az emberi jogokról szóló 1998-as törvény 1. szakaszának megfelelően).

Ugyancsak a jogalkotóra hárul az a kötelezettség is, hogy olyan szabályozást alkosson, amelynek alapján, illetve a szabályozásra tekintettel hozott intézkedések alapján a parlament, a legfelsőbb bíróság és a Court of Session ${ }^{32}$ tovább tudjon múködni. ${ }^{33}$

\subsection{Tárgyi és időbeli hatály}

A (szükség)rendeletek - a CCA-t megalkotó brit parlament döntése alapján - nagyon tág, ám mégis korlátozott tárgyi hatállyal rendelkeznek. Ezt kétféle kodifikációs technikával érte el a jogalkotó: általánosan korlátozott tárgyi hatály, illetve speciálisan korlátozott tárgyi hatály meghatározásával.

Bár a kivételes hatalom legfőbb jellemzője éppen a hatalom rendkívüli esetben biztosított „kvázi korlátlansága” lenne, a brit parlament mégis megpróbálta e hatalom jogalkotási tárgyköreit - azok meghatározásával - korlátozni. Ezt egyrészt generális módon, a lehetséges tárgykörök exemplifikatív felsorolásával ${ }^{34}$ éri el. A CCA itt egy listát rögzít (lehetséges

31 Vö.: CCA 20. $\$(5)$ bekezdés.

32 A Court of Session a skót polgárjogi legfelsőbb bíróság elnevezése. Lásd bővebben a skót bírósági honlapon: www. scotcourts.gov.uk/the-courts/supreme-courts/about-the-court-of-session (Letöltve: 2020. november 19.).

33 Vö.: CCA 23. \$ (5) bekezdés.

34 Vö.: CCA 22. \$ (2) bekezdés. 
törvényhozási tárgykörök),, ${ }^{35}$ valamint egy tágan megfogalmazott elöírást, ${ }^{36}$ amely szerint (szükség)rendeletben ezen túlmenően bármilyen rendelkezés elő́rhható, amely egyébként a parlamentben megalkotott törvény vagy királyi előjog gyakorlása által lenne szabályozható. ${ }^{37} \mathrm{~A}$ generális felsorolások mellett a CCA tilalmakat is meghatároz, méghozzá kétféle-

35 A lehetséges törvényhozási tárgykörök a következők:

— az emberi élet, egészség vagy biztonság védelme;

- emberi betegségek vagy sérülések kezelése;

- vagyon védelme vagy helyreállítása;

- pénz-, élelmiszer-, víz-, energia- vagy üzemanyag-ellátás védelme vagy helyreállítása;

- a kommunikációs rendszer védelme vagy helyreállítása;

- a szállításhoz szükséges létesítmények védelme vagy helyreállítása;

- az egészséggel kapcsolatos szolgáltatások nyújtásának védelme vagy helyreállítása;

— bankok vagy más pénzügyi intézmények tevékenységének védelme vagy helyreállítása;

- a talaj, a víz vagy a levegő szennyezésének megelőzése, korlátozása vagy csökkentése;

- a növény- vagy állati élet megzavarásának vagy megsemmisítésének megelőzése, csökkentése vagy enyhítése;

- a parlament, a skót parlament, az észak-írországi közgyúlés vagy a walesi nemzetgyúlés tevékenységeinek védelme vagy helyreállítása;

- a közfeladatok védelme vagy helyreállítása.

36 Vö.: CCA 22. \$ (3) bekezdés

37 A CCA - a jogalkalmazót segítendő - a generális szabályhoz is egy felsorolást kapcsol: a (szükség)rendeletek bármilyen rendelkezést elő́rhatnak, amely a parlamentben megalkotott törvény vagy királyi előjog gyakorlása által lenne elöírható; így különösen:

— a növény- vagy állati élet megzavarásának vagy megsemmisítésének megelőzése, csökkentése vagy enyhítése;

- feladatot ruházhatnak miniszteri rangú tisztviselőkre, a skót miniszterekre, a walesi nemzetgyủlésre, az északír minisztériumra, a CCA 24 . \$-a alapján kinevezett koordinátorra vagy bármely más meghatározott személyre (és az átruházott feladat különösen a következő lehet): hatáskör vagy kötelesség mérlegelési jogkör gyakorlására; hatáskör írásbeli vagy szóbeli utasítások kiadására;

- lehetôvé teheti a tulajdon visszaszolgáltatását vagy elkobzását (kártérítéssel vagy anélkül);

— lehetővé teheti tulajdon, állati vagy növényi élet megsemmisítését (kártérítéssel vagy anélkül);

- megtilthatja a mozgást egy meghatározott helyre vagy helyről;

— kötelezővé teheti a meghatározott helyre vagy onnan történő mozgást;

- megtilthatja a meghatározott típusú gyúlések meghatározott helyeken vagy időpontokban történő megtartását;

- meghatározott időpontokban megtilthatja az utazást;

- megtilthatja egyéb meghatározott tevékenységek végzését;

- büntetendővé teheti: a (szükség)rendeletek valamely rendelkezésének be nem tartását; a (szükség)rendeletek alapján adott utasítás be nem tartását; egy adott személy akadályozása a (szükség)rendelet által elöírt vagy az alapján gyakorolt feladatának ellátásában;

- eltekinthet egy jogszabály vagy a jogszabály alapján hozott rendelkezés alkalmazásától, vagy módosíthatja a jogszabályt vagy az annak alapján hozott rendelkezést;

- megkövetelheti, hogy egy személy vagy testület valamely funkció ellátása érdekében járjon el - függetlenül attól, hogy a funkciót a (szükség)rendeletek ruházzák-e fel vagy sem, és hogy e rendeletek elóírnak-e ezért díjazást vagy kompenzációt;

— lehetővé teheti a védelmi tanács számára, hogy engedélyezze Őfelsége fegyveres erőinek bevetését;

— jogszabályt alkothat (ideértve a tulajdonnal kapcsolatos hatáskörök átruházását) Ôfelsége fegyveres erői bevetésének megkönnyítésére;

— joghatóságot telepíthet egy bíróságra - beleértve a (szükség)rendelet által létrehozott bíróságot is;

- olyan szabályokat alkothat, amelyek a következőkkel kapcsolatban érvényesek: a parti tenger egy része; a brit halászati térségen belüli terület; a kontinentális talapzat területe;

— olyan rendelkezést hozhat, amely vagy általánosan, vagy csak meghatározott körülmények között, vagy csak meghatározott célra alkalmazandó;

— eltérő körülményekre vagy célokra eltérő rendelkezéseket alkothat. 
képpen: általános szabályozási tilalmakat és konkrét törvénymódosítási tilalmakat ír elő. ${ }^{38}$ A CCA által rögzített általános tilalmak a következők:

A (szükség)rendeletek csak akkor bocsáthatók ki, ha és amennyiben a jogalkotó meggyőződött arról, hogy a rendelkezés megfelelő annak a vészhelyzetnek vagy következménynek a megelőzésére, ellenőrzésére vagy enyhítésére, amelyre a szabályozás vonatkozik, és a rendelkezés hatása megfelelő arányban áll a vészhelyzet jellegével vagy hatásával.

A (szükség)rendeletekben meg kell határozni az Egyesült Királyság azon részeit vagy régióit, amelyekre a rendelkezések érvényesek.

A (szükség)rendeletek nem írhatják elő vagy nem adhatnak felhatalmazást annak az előírására, hogy egy személy katonai szolgálatot teljesítsen, illetve nem tilthatják meg vagy nem adhatnak felhatalmazást a sztrájkban vagy más ipari megmozdulásban való részvétel vagy ezzel kapcsolatos bármilyen tevékenység megtiltására.

A (szükség)rendeletek nem állapíthatnak meg - a CCA 22. \$ (3) bekezdés i) pontjában foglaltakat kivéve - búncselekményi tényállást; csak olyan kisebb súlyú büntetőjogi tényállást állapíthatnak meg, amely az alsóbb fokú bíróságok (magistrates' court), ${ }^{39}$ Skóciában a sheriff hatáskörébe (summary process) ${ }^{40}$ tartozik; csak olyan szabálysértési tényállást tartalmazhatnak, amelynek maximális tétele maximum három hónap szabadságvesztés vagy 5. szintnek megfelelő pénzbüntetés; ${ }^{41}$ valamint nem változtathatják meg a büntetőeljárási szabályokat.

Az általános korlátozásokon túlmenően - a kivételes hatalom elé állított speciális jogalkotói korlátozásként - a CCA konkrét törvénymódosítási tilalmakat is tartalmaz, amikor is két törvény, a CCA második része és az emberi jogokról szóló 1998-as törvény (Human Rights Act 1998 - a továbbiakban: HRA) módosítását még szükségállapot esetére is megtiltja. ${ }^{42}$ Azaz a kivételes hatalomról szóló szabályozás - beleértve a kivételes hatalom korlátait is - még szükségállapot idején sem változtatható meg. A második kivétel, a HRA az emberi jogok alapértékjellegére utal. Maga a törvény megemlítése inkább az alapértékek fontosságának hangsúlyozása miatt lehetett fontos a kodifikátorok számára, ugyanis ez a törvény az Emberi Jogok Európai Egyezményének ${ }^{43}$ (EJEE) brit jogrendbe való inkorporálásáról szól. Az EJEE 15. \$-a viszont lehetővé teszi az aláírók számára a szükséghelyzetben történő eltérést.

38 Vö.: CCA 23. \$ (1)-(4) bekezdés.

39 A magistrates' court hatáskörére lásd: www.judiciary.uk/you-and-the-judiciary/going-to-court/magistratescourt (Letöltve: 2020. november 19.).

40 Azok a büntetőügyek, amelyekben a seriff egyedül, esküdtszék nélkül jár el. Bővebben lásd:www.scotcourts. gov.uk/the-courts/sheriff-court/about-sheriff-courts (Letöltve: 2020. november 19.).

41 Ez jelenleg - a Criminal Justice Act 1982 37. \$ (2) bekezdése alapján - 5 ezer fontos pénzbüntetést jelent.

42 Vö.: CCA 23. $\$(5)$ bekezdés.

43 Más néven római egyezmény (Magyarországon becikkelyezte az 1993. évi XXXI. törvény). 
A CCA a kivételes hatalom birtokában megalkotott szabályok időbeli hatályát is korlátozza, ám ezt oly módon teszi, hogy egyúttal világos szabályozási kereteket is biztosít. ${ }^{44}$ A CCA kodifikátorai ugyanis jól érzékelték, hogy a jogbiztonság a jogállam érvényesülésének elengedhetetlen kelléke is, de különösen nagy szükség van rá rendkívüli körülmények között. A tömör, ám mégis részletes szabályok egyik alapvetô célja tehát a jogbiztonság rendkívüli helyzetben történő megőrzése. ${ }^{45}$

A CCA alapján készült (szükség)rendeletek maximum a meghozataluktól 30 napig maradhatnak hatályban. Ez természetesen nem zárja ki a rövidebb ideig tartó hatályt, amenynyiben a rendeletet kibocsátó erre nézve külön rendelkezik. A jogalkotó az alapesethez magyarázatot is fúzött, amelyben egyértelmúen kimondta, hogy a 30 napos korlátozott időbeli hatály egyrészt nem akadályozza új szabályozás megalkotását, másrészt pedig nem vonatkozik a még hatályos (szükség)rendeletek alapján megvalósult intézkedésekre.

\subsection{A kivételes hatalom parlamenti kontrollja}

A kivételes hatalmat korlátozó harmadik elem a parlamenti kontroll, amelyet a CCA - részben az esetleges visszaélések megelőzése érdekében - részletekbe menően szabályoz. ${ }^{46}$

Nincs kibúvó: a (szükség)rendeleteket megalkotásukat követően a brit parlament elé kell terjeszteni, amely dönthet a módosításukról vagy a hatályon kívül helyezésükről is. Az utólagos parlamenti kontroll azonban nem bír halasztó hatállyal: ha a (szükség)rendeletet megalkották, azonnal hatályos, annak alapján a hatóságok eljárhatnak, döntéseik érvényesek, ám a parlament közben a (szükség)rendeletet módosíthatja vagy hatályon kívül helyezheti. ${ }^{47}$ A korábban hatályos rendelet alapján hozott intézkedések érvényességét azonban a parlamenti döntés nem érinti, és a parlamenti ellenőrzés nem akadályozza új (szükség)rendelet alkotását. ${ }^{48}$

A parlament elé terjesztésnek nemcsak eljárási, de a (szükség)rendeletek időbeli hatályát is érintő szabályai vannak. A CCA úgy rendelkezik, hogy a (szükség)rendeleteket a megalkotásukat követô legrövidebb időn belül a parlament elé kell terjeszteni. Ha a parlament a beterjesztéstől számított hét napon belül nem hagyja azokat jóvá, a hetedik nap végén a törvény erejénél fogva hatályukat vesztik. ${ }^{49}$

44 Vö.: CCA 26. \$(1)-(2) bekezdés.

45 Másrészt pontosan egy ilyen kulcsfontosságú probléma, mint az időbeli hatály értelmezésekor válik egyértelművé, hogy a CCA felépítése és megszövegezése - bár elsőre riasztónak hat - valójában nemcsak a jogvégzett, de a laikus személyek általi megértést is próbálja segíteni.

46 Vö.: CCA 27-28. \$.

47 Vö.: CCA 27. \$.

48 Vö.: CCA 27. \$ (4) bekezdés.

49 CCA 27. $\$$ (1) bekezdés b) pont. 
A CCA a parlamenti határozatok joghatásairól is rendelkezik. Ha a parlament egyik háza a (szükség)rendeletek hatályon kívül helyezése mellett foglal állást, akkor azok hatályukat vesztik. ${ }^{50} \mathrm{Ha}$ az ilyen hatályon kívül helyező határozat

- határidőt is tartalmaz, akkor a határozatban foglaltaknak megfelelő időpontban;

- ha a parlamenti határozat nem tartalmaz határidőt, akkor a határozat elfogadását követő nap kezdetén;

- ha a két ház határozatai eltérő napot tartalmaznak, akkor a második határozat meghozatalát követő nap kezdetén

vesztik hatályukat a (szükség)rendeletek.

A CCA a (szükség)rendeletek parlamenti módosítására nézve is tartalmaz szabályokat. ${ }^{51}$ Ha a parlament valamelyik háza úgy határoz, hogy a (szükség)rendelet meghatározott módosítással lép hatályba, akkor ez a módosított verzió lesz majd hatályos:

- ha a határozat tartalmaz időpontot, akkor attól az időponttól;

- ha a határozat nem tartalmaz időpontot, akkor az elfogadást követő nap kezdetétől;

- ha a két ház határozatai eltérố napot tartalmaznak, akkor a második határozat meghozatalát követő nap kezdetétől.

A CCA előrelátó módon a parlamenti ülés elnapolásának, illetve az ülés berekesztésének esetére is tartalmaz rendelkezéseket.

Ha a (szükség)rendeletek megalkotásakor a parlament ülését elnapolták, és ez az állapot a rendeletek megalkotásától számítva öt napnál hosszabb ideig áll fenn, a Meeting of Parliament Act 1797 alapján az uralkodónak egy, az öt napon belüli időpontra a parlamentet össze kell hívnia..$^{52}$

Ha a (szükség)rendeletek megalkotásakor az alsóház ülését berekesztették, és ez az állapot a rendeletek megalkotásától számítva öt napnál hosszabb ideig áll fenn, az alsóház elnökének egy, az öt napon belüli időpontra az alsóház ülését össze kell hívnia. ${ }^{53} \mathrm{Ha}$ a (szükség)rendeletek megalkotásakor a felsőház ülését berekesztették, és ez az állapot a rendeletek megalkotásától számítva öt napnál hosszabb ideig áll fenn, a felsőház elnökének egy, az öt napon belüli időpontra a felsőház ülését össze kell hívnia. ${ }^{54}$

A CCA kodifikátorai még arra is figyelemmel voltak, hogy a szakasz végén egy értelmező rendelkezéssel az alsóház, illetve a felsőház elnökének fogalmát mindazon személyekre ki- 
terjesszék, akik a berekesztés időszakában a házszabályok alapján az alsóház, illetve a felsőház elnöke helyett eljárhatnának. ${ }^{55}$

\subsection{Eljárási szabályok}

A részletekbe menő anyagi jogi szabályozás mellett a CCA kiemelt figyelmet fordít az eljárási szabályok rögzítésére is. Mindenekelőtt rendezi a (szükség)rendeletek jogszabályi hierarchiában elfoglalt helyét, amikor kimondja, hogy a (szükség)rendeleteket rendeleti formában kell megalkotni, és e szabályokat a HRA ${ }^{56}$ szempontjából másodlagos joganyagnak ${ }^{57}$ kell tekinteni. ${ }^{58}$

Bizonyos esetekben a CCA konzultációs kötelezettséget ír elő a kivételes hatalom birtokosa számára. A konzultációt még a jogalkotást megelőzően, az autonómiával felruházott országrészek kormányzatával kell lefolytatni, azonban ez a konzultációs kötelezettség feltételes, vagyis egyes feltételek fennállása esetén mellőzhető.

A törvény alapján, amennyiben a (szükség)rendelet teljes egészében vagy részben Skóciát is érinti, csak a skót minisztertanáccsal való konzultációt követően készíthető el. Az egyeztetést egy vezetô beosztású kormánytagnak kell lefolytatnia, ${ }^{59}$ a lehetséges személyi kört a CCA egy másik helyen pontosan megadja ${ }^{60} \mathrm{~A}$ konzultációra kötelezett kormánytagok közétartozik a kincstár első lordja (vagyis a brit miniszterelnök), bármely államtitkár, valamint a kincstári megbízottak. ${ }^{61}$

Hasonló előzetes konzultációt kell lefolytatni Észak-Írország, illetve Wales kormányzatával még az ezen országrészeket érintő különleges jogrendi jogalkotás megkezdése előtt. Mentesül azonban a konzultációs kötelezettség alól a brit kormány, amennyiben a konzultációra kötelezett személy megítélése szerint erre a sürgős szükség miatt nincs lehetőség. Ilyen esetben a konzultációs kötelezettség elmaradása nem érinti a (szükség)rendelet érvényességét. ${ }^{62}$

Végül az eljárási szabályok között kell megemlékezni a szükséghelyzeti és a regionális koordinátorok kinevezésével kapcsolatos feladatokról. ${ }^{63}$ A kivételes hatalom birtokosának - konkrétan a jogszabály megalkotójának - ugyanis a (szükség)rendelet megalkotásával egyidejưleg szükséghelyzeti koordinátorokat kell kineveznie az Egyesült Királyság mindazon országrészeibe (Anglia kivételével, tehát Skócia, Észak-Írország és Wales), amelyeket a (szükség)rendeleti szabályozás érinteni fog, illetve regionális koordinátorokat kell kineveznie az Egyesült Királyság mindazon régiójába, amelyeket a (szükség)rendeleti sza-

55 CCA 28. $\$$ (4) bekezdés.

56 Vö.: HRA 21. $\$$ (1) bekezdés.

57 Bővebben lásd jelen fejezet 4. pontját.

58 Vö.: CCA 30. \$ (1)-(2) bekezdés.

59 Vö.: CCA 29. \$ (1) bekezdés.

60 Vö.: CCA 31. \$ (1) bekezdés és CCA 20. \$ (3) bekezdés.

61 A kormánytagokra vonatkozóan bővebb magyarázatot és hivatkozásokat lásd jelen fejezet 2.2. pontjában.

62 Vö.: CCA 29. \$ (4) bekezdés.

63 Vö.: CCA 24. \$. 
bályozás érinteni fog. A (szükség)rendeletben rögzíteni kell a szükséghelyzeti, illetve a regionális koordinátorok kinevezésének időtartamát, a munkavégzés körülményeit, valamint a koordinátorok díjazását és a koordinátorok feladatait. ${ }^{64}$

A koordinátorok legfontosabb feladatát a törvény maga szabályozza, amikor kimondja, hogy „a kinevezés elsődleges célja a (szükség)rendeletben foglalt tevékenységek összehangolásának megkönnyítése (akár csak abban az országrészben vagy régióban, ahová a kinevezés szólt, akár részlegesen: részben ott, részben bárhol másutt)". ${ }^{65} \mathrm{~A}$ koordinátornak feladatai ellátása során a vezetô beosztású kormánytag utasításait kell követnie, illetve köteles a vezető beosztású kormánytag útmutatójában foglaltakat betartani. ${ }^{66}$ Másképpen szólva a CCA a fenti szabályozás révén utasítási és útmutató-kibocsátási jogkört biztosít a vezető beosztású kormánytag számára a szükséghelyzeti és a regionális koordinátorok fölött. ${ }^{67}$

\section{Az alapjog-korlátozással kapcsolatos kérdések}

$\mathrm{Az}$ alapjog-korlátozás kérdésének tanulmányozása alapvetően két törvény, a CCA és a CVA vizsgálatát igényli.

A CCA esetében az előző pontban láthattuk, hogy a jogalkotó kiemelt esetként ${ }^{68}$ kezelte az Emberi Jogok Európai Egyezményének való megfelelést, illetve az abban foglalt alapvető jogok szükségállapot idején történő korlátozhatatlanságának biztosítását. Erre utal, hogy a CCA még szükségállapot idején is korlátozhatatlannak minősítette a HRA-t, amely az EJEE rendelkezéseit ültette be a brit jogba. ${ }^{69}$ Itt is szükséges megemlíteni, hogy a CCA alapján megalkotott (szükség)rendeletek jogforrási hierarchiában való elhelyezését a kodifikátorok részben az 1998-as emberi jogi törvényre visszautalással oldották meg,70 ami azt jelenti, hogy a (szükség)rendeletek másodlagos jogforrásnak minősülnek, amelyek - amennyiben tartalmuk az EJEE-vel ütközik - bíróság által megsemmisíthetók. Ez a lehetőség elsősorban nem az önmagukban korlátozott (harmincnapos) időbeli hatállyal bíró (szükség)-rendeletek, hanem az azok felhatalmazása alapján készült egyéb intézkedések miatt bír(na) kiemelt jelentőséggel. Tekintettel arra, hogy a CCA-t a gyakorlatban még nem alkalmazták, bírósági ítéletekben csak elméleti szinten, hatályos jogszabályként hivatkozzák.

64 CCA 24. $\$(2)$ bekezdés.

65 CCA 24. $\$$ (3) bekezdés.

66 CCA 24. \$(4) bekezdés.

67 Lásd a CCA tervezetéhez füzött miniszteri indokolást.

68 Fontos adalék, hogy eredetileg a brit alkotmány részét képező alapvető törvények korlátozhatatlanságát tervezték rögzíteni, de végül csak a legfontosabb elemek tételes felsorolása maradt a szövegben.

$69 \mathrm{Az}$ emberi jogi törvény tartalmára és a legfontosabb esetjogra lásd: www.equalityhumanrights.com/en/ human-rights/human-rights-act és www.equalityhumanrights.com/sites/default/files/human_rights_ human_lives_a_guide_for_public_authorities.pdf (Letöltve: 2020. november 25.).

70 Vö.: CCA 30. \$ (2) bekezdés. 
A 2020. évi járvány kezelésére a brit kormány külön szabályozás megalkotását kezdeményezte. A CVA egy speciális, a járványhoz kötött kivételes jogrendről szóló törvény, amely meghatározott ideig (alapesetben két évig) marad hatályban. Skóciában a járvánnyal kapcsolatban külön törvény elfogadására is ${ }^{72}$ sor került. ${ }^{73}$

A CVA rendelkezéseinek elsődleges célja a járvány kezelésének megkönnyítése és terjedésének lassítása, az állami szervek müködésének biztosítása és a gazdaság múködőképességének megőrzése. A CVA mindegyik célhoz kapcsolódóan - összhangban az Emberi Jogok Európai Egyezményével - lehetővé tesz bizonyos alapjogi korlátozásokat is. ${ }^{74} \mathrm{Az}$ előterjesztő ezeket az EJEE és az emberi jogokról szóló 1998-as törvény alapján még a törvényhozási vita során megvizsgálta (például hogy mennyiben arányos intézkedés a helyi önkormányzati választások egy évvel történő elhalasztása), ${ }^{75}$ és részletes magyarázatot adott az esetleges kollízió tekintetében. Vonatkozó bírói gyakorlat még a CVA vonatkozásában sem ismert.

\section{Egészségügyi vészhelyzet kezelése, koronavírus-járvány}

A brit kormánynak az 1930-as évek óta létezett olyan közegészségügyi törvénye, amely lehetővé tette az egyes fertőző betegségek elleni fellépést. ${ }^{76} \mathrm{~A}$ jelenleg hatályos közegészségügyi törvény, ${ }^{77}$ bár összegezte a területen lezajlott korábbi kodifikációs eredményeket, továbbra is csak a fertőző betegségek egy részével (kolera, pestis, sárgaláz) szembeni szabályozás megalkotását tette lehetôvé. A kormány - felismerve a jogalkotási szükséghelyzetet a közegészségügyi törvény 2008 -as módosításával ${ }^{78}$ lehetôvé tette, hogy a törvényt az újfajta kórokozók (például a SARS) elleni védekezésben is hasznosítani lehessen. ${ }^{79}$

2020-ban a koronavírus elleni védekezéshez szükséges első jogszabályokat ennek a modernizált közegészségügyi törvénynek a felhatalmazó rendelkezései alapján alkották meg.

71 A sunset-klauzula alkalmazására lásd még: https://commonslibrary.parliament.uk/social-policy/health/ coronavirus-bill-what-is-the-sunset-clause-provision (Letöltve: 2020. június 18.).

72 A CVA elfogadásához a skót parlament is hozzájárult 2020. március 24-én; a törvény 2020. március 25-én lépett hatályba.

$73 \mathrm{Ez}$ a Coronavirus (Scotland) Act 2020, amely 2020. április 6-án lépett hatályba. A törvényjavaslat indokolásának 3. pontja szerint CVAS célja a CVA pótlása és kiegészítése volt. Elérhetô: www.legislation.gov.uk/ asp/2020/7/notes/division/2 (Letöltve: 2020 . december 10.).

74 Ezeket részletesen lásd: https:/publications.parliament.uk/pa/bills/cbill/58-01/0122/Memorandum\%20 to $\% 20$ the $\% 20$ Joint $\% 20$ Committee\%200n\%20Human\%20Rights $\% 20-\% 20$ The $\% 20$ Coronavirus $\% 20$ Bill\%20 2020.pdf (Letöltve: 2020 . november 20.).

75 A választások elhalasztásáról lásd a törvényjavaslat indokolásának 450-489. pontját. Elérhető: https:// publications.parliament.uk/pa/bills/cbill/58-01/0122/en/20122enlp.pdf (Letöltve: 2020. november 20.).

76 Lásd még: https://woodfines.co.uk/2020/03/27/coronavirus-and-the-new-enforcement-powers (Letöltve: 2020. november 21.).

77 Public Health (Control of Diseases) Act 1984.

78 A módosításokat a Health and Social Care Act 2008 valósította meg.

79 Vö.: a Health and Social Care Act 2008 törvényjavaslatához készült indokolás 29-30. pont. Elérhető: www. legislation.gov.uk/ukpga/2008/14/notes/division/2 (Letöltve: 2020. november 21.). 
Az 1984-es közegészségügyi törvény hatálya azonban csak Angliára és Walesre terjed ki, Skóciára és Észak-Írországra külön törvények vonatkoznak. ${ }^{80} \mathrm{Ez}$ azt jelenti, hogy a koronavírussal kapcsolatos nemzeti szintű közegészségügyi intézkedéseket három különböző törvény felhatalmazása alapján kell(ett) megalkotni. ${ }^{81}$

A koronavírus a legújabb adatok szerint már 2019 decemberében megjelent az Egyesült Királyságban. ${ }^{82} \mathrm{Az}$ első koronavírussal kapcsolatos jogszabály, egy miniszteri rendelet ${ }^{83}$ 2020. február 10-én lépett hatályba a közegészségügyi törvényben biztosított felhatalmazás alapján. Ez csak Angliára és Walesre vonatkozott, és kötelezte a vizsgálat alá vont személyeket személyes információk (utazási adatok és tervek, megtörtént és tervezett találkozók) hatósággal történő megosztására, szűrővizsgálatok elvégzésére, a hatóság döntése alapján a karanténba vonulásra. A 2020. február 10. és március 20. közötti öt hét során a kormányzat jogalkotás helyett elsősorban kommunikációs eszközökkel próbálta a lakosságot önkorlátozásokra buzdítani ${ }^{84} \mathrm{~A}$ tanácsok, iránymutatások nagy része országrészenként eltérő volt.

A betegek számának folyamatos növekedését látva a brit kormány megvizsgálta a szükségállapot bevezetésének lehetőségét, és végül a CCA élesítése helyett egy kifejezetten a koronavírussal kapcsolatos helyzet kezelésére vonatkozó szükségállapoti törvény megalkotása mellett döntött, ez a CVA. Bár a törvény hatálya az Egyesült Királyság egész területére kiterjed, Angliában (és részben Walesben) a védekezést elsősorban az 1984-es közegészségügyi törvényben, míg Skóciában előbb a CVA-ban, majd a CVAS-ban biztosított felhatalmazás alapján kezelték. ${ }^{85}$ Észak-Írországban a védekezéshez szükséges felhatalmazást a helyben hatályos közegészségügyi törvény adta meg. ${ }^{86}$ Magát a CVA-t elsősorban a járvány közegészségügyi törvény alapján nem kezelhető hatásai elleni küzdelemre

80 Lásd: Public Health (Scotland) Act 2008 és Public Health (Northern Ireland) Act 1967, ezek ismertetésére azonban terjedelmi okok miatt itt nincs lehetőség.

81 Az egy országon belüli négy különböző védekezési módszer azonban csak részben köszönhetô az eltérô törvényi keretszabályozásnak, az okok inkább az egyes országrészeknek biztosított autonómiában (devolved administration) keresendők, amely alapján az egészségügyi intézkedések döntő többsége az egyes országrészek hatáskörébe került.

$82 \mathrm{Az}$ első koronavírusos halálesetre lásd: www.bbc.com/news/health-52589449 (Letöltve: 2020. november 19.) és https://metro.co.uk/2020/09/09/grandad-84-first-to-die-of-coronavirus-in-uk-fell-ill-two-weeks-beforechristmas-13244673 (Letöltve: 2020. november 19.).

83 The Health Protection (Coronavirus) Regulations 2020 (SI 2020/129).

84 Lásd: www.bbc.com/news/uk-51857856 (Letöltve: 2020. november 22.), www.bbc.com/news/uk-51917562 (Letöltve: 2020.11.20.) és www.bbc.com/news/uk-51952314 (Letöltve: 2020. november 22.).

85 Vö. például: The Health Protection (Coronavirus) (Restrictions) (Scotland) Regulations 2020, hatályba lépett: 2020.03.26.

86 Vö.: The Health Protection (Coronavirus, Restrictions) Regulations (Northern Ireland) 2020, hatályba lépett: 2020.03.28. 
használták (az egyes országrészekben), így például a bérletek felmondás elleni védelméhez szükséges szabályozás megalkotásához..$^{87}$

Tekintettel arra, hogy a CVA a koronavírus elleni küzdelem legmagasabb szintú jogszabálya, röviden ismertetni kell a megalkotásának célját és szerkezetét.

\subsection{A brit koronavírus-törvény}

A gyorsított eljárással elfogadott CVA az általános szükséghelyzeti szabályozáshoz (CCA) képest egy különös jogi rezsim, csak az adott vírusjárvány kormányzati kezelését kívánja megkönnyíteni, tehát nem célja a végrehajtó hatalom hatásköreinek általános bővítése. Ennek megfelelően a CVA hatálya korlátozott: alapesetben az elfogadástól számított 2 év, amely fél évvel csökkenthetô vagy fél évvel növelhető. ${ }^{88} \mathrm{~A}$ CVA egyik legfontosabb újítása ez a feltételes korlátozott hatály, amely lehetővé teszi a törvény egyes rendelkezéseinek hosszabb ideig történő hatályban tartását (vagyis a járvány által okozott helyzetek rugalmas, proaktív kezelését). ${ }^{89}$

A CVA-t a koronavírus-járvány elleni védekezés generális keretjogszabályaként alkották meg. Szabályai számos, az EJEE-ben rögzített jog korlátozását teszik lehetôvé (lásd fentebb). Ezenbelül a törvény a társadalom múködése szempontjából kiemelt fontosságú szolgáltatások, mint a kommunikáció, médiaszabályozás, gazdaság és közlekedés területén több korlátozási lehetőséget is biztosít a kormány számára.

A potenciálisan fertőző személyekkel kapcsolatos hatáskörök: ${ }^{\circ}$ a törvény biztosítja az Egyesült Királyság egyes országrészeinek kormányai részére, hogy az adott országot „vírusátadás-ellenőrzési időszakba" helyezzék. Ilyenkor a közegészségügyi tisztviselők előírhatják azon személyek elkülönítését, akiknek tesztje víruspozitív (vagy nem egyértelmû), vagy akik megítélésük szerint „potenciálisan fertőzők”. A bevándorlási tisztviselők és a rendőrség korlátozottabb hatáskörrel rendelkeznek azon személyek mozgásának korlátozására, akiknél a betegség gyanúja felmerül. Aki a törvény elöirásait megsérti, pénzbírsággal büntetendő.

A nyilvános összejövetelekre és helyiségekre vonatkozó hatáskörök: ${ }^{91}$ a törvény lehetővé teszi a miniszter számára az összejövetelek, rendezvények korlátozását vagy betiltását, valamint a helyiségekbe való belépés korlátozását (a melléklet részletesen körülírja a hatáskör

87 Lásd például: The Coronavirus Act 2020 (Assured Tenancies and Assured Shorthold Tenancies, Extension of Notice Periods) (Amendment) (Wales) Regulations 2020 (hatályos: 2020. 07. 24-től), illetve The Coronavirus Act 2020 (Residential Tenancies: Protection from Eviction) (Amendment) (England) Regulations 2020 (hatályos: 2020. 08. 28-tól) és The Business Tenancies (Coronavirus) (Restriction on Forfeiture: Relevant Period) (Northern Ireland) Regulations 2020 (hatályos: 2020. 06. 29-től).

88 Hasonlóan érvel a törvényjavaslat indokolása is a 173-175. pontban. Elérhető: https://publications.parliament. uk/pa/bills/cbill/58-01/0122/en/20122enlp.pdf (Letöltve: 2020. március 23.).

89 A 2 éves periódus látszólag mérsékelt, a korábbi, terrorizmus visszaszorításával kapcsolatos törvények 5 éves hatályt is ismertek. Vö.: https://commonslibrary.parliament.uk/social-policy/health/coronavirus-bill-whatis-the-sunset-clause-provision (Letöltve: 2020. március 23.).

90 CVA 51. \$ és 21 . melléklet.

91 CVA 50. \$ és 22. melléklet. 
terjedelmét). A miniszter csak akkor élhet ezzel a felhatalmazással, ha hivatalosan bejelentették, hogy a vírus „súlyos és közvetlen fenyegetést jelent” a közegészségügyre, és hogy a hatáskörök felhasználása hozzájárul a vírus terjedésének ellenőrzéséhez, vagy megkönnyíti az orvosi/sürgősségi források megfelelő felhasználását. Aki a törvényt megsérti, büncselekményt követ el, és pénzbírsággal büntetendő.

Oktatási intézmények és gyermekgondozók bezárásával kapcsolatos hatáskörök:92 a törvény felhatalmazza a minisztereket, hogy előírják az iskola vagy a regisztrált gyermekgondozó ideiglenes bezárását. Ha egy miniszter ilyen iránymutatást adna, az intézménynek észszerú lépéseket kell tennie annak megakadályozása érdekében, hogy az érintettek meghatározott ideig ezekre a helyekre belépjenek. A miniszter pontosabb utasításokat adhat a helyiségek egyes részeire vagy az érintettekre vonatkozóan is. A felhatalmazó rendelkezések alkalmazása előtt a jogalkotónak konzultálnia kell a közegészségügyi tisztviselőkkel.

A bérlők védelmével kapcsolatos intézkedések:93 lakóingatlanok esetében védelem a kilakoltatásoktól (a törvényes felmondási időt két hónapról három hónapra hosszabbították meg). Az üzleti bérleti díjak esetében védelem a bérlemény elkobzása ellen (ideiglenesen korlátozták a visszavétel lehetőségét a bérleti díj megfizetésének elmaradása esetén).

Élelmiszer-ellátás: ${ }^{94}$ a törvény - az élelmiszer-ellátási zavarok elkerülése, illetve kezelése érdekében - felhatalmazza a kormányt, hogy az élelmiszer-szállítókat és a kiskereskedőket kötelezze az élelmiszer-ellátási láncokkal kapcsolatos információik átadására.

Szakemberhiányból adódó problémák kezelése egyes nemzetbiztonsági területeken:95 az egyik kritikus terület a vizsgálatokról szóló törvény (Investigatory Act 2016 - a továbbiakban: IPA) alkalmazása, ugyanis ez a törvény teszi lehetôvé a nyomozati hatáskörök hírszerző és bûnüldöző szervek által történő felhasználását, amennyiben azok rendelkeznek az IPA alapján kibocsátott paranccsal (végzéssel). A vizsgálati jogkör alapján kiadott végzéseket az államtitkárnak és a 15 igazságügyi biztos egyikének kell aláírnia. Mivel a járvány a biztosok hosszabb időre történő kiesését eredményezheti, a törvény lehetôvé teszi további - ideiglenes - bírói biztosok kinevezését és a kinevezési folyamat módosítását. Az igazságügyi biztosoknak az elfogatóparancsot általában visszamenőleges hatállyal kell jóváhagyniuk annak meghozatalától számított három napon belül. A biztosokra nehezedő nyomás enyhítése érdekében a törvény lehetővé teszi ennek az időszaknak legfeljebb 12 napra történő emelését. A végzések általában maximum öt napig érvényesek. A törvényjavaslat ezt az időszakot legfeljebb 12 napra meghosszabbítja.

A CVA lehetôvé teszi továbbá, hogy a kormány az ujjlenyomatok és a DNS-profilok megőrzésének idejét hat hónapra meghosszabbítsa, ha az államtitkár úgy ítéli meg, hogy a koronavírus káros hatással van vagy valószínúleg káros hatással lesz azokra, akik a nemzetbiz-

92 CVA 37-38. \$ és 16-17. melléklet.

93 CVA 81-83. § és 29. melléklet.

94 CVA 25-29. \$.

95 CVA 22-24. és 50. \$. 
tonsági döntéseket meghozzák, és a nemzetbiztonság érdekében szükséges az ujjlenyomatok vagy a DNS-profilok megőrzése.

A törvény felhatalmazást ad a kikötők múködésének felfüggesztésére, ha a határőrség állományának csökkenése miatt nincs elegendő erőforrás a határ biztosításához. A kikötői mûveletek felfüggesztésével kapcsolatos kezdeti döntéseket a határőrség tisztviselője is meghozhatja, azonban a több mint 12 órás felfüggesztés esetében a miniszter dönt.

A korlátozásokon túlmenően a CVA célja a járvány kezelésének megkönnyítése. ${ }^{96}$ Ennek érdekében

- lehetôvé teszi az elérhető egészségügyi és szociális gondozói munkaerő létszámának növelését a már nyugdíjba vonult szakemberek, illetve a most egyetemre járó hallgatók bevonásával;

- lehetôvé teszi az első vonalban küzdő személyzetre háruló terhek csökkentését az adminisztratív terhek csökkentése, az intézkedési szabadság növelése, például az ellátásra szorulók kategorizálása révén;

- lehetôvé teszi a vírus terjedésének feltartóztatását, illetve lassítását a társas érintkezések számának csökkentésével és a karanténszabályok erősítésével (ezek közé tartozik többek között a soron következő választások elhalasztása is); ${ }^{97}$

- lehetôvé teszi a halálozások adminisztrációjának gyorsítását, továbbá a holttestek méltóságának megơrzéséhez szükséges intézkedések megtételét;

- bővíti a törvényes betegszabadság igénylésére jogosultak körét.

\subsection{Az ország lezárása (national lockdown és local lockdown)}

A kormány még a CVA elfogadása elôtt megkezdte az ország lezárását, országrészenként különböző, de általában a helyi közegészségügyi törvények felhatalmazása alapján kiadott rendeletekkel. A lezárásokhoz kapcsolódva fontos megjegyezni, hogy a járvány súlyosságától függően országon belül külön szabályozási enklávék is létrejöhettek. A helyi lezárások (local lockdowns) modelljét Angliában dolgozták ki, de más országrészekben (például Walesben ${ }^{98}$ és Skóciában ${ }^{99}$ ) is alkalmazták. Ezeket a rendeleteket szintén a közegészségügyi törvény alapján bocsátotta ki a központi (vagy az országrészi) kormány. A helyi lezárási jogi rezsimeket 2020. július 4. és 2020. október 14. között több településre, övezetre, régióra alkalmazták (először

96 Lásd bővebben a kormányzati honlapot: www.gov.uk/government/publications/coronavirus-bill-what-itwill-do/what-the-coronavirus-bill-will-do (Letöltve: 2020. március 23.).

97 A választások elhalasztásának ugyancsak járványügyi oka van, erre legutóbb 2001-ben került sor, szintén járványügyi okok miatt (száj- és körömfájásjárvány). Lásd bővebben: www.bbc.com/news/uk-politics-51876269 (Letöltve: 2020. március 23.).

98 Vö.: The Health Protection (Coronavirus Restrictions) (No. 2) (Wales) (Amendment) (No. 8) (Caerphilly) Regulations 2020, hatályos: 2020. 09. 08-tól, illetve The Health Protection (Coronavirus Restrictions) (No. 2) (Wales) (Amendment) (No. 10) (Rhondda Cynon Taf) Regulations 2020, hatálybe lépett: 2020. 09. 17.

99 Vö.: The Health Protection (Coronavirus, Restrictions) (Aberdeen City) Regulations 2020, hatályba lépett: 2020. 08. 05 . 
Leicesterre [Leicestershire], ${ }^{100}$ később más településekre [például: Luton, Bedfordshire vagy Blackburn, Darwen és Luton, Lancashire ${ }^{101}$ is).

A helyi lezárást - analógiával élve - nemcsak településekre, hanem akár jogi személyekre is ki lehetett szabni. Így akár egy adott céget is helyi lezárás alá lehetett vonni, ha ez közegészségügyi szempontból fontosnak számított (lásd például a Greencore Food to Go Ltd.-esetet). ${ }^{102}$

A központi kormányzat által közegészségügyi szempontból elrendelt helyi lezárásoktól el kell határolni a központi kormányzat által a helyi önkormányzatok számára biztosított jogalkotási felhatalmazást. Ez egyrészt a bezárások elrendelését, másrészt azok kikényszerítését tette lehetővé. Ezt még 2020 júliusában egy, a közegészségügyi törvény felhatalmazása alapján kibocsátott rendeletben adta meg az angliai helyi önkormányzatok számára az egészségügyi miniszter. ${ }^{103} \mathrm{~A}$ helyi önkormányzat által elrendelt lezárásokról minden esetben értesíteni kell az egészségügyi minisztert, és valamennyi, helyben meghozott intézkedést legkésőbb hétnaponta felül kell vizsgálni. ${ }^{104} \mathrm{Az}$ angliai példával később más országrészek kormányzata (Skócia, ${ }^{105} W^{10}$ les ${ }^{106}$ és Észak-Írország ${ }^{107}$ ) is élt.

Nagyjából egy hónapos teljes zárást követően 2020. április végétől egy több hónapos, lassú, fokozatos nyitás kezdődött, amelyet az egyes országrészek elsősorban a lezárást elrendelő jogszabályok többszöri módosítása révén értek el. A fokozatos enyhülés tavasztól kora őszig tartott, országrészenként eltérő ütemben.

2020. nyár végétől, ahogy az esetszám újra emelkedni kezdett, a központi kormány és az országrészek kormányzata is a korlátozások újabb bevezetése mellett döntött. Az ősz folyamán a helyi szintû́ korlátozásokat a települések többfokozatú besorolása váltotta fel. Angliában három-, Skóciában ötfokozatú skála bevezetése mellett döntöttek. ${ }^{108} \mathrm{~A}$ skálát végül

100 Vö.: az egészségvédelemről (koronavírus, korlátozások) (Leicester) szóló 2020. évi rendelet (SI 2020/685), hatályba lépett: 2020. 07. 04.

101 Vö.: The Health Protection (Coronavirus, Restrictions) (Blackburn with Darwen and Luton) Regulations 2020 (SI 2020/800), hatályba lépett: 2020. 07. 25. és The Health Protection (Coronavirus, Restrictions) (Blackburn with Darwen and Luton) Regulations 2020 (SI 2020/800), hatályba lépett: 2020. 07. 25.

102 Vö.: The Health Protection (Coronavirus, Restrictions) (Greencore) Regulations 2020 (SI 2020/921), hatályba lépett: 2020. 08. 29.

103 Vö.: The Health Protection (Coronavirus, Restrictions) (England) (No. 3) Regulations 2020 (SI 2020/750), hatályba lépett: 2020. 07.18.

104 The Health Protection (Coronavirus, Restrictions) (England) (No. 3) Regulations 2020 (SI 2020/750) 2. \$ (1) bekezdés és $12 . \$(1)-(2)$ bekezdés.

105 The Health Protection (Coronavirus Restrictions) (Functions of Local Authorities) (Wales) Regulations 2020, hatályos: 2020. 09. 14-től; The Health Protection (Coronavirus, Restrictions) (Directions by Local Authorities) (Scotland) Regulations 2020, hatályba lépett: 2020. 08. 28.

106 The Health Protection (Coronavirus Restrictions) (Functions of Local Authorities) (Wales) Regulations 2020, hatályba lépett: 2020. 09. 14.

107 The Health Protection (Coronavirus, Restrictions) (No. 2) (Amendment No. 8) Regulations (Northern Ireland) 2020, hatályba lépett: 2020. 10. 05.

108 Lásd még: www.instituteforgovernment.org.uk/blog/three-tiers-coronavirus-rebrand (Letöltve: 2020. november 25.). 
októberben részleges, novemberben országos lezárás váltotta fel, egyelőre december elejéig. ${ }^{109}$ Decemberben Angliában egy negyedik lezárási fokozatot is bevezettek, ${ }^{110}$ Skóciában továbbra is maradt az ötfokozatú skála. ${ }^{111}$

\section{A különleges jogrenddel és a járványügyi veszélyhelyzet kihirdetésével kapcsolatos tapasztalatok, jogviták}

Fentebb már említettük, hogy sem a CCA-val, sem a CVA-val kapcsolatban nincs még releváns bírói gyakorlat. Az előbbi esetben ennek legfóbb oka, hogy a törvénynek a jelen kötet szempontjából releváns második részét a gyakorlatban egyelöre még nem alkalmazták. Az utóbbi esetben a törvény megalkotása óta eltelt több mint fél évben egyértelmúvé vált, hogy a CVA elsődleges célja nem a kormány hatásköreinek bővítése, hanem a járvány kezelését megkönnyítő hatáskörük átmeneti biztosítása a végrehajtó hatalom számára. Másrészt a CVA gyakorlati alkalmazása megmutatta, hogy a törvényt elsősorban a közegészségügyi törvények mellett, kisegítő jelleggel használják.

Mindez azonban nem jelenti azt, hogy a koronavírus-járvány mentes lett volna a jogvitáktól. A viták három legfontosabb iránya:

- a védekezést és az alapjog-korlátozásokat elsősorban lehetővé tevő közegészségügyi törvénnyel és annak felhatalmazó rendelkezéseivel kapcsolatos problémák;

- a járvánnyal kapcsolatos lezárások szükségessége és arányossága (az EJEE rendelkezéseinek értelmezése);

— a járványból adódó jövőbeli feladatok és kötelezettségek alkotmányossága (például: egy esetleges védőoltás önkéntes vagy kötelező jellege).

A fenti problémák messzire vezetnek, hiszen a kérdések csak látszólag szólnak a felhatalmazások jogszerúségéről, valójában a békeidőben rendkívülinek számító korlátozások terjedelmét, az ezzel kapcsolatos döntések meghozatalára feljogosítottak személyét és eljárását érintik. 2020-ban tulajdonképpen a több mint hét évtizedes háborúmentes időszak legjelentősebb korlátozásait kényszerítette ki a kormányzat rövid pár hét alatt. Ennek nyomán szokások, életutak változtak meg, illetve szúkültek (eltérő mértékben) az egyének és egyes csoportok megélhetési lehetőségei. A kormányzat által bevezetett szabályok egyes esetekben

109 Az egyes országrészek eltérő szabályait bemutató áttekintő táblázatokat lásd: www.instituteforgovernment. org.uk/explainers/coronavirus-lockdown-rules-four-nations-uk (Letöltve: 2020. november 25.). A 2020. december elején bevezetett háromfokozatú angol skálára lásd: www.bbc.com/news/explainers-52530518 (2020. december 2.).

110 Lásd: www.theguardian.com/uk-news/2020/dec/19/Covid-tier-4-what-are-the-new-restrictions-for-londonand-south-east-england (2020. december 19.).

111 Lásd:www.bbc.com/news/explainers-52530518 és www.bbc.com/news/uk-scotland-55318075 (Letöltve: 2020. december 19.). 
egyéni életeket tettek ki közvetlen veszélynek közérdekre vagy mások jogos érdekére (például busz- vagy villamosvezetők a tömegközlekedésben) hivatkozással, esetleg több generáció alatt társadalmi normává vált magatartási szabályokat írtak felül.

Mindezekre tekintettel a változások mértéke, arányossága és szükségszerúsége értelemszerúen mélyreható jogi vizsgálatot igényel. Ugyanakkor azt is mérlegelni szükséges, hogy az EJEE által lehetôvé tett alapjog-korlátozások, illetve a közegészségügyi törvény által a járványok kezelésére biztosított felhatalmazások célhoz kötöttek, és az, hogy széles körú alkalmazásukat az elfogadásuk óta eltelt évtizedek alatt sikerült elkerülni, vagyis hogy jelenleg hiányzik a jogalkalmazói tapasztalat, csakis a véletlennek volt köszönhető.

A fenti kérdéseket egy vállalkozó által a kormány ellen indított kereset összegzi. ${ }^{112} \mathrm{~A}$ per 2020 júliusa óta több fórumot is megjárt, jelenleg (2020. 12. 15.) is folyamatban van.

A precedensértékú pertôl eltekintve az országos szintú lezárás alapjog-korlátozó hatása, illetve arányossága és szükségszerüsége, valamint a járvány elleni védőoltás önkéntessége vagy kötelező jellege már 2020 tavaszától elméleti vitákat generált egyes internetes jogi fórumokon. A különböző értékelések felhívták a figyelmet többek között az EJEE-ben foglalt egyes alapjogok - mint például az élethez való jog - kapcsán az államra háruló pozitív védelmi kötelezettségre, valamint arra is, hogy a járvány elleni védekezés elmulasztása - tekintettel az idősek és az egyes etnikai kisebbségek átlagon felüli fertőzöttségi rátájára - valószínúleg alkalmas lenne az EJEE 14. cikkében foglaltak (megkülönböztetés tilalma) állam általi megsértésének megállapítására. ${ }^{113}$

Olyan jogi vélemény is akad, amely az arányosság oldaláról közelítve - a brit bírói gyakorlat elemzésével - úgy ítéli meg, hogy az országos lezárások túlterjeszkedtek a jogszabályi kereteken (vagyis aránytalanok). ${ }^{114}$ Végül olyan véleményt is megfogalmaztak, amely szerint a kormány járvánnyal kapcsolatos intézkedései mind az EJEE, mind a brit jogszabályi környezet alapján arányosak és szükségesek voltak. ${ }^{115}$

A lezárások és az emberi jogok kollíziójának kérdésében a brit kormány részletesen is kifejtette álláspontját, amikor 2020 őszén részletes írásos beszámolót nyújtott be a parlament alsóháza emberi jogi bizottságának. ${ }^{116}$

112 A Simon Dolan-ügyben hozott elsőfokú ítélet: www.bailii.org/cgi-bin/format.cgi?doc=/ew/cases/EWHC/ Admin/2020/1786.htm (Letöltve: 2020. november 23.), valamint https://bdaily.co.uk/articles/2020/10/22/speakerintervenes-in-simon-dolans-legal-fight-against-lockdown (Letöltve: 2020. november 23.), https://bdaily.co.uk/ articles/2020/12/o1/simon-dolan-bid-to-take-fight-to-supreme-court (Letöltve: 2020. december 15.).

113 Elérhetô: https://ukhumanrightsblog.com/2020/04/30/the-coronavirus-lockdown-does-not-breach-humanrights-part-one-leo-davidson (Letöltve: 2020 . november 23.).

114 Elérhetô: https://ukhumanrightsblog.com/2020/04/21/a-disproportionate-interference-the-coronavirusregulations-and-the-echr-francis-hoar (Letöltve: 2020. november 23.).

115 Elérhető: https://ukhumanrightsblog.com/2020/05/11/leviathan-challenged-the-lockdown-is-compliant-withhuman-rights-law-part-two (Letöltve: 2020 . november 23.).

116 Bővebben lásd: https://publications.parliament.uk/pa/jt5801/jtselect/jtrights/265/26502.htm (Letöltve: 2020. november 23.). Az emberi jogi vonatkozásokra lásd még a Velencei Bizottság két jelentését: Venice Commission $2020 \mathrm{a}, 2020 \mathrm{~b}$. 
A folyamatban lévő, fentebb említett per kimenetele már csak e konkuráló jogértelmezések megerősítése vagy elvetése miatt is kiemelkedően fontos következménnyel járhat.

Végül - a jövőbe tekintve - itt kell megemlíteni a vakcináció kérdéskörét is, hiszen az eddigi tudományos vélemények alapján nem zárható ki a világjárványok ismétlődése. Vajon egy ilyen, teljes társadalmat veszélyeztetô betegség elleni oltás a brit esetjog és jogszabályok alapján lehet-e kötelező, és ha igen, maga a kötelezés arányos intézkedésnek tekinthető-e?"17

A kormányzat egyelőre az önkéntes oltást preferálja, ${ }^{118}$ de figyelembe kell venni, hogy a jogalkotó nemcsak közvetlen, de közvetett szabályozási módszerrel is élhet. ${ }^{119}$ Sőt, akár a vállalkozások is kikényszeríthetik egyes esetekben (például egyes repülőutak ${ }^{120}$ vagy általában a légi közlekedés) az oltások kötelező felvételét.

A lezárások esetében jól nyomon követhető volt a jogalkotó szabályozói koncepciójának folyamatos változása, ezért könnyen elképzelhetô, hogy ebben a kérdésben is sor kerül majd több különböző jogi álláspont kifejtésére, illetve ütköztetésére, és a kormány véleménye - a társadalmi, valamint a gazdasági érdekek függvényében - a későbbiekben akár meg is változhat.

\section{6. Összegzés}

A fentiekben a kivételes hatalom brit szabályozását mutattuk be. Ennek során egyrészt az általános szabályokat, a jogforrási hierarchiát, az anyagi és alaki szabályokat elemeztük, másrészt pedig e szabályrendszer egyetlen speciális helyzetben, a 2020-as koronavírus-járvány során történt alkalmazását vontuk vizsgálat alá.

Látható volt, hogy a polgári vészhelyzeti törvény hosszú, több évtizedes jogfejlődés eredményeképpen született meg, és bár a megalkotása óta eltelt másfél évtized alatt nem alkalmazták, kifinomult kodifikációs megoldásaival már csak azért is érdemes megismerkedni, mert nem egy hétköznapi jogszabályról, hanem egy speciális, a brit történeti alkotmány részét képező törvényről van szó. A CCA a kivételes hatalom gyakorlását több előfeltétel fennállásához köti, és ezek bekövetkezése esetén is korlátokat állít a kivételes hatalom birtokosa elé. A korlátok többfélék. Egy részük a (szükség)rendelet megalkotója számára próbálja csoportosítani a lehetséges jogalkotási tárgyakat, másik részük a (szükség)rendelet érvényességi feltételeit rögzíti (kibocsátó személye, időbeli és tárgyi hatály korlátai, utólagos

117 Bővebben lásd: https://ukhumanrightsblog.com/2020/11/05/compulsory-vaccination-the-next-step-forCovid-19 (Letöltve: 2020. november 23.).

118 Elérhető: www.thesun.co.uk/news/13218179/matt-hancock-refuses-rule-out-Covid-vaccine-mandatory (Letöltve: 2020 . november 23.).

119 Például előírhatja, hogy egy meghatározott helyen tartózkodáshoz szükséges az oltás felvétele. Vö.: www. dailymail.co.uk/news/article-9003321/Restaurants-bars-cinemas-turn-customers-without-Covid-jab-away. html (Letöltve: 2020 . december 2.).

120 Vö.: www.telegraph.co.uk/news/2020/11/28/airlines-mull-compulsory-Covid-19-vaccinations-passengerssolution (Letöltve: 2020. december 2.), valamint www.bbc.com/news/world-australia-55048438 (Letöltve: 2020. december 2.). 
parlamenti kontroll, kizárt jogalkotási tárgyak). A korlátok harmadik csoportja pedig egyéb eljárási kötelezettségeket ír elő a jogalkotó számára, de oly módon, hogy ezek megvalósítása a jogforrás tartalmát is érinti (feltételes konzultációs kötelezettség, koordinátorok kinevezésével kapcsolatos feladatok).

A (szülkség)rendelet megalkotója a CCA által lehetővé tett körben és mértékig a büntetôhatalom gyakorlására is jogosulttá válik, azonban büntetőjogi vagy szabálysértési tényállást csak a törvény által elôirt körben konstituálhat, pénzbírság kiszabását pedig csak a törvényben meghatározott mértékig írhatja eló.

Bár a CCA-t kifejezetten a kormány jogköreinek a szükségállapot kezeléséhez szükséges mértékben történő bővítése céljából alkották meg, a koronavírus-járvány kezelésére a brit parlament végül egy külön törvény, a koronavírus-törvény (CVA) megalkotása mellett döntött. Ezt részben a járvány súlyos következményeire (emberek tömeges megbetegedése, munkából való kiesése, munkanélkülivé válása, halála) való felkészüléssel, részben pedig a járvány időbeli elhúzódásával indokolták. Ez utóbbi helyzet kezelését a korlátozott feltételes hatály (egy kétéves időbeli hatályt előíró sunset-clause) beiktatásával kívánták megoldani.

Az első jogalkotói lépések megtétele azonban még a CVA megalkotása előtt szükségessé vált, így adta magát a közegészségügyi törvény által biztosított felhatalmazások alkalmazása. A közegészségügyi törvény nemcsak a gyors intézkedést, de a helyben legjobbnak tûnő szabályok bevezetését is lehetővé tette, ezért már 2020 tavaszán több országrészben is a járvány elleni jogalkotás elsődleges keretszabályává vált. A CVA-ban biztosított jogköröket végül mindeddig (2020. december 1-ig) csak részben kellett „élesíteni”.

A járvány elleni küzdelem során hozott korlátozó intézkedések arányossága és szükségessége rövid időn belül jogi természetú vitákat generált, kezdetben elméleti síkon, majd a gyakorlatban, bírósági kereset formájában is. A harmadik, az idő előrehaladtával egyre aktuálisabbá váló kérdéskör a védőoltás önkéntes vagy kötelező jellegének szabályozása körül alakul ki.

Fontos továbbá azt is megemlíteni, hogy a koronavírus-járvány elleni védekezés különböző koncepcióinak országrészenként eltérő eredményessége képes befolyásolni az egységes, illetve megosztott nemzeti szuverenitásról az uniós kilépés nyomán megélénkült (jogi) vitákat, már csak amiatt is, mert a helyi egészségüggyel kapcsolatos hatáskörök többsége már évekkel ezelőtt az egyes országrészek kormányzatának hatáskörébe került.

Végezetül röviden szólni kell a brit és magyar szabályozás hasonlóságairól és különbségeiről, valamint arról is, vajon a brit modell, illetve a koronavírus elleni védekezés tartogat-e tanulságokat a magyar jogalkotó számára.

Láthattuk, hogy a kivételes hatalom szabályozásának gyökerei mindkét államban több évszázadra nyúlnak vissza, ráadásul a jelenlegi szabályozás mindkét esetben a polgári hatóságok kezébe helyezi a rendkívüli helyzet menedzselését. Eltérőek azonban a szabályozási szintek és az esetkörök. Míg Magyarországon az elsődleges jogforrás e szabályozási tárgykör esetében is az Alaptörvény, amely több esetkört is részletesen elkülönít, addig az Egyesült Királyságban a kivételes hatalom - egy, a történeti alkotmány részét képező - külön tör- 
vényben került szabályozásra, amely csak egy esetkört ismer. A szabályozási aszimmetria a jogforrási hierarchia más szintjein is tetten érhető: Magyarországon a részletszabályokat törvények és ezek felhatalmazása alapján rendeletek, míg az Egyesült Királyságban rendeletek tartalmazzák.

Az általános szabályozás összehasonlítása mellett röviden a koronavírus-járványhoz kapcsolódóan megalkotott joganyagról is szólni szükséges. Az Egyesült Királyságban egy speciálisan a helyzet kezelésére szolgáló, meghatározott ideig (két évig) hatályos törvény megalkotására került sor, ám a védekezés nagy részét a közegészségügyi törvény felhatalmazása alapján kibocsátott rendeletekkel végezték el. Magyarországon ezzel szemben több törvény megalkotására is sor került, de a védekezés alapjául szolgáló joganyagot részben alkotmányi, részben törvényi felhatalmazások alapján bocsátották ki.

A védekezési stratégiák természetesen eltérőek voltak a két országban, de ennek egyik fó oka (a fertőzöttségi adatokban meglévő különbségek mellett) az eltérő közigazgatási szerkezetben keresendő. Bár elméletileg mindkét ország unitárius állam, az Egyesült Királyságban négy országrészi kormányzat múködik, és a helyi egészségügyi intézkedések a tartományi autonómia körébe tartoznak. Az eltérő közigazgatási szerkezetnek is köszönhető, hogy míg Magyarországon a járvány elleni védekezés a központosítás irányába hatott, addig az Egyesült Királyságban a kezdeti időszaktól eltekintve az intézkedések az országrészi kormányzatok szerepének folyamatos erősödésével jártak - igaz, e folyamat mögött ott feszült az uniós kilépés által újra felerősített szuverenitásvita is, amely a közeljövőben könnyen a Brit-szigetek uniójának felbomlását is magával hozhatja. Vagyis miközben Magyarországon a járvánnyal kapcsolatos védekezés elsődlegesen egy egészségügyi veszélyhelyzet jogi-politikai kezelését jelentette, addig az Egyesült Királyságban a koronavírus elleni küzdelem egyúttal az államközösség hatékony múködésének próbájaként is szolgált, és az egészségügyi veszélyhelyzet súlyos, az európai uniós tagság által korábban elfedett közjogi problémák megoldásával kapcsolódott (kapcsolódik) össze.

\section{Irodalomjegyzék}

Bowman, H. (1916) 'Martial Law and the English Constitution', Michigan Law Review, 15(2), 93-126. 0.

Clark, R. A. (2016) Business Continuity and the Pandemic Threat. Ely: IT Governance Publishing ConchA, Gy. (1885) Újkori alkotmányok II. (Anglia). 1. kiadás. Budapest: Magyar Tudományos Akadémia

Cotter, C. (1953) 'Constitutionalizing Emergency Powers: The British Experience', Stanford Law Review, 5(3), 382-417. o.

Csink, L. (2017) ‘Mikor legyen a jogrend különleges?', Iustum Aequum Salutare, 13(4), 7-16. o. 
EbuRn, M. (2017) Coordination of Federal, State and Local Disaster Management Arrangements in Australia. Lessons from the UK and the US [Online]. Elérhetô: www.jstor.org/stable/ resrepo4119 (Letöltve: 2020. december 6.)

FARKAS, Á., Kelemen, R. (szerk.) (2020) Szkülla és Kharübdisz között-Tanulmányok a különleges jogrend elméleti és pragmatikus kérdéseiról, valamint nemzetközi megoldásairól. 1. kiadás. Budapest: Magyar Katonai Jogi és Hadijogi Társaság

JAKAB, A., Till, Sz. (2019) 'A különleges jogrend' in Trócsányi, L., Schanda, B. (szerk.) Bevezetés az alkotmányjogba. Budapest: HVG-ORAC.

JÁnosi, F. (1867) Alkotmányok gyüjteménye I. (Anglia). 1. kiadás. Pest: Pfeiffer

KeLEMEN, R. (2019) 'Az Alaptörvény szükségállapot-szabályozásának kritikai áttekintése az egyes európai uniós tagállamok alkotmányainak figyelembevételével - Különös tekintettel a visegrádi államok alkotmányaira' in Bartkó, R. (szerk.) A terrorizmus elleni küzdelem aktuális kérdései a XXI. században. 1. kiadás. Budapest: Gondolat Kiadó

KojA, F. (2003) 'Állami szükségállapot és a szükségállapotra vonatkozó jog' in Takács, P. (szerk.) Államtan. 1. kiadás. Budapest: Szent István Társulat

RoSENFELd, M., SAJó, A. (szerk.) (2013) The Oxford Handbook of Comparative Constitutional Law. 1. kiadás. Oxford: Oxford University Press

SABJANics, I. (2014) 'Minősített időszakok az Alaptörvényen innen és azon túl' in Kovács, P. (szerk.) Religio et Constitutio. 1. kiadás. Budapest: Pázmány Press

TilL, Sz. (2019) 'Különleges jogrend' in Jakab, A., Fekete, B. (szerk.) Internetes Jogtudományi Enciklopédia [Online]. Elérhetó: https://ijoten.hu/uploads/kulonleges-jogrend.pdf (Letöltve: 2020. december 1.)

Tóтн, Á. (1967) 'A kivételes állapot intézményének kialakulása néhány burzsoá állam jogrendszerében', Acta Universitatis Szegediensis: Acta Juridica et Politica, 14(8), 3-19. o.

Venice Commission (2020a) Interim Report on the Measures Taken in the EU Member States as a Result of the Covid-19 Crisis and Their Impact on Democracy, the Rule of Law and Fundamental Rights (Opinion No. 995/2020) [Online]. Elérhető: www.venice.coe.int/webforms/ documents/default.aspx?pdffile $=\mathrm{CDL}-\mathrm{AD}$ (2020)o18-e (Letöltve: 2020 . december 15.)

Venice Commission (2020b) Respect for Democracy, Human Rights and the Rule of Law During States of Emergency: Reflections (Study No. 987/2020) [Online]. Elérhető: https://rm.coe.int/ respect-for-democracy-hu-man-rights-and-rule-of-law-during-states-of-e/16809e82co (Letöltve: 2020. december 15.) 


\title{
12. Fokozatosság elve és átfogó védelem: a különleges jogrend Észtországban
}

\author{
DORNFELD LÁSZLÓ
}

\section{A különleges jogrend allkotmányos és törvényi szintű szabályozása és esetkörei}

\begin{abstract}
A különleges jogrend vonatkozásában Észtországban mind az 1992-es alkotmány, ${ }^{1}$ mind bizonyos törvények tartalmaznak rendelkezéseket. Az alkotmány X. fejezete, amely a honvédelem témakörével foglalkozik, meghatározza a különleges jogrendi esetköröket: a szükségállapotot (erakorraline seisukord), ${ }^{2}$ valamint a hadiállapotot (sõjaseisukord). ${ }^{3} \mathrm{Az}$ alkotmányos szabályozás azonban csak a legszúkebb keretekre terjed ki, így csak azt mondja ki, hogy ki jogosult a különleges jogrend elrendelésére, milyen esetben és milyen időtartamra. A további szabályozás mindkét esetben külön törvényben található. Előbbi esetén a honvédelmi törvény tartalmaz rendelkezéseket, ${ }^{4}$ míg utóbbi kapcsán a szükségállapoti törvényben találhatók részletszabályok. ${ }^{5}$
\end{abstract}

I Az Észt Köztársaság alkotmánya (Eesti Vabariigi põhiseadus 1992. 06. 28.) (a továbbiakban: alkotmány).

2 Alkotmány 129. szakasz (a hivatalos angol nyelvú fordítás a state of emergency kifejezést használja).

3 Alkotmány 128. szakasz (a hivatalos angol nyelvủ fordítás a state of war kifejezést használja).

4 Honvédelmi törvény (Riigikaitseseadus 2015. 02. 11.) (a továbbiakban: Honvédelmi tv.).

5 Szükségállapoti törvény (Erakorralise seisukorra seadus 1996. 01. 10.) (a továbbiakban: Szükségállapoti tv.).

Dr. Dornfeld László

laszlo.dornfeld@mfi.gov.hu

kutató (Mádl Ferenc Összehasonlító Jogi Intézet)

Dornfeld, L. (2021) 'Fokozatosság elve és átfogó védelem: a különleges jogrend Észtországban' in Nagy, Z., Horváth, A. (szerk.) A különleges jogrend és nemzeti szabályozási modelljei, 277-300. o. Budapest: Mádl Ferenc Összehasonlító Jogi Intézet.

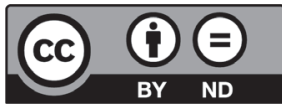


A harmadik legfontosabb törvény a kérdéskörben a veszélyhelyzeti törvény, ${ }^{6}$ amelyben a szükségállapotot el nem érő két szint kerül szabályozásra. ${ }^{7}$ Ezek a válsághelyzet (hädaolukord), ${ }^{8}$ valamint a veszélyhelyzet (eriolukord). ${ }^{9} \mathrm{Az}$ említett kifejezések nem szerepelnek az alkotmányban, így bár különleges felhatalmazást adnak, nem tekinthetók különleges jogrendi esetkörnek. Ennek megfelelően ezek a kategóriák egy későbbi pontban kerülnek részletes tárgyalásra. A két esetkör közötti különbséget az alkotmány is egyértelmúvé teszi: míg a Honvédelmi tv. és a Szükségállapoti tv. csak kétharmaddal módosítható, addig a Veszélyhelyzeti tv. nem szerepel a felsorolásban. ${ }^{10}$

A Honvédelmi tv. is megkülönböztet további esetköröket a hadiállapot előtt a helyzet súlyosságától függően; ezek az általános (üldine kaitsevalmidus) és a fokozott védelmi készültség (kôrgendatud kaitsevalmidus). ${ }^{11}$ Ezek szintén nem tekinthetők különleges jogrendnek, hanem az arra való felkészülést segítik elő, így később kerülnek tárgyalásra.

A fentiek értelmében Észtországban két különleges jogrendi esetkör különíthető el egymástól, a szükségállapot és a hadiállapot. A kettő között egyértelmú fokozatosság állapítható meg, ugyanis a szükségállapot véget ér a hadiállapot bevezetésével. ${ }^{12} \mathrm{~A}$ hadiállapot súlyosságát jelzi az is, hogy míg a szükségállapot elrendelésére csak határozott időre kerülhet sor, addig a hadiállapotot határozatlan időre rendelik el, és külön kell dönteni megszüntetéséről.

A szükségállapotot az alkotmány alapján az észt alkotmányos rendet érő fenyegetés esetén rendelheti el a parlament, a köztársasági elnök, a kormány vagy a törvényhozás képviselői többségének a javaslatára az ország egész területén legfeljebb három hónapos időtartamra. ${ }^{13}$ A szükségállapoti törvény pontosítja, mi az a három feltétel, ami szükséges az elrendeléshez: egyrészt Észtország alkotmányos rendjét fenyegetés éri, másrészt ez csak a különleges jogrend eszközeivel hárítható el, harmadrészt pedig a köztársasági elnök javaslatára a törvényhozás többsége támogatja azt. A törvény részletesebben meghatározza, mi tekinthető olyan fenyegetésnek, amely alapján a különleges jogrend elrendelhetô: $:^{14}$

— az alkotmányos rend megdöntésére irányuló erőszakos kísérlet;

- terrorista tevékenység;

6 Veszélyhelyzeti törvény (Hädaolukorra seadus 2017. 02. 08.) (a továbbiakban: Veszélyhelyzeti tv.).

7 Összességében tehát három szintje van a veszélyhelyzetnek, ezek súlyosság szempontjából: vészhelyzet, válsághelyzet, szükségállapot (Maruste, 2020).

8 A Veszélyhelyzeti tv. a hädaolukord kifejezést használja, amely a törvény hivatalos angol nyelvú változatában az emergency fordítást kapta.

9 A Veszélyhelyzeti tv. az eriolukord kifejezést használja, amely a törvény hivatalos angol nyelvú változatában az emergency situation fordítást kapta.

10 Alkotmány 104. szakasz (Maruste, 2020).

11 Honvédelmi tv. 12. szakasz (hivatalos angol fordításban: general defence readiness, illetve increased defence readiness).

12 Szükségállapoti tv. 16. szakasz.

13 Alkotmány 129. szakasz.

14 Szükségállapoti tv. 2-3. szakasz. 
- erőszakos kollektív kényszerítés;

— kiterjedt belső konfliktus különböző csoportok között;

— Észtország területe egy részének erőszakos elszigetelése;

- tartós erőszakos belső konfliktus.

Az alkotmányt érintő fenyegetésekről az állami szervek, községi és városi önkormányzatok haladéktalanul értesíteni kötelesek a köztársasági elnököt, a kormányt, illetve a védelmi erôk parancsnokát. ${ }^{15}$

A szükségállapot bevezetését illetően a törvény részletes szabályozást tartalmaz. ${ }^{16}$ Ebben szerep jut a kormány Válságbizottságának (Vabariigi Valitsuse kriisikomisjoni), valamint a Honvédelmi Tanácsnak (Riigikaitse Nốukogu). Mindkét szerv tanácsadó, elemző jellegú feladatot lát el, előbbi a kormány, ${ }^{17}$ utóbbi a köztársasági elnök mellett. ${ }^{18} \mathrm{~A}$ két szerv mellett a kormány is összeül, hogy tárgyaljon a szükségállapot bevezetésének indokoltságáról, majd a köztársasági elnök, mielőtt a javaslatot a törvényhozás elé vinné, azon személyekhez vagy csoportokhoz fordul, akiknek tevékenysége veszélyt jelent az észt alkotmányos rendre, és felszólítja őket ennek befejezésére. Ez a megkeresés tömegkommunikációs eszközök útján történik, a mûsorszolgáltatók kötelesek a felhívást változatlanul és azonnal közreadni. Amennyiben a felhívásnak nem tesznek azonnal eleget, az elnök a parlament elé viszi a javaslatot. ${ }^{19}$

Ez az utóbbi követelmény ugyanakkor a kormány által beterjesztett szükségállapoti javaslatra nem vonatkozik. A javaslatnak - terjessze bár be a köztársasági elnök vagy a kormány - tartalmaznia kell az elrendelésére okot adó alkotmányos fenyegetést is. Amennyiben a javaslat benyújtásakor a parlament nem ülésezik, a köztársasági elnök vagy a kormány írott javaslatot nyújt be a parlament elnökének rendkívüli ülés összehívására, a javaslat benyújtásától számított legalább 8 órán belül. Amennyiben a szükségállapoti javaslatot rendes ülésszakban terjesztik be, írott javaslatot kell benyújtani a parlament elnökének, hogy azonnal hívjon össze egy ülést. ${ }^{20} \mathrm{~A}$ parlament határozatában rendelkezni kell a szükségállapot alkotmány szerinti elrendeléséről, meg kell jelölni a bevezetés okát, valamint annak időtartamát. A határozat a nemzeti tömegtájékoztatásban való közzététele után válik hatályossá, ezt a músorszolgáltatóknak változatlanul és azonnal közzé kell tenniük. A határozat elfogadását követő első munkanapon azt közzé kell tenni az ország hivatalos lapjában is. ${ }^{21}$

15 Szükségállapoti tv. 7. szakasz.

16 Szükségállapoti tv. 8-11. szakasz.

17 A kormány válságbizottságának jogállásáról szóló kormányrendelet (Vabariigi Valitsuse kriisikomisjoni põhimäärus 2017. 06. 27.).

18 Lásd a köztársasági elnök honlapját: www.president.ee/en/president/institutions/1031-national-defencecouncil/5261-rules-of-procedure-of-the-national-defence-council-/layout-institution.html (Letöltve: 2020. december 5.).

19 Szükségállapoti tv. 12. szakasz.

20 Szükségállapoti tv. 13. szakasz.

21 Szükségállapoti tv. 14. szakasz. 
A szükségállapot bevezetése a krízishelyzet megoldásához három fontos szereplőnek juttat jogosítványokat: a kormánynak, a miniszterelnöknek mint a rendkívüli helyzet kezeléséért felelős vezetônek és a belügyminiszternek mint a belbiztonságért felelős vezetônek. Közöttük egyértelmú hierarchia figyelhető meg, ugyanis a kormány mind a két másik szereplö, míg a miniszterelnök a belügyminiszter utasításait visszavonhatja. ${ }^{22}$ Míg a kormány elsősorban jogszabályban határozhat meg korlátozásokat, addig a legfontosabb gyakorlati jogkörei és utasítási joga a miniszterelnöknek van, míg a közvetlenül alá tartozó belügyminiszter feladata a rendkívüli helyzet gyakorlati kezelése.

A kormány számos jogosítvánnyal élhet, amelyeket a törvény tételesen felsorol.23 A kormány ülésén a kormánytagokon kívül részt vesz még - felszólalási jogosultsággal a parlament elnöke vagy távollétében az alelnöke, a köztársasági elnök megbízott képviselője, valamint az Észt Védelmi Erők parancsnoka ${ }^{24}$ vagy távolléte esetén helyettese. A kormány által hozott rendkívüli jogszabályok a nemzeti tömegtájékoztatásban való közzétételt követôen válnak hatályossá, ám a kihirdetést követő első munkanapon az észt hivatalos lapban is közzé kell tenni azokat. ${ }^{25}$

A rendkívüli helyzet kezeléséért felelős vezető a miniszterelnök vagy távolléte esetén a miniszterelnöki jogköröket gyakorló miniszter. ${ }^{26} \mathrm{~A}$ miniszterelnök jogköre igen széles, utasítást adhat önállóan a belbiztonságért felelős vezetőnek és a kormányzati, valamint önkormányzati szervek vezetőjének a szükségállapotból eredő feladatok kapcsán; felfüggesztheti - a kormány értesítése mellett - a szükségállapot végéig a végrehajtó hatalom tisztségviselőjének státuszát, amennyiben feltételezhető, hogy az adott személy veszélyezteti tevékenységével az ország alkotmányos rendjét (ugyanez vonatkozik a községi és városi tisztségviselőkre is), áthelyezhet kormányzati és önkormányzati tisztviselőket, illetve további feladatokat telepíthet rájuk; korlátozhatja a mozgásszabadságot Észtország egy részén vagy egészén; információk kötelező közzétételét rendelheti el az országos tömegtájékoztatásban; valamint egyéb utasításokat is adhat a kormány felhatalmazására. Tevékenységéről köteles beszámolni a parlamentnek és a kormánynak, a parlament ülésén részt vesz az elnök és a Védelmi Erők parancsnoka vagy az általuk kijelölt személy is. ${ }^{27} \mathrm{~A}$ harmadik felhatalmazottja a különleges jogrendnek a belbiztonságért felelős vezetô, aki a belügyminiszter vagy távolléte esetén a belügyminiszteri hatásköröket gyakorló miniszter. Ôt a törvény egyértelmúen a miniszterelnök alá rendeli, és a rendkívüli helyzet gyakorlati kezelésével bízza meg. Az ő feladata továbbá a kormány által hozott rendkívüli jogszabályok betartatása is. Mindezek érdekében

22 Szükségállapoti tv. 17. szakasz (2) bekezdés, valamint 18. szakasz (3) bekezdés.

23 Szükségállapoti tv. 17. szakasz (1) bekezdés.

24 Nem összekeverendő a föparancsnokkal, aki az alkotmány 78. szakasza értelmében a köztársasági elnök (Dubrovnik, 2009, 25. o.).

25 Szükségállapoti tv. 17. szakasz (3)-(5) bekezdés.

26 Szükségállapoti tv. 18. szakasz (1) bekezdés.

27 Szükségállapoti tv. 18. szakasz. 
együttmúködik a kormányzati szervek és az önkormányzatok vezetőivel, valamint a védelmi erők parancsnokával. A belbiztonságért felelős vezetô utasítási jogkörrel rendelkezik. ${ }^{28}$

A hadsereg bevonható a rendkívüli helyzet kezelésébe a belbiztonságért felelős vezető a hadügyminiszterrel egyeztetett javaslata alapján a kormány döntése szerint, amihez a köztársasági elnök beleegyezése is szükséges. A védelmi erők bevonásáról szóló döntést kormányrendeletként kell formalizálni, és annak tartalmaznia kell a törvényben meghatározott információkat. A kijelölt feladatok ellátása során a védelmi erók parancsnoka vagy az általa meghatározott egység parancsnoka köteles magát alávetni a kormány által meghatározott civil tisztviselőnek. ${ }^{29}$

A rendkívüli helyzet kezeléséért felelős vezetô, illetve a belbiztonságért felelős vezető utasításai három esetben hatályosulnak: ha közzétették azt a hivatalos lapban vagy a nemzeti tömegtájékoztatásban, illetve ha közölték azt annak közvetlen végrehajtójával. ${ }^{30} \mathrm{~A}$ törvény előírja a községi és a városi polgármesterek számára, hogy kövessék a számukra kiadott utasításokat. ${ }^{31}$ Garanciák találhatók a szövegben a miniszterelnök által felfüggesztett tisztségviselők számára: a döntést bíróságon támadhatják meg, valamint az áthelyezett tisztségviselőkkel együtt ők is ugyanabban a bérezésben részesülnek, mint korábban a felfüggesztés, illetve áthelyezés idején. ${ }^{32}$

A szükségállapot vége kapcsán a törvény kizárólag egyetlen esetkört, a hadiállapot bevezetését nevesíti. ${ }^{33}$ Ezenkívül véget érhet a szükségállapot a bevezetésekor megszabott határidő lejártával, illetve a rendkívüli helyzet kezelésével.

A hadiállapotot az alkotmány szerint a köztársasági elnök javaslatára a parlament rendeli el, amely dönt a mozgósításról, demobilizációról, illetve a nemzetközi kötelezettségek teljesítéséről is (a NATO-tagság vonatkozásában). Ennek sajátos esetköre, ha Észtországot külső agresszió éri, ebben az esetben ugyanis a köztársasági elnök egymaga elrendelheti a különleges jogrendet és a mozgósítást. ${ }^{34}$

A honvédelemrôl szóló törvény mind a háború, mind a béke idejére tartalmaz rendelkezéseket. ${ }^{35} \mathrm{~A}$ hadiállapot elrendeléséről szóló rendelkezések első körben megismétlik az alkotmány idevágó passzusait. Ezt követően azonban arról is szó esik, hogy a honvédelmi feladat ellátásával, alapjogot korlátozó intézkedés megállapításával vagy betartásával megbízott hatóság vagy személy köteles az elrendelést követően ezen feladatainak eleget tenni. Abban az esetben, ha az adott tevékenység elengedhetetlen a fenyegetés gyors megelőzése

28 Szükségállapoti tv. 20. szakasz.

29 Szükségállapoti tv. 15. szakasz.

30 Szükségállapoti tv. 21. szakasz.

31 Szükségállapoti tv. 25. szakasz.

32 Szükségállapoti tv. 22-23. szakasz.

33 Szükségállapoti tv. 16. szakasz.

34 Alkotmány 128. szakasz.

35 Honvédelmi tv. 1. szakasz (1) bekezdés. Annak 2015-ös elfogadása előtt külön törvény - a hadiállapoti és a békeidei honvédelmi törvény - foglalkozott a két esetkörrel (Veebel, 2017, 20. o.). 
vagy leküzdése érdekében, akkor az elvégezhető a javaslat benyújtását követôen, mielőtt a parlament elfogadná azt. Amennyiben a törvényhozás nem támogatná a hadiállapot elrendelését, úgy az ezen állapothoz kötődő tevékenységeket be kell fejezni. ${ }^{36}$

A törvény felépítésében a fokozatosság elve jelenik meg, minden megjelenő szint magában foglalja az alacsonyabb szinteken meghatározott feladatokat és jogköröket is, azok nem kerülnek még egyszer felsorolásra. Így a hadiállapot esetén az általános, illetve a fokozott védelmi készültség esetén juttatott eszközök is alkalmazandók.

A törvény értelmében a védekezésért felelős vezető a miniszterelnök. ${ }^{37}$ Ennek megfelelően a törvény igen széles jogosítványokat juttat a számára. ${ }^{38}$ Felhatalmazása alapján hadiállapot esetén a miniszterelnök közigazgatási határozatokat hozhat a védelem megszervezése érdekében, illetve konkrét utasítást adhat a községi vagy városi tanács tagjának, az állami szerv és a helyi önkormányzat vezetőjének, tisztviselőjének és alkalmazottjának, valamint a belbiztonságért felelős miniszternek és a honvédelem megszervezéséért felelős miniszternek a védelem megszervezésével kapcsolatban. ${ }^{39}$ Ezen túlmenően a miniszterelnök hatályon kívül helyezheti a községi és városi önkormányzat, a községi és városi tanács, valamint az állami és önkormányzati hatóság vezetőjének közigazgatási határozatát, és nevükben új közigazgatási határozatot adhat ki, ha ők ezt nem teszik meg vagy nem időben teszik, amennyiben ez veszélyezteti az eredményes védelmet. ${ }^{40} \mathrm{~A}$ miniszterelnök továbbá felhatalmazást kap bizonyos alapjogokat korlátozó intézkedések elrendelésére is. ${ }^{41}$ Fontosságát jelöli az is, hogy a törvény értelmében ő dönt minden más olyan honvédelmi kérdésrôl is, amely az alkotmány vagy törvény alapján nem tartozik más hatóság vagy személy hatáskörébe. ${ }^{42}$

A törvény hadiállapot idejére a kormány egésze számára is fontos jogosultságokat juttat. ${ }^{43} \mathrm{~A}$ kormány is hozhat a miniszterelnökhöz hasonlóan közigazgatási határozatokat, illetve megállapíthat bizonyos alapjogokat korlátozó intézkedéseket. Ezenkívül benyújthatja a parlamentnek a költségvetés módosítását, illetve a kiegészítő költségvetés tervezetét. A kormány utasíthatja a védelmi erőket fegyverszünet kötésére és elrendelésére, illetve maga is dönthet a fegyverszünet és a békekötés kérdésében, amit a parlamentnek is jóvá kell hagynia. Ezeken túl a kormány dönthet valamilyen miniszteri, állami vagy helyi önkormányzati szerv, községi vagy városi tanács által hozott irányelv vagy rendelet alkalmazásának felfüggesztéséről, illetve ennek hatályon kívül helyezéséről is rendelkezhet.

36 Honvédelmi tv. 17. szakasz.

37 Honvédelmi tv. 9. szakasz (1) bekezdés.

38 Honvédelmi tv. 14. szakasz (2) bekezdés, illetve 18. szakasz (2) bekezdés.

39 Honvédelmi tv. 9. szakasz (2)-(3) bekezdés.

40 Honvédelmi tv. 9. szakasz (4) bekezdés.

41 Ezeket a honvédelmi tv. 15., illetve 19-20. szakasza határozza meg.

42 Honvédelmi tv. 18. szakasz (2) bekezdés 2) pont.

43 Honvédelmi tv. 14. szakasz (1) bekezdés, 18. szakasz (2) bekezdés. 
A belbiztonságért felelős miniszter szintén jogosult közigazgatási határozatokat hozni, valamint közvetlen utasításokat adni a hadiállapottal összefüggésben. ${ }^{44}$ Ezeken túl alapjogok korlátozásáról is dönthet.

A hadiállapot utolsó felhatalmazottja az Észt Védelmi Erők (Eesti Kaitsevägi) parancsnoka, illetve az általa felhatalmazott parancsnok, aki szintén jogosult közigazgatási határozatok hozatalára, illetve a belbiztonsági miniszterhez hasonló jogkörben adhat utasításokat. Ezenkívül dönthet fegyverszünet kötéséról, elrendeléséről, illetve annak megszüntetéséről, ha az ellenség nem tartja be a feltételeket. További fontos jogosultság, hogy a védelmi erők parancsnoka a kormány utasítását és rendeletét, miniszter, községi és városi tanács, illetve önkormányzat irányelveit és döntéseit figyelmen kívül hagyhatja, ha ezek közvetlenül akadályozzák a honvédelmet. ${ }^{45} \mathrm{~A}$ törvény ugyanakkor kiköti azt, hogy a miniszterelnök felszólíthatja a védelmi erők parancsnokát, illetve az általa felhatalmazott parancsnokot ezek betartására, amennyiben joggal hihetô az, hogy a rendelkezések betartása nem bír közvetlen hatással a honvédelemre. ${ }^{46} \mathrm{Ez}$ a rendelkezés azt is mutatja, hogy a védelmi erók parancsnoka közvetlenül a miniszterelnöknek van alárendelve. ${ }^{47}$

Az elnök kizárólag a hadiállapot elrendelésénél, illetve megszüntetésénél játszik szerepet, egyébként csak formális jelentősége van. A hadiállapotot a köztársasági elnök javaslatára a törvényhozás szünteti meg. ${ }^{48}$

\subsection{A különleges jogrendre való felkészülést segítő békeidejü szabályok és a kapcsolódó szervezetrendszer}

A Honvédelmi tv. a hadiállapot mellett megkülönbözteti az általános védelmi készültséget, valamint a fokozott védelmi készültséget. Az általános védelmi készültség a mindennapokra jellemző állapot, amikor az egyes szervek és személyek a honvédelemmel összefüggésben kizárólag a rendes feladataikat látják el, illetve felkészülnek a készültségi szint emelésére, valamint a mozgósításra és a demobilizációra. A fokozott védelmi készültség esetén már hárulnak rájuk pluszfeladatok, célja a külső fenyegetéssel szembeni fellépés és az állam múködőképességének a megőrzése. ${ }^{49} \mathrm{~A}$ kormány dönthet úgy, hogy elrendeli a védelmi készültség fokozását vagy az Észtország biztonságát érintő nemzetközi fenyegetettség miatt, vagy nemzetközi katonai múveletben való részvétel céljából. Erről azonnal értesíteni kell a parlamentet és a köztársasági elnököt, előbbinek pedig jóvá kell hagynia a döntést. Jóváhagyás hiányában újra általános védelmi készültség lép életbe. Amennyiben jóváhagyásra

44 Alkotmány 9. szakasz (5) bekezdés.

45 Honvédelmi tv. 14. szakasz (3) bekezdés, 18. szakasz (4) bekezdés.

46 Honvédelmi tv. 14. szakasz (4) bekezdés.

47 Veebel, 2017, 21. o.

48 Honvédelmi tv. 21. szakasz.

49 Honvédelmi tv. 12. szakasz. 
került a védelmi készültség szintjének emelése, úgy a parlament háromhavonta felülvizsgálja azt, és ha csökkent a fenyegetés, megszünteti a fokozott védelmi készültséget. ${ }^{50}$ Maga a kormány is dönthet a védelmi szint csökkentéséról. ${ }^{51} \mathrm{~A}$ fokozott védelmi készültség megszứntével a pluszfeladatokat nem kell tovább ellátni, valamint az alapjog-korlátozó intézkedések is hatályukat vesztik.

Az észt nemzetbiztonsági koncepció átfogó jellegü, amely az ellenálló képességen és az elrettentésen alapul. Észtország honvédelmi stratégiája előírja, hogy a honvédelem már nem korlátozódhat kizárólag a katonai védelemre, emellett hangsúlyt kell helyezni a nem katonai képességekre is. A honvédelmet és a kapcsolódó előkészületeket számos különböző intézmény, valamint a köz- és magánszféra, köztük a civil társadalom feladatainak tekintik. ${ }^{52}$ Ennek a döntésnek történelmi okai vannak, ebben pedig kiemelhető az ország létét folyamatosan veszélyeztető szomszédos Oroszország..$^{33}$ Emellett az ország védelmének garantálásában nagy szerepet játszik a nemzetközi együttmúködés, így különösen a NATOés EU-tagság. ${ }^{54}$ Regionális szinten a három balti állam saját védelmi rendszerének magas szintú összehangolásában jelentős szerepe van a tengerészeti BALTRON és légi megfigyelési BALTNET projekteknek..$^{55} \mathrm{Az}$ ország egyik legfontosabb nemzetbiztonsági dokumentuma a Nemzetbiztonsági Koncepció, ${ }^{56}$ amelyből a legutóbbit 2017-ben fogadták el. A dokumentum meghatározása szerint:

„Az észt biztonságpolitika célja a nemzet függetlenségének és szuverenitásának, a nép és az állam túlélésének, a területi integritásnak, az alkotmányos rendnek és a lakosság biztonságának biztosítása. A biztonságpolitika megvalósításakor Észtország tiszteletben tartja az alapvető jogokat és szabadságokat, és védi az alkotmányos értékeket."

A dokumentum meghatározza a nemzetbiztonsági célokat, alapelveket és a kapcsolódó tevékenységeket. Emellett fontos dokumentum még a honvédelmi stratégia, ${ }^{57}$ amelynek értelmében a honvédelem és a megfelelő előkészületek sok különböző intézmény és személy

50 Honvédelmi tv. 13. szakasz.

51 Honvédelmi tv. 16. szakasz.

52 Veebel-Ploom, 2019, 10. o.

53 Észtországot - a többi balti államhoz hasonlóan - 1918-as függetlenné válása után 22 évvel, 1940-ben annektálta a sztálini Szovjetunió. Az ország az 1991-es függetlenné válása után nem tekintette magát szovjet utódállamnak, hanem az 1940-ben külső fegyveres erőszak hatására megszakadt szuverenitása helyreállításának (Loeber, 1998, 2. o.).

54 Lásd az észt Külügyminisztérium honlapját: https://vm.ee/en/estonia-and-nato (Letöltve: 2020. december 15.) 55 Erről részletesebben lásd a kötet Litvániáról szóló fejezetét.

56 Elérhető: www.riigikantselei.ee/sites/default/files/content-editors/Failid/national_security_concept_2017.pdf (Letöltve: 2020. december 5.).

57 Elérhető: www.kaitseministeerium.ee/sites/default/files/elfinder/article_files/national_defence_strategy.pdf (Letöltve: 2020. december 5.). 
feladatai. A hatékony honvédelmet mind a katonai, mind a nem katonai képességek, az állami és a magánszektor, valamint a civil társadalom erőforrásai és tevékenységei együttesen biztosítják. ${ }^{58} \mathrm{~A}$ honvédelmi stratégia alapul szolgál a kormány által összeállított honvédelmi fejlesztési tervnek. Ennek implementálására hivatott a honvédelmi akcióterv, amelyet a hadügyminiszter állít össze négy évre, évente felülvizsgálva azt. Végül az utolsó fontos dokumentum a nemzeti honvédelmi terv, amely a honvédelmi stratégiában megfogalmazott célok mentén tartalmazza a honvédelmi feladatok ellátását, a rendelkezésre álló katonai képességek felhasználásával. Ezt a védelmi erők parancsnoka évente állítja össze, a hadügyminiszter jóváhagyásával..$^{59}$
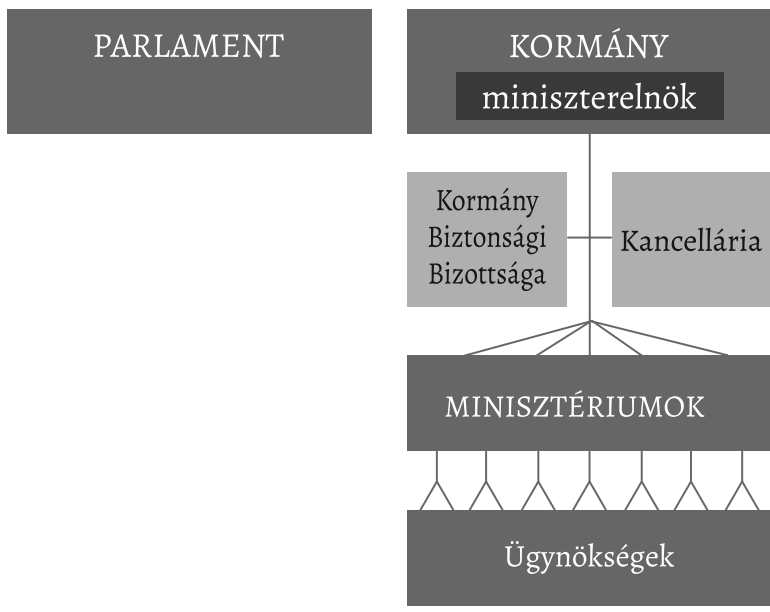

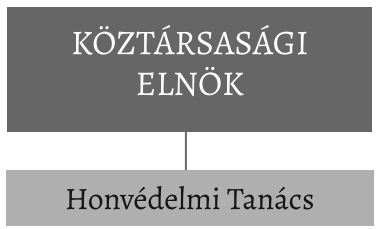

Honvédelmi Tanács

\begin{abstract}
6. ábra
Az észt honvédelem irányitási struktúrája

Forrás: a szerző összeállitása az észt Honvédelmi Minisztérium honlapja alapján ${ }^{60}$
\end{abstract}

$\mathrm{Az}$ észt stratégiai döntéshozatal három legfontosabb szerve a Honvédelmi Tanács, a kormány Biztonsági Bizottsága, illetve a kormány Válságbizottsága, amelyek tagsága és funkciói között nagy átfedések találhatók. ${ }^{61} \mathrm{~A}$ Válságbizottságnak a szükségállapottal, a Biztonsági Bizottságnak pedig a honvédelemmel kapcsolatos kérdésekben van nagy jelentősége. A Honvédelmi Tanács mind a két kérdéskörben érintett.

58 Elérhető: www.riigikantselei.ee/en/co-ordination-security-and-national-defence (Letöltve: 2020 . december 5.). 59 Elérhető: www.kaitseministeerium.ee/en/objectives-activities/basic-national-defence-documents (Letöltve: 2020. december 5.).

60 Elérhető: www.riigikantselei.ee/en/co-ordination-security-and-national-defence (Letöltve: 2020. december 10.).

61 Veebel, 2017, 12. o. 
A Honvédelmi tv. értelmében a kormány Biztonsági Bizottsága (Vabariigi Valitsuse julgeolekukomisjon) koordinálja a végrehajtó hatalom szerveinek tevékenységét a honvédelem tervezése, fejlesztése és megszervezése során. ${ }^{62} \mathrm{~A}$ bizottság tagjai a honvédelemmel kapcsolatos területekért felelős miniszterek (a miniszterelnök, az igazságügyi miniszter, a külügyminiszter, a pénzügyminiszter, a hadügyminiszter és a belügyminiszter). A bizottság további feladatait a biztonsági hatóságokról szóló törvény határozza meg. ${ }^{63} \mathrm{Ez}$ alapján koordinálja a biztonsági hatóságok tevékenységét, elemzi és értékeli az állam biztonsági helyzetét, meghatározza az állam igényét a biztonsággal kapcsolatos információkra, valamint más, törvény által meghatározott feladatokat is ellát. ${ }^{64}$

A nemzetbiztonsággal kapcsolatos kormányzati szakpolitika alakításában a kancellária (Riigikantselei) játssza a legfontosabb szerepet: tanácsot ad a miniszterelnöknek a nemzetbiztonsággal összefüggésben, megszervezi kormány Biztonsági Bizottságának munkáját, valamint irányítja a nemzetbiztonsági és a honvédelmi irányítás összehangolását. ${ }^{65} \mathrm{~A}$ kancellária emellett a szakpolitikai tartalom legfőbb szolgáltatója a bizottság számára, az észt biztonsági politika irányításáért felelős legmagasabb testület, ${ }^{66}$ ennek megfelelően elkészíti a nemzetbiztonsági koncepciót, illetve a honvédelmi stratégia alapján koordinálja a honvédelmi előkészületeket. ${ }^{67}$

A kormány Válságbizottsága létrehozásáról a Veszélyhelyzeti tv. rendelkezik, amely a kormányzati szint mellett négy regionális, valamint helyi válságbizottságok létrehozásáról is rendelkezik. A Válságbizottság munkáját a Belügyminisztérium szervezi meg, mint a válságkezelésért felelős fő szakpolitikai szerv. ${ }^{68}$ Jogállásával és múködésével külön kormányrendelet foglalkozik. ${ }^{69}$ Elnöke a belügyminiszter, összesen 21 taggal működik, köztük kilenc államtitkár és nyolc magas rangú tisztviselő található. Feladata a válságkezelési feladatok összehangolása, ${ }^{70}$ illetve az ország alkotmányos rendjét érő fenyegetés kapcsán kidolgozza az állami politikát és a cselekvési terveket; elemzi az információkat és azokat bemutatja a miniszterelnöknek a fenyegetésekkel kapcsolatban; véleményt nyilvánít a kormány számára a fenyegetést megelőző helyzetről, a veszély jellemzőiről, mértékéről és megszüntetéséről, valamint a szükségállapot kihirdetésének szükségességéről; illetve véleményt nyilvánít a kormánynak és a rendkívüli helyzet kezeléséért felelős vezetőnek a szükségállapoti intézkedések végrehajtásáról. ${ }^{11}$

62 Honvédelmi tv. 4. szakasz (1) bekezdés 1) pont.

63 Biztonsági hatóságokról szóló törvény (Julgeolekuasutuste seadus 2000. 12. 20.).

64 A biztonsági hatóságokról szóló törvény 10. szakasz.

65 Elérhető: www.riigikantselei.ee/en/government-office (Letöltve: 2020 . december 5.).

66 Veebel-Ploom, 2019, 16. o.

67 Elérhető:www.riigikantselei.ee/en/co-ordination-security-and-national-defence (Letöltve: 2020. december 15. )

68 Veszélyhelyzeti tv. 7. szakasz.

69 A kormány válságbizottságának jogállásáról szóló kormányrendelet (Vabariigi Valitsuse kriisikomisjoni põ-

himäärus 2017. 06. 22. nr 111.).

70 Veszélyhelyzeti tv. 4. szakasz.

71 Szükségállapoti tv. 8. szakasz. 
Végül szót kell még ejteni a Honvédelmi Tanácsról is, amely a köztársasági elnök mellett múködő tanácsadó szerv, és mint a neve is mutatja, elsősorban a fontos kérdések honvédelmi aspektusait vizsgálja, és véleményt nyilvánít ezek kapcsán. Tagjai a parlament házelnöke, a miniszterelnök, a parlament Honvédelmi Bizottságának és a Külügyi Bizottságának elnöke, a külügyminiszer, a hadügyminiszter, a pénzügyminiszter, a belügyminiszter, az igazságügyi miniszter, a gazdasági miniszter és a védelmi erők parancsnoka. A jogállását és múkködését köztársasági elnöki rendelet tartalmazza. ${ }^{72}$

\subsection{A válságkezelésre vonatkozó szabályok}

A válságkezeléssel kapcsolatos szabályokat a Veszélyhelyzeti tv. tartalmazza, amelyet 2017-ben fogadtak el, és ugyanezen év július 1-jén lépett hatályba. Elfogadásának kifejezett célja volt, hogy az eddig szektoriálisan, széttöredezetten szabályozott esetkörök kezelését egységesítse. Hatálya a katasztrófákon túl kiterjed az egyes alapvető szolgáltatások leállásának kezelésére is. ${ }^{73}$

A törvény a válságkezelés jogi alapját biztosítja, ideértve a veszélyhelyzetre való felkészülést és annak kezelését, valamint az alapvető szolgáltatások nyújtása folytonosságának biztosítását. Ezenkívül tartalmazza a válsághelyzet szabályait és a fegyveres erők válságkezelésbe való bevonásának szabályait is. A törvényt alkalmazni kell a szükségállapot, fokozott védelmi készültség és hadiállapot idején is, amennyiben a Szükségállapoti tv. vagy a Honvédelmi tv. másként nem rendelkezik. A törvény nem vonatkozik a nemzetbiztonságot vagy az alkotmányos rendet érintő fenyegetésekre való felkészülésre. ${ }^{74}$

A válsághelyzet a törvény meghatározása szerint „olyan esemény vagy eseménylánc vagy létfontosságú szolgáltatás nyújtásának megszakadása, amely sok ember életét vagy egészségét veszélyezteti, jelentős anyagi károkat, jelentős környezeti károkat vagy súlyos és kiterjedt zavarokat okoz a létfontosságú szolgáltatások nyújtásának folyamatosságában". Az ilyen helyzet megoldásához számos hatóság vagy személy megfelelően koordinált tevékenysége szükséges, a szokásostól eltérő utasítási rendszerben, valamint a szokásosnál több személyt és eszközt igényel. ${ }^{75}$

A törvény meghatározza az alapvető szolgáltatás fogalmát is, amely olyan szolgáltatás, amelynek döntő befolyása van a társadalom múködésére, és amelynek megszakítása közvetlen veszélyt jelent az emberek életére vagy egészségére, vagy egy másik létfontosságú

72 Elérhető: www.president.ee/en/president/institutions/1031-national-defence-council/5262-national-defencecouncil/layout-institution.html (Letöltve: 2020 . december 15.).

73 Elérhető: www.siseministeerium.ee/en/news/emergency-act-entered-force-1-july (Letöltve: 2020. december 15.).

74 Veszélyhelyzeti tv. 1. szakasz.

75 Veszélyhelyzeti tv. 2. szakasz (1) bekezdés. 
vagy közérdekú szolgáltatás müködésére. ${ }^{76} \mathrm{Az}$ alapvető szolgáltatások körét a törvény részletesen is tartalmazza. ${ }^{77}$ Ezek:

— áramszolgáltatás;

- földgázellátás;

— üzemanyag-ellátás;

— a nemzeti és helyi utak múködőképességének biztosítása;

- telefonszolgáltatás;

— mobiltelefon-szolgáltatás;

— adatátviteli szolgáltatás;

- digitális azonosítás és digitális aláírás;

— fizetési szolgáltatások;

- készpénzforgalom;

- távfưtés;

— vízellátás és csatornázás.

Észtországban 45 szolgáltatást tekintenek alapvetőnek. Ezeket összesen 167 szolgáltató biztosítja: 131 állami és magánvállalkozás, 19 alapítvány, 16 állami ügynökség és egy önkormányzati intézmény. ${ }^{78}$

A törvény úgy rendelkezik, hogy az alapvető szolgáltatások folyamatosságát biztosító hatóságok - amelyek lehetnek minisztériumok, pénzügyeknél a nemzeti bank, illetve önkormányzatok - összehangolják az alapvető szolgáltatás folyamatosságának biztosítását, tanácsot adnak az alapvető szolgáltatások nyúitóinak, felügyelik az alapvetô szolgáltatások folytonosságát, jóváhagyják az alapvető szolgáltatást nyújtó szolgáltatók folytonossági kockázatelemzéseit és terveit, valamint koordinálják a válsághelyzet megoldását, elkészítik a válsághelyzeti reagálási tervet, és megszervezik a kockázatkommunikációt és a válságkezelési gyakorlatokat. ${ }^{79}$

A törvény előírja kormányzati, regionális, illetve helyi válságbizottságok felállítását, amelyek különböző szinteken koordinálják a válságkezelést, illetve az eggyel magasabb szint számára éves jelentéseket készítenek munkájukról. ${ }^{80} \mathrm{~A}$ válságkezelés koordinálásában fontos szerep jut még a Belügyminisztériumnak, amely kidolgozza a nemzeti válságkezelési politikát és megtervezi annak végrehajtását, tanácsot ad a hatóságoknak és irányítja tevékenységüket a válságkezelés szervezésében, valamint felügyeli a törvény által a hatóságokra ruházott feladatok teljesítését. ${ }^{81}$

A törvény külön fejezetben foglalkozik a válsághelyzetre való felkészüléssel, annak megelőzésével, illetve kezelésével. A kormány külön rendeletben határozza meg azokat az ese-

76 Veszélyhelyzeti tv. 2. szakasz (4) bekezdés.

77 Veszélyhelyzeti tv. 36. szakasz.

78 Elérhető: www.siseministeerium.ee/en/activities/crisis-management (Letöltve: 2020. december 15.).

79 Veszélyhelyzeti tv. 37. szakasz.

80 Veszélyhelyzeti tv. 4-6. szakasz.

81 Veszélyhelyzeti tv. 7. szakasz. 
ményeket, amelyek válsághelyzethez vezetnek, és amelyek esetén kockázatelemzésnek van helye. A kockázatelemzés egy dokumentum, amely a válsághelyzet bekövetkezésének valószínűségét és feltehető hatásait tartalmazza. Elvégzésének feltételeit, illetve az előkészítés folyamatát az adott ágazatért felelős miniszter rendeletben határozza meg. ${ }^{82} \mathrm{~A}$ törvény elő́rja természetes személyek számára, hogy kötelesek értesíteni a hatóságokat egy válsághelyzet bekövetkeztéről, kivéve, ha feltehető, hogy arról már értesültek. ${ }^{{ }^{3}} \mathrm{~A}$ válsághelyzetekre való felkészülésben nagy szerepe van az elhárítási terveknek: a kormány külön rendeletben határozza meg azon válsághelyzeteket, amelyek kapcsán tervet kell készíteni, és kijelöli erre a megfelelő hatóságot. Ezeken túl az alapvetô szolgáltatások nyújtásának folytonosságáért felelős hatóságok is terveket készítenek arra az esetre, ha az adott alapvető szolgáltatás nyújtása megszakadna. ${ }^{84} \mathrm{~A}$ fejezet ezenkívül rendelkezik még a tömeges evakuációról, illetve a válságkezelési gyakorlatok tartásáról. ${ }^{85}$

A válsághelyzet kezelésének második, sokkal súlyosabb szintje a veszélyhelyzet, amelynek szabályai a törvény külön fejezetében kaptak helyet. A kormány természeti katasztrófa, katasztrófa vagy fertőző betegség okozta válsághelyzet kezelésére hirdetheti ezt ki, ha annak kezelése nem lenne lehetséges a veszélyhelyzeti eszközök alkalmazása nélkül. A törvény meghatározása szerint a katasztrófa emberi tevékenység okozta nagyszabású baleset, veszélyhelyzet vagy más hasonló hatású helyzet, ideértve az alapvető szolgáltatások nyújtásának súlyos következményekkel járó vagy elhúzódó megszakadását. ${ }^{86} \mathrm{~A}$ fertőző betegségeket külön törvény határozza meg. ${ }^{87}$

A veszélyhelyzet bevezetéséról a kormány dönt, az ország egész területén vagy annak egy részén. ${ }^{88} \mathrm{Az}$ ezzel kapcsolatos kormányrendeletnek tartalmaznia kell a veszélyhelyzet bevezetését, annak okát, az elrendelés területi hatályát, a veszélyhelyzet kezelésének fejét és minden egyéb fontos tényezôt.$^{89} \mathrm{~A}$ veszélyhelyzetet elrendelő, illetve megszüntető utasítást késedelem nélkül közzé kell tenni a nemzeti médiában, illetve egy napon belül Észtország hivatalos lapjában..$^{90} \mathrm{~A}$ veszélyhelyzet megszüntetéséról a kormány dönt. ${ }^{91}$

A veszélyhelyzet kezelésének feje a kormány által kijelölt miniszter, aki alárendelt a kormánynak, és a veszélyhelyzet kezelésén tevékenykedik. Utasítást adhat ezzel összefüggésben

82 Veszélyhelyzeti tv. 9. szakasz.

83 Veszélyhelyzeti tv. 12. szakasz (1) bekezdés.

84 Veszélyhelyzeti tv. 15. szakasz.

85 Veszélyhelyzeti tv. 16-18. szakasz.

86 Veszélyhelyzeti tv. 19. szakasz.

87 A fertőző betegségek megelőzéséről és csökkentéséről szóló törvény (Nakkushaiguste ennetamise ja tõrje seadus 2003. 02. 12.) 2. szakasza tartalmazza a definíciót, a törvény különbséget tesz fertőző betegség és súlyosan veszélyes fertőző betegség (például kolera, sárgaláz, pestis) között.

88 Veszélyhelyzeti tv. 20. szakasz.

89 Veszélyhelyzeti tv. 21. szakasz.

90 Veszélyhelyzeti tv. 23. szakasz.

91 Veszélyhelyzeti tv. 22. szakasz. 
az elhárítási munka vezetőjének, hatóságoknak, személyeknek. ${ }^{92}$ Ha a veszélyhelyzet során bevezetésre kerül a szükségállapot, a veszélyhelyzet kezelésének feje a rendkívüli állapot kezeléséért felelős vezető - vagyis a miniszterelnök - alárendeltségébe kerül.93

A veszélyhelyzet megoldásában a védelmi erők bevonhatók a veszélyhelyzeti munka elvégzésébe, illetve a forgalom szabályozásába és a biztonság biztosításába. ${ }^{94} \mathrm{~A}$ veszélyhelyzet és válsághelyzet során tevékenységet kifejtő nem katonai szervezetek múkködését és munkáját a mentési törvény szabályozza részletesen. ${ }^{95}$

\section{Az alapjogok korlátozására vonatkozó szabályok különleges jogrend idején}

Észtországban az alapjog-korlátozás kapcsán a negatív listás megoldás érvényesül,,96 vagyis az alkotmány azon alapjogok listáját határozza meg, amelyek korlátozhatatlanok a különleges jogrend idején. ${ }^{97}$ Ezt a tiltást a Honvédelmi tv. is megismétli. ${ }^{98}$

Az alkotmány mindemellett kimondja, hogy háborús helyzetben, illetve szükségállapot idején - a közrend és a nemzetbiztonság érdekében - az alapvetó jogok és szabadságok korlátozhatók, a kötelezettségek pedig kikényszeríthetők. Minderre csak törvény által meghatározott feltételek között, illetve eljárás során kerülhet sor. Az alapjog-korlátozó döntések minden esetben megtámadhatók közigazgatási bíróság előtt.99

Fontos kiemelni, hogy az észt alkotmány egy külön választási klauzulát is tartalmaz, amely kimondja, hogy a parlament, a köztársasági elnök és a helyi önkormányzatok megbízatása háborús helyzet, illetve szükségállapot időszakában nem járhat le. Az ilyen helyzetben lejáró megbízatás a háborús helyzet vagy szükségállapot végét követő három hónappal meghosszabbodik, és a választást ebben a három hónapos időszakban kell megtartani. ${ }^{100}$

92 Veszélyhelyzeti tv. 24. szakasz.

93 Szükségállapoti tv. 18. szakasz (7) bekezdés.

94 Veszélyhelyzeti tv. 34. szakasz.

95 Mentési törvény (Päästeseadus 2010. 05. 05.).

96 Gross, 2004, 21. o.

$97 \mathrm{Az}$ alkotmány 130. szakasza alapján a nem korlátozható alapjogok listája a következő: az állampolgársághoz való jog; jogegyenlőség és diszkrimináció tilalma; jogvédelem és konzuli védelem; az állami szervek alapjogvédelmi kötelezettsége; alapvető jogok sérelme esetén a bírósághoz fordulás joga; élethez való jog; a becsülethez és a jó hírnévhez fúződő jogok; embertelen bánásmód tilalma; személyi szabadság büntetőjogi célú korlátozásának lehetôsége; a büntetőjogi és büntetőeljárás-jogi garanciák; egyes polgári eljárásjogi garanciák; a jogtalan károkozásért kártalanításhoz való jog; a család védelméhez való jog; az egészség védelméhez való jog; észt polgárok jogalap nélküli kiadatásának tilalma; a gondolat-, lelkiismereti és vallásszabadság; a kisebbségi identitáshoz való jog; valamint a hivatalos ügyintézés során az észt nyelv használatához való jog. 98 Honvédelmi tv. 19. szakasz.

99 Maruste, 2020.

100 Alkotmány 131. szakasz. 
Mind a Honvédelmi tv., mind a Szükségállapoti tv. és a Veszélyhelyzeti tv. tartalmaz rendelkezéseket az alapjogok korlátozása vonatkozásában. A Szükségállapoti tv. alapján például felfüggeszthetô a nonprofit szervezetek - ideértve a politikai pártokat és a szakszervezeteket is - múködése a szükségállapot idejére, amennyiben tevékenységük veszélyezteti Észtország alkotmányos rendjét. Az ezzel kapcsolatos javaslatot a miniszterelnök nyújtja be a Legfelsőbb Bíróságnak, amely dönt a kérdésben..$^{101} \mathrm{~A}$ kormány és a belbiztonságért felelős vezető is dönthet bizonyos alapjog-korlátozó intézkedések bevezetéséről. A kormány felfüggeszthet jogszabályokat, illetve azok alkalmazását, megtilthatja az országba lépést vagy annak elhagyását, kijárási tilalmat rendelhet el, bizonyos információk továbbítását megtilthatja, illetve megtilthatja bizonyos médiatermékek megjelenését, megtilthatja a sztrájkokat és az összejöveteleket, bizonyos termékek eladása kapcsán intézkedéseket hozhat (például jegyrendszer bevezetése). ${ }^{102} \mathrm{~A}$ belbiztonságért felelős vezető például korlátozhatja a közlekedést, a kijárási tilalom idején dokumentumok ellenőrzését szabhatja meg, dönthet személyek lakhelyének megváltoztatásáról, korlátozhatja a küldemények és üzenetek bizalmasságát, elkobozhatja a fegyvereket, a mérgező és robbanóanyagokat stb. ${ }^{103}$ Hadiállapot esetén a kormány hozhat döntést az alapjogok korlátozásáról. Így például korlátozható a gyülekezési jog, megtilthatók a sztrájkok, korlátozható bizonyos ingóságok kereskedelme, valamint a kommunikációs eszközök igénybevétele és a tömegtájékoztatásban közzétett információk köre, illetve bizonyos sajtótermékek megjelenése megtiltható. ${ }^{104}$ Ezeken túl a fokozott védelmi készültség idején elrendelhető korlátozások hadiállapot idején is alkalmazhatók.

Fontos megjegyezni, hogy a különleges jogrendnek nem minősülő felhatalmazás esetköreiben is lehetőség van alapjogok korlátozására. A fokozott védelmi készültség esetén megtilthatja az ország elhagyását azon személyek számára, akik szolgálati vagy munkaviszonyuk alapján munkakötelezettséggel bírnak. A fokozott készültség idején a személyekre további honvédelmi kötelezettségek róhatók. ${ }^{105}$ Veszélyhelyzet esetén a Veszélyhelyzeti tv. számos eszköz alkalmazását teszi lehetôvé, így elrendelhető munkakötelezettség, bizonyos ingóságok (üzemanyag, élelmiszer, gyógyszerek, más fogyócikkek) kisajátítása, bizonyos nem ingó eszközök, ingatlanok kormányzati használatba bocsátásra való kötelezettség, helyszíni válsághelyzeti munka elvégzésére való kötelezés, tartózkodási tilalom és a mozgásszabadság egyéb korlátozásai, nyilvános gyưlések és események korlátozása, valamint közigazgatási kényszerítő intézkedések elóírása és alkalmazása. ${ }^{106}$

A veszélyhelyzet esetén az alapjog-korlátozás alapja a Veszélyhelyzeti tv. felhatalmazása, amely ugyanakkor nem minősül különleges jogrendnek, és az alkotmány a 130. szakaszában

101 Szükségállapoti tv. 19. szakasz.

102 Szükségállapoti tv. 17. szakasz (1) bekezdés.

103 Szükségállapoti tv. 20. szakasz.

104 Honvédelmi tv. 20. szakasz.

105 Honvédelmi tv. 15. szakasz.

106 Veszélyhelyzeti tv. 26-33. szakasz. 
sem nevesíti mint olyan esetkört, amikor az alapvető jogok korlátozhatók. Maruste véleménye szerint a törvény elfogadásával átadta alkotmányos funkcióját a végrehajtó hatalomnak. Ráadásul a válsághelyzeti rendeletek és utasítások így magát az alkotmányt írják felül, ami súlyos hiányosság, és teljesen szembemegy a jogszabályi hierarchiával. ${ }^{107}$

\section{A koronavírus-járványra adott állami reakció}

A koronavírus-járvány kapcsán nem került sor különleges jogrend bevezetésére, mivel a szükségállapot elrendeléséhez szükséges feltételek nem álltak fenn. Járványhelyzetek kapcsán a Veszélyhelyzeti tv. rendelkezései irányadók, és annak alapján március 12-én bevezetésre került a veszélyhelyzet, első alkalommal a törvény 2017-es elfogadása óta. A veszélyhelyzet bevezetését a kormány mellett müködő állandó Válságbizottság javasolta, és eredetileg május 1-jéig került bevezetésre. ${ }^{108} \mathrm{~A}$ veszélyhelyzetet a kormány később meghoszszabbította május 17-ig. ${ }^{109}$ (Több sajtótermékben, illetve hivatalos dokumentumban is található a bevezetett intézkedés megnevezésével kapcsolatosan tévedés, amely valószínúleg ezek angol nyelvứ változatának hasonlóságából ered. ${ }^{110}$

A rendelkezések az élet számos területére kiterjedtek, így például elrendelték az oktatási és kulturális intézmények bezárását és a kulturális, oktatási és sporttevékenységek törlését; a szociális ellátóintézményekben és kórházakban látogatási tilalmat vezettek be, akárcsak a börtönökben; a mozgás szabadságának korlátozására is sor került, így a szigetek és a szárazföld között közlekedő hajókon; illetve ideiglenes ellenőrzési intézkedések is bevezetésre kerültek a határon (ideértve a veszélyesnek ítélt országokból érkező személyek két hétre történő karanténba zárását); valamint a mozgáskorlátozásra és a szabadidő eltöltésére vonatkozó további korlátozások is megállapításra kerültek. ${ }^{111} \mathrm{Az}$ ország március 20 -án az emberi jogok európai egyezménye 15. szakasza szerint tájékoztatást küldött az Európa Tanácsnak arról, hogy felfüggeszti az egyezmény egyes részeinek alkalmazását a pandémia idejére. ${ }^{112} \mathrm{~A}$ felfüggesztés visszavonására a veszélyhelyzet végével, május 18-án került sor.

107 Maruste, 2020.

108 Elérhető: www.valitsus.ee/en/news/government-declared-emergency-situation-estonia-until-1-may (Letöltve: 2020 . december 15.).

109 Elérhető:www.valitsus.ee/en/news/special-notice-government-has-extended-emergency-situation-estoniauntil-may-17 (Letöltve: 2020. december 15.); Venice Commission, 2020, 16. 0. 50. pont.

110 Lásd például a Velencei Bizottság kapcsolódó anyagát, ahol szükségállapot bevezetéséről írnak a járványkezeléssel összefüggésben, ugyanakkor a kapcsolódó lábjegyzetben már helyesen jelölik a jogintézményt (Venice Commission, 2020, 10. 0.35. pont).

111 Elérhető: www.europarl.europa.eu/RegData/etudes/BRIE/2020/651914/EPRS_BRI(2020)651914_EN.pdf (Letöltve: 2020 . december 15.).

112 Venice Commission, 2020, 6. o. 16. pont. 
Az ország hasonló okból tájékoztatást küldött az ENSZ-nek a Polgári és Politikai Jogok Nemzetközi Egyezségokmánya 4. szakasza alapján az egyezménytől való eltérésről. ${ }^{113}$

A koronavírus során bevezetett veszélyhelyzet tapasztalatai komoly aggályokat vetnek fel a jogintézmény kapcsán. Először is azáltal, hogy a parlament teljes egészében kimaradt annak bevezetéséből, hiszen a törvény ezt nem is teszi szükségessé. A parlament bevonására kizárólag akkor került sor, amikor a veszélyhelyzet bevezetését követően néhány héttel javaslatot nyújtottak be a parlamenthez a veszélyhelyzet gyakorlati alkalmazásához kapcsolódó törvények módosítása, illetve kiegészítő költségvetés elfogadása végett. A 33 törvényt módosító javaslatcsomagot 54:40 szavazatarányban elfogadta a törvényhozás. Ez három különböző típusú módosítással operált: először is, a különféle engedélyek érvényességével, valamint a különféle típusú eljárások időtartamával és határidejével kapcsolatos kivételek a vészhelyzet idejére, másodsorban a különböző hatóságok és személyek hatáskörének és feladatainak kiterjesztését célzó kivételek a vészhelyzet idejére, harmadszor a vészhelyzet miatt eredetileg szükséges módosítások, amelyek azonban lényegében állandó jellegűek. ${ }^{114}$ A parlament kísérletet tett a Veszélyhelyzeti tv. módosítására is, ám ez nem járt sikerrel. ${ }^{115}$

A veszélyhelyzet bevezetése ugyan formálisan jogszerú volt a Veszélyhelyzeti tv. rendelkezései alapján, azonban az a tény, hogy a parlament kihagyható a folyamatokból, nehezen egyeztethető össze a parlamentáris demokrácia alkotmányos alapelveivel. Nehezen magyarázható, hogy a komoly alapjogi korlátozások bevezetése miért nem igényli a parlament hozzájárulását semmilyen módon. A törvény alapján a kormány rendeleti úton, utasításokkal vezette az országot, amelyek komolyan kihatottak a társadalom egészére, a gazdaságra és az alapjogokra. A törvény értelmében a rendeletek végrehajtását és azok törvényi megfelelőségét maga a kormány vizsgálja. Ugyan közigazgatási bíróság előtt megtámadhatók az alapjogokat sértő rendelkezések, ezeket csak utólagosan vizsgálja a bíróság rendes eljárásban. ${ }^{116}$ Fontos ugyanakkor megjegyezni, hogy ezek a fejlemények nem vezettek autoriter törekvésekre a kormány részérôl, még ha a demokrácia alapelveit sértették is. A kritikák között volt említhető az is, hogy az egyes veszélyhelyzeti rendelkezések egyáltalán nem tartalmaztak lejárati idôt. ${ }^{117}$

A veszélyhelyzet május 17-i végével a sokkal enyhébb válsághelyzeti állapot került bevezetésre, amely a kézirat lezárásának időpontjában is fennállt. ${ }^{118}$

113 Venice Commission, 2020, 6. o. 16. pont. Lásd még az észt külügyminisztérium honlapját: https://vm.ee/en/ obligations-ministry-foreign-affairs-inform-international-organisations-emergency-situation-measures (Letöltve: 2020. december 15.).

114 Elérhetô:https://m.riigikogu.ee/en/sitting-reviews/riigikogu-passed-act-relating-implementation-emergencysituation/ (Letöltve: 2020. december 15.).

115 A Veszélyhelyzeti tv. módosítása kapcsán a parlamenti vitában az egyik párt két, egymással is összefüggő módosítási javaslatot is benyújtott, ám ezek közül csak az egyiket fogadta el a törvényhozás, ami komoly értelmezési és gyakorlati problémákhoz vezethet. Elérhető: https://news.err.ee/1088740/riigikogu-vote-leavescrisis-situation-law-defective (Letöltve: 2020. december 15.).

116 Maruste, 2020.

117 Makarychev-Romashko, 2021.

118 Az intézkedések köréról lásd:www.riigiteataja.ee/en/eli/518122020003/consolide (Letöltve: 2020. december 15.). 


\section{A különleges jogrend a gyakorlatban: viták és kihívások}

Észtország a függetlenség 1991-es kikiáltása óta egyszer sem alkalmazta a különleges jogrendet. Az ország alkotmánya a függetlenség egyik garanciájaként tartalmazza a rendelkezéseket, ${ }^{119}$ és több olyan krízis is bekövetkezett, amely indokolttá tette volna alkalmazását, erre mégsem került sor. Akárcsak a szükségessége, a legvégső eszközként való alkalmazása és garanciákkal történő körülbástyázása is történelmi tapasztalatokon alapul. ${ }^{120}$ Alkalmazásának lehetősége először 1992-ben merült fel a gazdasági nehézségek kezelésére, különösen a fővárost sújtó élelmiszerhiány miatt. Végül a kormány nem tudta keresztülvinni akaratát és megbukott, az ezt követő szakértői kormány pedig elzárkózott a különleges jogrend bevezetésétől. ${ }^{121}$

2007. április 27. és május 18. között Észtországot igen komoly és kiterjedt, orosz hátterú kibertámadás érte, miután egy világháborús szovjet hősi emlékmú eltávolításáról döntöttek, és ez súlyos konfliktusokhoz vezetett az ország orosz ajkú lakosságával. Bár a támadás számos állami funkció múködését akadályozta vagy lehetetlenítette el, különleges jogrend bevezetésére mégsem került sor. ${ }^{122} \mathrm{~A}$ később elfogadott Veszélyhelyzeti tv. alapján azonban egy hasonló súlyú kibertámadás esetén akár veszélyhelyzet is elrendelhetổ lenne, hiszen az megfelel a „katasztrófa” törvényi fogalmi felételeinek. 2011-ben a kockázatelemzésen a kiterjedt kibertámadás „nagyon magas”, míg 2013-ban „magas” veszélyességi besorolást kapott. ${ }^{123}$

Az ország igen komolyan veszi a digitális veszélyeket. 2017-ben a személyi igazolványokban található okoskártyachipekben fedeztek fel sérülékenységet, amelyeket ekkoriban már a lakosság fele használt. A kártyákban lévő chipek segítségével lehetett az állami e-szolgáltatásokat igénybe venni, elektronikus aláirást készíteni és akár szavazni is. A kormány döntése alapján a szolgáltatást nyújtó jogi személy korlátozta a személyi igazolványok tanúsítványait tartalmazó nyilvános adatbázishoz való hozzáférést, amelyhez így csak a cég szerződéses partnerei férhettek hozzá. Mivel ezek közérdekú információk, semmiféle jogi alapja nem volt ennek a korlátozásnak, azt csak a szükségállapot bevezetése teremtette volna meg. A szolgáltató vissza kívánta volna vonni az érintett sérülékeny tanúsítványokat, ám ez

119 Loeber, 1998, 6. o.

120 Az észt függetlenség 1918-as kikiáltását követően állandósult a részleges szükségállapot az országban. 1933ban a kormány a szélsőjobboldali Észt Szabadságharc Résztvevőinek Uniója (a Vaps Mozgalom) hatalomátvételétől tartva szükségállapotot vezetett be. Miután a Vaps Mozgalom által benyújtott alkotmánytervezetet népszavazáson elfogadták, a kormány lemondott, és Konstantin Päts alakított ideiglenes kormányt. Päts 1934-ben az új alkotmány felhatalmazásai alapján alkotmányos puccsot hajtott végre, és betiltotta a Vaps Mozgalmat, illetve az összes pártot. Päts elnök idején új szükségállapoti törvényt fogadtak el 1938-ban, ami nélkülözte a szükségállapot fenntartásának bármilyen objektív feltételét, és a kormányzás egyfajta általános eszközévé vált, amelyet a politikai elit hatalmának fenntartása érdekében alkalmaztak. Päts egyeduralma az ország 1940-es szovjet megszállásáig megmaradt, azt követően pedig a szovjetbarát kormány használta azt saját céljaira (Kenkmann, 2018; Valge, 2011).

121 Smith, 2001, 77. o.; Lane et al., 2013, 77. o.

122 Elérhető: https://ccdcoe.org/uploads/2018/10/Ottis2008_AnalysisOf2007FromTheInformationWarfarePersp ective.pdf (Letöltve: 2020 . december 15.).

123 Osula, 2015. 
az észt e-állam teljes összeomlásához vezetett volna. A kormány vizsgálta a Veszélyhelyzeti tv. alkalmazásának a lehetőségét: mivel a szolgáltató alapvető szolgáltatást nyújtónak minősül a törvény szerint, így kötelezhetô a szolgáltatás folyamatos nyújtására. Ugyanakkor ez a fajta jogi érvelés nem állja meg a helyét: a cég nem szüntette volna meg a bizalmi szolgáltatások nyújtását, sốt, valójában az ezek nyújtásával kapcsolatos kötelezettségeinek tett volna eleget azzal, ha a sérülékeny tanúsítványokat visszavonja. ${ }^{124}$

$\mathrm{Az}$ alkotmánybírósági funkciót is betöltő észt legfelsőbb bíróság gyakorlatában csak elvétve jelennek meg a különleges jogrenddel kapcsolatos kérdések, ami nem meglepő, tekintettel arra, hogy bevezetésére eddig még sosem került sor. A bíróság a fegyveres erôk katasztrófahelyzetben történő alkalmazása kapcsán kimondta, hogy arra csak különleges jogrend esetén kerülhet sor. ${ }^{125}$ Komoly vitákhoz vezetett az a 2019-ben elfogadott törvényjavaslat, amely lehetôvé tette volna a Védelmi Erốk számára, hogy különleges jogrend, illetve veszélyhelyzet esetén hozzáférhessenek természetes és jogi személyek adataihoz, illetve egyéneket megfigyelés alá vegyenek. A köztársasági elnök megtagadta a törvény aláírását, és a legfelsőbb bíróságnak küldte meg azt, amely az elnök álláspontjával egyetértve alkotmányba ütközőnek találta a jogszabályt. ${ }^{126}$

A koronavírus-járvány idején bevezetett intézkedések kapcsán számos jogi eljárás indult. Például az Egészségügyi Minisztérium döntését a magánklinikák fogászati kezelésének ideiglenes beszüntetéséról bíróságon támadták meg, az Igazságügyi Minisztérium pedig megsemmisítette azt a helyi önkormányzati döntést, amely értelmében bizonyos közterületeket elzárnak a „kívülállóktól”, valamint bíróság vizsgálta felül szülők kezdeményezésére egy középiskola azon döntését, amely alapján a tavaszi szünetet eltörölték volna. ${ }^{127}$ Egy ügy a legfelsőbb bíróságig is eljutott, amely a Kulturális Minisztérium által a megszorult helyzetbe került kulturális intézményeknek juttatott rendkívüli támogatással volt kapcsolatos. A minisztérium ugyanis még a kapcsolódó kormányrendelet hatálybalépése előtti dátumot adott meg határidőként a támogatásért fordulók számára, így akadt olyan jelentkező, aki lecsúszott erről. Ezt a gyakorlatot a legfelsőbb bíróság az alkotmányba ütközőnek találta. ${ }^{128}$ Az észt igazságügyi biztos is fogalmazott meg kritikákat, így több panasz esetén is hangot adott annak a véleményének, hogy az önkormányzatok nem hozhatnak olyan rendeleteket, amelyek korlátozzák a lakosok alapjogait. ${ }^{129}$

124 Bővebben lásd: Parsovs, 2020.

125 Ügyszám: III-4/1-11/94, elérhető: www.riigiteataja.ee/kohtulahendid/detailid.html?id=206122715 (Letöltve: 2020. december 15.).

126 Ügyszám: 5-9-13, elérhető: https://freedomhouse.org/country/estonia/freedom-net/2020 (Letöltve: 2020 . december 15.).

127 Makarychev-Romashko, 2021.

128 Elérhető: https://news.err.ee/1216135/supreme-court-theater-missing-out-on-Covid-19-state-aid-unconstitutional (Letöltve: 2020 . december 15.).

129 Lásd például a 7-8/201491/2004979 ügyet és a 7-8/201491/2005008 ügyet. Elérhető: https://adr.rik.ee/okk/ dokument/7519681, valamint https://adr.rik.ee/okk/dokument/7525164 (Letöltve: 2020. december 15.). 


\section{5. Összegzés}

\begin{tabular}{|c|c|c|}
\hline & Szükségállapot & Hadiállapot \\
\hline $\begin{array}{l}\text { Szabályozás } \\
\text { szintje }\end{array}$ & \multicolumn{2}{|c|}{$\begin{array}{l}\text { Alkotmányos és törvényi } \\
\text { (Szükségállapoti tv., Honvédelmi tv.) }\end{array}$} \\
\hline $\begin{array}{l}\text { Elrendelési } \\
\text { okok }\end{array}$ & $\begin{array}{l}\text { - az alkotmányos rend megdöntésére } \\
\text { irányuló erőszakos kísérlet } \\
\text { — terrorista tevékenység } \\
\text { — erőszakos kollektív kényszerítés } \\
\text { — kiterjedt belső konfliktus különböző } \\
\text { csoportok között } \\
\text { - Észtország területe egy részének erő- } \\
\text { szakos elszigetelése } \\
\text { — tartós erőszakos belső konfliktus }\end{array}$ & $\begin{array}{l}\text { — külső fegyveres fenyegetés } \\
\text { — az országot külső agresszió éri }\end{array}$ \\
\hline Elrendelés & $\begin{array}{l}\text { A parlament rendeli el, a köztársasági } \\
\text { elnök, a kormány vagy a törvényhozás } \\
\text { képviselői többségének a javaslatára } \\
\text { az ország egész területén legfeljebb } \\
\text { három hónapos időtartamra. }\end{array}$ & $\begin{array}{l}\text { A parlament rendeli el a köztársasági } \\
\text { elnök javaslatára; } \\
\text { külső agresszió esetén a köztársasági } \\
\text { elnök maga dönthet. }\end{array}$ \\
\hline Felhatalmazott & $\begin{array}{l}\text { A rendkívüli helyzet kezeléséért felelős } \\
\text { vezető (miniszterelnök), kormány, belbiz- } \\
\text { tonságért felelős vezető (belügyminiszter) }\end{array}$ & $\begin{array}{l}\text { A védekezésért felelős vezető } \\
\text { (miniszterelnök), kormány, belügy- } \\
\text { miniszter, az Észt Védelmi Erők } \\
\text { parancsnoka }\end{array}$ \\
\hline $\begin{array}{l}\text { Előkészítő } \\
\text { szervek }\end{array}$ & $\begin{array}{l}\text { A kormány Válságbizottsága, Honvé- } \\
\text { delmi Tanács, Belügyminisztérium }\end{array}$ & $\begin{array}{l}\text { A kormány Biztonsági Bizottsága, } \\
\text { Honvédelmi Tanács, kancellária }\end{array}$ \\
\hline $\begin{array}{l}\text { Gyakorlati } \\
\text { esetek }\end{array}$ & \multicolumn{2}{|c|}{ Nincs } \\
\hline $\begin{array}{l}\text { Különleges } \\
\text { jogrendnek nem } \\
\text { minősülő rend- } \\
\text { kívüli helyzet }\end{array}$ & $\begin{array}{c}\text { Válsághelyzet, } \\
\text { veszélyhelyzet } \\
\text { (fokozatosság elve a veszélyhelyzetről } \\
\text { szóló törvény alapján) }\end{array}$ & Fokozott védelmi készültség \\
\hline
\end{tabular}

7. táblázat

Észtország különleges jogrendi szabályainak összegzése

Forrás: a szerző saját szerkesztése

Az észt különleges jogrenddel kapcsolatos alapvető szabályozás az alkotmányban található meg, amely a szükségállapotot és a hadiállapotot nevesíti. A két jogintézménnyel kapcsolatos szabályok többségét külön törvény tartalmazza: előbbi esetén a Szükségállapoti tv., utóbbinál a Honvédelmi tv. A szükségállapotot az Észtország alkotmányos rendjét, te- 
rületi egységét érő belső fenyegetések esetén lehet elrendelni. A hadiállapot esetén kizárólag az Észtországot érő külső agresszió kerül külön nevesítésre, ám ez csak a könnyebb bevezetést lehetôvé tevő rendelkezésnél, így feltehető, hogy alkalmazására más külső fegyveres fenyegetés esetén is van lehetőség.

A két különleges jogrendi esetkörhöz kapcsolódnak bizonyos rendkívüli helyzetek, amelyek megelőzik a különleges jogrend bevezetését. Ezek a szükségállapot esetén a Veszélyhelyzeti tv.-ben található válsághelyzet és veszélyhelyzet, míg hadiállapot esetén a fokozott védelmi készültség. A válsághelyzet az egyszerủ krízishelyzetnél súlyosabb esemény vagy alapvető szolgáltatást érintő leállás, amely hosszabb időtartamú, súlyosabb következményekkel jár, kezeléséhez a szokásosnál több erőforrás szükséges, ideértve adott esetben a külföldi országok és a nemzetközi szervezetek erőforrásait is, illetve együttmúködést igényel. A veszélyhelyzet még súlyosabb, itt ugyanis természeti katasztrófa, emberi tevékenység okozta katasztrófa, illetve fertőző betegség okozta vészhelyzet kezelésére vezetik be. Ennek bevezetéséről a kormány dönthet, a parlament bevonása nélkül. A fokozott védelmi készültség bevezetése szintén a kormány hatásköre, ám itt már szükséges a törvényhozás jóváhagyása is. Bevezetésére az Észtország biztonságát érintő nemzetközi fenyegetettség miatt vagy nemzetközi katonai műveletben való részvétel céljából kerülhet sor.

Észtország átfogó honvédelmi és nemzetbiztonsági politikával rendelkezik, vagyis a társadalom egésze bevonásra kerül a különleges jogrendi helyzetek kezelésébe. Ennek megfelelően az egyes esetkörök között fokozatosság áll fenn, és az egyes szintek a korábbi szinteknél meghatározott intézkedésekre épülnek. A veszélyhelyzet közben bevezethetô a szükségállapot is, ekkor a veszélyhelyzet kezelésével megbízott miniszter a miniszterelnök alárendeltje lesz. A veszélyhelyzet különlegesnek mondható, ugyanis a Veszélyhelyzeti tv. rendelkezéseit szükségállapot és hadiállapot idején is alkalmazni lehet. Ezzel szemben, ha bevezetésre kerül a hadiállapot, a szükségállapot azonnal megszúnik, és így a szükségállapoti törvény rendelkezéseit sem kell tovább alkalmazni.

Mindkét különleges jogrendi esetkörnél a parlament dönt annak elrendeléséről. Szükségállapot esetén erre javaslatot a kormány és a köztársasági elnök, illetve a törvényhozás képviselőinek többsége tehet. Hadiállapot esetén a köztársasági elnök jogosult javaslatot tenni. Az egyetlen kivétel az Észtországot ért külső agresszió, ebben az esetben a köztársasági elnök maga dönthet a hadiállapot bevezetéséről. A védekezésért felelős vezető mindkét esetben a miniszterelnök, aki így az egyik legfontosabb szereplőnek tekinthető a különleges jogrend idején. Mindkét esetkörben jelentős szerep jut a kormánynak, főleg a kapcsolódó rendkívüli jogszabályalkotásban. Szükségállapot idején a belső védelem vezetője, a belügyminiszter is igen fontos gyakorlati jogosítványokkal bír. Hadiállapot esetén is kap felhatalmazást a belügyminiszter, de ez jóval szúkebb körú, illetve az Észt Védelmi Erők parancsnoka is, aki akár utasításokat is figyelmen kívül hagyhat az eredményes védekezés érdekében.

A különleges jogrend bevezetésére való felkészülésben egy sor szerv játszik fontos szerepet. A veszélyhelyzet és a szükségállapot kapcsán ki kell emelni a kormány Válságbizott- 
ságát, míg a hadiállapot kapcsán a kormány Biztonsági Bizottságát. A köztársasági elnök mellett tanácsadó szervként múködő Honvédelmi Tanács mind a két különleges jogrendi esetkör bevezetése kapcsán fontos szereppel bír. Ezen stratégiai szervek mellett fontos szakpolitikai szervként jelenik meg a nemzetbiztonsági kérdésekben a Belügyminisztérium, míg a honvédelmi kérdésekben a kancellária.

Az alapjogok korlátozása terén kiemelendő, hogy az észt alkotmány az egyes alapjogoknál tesz említést azok korlátozhatóságáról, illetve a honvédelemről szóló fejezetben általánosságban kimondja, hogy az alkotmányban és a törvényekben foglalt alapjogok korlátozhatók különleges jogrend idején. Ugyanezen passzus meghatározza a korlátozhatatlan alapjogok listáját is. A Szükségállapoti és Honvédelmi tv. részletesen tartalmaz rendelkezéseket az alapjogok korlátozásával kapcsolatban. A válsághelyzet során történő alapjogkorlátozás ugyanakkor aggályokat vet fel, hiszen ez az esetkör nem tekinthető különleges jogrendnek, nem kerül nevesítésre az alkotmányban sem, és annak bevezetése nem igényel parlamenti hozzájárulást sem.

A magyar különleges jogrendi rezsimmel összehasonlítva elmondhatjuk, hogy a jelenlegi magyar szabályozásnál jóval átgondoltabb koncepciót valósít meg, amelynél nemcsak az esetkörök száma jóval kisebb (kettő az észt, míg hat a magyar jogrendszerben). A két észt esetkör közül a hadiállapot a súlyosabb, annak érvényesülése esetén a szükségállapot megszûnik. Ezekhez a fokozatosság elve alapján enyhébb, rendkívüli felhatalmazással járó jogintézmények is kapcsolódnak, amelyek közül kettő a magyar jogban különleges jogrendnek minősül: a veszélyhelyzet, illetve az észt fokozott katonai készültséggel párhuzamba állítható megelőző védelmi helyzet. Az észt fokozatos rendszer lehetôvé teszi a fenyegetések differenciált leküzdését, és utolsó eszközzé teszi a különleges jogrendet, annak eredeti rendeltetésének megfelelôen. Ugyanakkor ebből bizonyos alkotmányos problémák is keletkeznek, különösen a veszélyhelyzet terén, ahol nem szükséges a parlament jóváhagyása még utólagos formában sem, mint a magyar jogrendszerben.

Az Alaptörvény 9. módosításával jelentősen hasonlóbb lesz az észt és a magyar különleges jogrendi rendszer. Megjelenik idehaza is a hadiállapot kifejezés, mellette megmarad a szükségállapot és a veszélyhelyzet. A fó különbség így már inkább csak az észt fokozatossági rendszerben lesz, a jogintézmény eltérő szintjében a veszélyhelyzet és a fokozott védelmi készültség vonatkozásában. Különbségként állapítható még meg, hogy az észt szükségállapot egyértelmúen tartalmazza a terrorcselekményeket - ez idehaza az új szövegben sehol sem került nevesítésre -, valamint az ország egy részének erővel történő elszakítását is. Ez utóbbi bizonyosan az orosz ajkú lakosság miatt került a törvénybe, ami geopolitikai sajátosság Ukrajna elszakított területeinek példája alapján. Kiemelhető még az eltérő szabályozási megoldás is: míg az észt alkotmány csak minimumszabályokat tartalmaz, és részletes törvény foglalkozik a különleges jogrendi esetkörökkel, addig az Alaptörvénybe azok részletes szabályozását foglalták. 
Különbség mutatkozik az elrendelésben is: míg az észteknél a parlament rendeli el őket, addig idehaza, bár a legtöbb esetben az Országgyúlés jogosult erre, két esetkörben a Kormány rendelkezik erről. Az új Alaptörvény-módosítás alapján ez a szabályozás is jóval hasonlóbbá válik: a hadiállapot és a szükségállapot bevezetéséról az Országgyuulés, a veszélyhelyzet bevezetéséről a Kormány dönt. A veszélyhelyzet kapcsán különbségként állapítható meg azonban, hogy idehaza csak korlátozott időre hozható és csak az Országgyưlés döntése alapján hosszabbítható meg, míg Észtországban a parlamentnek semmilyen módon nem kell hozzájárulnia ahhoz, az teljesen a kormány hatáskörébe tartozik.

A felhatalmazás jelenlegi szabályai kapcsán elmondható, hogy az észt rendszerben nagy szerep jut a miniszterelnöknek, aki a különleges jogrend kezeléséért felelős vezetőként számos jogosultsággal bír, mellette a kormány a legfontosabb szerv, míg a tényleges operatív feladatokat a belügyminiszter, illetve hadiállapot esetén a védelmi erők parancsnoka látja el. Ezzel szemben idehaza elmondható, hogy a miniszterelnök nem kerül külön kiemelésre jogszabályi szinten és pluszjogosítványai sincsenek, a Kormány vezető szerepe pedig nem minden esetben egyértelmú: rendkívüli állapot esetén feladatait a Honvédelmi Tanács veszi át, míg szükségállapot idején nagyobb szerep jut a köztársasági elnöknek. Az új szabályozásban ez is megváltozik, a Kormány egyértelmú primátusra tesz szert a különleges jogrend minden esetköre során.

Az alapjogok korlátozása kapcsán elmondható, hogy mind a két szabályozás hasonló megoldással, a korlátozhatatlan alapjogok listájának megadásával operál, ugyanakkor megjegyezhető, hogy az Alaptörvényben sokkal átláthatóbban jelennek meg az egyes alapjogok. Észt sajátosságként meg kell azonban azt is jegyezni, hogy nem csak az alkotmány állapíthat meg alapjogokat.

A válságkezelés vonatkozásában szintén az észt jogrendszer megoldása tekinthető jobbnak: a válsághelyzetek külön törvényekben történő szabályozása helyett egy átfogó Veszélyhelyzeti tv. foglalkozik ezekkel, így jóval egységesebben valósulhat meg a válságkezelés, és átláthatóbb az ezzel kapcsolatos szabályozás. A válsághelyzet ráadásul egységes fogalmi keretek között kerül meghatározásra, amelynek átültetését a hazai jogalkotó számára is érdemes lenne megfontolni. Itt is jut ugyanakkor szerep az ágazati sajátosságoknak, például a fertőző betegségek kapcsán külön törvénybe foglalt intézkedések hozhatók, ugyanakkor ezek nem tekintendők jogi értelemben válsághelyzetnek. 


\section{Irodalomjegyzék}

Dubrovnik, T. (2009) 'The Position, Election and Powers of the President of the Republic of Estonia', Lex localis - Journal of Local Self-Government, 7(1), 19-32. o.

Gross, O. (2004) 'Providing for the Unexpected: Constitutional Emergency Provisions' in Dinstein, Y., Domb, F. (szerk.) Israel Yearbook of Human Rights. 1. kiadás. Tel Aviv: Faculty of Law of Tel Aviv University

KENKMANN, P. (2018) '„Universal Means of Governance”: the State of National Emergency in the Republic of Estonia in 1938-1940', TUNA, 21(1), 20-38. o.

Lane, T., Pabriks, A., Purs, A., Smith, D. J. (2013) The Baltic States: Estonia, Latvia and Lithuania. 1. kiadás. London-New York: Routledge

Loeber, D. A. (1998) 'Regaining Independence - Constitutional Aspects: Estonia, Latvia, Lithuania', Review of Central and East European Law, 24(1), 1-7. o.

Makarychev, A., Romashro, T. (2021) 'Precarious Sovereignty in a Post-liberal Europe: The COVID-19 Emergency in Estonia and Finland', Chinese Political Science Review, 6(1), 63-85. o.

Maruste, R. (2020) State of Emergency in Estonia [Online]. Elérhető: https://verfassungsblog. de/state-of-emergency-in-estonia/ (Letöltve: 2020. december 3.)

Osula, A. (2015) National Cyber Security Organistation: Estonia [Online]. Elérhető: https:// ccdcoe.org/uploads/2018/10/CS_organisation_ESTONIA_032015_1-1.pdf (Letöltve: 2020. december 3.)

PARsovs, A. (2020) 'Solving the Estonian ID Card Crisis: the Legal Issues' in Hughes, A. L., McNeill, F., Zobel, C. (szerk.) Proceedings of the 17th ISCRAM Conference - Blacksburg, VA, USA May 2020. 1. kiadás. CoRe Paper - Ethical, Legal, and Social Issues

SMITH, D. (2001) Estonia: Independence and European Integration. 1. kiadás. London: Routledge

VALGE, J. (2012) 'Foreign Involvement and Loss of Democracy, Estonia 1934', Journal of Contemporary History, 46(4), 788-808. o.

Veebel, V. (2017) Planning and Developing the Estonian Military Forces: Progress, Challenges and Dilemmas. 1. kiadás. Tallinn: Estonian Foreign Policy Institute

Veebel, V., Ploom, I. (2019) 'Estonia's Comprehensive Approach to National Defence: Origins and Dilemmas', Journal on Baltic Security, 4(2), 10-22. o.

Venice Commission (2020) Interim Report on the Measures Taken in the EU Member States as a Result of the Covid-19 Crisis and Their Impact on Democracy, the Rule of Law and Fundamental Rights (Opinion No. 995/2020) [Online]. Elérhető: www.venice.coe.int/webforms/documents/ default.aspx?pdffile=CDL-AD(2020)018-e (Letöltve: 2020 . december 15.) 


\title{
13. Amikor az alkotmány hallgat: Finnország különleges jogrendje
}

\author{
DORNFELD LÁSZLÓ
}

\section{A különleges jogrend alkotmányos és törvényi szintű szabályozása, illetve esetkörei}

Finnország azon országok körébe tartozik, ahol az alkotmány ${ }^{1}$ semmilyen rendelkezést nem tartalmaz a különleges jogrend esetköreivel kapcsolatosan. Az alkotmány kizárólag egy 2011-es módosítással elfogadott rendelkezésben tesz említést a különleges jogrendről, az alapjogok védelmének kontextusában. ${ }^{2}$ Ez kimondja, hogy az alapjogok ideiglenesen korlátozhatók - a nemzetközi jogi kötelezettségekkel összhangban -, amennyiben az országot támadás éri, vagy bármilyen más komoly veszélyt jelentő helyzet esetén. Ekkor törvényben vagy kormányrendeletben, külön törvény felhatalmazása alapján, pontosan körülírt alkalmazási körre figyelemmel lehetséges az alapjogok korlátozása.

Ez a megfogalmazás igen összetett, és a rövidsége ellenére számos lényegi elem derül ki belőle. Az alapjogok két esetben korlátozhatók: külső támadás, illetve külön törvényben

I Finnország alkotmánya (Suomen perustuslaki 11.6.1999/731) (a továbbiakban: alkotmány). Az 1999-ben elfogadott alkotmány Európa egyik legfiatalabbjának számít.

2 Alkotmány 23. szakasz.

Dr. Dornfeld László

laszlo.dornfeld@mfi.gov.hu

kutató (Mádl Ferenc Összehasonlító Jogi Intézet)

Dornfeld, L. (2021) 'Amikor az alkotmány hallgat: Finnország különleges jogrendje’ in Nagy, Z., Horváth, A. (szerk.) A különleges jogrend és nemzeti szabályozási modelljei, 301-321. o. Budapest: Mádl Ferenc Összehasonlító Jogi Intézet.

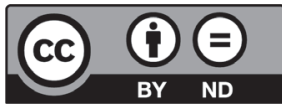


meghatározott vészhelyzet esetén. Az ideiglenes korlátozó intézkedéseket a parlament hagyja jóvá egyszerú többséggel, ugyanakkor a parlament törvényben átruházhatja a kormányra a jogot, hogy meghatározott témakörökben kormányrendelettel korlátozzon alapjogokat. Ezeknek a rendelkezéseknek meg kell felelniük az ország nemzetközi jogi kötelezettségeinek. A parlament múkködése folyamatos kell legyen a különleges jogrendi állapot idején, de a rendes jogalkotás helyett csak vétójoggal. ${ }^{3}$

A különleges jogrenddel kapcsolatos finn megoldás két jogi sajátossággal is bír. Először is, az alkotmányban megjelölt külön törvény megalkotása és jogi státusza. Az alkotmány ugyanis lehetôvé teszi az úgynevezett kivételes jogalkotást, amely az alkotmány rendes jogrendi szabályaitól való korlátozott eltérésre ad lehetőséget. ${ }^{4}$ Ezek a jogszabályok a gyakorlatban felülírják az alkotmány rendelkezéseit, anélkül, hogy az alkotmányt magát módosítani kéne, és ugyanolyan eljárásrendben kerülnek elfogadásra, mint az alkotmánymódosítások. ${ }^{5}$ A témánk szempontjából egyik leglényegesebb törvény, a 2011-ben elfogadott vészhelyzeti hatáskörökről szóló törvény ${ }^{6}$ azonban jócskán túllép ezen a határon. A másik igen érdekes megoldás, hogy az alapjogokat korlátozó egyes kormányrendeleteket külön is jóvá kell hagynia a parlamentnek, mielőtt azok hatályba léphetnek.?

A Vészhelyzeti tv. nem nevesíti a különleges jogrend általa szabályozott formáját, kizárólag kivételes körülményekről (poikkeusolojen) tesz említést, amelyek okot adnak a kormány számára a különleges jogkörök gyakorlására. A nemzetközi szakirodalom, ${ }^{8}$ illetve a finn kormány angol nyelvú kommunikációja9 egységesen szükségállapotként hivatkozik erre az állapotra, így az egyszerűség kedvéért a fejezetben is így említjük.

A másik fontos törvény a külső fegyveres támadás esetén alkalmazandó honvédelmi törvény. ${ }^{10} \mathrm{Ez}$ a törvény teremt lehetőséget a védelmi állapot (puolustustila) bevezetésére. ${ }^{11}$ Ezek alapján a finn jogrendben a különleges jogrend két formája, a szükségállapot (kivételes körülmények) és a védelmi állapot különböztethetô meg.

A szükségállapot alkalmazására a Vészhelyzeti tv. szerinti kivételes körülmények fennállása esetén van lehetőség, aminek célja a lakosság védelme, megélhetésének és gazdasági életének megőrzése, a rend és az alapvető emberi jogok fenntartása, valamint az állam területi integritásának és függetlenségének megőrzése. ${ }^{12} \mathrm{~A}$ kivételes körülmények a követ-

3 Scheinin, 2020.

4 Alkotmány 73. szakasz.

5 Ojanen, 2007, 207. o.; Cornell-Salminen, 2018, 237. o.

6 Valmiuslaki 2011/1552 (a továbbiakban: Vészhelyzeti tv.).

7 Alkotmány 23. szakasz.

8 A legtöbb helyen az ennek megfelelő state of emergency angol fogalmat használják (Cornell-Salminen, 2018; Husa, 2011; Scheinin, 2020).

9 Elérhető: https://valtioneuvosto.fi/en/-//10616/hallitus-totesi-suomen-olevan-poikkeusoloissa-koronavirustilanteen-vuoksi (Letöltve: 2020. december 15.).

10 Puolustustilalaki 22.7.1991/1083 (a továbbiakban: Honvédelmi tv.).

11 A hadiállapot megfogalmazás nem helytálló, ugyanis elrendeléséhez nem szükséges külső fegyveres konfliktus.

12 Vészhelyzeti tv. 1. szakasz. 
kezők lehetnek: fegyveres vagy hasonló támadás Finnország ellen és annak közvetlen következményei; Finnország elleni fegyveres vagy hasonló támadás jelentős veszélye; a lakosság megélhetését vagy az ország gazdaságának alapjait különösen súlyosan érintő esemény vagy veszély, amelyek jelentős kockázatot jelentenek a társadalom létfontosságú funkcióira; súlyos baleset és annak közvetlen következményei; nagyon széles körben elterjedt veszélyes fertőző betegség. ${ }^{13}$

A hatóságok a törvény szerinti hatásköreiket kivételes körülmények között is csak a cél eléréséhez szükséges ideig és a cél elérésével arányosan gyakorolhatják, amennyiben az adott helyzet az általános szabályok szerint nem kezelhetô. ${ }^{14} \mathrm{~A}$ kivételes körülmények fennállását a kormány és a köztársasági elnök együttesen állapítja meg, majd a kormány elkészíti a szükséges végrehajtó rendeleteket. Fontos, hogy magával a szükségállapot elrendelésével kapcsolatban nem szükséges a törvényhozás hozzájárulása, csak az az alapján hozott intézkedések esetén. ${ }^{15}$

A Vészhelyzeti tv. alapján a konkrét jogkorlátozó intézkedéseket tartalmazó úgynevezett végrehajtási kormányrendeletek alkothatók, kétféle eljárásban:

- általános eljárásban: a kormányrendelet legfeljebb hat hónapra adható ki, de az elfogadásától számított egy héten belül be kell nyújtani azt a finn parlamentnek; ellenkező esetben a kormányrendelet hatályát veszti. A kormányrendelet egyebekben a parlament által jóváhagyott tartalommal marad hatályban;

— sürgősséggel: a kormányrendelet legfeljebb három hónapra adható ki, és haladéktalanul be kell nyújtani azt a parlamentnek. Ha egy héten belül a parlament nem kapja meg a kormányrendeletet, az hatályát veszti.

A kivételes körülmények fennállása esetén meghozott végrehajtási kormányrendeletnek tartalmaznia kell az alkalmazni kívánt eszközöket, valamint az alkalmazás területi hatályát, amennyiben nem az ország teljes területére történik. A rendelet hatálya kormányrendelettel - egy alkalommal - legfeljebb hat hónappal meghosszabbítható, de a módosító rendeletet a parlamentnek be kell nyújtani. ${ }^{16} \mathrm{~A}$ kivételes körülmények végével a szükségállapotot meg kell szüntetni. A szükségállapot végével az összes az alapján hozott rendelkezés is hatályát veszíti. ${ }^{17}$

A Vészhelyzeti tv. II. része az egyes esetkörökre lebontva tartalmazza azon rendelkezéseket, amelyek meghozhatók. A 4. fejezet a pénzügyi piacok biztonságát érintő intézkedésekkel

13 Vészhelyzeti tv. 3. szakasz.

14 Vészhelyzeti tv. 4. szakasz.

15 Scheinin, 2020; valamint lásd a Miniszterelnöki Hivatal tájékoztatóját: https://valtioneuvosto.fi/ documents/10184/3785983/Beredskapslagen+160320.pdf/558a48cb-543d-57e6-fafe-b843ba0350e7/ Beredskapslagen+160320.pdf 2. o. (Letöltve: 2020. december 15.) „A rendkívüli körülmények fennállásának megállapításáról szóló kormányhatározat azonnal hatályba lép, és további értesítésig hatályos, és ez lehetővé teszi a végrehajtási rendelet kiadását.".

16 Vészhelyzeti tv. 6-9. szakasz.

17 Vészhelyzeti tv. 11. szakasz. 
foglalkozik, az 5. fejezet az áruk eloállításának és elosztásának, valamint az energiaellátásnak a biztosítása terén tartalmaz rendelkezéseket. A 6. fejezet az építési projektekkel, valamint az építőanyagokkal foglalkozik. A 7. fejezet a lakhatással kapcsolatosan fogalmaz meg rendelkezéseket, míg a 8. fejezet a társadalombiztosítással foglalkozik, a 9. fejezet az elektronikus információs és kommunikációs rendszerek működésének és a postai szolgáltatások elérhetősége biztosításának eszközeit tartalmazza. A 10. fejezet a közlekedés és az üzemanyag-ellátás kérdéseivel foglalkozik, a 11. fejezet a szociális és egészségügyi intézmények feladataival kapcsolatos, a 12. fejezet a költségvetési kérdésekkel, míg a 13. fejezet a munkavállalás kérdéseivel foglalkozik, a 14. fejezet pedig a munkakötelezettség kérdéseit taglalja. A 15. fejezet a kormányzati szervezet kérdéseivel, a 16. fejezet a katonai készültséggel kapcsolatos, míg a 17. szakasz a polgári védelemmel és kitelepítéssel kapcsolatos szabályozást tartalmazza.

Ez a szabályozás igen szerteágazó, és kizárólag az egyes különleges jogrendi eszközök szempontjából csoportosít. A rendelkezések túlnyomó többségének a felhatalmazottja a kormány vagy valamelyik minisztérium, valamely más központi szerv (például a nemzeti bank), esetleg a védelmi erók. A felhatalmazás alapján meghozott, a II. részbe tartozó intézkedések valamelyikét elrendelő kormányrendeletet haladéktalanul meg kell küldeni a törvényhozás számára, amely egyszerú többséggel dönt arról, hogy hatályban maradjanak-e. ${ }^{18}$ Ez a gyakorlatban azt jelenti, hogy ezeket a rendelkezéseket a parlament csak utólagosan vizsgálja felül, és már a parlament döntését megelőzően hatályba lépnek, alkalmazásukra azonban csak a parlamenti jóváhagyást követően kerülhet sor. ${ }^{19}$

A védelmi állapot bevezetése a Honvédelmi tv. értelmében akkor lehetséges, ha Finnországot támadás éri, vagy hasonló belső erőszakos zavargások az alkotmányos rend megváltoztatására irányulnak. A védelmi állapot alkalmazásának célja a függetlenség és a rend megőrzése a fenyegetéssel szemben. ${ }^{20}$ Elrendelésére a köztársasági elnök jogosult rendelettel, abban az esetben, ha a Vészhelyzeti tv. rendelkezései nem bizonyulnának elégségesnek a kialakult helyzetben. ${ }^{21}$ Akárcsak a szükségállapotnál, itt is meghatározott időre, legfeljebb három hónapra lehet dönteni a bevezetésről, amelyet a törvényhozásnak nem kell megerősíteni. Ebben az esetben is csak a különleges jogrend kapcsán hozott rendelkezések szorulnak parlamenti megerősítésre. Amenynyiben a parlament azt nem szavazza meg, vagy pedig egy héten belül nem kerül beterjesztésre a törvényhozás elé, úgy az adott rendelet hatályát veszíti. ${ }^{22}$ Amennyiben az elrendelés okai továbbra is fennállnak, a köztársasági elnök az adott végrehajtási rendeletet meghosszabbíthatja egy alkalommal, legfeljebb egy évvel. Ezt a rendelkezést a parlamentnek az eredeti határozathoz hasonlóan meg kell erősítenie. ${ }^{23}$ Amennyiben a hosszabbító rendelkezést a parlament elfogadja,

18 Vészhelyzeti tv. 10. szakasz.

19 Scheinin, 2020.

20 Honvédelmi tv. 1. szakasz.

21 Honvédelmi tv. 2. szakasz.

22 Honvédelmi tv. 3. szakasz.

23 Honvédelmi tv. 4. szakasz. 
az abban szereplő rendelkezések az eredeti három hónapos határidő letelte után is hatályban maradnak. Ha a törvényhozás még nem szavazott a kérdésben, és a lejárat elött legalább két héttel megküldésre került számukra a hosszabbításról rendelkező köztársasági elnöki rendelet, úgy a rendelkezések továbbra is hatályban maradnak a parlament döntésének megszületéséig. ${ }^{24}$ Az elrendeléshez vezetó körülmények megszúntével a védelmi állapotot elrendelő vagy meghoszszabbító köztársasági elnöki rendeletet hatályon kívül kell helyezni. A védelmi állapot megszúnését követően az az alapján hozott egyéb rendelkezések is hatályukat veszítik. ${ }^{25}$

A védelmi állapot során a Honvédelmi tv. a fokozatosság elve alapján nem zárja ki a Vészhelyzeti tv. rendelkezéseinek az alkalmazását, kivéve, ha a törvény kifejezetten kitér rá. ${ }^{26}$ Ennek megfelelően a Honvédelmi tv. már csak azon rendelkezéseket tartalmazza, amelyek a másik törvényben nem találhatók meg. A Honvédelmi tv. 2. fejezete az általános rendelkezéseket, míg a 3. fejezet a katonai és gazdasági védelem eszközeit tartalmazza. A rendelkezések felhatalmazottja az esetek többségében a kormány, valamely minisztérium, illetve a védelmi erők. A katonai hatóságok döntéshozatali jogköre szúkre szabott, amennyiben bizonyos rendelkezéseik időtartama meghaladná a két hetet, úgy a kormányzatnak kell döntenie azok fenntartásáról, és azt a hivatalos lapban is közzé kell tenni. ${ }^{27}$

\subsection{A különleges jogrendre való felkészülést segítő békeidejü szabályok és a kapcsolódó szervezetrendszer}

Finnországban régóta mûködik a felkészültségi rendszer, és az úgynevezett átfogó védelmi megközelítés évtizedek óta uralkodó nézet. Ez azt jelenti, hogy a társadalom egésze, a közigazgatás, a magánszektor és a polgárok együttesen biztosítják, hogy bármilyen helyzetben múködőképes maradjon a társadalom. Ez a fajta megközelítés megteremtette az alapot az állami és a magánszektor felkészültségi intézkedéseinek, valamint a polgárok önkéntes tevékenységeinek összehangolására. ${ }^{28} \mathrm{~A}$ finn védelmi politika arra épül, hogy a nemzetbiztonsági hatóságoknak már a különleges jogrend elrendelését megelőzően is legyen jogalapjuk fellépni a fenyegetésekkel szemben. ${ }^{29}$

A különleges jogrendszerre való felkészülés legfontosabb szerve a kormány, amely köré a teljes készültségi szervezetrendszer épül. A kormány feje a miniszterelnök, aki elnököl a plenáris ülésen, illetve az állandó bizottságokban. A kormány alkotja meg a társadalmi

\footnotetext{
24 Honvédelmi tv. 5. szakasz.

25 Honvédelmi tv. 6. szakasz.

26 Khakee, 2009, 26. o.

27 Honvédelmi tv. 27. szakasz.

28 Finnish Security and Defence Policy 2009. Government Report (84-85.) Elérhetô: www.files.ethz.ch/isn/156933/ Finland_English-2009.pdf (Letöltve: 2020. december 15.).

29 Például a krími helyzethez hasonló, felségjelzés nélküli katonák beszivárgásának elhárítása érdekében a határvédelmi törvény rendelkezéseit módosították (Salonius-Pasternak, 2019).
} 
biztonsági stratégiát, ${ }^{30}$ amely a felkészültség alapdokumentuma, és meghatározza a legfontosabb veszélyeket és kihívásokat. ${ }^{31}$ Kivételes körülmények fennállása esetén a kormány rendelete vezeti be a szükségállapotot. Finnország nem rendelkezik elkülönült nemzetbiztonsági csúcsszervvel, habár 1924-tôl az 1990-es évekig - hosszabb megszakításokkal - múködött a Védelmi Tanács, amely a honvédelmi stratégiáért felelős fó szerv volt. ${ }^{32} 2009$-ben felmerült annak lehetôsége, hogy életre hívjanak egy biztonsági tanácsot a komplex nemzetbiztonsági kihívások kezelése érdekében, ám ez végül sosem valósult meg. ${ }^{33} \mathrm{~A}$ kormány legfontosabb nemzetbiztonsági szerve a Külügyi és Biztonságpolitikai Miniszteri Bizottság, amely előkészíti a kül- és biztonságpolitika fontos szempontjait, valamint az egyéb ügyeket, amelyek érintik Finnország más államokkal fenntartott kapcsolatait, a kapcsolódó kulcsfontosságú belső biztonsági kérdéseket és az átfogó védelemmel kapcsolatos fontos kérdéseket. A bizottság elnöke a miniszterelnök, tagjai a külügyminiszter és a honvédelmi miniszter, valamint legfeljebb még négy, kormány által delegált miniszter, üléseit a köztársasági elnökkel közösen tartja. Tagjain kívül az ülésen még jelen van a belügyminiszter, ha az ő tárcáját érintő kérdést tárgyalnak, valamint bármely más miniszter. ${ }^{34}$

A miniszterelnök mellett múködő Miniszterelnöki Hivatal múködteti a Kormányzati Eseményközpontot, amelynek jogállását törvény tartalmazza. ${ }^{35}$ Ez valós időben követi a vészhelyzeti események kialakulását a beérkező adatok alapján, és egyúttal NATO és ENSZ polgári védelmi, valamint EU válságkezelési nemzeti kapcsolattartó pontként is funkcionál. A szerv a nyilvánosan elérhető, illetve a hatóságoktól kapott információk alapján figyeli a Finnországot érintő természeti katasztrófák, valamint fenyegetések alakulását. A szerv információkkal látja el a kormány Külügyi és Biztonságpolitikai Miniszteri Bizottságát.

Fontos szerep jut a minisztériumoknak, amelyek saját területükön felelnek a készültségért. A Belügyminisztérium az egyik legfontosabb ezek közül. A mentési múveletek mellett számos más, a krízisekre és balesetekre reagálás szempontjából releváns mưveletért is felelős, mint például a közrend és a közbiztonság, a rendőrség igazgatása, a magánbiztonsági szektor, a vészhelyzeti reagálási központok múveletei, a határbiztonság, a tengeri mentőszolgálatok, a nemzeti készültség, a polgári válságkezelés és a regionális közigazgatás felkészültsége a kivételes körülményekre és a zavarokra. ${ }^{36} \mathrm{Az}$ országot érintő veszélyek felmérése érdekében háromévente nemzeti kockázatelemzés készül, amely meghatározza az embe-

30 A nemzetközi gyakorlatban a nemzeti biztonsági stratégia fogalmának felel meg.

31 Elérhető: https://turvallisuuskomitea.fi/en/security-strategy-for-society/ (Letöltve: 2020. december 15.).

32 Penttila, 1991, 89-90. o.

33 A tervek szerint a tanács tagjai az ország legfőbb politikai vezetői, valamint a legfontosabb polgári és katonai tisztviselői lettek volna. A tanács a miniszterelnök felügyelete alatt múködött volna, és a biztonsági erőfeszítések összehangolása lett volna a feladata. Elérhető: https://yle.fi/uutiset/osasto/news/finland_considers_ establishment_of_national_security_council/5723069 (Letöltve: 2020. december 15.).

34 Elérhető: https://valtioneuvosto.fi/en/government/ministerial-committees (Letöltve: 2020. december 15.). 35 A Kormányzati Eseményközpontról szóló 300/2017. törvény (Laki valtioneuvoston tilannekeskuksesta).

36 Elérhető: www.ifrc.org/Global/Publications/IDRL/Publications/HNSG_EN_FINLAND\%202014.pdf (Letöltve: 2020 . december 15.). 
reket, a környezetet, a vagyont és a kritikus rendszereket és szolgáltatásokat fenyegetô különféle kockázatokat, amelyekre a hatóságoknak fel kell készülniük minden tevékenységük során..$^{37} \mathrm{~A}$ jelentést a Belügyminisztérium készíti el..$^{88}$

A Védelmi Minisztérium alatt múködik a Biztonsági Bizottság, amelyet 2013-at megelőzően Biztonsági és Védelmi Bizottságnak neveztek, jogállásáról pedig kormányrendelet rendelkezik. ${ }^{39} \mathrm{Ez}$ a szerv segíti mind a minisztériumot, mind a kormány Külügyi és Biztonságpolitikai Miniszteri Bizottságát az átfogó védelmi megközelítéssel kapcsolatos kérdésekben. Összesen húsz tagból és négy szakértőből áll, akik a kormányzatból, a közigazgatásból és az üzleti életből érkeztek. A bizottság havonta egyszer ülésezik, állásfoglalásokat és ajánlásokat készít az átfogó, védelemmel kapcsolatos kérdésekben, leggyakrabban a felelős minisztérium vagy más megrendelésére. A finn kiberbiztonsági stratégia és annak végrehajtási programja jó példa a bizottság irányítása alatt elvégzett munkára. ${ }^{40}$

\subsection{A válságkezelésre vonatkozó szabályok}

A finn válságkezelés nem rendelkezik egységes szabályozással, azt ágazati törvények szétszórtan tartalmazzák. A válsághelyzet, mint olyan, külön nevesítésre nem kerül, de bizonyos törvényi helyzetek megfeleltethetők a magyar válsághelyzeti szabályozásnak. A válságkezeléssel kapcsolatos legfontosabb rendelkezések az egészségügyi ellátásról ${ }^{41}$ és a fertőző betegségekről szóló törvényben, ${ }^{42}$ a mentési törvényben, ${ }^{43}$ a rendőrségi törvényben, ${ }^{44}$ valamint a bevándorlási törvényben találhatók. ${ }^{45}$

A katasztrófavédelmi szabályokat több finn törvény is részletezi. A legfontosabb ezek közül a Mentési tv., amely a polgári védekezés és felkészülés lehetőségeit részletezi. A törvény fố célja a tûz- és más balesetek megelőzése, felkészülés a balesetekre és a múveletekre, ha balesetveszély áll fenn, vagy ha baleset történik, illetve a balesetek következményeinek korlátozása. Ezeket úgy kell megtervezni és végrehajtani, hogy a kivételes körülmények fennállása esetén bevezetett szükségállapot során is elláthatók legyenek. ${ }^{46} \mathrm{~A}$ törvény meghatározza a „mentési múveletek” fogalmát, amelyek a mentőszolgálat olyan sürgős feladatai, amelyek célja az emberéletek, a vagyon és a környezet megmentése és védelme balesetveszély

37 Elérhető: https://intermin.fi/en/rescue-services/preparedness/national-risk-assessment (Letöltve: 2020. december 15.).

38 Elérhető: https://intermin.fi/julkaisut/julkaisu?pubid=URN:ISBN:978-952-324-249-4 (Letöltve: 2020. december 15.).

39 A Biztonsági Bizottságról szóló 77/2013. kormányrendelet (Valtioneuvoston asetus Turvallisuuskomiteasta).

40 Elérhető: https://turvallisuuskomitea.fi/en/security-committee/ (Letöltve: 2020. december 15.).

41 Terveydenhuoltolaki 1326/2010 (a továbbiakban: Eütv.).

42 Tartuntatautilaki 1227/2016 (a továbbiakban: Fertőzés tv.).

43 Pelastuslaki 29.4.2011/379 (a továbbiakban: Mentési tv.).

44 Poliisilaki 22.7.2011/872 (a továbbiakban: Rendőrségi tv.).

45 Ulkomaalaislaki 30.4.2004/301 (a továbbiakban: Bevándorlás tv.).

46 Mentési törvény 2. szakasz. 
esetén vagy baleset bekövetkeztekor, valamint a baleset okozta károk korlátozása és a baleset következményeinek enyhítése. ${ }^{47} \mathrm{~A}$ mentési mûveletekben fontos szerep jut a mentési múvelet irányítójának, aki vagy a mentési régióból érkezik, vagy a Belügyminisztérium delegálja. ${ }^{48}$ Ő többek között elrendelheti bizonyos területek kiürítését, szükséges esetben kárt okozhat az ingó és ingatlan vagyonban, elrendelheti a szükséges eszközök, kommunikációs vonalak, épületek elérhetôvé tételét, valamint minden egyéb szükséges lépést megtehet. A mentési munkában való részvételre minden munkaképes felnőtt kötelezhető a parancsnok által. ${ }^{49}$

A Rendőrségi tv. részletekbe menően szabályozza a rendőrségi eljárásokat, illetve rögzíti a titkos információgyűjtés korlátait. A rendőr polgári szabadságjogokat - így például a mozgásszabadságot korlátozó, a más tulajdonába való belépés jogát, egy adott terület lezárását vagy tömeg oszlatását lehetôvé tevő - korlátozó intézkedési jogkörét is ez a törvény határozza meg. ${ }^{50}$ Ezeket az intézkedési jogköröket a rendőr válsághelyzetben is gyakorolhatja - erre utalnak a törvénynek a „közrend, közbiztonság védelme érdekében” alkalmazott fordulatai. ${ }^{51}$ A belső zavargások kezelése már előkészületi állapotban is lehetséges a törvény alapján különböző rendőri intézkedésekkel, így például területlezárásokkal vagy tömegoszlatással. ${ }^{52}$ Egyes, belső zavargásokra utaló cselekményekkel kapcsolatban lehetőség nyílik a titkos információgyuujjtési módszerek alkalmazására is. ${ }^{53} \mathrm{~A}$ már megvalósult belső zavargások kezelésekor a rendőrség mellett a honvédség bevetése is lehetővé válik a Honvédelmi tv. révén. ${ }^{54}$

Az egészségügyi válságkezeléssel kapcsolatos szabályozás az Eütv.-ben és a Fertôzés tv.-ben található. Előbbi az ezzel kapcsolatos tervek elkészítését szabályozza, míg az utóbbi a fertőző betegségek és az általuk okozott járvány elleni védekezés részletszabályait tartalmazza. A Fertőzés tv. a hatásköröket (bejelentési és nyilvántartási kötelezettségek, információk megosztása és továbbítása, ellenőrzési feladatok és vizsgálatok lebonyolítása) központi, regionális és helyi szinten osztja meg, elsődleges célként pedig a megelőzést jelöli ki. A törvény rendelkezéseket tartalmaz például a karantén elrendeléséről és szabályairól, valamint az oktatási, egészségügyi, napközi, társasházi épületek bezárásáról, illetve a közterületeken történő gyúlések és nyilvános rendezvények korlátozásáról. A Fertőzés tv. alkalmazásában fertőző betegségnek számít az emberi testben szaporodó mikrobák, komponenseik vagy paraziták által okozott bármilyen betegség vagy fertőzés. ${ }^{55}$ Még ha a hatáskörök sok esetben decentralizáltak is, a gyakorlat azt mutatta, hogy ezek központi

47 Mentési törvény 2. szakasz (2) bekezdés.

48 Mentési törvény 34. szakasz.

49 Mentési törvény 36-37. szakasz.

50 Rendőrségi tv. II. fejezet 2., 6., 8., 9., 10-19. szakasz.

51 A más tulajdonába való belépés jogát biztosító törvényhely például már életet, egészséget, személyes szabadságot, vagyonbiztonságot vagy a környezetet érintő cselekedet vagy esemény bekövetkeztének veszélye esetén is lehetővé teszi a rendőr fellépését (Rendőrségi tv. II. fejezet 6. szakasz).

52 Rendőrségi tv. II. fejezet 2-19. szakasz.

53 Rendőrségi tv. V. fejezet 2-3. szakasz.

54 A védelmi erőkről szóló törvény (Laki puolustusvoimista 11.5.2007/551) 2. szakasz (1) bekezdés b) pontja és (2) bekezdés a) pontja.

55 Fertőzés tv. 3. szakasz. 
kormányzati összehangolására van szükség a koronavírushoz hasonló nagyobb járvány esetén. ${ }^{56}$ A törvényhez tartozik egy rendelet is, amely a fertőző betegségek listáját tartalmazza. ${ }^{57}$

A tömeges bevándorlással kapcsolatos szabályozás - amit a magyar jog külön jogintézményként bontott $\mathrm{ki}^{\mathrm{i}}{ }^{8}$ - a finn jogban a bevándorlási törvényben nyert elhelyezést, egy egészen rövid technikai utalás formájában. Eszerint, ha olyan nagyszámú bevándorló érkezik az országba, hogy nem lehetséges meghatározni a beutazás feltételeit és a bevándorlókat rendes eljárás szerint nyilvántartásba venni, a kormány legfeljebb három hónapig terjedő időre dönthet speciális menekültügyi központokba kerülésükről, amelyet tilos elhagyniuk a nyilvántartásba vétel idejéig. ${ }^{59}$

\section{Az alapjogok korlátozására vonatkozó szabályok különleges jogrend idején}

Az alkotmány egyetlen különleges jogrenddel kapcsolatos rendelkezése az alapjogok korlátozásával kapcsolatos. ${ }^{60} \mathrm{Az}$ alkotmány nem nevesíti egyértelmúen a kormányt mint a különleges jogrend elrendelőjét és felhatalmazottját. A Vészhelyzeti tv. pótolja ezt a hiányosságot, ennek a felhatalmazásnak pedig két korlátja van: először is a parlament jelentős szerepe az egyes alapjog-korlátozó rendelkezések felülvizsgálatában, másrészt a nemzetközi kötelezettségeknek való megfelelés követelménye. ${ }^{61} \mathrm{~A}$ koronavírus-járvány idején történő gyakorlat azt mutatja, Finnország nagy hangsúlyt helyez arra, hogy a végrehajtó hatalom határozatainak alkotmányosságát és jogi megfelelőségét állandó bizottságok, illetve külső alkotmányjogi szakértők segítségével biztosítsa különleges jogrend idején is. ${ }^{62}$

A Vészhelyzeti tv. számos rendelkezést tartalmaz, amelyek felhatalmazása alapján a kormány, minisztérium vagy más szerv alapjog-korlátozó rendelkezést hozhat szükségállapot idején. Ezek a rendelkezések nem általánosak, hanem az alkalmazható eszközök felsorolását adják. Fontos megjegyezni, hogy mindezen eszközök mellett az alkotmány 23. szakasza alapján bármilyen más alapjog-korlátozó jogszabály megalkotható a különleges jogrend idején, az egyetlen különbség, hogy rendeleti forma helyett törvényként kerül elfogadásra. A törvényben szereplő eszközök részletes feldolgozása szétfeszítené a tanulmány kereteit, így csak a legfontosabb csoportok bemutatására kerül sor.

A Vészhelyzeti tv. először a pénzügyi piacok biztonságát érintő intézkedésekkel foglalkozik, így például értékpapírok, pénz kivitele vagy behozatala csak a nemzeti bank engedé-

56 Scheinin, 2020.

57 A fertőző betegségekről szóló kormányrendelet (Valtioneuvoston asetus tartuntataudeista 146/2017).

58 A menedékjogról szóló 2007. évi LXXX. törvény X/A. fejezet.

59 Bevándorlási tv. 133. szakasz.

60 Alkotmány 23. szakasz.

61 Cornell-Salminen, 2018, 242. o.

62 Grogan, 2020. 
lyével lehetséges, az állampolgárok kötelezhetők a külföldi valuta leadására, ahogy az állampolgárok külföldi tranzakciói is korlátozhatók. ${ }^{63} \mathrm{Az}$ exporttilalom alól azonban mentességet lehet adni, például ha az szükséges a lakosság jólétéhez és az ország gazdaságának müködéséhez, vagy külföldi finn tulajdonnal függ össze. ${ }^{64}$ További rendelkezések a hitelezéssel, valamint a biztosításokkal, illetve az értékpapírok kibocsátásával, kereskedelmével kapcsolatosan tartalmaznak korlátozásokat, bizonyos sebezhető fizetési módozatok kizárását teszik lehetővé, valamint a csőd- és felszámolási eljárások esetén teszik lehetővé bizonyos kivételek alkalmazását. ${ }^{65}$

Az eszközök következő csoportja az áruk előállításának és elosztásának, valamint az energiaellátásnak a biztosítása kapcsán tartalmaz rendelkezéseket. Itt különféle korlátozásokat állapít meg a törvény, így például az üzemanyagok hatósági vételárassá tehetők, bizonyos, mezőgazdaságban használatos javak birtoklása és kereskedelme korlátozható, a kiskereskedelmi áruforgalom, illetve az iparban szükséges fémek, ötvözetek, elektromos eszközök stb. használata korlátozható. ${ }^{66}$ Korlátozható továbbá a külföldre irányuló áruforgalom, az elektromos hálózat használata, sőt, akár fel is függeszthetô, a távfútés korlátozható, valamint a fứtőolaj kereskedelmének korlátozása is elrendelhető. ${ }^{67}$

A Vészhelyzeti tv. az építési projektekkel, valamint az építőanyagokkal kapcsolatosan is tartalmaz rendelkezéseket. Így például a szükségállapot ideje alatt az építkezések elkezdése, illetve folytatása külön engedélyhez köthető, ahogy az építőanyagok beszerzése is engedélykötelessé tehető. ${ }^{68} \mathrm{~A}$ lakhatással kapcsolatosan is megfogalmazódnak szabályok, így például előírható, hogy a lakáskiadó tulajdonos bejelentse a bérlőjét a megfelelő hatóságnál, ahogy ideiglenesen a lakbér emelése is tilalmazható. ${ }^{69} \mathrm{Az}$ eszközök következő csoportja a társadalombiztosítással kapcsolatos. Így például a kötelező biztosítás és az ellátás három hónapig terjedő időre felfüggeszthetô vagy elhalasztható, vagy a kifizetés mértéke legfeljebb felére csökkenthető, ami vonatkozik egyes speciális ellátásokra is (például anyasági támogatás, nemzetközi örökbefogadás támogatása, tartásdíj). ${ }^{70} \mathrm{~A}$ törvény tartalmaz eszközöket az elektronikus információs és kommunikációs rendszerek múködésének és a postai szolgáltatások elérhetőségének biztosítására is, így például a rádiófrekvenciákkal kapcsolatos döntéseket, illetve a különböző biztonsági intézkedések kötelező elôirásának a lehetőségét, valamint a telekommunikációs és infokommunikációs szolgáltatás üzemeltetését ideiglenesen a megfelelő minisztérium alá rendelheti. ${ }^{71}$

63 Vészhelyzeti tv. 15. szakasz.

64 Vészhelyzeti tv. 16. szakasz.

65 Vészhelyzeti tv. 17-23. szakasz.

66 Vészhelyzeti tv. 30-34. szakasz.

67 Vészhelyzeti tv. 35-41. szakasz.

68 Vészhelyzeti tv. 47-48. szakasz.

69 Vészhelyzeti tv. 51-55. szakasz.

70 Vészhelyzeti tv. 58-59. szakasz.

71 Vészhelyzeti tv. 61-64. szakasz. 
Az eszközök következő nagy csoportja a közlekedés és az üzemanyag-ellátás kérdéseivel foglalkozik. Ez alapján korlátozások vezethetők be az üzemanyag-kereskedelem, ${ }^{72}$ valamint a közúti közlekedés igénybevétele terén, ${ }^{73}$ a tulajdonosok kötelezhetôk a gépjármúvek átadására. ${ }^{74}$ Korlátozás alá vonható a vízi közlekedés és a légi közlekedés, és az ezen eszközök múködéséhez szükséges üzemanyag kereskedelme korlátozható. Korlátozható ezenkívül a vasúti közlekedés is. ${ }^{75} \mathrm{~A}$ törvény következő eszközcsoportja a szociális és egészségügyi intézmények feladataival kapcsolatos. Így például a kórházakban gondozásra szoruló személyeket a kezelőegységben helyezhet el, korábbi megegyezéstől vagy előirástól függetlenül. ${ }^{76}$ Az intézkedések következő csoportja a munkavállalás kérdéseivel foglalkozik, így külön kormányrendelet határozhatja meg bizonyos, az adott vészhelyzettel kapcsolatban kiemelt jelentőségú szektorokban (például egészségügy, állami szféra stb.) az új munkatársak felvételével, a béremelés mértékével kapcsolatos szabályokat, eltérést engedhet a munkaszerződéstől például a munkaórák és pihenőidő tekintetében, valamint korlátozhatja az elbocsátásokat. ${ }^{77} \mathrm{~A}$ törvény alapján lehetőség van munkakötelezettség megállapítására a megfelelő, létfontosságú szektorokban (külön nevesítve az egészségügyi képzettséggel rendelkezőket), amely a 18 és 67 év közöttiekre vonatkozik. Számukra a hatóságok állíthatnak ki munkautasítást, meghatározva a munkakötelezettség helyét és idejét. ${ }^{78} \mathrm{~A}$ munkaügyi hatóság állítja ki a munkarendet a munkavállaló számára, ugyanakkor ennek korlátait maga a törvény tartalmazza. ${ }^{79} \mathrm{~A}$ törvény lehetőséget biztosít a közigazgatási szervezetrendszert és múködést érintő kérdések ideiglenes átszervezésére is. ${ }^{80}$ Elkülönítve tartalmazza a törvény a katonai készültséggel kapcsolatos szabályozást: ezek az intézkedések részben már szerepelnek a törvényben, annyi különbséggel, hogy nem a civil hatóságok, hanem a védelmi erők rendelkezhetnek annak alkalmazásáról. Így például előírhatják javak bizonyos kötelező leadását, bizonyos szolgáltatások nyújtását, szárazföldi, vízi, légi jármúvek átadását, bizonyos magánterületek átadását. ${ }^{81}$ Végezetül a törvény a mentésben részt vevő szervek számára teszi lehetôvé hasonló különleges jogkörök gyakorlását. ${ }^{82}$

A Honvédelmi tv. először az általános rendelkezéseket fogalmazza meg, így például az olyan személy, akiről feltételezhető, hogy hazaáruló vagy más módon veszélyezteti a védelmi erőfeszítéseket, kötelezhető a rendőrség által meghatározott helyen maradni, a lakhe-

72 Vészhelyzeti tv. 67-73. szakasz.

73 Vészhelyzeti tv. 74-76. szakasz.

74 Vészhelyzeti tv. 78. szakasz.

75 Vészhelyzeti tv. 79-83. szakasz.

76 Vészhelyzeti tv. 86. szakasz.

77 Vészhelyzeti tv. 91-94. szakasz.

78 Vészhelyzeti tv. 95. szakasz.

79 Vészhelyzeti tv. 97-99. szakasz.

80 Vészhelyzeti tv. 104-109. szakasz.

81 Vészhelyzeti tv. 110-113. szakasz.

82 Vészhelyzeti tv. 116-122. szakasz. 
lyének elhagyására kötelezhető vagy pedig az ellenőrzés alá vonható. ${ }^{83}$ Ezzel szemben fellebbezéssel lehet élni a helyi bíróság felé, ugyanakkor az érintett rendőrségi őrizetbe vehetô, amíg bíróság dönt a kérdésről. ${ }^{84}$ Amennyiben valamilyen egyesület veszélyeztette a védelmi erőfeszítéseket, úgy a kormány részben vagy egészben felfüggesztheti annak múködését. ${ }^{85} \mathrm{~A}$ gyứlések előzetes, írásban történő bejelentésének kötelezettsége elôirható, amit legkésőbb három nappal az esemény elôtt írásban kell megtenni. ${ }^{86}$ Amennyiben a gyúlés veszélyezteti a védelmi erőfeszítéseket, úgy a rendőrség dönthet úgy, hogy nem engedélyezi. A regionális közigazgatási szervek korlátozhatják vagy megtilthatják az utcai tartózkodást, ha a védelem érdekei ezt kívánják. ${ }^{87}$

A Honvédelmi tv. ezt követően a katonai és gazdasági védelem speciális eszközeit taglalja. A kormány például elooírhatja a vállalatoknak bizonyos javak eloállítását, és megtilthatja más javak elóállítását, ${ }^{88}$ míg a Belügyminisztérium dönthet bizonyos javak elkobzásáról vagy állami felügyelet alá helyezésérooll. ${ }^{89} \mathrm{~A}$ katonai hatóságok főleg operatív kérdésekben dönthetnek, például a lakosság kitelepítéséről a harcok által érintett területen, ám ezen döntések időben korlátozottak, két hetet meghaladó időtartam esetén a kormánynak kell döntenie róluk.90

\section{A koronavírus-járványra adott állami reakció}

Finnországban már a járvány kitörését követően nem sokkal, 2019. novemberben ülésezett a kormány a szükségállapot bevezetésének feltételeivel kapcsolatosan. ${ }^{91} \mathrm{Az}$ első koronavírus-fertőzöttet 2020. január 29-én találták meg. A vírus felkerült a fertőző betegségek jogszabályi listájára egy február 13-i döntéssel. A fertőzések száma az országban március elején ugrott meg, miután az előző hónapban az Alpokban síelő finn turisták hazatértek. ${ }^{92}$ Erre válaszul március 16-án a köztársasági elnök és a kormány a szükségállapot bevezetése mellett döntött, az ország történetében először a vonatkozó törvények elfogadása óta.93 A kivételes körülmények alapján az egészségügyi és gazdasági vészhelyzet is megállapításra került, mint a szükségállapot jogalapja. ${ }^{94}$ Számos intézkedésre került sor a Vészhelyzeti tv.

83 Honvédelmi tv. 8. szakasz.

84 Honvédelmi tv. 9. szakasz.

85 Honvédelmi tv. 10. szakasz.

86 Honvédelmi tv. 11. szakasz.

87 Honvédelmi tv. 12. szakasz.

88 Honvédelmi tv. 17. szakasz.

89 Honvédelmi tv. 20. szakasz.

90 Honvédelmi tv. 23-27. szakasz.

91 Elérhető: www.helsinkitimes.fi/finland/finland-news/domestic/18360-finland-close-to-but-not-quite-yetin-state-of-emergency-write-hs-and-yle.html (Letöltve: 2020. december 15.).

92 Tiirinki et al., 2020.

93 Salminen, 2020, 1116. o.

94 Scheinin, 2020. 
és más törvények releváns rendelkezései alapján. ${ }^{95}$ Habár a fertőzések elsősorban a fôváros, Helsinki régióját érintették, a korlátozó intézkedések alkalmazását az egész országra elrendelték. Az intézkedések mögött teljes politikai egyetértés állt. ${ }^{96}$

A kormány összesen mintegy húsz rendeletet adott ki, illetve hosszabbította meg azok hatályát a Vészhelyzeti tv. alapján az egészségügyi és szociális ellátóegységek múködésével kapcsolatban; az egészségügyi szolgáltatásokban használt gyógyszerek, áruk és szolgáltatások értékesítésének korlátozásáról; egészségügyi és szociális jóléti szolgáltatásokról és egészségvédelemről; a munkaviszonyok és az elbocsátások feltételeitől való eltéréseket állapítottak meg, illetve munkakötelezettséget, valamint az iskolák és más oktatási intézmények bezárásáról rendelkeztek. A kormány 2020. március 28. és április 15. között korlátozta az emberek mozgását Uusimaa régió és az ország más területei között. Az éttermek, kávézók és bárok zárva voltak május 31-ig, kivéve az elviteli és kiszállítási szolgáltatásokat. ${ }^{97}$ Míg a kormányrendeletek többségét a Vészhelyzeti tv. alapján fogadták el, ez utóbbi jogszabályt az alkotmány 23. szakaszában foglalt rendkívüli helyzetekben alkalmazható alapjog-korlátozási lehetőség alapján alkották meg, törvényi formában.$^{98}$ Egyéb intézkedésekre is sor került, amelyeket nem a szükségállapot alapján, hanem a vonatkozó ágazati törvények alapján hoztak meg. Például a határellenőrzés szigorítására a határőrségről szóló törvény99 alapján került sor. ${ }^{100}$

Fontos ugyanakkor megjegyezni, hogy a tényleges jogi korlátozások mellett számos soft law jellegú, javaslati formájú rendelkezésre is sor került a Fertőzés tv. előírásai szerint. Így például a társadalmi távolságtartás vonatkozásában, amelyet csak javasoltak a hatóságok a munkáltatóknak és a közvéleménynek. ${ }^{101} \mathrm{~A}$ Szociális és Egészségügyi Minisztérium létrehozott egy munkacsoportot a szociális és egészségügyi területen hozott intézkedések tervezésére, végrehajtására és koordinálására. Ezzel együtt több hazai és nemzetközi ügynökséggel is egyeztetéseket indított a gyógyszerészeti szolgáltatások és ellátás folyamatosságának biztosítása érdekében. Ajánlásokat fogalmaztak meg a helyi és regionális hatóságoknak, illetve a munkáltatóknak a fertőzés terjedésének visszaszorítása érdekében. ${ }^{102}$ A korlátozások mellett a finn kormány jelentős összegeket fordított a bajba jutott vállalkozások megsegítésére, amelyek összege nyárra elérte a 15 milliárd eurót is. ${ }^{103}$

$95 \mathrm{Az}$ intézkedések teljes listáját lásd: Tiirinki et al., 2020 (2. táblázat).

96 Moisio, 2020.

97 Elérhető: www.europarl.europa.eu/RegData/etudes/BRIE/2020/651972/EPRS_BRI(2020)651972_EN.pdf(Letöltve: 2020 . december 15.).

98 A szállás- és vendéglátóhelyekról szóló törvény ideiglenes módosítása (Laki majoitus- ja ravitsemistoiminnasta annetun lain väliaikaisesta muuttamisesta 153/2020); lásd még: Scheinin, 2020.

99 2005/578. Rajavartiolaki (a továbbiakban: Határőrség tv.).

100 Salminen, 2020, 1117. o.

101 Scheinin, 2020.

102 Elérhető: https://valtioneuvosto.fi/en/information-on-coronavirus/ministry-of-social-affairs-and-health (Letöltve: 2020. december 15.).

103 Moision, 2020. 
A különleges jogrend bevezetésével és alkalmazásával kapcsolatosan több probléma is felmerült. Ezek némelyike általános az ilyen helyzetekben, így például az alapjogok sérülése és a kormányzati hatalom növekedése, ezzel összefüggésben pedig a felelősségi kérdések elmosódása. ${ }^{104}$ Specifikus problémák is említhetők azonban, így például az, hogy bár a gazdasági vészhelyzet is jogalapként került feltüntetésre a szükségállapot bevezetésénél, a gazdasági intézkedésekre végül nem a törvény keretei között került sor. Problémát jelentett továbbá a Vészhelyzeti tv. komplikált felépítése, amelynek alkalmazása sokszor nem állt összhangban az alkotmány 23. szakaszával. A szükségállapoti kormányrendeletek megfogalmazása a megfelelő jogi és alkotmányos ismeretek hiányáról árulkodott, sokszor túl egyszerủ volt a megszövegezés, az nem hivatkozott az elfogadás jogalapjára és a nemzetközi kötelezettségeknek való megfelelőségre. A jogi szakértelem hiánya a törvényhozásnál is hiányzott, ahol sokszor nem bontották ki egy-egy kérdés nemzetközi jogi dimenzióját, illetve bizonyos esetekben az alkotmányosság háttérbe szorult a politikai konszenzus mögött. Sok esetben a nemzetközi jogi kötelezettségek teljesítése a háttérbe szorult, ami azért is különösen fontos, mert az alkotmány nem határoz meg korlátozhatatlan alapjogokat, ebben teljes egészében a nemzetközi jogi instrumentumokra bízva a jogalkotót. Uusimaa régió - ahol a népesség harmada él - elszigetelése az ország többi részétől csak mint a mozgásszabadság korlátozása került a jogalkotó elé, ugyanakkor a régióban magában nem vezettek be az ott élő veszélyeztettek védelmére szolgáló korlátozó intézkedéseket, ami a legrosszabb esetben közvetetten az ott élók élethez való jogát is súlyosan érinthette volna. ${ }^{105}$

Maga a törvényhozás Alkotmányjogi Bizottsága is számos alkalommal fogalmazott meg kritikát azzal kapcsolatosan, ahogy a kormány a különleges jogrendi helyzetet és a kapcsolódó jogalkotást kezeli. ${ }^{106}$ Például szóvá tette azt, hogy habár az elrendelés alapjának tette meg, a kormány egyetlen rendelkezése sem alapul a gazdasági vészhelyzeten ${ }^{107} \mathrm{~A}$ bizottság meglehetősen kritikusnak bizonyult, és bár minden rendelkezést jóváhagyott, ezek rendszeresen tartalmaztak valamilyen kritikát. Két esetben maga a kormány döntött a rendelet visszavonásáról a súlyos kritikák hatására, ezek esetén könnyedén elképzelhető, hogy azokat a törvényhozás nem hagyta volna hatályban. ${ }^{108}$ Uusimaa régió elszigetelése az ország többi részétől az egyik legnehezebb döntésnek bizonyult a járvány kezelése során. A szigorú parlamenti felülvizsgálatnak is köszönhetően a kormány megnövekedett hatalma nem vezetett autoriter törekvésekhez. ${ }^{109}$

Számos pozitívumot is el lehet azonban mondani a finn járványkezelésről. Bár a törvényhozás kiemelt szerepe a rendkívüli jogalkotásban lassítja és nehezíti az eredményes fel-

104 Salminen, 2020, 1117. o.

105 Scheinin, 2020.

106 Salminen, 2020, 1117. 0.; Neuvonen, 2020.

107 Salminen, 2020, 1124. 0 .

108 Salminen, 2020, 1124-1225. o.

109 Makarychev-Romashko, 2021. 
lépést, jogi biztosítékot is jelent a hatalmi túlkapások ellen. Ez azért is különösen fontos, mivel az országban nem múködik elkülönült alkotmánybíróság. ${ }^{10}$ Egyértelmúen a jó gyakorlatok közé sorolható, hogy külső jogi és alkotmányjogi szakértőket is bevontak a döntések alkotmányosságának vizsgálatába. ${ }^{111} \mathrm{Az}$, hogy számos esetben jogi kötőerôvel nem bíró ajánlásokat tettek a polgároknak a jogi kikényszerítés helyett, segített fenntartani a normalitás érzését. Az összes meghozott rendelet tartalmazott alkalmazási határidőre vonatkozó klauzulát a törvény szövegével összhangban. ${ }^{112}$ Számos olyan intézkedés került bevezetésre, amely a lezárások alatt a polgárok mentális egészségének és szabadságának megőrzésére szolgáltak, ami az egész társadalom összefogásával valósult meg. ${ }^{113}$

2020. május 6-án a kormány bejelentette, hogy Finnország „hibrid stratégiára” tér át, ami azt jelenti, hogy a korlátozásokat lassan megszüntetik, és a nagy tömegrendezvényekkel, éttermekkel kapcsolatos szigorú szabályozások és az idősek védelme kerül előtérbe. ${ }^{114}$ Május 14-én folytatódott az iskolai oktatás, és megindult a határokon a közlekedés. Június 1-jére engedélyezték az 50 fő alatti köztéri gyưléseket, és a nyilvános helyek újra kinyitottak. Június 15-én a kormány döntött a szükségállapot végéről, és azt június 16-i hatállyal megszüntette. ${ }^{115}$

\section{A különleges jogrend a gyakorlatban, viták és kihívások}

Mint a térség számos államában, a finn függetlenedés történelme is szorosan összekapcsolódik a különleges jogrenddel. ${ }^{116} \mathrm{~A}$ fiatal ország függetlensége számára a fenyegetés elsősorban kívülrôl érkezhetett, így az elsődleges cél a külső fegyveres veszély elhárítása volt. Ennek megfelelően különleges jogrendról csak háborús helyzetben lehetett beszélni. ${ }^{117} \mathrm{~A}$ nem fegyveres agresszióhoz kapcsolódó különleges jogrendi szabályozás kidolgozása egészen az 1990-es évekig váratott magára, ekkor fogadták el az első vészhelyzeti törvényt, amely a Honvédelmi tv.-ben található védelmi állapottól elkülönülten szabályozta a különleges jogrendet. Az 1999-ben elfogadott alkotmány megreformálta Finnország jogrendszerét, és hamarosan nyilvánvaló vált, hogy a korábbi vészhelyzeti törvény az új alkotmányba ütközik, ezért 2011-ben felváltották azt a jelenleg hatályos törvénnyel. Bár a cél az volt, hogy az alkotmányos rendbe illeszkedő új tör-

110 Neuvonen, 2020.

111 Grogan, 2020.

112 Scheinin, 2020.

113 Makarychev-Romashko, 2021.

114 Elérhető: https://valtioneuvosto.fi/-/10616/valtioneuvoston-periaatepaatos-suunnitelmasta-koronakriisinhallinnan-hybridistrategiaksi (Letöltve: 2020. december 15.).

115 Elérhető: www.europarl.europa.eu/RegData/etudes/BRIE/2020/651972/EPRS_BRI(2020)651972_EN.pdf(Letöltve: 2020. december 15.).

$116 \mathrm{Az}$ ország hosszú évszázadokon keresztül állt előbb svéd, majd orosz uralom alatt, és függetlenségét csak 1917-ben nyerte vissza, amelyet rögtön a fehérek és vörösök közötti polgárháború követett 1918-ban. Orosz szomszédjával ezt követően többször háborúra kényszerült (Moisio, 2020).

117 Cornell-Salminen, 2018, 238. o. 
vényt hozzanak, a kormányzat széles körú felhatalmazása, valamint a gazdasággal kapcsolatos esetkörök különleges jogrend alá vétele komoly alkotmányjogi aggályokat vetett fel. Mindezen okokból került sor a törvény kivételes jogalkotási eljárással történő elfogadására, amely azonban ma már igen ritkán alkalmazott megoldás, és sok kritikára adott okot. ${ }^{118}$

Felmerült annak lehetősége, hogy bizonyos jogok jelenlegi szúk korlátozásán túlmenően szélesebb körü beavatkozást tegyenek lehetôvé, de ez az elképzelés elhalt. İgy, bár a hatályos törvényben jelentőségét csökkentették valamelyest, igen érdekes módon továbbra is jelentős szerep jut a törvényhozásnak a különleges jogrend alkalmazása során. A különleges jogrendi szabályozás semmilyen útmutatást nem tartalmaz arra az esetre, ha a parlament valamilyen okból nem tudna összeülni. A jelenleg hatályos törvény sokkal inkább konform a 2012-es finn alkotmányreform utáni alkotmányos renddel, mint azt megelőzően, ám a kivételes jogalkotással történő elfogadás, valamint az a tény, hogy tisztán gazdasági esetkörök továbbra is a szükségállapot alá tartoznak, továbbra is komoly alkotmányjogi aggályokat vet fel. ${ }^{119}$

2000 óta számos változás történt a különleges jogrend szabályozásában. Először is, a kivételes körülmények fogalmát egyszerúsítették, hogy jobban illeszkedjen Finnország nemzetközi kötelezettségvállalásaihoz. Másodszor, az alkotmány 2012. évi felülvizsgálata után már nem szükséges, hogy minden esetben a törvényhozás alkossa meg az alapvető jogokat korlátozó jogszabályokat, hanem törvény - így a Vészhelyzeti tv. - felhatalmazása alapján a kormány is alkothat ilyen jogszabályt. ${ }^{120}$

A Vészhelyzeti tv.-t a megalkotása óta csak egyetlen alkalommal alkalmazták, a koronavírus-járvány idején, 2020 tavaszán. Ennek megfelelően a törvénnyel kapcsolatos bírósági joggyakorlat sem alakult ki, azzal nem foglalkoznak bírói ítéletek.

\section{5. Összegzés}

Az alábbi táblázat tartalmazza a finn különleges jogrendi esetkörökkel kapcsolatos legfontosabb szabályozásokat:

118 Cornell-Salminen, 2018, 240-241. o.

119 Cornell-Salminen, 2018, 245. o.

120 Cornell-Salminen, 2018, 246. o. 


\begin{tabular}{|c|c|c|}
\hline & Szükségállapot & Védelmi állapot \\
\hline $\begin{array}{l}\text { Szabályozás } \\
\text { szintje }\end{array}$ & \multicolumn{2}{|c|}{$\begin{array}{l}\text { Minimális alkotmányos, részletes törvényi } \\
\text { (Vészhelyzeti tv., Honvédelmi tv.) }\end{array}$} \\
\hline Elrendelési okok & $\begin{array}{l}\text { — fegyveres vagy hasonló támadás } \\
\text { Finnország ellen és annak közvetlen } \\
\text { következményei } \\
\text { — Finnország elleni fegyveres vagy } \\
\text { hasonló támadás jelentôs veszélye } \\
\text { — a lakosság megélhetését vagy } \\
\text { az ország gazdaságának alapjait } \\
\text { különösen súlyosan érintő esemény } \\
\text { vagy veszély, amelyek jelentős } \\
\text { kockázatot jelentenek a társadalom } \\
\text { létfontosságú funkcióira } \\
\text { — súlyos baleset és annak közvetlen } \\
\text { következményei } \\
\text { — nagyon széles körben elterjedt ve- } \\
\text { szélyes fertőző betegség }\end{array}$ & $\begin{array}{l}\text { — külső fegyveres fenyegetés } \\
\text { — az alkotmányos rend megváltoz- } \\
\text { tatására irányuló belső erőszakos } \\
\text { zavargások }\end{array}$ \\
\hline Elrendelés & $\begin{array}{l}\text { — A kormány és a köztársasági elnök } \\
\text { közösen dönt róla, majd a kormány } \\
\text { kormányrendeletet alkot; } \\
\text { — az intézkedéseket tartalmazó kor- } \\
\text { mányrendeletek vonatkozásában } \\
\text { a törvényhozás dönt; } \\
\text { — ezek három, illetve hat hónapig } \\
\text { alkothatók meg, hatályuk egy } \\
\text { alkalommal legfeljebb hat hónappal } \\
\text { meghosszabbítható, parlamenti } \\
\text { jóváhagyással. }\end{array}$ & $\begin{array}{l}\text { - A köztársasági elnök rendeletben } \\
\text { dönt a bevezetésről; } \\
\text { — az alapján hozott rendelkezés } \\
\text { legfeljebb három hónapra hozható, } \\
\text { a parlament megerósítése szük- } \\
\text { séges hozzá; } \\
\text { — hatálya egy évvel } \\
\text { meghosszabbítható. }\end{array}$ \\
\hline Felhatalmazott & \multicolumn{2}{|c|}{ A kormány, minisztériumok, a Védelmi Erők } \\
\hline $\begin{array}{l}\text { Előkészítő } \\
\text { szervek }\end{array}$ & \multicolumn{2}{|c|}{$\begin{array}{c}\text { A kormány Külügyi és Biztonságpolitikai Miniszteri Bizottsága, Biztonsági } \\
\text { Bizottság, Kormányzati Eseményközpont, minisztériumok }\end{array}$} \\
\hline Gyakorlati esetek & Covid-19-járvány kezelése & Nincs \\
\hline $\begin{array}{l}\text { Különleges } \\
\text { jogrendnek nem } \\
\text { minősülö rend- } \\
\text { kívüli helyzet }\end{array}$ & \multicolumn{2}{|c|}{ Nem kerül nevesítésre, több törvény is tartalmaz rendelkezéseket. } \\
\hline
\end{tabular}

\section{8. táblázat}

Finnország különleges jogrendi szabályozásának összefoglalása

Forrás: a szerző saját szerkesztése 
A finn különleges jogrend szabályozása sok szempontból sajátosnak mondható. Az alkotmány a különleges jogrend kérdésében nem tartalmaz rendelkezéseket, csak az alapjog-korlátozás szempontjából. ${ }^{121}$ Ez lehetőséget teremt arra, hogy háború, illetve egyéb krízishelyzet esetén az alapjogokat korlátozzák. Az érdemi szabályozást két törvény tartalmazza: a védelmi helyzet szabályozását a Honvédelmi tv., a szükségállapot szabályozását a Vészhelyzeti tv. Utóbbi érdekessége, hogy úgynevezett kivételes jogalkotási eljárásban került elfogadásra, ami azt jelenti, hogy tartalma kivételt jelent az alkotmány alól, tulajdonképpen szétfeszíti az alkotmány kereteit, és saját tartalommal tölti ki azokat. Ennek megfelelően az elfogadási eljárása az alkotmánymódosításokéhoz hasonló. Ezt a fajta jogalkotást a finn jogalkotó is sok kritikával illeti, és igyekszik mellőzni használatát. Hogy végül mégis így került sor a törvény elfogadására, annak köszönhető, hogy a különleges jogrendi szabályozás és az alkotmány reformja párhuzamosan futott, és rendes eljárásban a törvény nem illeszkedett volna megfelelően az új alkotmány előírásaihoz (például a kizárólag gazdasági jellegú esetkörök különleges jogrend alá vonása miatt), rákényszerítve ezzel a jogalkotót a kivételes jogalkotási eljárásra.

A szükségállapot elrendelésére kivételes körülmények fennállása esetén kerülhet sor, ezek listáját a törvény részletesen felsorolja. Ezek között szerepel a fegyveres támadás vagy annak közvetlen veszélye, olyan veszély, amely súlyosan fenyegeti a társadalom létfontosságú funkcióit, súlyos baleset, illetve súlyos fertőző betegség. Védelmi állapotot külső fegyveres támadás, illetve az alkotmányos rend megváltoztatására irányuló belső erőszakos zavargások esetén lehet elrendelni. A szükségállapot bevezetéséról a kormány és a köztársasági elnök közösen dönt, míg a védelmi állapotról a köztársasági elnök dönt. A finn szabályozás újabb sajátossága itt is megtalálható: a különleges jogrend bevezetéséról szóló döntés semmilyen parlamenti kontroll alatt nem áll, alkalmazásának határideje sincs meghatározva. Ahol a törvényhozás szerepe jelentős, az az egyes jogkorlátozó, úgynevezett végrehajtási rendeletek felülvizsgálata, amelyet az adott törvények részletes katalógusa alapján hozhatnak meg. Ezek már rendelkeznek alkalmazási határidővel, szükségállapot esetén ez általánosan hat hónap, sürgősség esetén három hónap, egyszeri hat hónapos hosszabbítási lehetőséggel. A védelmi állapotnál a határidő három hónap, amely egyszeri alkalommal hat hónappal meghosszabbítható. A végrehajtási rendeletek azonnal hatályba lépnek, ám alkalmazásuk nem történhet meg addig, amíg a törvényhozás felül nem vizsgálja őket (kivétel a sürgősségi rendeletek). Bár nevesítésre nem kerül, a törvény alapján egyértelmú, hogy a szükségállapot esetén a kormány, míg a védelmi állapot esetén a köztársasági elnök szerepe jelentős. A két vonatkozó jogszabály együttes alkalmazása - törvény eltérő rendelkezése nélkül - nem kizárt, a két típus közül a védelmi állapot számít súlyosabbnak.

A finn szabályozás alapelve, hogy a jogalkotó csak a legvégső esetben nyúljon a különleges jogrend eszköztárához. Ennek megfelelően az egyes ágazati törvények is széles körü 
jogosítványokat tartalmaznak a kivételes körülmények szintjét el nem érô események kezelésére. Például a Határőrség tv. lehetôvé teszi a határôrizet szigorítását, a Fertőzés tv. járványügyi intézkedések meghozatalát, a Rendőrségi tv. jogosítványokat biztosít a zavargások kezelésére, míg a Mentési tv. „mentési műveletek” során ad lehetőséget a katasztrófavédelmi akciókra. A különleges jogrendet megelőző, felkészülést segítő szervek is igen szerteágazóak, aminek a célja szintén az, hogy az alkalmazás előtt a kormány minden rendes eszközt kimerítsen a probléma kezelésére. Legfontosabb szerepe a kormánynak van, amely megalkotja a társadalmi biztonsági stratégiát, amely a legkomolyabb fenyegetéseket azonosítja be. A kormány mellett múködik a Külügyi és Biztonságpolitikai Miniszteri Bizottság, amely a legfontosabb nemzetbiztonsági szerv, elnöke a miniszterelnök, tagjai a miniszterek, üléseit pedig a köztársasági elnökkel közösen tartja. A miniszterelnök mellett múködő miniszterelnöki hivatal múködteti a Kormányzati Eseményközpontot, amely valós idejű módon követi a vészhelyzeti események kialakulását a nyilvános és az államapparátustól érkező információk alapján. Fontos szerep jut még a minisztériumoknak: a Belügyminisztérium az országot érintő veszélyek felmérése érdekében háromévente nemzeti kockázatelemzést készít, míg a Védelmi Minisztérium mellett múkködő Biztonsági Bizottság az átfogó védelem kérdéseiben nyújt segítséget. A finn átfogó védelmi koncepció azt jelenti, hogy a vészhelyzetek elhárításában a társadalom egésze részt vállal.

Az alapjogok korlátozása kapcsán az alkotmány 23. szakasza az irányadó. Az alkotmány hiányossága, hogy nem határozza meg a korlátozhatatlan alapjogok listáját, ezt kizárólag a nemzetközi egyezményeknek való megfelelőség kritériumára bízva. Ez azért is különösen jelentős, mert az ország nem létezik elkülönült alkotmánybírósággal. A szakasz az országot érő támadás vagy bármilyen más komoly veszélyt jelentő vészhelyzet esetén teszi lehetôvé az alapjogok korlátozását. Az egyes különleges jogrendi törvényekben található esetkörök mellett bármilyen, ott nem nevesített korlátozásra is sor kerülhet, az alkotmány 23. szakasza alapján elfogadott törvény alapján.

A jelenlegi magyar szabályozással összehasonlítva elmondható, hogy a finn szabályozás mindössze két esetkörrel operál, szemben a magyar jogrendben található hat esetkörrel. A finn esetkörök nem különíthetők el egymástól élesen, sőt, a kapcsolódó törvények egyidejû́ alkalmazása sem kizárt, több elrendelési esetkör átfedést mutat egymással (például a fegyveres támadás). Ezzel szemben a magyar szabályozás esetén az egyes különleges jogrendi típusok tartalmi elemei élesen elkülönülnek egymástól. A finn szükségállapot a magyar hadiállapot mellett a veszélyhelyzet és több válsághelyzeti szabályozás jegyeit is magában foglalja, hiszen azt súlyos baleset, katasztrófa és fertőző betegség esetén is el lehet rendelni. Ráadásul a finn védelmi állapot sem feleltethetô meg a magyar rendkívüli állapotnak, hiszen előbbi magában foglalja a magyar szükségállapot alatt szabályozott alkotmányos rend megváltoztatására irányuló erőszakos fellépést. Az Alaptörvény kilencedik módosítása alapján a két szabályozás nem sokban közeledik egymáshoz. Ugyan a magyar szabályozásban is összeolvad több különleges jogrendi jogintézmény, és csak a hadiállapot, a szükségállapot, 
valamint a veszélyhelyzet marad, a két jogrend esetköreit még így is nehéz összehasonlítani egymással. A finn szükségállapot például továbbra is részben a magyar hadiállapot (külső fegyveres támadás), valamint a veszélyhelyzet jegyeit is magán viseli majd.

Az elrendelés kapcsán is éles eltérés mutatkozik: idehaza esetkörtől függően az Országgyúlés (szükség-, illetve hadiállapot) vagy a Kormány (veszélyhelyzet) jogosult azok elrendelésére, míg a finn szabályozásban a szükségállapotot a kormány és a köztársasági elnök, addig a hadiállapotot a köztársasági elnök rendeli el. Míg idehaza erôs a parlamenti kontroll az elrendelés kapcsán, addig a finneknél semmilyen parlamenti hozzájárulás nem szükséges a különleges jogrend bevezetéséhez. Kizárólag az egyes végrehajtási rendeletek esetén van szükség a törvényhozás utólagos jóváhagyására. Ez a fajta megoldás a magyar veszélyhelyzet jelenlegi szabályozásához hasonlítható, ám nem teljes egészében, különösen az Alaptörvény kilencedik módosítása szerinti új szabályozás alapján nem, amely utóbbi értelmében hazánkban magát a veszélyhelyzetet kell meghosszabbítani a határidőn túl, nem pedig az egyes veszélyhelyzeti kormányrendeletek hatályát. A két határidő egyébként lényegesen eltér: míg idehaza 15 nap, Finnországban 3-6 hónap. Bár az eltérések kétségkívül jelentősek, mégsem mondható, hogy a finneknél alacsonyabb lenne a különleges jogrend esetén a kormány feletti országgyúlési kontroll, mint idehaza. Ennek oka az, hogy a különleges jogrend ugyan formailag elrendelhetô a törvényhozás hozzájárulása nélkül, tényleges tartalommal csak annak hozzájárulásával tölthetô ki.

Mindezek alapján elmondható, hogy a magyar és finn szabályozás nehezen hasonlítható össze, ugyanis lényegesen eltérő rendszerben gondolkodnak. A finneknél bizonyos szempontból nagyobb hangsúly jut a törvényhozásnak a különleges jogrend során - amely esetén még utalás sem történik arra az esetre, ha a parlament nem tud ülésezni és elvégezni a kontrollt a végrehajtási rendeletek felett -, ami alkotmányos szempontból biztosabb, ám csökkenti annak hatékonyságát. Ugyanakkor más szempontból jóval kisebb a törvényhozás szerepe, hiszen ott a parlament nem szólhat bele a különleges jogrend elrendelésébe, csak annak szabályai kapcsán gyakorol kontrollt. Jelentős eltérés mutatkozik nemcsak az egyes különleges jogrendi esetkörök terén, de abban is, hogy mit tekint az adott jogrendszer a különleges jogrend részének. A finn rendszer ugyanakkor számos problémával küzd, így például azzal, hogy a szükségállapoti szabályozást tartalmazó törvény nehezen illeszthető be az alkotmányos rendbe, annak szerkezete pedig túlságosan is szerteágazó és bonyolult. Ráadásul a különleges jogrendi törvények mellett az alkotmány 23. cikke alapján is lehet alapjog-korlátozó intézkedéseket hozni. Mindezek alapján kijelenthető, hogy a magyar szabályozás - különösen a kilencedik Alaptörvény-módosítást követően - sokkal gördülékenyebb és jobban beágyazott a jogrendszerbe. 


\section{Irodalomjegyzék}

Cornell, A. J., SAlminen, J. (2018) 'Emergency Laws in Comparative Constitutional Law The Case of Sweden and Finland", German Law Journal, 19(2), 219-250. 0.

Grogan, J. (2020) States of Emergency [Online]. Elérhető: https://verfassungsblog.de/states-ofemergency/ (Letöltve: 2020. december 15.)

HusA, J. (2011) The Constitution of Finland: A Contextual Analysis. Oxford-Portland: Hart Publishing

KHAKEE, A. (2009) Securing Democracy? A Comparative Analysis of Emergency Powers in Europe [Online]. Elérhető: www.files.ethz.ch/isn/99550/PP30_Anna_Khakee_Emergency_ Powers.pdf (Letöltve: 2020. december 15.)

Makarychev, A., Romashko, T. (2021) 'Precarious Sovereignty in a Post-liberal Europe: The COVID-19 Emergency in Estonia and Finland', Chinese Political Science Review, 6(1), 63-85. o.

MoIsio, S. (2020) 'State Power and the COVID-19 Pandemic: The Case of Finland', Eurasian Geography and Economics, (61)4-5, 598-605. o.

Neuvonen, P. J. (2020) 'The COVID-19 Policymaking under the Auspices of Parliamentary Constitutional Review: The Case of Finland and Its Implications', European Policy Analysis, 6(2), 226-237. 0.

OJANEN, T. (2007) 'EU Law and the Response of the Constitutional Law Committee of the Finnish Parliament' in Wahlgren, P. (szerk.) Scandinavian Studies in Law. Stockholm: Stockholm University Law Faculty

Penttila, R. (1991) Finland's Search for Security through Defence, 1944-89. New York: Palgrave Macmillan

SAlminen, J. (2020) 'Finsk krishantering i fredstid - beredskapslagen tillämpas för första gången', Svensk Juristtidning, 105(10), 1116-1129. o.

SAlONIUS-PASTERNAK, C. (2019) 'Finland's amibigiuous deterrence' in Vanaga, N., Rostoks, T. (szerk.) Deterring Russia in Europe: Defence Strategies for Neighbouring States. New York: Routledge

Scheinin, M. (2020) The COVID-19 Emergency in Finland: Best Practice and Problems [Online]. Elérhető: https://verfassungsblog.de/the-Covid-19-emergency-in-finland-best-practiceand-problems/ (Letöltve: 2020. december 15.)

Tiirinki, H., Tynkkynen, L-K., Sovala, M., Atkins, S., Koivusalo, M., Rautiainen, P., Jormanainen, V., Keskimäki, I. (2020) 'COVID-19 Pandemic in Finland - Preliminary Analysis on Health System Response and Economic Consequences', Health Policy and Technology, 9(4), 649-662. o.

Vanaga, N., Rostoks, T. (2018) Deterring Russia in Europe: Defence Strategies for Neighbouring States. 1. kiadás. New York: Routledge 


\title{
14. Franciaország: folyamatosan különleges jogrend, a koronavírus idején is
}

\author{
STOLLSTEINER GABRIEL
}

\section{A különleges jogrend szabályozása és esetkörei}

Viharos 19. és 20. századi történelméből következően Franciaország különböző különleges jogrendre vonatkozó szabályokkal rendelkezik. Minden egyes különleges jogrend olyan körülményeknek köszönheti a megjelenését, amelyek esetében szükségesnek ítélték alkalmazását. Ennek eredményeként a kivételes rendszerek mind forrásukban, mind alkalmazásukban eltérnek. Más országokkal ellentétben, ahol az alkotmány a különleges jogrendek minden esetét szabályozza, a francia rendszer a különböző szintú - különböző helyzetek kezelésére szolgáló - szabályok egymás mellé rendelésének következménye.

A 2015-ös terrortámadásokat követően felvetődött a különleges jogrend meghatározásának kérdése. A vita a 2000-es évek elején kezdődött a szeptember 11-i támadásokat követően: a szükségállapot két fogalma szembesül egymással. Első, klasszikus értelemben a különleges jogrenden azt az időszakot értjük, amely alatt a békés időszakokra előírt törvényi szabályokat a veszély függvényében átlépik, felfüggesztik vagy félreteszik. ${ }^{1}$ Ebben az időszakban egyrészt a hatalom koncentrációja zajlik, általában a végrehajtó hatalom

1 Saint-Bonnet, 2008, 30. o.

Stollsteiner Gabriel

gabriel.stollsteiner@mfi.gov.hu

PhD-hallgató, tanársegéd (Université Paris-Est Créteil)

kutató (Mádl Ferenc Összehasonlító Jogi Intézet)

Stollsteiner, G. (2021) 'Franciaország: folyamatosan különleges jogrend, a koronavírus idején is’ in Nagy, Z., Horváth, A. (szerk.) A különleges jogrend és nemzeti szabályozási modelljei, 322-340. o. Budapest: Mádl Ferenc Összehasonlító Jogi Intézet.

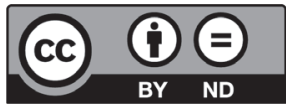

https://doi.org/10.47079/2021.nzha.kulon.4_14 
javára, másrészt pedig a béke idején alapvetőnek tekintett jogok korlátozása vagy felfüggesztése. E meghatározás szerint egy adott veszéllyel való szembenézés érdekében létrejövő ideiglenes időszakról van szó. A közelmúltban keletkezett második jelentésében a szükségállapot bizonyos jogrendszerek mélyreható átalakításából áll: olyan tartós veszélyek ellen, mint például a terrorizmus. ${ }^{2}$ A módosítások azért mélyrehatóak, mert a szabályok a hatályban lévő politikai és jogi rendszerre jellemzővé válnak. Ebben a helyzetben az ideiglenesnek hirdetett kivételes jogrend tartóssá válhat, és az állam múködésében „a kivétel lesz a normális”. ${ }^{3}$ Ebben a fejezetben a különleges jogrend az első meghatározásra utal, amely valóban kivételt képez az úgynevezett „normális” jogrend alól. Ez a tanulmány a francia különleges jogrendszerre összpontosít, és nem foglalkozik az úgynevezett „állandósult kivételesség” kérdésével, amelynek hatása mégis fontos. ${ }^{4}$

A francia jogrendben a különleges jogrend nevesített esetkörei a következők: ostromállapot, rendkívüli elnöki jogkör és szükségállapot. A szövegek által elöírt jogrendekhez társul hasonló céllal a „kivételes körülmények” bírósági gyakorlata. Az egyértelmúség kedvéért a kivételes rendszereket a normahierarchiában elfoglalt rangjuk szerint mutatjuk be, amely nagymértékben megfelel a megjelenésük időrendjének.

\subsection{Az ostromállapot}

Az ostromállapot (état de siège) a legrégibb olyan különleges jogrend, amelyet a konfliktus jellegú helyzetekre alkalmaznak: súlyos zavargások az ország területén, polgárháború vagy megszállás. Ahogy a neve is mutatja, az eredeti, 1791-es törvény az ostromlott erődök védelmének megszervezését tûzte ki célul, ${ }^{5}$ ezért engedélyezte a rendőri hatáskörök átadását a polgári hatóságtól a katonai hatóságnak. A későbbi törvények pedig a katonai bíróságok létrehozását és a rendőri hatáskörök kiterjesztését engedélyezték. ${ }^{6}$ Eközben megjelenik a politikai ostromállapot ${ }^{7}$ fogalma, amely eltér a katonai értelemben vett ostromállapottól. Az ostromállapot hatályának kiterjesztése tehát együtt járt a pontosabb jogi kerettel.

Az V. köztársaság 1958. október 4-én elfogadott alkotmánya ${ }^{8}$ értelmében az ostromállapotot minisztertanácsi rendelet hirdeti ki, 12 napon túli meghosszabbításáról pedig kizá-

2 Bővebben lásd: Agamben, 2005.

3 Ságvári, 2017.

4 A szükségállapotra vonatkozó rendelkezéseknek az általános jogba történő átültetését az alábbiakban tárgyaljuk; a globális biztonságról és szeparatizmusról szóló törvényjavaslatokat, amelyek a sajtószabadságot és a magánélet tiszteletben tartását érintik, azonban nem.

5 1791. július 10-i törvény (Loi du 10 juillet 1791 concernant la conservation et le classement des places de guerre et postes militaires, la police des fortifications et autres objets y relatifs).

6 1849. augusztus 9-i törvény az ostromállapotról, 1878. április 3-i törvény az ostromállapotról (Loi du 9 août 1849 sur l'état de siège; Loi du 3 avril 1878 relative à l'état de siège).

7 Manin, 2015.

8 Constitution française du 4 octobre 1958 (a továbbiakban: alkotmány). 
rólag a parlament dönthet. ${ }^{9}$ A rendelet kijelöli azt a területet, amelyre vonatkozik, és meghatározza alkalmazásának időtartamát. A 2005-ben elfogadott honvédelmi törvénykönyv ${ }^{10}$ pedig előírja, hogy az ostromállapot elrendelésére külső támadás vagy fegyveres felkelés közvetlen veszélye esetén kerülhet sor. ${ }^{11}$

Bizonyos jogok gyakorlását felfüggesztik: ilyen a magánlakás sérthetetlensége, a sajtószabadság, a gyülekezési szabadság és a mozgásszabadság. A katonai hatóságnak joga van kijárási tilalom kiírására, nappali és éjszakai házkutatásra az állampolgárok otthonában, fegyverek és lőszerek átadásának elrendelésére, felkutatására és eltávolítására, illetve a rendbontásra felbujtó vagy fenntartó publikációk és találkozók megtiltására. A katonai bíróságok hatáskörébe tartoznak az állambiztonság elleni büncselekmények. ${ }^{12}$

Összességében a politikai és katonai körülmények alakulásával - az aszimmetrikus hadviseléssel - ez a különleges jogrend elavulttá vált. Helyette a polgári megfelelőjét, a szükségállapotot használják, amelyről később lesz szó.

\subsection{A rendkiviüli elnöki jogkör}

A rendkívüli elnöki jogkör (pouvoirs exceptionnels) az V. köztársaság alkotmányának szövegében jelenik meg először. ${ }^{13}$ Amikor a köztársaság intézményei, a nemzeti függetlenség vagy a területi integritás, esetleg amikor az ország nemzetközi kötelezettségvállalásainak teljesítése súlyos és közvetlen veszélyben van, és az alkotmányos intézmények rendes múködése nem biztosított, az elnök megteszi a szükséges intézkedéseket, miután egyeztetett a miniszterelnökkel, a parlament két házának elnökével és az Alkotmánytanáccsal. ${ }^{14}$ Errôl az elnök hivatalosan tájékoztatja a nemzetet. ${ }^{15} \mathrm{Az}$ elnök gyakorlatilag teljes hatáskörrel rendelkezik az intézmények rendszeres müködésének gyors helyreállításához szükséges intézkedések megtételére - az Alkotmánytanács erről véleményt ad. ${ }^{16}$ E különleges jogrend ideje alatt a parlament továbbra is ülésezik; az első kamaraként szolgáló Nemzetgyúlés nem oszlatható fel. ${ }^{17}$ A 2008-ban elfogadott alkotmánymódosítás határidôket szabott a rendkívüli jogkör gyakorlására: az intézkedések megkezdése után 30 nappal az Alkotmánytanács megvizsgálhatja, hogy a fent meghatározott feltételek to-

\footnotetext{
9 Alkotmány 36. cikk.

10 Code de la défense (a továbbiakban: Honvédelmi tv.).

11 Honvédelmi tv. L2121-1 cikk.

12 Honvédelmi tv. L2121-3 cikk.

13 Alkotmány 16. cikk.

14 Alkotmány 16. cikk (1) bekezdés.

15 Alkotmány 16. cikk (2) bekezdés.

16 Alkotmány 16. cikk (3) bekezdés.

17 Alkotmány 16. cikk (4)-(5) bekezdés.
} 
vábbra is teljesülnek-e. ${ }^{18} 60$ nap elnöki jogkörgyakorlás után az Alkotmánytanács hivatalból köteles a kérdést megvizsgálni.

A rendkívüli elnöki jogkör eredetileg az 1958-ban megszavazott teljhatalom alkotmányossá tételét jelentette. ${ }^{19} \mathrm{~A}$ teljhatalmat elsősorban az algériai zavargások megszüntetése érdekében szavazták meg a IV. köztársaság összeomlása során. Ez szorosan összefügg a dekolonizáció folyamatával és különösen az algériai eseményekkel. Az Algériában szimpatizánsai által szervezett katonai felkelés során az addig politikailag visszavonult De Gaulle-t a parlament teljes jogkörrel szavazta meg. Ez hasonló körülmények közt történt, mint amikor az 1940. július 11-én, a Vichyben összehívott nemzetgyứlés teljhatalommal ruházta fel Pétaint. A módozatai azonban különböznek, ugyanis az 1958-as teljhatalom hat hónapra szólt. Ebből kiérződik az ókori római köztársasági diktatúra intézményének a sugallata, amikor is súlyos veszély esetén a szenátus kezdeményezésére és felhatalmazására az egyik konzult nevezték ki, általában hat hónapra (kezdetben egy katonai hadjárat idejére). ${ }^{20}$

Azt az állítást, miszerint az V. köztársaságot De Gaulle-ra szabták, közhelynek tekintik, ugyanakkor a 16. cikk esetében egyet kell értenünk abban, hogy a kivételes hatáskörök szorosan megfelelnek a De Gaulle-ra jellemző intézményi elképzeléseknek, napjainkban ezért is tartják anakronisztikusnak ezeket. ${ }^{21}$ Bár többször felmerült, eltávolítására eddig nem került sor. De Gaulle utódai föként az egyébként lenézett ${ }^{22}$ IV. köztársaságtól örökölt rendelkezést használták: a szükségállapotot.

\subsection{A szükségállapot}

A szükségállapotra (état d’urgence) vonatkozó jogszabályokat az algériai háború alkalmával hozták létre, és 1955 és 2015 között hatszor alkalmazták. ${ }^{23}$ Rendszere közel áll az ostromállapothoz, a fó különbség az, hogy az utóbbi a katonai hatóságot hatalmazza fel. A szükségállapotot a Minisztertanács rendeletben hirdeti ki a teljes államterületre vagy annak egy részére, az alábbi két esetben: egyrészt a közrend súlyos megsértéséből eredő közvetlen veszély esetén, másrészt olyan események bekövetkeztekor, amelyek természetüknél fogva és súlyosságukat tekintve közveszély előidézésére alkalmasak. Ennek a helyzetnek a tizenkét napon túl történő meghosszabbítását a törvény engedi, meghatározva annak végső időtartamát.

18 Ehhez a Nemzetgyưlés elnökének, a Szenátus elnökének, hatvan képviselőnek vagy hatvan szenátornak az indítványára van szükség [Alkotmány 16. cikk (6) bekezdés].

19 René Capitant (1901-1970) jogásznak tulajdonítják a jóindulatú értelmezést, amely szerint a 16. cikk emeli alkotmányos szintre az 1940. június 18-i De Gaulle-beszédet (amelyet a német megszállással szembeni ellenállás megalapozásának tekintenek) (Sirinelli, 1995, 842. o.).

20 Pierré-Caps, 2016.

21 Platon, 2008.

22 Garrigou, 2017.

23 Rendszerét az 1955. április 3-i törvény szabályozza, amelyet az 1960. április 15-i 60-372. sz. rendelet módosított, és a 2015. november 20-i 2015-1501. sz. törvény alaposan átdolgozott. 
A szükségállapot a következő esetekben ér véget:

— az azt kihirdető rendelet vagy törvény által előírt határidő lejártával;

- a kormány lemondását vagy a Nemzetgyúlés feloszlatását követően; vagy

- ha a meghosszabbítást engedélyező törvény előírja, hogy a szükségállapot minisztertanácsi rendelettel megszüntethető az előírt határidő lejárta előtt.

A szükségállapot kiterjeszti a polgári hatóságok hatáskörét, beleértve a kormány és a - területi szintû megbízottjainak tekinthető - prefektusok hatáskörét is. A belügyminiszter házi őrizetbe helyezheti azt a személyt, akinek tevékenységét a közbiztonságra és a közrendre veszélyesnek tekinti. Ez az intézkedés megtámadható egy bizottság előtt, és adott esetben a közigazgatási bíróság előtt, amelynek egy hónapon belül döntést kell hoznia. A 2015. november 20-i törvény módosította a házi őrizet rendszerét, kiterjesztve azt minden olyan személyre, akivel kapcsolatban „komoly okkal feltételezhető, hogy viselkedése veszélyezteti a közbiztonságot és a közrendet”. ${ }^{24} \mathrm{~A}$ belügyminiszter bármely, házi őrizetben lévő személy számára elöirhatja a rendőrség vagy a csendőrség egységei részére történő időszakos bejelentési (naponta legfeljebb háromszor) és személyazonosító okmányai átadási kötelezettségét. A házi őrizetben lévő személynek tilos közvetlen vagy közvetett kapcsolatba lépni a közrendet sértő cselekmények előkészítésével gyanúsított személyekkel.

A szükségállapot lehetôvé teszi olyan egyesületek vagy olyan tényleges csoportok feloszlatását, amelyek részt vesznek a közrendet súlyosan aláásó cselekmények elkövetésében, vagy elősegítik, illetve ösztönzik ezeket, és amelyek magukban foglalják a házi őrizetben lévő személyeket. Megszünt az 1955. április 3-i törvényben előírt sajtó- és rádióellenőrzés. A belügyminiszter betilthatja a terrorcselekmények elkövetésére buzdító vagy ezeket üdvözlő webhelyeket.

A belügyminiszter és a prefektusok felhatalmazást kapnak, hogy

- megtiltsák a felvonulásokat és a gyülekezést a közutakon (feltéve, hogy a közigazgatási hatóság a rendelkezésére álló eszközök alapján indokolja, hogy nem tudja biztosítani a biztonságukat);

— elrendeljék mindenféle helyiség ideiglenes bezárását, beleértve az előadótermek, ivóhelyek és gyülekezőhelyek bezárását, illetve „minden olyan vallási épületét, ahol olyan nyilatkozatokat tesznek, amelyek gyúlöletkeltésnek, erőszakos provokációnak vagy terrorcselekmények elkövetésére való felhívásnak vagy ezek dicsőítésének minősülnek";

— házkutatásokat rendeljenek el.

24 2015. november 20-i 2015-1501. sz. törvény a rendkívüli állapotról szóló, 1955. április 3-i 55-385. sz. törvény alkalmazásának kiterjesztéséről és rendelkezéseinek hatékonyságának megerősítéséről (Loi n² 2015-1501 du 20 novembre 2015 prorogeant l'application de la loi n ${ }^{\circ}$ 55-385 du 3 avril 1955 relative à l'état d'urgence et renforçant l'efficacité de ses dispositions). 
Semmilyen közigazgatási hatáskörben elrendelt házkutatás nem irányulhat olyan helyiségekre, amelyeket parlamenti mandátum gyakorlásához, illetve ügyvédek, bírók vagy újságírók szakmai tevékenységéhez rendeltek. Az államügyész tájékoztatást kap minden házkutatás elrendelésérőli; a kutatás rendôr jelenlétében történik.

A szükségállapot kihirdetése felhatalmazza a prefektust, hogy

- korlátozza az emberek vagy a jármúvek mozgását, és olyan védelmi vagy biztonsági övezeteket hozzon létre, ahol az emberek tartózkodása szabályozott;

— elrendeljen személyazonosság-ellenőrzést, szemrevételezést és poggyászátkutatást, valamint jármúellenőrzést.

Az alkotmányjogászok nagy része kritikusan fogadja a szükségállapot módozatait, vagy akár annak létét is. ${ }^{25}$ 2015-ben élénk vitákat kiváltó kísérlet történt arra, hogy ezt a jogintézményt az alkotmányban szabályozzák. A mellette szóló érv az volt, hogy végre egyértelmú, világos keretet lehetett volna adni e különleges jogrendnek. ${ }^{26} \mathrm{~A}$ fenntartások az ellenőrzések elégtelenségére és annak szükségességére vonatkoztak, hogy ezt az állítólagosan kivételes rendszert ne véglegesítsék. Végül a szükségállapot alkotmányba való beépítése elmaradt. Ezzel szemben az ország 2017-ben hivatalosan megszüntette a szükségállapotot, amelyben már majdnem két éve élt - ugyanakkor a szükségállapot fokozatosan beépült a normális jogrendbe. ${ }^{27} \mathrm{~A}$ 2017-ben elfogadott törvény ${ }^{28}$ négy olyan intézkedést vezetett be, amelyeket sokan aggályosnak tartanak az alkotmányosan garantált jogok és szabadságok tiszteletben tartása szempontjából:

— védelmi kerületek létrehozása;

— istentiszteleti helyek bezárása;

— egyedi adminisztratív ellenőrzési és felügyeleti intézkedések; valamint

- házkutatások.

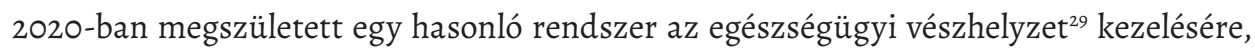
amelyet az alábbiakban tárgyalunk. Ezt megelőzően a miniszterelnök rendeletben szabályozta az utazást ${ }^{30}$ a kivételes körülmények elméletének szellemében.

25 Bővebben lásd: Cassia, 2016; Beaud-Guérin-Bargues, 2016; Rousseau, 2015.

26 Esplugas-Labatut, 2018.

27 Champeil-Desplats, 2017.

28 2017. október 30-i 2017-1510. sz. törvény a belső biztonság megerősítéséről és a terrorizmus elleni küzdelemról (Loi n²017-1510 du 30 octobre 2017 renforçant la sécurité intérieure et la lutte contre le terrorisme).

29 2020. március 23-i 2020-290. sz. törvény a Covid-19-járvány kezelésére (Loi n²020-290 du 23 mars 2020 d'urgence pour faire face à l'épidémie de Covid-19).

30 2020. március 16-i 2020-260. sz. rendelet az utazás szabályozásáról a Covid-19 vírus terjedése elleni küzdelem keretében (Décret n²020-260 du 16 mars 2020 portant réglementation des déplacements dans le cadre de la lutte contre la propagation du virus Covid-19). 


\subsection{A kivételes körülmények elmélete}

A kivételes körülmények lehetővé teszik a közigazgatási hatóság számára, hogy ne tartsa tiszteletben a szokásos törvényességet, feltéve, hogy

— bírói felügyelet alatt jár el;

— az események ezt megkövetelik;

- a közszolgáltatások folyamatosságát hivatott biztosítani.

A válsághelyzet okozta, a nemzet létfontosságú elemeit súlyosan veszélyeztető helyzet kezelésére az ítélkezési gyakorlat a „kivételes körülmények” elmélete révén olykor igen jelentős jogi kiigazításokat fogad el - ezeket a körülmények súlyossága teszi szükségessé. Bíróság határozta meg a „kivételes körülmények” alkalmazásának feltételeit az első világháború alatt hozott ítéletekben..$^{31} \mathrm{Az}$ Államtanács ezt követően elismerte a „kivételes körülmények” fennállását súlyos természeti katasztrófa esetén is. ${ }^{32} \mathrm{~A}$ közigazgatási hatóság minden esetben a szükség nevében szerez fontos hatásköröket, elsősorban a rendfenntartás területén, bár ez más közszolgáltatások múködését is érintheti, az alábbi két feltétel teljesülése esetén.

Egyrészt szükséges, hogy a körülmények valóban kivételes helyzetre vonatkozzanak, ami magában foglalja annak súlyosságát, rendellenességeit és kiszámíthatatlanságát (háborúk, zavargások vagy természeti katasztrófák esetén). Másrészt szükséges, hogy a körülmények elképzelhetetlenné tegyék a normális törvényesség tiszteletben tartását.

Törvényes kereteken kívül a hatáskör szabályai és a normahierarchia felborulnak: a végrehajtó hatalom olyan intézkedéseket hozhat meg, amelyek általában a törvényhozási, illetve az igazságügyi hatóság alá tartoznak, vagy de facto tisztviselők veszik át a hiányzó rendőri szervek helyét. A formai és eljárási szabályok alkalmazása felfüggeszthető. Ez a közigazgatás hatáskörének kivételes kiterjesztését eredményezi, mivel kivételes körülmények között a közigazgatási hatóságok rendkívül sürgős intézkedéseket tehetnek a pillanatnyi szükségletek kielégítése érdekében. Az időszak követelményeitől függően a szabadságjogokat olyan feltételekkel korlátozhatják, amelyek ilyen helyzet hiányában törvényellenesek vagy akár önkényesek.

Mindezek az intézkedések, határozatok sem esnek kívül a bírósági felülvizsgálat hatókörén, noha annak valódi hatálya kivételes válsághelyzetekben korlátozott. A bíró mindig alkalmazza a rendőri intézkedésekre az arányosság elvét. Az eltérést a bíró csak akkor engedélyezi, ha a különösen válságos körülmények között elérendő célok érdekében és a szabadságjogokba való beavatkozás mértékének arányában feltétlenül szükséges a megtett intézkedés - vagyis csak akkor, ha a jogtól való eltérés tökéletesen arányos a helyzettel. A bírói

31 CE 28 juin 1918, Heyriès, req. n 63412: az ügyre vonatkozó iratok előzetes közlése nélkül kimondott elbocsátásról; CE 28 févr. 1919, Dames Dol et Laurent, req. n 61593: az egyének szabad mozgását érintő rendőri intézkedésekről.

32 A Soufrière-vulkán kitörése Guadeloupe-ban (CE 18 mai 1983, Rodes, req. n² 25308). 
felülvizsgálat idővel fokozatosan erősödött, különösen az általános jogelvek elméletének az 1950-es évek elején történt fejlődésével. ${ }^{33}$

Anélkül, hogy önálló különleges jogrendet alkotna, a kivételes körülmények elmélete lehetôvé teszi a közigazgatási hatóságok bizonyos rugalmasságát a súlyos és előre nem látható körülményekre való reagálásban. Ezt az intézkedést az alapvető jogok tiszteletben tartásával hajtják végre, az utólagos bírói ellenőrzés mellett.

\section{Az alapjogok korlátozására vonatkozó szabályok különleges jogrend idején}

Tekintettel a rendkívüli elnöki jogkör széles körére, ezek a különleges jogrendben hozott intézkedések bármely alapvető jogot érinthetnek. Az ebből adódó jogsértések azonban elméleti jellegűek, mivel ezt a jogrendet már nem használják.

Az ostromállapot és a szükségállapot hasonló hatáskörre vonatkoznak, és ugyanazokat az alapvető jogokat érinthetik:

— a személy sérthetetlenségéhez és a magánlakás sérthetetlenségéhez füződő jog;

- a szabad mozgáshoz és a lakhatáshoz való jog;

— a gyülekezési jog és az üzleti tevékenység végzéséhez való jog.

Korábban a sajtószabadságot is korlátozni lehetett, a vonatkozó rendelkezéseket azonban azóta hatályon kívül helyezték.

Különösen tág a jogsértések területe, amelyet a bíró a kivételes körülmények elmélete nevében érvényesíthet. A múltban a bíróság ennek alapján indokolta meg a mozgásszabadság, valamint a tulajdonhoz való jog és a védelem jogának korlátozását.

$\mathrm{Az}$ alapjogokat különleges jogrend idején is garantálja az alkotmány. Idetartozik az 1789-es Emberi és polgári jogok nyilatkozata, az 1946-os alkotmány preambulumában biztosított jogok, valamint az ítélkezési gyakorlattal létrehozott jogok. E jogok tiszteletben tartását az Alkotmánytanács közvetett igénybevétele garantálja. A szabályok hierarchiájának megfelelően a közigazgatási bíró ellenőrzi bármely közigazgatási intézkedés jogszerűségét, beleértve a kormány vagy bármely helyi végrehajtó hatóság döntését. A bíró figyelembe veszi a különleges jogrend alkalmazását, és ellenőrzi, hogy az alapjogok korlátozása szükséges és arányos-e a kitûzött céllal (amely általában a közrend védelme).

33 Massot, 2013. 


\section{A koronavírus-járvány miatt bevezetett különleges jogrend Franciaországban}

\subsection{Az egészségügyi szülkségállapot}

Az egészségügyi szükségállapot ${ }^{34}$ olyan különleges jogrend, amelyet 2020-ban hoztak létre a Covid-19-járvány kezelésére. Ez a szükségállapotnak egy változata, amely meghatározott körülmények között alkalmazható „olyan egészségügyi katasztrófa esetén, amely jellegénél és súlyosságánál fogva veszélyezteti a lakosság egészségét”. ${ }^{35} \mathrm{Ez}$ a jogrend azonban ideiglenes: a közegészségügyi törvénykönyvbe ${ }^{36}$ ideiglenesen vezették be, és szükség esetén csak 2021. április 1-ig tartható fenn.

Amikor egy egészségügyi katasztrófa természeténél és súlyosságánál fogva veszélyezteti a lakosság egészségét, a Minisztertanács rendeletben (az egészségügyi miniszter jelentése alapján) dönt az egészségügyi szükségállapot kihirdetéséről. Ez a rendelet megindokolja és meghatározza azokat a területi körzeteket, amelyeken belül hatályba lép. A döntést motiváló (az egészségi helyzetról rendelkezésre álló) tudományos adatokat nyilvánosságra hozzák. A kormány haladéktalanul tájékoztatja a parlamentet az egészségügyi szükségállapotra vonatkozó intézkedésekről. Egy hónapon túl az egészségügyi szükségállapot meghoszszabbítását csak törvény engedélyezheti a Tudományos Tanáccsal ${ }^{37}$ folytatott konzultációt követően. A törvény meghatározza a meghosszabbítás időtartamát. Az egészségügyi szükségállapot azonban a jogszabályban meghatározott időtartam letelte elött minisztertanácsi rendelettel megszüntethetô.

A közegészségügyi törvénykönyv ${ }^{38}$ tíz olyan esetkört sorol fel, amelyben szabadságot korlátozó intézkedések hozhatók meg (kizárólag a közegészség garantálása céljából és olyan területeken, ahol egészségügyi szükségállapotot hirdettek ki). Ennek érdekében a miniszterelnök rendeletben (az egészségügyért felelős miniszter jelentése alapján) a következő intézkedéseket teheti:

— az emberek és a jármúvek mozgásának szabályozása vagy megtiltása, valamint a közlekedési eszközökhöz való hozzáférés és használatuk feltételeinek szabályozása;

- megtilthatja az embereknek, hogy elhagyják otthonukat, olyan utazás kivételével, amely családi vagy egészségügyi szükségletek tekintetében elengedhetetlen;

34 État d'urgence sanitaire.

35 2020. március 23-i 2020-290. sz. törvény a Covid-19 járvány kezelésére (Loi nº 2020-290 du 23 mars 2020 d'urgence pour faire face à l'épidémie de Covid-19).

36 Code de la santé publique (L. 3131-12 - L. 3131-20 cikk).

37 A Francia Köztársaság elnökének felkérésére a Covid-19 Tudományos Tanácsot (Conseil scientifique) 2020. március 11-én a szolidaritás és az egészségügy minisztere hozta létre, hogy tanácsot adjon a kormánynak a koronavírushoz kapcsolódó egészségi helyzet kezelésében.

38 Közegészségügyi törvénykönyv L. 3131-15. cikk. 
— elrendelheti az érintett személyek karanténját;

- elrendelheti az érintett személyek elkülönítését;

- a nyilvános és találkozóhelyek ideiglenes bezárásának elrendelése, biztosítva az emberek hozzáférését az alapvető árukhoz és szolgáltatásokhoz;

- a közutakon való összejövetelek, valamint bármilyen találkozók korlátozása vagy megtiltása;

— az egészségügyi katasztrófa elleni küzdelemhez szükséges összes áru és szolgáltatás igénybevétele;

— ideiglenes hatósági árszabályozást vezethet be olyan termékek esetében, amelyek bizonyos termékek piacán tapasztalt feszültségek megelőzéséhez és orvoslásához szükségesek;

— szükség esetén meghozhat minden olyan intézkedést, amely lehetővé teszi a betegek számára megfelelő gyógyszerek biztosítását, az egészségügyi katasztrófa elhárítását;

- szükség szerint rendelkezhet bármilyen más szabályozásról, amely korlátozza a vállalkozás szabadságát, kizárólag az említett egészségügyi katasztrófa elhárítása céljából.

A törvény előírja, hogy ezeknek az intézkedéseknek szigorúan arányosaknak kell lenniük a felmerülő egészségügyi kockázatokkal, és meg kell felelniük az adott helyen és időben uralkodó körülményeknek. Ha már nincs szükség rájuk, haladéktalanul meg kell szüntetni őket.

Az egészségügyi szükségállapotot 2020. március 24-től két hónapos időtartamra hirdették ki az ország egész területére. Ezt követően 2020. július 10-ig meghosszabbították. Az egészségügyi szükségállapotot 2020. október 17-től ismét rendeletben hirdették ki a Francia Köztársaság egész területére, majd 2021. február 16-ig meghosszabbították. Ez a kivételes rendszer lehetővé tette, hogy 2020 márciusától kezdve különféle eszközöket hozzanak létre a Covid-járvány elleni küzdelemben, például a kormány felhatalmazását arra, hogy többféle hatáskörben rendelettel fogadjon el jogszabályokat. A karantén ideje 2020. március 17-től május 11-ig tartott, a "kijárási tilalom” 21 és 6 óra között volt érvényes egyes országrészeken. Új országos karanténról döntöttek 2020. október 30-ával kezdődően.

\subsection{A koronavírus-járvány okozta rendkivüli állapot leküzdése érdekében bevezetett alapjog-korlátozás}

Amint azt a Velencei Bizottság 2020. október 8-i jelentésében megjegyezte, a Covid-19 elleni küzdelemmel kapcsolatos korlátozások a mozgás és a gyülekezés szabadsága mellett a vallásgyakorlás szabadságát és a magánélet tiszteletben tartásához való jogot is érintik egész Európában. ${ }^{39}$ Franciaországban 2020. május 18-án az Államtanács aránytalannak

39 Venice Commission, 2020, 15. o. 
nyilvánította az istentiszteleti helyek általános és abszolút bezárását. A 2020. szeptember 6-i ideiglenes határozatában pedig a nyilvános helyeken elő́rt kötelező maszkviseléssel foglalkozott a testület. Az Államtanács úgy határozott, hogy az arcmaszk viselése nagyobb földrajzi területre vonatkozóan is kötelezővé tehető annak érdekében, hogy a kötelezettség minden állampolgár részére egyértelmú legyen. Ehhez azonban igazolni kell az erősen fertőzésveszélyes gócok meglétét. ${ }^{40}$

A Velencei Bizottság jelentése megemlíti az Európában egyedülálló franciaországi esetet: az önkormányzati választások második fordulóját három hónappal elhalasztották, ami bizonyos hiányosságokat tárt fel a francia választási törvényben. Az Alkotmánytanács mindennek ellenére nem kifogásolta az első és a második szavazás közötti három hónapos különbséget. ${ }^{41}$

A Covid-19-válság "sajátos körülményeire” alapozva az Alkotmánytanács jóváhagyott egy sürgősségi törvényt ${ }^{42}$ annak ellenére, hogy azt az alkotmány 46. cikkét megsértve szavazták meg. Ez a cikk előírja, hogy tizenöt napnak kell eltelnie az organikus törvény első bevezetése és az első parlamenti vita között. Az organikus törvény felfüggesztette az Alkotmánytanács előzetes alkotmányossági felülvizsgálatának határidejét.

Franciaországban az elsőbbségi alkotmányossági kérdést, ${ }^{43}$ amelyben a peres fél megtámadhatja a saját jogesetére vonatkozó törvény alkotmányosságát, a bíróság a Semmítőszékhez vagy az Államtanácshoz továbbítja. Amennyiben jogos a kérdés, ezt az Államtanács vagy a Semmítőszék az Alkotmánytanács elé terjeszti. Ezt az előzetes ellenőrzést három hónapon belül be kell fejezni, ennek hiányában a kérést közvetlenül továbbítják az Alkotmánytanácsnak, amelynek három hónapon belül döntést kell hoznia. ${ }^{44} \mathrm{~A}$ bíróságok (járvány miatt) várható bezárásával az Alkotmánytanács tagjai azzal a lehetőséggel szembesültek, hogy gyengén indokolt kérelmek sokasága halmozódik fel az asztalukon. A parlament ezért sürgősségi törvényt fogadott el, amely felfüggesztette a kérdés Alkotmánytanácshoz történő továbbításának határidejét. ${ }^{45}$ Noha kétségtelenül érintette a polgárok tisztességes és gyors tárgyaláshoz való jogát, az ilyen eseti és ideiglenes intézkedés hatása korlátozott maradt. A jogszabályok elfogadásának módja, valamint az Alkotmánytanács érvelése azonban aggodalmat keltett az alkotmányjogászok körében. ${ }^{46}$

$\mathrm{Az}$ ország legfőbb politikai és igazságszolgáltatási szerveinek müködésében bármilyen módosításnak - ahogyan ez itt az Alkotmánytanács esetében történt - organikus

40 Venice Commission, 2020, 24. o.

41 Venice Commission, 2020, 27. o.

42 Conseil Constitutionnel, décision n 2020-799 DC du 26 mars 2020, Loi organique d'urgence pour faire face à l'épidémie de Covid-19.

43 Alkotmány 61-1. cikk (ez hozzávetőlegesen a magyar alkotmányjogi panasznak felel meg).

44 2009. december 10-i 2009-1523. sz. organikus törvény az Alkotmány 61-1. cikk alkalmazásáról (Loi organique n 2009-1523 du 10 décembre 2009 relative à l'application de l'article 61-1 de la Constitution).

45 2020. március 30-i 2020-365. sz. organikus törvény a Covid-19-járvány kezelésére (Loi organique n²020-365

du 30 mars 2020 d'urgence pour faire face à l'épidémie de Covid-19, JORF n0078 30/03/2020).

46 Gicquel, 2020; Benzina, 2020. 
törvény formájában kell történnie. ${ }^{47} \mathrm{Az}$ alkotmány elöírja, hogy egy organikus törvényjavaslat a benyújtás napjától számított legalább hat hét elteltével megvitatásra kerül, először a parlamentben.

Az időszak legalább hat hétig tart, ha a szokásos eljárást követik, illetve a gyorsított eljárás alkalmazása esetén ${ }^{48}$ a törvény benyújtását követő tizenöt napos időszak lejártáig. A kormány az utóbbi, rövidített időszakot választotta. Az alkotmány azonban még rendkívüli körülmények között sem kínál lehetőséget ennek a tizenöt napos időszaknak a csökkentésére. Az organikus törvényt ennek ellenére huszonnégy órán belül elfogadták a benyújtása után. Az alkotmány azt is előírja, hogy „az organikus törvényeket csak akkor lehet kihirdetni, ha az Alkotmánytanács kinyilvánította az alkotmánynak való megfelelést”. ${ }^{49}$

Az Alkotmánytanács tehát két kockázatos javaslattal nézett szembe:

- vagy a pragmatikus megközelítést követve, azonnali érdekének megfelelően megalkotott intézményi törvényt érvényesítsen, nyilvánvalóan megsértve ezzel az alkotmány formai rendelkezéseit;

— vagy pusztán formai okokból ítéljen el olyan törvényt, amelynek tartalma szinte semmilyen ellenzést nem váltott ki.

Az Alkotmánytanács az előbbi megoldás mellett döntött.

A francia bíróságok döntéseit a tömörség hagyománya jellemzi. Azokban a ritka esetekben azonban, amikor szükségesnek tartják a törvény kifejezett rendelkezése elleni döntést, rendkívül fontos, hogy a bíró ezt kellően megindokolja:

— vagy minimalizálja a kivétel súlyosságát azáltal, hogy összekapcsolja egy bevett ítélkezési gyakorlattal;

— vagy alaposan elmagyarázza azokat a nagyon sajátos körülményeket, amelyek ilyen rendkívüli jogsértéshez vezettek.

Határozatában a francia Alkotmánytanács egyiket sem tette meg. Ehelyett a „jelenlegi körülményekre" hivatkozva (amelyek láthatólag különböztek a közigazgatási bíróságok által alkalmazott százéves "kivételes körülmények elméletétől”) ${ }^{50}$ úgy ítélte meg, hogy - az említett körülmények miatt - „nincs szükség” megítélni, hogy az eljárás ellentétes az Alkotmánnyal.

Noha az organikus törvény potenciálisan késleltette a peres felek hozzáférését az Alkotmánytanácshoz, mégis rendelkezett egy „megszüntetési záradékkal”, amely 2020.

47 Az alkotmány 46. cikkében meghatározott külön eljárást követve, a szokásos törvényekénél magasabb fokú formalitással.

48 Alkotmány 45. cikk.

49 Alkotmány 45. cikk.

50 Champeil-Desplats, 2020. 
június 30-tól lépett hatályba. Önmagában az Alkotmánytanács határozatának alig volt más azonnali hatása, mint az, hogy lehetôvé tette az Alkotmánytanácshoz való hozzáférés késleltetését. Az eset nem jelenti a joghatóság hirtelen megváltozását, mivel az eljárás kérdésére összpontosított. Például egy nemrégiben hozott (a terrorizmushoz kapcsolódó bûncselekmények miatt elítélt volt foglyokról szóló törvényt megsemmisítő) ${ }^{51}$ itélet azt jelzi, hogy az Alkotmánytanács továbbra is az emberi jogok és a jogállamiság fenntartását kívánja megvalósítani. Összességében az Alkotmánytanács döntését az eljárási kérdések iránti engedékenység mutatójaként elemezték..$^{52}$ Megkérdőjelezték ennek az engedékenységnek a célszerüségét: bár a Covid-19-járvány minden bizonnyal vészhelyzetnek minősül, ebben a konkrét esetben semmi sem akadályozta a tizenöt napos időszak alkalmazását. Még az Alkotmánytanács döntéseinek esetleges késedelme sem okozott volna jogi következményt.

A határozatot a strukturált érvelés hiánya miatt is erősen bírálták:53 nem mutatott logikus következetességet az engedékenység tekintetében, mivel a bírók nem határoztak meg egyértelmú feltételeket, amelyek alapján a jövőben hasonló helyzetet hasonló módon lehet majd elbírálni. Talán ennél is fontosabb, hogy az eljárásnak, különösen az alkotmányos kérdésekben, mindig komoly jelentősége van. Alapvető érdeme, hogy megakadályozza az intézményi mechanizmusok elhamarkodott módosítását, például abban az esetben, ha egy autoriter hatalom a demokratikus intézmények csorbítására kívánna felhasználni egy vészhelyzetet. Ebben az értelemben az Alkotmánytanács döntése a célszerúséget választotta az egységesség helyett. Szerencsétlen precedenst teremtett azáltal, hogy ajtót nyitott az alkotmányos norma megsértésének, legalábbis annak alaki rendelkezéseiben. Jelen helyzetben a demokratikus intézmények szilárdsága sikertelen tesztjeként értékelhetjük - vészhelyzetben, éppen akkor, amikor szerepüknek meghatározóbbnak kell lenni, mint valaha. ${ }^{54}$ Tekintettel arra, hogy sem felülvizsgálat, sem fellebbezés tárgya nem lehet, ez a határozat az Alkotmánytanács politikai jellegére emlékeztet az igazságszolgáltatáson felül. Bár a jogszabályoknak az a szerepük, hogy a szabályokat a körülmények változásához igazítsák, az Alkotmánytanácsnak a politikai választások döntnökeként való fellépése árnyékot vethet Franciaország jogállamiságára. ${ }^{55}$

\section{A különleges jogrend kihirdetésének gyakorlati esetei}

Az ostromállapot első alkalmazásai Franciaországban a belső zavargások és a forradalmak elhárítására irányultak 1848-ban, 1849-ben, de 1871-ben, a párizsi kommün alatt is

51 Decision n 2020-805 DC, 7 août 2020, Loi instaurant des mesures de sûreté à l'encontre des auteurs d'infractions terroristes à l'issue de leur peine.

52 Jeanneney, 2020.

53 Gicquel, 2020; Benzina, 2020; Jeanneney, 2020.

54 Derosier-Cartier, 2020.

55 Jacquin, 2020. 
bevezették. Az ostromállapotot a két világháború során hirdették ki, az V. köztársaság alatt azonban soha.

A rendkívüli elnöki jogkör egyetlen alkalmazása 1961. április 23. és 1961. szeptember 30. között, szintén hat hónapig tartott, holott az úgynevezett tábornokok algériai puccsa három nap alatt megbukott. Noha az alkalmazásához szükséges körülmények találkozása vita tárgyát képezi, az Alkotmánytanács hozzájárulása biztosítja a törvényesség tiszteletben tartását. ${ }^{56}$ Mindazonáltal arra is rá kell mutatni, hogy 15 évvel később ugyanezen Alkotmánytanács elnöke megerősítette, hogy a puccs leverése után „jogi szempontból kétségtelen”, hogy „a 16. cikk szerinti rendszer fenntartása ellentétes volt e szöveg szellemével és betújével egyaránt". ${ }^{77}$ Tekintettel arra, hogy közel 60 évig nem volt példa az alkalmazására, a rendkívüli elnöki jogkör pontos mértéke továbbra is bizonytalan, különös tekintettel az Alkotmánytanács szerepének azóta történt jelentős kiterjesztésére. ${ }^{58}$

A szükségállapotot 1955 és 2015 között hatszor alkalmazták. A szükségállapotot az algériai háború idején, az 1984-es események során Új-Kaledóniában, a 2005. októberi városi zavargások és a 2015. novemberi terrortámadások után vezették be. Az algériai háború idején a szükségállapot indokolta a szabad mozgás és a sajtószabadság korlátozását. A 2015. novemberi párizsi és saint-denis-i támadásokat követően szükségállapotot vezettek be, majd három hónappal meghosszabbították azt. A 2016. júliusi nizzai terrortámadás a szükségállapot hat hónappal történő meghosszabbítását eredményezte. Ezt követően kétszer hosszabbították meg 2017. november 1-ig. Ez azt mutatja, hogy a szükségállapot jelentős időtartamra meghosszabbítható, amennyiben azt a parlament rendszeresen jóváhagyja és határidőhöz köti. ${ }^{59}$

A kivételes körülmények elméletét főként a két világháború alatt, valamint közvetlenül a háború utáni időszak összefüggésében használták. Használata a fent említett különleges jogrendek kialakulásával ritkábbá vált. A közigazgatási hatóság sikertelenül hivatkozott a kivételes körülményekre az 1968. májusi események nyomán, ${ }^{60}$ valamint egy ciklon pusztítása után Guadeloupe-ban. ${ }^{61} \mathrm{~A}$ kivételes körülmények elméletének legutóbbi, 1989-es alkalmazása az új-kaledóniai zavargásokhoz kapcsolódik. ${ }^{62} \mathrm{Az}$ ítélkezési gyakorlat szigorú feltételeket támaszt a kivételes körülmények fennállásának elismerésével szemben. Feltételezi a közrend elleni támadást, amely lehetetlenné teszi a közhatalmak normál múködését.

56 Lásd az Alkotmánytanács 1961. április 23-i, 61-1 AR16 sz. döntését: www.conseil-constitutionnel.fr/ decision/1961/611AR16.htm (Letöltve: 2020. november 18.).

57 Noël, 1976, 155. o.

58 Lásd az Alkotmánytanács 1971. július 16-i, 71-44 DC sz. döntését: www.conseil-constitutionnel.fr/ decision/1971/7144DC.htm (Letöltve: 2020. november 18.).

59 Baranger, 2016, 453. o.

60 CE 12 juillet 1969, Chambre de commerce de Saint-Étienne, req. $n^{\circ} 76089$.

61 TC 22 juin 1998, req. $n^{\circ}$ 98-03.105.

62 CE 3 nov. 1989, req. n 66118 (egy önkormányzati tanács feloszlatásáról). 


\section{5. Összegzés}

Az alábbi táblázat összefoglalja a francia különleges jogrendi szabályozással kapcsolatos legfontosabb rendelkezéseket:

\begin{tabular}{|c|c|c|c|c|}
\hline & $\begin{array}{l}\text { Rendkívüli elnöki } \\
\text { intézkedési jogkör }\end{array}$ & Ostromállapot & Szülkségállapot & Kivételes körülmények \\
\hline $\begin{array}{c}\text { Szabályozás } \\
\text { szintje }\end{array}$ & \multicolumn{2}{|c|}{ alkotmányos } & törvényes & bírósági gyakorlat \\
\hline $\begin{array}{c}\text { Elrendelési } \\
\text { okok }\end{array}$ & $\begin{array}{l}\text { Súlyos és közvetlen } \\
\text { veszély fenyegeti: } \\
\text { — a köztársaság } \\
\text { intézményeit; } \\
\text { — a nemzet } \\
\text { függetlenségét } \\
\text { vagy területi } \\
\text { integritását; } \\
\text { — az ország nem- } \\
\text { zetközi kötele- } \\
\text { zettségvállalásai } \\
\text { teljesítését. }\end{array}$ & $\begin{array}{l}\text { — Külföldi } \\
\text { háború; } \\
\text { — fegyveres } \\
\text { felkelés; } \\
\text { — közvetlenül } \\
\text { fenyegető } \\
\text { veszély. }\end{array}$ & $\begin{array}{l}\text { - A közrend } \\
\text { súlyos meg- } \\
\text { sértésének } \\
\text { közvetlen } \\
\text { veszélye; } \\
\text { — közveszély } \\
\text { előidézésére } \\
\text { alkalmas } \\
\text { események } \\
\text { megtörténte } \\
\text { esetén. }\end{array}$ & $\begin{array}{l}\text { Súlyos, rendellenes } \\
\text { és kiszámíthatatlan } \\
\text { helyzet, amely elkép- } \\
\text { zelhetetlenné teszi } \\
\text { a normális törvényesség } \\
\text { tiszteletben tartását. }\end{array}$ \\
\hline Elrendelés & $\begin{array}{c}\text { Az elnök által, } \\
\text { miután egyeztetett } \\
\text { a miniszterelnökkel, } \\
\text { a parlament két } \\
\text { házának elnökével } \\
\text { és az Alkotmányta- } \\
\text { náccsal. }\end{array}$ & \multicolumn{2}{|c|}{$\begin{array}{l}\text { A Minisztertanács által, } 12 \text { napon túli } \\
\text { meghosszabbításáról kizárólag } \\
\text { a parlament dönthet. }\end{array}$} & $\begin{array}{l}\text { Fennállását a bíróságok } \\
\text { utólag állapítják meg, } \\
\text { eljárás során. }\end{array}$ \\
\hline $\begin{array}{l}\text { Felhatal- } \\
\text { mazott }\end{array}$ & elnök & $\begin{array}{l}\text { katonai } \\
\text { hatóságok }\end{array}$ & polgári hatóságok & közigazgatási hatóságok \\
\hline $\begin{array}{c}\text { Gyakorlati } \\
\text { esetek }\end{array}$ & $\begin{array}{c}\text { 1961. április 23. - } \\
\text { 1961. szeptember } 30 .\end{array}$ & $\begin{array}{l}\text { a II. világ- } \\
\text { háború óta nem } \\
\text { alkalmazott }\end{array}$ & \multicolumn{2}{|c|}{ Lásd a fejezet 1.3. és 1.4. pontját } \\
\hline
\end{tabular}

9. táblázat

Franciaország különleges jogrendi szabályozásának összefoglalása

Forrás: a szerző saját szerkesztése

A francia különleges jogrendszer sokrétû és részben elavult. Sokrétû, mivel az alkotmánnyal, a törvényekkel, de a joggyakorlattal kapcsolatos előírások is szabályozzák. 
Az alkotmányi szintû́ jogrendeket ma már nem alkalmazzák: inkább a meglévő törvényi szintû́ rendelkezéseket, illetve új ad hoc törvények létrehozását részesítik előnyben. Így az alapvető jogok megsértése, amelyet az utóbbi években elítéltek Franciaországban, inkább a rendes jogrendi törvények alkalmazásából fakad, mintsem egy különleges jogrend alkalmazásából. Az alkotmányban meglévő rendkívüli elnöki intézkedési jogkört és ostromállapotot már nem alkalmazzák. A jelenlegi válságok kezelésére a kormány elsősorban a szükségállapotot alkalmazza, amelyet egy 1955-ös törvény hozott létre, és amelyet a „kivételes körülmények" esetjogi elmélete kiegészít. Az V. köztársaság olyan rendszer, amelyben a mérleg nyelve a hatalom szétválasztása során a végrehajtó hatalmi ág felé hajlik. A végrehajtó hatalom lényegében döntéshozó, míg a jogalkotó hatalmat tanácskozó testületek alkotják. Következésképpen a különleges jogrendek alkalmazása a végrehajtó hatalom hatásköreinek fokozottabb koncentrációjához vezet; ez az intézményrendszer jellegére való tekintettel feleslegesnek vagy akár károsnak is tekinthető. Az elnök személyében megtestesülő végrehajtó hatalmat - helyesen vagy helytelenül - egyedüli döntéshozónak és ezért a válság kezeléséért egyedüli felelősnek tekintik.

A magyar Alaptörvény kilencedik módosítása az észszerúsítés és az egyszerűsítés céljából gyökeresen átalakítja a különleges jogrendre vonatkozó szabályozást. Ezzel megszüntet néhány alkalmi rendelkezést, például a „terrorveszélyhelyzetet”, amely egyértelmúen a 20152016-os franciaországi terrortámadások nyomán jött létre. Franciaországban egy hasonló reform nem lenne haszontalan, azonban néhány akadály áll az útjában: először is, a jelen politikai tényezôk megnehezítik az alkotmánymódosítást. Az alkotmány módosításához a parlament háromötödös többsége szükséges, vagy alternatív megoldásként a népszavazás kockázatos gyakorlatához lehetne folyamodni. Ezenkívül a francia alkotmánytörténet azt mutatja, hogy az intézményi gyakorlatot a mindenkori követelményekhez igazítják, az alkotmányt ritkábban módosítják azért, hogy a gyakorlathoz igazodjon. Ezért a különleges jogrendek teljes átalakítása a közeljövőben nem valószínú. Franciaországban 1970 óta nem került szóba a különleges jogrendszer komolyabb átalakítása. Az a terv azért volt sikertelen, mert hasznosságát elégtelennek tartották, és az akkori turbulens politikai helyzetben nyugtalanságot kelthetett volna. Mindenesetre nem túnik szükségesnek a végrehajtó hatalom megerősítése, amely az V. köztársaság rendszerében amúgy is túlsúlyban van. Az eljövendő magyar jogrendben a hadiállapot megfelelője a francia jogrendben az ostromállapot lenne, amely fegyveres konfliktust jelent az ország területén. A francia rugalmas szükségállapot mind a veszélyhelyzetnek, mind a szükségállapotnak megfelel, bár utóbbi esetben az események súlyossága elvben a rendkívüli elnöki jogkör alkalmazását igazolhatná.

A koronavírus-járványhoz kapcsolódó válság láthatóvá tette a meglévő mechanizmusok elégtelenségét, hiszen szükségesnek találták egy új, bár elvileg ideiglenes különleges jogrend megvalósítását, azaz az egészségügyi szükségállapotot. Az ez alkalomból létrehozott egész- 
ségvédelmi tanács átláthatatlansága és a döntések központosítása kritika tárgyát képezi. ${ }^{63}$ A hosszú távú egészségügyi sürgősségi kezelési rend létrehozásáról szóló törvényjavaslat, amelyet a minisztertanács elé terjesztettek 2020 végén, összehasonlítható a veszélyhelyzet megszúnésével összefüggő átmeneti szabályokról és a járványügyi készültségről szóló 2020. évi LVIII. törvénnyel, amennyiben ez a különleges jogrend alapvető jellemzőinek a normális jogrendbe beépítését eredményezi: nevezetesen a kormány felhatalmazását bizonyos szabadságok gyakorlásának korlátozására anélkül, hogy előzetesen konzultálna a parlamenttel. Hasonlóképpen megkülönbözteti az egészségügyi válsághelyzetet és az egészségügyi vészhelyzetet (vagy a francia kifejezés szerinti szükségállapotot).

Összehasonlító szempontból az alapvető jogok tiszteletben tartása és a hatalom szétválasztásának tiszteletben tartása kétféle módon biztosított. Egyrészt a kormánynak rendszeres időközönként konzultálnia kell a parlamenttel, a törvény meghatározza a kormányra bízott hatásköröket, és szisztematikusan határidőt ír elő. Emlékszünk arra, hogy a magyar esetben mindenekelőtt a határidő hiánya okozott nehézségeket. A francia parlament külön vizsgálóbizottságokat is létrehozott a vészhelyzet kezelése érdekében. ${ }^{64}$ Másrészt a kormány fellépése továbbra is bírói ellenőrzés alatt áll. A közigazgatási bíró megvizsgálja a végrehajtó hatalom intézkedéseinek jogszerűségét. Az Alkotmánytanács, amelynek hatásköre az 1970-es évek óta folyamatosan nőtt, ma kiemelt szerepet játszik az alapvető jogok és szabadságok védelmében. Ebből a szempontból a magyar eset fordított tendenciát mutat, az alkotmánybíróság szerepének korlátozása felé a parlamenti szuverenitás javára - a parlament mozgástere azonban korlátozottnak túnik a végrehajtó hatalom tekintetében, mivel a Kormány nagy többséggel rendelkezik, ami megkönnyíti a fegyelmet a parlamenti csoporton belül.

\section{Irodalomjegyzék}

Agamben, G. (2005) State of Exception. Chicago: University of Chicago Press

BARANGER, D. (2016) 'Létat d'urgence dans la durée', Revue française de droit administratif, 32(3), 447-454. o.

Beaud, O., Guérin-Bargues, C. (2016) L'état d'urgence. Étude constitutionnelle, historique et critique. 1. kiadás. Paris: LGDJ

Benzina, S. (2020) La curieuse suspension des délais d'examen des questions prioritaires de constitutionnalité [Online]. Elérhetô: http://blog.juspoliticum.com/2020/04/03/la-curieusesuspension-des-delais-dexamen-des-questions-prioritaires-de-constitutionnalite-parsamy-benzina\%e2\%80\%a8/ (Letöltve: 2020. november 18.)

63 Hirsch, 2021; Blondiaux, 2021.

64 Venice Commission, 2020, 19. o. 
Blondiaux, L. (2021) 'De la démocratie en France. En finir avec les faux-semblants', Esprit, 2021/4, 87-99. 0.

Cassia, P. (2016) Contre l'état d'urgence. 1. kiadás. Paris: Dalloz

Champeil-Desplats, V. (2017) 'Histoire de lumières françaises: l'état d'urgence ou comment l'exception se fond dans le droit commun sans révision constitutionnelle', Revue interdisciplinaire d'études juridiques, 79(2), 205-227. o.

Champeil-Desplats, V. (2020) 'Le Conseil constitutionnel face à lui-même', La Revue des droits de l'homme [Online]. Elérhető: https://journals.openedition.org/revdh/9029 (Letöltve: 2020. december 10.)

Derosier, J.-P., CARTIER, E., (2020) 'Chronique de droits fondamentaux et libertés publiques (janvier 2020 à juin 2020)', La sécurité juridique, 5(7), 99-111. o.

Esplugas-Labatut, P. (2018) 'Pour la constitutionnalisation de l'état d'urgence', Revue française de droit constitutionnel, 2018/3, 485-496. 0.

GARrigou, A. (2017) La politique en France: De 1940 à nos jours. 1. kiadás. Paris: La Découverte

Gicquel, J.-E. (2020) 'La loi organique Covid-19 et l'irrespect non sanctionné de la Constitution', Gazette du Palais, 2020/14, 27-29. o.

Hirsch, E. (2021) Une démocratie confinée: L'éthique quoi qu'il en coûte. 1. kiadás. Toulouse: Érès JACQUIN, J.-B. (2020) Coronavirus: L'état d'urgence sanitaire ouvre des brèches dans l'État de droit [Online]. Elérhető: www.lemonde.fr/societe/article/2020/03/28/coronavirus-l-etat-durgence-sanitaire-ouvre-des-breches-dans-1-etat-de-droit_6034751_3224.html (Letöltve: 2020. december 15.)

JEANNENEY, J. (2020) 'La non-théorie des «circonstances particulières»', Droit administratif, 76(15), 843-847. 0 .

Manin, B. (2015) Le paradigme de l'exception [Online]. Elérhető: https://laviedesidees.fr/Leparadigme-de-l-exception.html (Letöltve: 2020 . november 18.)

Massot, J. (2013) 'Le Conseil d'État face aux circonstances exceptionnelles', Les Cahiers de la Justice, 2013/2, 27-39. o.

NoËL, L. (1976) De Gaulle et les débuts de la Ve République. 1. kiadás. Paris: Plon

Pierré-CAPS, S. (2016) 'Constitutionnaliser l'état d'urgence?', Civitas Europa, 2016/1, 141-154. o.

Platon, S. (2008) 'Vider l'article 16 de son venin: les pleins pouvoirs sont-ils solubles dans l'état de droit contemporain?', Revue française de droit constitutionnel, 2008/5, 97-116. o.

ROUSSEAU, D. (2015) Un projet de révision constitutionnelle recevable mais qui doit être réécrit [Online]. Elérhető: www.lemonde.fr/idees/article/2015/12/21/un-projet-de-revision-constitutionnellerecevable-mais-qui-doit-etre-reecrit_4835966_3232.html (Letöltve: 2020. december 15.)

SÁGVÁRI, Á. (2017) 'Különleges jogrend a francia jogban', Iustum Aequum Salutare, 13(4), 179188. 0.

SAINT-BONNET, F. (2008) 'L'état d'exception et la qualification juridique', Cahiers de la recherche en droits fondamentaux, 2008/6, 29-38. 0. 
SIRINELLI, J.-F. (főszerk.) (1995) Dictionnaire historique de la vie politique au XXe siècle. 1. kiadás. Paris: PUF

Venice Commission (2020) Interim Report on the Measures Taken in the EU Member States as a Result of the COVID-19 Crisis and Their Impact on Democracy, the Rule of Law and Fundamental Rights (Study No. 995/2020) [Online]. Elérhető: www.venice.coe.int/webforms/documents/?pdf=CDL$\mathrm{AD}$ (2020)018-e (Letöltve: 2020. december 15.) 


\title{
15. Különleges felhatalmazás különleges jogrend kihirdetése nélkül, avagy járványkezelés holland módra
}

\author{
MARINKÁS GYÖRGY
}

\section{A különleges jogrend alkotmányos és törvényi szintü szabályozása}

A holland jogrendszer négy különleges jogrendi helyzetet ismer, ${ }^{1}$ ebből kettő alkotmányos ${ }^{2}$ és törvényi szinten egyaránt rögzített, kettő pedig csak törvényi szinten. (A különleges jogrendi helyzeteket és a rájuk vonatkozó szabályokat a fejezet végén található táblázat foglalja össze áttekintő jelleggel.) Az alkotmány ${ }^{3}$ határozza meg az általános szükségállapot (algemene noodtoestand) és a korlátozott szükségállapot (beperkte noodtoestand) esetköreit. ${ }^{4}$ A szükségállapot két fajtájának részletszabályait - a kihirdetés és a hatalom gyakorlásának módját, valamint a korlátozható alapjogok körét - két törvény, a háborús állapotról szóló

1 Amint azt Anna Khakee - a Máltai Egyetem és a Policy Practice munkatársa - írja, az ilyen tagoltabb rendszerek előnyösebbek, mint az egy-két különleges jogrendi helyzetet szabályozó vagy a svájci mintájú biankó csekket garantáló megoldások, tekintve, hogy jobban elősegítik az előállott helyzetre adott adekvát választ, elkerülve a „kormányzati túlreagálást” (Khakee, 2009, 6. o.).

2 Ily módon a holland különleges jogrendi szabályozás nem tekinthető a Carl Schmitt-féle iskola követőjének (Kelemen, 2019, 3. o.).

3 Grondwet voor het Koninkrijk der Nederlanden (a továbbiakban: alkotmány).

4 Alkotmány 96. és 103. cikk.

Dr. Marinkás György, PhD

gyorgy.marinkas@mfi.gov.hu

kutató (Mádl Ferenc Összehasonlító Jogi Intézet)

adjunktus (Miskolci Egyetem Állam- és Jogtudományi Kar, Európai és Nemzetközi Jogi Intézet)

Marinkás, Gy. (2021) 'Különleges felhatalmazás különleges jogrend kihirdetése nélkül, avagy járványkezelés holland módra' in Nagy, Z., Horváth, A. (szerk.) A különleges jogrend és nemzeti szabályozási modelljei, 341357. o. Budapest: Mádl Ferenc Összehasonlító Jogi Intézet.

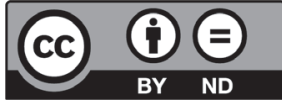


törvény ${ }^{5}$ és a különleges helyzetekről szóló törvény ${ }^{6}$ határozza meg, amelyeket 1996-ban egy átfogó reform keretében fogadtak el.

A különleges jogrend másik két esetét az alkotmány nem rögzíti, azokat - egy újabb átfogó törvényi reform eredményeként - a biztonsági körzetekről szóló törvényben ${ }^{7 o ̈ g z i ́-~}$ tették. A törvény meghatározza a katasztrófahelyzet és a krízishelyzet fogalmát, valamint az ilyen helyzetekben cselekvésre jogosultak körét és azok feladatait.

A koronavírus-járvány kezelése érdekében a négy különleges jogrendi helyzet közül egyiket sem hirdették ki. ${ }^{8}$ Jóllehet a krízishelyzet kihirdetése a külső szemlélő számára kézenfekvő döntés lett volna a kormány részéről, tekintve, hogy azt - többek között - a járványos fertőző betegségek elleni fellépésre szabták, a holland kormány más utat választott: nem hirdetett ki különleges jogrendi helyzetet, és nem kért különleges felhatalmazást. Helyette a 2008-as közegészségügyi törvény9 rendelkezéseire alapozva - az abban az egészségügyi miniszterre ruházott jogkörök révén - biztosította, hogy a járvány elleni fellépés országos szinten egységes legyen. ${ }^{10} \mathrm{~A}$ kormány a Közeü.tv. által rögzített felhatalmazással élve egyrészt az önkormányzati törvény, ${ }^{11}$ valamint a Biztonsági körzetek tv. egyes rendelkezéseit léptette életbe. (A kormány által választott megoldás elemzésére és értékelésére a 3.2. pontban kerül sor.)

A magyar Alaptörvénnyel ellentétben a Különleges helyzetek tv. nem tesz különbséget külső és belső eredetû veszély között, ${ }^{12}$ azaz a hadiállapot (staat van oorlog) is szükségállapotnak (noodtoestand) minősül, vagyis nem képez önálló kategóriát. Amint fentebb említettük, a holland szabályozás korlátozott és általános szükségállapotot ismer. A kettő közötti különbség az alapjogok korlátozhatóságának mértékében és a kormányzatra ruházott jogosultságok kiterjedtségében mutatkozik meg. Korlátozott szükségállapot esetén a jogok korlátozása azt a célt szolgálja, hogy a hadsereg minél hatékonyabban láthassa el az adott területen a katasztrófaelhárítási tevékenységet, példának okáért az evakuálást, az orvosi ellátás megszervezését, valamint a közrend és közbiztonság fenntartását. Általános szükségállapot esetén a katonaság gyakorlatilag átveszi a közigazgatási szervek összes feladatát, és a kormány irányítása - valamint bizonyos szervek felügyelete mellett - rendelkezést nyer az ország összes anyagi és humánerőforrása felett. ${ }^{13}$

Az alkotmány törvényi útra tereli a részletszabályok megállapítását azt illetően, hogy mely esetekben hirdethető ki a szükségállapot „a belső és külső biztonság fenntartásához”,

5 Oorlogswet voor Nederland (Wet van 3 april 1996) (a továbbiakban: Háborús tv.).

6 Coördinatiewet uitzonderingstoestanden (Wet van 3 april 1996) (a továbbiakban: Különleges helyzetek tv.).

7 Wet veiligheidsregio's (Wet van 11 februari 2010) (a továbbiakban: Biztonsági körzetek tv.).

8 Bentzen et al., 2020, 7-9. o.

9 Wet publieke gezondheid (Wet van 9 oktober 2008) (a továbbiakban: Közeü.tv.).

10 Cavalcanti-Terstegge, 2020, 1702. o.

11 Gemeentewet (Wet van 14 februari 1992) (a továbbiakban: Önkormányzati tv.).

12 Különleges helyzetek tv. 1. \$(1) bekezdés.

13 A két szükségállapoti helyzet egyszerre értelemszerúen nem rendelhető el (Cavalcanti-Terstegge, 2020, 1704. o.). 
és hogy a szükségállapot kihirdetését követően a jogalkalmazó milyen felhatalmazást kap, illetve mely alapjogokat korlátozhatja..$^{14}$

Az általános és korlátozott szükségállapot kihirdetésére okot adó körülményeket a Különleges helyzetek tv. rögzíti: amennyiben a különleges körülmények azt szükségessé teszik, a miniszterelnök javaslatára az uralkodó királyi rendeletben hirdeti ki a korlátozott vagy az általános szükségállapotot. ${ }^{15} \mathrm{~A}$ rendeletet a hivatalos lapban kell közzétenni. ${ }^{16}$

Az alkotmány értelmében hadiállapotot csak a parlament előzetes hozzájárulásával lehet kihirdetni, ${ }^{17}$ erről a két kamara együttes ülésen dönt. ${ }^{18}$ Ezalól kivételt képez az a helyzet, amikor a ténylegesen fennálló hadiállapot miatt a törvényhozással való konzultáció kivitelezhetetlen. ${ }^{19}$ (A háború befejeztének kihirdetésére az előbbi rendelkezéseket kell alkalmazni.) ${ }^{20}$ Említést érdemel továbbá, hogy önmagában a háborús állapot deklarálása, amennyiben arra a szövetségi kötelezettségek ${ }^{21}$ teljesítése végett kerül sor, az Alaptörvény kilencedik módosítása révén 2023-tól hatályba lépő magyar szabályozási megoldással ellentétben nem jár különleges jogrendi állapot kihirdetésével. (Az ezzel kapcsolatos holland közjogi vitákat lásd a 4. pontban.)

A katasztrófahelyzet és a krízishelyzet fogalmát a Biztonsági körzetek tv. rögzíti. ${ }^{22} \mathrm{~A}$ katasztrófahelyzet olyan helyzetet jelöl, amely komolyan fenyegeti vagy veszélyezteti az állampolgárok életét és jólétét, illetve a természeti és épített környezetet, és amelynek elhárítása, illetve a károk csökkentése érdekében a hatóságok és egyéb szervezetek összehangolt munkája szükséges. Ez utóbbi megfeleltethető a magyar Alaptörvény 53. cikkének. ${ }^{23} \mathrm{~A}$ krízishelyzet a társadalom alapvető érdekeit veszélyeztető eseményt - példának okáért nukleáris balesetet vagy fertőző betegség okozta járványt - vagy az ilyen esemény bekövetkeztével fenyegető helyzetet jelent. ${ }^{24}$

A katasztrófa- és a krízishelyzet közötti elhatárolás alapja alapvetően az irányítás centralizált vagy decentralizált voltában nyilvánul meg: a katasztrófahelyzetek (például kisebb ipari balesetek, árvizek) elhárítása a Biztonsági körzetek tv. értelmében alapvetően a helyi önkormányzatok feladata, ${ }^{25}$ amelyek csak akkor kérnek tartományi vagy kormányzati szintû beavatkozást, amennyiben a feladat helyi szinten kezelhetetlennek bizonyul. ${ }^{26} \mathrm{~A}$ krízis-

14 Alkotmány 103. cikk (1) bekezdés.

15 Különleges helyzetek tv. 1. cikk (1) bekezdés.

16 Különleges helyzetek tv. 1. cikk (3) bekezdés.

17 Alkotmány 96. cikk (1) bekezdés.

18 Alkotmány 96. cikk (3) bekezdés.

19 Alkotmány 96. cikk (2) bekezdés.

20 Alkotmány 96. cikk (4) bekezdés.

21 Például a NATO-szerződés 5. cikke alapján.

22 Biztonsági körzetek tv. 1. \$ (1) bekezdés.

23 Az Alaptörvény 53. cikkét illetően lásd: Horváth, 2020.

24 Kuipers-Boin, 2014, 8-9. o.

25 Biztonsági körzetek tv. 2. cikk.

26 A katasztrófahelyzetek idején alkalmazott holland gyakorlat azt mutatja, hogy a hadsereg bevonását - amennyire lehetséges - igyekeznek kerülni; jóllehet volt arra példa, hogy igénybe vették, elsősorban a lakosság evakuálásának hatékony lebonyolítása érdekében. Lásd: Kuipers-Boin, 2014, 8-9. o. 
helyzet elhárítása ezzel szemben vagy a biztonsági körzetek szintjén - a kormány esetleges iránymutatásával -, vagy centralizáltan, közvetlenül a kormány irányítása alatt történik.

A Biztonsági körzetek tv. a katasztrófahelyzet elhárítását elsődlegesen az önkormányzatok feladatává teszi, a polgármestert jelöli meg mint a katasztrófaelhárítás koordinálásáért felelős személyt. ${ }^{27} \mathrm{Az}$ Önkormányzati tv. rögzíti a polgármesterek ehhez kapcsolódó, a közrend és közbiztonság fenntartására irányuló hatásköreit. ${ }^{28}$ Kiemelendő, hogy a polgármesterek szükséghelyzeti határozatot (noodbevelen) vagy szükséghelyzeti rendeletet (noodverordeningen) bocsáthatnak ki. ${ }^{29} \mathrm{~A}$ kettő közötti különbség, amint azt az Államtanács ${ }^{30}$ Közigazgatási Kollégiuma $^{31}$ egy 2019-es ügyben ${ }^{32}$ kifejtette, hogy míg az előbbi közigazgatási jellegú aktus, amely meghatározott személyt vagy személyek egy csoportját kötelezi egy meghatározott feladat kapcsán, utóbbi általános hatályú, „kvázi törvényhozási” aktus, amely mindenkire vonatkozik az önkormányzat illetékességi területén, és jellemzően huzamosabb ideig marad érvényben. Ennek megfelelően utóbbi elfogadása esetében több eljárási garancia érvényesülését is megkívánja a törvény: egyrészről az intézkedéseknek meg kell felelniük az alkotmány rendelkezéseinek, másrészről a rendelkezéseket jóvá kell hagynia az önkormányzat tanácsának, ${ }^{33}$ majd pedig továbbítani kell azt a tartomány vezetőjének,,34 illetve a körzeti ügyészség vezetőjének. Az önkormányzat tanácsának jóváhagyása a demokratikus kontroll miatt bír kiemelkedő fontossággal: a polgármesterek Hollandiában nem választott tisztségviselők - a bel- és igazságügyi miniszter nevezi ki őket az önkormányzat tanácsa és a tartomány vezetőjének javaslatára ${ }^{35}$-, így a demokratikus kontrollt a közvetlenül választott önkormányzati tanács gyakorolja a tevékenységük felett. ${ }^{36} \mathrm{E}$ kontroll magában foglalja a fent említett jóváhagyást. Amennyiben a tanács nem hagyja jóvá a szükséghelyzeti rendeletet az elfogadását követô első ülésén, úgy annak hatálya megszû́nik. ${ }^{37} \mathrm{~A}$ két instrumentum közötti különbség az ellenük benyújtható jogorvoslatok terén is megmutatkozik: míg előbbi ellen a közigazgatási bíróságok előtt indítható eljárás, utóbbi a rendes polgári bíróság elôtt támadható meg, és a hatályon kívül helyezésére

27 Biztonsági körzetek tv. 5. cikk.

28 Önkormányzati tv. 172-177. cikk.

29 Önkormányzati tv. 175. cikk.

30 Hollandiában az Államtanács (Raad van State) kettős funkcióval bír: egyrészrôl független tanácsadó szervként segíti a kormány és a parlament munkáját törvényhozási és közigazgatási ügyekben. Másrészről az állam legfelsőbb közigazgatási bírói fórumaként jár el. Ez utóbbi funkciót egy 1963-as törvényhozási reform ruházta az Államtanácsra. Az említett reform arról is rendelkezett, hogy az Államtanács tanácsadói és a bírói funkciót ellátó két ága személyileg és szervezetileg is elkülönül egymástól. Előbbi tíz főbool áll, elnöke a mindenkori uralkodó. Utóbbi ágában pedig hivatásos bírák látják el a szolgálatot. Lásd az Államtanács honlapját: www. raadvanstate.nl/overrvs/raad-state-kort/ (Letöltve: 2020. december 15.).

31 De Afdeling Bestuursrechtspraak van de Raad van State (ABRvS).

32 ABRvS, 201900824/1/A3 (18.12.2019).

33 Gemeenteraad.

34 Commissaris van de Koning (CvdK).

35 Önkormányzati tv. 61. cikk.

36 Önkormányzati tv. 10. cikk.

37 Önkormányzati tv. 176. cikk (3) bekezdés. 
csak abban az esetben van lehetőség, amennyiben ellentétes a jogszabályi hierarchiában felette álló normákkal és a jogrendszer alapvető elveivel.

Az önkormányzatok kompetenciáját meghaladó rendkívüli események kezelése a biztonsági körzet vezetőjéboól ${ }^{38}$ és a körzetébe ${ }^{39}$ tartozó polgármesterekből álló testület (bestuur van de veiligheidsregio) feladata. ${ }^{40} \mathrm{~A}$ testület többségi szavazással dönt; ${ }^{41}$ szavazategyenlőség esetén a biztonsági körzet vezetôjének szavazata dönt. A testület üléseire ${ }^{42}$ tanácskozási joggal meghívják a legfőbb körzeti ügyészt, a területileg illetékes vízügyi főhatóság vezetőjét, valamint a tartomány vezetőjét. Utóbbi akkor jut szerephez mint „döntőbíró”, ha valamilyen hatásköri összeütközés áll fenn. ${ }^{43} \mathrm{~A}$ biztonsági körzetek említett testülete felelős a szükséghelyzeti cselekvési terv ${ }^{44}$ kidolgozásáért és annak legalább négyévente történő felülvizsgálatáért.

A Biztonsági körzetek tv. rögzíti a több biztonsági körzetet érintő krízishelyzetek esetén alkalmazandó szabályokat. ${ }^{45}$ Jóllehet a polgármesterek ez esetben is véleményt nyilváníthatnak előzetesen - illetve utólag tiltakozást nyújthatnak be -, a törvény 39-43. cikkének értelmezéséből az következik, hogy ez esetben a helyi önkormányzatok csak végrehajtói a biztonsági körzetek vezetőin keresztül érvényesülő, a kormánytól és a tartományok vezetőitől érkező utasításoknak. A krízishelyzet esetén követendő protokollt országos szinten a 2016. szeptember 6-i miniszterelnöki rendelet, ${ }^{46}$ valamint a Krízishelyzetekben történő döntéshozatalról szóló nemzeti útmutató címú dokumentum ${ }^{47}$ szabályozza, amelyek meghatározzák a Miniszteri Szintû Válságkezelő Bizottság, valamint a többi, a válságkezelésben részt vevő szerv és intézmény ${ }^{48}$ összetételét és feladatait.

38 A biztonsági körzetek vezetőit a Biztonsági körzetek tv. 11. cikke értelmében királyi rendelet útján nevezik ki és királyi rendelet útján menesztik, amennyiben az szükséges. A kinevezést megelőzően a biztonsági körzetbe tartozó polgármesterek és az adott tartomány vezetôje véleményt nyilváníthatnak a jelöltet illetően.

39 A Biztonsági körzetek tv. 8. cikkének melléklete tartalmazza az önkormányzatok biztonsági körzetek szerinti beosztását.

40 Biztonsági körzetek tv. 8. cikk.

41 Biztonsági körzetek tv. 11. cikk.

42 Biztonsági körzetek tv. 12-13. cikk.

43 Biztonsági körzetek tv. 42., 53., 59. cikkek.

44 Biztonsági körzetek tv. 14-16. cikk.

45 Biztonsági körzetek tv. 39. cikk.

46 Order of the Prime Minister (Minister of General Affairs) of 6 September 2016, no. 3889766, establishing the Ministerial Crisis Management Committee (Government Gazette, 12 September 2016, no. 48258) (a rendelet a Biztonsági körzetek tv. 37. cikkében található felhatalmazáson alapul).

47 Nationaal Handboek Crisisbesluitvorming. Közzétéve: Kormányzati Közlöny, 2013. április 24. (11207. szám). A Nemzeti Biztonsági és Terrorelhárító Központ (Nationaal Coördinator Terrorismebestrijding en Veiligheid) kiadványa: www.preventionweb.net/files/submissions/61145_nlnationalhandbookondecisionmakingincrisissi tuationsnetherlands.pdf (Letöltve: 2020. december 15.).

48 További szervek a teljesség igénye nélkül: Tanácsadó Csoport (Adviesteam), Tárcaközi Válságkezelő Bizottság (Interdepartementale Commissie Crisisbeheersing); Nemzeti Krízisközpont (Nationaal Crisiscentrum); Nemzeti Mủveleti Koordinációs Központ (Landelijk Operationeel Coördinatiecentrum); Nemzeti Biztonsági és Terrorelhárító Központ (Nationaal Coördinator Terrorismebestrijding en Veiligheid), Nemzeti Válságkommunikációs Stáb (Nationaal Kernteam Crisiscommunicatie). 


\section{Az alapjogok korlátozására vonatkozó szabályok különleges jogrend idején}

Az alkotmány felsorolja azokat az alkotmányos rendelkezéseket, illetve alapjogokat, amelyek korlátozhatók szükségállapot idején. ${ }^{49}$ Ennek megfelelően alkotmányos szinten szabályozott a következő alapjogok korlátozása: ${ }^{50}$ a vallási és a lelkiismereti szabadság körébe eső tevékenységek (6. cikk), amennyiben azok nem beltérben vagy más zárt helyen történnek; a véleménynyilvánítás és a sajtó szabadsága (7. cikk). Továbbá az egyesülési szabadság (8. cikk); a gyülekezési jog (9. cikk); a magánlakás sérthetetlenségéhez való jog (12. cikk); a levéltitokhoz való jog (13. cikk). Az alkotmány a részletszabályok megállapítását törvényi szintre utalja, ahogyan a további korlátozható jogok körét, a korlátozás részletes szabályait, valamint az általános szükséghelyzet esetén az országot irányító katonai kormányzat jogköreinek meghatározását is. Mindezeket a Különleges helyzetek tv. rögzíti a Háborús tv. paragrafusainak megjelölése révén.

Korlátozott szükséghelyzet esetén az úgynevezett "A” listás ${ }^{51}$ jogok esnek korlátozás alá. Amint fentebb utaltunk rá, az alapjogok csak az alkotmányban meghatározott mértékben korlátozhatók. A korlátozott szükségállapot elrendelése esetén a kormány - azon belül különösen a védelmi miniszter - és a hadsereg olyan jogosítványokat kap, amelyek a korlátozott szükségállapot elrendelésére okot adó körülmény elhárításához szükségesek. (Ilyen például a lakosság teljes vagy részleges kitelepítése, ezzel együtt egyes körzetek teljes lezárása, ingó és ingatlan dolgok kisajátítása, a telekommunikációs eszközök és a közúti közlekedés feletti teljes rendelkezés átvétele.)

Általános szükséghelyzet esetén az úgynevezett „B” listás jogok ${ }^{52}$ korlátozhatók. A katonai kormányzat általános sorkötelezettséget rendelhet el minden 18. életévét betöltött személy számára. Ezzel egyidejûleg az alapjogok komoly korlátozás alá esnek. Így például az alkotmányban szabályozott büntetôjogi alapelvek ${ }^{53}$ - úgymint a törvényes bíróhoz való jog a büntetőügyek elbírálása és a szabadságvesztés-büntetés kiszabása során - is csak korlátozottan, „a körülmények által lehetôvé tett mértékben” érvényesülnek. ${ }^{54}$

Katasztrófa- és krízishelyzet esetén olyan alapjogok korlátozhatók, mint a gyülekezés és az egyesülés szabadsága, a vallásszabadság, illetve az oktatáshoz és az igazságszolgálta-

49 Alkotmány 103. cikk (2) bekezdés.

50 E helyütt érdemes felhívni rá a figyelmet, hogy a holland alkotmány és a magyar Alaptörvény eltérően közelíti meg a kérdést: míg előbbi a korlátozható jogok körét sorolja fel, utóbbi azokat, amelyeket még különleges jogrend esetén sem lehet korlátozni (Khakee, 2016, 16. o.).

51 Háborús tv. 9-23. cikk.

52 Háborús tv. 9-53. cikk.

53 Alkotmány 113. cikk (1)-(3) bekezdés.

54 Háborús tv. 42. cikk. Érdemes megjegyezni, hogy a magyar Alaptörvény a holland alkotmánnyal ellentétben még különleges jogrend esetén sem töri át ezt a fontos alapjogi garanciát. Az Alaptörvény 54. cikke értelmében - többek között - a XXVIII. cikk (2)-(6) bekezdésében megállapított alapvető jogok még különleges jogrend idején sem függeszthetők fel. 
táshoz való hozzáférés. E jogok korlátozásának szabályait az alkotmány, az Önkormányzati tv. és a Biztonsági körzetek tv. rögzítik. ${ }^{55} \mathrm{~A}$ vallás- és a lelkiismereti szabadság körébe eső tevékenységek - feltéve, hogy azok nem beltérben vagy más zárt helyen kerülnek megtartásra az alkotmány alapján, ${ }^{56}$ a törvényben meghatározottak szerint korlátozhatók a közegészség védelme, a közlekedés zavartalanságának biztosítása, illetve katasztrófa megelőzése vagy elhárítása érdekében. Hasonlóképpen, a gyülekezési jog a törvényben meghatározott esetekben korlátozható a közegészség védelme, a közlekedés zavartalanságának biztosítása, illetve a katasztrófa megelőzése vagy elhárítása érdekében. ${ }^{57}$

\section{A koronavírus-járvány miatt bevezetett különleges intézkedések és az alapjogok korlátozásának alkotmányossága}

\subsection{A 2020 tavaszán bevezetett intézkedések}

A holland kormány arra az álláspontra helyezkedett, hogy a koronavírus-járvány elleni hatékony fellépés - és a lakosság egészségének megőrzése mint alkotmányos kötelezettség ${ }^{58}$ teljesítése - érdekében nem szükséges különleges jogrendi állapot kihirdetése ${ }^{59} \mathrm{~A}$ kormány által meghozott intézkedések a Közeü.tv. rendelkezésein alapultak. A törvény értelmében a fertőző betegségek a súlyosságuk szerint A, B1, B2 és C kategóriába eshetnek egy olyan skálán, amelyen az A kategória a legsúlyosabb. ${ }^{60} \mathrm{~A}$ betegség súlyosság szerinti osztályozása egyben meghatározza a kormány és a decentralizált szervek közötti feladatmegosztást, illetve a korlátozható alapjogok körét. ${ }^{61}$

Az egészségügyi miniszter a koronavírust 2020. január 28-án nyilvánította $\mathrm{A}$ kategóriás fertőző betegséggé, amelynek következtében a Közeü.tv.-ben biztosított felhatalmazással ${ }^{62}$ élve átvette a vírus elleni védekezés irányítását anélkül, hogy krízishelyzetet hirdettek volna ki. A biztonsági körzetek vezetői felhatalmazást kaptak, hogy átvegyék a védekezés megszervezésével kapcsolatos - az Önkormányzati tv.-ben rögzített ${ }^{63}$ - hatáskörök gyakorlását

55 Ezek részletesen a jelen fejezet 3. pontjában kerülnek ismertetésre.

56 Alkotmány 6. cikk (2) bekezdés.

57 Alkotmány 9. cikk (2) bekezdés.

58 Alkotmány 22. cikk (1) bekezdés.

59 Hendriks, 2020, 950. 0.

60 Közeü.tv. 1. cikk.

61 Egy A kategóriás fertőző betegség esetén például a Közeü.tv. 38. cikk (1) bekezdése értelmében az érintett az akarata ellenére és a beleegyezése nélkül is karanténba helyezhető, amennyiben azt a biztonsági körzet vezetője elrendeli. Az ilyen betegség diagnosztizálása vagy a betegség gyanúja esetén a 22. cikk (1) bekezdése értelmében az orvos jelenteni köteles a közhatalmi szervek irányába.

62 Közeü.tv. 6. cikk (4) bekezdés, 7. cikk (1) bekezdés.

63 Önkormányzati tv. 172-177. cikk. 
a polgármesterektől; továbbá az egészségügyi miniszter felhatalmazást kapott a biztonsági körzetek vezetőinek utasítására. ${ }^{64}$

Az első kormányzati szintû́ intézkedéscsomagot 2020. március 12-én jelentette be Mark Rutte miniszterelnök, az egészségügyi miniszter ugyanazon a napon kelt javaslatával ${ }^{65}$ egyező tartalommal. A kormány megtiltotta minden, száz főnél nagyobb rendezvény tartását, valamint felkérte az állampolgárokat, hogy amennyiben a koronavírus tüneteit fedezik fel magukon, úgy maradjanak otthon. Az időseket és a más okból gyenge immunrendszerrel rendelkezőket arra kérte, hogy tartózkodjanak a nagyobb létszámú csoportosulással járó események látogatásától, illetve felhívta az egészségügyben dolgozókat, hogy ne utazzanak külföldre.

A kormányzati intézkedések bejelentését követően a biztonsági körzetek vezetői kibocsátották a saját biztonsági körzetükre vonatkozó szükséghelyzeti rendeleteket. Míg e rendeletek egy része szóról szóra ismételte az egészségügyi miniszter levelében foglaltakat, más körzeti vezetők eltérő tartalommal töltötték azt meg, élve az Önkormányzati tv.-ben rögzített felhatalmazással. ${ }^{66}$ Annak érdekében, hogy a szükséghelyzeti rendeletek alkalmazása egységes módon történjen, a biztonsági körzetek vezetőinek tanácsa (veiligheidsberaad) kidolgozott egy modell szükséghelyzeti rendeletet, amelyből kiindulva minden egyes biztonsági körzet vezetője - az egészségügyért felelős miniszter felügyeleti jogának fenntartása mellett - kidolgozhatta a saját körzete igényeinek megfelelő szükséghelyzeti rendeletet.

$\mathrm{Az}$ egészségügyi miniszter 2020. március 17 -én rendelte $\mathrm{el}^{67}$ az óvodák és az oktatási intézmények, az éttermek és egyéb vendéglátóhelyek, valamint a sportlétesítmények bezárását. E rendelkezések a biztonsági körzetek vezetôi által a következő napokban elfogadott vészhelyzeti rendelkezések révén váltak kötelezővé. A miniszter 2020. március 25 -én gyakorlatilag a résztvevők számától függetlenül minden csoportosulással járó tevékenységet megtiltott, amely alól csak a városi tanácsok, a parlament és az állam múködéséhez szükséges közigazgatási szervek tevékenysége, továbbá a harminc fônél kevesebb személy részvételével tartott esküvők és temetések, valamint vallási összejövetelek képeztek kivételt - feltéve, hogy az alkalmazottak, illetve utóbbi három esetében a résztvevők maszkot viselnek.

A biztonsági körzetek vezetói - élve a törvényes felhatalmazásukkal - további rendelkezéseket hoztak: Zeeland tartományban például a biztonsági körzet vezetője betiltotta a fizetett szálláshelyek múködését. ${ }^{68}$

A fenti rendelkezések megszegésének esetére az egészségügyi miniszter pénzügyi szankciók kiszabását javasolta. A biztonsági körzetek vezetői által kibocsátott szükséghelyzeti rendeletek is jellemzően pénzügyi szankciót rendeltek alkalmazni az elő́rásokat megszegókkel szemben. Jogértelmezési kérdést vetett fel ugyanakkor, hogy a biztonsági körzet ve-

64 Biztonsági körzetek tv. 39. cikk.

65 Kamerstukken, 2019/2020, 25295, n.124.

66 Önkormányzati tv. 174. cikk.

67 Kammerstukken II, 2019/2020, 25295, n.175; Kamerstukken II, 2019/2020, 31289, n.416.

68 Noodverordening COVID-19, Veiligheidsregio Zeeland, 27 March 2020. 
zetőjének jogában áll-e közigazgatási bírság kiszabását elöírni a szükséghelyzeti rendeletben. Az Önkormányzati tv. ugyanis feljogosítja erre a polgármestert. ${ }^{69} \mathrm{~A}$ Biztonsági körzetek tv. 39. cikke ugyanakkor az Önkormányzati tv. 125. cikkében rögzített hatáskörök átszállásáról nem rendelkezik. Az igazságügyi miniszter a hozzá intézett kérdésre válaszul70 arra az álláspontra helyezkedett, hogy bár a Biztonsági körzetek tv. 39. cikke nem említi expressis verbis az Önkormányzati tv. 125. cikkét, a törvényt úgy kell értelmezni, hogy a hatáskörök átruházása magában foglalja a szankciós jogkörök átszállását is. A kérdést tisztázandó, a Közeü.tv. módosítását célzó 2020. júliusi törvényjavaslat - amelyről a 3.3. pontban esik szó részletesen expressis verbis rendelkezik a biztonsági körzetek vezetőinek szankcionálási jogáról.

A kormány a fent említett intézkedéseket 2020. május 11-én kezdte el fokozatosan feloldani, amikor az intenzív osztályon ápolt páciensek létszáma egy meghatározott szint alá csökkent. ${ }^{71}$

\subsection{A bevezetett intézkedések értékelése a jogállamiság és a demokratikus elszámoltathatóság szempontjából}

A koronavírus-járvány kapcsán hozott korlátozások értékelése során a mérlegelendő szempont, hogy az alapjogok korlátozása arányos volt-e az alkotmány 22. cikk (1) bekezdésében rögzített céllal. E mérlegelés elvégzése Hollandiában a rendes bíróságok, valamint a legfelsőbb bíróság és az Államtanács Közigazgatási Kollégiuma, illetve egyéb különleges hatáskörű bíróságok feladata. E helyütt érdemes utalni a hollandok „különutasságára”² e téren: Hollandiának - ellentétben a kelseni tanokkal és a többségükben e tanokat követő európai országokkal - nincs sem alkotmánybírósága, sem olyan legfelsőbb bírósága, amely a joggyakorlata fejlesztése során magának vindikálta volna a törvények alkotmányossági felülvizsgálatának jogát, ahogyan azt az Egyesült Államok legfelsőbb bírósága tette. A holland alkotmány expressis verbis tiltja a bíróságok számára, hogy alkotmányossági szempontú felülvizsgálatot végezzenek a parlament által meghozott törvények és az ország által kötött nemzetközi szerződések felett. ${ }^{73} \mathrm{E}$ hiányosságot ugyanakkor valamelyest ellensúlyozza az ország nemzetközi jog elsőbbsége iránti elkötelezettsége ${ }^{74}$ amelynek értelmében a bíróságok kötelesek „félretenni” a nemzeti jogot, amennyiben az ellentétes valamely, a személyekre közvetlenül jogot ruházó nemzetközi szerződéssel vagy valamely nemzetközi szervezet által kibocsátott határozattal, amennyiben az a személyekre közvetlenül jogot alapít.

A szakirodalom vegyes a kormány azon döntésének megítélésében, hogy nem vezetett be különleges jogrendi állapotot, valamint az általa rendes jogrend alapján hozott intéz-

69 Önkormányzati tv. 125. cikk.

70 Handelingen 2019/20, No. 2307, 01.04.2020.

71 Antonides-van Leeuwen, 2020, 4. o.

72 E különutasság kapcsán részletesen lásd: Uzman et al., 2010.

73 Alkotmány 120. cikk.

74 Alkotmány 94. cikk. 
kedések jogi szempontú megítélését illetően. Cavalanti és Terstegge szerint a Közeü.tv. és a Biztonsági körzetek tv. rendelkezései kellő jogalapot szolgáltattak a meghozott intézkedésekhez, amelyek az arányosság próbáját is kiállták. Mi több, álláspontjuk szerint a holland kormány által hozott kezdeti - az állampolgárok meggyőzésére alapuló - intézkedések túlzottan enyhék voltak a szükségeshez képest. ${ }^{75}$

A kormány a kezdeti enyhe intézkedéseket, illetve később a különleges jogrendi helyzet mellőzését azzal indokolta, hogy bízik az állampolgárok felelősségteljes magatartásában. ${ }^{76}$ Broeksteeg, ${ }^{77}$ valamint Buyse és de Lange ${ }^{78}$ ezzel szemben arra hívják fel a figyelmet, hogy a kormány tulajdonképpen azért nem hirdetett ki krízishelyzetet - vagy más különleges jogrendi helyzetet -, mert ily módon a Közeü.tv. rendelkezéseiben található „kiskaput” felhasználva úgy biztosíthatta az általa hozott intézkedések egész országban történő érvényesülését, hogy közben megkerülte a demokratikus kontrollt és az alapjogok korlátozásának alkotmányos garanciáit. A kormány a demokratikus kontroll megkerülését oly módon érte el, hogy a Közeü.tv. fent említett rendelkezéseire alapozva elvonta a polgármesterek döntési jogkörét, és a biztonsági körzetek vezetőinek kezébe helyezte azt, akik a kibocsátott szükséghelyzeti rendeleteiket nem kötelesek jóváhagyatni az önkormányzat tanácsával. Az ő esetükben, amennyiben sor kerül krízishelyzet kihirdetésére, az ellenőrzést - ám nem a demokratikus kontrollt ${ }^{79}$ - a Biztonsági körzetek tv. alapján a körzetükbe tartozó polgármesterekkel, valamint a kerületi legfőbb ügyésszel való kötelező előzetes egyeztetés, illetve a körzetbe tartozó önkormányzati tanácsok kérdezési joga garantálja ${ }^{80}$ Tekintve azonban, hogy a kormány nem hirdetett ki krízishelyzetet, a Közeü.tv. pedig nem ír elő semmilyen hasonló egyeztetési kötelezettséget, a biztonsági körzetek vezetőinek kezét még ez az előírás sem kötötte - ehelyett azok végig az egészségügyi miniszter kottájából játszottak.

A jogalkalmazás terén további problémaként jelentkezett, hogy a jogalkalmazók a koronavírus-járvány elleni védekezés során több esetben a kevesebb garanciális szabály mellett kibocsátható szükséghelyzeti határozatokat alkalmazták „kvázi szükséghelyzeti rendeletként" olyan esetekben is, amikor a törvény értelmében egyébként szükséghelyzeti rendeleteket kellett volna kibocsátaniuk. ${ }^{81}$

Az alapjogok korlátozása kapcsán Wierenga és szerzőtársai ${ }^{82}$ - valamint a fentebb említett Buyse és de Lange - az alkotmány 103. cikkének (2) bekezdésében rögzített, a vallásszabad-

75 Cavalanti-Terstegge, 2020, 1708-1709. o.

76 Továbbá, ahogyan a miniszterelnök fogalmazott: nem akar „főnököt” játszani, aki megmondja másoknak, hogy mit csináljanak (Antonides-van Leeuwen, 2020, 1. o.).

77 Broeksteeg, 2020.

78 Buyse-de Lange, 2020.

79 Emlékeztetni kell, hogy a krízishelyzet esetében helyi szinten demokratikus elszámoltathatóságról eleve nem lehet beszélni, mivel ez esetben az önkormányzatok feladata a kormány döntéseinek végrehajtása. Az intézkedésekért tehát ez esetben a kormány felel a választók előtt.

80 Biztonsági körzetek tv. 40. cikk.

81 van der Kolk, 2020 .

82 Wierenga et al., 2020. 
ságra és a gyülekezési jogra vonatkozó rendelkezéseket illetik jogállamisági optikájú kritikával. Amint írják, amennyiben a kormány szükséghelyzetet hirdetett volna, úgy kizárólag az említett alapjogok nyilvánosan történő gyakorlását korlátozhatta volna, azt is csak a törvényhozás ellenőrzése alatt, nem pedig a biztonsági körzetek vezetôi által - az egészségügyi miniszter kézi vezérlése alatt - kiadott szükséghelyzeti rendeletek útján. Amint fentebb bemutattuk, a kibocsátott szükséghelyzeti rendeletek elő́rásokat - maximális létszám, kötelező maszkviselés - tartalmaztak a zárt térben történő vallásgyakorlásra vonatkozóan, illetve minden gyülekezést betiltottak létszámtól függetlenül. További példaként említik az egészségügyi és szociális ellátóintézményekben bevezetett látogatási tilalmat, amely ellen az alkotmány, illetve a vonatkozó törvények - a kormány által választott megoldásból kifolyólag - nem garantálnak érdemi, az ellentétes jogokat és érdekeket mérlegelő felülvizsgálati fórumot az érintettek számára. E helyütt szükséges emlékeztetni a fentebb írottakra, miszerint a szükséghelyzeti rendeletek csak abban az esetben helyezhetők hatályon kívül, amennyiben ellentétesek a hierarchiában felettük álló jogszabályokkal vagy a jogrendszer alapvető elveivel.

További kritikaként említhető, hogy bár a holland parlament múködött a járványügyi megszorítások idején is, az általa érvényesített kontroll meglehetősen felületes volt. Mindez következett abból is, hogy az alsóház, ${ }^{83}$ amely rendszerint heti háromszor ülésezik, lecsökkentette az ülések számát heti egyre, a felsőhá $z^{84}$ pedig teljesen átállt az online ülésezésre. A felsőház a döntés meghozatala előtt jogértelmezést kért és kapott az Államtanácstól, amelynek álláspontja ${ }^{85}$ a következők szerint foglalható össze: a holland alkotmány nem zárja ki az online ülésezést, feltéve, hogy a nyilvánosság és a sajtó számára biztosítják, hogy az ülést videoközvetítés útján nyomon követhessék, és azt, hogy a közvetítés során a felszólaló képviselők egyértelmúen beazonosíthatók legyenek. Az Államtanács véleménye alapján azonban online szavazást nem lehet tartani, mivel a véleménykibocsátásnak az időpontjában még nem állt rendelkezésre olyan technológia, amely garantálta volna a szavazás titkosságát.

\subsection{A törvényi reform}

Az előző alpontban ismertetett kritikákra tekintettel a holland kormány 2020 júliusában benyújtott egy törvénymódosítási javaslatot, amelynek célja az volt, hogy - a fentebb ismertetett kritikákat figyelembe véve - a jogállamiság követelményének megfelelő jogalapot szolgáltasson a járvány második hulláma elleni védekezés során meghozott intézkedésekhez ${ }^{86} \mathrm{~A}$ Covid-19járvány kezeléséhez szükséges átmeneti intézkedésekról szóló törvényjavaslatot 2020. október

83 Tweede Kamer der Staten-Generaal.

84 Eerste Kamer der Staten-Generaal.

85 Raad van State (17 April 2020) Summary of Information about the Functioning of the Senate during the Corona Crisis. Elérhető: www.raadvanstate.nl/actueel/nieuws/@120871/voorlichting-eerste-kamer-coronacrisis/ (Letöltve: 2020. december 15.).

86 van den Hoven-van Genderen, 2020. 
27-én fogadták el. ${ }^{87} \mathrm{~A}$ törvény $\mathrm{X}$. fejezete értelmében a hatálybalépés dátumát királyi rendelet határozza meg. A törvény 2020. december 1-jén lépett hatályba, és iktatta be a Közeü.tv.-be az V/a. fejezetet és a fejezetet alkotó 58a-68u. cikkeket. A törvénymódosítás a VIII. cikkében a hatályon kívül helyezés dátumát is meghatározza, amelyet 2021. március 1-jében jelöltek meg. ${ }^{88}$

A törvénymódosítást követően a Közeü.tv. rögzíti a koronavírus-járvány elleni védekezés során használt fogalmakat, ${ }^{89}$ több olyat is, amelynek korábban - szükség híján - nem volt törvényi definíciója, példának okáért a személyek közötti „védőtávolság” fogalmát, amelynek mértékét a Holland Népegészségügyi és Környezetvédelmi Intézet (Rijksinstituut voor Volksgezondheid en Milieu) határozza meg..$^{90} \mathrm{~A}$ védôtávolságot az otthonán kívül mindenki köteles betartani, ${ }^{91}$ kivéve az 58f. cikk (3) bekezdésében rögzített kivételek hatálya alá tartozó személyeket. A kivételek hatálya alá tartoznak azok, akik egy háztartásban élnek, vagy akik meghatározott tevékenységet végeznek, és e tevékenység jellegéből adódóan a védőtávolság betartása esetén a munkájukat nem tudnák elvégezni (e kategóriába tartoznak többek között az orvosok, ápolók és a rendőrök is).

A Közeü.tv. értelmében a kormány miniszteri rendeletekben rögzíti a járvány elleni védekezéshez szükséges intézkedéseket.92 A rendeletet a kibocsátását követő két napon belül meg kell küldeni a törvényhozás mindkét házának. ${ }^{93} \mathrm{~A}$ törvényhozás egy héten belül dönt a rendelet megerősítéséről, amely a határidő lejárta előtt, illetve a törvényhozás bármely házának elutasító döntése esetén nem lép hatályba. E szabálytól csak abban az esetben lehet eltérni, amennyiben olyan sürgetố körülmény (dringende omstandigheid) áll fenn, amely a veszély azonnali mérséklését szolgáló intézkedés meghozatalát követeli meg. ${ }^{94} \mathrm{Az}$ elfogadást követő két napon belül a rendeletet - a kényszerítő okokat részletező levél kíséretében - továbbítani kell a törvényhozás két házának jóváhagyásra. Amennyiben a törvényhozás bármely háza egy héten belül leszavazza a sürgetô körülmény miatt hozott rendeletet, úgy az hatályát veszti.

A Közeü.tv. pontosítja, hogy az egészségügyi miniszter - mely törvényi szempontok figyelembevételével és milyen személyi körrel folytatott konzultációt követően - ruházhatja a biztonsági körzet vezetőjére az egyébként a polgármestereket megillető jogkörök gyakorlását, ideértve az Önkormányzati tv. 125. cikkében rögzített szankcionálási jogkört. ${ }^{95} \mathrm{~A}$ törvény e tekintetben tehát egyrészt új jogalapot teremtett a hatáskör-átruházásra

87 Tijdelijke wet maatregelen Covid-19 (Wet van 28 oktober 2020). Lásd továbbá: The Brussels Times (27 October 2020): Netherlands Adopts 'Corona Law' to Give Legal Base to Lockdown. Elérhető: www.brusselstimes.com/news/ world-all-news/137888/mask-public-space-mark-rutte-netherlands-adopts-corona-law-to-give-legal-baseto-lockdown/ (Letöltve: 2020. december 15.).

88 Abban bízva, hogy az oltás révén addigra a bevezetett rendelkezések szükségtelenné válnak.

89 Közeü.tv. 58a. cikk.

90 Közeü.tv. 58f. cikk (2) bekezdés.

91 Közeü.tv. 58f. cikk (1) bekezdés.

92 Közeü.tv. 58c. cikk (1) bekezdés.

93 Közeü.tv. 58c. cikk (2) bekezdés.

94 Közeü.tv. 58c. cikk (3) bekezdés.

95 Közeü.tv. 58d. cikk. 
a Közeü.tv. sokat kritizált 6. és 7. cikkei helyett; másrészt pontot tett arra a fentebb említett jogértelmezési kérdésre, hogy a hatáskör-átruházás magában foglalja-e a szankcionálási jogkör átruházását.

A Közeü.tv. rögzíti a kormány azon jogát, hogy betiltson bármilyen létszámú gyülekezést, korlátozza vagy feltételhez kösse a zárt térben történő vallásgyakorlást, továbbá hogy feltételekhez kösse, korlátozza vagy betiltsa egyes nyilvános helyek látogatását, az éttermek, a szállodák és egyéb szabadidős tevékenységek helyszínéül szolgáló létesítmények múködését. ${ }^{96}$ Ily módon tehát e kérdések is törvényi szinten, megfelelő garanciák mentén kerülnek korlátozásra. A törvény rendelkezik a fentebb említett rendelkezések megsértőivel szemben kiszabható bírságokról is.97

\section{A különleges jogrend kihirdetésének gyakorlati esetei és az azokat övező politikai és közjogi viták}

Az alkotmány legutolsó - 1983-as - reformja óta nem került sor az alkotmány 103. cikkében rögzített szükségállapot kihirdetésére, katasztrófa- és krízishelyzetet viszont több alkalommal is kihirdetett a kormány. A 96. cikkben rögzítettek szerint háborús állapot csak a törvényhozás előzetes beleegyezésével hirdethető ki. A kormány e rendelkezés kapcsán egy olyan értelmezést próbált érvényesíteni, amely szerint a 96. cikk csak formális hadüzenet esetén alkalmazandó. Jóllehet ezen értelmezést a törvényhozás alsóháza és a Hágai Kerületi Bíróság is elfogadta, a szakirodalom kétségbe vonja annak megalapozottságát: az alkotmány ugyanis nem véletlenül alkalmazza a megállapító jellegú „háborúban áll” kifejezést a nemzetközi jogból szinte teljesen kikopott hadüzenet helyett. ${ }^{98}$ A 100. cikk kapcsán a törvényhozás szerepének csökkentésére irányuló kormányzati törekvés okozott közjogi vitát: a kormány értelmezése szerint a törvényhozást elegendő a kormány döntését követően informálni. A törvényhozás nem értett egyet ezen értelmezéssel.99

96 Közeü.tv. 58g., 58j., 58k. és 58m. cikk.

97 Közeü.tv. 58u. cikk.

98 Besselink, 2012, 15. o.

99 A kormány ezt azzal indokolta, hogy amennyiben a törvényhozás elutasító álláspontra helyezkedik a 100. cikk alkalmazása kapcsán, a kormány olyan helyzetbe kerülhet, hogy választania kell az országot kötelező nemzetközi szerződés megszegése és a törvényhozás kifejezett akaratával szembeni cselekvés lehetősége között. Ennek megfelelően a kormány arra az álláspontra helyezkedett, hogy a NATO-szerződés 5. cikkéből eredő kötelezettség teljesítése nem követeli meg a törvényhozás beleegyezését, következésképpen azt a kormány döntését követően is elég tájékoztatni. A kérdést vizsgáló parlamenti bizottság ezzel szemben arra a következtetésre jutott, hogy a törvényhozást azelőtt kell informálni, hogy a kormány meghozta volna az érdemi döntését, ellenkező esetben ugyanis a törvényhozás jogosítványai kiüresednek. Lásd: Report of the Tijdelijke commissie besluitvorming uitzendingen. Tweede Kamer der Staten-Generaal. Vergaderjaar 1999-2000 (26454, $n \mathrm{r}$. 8) (az elnöke után Bakker-bizottságként is ismert); lásd még: Besselink, 2012, 15. o. 
A koronavírus-járvány kezelését megelőzően utoljára a 2019 márciusában - az esetleges hard brexitre való felkészülés ${ }^{100}$ jegyében - elfogadott brexit-salátatörvény ${ }^{101}$ váltott ki a különleges jogrendet érintő közjogi vitát. ${ }^{102} \mathrm{~A}$ törvénytervezet eredeti változata kvázi biankó csekket adott volna a kormánynak: többek között akár rendeleti úton is hatályon kívül helyezhetett volna törvényeket meglehetősen korlátozott parlamenti ellenőrzés mellett. A kormány ilyen páratlan hatáskörökkel történő felruházását még a kormánypárti képviselők többsége sem támogatta. A törvényt végül a kormány által tett engedményeket követően fogadták el. ${ }^{103}$

Amint az előző fejezetben kifejtettük, a koronavírus-járvány kezelése érdekében nem került sor különleges jogrendi helyzet kihirdetésére. Ebben az esetben éppen ennek elmaradása generált közjogi vitát: egyes álláspontok szerint a kormány - ellentétben a saját maga által kínált narratívával - azért nem kért különleges felhatalmazást, hogy ily módon kerülje meg a különleges jogrend esetén érvényesülő demokratikus kontrollt és a jogállamisági garanciáknak való megfelelés kötelezettségét.

\section{5. Összegzés}

A holland szabályozás egy része a magyarhoz hasonlóan újnak - vagy viszonylag újnak - tekinthetô, és a különleges jogrendi kategóriák számát tekintve is hasonlítanak: míg a holland szabályozás négy, a hatályos magyar szabályozás hat különleges jogrendi helyzetet különböztet meg. ${ }^{104} \mathrm{~A}$ holland szabályozás kellően cizelláltnak tekinthető a négy, egymástól jól elkülöníthető különleges jogrendi helyzet megkülönböztetéséből, valamint a cselekvésre jogosultak körének alapos elhatárolásából kifolyólag. A magyar Alaptörvénnyel összehasonlítva megállapítható ugyanakkor, hogy a holland alkotmány szükségállapot idején több büntetőjogi garanciát tör át, mint az Alaptörvény.

A koronavírus-járvány kezelése kapcsán a holland kormány által választott válságkezelési stratégia felszínre hozta a holland különleges jogrendi szabályozásban - a Közeü.tv. módosításának 2020. december 1-jei hatálybalépése elôtt - rejlő hiányosságot. Jelesül azt, hogy a krízishelyzet esetére a Biztonsági körzetek tv. és az Önkormányzati tv. által garantált demokratikus kontroll és jogállamisági garanciák könnyedén megkerülhetők, amennyiben a kormány él a Közeü.tv. 6. és 7. cikkében rögzített felhatalmazással, és az egészségügyi mi-

100 A holland külügyminiszter 2018. szeptember 7-i levele az alsóháznak a brexitre való felkészülés aktuális állásáról.

101 Verzamelwet Brexit (Wet van 27 maart 2019).

102 Pieters, 2018.

103 Dutch News (25 January 2019) Dutch Water Down 'Undemocratic' Brexit Emergency Powers Legislation. Elérhető: www.dutchnews.nl/news/2019/01/dutch-water-down-undemocratic-brexit-emergency-powers-legislation/ (Letöltve: 2020. december 15.).

104 Jóllehet e szám - amint az fentebb említésre került - 2023. júliustól háromra csökken. 
niszter - átvéve a járvány elleni védekezés megszervezését - a biztonsági körzetek vezetőire ruházza az egyébként a polgármestereket megillető jogosultságok gyakorlását. A kormány az általa választott válságkezelési stratégiát ért kritikákra válaszul 2020 júliusában nyújtotta be a 2020. október végén elfogadott törvénymódosítást, amely egy új fejezetet iktatott a Közeü.tv. rendelkezései közé. Az új fejezet célja, hogy megteremtse a kormány által a vírus második hulláma elleni küzdelem során meghozandó intézkedések - alkotmányossági szempontból megfelelő - jogalapját, illetve a törvényhozás számára garantált felügyeleti jogkörök révén biztosítsa a demokratikus kontrollt. Tekintve, hogy az új törvény csak két héttel a kézirat lezárását megelőzően lépett hatályba, a hatását és az alkalmazását illetően megalapozott következtetéseket levonni egyelöre nem lehetséges, az azonban kijelenthető, hogy a törvényjavaslat előkészítése során figyelembe vették a kormány által választott válságkezelési stratégiát ért - a 3.2. pontban részletesen kifejtett -, a demokratikus elszámoltathatóság és a jogállamisági kritériumok érvényesülésének hiányára vonatkozó kritikákat. Ennek megfelelően az alkotmányos és törvényi szabályokkal összhangban lévő jogalapot teremtettek a meghozott válságkezelő intézkedések számára, illetve törvényileg szabályozták a korábban a jogalkalmazás során fellépő kérdéseket.

\begin{tabular}{|c|c|c|c|c|}
\hline & $\begin{array}{c}\text { Általános } \\
\text { szülkségállapot }\end{array}$ & $\begin{array}{c}\text { Korlátozott } \\
\text { szülkségállapot }\end{array}$ & Katasztrófahelyzet & Krízishelyzet \\
\hline Szabályozás szintje & Alkotmányos és törvényi & \multicolumn{2}{|c|}{ Törvényi } \\
\hline Elrendelési okok & Az állam létét fenyegető külső és & $\begin{array}{c}\text { Olyan helyzetet jelöl, } \\
\text { amely komolyan } \\
\text { fenyegeti vagy veszé- } \\
\text { lyezteti az állampol- } \\
\text { gárok életét és jólétét } \\
\text { vagy a természeti } \\
\text { és épített környe- } \\
\text { zetet, és amelynek esetén. } \\
\text { elhárítása, illetve } \\
\text { a károk csökkentése } \\
\text { érdekében a ható- } \\
\text { ságok és egyéb szer- } \\
\text { vezetek összehangolt } \\
\text { munkája szülkséges. }\end{array}$ & $\begin{array}{c}\text { A társadalom } \\
\text { alapvetón érde- } \\
\text { keinek veszé- } \\
\text { lyeztetését vagy } \\
\text { az azzal való } \\
\text { fenyegetést jelent. }\end{array}$ \\
\hline
\end{tabular}




\begin{tabular}{|c|c|c|c|c|}
\hline & $\begin{array}{c}\text { Általános } \\
\text { szükségállapot }\end{array}$ & $\begin{array}{c}\text { Korlátozott } \\
\text { szükségállapot }\end{array}$ & Katasztrófahelyzet & Krízishelyzet \\
\hline Elrendelés & \multicolumn{2}{|c|}{$\begin{array}{c}\text { Az uralkodó a miniszterelnök } \\
\text { javaslatára }\end{array}$} & $\begin{array}{l}\text { A helyi és regionális } \\
\text { önkormányzatok }\end{array}$ & A miniszterelnök \\
\hline Felhatalmazott & $\begin{array}{l}\text { A kormányzás f } \\
\text { az uralkodó, aki } \\
\text { javaslatára kira } \\
\text { révén irányítja }\end{array}$ & $\begin{array}{l}\text { elhatalmazottja } \\
\text { a miniszterelnök } \\
\text { ályi rendeletek } \\
\text { a az országot. }\end{array}$ & $\begin{array}{c}\text { Az önkormányzatok, } \\
\text { illetve amennyiben } \\
\text { az önkormányzatok } \\
\text { nem képesek kezelni, } \\
\text { a biztonsági körzet } \\
\text { vezetője. }\end{array}$ & $\begin{array}{l}\text { A biztonsági } \\
\text { körzet vezetője, } \\
\text { illetve szükség } \\
\text { esetén a Mi- } \\
\text { niszteri Szintű } \\
\text { Válságkezelő } \\
\text { Bizottság. }\end{array}$ \\
\hline Gyakorlati esetek & \multicolumn{2}{|c|}{$\begin{array}{l}\text { Az alkotmány 1983-as reformja } \\
\text { óta nem került kihirdetésre. }\end{array}$} & \multicolumn{2}{|c|}{ Számtalan esetben } \\
\hline $\begin{array}{l}\text { Rendkívüli felhatal- } \\
\text { mazás esetkörei }\end{array}$ & \multicolumn{4}{|c|}{$\begin{array}{l}\text { - A brexit-salátatörvény; } \\
\text { — a koronavírus-járvány kezelése érdekében a kormány nem kért külön- } \\
\text { leges felhatalmazást. }\end{array}$} \\
\hline
\end{tabular}

10. táblázat

Különleges jogrendi esetkörök Hollandiában

Forrás: a szerző saját szerkesztése

\section{Irodalomjegyzék}

Antonides, G., Van Leeuwen, E. (2020) 'Covid-19 Crisis in the Netherlands: Only Together We Can Control Corona', Mind \& Society [Online]. Elérhető: https://link.springer.com/ article/10.1007/s11299-020-00257-x (Letöltve: 2020. december 15.)

Bentzen, N., Boström, A., Del Monte, M., Odink, I., Prpic, M., Tuominen, M. (2020) States of Emergency in Response to the Coronavirus Crisis: Situation in Certain Member States III. [Online]. Elérhető: www.europarl.europa.eu/RegData/etudes/BRIE/2020/651972/EPRS_ BRI(2020)651972_EN.pdf(Letöltve:2020. december 15.)

Besselink, L. (2012) 'The Legal and Constitutional Position of the Netherlands Armed Forces and International Military Cooperation' in Nolte, G. (szerk.) European Military Law Systems. 1. kiadás. Berlin: De Gruyter 
BROEKSTEEG, J. L. W. (2020) Corona en noodverordeningen [Online]. Elérhető: www.montesquieuinstituut.nl/id/vl7ah9uq3xl7/nieuws/corona_en_noodverordeningen (Letöltve: 2020. december 14.)

Buyse, A., De LAnge, R. (2020) The Netherlands: Of Rollercoasters and Elephants [Online]. Elérhetô: https://verfassungsblog.de/the-netherlands-of-rollercoasters-and-elephants/ (Letöltve: 2020. december 15.) DOI: 10.17176/20200508-133220-0

Cavalcanti, M. F., Terstegge, M. J. (2020) 'The Covid-19 Emergency in the Netherlands: A Constitutional Law Perspective', DPCE Online, 43(2), 1691-1710. o.

HENDRIKs, A. (2020) Nood breekt wet in Tijden van Corona [Online]. Elérhetố: www.navigator.nl/ document/idiba9e1943bfc4a9897e3dd333f0626a2/nederlands-juristenblad-nood-breektwet-in-tijden-van-corona?ctx=WKNL_CSL_85 (Letöltve: 2020 . december 15.)

HoRVÁTH, A. (2020) 'A veszélyhelyzet közjogi és jogalkotási dilemmái - mérlegen az Alaptörvény 53. cikke', Közjogi Szemle, 13(4), 17-25. o.

KELEMEN, R. (2019) 'A különleges jogrend szabályozása az egyes alkotmányokban I. Általános alapvetés, fogalmi elhatárolás', Vélemények a Katonai Jog Világából, 2019/1.

Khakee, A. (2009) Securing Democracy? A Comparative Analysis of Emergency Powers in Europe. Geneva Centre for the Democratic Control of Armed Forces. Policy Paper No. 30/2009

Kuipers, S., BoIn, A. (2014) Crisis and Disaster Management in the Netherlands. A description of Structure and Processes. 1. kiadás. Leiden: Crisisplan BV

PIETERS, J. (2018) Dutch MPS Against Emergency Law for No-Deal Brexit [Online]. Elérhetö: https:// nltimes.nl/2018/12/12/dutch-mps-emergency-law-deal-brexit (Letöltve: 2020. december 15.)

Uzman, J., BArkhuysen, T., van Emmerik M. L. (2010) 'The Dutch Supreme Court: A Reluctant Positive Legislator?', Electronic Journal of Comparative Law, 14(3), 1-35. o.

van Den Hoven van Genderen, R. (2020) The New Netherlands Emergency Law: The Neverending Story of Privacy-and Other Fundamental Rights Containment on Basis of Corona [Online]. Elérhető: www.switchlegal.nl/the-new-netherlands-emergency-law-the-never-endingstory-of-privacy-and-other-fundamental-rights-containment-on-basis-of-corona/ (Letöltve: 2020. december 15.)

VAN DER KOLK, A. (2020) Coronavirus Breaking the Law? [Online]. Elérhető: www.rug.nl/ news/2020/03/corona-breekt-wet?lang=en (Letöltve: 2020. december 13.)

Wierenga, A. J., Brouwer, J. G. (2020) Coronacrisis en het recht (deel 8) De handhavers van de nooodverordening [Online]. Elérhető: www.openbareorde.nl/tijdschrift/coronacrisis-enhet-recht-deel-8/ (Letöltve: 2020. december 14.)

Wierenga, A. J., Schilder, A. E., Brouwer, J. G. (2020) Coronacrisis en het recht deel 13. Rechtvaardiging van noodverordeningen [Online]. Elérhető: www.openbareorde.nl/ tijdschrift/coronacrisis-en-het-recht-deel-13/ (Letöltve: 2020. december 14.) 


\section{Különleges jogrendi szabályok Lengyelországban}

NÉMETH ZOLTÁN

\section{A különleges jogrend alkotmányos és törvényi szintủ szabályozása, valamint a különleges jogrend esetkörei}

A lengyel alkotmány ${ }^{1}$ XI. fejezete rendelkezik a kivételes hatalomgyakorlás során alkalmazható rendkívüli intézkedések köréről. Azon rendkívüli helyzetekben, amikor a normál időszaki alkotmányos intézkedések nem elégségesek, az alábbi rendkívüli helyzetek vezethetők be: hadiállapot (stan wojenny), szükségállapot (stan wyjątkowy), illetve veszélyhelyzet (stan klęski żywiotowej). ${ }^{2}$

A hadiállapotot a Minisztertanács ${ }^{3}$ kérelmére az állam külső fenyegetettsége, a Lengyel Köztársaság területe ellen elkövetett fegyveres agresszió esetén, valamint akkor, ha a nemzetközi egyezmény agresszióval szembeni közös védelmi kötelezettséget ír elő, a köztársasági elnök az állam egész területére vagy annak valamelyik részére hirdeti ki. ${ }^{4}$ Mindezt

1 A Lengyel Köztársaság alkotmánya (Konstytucja Rzeczypospolitej Polskiej z dnia 2 kwietnia 1997 r.) (a továbbiakban: alkotmány).

2 Lakatos, 2014, 8. o.

3 Lengyelországban a kormány hivatalos elnevezése Minisztertanács.

4 Alkotmány 229. cikk.

Dr. Németh Zoltán, LLM

zoltan.nemeth@mfi.gov.hu

kutató (Mádl Ferenc Összehasonlító Jogi Intézet)

Németh, Z. (2021) 'Különleges jogrendi szabályok Lengyelországban’ in Nagy, Z., Horváth, A. (szerk.) A különleges jogrend és nemzeti szabályozási modelljei, 358-375. o. Budapest: Mádl Ferenc Összehasonlító Jogi Intézet.

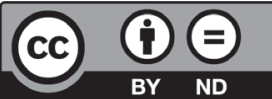


a hadiállapotról szóló törvény ${ }^{5}$ akként egészíti ki, hogy Lengyelország függetlensége, területi integritása, jelentős gazdasági érdekeltségei elleni támadás, illetve külső fenyegetettség esetén olyan helyzetben lehet elrendelni, amely akadályozza, illetve gátolja az államapparátus rendes múködését. ${ }^{6} \mathrm{~A}$ Minisztertanács megállapítja a hadiállapot elrendelésének okait, és javaslatot tesz a jogok korlátozására a fenyegetés komolyságához mérten. A hadiállapot bevezetésétől számított 48 órán belül a köztársasági elnök kezdeményezi rendeletének képviselőházi ellenjegyzését. A képviselőház (Sejm) a kezdeményezést haladéktalanul megtárgyalja, és a képviselók legalább felének jelenlétében abszolút többséggel hatályon kívül helyezheti azt.7 Amennyiben a képviselőház nem helyezi hatályon kívül a köztársasági elnök rendeletét, azt nemcsak a szokásos módon (a hivatalos közlönyben), hanem a helyi önkormányzatokon keresztül, valamint a tömegmédiában is közzé kell tenni. ${ }^{8}$ A külügyminiszter pedig köteles a hadiállapot bevezetésének tényét és okát az ENSZ és az Európa Tanács footitkárának bejelenteni. ${ }^{9}$

A hadiállapotot az elnök a Minisztertanács kérelmére kiadott rendeletével szünteti meg akkor, ha a fenyegetettség megszúnt, és az állam rendes múködése helyreállt. ${ }^{10}$

A hadiállapotot az alkotmánybíróság is megszüntetheti, ugyanis a rendelet, amellyel a hadiállapotot a köztársasági elnök elrendeli, központi állami szerv által kiadott jogi aktusnak minősül, amelynek alkotmánnyal, ratifikált nemzetközi egyezményekkel és törvényekkel való összhangja tekintetében az alkotmánybíróság határoz. Ha az alkotmánybíróság ütközést talál, a rendelet érvénytelenné válik. ${ }^{11}$

A szükségállapot elrendelésének szabályait az alkotmány mellett egy külön szükségállapoti törvény ${ }^{12}$ is szabályozza. Az állam alkotmányos rendjének, az állampolgárok vagy a közrend fenyegetettsége esetén a Minisztertanács kérelmére a köztársasági elnök kilencven napnál nem hosszabb, meghatározott időre az állam egész területére vagy annak valamelyik részére kihirdeti a szükségállapotot. ${ }^{13}$ Mindezeken túl a Szükségállapoti tv. alapján szükségállapot rendelhető el terrorcselekmény kapcsán, valamint a kibertér biztonsága érdekében. ${ }^{14}$

5 A hadiállapotról, a fegyveres erők legfelsőbb parancsnokának hatásköréről és a Lengyel Köztársaság alkotmányos szerveinek való alárendelés szabályairól szóló 2002. augusztus 29-i 1301. törvény (Dz.U. 2002 nr 156 poz. 1301 Ustawa z dnia 29 sierpnia 2002 r. o stanie wojennym oraz o kompetencjach Naczelnego Dowódcy Sił Zbrojnych i zasadach jego podległości konstytucyjnym organom Rzeczypospolitej Polskiej) (a továbbiakban: Hadiállapot tv.).

6 Hadiállapot tv. 2. cikk 1a. bekezdés.

7 Alkotmány 231. cikk.

8 Hadiállapot tv. 4-5. cikk.

9 Hadiállapot tv. 6. cikk.

10 Hadiállapot tv. 8. cikk.

11 Alkotmány 188. cikk.

12 A szükségállapotról szóló (2002. július 21-i) törvény (Ustawa z dnia 21 czerwca 2002 r. o stanie wyjątkowym) (a továbbiakban: Szükségállapoti tv.).

13 Alkotmány 230. cikk 1. bekezdés.

14 Szükségállapoti tv. 2. cikk (1) bekezdés. 
A köztársasági elnök szükségállapotot kihirdető rendeletének képviselőházi ellenjegyzése, valamint közzététele a hadiállapotnál leírtak szerint zajlik.15

Az állam alkotmányos rendje elleni támadás definícióját, amely a szükségállapot elrendelésének feltételeként került rögzítésre, sem az alkotmány, sem más törvény nem tartalmazza. Ugyanígy az állampolgárok fenyegetettségének sincs egységes definíciója, ez a meghatározás az állampolgároknak nem csupán a fizikai, hanem a gazdasági biztonságára is vonatkozik.

Fôszabály szerint a szükségállapot megszúnik az elrendelt határidő lejártával, azonban ha annak közeledtével a szükségállapot elrendelésének okai még nem szűntek meg, illetve az állam rendes múködését nem állították helyre, a köztársasági elnök a képviselőház jóváhagyásával a szükségállapotot egyszer, hatvan napnál nem hosszabb időre rendeletével meghosszabbíthatja. ${ }^{16} \mathrm{~A}$ köztársasági elnök a szükségállapotot - a határidő lejárta előtt - a Minisztertanács kérelmére rendeletével meg is szüntetheti, ha az elrendelés okai megszúntek, és az állam rendes múködése helyreállt. ${ }^{17}$ Ugyancsak megszüntethető a szükségállapot - a hadiállapot vonatkozásában leírtak szerint - az alkotmánybíróság döntésével.

A különleges jogrend fent ismertetett két esetkörével ellentétben a veszélyhelyzetet nem a köztársasági elnök, hanem a Minisztertanács hirdeti ki természeti katasztrófa vagy ahhoz hasonló jellegú múszaki baleset következményeinek megelôzése vagy elhárítása céljából harminc napnál nem hosszabb, meghatározott időre az állam egész területére vagy annak valamelyik részére. A veszélyhelyzet meghosszabbításához vagy kiterjesztéséhez szükséges a képviselőház jóváhagyása is. ${ }^{18} \mathrm{~A}$ veszélyhelyzetről szóló törvény ${ }^{19}$ alapján azon természeti katasztrófák és múszaki hibák esetén rendelhető el veszélyhelyzet, amelyek nagyszámú ember életét vagy egészségét, jelentős mértékû́ vagyont, illetve a környezetet nagy területen veszélyeztetik, és mindezek védelme csak rendkívüli intézkedésekkel lehetséges. Emellett rögzíti, hogy veszélyhelyzet rendelhető el terrorcselekmény és kibertámadás esetén is. A törvény az értelmező rendelkezései között rögzíti mind a természeti katasztrófa, mind pedig a müszaki hiba fogalmát. ${ }^{20}$ Előbbi körébe a természeti erők múködésével kapcsolatos események tartoznak, mint például az erős szél, heves csapadék, szélsőséges hőmérséklet hosszan tartó előfordulása, földcsuszamlások, tüzek, aszály, árvizek, folyók, a tenger, tavak és víztartályok jegesedése, kártevők tömeges előfordulása, növényi vagy állatbetegségek, illetve az emberi fertőző betegségek. A műszaki hiba körébe pedig az épületek, műszaki eszközök vagy műszaki eszközrendszerek olyan hirtelen, váratlan károsodása vagy megsemmisülése tartozik, amely ezek használhatóságának megszúnését vagy tulajdonságainak elvesztését okozza. ${ }^{21} \mathrm{~A}$ Minisztertanács a veszély-

15 Alkotmány 231. cikk.

16 Alkotmány 230. cikk 2. bekezdés.

17 Szükségállapoti törvény 5. cikk (2) bekezdés.

18 Alkotmány 232. cikk.

19 A veszélyhelyzetról szóló 2002. április 18-i törvény (Ustawa z dnia 18 kwietnia 2002 r. o stanie klęski żywiołowej) (a továbbiakban: Veszélyhelyzeti tv.).

20 Veszélyhelyzeti tv. 3. cikk (1)-(2) bekezdés.

21 Veszélyhelyzeti tv. 3. cikk. 
helyzetet saját maga is kezdeményezheti, azonban hozhat ilyen tárgyú rendeletet az érintett vajdaság kérelmére is. A rendeletben köteles meghatározni a veszélyhelyzet okát, bevezetésének idôpontját, terjedelmét és időtartamát, valamint az emberi és polgári jogok szükséges korlátozásainak típusait. A rendeletet pedig mind az újságok, mind pedig a rádió- és televíziós műsorok músorszolgáltatói kötelesek haladéktalanul és ingyenesen nyilvánosságra hozni. ${ }^{22}$

A veszélyhelyzet a Minisztertanács képviselőházi hozzájárulás után kiadott rendeletével határozott idôtartamra meghosszabbítható. Főszabály szerint pedig akkor szúnik meg, ha az idő, amelyre elrendelték, eltelt. Annak lejárta előtt a Minisztertanács jogosult azt megszüntetni, amennyiben bevezetésének okai már nem állnak fenn. Emellett - a hadiállapotnál leírtak alapján - az alkotmánybíróság is megszüntetheti a veszélyhelyzetet a Minisztertanács azt elrendelő döntésével. ${ }^{23}$

\section{Az alapjogok korlátozásával kapcsolatos kérdések}

Az alkotmány második fejezete tartalmazza azokat az általános alapelveket, amelyek rendelkeznek többek között az alapjogok korlátozhatóságáról. Az alkotmány kimondja, hogy az ember veleszületett és elidegeníthetetlen méltósága az emberi és állampolgári szabadságok és jogok forrása. Ez a jog sérthetetlen, tiszteletben tartása és védelme a közhatalmi szervek kötelezettsége. ${ }^{24}$

Az alkotmány rögzíti, hogy az alkotmányos jogok és szabadságok gyakorlását csak törvény korlátozhatja, és csak olyan esetekben, amikor ez egy demokratikus államban a biztonság, a közrend, a természetes környezet, az egészség, a közerkölcs vagy mások szabadságai és jogai védelmében szükséges. Fontos kiemelni, hogy ezek a törvények nem sérthetik a szabadságok és jogok lényeges tartalmát. ${ }^{25}$

\begin{tabular}{|l|l|}
\hline \multicolumn{1}{|c|}{ Korlátozható alapjog } & \multicolumn{1}{c|}{ A korlátozó rendelkezés tartalma } \\
\hline $\begin{array}{l}\text { szabadsághoz való jog } \\
\text { (41. cikk) }\end{array}$ & $\begin{array}{l}\text { törvényben meghatározott okokból és törvényben meghatározott } \\
\text { eljárás alapján }\end{array}$ \\
\hline $\begin{array}{l}\text { tulajdonhoz való jog } \\
\text { (46. cikk) }\end{array}$ & $\begin{array}{l}\text { ellkobozni csak törvényben meghatározott esetekben és jogerős } \\
\text { bírósági határozat alapján lehet }\end{array}$ \\
\hline szülői jogok (48. cikk) & $\begin{array}{l}\text { csak törvényben meghatározott esetekben és jogerős bírósági } \\
\text { határozat alapján lehet }\end{array}$ \\
\hline
\end{tabular}

22 Veszélyhelyzeti tv. 5. cikk (3).

23 Veszélyhelyzeti tv. 6. cikk (1).

24 Alkotmány 30. cikk.

25 Alkotmány 31. cikk. 


\begin{tabular}{|c|c|}
\hline Korlátozható alapjog & A korlátozó rendelkezés tartalma \\
\hline $\begin{array}{l}\text { közlés szabadsága és titkossága } \\
\text { (49. cikk) }\end{array}$ & csak törvényben meghatározott esetekben és módon \\
\hline $\begin{array}{l}\text { magánlakás sérthetetlensége } \\
\text { (50. cikk) }\end{array}$ & csak törvényben meghatározott esetekben és módon \\
\hline $\begin{array}{l}\text { személyes adat szolgáltatása } \\
\text { (51. cikk) }\end{array}$ & csak törvényben meghatározott kivételekben \\
\hline $\begin{array}{l}\text { mozgásszabadság, lakóhely } \\
\text { és tartózkodási hely szabad } \\
\text { megválasztása } \\
\text { (52. cikk) }\end{array}$ & korlátait törvény határozza meg \\
\hline $\begin{array}{l}\text { lelkiismereti és vallássza- } \\
\text { badság (53. cikk) }\end{array}$ & $\begin{array}{l}\text { nyilvános gyakorlása csak törvénnyel korlátozható, és csak olyan } \\
\text { esetekben, amikor ez az állambiztonság, a közrend, egészség, } \\
\text { erkölcs vagy mások jogai és szabadságai védelmének érdekében } \\
\text { szülkséges }\end{array}$ \\
\hline $\begin{array}{l}\text { véleménynyilvánítás sza- } \\
\text { badsága, sajtószabadság } \\
\text { (54. cikk) }\end{array}$ & előzetes cenzúra és a sajtó előzetes engedélyezése tilos \\
\hline gyülekezési jog (57. cikk) & csak törvény korlátozhatja \\
\hline $\begin{array}{l}\text { egyesülés szabadsága } \\
\text { (58. cikk) }\end{array}$ & szabad, de kereteit törvény határozza meg \\
\hline $\begin{array}{l}\text { munkahely megválasztásának } \\
\text { szabadsága (65. cikk) }\end{array}$ & törvény állapíthat meg kivételeket \\
\hline $\begin{array}{l}\text { biztonságos és egészséges } \\
\text { munkakörülményekhez való } \\
\text { jog (66. cikk) }\end{array}$ & alkalmazásának módját törvény állapítja meg \\
\hline $\begin{array}{l}\text { szociális biztonsághoz való jog } \\
\text { (67. cikk) }\end{array}$ & terjedelmét és formáit törvény állapítja meg \\
\hline $\begin{array}{l}\text { egészséghez való jog } \\
\text { (68. cikk) }\end{array}$ & feltételeit törvény határozza meg \\
\hline $\begin{array}{l}\text { oktatáshoz való jog } \\
\text { (70. cikk) }\end{array}$ & $\begin{array}{l}\text { az oktatási kötelezettségek teljesítésének módját törvény hatá- } \\
\text { rozza meg }\end{array}$ \\
\hline
\end{tabular}

11. táblázat

Az egyes alapjogok korlátozása a lengyel alkotmányban

Forrás: a szerzô saját összeállitása 
A különleges jogrendi esetkörök tartalma kapcsán említésre érdemes az ezen időszakokban korlátozható jogok kérdése, amelyet az adott időszakra vonatkozó törvényekben kell rendezni. Az alkotmány meghatározza, hogy melyek azok az állampolgári szabadságok és jogok, amelyek a különleges jogrendi szituációkban sem korlátozhatók.

Így hadiállapot és szükségállapot idején sem korlátozható jogok: az emberi méltóság, állampolgárság, az élet védelme, az emberi bánásmód, a büntetőjogi felelősség kérdésköre, a bírósághoz fordulás joga, a személyhez fúződő jogok, a lelkiismereti és vallásszabadság, a petíció joga. Továbbá nem lehet az emberi és állampolgári szabadságokat és jogokat kizárólag fajra, nemre, nyelvre, vallásra vagy annak hiányára, társadalmi helyzetre, származásra vagy tulajdonra tekintettel korlátozni. ${ }^{26}$

A Hadiállapot tv., illetve a Szükségállapot tv. alapján korlátozható a gyülekezési jog, a sajtószabadság, a magántitokhoz való jog, a mozgás szabadsága és a tartózkodási hely szabad megválasztásának joga, illetve szükségállapotban időlegesen megfosztható szabadságától az a 18. életévét betöltött személy, akiről alaposan feltehető, hogy ennek hiányában az állam alkotmányos rendjét, az állampolgárokat vagy a közrendet fenyegeti. A veszélyhelyzet kapcsán az alkotmány úgy rendelkezik, hogy törvény korlátozhatja a gazdasági tevékenység szabadságát, a személyes szabadságot, a magánlakás sérthetetlenségét, a mozgásés letelepedési szabadságot, a sztrájkjogot, a tulajdonhoz való jogot, a munkához való jogot, a biztonságos és egészséges munkakörülményekhez való jogot, valamint a pihenéshez való jogot. ${ }^{27}$

\begin{tabular}{|c|c|c|c|}
\hline & Hadiállapot & gállapot & Ves: \\
\hline $\begin{array}{c}\text { Nem } \\
\text { korlátozható }\end{array}$ & \multicolumn{3}{|c|}{$\begin{array}{l}\text { — az emberi méltóság } \\
\text { — állampolgárság } \\
\text { — az élet védelme } \\
\text { — az emberi bánásmód } \\
\text { — a büntetőjogi felelősség kérdésköre } \\
\text { — a bírósághoz fordulás joga } \\
\text { — a személyhez fúződő jogok } \\
\text { — a lelkiismereti és vallásszabadság, a petíció joga } \\
\text { — nem lehet az emberi és állampolgári szabadságokat és jogokat kizárólag fajra, } \\
\text { nemre, nyelvre, vallásra vagy annak hiányára, társadalmi helyzetre, szár- } \\
\text { mazásra vagy tulajdonra tekintettel korlátozni }\end{array}$} \\
\hline
\end{tabular}

26 Alkotmány 233. cikk 1. bekezdés.

27 Alkotmány 233. cikk 2. bekezdés. 


\begin{tabular}{|c|c|c|c|}
\hline & Hadiállapot & Szülsségállapot & Veszélyhelyzet \\
\hline Korlátozható & \multicolumn{2}{|c|}{$\begin{array}{l}\text { — a gyülekezési jog } \\
\text { — a sajtószabadság } \\
\text { — a magántitokhoz való jog } \\
\text { — a mozgás szabadsága és a tartózkodási hely } \\
\text { szabad megválasztásának joga } \\
\text { — szükségállapotban időlegesen megfosztható } \\
\text { szabadságától az a 18. életévét betöltött személy, } \\
\text { akiról alaposan feltehető, hogy ennek hiányában } \\
\text { az állam alkotmányos rendjét, az állampol- } \\
\text { gárokat vagy a közrendet fenyegeti }\end{array}$} & $\begin{array}{l}\text { - a gazdasági tevékenység } \\
\text { szabadsága } \\
\text { — a személyes szabadság } \\
\text { — a magánlakás } \\
\text { sérthetetlensége } \\
\text { — a mozgás- és le- } \\
\text { telepedési szabadság } \\
\text { — a sztrájkjog } \\
\text { — a tulajdonhoz való jog } \\
\text { — a munkához való jog } \\
\text { — a biztonságos és } \\
\text { egészséges munka- } \\
\text { körülményekhez való jog }\end{array}$ \\
\hline
\end{tabular}

12. táblázat

A nem korlátozható és a korlátozható alapjogok Lengyelországban

Forrás: a szerző saját összeállitása

\section{Az egészségügyi válsághelyzet kezelése és a koronavírus-járvány}

A válságkezelésról szóló törvény ${ }^{28}$ alapján járványhelyzetben válságkezelési tervet kell készíteni, amelynek egyik sarkalatos pontja a szociális és orvosi ellátás megszervezése, ideértve a sürgősségi orvosi szolgáltatásokat is. Erről külön törvény, az állami sürgősségi orvosi szolgálatról szóló törvény ${ }^{29}$ rendelkezik.

Vajdasági szinten múködnek válságkezelő központok, amelyek gondoskodnak az egészségügyi ellátás megszervezéséről. Természeti katasztrófák esetén például a válságkezelő központ orvoskoordinátora gondoskodik arról, hogy az érintett intézményt a fennálló veszélyhelyzethez igazítva magasabb készültségi szintre állítsa.

Lengyelország egy részletesen szabályozott sürgősségi orvosi rendszert múködtet, amely egészségügyi vészhelyzetekben egy előre kialakított protokoll alapján végzi tevékenységét. ${ }^{30}$ A lengyel egészségügyi rendszer az alábbi jogszabályokon alapul:

- alkotmány;

28 2007. évi 89. számú törvény a válságkezelésről (Ustawa z dnia 26 kwietnia 2007 r. o zarządzaniu kryzysowym).

29 Ustawa z dnia 8 września 2006 r. o Państwowym Ratownictwie Medycznym.

30 A protokoll elérhetőa lengyel egészségügyi minisztérium honlapján:www.gov.pl/web/zdrowie/obowiazkoweubezpieczenie-zdrowotne (Letöltve: 2020. december 15.). 
— a betegek jogairól és a betegek ombudsmanjáról szóló törvény;31

— a közpénzekből finanszírozott egészségügyi szolgáltatásokról szóló törvény;32

— az orvosi tevékenységekről szóló törvény; ${ }^{33}$

— a mentális egészség védelméról szóló törvény. ${ }^{34}$

Az alkotmány rendelkezik arról, hogy mindenkinek joga van az egészsége megőrzéséhez, és ehhez a közhatalmi szervek által fenntartott intézményrendszer társul. ${ }^{35}$ Járványhelyzet esetén, amilyen például a koronavírus-járvány is, a veszélyhelyzetre vonatkozó jogi normákat kell alkalmazni, azaz a következő alapjogok korlátozhatók egészségügyi veszélyhelyzet idején: a gazdasági tevékenység szabadsága, a személyes szabadság, a magánlakás sérthetetlensége, a mozgás- és letelepedési szabadság, a sztrájkjog, a tulajdonhoz való jog, a munkához való jog, a biztonságos és egészséges munkakörülményekhez való jog, a pihenéshez való jog.

Konkrétan a járványügyi helyzetben alkalmazott korlátozásokrób ${ }^{36}$ a 2020. április 1 . és 2020. június 30. között hatályos jogszabály rendelkezik. Ebben részletesen felsorolják a lehetséges korlátozó intézkedéseket:

— az üzleti tevékenység meghatározott területeinek ideiglenes korlátozása;

- a készlet átmeneti meghatározása egy bizonyos típusú termékcsoport esetén;

- betegek és betegséggyanús személyek orvosi vizsgálata, valamint egyéb megelőző intézkedések és kezelések alkalmazásának kötelezettsége;

- a karantén elrendeléséről szóló rendelkezés aláirására vonatkozó kötelezettség;

- karanténlétesítmény kijelölése;

- a helyiségek vagy területek használatának ideiglenes korlátozása és azok biztosításának kötelezettsége;

- meghatározott időponttól történő evakuálási utasítás meghatározott helyekről, területekról és létesítményekből;

- a meghatározott helyeken és létesítményekben, valamint bizonyos területeken való tartózkodás elrendelésének tilalma;

— beteg és betegséggyanús személyek számára a „nulla” zónából való kilépés tilalma;

— a szabad mozgás korlátozása. ${ }^{37}$

31 A betegek jogairól és a betegek ombudsmanjáról szóló, 2008. november 6-i törvény (Ustawa z dnia 6 listopada 2008 r.o prawach pacjenta i Rzeczniku Praw Pacjenta).

32 2004. augusztus 27-i törvény a közpénzekből finanszírozott egészségügyi szolgáltatásokról (Ustawa z dnia 27 sierpnia 2004 r. o świadczeniach opieki zdrowotnej finansowanych ze środków publicznych).

$33 \mathrm{Az}$ orvosi tevékenységről szóló 2011. április 15-i törvény (Ustawa z dnia 15 kwietnia 2011 r. o działalności leczniczej).

34 A mentális egészség védelméről szóló 1994. augusztus 19-i törvény (Ustawa z dnia 19 sierpnia 1994 r. o ochronie zdrowia psychicznego).

35 Alkotmány 68. cikk.

36 Az emberi fertőzések és fertőző betegségek megelőzéséről és leküzdésérôl szóló 2008. december 5-i törvény (Zasady postępowania w razie stanu zagrożenia epidemicznego i stanu epidemii) (a továbbiakban: Járványügyi tv.).

37 Járványügyi tv. 46b. cikk. 
Fontos rendelkezés még, hogy a közszolgáltatási szerződések nem vonatkoznak a járvány megelőzésével vagy felszámolásával kapcsolatban odaítélt szolgáltatási, árubeszerzési vagy építési beruházási szerződésekre olyan területen, ahol járványügyi vészhelyzetet vagy járványállapotot állapítanak meg. ${ }^{38}$

\subsection{A koronavírus-járvány első hulláma Lengyelországban}

A Lengyel Köztársaságban nem rendeltek el veszélyhelyzetet. ${ }^{39}$ Azonban - még az első lengyelországi fertőzött regisztrálása előtt kezdeményezve - március 8-i hatállyal elfogadták a Covid-19 és más fertőző betegségek, valamint az általuk okozott vészhelyzetek megelőzésével és leküzdésével kapcsolatos speciális megoldásokról szóló törvényt (a továbbiakban: Covid-19 tv.). A számos módosítást megélt törvény a koronavírus-járvány során alkalmazandó alapelvek, eljárások, illetve a közigazgatási szervek feladatainak meghatározásán túl ${ }^{40}$ - egyéb más jogszabály mellett - jelentősen módosította az emberi fertôzések megelőzéséről és leküzdéséről szóló törvényt (a továbbiakban: Járványügyi tv.), különös tekintettel annak járványveszélyről (stanu zagrożenia epidemicznego) és járványhelyzetről (stanu epidemii) szóló rendelkezéseire. ${ }^{41} \mathrm{~A}$ Járványügyi tv. korábban is lehetőséget adott arra, hogy - a járvány által érintett vajdaságok számának függvényében - a vajda vagy az egészségügyért felelős miniszter a tartományi, illetve állami szintû egészségügyi felügyelőséggel (Inspektorat Sanytarny) konzultálva rendeletével járványveszélyt vagy járványhelyzetet hirdessen ki, és annak megfelelő intézkedéseket alkalmazzon. ${ }^{42}$ A törvénymódosítás - olyan mértékú járvány esetén, amely meghaladja az illetékes kormányzati, illetve önkormányzati szervek lehetôségeit - rendeletalkotási joggal ruházza fel a Minisztertanácsot, amely ez alapján a veszélyeztetettségnek megfelelően zónákat hozhat létre, és a Járványügyi tv. adta keretek között korlátozó intézkedéseket hozhat. ${ }^{43}$ Mindezek alapján az egészségügyért felelős miniszter rendeletével március 13 -án járványveszélyt, ${ }^{44}$ majd pedig március 20-tól járványhelyzetet hirdetett ki a Lengyel Köztársaság egész területére. ${ }^{45}$

Magyarországhoz hasonlóan Lengyelországban is intenzív jogalkotási munkát követelt az első hullám, amelynek eredménye négy úgynevezett Covid-törvény:

38 Járványügyi tv. 46b. cikk.

39 Hojnyák-Ungvári, 2021.

40 Covid-19 tv. 1. cikk.

41 Covid-19 tv. 25. cikk.

42 Járványügyi tv. 46. cikk (1)-(2) bekezdés.

43 Járványügyi tv. 46a. cikk.

44 Az egészségügyi miniszter 2020. március 13-i rendelete a járványveszély Lengyel Köztársaság területén való bevezetéséről.

45 Az egészségügyi miniszter 2020. március 20-i rendelete a járványhelyzet Lengyel Köztársaság területén való bevezetéséről. 
— a Covid-19-rôl szóló első törvény, amely 2020. március 31-én és április 1-jén lépett hatályba; ${ }^{46}$

— a Covid-19-rôl szóló második törvény, amely 2020. április 18 -án lépett hatályba; ${ }^{47}$

- a Covid-19-rôl szóló harmadik törvény, amely a Covid-19 elterjedése megakadályozásának érdekében hozott különböző törvények megváltoztatásáról szól, és 2020. május 16-án lépett hatályba; ${ }^{48}$

- a Covid-19 negyedik törvénye 2020. június 19-én kelt, a vállalkozásoknak nyújtott banki kölcsönök kamatlábainak állami támogatásáról szól, és 2020. június 24-én lépett hatályba. ${ }^{49}$

Fontos hangsúlyozni, hogy a koronavírus-járvány a jogalkotást is új kihívások elé állította, és szorosabb együttmúködést követel meg a központi kormányzatok és parlamentek között. Ez a helyzet Lengyelországra is igaz, mivel a járvány kitörése óta a képviselőház és a szenátus szorosabb együttmúködésben tevékenykedik..50

A járvány hatékony megelőzése érdekében többek között az alábbi egészségbiztonsági intézkedéseket írták elő:

2020. március 15-én lezárták az ország határait;

- kötelező karantént rendeltek el a külföldiek és a hazájukba visszatérő lengyelek számára;

- a közoktatási és felsőoktatási intézményeket bezárták;

- az élelmiszerboltok, gyógyszertárak, benzinkutak kivételével bezárták a bevásárlóközpontokat;

— betiltották a nyilvános összejöveteleket;

- 2 méteres kötelező távolságtartást vezettek be;

- lezárták a játszótereket, parkokat;

— korlátozták a tömegközlekedési eszközökön utazók számát;

— bezárták az éttermeket, és csak elviteles kiszolgálást engedélyeztek;

46 A Covid-19, az egyéb általa okozott fertőző betegségek és vészhelyzetek megelőzésével és leküzdésével kapcsolatos különleges megoldásokról szóló törvény (Ustawa z dnia 31 marca 2020 r. o zmianie ustawy o szczególnych rozwiązaniach związanych z zapobieganiem, przeciwdziałaniem i zwalczaniem COVID-19, innych chorób zakaźnych oraz wywołanych nimi sytuacji kryzysowych oraz niektórych innych ustaw).

47 2020. április 16-i törvény a SARS-CoV-2 vírus terjedésével összefüggésben meghatározott támogató eszközökről (Ustawa z dnia 16 kwietnia 2020 r. o szczególnych instrumentach wsparcia w związku z rozprzestrzenianiem się wirusa SARS-CoV-2).

48 2020. május 14-i törvény a SARS-CoV-2 vírus terjedésével összefüggésben hozott egyes jogszabályok módosításáról (Ustawa z dnia 14 maja 2020 r. o zmianie niektórych ustaw w zakresie działań osłonowych w związku $\mathrm{z}$ rozprzestrzenianiem się wirusa SARS-CoV-2).

49 2020. június 19-i törvény a Covid-19 hatásai által érintett vállalkozóknak nyújtott banki kölcsönök kamattámogatásáról (Ustawa z dnia 19 czerwca 2020 r. o dopłatach do oprocentowania kredytów bankowych udzielanych przedsiębiorcom dotkniętym skutkami COVID-19 oraz o uproszczonym postępowaniu o zatwierdzenie układu w związku z wystąpieniem COVID-19).

50 Krzysztof-Rudnicki, 2020, 105. o. 
— a fitneszklubok, éjszakai klubok, mozik, fürdők, színházak, uszodák is bezárásra kerültek;

— korlátozták az egyes üzletekben tartózkodók létszámát;

- bevezették az idősek vásárlási idősávját;

— a vallási istentiszteleteken részt vevők számát is korlátozták.

\subsection{A koronavírus-járvány második hulláma Lengyelországban}

A kézirat lezártakor is hatályban lévő intézkedések sokkal részletesebbek és kiterjedtebbek, mint az első hullám idején, és gyakorlatilag az élet minden területére kihatnak. A lengyel szabályozás előírja, hogy gyalogosok között kötelező legalább 1,5 méteres távolságot tartani, ami alól mentesülnek a 13 évnél fiatalabb gyermeket gondozó szülők, az ugyanazon háztartásban élők, valamint a fogyatékossággal élő, önállóan mozogni képtelen személyek, sajátos nevelési igényủ személyek és gondozóik.

A járvány lassítása szempontjából Lengyelországban is részletesen szabályozták a maszkviselést, miszerint kötelező maszkot viselni az utcákon, utakon és a városi tereken, temetőkben, sétányokon, közutakon, parkolókban, buszokon, villamosokon és vonatokon, üzletekben, bevásárlóközpontokban, bankokban, piacokon és postahivatalokban, mozikban és színházakban, orvosi rendelőkben, járóbeteg-rendelőkben és kórházakban, masszázsés tetoválószalonokban, templomokban, iskolákban és egyetemeken, és a kormányhivatalokban is. Az erdőkben, parkokban, zöld tereken, botanikus kertekben, történelmi kertekben, családi közösségi kertekben és a strandokon, valamint személygépkocsival történő utazás közben azonban a maszk viselése nem kötelező. ${ }^{51}$

A kézirat lezártakor hatályos szabályok ${ }^{52}$ jelentősen korlátozták egyes korcsoportok személyes mozgását is. İgy például hétfőtől péntekig, reggel 8 és 16 óra között a 16 éven aluli gyermekeket szülő vagy gondozó felügyelete alatt kell tartani, miközben egyik helyról a másikra mennek. A szabály nem vonatkozik az iskolába utazó vagy az iskolából hazatérő gyermekekre és a hétvégékre sem.

51 A koronavírus-helyzetre vonatkozó szabályokat tartalmazó tematikus oldal: www.gov.pl/web/coronavirus/ temporary-limitations (Letöltve: 2020. december 15.)

52 2020. december 9-i törvény a Covid-19, más fertőző betegségek és az általuk okozott krízishelyzetek megelőzésével és leküzdésével kapcsolatos speciális megoldásokról szóló törvény és néhány más törvény módosításáról (Ustawa z dnia 9 grudnia 2020 r. o zmianie ustawy o szczególnych rozwiązaniach związanych z zapobieganiem, przeciwdziałaniem i zwalczaniem COVID-19, innych chorób zakaźnych oraz wywołanych nimi sytuacji kryzysowych oraz niektórych innych ustaw Dz.U.2020.2255). 
2020. november 28-tól ${ }^{53}$ új szabályok vonatkoznak a karanténra (egészséges egyén bezárása fertőzésnek való kitettség miatt) és az izolációra (egy személy izolálása az első Covid-19 diagnosztikai teszt pozitív eredménye miatt). Az otthoni elszigetelés 10 napig tart, feltéve, hogy a beteg nem mutat Covid-19-tüneteket. Ha a koronavírus tünetei az izoláció során jelentkeznek, akkor az elsődleges egészségügyi orvos meghosszabbítja az elszigetelés időtartamát, amely nem érhet véget korábban, mint a tünetek megjelenésétől számított 13 napon belül. A kórházakban és elszigetelő osztályokon történő elszigetelés esetén annak időtartama végét a betegért felelös orvos határozza meg, de nem következhet be korábban, mint a tünetek megjelenésétől számított 13 napon belül, ahol az utolsó három napnak tünetmentesen kell eltelnie.

A karantén 10 napig tart, ha a Covid-19 tünetei nem jelentkeztek. A tünetmentes személyek karanténban történő tesztelésével felhagytak. A karantén ideje alatt a karanténban lévő nem hagyhatja el otthonát, nem sétálhat a kutyájával, nem vásárolhat, orvoshoz nem látogathat; ha a karanténban lévő személy szoros kapcsolatban áll más személyekkel otthon, akkor ôket is karanténba kell helyezni, amennyiben pedig a betegség tüneteit tapasztalja (rossz közérzet, láz, köhögés, légszomj), ezt telefonon be kell jelentenie az egészségügyi és járványügyi állomásra..$^{54}$

A kulturális intézmények, köztük a színházak, mozik, múzeumok, múvészeti galériák és kulturális központok tevékenysége fel van függesztve. November 28-tól könyvtárak nyithatnak, feltéve, hogy a létesítményben tartózkodó minden személy számára $15 \mathrm{~m}^{2}$ terület áll rendelkezésre a gyưjtemények rendelkezésre bocsátására. Ez a rendelkezés 2020. december 27-ig hatályos. ${ }^{55}$

A templomokban az emberek száma korlátozott: $15 \mathrm{~m}^{2}$-enként legfeljebb 1 fó, legalább 1,5 m távolságot tartva másoktól. Ha egy adott esemény egy épületen kívül zajlik, a résztvevőknek 1,5 m távolságot kell tartaniuk, és el kell takarniuk a szájukat és az orrukat.

Az egyéb szabadtéri rendezvények esetén $1,5 \mathrm{~m}$ távolságot kell tartani másoktól, és el kell takarni a szájat és az orrot. A nyilvános összejöveteleken legfeljebb 5 fó vehet részt. A résztvevők kötelesek eltakarni a szájukat és az orrukat és 1,5 méter távolságot tartani egymástól. Ezenkívül az összejöveteleket nem lehet 100 m-nél kisebb távolságra szervezni. Az esküvőket és egyéb ünnepléseket betiltották. Az éjszakai klubok és egyéb helyek is bezá-

53 A Covid-19, az általuk okozott egyéb fertőző betegségek és vészhelyzetek megelőzésével és leküzdésével kapcsolatos speciális megoldásokról szóló törvény módosításáról szóló, 2020. november 27-i törvény (Ustawa z dnia 27 listopada 2020 r. o zmianie ustawy o szczególnych rozwiązaniach związanych z zapobieganiem, przeciwdziałaniem i zwalczaniem COVID-19, innych chorób zakaźnych oraz wywołanych nimi sytuacji kryzysowych oraz niektórych innych ustaw).

54 A Minisztertanács 2020. november 26-i rendelete a járvány kapcsán egyes korlátozások, parancsok és tilalmak megállapításáról (Rozporządzenie Rady Ministrów z dnia 26 listopada 2020 r. w sprawie ustanowienia określonych ograniczeń, nakazów i zakazów w związku z wystąpieniem stanu epidemii) (a továbbiakban: Járvány r.) 2. fejezet.

55 Járvány r. 10. $\$$ (1) bekezdés. 
rásra kerültek. Vásárokat, kiállításokat, kongresszusokat és konferenciákat csak online lehet megrendezni..$^{56}$

2020. június 13-án Lengyelország újraindította a határforgalmat az EU belső határain belül. Ez azt jelenti, hogy az EU belső határainak utazása és átlépése megengedett. Az utazók visszanyerték jogukat a Lengyel Köztársaság területére való szabad belépéshez, elhagyáshoz vagy átszállításhoz. Karantén nem szükséges. Figyelembe kell venni a szomszédos országban érvényben lévő korlátozásokat, miközben külföldi utazást tervezünk. A korlátozások azokra a külföldiekre vonatkoznak, akik átlépik az EU külső határát.

Az éttermekben tilos üzleti tevékenységet folytatni, és csak elvitelre lehet ételt készíteni. $\mathrm{Ez}$ a tilalom az iskolai étkezdék üzemeltetésére is vonatkozik. Az ételeket csak az általános iskola 1-3. osztálya és az oktatási személyzet számára lehet megfeleló egészségügyi óvintézkedések bevezetése után felszolgálni. Étterem üzemeltetése a szállodákban engedélyezett, de csak a szálloda vendégeinek, akik legalább egy éjszakát ott töltenek. Megengedett a szálloda éttermeinek múködtetése, de az ételeket a szálloda vendégeinek a szobájukba kell szállítani. ${ }^{57}$

Országszerte szépségszalonok, tetoválószalonok, fodrászok és kozmetikusok múködhetnek megfelelő óvintézkedések mellett. A munkaállomásoknak legalább 1,5 m-re kell lenniük egymástól, kivéve, ha a padló felületétől legalább 2 m magas válaszfalak választják el ôket.

A szállodák korlátozottan múködnek, és csak üzleti úton lévő vendégek, edzôtáborokban és sportversenyeken részt vevő sportolók, egészségügyi szakemberek, betegek és gondozóik szállásfoglalása engedélyezett. A munkavállalók szállói is múködhetnek. ${ }^{58}$

Az uszodák, aquaparkok, edzőtermek, fitneszklubok és -központok múködése országszerte szünetel, kivéve azokat, amelyek terápiás tevékenységeket végeznek, sportversenyek, sporttevékenységek vagy -események részeként sportolók számára készültek, diákok és tanulók számára készültek az egyetemi vagy iskolai órák részeként. ${ }^{59}$

Országszerte sportversenyeket, -foglalkozásokat és -rendezvényeket szerveznek a nyilvánosság részvétele nélkül. A sportórákon, -eseményeken és -versenyeken (kivéve a golfpályákat, teniszpályákat, istállókat, ménesbirtokokat és lóversenypályákat, a vízi és a légi sport infrastruktúráját, amely nem korlátozódik a maximálisan engedélyezett létszámra) legfeljebb 250 résztvevő lehet egyszerre, az eseményt szervező embereket nem számítva. ${ }^{60}$ 


\section{A különleges jogrend és a járványhelyzet kihirdetésével kapcsolatos tapasztalatok, jogviták}

Komoly közjogi viták alapját képezte, ${ }^{61}$ hogy a veszélyhelyzet kihirdetése helyett - a Covid-19 tv. elfogadásával és a járványhelyzet kihirdetésével - egy negyedik, kvázi rendkívüli intézkedést fogadtak el az alkotmány megkerülésével. Ugyanis előbbi elrendelése egyes vélemények szerint megalapozott lett volna, a járványhelyzet pedig - azáltal, hogy különös veszély miatt rendelték el, annak keretében alapvető jogokat és szabadságokat korlátoznak, és az államapparátus rendes müködését is megváltoztatják - magán hordozza a különleges jogrendi szituációk jellemzőit. ${ }^{62}$

Az előbbieken felül Lengyelországban heves közjogi vita folyt az elnökválasztás időzítéséről. A vírus felgyorsulása és a kormány által a további terjedés elkerülése érdekében bevezetett egyre korlátozóbb intézkedések heves vitát váltottak ki azzal kapcsolatban, hogy az elnökválasztás egyáltalán folytatódhat-e. Az összes ellenzéki jelölt a választás elhalasztása mellett állt ki, azzal érvelve, hogy az ország tényleges szükségállapotban van, ami gyakorlatilag lehetetlenné teszi a normális választási kampányt. Azzal vádolták a Jog és Igazságosság Pártját, hogy a lengyelek egészségét politikai haszonszerzés céljából feláldozzák azzal, hogy választásokat folytatnak, amikor ez veszélyes. Érvelésük szerint a legfontosabb, hogy a hatóságok mindent megtegyenek a vírus elleni küzdelemben és megvédjék a gazdaságot. Március végén az ellenzéki jelölt, Małgorzata Kidawa-Błońska teljesen felfüggesztette kampányát, és a választások bojkottjára szólított fel.

A Jog és Igazságosság Pártja azonban nem volt hajlandó engedni az ellenzéki követeléseknek, és ragaszkodott ahhoz, hogy a választásokat a tervezett ütemtervnek megfelelően tartsák meg, azzal érvelve, hogy az elhalasztás korai lenne, és válság idején destabilizálná a politikai rendszert. Azt állították, hogy az ellenzék önérdekből követelte a választás elhalasztását, és céljuk volt egy olyan választás legitimitásának megkérdőjelezése, amelyet nagy valószínúség szerint el fognak veszíteni.

Mindazonáltal - annak ellenére, hogy léteznek feltételek a választási kampány lebonyolításához - néhány szakértő azzal érvelt, hogy egy epidemiológiai vészhelyzetben egyszerúen múszakilag lehetetlen választásokat lebonyolítani. Figyelmeztettek, hogy ilyen körülmények között történő próbálkozás aláássa a választások hitelességét, ami - tekintettel arra, hogy a demokrácia az állami intézményekbe és a választási eljárásokba vetett bizalomra épül - súlyos következményekkel járhat a lengyel politikai rendszer és a nemzeti stabilitás szempontjából, különösen egy ilyen politikailag megosztott és polarizált helyzetben lévő országban. A választások megszervezése óriási logisztikai kihívás, amely Lengyelországban körülbelül egymillió (gyakran idős) embert érint, akiket (általában nagy csoportokban) ki 
kell képezni, ráadásul sok lengyel jelenleg külföldön, „bezárt” országokban él, és elutasítja a szavazást, míg az idősebb és sérülékenyebb szavazókat valószínúleg még májusban karanténba helyezték, sokan mások önként vonultak karanténba, vagy egyszerüen nem akarták kockáztatni a részvételt. ${ }^{63}$

A lengyel alkotmány - garanciális szabályként - rendkívüli jogrend idején és annak megszúnését követő kilencven napon belül nem teszi lehetővé országos népszavazás és választások megtartását, így például a köztársasági elnök megbízási ideje ilyenkor meghoszszabbodik. ${ }^{64}$ Azáltal azonban, hogy a Minisztertanács nem hirdetett ki veszélyhelyzetet, az elnökválasztásnak nem volt alkotmányos akadálya, ${ }^{65}$ emiatt pedig sokan sejtettek politikai okot a különleges jogrend bevezetésének elmaradása mögött. ${ }^{66}$

Lengyelországban 2020. május 21-én a maszkviselés szabályaival kapcsolatban is alakult ki jogi vita a kormány és az ombudsman ${ }^{67}$ között. Az ombudsman állásfoglalásában kifejtette, hogy a kötelező maszkviselésnek elsősorban az állampolgárok magatartásából kell létrejönnie, nem egy rendelet miatt. Az alkotmány ${ }^{68}$ alapján a rendeleteket az alkotmányban meghatározott szervek adják ki, alapszabály részletes felhatalmazása alapján és annak végrehajtása céljából. Ez azt jelenti, hogy a maszkviselés szabályait törvényi szinten kellett volna rögzíteni, mivel így garantálható annak társadalmi elfogadottsága, támogatottsága.

A járványügyi intézkedésekkel kapcsolatban az ombudsman rámutatott arra is, hogy törvényi alap nélkül a hatóságok korlátozták az állampolgárok három fontos szabadságát: az emberi és állampolgári jogok szabadságát, ${ }^{69}$ a Lengyel Köztársaság területén belüli szabad mozgást, ${ }^{70}$ valamint a lelkiismeret és a vallás szabadságát. ${ }^{71} \mathrm{Az}$ alkotmány itt egyértelmúvé teszi: ezek túl fontos jogok ahhoz, hogy egy miniszter döntsön róluk, azaz ezek nem korlátozhatók rendeleti szinten. ${ }^{72}$

63 Szczerbiak, 2020.

64 Alkotmány 228. cikk (7) bekezdés.

65 Végül a lengyel elnökválasztás első fordulóját 2020. június 28-án, a másodikat pedig július 13-án tartották meg.

66 Drinóczi-Bien-Kacala, 2020, 190. o.

67 Ombudsmani állásfoglalás a maszkviselésről. Elérhető: www.rpo.gov.pl/pl/content/koronawirus-rponakaz-zakrywania-ust-nosa-niezgodny-z-zasadami-tworzenia-prawa (Letöltve: 2020. december 15.).

68 Alkotmány 1 . cikk.

69 Alkotmány 30. cikk.

70 Alkotmány 52 . cikk.

71 Alkotmány 53. cikk.

72 Ombudsmani állásfoglalás az egészségügyi miniszter rendeleteiről. Elérhető: www.rpo.gov.pl/pl/content/ koronawirus-rpo-rozporzadzenia-MZ-niezgodne-z-ustawa (Letöltve: 2020. december 15.). 


\section{5. Összegzés}

A magyar Alaptörvényben szabályozottakhoz képest a lengyel szabályozásban a különleges jogrendi esetkörök lényegesen egyszerübben szabályozottak. A lengyel környezetben a szabályozási esetkörök szưkebbre szabottsága mellett a jogosítotti kör sem heterogén, ennek következtében a felelősség is egy magasabb - jelen esetben a lengyel minisztertanácsi/ államfői - szinten manifesztálódik.

A lengyel alkotmány megfeleló mintát szolgáltat a fogalmi letisztázáshoz, az operativitás növeléséhez amellett, hogy rövid időn belül lehetôséget teremt a törvényhozás számára, hogy annulálja az elrendelést, és ha szükséges, megkezdje a felelősségre vonást. ${ }^{73}$

Az alkotmány részletesen felsorolja, hogy mely alapjogok nem korlátozhatók, és melyek azok, amelyek ha a körülmények úgy alakulnak, akkor korlátozás alá eshetnek. Ezen belül is elkülönítik a hadiállapot és szükségállapot alatt korlátozható alapjogokat a veszélyhelyzet idején korlátozható alapjogoktól.

Fontos megemlíteni, hogy a jelenlegi, koronavírus okozta helyzetben szigorú korlátozó intézkedések kerültek bevezetésre. A lengyel rendszer a magyarnál kevésbé túlszabályozott, ami a különleges jogrendi esetköröket illeti. Több más aspektusában is egyszerúbb a lengyel szabályozás, így egyik szituáció során sem kerül sor új szerv megalkotására, és mindhárom esetben a Minisztertanács jogosult rendeleti kormányzásra. Mindezek pedig segítik az átállás nehézségeinek leküzdését, valamint az operativitást. A lengyel szabályozás továbbá lehetőséget teremt arra, hogy a törvényhozás rövid időn belül annulálja a különleges jogrend elrendelését, hiszen a hadiállapot és a szükségállapot bevezetésétől számított 48 órán belül a köztársasági elnöknek kezdeményeznie kell a rendelet képviselőházi ellenjegyzését. A képviselőház pedig annak haladéktalan megtárgyalását követően a képviselők legalább felének jelenlétében, abszolút többséggel hatályon kívül helyezheti a különleges jogrendet kihirdető rendeletet. Veszélyhelyzet esetén pedig annak az egész ország területére való kiterjesztéséhez szükséges a képviselőház jóváhagyása.

Az alábbi táblázat összefoglalja azt, hogy a lengyel alkotmányos és törvényi szintú szabályok egészen pontosan milyen rendkívüli jogrendi helyzeteket szabályoznak, és azokat mikor és mely szerv rendelheti el.

73 Kelemen, 2019, 9. o. 


\begin{tabular}{|c|c|c|c|}
\hline & Hadiállapot & Szükségállapot & Veszélyhelyzet \\
\hline $\begin{array}{c}\text { Szabályozás } \\
\text { szintje }\end{array}$ & \multicolumn{3}{|c|}{ alkotmányos és törvényi szint } \\
\hline Elrendelési okok & $\begin{array}{l}\text { — az állam külső } \\
\text { fenyegetettsége } \\
\text { — a Lengyel Köztársaság } \\
\text { területe elleni fegyveres } \\
\text { agresszió } \\
\text { — nemzetközi egyezmény } \\
\text { szerinti közös védelmi } \\
\text { kötelezettség }\end{array}$ & $\begin{array}{l}\text { — az alkotmányos rend } \\
\text { fenyegetettsége } \\
\text { — az állampolgárok } \\
\text { fenyegetettsége } \\
\text { — a közrend } \\
\text { fenyegetettsége }\end{array}$ & $\begin{array}{l}\text { - természeti } \\
\text { katasztrófa } \\
\text { — múszaki baleset }\end{array}$ \\
\hline Elrendelés & \multicolumn{2}{|c|}{$\begin{array}{l}\text { A Minisztertanács kérelmére a köztársasági elnök } \\
\text { hirdeti ki, azonban a bevezetésétől számított } 48 \text { órán } \\
\text { belül kezdeményezi a rendelet képviselőházi ellen- } \\
\text { jegyzését. A képviselőház pedig a képviselők legalább } \\
\text { felének jelenlétében, abszolút többséggel hatályon } \\
\text { kívül helyezheti a köztársasági elnök rendeletét. }\end{array}$} & $\begin{array}{l}\text { A Minisztertanács } \\
\text { hirdeti ki, kiterjeszté- } \\
\text { séhez viszont a képvi- } \\
\text { selőház jóváhagyása } \\
\text { szükséges. }\end{array}$ \\
\hline Felhatalmazott & \multicolumn{3}{|c|}{ Minisztertanács } \\
\hline Gyakorlati esetek & \multicolumn{2}{|c|}{ Nem került sor az elrendelésükre. } & $\begin{array}{l}\text { Elrendelésére nem } \\
\text { került sor, azonban } \\
\text { több alkalommal } \\
\text { komolyan felmerült } \\
\text { a lehetősége (például } \\
\text { a 2010-es és a 2013-as } \\
\text { árvizek idején). }\end{array}$ \\
\hline $\begin{array}{l}\text { Rendkívüli felha- } \\
\text { talmazás esetkörei }\end{array}$ & \multicolumn{3}{|c|}{$\begin{array}{l}\text { — terrorizmus (a különleges jogrendi törvények alapján) } \\
\text { — válsághelyzet (a válságkezelésről szóló törvény alapján) }\end{array}$} \\
\hline
\end{tabular}

\section{3. táblázat}

A különleges jogrendi esetkörök Lengyelországban

Forrás: a szerző saját összeállítása 


\section{Irodalomjegyzék}

BAŁA, P. (2020) 'Constitutional Failure. Regulacja stanów nadzwyczajnych i zbliżonych w Konstytucji RP z 2 kwietnia 1997 r. a praktyka ustrojowa zwalczania epidemii COVID-19/ SARS-CoV-2', Przegląd Konstytucyjny, 2020/2, 68-121. o.

Drinóczi, T., Bien-KacAla, A. (2020) 'COVID-19 in Hungary and Poland: Extraordinary Situation and Illiberal Constitutionalism', The Theory and Practice of Legislation, 8(1-2), 171-192. 0 .

HoJNYÁK, D., UngVÁRI, Á. (2021) 'A Visegrádi Együttműködés országainak koronavírusjárványra adott válasza', Iustum Aequum Salutare, (17)1, 305-323. o.

KELEMEN, R. (2019) 'A különleges jogrend szabályozása az egyes alkotmányokban II. A lengyel, cseh és szlovák különleges jogrend alkotmányos szabályai', Vélemények a katonai jog világából, 2019/2. [Online]. Elérhető: https://epa.oszk.hu/02700/02733/00010/pdf/ EPA02733_velemenyek_katonai_2019_02.pdf (Letöltve: 2020. december 10.)

KrzyszTOF, K., RUDNICKI, J. (2020) 'The COVID Crisis as a Sample Tube with Contemporary Legal Phenomena', Central European Journal of Comparative Law, 1(2), 105-121. o.

LAKATOS, L. (2014) 'A különleges jogrend és a honvédelem szabályzása' MTA Law Working Papers, 2014/49 [Online]. Elérhető: https://jog.tk.hu/mtalwp/a-kulonleges-jogrend-es-ahonvedelem-szabalyzasa (Letöltve: 2020 . december 8.)

Szczerbiak, A. (2020) How Is the Coronavirus Pandemic Affecting Polish Politics? [Online]. Elérhető: https://polishpoliticsblog.wordpress.com/2020/04/02/how-is-the-coronaviruspandemic-affecting-polish-politics/ (Letöltve: 2020. december 15.) 


\title{
17. Lettország készen állt: egy könnyûszerkezetes jogrendszer példája
}

\author{
SZŐKE PÉTER
}

\section{A különleges jogrend alkotmányos és törvényi szintű szabályozása és esetkörei}

\begin{abstract}
A lett jogrend a különleges jogrend több fajtáját és esetét ismeri és szabályozza alkotmányos, illetve törvényi szinten is. A lett alkotmányban ${ }^{1}$ ezek közül az első a hadiállapot, ${ }^{2}$ amelyre egyébként nem használja a különleges jogrend fogalmát sem az alkotmány, sem a törvények. Az alkotmány a köztársasági elnököt ruházza föl azzal a joggal, hogy a parlament határozata alapján hadat üzenjen. ${ }^{3}$ Ennek magától értetődő nemzetközi következményeit nem fejti ki az alkotmány, de nem tér ki az ennek nyomán esetleg beálló belső jogi változásokra sem, hacsak arra nem, hogy a rendes bíróságok mellé belépnek a katonai bíró-
\end{abstract}

I Latvijas Republikas Satversme (1922) (a továbbiakban: alkotmány). A hatályos alkotmány úgy jött létre, hogy a függetlenség visszanyerésekor egyszerúen újra hatályba léptették a régi, 1922-es alkotmányt (Kruma-Statkus, 2019, 951. o.). Igaz, ez a dokumentum 1996 és 1998 között lényeges módosulásokon ment keresztül.

2 Alkotmány 43.cikk. A lett alkotmánynak a lett köztársasági elnöki hivatal honlapján található angol nyelvú szövegét használtuk forrásként: www.president.lv/en/republic-of-latvia/the-constitution-of-the-republicof-latvia\#gsc.tab=0 (Letöltve: 2020 . december 14.).

3 Alkotmány 43. cikk.

Dr. Szőke Péter

peter.szoke@mfi.gov.hu

kutató (Mádl Ferenc Összehasonlító Jogi Intézet)

Szőke, P. (2021) 'Lettország készen állt: egy könnyúszerkezetes jogrendszer példája' in Nagy, Z., Horváth, A. (szerk.) A különleges jogrend és nemzeti szabályozási modelljei, 376-397. o. Budapest: Mádl Ferenc Összehasonlító Jogi Intézet.

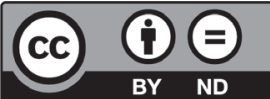


ságok. ${ }^{4} \mathrm{Az}$ alkotmányban ugyancsak szereplő rendkívüli állapotot ${ }^{5}$ a kormány hirdetheti ki, ha az államot külső ellenség fenyegeti, vagy a fennálló államrendet veszélyeztetô vagy ilyen veszéllyel fenyegetô zavargás támad az országban vagy annak valamely részében. Rendkívüli állapot bevezetése esetén a kormány 24 órán belül értesíti a parlament elnökségét, ${ }^{6}$ amely a kormánydöntést haladéktalanul a parlament elé terjeszti. Miután a külső ellenség fenyegetése a kihirdetés lehetséges okai között szerepel, feltételezhetô, hogy hadüzenet vagy Lettországot érő vagy fenyegető agresszió esetén rendkívüli állapotot hirdetnének.

A különleges jogrend esetköreinek vizsgálatakor törvényi szinten két jogszabály jön számításba. A nemzetbiztonságról szóló törvény ${ }^{7}$ a hadiállapottal már mint alkotmány adta lehetőséggel számol. Erre az eshetőségre rendelkezni kell az állami védelmi tervben, az országos mozgósítási tervben és az állami polgári védelmi tervben. ${ }^{8}$ Eszerint a parlament dönt a hadüzenetről és az esetleges harci cselekmények megkezdéséról, valamint vizsgálja a mozgósítás jogosságát és indokoltságát. Sajátosan előrelátó a törvény arra az esetre, ha az ország légterében olyan repülőgépet észlelnek, amelyről alaposan feltehető, hogy azt emberek elpusztítására fegyverként akarják használni. Ilyenkor - legvégső esetben - a miniszterelnök katonai akciót rendelhet el a merénylet megakadályozására. ${ }^{9}$ Ez a rendelkezés egyébként a NATO 2002-ben elfogadott RENEGADE koncepciójának végrehajtását szolgálja, amely a 2001. szeptember 11-i terrortámadások nyomán született, és valamennyi - fenntartással nem élő - tagállam elfogadott ennek megfelelő jogi szabályozást. ${ }^{10} \mathrm{~A}$ kollektív védelemre szintén példa a három balti állam együttmúködésében megvalósuló BALTNET és BALTRON projektek (részletesebben lásd a Litvániáról szóló fejezetet).

Témánk szempontjából lényegesebb a vészhelyzetről és a rendkívüli állapotról szóló törvény. ${ }^{11}$ Figyelemre méltó módon ugyanis ez a törvény explicite bevezeti a „különleges jogrend" kategóriáját, amely ilyen általános gyuujtőfogalomként kevés európai jogrendben használatos, és általában csak a következményekből lehet a létére visszakövetkeztetni. Ez a jogszabály pontosítja a rendkívüli állapot szabályait, illetve bevezeti a vészhelyzet fogalmát.

4 Alkotmány 82. cikk.

5 Alkotmány 62. cikk. Itt ütközik ki a lett források egyik problémája. A különböző jogszabályok angol nyelvű fordításai ugyanazt a fogalmat, jogintézményt nem egységesen fordítják. Az alkotmány e helyén a lett izñemuma stāvokli szerepel, ami a köztársasági elnöki honlap angol verziójában - véleményünk szerint helyesen state of emergency, amit magyarra általában rendkívüli állapotként szokás fordítani. Ugyanez a lett terminus az alább ismertetendő, a vészhelyzetről és a rendkívüli állapotról szóló törvényben már a state of exception fordítást kapja, míg a vészhelyzet (ārkārtējās situācijas) angol fordításaként extraordinary situation szerepel.

6 A törvényhozás nemcsak házelnököt, hanem elnökséget választ az alkotmány 16. cikke értelmében, amelynek tagjai a törvényhozás elnöke, két alelnöke, valamint meg nem nevezett számú titkár. A másutt általában a házelnökök által gyakorolt jogosítványokkal itt az elnökség rendelkezik.

7 Nacionālās drošības likums (a továbbiakban: Nbtv.) 29. cikk.

8 Nbtv. 29., 35. és 36. cikk.

9 Nbtv. 9. cikk (5) bekezdés.

10 A hazai szabályozásra lásd a honvédelemről és a Magyar Honvédségről, valamint a különleges jogrendben bevezethető intézkedésekről szóló 2011. évi CXIII. törvény 62. \$ (3)-(4) bekezdését.

11 Par ārkārtējo situāciju un izṇēmuma stāvokli (a továbbiakban: Vészhelyzeti tv.). 
Vészhelyzet ${ }^{12}$ hirdethető, amennyiben a nemzetbiztonságot vagy a létfontosságú infrastruktúrát természeti csapás vagy ember okozta baleset éri vagy fenyegeti olyan súlyosan, hogy amiatt az állam, a társadalom, a környezet, a gazdasági élet vagy emberek élete vagy egészsége komoly veszélybe kerül. A Vészhelyzeti tv. rögzíti, hogy vészhelyzet elrendelése esetén a kormánynak joga van korlátozni a közigazgatási és helyi önkormányzati szervek jogköreit, valamint a természetes és jogi személyek jogait és szabadságát, továbbá a kormány jogosult egyéb kötelezettségeket elôirni. ${ }^{13} \mathrm{~A}$ jogszabály pontosító rendelkezést ${ }^{14}$ tartalmaz, miszerint a kormány csak határozott idôtartamra, de legfeljebb három hónapra rendelhet el vészhelyzetet. A kormány szükség esetén egyszer, legfeljebb három hónapra meghosszabbíthatja a vészhelyzetet; szükség esetén pedig visszavonja ezt a döntését.

A kormány a parlament elnökségével 24 órán belül köteles közölni a vészhelyzet kihirdetésérôl, módosításáról, meghosszabbításáról szóló döntését, amelyet az haladéktalanul megtárgyal. Ha a döntést elutasítja, akkor egyidejúleg hatályon kívül is helyezi, a bevezetett intézkedéseket pedig haladéktalanul vissza kell vonni. ${ }^{15}$ (Vagyis nem veszítik automatikusan hatályukat.)

Mint az imént említettük, a Vészhelyzeti tv. széles körủ, egyes alapjogokat korlátozó és különleges kötelezettségeket kirovó intézkedési lehetőséggel ruházza föl a kormányt vészhelyzet esetére, amelyet a következő pontban ismertetünk.

Ugyanezen törvény szabályozza részletesebben az alkotmányban is szereplő rendkívüli állapot jogintézményét is, amelynek kihirdetése és jogkövetkezményei a vészhelyzetnél tárgyaltakhoz hasonlók. A rendkívüli állapotot ki lehet hirdetni katasztrófa vagy annak veszélye vagy a kritikus infrastruktúrát érő fenyegetés esetén, ha az az államra, a társadalomra, a környezetre, a gazdasági biztonságra, az emberi egészségre vagy az életre súlyos kockázatot jelent. Rendkívüli állapot idején a kormánynak joga van korlátozni az állami közigazgatás és a helyi önkormányzatok jogköreit, a természetes és jogi személyek jogait és szabadságát, valamint a törvénnyel összhangban meghatározott kötelezettségeket előírni számukra. A kormány határozott időtartamra, legfeljebb hat hónapra rendelhet el rendkívüli állapotot, amennyiben az államot külső ellenség fenyegeti, vagy olyan belső zavargások törtek ki vagy fenyegetnek kitöréssel, amelyek az állam „demokratikus struktúráját veszélyeztetik”. ${ }^{16}$ A kormány dönt a rendkívüli állapot kihirdetéséről, módosításáról, meghosszabbításáról. A kormány a rendkívüli állapot elrendeléséről vagy az azzal kapcsolatos változtatásokról (például a területi hatályt illetően) huszonnégy órán belül tájékoztatja a parlament elnökségét. A rendkívüli állapotot kiváltó körülmények megszûnését követően a kormány haladéktalanul köteles hatályon kívül helyezni azt, függetlenül az eredetileg meg-

12 Vészhelyzeti tv. II. fejezet.

13 Vészhelyzeti tv. 4. cikk (1) bekezdés.

14 Vészhelyzeti tv. 5. cikk.

15 Vészhelyzeti tv. 9. cikk.

16 Vészhelyzeti tv. 11. cikk (2) bekezdés. 
szabott határidőtôl. Ha azonban továbbra is indokoltnak látja, akkor legfeljebb hat hónap elteltével tovább, legfeljebb ugyancsak hat hónapra meghosszabbíthatja, amíg indokoltnak látja - de természetesen parlamenti kontroll mellett. Érdekesség, hogy az ombudsman vagy egy általa meghatalmazott személy is részt vehet a kormány ülésein, és kifejtheti véleményét a döntésrôl. Ez a rendelkezés világosan utal arra, hogy a jogalkotó a rendkívüli állapotot az alapvető jogok lehetséges korlátozása felől szemléli, és garanciákat vagy legalább törekvést szeretne látni arra nézve, hogy ezek a korlátozások nem lépik át a szükséges és arányos mértéket. A határozatnak nemcsak a rendkívüli állapot bevezetésének okáról, idő- és térbeli hatályáról kell rendelkeznie, hanem tartalmaznia kell azokat a tervezett intézkedéseket, amelyek a rendkívüli állapotot kiváltó helyzet kezelését célozzák. Ugyancsak rendelkeznie kell azokról a jog-, illetve hatásköri korlátozásokról, valamint különleges kötelezettségekről, amelyek meghatározott jogalanyokat (természetes és jogi személyeket) egyaránt érintenek, de ehhez hasonlóan rendkívüli felhatalmazásokat és hatásköröket is ruházhat a központi vagy területi közigazgatásra. Meg kell határozni azt az eljárásrendet, amelyben a köztársasági elnököt, a parlament elnökségét, valamint a legfőbb ügyészt tájékoztatják a fenyegetés elhárításának állásáról. A kormány meghatározhatja azoknak a nemzetközi szervezeteknek és idegen államoknak a körét, amelyeket a rendkívüli állapotról értesíteni kell. ${ }^{17}$

Világos, hogy a rendkívüli állapot bevezetésében és menedzselésében is a kormány van központi és cselekvő szerepben. A parlament ellenőrző szerepe azonban ugyancsak teljes körü, tehát a parlament szuverenitása nem szenved csorbát. A törvényhozás elnöksége haladéktalanul napirendre túzi a kormány rendkívüli állapottal kapcsolatos határozatait. Ha a parlament felülbírálja a kormány határozatát, vagyis nem hagyja jóvá a rendkívüli állapot bevezetését vagy annak kiterjesztését térben vagy időben, illetve nem hagyja jóvá jogok további korlátozását, úgy a kormány határozata nyomban hatályát veszíti, az annak alapján hozott intézkedéseket pedig ugyancsak haladéktalanul vissza kell vonni. ${ }^{18} \mathrm{~A}$ törvény rendelkezik arról is, hogyan kell a lakosságot széles körben, ingyenesen tájékoztatni, előnyben részesítve az elektronikus hírközlési csatornákat. ${ }^{19}$ Rendkívüli állapot idején a kormány átrendezheti egyes állami szervek alá- és fölérendeltségi viszonyait. ${ }^{20}$

A törvény részletesen felsorolja a kormány jogosultságait rendkívüli állapot esetén (a nemzetbiztonsági fenyegetés típusától, intenzitásától és természetétől függően). Ezekre a következő pontban térünk ki.

Különleges jogrendnek nem minősül, de témánkba vágó, rendkívüli felhatalmazásra ad lehetőséget a lett önkormányzati törvény ${ }^{21}$ Eszerint a városi tanácsok hatáskörébe tartozik

17 Vészhelyzeti tv. 11-13. cikk.

18 Vészhelyzeti tv. 14. cikk.

19 Vészhelyzeti tv. 15. cikk.

20 Vészhelyzeti tv. 16. cikk.

21 Par pašvaldībām (a továbbiakban: Önkormányzati tv.). 
kötelező érvényú rendeletek kiadása és közigazgatási felelősség biztosítása azok megsértése esetén - kivéve, ha a törvény erről rendelkezik - az alábbi kérdésekben:

— a járványok terjedésének megakadályozására szolgáló intézkedések;

- természeti katasztrófák vagy más rendkívüli körülmények esetén az azok következményeinek megelózésére szolgáló intézkedések;

— a város speciálisan védett természeti tárgyai, valamint kulturális emlékek védelme;

- törvény vagy kormányrendelet által meghatározott egyéb kérdések. ${ }^{22}$

A továbbiakban szükséges kitérni a válságkezelés szabályaira és intézményeire is. A válságkezelés központi szerve nem a különleges jogrendhez, nem is a polgári és katasztrófavédelmi törvényhez, hanem az Nbtv.-hez köthető. Ez rendelkezik a Válságkezelési Tanács (Krizzes vadības padome) ${ }^{23}$ felállításáról, és szabályozza összetételét, jogállását, feladat- és hatásköreit. A tanács lényegében a kormány szerve, kabinet a kormányon belül. Elnöke a miniszterelnök, tagjai pedig a kormány miniszterei közül kerülnek ki: a védelmi, külügy-, gazdasági, pénzügy-, belügy-, igazságügy-, egészségügyi, közlekedésügyi, környezetvédelmi és területfejlesztési miniszterek. Nem döntéshozó, hanem koordinatív testület - a döntést a kormány hozza. A tanáccsal kapcsolatos részletes szabályokat a kormány végrehajtási rendeletben ${ }^{24}$ határozta meg. A tanács feladata, hogy összehangolja az állami és az önkormányzati intézmények, hatóságok fellépését az államot érintő veszélyek megelőzésére és elhárítására, és felszámolja ezek következményeit. A hatóságok körébe a polgári és katonai hatóságok egyaránt beleértendők. Nagyon fontos hatásköre egyebek között, hogy javaslatot tehet a kormánynak vészhelyzet és mozgósítás, de nem a rendkívüli állapot elrendelésére. Feladatai közé sorol a rendelet mindent, ami a hatékony válságkezelés koordinációjához szükséges: információt gyuujt be és elemez; a számára releváns rendelettervezeteket véleményezi, és egyeztet a szakmai, illetve ágazati álláspontok között. Hatásköre nemzetközi szerepvállalásra is kiterjed: külföldre juttatandó lett, illetve külföldről Lettországba érkező humanitárius segítségnyújtást koordinál. Javaslatot tesz a kormánynak a válságkezelő intézkedések finanszírozására. Válsághelyzeten kívül is feladata a válságkezelő rendszer és apparátus javításán munkálkodni, a kormánynak vonatkozó javaslatokat tenni. Jogában áll információt kérni önkormányzatoktól és magánszemélyektől is, szakértői munkacsoportokat hívhat életre. A tanács legkevesebb félévente egy alkalommal ülésezik, tehát válsághelyzeten kívül is - nyilvánvaló tehát, hogy feladata a válságkezelésen kívül kiterjed az állami válságkezelési képesség fejlesztésére. A rendelet viszonylagos részletességgel határozza meg a tanács ügyrendjét. A szervezeti felépítést illetően említésre méltó, hogy a tanács titkárságát

22 Vészhelyzeti tv. 23. cikk.

23 Nbtv. $23^{1}-23^{4}$ cikk.

24 Az Nbtv. 23. cikke alapján fogadta el a kormány 2011. január 18-án a 42. számú kormányrendeletet a Válságkezelési Tanácsról (Krìzes vadības padomes nolikums). 
a Belügyminisztérium adja. Ha a tanács szakértői csoportok felállítását határozza el, akkor ezeket a minisztériumok delegálják, a téma függvényében.

\section{Az alapjogok korlátozására vonatkozó szabályok különleges jogrend idején}

Mindenekelőtt érdemes röviden megvizsgálni a lett alkotmány alapjogi fejezetét és az általános alapjogi záradékot. Az Alapvetôemberi jogok címú VIII. fejezetet az alkotmányozó nemzetgyúlés csak 1998-ban, az alkotmány negyedik módosítása során illesztette be a lett alkotmányba, ${ }^{25}$ amellyel a most hatályos alkotmányt folytonosnak tekintik, mintegy megtagadva az elismerést a szovjet-orosz uralom közjátékától. Az alapjogi fejezet 1. cikke - mintegy alapjogi klauzulaként - deklarálja, hogy az állam elismeri és védi az alapvető emberi jogokat a jelen alkotmánnyal, a törvényekkel, valamint a Lettországra kötelező nemzetközi szerződésekkel összhangban. ${ }^{26} \mathrm{~A}$ lett alkotmány - az európai alkotmányokhoz hasonlóan - rögzíti tehát az állam kettős kötelezettségét: az alapvetố jogokat elismeri, tiszteletben tartja (negatív oldal) és védi (pozitív oldal). Az általános alapjogi záradék rögzítését követően az alkotmány felsorolást ad és rendelkezik az alapvető emberi jogokról.

Az alkotmány az alapjogok korlátozására konkrétan, az egyes alapjogok vonatkozásában utal. Általánosságban kinyilvánítja, hogy mindenkit megillet a személyes szabadság és a biztonság; majd rögzíti, hogy a törvényben meghatározott eseteken kívül senkit sem lehet szabadságától megfosztani vagy abban más módon korlátozni. ${ }^{27} \mathrm{Az}$ egyes jogok között felsorolja az egészség védelmét mint állami kötelezettséget és az alapfokú orvosi ellátáshoz való jogot, valamint az oktatáshoz való jogot is. (Ennek - mint látni fogjuk - a koronavírus-járvány miatt kihirdetett vészhelyzet idején különös jelentősége van: a vészhelyzeti rendelkezések az egészség védelmét célozzák, másrészt gyengítik, amikor a korlátozott erőforrásokat a járvány elleni védekezésre csoportosítják át egyéb ellátási szükségletek rovására. Az oktatáshoz füződő jog is sérülhet az egészség védelme érdekében előirt és a nehéz helyzetben lévő gyerekek számára nehezebben teljesíthető távoktatás bevezetésével, ami a nehéz anyagi vagy családi helyzetben élő gyermekeket hátrányos helyzetbe hozza.) Hasonló rendelkezéseket találunk a tulajdonjog vonatkozásában is. Az alkotmány deklarálja, hogy mindenkinek joga van a magántulajdonhoz, de rögzíti, hogy a tulajdont nem lehet a közérdekkel ellentétes célra használni, valamint a tulajdonjog kizárólag a törvénnyel összhangban korlátozható. A közérdekből történő kisajátítás csak kivételes esetben, külön törvény alapján és tisztességes kár-

25 A parlament 1998. október 15-én fogadta el az alkotmány módosítására irányuló javaslatot, míg a módosított - pontosabban az alapjogi részt tartalmazó VIII. fejezettel kiegészített - alkotmányszöveg 1998. november 6-án lépett hatályba.

26 Alkotmány 89. cikk.

27 Alkotmány 94. cikk. 
talanítás mellett lehetséges ${ }^{28} \mathrm{Az}$ alapjogi fejezetet záró rendelkezés pedig meghatározza, hogy a személyes szabadság és biztonság, valamint a tulajdonjog mellett mely más alapjogok korlátozása és milyen esetekben lehetséges. Általános szabályként azt szögezi le, hogy e jogok más személyek jogainak érvényesülése, az állam demokratikus berendezkedése, a közbiztonság, a jólét és a közerkölcs érdekében korlátozhatók. ${ }^{29}$

E feltételekkel tehát az alábbi alapjogok korlátozhatók:

- a magánélet, a magánlakás, valamint a magánlevelezés sérthetetlensége;

- a szabad mozgáshoz és a lakóhely szabad megválasztásához való jog;

- a mozgás szabadsága, azaz az ország elhagyásának mindenkit, az oda visszatérésének minden lett állampolgárt megillető joga, amely utóbbi a diplomáciai és konzuli védelemhez való jogot is magában foglalja;

- a véleménynyilvánítás szabadsága (amely alapjog magában foglalja az információ szabad megszerzésének, megtartásának, terjesztésének jogát és a saját meggyőződés kifejezésének szabadságát is);

— egyesülési jog (mindenki jogosult egyesület, politikai párt és más nyilvános szervezet alapítására és az ezekhez való csatlakozásra);

— gyülekezési jog (az állam védi az előzetesen bejelentett békés gyúlések, utcai rendezvények és tüntetések szabadságát);

- munkához való jog (mindenkinek joga van arra, hogy képességeihez és tanulmányaihoz mérten szabadon válassza meg munkáját és munkahelyét);

— a kollektív szerződés joga és sztrájkjog. ${ }^{30}$

Habár a felsorolásból kimaradt a gondolat-, lelkiismereti és vallásszabadság, az előbb említett általános feltételekkel a vallási nézetek kifejezése is korlátozható. ${ }^{31}$

A lett alkotmány is ismer azonban korlátozhatatlan (abszolút) jogokat és tilalmakat, jóllehet ez a kategória nem jelenik meg sehol explicit módon. Inkább arról van szó, hogy Lettországnak a különböző nemzetközi szerződésekben foglalt kötelezettségeiből következik, hogy az élethez, valamint az emberi méltósághoz, becsülethez való jogok feltétlen jellegúek, azok korlátozására nincs mód..$^{32} \mathrm{~A}$ jog logikájából és koherenciájából ugyanakkor az is következik, hogy az ártatlanság alkotmányban rögzített vélelme, ${ }^{33}$ valamint a tisztességes eljáráshoz való jog más alkotmányos jog védelmére hivatkozva nem korlátozható. A korlátozhatatlanság ugyanakkor nemcsak abszolút jogokat, hanem - mintegy a jogérvényesülés

28 Alkotmány 105. cikk.

29 Alkotmány 116. cikk.

30 Alkotmány 96., 97., 98., 100., 102., 103., 106. és 108. cikk.

31 Az alkotmányozó valamilyen okból a lelkiismereti és vallásszabadságot biztosító 99. cikket kihagyta a felsorolásból, és ennek korlátozhatóságát külön említi a 116. cikk záró fordulatában.

32 Alkotmány 93. és 95 . cikk.

33 Alkotmány 92 . cikk. 
garanciájaként - abszolút tilalmakat is magában foglal. Ez alapján a lett alkotmány az alábbi feltétlen tilalmakat állítja fel: az emberi becsületről és méltóságról szóló cikk rögzíti, hogy a kínzás vagy más kegyetlen, megalázó bánásmód minden emberrel szemben tilos, valamint senkit sem lehet embertelen, megalázó büntetésnek alávetni. ${ }^{34} \mathrm{~A}$ lett alkotmány a munkához való jog kapcsán rögzíti továbbá a kényszermunka tilalmát. ${ }^{35}$

A lett alkotmányban a különleges jogrenddel összefüggően alapjog-korlátozásra vonatkozó rendelkezések nem találhatók; e kérdéskört törvényi szinten szabályozzák. A különleges jogrendre vonatkozó szabályanyag alapvetően az előző pontban már ismertetett két jogszabályban, az Nbtv.-ben, valamint a Vészhelyzeti tv.-ben jelenik meg. A kutatott téma szempontjából különösen az utóbbi törvény releváns, hiszen e jogszabály rögzíti, hogy vészhelyzet, valamint rendkívüli állapot elrendelése esetén milyen formában és hogyan kerülhet sor az alapjogok korlátozására.

A két esetkör közül nyilván a vészhelyzet az enyhébb, ezért az elrendelhető jogkorlátozások is kevésbé súlyosak; inkább gyakorlati célok elérésére alkalmasak, jellemzően nem a politikai, hanem inkább a személyes szabadságjogokat érintik. A kormány korlátozhatja a mozgásszabadságot és a gyülekezés jogát, illetve különleges eljárásokat vezethet be ezekre nézve (a törvény ezt a szabályt külön is megismétli a járművek közlekedésére is), ezenfelül megtilthatja vagy külön engedélyhez kötheti a bizonyos helyeken való tartózkodást. Korlátozható a gazdasági tevékenység, ezzel a szabad vállalkozáshoz való jog, amely szabályt ugyanez a cikk világossá és pontosabbá teszi azzal, hogy nevesít bizonyos készletgazdálkodási és ellátási szabályokat áruk, különösen gyógyszerek, energiaforrások, szolgáltatások és egyéb anyagi és technikai forrásokhoz való hozzáférés tekintetében. Lehetőség van a magánlakás sérthetetlenségéhez füződő jog korlátozására: nemcsak a kormány, hanem a helyi önkormányzat is elrendelheti és ki is kényszerítheti személyek és tárgyak evakuálását, valamint az ingatlanokba történő behatolást. A személyes szabadság különböző szintú korlátozásai is elrendelhetók: nemcsak a központi, hanem önkormányzati hatóságok is ôrizetbe vehetik azt, aki a vészhelyzettel kapcsolatos intézkedésekkel szembehelyezkedik. Végül idesorolja a törvény a kormánynak azt a jogát, hogy a Lettország által nemzetközi szerződésben vállalt kötelezettségek végrehajtását egészen vagy részlegesen felfüggessze, amennyiben azok végrehajtása kedvezőtlen hatással lenne a nemzetbiztonságot (!) ${ }^{36}$ fenyegető veszély megelőzésére vagy elhárítására.

A törvény ugyanakkor rögzíti, hogy a kormány a fentieken túl a vészhelyzet megelőzéséhez vagy elhárításához szükséges további intézkedések meghozatalára is jogosult. ${ }^{37}$

34 Alkotmány 95. cikk.

35 Alkotmány 106. cikk.

36 A nemzetbiztonságra utalás anomáliának tủnik a normaszöveg e helyén. Itt elég lett volna talán a vészhelyzet leküzdésének céljaihoz kötni ezt a felhatalmazó rendelkezést.

37 Vészhelyzeti tv. 8. cikk. 
A rendkívüli állapot ennél keményebb, más jellegủ korlátozásokhoz is vezethet. A vészhelyzeti szabályokkal megegyező szankciót, azaz őrizetbe vételt és büntetőeljárást helyez kilátásba az ellenszegülők számára, ami azonban kiegészül egy külföldiekre vonatkozó szigorúbb szabállyal: őket ugyanis ki lehet toloncolni, amihez nem szükséges a hatóságokkal való szembeszegülés, hanem már a nemzetbiztonságot és honvédelmi érdekeket veszélyeztető „propaganda” is elég. Ugyancsak a vészhelyzethez hasonlóak az evakuálásról szóló és a magánlakba történő behatolásra vonatkozó szabályok azzal a különbséggel, hogy itt a jogalkotó specifikus célhoz és feltételhez köti ezeket a felhatalmazásokat: ezek pedig az élet- és vagyonvédelem, valamint a nemzetbiztonsági vagy honvédelmi okok (e két utóbbi feltétel valójában kevésbé specifikus, mint inkább generikus, a hatóságok által tágan értelmezhető kategória); külön albekezdés nevesíti a fegyverek, robbanószerek, vegyszerek, sugárzó anyagok és más, hasonló tárgyak elkobzását. A rendkívüli állapotban ezen túlmenően már a tulajdonjog is korlátozható, amennyiben az előbbi célból és feltételekkel az ingó és ingatlan tulajdon lefoglalása is elrendelhetô. Igen tágan értelmezhető az a felhatalmazás, amely szerint felfüggeszthetik törvényben vagy más jogszabályban biztosított jogok gyakorlását, beleértve a kiadott engedélyek, igazolványok alapján gyakorolt tevékenységeket. A vészhelyzeti korlátozásokon jócskán túlmegy a levéltitok és a sajtószabadság lehetséges korlátozhatósága, amely kiterjed a magánlevelezés ellenőrzésére, valamint a teljes média múködésére, beleértve egyes sajtótermékek beszüntetését, amennyiben azok a nemzetbiztonságot fenyegető információt terjesztenek, a nemzetbiztonság vagy a honvédelem érdekeit sértő propagandát (!) folytatnak; lényegében ugyanez vonatkozik az internetes adatforgalomra és tartalomszolgáltatásra, valamint a rádió- és tévéadásokra is. ${ }^{38}$

A törvény közös rendelkezéseket is tartalmaz a különleges jogrend két fajtája, a vészhelyzet, valamint a rendkívüli állapot idején elrendelt alapjog-korlátozásokra nézve. A kormány intézkedéseinek ki kell állniuk az általános alapjogi tesztet, azaz meg kell felelniük az alábbi kritériumoknak: legitim jogalkotói célhoz kötöttség, arányosság, diszkriminációmentesség, indokoltság és szükségszerűség. Az intézkedések csak a döntésben meghatározott földrajzi területre terjedhetnek ki. (Amennyiben a vészhelyzetet vagy a rendkívüli állapotot az országnak csak bizonyos területeire hirdették ki.) Az intézkedések nem lehetnek ellentétesek az emberi jogok nemzetközi normáival, és nem eredményezhetik az állam alkotmányos intézményei hatáskörének korlátozását. ${ }^{39}$ A tulajdonjog is korlátozható, de csak az elvett vagyon értékével megegyező kártalanítás mellett; az érték megállapítására a törvény külön eljárást rendel, amelynek eredményét a károsult - kártalanításra jogosult természetes vagy jogi személy vitathatja. A kártalanítási eljárásra vonatkozó határidőket is tartalmazza a jogszabály. ${ }^{40}$

38 Vészhelyzeti tv. 18. cikk.

39 Vészhelyzeti tv. 19. cikk (4)-(5) bekezdés.

40 Vészhelyzeti tv. 19. cikk. 
Lényeges garancia, hogy a különleges jogrend hatálya alatt sem csorbul a közigazgatási intézkedések, egyedi aktusok fölötti bírói ellenőrzés. Az e körben felmerülő jogviták eldöntéséhez a közigazgatási perrendtartást kell alkalmazni, de a bírósághoz benyújtott felülvizsgálati kérelemnek nincs végrehajtást halasztó hatálya, amennyiben a kifogásolt intézkedés közvetlenül kötődik a különleges jogrend céljához. ${ }^{41}$

Vessünk egy pillantást a közegészségügyi okból elrendelt vészhelyzetben alkalmazható korlátozások körére! A lett jogi szabályozás alapján közegészségügyi okból különleges jogrend elrendelésére a fentebb már ismertetett vészhelyzet keretein belül kerülhet sor. A vészhelyzet törvényi definíciója expressis verbis utal az emberek egészségét veszélyeztető fenyegetésre mint a vészhelyzet elrendelését megalapozó egyik körülményre. A vészhelyzetről és rendkívüli állapotról szóló törvény bekezdése a következóképpen definiálja a vészhelyzet kategóriáját: „A kormány vészhelyzetet rendelhet el olyan, a nemzetbiztonságot fenyegető veszély esetén, amely katasztrófával vagy annak veszélyével vagy a kritikus infrastruktúrát fenyegetô veszéllyel jár, ha az állam, a társadalom, a környezet és a gazdaság biztonsága vagy az emberek élete és egészsége jelentős mértékben veszélybe kerül. ${ }^{\text {中2 }} \mathrm{Az}$ egészségügyi okból elrendelt vészhelyzetre a vészhelyzet kapcsán általában rögzített szabályok irányadók, így az alapjog-korlátozás tekintetében is a korábban már hivatkozott rendelkezéseket kell alkalmazni. E helyen nem ismételjük meg ezeket, csupán utalunk rá, hogy a kormány az egészségügyi okból elrendelt vészhelyzet esetén is élhet a vészhelyzetrôl és a rendkívüli állapotról szóló törvényben kapott felhatalmazással, azaz korlátozhat bizonyos jogokat, róhat ki bizonyos kötelezettségeket.

A vészhelyzet mellett röviden szükséges szólni a polgári védelemről és katasztrófakezelésről szóló törvény ${ }^{43}$ által szabályozott helyzetekről is. E jogszabály a katasztrófák két fó fajtáját határozza meg: a természeti, valamint az ember által okozott katasztrófákat. A természeti eredetú katasztrófák csoportján belül nevesíti a biológiai katasztrófákat, amely alkategória a járványveszélyt és a járványhelyzetet foglalja magában. ${ }^{44} \mathrm{Azt}$ látjuk tehát, hogy az egészségügyi válsághelyzet megalapozhatja katasztrófahelyzet elrendelését is. A katasztrófahelyzetet a vészhelyzettel összevetve pedig azt a következtetést vonhatjuk le, hogy amennyiben az egészségügyi válsághelyzet intenzitásának foka csekélyebb mértékú, a lett jogi szabályozás e kérdéskört a polgári védelemről és katasztrófakezelésről szóló törvény alapján a katasztrófavédelem keretein belül kezeli, míg súlyosabb esetben a vészhelyzetről és a rendkívüli állapotról szóló törvény alapján vészhelyzet elrendelésére van lehetőség. Fontos ugyanakkor azt is rögzíteni, hogy amennyiben az egészségügyi válsághelyzet kezelésére a katasztrófavédelmi szabályok alapján kerül sor, annak koordinációjáért az Egészségügyi

41 Vészhelyzeti tv. 20. cikk.

42 Vészhelyzeti tv. 4. cikk (2) bekezdés.

43 Civilās aizsardzības un katastrofas pārvaldīšanas likums (a továbbiakban: Polgári védelmi tv.).

44 Polgári védelmi tv. 4. cikk (1) bekezdés 1) pont e) alpont. 
Minisztérium felel. ${ }^{45}$ Fontos különbség, hogy a katasztrófahelyzet nem eredményez rendkívüli jogrendet, így ez a törvény az alapjogok korlátozását lehetővé tévő szabályokat sem tartalmaz.

A lett jogi szabályozás szúkszavú a helyi önkormányzatoknak az egészségügyi válsághelyzettel összefüggő hatáskörei kapcsán. Az Önkormányzati tv. rögzíti, hogy azonos tárgyú törvényi szabályozás híján a városi és községi tanácsok jogosultak kötelező erejŭ rendeletek kibocsátására - több más terület mellett - a járványok terjedésének megakadályozása érdekében. ${ }^{46} \mathrm{Az}$ Önkormányzati tv. e rendelkezését mintegy kiegészíti a járványvédelmi törvény ${ }^{47}$ helyi önkormányzatok járványhelyzettel összefüggő hatáskörérool szóló szakasza. Ez rögzíti, hogy a helyi önkormányzatok a törvényekben és rendeletekben megállapított eljárásokkal összhangban döntéseket hozhatnak a járványok megelőzése és a következmények elhárítása érdekében. A törvény úgy rendelkezik továbbá, hogy azokban az esetekben, amikor fennáll a fertőző betegségek terjedésének veszélye, a Betegségmegelőzési és Járványvédelmi Központ regionális osztályának vezetője vagy az Egészségügyi Felügyelőség helyi vezetője által tett ajánlások alapján a helyi önkormányzat jogosult döntéseket hozni az oktatási, gyógykezelési és szociális intézményekben alkalmazandó karanténintézkedések meghozataláról; a nyilvános rendezvények szervezésének korlátozásáról vagy betiltásáról; valamint a helyi önkormányzat által elrendelt karantén- és egyéb korlátozó intézkedések megszüntetéséről. ${ }^{48}$

\section{A koronavírus-járvány miatt bevezetett különleges jogrend Lettországban}

Lettországban a kormány a koronavírus-járvány miatt 2020. március 12-én különleges jogrendet, ezen belül pedig vészhelyzetet hirdetett az ország teljes területére előbb május 12-ig, majd június 9-ig. A vészhelyzetet kihirdetô kormányrendelet ${ }^{49}$ számos alapjogot korlátozó rendelkezést tartalmaz, amely rendelkezések összhangban állnak a Vészhelyzeti tv.-ben rögzített alapjog-korlátozásra vonatkozó szabályokkal. Úgy tûnik tehát, hogy a lett jogrendszert a világjárvány felkészülten érte. Az alapjog-korlátozással is járó különleges jogrend bevezetéséről Lettország március 15-én jegyzékben értesítette az Európa Tanács főtitkárságát az Európai Emberi Jogi Egyezmény 15. cikkében foglalt eljárás szerint, amely ilyen esetekre átmeneti mentességet adhat az egyezmény egyes rendelkezései, azaz meghatározott jogok garantálása alól. Ahogyan a járvány első hulláma lecsengett, és a lett hatóságok

45 Polgári védelmi tv. 6. cikk (1) bekezdés 7) pont.

46 Önkormányzati tv. 44. cikk 1) pont.

47 Epidemiolog̣iskās drošības likums (a továbbiakban: Járványvédelmi tv.).

48 Járványvédelmi tv. 8. cikk (1)-(2) bekezdés.

49 Ministru kabineta rīkojums Nr. 103. Rīgā 2020. gada 12. martā (prot. Nr. 11 1. §) Par ārkārtējās situācijas izsludināšanu. 
az intézkedéseken enyhítettek, úgy a derogációk visszavonásáról és a jogok helyreállításáról újabb jegyzékekben értesítették az Európa Tanácsot. Június 9-én például a gyülekezési és oktatási jogokra vonatkozó korlátozások feloldását közölték, miközben a többit érintetlenül hagyták. A jegyzékekből jól kirajzolódik az intézkedések szigorításának, illetve enyhítésének hullámzása a járvány alakulása szerint..$^{50}$ Itt érdemes megjegyezni, hogy Lettországot a járvány első hullámának sikeres kezelése miatt nemzetközi szervezetek, mint például az OECD elismeréssel illették. Ugyanakkor bírálat is érte az országot, amiért az elhamarkodott enyhítésekkel ezeket az eredményeit eltékozolta. ${ }^{51}$

A rendelet preambulumának első hivatkozása az Egészségügyi Világszervezet (WHO) előző napi (!), március 11-én kelt közleménye, amely szerint a Covid-19-fertőzés világjárvánnyá vált. Ezután hivatkozik a belső jogszabályok (Polgári védelmi tv., Vészhelyzeti tv., Járványvédelmi tv.) felhatalmazó rendelkezéseire. Az említettek közül egyedül a Vészhelyzeti tv. az, amely valódi felhatalmazó rendelkezést tartalmaz a rendeletalkotásra, míg a többi csak a részletes, a helyzet kezelésére alkalmas szakpolitikai mandátumot ad. A preambulum előrebocsátja, hogy az intézkedések nem kizárólag epidemiológiai és higiéniai, hanem egyéb tárgyúak is lesznek.

A főbb intézkedések, amelyeket a vészhelyzet keretében elrendeltek, hasonlóak voltak az európai országok többségében elrendelt korlátozásokhoz. Bezárták az oktatási intézményeket és távoktatásra álltak át; az embereket minden nyilvános helyen egymástól két méter távolság tartására kötelezték; rövidített nyitvatartás a kulturális, szabadidôs és szabadtéri sportlétesítmények esetében; a nem létfontosságú üzletek zárva tartása hétvégenként; minden nyilvános esemény, találkozó, felvonulás, sztrájkőrség, vallási szertartás, beltéri sportesemény és magánrendezvény betiltása. Leállították a nemzetközi utasforgalmat, bizonyos szúk kivételekkel (mint az állami és katonai szállító járművek, öt fơnél több utast nem szállító légijármûvek); az EU külső határát jelentő lett szárazföldi, tengeri és légi határátkelőhelyeken minden határátkelést megtiltottak az áruszállításhoz szükséges átlépések kivételével. Az első hullám elleni küzdelem sikerét mutatta azonban, hogy Lettország a két másik balti állam viszonylatában május 15. és szeptember 12. között fenn tudta tartani a minden korlátozástól mentes kölcsönös áru- és utasforgalmat, a nemzetközi sajtóban és szakirodalomban csak balti buroknak (Baltic Bubble) nevezett együttmúködést..$^{52} \mathrm{~A}$ külföldről érkezők számára 14 napos karantént írtak elő saját lakó- vagy tartózkodási helyükön, és mindenki számára, aki koronavírus-fertőzöttel érintkezett. Az állami - tehát nem a helyi! - rendőrség felhatalmazást kapott arra, hogy felkutassa és karhatalommal a karantén céljára kijelölt helyre szállítsa az igazolt Covid-19-fertőzötteket vagy kontaktjaikat; a rendőrségnek ugyancsak jogában állt felvilágosítást kérni az ilyen személyek telefonszámairól és tartóz-

50 A jegyzék szövegére lásd: www.coe.int/en/web/conventions/full-list/-/conventions/treaty/005/declarations?p_auth=oCoowpDO (Letöltve: 2020 . december 20.).

51 Palkova, 2020.

52 Palkova, 2020. 
kodási helyéről járványügyi vizsgálatuk és mozgásuk nyomon követése érdekében. Közigazgatási és büntetőjogi szankciókat vezettek be az intézkedések megszegői vagy a hamis adatszolgáltatást nyújtók számára. A parlament április 3-án módosította a szabálysértési törvényt, és megemelte a kiszabható pénzbírság mértékét. ${ }^{53}$ Látható tehát, hogy a kormány mellett a törvényhozás is részt vett a járvány és a nyomában járó gazdasági válság kezelésében. A lett közjog - amint láttuk - ismeri a rendes és a rendkívüli jogrend fogalmát és intézményeit, de a rendeleti jogalkotást nem: 2007-ben ugyanis törölték az alkotmány 81. cikkében szereplő ez irányú felhatalmazás lehetőségét, vagyis ez a hatáskör nem volt delegálható a kormányra. Valamilyen megoldást kellett tehát találni, amely a járvány elleni védekezéshez szükséges gyorsaságot és hatékonyságot garantálja. Ezt az alkotmányos intézmények közötti új, rendkívüli párbeszédben találták meg. ${ }^{54}$ A Velencei Bizottság 2020. évi előzetes jelentése is kiemeli az alkotmányos intézmények közötti együttmúködést: a köztársasági elnök, a házelnök, a miniszterelnök és az alkotmánybíróság, valamint a legfelsőbb bíróság elnökei precedens nélküli módon közös ülést tartottak, amelyben megállapodtak az állam múködésének alapelveiről a különleges jogrend idején. A legfőbb szempont az volt, hogy fenntartsák a hatalmi ágak szétválasztását és az alkotmányos intézmények folyamatos múködését. ${ }^{55} \mathrm{Az}$ ülésen elfogadott megállapodásról az államfó március 23-án külön jegyzéket adott ki. Ebben egyebek között arra szólítják föl az intézményeket, hatóságokat, tisztségviselőket, hogy erősítsék az együttmüködést és az egyeztetést. Felhívja a figyelmet a jogi formalizmus és hatáskörféltés veszélyeire, mint amelyek akadályozzák az alkotmányos célok megvalósulását, különösen szükséghelyzetben. Mindezek érdekében elő kell mozdítani az online munkavégzést, a távolságtartást, a rugalmasságot az eljárásoktól való esetleges eltérésekben. A válságkezelés központi szerve a kormány, de a fékek és ellensúlyok rendszere, a többi alkotmányos intézmény múködésének fenntartása mellett. ${ }^{56}$

A parlament törvényeket fogadott el a válság által leginkább sújtott ágazatokban múködő vállalkozások támogatása érdekében: az intézkedések adókönnyítéseket, a munkanélküliség enyhítését célzó lépéseket, valamint kedvezményes állami hitelek nyújtását foglalták magukban. Ugyancsak elfogadtak családtámogatási intézkedéseket, és bővítették a munkanélküli-ellátásra jogosultság körét. A Schumann Alapítvány által megjelentetett, a parlamentek szerepét vizsgáló egyik tanulmány szerint a lett parlament volt a világ első, otthoni üzemmódra átállított törvényhozó testülete, ami ösztönözte minden minisztérium, közintézmény stb. átállását online távmunkára. ${ }^{57}$

53 Elérhető: www.saeima.lv/en/news/saeima-news/28864-increased-fines-for-violating-restrictions-introduced-during-the-state-of-emergency (Letöltve: 2020. december 20.).

54 Rodina-Lỉbina-Egnere, 2020, 5. o.

55 Venice Commission, 2020, 56. és 32. o.

56 Valsts prezidenta pazinojums Nr. 8 Rīgā 2020. gada 23. martā - Valsts konstitucionālo orgānu darbības pamatprincipi ārkārtējā situācijā. Elérhetô: https:/likumi.lv/ta/en/en/id/313400-basic-principles-of-activityof-state-constitutional-bodies-in-an-emergency-situation (Letöltve: 2020 . december 20.).

57 Rodina-Lïbina-Egnere, 2020, 2. o. 
A járvány első hullámának enyhülésével a kormány május 7-én az intézkedések fokozatos enyhítését, egyidejúleg a vészhelyzet június 9-ig történő hatályban tartását jelentette be. Az enyhítések részletes ismertetésétől eltekintünk; elég annyit leszögezni ismét, hogy az alapjogok közül a személyes szabadsághoz, a magánélethez, az oktatáshoz, a vállalkozáshoz és a szabad helyváltoztatáshoz való jogok továbbra is korlátozás alatt maradtak a különleges jogrendből - azaz a vészhelyzetből - kifolyólag. ${ }^{58} \mathrm{~A}$ vészhelyzetet a kormány június 10. után nem hosszabbította meg. A második hullám azonban kikényszerítette egy második országos vészhelyzet elrendelését 2020. november 9-én kezdődő, 2021. január 11-ig tartó hatállyal, amely hasonló - alapjogokat is érintő - korlátozásokat vezetett be újra. A november 6-án kelt újabb kormányrendelet ${ }^{59}$ preambuluma már nem hivatkozik a WHO-ra, viszont a nemzeti törvényi hivatkozások változatlanok maradnak. Célként a járvány ellenőrizhető mértékứre történő visszaszorítását és az állam legfontosabb funkciói és a szolgáltatások folyamatos fenntartását nevezi meg.

Bár a különleges jogrend célja a kormány eszköztárának bővítése a védekezés hatékonysága érdekében, a lett szabályozásban és a Covid-19 ellen elrendelt intézkedésekben a törvényhozás érdemi szerepet játszott. A kormány március 12-én értesítette a parlamentet arról, hogy vészhelyzetet kíván hirdetni. A parlament másnap rendkívüli ülésen hagyta jóvá a kormány döntését. Az ezt követő hetekben a parlament megtárgyalt és utólag jóváhagyott számos, az eredeti intézkedéscsomaghoz fúzött módosítást. A parlament rendes múködését felfüggesztette, és rendszeresen összeült az online térben (tehát videokonferencia-alkalmazásokat használva), hogy a kormány járványügyi intézkedéseit megtárgyalja és elfogadja. ${ }^{60}$

Az első vészhelyzet lejárta előtt a parlament tehát három törvényt is elfogadott a koronavírus-járvány átfogó kezeléséről. Az első a 2020. március 20-i törvény az államot érő fenyegetés és következményeinek megelőzéséről és elhárításáról a Covid-19-járvány terjedése kapcsán ${ }^{61}$ (a továbbiakban: Covid I. tv.). A második a 2020. május 7-én elfogadott törvény azállami hatóságok múkködéséról a Covid-19-járvánnyal összefüggésben elrendelt vészhelyzet idején ${ }^{62}$ (a továbbiakban: Covid II. tv.). Ennek célja és tárgya - a címével összhangban -, hogy az állami szervek megfelelő múködését biztosítsa a járvány idejére, és az új körülményekhez igazítsa. Ezenkívül azt is célul tû́zte ki, hogy megfogalmazza azokat az elveket, amelyek ebben a helyzetben egyfelől az egyéni jogok és kötelezettségek, másfelől az állami hatóságok jogosultságai és felelőssége közötti viszonyt meghatározzák. ${ }^{63} \mathrm{~A}$ Covid I. tv.-t hamar hatályon

58 Az első hullám idején bevezetett intézkedések elemzésére lásd: Dimitrovs, 2020.

59 Ministru kabineta rīkojums Nr. 655 Rīgā 2020. gada 6. novembrī (prot. Nr. 69 2. \$) Par ārkārtējās situācijas izsludināšanu.

60 A tagállamok, köztük Lettország intézkedéseinek tömör összefoglalása elérhető az Európai Parlament honlapján: www.europarl.europa.eu/RegData/etudes/BRIE/2020/651914/EPRS_BRI(2020)651914_EN.pdf (Letöltve: 2020. december 20.).

61 Par valsts apdraudējuma un tā seku novēršanas un pārvarēšanas pasākumiem sakarā ar Covid-19 izplatību

62 Par valsts institūciju darbību ārkārtējās situācijas laikā saistībā ar Covid-19 izplatību.

63 Covid II. tv. 1. cikk (1)-(2) bekezdés. 
kívül helyezte és felváltotta a Covid-19-járvány terjedésének kezeléséról 2020. június 5-én elfogadott törvény ${ }^{64}$ (a továbbiakban: Covid III. tv.). A törvény bevezetô rendelkezéseiben kinyilvánított célja, hogy helyreállítsa a rendes jogrendet olyan intézkedések elrendelése által, amelyek a magánszemélyek jogai és a járvány elleni küzdelem érdekei közötti helyes arányt célozzák. ${ }^{65} \mathrm{Ez}$ a törvény tehát arra tesz kísérletet, hogy a kivételes jogrend lejártát követően dinamikus egyensúlyt tartson az alapvető jogok érvényesülése és a változó mértékú járványfenyegetettség elleni védekezés között. ${ }^{66}$ Ennek érdekében három alapelvet állít fel:

- a jogkorlátozás minimalizálása: az alapvető emberi jogokat csak akkor lehet korlátozni, ha ennek a járvány elleni védekezésben nincs alternatívája;

- a közegészségügyi fenyegetettség minimalizálása: az óvintézkedéseket a hazai és nemzetközi járványügyi adatok gondos kockázatelemzése mellett kell meghozni;

— közszolgáltatások megszüntetésének tilalma: ezeket korlátozni legfeljebb az egészségvédelmi érdeknek megfelelő mértékig lehet. ${ }^{67}$

Példa ezen elvek múködéséről a törvény rendelkezései közül, hogy az állami hatóságok helyre kell hogy állítsák müködésüket, hacsak törvény másként nem rendeli, de szolgáltatásaikat lehetőleg online nyújtsák. ${ }^{68}$

A Covid III. tv. úgy is fölfogható, mint a rendeleti kormányzás és jogalkotás kiküszöbölése. Különleges jogrend keretein kívül, ilyen kihirdetése nélkül ad felhatalmazást a hatóságoknak különféle restrikciókra, tehát rugalmasan igyekszik kezelni a járványra jellemzően változó helyzetet, és annak súlyosbodásától vagy enyhülésétől függően teszi lehetővé korlátozó intézkedések bevezetését. Ettől teszi függővé például a gyülekezési, a sztrájkjog gyakorlásának korlátozását, illetve annak jellegét és mértékét, beleértve a vallási jellegú összejöveteleket. Eszerint a kormány korlátozhatja kulturális és sportrendezvények megtartását - de a törvény ezeknek más aspektusait is szabályozza: milyen higiéniai felszereltséget kell biztosítani a rendezvények helyszínein; milyen szabályokat kell követni abban az esetben, ha a járvány miatt lefújt rendezvény, előadás miatt már kifizetett jegy árát igénylik vissza stb. ${ }^{69}$

Ám a törvény célja nem kizárólag az alapjogok érvényesülése és a járványügyi érdekek közötti egyensúly keresése. A jogalkotó arra is vállalkozik, hogy átállítsa a bíróságok, hatóságok és egyes közhivatalok múködését különösen az ügyfelekkel történő kapcsolattartás terén: megteremti, illetve kiszélesíti az online vagy telefonos ügyintézés lehetőségeit valamennyi esetre, amikor az ügyfél személyazonossága az ügyintéző számára megnyugtató

64 Covid-19 infekcijas izplatības pārvaldības likums.

65 Covid III. tv. 1. cikk (1) bekezdés.

66 A jogkorlátozásokról lásd: FRA, 2020.

67 Covid III. tv. 1. cikk (2) bekezdés 1)-3) pont.

68 Covid III. tv. 2 . cikk.

69 E rendelkezések vonatkozásában lásd a Covid II. tv. II. fejezetét. 
módon megállapítható; részletezi a nem személyes ügyintézés, hatósági eljárás alkalmazásának körét, szabályait, feltételeit, eljárási elemeit. A nem személyes érintkezés lehetőségét még a szabálysértési eljárásokra is alkalmazni rendeli. A polgári és büntetőperes, illetve más, nem peres eljárásokban is megteremti a lehetőségét annak, hogy eljárási cselekményeket bizonyos feltételek mellett személyes megjelenés nélkül lehessen lefolytatni. A büntetőeljárásokban - garanciális okokból - a személyes jelenlétet nem igénylő eljárási cselekmények körét kevésbé nagyvonalúan terjeszti ki. A törvény rendezi a vészhelyzet által érintett eljárási határidők vagy okirat-érvényességi idők meghosszabbítását. A külügyminiszter az egészségügyi miniszterrel együttmúködésben ellenőrzi a járvány elleni védekezésben használt orvosi eszközök, illetve összetevőik exportját. A lejáró tartózkodási és munkavállalási engedélyư külföldiek helyzetét is rendezi. ${ }^{70}$ Külön rendelkezések vonatkoznak a büntetés-végrehajtásra, ahol a járvány terjedésének fékezése végett a börtönparancsnok saját hatáskörben korlátozhatja a látogatást. A felfüggesztett börtönbüntetésre ítéltek pártfogói szolgálata szintén csak korlátozott szolgáltatásokat nyújt a vészhelyzetben, de ehhez hasonlóan a büntetés-végrehajtás megkezdésének ideje is halasztódik. A törvény az oktatás, sport és idegenforgalom területén is igyekszik előmozdítani az alkalmazkodást a járványhelyzethez..$^{71}$ Így például az egyetemek és főiskolák lejáró akkreditációja meghosszabbodik. Rendezik a tanévvég, tanévkezdés, halasztások kérdését. Az idegenforgalomban a járvány miatt lemondott, szervezett utazások után járó kompenzációt is szabályozza. Az egészségügyi és szociális intézményekre új rendelkezéseket vezet be. Az egészségügyi intézményekbe történő felvétel lehetséges, amennyiben az intézmény biztosítani tudja a járványügyi intézkedések megtartását. Rendelkezik a szociális ellátásra jogosult személyek és családok számára eddig folyósított juttatások folytatólagos utalásáról..$^{72} \mathrm{~A}$ törvény ezenfelül meghatározza a szabálysértési felelősség megállapításának szabályait a járványügyi előírások megszegői számára.737 Itt jegyezzük meg, hogy a jogszabály többszörös módosításon ment keresztül a járványügyi helyzet alakulása szerint. Az október 29-i módosítással került be az arcmaszkviselési kötelezettség megszegése miatti bírság szigorítása. Ez is arra utal, hogy a lett jogalkotó mintha igyekezne törvényi szinten, az erre megalkotott kerettörvény folytonos és rugalmas módosításával kezelni a járványt, rendeletek helyett törvénnyel, egyedi intézkedések helyett inkább normatív úton. Ez a törvényhozás részéről rugalmasságot és hatékonyságot igényel ugyan, és nyilván növeli a leterheltségét. Viszont ez a megoldás az alkotmányosság próbáját könynyebben állja ki, és erősíti az intézkedések legitimációját. További jellemzője, hogy a törvényhozás a kezdeményezést, a válságkezelésben játszott központi szerepet mintha ezáltal nem engedné át egészen a kormánynak.

70 Covid III. tv. III. fejezet.

71 Covid III. tv. V. fejezet.

72 Covid III. tv. VI. fejezet.

73 Covid III. tv. VII. fejezet. 


\section{A különleges jogrend kihirdetésének gyakorlati esetei}

A másik két balti államhoz hasonlóan Lettországot a Szovjetunió 1940-ben annektálta, és csak fél évszázados kommunista diktatúrát követően, 1991-ben, a Szovjetunió felbomlásának évében nyerte vissza szuverenitását. A függetlenség kikiáltása óta eltelt szúk három évtizedben mindössze két alkalommal került sor különleges jogrend bevezetésére, mindkét alkalommal vészhelyzet formájában. A lett kormány először 2011 januárjában hirdetett vészhelyzetet az ország negyven régiójában az elhúzódó és komoly károkat okozó energiaellátási zavarok miatt. A különleges jogrend kihirdetése akkoriban lehetôvé tette a kormány számára, hogy ne alkalmazza a közbeszerzési eljárásokat, és előzetes egyeztetés nélkül kivágja a hó által letört fákat az elektromos vezetékek védelmi övezetein kívül és a magánerdőkben is. ${ }^{74} \mathrm{~A}$ második példa pedig a koronavírus-járvány miatt kihirdetett, az előbbiekben tárgyalt vészhelyzet.

Mivel különleges jogrend ritkán és rövid időre volt hatályban, feltételeztük, hogy nem keletkezett bírói esetjog. Mindamellett megvizsgáltuk a legfelsőbb bíróság és az alkotmánybíróság adatbázisát. Két ilyen jogvitának bukkantunk nyomára. Az egyik az alkotmánybíróság 4. sz. kollégiumának 2020. július 1-jén kelt határozata, ${ }^{75}$ amely azonban nem érdemi, hanem csupán az eljárás megindíthatóságára vonatkozó - egyébként elutasító - döntést tartalmaz. A kérelmező annak megállapítását kérte az alkotmánybíróságtól, hogy a vészhelyzetről és a rendkívüli állapotról szóló törvény, valamint a vészhelyzetet kihirdetô 2020. március 12-i kormányrendelet több ponton ellentétes az alkotmánynak a népszuverenitást kinyilvánító, az alapvető emberi és szabadságjogokat, különösen a szabad véleménynyilvánításhoz és a gyülekezési szabadsághoz füződő jogokat biztosító rendelkezéseivel. ${ }^{76} \mathrm{~A}$ kérelmezőt a rendőrség előzőleg szabálysértési őrizetbe vette, amiért megsértette a gyülekezésre vonatkozó korlátozó rendelkezéseket. Az alkotmánybíróság a beadvány tárgyalását azért utasította el, mert a kérelmező nem merítette ki a rendes jogorvoslati lehetőségeket.

Ennél érdekesebb a második, az alkotmánybíróság által érdemben 2020. december 11-én elbírált eset. ${ }^{77}$ Ennek tárgya a Covid I. tv. 8-9. cikke volt. Ezek felhatalmazták a szerencsejáték-felügyeletet arra, hogy a szerencsejáték-engedélyeket felfüggessze nemcsak a fizikai, hanem a virtuális térben is. Az indítványt egy online sportfogadási és kaszinójáték-társaság, az Optibet nyújtotta be az alkotmánybírósághoz azzal az indoklással, hogy az internetes szerencsejáték nem terjeszti a járványt, megtiltása viszont sérti a lett alkotmány 105. cikkében kodifikált, a vál-

74 Elérhető: www.tvnet.lv/5507604/izsludina-arkartas-situaciju-40-novados (Letöltve: 2020. december 15.).

75 A határozat a 114/2020. számú kérelem nyomán született. Elérhető: www.satv.tiesa.gov.lv/decisions/ kolegijas-2020-gada-1-julija-lemums-pieteikums-nr-114-2020/ (Letöltve: 2020. december 15.). A kérelmezőrôl - feltehetőleg adatvédelmi okokból - a határozat nem közöl semmit, csupán érvelését foglalja össze.

76 Alkotmány 2., 89., 100. és 103. cikk.

77 2020-26-0106. sz. ügy. A vonatkozó, angol nyelvú sajtóközlemény elérhető: www.satv.tiesa.gov.lv/en/ press-release/the-constitutional-court-terminates-proceedings-in-the-case-with-regard-to-a-provisionrestricting-gambling-during-the-state-of-emergency/ (Letöltve: 2020. december 20.). A teljes ítélet lett nyelven: www.satv.tiesa.gov.lv/web/viewer.html?file=https:/www.satv.tiesa.gov.lv/wp-content/uploads /2020/05/2020-26-0106_Spriedums.pdf\#search=2020-26-0106 (Letöltve: 2020. december 20.). 
lalkozás szabadságát is magában foglaló tulajdonjogot, valamint az Európai Unió múködéséról szóló szerződés 49. cikkét. Az alkotmánybíróság helyt adott a kérelemnek, mert a jogalkotó nem vizsgálta kellóképpen, hogy teljesülnek-e a szükségesség és arányosság, valamint a diszkriminációmentesség feltételei. A jogalkotó célja az volt, hogy a bezártságban könnyebben kialakuló függőség eseteit megelőzze, amit azonban az alkotmánybíróság nem fogadott el mint a járvány elleni küzdelemhez közvetlenül kapcsolódó célt, miközben például az online alkoholvásárlást a jogalkotó nem korlátozta, hanem inkább ösztönözte. (Az inkriminált rendelkezést tartalmazó törvényt időközben hatályon kívül helyezték, amint arról fent már írtunk.)

\section{5. Összegzés és konklúziók}

A különleges jogrend alkalmazására természeténél és definíciójánál fogva éles helyzetben kerül sor, amikor a jogalkotó és a jogalkalmazó akár az alkotmányosság és az alkotmányon kívüliség között húzódó elmosódó határvonalon is táncolni kényszerülhet. A szabályozás megértéséhez fontos ismerni a bírói esetjogot, ami ennek a témakörnek a jogdogmatikai tisztázásához, a jogok és felelősségek arányának megállapításához is szükséges. A fiatal Lettországban azonban a három különleges jogrend közül az első kettő eddig papíron létezett, a harmadik, a vészhelyzet országos hatályú kihirdetése sem történt volna meg a koronavírus-járvány nélkül. İgy a bírói gyakorlat és a szakirodalom sovány corpust jelent csupán. Az alábbi táblázatból is kitûnik, hogy a lett szabályozás egyszerú, könnyen áttekinthető, különösebben eredeti vagy vitatott megoldásokat nem tartalmaz.

\begin{tabular}{|c|c|c|c|}
\hline & Hadiállapot & Rendkívüli állapot & Vészhelyzet \\
\hline Szabályozás szintje & Alkotmány, törvény & Alkotmány, törvény & Törvény \\
\hline Elrendelési okok & Hadüzenet & $\begin{array}{l}\text { — Az államot külső ellenség } \\
\text { fenyegeti, vagy } \\
\text { — az államrendet fenyegető } \\
\text { vagy veszélyeztetô belső } \\
\text { zavargás (alkotmány), } \\
\text { továbbá } \\
\text { — katasztrófa vagy annak } \\
\text { veszélye, } \\
\text { — kritikus infrastruktúrát } \\
\text { érő fenyegetés, ha az ál- } \\
\text { lamra, a társadalomra, } \\
\text { a környezetre, a gazdasági } \\
\text { biztonságra, az emberi } \\
\text { egészségre vagy az életre } \\
\text { súlyos kockázatot jelent } \\
\text { (törvény). }\end{array}$ & $\begin{array}{l}\text { Elemi csapás vagy } \\
\text { ember okozta baleset } \\
\text { vagy annak veszélye, } \\
\text { amely a nemzetbiz- } \\
\text { tonságot vagy létfon- } \\
\text { tosságú infrastruktúrát } \\
\text { éri az állam, a társa- } \\
\text { dalom, a környezet, } \\
\text { a gazdasági élet vagy } \\
\text { emberek élete vagy } \\
\text { egészsége komoly } \\
\text { veszélyeztetésével. }\end{array}$ \\
\hline
\end{tabular}




\begin{tabular}{|c|c|c|c|}
\hline & Hadiállapot & Rendkívüli állapot & Vészhelyzet \\
\hline Elrendelés & $\begin{array}{l}\text { A köztársasági } \\
\text { elnök, parlamenti } \\
\text { határozat alapján. }\end{array}$ & $\begin{array}{l}\text { A kormány, de } 24 \text { órán belül } \\
\text { értesíti a parlamentet, amely } \\
\text { hatályon kívül helyezheti. }\end{array}$ & $\begin{array}{l}\text { A kormány, de } 24 \text { órán } \\
\text { belül értesíti a parla- } \\
\text { mentet, amely hatályon } \\
\text { kívül helyezheti. }\end{array}$ \\
\hline Felhatalmazott & Köztársasági elnök & Kormány & Kormány \\
\hline Gyakorlati esetek & Nincs & Nincs & $\begin{array}{l}\text { — 2011. január: ener- } \\
\text { giaellátási zavar } \\
\text { miatt, részleges } \\
\text { — 2020. március- } \\
\text { június országos, } \\
\text { Covid-19-járvány } \\
\text { miatt } \\
\text { — 2020. novembertől } \\
\text { országos, Covid-19- } \\
\text { járvány miatt }\end{array}$ \\
\hline
\end{tabular}

14. táblázat

A Lett Köztársaság különleges jogrendi szabályainak összegzése

Forrás: a szerző saját szerkesztése

A különleges jogrend magyar szabályozásával történő összehasonlítás az alábbi tanulságokat kínálja. Az összehasonlítást három szempont szerint kívánjuk megtenni:

— a különleges jogrend fajtáinak (esetköreinek) száma;

— e jogrendek „különlegességének” mibenléte, mértéke;

- ezen belül az alapjogok korlátozhatósága.

Lettország - az egykori keleti tömb más országaihoz képest - szúkszavú, jellemzően eljárási jellegú alkotmánnyal rendelkezik. ${ }^{78} \mathrm{~A}$ magyar Alaptörvénnyel ellentétben nem használja a különleges jogrend fogalmát. Tartalmaz ugyanakkor - sok más alkotmányhoz hasonlóan - néhány alapvetô rendelkezést a hadüzenetről és a rendkívüli állapotról, anélkül azonban, hogy részletesen eligazítana a tekintetben, hogy ezek bármelyikének alkalmazása milyen következményekkel jár a belső jogban. Ezt pótolja a törvényi szint, a kifejezetten erre a célra elfogadott, fentebb részletesen is elemzett Vészhelyzeti tv., valamint - témánk szempontjából kevésbé releváns módon - az Nbtv. három országcsoportot állít fel aszerint, hogy az EU tagállamai (Svájcot és Norvégiát is ideértve) mennyire kodifikálták kimerítően a különleges jogrend fajtáit. Lettország eszerint a közepesen, míg hazánk az erősen szabá- 
lyozó tagállamok közé tartozik. ${ }^{79}$ Khakee elemzésének megjelenése idején (2009) hatályos alkotmány négy-, a hatályos Alaptörvény pedig hatféle különleges jogrendet ismer. A lett hadiállapot - rendkívüli állapot - vészhelyzet hármas a kihirdetésüket kiváltó okok tekintetében lefedi a hat magyar esetkört (bár érdekes módon a terrorista fenyegetést egyik sem nevesíti). Ez a különbség csökken majd az Alaptörvény kilencedik módosításának hatálybalépésével, amikor is a különleges jogrend fajtáinak száma a magyar alkotmányban is háromra szúkül.

Arra a kérdésre, hogy mennyire különleges az adott különleges jogrend, szintén több szempont szerint kereshetjük a választ. Az egyik kérdés, hogy a különleges jogrendben megjelennek-e új alkotmányos szereplők, új jogforrásfajták, vagy a régiek hierarchiájában áll-e be változás. A parlament és a rá épülő alkotmányos berendezkedés nem tartalmaz ilyet; a magyar Alaptörvény viszont csak a rendkívüli állapot esetére ismeri a Honvédelmi Tanácsot, az általa kibocsátható rendeletet, valamint a köztársasági elnök szükségállapoti rendeletét mint különleges jogforrásokat. A kilencedik módosítás felszámolja a Honvédelmi Tanácsot, annak hatásköreit lényegében a Kormányra ruházva. A másik lehetséges szempont, hogy a végrehajtó hatalom mennyire és hogyan erősödik meg, esetleg a másik két hatalmi ág rovására. Mindkét ország esetében elmondható, hogy a parlamentnek mint a népszuverenitás végső letéteményesének ellenőrző szerepe megmarad. A törvényhozást fel nem oszlathatják, múködését fel nem függeszthetik rendkívüli jogrend idején sem. Ezen túl a rendkívüli jogrend kihirdetésében vagy ellenőrzésében is döntő szerepet játszik a lett parlament, illetve a magyar Országgyủlés. A lett jogrendben a hadiállapot a köztársasági elnök által a parlament határozata nyomán kinyilvánított hadüzenettel áll be, míg a másik két rendkívüli jogrend kihirdetése és meghosszabbítása a kormány hatáskörébe tartozik, de parlamenti jóváhagyással. Az Alaptörvény inkább a törvényhozásra telepíti a kezdeményezés jogát: a hat esetkörből csak a váratlan támadás és a veszélyhelyzet kihirdetését bízza a kormányra. (A kilencedik módosítás nyomán az arány 2:1 lesz, továbbra is a törvényhozás javára; a veszélyhelyzetet hirdetheti ki a Kormány, a hadiállapotot és a szükségállapotot továbbra is az Országgyưlés). Mindkét ország rendkívüli jogrendjében lehetséges, hogy a legfőbb jogalkotói hatalom, a parlament mellett a kormány (Magyarországon pedig még a köztársasági elnök és a Honvédelmi Tanács) olyan rendeletet alkosson, amelyek törvényektől eltérhetnek, de ezek fölött a parlamenti kontroll nem vész el: a magyar Országgyúlés például vagy hatályon kívül helyezheti őket, vagy a rendkívüli jogrend megszúnése után hatályukat veszítik. Lettországban a vészhelyzet és a rendkívüli állapot is csak meghatározott - bár hosszabbítható - ideig tarthat, minden esetben parlamenti jóváhagyással. A parlamenti jóváhagyás hiánya valamennyi rendkívüli intézkedés hatályának megszúnésével jár. Az Alaptörvény ezt is a lett alkotmánynál részletesebben - és bonyolultabban - szabályozza, a hatféle esetkörnek megfelelően vagy az alapul szóló körülmények megszûnéséig, vagy a Kormány által történő visszavonásig tartanak. Viszont például a veszélyhelyzeti rendeletek csak 15 napig maradnak

79 Khakee, 2009, 15. o. 
hatályban (hacsak a Kormány - az Országgyưlés felhatalmazásával - a rendelet hatályát meg nem hosszabbítja), tehát még a különleges jogrend vége elött „lejárnak”. A kilencedik módosítással ez a kettősség megszúnik, és mind a veszélyhelyzet - 30 napon túli - időtartama, mind pedig a veszélyhelyzeti kormányrendeletek hatálya az Országgyưlés döntésétől függ majd. Eddig tehát a veszélyhelyzeti kormányrendeletek hatályának meghosszabbításához kellett az Országgyúlés, ezentúl viszont a veszélyhelyzet időtartamának meghosszabbításához lesz szükség a parlamenti felhatalmazásra.

Végezetül kitérünk az alapvető jogok korlátozhatóságának kérdésére. Fönt már utaltunk rá, hogy a lett alkotmány 116. cikke megengedi a jogkorlátozást meghatározott egyéni jogokra nézve meghatározott okokból és célokból, taxatíve felsorolva azokat a cikkeket, amelyek e jogokat rögzítik. Az okok között a különleges jogrend nem szerepel, de a különleges jogrend által védendő életviszonyokból ez a felhatalmazás levezethető, és a vészhelyzetről és rendkívüli állapotról szóló törvény meg is adja a felhatalmazást az általános alapjogi teszt fenntartásával. A fel nem sorolt cikkek következésképpen viszont olyan jogokat garantálnak, amelyek feltétlen védelmet élveznek, és így rendkívüli jogrend esetén sem korlátozhatók. Ezek a mintegy huszonhét, az alkotmányban kifejezetten rögzített jog körülbelül egyharmadát teszik ki. ${ }^{80}$ Érdekes, hogy ez a jogkorlátozó záradék az alkotmány legutolsó cikkében található. A magyar Alaptörvény e tekintetben is összetettebb szabályokat, kétlépcsős korlátozási lehetőséget tartalmaz. Egyrészt mindjárt az I. cikkben, a Szabadság és felelősség címü fejezet elején hozza az általános felhatalmazást a kritériumok klasszikus triászával: célhoz kötöttség (más alapvető jog vagy alkotmányos érték védelme), szükségesség, arányosság; hozzávéve ehhez, hogy a korlátozásnak is megvannak a tartalmi korlátai. Másrészt a különleges jogrendre vonatkozó közös szabályok és egyben az Alaptörvény végén, az 54. cikkben specifikusabb, a különleges jogrend céljait szolgáló felhatalmazást találunk az alapjogoknak az I. cikkben megadott mértéken túlmenő korlátozására. E záradék logikája fordított a neki félig-meddig megfelelő, előbb említett lett szabályhoz képest: ez ugyanis nem a korlátozható, hanem a feltétlen érvényességú jogokat (emberi méltóság, élet és ezekhez közvetlenül kapcsolódó jogok, büntetőeljárási garanciákhoz fűződő jogok) jelöli meg, így engedve meg a felsorolásból kimaradók korlátozását.

80 Krūma-Statkus, 2019, 963. o. 


\section{Irodalomjegyzék}

Dimitrovs, A. (2020) COVID-19 in Latvia: Precaution Above All [Online]. Elérhető: https:// verfassungsblog.de/Covid-19-in-latvia-precaution-above-all/ (Letöltve: 2020. december 20.)

FRA (European Union Agency for Fundamental Rights) (2020) Coronavirus Pandemic in the EU - Fundamental Rights Implications [Online]. Elérhető: https://fra.europa.eu/sites/default/ files/fra_uploads/lv_report_on_coronavirus_pandemic_july_2020.pdf (Letöltve: 2020. december 20.)

KHAKeE, A. (2009) Securing Democracy? A Comparative Analysis of Emergency Powers in Europe (Geneva Centre for the Democratic Control of Armed Forces Policy Paper - No. 30) [Online]. Elérhetó: www.files.ethz.ch/isn/99550/PP30_Anna_Khakee_Emergency_ Powers.pdf (Letöltve: 2020. december 15.)

KrŪMA, K., StatkUS, S. (2019) 'The Constitution of Latvia - A Bridge Between Traditions and Modernity' in Albi, A., Bardutzky, S. (szerk.) National Constitutions and Global Governance: Democracy, Rights, the Rule of Law. 1. kiadás. The Hague: Asser Press

Palkova, A. (2020) Latvia during Covid: How Success Bred Complacency [Online]. Elérhető: https://ecfr.eu/article/latvia-during-Covid-how-success-bred-complacency/ (Letöltve: 2020. december 20.)

Rodina, A., LīBIN̦A-Egnere, I. (2020) The Latvian Parliamentand the Covid-19 Pandemic. E-Saeima, One of the First Parliaments in the World Ready to Work in Fully Remote Mode in The Parliament in the Time of Coronavirus [Online]. Robert Schuman Foundation. Elérhető: www.robertschuman.eu/en/doc/ouvrages/FRS_Parliament_Latvia.pdf (Letöltve: 2020. december 20.) Venice Commission (2020) Interim Reporton the Measures Taken in the EU Member Statesas a Result of the COVID-19 Crisis and Their Impact on Democracy, the Rule of Law and Fundamental Rights (Study No. 995/2020) [Online]. Elérhető: www.venice.coe.int/webforms/documents/?pdf=CDL$\mathrm{AD}$ (2020)018-e (Letöltve: 2020. december 15.) 


\section{A különleges jogrendi esetkörök szabályozása Litvániában}

SZENTPÁLI-GAVALLÉR PÁL

\section{A különleges jogrend alkotmányos és törvényi szintû́ szabályozása, esetkörei}

A különleges jogrend alkotmányos és törvényi szintû szabályozása tekintetében Litvániában az alkotmány ${ }^{1}$ a különleges jogrendi időszaknak és helyzeteknek kettő változatát, a hadiállapotot (karo padèties)² és a szükségállapotot (nepaprastoji padètis) ${ }^{3}$ ismeri.

Az első tényállás a hadiállapot, amelyet elsősorban a parlament jogosult bevezetni, azonban e vonatkozásban szerepet kaphat a Litván Köztársaság elnöke is. Ha az állam szuverenitását vagy területi integritását veszélyeztető fegyveres, illetve katonai támadás áll fenn, meghozza a szükséges intézkedéseket, amely határozatait a parlament utóbb jóváhagyhatja vagy hatályon kívül helyezheti. Ugyanígy kap a parlament vagy a köztársasági elnök egyfajta rendkívüli szerepkört, ha általános választás esedékes háborús időben, mert dönthetnek

1 Alkotmány (Lietuvos Respublikos Konstitucija).

2 Hivatalos angol fordításban: martial law.

3 Hivatalos angol fordításban: state of emergency.

Dr. Szentpáli-Gavallér Pál

pal.szentpali-gavaller@mfi.gov.hu

kutató (Mádl Ferenc Összehasonlító Jogi Intézet)

PhD-hallgató (Miskolci Egyetem, Deák Ferenc Állam- és Jogtudományi Doktori Iskola)

Szentpáli-Gavallér, P. (2021) 'A különleges jogrendi esetkörök szabályozása Litvániában' in Nagy, Z., Horváth, A. (szerk.) A különleges jogrend és nemzeti szabályozási modelljei, 398-413. o. Budapest: Mádl Ferenc Összehasonlító Jogi Intézet.

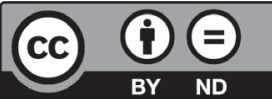

https://doi.org/10.47079/2021.nzha.kulon.4_18 
a mandátumok meghosszabbításáról. ${ }^{4}$ Általános jelleggel a végrehajtó hatalom általános szerve intézi az ország ügyeit, védi a Litván Köztársaság területének sérthetetlenségét. ${ }^{5}$

A litván szabályozásban a második tényállás a szükségállapot. Ez utóbbi elrendelésére is a parlament jogosult, azonban csak hat hónapot meg nem haladó időre. Ebben az esetben is fennáll a rendkívüli szerepköre a köztársasági elnöknek, ha a parlament nem ülésezik, ekkor ő maga dönt, egyidejúleg összehívja a parlament rendkívüli ülését a kérdés megvitatására. ${ }^{6}$ A szabályozás szerint a kormány az intézkedések megtételére általánosan felhatalmazott szerv, amely biztosítja az állam biztonságos múködését és a közrendet.7

Az előzőekben tárgyalt különleges jogrendi esetkörök, azaz a hadiállapot és a szükségállapot részletes szabályait Litvániában törvény állapítja meg. ${ }^{8}$ Ilyen különleges jogrendi állapotok idején alkotmánymódosításra nem kerülhet sor. ${ }^{9}$

A litván szabályozásban a különleges jogrendnek minősülő rendkívüli felhatalmazás esetköreit, alkotmányos és törvényi szabályozását ${ }^{10}$ érintően a hadiállapot részletszabályait ${ }^{11}$ lefektető törvény, valamint a szükségállapot részletszabályait ${ }^{12}$ megállapító törvény minősül a legfontosabb jogszabálynak. Ugyanakkor ezek a törvények közvetlenül kapcsolódnak a különleges jogrendhez is. Ezek a törvények szabályozzák e helyzetek meghatározását, a bevezetés feltételeit, a kihirdetés eljárásrendjét, valamint a kezelés szervezeti rendjét. ${ }^{13}$

További igen lényeges szabályozási forrás e területen a nemzetbiztonsági törvény, ${ }^{14}$ amely rendezi az állam területi épségének védelmét. Kiemelkedően fontos a civil lakosság felkészültségére, tájékoztatására vonatkozó rész, a felkészülés, valamint a civil lakosságnak a védelem és reagálás megszervezésébe való aktív bevonása. ${ }^{15}$

A polgári védelmi jogszabály ${ }^{16}$ fekteti le a jogi és szervezeti hátterét a polgári védelem litván rendszerének (erről részletesebben lásd az egészségügyi vészhelyzet kezeléséről szóló alfejezetet), így a hatáskörök részletszabályait, egyéb érintettek jogait és kötelezettségeit. Kiemelkedő tehát a jelentősége ennek a jogszabálynak a vészhelyzeti esemény (ivvykis) meghatározása okán, amely olyan természeti, technikai, ökológiai vagy társadalmi esemény, amely nem érte el a szükségállapot szintjét, mindemellett pedig veszélyezteti a lakosság életét vagy egészségét, társadalmi viszonyait, vagyonát, illetve környezetét. Míg a szükségállapot ehhez

\footnotetext{
4 Alkotmány 142 . cikk.

5 Alkotmány 94. cikk.

6 Alkotmány 144. cikk.

7 Alkotmány 94. cikk.

8 Alkotmány 144. cikk.

9 Alkotmány 147. cikk.

10 Elérhető: https://erccportal.jrc.ec.europa.eu/vademecum/lt/2-lt-1.html (Letöltve: 2019. december 14.).

11 A hadiállapotról szóló törvény (Lietuvos Respublikos karo padėties įstatymas).

12 A szükségállapotról szóló törvény (Lietuvos Respublikos nepaprastosios padėties įstatymas).

13 Survila et al., 2016.

14 A nemzetbiztonságról szóló törvény (Lietuvos Respublikos nacionalinio saugumo pagrindų įstatymas).

15 Survila et al., 2016, 40. o.

16 Polgári védelmi törvény (Lietuvos Respublikos civilinės saugos įstatymas) (a továbbiakban: Polgári védelmi tv.).
} 
képest olyan helyzet, amely vészhelyzeti esemény által jön létre, és hirtelen és súlyos veszélyt jelent a lakosság életére vagy egészségére, tulajdonukra, a környezetre, vagy halált, maradandó károsodást okoz, illetve fennáll annak a valószínűsége, hogy egyéb kárral jár együtt. E keretek között meghatározó a polgári védelem az állami, önkormányzati és egyéb szervek, gazdasági szereplők, valamint a lakosság felkészültsége vonatkozásában. Ki kell emelni a nemzetbiztonsági stratégiát $t^{17}$ is, amely a közpolitikai prioritások kijelölése kapcsán kap lényeges szerepet. Az állam egészét érintő vészhelyzetek elkerülése és következményeik mérséklése miatt Litvánia számára kiemelt fontosságú a lakossági képzés, a társadalmi minimumellátások biztosítása, végül pedig a polgári védelmi rendszer képességeinek és készségeinek növelése.

A különleges jogrend kihirdetésének gyakorlati esetei vonatkozásában említésre méltóak az utóbbi években azon esetek, amelyek élelmiszer-egészségügyi és időjárási okokkal voltak összefüggésben. Az afrikai sertéspestis terjedése miatt az országban szükségállapotot hirdettek ki, ${ }^{18}$ akárcsak 2018 során a nagymértékú szárazság miatt. ${ }^{19}$ Alkotmányjogi értelemben a viták nem is a különleges jogrendi időszaknak vagy helyzeteknek az alkotmányi szabályozásával, hanem a részletszabályok lefektetésével voltak kapcsolatosak. A hadiállapot részletszabályai esetében 2000-ig nem is fogadták el a kapcsolódó törvényt, azt követően is többször módosították, főlleg azt illetően, hogy az egyes felhatalmazottak és érintettek között milyen legyen az együttmúködés rendje. ${ }^{20}$

A leglényegesebb közjogi viták az utóbbi időben nem a konkrét szabályozás tárgyköréhez kötődtek, hanem hogy a hibrid hadviselés korában miként lehet értékelni egy kiprovokált konfliktust adott esetben a helyi (orosz ajkú) kisebbség körében történő nyugtalanság szításával - tekintettel a 2014-es ukrán eseményekre. Mennyiben lehetséges ilyenkor a NATO-szövetségi rendelkezések alkalmazása? Egyáltalán a hibrid hadviselés ilyen formáival szemben mi lenne a helyes védekezési mód?²1 Egyértelmú a balti államok lépése ebben a tekintetben, így igyekeznek kihasználni az összevont védelmi rendszerek kiépítéséből fakadó előnyöket, illetve illeszkedni az Európai Unió által nyújtott keretekhez. A három balti állam saját védelmi rendszerét magas szinten összehangolja a tengerészeti BALTRON ${ }^{22}$ és a légi megfigyelési BALTNET ${ }^{23}$ projektekben. A BALTRON-t 1998-ban alapították, és a tenge-

17 A Litván Köztársaság parlamentjének 2002. május 28-i IX-907. számú határozata a 2002. évi nemzetbiztonsági stratégia jóváhagyásáról (Lietuvos Respublikos Seimas nutarimas dèl nacionalinio saugumo strategijos patvirtinimo $2002 \mathrm{~m}$. gegužès $28 \mathrm{~d}$. Nr. IX-907).

18 Elérhető: https://ithuaniatribune.com/state-of-emergency-declared-in-north-east-lithuania-over-africanswine-fever/amp/ (Letöltve: 2019. december 13.).

19 Elérhetô: www.lrt.lt/en/news-in-english/19/1075163/lithuania-declares-state-of-emergency-over-drought?fb clid=IwARoD3PltFEQOuQ9LmkdL7zp21OA7VZoJ9kb5P55D17viBymhEoZERMpqwrU (Letöltve: 2019. december 13.).

20 Elérhetó: www.lrs.lt/sip/portal.show?p_r=10140\&p_k=2\&p_t=150608 (Letöltve: 2019 . december 11.).

21 Elérhetô: https://lithuaniatribune.com/how-long-could-lithuania-resist-open-military-aggression/ (Letöltve: 2019. december 10.).

22 Angolul: Navy squadron of the Baltics.

23 Angolul: Air defense and air space. 
részeti együttmúködés egyik legfontosabb projektje lett a térségben, hasonlóan a légi megfigyelés területén 1994-ben alapított BALTNET-hez. ${ }^{24} \mathrm{Az}$ EU és a NATO együttmúkködésével Finnországban létrejött a Hibrid Fenyegetések Elleni Központ, valamint a Kommunikációs Munkacsoport, hogy felvegye a küzdelmet az orosz hírportálok tevékenységével.

Meg kell említeni a 2007-es tallini bronzkatona (felszabadulási emlékmû) ügyét, ugyanis ekkor azt el kívánták távolítani az észt szervek, ami az orosz ajkú lakosság heves tiltakozását váltotta ki, valamint orosz szerverekről számtalan kibertámadás kísérte, az észt alapvető fontosságú ellátórendszereket és infrastruktúrát megtámadva. Az ezek után kiépített észt szerv meghatározó jelentőségủ lett a másik két balti állam számára is.

\section{Az alapjogok korlátozásával kapcsolatos kérdések}

A litván szabályozás esetében általános alapjog-korlátozási klauzulát nem alkalmaznak. Békeidőben az alapjog-korlátozási szabályok vonatkozásában az alkotmány és a kapcsolódó törvények ${ }^{25}$ betartása és betartatása jelenti Litvániában az alapjogok és szabadságjogok általános korlátját. Vaičaitis megállapítása ${ }^{26}$ szerint a litván jogtudományban és az ítélkezési gyakorlatban az alapjogoknak nincs koherens és meghatározott definíciója. Erre tekintettel és ettől függetlenül is elsődlegesen az alkotmány, valamint az alkotmánybíróság fellelhetô gyakorlata alapián szükséges vizsgálni Litvánia alapjogi szabályozását. Az alkotmánybírósági gyakorlat szerint az alapjog-korlátozás csak törvény alapján vagy törvényi szabályozás útján valósulhat meg, és csak az arányosság elve mentén, oly módon, hogy az alapjogok, valamint szabadságjogok lényege nem csorbulhat. A gyakorlatban például a tulajdonjoggal kapcsolatos korlátozás, azaz a kisajátítás törvényi szintû szabályozás alapján és megfelelő kártalanítás mellett történhet meg. ${ }^{27}$

Az állampolgárok szabad gyülekezési joga nem korlátozható. ${ }^{28}$ Ezt a jogot csak törvény korlátozhatja, és csak akkor, ha erre az állam vagy a társadalom biztonsága, a közrend, az emberek egészségének vagy erkölcsének, illetve más személyek jogainak vagy szabadságának megóvása érdekében van szükség. A litván szabályozás esetében általános alapjog-korlátozási klauzulát nem alkalmaznak.

Azon alapjogok tehát, amelyeket nem lehet korlátozni, vagy csak kivételesen, törvény alapján korlátozhatók: a véleménynyilvánítás joga, a lelkiismereti és vallásszabadság joga, a mozgásszabadsághoz való jog, valamint a gyülekezési jog. ${ }^{29} \mathrm{Az}$ alkotmány alapján korlátozhatatlan a kultu-

24 A BALTRON projektről lásd bővebben: www.mod.gov.lv/en/nozares-politika/international-and-regionalcooperation/regional-cooperation/navy-cooperation; a BALTNET projektről lásd bővebben az alábbi oldalt: www.mil.ee/en/defence-forces/international-co-operation/baltnet (Letöltve: 2019. december 10.).

25 Galginaitis, Himmelreich és Vrubliauskaité, 2010, 23-24. o.

26 Vaičaitis, 2020, 1078. 0.

27 Alkotmány 23. cikk (3) bekezdés.

28 Alkotmány 36. cikk (2) bekezdés.

29 Alkotmány 25. cikk (3) bekezdés, 26. cikk (1) bekezdés, 32. cikk (2) bekezdés, 36. cikk (2) bekezdés. 
rális, tudományos, kutatási és oktatási tevékenység. ${ }^{30} \mathrm{Az}$ előzőekkel összhangban az alkotmánybírósági gyakorlat rámutat, hogy az alapjog-korlátozás csak törvényi felhatalmazás alapján vagy törvényi szabályozás útján valósulhat meg, és csak az arányosság elve mentén oly módon, hogy az alapjogok, valamint szabadságjogok lényege nem csorbul. Ahogy arról már szó esett, az alkotmány a különleges jogrendi állapotnak két változatát ismeri: egyrészt a hadiállapotot, másrészt a szükségállapotot. A hadiállapot és szükségállapot kihirdetése esetén egyes ${ }^{31}$ jogok ideiglenesen korlátozhatók. ${ }^{32}$ Ilyen különleges jogrendi állapotok idején alkotmánymódosításra nem kerülhet sor. ${ }^{33} \mathrm{Ha}$ az általános választások háború idejére esnek, ${ }^{34}$ a parlament vagy az elnök dönti el, hogy meghosszabbítja-e a parlament, az elnök vagy az önkormányzatok hivatali idejét. Ilyen esetekben a választásokat a háború vége után három hónapon belül kell meghirdetni.

A Polgári védelmi tv. szabályozási területéhez kapcsolódó kormányhatározat ${ }^{35}$ mellékletét képező, az anyagi erőforrások biztosításának és az azokért fizetett kártalanítás eljárásrendjéről szóló dokumentum a következő együttmúködési kötelezettséget írja elő: olyan sürgős esetekben, amikor a lakosok életére, egészségére, vagyonára vagy környezetére vonatkozóan súlyos veszély merül fel, a rendelkezésre álló anyagi erőforrásokat a települési önkormányzat igazgatójának írásbeli kérésére szükség szerint átadják a mentési mûveletek parancsnokának vagy a gazdálkodó egységek és egyéb ügynökségek parancsnoka részére, akikkel e tárgykörben külön megállapodások még nem születtek. A tanulmány előző pontjához hasonlóan itt is ki kell emelni a területre vonatkozó meghatározó szabályok közül a nemzetbiztonsági stratégiát, amely a közpolitikai prioritások kijelölése kapcsán kap lényeges szerepet. Az állam egészét érintő vészhelyzetek elkerülése és következményeik mérséklése miatt Litvánia számára kiemelt fontosságú a lakossági képzés, a társadalmi minimumellátások biztosítása, valamint további cél a polgári védelmi rendszer szereplői képességeinek és készségeinek növelése. ${ }^{36}$ Idetartozik, hogy Litvániában a vonatkozó uniós irányelv átültetése $\mathrm{e}^{37}$ is elsősorban az információs rendszerek és az IT-kommunikációs rendszerek kapcsán lényeges szabályozást érintette. ${ }^{38}$

30 Alkotmány 42. cikk (1) bekezdés.

$31 \mathrm{Az}$ ideiglenesen korlátozható jogok közé tartozik a litván szabályozás szerint: a magánélet sérthetetlensége és a családi élet védelme, a levéltitok és egyéb közlések sérthetetlensége, a tulajdon sérthetetlensége, a véleménynyilvánítás szabadsága, a szabad mozgás és tartózkodás joga, valamint az egyesülési szabadság és a gyülekezési jog.

32 Alkotmány 145. cikk.

33 Alkotmány 147. cikk.

34 Khakee, 2009, 39. o.

35 A Litván Köztársaság kormányának 1107. számú határozata az anyagi erőforrások biztosításának és az állami ellátás megtérítésének, valamint a rendkívüli helyzetben felmerült károk miatti állami támogatás nyújtására vonatkozó eljárás jóváhagyásáról, 2010. július 21. (Dẻl materialinių išteklių teikimo ir kompensavimo už jų teikimą tvarkos aprašo ir valstybės paramos už žalą, patirtą dèl ekstremaliosios situacijos, teikimo tvarkos aprašo patvirtinimo $2010 \mathrm{~m}$. liepos $21 \mathrm{~d}$. Nr. 1107).

36 Polgári védelmi tv. 41.

37 Az Európai Parlament és a Tanács (EU) 2016/1148 irányelve (2016. július 6.) a hálózati és információs rendszerek biztonságának az egész Unióban egységesen magas szintjét biztosító intézkedésekről.

38 A nevezett irányelv átültetése miatt elfogadott új vagy módosított rendelkezések köre megtalálható az alábbi oldalon: https://eur-lex.europa.eu/legal-content/HU/NIM/?uri=CELEX:32016L1148\&qid=1576188128492 (Letöltve: 2019. december 6.). 


\section{A koronavírus-járvány és az egészségügyi vészhelyzet kezelése}

Ahogy azt már fentebb említettük, az alkotmányos szabályozásban ${ }^{39}$ foglaltakkal kapcsolatosan a közzétett szakirodalom megjegyzi, ${ }^{40}$ hogy a koronavírus-járvány idején bevezetett karantén megköveteli, hogy az azzal kapcsolatos korlátozásokat törvény írja elő, valamint elvárás az is, hogy a korlátozások megfeleljenek a szükségesség és az arányosság elvének, és törvényes célt kövessenek, amely cél a kérdéses jogtól függően változik.

A litván szabályozásban - a rendelkezésre álló információink szerint - nincsen egészségügyi vész- vagy válsághelyzetszerủ kategória önállóan szabályozva. A polgári védelmi törvényben ${ }^{41}$ található meg a korábban már említett veszélyhelyzet eseményének meghatározása. A polgári védelem területe az állami, önkormányzati és egyéb szervek, gazdasági szereplôk és a lakosság felkészültsége szempontjából kiemelten releváns. ${ }^{42}$ Ehhez a tárgykörhöz kapcsolódik az előző alfejezetben már részletezett és hivatkozott kormányhatározat. ${ }^{43} \mathrm{~A}$ Polgári védelmi tv. meghatározza a polgári védelmi-mentési rendszer megszervezésének és múködtetésének alapelveit, valamint az állami és önkormányzati intézmények, gazdasági társaságok, állami szervezetek és lakosok feladatait és jogait. ${ }^{44} \mathrm{~A}$ polgári védelmi rendszer céljai ${ }^{45}$ között kiemelt helyet foglal el az állami források optimális felhasználása, valamint a közbiztonság és a nemzetgazdaság múkködése. A célok és a feladatok végrehajtása érdekében a polgári védelmi intézményeknek a rendszer felépítésére és múködésére vonatkozó alapelvek mentén kell múködniük, ezenfelül a jogszabály meghatározza a polgári védelmi rendszer felépítésének és múködésének legfontosabb alapelveit ${ }^{46}$ is. A területi elv a polgári védelem nemzeti szintú szervezésére vonatkozik, amely magában foglalja az egész lakosságot, valamint a Litvánia területén tartózkodó külföldi állampolgárokat. A differenciálás elve szerint a polgári védelmi intézkedéseket és a mentési mûveletekre való felkészülést az egyes közigazgatási egységekben hajtják végre, figyelembe véve az állam területén várható veszély szintjét, valamint annak mértékét. A kényszeralkalmazás jogosultsága alatt értendő, hogy a polgári védelmi intézkedések kötelezőek

39 Alkotmány 145. cikk.

40 Dagilytè-Padskočimaite-Vainorienè, 2020.

41 Polgári védelmi tv. 5-6.

42 Polgári védelmi tv. 40.

43 A Litván Köztársaság kormányának 1107. számú határozata az anyagi erőforrások biztosításának és az állami ellátás megtérítésének, valamint a rendkívüli helyzetben felmerült károk miatti állami támogatás nyújtására vonatkozó eljárás jóváhagyásáról, 2010. július 21. (Dẻl materialinių išteklių teikimo ir kompensavimo už jų teikimą tvarkos aprašo ir valstybės paramos už žalą, patirtą dẻl ekstremaliosios situacijos, teikimo tvarkos aprašo patvirtinimo $2010 \mathrm{~m}$. liepos $21 \mathrm{~d}$. Nr. 1107).

44 Polgári védelmi tv. 1.

45 A polgári védelmi rendszer céljai: az állami források optimális felhasználásának garantálása, a közbiztonság biztosítása, a nemzetgazdaság működőképességének fenntartása, a vészhelyzetek lokalizálása és ezek hatásainak enyhítése, a nyilvánosság felkészítése vészhelyzet esetén a gyakorlati intézkedésekre és a polgári védelmi rendszerbe vetett bizalom erősítése.

46 A legfontosabb alapelvek: a területi differenciálás, a kényszer gyakorlásának jogosultsága, az átláthatóság, az állandó készenlét és az interoperabilitás. 
a közigazgatás és az önkormányzatok minden intézményére, minden gazdasági szervezetre és lakosra. Az átláthatóság elve a közigazgatás és az önkormányzati intézmények polgári védelem területén végzett tevékenységére vonatkozik, amelynek átláthatónak kell lennie a nyilvánosság és a tömegtájékoztatás szempontjából. A készenlét elve alapján a polgári védelmi rendszer intézményeinek és a haderônek folyamatos készenlétben kell lenniük a vészhelyzetben való intézkedés érdekében. Az interoperabilitás elve magában foglalja a polgári védelmi intézkedések és a vészhelyzetekben végrehajtott intézkedések hatékonyságát, amelyet biztosítani kell a közigazgatás és az önkormányzati intézmények, a polgári védelmi rendszer haderôi részére, azok interoperabilitási terveinek és irányítási rendszerének összehangolásával.

A polgári védelmi rendszer intézményeit az alkotmány, a parlament által elfogadott törvények és egyéb jogi aktusok, a köztársasági elnök döntései, a kormány határozatai, ${ }^{47}$ a miniszterelnöki rendeletek, a honvédelmi miniszter utasításai és a nemzetközi szerződések határozzák meg. Az államszervezet múködése szempontjából a különleges jogrend kihirdetése a kormány felelőssége, valamint ezen túlmenően a kormányzati felelősségi körbe tartoznak a különleges jogrend megszüntetésével ${ }^{48}$ kapcsolatos feladatok. A litván védelmi erôk és önkéntesek szükség esetén segítséget nyújthatnak válsághelyzetben. A korábbiakban már leírtakon túl a kormány felelősségi körébe tartoznak egyéb, lényegesnek nevezhetô tárgykörök ${ }^{49}$ is.

Békeidóben a honvédelmi minisztérium más intézményekkel együttmúködve végrehajtja a kormány polgári védelmi politikáját, valamint össze kell hangolnia a polgári védelmi rendszer intézményeinek tevékenységét a hatáskörükhöz rendelt feladatok végrehajtása során. A hivatalos kormányüléseken folytatott tevékenységen túl fontos szerepet kap a Stratégiai Bizottság, amelynek tagjai között szerepel a kabinetminiszteren és a kancelláron kívül egy miniszterelnök-helyettes. A Stratégiai Bizottság kezeli a kormány által meghatározott

47 Spassov-Petkov-Tagarev, 2016, 2. és 18. o. A válságkezelés területén a litván kormány alábbi határozatai meghatározók: az 551. számú, 2000. november 8-i határozat; az 512. számú, 2010. május 4-i határozat; az 555. számú, 2004. május 4-i határozat; a Litván Köztársaság polgári védelmi rendszerével kapcsolatos eljárásról szóló 2010. évi 1108. számú határozat; a mentési, kutatási és sürgősségi események, katasztrófák és vészhelyzetek felszámolására és következményeik felszámolására, valamint azok kiküszöbölésére vonatkozó 2010. évi 1212. számú határozat, a sürgősségi múveleti központok létrehozásáról és szervezéséről szóló 1213. számú határozat; a lakosság evakuálásáról szóló 2010. évi 1502. számú határozat, a 2010. évi állami vészhelyzetkezelési tervről szóló 1503. számú határozat.

48 A vészhelyzet megszüntetésével kapcsolatos feladatok a következők: a vészhelyzet megszüntetése; a mentési, kutatási és sürgős intézkedések megszervezése; a vészhelyzetekre való reagálás; a vészhelyzet következményeinek enyhítése; az evakuálási intézkedések, valamint a menedékhelyek és más kollektív védelmi mechanizmusok biztosítása.

49 Egyéb meghatározó kormányzati tárgykörök: a polgári védelmi rendszerek fejlesztési programjainak kidolgozása és a parlamenthez jóváhagyás céljából benyújtása; a polgári védelmi rendszerek prioritási fejlesztési trendjeinek végrehajtását szolgáló eljárás kidolgozása; a sürgősségi megelőzési eljárás kialakítása; a polgári védelem felkészültsége és a sürgősségi kritériumok jóváhagyása; a polgári védelmi vészhelyzeti felkészültség nemzeti szintû terveinek jóváhagyása; az anyagi erőforrások vészhelyzet esetén történő felhasználása, valamint az állami tartalék összetételének meghatározása; a polgári védelmi képzés; az elnök és a parlament a vészhelyzetről, annak következményeiről és okairól való értesítése. 
prioritásokat, valamint a kormányzati politikát és stratégiát. Egy másik kormánybizottság, a Válságkezelő Bizottság a válságkezeléssel kapcsolatban ad tanácsot a kormánynak..$^{50} \mathrm{~A}$ honvédelmi minisztérium ${ }^{51}$ felel továbbá:

- a Vészhelyzet-menedzsment Központ értesítési eljárásának meghatározásáért;

- a menedékhelyek és más kollektív védelmi struktúrák szükségleteinek biztosításáért;

- a lakosság egyéni védelmi eszközökkel történő ellátásával kapcsolatos normák jóváhagyásáért;

— a nemzeti szintû polgári védelmi gyakorlat és a hallgatók polgári védelmi képzési központba való beiratkozására vonatkozó éves terv jóváhagyásáért;

— a polgári védelmi osztály éves tevékenységi tervének jóváhagyásáért;

— valamint általános információkkal látja el a kormányt a polgári védelmi és mentési rendszer állapotáról.

Nemzeti szinten a kormányon belül a Vészhelyzet-menedzsment Központ mellett a Kormányzati Katasztrófavédelmi Bizottságközpont is segíti a kormányzati feladatok ellátását. ${ }^{52}$ A Belügyminisztérium Polgári Védelmi Osztálya a polgári védelmi rendszer nélkülözhetetlen része, amelynek főbb feladatai: ${ }^{53}$

— irányítja a polgári védelmi rendszer tevékenységeit, valamint a vészhelyzetek megelőzése érdekében folytatja a tevékenységét;

- összehangolja a közintézmények és az ökoszervezetek tevékenységét a polgári védelem területén; és

- előkészíti a polgári védelmi feladatok végrehajtásához szükséges nemzeti felkészültség tervét békebeli és háborús vészhelyzetek esetén.

Az Állami Túzoltóság és Mentőszolgálat is a polgári védelmi rendszer része, amely folyamatos készenlétben van, és intézkedik a tüzoltás, a sérültek felkutatása és mentése érdekében, valamint vészhelyzet esetén elsősegélyt nyújt. A mentőszolgálat a Belügyminisztérium Túzmegelőzési és Mentési Osztálya alárendeltségébe tartozik.

50 Nakrosis-Vilpisauskas-Jahn, 2016, 45. o.

51 Spassov-Petkov-Tagarev, 2016, 2. és 18. o.

52 Spassov-Petkov-Tagarev, 2016, 2. és 18. o.

53 A Polgári Védelmi Osztály előbb felsorolt főbb feladatain kívül - a polgári védelmi rendszer céljai között a polgári védelmi törvény által is elsők között meghatározott optimális forrásfelhasználáson túl - egyéb kötelezettségeket is teljesítenie kell, amelyek a következők: az állami intézmények, a gazdasági szereplők és a lakosság tájékoztatása vészhelyzet esetén az országos szintủ fenyegetettségről; az állami források optimális felhasználásának, a vészhelyzet térsége lokalizálásának és a válság következményeinek enyhítését célzó intézkedések megtervezése; a potenciálisan veszélyes nemzeti jelentôségú objektumok nyilvántartásának vezetése; a polgári védelmi rendszer tevékenységeinek ellenőrzése; a közigazgatási intézmények és a közösség vészhelyzetre való felkészültségének megszervezése; valamint a nemzeti szintủ polgári védelmi gyakorlat megszervezése és irányítása. 
Az előzőekben taglalt polgári védelmi rendszer fontosságát kiemeli az a tény is, hogy a Velencei Bizottság tavaly őszi jelentése is foglalkozik az új koronavírus litván szabályozásával. ${ }^{54} \mathrm{~A}$ jelentésben foglaltak szerint egyes országokban (például Ciprus, Görögország, Írország) vannak olyan mechanizmusok, amelyek a vészhelyzetekre reagálnak, mások (mint például Litvánia) pedig számos sürgősségi mechanizmussal rendelkeznek, amelyek megkülönböztetik a különböző típusú fenyegetéseket. Litvánia különleges sürgősségi intézkedéseket fogadott el a polgári védelemről szóló törvény, valamint az emberek fertőző betegségeinek megeloozésérôl és ellenőrzéséről szóló törvény, és nem az alkotmány ${ }^{55}$ alapján (tehát hivatalos formális szükségállapot kihirdetése nélkül).

Az új koronavírus-pandémiával kapcsolatos, ${ }^{56} 2020$ márciusában elrendelt korlátozásokat a három balti állam 2020. május 15-én egymás vonatkozásában feloldotta. Ezt követően, 2020. június 1-jén Litvánia több EU-tagállam - köztük Magyarország vonatkozásában is - a belépési tilalom megszüntetése iránt tett intézkedéseket.

A litván kormányzat a koronavírusra való tekintettel a következőkben bemutatott intézkedéseket ${ }^{57}$ rendelte el 2020. június 17-től: a határokon az ellenőrzés tekintetében - elsődlegesen korlátozó jellegû́ - szigorításokat léptettek életbe, ${ }^{58}$ a gazdaságban, tehát a szolgáltatásokat és a kereskedelmet érintően elsősorban - a hazai szabályozáshoz hasonlóan - a távolságtartást szolgáló intézkedéseket alkalmazták. ${ }^{59}$

54 Venice Commission, 2020, 14. o.

55 Alkotmány 144. cikk.

56 Elérhető: www.schengenvisainfo.com/news/timeline-of-eu-member-states-reopening-their-borders/ (Letöltve: 2020 . június 22.).

57 Lásd a litván kormányzati honlapot: http://koronastop.lrv.lt/en/news/Covid-19-related-restrictions-as-of-17june-2020 (Letöltve: 2020. július 24.).

58 A szigorítások között említésre méltók a következők: az érintett országokból Litvániába érkező rendszeres járatok és kompok korlátozása; az ellenőrzéseket a repülőtereken, a Klaipẻda tengeri kikötőben, valamint a Fehéroroszországgal és Oroszországgal folytatott külső uniós határátkelőhelyeken végzik (ez magában foglalja a testhőmérséklet mérését, elektronikus regisztrációval vagy papíralapú formanyomtatvány kitöltésével együtt az utaskártya kötelező kitöltése 48 órán belül, 14 napos elkülönítés ajánlott mindenkinek, adott esetben pedig betegállomány); az utasok tájékoztatása és konzultáció a további lépésekről, ha az utasoknál tünetek jelentkeznek; az utasok ellenőrzését az EU belső határain nem hajtják végre.

59 A szolgáltatásokat és a kereskedelmet érintő intézkedések esetében a következőket kell megemlíteni: kétméteres védőtávolság betartatása, amely válaszfalak alkalmazása vagy személyi védőfelszerelés viselése esetén kisebb lehet; a sorok közötti szükséges távolság legalább 1 méter; fertőtlenítés; bevásárlókocsik, illetve -kosarak fertőtlenítése az értékesítési pontokon, üzletekben; kézhigiénia (kézmosás, illetve kézfertőtlenítés); a tünetek megjelenése vagy elkülönítés esetén tilos a munkavégzés; javasolt, hogy mind a látogatók, mind a személyzet viseljen személyi védőfelszerelést. 
Az előzőekhez hasonlóan a szórakozóhelyek és vendéglátóhelyek ${ }^{60}$ esetében elsődlegesen a távolságtartásra és a higiéniára helyezték a hangsúlyt, valamint hasonló szabályozást alkalmaztak a kaszinók, játéktermek, szerencsejáték szervezésére szolgáló helyiségek tevékenységével kapcsolatban is.

A rendezvények vonatkozásában idősávonként lett szabályozva a nézők és a résztvevők száma, amelyet a következő táblázat szemléltet.

\begin{tabular}{|c|c|c|}
\hline Idősáv & $\begin{array}{c}\text { Kültéri rendezvények megen- } \\
\text { gedett maximális létszáma (fó) }\end{array}$ & $\begin{array}{c}\text { Beltéri (fedett térben) rendez- } \\
\text { vények megengedett maximális } \\
\text { létszáma (fó) }\end{array}$ \\
\hline $\begin{array}{c}\text { 2020. június 17-től } \\
\text { 2020. június 30-ig }\end{array}$ & 700 & 150 \\
\hline $\begin{array}{c}\text { 2020. július 1-jétől } \\
\text { 2020. július 16-ig }\end{array}$ & 1000 & 200 \\
\hline
\end{tabular}

\section{5. táblázat \\ A litván korlátozás változása 2020 nyarán \\ Forrás: a szerző saját szerkesztése}

A rendezvényekkel kapcsolatban megalkotott szabályok szerint javasolttá vált az egyéni védőeszközök viselése, fertőtlenítés, kézhigiénia (kézmosás, illetve -fertőtlenítés), a tünetek megjelenése vagy a személy karanténba kerülése esetén tilos a munkavégzés. Az oktatási tevékenység korlátlanul végezhető, ha a higiénia és a résztvevőknek a szükséges személyi védőeszközökkel történő ellátása biztosított, azonban ehhez további előírások is kapcsolódnak, úgy, mint az előző rendezvényekre vonatkozó hasonló szabályoknál: fertőtlenítés, kézhigiénia (kézmosás, illetve -fertőtlenítés), a tünetek megjelenése vagy az érintett személy elkülönítése esetén tilos a munkavégzés. Távoktatást kell alkalmazni, ha az előbbi feltételek nem teljesülnek.

A szociális szolgáltatások nyújtása esetén alkalmazandó szabályok szintén hasonló követelményrendszert ${ }^{61}$ tartalmaztak, mint a korábban már megismert intézmények sza-

60 Szórakozóhelyek esetében alkalmazott intézkedések: sorok között legalább egy méter; kötelező fertőtlenítés; kézhigiénia (mosás, illetve fertőtlenítés); a tünetek megjelenése vagy elkülönítés esetén tilos a munkavégzés; javasolt, hogy a személyzet személyi védőfelszerelést viseljen. A vendéglátóhelyek (éttermek, kávézók, bárok, éjszakai klubok és egyéb szórakozóhelyek) esetében bevezetett intézkedések: az asztalnál ülő személyek között kétméteres védőtávolság, amely lehet kisebb, ha válaszfalak vannak felszerelve; fertôtlenítés; kézhigiénia (kézmosás, illetve -fertőtlenítés); a tünetek megjelenése vagy elkülönítés esetén tilos a munkavégzés; ajánlott, hogy a személyzet személyi védőfelszerelést viseljen; az ételek bármilyen kiszerelése korlátlan (svédasztal, pult); a munkaidő sem korlátozott.

61 A szociális területet érintő követelményrendszer a következő: fertőtlenítés; kézhigiénia (kézmosás, illetve -fertôtlenítés); a tünetek megjelenése vagy elkülönítés esetén tilos a munkavégzés; ajánlott egyéni védőeszközök használata. 
bályozása. A szociális területhez képest az egészségügyi szolgáltatások terén - értelemszerúen - a szigorúbb előírások érvényesültek. ${ }^{62}$

2020. november 7.00:00 órától 2020. november 29. 24:00 óráig Litvánia ${ }^{63}$ karantént vezetett be az ország teljes területén. A litván kormányzati honlapon közzétett korlátozó intézkedések szerint tilos beltéri vagy kültéri, kereskedelmi vagy nem kereskedelmi jellegú, kulturális, szórakoztató, sportesemények, ünnepségek, vásárok, fesztiválok vagy más tömeges összejövetelek megtartása, ez alól kivételt képeznek egyrészt a zártkapus (nézők nélküli) nagy sportesemények, másrészt a temetések legfeljebb tíz fő részvételével.

Az előbbieken túl a kormányzat javasolta a magánszemélyeknek, hogy a lakóhely elhagyását csak a munka, a vásárlás, az egészségügyi és egyéb szolgáltatások körére korlátozzák. Továbbá javasolt a magánterületen tartott összejövetelek mellőzése vagy legfeljebb tíz olyan ember részvételével való megtartása, akik arcmaszkot viselnek, ezen túlmenően érdemes más családok, illetve háztartások tagjaival korlátozni a kapcsolattartást.

A vendéglátóhelyeket, a közétkeztetési létesítményeket, éttermeket, kávézókat, bárokat, éjszakai klubokat, más szórakozóhelyeket, kaszinókat, játéktermeket, bingótermeket bezárták, kivéve az ételt elvitelre árusító, természetes és jogi személyek által fenntartott üzleteket. A vendéglátásban dolgozó személyzet számára az ilyen vállalkozások, létesítmények területén védőmaszkok használata kötelező. Továbbá a védőmaszkok használata minden nyilvános helyen kötelező (mindenki számára hatéves kortól), e kötelezettség alóli kivételt képeznek: az egyéni edzések, olyan szolgáltatások nyújtása, amikor a szolgáltatás nem teljesíthetô, ha az ügyfél maszkot visel, továbbá azon fogyatékossággal élő személyek, akik egészségi állapotuk miatt nem viselhetnek maszkot. A közös helyiségekben arcmaszkot kötelező viselni. Nyilvános helyeken legfeljebb öt fő gyülekezhet, kivéve a családtagokat.

A tömegközlekedésen az utasok ülve utazhatnak, és legalább egy méter távolságot kell tartaniuk egymás között.

Az állami szektor vonatkozásában vegyes- vagy távmunka bevezetése vált szükségessé, kivéve, ha a feladatokat nem lehet távolról ellátni. E követelmény teljesítése a magánszektor számára is ajánlott.

Az üzletekben, szupermarketekben, piactereken és más nyilvános értékesítési helyeken, valamint azok környezetében látogatónként biztosítani kell a tíz négyzetméteres teret, vagy egyszerre csak egy látogatót lehet kiszolgálni.

A szálláshely-szolgáltatás esetén a teljesítendő követelmények közé tartozik, hogy legfeljebb két fő elhelyezése lehetséges egy szobában, kivéve a családtagokat, biztosítani kell,

62 E szigorúbb elöírások a következők: szolgáltatásmegújítási terv készítése; a betegforgalom kezelése az intézmény vezetője által megállapított eljárásrendnek megfelelően; a távszolgáltatások támogatása, lehetővé téve az egészségügyi szolgáltatások azon módszerének megválasztását, amely a legjobban megfelel a beteg elvárásainak; fokozott fertőzöttség-ellenőrzés; személyi védőeszközök biztosítása és használata; tesztelési stratégia alkalmazása.

63 Lásd Litvánia kormányzati honlapját: https://koronastop.lrv.lt (Letöltve: 2020. november 11.). 
hogy mindenki viseljen arcmaszkot, és legalább kétméteres távolság legyen a közös helyiségekben élő emberek között. A rekreációs, kulturális, szabadidős, szórakoztató szolgáltatásokat nyújtó vendéglátóegységek zárva tartanak.

Az óvodai és az általános iskolai nevelést és oktatást a múveleti parancsnok határozatában megszabott feltételeknek megfelelően kell biztosítani. A felnőttképzést és a szakképzést távoktatás keretében tartják meg.

$\mathrm{Az}$ egészségügyi intézményekben látogatási tilalmat rendeltek el, kivéve például a 14 évesnél fiatalabb gyermekek és a szülészeti osztályokon lévő betegek látogatását az adott intézmény vezetőjének engedélyével. A járóbeteg-szakellátás során a szolgáltatás érdekének legjobban megfelelő szolgáltatási módot kell alkalmazni, amely lehet előjegyzéses vagy telefonos konzultáció. A nemzeti sürgősségi múveletek állami parancsnoka dönt az egészségügyi intézmények tevékenységi koordinátorának kinevezéséről a Covid-19-szolgáltatások nyújtásának koordinálása érdekében. A koordinátor a polgármesterekkel és a helyi vezetőkkel együttmúködve szervezi a Covid-19-járvánnyal kapcsolatos szolgáltatások nyújtását. A koordinátor utasításai mind a szervező egészségügyi intézmények, mind a mozgósított egészségügyi intézmények számára kötelezők, hacsak jogszabály eltérően nem rendelkezik.

A korlátozó intézkedések hatályát 2020. november 25. napján a litván kormányzat 2020. december 17. napjáig meghosszabbította. ${ }^{64}$

\section{4. Összegzés}

Ahogy arról már szó esett, a különleges jogrend litván és a hazai hatályos szabályozása közötti lényegi eltérés az, hogy míg az előbbi két szabályozási tárgykört (hadiállapot és szükségállapot), addig az utóbbi, Alaptörvényben foglalt magyar szabályozás hat tényállást (rendkívüli állapot, szükségállapot, veszélyhelyzet, váratlan támadás, megelőző védelmi helyzet, terrorveszélyhelyzet) állapít meg.

A litván szabályozáshoz hasonlóan, a magyar szabályozás szerint az Országgyưlés hadiállapot kinyilvánítása vagy idegen hatalom fegyveres támadásának közvetlen veszélye (háborús veszély) esetén kihirdeti a rendkívüli állapotot, viszont a vizsgált ország szabályozásától eltérően az Alaptörvényünk szerint Honvédelmi Tanács létrehozására is sor kerül. Ahogy arról már az előzőekben is szó volt, a magyar szabályozás szerint a rendkívüli állapot idején a Honvédelmi Tanács gyakorolja a parlament által rá átruházott jogokat a köztársasági elnök jogai mellett, ehhez társulnak még a Kormány jogai. A Honvédelmi Tanács rendeletet alkothat, amely a rendkívüli állapot megszúnésével hatályát veszti, kivéve, ha az Országgyúlés a rendelet hatályát meghosszabbítja.

64 Litvánia kormányzati honlapja elérhető: https://koronastop.lrv.lt/lt/naujienos/su-Covid-19-susije-ribojimaiinformacija-atnaujinta-2020-m-lapkricio-25-d (Letöltve: 2020. december 2.). 
Szükségállapot idején az Országgyưlés akadályoztatása esetén a köztársasági elnök dönt a Magyar Honvédség felhasználásáról. Ebben az időszakban a rendkívüli intézkedéseket rendeleti úton a köztársasági elnök vezeti be. A rendeleti úton bevezetett rendkívüli intézkedések harminc napig maradnak hatályban, kivéve, ha hatályukat az Országgyúlés - akadályoztatása esetén a honvédelmi ügyekkel foglalkozó bizottsága - meghosszabbítja. A köztársasági elnök rendelete a szükségállapot megszúnésével hatályát veszti.

A litván szabályozással párhuzamosan az Alaptörvényünk szerint a törvényes rend megdöntésére vagy a hatalom kizárólagos megszerzésére irányuló fegyveres cselekmények, továbbá az élet- és vagyonbiztonságot tömeges méretekben veszélyeztető, fegyveresen vagy felfegyverkezve elkövetett súlyos, erőszakos cselekmények esetén szükségállapot kihirdetésére kerül sor. A hatályos magyar szabályozás szerint a különleges jogrend kihirdetéséhez az országgyưlési képviselők kétharmadának szavazata szükséges, ez eltérést jelent a litván szabályozáshoz képest, mert utóbbiban ilyen szavazati arány (azaz küszöb) nincs meghatározva. A két szabályozás közötti érdemi eltérést tehát az jelenti, hogy a magyar jogalkotás során cizelláltabb szabályozásra törekedtek. Egyúttal érdemes arra is felhívni a figyelmet, hogy a litván szabályozás általánosabb megfogalmazása szélesebb kereteket biztosít a rugalmasabb jogalkalmazásra, azonban ugyanezt más szempontból nézve - a magyar szabályozáshoz képest a litván jog nem alkalmaz minden tekintetben egyértelmú megfogalmazást, így megnyitja a többértelmúség, adott esetben az ezzel együtt járó jogbiztonság csökkenése előtti „utat”.

A litván szabályozás lényegének bemutatását szolgálja a következő táblázat.

\begin{tabular}{|c|c|c|}
\hline & Hadiállapot & Szülkségállapot \\
\hline Szabályozás szintje & \multicolumn{2}{|c|}{ Alkotmányos és törvényi szint } \\
\hline Elrendelési okok & $\begin{array}{l}\text { Az állam szuverenitását vagy te- } \\
\text { rületi integritását veszélyeztető: } \\
\text { — fegyveres támadás, } \\
\text { — katonai támadás. }\end{array}$ & $\begin{array}{l}\text { Az állam területén } \\
\text { bekövetkezett: } \\
\text { — vészhelyzet vagy } \\
\text { — válság. }\end{array}$ \\
\hline Elrendelés & \multicolumn{2}{|c|}{$\begin{array}{l}\text { A parlament jogosult bevezetni a Litván Köztársaság elnökével } \\
\text { együttmüködve. }\end{array}$} \\
\hline Felhatalmazott & \multicolumn{2}{|c|}{ Parlament } \\
\hline Gyakorlati esetek & Nem rendelték el. & $\begin{array}{l}\text { Két alkalommal: } \\
\text { - 2014: afrikai sertéspestis } \\
\text { - 2018: szárazság. }\end{array}$ \\
\hline $\begin{array}{l}\text { Különleges jogrendnek nem } \\
\text { minősülő rendkívüli helyzet }\end{array}$ & \multicolumn{2}{|c|}{ Veszélyhelyzeti esemény } \\
\hline
\end{tabular}

16. táblázat

Különleges jogrendi esetkörök Litvániában

Forrás: a szerző saját összeállítása 
Magyarország Kormánya 2020. november elején az Országgyúlésnek benyújtotta a Magyarország Alaptörvényének kilencedik módosításáról szóló tervezetet, amelyet az Országgyưlés 2020. december 15. napján elfogadott, és a vonatkozó rendelkezések 2023-ban lépnek hatályba.$^{65}$ Ennek értelmében - a két litván jogintézményhez képest - az Alaptörvény a kilencedik módosítását követően már csak három különleges jogrendi tényállást fog szabályozni: a hadiállapotot, a szükségállapotot és a veszélyhelyzetet. E módosítással - külföldi példák nyomán - a jogalkotó átláthatóbbá ${ }^{66}$ kívánja tenni a korábbi hat helyett három esetkörre módosuló különleges jogrendi tényállások rendszerét, amely a fegyveres védelmi és biztonsági tevékenységekben érintett szervezetekre vonatkozó szabályokkal egy korszerúbb, a változó biztonsági környezethez jobban alkalmazkodó és az elmúlt évek válságkezeléseinek tapasztalataira építő, hatékony rendszer kialakítására törekszik. A módosítás a korszerűsítés és a rendszerszintû megújítás mellett számos ponton többletgaranciákat épít be a védelmi és biztonsági funkciók ellátásának szervezeti, múködési és szabályozási keretei vonatkozásában is. A különleges jogrend intézményrendszerében - a módosítás eredményeként a köztársasági elnök és a Honvédelmi Tanács nem kap szerepet, és ennek következményeként a Kormány szerepe megerősödik, amit jelez a különleges jogrendre vonatkozó közös szabályokban foglalt rendeletalkotási jogkör hangsúlyossá válása. A módosítás nyomán a jövőbeli magyar és a litván szabályozás a tényállások száma és átláthatósága tekintetében hasonló lesz. A 2023-ban hatályba lépő magyar szabályozás két tényállása (a hadiállapot és a szükségállapot) elnevezésében megegyezik a litván szabályozás két tényállásával, viszont egyértelmú eltérés a két szabályozás között az, hogy a magyar szabályozásban a Kormány kap meghatározó szerepet a rendeletalkotási jogkörének köszönhetően.

Litvániában a leglényegesebb közjogi viták az utóbbi években - ahogyan arra korábban már utaltunk - nem a konkrét szabályozás tárgyköréhez tartoztak, valamint a járványügyi vészhelyzet kihirdetéséhez kapcsolódtak, hanem hogy a hibrid hadviselés korában miként lehet értékelni egy kiprovokált konfliktust adott esetben a helyi (orosz ajkú) kisebbség körében történő nyugtalanság szításával, tekintettel a 2014-es ukrán eseményekre. Mennyiben lehetséges ilyenkor a NATO-szövetségi rendelkezések alkalmazása? Egyáltalán a hibrid hadviselés ilyen formáival szemben mi lenne a helyes védekezési mód? Egyértelmú a balti államok lépése ebben a tekintetben, így igyekeznek kihasználni az összevont védelmi rendszerek kiépítéséből fakadó előnyöket, illetve illeszkedni az Európai Unió által nyújtott keretekhez. A három balti állam saját védelmi rendszerét a korábban leírtak szerint magas szinten összehangolja a tengerészeti BALTRON és a légi megfigyelési BALTNET projektekben.

A magyar szabályozás számára példaértékủ lehet a litván szabályozásban, hogy igen nagy hangsúlyt fektetnek a civil lakosság bevonására a polgári védelem területén és az egyéb vészhelyzetek leküzdésének kezelésében. Bár ebben a tekintetben a magyar katasztrófavé-

65 T/13647. számú tervezet: www.Parlament.hu/irom41/13647/13647.pdf (Letöltve: 2020. december 15.). A módosítást a kézirat lezártakor még nem hirdették ki a Magyar Közlönyben.

66 Vö.: Till, 2017, 73-75. o. 
delmi szabályozás is elkezdett bizonyos lépéseket megtenni (önkéntesen segítséget nyújtó személyek, az önkéntesen közremúködő társadalmi és karitatív szervezetek részt vehetnek a katasztrófák elleni védekezéssel összefüggő feladatok ellátásában). ${ }^{67} \mathrm{~A}$ civil lakosság ilyen formában való mélyebb bevonása lehetôvé teszi a közös fellépés eredményességének növelését, az ezzel foglalkozó szervek társadalmi elfogadottságának növelését, a további együttmúködés elmélyítését.

Litvániában a célok és a feladatok végrehajtása érdekében a polgári védelmi intézményeknek a rendszer felépítésére és múködésére vonatkozó alapelvek mentén kell mưködniük, ezért a litván polgári védelmi intézmények alapelveinek (a területi elvnek, a differenciálás elvének, a kényszeralkalmazás jogosultságának, az átláthatóság elvének, a készenlét elvének, az interoperabilitás elvének) szerepe kiemelendő, ugyanis mint lehetséges minta tartható számon a magyar joggyakorlat szempontjából.

Kiemelkedően fontos lehet a - már folyamatban lévő - határon átnyúló együttmúködési lehetőségek feltérképezése és megerősítése Magyarország esetében is, ami a kapcsolódó szabályozási környezet ismeretét elengedhetetlenné teszi. Emellett pedig a többi állammal való összefogás és a közös kapacitás kialakítása, kiépítése, megerősítése nem pusztán az anyagi eszközök szintjén lényeges, hanem a közös fellépés nagyobb elrettentő - természeti csapások esetén elhárító, továbbá katasztrófavédelmi - erőt is képvisel, valamint további együttmúködési pontok kiépítésére ad lehetőséget. Ennek az összefogásnak első lépése lehetne a V4 együttmúkködési kereteinek - akár északi irányú - bővítése, hiszen a balti államok Lengyelország, és így a V4 közvetlen szomszédságában vannak. Az esetleges bővítés további indokaként tartható számon az a tény, hogy meghatározók (voltak) az elmúlt három évtized történelmi párhuzamai, valamint hasonlóan szignifikánsak a kulturális hasonlóságok, így ezek egyaránt megalapozzák egy esetleges bővítés lehetőségét.

\section{Irodalomjegyzék}

Aleknavičıus, P. (2013) 'Agrarian Land Use Regulation in the Republic of Lithuania', Balanced Nature Using, 2013/2-3, 18-26. o.

Dagilytė, E., Padskočimaité, A., VainorienĖ, A. (2020) Lithuania's Response to COVID-19: Quarantine Through the Prism of Human Rights and the Rule of Law [Online]. Elérhetô: https:// verfassungsblog.de/lithuanias-response-to-Covid-19-quarantine-through-the-prism-ofhuman-rights-and-the-rule-of-law/ (Letöltve: 2020. szeptember 15.)

Galginaitis, J., Himmelreich, A., Vrubliauskaité, R. (2010) Einführung in das litauische Recht. 1. kiadás. Berlin: BWV Berliner Wissenschafts-Verlag

67 A katasztrófavédelemről és a hozzá kapcsolódó egyes törvények módosításáról szóló 2011. évi CXXVIII. törvény, megállapította a 2013. évi CXCII. törvény 21. \$ (1) bekezdés, hatályos: 2013. 11. 29-től. 
Greicius, M. (2009) States of Emergency and Fundamental Rights: Lithuanian Perspective [Online]. Elérhetô: $\quad$ www.jus.unitn.it/cocoa/papers/PAPERS\%204TH\%20PDF/Emergency\%20Lithuania\%20Greicius.pdf (Letöltve: 2020. december 15.); www.sgi-network.org/docs/2016/ country/SGI2016_Lithuania.pdf (Letöltve: 2020. december 15.)

KELEMEN, R. (2020)'Különlegesjogrend az Európai Unióegyestagállamainakalkotmányaiban' in Farkas, Á., Kelemen, R. (szerk.) Szkülla és Kharübdisz között - Tanulmányok a különleges jogrend elméleti és pragmatikus kérdéseiról, valamint nemzetközi megoldásairól. 1. kiadás. Budapest: Magyar Katonai Jogi és Hadijogi Társaság

Khakee, A. (2009) Securing Democracy? A Comparative Analysis of Emergency Powers in Europe. Geneva Centre for the Democratic Control of Armed Forces. Policy Paper No. 30/2009

NAKRosis, V., VILPISAUSKAS, R., JAHN, D. (2016) Lithuania Report. Sustainable Governance Indicators 2016 [Online]. Elérhető: www.researchgate.net/publication/306380796_Lithuania_report_ Sustainable_governance_indicators_2016 (Letöltve: 2020. december 15.)

SADURSKI, W. (2005) Rights Before Courts: A Study of Constitutional Courts in Postcommunist States of Central and Eastern Europe. 1. kiadás. Dordrecht: Springer

Spassov, P., Petkov, V., Tagarev, T. (2016) Lithuania Policy, Legislation, Organisation, Procedures \& Capabilities (PLOPC) in Crisis Management and Disaster Response (Driving Innovation in Crisis Management for European Resilience) [Online]. Elérhető: www. driver-project.eu/wp-content/uploads/Crisis-Management-Organisations-Reportincluding-Procurement-Regulations-AND-Policy-and-Legislation-Report.pdf (Letöltve: 2020. december 11.)

Survila, A., RakšnYs, A. V., TVaronavičiené, A., Vainiutė, M. (2016) 'Systemic Changes in Disaster Management in the Context of Public Sector Modernization', Journal of Security and Sustainability Issues, 6(1), 37-52. o.

TILL, Sz. (2017) 'A különleges jogrendi kategóriarendszer egyszerủsítésének jövőbeli esélyei', Iustum Aequum Salutare, 13(4), 55-75. o.

VAIČAitis, A. V. (2020) 'Lithuania (Lithuanian Constitutional Law)' in Alen, A., Haljan, D. (szerk.) International Encyclopedia for Constitutional Law. Wolters Kluwer Online

Venice Commission (2020) Interim Reporton the Measures Taken in the EU Member States as a Result of the COVID-19 Crisis and Their Impacton Democracy, the Rule of Law and Fundamental Rights (Study No. 995/2020) [Online]. Elérhetô: www.venice.coe.int/webforms/documents/?pdf=CDL$\mathrm{AD}(2020) 018$-e (Letöltve: 2020. december 15.) 


\title{
19. Németország, \\ a többszintú válságkezelés iskolapéldája
}

\author{
DE NEGRI LAURA
}

\section{A különleges jogrend alkotmányos és törvényi szintủ szabályozása és esetkörei}

Németországban a különleges jogrend esetkörei a normahierarchia legmagasabb szintjén, az alaptörvényben ${ }^{1}$ kerülnek szabályozásra. A különleges jogrend mint az általánostól eltérő állapotokat rögzítő gyưjtőfogalom azonban a magyar nyelvben használt kifejezéssel megegyező formában nem jelenik meg a német jogrendszerben. Ehelyett a német nyelv a sürgősségi törvények (Notstandsgesetze) vagy sürgősségi alkotmány (Notstandsverfassung) kifejezést használja a magyar értelemben vett különleges jogrendi szabályozás meghatározására. Az általánostól eltérő állapotok szabályozási koncepciója kapcsán kiemelendő, hogy az egyes esetkörökre vonatkozó rendelkezések az alaptörvényben egymástól függetlenül, eltérő helyen találhatók meg, és ebből következően nem alkotnak elkülönült fejezetet az alaptörvényben. Ugyanakkor annak ellenére, hogy e rendelkezések a szabályozás felépítése szempontjából nem alkotnak külön egységet, a német jogrendszerben az alaptörvény

I Németország alaptörvénye (Grundgesetz für die Bundesrepublik Deutschland).

Dr. De Negri Laura

laura.negri.de@mfi.gov.hu

kutató (Mádl Ferenc Összehasonlító Jogi Intézet)

PhD-hallgató (Andrássy Egyetem, Interdiszciplináris Doktori Iskola)

De Negri, L. (2021) 'Németország, a többszintû́ válságkezelés iskolapéldája' in Nagy, Z., Horváth, A. (szerk.) A különleges jogrend és nemzeti szabályozási modelljei, 414-433. o. Budapest: Mádl Ferenc Összehasonlító Jogi Intézet.

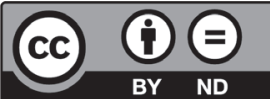


ezen rendelkezéseit közös jellegüknél fogva gyüjtőnéven sürgősségi alkotmánynak nevezik. A sürgősségi alkotmány olyan jogszabályi rendelkezések összességét képezi, amelyek lehetôvé teszik bizonyos rendkívüli intézkedések bevezetését. Németországban a sürgősségi alkotmány elsősorban az alaptörvény kiegészítéseként a Bundestag által 1968. május 30-án elfogadott sürgősségi törvényekből áll, amelyek a rendkívüli állapot esetköreit szabályozzák. A sürgősségi alkotmány elfogadását heves belpolitikai viták előzték meg, amelyek az 1968-as megmozdulásokhoz köthetők, amikor a parlamenten kívüli ellenzéki mozgalom utcai demonstrációk keretében rendkívül hevesen támadta azok bevezetését. ${ }^{2}$ A sürgősségi alkotmány rendelkezései 1968. június 28 -án léptek hatályba, és ezzel véget ért a közel tíz évig folyó vita a parlamenti és a parlamenten kívüli ellenzék között. ${ }^{3}$

A sürgősségi szabályok megalkotása során a többségi értelmezés szerint olyan sürgősségi szabályrendszert kellett létrehozni, amely válsághelyzetben nem írja felül az alaptörvényt, hanem speciális eszközökkel tartja fenn annak rendelkezéseit. Ezt alátámasztja az az érvelés is, amely szerint az olyan alkotmány, amelyet rendkívüli állapotban nem lehet fenntartani, értelmét veszti. ${ }^{4}$ Ugyanezt az álláspontot világosan taglalja az 1967-es alaptörvény-módosítási javaslat indokolása ${ }^{5}$ is, amely két korábbi sikertelen javaslat után megalapozta a végül 1968-ban hatályba lépő sürgősségi alkotmányt. A javaslat indokolása szerint az alaptörvénynek kötelező érvényú alaprendet kell meghatároznia az állam teljes jogi, politikai és társadalmi létére vonatkozóan. Ez alapvetően a nyugalom állapotára, a békés időszakok idejére vonatkozik, azonban ugyanúgy a válság idejére is érvényesnek kell lennie. Az alkotmány alapjául szolgáló és annak alapját képező alapértékeknek - hacsak az alkotmány nem akarja önmagát megkérdőjelezni - mindig ugyanazoknak kell lenniük, így békeidőben és válsághelyzetben is. Végrehajtásuk formáját és eszközeit azonban szükség esetén az adott körülményekhez kell igazítani, amennyiben hatékonyságuk ilyenformán fokozható. ${ }^{6}$

A német sürgősségi szabályozás 1968-ra teljességében kiforrta magát, és az alaptörvény kiegészült az általánostól eltérő állapotokra vonatkozó szabályozással, az alaptörvény 17. módosítására vonatkozó törvénnyel.7 A német alaptörvény ekkortól tartalmaz bizonyos vészhelyzetekre és válsághelyzetekre vonatkozó szabályokat. Az 1968-ban bevezetett sürgősségi alkotmány rendelkezései lényegesebb módosítások nélkül ma is érvényesek. ${ }^{8}$ Mindazonáltal szükséges megjegyezni, hogy a gyakorlatban az alaptörvényben sürgősségi alkotmány

2 A német alsóház (Bundestag) anyaga az 1968-as eseményekről összefoglaló jelleggel megtalálható: www. bundestag.de/dokumente/textarchiv/25458537_debatten05-200088 (Letöltve: 2020. december 3.).

3 Schweiger, 2005, 2. o.

4 Maunz-Dürig, 2020, Art. 115a Rn. 14.

$5 \mathrm{Az}$ alaptörvény módosítására irányuló törvényjavaslat (Entwurf eines Gesetzes zur Ergänzung des Grundgesetzes. V/1879.). Elérhető: http://dipbt.bundestag.de/doc/btd/05/018/0501879.pdf (Letöltve: 2020. december 3.).

6 Maunz-Dürig, 2020, Art. 115a Rn. 12-14.

$7 \mathrm{Az}$ alaptörvény módosítására irányuló 17. számú törvény (Siebzehntes Gesetz zur Ergänzung des Grundgesetzes vom 24. Juni 1968).

$8 \mathrm{Az}$ alaptörvény 35. cikk (2) bekezdésének 1. mondata kivételével, amelyet csak 1972-ben adtak hozzá. 
keretébe tartozó rendelkezések szövetségi szinten az eddigiek során - bármennyire is meglepő - még nem kerültek alkalmazásra. ${ }^{9}$

A német szövetségi alaptörvény a különleges jogrendi helyzeteknek két változatát ismeri: a külső és a belső rendkívüli helyzetet, amely esetkörök kapcsán külön alkategóriákat is nevesít. Külső rendkívüli helyzetről abban az esetben beszélhetünk, ha az ország területét fegyveres hatalom támadta meg, vagy ha ilyen támadás közvetlenül fenyeget. ${ }^{10}$ Belső vészhelyzet elrendelésének az az alapja, ha a szövetség vagy valamely tartomány létét, illetve szabad, demokratikus alaprendjét fenyegető veszély áll fenn, amely a fegyveres erők kibővített igénybevételének lehetőségét vonja magával, illetve a szövetségi kormányzat részére biztosít többletjogosítványokat. ${ }^{11} \mathrm{~A}$ külső és a belső rendkívüli helyzet kategóriáit az alaptörvény tovább bontja. Két esetkör vonatkozik a külső támadásokkal szembeni védekezésre, így a védelmi helyzet (Verteidigungsfall) és azt megelőzően, mintegy a védelmi helyzet előkészítési fázisaként a szükséghelyzet (Spannungsfall), míg a belső támadások elhárítására irányadó rendelkezések is két esetkörre fókuszálnak, a belső vészhelyzetre (innere Notstand) és a katasztrófahelyzetre (Katastrophenfall).

\subsection{Védelmi helyzet}

A német jogrendszerben a különleges jogrendi esetkörök között messze a legszélesebb körben szabályozott esetkör a védelmi helyzet esete. Az alaptörvény külön fejezetet, ${ }^{12}$ azon belül pedig tizenegy cikket szentel neki. ${ }^{13} \mathrm{~A}$ védelmi helyzet ${ }^{14}$ feltételezi, hogy a Német Szövetségi Köztársaság területét fegyveres hatalom támadta meg, vagy hogy egy ilyen támadás közvetlenül fenyeget. Mivel a védelem esete a külföldi katonai akciók okozta veszélyekre irányul, ez az esetkör egyértelmúen külső vészhelyzetnek számít. A védelmi helyzetet az alkotmány 82. cikkével összhangban a szövetségi elnök hirdeti ki a szövetségi hivatalos közlönyben. ${ }^{15} \mathrm{Ha}$ ez időben nem lehetséges, akkor más módon hirdeti ki, azonban amint a körülmények lehetővé teszik, a szövetségi hivatalos közlönyben is közzé kell tenni. ${ }^{16}$

A védelmi helyzet kihirdetésének következménye, hogy a szövetségi szint jogalkotási lehetôségei kibővülnek, és a törvényalkotással kapcsolatos követelmények egyszerübbé válnak. Ennek megfelelően a szövetség konkuráló törvényhozási jogkörrel rendelkezik azokban

9 Németországban az Európai Unió más tagállamaival ellentétben a jelenlegi Covid-19-válság kapcsán elfogadott intézkedések és az alapvetô jogok korlátozásai nem a szövetségi alaptörvényben lefektetett rendkívüli állapotokra vonatkozó rendelkezéseken alapulnak.

10 Németország alaptörvénye 115. cikk (1) bekezdés.

11 Németország alaptörvénye 91. cikk.

12 Lásd Németország alaptörvényének X/A. fejezetét.

13 Schäfer, 2020.

14 Németország alaptörvénye 115/A. cikk (1) bekezdés.

15 Németország alaptörvénye 115/A. cikk (3) bekezdés.

16 Németország alaptörvénye 115/A. cikk (3) bekezdés. 
a tárgykörökben is, amelyek egyébként a tartományok törvényhozási hatáskörébe tartoznak, azonban ebben az esetben is szükséges a Szövetségi Tanács jóváhagyása. ${ }^{17}$

A törvényhozási eljárás egyszerúbbé válásának keretében a kormány mindkét házhoz egyszerre nyújtja be törvényjavaslatait, amelyeket haladéktalanul együtt vitat meg a Szövetségi Gyúlés (első kamara) és a Szövetségi Tanács (második kamara), itt az ügyrendi szabályok is részben eltérnek, amelynek részleteit a Szövetségi Gyúlés által elfogadott és a Szövetségi Tanács által jóváhagyott ügyrend szabályozza. ${ }^{18} \mathrm{~A}$ fegyveres erők feletti közvetlen irányítási jog a kancellárt illeti meg, ${ }^{19}$ a kormányzat pedig a szövetségi határőrség egységeit a szövetségi köztársaság egész területén bevetheti, és a tartományi egységeknek is utasításokat adhat. ${ }^{20}$

Annak megállapítására, hogy az ország területét fegyveres hatalom támadta meg, vagy hogy egy ilyen támadás közvetlenül fenyeget, a Szövetségi Tanács jóváhagyásával a Szövetségi Gyúlés jogosult. A megállapítás a szövetségi kormány javaslatára történik, és a Szövetségi Tanács tagjai több mint felének jelenléte esetén a leadott szavazatok kétharmados többségére van szükség. ${ }^{21} \mathrm{Ha}$ a helyzet halaszthatatlanul azonnali cselekvést igényel, és a Szövetségi Gyúlés időben történő összeülése leküzdhetetlen akadályokba ütközik vagy nem határozatképes, akkor a Közös Bizottság jogosult a védelmi helyzet megállapítására. Ilyenkor a tagok több mint felének jelenléte esetén a leadott szavazatok kétharmadára szükség van..$^{22}$ A Közös Bizottság ilyenkor átveszi mindkét ház jogköreit, ám törvényével az alaptörvényt sem megváltoztatni, sem egészében vagy részben hatályon kívül helyezni vagy felfüggeszteni nem jogosult. Adott szabályozási tárgykörök tekintetében is korlátozott a törvényalkotási joga. ${ }^{23}$ A Közös Bizottság kétharmad részben a Szövetségi Gyưlés képviselőiből, egyharmad részben a Szövetségi Tanács tagjaiból áll. Ennek képviselőit a Szövetségi Gyúlés a frakciók erőviszonyainak megfelelően nevezi ki, de nem lehetnek tagjai a szövetségi kormánynak. Minden tartományt a Közös Bizottságban a Szövetségi Tanács egy-egy általa kinevezett tagja képvisel, ezeket a tagokat semmiféle utasítás nem köti. A Közös Bizottság szervezetét és eljárását külön ügyrend szabályozza, amelyet a Szövetségi Gyuulés fogad el, ám szükséges hozzá a Szövetségi Tanács egyetértése. ${ }^{24}$

\subsection{Szükséghelyzet}

A védelmi helyzet kihirdetésének megelőző esetkörét képezi a Szövetségi Gyúlés által megállapítható szükséghelyzet, amelynek keretében a törvények a védelmi készültség megemelésére, a harci erők és a polgári lakosság ellátásának biztosítására nyújtanak lehetőséget.

17 Németország alaptörvénye 115/C. cikk (1) bekezdés.

18 Németország alaptörvénye $115 / \mathrm{D}$. cikk (2) bekezdés.

19 Németország alaptörvénye 115/B. cikk.

20 Németország alaptörvénye 115/F. cikk (2) bekezdés.

21 Németország alaptörvénye 115/A. cikk (1) bekezdés.

22 Németország alaptörvénye 115/A. cikk (2) bekezdés.

23 Németország alaptörvénye 115/E. cikk (1)-(2) bekezdés.

24 Németország alaptörvénye 53/A. cikk. 
A szükséghelyzetet az alaptörvény nem konkretizálja és nem tárgyalja a védelmi helyzethez hasonló részletességgel. Ez az állapot kiéleződött külpolitikai konfliktushelyzetet jelent, ami nagy valószínűséggel fegyveres támadáshoz vezethet. A szükséghelyzet tehát a védelmi helyzetet megelőző állapot, amely akkor áll fenn, ha okkal valószínúsíthető, hogy egy külpolitikai konfliktushelyzet kiéleződik és fegyveres támadáshoz vezet. Ez az értelmezés megfelel annak az alkotmány meghozatala során jellemző elképzelésnek is, amely a hidegháború kontextusában létrehozta a sürgősségi alkotmányt. ${ }^{25}$

A szükséghelyzet megállapítására a Szövetségi Gyuulés jogosult a leadott szavazatok kétharmados többségével, de ezeket az intézkedéseket is hatályon kívül kell helyezni, ha a Szövetségi Gyúlés azt kívánja. ${ }^{26}$ Polgári objektumok védelmét és a forgalomszabályozást szükséghelyzetben a fegyveres erôk látják el. ${ }^{27} \mathrm{Az}$ alaptörvény nemcsak nem határozta meg a szükséghelyzetet, de ennek az esetkörnek a jogi következményei is nagyrészt nem magából az alaptörvényből fakadnak, hanem a klasszikus törvények azon rendelkezéséből, amelyek az alaptörvény 80a. cikkén alapulnak, vagyis amely törvényi rendelkezések abban az esetben alkalmazhatók, ha a Szövetségi Gyúlés megállapítja a szükséghelyzet beálltát, vagy ha e bizonyos törvényi rendelkezések alkalmazását külön jóváhagyták. A szóban forgó törvényi rendelkezések célja főként a közélet fontos területeinek fenntartása válság esetén, mint például az élelmiszer- és energiaellátás, valamint a közlekedés és az orvosi ellátás.

Az általánostól eltérő állapotok körébe tartozó esetkörök között a külső vészhelyzet mellett a német jogrendszer a belső támadások elleni eseteknek is két fajtáját ismeri: a belső vészhelyzetet és a katasztrófahelyzetet.

\subsection{Belső vészhelyzet}

A belső vészhelyzet tényállására az alaptörvény szintén nem tartalmaz explicit meghatározást, azonban a belső vészhelyzetre vonatkozó alaptörvényi rendelkezésekből megállapítható, hogy ez akkor áll fenn, ha a szövetségi kormány, illetve egy tartomány létét vagy szabad demokratikus alaprendjét fenyegető veszély elhárítása szükséges. ${ }^{28}$ Belső vészhelyzet esetén a tartománynak lehetősége nyílik arra, hogy igénybe vegye más tartományok rendőri erejét, egyéb intézmények, valamint a szövetségi határőrség személyi állományát. Ha az érintett tartomány nem képes a veszély leküzdésére, a szövetségi kormány e tartomány vagy más tartományok rendőri erőit utasítása alá vonhatja, valamint igénybe veheti a szö-

25 Schäfer, 2020, 6. o.

26 Németország alaptörvénye 80/A. cikk.

27 Németország alaptörvénye 87/A. cikk (4) bekezdés.

28 Németország alaptörvénye 91 . cikk (1) bekezdés. 
vetségi határőrség egységeit is. ${ }^{29}$ Amennyiben a vészhelyzet egynél több tartományt érint, úgy a szövetségi kormány utasíthatja a tartományok kormányait. ${ }^{30}$

\subsection{Katasztrófahelyzet}

Az alaptörvény 35. cikke a katasztrófaesemények körébe a természeti katasztrófákat és a különösen súlyos baleseteket (besonders schwerer Unglücksfall) sorolja. A tényállás szempontjából nincs jelentősége annak, hogy adott esetben a katasztrófaesemény az ország határain kívülre nyúlik, vagy ha a különös intézkedést kívánó helyzet nem csupán egy tartományt érint. ${ }^{31}$ A katasztrófahelyzet leggyakrabban a természeti katasztrófákkal azonosítható. Ilyenformán a természeti katasztrófa kifejezése magában foglalja például az áradásokat, a rendkívüli havazást, az aszályt vagy az erdőtüzeket.

Különösen súlyos baleset az, amely fontossága miatt különösen jelentős negatív hatást gyakorol a közjavakra, és emberi tévedések vagy technikai hiányosságok eredménye. A különösen súlyos baleset fogalma nyitott fogalom, és pontos meghatározása okkal hiányzik, hiszen azok a tényezők, amelyek meghatározók lehetnek a balesetek különös súlyossága szempontjából, annyira változatosak, hogy a különösen súlyos baleset fogalmának meghatározását nem teszik lehetővé. ${ }^{32} \mathrm{~A}$ különösen súlyos balesetek közé tartoznak például a súlyos károkat okozó vasúti balesetek, repülőgép-szerencsétlenségek vagy reaktorbalesetek, ám a fogalom nyitottságából fakadóan ez az esetkör számos egyéb, előre meg nem határozott helyzetre is kiterjed..$^{33}$

A katasztrófahelyzet esetére hasonló rendelkezéseket találunk, mint a belső vészhelyzetre vonatkozóan. A fó felhatalmazott a szövetségi kormány, amely az eredményes védekezéshez szükséges mértékben a tartományi kormányoknak elrendelheti, hogy rendfenntartói erőiket bocsássák más tartományok rendelkezésére, valamint a szövetségi határőrség és rendőrség erőit/egységeit vessék be a rendfenntartó erők támogatására. ${ }^{34}$

Tekintettel arra, hogy Németország szövetségi állam, a német modellben a rendkívüli helyzetek kezelésének hatásköre megoszlik a szövetségi szint és a tartományok között. A szövetségi alkotmány rendszerében a szövetségi kormányzat felel a háborús helyzetekkel öszszefüggő veszélyekkel szembeni fellépésért, míg békeidőben a tartományok felelnek a jelentősebb természeti katasztrófákkal és szerencsétlenségekkel szembeni védelemért. A külső és a belső vészhelyzet közötti különbség megjelenik a támadás irányában, az érintett földrajzi terület nagyságában, gazdasági hatásaiban, a személyek és jogintézmények körében

29 Németország alaptörvénye 87/A. cikk.

30 Németország alaptörvénye 91 . cikk.

31 Maunz-Dürig, 2020, Art. 35 Rn. 127.

32 Maunz-Dürig, 2020, Art. 35 Rn. 128.

33 Maunz-Dürig, 2020, Art. 35 Rn. 130.

34 Németország alaptörvénye 35 . cikk. 
csakúgy, mint a tevékenységre feljogosított szervek szintjében. Közös jellemző, hogy a támadások eredményeként az állami élet jelentős zavara jön/jöhet létre, amely általában nem kezelhető az alaptörvényben elő́rt „szokásos” eszközökkel, hanem különleges intézkedések megtételét igényeli.

Említést érdemel, hogy a német modellben a védelmi helyzetre vonatkozó rendelkezések oly módon lettek kialakítva, hogy az alkotmányos rend és a parlamenti kormányzati rendszer megfelelő müködésének fenntartása az általánostól eltérő állapotokban is fenntartható legyen, amennyire azt a körülmények lehetôvé teszik. ${ }^{35}$

Az alaptörvényben szabályozottól eltérő rendkívüli felhatalmazási esetköröket nem találunk. Alapvetően az alaptörvényben szabályozottaknak részletesebb rendelkezéseit foglalják össze a további törvényi szabályok, illetve a polgári és katasztrófavédelem területén való fellépést fektetik le további törvényi rendelkezések, amelyeknek központi kérdése a szövetségi szint és a tartományok közötti hatáskörök megosztása. Ugyancsak törvényi szinten nyert szabályozást az alapjogok korlátozhatósága a rendkívüli helyzetek esetében.

A német jog egyik sajátosságának tekinthetô, hogy nincs külön végrehajtási törvény sem a sürgősségi alkotmány egészére, sem pedig az egyes rendkívüli helyzetekre. Egyes törvények az „általános helyzetre” vonatkozó előírások mellett tartalmaznak olyan speciális szabályokat is, amelyek csak rendkívüli helyzetben alkalmazhatók. Innen ered ezen törvényi rendelkezéseknek a ,tároló jellegư” jellemzése. Nevezetesen, a jogszabályok tároló jellege oly módon értelmezendő, hogy a rendkívüli helyzetekre vonatkozó szabályok ugyan már hatályba léptek, azonban joghatást csak akkor fejtenek ki, ha a rendkívüli állapotok valamely esetköre kihirdetésre kerül. Az elővigyázatosságból korábban már meghozott és hatályba léptetett rendkívüli helyzetek kezelésére szolgáló jogszabályok tehát csak akkor alkalmazhatók, ha a rendkívüli helyzet valóban létrejött.

\section{Az alapjogok korlátozása különleges jogrend keretében}

Az alapjogok korlátozására vonatkozóan le kell szögezni, hogy a német jogrendszer különbséget tesz a különleges jogrend idején alkalmazható alapjog-korlátozási lehetőségek között és a különleges jogrenden kívül alkalmazható korlátozások között. A német alaptörvény több alapjog-korlátozási lehetőséget is ismer, míg a korlátozások konkretizációja az ágazati szabályozásban jelenik meg az alaptörvényi felhatalmazás mentén.

Az alaptörvény 19. cikke a korlátozások általános követelményeit fekteti le. Így amenynyiben az alaptörvény értelmében alapjogot törvénnyel vagy törvény alapján korlátozni lehet, a törvény általánosságban és nem csak egyedi esetben hatályos. ${ }^{36}$ Ezenkívül a törvénynek 
meg kell jelölnie az alapjogra vonatkozó cikket. Alapjog lényeges tartalmát semmiképpen nem lehet érinteni. ${ }^{37} \mathrm{Az}$ alapjogok belföldi jogi személyekre is vonatkoznak, amennyiben azok lényegüknél fogva az alapjogok alkalmazási körébe esnek..$^{38}$ Amennyiben a közhatalom valaki jogát megsérti, annak a törvényes út nyitva áll jogorvoslatra. Amennyiben egyéb hatáskör megállapítására nincs mód, a rendes bíróságokhoz kell fordulni (kivéve titokkörök korlátozásának népképviseleti felülvizsgálata esetén). ${ }^{39}$

Emellett az alaptörvény rendelkezik az alapjogok esetleges elvesztéséről is. A 18. cikk szerint az, aki a véleménynyilvánítás szabadságát, különösen a sajtószabadságot, a tanítás szabadságát, a gyülekezési szabadságot, az egyesülési szabadságot, a levél-, postai és távközlési titkot, a tulajdon szabadságát vagy a menedékjogot a szabad, demokratikus alaprend elleni küzdelem céljára történő visszaélésekre használja fel, ezeket az alapjogokat elveszíti. Az elvesztést és annak terjedelmét a szövetségi alkotmánybíróság állapítja meg. ${ }^{40}$

Az általános alapjog-korlátozási lehetőségek mellett az alaptörvény bizonyos rendelkezései a különleges jogrendi helyzetekre állapítanak meg alapjog-korlátozási szabályokat.

Az alaptörvény 10. cikke szerint a levéltitokkal, valamint a postai és távközlési titokkal kapcsolatos korlátozásokat csak törvény alapján lehet elrendelni. Ha a korlátozó intézkedések az ország vagy valamely tartomány szabad és demokratikus alaprendjének vagy biztonságának védelmét szolgálják, törvény úgy rendelkezhet, hogy ezeket az intézkedéseket nem hozzák az érintett személy tudomására, és ezt a bírósági eljárás helyett a népképviselet által kinevezett szerv és annak segítő szervei vizsgálják felül. ${ }^{41}$

Az alaptörvény 11. cikke szerint a mozgásszabadság akkor korlátozható, ha az a Szövetség vagy valamely tartomány szabad és demokratikus alaprendjét fenyegetô veszély elhárítása, járvány elleni harc, természeti katasztrófa vagy más különlegesen súlyos szerencsétlenség esetén feltétlenül szükséges. ${ }^{42}$

Az alaptörvény 12/A. cikke a hadkötelezettséget szabályozza. Eszerint, aki lelkiismereti okok miatt a fegyveres hadi szolgálatot megtagadja, az kisegítő szolgálatra kötelezhetô. Azok a hadkötelesek, akiket szolgálatra nem hívtak be, a védelem szükségességének idején törvényben vagy törvény alapján védekező célú polgári szolgálat teljesítésére kötelezhetők, beleértve a polgári lakosság védelmét is. ${ }^{43} \mathrm{~A}$ védelem szükségességének idején a szolgálatteljesítés a polgári egészségügy és a gyógyítás területén, úgyszintén az állandó katonai kórházban nem önkéntes alapon látható el, tizennyolcadik életévüket betöltött nők ötvenöt éves korukig törvény alapján hasonló polgári szolgálatteljesítésre vonultathatók be. Ők fegyveres szolgálatra semmilyen esetben nem kötelezhetők. A védelmi helyzetet megelőző időszakban

\footnotetext{
37 Németország alaptörvénye 19. cikk (2) bekezdés.

38 Németország alaptörvénye 19. cikk (3) bekezdés.

39 Németország alaptörvénye 19. cikk (4) bekezdés.

40 Németország alaptörvénye 18. cikk (1) bekezdés.

41 Németország alaptörvénye 10. cikk.

42 Németország alaptörvénye 11. cikk (2) bekezdés.

43 Németország alaptörvénye 12/A. cikk (3) bekezdés.
} 
a polgári szolgálatteljesítés csak a 80/A. cikk (1) bekezdése, azaz szükséghelyzeti feltételek alapján rendelhető el. Amennyiben e polgári szolgálatteljesítéshez különleges ismeretek vagy jártasságok szükségesek, törvényben vagy törvény alapján kiképzésben való kötelező részvétel írható elő. Ha a védelem szükségessége alapján a fegyveres erők, az azokat ellátó szolgáltatók vagy a közigazgatás területén olyan munkaerőigény állna elő, amelyet önkéntes alapon nem lehet kielégíteni, a németek hivatásuk betöltésére vagy munkahelyválasztására elismert jogai törvényben vagy törvény alapján felfüggeszthetők. ${ }^{44}$

Az alaptörvény 13. cikke a magánlakás sérthetetlensége kapcsán lefekteti, hogy beavatkozás és korlátozás csak törvény alapján, általános veszély, egyes személyeket érintő életveszély, valamint a közbiztonságot és közrendet fenyegető közvetlen veszély megelőzése, különösen lakáshiány enyhítése, járványveszély leküzdése, valamint veszélyeztetett fiatalkorúak védelme érdekében lehetséges. ${ }^{45}$

Az alaptörvény 17/A. cikke alapján különleges esetekben van az alapjogok korlátozásának egy speciális, kollektív joggyakorlás korlátozására vonatkozó esetköre is. Így a katonai és kisegítő szolgálatról rendelkező törvények korlátozhatják a katonai vagy kisegítő szolgálat idején a fegyveres erôk és a kisegítő szolgálat tagjainak a szóban, írásban és kép formájában történő szabad véleménynyilvánításhoz és annak terjesztéséhez való jogát, a gyülekezési szabadsághoz való alapjogot, valamint a petíciós jogot. Azok a törvények, amelyek a honvédelmet - beleértve a polgári lakosság védelmét is - szolgálják, meghatározzák a szabad mozgás és a lakóhely szabad megválasztásának sérthetetlenségére vonatkozó alapvető jog korlátozását. ${ }^{46}$

A hadkötelezettségre vonatkozó szabályok alapját az alaptörvény mellett a katonai szolgálatról szóló törvény ${ }^{47}$ képezi. E források különbséget tesznek a békeidejư, illetve a védelmi helyzetben irányadó hadkötelezettségi szabályozás között. A törvény a katonai szolgálat többféle típusát ismeri, ${ }^{48}$ az alapvető katonai szolgálattól, illetve gyakorlattól az önkéntes kiegészítő katonai szolgálaton át a külföldi, illetve belföldi alternatív (polgári) szolgálatig. Főszabályként - így békeidőben - a hadkötelezettség annak az évnek a végéig áll fenn, amikor a kötelezett betölti 45. életévét. Védelmi vagy szükséghelyzet elrendelése esetén azonban ez kitolódik a 60. életévig. 2011 óta békeidőben nem él az általános sorkatonai kötelezettségre vonatkozó szabály, ugyanakkor az alaptörvény értelmében minden 18. életévét betöltött férfi állampolgár kötelezhető a haza védelmére. ${ }^{49} \mathrm{E}$ rendelkezés békeidőre azonban nem eltörlésre, hanem felfüggesztésre került, így - például szükségállapot elrendelése esetén - visszaállítható.

A szövetségi polgári és katasztrófavédelmi törvény ${ }^{50}$ is visszautal a különleges jogrendi esetkörökre. A hatáskörmegosztási elv alapján, ha e törvény a tartományokat, beleértve

44 Németország alaptörvénye 12/A. cikk (6) bekezdés.

45 Németország alaptörvénye 13. cikk (7) bekezdés.

46 Németország alaptörvénye 17/A. cikk.

47 A katonai szolgálatról szóló törvény (Wehrpflichtgesetz [WPflG]).

48 A katonai szolgálatról szóló törvény 4. cikk.

49 Németország alaptörvénye 12/A. cikk (1) bekezdés.

50 Gesetz über den Zivilschutz und die Katastrophenhilfe des Bundes (a továbbiakban: Kat.védelmi tv.). 
az önkormányzatokat kötelezi, akkor azok a szövetség nevében járnak el. Ha másképp nem fektették le, az eljáró hatóságok hatáskörére és eljárására a tartományok katasztrófavédelmi rendelkezéseit kell megfelelően alkalmazni. ${ }^{51}$ Ezen túlmenően szövetségi szerv felel a katasztrófavédelemért, amely elsősorban az egységes védelmi tervezés tekintetében a szövetségi szervek közti koordinációs feladatok ellátását jelenti. ${ }^{52}$ Önvédelmi felkészülés védelmi helyzetekben elsősorban az önkormányzatok feladata..$^{53}$ Tartózkodási hely kijelölése (mint alapjog-korlátozás) és a katasztrófavédelmi szervek szélesebb körú bevonása, egészségügyi ellátás megszervezése kapcsán is visszautal e törvény a védelmi helyzetre (amikor általában a tartományi szervek fellépése elsődleges). ${ }^{54}$ Ennek keretében azt is rögzíti, hogy az abban meghatározott mértékig a sérthetetlenség, a személyes szabadság és szabad mozgás joga, valamint a magánlakás sérthetetlensége mint alapjogok és alapjogi garanciák korlátozhatók. ${ }^{55}$

Hasonló korlátozásokat tartalmaz a járványügyi szabályozás is. Az alapjogok korlátozása kapcsán ki kell térni a fertőző betegségek leküzdéséről és megelőzéséről szóló törvény ${ }^{56}$ rendelkezéseire. A törvény előírja, hogy jelentési kötelezettség keletkezik adott törvényi körbe tartozó betegségtípusok miatti halál vagy adott kórokozók miatti közvetlen fertőzés vagy arra utaló jelek esetén, valamint akkor is, ha bármely fertőző betegség felmerülése fenyeget. ${ }^{57}$ A szövetségi katasztrófavédelmi törvény szerint védelmi helyzetekben a lakosság egészségügyi ellátásával kapcsolatban kiegészítő feladatai vannak a tartományi jog szerint meghatározott szerveknek és a szövetségnek. ${ }^{58}$

\section{Az egészségügyi vészhelyzet kezelése és a koronavírus-járvány}

Amint azt már e fejezet elején említettük, az alaptörvény sürgősségi szabályozásának eddig nem volt szerepe a német jogi gyakorlatban. Ez a koronavírus okozta válság idején sem változott, noha a válság részeként hozott intézkedések köre kétségkívül megfeleltethetô egy kivételes helyzetnek. Ennek ellenére Németországban az egészségügyi vészhelyzet nem képez különleges jogrendi esetkört, ehelyett egy külön, speciális kategóriát alkot. Ennek kapcsán tisztázandó, hogy Németországban a járványkezelés keretében hozott intézkedések

51 Kat.védelmi tv. 2. cikk (1) bekezdés.

52 Kat.védelmi tv. 4. cikk.

53 Kat.védelmi tv. 5. cikk.

54 Kat.védelmi tv. 10-11. cikk.

55 Kat.védelmi tv. 31. cikk.

56 Gesetz zur Verhütung und Bekämpfung von Infektionskrankheiten beim Menschen (a továbbiakban: Fertőzésvédelmi tv.).

57 Fertőzésvédelmi tv. 6. cikk.

58 Kat. védelmi tv. 21-24. cikk. 
és a vírushelyzetben alkalmazott alapvetô jogok korlátozásai nem a szövetségi alaptörvényben lefektetett rendkívüli helyzetekre vonatkozó rendelkezéseken alapulnak.

A koronavírussal összefüggésbe hozható német szabályozás alapvetően ágazati szabályozási elemek módosításával valósult meg. Ez pedig a járvány leküzdésével összefüggő új intézkedésre való felhatalmazás formájában konkretizálódott. Az alaptörvény 74. cikke kimondja, hogy az emberekre veszélyes vagy embereket fertőző betegségek elleni intézkedések meghozatala során konkuráló jogalkotási hatáskör áll fenn..$^{59}$

Németországban a koronavírus-járvány leküzdését célzó intézkedések első mozzanata a társadalmi kapcsolatok korlátozására vonatkozó iránymutatások voltak, amelyekről a szövetségi kancellár és a szövetségi államok kormányfői 2020. március 12-én állapodtak meg, és amelyeket 2020. március 22-én tovább bővítettek. ${ }^{60} \mathrm{Az}$ első lépéseket követően, három nappal később, március 25-én a Szövetségi Gyúlés egy jogszabálycsomagot fogadott el a koronavírus-járvánnyal kapcsolatban, amelyet a Szövetségi Tanács 2020. március 27-én jóváhagyott, majd ugyanazon a napon közzétettek a szövetségi hivatalos közlönyben.

Az elfogadott törvénycsomag ${ }^{61}$ leglényegesebb eleme a Fertôzésvédelmi tv. módosítása. Emellett egy sor intézkedést hoztak az élet egyéb területeire vonatkozóan, valamint ezen intézkedések finanszírozására kiegészítő költségvetést fogadtak el.

Ugyancsak 2020. március 25-én a Szövetségi Gyúlés úgy határozott, hogy megváltoztatja eljárási szabályzatát annak érdekében, hogy a járványhelyzet idejére is fenntarthassa határozatképességét. Az eljárási szabályzat 126a. cikke szerint a Szövetségi Gyúlés 2020. szeptember 30-ig határozatképes volt, ha tagjainak több mint egynegyede jelen van az ülésteremben; a tagok több mint fele helyett, ami egyébként a járványhelyzetet megelőző általános követelmény volt. A javaslatban megfogalmazott indokolás alapját az képezte, hogy a koronavírus által okozott negatív hatások ellenére is biztosítani kell a német Szövetségi Gyúlés múködését, illetve azt, hogy a Szövetségi Gyưlés mindenkor elvégezhesse alkotmányos feladatait. Ugyanakkor biztosítani kell azt is, hogy a fertőzésveszély elleni intézkedéseket mindenki betartsa. Ennek értelmében az új eljárási szabályzat azt is elöírja, hogy a szavazáshoz és a döntéshozatalhoz elektronikus kommunikációs eszközök is alkalmazhatók. ${ }^{62}$

A Szövetségi Gyúlés a Covid-19-törvénycsomag elfogadásával párhuzamosan nemzeti jelentőségú járványhelyzetet hirdetett ki. Ezt a különösen fertőző betegségek leküzdéséről

59 Németország alaptörvénye 74. cikk (1) bekezdés 19. pont.

60 A társadalmi kapcsolatok korlátozása érdekében elfogadott iránymutatások bővítése (Erweiterung der beschlossenen Leitlinien zur Beschränkung sozialer Kontakte). Elérhetô: www.bundesregierung.de/breg-de/themen/ coronavirus/besprechung-der-bundeskanzlerin-mit-den-regierungschefinnen-und-regierungschefs-derlaender-1733248 (Letöltve: 2020 . december 10.).

61 A lakosság védelméről szóló 2020. március 27-i törvény nemzeti járványhelyzet idején (Gesetz zum Schutz der Bevölkerung bei einer epidemischen Lage von nationaler Tragweite vom 27. März 2020.).

62 A Szövetségi Gyúlés eljárási szabályzatának módosítása (Änderung der Geschäftsordnung des Deutschen Bundestages hier: Regelung zur besonderen Anwendung der Geschäftsordnung aufgrund der allgemeinen Beeinträchtigung durch COVID-19 sowie Änderung der Anlage 6 GO-BT. 19/18126.). Elérhető: https://dip21. bundestag.de/dip21/btd/19/181/1918126.pdf (Letöltve: 2020. december 7.). 
és megelőzéséről szóló törvényben eszközölt módosítások tették lehetôvé. A módosított törvény 5. cikke rögzíti, hogy a német Szövetségi Gyûlés országos következményekkel járó járványhelyzetet hirdethet, továbbá hogy az országos szintû járványhelyzetet megszünteti, ha annak feltételei már nem állnak fenn. A járványhelyzet kihirdetését és megszüntetését közzé kell tenni a szövetségi hivatalos közlönyben. ${ }^{63} \mathrm{~A}$ törvény ezen a ponton meghatározza az országos szintú járványhelyzet fogalmát is. Eszerint országos jelentőségú járványhelyzet akkor áll fenn, ha a Német Szövetségi Köztársaság egész területén a közegészségügy komoly kockázatnak van kitéve, mert az Egészségügyi Világszervezet nemzetközi kiterjedésú egészségügyi vészhelyzetet hirdetett, és fertőző betegségnek az országba történő behozatala fenyeget, vagy ha fertőző betegség dinamikus terjedése a Német Szövetségi Köztársaság több tartományát fenyegeti, vagy fertőző betegség terjedése zajlik. ${ }^{64}$

A fertőző betegségek leküzdéséről és megelőzéséről szóló törvény legnagyobb újítása kétségkívül az, hogy a nemzeti jelentőségú járványhelyzetben a szövetségi államok hatásköreinek sérelme nélkül a Szövetségi Egészségügyi Minisztérium felhatalmazást kap minden olyan intézkedés megtételére, amely a járványhelyzet szempontjából releváns. Németországban tehát a járványügyi törvény módosítása alapján az egészségügyi miniszter számos jelentős jogosítványhoz jutott, így különösen ahhoz, hogy a járványhelyzet leküzdése érdekében rendeleteket is alkothat. ${ }^{65}$

A fertőző betegségek leküzdéséról és megelőzéséről szóló törvény a koronavírussal szembeni harc keretében hozott intézkedések kapcsán lefekteti azok tartamát is. A törvény kimondja, hogy a szövetségi tartományok által bevezetett korlátozó rendelkezések érvényességi ideje négy hét, ez az időtartam azonban meghosszabbítható. ${ }^{66} \mathrm{~A}$ továbbiakban a törvény rögzíti azt is, hogy azon rendelet, amelyet a helyzet szükségessége miatt a Szövetségi Egészségügyi Minisztérium a Szövetségi Gyủlés jóváhagyása nélkül hozott meg, a hatálybalépést követő egy év után hatályát veszti, azonban a Szövetségi Gyưlés hozzájárulásával hatálya meghosszabbítható. ${ }^{67}$ A Fertőzésvédelmi tv. szerint a tartományok kapcsolódó részletszabályokat fektethetnek le. ${ }^{68}$ Ezenkívül a tartományok saját hatáskörben dönthetnek a szövetségi iránymutatástól való regionális eltérésről, azok módosításáról, korlátozó intézkedések enyhítéséről vagy azok szigorításáról. A Fertőzésvédelmi tv. rendelkezéseinek végrehajtása az alaptörvény 83. cikkével összhangban a szövetségi tartományok közigazgatásának hatáskörébe tartozik.

A járványhelyzet kezelése során a szövetségi tartományok kormányai maradtak az elsődleges szereplők. A tartományok és a szövetség közötti megosztott hatáskörök rendszere

63 Fertőzésvédelmi tv. 5. szakasz (1) bekezdés.

64 Fertőzésvédelmi tv. 5. szakasz (2) bekezdés.

65 Fertőzésvédelmi tv. 5. szakasz (4) bekezdés.

66 Fertőzésvédelmi tv. 28a. cikk (5) bekezdés.

67 Fertőzésvédelmi tv. 15. szakasz (2) bekezdés.

68 Az egyes tartományi részletszabályokról lásd bővebben az alábbi forrást: www.bundesregierung.de/breg-de/ themen/coronavirus/corona-bundeslaender-1745198 (Letöltve: 2020. június 9.). 
szerint a szövetségi törvények végrehajtására a tartományok rendelkeznek kizárólagos hatáskörrel, és ezt a Fertőzésvédelmi tv. 32. szakasza is megerősíti. Ennek eredményeként a Fertőzésvédelmi tv.-ben felsorolt intézkedéseket csak a tartományok kormányai hajthatják végre. Ugyanígy a tartományok kormányai felelősek a korlátozások fokozatos feloldásáért is.

A Fertőzésvédelmi tv. alapján hozott intézkedéseken kívül előfordult olyan eset is, hogy egy tartomány a saját területére nézve katasztrófahelyzetet hirdetett. İgy történt például, hogy Bajorország a járványhelyzet miatt katasztrófahelyzetet hirdetett, ami a bajor katasztrófavédelmi törvény alkalmazását hozta magával. Ez a különleges rendszer lehetôvé tette a bajor belügyminisztérium számára, hogy az egész területet érintő összes illetékes hatóság fellépését koordinálja. Hasonló rendelkezések találhatók más tartományok jogszabályaiban, mivel a katasztrófavédelem a tartományok hatáskörébe tartozik.

A szövetségi szintû Fertőzésvédelmi tv. mellett két tartományi parlament további fertőzésvédelmi törvényeket is alkotott saját területére nézve. Bajorország parlamentje már 2020. március 25 -én elfogadta a Bajor fertőzésvédelmi törvényt, ${ }^{69}$ nem sokkal később pedig Észak-Rajna-Vesztfália is hatályba léptette a tartományi szintű fertőzésvédelemre és ehhez kapcsolódó jogkörökre vonatkozó törvényt ${ }^{70}$ saját területére nézve. ${ }^{71}$

\section{A járványügyi vészhelyzet kihirdetésével kapcsolatos jogviták}

A közéletet 2020. március közepe óta jelentős mértékben korlátozó intézkedések számos jogi eljárás tárgyát képezték és képezik jelenleg is Németországban. Az említett eljárások nagyrészt a koronavírus elleni küzdelem érdekében hozott intézkedések jogi megalapozottságát és alkotmányosságát vizsgálják, valamint a bevezetett intézkedések arányosságának kérdésével foglalkoznak, különös tekintettel az egyének (felperesek) alapvető jogainak korlátozása (mozgásszabadság, gyülekezési jog, vallásszabadság stb.) és a lakosságot fenyegető fertőzés elleni védelem közötti egyensúly kérdését feszegetve. A fertôzés elleni védelem keretében már számos döntés született gyülekezési tilalmakról, a vallási szertartásokon történő részvétel tilalmáról, kijárási korlátozásokról, az üzletek és más szolgáltatóipari egységek bezárásáról, valamint a szövetségi tartományok koronavírusra vonatkozó rendeletei alapján hozott egyéb intézkedésekről.

Az eddigi határozatokban a bíróságok országszerte támogatták az állam korlátozó intézkedéseit, néhány eset kivételével. Ez azt jelenti, hogy a német közigazgatási bírák megalapozottnak találták a vírus elleni küzdelemben hozott intézkedések túlnyomó részét. Ugyanakkor a bíróságok több ízben is egyértelmúvé tették, hogy ezeket a korlátozásokat csak

69 Bajor fertőzésvédelmi törvény (Bayerisches Infektionsschutzgesetz [BayIfSG]).

70 Észak-Rajna-Vesztfália fertőzésvédelmi és ehhez kapcsolódó jogkörökről szóló törvénye (Infektions- und Befugnisgesetz, [IfSBG NRW]).

71 Venice Commission, 2020. 
egyértelmúen meghatározott ideig lehet fenntartani. Egy hasonló döntés született például 2020 októberében, amelyben a koblenzi közigazgatási bíróság határozata indoklásában kifejtette, hogy a karantén tartamát annak elrendelése esetén időben korlátozni kell. ${ }^{72}$

A témára reflektáló szakcikkekben, amelyek 2020. március közepe óta reagálnak a Covid-19-járvány kezelésére, a meghozott intézkedések kivételes jellege többször is kritika tárgya volt, továbbá egyes szerzők a téma kapcsán egészen addig merészkednek, hogy a jelenlegi állapotot Németország eddigi legmasszívabb alapjogi beavatkozásaként aposztrofálják. ${ }^{73}$ Akad olyan álláspont is, amely szerint a fertőző betegségek leküzdéséről és megelőzéséről szóló törvény általánossá teszi a szükségállapotot: a szövetségi egészségügyi miniszter azon jogosítványát, hogy szinte bármilyen intézkedést meghozzon, ${ }^{74}$ a weimari sürgősségi rendeletekkel ${ }^{75}$ állítják párhuzamba. ${ }^{76}$

A jogirodalomban szintén kulcsfontosságú szerepet tölt be az a kérdés, hogy a fertőző betegségek leküzdéséről és megelőzéséről szóló törvény alapján bevezethető rendelkezések megfelelő jogalapot képeznek-e a drasztikus kijárási korlátozások, kapcsolattartási és gyülekezési tilalmak elrendeléséhez. Erősen vitatott, hogy ezek a szabályok alapul szolgálnak a kereskedelmi, kulturális és vallási tevékenységek általános tilalmának. ${ }^{77}$ Ezenkívül a kritikus hangok arra figyelmeztetnek, hogy a megtett intézkedéseknek tiszteletben kell tartaniuk az arányosság elvét. Különösen az egyéni szabadságjogok korlátozását kell egyensúlyba hozni a járványok elleni küzdelemre vonatkozó korlátozó intézkedések várható előnyeivel. ${ }^{78}$

Ezenkívül vitatott kérdéskör az is, hogy a fertőző betegségek leküzdéséről és megelőzéséről szóló törvény tágan értelmezhető és „homályos” rendelkezései, amelyek előírják a szövetségi egészségügyi minisztérium rendeletalkotási jogát és a járvány leküzdése érdekében minden szükséges intézkedés megtételét a Szövetségi Gyưlés beleegyezése nélkül, megfelelnek-e az alkotmányos követelményeknek.

További szerzők a kihirdetett egészségügyi válsághelyzetet úgynevezett „hamis” szükségállapotként írják le, amely megtöri a vészhelyzetek alkotmányos típusú elméletét. ${ }^{79} \mathrm{~A}$ járványhelyzet, annak ellenére, hogy nem sorolandó az alaptörvényben lefektetett rendkívüli állapotok körébe, egyértelmúen párhuzamba vonható a védelmi helyzet és a szükséghelyzet esetéről szóló alkotmányos rendelkezésekkel. Ez vonatkozik az országos szintú járványhelyzet kialakulásának jogi következményeire is, amelyek lehetővé teszik a végrehajtó hatalom számára, hogy rendeleteket és utasításokat adjon ki. Ugyanígy a határozatképesség

72 A jogeset kapcsán lásd bővebben a koblenzi közigazgatási bíróság indokolását: VG Koblenz, Urt. v. 05.10.2020, 3 K $489 / 20$. KO.

73 Möllers, 2020.

74 Fertőzésvédelmi tv. 5. szakasz (2) bekezdés.

75 A weimari köztársaság utolsó szakaszának eseményei, amikor a rendkívüli állapot állandóvá vált, és a parlamenti rendszernek utat kellett engednie a birodalmi elnök diktatúrájának (1930-1933).

76 Frankenberg, 2020.

77 Möllers, 2020.

78 Thielbörger-Behlert, 2020.

79 Frankenberg, 2020. 
egyszerúsítésének a Szövetségi Gyülés eljárási szabályzatában is van bizonyos sürgősségi jellege, mivel ez (a védelmi helyzet esetén a Közös Bizottsághoz hasonlóan) a parlamenti rendszer funkcionalitásának kivételes körülmények között történő fenntartását szolgálja.

A kritikai meglátások mellett olyan véleménnyel is találkozni, amely a bevezetett intézkedések mellett szól, nem talál kivetnivalót bevezetésük módjában sem, s azokat teljességében indokoltnak tartja. Ezt azzal támasztja alá, hogy a koronavírus okozta válságban az alapvetó jogok korlátozásainak alkotmányosságát nem könnyú megítélni. Amikor 2020 márciusának közepén elrendelték az intézkedéseket, az életet bizonytalanság jellemezte, és drámai viszonyoktól tartottak Németországban is. Ha az állam nem cselekszik határozottan ebben a válságban, akkor a lakosságban a tehetetlenség és felelőtlenség benyomását keltheti, nő a bizonytalanság, és pánik keletkezik. Kiindulópontként teljesen érthető, hogy drasztikus intézkedéseket hoztak a járvány visszaszorítására. ${ }^{80}$

Tekintettel arra a kockázatra, amelyet a koronavírus-járvány jelent a lakosság egészségére, és tekintettel az e fenyegetés leküzdésére tett komoly intézkedésekre, a témával foglalkozók körében felmerül a kérdés, hogy nem lett volna-e inkább helyénvaló az alaptörvény szerinti sürgősségi rendelkezések alkalmazása a jelenlegi válság leküzdésére. E körben arra mutatnak rá, hogy a klasszikus és a kivételes állapotok egyértelmú elkülönítésének hiánya révén a jelenlegi állapot az egyre szigorúbb korlátozások fokozatos normalizálásához vezethet. Arra is rámutatnak, hogy a vírushelyzet okozta állapotra vonatkozó alkotmányos szabályozás híján az „egyszerư” szövetségi törvény alapján kell a szövetségi és a tartományi kormányoknak közösen iránymutatásokat kidolgozniuk, majd azokat ténylegesen végrehajtaniuk. ${ }^{81}$ Valós rendkívüli helyzetben viszont szigorú kompetencia-előírások lennének érvényben annak érdekében, hogy ne kelljen minden intézkedéshez külön konszenzust elérni. Ugyanakkor ehhez kapcsolódóan az is kérdéses, hogy az alaptörvény sürgősségi rendelkezései mennyiben illeszkednek a járványhelyzet előidézte állapothoz. A koronavírus okozta válság nem jelent védelmi helyzetet, sem pedig szükséghelyzetet, ennek értelmében a külső rendkívüli helyzet esetkörei azonnal kizárhatók. Továbbá nem fenyegeti veszély a szövetségi állam létét vagy szabad demokratikus alaprendjét sem, így a belső rendkívüli helyzet esetköreire vonatkozó szabályok sem alkalmazhatók. Legfeljebb az alaptörvény 35. cikke értelmében lehetne a Covid-19-járványt régión felüli természeti katasztrófának minősíteni, mindazonáltal világos, hogy a katasztrófahelyzetre vonatkozó normák jogi következményei inkább a földrengésekre, viharokra és árvízkatasztrófákra, mint a járványokra vonatkoznak. Összegzésként tehát le kell szögezni, hogy a német alaptörvény által előírt rendkívüli helyzetek esetköreinek egyike sem felel meg a járvány okozta válsághelyzetnek. 


\section{5. Összegzés}

Az alábbi táblázatban összegző jelleggel bemutatjuk a német rendkívüli helyzet szabályozásával kapcsolatos legfontosabb jellemzőket.

\begin{tabular}{|c|c|c|c|c|}
\hline & \multicolumn{2}{|c|}{ Külső rendkívüli helyzet } & \multicolumn{2}{|c|}{ Belső rendkívüli helyzet } \\
\hline & Védelmi helyzet & Szükséghelyzet & Belső vészhelyzet & $\begin{array}{c}\text { Katasztrófa- } \\
\text { helyzet }\end{array}$ \\
\hline $\begin{array}{c}\text { Szabályozás } \\
\text { szintje }\end{array}$ & \multicolumn{4}{|c|}{ Alaptörvény } \\
\hline $\begin{array}{c}\text { Elrendelési } \\
\text { okok }\end{array}$ & $\begin{array}{l}\text { A Német Szö- } \\
\text { vetségi Köztár- } \\
\text { saság területét } \\
\text { fegyveres hatalom } \\
\text { támadta meg, } \\
\text { vagy ilyen tá- } \\
\text { madás fenyeget. }\end{array}$ & $\begin{array}{l}\text { A védelmi helyzetet } \\
\text { megelőző állapot, } \\
\text { amely akkor áll fenn, } \\
\text { ha okkal valószínú- } \\
\text { síthető, hogy egy } \\
\text { külpolitikai konflik- } \\
\text { tushelyzet kiéleződik } \\
\text { és fegyveres táma- } \\
\text { dáshoz vezet. }\end{array}$ & $\begin{array}{c}\text { Ha a szövetségi } \\
\text { kormány vagy egy } \\
\text { szövetségi tartomány } \\
\text { létét vagy szabad } \\
\text { demokratikus alap- } \\
\text { rendjét fenyegető } \\
\text { veszély elhárítása } \\
\text { szülkséges. }\end{array}$ & $\begin{array}{l}\text { Természeti } \\
\text { katasztrófák } \\
\text { és különösen } \\
\text { súlyos balesetek } \\
\text { esetén. }\end{array}$ \\
\hline Megállapítás & $\begin{array}{c}\text { A Szövetségi } \\
\text { Tanács jóváhagyá- } \\
\text { sával a Szövetségi } \\
\text { Gyűlés. } \\
\text { Ha a helyzet } \\
\text { halaszthatatlan, } \\
\text { azonnali cse- } \\
\text { lekvést igényel, } \\
\text { akkor a Közös } \\
\text { Bizottság. }\end{array}$ & $\begin{array}{l}\text { A Szövetségi Gyúlés } \\
\text { a leadott szava- } \\
\text { zatok kétharmados } \\
\text { többségével. }\end{array}$ & $\begin{array}{l}\text { Szövetségi } \\
\text { tartományok }\end{array}$ & $\begin{array}{l}\text { Szövetségi } \\
\text { tartományok }\end{array}$ \\
\hline Felhatalmazott & \multicolumn{2}{|c|}{ Szövetségi kormány } & \multicolumn{2}{|c|}{ Tartományi kormány } \\
\hline $\begin{array}{l}\text { Gyakorlati } \\
\text { esetek }\end{array}$ & Ez idáig nem ke & erült kihirdetésre. & $\begin{array}{r}\text { A koronavírus okozta } \\
\text { 2020-ban néhány ta } \\
\text { területére nézve kata } \\
\text { hirdete }\end{array}$ & $\begin{array}{l}\text { válsághelyzetben } \\
\text { artomány saját } \\
\text { sztrófahelyzetet } \\
\text { tt. }\end{array}$ \\
\hline \begin{tabular}{|} 
Különleges \\
jogrendnek \\
nem minősülő \\
rendkívüli \\
helyzet
\end{tabular} & \multicolumn{4}{|c|}{ Járványügyi vészhelyzet } \\
\hline
\end{tabular}

17. táblázat

Németország rendkívüli helyzetre vonatkozó szabályozása

Forrás: a szerző saját összeállitása 
A magyar és a német különleges jogrendi szabályozási koncepciók összehasonlítása során mindkét ország tekintetében megállapítható, hogy az általánostól eltérô állapotokat a legmagasabb szinten, az alaptörvényben fektetik le. Ugyanakkor az esetkörök számában és az intézkedésre jogosultak körében a szabályozás eltérést mutat. Míg a magyar Alaptörvény összesen hat különleges jogrendi esetkört ${ }^{82}$ nevesít, a német alaptörvény az esetkörök számát négyre ${ }^{83}$ korlátozza, s ezeket egyértelmúen elhatárolja külső és belső rendkívüli helyzetekre.

A szabályozás felépítését tekintve szembetűnő, hogy a német alaptörvény nem követi azt az egyértelmú és összetéveszthetetlen rendszert, amelyet a magyar Alaptörvény alkalmaz a különleges jogrendre vonatkozó szabályok rendezése kapcsán. Míg a magyar Alaptörvényben Különleges jogrend címszó alatt egyértelmúen elkülönülnek az általánostól eltéró állapotokra vonatkozó szabályok, a német alaptörvény ezeket elszórtan, rendszerezés nélkül tartalmazza.

A különleges állapotokra vonatkozó jog céljának értelmezése kapcsán is mutatkozik némi különbség a magyar és a német gondolkodás között. A magyar megközelítés szerint a különleges állapotok jogának célja, hogy a jogrend visszaálljon a normális alkotmányos helyzetbe,$^{84}$ míg a német értelmezés szerint a sürgősségi szabályrendszer az alkotmányos rendet speciális eszközökkel tartja fenn, így a német értelmezés szerint nem merül fel az alkotmányos rend általánosról különleges állapotra történő változása, és annak visszaállítása sem szükséges.

Az alapjogok korlátozása kapcsán a magyar Alaptörvény különleges jogrend esetén az általános szabályozáshoz képest szélesebb körben teszi lehetôvé az alapjogok korlátozását. Ilyenkor az alapvető jogok gyakorlása - bizonyos kivételekkel (mint például az élethez és az emberi méltósághoz való jog, ártatlanság vélelme) - felfüggeszthető vagy az általános szabályok szerinti mértéken túl is korlátozható. Ez igaz a német szabályozásra is. A német alaptörvény szintén több alapjog-korlátozási lehetőséget ismer, míg az ágazati szabályozás az alaptörvényi felhatalmazás alapján ezeket konkretizálja.

A magyar szabályozás számára a német szabályozás mindig is meghatározó jelentőséggel bírt, e tekintetben azonban figyelemmel kell lennünk a szükségszerüen felmerülő különbségekre is. Tekintettel arra, hogy Németország államformáját tekintve szövetségi köztársaság, a szabályozási koncepció sok esetben a szövetség és a tartományok közötti hatáskörök és jogkörök megosztását határozza meg, továbbá számos esetben a tartományi jog szabályoz fontos kérdéseket. Ennek okán a különleges jogrendi szabályozás adott részei és a jogalkotásra való felhatalmazás kevésbé vethető össze a magyar szabályozási koncepcióval.

82 Rendkívüli állapot, szükségállapot, megelőző védelmi helyzet, váratlan támadás, veszélyhelyzet, terrorveszélyhelyzet.

83 Védelmi helyzet, szükséghelyzet, belső vészhelyzet, katasztrófahelyzet.

84 Jakab-Till, 2019, 436. o. 
Meghatározó különbség a két ország között, hogy Németországban a gyakorlatban az alaptörvényben lefektetett rendkívüli helyzetek eddig még nem kerültek kihirdetésre kivételt képeznek ezalól azok az esetek, amikor a jelenlegi koronavírus-járvány idején néhány tartomány belső rendkívüli helyzet keretében katasztrófahelyzetet hirdetett ki. Magyarország esetében a különleges jogrendi esetkörök gyakorlatban történő megnyilvánulására ${ }^{85}$ már korábban is számos alkalommal, összesen 16-szor volt példa. ${ }^{86}$

A koronavírus okozta válságkezelés kapcsán alapvető különbség, hogy Németország az ágazati szabályozás módosítása révén teremtett egy speciális, különleges jogrendnek nem minősülő rendkívüli helyzetet, míg Magyarországon a járványhelyzet kezelése szorosabban függ össze az Alaptörvény különleges jogrendre vonatkozó rendelkezéseivel. Németország az Európai Unió más tagállamaival, így Magyarországgal ellentétben nem reagált a sürgősségi alkotmányjog eszközeivel. Németországban a járványkezelés egyik legfontosabb és legtöbb jogosítvánnyal rendelkező szereplője az egészségügyi miniszter, akinek többek között rendeletalkotási joga van, míg Magyarországon a víruskezeléssel összefüggő intézkedések kormányrendeletek formájában manifesztálódtak, így hazánkban a Kormánynak van meghatározó szerepe a járványkezelés terén. A magyar alkotmányos szabályrendszert és Németországnak a jelenlegi járványügyi helyzetben alkalmazott gyakorlatát vizsgálva megállapítható, hogy Németországban - megfelelő szabályozás híján - nem volt lehetőség alkotmányos szabályokon alapuló különleges jogrendet bevezetni.

A különleges jogrendi szabályozás összehasonlítása során a fejezet végén, tekintettel a téma aktualitására, elengedhetetlen utalni Magyarország Alaptörvényének kilencedik módosítására. A módosított rendelkezések - amelyek jelen állás szerint meglehetôsen sokára, 2023. július 1-jén lépnének hatályba - hatálybalépésük esetén gyökeresen átalakítják az Alaptörvény különleges jogrendre vonatkozó szabályait. ${ }^{87}$ Az egyik legmeghatározóbb változás a különleges jogrendi esetkörök számának csökkentése lesz. ${ }^{88}$

A 9. magyar Alaptörvény-módosítás egy másik szembetúnő változása, hogy a különleges jogrendi helyzetek kezelése kormányközpontúvá válik. A módosítási javaslat egyik fő jellemvonása az, hogy a különleges jogrendi rendeletalkotás címzettjévé minden esetkörben a Kormányt teszi. Ennek oka, hogy a különleges jogrend kihirdetését követően gyors, operatív és mind politikai, mind jogi értelemben felelős döntéshozatal biztosítása szükséges, amire a magyar alkotmányos rendszerben a Kormány mutatkozik alkalmasnak. ${ }^{89}$

8515 esetben árvíz és/vagy belvíz miatt, egy alkalommal pedig - a 2010-es kolontári iszapkatasztrófa nyomán ipari baleset okán.

86 Horváth, 2020, 17. 0.

87 Horváth, 2020, 17. o.

88 A szúkített esetkör a következőket tartalmazza: veszélyhelyzet, szükségállapot, hadiállapot.

89 Magyarország Alaptörvényének kilencedik módosításáról szóló T/13647. számú törvényjavaslat. Elérhető: www.parlament.hu/irom41/13647/13647.pdf (Letöltve: 2020. december 3.). 
Ez a változtatás több kapcsolódást mutat a német rendkívüli helyzeti felhatalmazás rendszerével, amelyben a kormánynak szintén meghatározó szerep jut azzal, hogy a német rendszerben rendkívül erôs parlamenti kontroll valósul meg.

A német szabályozással kapcsolódást mutat a magyar Alaptörvény 9. módosításának az a pontja is, amelynek nyomán a Kormány különleges jogrend idején köteles minden olyan intézkedést megtenni, amely az Országgyuulés folyamatos müködését szavatolja. ${ }^{90} \mathrm{Ez}$ az elmélet teljességében megegyezik a német meglátással, amely szintén azt az elvet vallja, hogy rendkívüli helyzet idején is biztosítani kell, hogy a Szövetségi Gyúlés elláthassa alkotmányos feladatait. Összegzésként tehát megállapítható, hogy a 9. Alaptörvény-módosítás szabályai alapján - azok hatálybalépésének esetén - a magyar alaptörvényi szabályozás több hasonlóságot mutat majd a német alaptörvény rendkívüli helyzetre vonatkozó szabályozási koncepciójával.

\section{Irodalomjegyzék}

BADURA, P. (1986) Staatsrecht. Systematische Erläuterung des Grundgesetzes für die Bundesrepublik Deutschland. 5. kiadás. München: C. H. Beck

Binder, K., Diaz Crego, M., Eckert, G., Kotanidis, S., Manko, R., Del Monte, M. (2020)

States of Emergency in Response to the Coronavirus Crisis: Situation in Certain Member States [Online]. Elérhető: www.europarl.europa.eu/RegData/etudes/BRIE/2020/649408/EPRS_ BRI(2020)649408_EN.pdf (Letöltve: 2020. december 7.)

ERKENS, T. (2017)'Die Krisenmechanismen des Grundgesetzes im Wandel der Bedrohungslagen.

Was ist und wozu taugt die Notstandsverfassung?', Zeitschrift für Außen- und Sicherheitspolitik, 4/2017, 10:485-510. o.

FRANKENBERG, G. (2020) Covid-19 und derjuristische Umgang mitUngewissheit [Online]. Elérhetô: https://verfassungsblog.de/Covid-19-und-der-juristische-umgang-mit-ungewissheit/ (Letöltve: 2020. december 11.)

HoRváth, A. (2020) 'A veszélyhelyzet közjogi és jogalkotási dilemmái - mérlegen az alaptörvény 53. cikke', Közjogi Szemle, 13(4), 17-25. o.

JAKAB, A. (2019) 'German Constitutional Law and Doctrine on State of Emergency Paradigms and Dilemmas of a Traditional (Continential) Discourse.' German Law Journal, 7(5), 453-477. o.

Jarass, H., Pieroth, B. (2020) Grundgesetz für die Bundesrepublik Deutschland. Kommentar. 16. kiadás. München: $\mathrm{C}$. H. Beck

KatZenmeier, C. (2020) 'Grundrechte in Zeiten von Corona', MedR, 2020/38, 461-465. o.

90 Magyarország Alaptörvényének kilencedik módosításáról szóló T/13647. számú törvényjavaslat 52. cikk (3) bekezdés. 
Khakee, A. (2009) Securing Democracy? A Comparative Analysis of Emergency Powers in Europe. Genf: Geneva Centre for the Democratic Control of Armed Forces [Online]. Elérhetô: www.files.ethz.ch/isn/99550/PP30_Anna_Khakee_Emergency_Powers.pdf (Letöltve: 2020. december 5.)

LAKatos, L. (2014) 'A különleges jogrend és a honvédelem szabályzása', MTA Law Working Papers, 2014/49 [Online]. Elérhető: https://jog.tk.hu/mtalwp/a-kulonleges-jogrend-es-ahonvedelem-szabalyzasa (Letöltve: 2020. december 8.)

MAUnZ, T., DÜRIG, G. (2020) Grundgesetz Kommentar. 92. kiadás. München: C. H. Beck (Beckonline)

MölLERS, C. (2020) Parlamentarische Selbst - Entmächtigung im Zeichen des Virus [Online]. Elérhető: https://verfassungsblog.de/parlamentarische-selbstentmaechtigung-im-zeichendes-virus/ (Letöltve: 2020. december 14.)

Nemzeti alkotmányok az Európai Unióban (2019). Budapest: Wolters Kluwer

SÁGVÁRI, Á. (2016) Különleges jogrenddel a terror ellen - kitekintés az európai gyakorlatra [Online]. Elérhetô: https://jog.tk.hu/blog/2016/o2/kulonleges-jogrenddel-a-terror-ellen (Letöltve: 2020. december 8.)

SCHÄFER, B. (2020) 'Das Recht des Ausnahmezustandes im Vergleich. Deutschland: Ungenutztes Notstandsrecht und Intergration des Ausnahmefalls in das einfache Recht', Wissenschaftlicher Dienst des Europäischen Parlaments [Online] Elérhető: www. europarl.europa.eu/RegData/etudes/IDAN/2020/651938/EPRS_IDA(2020)651938_DE.pdf (Letöltve: 2020. december 7.)

SCHWEIGER, G. (2005) Die Notstandsverfassung. 1. kiadás. München: GRIN Verlag

SzaBó, I. (2002) Német alkotmányfejlődés 1806-1945 - Különös tekintettel az államszervezeti változásokra. 1. kiadás. Budapest: Szent István Társulat

The Minerva Center for the Rule of Law under Extreme Conditions (2016) Law and Emergencies [Online]. Elérhető: https://minervaextremelaw.haifa.ac.il/images/Emergency_Laws_and_ Regulations_-in_Japan-_19-_Jan2016.pdf (Letöltve: 2020. december 15.)

Thielbörger, P., Behlert, B. (2020) COVID-19 und das Grundgesetz: Neue Gedanken vor dem Hintergrund neuer Gesetze [Online]. Elérhető: https://verfassungsblog.de/Covid-19-unddas-grundgesetz-neue-gedanken-vor-dem-hintergrund-neuer-gesetze/ (Letöltve: 2020. december 11.)

JAKAB, A., TILL, Sz. (2019) 'A különleges jogrend' in Trócsányi, L., Schanda, B., Csink, L. (szerk.) Bevezetés az alkotmányjogba. AzAlaptörvényés Magyarország alkotmányos intézményei. 6. kiadás. Budapest: HVG-ORAC

Venice Commission (2020) Observatory on Emergency Situations/Germany [Online]. Elérhető: www.venice.coe.int/files/EmergencyPowersObservatory/GER-E.htm (Letöltve: 2020. december 15.) 


\title{
20. Norvégia, \\ a kivételes intézkedések országa
}

\author{
CSEMÁNÉ VÁRADI ERIKA
}

\section{A különleges jogrend alkotmányos és törvényi szintü szabályozása}

Norvégia - államberendezkedéséből adódóan - számtalan, a magyartól eltérő múködési mechanizmust és szabályozási megoldást alkalmaz. Ugyanakkor - bár nem tagja az Európai Uniónak - sok hasonlóság is megfigyelhető más EU-s tagországgal, így elsősorban Svédországgal, illetve Dániával. Ennek hátterében a három ország történelmében 1029-tôl végig jelen lévő közös királyságok, ${ }^{1}$ uniók, illetve (elsősorban a svédek ellen vívott) háborúk állnak. A II. világháború után megindult skandinavista egyesülési folyamat keretében pedig más

1 1029-ben volt először közös királya Dániának és Norvégiának, 1397-től pedig Kalmári Unióként Svédországgal együtt közös uralkodó irányította a birodalmat. Svédország 1523-as kilépése után 300 évig a dán-norvég perszonálunió tovább élt, bár Norvégia 1536-tól már csak mint dán tartomány jelent meg (és nem önálló királyság). A svédekkel folytatott folyamatos háborúzás után 1814-től az ország Svédország birtokába került. 1905. június 7-én a norvég parlament egyhangúlag mondta ki az unió felbontását. Ezt követően egészen napjainkig a dán király, illetve a királyi család leszármazottjai birtokolják a norvég trónt (Universitetet i Oslo, 2020).

Csemáné Dr. Váradi Erika, PhD, LLM

judit.erika.varadi.csemane@mfi.gov.hu vezető kutató (Mádl Ferenc Összehasonlító Jogi Intézet)

egyetemi docens (Miskolci Egyetem Állam- és Jogtudományi Kar, Bűnügyi Tudományok Intézete)

Csemáné Váradi, E. (2021) 'Norvégia, a kivételes intézkedések országa' in Nagy, Z., Horváth, A. (szerk.) A különleges jogrend és nemzeti szabályozási modelljei, 434-456. o. Budapest: Mádl Ferenc Összehasonlító Jogi Intézet.

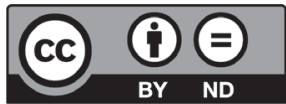


formában ugyan, de tovább folytatódott az együttmúködés. ${ }^{2}$ Így például a hidegháború sújtotta nemzetközi légkör ellenére már 1952-ben létrejött a mindhárom országot érintő Északi Tanács és az Északi Útlevélunió. Ez a szoros történelmi „együttjárás” számos közös müködési jellemzốt eredményez; ilyen például a bíróságok különösen erős szerepe. Mindhárom ország az alkotmánybíráskodás amerikai modelljét követi - azaz nincs szervezetileg elkülönült alkotmánybíróság, alkotmányjogi vita esetén a legfelsőbb bíróság dönt. ${ }^{3}$

Norvégia mint parlamentáris, demokratikus és egységes alkotmányos monarchia élén is a király áll, akinek - bár hatalma szúkült az elmúlt időszakban - szerepe ma sem szimbolikus; aktív résztvevője az ország politikai életének. Széles körü kinevezési jogkörrel rendelkezik, viszonylag erős vétójoggal bír a törvényhozással szemben, emellett a hadsereg fôparancsnoka. ${ }^{4} \mathrm{~A}$ törvények keretei között rendeleteket is alkothat. Elvileg a végrehajtó hatalom letéteményese, hatásköre azonban jórészt ellenjegyzési jog formájában testesül meg. A valódi döntések többnyire a kormányként múködő Államtanácsban születnek. A végrehajtó hatalmat elsősorban gyakorló szervet a miniszterelnök vezeti, tagjai kinevezéséről és felmentéséről az uralkodó dönt, munkájáról a parlamentnek és az uralkodónak egyaránt felelősséggel tartozik.

A különleges jogrenddel összefüggésben az alkotmány mellett egyéb (jog)források is - így különösen a vészhelyzeti felkészültségi törvény ${ }^{5}$ - relevanciával bírnak.

A norvég alkotmány 1814-ben született, és azóta - természetesen módosításokkal, de folyamatosan hatályban van; ezzel Európa legrégebbi ilyen dokumentuma. Mindez jelzi, hogy Norvégia az elmúlt évszázadokban nem állt a történelem viharainak olyan kereszttüzében, mint sok más - főként közép- - európai ország. Másrészt a norvég alkotmány ${ }^{6}$ elsősorban a fóbb elveket és kereteket határozza meg, és nem tartalmaz - például a különleges jogrenddel kapcsolatban - olyan részletszabályokat, mint a magyar. A dán nyelven íródott alaptörvény ma is dán nyelvú, a hivatalos szöveg jórészt a nyelv 19. század elején használt formájában érhetô el. Bár az újabb módosításokkal - minden ellenkező törekvés dacára a modern norvég nyelv is bekerült a szövegbe, az egységes nyelvezetû alkotmányszöveg kialakítása évtizedek óta a norvég alkotmányjogi viták kulcskérdése.7

Az alkotmány 26.cikke rögzíti, hogy a királynak joga van csapatokat összehívni, háborút indítani a birodalom (az ország) védelme érdekében, békét, szerződéseket (nemzetközi jogi

2 A három ország speciális viszonyára utal a mondás, miszerint Észak-Európában minden újdonság útja az, hogy „a norvég kitalálja, a svéd megcsinálja, a dán nagy haszonnal eladja” (Idézi: Gergely, 1994).

3 Szentgáli-Tóth, 2014. A norvég alkotmányról lásd még: Justis- og beredskapsdepartementet, 2014.

4 Szentgáli-Tóth, 2014.

5 Törvény a háború, a háborús veszély és más hasonló körülmények alatti különleges intézkedésekről (Lov om særlige rådgjerder under krig, krigsfare og liknende forhold [beredskapsloven]; No: LOV-1950-12-15-7) (a továbbiakban: Vészhelyzeti felkészültségi tv.).

6 A Norvég Királyság alkotmánya (Kongeriket Norges Grunnlov).

7 Szentgáli-Tóth, 2014. 
megállapodásokat) kötni és utóbbiakat felmondani, diplomáciai megbízottakat küldeni és fogadni.

A különös jelentőséggel bíró kérdésekről szóló szerződések és - minden esetben - azok a szerződések, amelyek végrehajtása az alkotmány szerint új törvény alkotását vagy az egykamarás parlament (Storting) határozatát teszi szükségessé, addig nem kötelezőek, amíg a parlament azokhoz beleegyezését nem adja, ugyanis a parlament feladata a törvények elfogadása és hatályon kívül helyezése. ${ }^{8}$

Amennyiben a jogalkotási folyamatban a király akadályozott, úgy a távolléte alatt hozott döntéseket a király nevében kell elkészíteni, és azokat az Államtanács írja alá. ${ }^{9}$ Egyes nevesített esetektől eltekintve ${ }^{10}$ a király hiányában a birodalmat az Államtanács irányítja. ${ }^{11}$

A különleges jogrendi szabályozás alapja, hogy minden, a speciális helyzetekből - így a háborúból, szükségállapotból stb. - adódó korlátozásnak összhangban kell lennie a jogszabályokkal.

A skandináv államok újkori történelmét végigkísérte az emberi jogok ${ }^{12}$ kiemelt fontossága, az ott lezajló változásokra, trendekre való fokozott érzékenység. ${ }^{13}$ Így nemcsak a norvég, de az összes skandináv alkotmány által deklarált jogállamiság elvéből következik, ${ }^{14}$ hogy az emberi jogok korlátozása mindig a nemzeti parlament által elfogadott törvény alapján lehetséges. Ez a követelmény - nemzetközi dokumentumokra alapítottan - a norvég jogtudomány szerint ${ }^{15}$ is olyan jogállamisági kritériumokat foglal magában az emberi jogi korlátozásokat tartalmazó jogalkotási aktusok vonatkozásában, mint például

- a transzparencia, a világos, pontos és érthető megfogalmazás követelménye;

- a legitim cél követelménye (a korlátozás megfelel az olyan általános érdekú céloknak, mint a biztonság és/vagy mások jogainak és szabadságainak védelme);

- a szükségesség és az arányosság követelménye;

- a jogok lényegi (immanens) részének sérthetetlensége (korlátozhatatlansága).

Kiemelendő, hogy egy elvi és elméleti szintú, egységes kritériumrendszer - illetve ezekre való hivatkozás - nem jelenik meg írott, tételes formában a norvég alkotmányban. Ez azonban nem egyedi, hasonló megállapítások tehetôk más skandináv alkotmányokat érintően is. Így míg például a Svédországban a kormányzatról szóló alaptörvény 20-25. cikke meglehetôsen részletesen meghatározza az alkotmány által garantált jogok és szabadságok

8 Alkotmány 75. cikk a) pont.

9 Alkotmány 32. cikk.

10 Alkotmány 39-41. cikk.

11 Külön rendelkezés vonatkozik azonban arra, ha az akadályoztatás állandó jellegú, például a király halála vagy tartós betegsége okán.

12 Alkotmány 92-113. cikk.

13 Vik et al., 2018, 190. o.

14 Ojanen, 2018, 146. o.

15 Smet, 2010, 184. o. 
korlátozásának különféle feltételeit, addig a finn alkotmány nem rögzít általános záradékot az emberi jogok megengedett korlátozásáról, noha számos olyan rendelkezést tartalmaz, amelyek különféle módon határozzák meg ezen jogok korlátozásának lehetőségét.

A norvég alkotmány speciális körülményekre alig utal. A norvég Államtanács tagja a miniszterelnök és még legalább 7 személy, akik között a feladatokat a király osztja meg. ${ }^{16}$ Rendkívüli körülmények között a király más norvég állampolgárt is felkérhet a kabinetben való közremúködésre, függetlenül attól, hogy nem tagja a parlamentnek.

Hogy mit jelenthet a rendkívüli körülmény, arra az alkotmány 68. cikkében található példa. A parlament rendszerint minden év októberének első hétköznapján ül össze a birodalom fővárosában, kivéve, ha a király rendkívüli körülmények, például ellenséges invázió vagy fertőző betegség miatt egy másik várost jelöl ki erre a célra. Egyetlen kritérium, hogy egy ilyen döntést kellő időben nyilvánosan közzé kell tenni.

A norvég alkotmány nem ismeri a rendkívüli állapot fogalmát, s nincs speciális, vészhelyzeti alkotmány sem. Norvégia tehát azon államok közé tartozik - Ausztriához, Dániához vagy épp Finnországhoz hasonlóan -, amelyek alkotmányai gyakorlatilag „hallgatnak” a kérdésről. ${ }^{17}$ Fontos azonban kiemelni, hogy noha az alkotmány nemcsak a rendkívüli állapot, de - a 68. cikkében található példáktól eltekintve - más, a különleges jogrendet megalapozó körülmény létét sem nevesíti, a gyakorlatban ismert és elfogadott az úgynevezett „alkotmányos szükségesség"18 íratlan szabálya.

Norvégia hosszú idő óta nem állt háborúban más nemzettel. Az ország a II. világháború hadmüveleteiben sem vett részt, azonban ellenállási mozgalmat folytatott a Német Birodalom ellen, amely 1940. április 9-én, a Weserübung hadmúvelettel lerohanta azt. A kezdeti harcok és Haakon király megadást megtagadó nyilatkozatai után az ország végül június 10-én kapitulált, az uralkodó család és a kormány Nagy-Britanniába menekült. ${ }^{19}$ Bár a fegyverszünet megköttetett, a parlament - az „alkotmányos szükségesség” elvére hivatkozva átruházta hatalmát a számúzetésben lévő kormányra.

$\mathrm{Az}$ „alkotmányos szükségesség” tézisét ma is ismeri a norvég alkotmányjog-elmélet, azonban - íratlan szabály lévén - annak pontos hatálya és korlátai nem kimunkáltak és egyértelműek. Alkalmazhatóságának nem vitatott előfeltétele a súlyos vészhelyzet mint szükségességi követelmény, elvei a célorientált arányosság, szükségesség és indokoltság.

16 Alkotmány 12. cikk.

17 Az eltérő szabályozási gyakorlat jól szimbolizálja az uniós tagállamok között e tekintetben fennálló elméleti törésvonalakat. Az országok egy része ugyanis Carl Schmitt nyomán úgy véli, hogy a vészhelyzeteket csak az alkotmányon kívül lehet kezelni, míg mások épp annak fontosságát hangsúlyozzák, hogy ez az alkotmány által a leginkább körülhatárolt és korlátozott kérdéskör kell legyen (Khakee, 2009, 18. o.).

18 Lásd a Velencei Bizottság Norvégiáról szóló országjelentését: „...there is an unwritten but long-established rule that derogations can be made according to an unwritten rule of constitutional necessity". Elérhetó: www.venice.coe.int/files/EmergencyPowersObservatory/NOR-E.htm (Letöltve: 2020. november 11.).

19 Múlt-Kor, 2018. 
A norvég alkotmány a különleges jogrendet megalapozó esetköröket érintően elvétve tartalmaz rendelkezést, hatályban van azonban több olyan konkrét törvény, amely lehetôséget biztosít a veszélyhelyzetek kezelésére. Ilyen például a fertőzéskontrollról szóló törvény, ${ }^{20}$ az egészségügyi felkészültségi törvény, ${ }^{21}$ az ipari felkészültségi törvény ${ }^{22}$ és a polgári védelmi törvény, ${ }^{23}$ míg más jogszabályok egyes szakaszai foglalkoznak veszélyhelyzeti eljárási rendekkel. Utóbbira példa a sugárvédelmi törvény, amely részben rendelkezik a munkavállalók egészségvédelmének biztosítása érdekében a szervezetek oktatási-képzési kötelezettségeiről (például: oktatás, tájékoztatás, írásos utasítás, munkamódszer kidolgozása), ${ }^{24}$ másrészt a rendkívüli események kapcsán követendő lépésekről. Eszerint a társaság köteles készenléti tervet készíteni és a releváns intézkedéseket végrehajtani a balesetek és rendkívüli események kezelésére való képességének fenntartása érdekében. ${ }^{25} \mathrm{~A}$ készenléti tervnek kockázatértékelésen kell alapulnia, és tartalmaznia kell - többek között - az értesítési rutinokat, a készenléti események megszervezését, a felelősségmegosztást, az előre megtervezett protokollokat a különböző helyzetek kezelésére, az esemény mértékének feltérképezésére, a kommunikációra, így az érintett személyzet, a hatóságok és a lakosság tájékoztatására.

Külön is kiemelkedő szerephez jut az 1950-ben elfogadott, de azóta többször módosított Vészhelyzeti felkészültségi tv. A háború, háborús veszély, illetve hasonló körülmények mentén történő mưködésrôl is rendelkező törvény a királynak speciális felhatalmazást ad azokra az esetekre, amikor a parlament az említett körülmények, így a háború miatt nem tudja folytatni tevékenységét. Azaz szabályokat tartalmaz a döntéshozatal és a hatalommegosztás menetére súlyos válságok esetén, beleértve a katonai és a polgári hatalom közötti kapcsolatot (III. fejezet) vagy a büntetöügyek kezelésére vonatkozó különös szabályokat (IV. fejezet).

20 Törvény a fertőző betegségek elleni védelemről (a továbbiakban: Fertőzéskontroll tv.) (Lov om vern mot smittsomme sykdommer [smittevernloven]; No: LOV-1994-08-05-55).

21 Törvény az egészségügyi és szociális biztonságról (a továbbiakban: Eü. felkészültségi tv.) (Lov om helsemessig og sosial beredskap [helseberedskapsloven]; No: LOV-2000-06-23-56).

22 Ipari felkészültségi törvény (Lov om næringsberedskap [næringsberedskapsloven]; No: LOV-2011-12-16-65).

23 Törvény az önkormányzati készenlétről, a polgári védelmi intézkedésekről és a polgári védelemről (a továbbiakban: Polgári védelmi törvény) (Lov om kommunal beredskapsplikt, sivile beskyttelsestiltak og Sivilforsvaret [sivilbeskyttelsesloven]; No: LOV-2010-06-25-45).

24 2000. évi törvény a sugárvédelemról és a sugárzás felhasználásáról (a továbbiakban: Sugárvédelmi tv.) (2000-loven om strålevern og bruk av stråling [LOV-2000-05-12-36]) 7. \$, valamint a sugárvédelemról és a sugárzás felhasználásáról szóló rendelet (a továbbiakban: Sugárvédelmi szabályzat) (Forskrift om strålevern og bruk av stråling [FOR-2016-12-16-1659]) 16. \$.

25 Sugárvédelmi tv. 8. \$, Sugárvédelmi szabályzat 19-20. \$. 


\section{Az alapjogok korlátozására vonatkozó szabályok különleges jogrend idején}

A különleges jogrend eseteit a norvég alkotmány - a hazaihoz hasonló formában - nem határozza meg. A háborús helyzetre is mindösszesen egyetlen, a már idézett 26. cikkében utal.

Az alkotmány nevesíti azokat a jogszabályokat, illetve egyéb jogi dokumentumokat, amelyek nem mellőzhetik a parlament hozzájárulását, illetve a parlament és a király, valamint az Államtanács múködési kereteit. Ezekhez képest a Vészhelyzeti felkészültségi tv. jelentősen eltérő, számos alapjogot korlátozó szabályt határoz meg.

$\mathrm{Az}$ alkotmány szerint a különösen fontos kérdésekkel kapcsolatos szerződések ${ }^{26} \mathrm{csak}^{2}$ akkor válnak kötelezővé, ha ahhoz a parlament hozzájárulását adta. A parlament általános szabályok szerinti múködését akként rendezi az alkotmány, ${ }^{27}$ hogy megalakulását követően a király - vagy az általa erre a célra kinevezett személy - beszédével nyitja meg a parlament eljárását, amelyben tájékoztat a birodalom helyzetéről és azokról a kérdésekről, amelyekre különösen fel kívánja hívni a parlament figyelmét. Egyebekben a király jelenlétében semmilyen tárgyalás nem lehetséges. A parlament ülésének megkezdésekor a miniszterelnöknek és az Államtanács tagjainak azonban joguk van jelen lenni és - mint annak szavazati jog nélküli tagjai - részt venni minden nyílt ülésen. A parlament zárt ülése esetén a tárgyalandó kérdésekbe csak annak engedélyével, az általa megengedett mértékben kapcsolódhatnak bele. A parlament csak akkor tarthat ülést, ha a tagok legalább fele - alkotmánymódosítás esetén legalább a kétharmada - jelen van. ${ }^{28} \mathrm{~A}$ parlament által elfogadott jogszabályok csak abban az esetben válhatnak Norvégia törvényévé, ha ahhoz az uralkodó áldását adja. Az alkotmány szerin ${ }^{29}$ ugyanis ha a király hozzájárul a törvényjavaslathoz, akkor aláírásával látja el, amellyel ez törvénnyé válik. Arra az esetre is tartalmaz rendelkezéseket az alkotmány, ha a király megtagadná hozzájárulását a parlament által elfogadott törvényjavaslatok bármelyikétől - bár erre a Norvégia és Svédország közötti unió 1905-ös felbomlása óta nem volt példa.

Ezzel szemben a Vészhelyzeti felkészültségi tv. előirja, hogy ha a parlament a háború miatt nem tud megfelelően múködni, akkor a király (gyakorlatban a kormány) jogosult minden olyan döntést meghozni, amely az ország érdekeinek védelme (illetve a békés körülményekre való átmenetre felkészülés) érdekében szükséges. Feltétel, hogy ezekről a döntésekről a parlamentet a lehető leghamarabb értesíteni kell. Amennyiben ezen rendelkezéseket a parlament - vagy a király maga - korábban nem vonja vissza, akkor azok legkésőbb az első, a kérdést tárgyaló parlamenti ülés lezárását követően hatályon kívül helyeződnek.30

26 Ugyanez vonatkozik minden olyan szerződésre, amelyet az alkotmány szerint nem lehet új törvény vagy új parlamenti határozat nélkül végrehajtani.

27 Alkotmány 74. cikk.

28 Alkotmány 73. cikk.

29 Alkotmány 78. cikk.

30 Vészhelyzeti felkészültségi tv. 1-2. \$. 
A király speciális felhatalmazással bír, hogy háborúban, a háború közvetlen veszélye, illetve az ország biztonságát vagy szuverenitását fenyegető más veszélyek fennállása esetén törvényi erôvel bíró rendeleteket adjon ki, többek között az ország biztonsága, a közrend, a közegészség, valamint az alapvető javak biztosítása, a katonai, polgári és vagyonvédelmi intézkedések elősegítése és biztosítása érdekében. De mentesíthet a munkavégzés alól, ha azt katonai vagy polgári célok szükségessé teszik. Fontos felhatalmazási elem, hogy az így hozott rendelkezései eltérhetnek az irányadó jogtól is.

Jogbiztonsági célokat szolgál, hogy e döntésekről a lehető leghamarabb szükséges a parlamentet értesíteni és azt azonnal összehívni. Az így hozott döntéseket mind a király, mind a parlament hatályon kívül helyezheti. A parlament határozhat ezek érdemben történő fenntartásáról is; ez esetben a megfelelő eljárás keretében kell őket törvénybe iktatni. ${ }^{31}$

A Vészhelyzeti felkészültségi tv. tartalmaz rendelkezéseket az országnak a kormány ellenőrzése alól háború vagy más súlyos válság miatt kivont területeire, valamint a háború tényleges helyszíneire. Ez esetben a király felhatalmazhatja a megye kormányzóját vagy más helyi hatóságot - ideértve a katonai hatóságokat is - a rendelkezések megtételére. ${ }^{32} \mathrm{Ha}$ nélkülözhetetlen a társadalmilag fontos érdekek védelme, akkor a megyei kormányzó ezen jogokat úgy is gyakorolhatja, hogy az erre vonatkozó felhatalmazás a királytól még nem áll rendelkezésére. ${ }^{33}$

A király dönthet a rendőrség, az egyes rendőri erők vagy az egyes kerületi kapitányságok állományának katonai erőbe történő bevonásáról is. ${ }^{34}$

Az említett vészhelyzetben a büntetőtörvények is megváltozhatnak, ${ }^{35}$ amikor az ország biztonsága vagy szuverenitása veszélyben van. Ezek a rendelkezések komoly jogkorlátozó jelleggel bírnak, s számtalan büntetőeljárás-jogi garanciális alapelv átlépését teszik lehetővé. Így például a gyanú alapjául szolgáló bûncselekmény törvényi büntetési tételeinek nagyságától függetlenül foganatosítható a letartóztatás, eltérő határidők mentén (8. \$). Ezen túl is: a 9 . $\$$ szerint ha a késedelem veszéllyel járna, a vádemelés kérdésében semmiképpen sem kell megkeresni a legfőbb ügyészt. Hasonló feltételek mellett a rendőrfőkapitány gyakorolhatja (a büntetőeljárás-jogi törvény szerint) az államügyészt megillető vádlói hatalmat, míg helyettese (felügyelő) ${ }^{36}$ pedig a rendőrfőkkapitányt megillető végrehajtói hatalmat. A további különös rendelkezések is az eljárás gyorsítását, illetve egyszerúsítését célozzák, a veszélyhelyzetre tekintettel. Ez érinti többek között az egyes bíróságok hatáskörét és illetékességét (10. \$), ${ }^{37}$ a fellebbezéshez való jogot és annak kereteit, illetve jogi relevanciáját (13-14. \$). Feltétel, hogy a háború, háborúval való fenyegetettség vagy a királyság függetlenségének, il-

31 Vészhelyzeti felkészültségi tv. 3. \$.

32 Vészhelyzeti felkészültségi tv. 5. \$.

33 Vészhelyzeti felkészültségi tv. 5. \$.

34 Vészhelyzeti felkészültségi tv. 6. \$.

35 Vészhelyzeti felkészültségi tv. 7-14.\$.

36 A törvény norvég, svéd, illetve angol nyelvú változata eltérő terminológiát alkalmaz.

37 Így a fellebbviteli bíróság helyett a kerületi bíróság járhat el az ügyekben. 
letve biztonságának veszélye miatt a jogorvoslat, illetve a fellebbviteli tárgyalás aránytalan és káros késlekedéshez vezessen.

Néhány kérdésre, így például a demokratikus rend fennmaradásának védelmére szolgáló különös rendelkezésekre nem tartalmaz iránymutatást a jogszabály.

Fontos, a jogelméletben fellelhetô tétel a szükségszerűség doktrínája. ${ }^{38}$ Eszerint „a vészhelyzetek legitimálják az olyan tevékenységet, amely normál körülmények között az alkotmány megsértését vonná maga után". ${ }^{39}$ Súlyos válság esetén ezen elv mentén - amely a norvég történelmi tapasztalatokban gyökerezik - akár az alkotmánnyal ellentétes döntések is születhetnek. Fontos feltétel a súlyos vészhelyzet, valamint az, hogy a szokásos szabályok betartása sem elegendő a nemzeti érdekek védelmében. Ez a parlament hatalmának csökkentésével vagy megszüntetésével jár(hat).

Bár a rendkívüli felhatalmazás esetköreire a korábban jelzettek szerint elsősorban a különböző ágazati jogszabályokban találhatunk példát, Norvégia napjainkra nemzetközi vonatkozásokban is kiemelkedő gyakorlatot alakított ki a vészhelyzetek megelőzése, illetve kezelése vonatkozásában. ${ }^{40} \mathrm{E}$ komplex intézményrendszer, feladatmegosztás és protokoll tekintetében három kérdéskört érdemes kiemelni: a Vészhelyzeti Felkészültségi Bizottság múködését, a katasztrófavédelem felépítését és a kockázatelemzési eljárást.

A kormány vagy egy minisztérium bizottságokat és munkacsoportokat hozhat létre, amelyek a társadalom számára különböző szempontok mentén meghatározó, azokat érintő kérdésekkel foglalkoznak. Tevékenységük eredményét vagy mindenki számára elérhető nyilatkozatokban, vagy jelentés formájában készítik el. A Norvég Nyilvános Vizsgálatok (Noregs Offentlege Utgreiingar, röviden NOU) keretében évente több, az állam müködésének legszélesebb területét lefedő eljárás ${ }^{41}$ zajlik, többek között a családon belüli erőszaktól a jövő kompetenciáin át a városi életfeltételekig, amelyek megállapításait publikálják. E sorozat részeként jelent meg a Når krisen inntreffe (Amikor a válság bekövetkezik) címú jelentés, amelyet 2019. június 14-én nyújtott be ${ }^{42}$ a Vészhelyzeti Felkészültségi Bizottság. A szervezet 2018. február 9-én királyi rendelettel azzal a céllal jött létre, hogy áttekintse a vészhelyzetekre való felkészülésről szóló jogszabályokat, s készítse elő a szükséges módosító javaslatokat.

A krízisszabályozásról szóló III. fejezet bevezetője ${ }^{43}$ (7.1.) utalt arra, hogy Norvégiában aktuálisan számos ágazati törvény létezik, amelyek az egyes ágazatok számára különféle vészhelyzeti felkészülési rendszereket tartalmaznak, például válságok vagy katasztrófák esetére. De külön ágazati szintű törvények szólnak többek között a polgári védelemről. A jelentés részben azt vizsgálta, hogy milyen gátló tényezők áll(hat)nak fenn a jelenlegi rendelke-

38 Lásd erről részletesebben: Andenæs-Fliflet, 2017.

39 Andenæs-Fliflet, 2017, 502. o.

40 A veszélyhelyzetekkel kapcsolatos felelősségi kérdések változására lásd: Magnussen, 2005.

41 Lásd erről részletesebben a NUO honlapját: www.regjeringen.no/no/dokument/nou-ar/id1767/ (Letöltve: 2020. december 15.).

42 NOU, 2019.

43 NOU, 2019, 57-95. o. 
zések érvényesítésével összefüggésben, és ezek fényében szükség van-e módosításra, illetve hogy a jelenlegi vészhelyzeti felkészülési rendszerek mellett ágazati szinten szükséges-e ezen tevékenységek jogalapjának megteremtése. A jelentés érintette a vészhelyzetre való felkészülést, ezenbelül az önkormányzati és regionális egészségügyi szolgáltatásokat, az Eü. felkészültségi tv.-t, a fertőzéskontroll kérdését, valamint az ipari felkészültséget szabályozó rendelkezéseket - többek közt a különleges intézkedésekról szóló határozatokat, a polgári védelmet, a nyilvánosság segítségnyújtási kötelezettségét vészhelyzet esetére, a szolgálati kötelezettség vészhelyzetben történő igénybevételét -, a nukleáris baleseti felkészültséget, a biztonság és hírszerzés körét. Vizsgálta az egyes ágazati szereplőket, így a rendőrség, túzoltóság, határellenőrzés munkáját, valamint a bevándorlást szabályozó törvényeket. Ezen túl külön alfejezet foglalkozott az energia- és áramellátás, a közlekedési, infrastruktúra- és kommunikációs hálózatok, a média, a banki és pénzügyek, a természet- és környezetvédelem releváns területeivel.

A 8. fejezet ${ }^{44}$ a speciális kompetencia- (hatásköri) alapokat vette górcső alá. Azaz az előző (7.) fejezetben említett rendkívüli esetekre vonatkozó jogszabályok releváns részei a 8. fejezetben tárgyalt hatásköri rendelkezésekre figyelemmel alkalmazhatók. Így például a 8.2. pont írja le a király számára az ideiglenes rendeletek alkalmazhatóságát azokban az esetekben, amikor a parlament nem ül össze. A 8.3-8.5. pont határozza meg a háború, politikai válság vagy a rendkívüli helyzet esetén követendő jogi rendelkezéseket (amelyekre korábban már utaltunk). A 8.5. pont az alkotmányos sürgősségi joggal, a 8.6. pont a vészhelyzeti szabályozással foglalkozik.

A jogszabályi keretek kapcsán a jelentés több kritikai megjegyzést is tett. Rögzítette, hogy a Vészhelyzeti felkészültségi tv. az alkotmány egyes releváns rendelkezéseinek konkretizálását célozza. E vonatkozásban a hatalom súlyos válsághelyzetben való gyakorlásának szabályozása a kiszámíthatóság és a jogállamiság szempontjából indokolt. Ugyanakkor az alkotmányos szabályozás szúkössége okán (például rendkívüli állapot elrendelése) nincs „pozitív joga” a békeidejú szabályoktól való eltérésre. Ez kihat az egyéb felkészültségi szabályok alkalmazhatóságára is, s mindig konkrét, egyedi, diszkrecionális értékelésen múlik, hogy a rendes körülmények között az alkotmány megsértését okozó cselekedet a vészhelyzet következtében indokoltnak minősül-e. Elutasításra került az Emberi Jogi Bizottságnak az alkotmány ez irányú módosítását célzó javaslata, ${ }^{45}$ míg a Vészhelyzeti felkészültségi tv. megalkotásakor az Igazságügyi Bizottság több tagja állt ki amellett, hogy a kríziseket teljeskörúen lefedô szabályozás kivitelezhetetlen a veszélyhelyzetek sokszínú és eltérő volta miatt. ${ }^{46}$ Pedig

44 NOU, 2019, 78-83. o.

45 A javaslat szerint az alkotmány kiegészült volna azzal, hogy a garantált jogoktól való eltérésre akkor kerülhet sor, ha egy kihirdetett háború vagy válsághelyzet nyilvánvalóan szükségessé teszi azt a demokrácia, a jogállamiság és a királyság létének biztosítása érdekében (NUO, 2019, 81. o.).

46 A bizottság javaslatai a születő Vészhelyzeti felkészültségi tv.-hez (Innstilling fra justisnemnda til midler tidig lov om særlige rådgjerder under krig, krigsfare og lignende forhold 1950); hivatkozza: NUO, $2019,81.0$. 
a felkészültségi törvények számos alapjog-korlátozó intézkedési lehetőséget nevesítenek. Így például a rendőrségi törvény széles körú - eljárási korlátozások nélküli - beavatkozást biztosít a közrendsértések megfékezésére, illetve arra az esetre, ha olyan körülmények állnak fenn, amelyek az ilyen rendzavaró magatartásokhoz kapcsolódóan félelmet idéznek elő. A jelentés ezen túl is komoly jogi hiányosságokra hívta fel a figyelmet a rendőrségi törvény kapcsán, például a drónhasználatot vagy a rádiójelek blokkolását illetően.

A második nagy terület a krízishelyzetekben történő koordinációt felölelő katasztrófavédelem. Ez mind országos, mind regionális szinten jól szervezett, állami és civil szervezetek és az állampolgárok aktív részvételén és szervezett tevékenységén alapuló rendszer. A 2003-ban országos felhatalmazással alapított tønsbergi Polgári Védelmi és Vészhelyzeti Felkészültségi Igazgatóság (DSB) ${ }^{47}$ célja a társadalmi kockázatok és sebezhetőség teljes áttekintése, a balesetek, válságok és más nem kívánt események megelőzését célzó intézkedések előmozdítása, valamint a megfeleló vészhelyzeti tervezés, illetve a balesetek és krízisek hatékony kezelése. Ennek érdekében a szervezet támogatja az Igazságügyi Minisztériumot és a rendőrséget koordinációs szerepük ellátásában, kidolgozza és múködteti a nemzeti vészhelyzeti felkészültségi és reagálási terveket, tanácsot ad és jelentést készít a minisztérium és a kormány felé a nemzeti válságkezeléssel kapcsolatban.

Megyei szinten a helyi ügyekért felelős, az állampolgárok által választott megyei tanács, illetve a király és a kormány képviselőjeként a parlament és a király által kinevezett, a kormány döntéseinek megyei szintú végrehajtásáért felelős kormányzó egyaránt részt vesz a munkában.

A DSB nagyon széles körủ és összetett feladatai közül kiemelendő a szervezési, koordinációs, ellenőrzési, nyomon követési stb. tevékenységek, a nemzeti sebezhetőség kialakulásával és a változó fenyegetési forgatókönyvekkel kapcsolatos kutatások, tanulmányok és dokumentációk létrejöttének támogatása - enélkül nem lehetne eredményes a reagálás és a prioritások megtervezése. (Így célorientált kapcsolatrendszerrel más, a területen releváns aktivitást folytató olyan civil szervezetekkel is együttmúködik, mint például a NORSAR [Norwegian Seismic Array] nemzetközileg elismert, független, a geotudományok, a szeizmológia, az alkalmazott geofizika nonprofit kutatási alapja.) Ugyanakkor a minőségbiztosítási szempontok is komoly szerephez jutnak, amennyiben az igazgatóság stratégiai menedzsmenttel kapcsolatos válságkezelési és válságkommunikációs gyakorlatokat tervez és vezet mind nemzeti, mind regionális, mind helyi szinten.

A szervezet jelentőségét mutatja, hogy tevékenységének ellátása során olyan szakintézmények munkájáért is felel, mint például a Norvég Polgári Védelem (Norge Sivilforsvaret), a Nemzeti Közösségi Biztonsági és Vészhelyzeti Felkészültségi Oktatási Központ (Nasjonalt Utdanningssenter for Samfunnssikkerhet og Beredskap) vagy a Norvég Túzoltó-akadémia (Norges Brannskole). Nemzetközi szinten is lát el feladatokat; így a Norvég Támogatói Csoport (Norsk

47 Direktoratet for Samfunnssikkerhet og Beredskap (DBS) (A szervezet honlapja elérhetô: www.dsb.no/). 
Support Team) első határon túli feladata a koszovói válságot követően kialakult helyzetben tábor létesítése az ENSZ segélyszervezetei számára.

A DSB múködését már a kezdetektôl több jogszabály is rögzíti, ${ }^{48}$ de a szervezet maga is fontos szerepet tölt be a katasztrófavédelem szempontjából releváns szabályok betartása érdekében. A szervezeti alá- és fölérendeltségi kérdések pontosan meghatározottak, így nem jelent problémát az együttmúködés az olyan, önmagában is integrált koordinációs struktúrát múködtető szakmai szervezetekkel, mint a Norvég Kereső- és Mentőszolgálat (Norsk søk-og redningstjeneste). ${ }^{49}$ Segítségével minden egyes mentési koordinációs központ felkészült a szárazföldi, tengeri vagy légi múveletek, a tengeri olaj-vagy gázipari létesítmények mentési és a nemzetközi együttmúködést igénylő egyéb múveletek kezelésére.

A nemzet sebezhetőségének és fenyegetettségének meghatározásakor kiemelkedő jelentősége van a kockázatértékelésnek. Erre figyelemmel Norvégia a kockázatértékelés több formáját $t^{50}$ is alkalmazza - így a biztonság és védelem területén is folyamatosan készülnek kockázatelemzések. Ezek ${ }^{51}$ részben arra is fókuszálnak, hogy a két igény - biztonság és védelem - tekintetében mennyiben azonosak, illetve különbözőek a kockázati tényezők és a kezelési lehetőségek. Számtalan esemény következhet be, amelyek különböző mértékben érinthetik a két igényt; így szélsőséges időjárás, áradások, földcsuszamlások, fertőző betegségek, erdei tűz, időjárási körülmények, vulkáni tevékenység, földrengés, veszélyes anyagok, atombalesetek, tengeri balesetek, közlekedési balesetek, áramszolgáltatás, terrorizmus, politikai válságok, digitális támadások. Ennek megfelelően például 2018-ban 27 kockázatelemzés történt 17 kockázati területen belül, ${ }^{52}$ amelyek során több szempont is értékelésre került: a fenyegetés valószínűsége, a biztonsági rés nagysága és a lehetséges következmények, amelyek együttesen megadják az ország vagy az adott szektor sebezhetőségét is. Ugyanakkor annak meghatározása, hogy az esemény bekövetkezte mennyire valószínú, bár komoly háttérismereten kell alapuljon, hordoz magában bizonyos fokú szubjektivitást is. Ennek ellenére mind társadalmi, mind közösségi, mind akár gazdasági-piaci szereplői ${ }^{53}$ területen kiemelkedően fontos. 2020-ban - még a Covid-19 megjelenése elôtt - készült nemzeti fenyegetésérzékelési vizsgálat ${ }^{54}$ a norvég biztonságot veszélyeztető legsúlyosabb fenyegetések három formáját azonosította: a kormányra, a parlamentre és a fegyveres erőkre irányuló külföldi hírszerzési

48 Lásd erről részletesebben az Európai Bizottság honlapját: https://ec.europa.eu/echo/files/civil_protection/ vademecum/no/2-no-1.html (Letöltve: 2020. szeptember 10.).

49 Ez egyben biztosítja Norvégia aktív részvételét a tengeri kutatásról és mentésról szóló 1979-es nemzetközi SAR-konvenció végrehajtásában (International Convention on Maritime Search and Rescue).

50 Lásd a nemkívánatos szándékos tevékenységek kockázatértékelésének megközelítéseire például: Busmundrud et al., 2015.

51 Midtgaard, 2018.

52 Így többek között a pénzmosás és a terrorizmus finanszírozása kérdéskörben is. Lásd erről részletesebben: www.regjeringen.no/contentassets/58f96ea9756d4457be3095609624d96d/nasjonal-riskikovurdering.pdf (Letöltve: 2020. december 15.).

53 Lásd például: Holter, 2010.

54 PST, 2020. 
aktivitást, a kritikus infrastruktúrák digitális felderítésének és szabotálásának veszélyét, valamint a terrorista támadások lehetőségét, amelyeket jobboldali szélsőségesség vagy szélsőséges iszlamista ideológia motivál.

Az év során - már a pandémia időszakában - a Nemzetbiztonsági Bizottság5 által készített kockázatértékelés ${ }^{56}$ az ország fokozott sebezhetőségét a digitalizációban, illetve a nemzeti (vállalati) értékek, a társadalom legtöbb szektorában a funkciók és szolgáltatások virtuális térbe való helyezésében látja. A külföldi államok befolyásolási törekvései, a hírszerző szolgálatok kutatási és technológiafejlesztési környezetekhez való hozzáférési kísérletei, az érzékeny információk és üzleti titkok megszerzésének célja nem új keletú jelenség, mértéke és intenzitása - a mindennapi tevékenységek digitális térbe szorulása miatt is -, illetve jelentősége 2020-ban tovább fokozódott. Így a jelentésben nevesített mindhárom fó nemzetbiztonsági kockázati tényező a kiberbiztonsághoz kapcsolódik: a társadalom növekvő függősége az elektronikus hírközléstől és a múholdas alapú szolgáltatásoktól; a digitális infrastruktúráktól és a határainkon túli értékláncoktól való fokozódó függés; az együttes eszközhasználat, többek között stratégiai akvizíciók, beruházások és befolyás formájában.

\section{A különleges jogrend kihirdetésének gyakorlati esetei}

Különleges jogrend kihirdetésére, szükségállapot, rendkívüli állapot elrendelésére a rendelkezésre álló információk szerint Norvégiában az elmúlt időszakban különböző okok miatt még a járványhelyzetet megelőzően nem került sor.

A különleges jogrend alkalmazását megalapozó esetek tekintetében az ország fekvéséből és energiaipari pozicionálásából adódóan elsősorban a természeti és ipari katasztrófák jelennek meg különös súllyal. A természeti katasztrófák közül az utóbbi időben a klímaváltozás okoz gondot - így például a világ különösen gyorsan melegedő területén, a Spitzbergákon rénszarvasok százai halnak éhen, míg más területeken komoly földmozgások, hegyomlások miatt kell embereket evakuálni. ${ }^{57}$ Ugyanakkor a kormány mára nemcsak komplex rendszert dolgozott ki az ilyen helyzetek kezelésére, de proaktivitás ${ }^{58}$ is jellemzi. Az elmúlt években egységesített katasztrófavédelmi rendszer kialakítását olyan ipari katasztrófák is segí-

55 Nasjonal sikkerhetsmyndighet (NSM).

56 NSM, 2020, 5. o.

57 Így legutóbb például a Veslemannen hegycsúcs leomlása miatt. Elérhető:https://hvg.hu/tudomany/20190908_ Hegyomlas_evakualas_elo_adas_Norvegiaban (Letöltve: 2020. november 11.).

58 A kormány tulajdonában lévő Globális Terménydiverzitási Szövetség (Global Crop Diversity Trust) látja el a Svalbargi Globális Magtár (SGSV) múködtetését, amely több mint 800 ezer növényfaj magmintáját őrzi abból a célból, hogy egy globális katasztrófa (például atomháború, földrengés vagy világméretú járvány) bekövetkezte esetén is megőrizze az emberiség a termények biológiai sokszínűségét. Az ötlet több mint 30 éves; a skandináv országok 1984-ben már létrehoztak egy magtárolót a szigetcsoport egyik elhagyatott szénbányájában. Elérhető: http://ecolounge.hu/nagyvilag/a-spitzbergaki-globalis-magbunker (Letöltve: 2020. november 11.). 
tették, mint az úszó hotelként funkcionáló Alexander L. Kielland félig merülő fúrótorony 1980. március 27-i elsüllyedése. ${ }^{59}$

Az ország békés, belső és külső támadásoktól mentes mindennapi élete 2011-ben azonban jelentősen megváltozott. A kiugróan jó közbiztonsági helyzetet jól jellemzi, hogy például 2010-ben összesen 29 emberölést követtek el (a kétszer olyan nagy lélekszámú Magyarországon 150-et), ${ }^{60}$ és a rend fenntartása érdekében a norvég rendőrök az 1994-2004 közötti 10 év alatt - a 2004-es stavangeri NOKAS-bankrabláson kívülli - csupán 31 alkalommal használták fegyvereiket. Bár terrorcselekményként minősíthető bủncselekmények elkövetésére is akadt példa, ${ }^{62}$ ezek száma csekély volt: 2004-2010 közötti adatok alapján Norvégia a Worldwide Incident Tracking System (WITS) terrorizmus-adatbázisában sem szerepelt. Ahhoz, hogy mára a különböző kihívásokra megfelelően felkészült legyen, sokat „tett hozzá” Anders Behring Breivik 2011. július 22-i, az országot teljesen váratlanul érő és sokkoló, Oslóban és Utøya szigetén elkövetett merénylete. A 77 halálos áldozatot és 96 sebesültet követelő bưncselekmény létrejöttében ugyanis jelentős szerepet játszott számos körülmény, így a lőfegyverhez jutás nagyon liberális feltételei; az a tény, hogy a norvég rendőrök alanyi jogon nem viselhetnek fegyvert; a több száz fôs ifjúsági tábort csupán egyetlen, fegyver nélküli rendőr biztosította; a rendőrök által igénybe vett utazási eszköz és a különleges erők által választott helyszín téves volta; a fiatalokat mentő helyi civilek tevékenységének leállítása a különleges erők megérkeztéig. Összességében szervezetlen, nem kellően összehangolt és felkészületlen volt a hatóság reagálása a cselekményre, ami önvizsgálathoz és több változtatáshoz is vezetett.

Más történések is a minőségbiztosítási szempontok belső fókuszba állitását igényelték. Bár a norvég kormány krízishelyzeteket kezelő mechanizmusa már korábban is jól kimunkált volt, a potenciális (például környezet- és egészségkárosító) rizikótényezőként megjelenő esetek egy részére csak áttételes hatása lehetett. ${ }^{63}$ Ezek egyik legsúlyosabbika a K-278-as jelzésú, harmadik generációs atom-tengeralattjárók közé tartozó Komszomolec 1989. április 7-én a norvég fennhatóság alatt álló Medve-szigetek közelében történő elsüllyedése. A hadijármú a hagyományos és nukleáris robbanófejjel egyaránt felszerelhető torpedókon kívül

59 A 123 emberéletet követelő katasztrófa létrejöttéhez számtalan tényező vezetett: a tornyot tartó egyik láb megrepedt; ezt a tényt a torony múszaki felülvizsgálatakor nem észlelték, mivel a lábakat nem ellenőrizték (inadekvát biztonsági ellenőrzések); a műszaki leírásban nem szerepelt, hogy mekkora megterhelésnek lehet kitenni a platformot; nem volt elég hozzáférhető mentőmellény, és nem volt olyan vészforgatókönyv sem, amit elpróbáltak és egységesen követhettek volna az ott dolgozók. Elérhető: https://iparikatasztrofak.blog. hu/2017/12/13/igy_sullyed_el_egy_furotorony_15_perc_alatt (Letöltve: 2020. november 11.).

60 Tálas et al., 2011, 1. o.

61 Itt 48 alkalommal került rá sor.

62 A Global Terrorism Database (GTD) szerint 1979 és 2010 között 15 terrorcselekmény, ezen belül két robbantásos merénylet volt (1987, 1994), amelyek 17 áldozatot követeltek (köztük egy halálos). Tálas et al., 2011, 2. o.

63 A számos szovjet/orosz tengeralattjáró-baleset széles körủ kihatásait jól mutatja, hogy például a 2000. augusztus 12-én az orosz hadsereg Barents-tengeren tartott hadgyakorlata során elsüllyedt Kurszk atom-tengeralattjárón történt robbanásokat a norvég földrengés-megfigyelő rendszer azonnal észlelte, míg Oroszország hivatalosan csak két nappal később jelentette be a tragédiát. 
képes volt atomtöltettel rendelkező interkontinentális ballisztikus rakéták indítására is, így a roncsok komoly ökológiai veszélyforrást jelentenek. ${ }^{64}$

Az említett esetek közül önvizsgálatot ${ }^{65}$ és intenzív társadalmi és szakmai diszkussziót leginkább a Breivik-ügy - illetve az azzal kapcsolatban feltárt rossz múködési mechanizmusok köre - váltott ki.

Az utóbbi időszakban az ország közbiztonsági helyzete a külső és belső társadalmi változások hatására - bár csekély mértékben, de - negatív irányban változott; emellett az esetleges vészhelyzetet előidéző támadások részben más síkra terelődtek. Ennek hatására 2019 novemberében a Nemzetbiztonsági Bizottság részeként megalakult a Nemzeti Kiberbiztonsági Központ (Nasjonalt cybersikkerhetssenter).

Ezen, összességében pozitív folyamatok ellenére a különleges jogrend szabályozását, annak tartalmi kérdéseit, esetköreit és a vészhelyzetekben való gyakorlati alkalmazhatóságát érintően számtalan kritika ${ }^{66}$ fogalmazódott meg már a korábbi évek során is.

Élénk - politikai, szakmai - vitát generált a közelmúltban a külföldi katonai szerepvállalás kérdése. Az alkotmány 25. cikkének módosítása azért merült fel, mert bevett gyakorlattá vált a norvég katonák külföldre irányítása a parlament döntése nélkül. ${ }^{67} \mathrm{Az}$ alkotmány szigorú értelmezése szerint Norvégia külföldi háborús részvételéről a parlament dönt, nem pedig a kormány. A norvég katonák azonban - mint NATO-tagok - részt vettek és vesznek különböző nemzetközi rendfenntartó akciókban, aminek a nemzetet megérintő érzelmi következményei is vannak; például 2001-2012 között 10 norvég katona vesztette életét Afganisztánban ${ }^{68}$ a NATO vezette nemzetközi biztonsági erôk tagjaként. Ugyanakkor az alkotmány sem a norvég katonák külföldre küldését, sem külföldi katonák érkezését nem támogatja. Ennek ellenére - a II. világháború óta először - 2017 januárjától amerikai tengerészgyalogosok állomásoztak ${ }^{69}$ az ország területén. A javasolt alkotmánymódosítás célja a helyzet tisztázása, az átláthatóbb és demokratikusabb parlamenti vitához való hozzájárulás, egyben olyan biztonsági „szelepek” beiktatása volt, amelyek garantálhatják a kormány gyors cselekvési képességét - akár az ország határain kívül is, ha ez indokolt -, kifejezetten Norvégia határainak védelme érdekében. ${ }^{70} \mathrm{Az}$ így módosított és jelenleg hatályos alkotmány már rögzíti a parlament hatalmát, és egyben kizárja, hogy parlamenti jóváhagyás nélkül a norvég fegyveres erők ,idegen hatalmak szolgálatába álljanak”, avagy idegen hatalom ka-

64 Lásd erről részletesebben például: Múlt-Kor, 2019.

65 A kormány felelősségéról és más kérdésekről lásd részletesebben: Lægreid et al., 2014, 66-77. 0.

66 Lásd erről részletesebben: Wind, 2009, 131-141. o.

67 A külföldön zajló norvég háborús részvétel kapcsán nagyobb átláthatóságot elérni kívánó alkotmánymódosító javaslatra lásd: www.stortinget.no/no/Saker-og-publikasjoner/Publikasjoner/Innstillinger/ Stortinget/2015-2016/inns-201516-287/?lvl=0 (Letöltve: 2020. szeptember 6.).

68 Elérhetô: https://honvedelem.hu/cikk/norveg-katonakra-tamadtak-afganisztanban/ (Letöltve: 2020. szeptember 27.).

69 Elérhető: https://hu.euronews.com/2018/06/12/tobb-amerikai-katonat-ker-norvegia (Letöltve: 2020. szeptember 27.).

70 Lásd a fentebb hivatkozott alkotmánymódosító javaslatot. 
tonái a királyság területére lépjenek (még ha ellenséges támadások ellen fellépő csapatok tagjai is). Kivételt jelentő eset, hogy a királyság védelmi erőit a királyság határain kívül használhatják a parlament beleegyezése nélkül is, amennyiben ez az ország védelme érdekében feltétlenül szükséges.

A különleges jogrenddel kapcsolatos konkrét ügyeket érintő jogvitákra a norvég legfelsőbb bíróság előtt kerülhet sor. Tønder legfelsőbb bírósági bíró erre vonatkozó tanulmányában ${ }^{71}$ is rögzíti a törvényhozó és a végrehajtó hatalom norvég bíróságok általi ellenőrzésének speciális jellegét. A törvényhozó hatalom tekintetében ez annak biztosítását jelenti, hogy a jogalkotás összhangban van az alkotmánnyal, a végrehajtó hatalom vonatkozásában pedig a polgárokkal szembeni közhatalom gyakorlásának a közigazgatási jog hatáskörébe tartozását. „Norvégia tehát nem rendelkezik közigazgatási bíróságokkal a hatalom nyilvános gyakorlására vonatkozó esetek megvizsgálására, sem alkotmánybíróságokkal alkotmányos kérdések kezelésére."ᄁ2 Egyebekben a rendes bíróságok felülvizsgálják a jogszabályok kapcsolatát a norvég jog részévé vált emberi jogi egyezményekkel, valamint az ország EU-val kötött megállapodásával is.

A különleges jogrendet érintő esetkörök közül példaként említhető az a terrorista cselekmények elkövetésével kapcsolatos konkrét büntetőügy,73 amely indoklásában - egyes törvényhelyek értelmezésbeli különbözésével összefüggésben - kifejtésre került, hogy nem volna szerencsés, ha Norvégia jelentené a „rést”"74 az európai országok (és az EU) terrorizmusellenes szabályozásában.

A kimondottan stabil államtörténelemmel bíró Norvégiában az 1814. évi alkotmány veszélyhelyzeti vagy rendkívüli körülmények alatti müködését elsősorban az 1940-1945 közötti háborúban „tesztelték”. Bár a pandémia megjelenése teljesen más támadást jelent, az egész országot és annak minden müködési szintjét érintő jellege olyan új helyzetet váltott ki, amely komolyan megmérette a norvég szabályozást, rég nem tapasztalt heves tiltakozást kiváltva és mintegy előtérbe hozva a sürgősségi jogalkotás kérdését (amely már korábban is a szakmai-tudományos környezet kiemelt figyelmében állt).75

Az alkotmányokat általában egy ország megszokott múködési feltételeire írják, s így sokszor gondot jelent a rendkívüli helyzetek generálta rendkívüli igények kielégítése legyen szó természeti katasztrófákról, politikai zavargásokról, háborúkról vagy terrorista akciókról. Nemzetközi szinten is igaz, hogy a rendkívüli helyzetek az alkotmány - ideiglenes - „felfüggesztésének” egyik tipikus okává váltak. Ezt a folyamatot tovább erősítették

71 Részletesebben lásd: Tønder, 2014, 74-84. 0.

72 Tønder, 2014, 74. o.

73 Lásd a legfelsőbb bíróság HR-2018-1650-A (case no. 18-044407STR-HRET) számú ítéletét: www.domstol.no/ globalassets/upload/hret/decisions-in-english-translation/hr-2018-1650-a.pdf (Letöltve: 2020. november 11.).

74 Norvégiát tehát egyfajta „biztonságos menedéknek” lehet tekinteni, ahol bizonyos korlátok között propagandatevékenység fejthető ki.

75 Michalsen, 2013. 
a 2001 után egyre gyakoribbá váló - immár direkten a kormányokat célzó - terrorista akciók, amelyek kiterjedt nemzeti és nemzetközi jogalkotásra ösztönözték az államokat. ${ }^{76}$ Így számos országban - beleértve Norvégiát is - az „alkotmányos szükségesség” a sürgősségi törvényhozás egyik változatává vált, amely felhatalmazást ad a kormánynak az alkotmány egyes részeinek felfüggesztésére. Ez a gyakorlat azonban már eddig is komoly garanciális kérdéseket vetett fel, elsősorban az alkotmányos jogállamiság és az állam biztonság iránti igénye közötti egyensúlyteremtés kapcsán; a járványkezelés lehetséges válaszaként pedig kétségessé tette annak alkalmazhatóságát.

A járványhelyzet kezelésével összefüggésben Norvégiában nem került sor sem különleges jogrendi szabály alkalmazására, sem rendkívüli állapot elrendelésére. Utóbbit a norvég alkotmány nem ismeri, míg előbbi kapcsán is csekély számú konkrét rendelkezést tartalmaz. Az egészségügyi vészhelyzet kezelését - mint sok más országban - itt is a rendes jogszabályok határozzák meg, így többek között a Fertőzéskontroll tv. és az Eü. felkészültségi tv. Ezek kiterjedt hatáskörökkel ruházzák fel a kormányt. Bár - ahogy már rögzítettük - az alkotmány nem ismeri el az emberi jogoktól való általános eltérési záradékot, elméletileg egy egészségügyi veszélyhelyzet, amennyiben ennek súlyát úgy ítélik meg, lehetőséget adhat az úgynevezett alkotmányos szükségesség elve alapján az alkotmányban rögzítettektől eltérő jogalkotási gyakorlatra az arányosság követelményének szem előtt tartásával. 2020 szeptemberéig 10 tagállam jelentette be, ${ }^{77}$ hogy az EJEE 15 . cikke alapján a feltételek ${ }^{78}$ szigorú betartásával ideiglenesen eltér szokásos egyezményes kötelezettségeitől a Covid-19-cel szembeni eredményes fellépés érdekében, de Norvégia nem csatlakozott e körhöz.

Elsősorban a járványkezelés konkrét módját illetően számos kritika fogalmazódott meg. Ezek közül a legélesebbek egyenesen azt üzenték, hogy a norvég hatalom eljárása ez esetben nemcsak az egészséget, hanem a jogállamiságot is támadja. ${ }^{79}$ Norvégiát mint rossz példát állították ki, amely veszélyeztetheti a Covid-19-cel szembeni intézkedések elfogadásának demokratikus folyamatát, s olyan jelenségekkel átitatott, mint a hatóságok hatásköri túllépései, az átláthatóság hiánya és a nyilvánosság kizárása a döntéshozatalból, valamint a központi kormányzat és a helyi hatóságok közötti folyamatos küzdelem a szabályozás „birtoklásáért”.

Természetesen a járvánnyal szembeni intézkedések Norvégiában is az ismert eszközöket vették igénybe ${ }^{80}$ a karantén elrendelésétől a boltok, intézmények bezárásáig. ${ }^{81}$ A rendel-

76 Érdekes tény, hogy Izlandon például a 2000-es évek során bekövetkezett pénzügyi válság vezetett el a sürgősségi jogalkotás elfogadásához. Lásd errôl részletesebben: Krunke et al., 2018.

77 Ezek a következők: Albánia, Örményország, Észtország, Grúzia, Lettország, Észak-Macedónia, Moldova, Románia, San Marino és Szerbia (Radjenovic-Eckert, 2020).

78 Lásd erre részletesebben: Jovičić, 2020.

79 Lásd erre részletesebben: Graver, 2020 a.

80 A koronavírus-helyzettel kapcsolatos legfontosabb információk és reakciók elérhetők norvég nyelven a következő honlapon: www.regjeringen.no/no/tema/Koronasituasjonen/id2692388/ (Letöltve: 2020. december 15.).

81 Lásd erről részletesebben: www.regjeringen.no/en/topics/koronavirus-Covid-19/timeline-for-news-fromnorwegian-ministries-about-the-coronavirus-disease-Covid-19/id2692402/ (Letöltve: 2020. december 15.). 
kezések alapját elsősorban a Fertőzéskontroll tv. adta, így különösen annak 4. fejezete (Egyéb fertôzésvédelmi intézkedések). Ez széles körben nyújt felhatalmazást alapjogok korlátozásával való intézkedések alkalmazására, azok jellegétől függően az önkormányzati tanácsot, a Járványügyi Központot, a megye kormányzóját vagy épp a királyt felruházva a döntéshozatal jogával. ${ }^{82} \mathrm{Az}$ iskolákat és óvodákat bezárták, a gyülekezést ugyanúgy tiltották, mint például a különböző, közvetlen emberi interakciókat feltételező szolgáltatásokat (például fodrász, fogorvos, edzőterem igénybevétele). Ugyan általános kijárási tilalmat nem rendeltek el, de arra ösztönözték a lakosságot, hogy kerüljék a tömegközlekedést, vegyék igénybe a home office-t, és ne fogadjanak otthonukban vendégeket. Ezzel párhuzamosan módosították az eljárási törvényeket a közigazgatást és a közszolgáltatásokat (például igazságszolgáltatás, oktatás) érintően, széles körben lehetővé téve a virtuális kommunikációt és feladatellátást. Pozitív hatásként értékelhető, hogy Norvégia jelentős gazdasági támogatást is nyújtott az érintett gazdasági szereplók és munkavállalók számára.

Ugyanakkor a számtalan Covid-19 tárgyú rendelet, illetve törvénymódosítás jelentős alapjog-korlátozó elemeket is tartalmazott. Így például a koronavírus kitörésével összefüggő, a fertőzés elleni intézkedésekről szóló, 2020. március 27-i 470. sz. rendelet a beutazási és karaténszabályok vonatkozásában vagy a Covid-19 kitörése következményeinek orvoslását célzó integrációról szóló törvény módosítása. ${ }^{83} \mathrm{E}$ körben fontos kiemelni, hogy például az országot 2020. március 12-ével lezáró határozatot hivatalosan a Norvég Egészségügyi Igazgatóság hozta meg, noha az alkotmány értelmében az ilyen döntések a kabinet hatáskörébe kell tartozzanak. A Fertőzéskontroll tv. kereteit az állam és a helyi hatóságok (is) a végletekig kitágították. ${ }^{84}$

Az intézkedések tehát jellegükben és irányukban nem tértek el más országok gyakorlatától, azonban az emberi jogokra igen érzékeny országban ${ }^{85}$ nagyon hamar megjelentek az első kritikák. ${ }^{86}$ Ezek középpontjában először az arányosság kérdése állt. A helyi szokásoknak és életvitelnek megfelelóen a norvég - fóként városi - lakosság tipikusan rendelkezik egy hyttével, azaz hétvégi házzal a hegyekben vagy a tenger mellett, ahol eltölti az ünnepeket, vagy egyszerủen hétvégén kikapcsolódik. A szabad mozgást korlátozó rendelkezések jelentősen érintették ezt a szokást, elsősorban annak érdekében, hogy az egyébként általában

82 Lásd az önkormányzati szabályozással kapcsolatos kormányzati ajánlásokat részletesebben: Nicolaisen et al., 2020.

83 LOV-2020-12-18-154. A Covid-19 kezelésével összefüggésben született, a gazdaságot érintő jogszabályok listája elérhető például a következő honlapról: www.skatteetaten.no/en/measures/ (Letöltve: 2020. december 15.). 84 Graver, 2020b, 167. o.

85 Ez alapján Norvégia a második helyen állt 2019-ben és 2020-ban is a World Justice Project (WJP) jogállamisági indexe szerint (WJP, 2020, 7. o.). Ugyanakkor a legfőbb jogállami kihívások között szerepel a hatóságok hatáskörének túllépése, az átláthatóság hiánya és a nyilvánosság kizárása a nyilvános döntéshozatalból és a joghatóság feletti harc a központi kormányzat és a helyi hatóságok között.

$86 \mathrm{Az}$ Oslói Egyetem Norvég Emberi Jogi Központja (Norwegian Centre for Human Rights) fokozott figyelemmel kíséri a járványkezelést. Az ezzel kapcsolatos tanulmányok elérhetők a szervezet honlapján:www.jus.uio.no/ smr/english/?vrtx=search\&query=Covid-19 (Letöltve: 2020 . december 15.). 
ritkán lakott, zárt vidéki közösségeket megóvják a nagyobb népsűrűségú, így nagyobb fertőzésveszélynek kitett városi lakosokkal való érintkezéstől. Ezek a rendelkezések több alapvető - társadalmi és gazdasági jellegû - jogot is érintettek, így 10 nappal a hatálybalépést követően az Emberi Jogi Intézet igazgatója már megfogalmazta aggályait. Ezek középpontjában elsősorban az állt, hogy a kormány a rendelet elfogadása előtt nem tárt fel elegendő bizonyítékot az intézkedések szükségességének és arányosságának indoklására. A kormány arra hivatkozott, hogy a területek egészségügyi szolgáltatásai nem készültek fel az esetlegesen ott megbetegedő hétvégi nyaralók megnövekedett számának ellátására. Noha a vita végén az Államtanács is elismerte, hogy az egészségügyi szolgáltatások kapacitásvédelme más módon is biztosítható, s ezek mérlegelését az előkészítés során nem vizsgálták, de a rendeletet ezzel együtt nem módosították.

A Fertőzéskontroll tv. alapján a király számos jogkörrel felruházott ugyan, az így hozott rendelkezéseket ugyanakkor a lehetô leghamarabb be kell nyújtani a parlamentnek, hogy az gyakorolhassa jogait, sor kerülhessen nyilvános konzultációra és a parlamenti felülvizsgálatra. A gyors kormányzati reagálás Norvégiában is lényeges szempont volt, így - a már ismert rendelkezéseken túl - számos jogszabály született, amelynek célja a hatékony fellépés volt. E körben különösen komoly kritikát ${ }^{87}$ váltott ki, hogy a kormány - a nyilvánosság szokásos tájékoztatása nélkül, az érintett intézményekkel való egyeztetés és érdekeik, illetve szükségleteik megismerését mellőzve - készítette el a vészhelyzeti törvény javaslatát, amely a sürgősségi jogalkotás hatásköreit is jelentősen érintette. Ennek során titkos üléseket tartottak; sőt, az ellenzéki pártok vezetőivel is megállapodtak annak érdekében, hogy a törvény akadály nélkül elfogadásra kerülhessen (a vita látszólagos lefolytatása mellett). A vészhelyzeti törvény a tervek szerint a kormányt jelentős jogkörökkel ruházta volna fel; egyrészt lehetőséget adva neki a jogszabályok parlament bevonása nélküli elfogadására, másrészt arra, hogy ha azt a társadalom múködési zavarainak korlátozása vagy épp a lakosságra, a gazdasági életre vagy a közszféra szereplőire háruló terhek enyhítése megkívánja, eltérhessen a hatályos törvények rendelkezéseitől. Új parlamenti ellenőrzési mechanizmusok kialakítását is tartalmazta a tervezet, lehetővé téve az elektronikusan (e-mail útján) történő hivatalos véleménynyilvánítást és joggyakorlást. A 2020. márciusi javaslattal szemben - különösen annak előkészítési módja okán - jelentős ellenérzések fogalmazódtak meg, kiemelve a tervezet alacsony szakmai színvonalát, sietős előkészítését, a magyarázatok és a háttérelemzések teljes hiányát. Elvi szinten különös súllyal jelent meg, hogy az nem felel meg a hatalomszétválasztás, a demokratikus biztosítékok és a jogállamiság elvének (legfeljebb súlyos kompromisszumok árán). A szakemberek számára a legaggályosabb üzenet az volt, hogy a kormány készen állt (volna) a törvényalkotás demokratikus folyamatának mellőzésére.

A törvényjavaslat 2020. március 18 -i előterjesztését követően ${ }^{88}$ azonban a fenti tények ismertté váltak, így a parlament a gyors meghallgatás kezdeményezése mellett döntött, 
amelyre meghívta képviselői révén többek között a Norvég Ügyvédi Kamarát, a Norvég Bírói Szövetséget, az Emberi Jogi Központot csakúgy, mint számos kiemelkedő jogtudóst, hogy véleményüket megismerhesse. Ezek beillesztésével alakítottak a javaslaton, s végül március 21-én a parlament el is fogadta a norvég korona- (Covid-19-) törvényt, amely azonban már jóval szükebb felhatalmazást ad a kormánynak a Covid-19 és annak társadalomra gyakorolt következményei elleni küzdelemre, mint az eredeti tervezet.

A számos ellenvélemény, szakmai aggály ellenére is fontos ugyanakkor kiemelni, hogy a végül elfogadott Covid-19-törvény több garanciális elemet tartalmaz ${ }^{89}$ a jogszabály érvényességi időtartamától kezdve (egy hónap) az alkalmazási előfeltételein át annak bírósági kontrolljáig. A folyamatosan módosuló, illetve rendeletekkel kiegészülő Covid-19-jogszabályok fố célja többek között a kompenzációt nyújtó gazdasági intézkedések elfogadása, a digitális bíróságok és igazgatás múködésének lehetővé tétele (például virtuális meghallgatások, digitális aláirás) vagy a bevándorlás-ellenőrzés aktuális intézkedési formáinak meghatározása volt. A törvénybe a parlament által beillesztett utólagos kontrollt erősítő rendelkezés kimondja, hogy a törvény szerinti intézkedések jogszerüségét és arányosságát teljes bírósági felülvizsgálatnak kell alávetni.

Egyéb - elsősorban a jogszabályok, konkrét rendeletek végrehajtásával kapcsolatos problémák is kritikai vizsgálat alá kerültek; így például a helyi intézkedések koordinálatlansága vagy a hatáskörtúllépések, amelyek jelentősen rontottak a Covid-19 elleni védekezés hatékonyságán.

\section{4. Összegzés}

A norvég alkotmány, mint a legidősebb Európában, felépítésében és szabályozási megoldásaiban visszatükrözi annak az országnak a békés történelmét, amely 21. századi múködési kereteinek alapját egy 1814-ben született alaptörvény testesítheti meg.

Ennek megfelelően az alkotmány nem tartalmaz részletes szabályokat a különleges jogrendet illetően, nem ismeri a rendkívüli állapot fogalmát, nem határoz meg vészhelyzeti rendelkezéseket, és elvétve szól a sürgősségi jogalkotásról. E tekintetben legjelentősebb szerepe az egyéb jogszabályoknak, így különösen a Vészhelyzeti felkészültségi tv.-nek van.

Mind az alkotmány, mind a Vészhelyzeti felkészültségi tv. speciális jogokat biztosít a királynak arra az esetre, ha például háború vagy háborús fenyegetés okán nem tudna ülésezni a parlament. Ez egyben azt is jelenti, hogy a király - meghatározott feltételek mellett - törvényerejü rendeleteket hozhat (akár az egyebekben hatályos és irányadó jogszabályi háttérrel ellentétes tartalommal is). E felhatalmazás korlátját számos rendelkezés garantálja, amelyek a parlament egyidejû tájékoztatásának és mihamarabbi összehívásának kötelezettségét

89 Graver, 2020b, 172-173. o. 
csakúgy rögzítik, mint a rendeletek hatályban maradásának időbeli korlátját. A jogokkal a gyakorlatban nem a király, hanem az Államtanács (azaz a kormány) él(ne).

Ezen túl a jogelmélet ismeri a szükségszerüség doktrínáját, amely szerint „a vészhelyzetek legitimálnak egy olyan tevékenységet, amely normál körülmények között az alkotmány megsértését vonná maga után". ${ }^{\circ 0}$ Fontos feltétel a súlyos vészhelyzet, valamint az, hogy a nemzeti érdekek védelme az irányadó jogszabályok betartása mellett nem garantálható. Így számos országban - beleértve Norvégiát is - az „alkotmányos szükségesség” a sürgősségi törvényhozás egyik változatává vált, amely felhatalmazást ad a kormánynak az alkotmány egyes részeinek időleges „felfüggesztésére”.

Bár Norvégiában a krízishelyzetek előfordulása ritka, azonban az ország - részben a 2011-es terrortámadásra is reagálva - iránymutató gyakorlatot alakított ki a vészhelyzetek megelőzése, illetve kezelése vonatkozásában, ahol mind az érintett komplex intézményrendszer, mind a feladat-, döntés- és felelösségmegosztás pontosan meghatározott. Ezek nemcsak az ágazati jogszabályokban rögzítettek, de a Vészhelyzeti Felkészültségi Bizottság jelentései, a katasztrófavédelem szabályozása is rögzíti ezeket. A komplex, széles körú hatósági és civil szervezeti körre és az állampolgárok bevonására épülő, többszintủ katasztrófavédelem és krízismechanizmus példaértékűnek tekinthető. Mindez jól kommunikált, áttekinthető szisztémaként múködik, amely biztosítja a folyamatos minőségbiztosítást, ${ }^{91}$ szükség esetén az újratervezést, utánkövetést, valamint az állampolgárok és szervezetek széles körú tájékoztatását.92

Az országban az emberi jogok és a jogállamiság kérdése kiemelten a figyelem középpontjában van, ennek ellenére a pandémiával kapcsolatos, alapvetően a Fertőzéskontroll tv.-en alapuló szabályozás, illetve a járványhelyzet kezelése az első időszakban számtalan kritikát kapott, és több szakmai aggály fogalmazódott meg, részben azok gyakorlati megvalósulásával kapcsolatban. A végül elfogadott Covid-19-törvény azonban már megfelel mindazoknak a garanciális szempontoknak, amelyek megalapozzák annak támogatottságát.

Elméleti síkon a norvég szabályozás sajátossága, hogy a parlament kontrollszerepét rögzítő garanciális korlátok mellett a döntés a király (kormány) hatáskörébe kerül, nagyon súlyos válság esetén pedig a szükségesség doktrínája gyakorlatilag minden hatalmat e körbe koncentrálhat, megengedve az alkotmány elveivel és rendelkezéseivel szemben álló döntés meghozatalát is. Az alkotmány fennállta óta erre azonban alig akadt példa. Sokkal inkább állítható Hans Petter Graver nyomán, hogy Norvégia a kivételek állama. ${ }^{93}$ Carl Schmitt gondolatai visszatükröződtek a norvég vészhelyzeti kodifikációs munkákban: csak normatív módon nem lehet előre szabályozni minden szükséghelyzetet; a kivételhez az általános

90 Andenæs-Fliflet, 2017, 502. o.

91 Így például: Cosgrave et al., 2008.

92 Lásd erre például: MOD, MOJ, 2018.

93 Graver, 2020b. 
normák által nem kötött döntés szükséges ${ }^{94}$ Hogy ez nem vezet szükségképpen diktatúrához, arra épp Norvégia lehet az egyik példa, amely Scheppele ${ }^{95}$ jogállamiság és a rendkívüli állapot közötti összefüggéseket felvázoló hármas tipológiájából a harmadik csoportba tartozik. Noha a Covid-19 vírussal szembeni fellépés során alapvető jogok túlzott korlátozására is akadt példa, sőt, a válsághelyzet megoldására való hivatkozás lehetőséget tưnt biztosítani a kormány hatalmának kibővítésére, a garanciális és jogállamisági szempontok ennek gátját szabták.

Bár „[a] hivatalos norvég alkotmány »régi kastélyként« jelenhet meg, de gyakorlata nem feltétlenül áll olyan távol a »stílusos modern operaháztól«" ${ }^{96}$ A parlamenti szuverenitás erős beágyazódása az alkotmány parlamenti szavazás útján történő módosításával, illetve a „negatív parlamentarizmus" pragmatikus elfogadása az alkotmányok speciális csoportjába sorolja a norvég alaptörvényt, amely azonban egyre inkább hasonlít más alkotmányokra többek között a jogok széles körének bírósági felülvizsgálatára való áttérés okán.

\section{Irodalomjegyzék}

ANDENÆS, J., Fliflet, A. (2017) Statsforfatningen i Norge. 11. kiadás. Oslo: Universitetsforlaget Busmundrud, O., MaAl, M., Hagness, J. K., Endregard, M. (2015) Tilnœerminger til risikovurderinger for tilsiktede uønskede handlinger. Kjeller: Forsvarets forskningsinstitutt

Cosgrave, J., LAegreid, T., Sørvald, M., BrusSet, E., Jørgensen, S. (2008) Evaluation of the Norwegian Emergency Preparedness System (NOREPS) - Evaluation Report 1. Oslo: Norwegian Agency for Development Cooperation

GERGELY, Á. (1994) Közép-Európa ígéret volt. 1. kiadás. Budapest: Balassi Kiadó

Graver, H. P. (2020a) Fighting the Virus and the Rule of Law - A Country Report on Norway [Online]. Elérhető: https://verfassungsblog.de/fighting-the-virus-and-the-rule-of-law-acountry-report-on-norway/ (Letöltve: 2020. december 1.)

Graver, H. P. (2020b) 'Covid-19 Regulation in Norway and State of Exception' in Serna de la Garza, J. M. (szerk.) Covid-19 and Constitutional Law. Mexico City: Universidad Nacional Autonoma de Mexico

94 Lásd erről részletesebben: Mehring, 2020a, 2020b.

$95 \mathrm{Az}$ első esetben a hatalom maga irányítja a helyzetet, ami végül rendkívüli állapothoz vezet. A második esetben a hatalom birtokosai szándékosan használják ki a valódi fenyegetést olyan intézkedések megtételére, amelyek meghaladják a tényleges veszély leküzdéséhez szükséges mértéket. Az előbbi kapcsán elrendelt rendkívüli állapot a jogállamiság „halála”, míg utóbbi károsítja azt. A harmadik esetkör a természeti katasztrófákhoz kapcsolódik. Ezek alapvetően nem veszélyesek a jogállamiságra - legalábbis kezdetben, míg a politikai elemek kisebb szerepet játszanak (Scheppele, 2020). Schmitt rendkívüli állapottal, különleges jogrenddel és az állami szuverenitással kapcsolatos tanainak elemzéséhez lásd még: Scheppele, 2004.

96 Langford et al., 2019, 228. o. 
HolteR, S. (2010) Risikostyring i kraftbransjen. in proactima.no, 14. Oktober 2010 [Online]. Elérhető: https://docplayer.me/373087-Risikostyring-i-kraftbransjen.html (Letöltve: 2020. szeptember 10.)

Jovičić, S. (2020) 'COVID-19 Restrictions on Human Rights in the Light of the Case-law of the European Court of Human Rights', ERA Forum, 21(4), 545-560. o.

Justis- og beredskapsdepartementet (2014) Norges Grunnlov. Utforsk ord, uttrykk, begreper og historiske versjoner av Norges Grunnlov fra 1814 til 2014. in Lovdata, 25 Mai 2014 [Online]. Elérhető: https://grunnloven.lovdata.no/ (Letöltve: 2020. november 9.)

KHAKEE, A. (2009) Securing Democracy? A Comparative Analysis of Emergency Powersin Europe (Geneva Centre for the Democratic Control of Armed Forces Policy Paper - No. 30) [Online]. Elérhetô: www.files.ethz.ch/isn/99550/PP30_Anna_Khakee_Emergency_Powers.pdf (Letöltve: 2020. december 15.)

Krunke, H., Thorarensen, B. (szerk.) (2018) The Nordic Constitutions. A Comparative and Contextual Study. 1. kiadás. Bloomsbury: Hart Publishing

LANGFord, M., Berge, B. K. (2019) 'Norway's Constitution in a Comparative Perspective', Oslo Law Review, 6(3), 198-228. o.

LÆGreid, P., RYkKJA, L. H. (2014) 'Coordinating for Crisis Management in Norway after the Terrorist Attack in 2011' in Lægreid, P., Sarapuu, K., Rykkja, L. H., Randma-Liiv, T. (szerk.) Organizing for Coordination in the Public Sector. Public Sector Organizations. 1. kiadás. London: Palgrave Macmillan

MagnuSSEN, A.-M. (2005) Domstolskapt rett. En institusjonell analyse av utviklingen av regelen om ulovfestet objektivt ansvar fra 1866-2003. 1. kiadás. Bergen: Universitetet Bergen

Mehring, R. (2020a) Carl Schmitt und die Pandemie. Teil II. [Online]. Elérhetó: https:// verfassungsblog.de/carl-schmitt-und-die-pandemie-teil-ii/ (Letöltve: 2020 . november 11.)

Mehring, R. (2020b) Carl Schmitt und die Pandemie. Teil I. [Online]. Elérhetô: https:// verfassungsblog.de/carl-schmitt-und-die-pandemie-teil-i/ (Letöltve: 2020. november 11.)

MichaLSEN, D. (szerk.) (2013) Unntakstilstand og forfatning. Brudd og kontinuitet i konstitusjonell rett. 1. kiadás. Oslo: Pax Forlag

MIDTGAARD, A. K. (2018) Risikoanalyser innen safety og security på samfunnsnivå-hva er likt og hva er ulikt? [Online]. Elérhető: https://tinyurl.com/w4jtaaw3 (Letöltve: 2020 . november 1.)

Nicolaisen, C., Wetlesen, M., Brøndmo, P. (2020) Covid-19 Legislation: Norway [Online]. Elérhetô: www.coronavirus-legislation.com/home/norway (Letöltve: 2020. november 11.) NOU (Norges offentlige utredninger) (2019) Når krisen inntreffer. Oslo: Departementenes sikkerhets- og serviceorganisasjon

NSM (Nasjonal sikkerhetsmyndighet) (2020) Risiko 2020. Sandvika: Nasjonal sikkerhetsmyndighet

MOD (Norwegian Ministry of Defence), MOJ (Norwegian Ministry of Justice and Public Security) (2018) Support and Cooperation. A Description of the Total Defence in Norway. Oslo: MOD, MOJ 
Múlt-Kor (2018) Megelőzték a németek a szövetségeseket Norvégia megszállásával [Online]. Elérhető: https://mult-kor.hu/megeloztek-a-nemetek-a-szvetsegeseket-norvegia-megszallasaval20181004?pIdx=1 (Letöltve: 2020. november 11.)

Múlt-Kor(2019)Ahatárértékszázezerszeresévelsugározaz1989-benelsüllyedtszovjetatom-tengeralattjáró [Online]. Elérhető: https://mult-kor.hu/a-hatarertek-szazezerszeresevel-sugaroz-az-1989ben-elsullyedt-szovjet-atom-tengeralattjaro-20190710 (Letöltve: 2020. november 19.)

SCHEPPELE, K. L. (2004) 'Law in a Time of Emergency: States of Exception and the Temptations of 9/11', University of Pennsylvania Journal of Constitutional Law, 6(5), 1001-1083. o.

SCHEPPELE, K. L. (2020) Underreaction in a Time of Emergency: America as a Nearly Failed State [Online]. Elérhetó: https://verfassungsblog.de/underreaction-in-a-time-of-emergencyamerica-as-a-nearly-failed-state/ (Letöltve: 2020 . november 11.)

SMET, S. (2010) 'Freedom of Expression and the Right to Reputation: Human Rights in Conflict', American University International Law Review, 26(1), 183-236. o.

OJANEN, M. M.-T. (2018) 'Human Rights in Nordic Constitutions and the Impact of International Obligations' in Krunke, H., Thorarensen, B. (szerk.) The Nordic Constitutions: A Comparative and Contextual Study. 1. kiadás. London: Hart Publishing

PST (Politiets sikkerhetstjeneste) (2020) Nasjonal trusselvurdering 2020 [Online]. Elérhető: www.pst.no/alle-artikler/trusselvurderinger/nasjonal-trusselvurdering-2020/ (Letöltve: 2020. december 2.)

RADJENOviC, A., ECKERT., G. (2020) Upholding Human Rightsin Europe during the Pandemic' (European Parliamentary Research Service) [Online]. Elérhető: www.europarl.europa.eu/RegData/etudes/ BRIE/2020/652085/EPRS_BRI(2020)652085_EN.pdf (Letöltve: 2020. november 11.)

ReusCH, C. (2020) The Norwegian Parliament Adopts New Corona Act [Online]. Elérhetô: https:// svw.no/artikler/the-norwegian-parliament-adopts-new-corona-act (Letöltve: 2020. december 1.)

SzENTGÁLI-Tóth, B. (2014) Európa legrégibb hatályos alkotmánya: Norvégia [Online]. Elérhetô: https://arsboni.hu/europa-legregibb-hatalyos-alkotmanya-norvegia/ (Letöltve: 2020. november 9.)

TÁLAs, P., CsíkI, T. (2011) 'Az oslói/utøyai merényletről', ZMNE Stratégiai Védelmi Kutató Központ Elemzések, 2011/8.

TøNDER, B. (2014) 'The Control of the Legislative and the Executive Power by Norwegian Courts', Panstwo i Prawo, 69(5), 74-84. o.

Universitetet i Oslo (2020) Norges historie, fra steinalderen til i dag. Fortalt av fagfolk [Online]. Elérhető: www.norgeshistorie.no/ (Letöltve: 2020. november 9.)

Vik, H. H., Jensen, S. L. B., Lindkvist, L., Strang, J. (2018) 'Histories of Human Rights in the Nordic Countries', Nordic Journal of Human Rights, 36(3), 189-201. o.

WIND, M., FøLLESDAL, A. (2009) 'Introduction - Nordic Reluctance Towards Judicial Review Under Siege', Nordisk Tidsskrift for Menneskerettigheter, 27(2), 131-141. o.

WJP (2020) World Justice Project Rule of Law Index 2020. Washington: WJP 


\title{
21. A különleges jogrendi szabályozás Olaszországban: a hadiállapot és a kivételes hatalomgyakorlás egyéb esetkörei
}

\author{
UNGVÁRI ÁLMOS
}

\section{A különleges jogrend alkotmányos és törvényi szintủ szabályozása}

Az Olasz Köztársaság különleges jogrendi szabályozása mind alkotmányos, mind pedig törvényi szinten alulszabályozott. Az 1948. január 1-je óta hatályos alkotmány ${ }^{1}-$ szemben például Magyarország Alaptörvényével - nem rendelkezik önálló különleges jogrendi fejezettel, abban nincs kidolgozva egy - sok más európai alkotmányban megtalálható - „alkotmány az alkotmányban" mechanizmus. A három nagy egységből, az alapelvekről, az állampolgárok jogairól és kötelezettségeiről, illetve a köztársaság szervezetéről szóló részből álló alkotmányban elszórtan találhatunk a tárgyalt témához kapcsolódó rendelkezéseket. Bár Olaszország elutasítja a háborút mint más népek szabadságának megsértését és a nemzetközi viták megoldásának eszközét, ${ }^{2}$ az egyetlen klasszikus különleges jogrendi helyzet

1 Costituzione della Repubblica Italiana (a továbbiakban: alkotmány).

2 Alkotmány 11. cikk.

Dr. Ungvári Álmos

almos.ungvari@mfi.gov.hu

kutató (Mádl Ferenc Összehasonlító Jogi Intézet)

PhD-hallgató (Pázmány Péter Katolikus Egyetem, Jog- és Államtudományi Doktori Iskola)

Ungvári, Á. (2021) 'A különleges jogrendi szabályozás Olaszországban: a hadiállapot és a kivételes hatalomgyakorlás egyéb esetkörei’ in Nagy, Z., Horváth, A. (szerk.) A különleges jogrend és nemzeti szabályozási modelljei, 457-479. o. Budapest: Mádl Ferenc Összehasonlító Jogi Intézet.

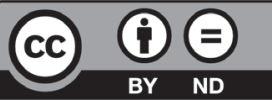


mégis a hadiállapot (stato di guerra). Annak kihirdetéséről a törvényalkotás menetéről, illetve a köztársasági elnök hatásköréről szóló szakaszok között rendelkezik az alkotmány, ${ }^{3}$ ezen túlmenően azonban csak a katonai bíróságok hatásköre vonatkozásában ${ }^{4}$ említi meg. A hadiállapot így sem alkotmányos, sem pedig törvényi szinten nincs átfogóan szabályozva. Az olasz jogrendszerben a hadiállapoton kívül három, a különleges jogrend jegyeit magán hordozó szituációt különböztetünk meg, amelyek során lehetôség van rendkívüli jogalkotásra, illetve az alkotmányban rögzített hatásköri szabályok megváltoztatására. E három helyzetből kettőrool, a sürgősségi rendeleti kormányzásról (decretazione d'urgenza) és a központi hatáskörelvonásról (potere sostitutivo) szintén az alkotmány rendelkezik.

A harmadik, szükségállapotként (stato di emergenza) lefordítható szituáció azonban csak törvényi szinten szabályozott polgári védelmi kategória. A tárgyalt téma vonatkozásában releváns jogszabály így a Nemzeti Polgári Védelmi Szolgálat létrehozásáról szóló törvényt ${ }^{5}$ hatályon kívül helyező Polgári Védelmi Kódex, ${ }^{6}$ amely a polgári védelem alapelveinek meghatározása mellett tipizálja a kockázatokat és válsághelyzeteket, rögzíti a Nemzeti Polgári Védelmi Szolgálat ${ }^{7}$ szervezetét, valamint meghatározza a különböző hatóságok és szervek feladat- és hatáskörét.

A fenti jogintézmények egyike kapcsán sem beszélhetünk egyetlen, azok részletszabályait rögzítő törvényről, azonban mindegyik vonatkozásában találhatunk releváns rendelkezéseket különböző jogszabályokban. İgy a sürgősségi rendeletalkotásról a kormány tevékenységéről és a Minisztertanács elnökségének szervezetéról szóló törvény, ${ }^{8}$ a központi hatáskörelvonásról a 2001. évi alkotmánymódosítást a köztársaság jogrendszeréhez igazító törvény, ${ }^{9}$ illetve az európai uniós jogszabályok és politikák olaszországi végrehajtásának általános szabályairól szóló törvény, ${ }^{10}$ a hadiállapotról pedig a katonai törvénykönyv ${ }^{11}$ szakaszai között találunk rendelkezéseket. Ez utóbbi - a védelmi igazgatás és nemzetbiztonság elveit és szabályait, valamint a fegyveres erők szervezetét rögzítő - törvénykönyv a szükségállapot idejére is tartalmaz rendelkezéseket az olasz hadsereg, a haditengerészet, a légierő és a csendőrség által nyújtott logisztikai és operatív támogatás vonatkozásában. Emellett a katonai

3 Alkotmány 78. és 87. cikk.

4 Alkotmány 103. cikk és 111. cikk (7) bekezdés.

5 Legge 24 febbraio 1992, n. 225: Istituzione del Servizio nazionale della protezione civile.

6 Decreto Legislativo 2 gennaio 2018, n. 1: Codice della protezione civile (a továbbiakban: Polgári Védelmi Kódex).

7 Servizio nazionale della protezione civile.

8 Legge 23 agosto 1988, n. 400: Disciplina dell'attivita' di Governo e ordinamento della Presidenza del Consiglio dei Ministri (a továbbiakban: Kormány tv.).

9 Legge 5 giugno 2003, n. 131: Disposizioni per l'adeguamento dell'ordinamento della Repubblica alla legge costituzionale 18 ottobre 2001, n. 3.

10 Legge 24 dicembre 2012, n. 234: Norme generali sulla partecipazione dell'Italia alla formazione e all'attuazione della normativa e delle politiche dell'Unione europea (a továbbiakban: EU tv.).

11 Decreto Legislativo 15 marzo 2010, n. 66 Codice dell'ordinamento militare (a továbbiakban: Katonatv.). 
törvénykönyv rendelkezik az alkotmányos jogállású - konzultatív és döntéshozó jogkörrel rendelkező - Legfelső Védelmi Tanács ${ }^{12}$ szervezetéről és müködéséről is. ${ }^{13}$

Megállapítható, hogy az olasz különleges jogrendi szabályozás európai viszonylatban - a magyarországi rendelkezésekhez képest pedig különösen is - rendkívül szúkszavú és hiányos. Ennek oka egyrészt az 1946 júniusában összeült Alkotmányozó Gyûlés ideológiai széttagoltságára és az abból fakadó politikai vitákra, ${ }^{14}$ másrészt pedig arra vezethető vissza, hogy az alkotmányozás idején még élénken élt a köztudatban Mussolini fasiszta rendszerének emléke. Ez a hiányosság annak fényében is érdekes, hogy a múlt század második felében Olaszország számos terrorcselekmény színhelye volt, ami okot adhatott volna a különleges jogrendi szabályozás felülvizsgálatára, amely igény azóta is rendszeresen felmerül. ${ }^{15}$

A fentiekben kifejtettek alapján klasszikus értelemben vett különleges jogrendi helyzetként a hadiállapot mutatható be, azonban érdemes megvizsgálni a sürgósségi rendeleti kormányzás és központi hatáskörelvonás kérdéskörét, valamint a - polgári védelmi kategóriaként is rendkívüli jogrendi elemeket tartalmazó - szükségállapoti kategóriát.

\subsection{Hadiállapot}

A parlament kamarái - a képviselóház és a szenátus - nyilvánítják ki a hadiállapotot, és adják meg a kormánynak ${ }^{16}$ a megfelelő felhatalmazást, ${ }^{17}$ annak kihirdetését viszont a köztársasági elnök hatáskörébe utalja az alkotmány. ${ }^{18}$ Nem rendelkezik azonban sem a kormányzati felhatalmazás mibenlétéról, sem pedig arról, hogy a hadiállapot elrendelésére mely események bekövetkezése esetén kerülhet sor. Tekintettel arra, hogy a hadiállapot kamarák általi kinyilvánítására vonatkozó szakasz az alkotmány törvényalkotás menetéról szóló alfejezetében, közvetlenül a kormány kivételes jellegû törvényalkotási feladatai és a sürgősségi rendeletalkotás után került rögzítésre, kijelenthető, hogy a hadiállapot során a kormány kivételes jogalkotási hatáskörrel rendelkezik, ám a rendeleti kormányzás szabályai nincsenek részletezve. ${ }^{19}$ Figyelembe véve, hogy Olaszország elutasítja a háborút, azonban a haza védelmét az állampolgárok szent kötelezettségeként ${ }^{20}$ határozza meg, a hadiállapot kihirde-

12 Consiglio supremo di difesa.

13 Katonatv. II. fejezet.

14 Egresi, 2013, 93-99. o.

15 De Minico, 2016, 31. o.; De Vergottini, 2001, 275. o.

16 Az olasz alkotmány értelmében az Olasz Köztársaság kormánya a miniszterelnökből és a miniszterekből áll, ők együtt alkotják a Minisztertanácsot. Alkotmányjogi értelemben tehát a Minisztertanácsot nevezhetjük szúk értelemben vett kormánynak. Ezzel szemben a kormány tágabb értelemben magában foglalja a miniszterelnök helyettesét, a tárca nélküli minisztereket, az államtitkárokat, a kabinettanácsot és a minisztériumközi bizottságok szerveit (Egresi, 2013, 229. o.). Jelen tanulmány vonatkozásában mindez nem bír komoly jelentőséggel, így a kormány és a Minisztertanács fogalmak rokon értelmű kifejezésekként vannak használva.

17 Alkotmány 78. cikk.

18 Alkotmány 87. cikk (9) bekezdés.

19 Zarcone, 2019.

20 Alkotmány 52 . cikk (1) bekezdés. 
tésének lehetősége nem támadó jellegú háború indítása, hanem külső támadással szembeni arányos védekezés, illetve nemzetközi egyezmény agresszió esetére előírt közös védelmi kötelezettség, vagyis az Egyesült Nemzetek Szervezetének alapokmányában is rögzített egyéni vagy kollektív önvédelem jogának gyakorlása ${ }^{21}$ során merülhet fel. ${ }^{22} \mathrm{~A}$ különleges jogrendi szabályozás hiányosságára mutat rá az is, hogy nincsenek meghatározva a parlament hadiállapotot kinyilvánító döntésének formai követelményei. İgy sem a döntés elfogadásához szükséges többség, sem pedig az nincs rögzítve, hogy annak elfogadására a parlament együttes ülésén kerül sor, vagy arról a törvényalkotási eljárás szabályai szerint a képviselőház és a szenátus külön-külön dönt. Előbbi annak fényében kizárható, hogy a parlament kizárólag az alkotmány által előírt esetekben ül össze együttes ülésre. ${ }^{23} \mathrm{Az}$ viszont csak a köztársasági elnök megválasztása, hưségesküje, illetve vád alá helyezése, ${ }^{24}$ valamint a Legfelsőbb Igazságszolgáltatási Tanács ${ }^{25}$ és az alkotmánybíróság ${ }^{26}$ tagjainak megválasztása ${ }^{27}$ vonatkozásában kerül kifejezett említésre, így a hadiállapot kinyilvánításáról a parlament kamarái külön-külön határoznak. Érdemes ugyanakkor kiemelni, hogy a hadiállapot kihirdetése során is érvényesül a hatalmi ágak egyensúlya. Ugyan a parlament dönt annak elrendeléséról, és ruházza fel a szükséges hatáskörökkel a kormányt, amely így kizárólagos jogosultsággal rendelkezik a rendkívüli intézkedések meghozatalára, azonban - a kihirdetéssel összefüggésben - a köztársasági elnök mérlegeli a kinyilvánítás alkotmányosságát. ${ }^{28}$

Mindezeken túlmenően az alkotmány a katonai bíróságok vonatkozásában említi a hadiállapotot, rögzítve egyrészt, hogy háború idején a katonai bíróságok - amelyeknek békeidőben csak a fegyveres erők tagjai által elkövetett katonai bủncselekményekre kiterjedő hatáskörük van - különleges joghatósági hatáskört gyakorolnak, másrészt korlátozza a Semmítőszékhez benyújtható jogorvoslat lehetőségét a katonai bíróságok háború esetén hozott döntései vonatkozásában. ${ }^{29}$

Hasonlóan az alkotmányhoz, a katonai törvénykönyv is elszórtan tartalmaz a hadiállapotra vonatkozó rendelkezéseket, amelyek közül érdemes kiemelni a Legfelső Védelmi Tanácsról szóló fejezetet. Az évente legalább két alkalommal ülésező Legfelső Védelmi Tanács felülvizsgálja a honvédelemmel kapcsolatos politikai és technikai problémákat, irányelveket fogalmaz meg, továbbá összehangolja a honvédelmi tevékenységeket. Elnöke a köztársasági elnök, tagjai között pedig a miniszterelnökön és a védelmi miniszteren kívül hivatalból helyet kap a külügyi, a belügyi, a gazdasági, valamint a gazdaságfejlesztési tárcát vezető miniszter

21 Egyesült Nemzetek Szervezetének alapokmánya 51. cikk.

22 Zarcone, 2019.

23 Alkotmány 55. cikk (2) bekezdés.

24 Alkotmány 83. cikk (1) bekezdés, 85. cikk (2) bekezdés, 90. cikk, 91. cikk.

25 Consiglio superiore della magistratura.

26 Corte Costituzionale.

27 Alkotmány 104. cikk (4) bekezdés; 135. cikk (1) bekezdés.

28 Buscema, 2019, 219-220. o.

29 Alkotmány 103. cikk (3) bekezdés; 11. cikk (7) bekezdés. 
is, de a köztársasági elnök meghívására a kormány további tagjai is részt vehetnek az ülésen. Ezáltal biztosított a különböző minisztériumok védelmi tervezésben és felkészülésben való részvétele. ${ }^{30}$

\subsection{Sürgősségi rendeleti kormányzás}

A hadiállapothoz képest jelentősen gyakoribb tényállásokat feltételez, azonban extra ordinem jogalkotásnak tekinthetô a sürgősségi rendeleti kormányzás, hiszen az alkotmány alapján a kormányra törvényhozási feladatokat csak korlátozott időre, meghatározott tárgykörben, az alap- és irányelvek rögzítésével lehet átruházni, illetve föszabály szerint törvényerejû́ rendeleteket sem hozhat a kormány a parlament kamaráinak felhatalmazása nélkül. ${ }^{31}$ Mindezek hangsúlyosabbá teszik annak kivételes jellegét, hogy rendkívüli és sürgős esetben a kormány saját felelősségére törvényerejủ rendeletet bocsáthat ki. Azonban csak komoly korlátok között illeti meg ez a kivételes jogalkotási hatáskör a kormányt. Egyrészt köteles még aznap a törvényerejû́ rendeletet - törvénnyé alakítás céljából - a parlament mindkét kamarájának bemutatni, és amennyiben azok nem alakítják azt 60 napon belül törvénnyé, ex tunc hatályát veszti. Másrészt pedig a kormány tevékenységéről és a Minisztertanács elnökségének szervezetéről szóló törvény szûkíti a sürgősségi rendeletalkotás tárgyi hatályát. Így a kormány törvényerejü rendeletével nem bővítheti jogalkotási hatáskörét, nem rendelkezhet alkotmányos, választási és a pénzügyi mérleget jóváhagyó törvények, valamint nemzetközi szerződések ratifikálása kapcsán, nem újíthatja meg azon törvényerejû́ rendeletek szabályait, amelyek törvénnyé alakítását a parlament megtagadta, nem léptetheti hatályba az alkotmánybíróság által hatálytalannak minősített törvényerejŭ rendeleteket, illetve nem szabályozhatja a törvénnyé nem vált törvényerejủ rendeletek alapján fennálló jogviszonyokat. ${ }^{32}$ Ez utóbbi vonatkozásában a kamarák - amelyek a törvényerejû́ rendelet bemutatását követő öt napon belül akkor is kötelesek összeülni, ha korábban feloszlatták őket - jogosultak törvényt alkotni.

A kormány tehát meghatározott feltételek esetén rendkívüli hatásköröket kap, amely jogalkotási funkció abban is eltér a felhatalmazáson alapuló rendeletalkotástól, hogy a sürgősségi rendeleti kormányzás vonatkozásában hangsúlyozza az alkotmány a kormány politikai felelősségét. ${ }^{33}$ Ezen kivételes jellegú jogintézmény komoly fejlődésen ment át mind a jogalkotás, mind pedig a jogirodalom területén. ${ }^{34}$ Sok esetben felmerült, hogy a kormány - a rendkívüliség és sürgősség előfeltételének hiányában - alkotmányellenes módon hasz-

30 Katonatv. 2-4. cikk.

31 Alkotmány 76. cikk, 77. cikk (1) bekezdés.

32 Kormány tv. 15. cikk (2) bekezdés.

33 Nevola, 2017, 17. o.

34 Morrone, 2009, 133-184. o. 
nálja a törvényerejú rendelet eszközét. ${ }^{35} \mathrm{Az}$ ilyen problémákat idôvel az alkotmánybíróság döntéseivel orvosolta, egységes gyakorlatot alakítva ki mára a rendeletalkotás szükségessége, a rendkívüliség és sürgősség feltételei, a kibocsátott törvényerejû́ rendelet homogenitása, az átalakítást megvalósító törvény tartalma és a parlament kamaráinak hatásköre vonatkozásában. ${ }^{36} \mathrm{Az}$ alkotmánybírósági gyakorlat értelmében az eset rendkívüli jellege számos, az emberi életet, a testi épséget vagy a vagyonbiztonságot veszélyeztető természeti esemény, emberi tevékenység, illetve hatósági rendelkezés lehet, amelyek közös jellemzője, hogy kiszámíthatatlanok, nem határozhatók meg előre merev feltételek vagy taxatív felsorolások alapján. A szükségesség és sürgősség fennállása pedig akkor állapítható meg, ha az azonnali beavatkozást igénylő helyzetek a kormány rendes jogosítványaival nem kezelhetők eredményesen. ${ }^{37}$ Történelmi jelentőségûnek mondhatóo ${ }^{38}$ az alkotmánybíróság 2007. évi 171. számú döntése, amely a szükségesség és sürgősség feltételeinek nyilvánvaló hiánya miatt mondta ki egy törvényerejú rendelet alkotmányellenességét. Annak ellenére, hogy bonyolult és rendkívül változatos beavatkozásokat igénylő szituációkban bocsátják ki, a törvényerejû́ rendeletnek tartalmát tekintve koherensnek kell lennie, az meg kell hogy feleljen a jogszabály címének ${ }^{39}$ Kifejezetten tiltott az a - korábban alkalmazott - gyakorlat, amely során a korábbi, törvénnyé át nem alakított, hatályát vesztett törvényerejủ rendelet rendelkezéseinek a sürgősségi rendeletalkotás keretében való megismétlésére kerül sor, kiüresítve ezáltal az alkotmány sürgősségi rendeleti kormányzást biztosító szakaszát. ${ }^{40} \mathrm{~A}$ törvénynek, amely a - hivatalos közlönyben ${ }^{41}$ is közzétett - törvényerejú rendeletet törvényi szintre emeli, ezt a homogenitást tiszteletben kell tartania, így nem vezethet be az eredeti jogszabály tárgyától és céljától jelentôs mértékben eltérô változtatásokat. ${ }^{42} \mathrm{~A}$ parlament által elfogadott szövegnek visszavezethetőnek kell lennie az alapját képező törvényerejú rendeletre vagy annak legalább domináns részére. ${ }^{43} \mathrm{Az}$ átalakítást megvalósító törvény speciális funkcionális jellege miatt nem nyitható meg a céljához nem kapcsolódó normatív tartalmaknak.44 Bármilyen, az átalakítás során mégis megvalósuló esetleges változtatás - a törvény eltérő rendelkezése hiányában - a kihirdetést követő napon lép hatályba..$^{45} \mathrm{Nem}$ helyettesíthetik az átalakító törvényt azok a törvények, amelyekkel a parlament kamarái a törvénnyé nem vált rendeletek alapján keletkezett jogviszonyokat szabályozzák. ${ }^{46}$ Ez utóbbiak egyébként

35 Celotto, 2002, 55-73. 0.

36 Nevola 2017, 17-25. o.

37 Alkotmánybíróság 1961/32. döntése; 1983/69. döntése; 1992/221. döntése; 1995/29. döntése; 2011/93. döntése.

38 Formuso, 2015, 82-87. o.

39 Kormány tv. 15. cikk (3) bekezdés; alkotmánybíróság 2017/170. döntése; 2016/244. döntése; 2012/22. döntése.

40 Alkotmánybíróság 1996/36. döntése.

41 Gazzetta Ufficiale.

42 Alkotmánybíróság 2015/145. döntése; 2014/251. döntése.

43 Alkotmánybíróság 2017/169. döntése; 2016/94. döntése; 2015/154. döntése.

44 Alkotmánybíróság 2015/186. döntése; 2013/34. döntése.

45 Kormány tv. 15. cikk (5) bekezdés.

46 Alkotmánybíróság 1983/307. döntése; 1982/59. döntése. 
sem rendelkezhetnek jövőbeli kapcsolatokról, csak és kizárólag a már hatálytalan rendelet alapján fennállókról. ${ }^{47}$

\subsection{Központi hatáskörelvonás}

A központi hatáskörelvonás kapcsán szükséges lejegyezni, hogy az Olasz Köztársaság önálló hatás- és feladatkörrel, valamint saját statútummal rendelkező községekre ${ }^{48}$ tartományokra, ${ }^{49}$ nagyvárosokra ${ }^{50}$ és régiókra ${ }^{51}$ tagozódik. ${ }^{52} \mathrm{~A}$ törvényhozó hatalmat pedig - az alkotmánnyal, az Európai Unió által meghatározott korlátozásokkal, valamint a nemzetközi kötelezettségekkel összhangban - az állam és a régiók közösen gyakorolják. Az alkotmány rögzíti az állam kizárólagos, valamint az állam és a régiók párhuzamos hatáskörébe tartozó törvényhozási tárgyköröket. Előbbibe többek között az állam külpolitikája és nemzetközi kapcsolatai, a bevándorlás, a köztársaság és a vallási felekezetek viszonya, a honvédelem és az állampolgárság, utóbbiba pedig a régiók nemzetközi kapcsolatai, az egészségvédelem, a sportszabályozás, a katasztrófaelhárítás, illetve a környezeti és kulturális örökség támogatása tartozik. Minden olyan törvényhozási tárgykör, amely az alkotmány alapján nincs kifejezetten az állam számára fenntartva, a régiók hatáskörébe esik. A nemzetközi kötelezettségek és az uniós aktusok végrehajtását állami törvényben meghatározott felügyelet mellett szintén a régiók - valamint Trento és Bolzano autonóm tartományok - biztosítják. A községek, tartományok és nagyvárosok mind saját igazgatási funkcióval rendelkeznek. Fôszabály szerint minden igazgatási funkció a községre tartozik, az azonban az egységes gyakorlat érdekében a szubszidiaritás, a differenciálás és a megfelelés elveinek megtartásával a tartományra, a nagyvárosra, a régióra vagy az államra átruházható. ${ }^{53}$

A központi hatáskörelvonás intézménye lehetôséget teremt arra, hogy a régió, a nagyváros, a tartomány vagy a község hatóságai helyett - a szubszidiaritás, a tisztességes együttmúködés és az arányosság elvei által meghatározott keretek között - a kormány járjon el. Erre abban az esetben kerülhet sor, ha azok megsértik a nemzetközi jogrendet vagy szerződéseket vagy a közösségi jogot, amennyiben a közbiztonság súlyosan veszélyeztetett, és amennyiben ilyen helyettesítés szükséges a nemzeti jog gazdasági egységének, különösen a jóléti életszínvonallal kapcsolatos polgári és szociális jogok védelme céljából, a helyi önkormányzatok határai figyelembevételének mellőzésével. ${ }^{54}$ Ilyenkor a miniszterelnök - az illetékes miniszter vagy a régiók, illetve helyi hatóságok javaslatára - előbb határidôt tủz ki

\footnotetext{
47 Alkotmánybíróság 464/1994/464. döntése; 1977/430. döntése; 1989/544. döntése.

48 Comuni.

49 Province.

50 Città metropolitane.

51 Regioni.

52 Alkotmány 114. cikk.

53 Alkotmány 117-118. cikk.

54 Alkotmány 120. cikk (2)-(3) bekezdés.
} 
a szükséges vagy elmulasztott intézkedések meghozatalára, és csak annak eredménytelen leteltét követően dönt a hatáskörelvonásról, amelynek keretében jogalkotásra, valamint biztos kinevezésére kerülhet sor. Az erről szóló minisztertanácsi ülésen az érintett régió regionális kabinetének elnöke is részt vehet. Olyan rendkívül sürgős esetben, amikor a hatáskörelvonásról való döntés a védett célok veszélyeztetése nélkül nem késleltethető, a Minisztertanács - az illetékes miniszter vagy a régiók kezdeményezésére - elfogadja a szükséges intézkedéseket, és azokat késedelem nélkül az állam és régiók közötti kapcsolatot biztosító konferencia, valamint a helyi szervek tudomására hozza. ${ }^{55} \mathrm{~A}$ központi hatáskörelvonás komoly jelentőséggel bír a Polgári Védelmi Kódex szabályai vonatkozásában is.

E jogintézmény képezi alapját ugyanis a polgári védelmi tevékenység célját, gyakorlati alapelveit, illetve a Nemzeti Polgári Védelmi Szolgálat szervezetét és feladatait rögzítő törvénykönyv egyes, különleges jogrendi elemeket tartalmazó rendelkezéseinek. A kódex tipologizálja a szükséghelyzeteket az azzal érintett terület kiterjedtsége és az annak kezelése kapcsán hatáskörrel rendelkező szervek alapján. Ezzel három kategóriát alakít ki: a helyi szintû közigazgatási szervek szokásos eszközeit és a regionális szinten irányított, több helyi közigazgatási szerv összehangolt tevékenységét igénylő, valamint a nemzeti szintû szükségállapotot. Utóbbi kettő esetében emeli ki a rendelkezés a szokásostól eltérô, rendkívüli hatáskörök és eszközök szükségességét. A törvénykönyv megfogalmazása alapján a nemzeti szintû́ szükségállapot olyan események esetén rendelhető el, amelyekkel - intenzitásuk és kiterjedésük miatt - azonnali intézkedéssel, illetve kivételes felhatalmazás birtokában kell felvenni a küzdelmet. A rendkívüli hatáskörök kapcsán azonban hangsúlyozza azok korlátozott, kizárólag meghatározott határidőig gyakorolható voltát. A Polgári Védelmi Kódex a szükségállapot mindhárom kategóriájának alapjául szolgáló esemény vonatkozásában rögzíti, hogy az egyaránt lehet természeti csapások vagy emberi tevékenységgel összefüggő szerencsétlenségek következménye. ${ }^{56}$

A különleges jogrendi jelleg leginkább a nemzeti szintú szükségállapot vonatkozásában mutatkozik meg, egyrészt annak elrendelése, másrészt az annak keretében hozott intézkedések kapcsán. A nemzeti szintú szükségállapotot ugyanis - a fentiekben meghatározott események bekövetkezése vagy azok közvetlen veszélye esetén - a miniszterelnök vagy az érintett régiók - illetve autonóm tartományok - elnökének javaslatára a Minisztertanács határozatával hirdeti ki, megjelölve annak időbeli és területi hatályát, valamint az elrendelés alapjául szolgáló esemény természetét. A minisztertanácsi határozat a szükséges intézkedéseken túlmenően biztosítja gyorssegély nyújtását és a Nemzeti Katasztrófavédelmi Alap ${ }^{57}$ szükséges mértékig való felhasználását. A szükségállapot időtartama nem haladhatja meg

55 2003/131. tv. 8. cikk.

56 Polgári Védelmi Kódex 7. cikk.

57 Fondo per le emergenze nazionali. 
a 12 hónapot, amely határidő legfeljebb újabb 12 hónappal hosszabbítható meg. Visszavonásáról az elrendeléskor is lefolytatott procedúra alkalmazásával lehet határozni. ${ }^{58}$

A nemzeti szükségállapot kezelése érdekében hozott intézkedéseket polgári védelmi rendelkezések ${ }^{59}$ útján hangolják össze. Ezek a szükségállapot elrendeléséről szóló határozatban foglalt keretek, a jogrend, illetve az Európai Unió alapelvei megtartásával eltérhetnek a hatályos jogszabályoktól. Ezen túlmenően a polgári védelmi rendelkezések általi derogáció további korlátját nem határozza meg a kódex, az a szükségállapot alapjául szolgáló események előreláthatatlansága, kiszámíthatatlansága és kivételessége miatt valószínúleg nehezen lehetne alkalmazható konkrét esetekben. Fontos garanciális szabályozás azonban, hogy ha a rendelkezés eltér valamely hatályos törvénytől, abban meg kell jelölni az eltérés okát, illetve az azzal érintett jogszabályt. A hatályos jogszabállyal ellentétes szabályozás indokolása keretében elsősorban annak arányosságát kell igazolni, azt, hogy a polgári védelmi rendelkezés időben és térben is arra korlátozódik, hogy a kivételes eseményt elhárítsa. ${ }^{60} \mathrm{~A}$ rendelkezés kiterjedhet többek között a mentési beavatkozások megszervezésére és végrehajtására, a stratégiai fontosságú infrastruktúrák és hálózatok helyreállítására, a gazdasági és társadalmi struktúra azonnali támogatását célzó intézkedések bevezetésére, valamint további károk megelőzésére. A rendelkezések kibocsátására a polgári védelmi parancsnok jogosult, kivéve, ha a szükségállapot elrendelése során másként határoznak, ilyen esetben a rendelkezési jog a miniszterelnököt és a polgári védelem koordinációjáért felelős minisztert is megilletheti, azonban a rendelkezések végrehajtása ez esetben is a polgári védelem parancsnokának feladatkörébe tartozik. A polgári védelmi rendelkezések - amelyeket a hivatalos közlönyben is közzétesznek - főszabály szerint elfogadásuk napján hatályba lépnek, azonban tájékoztatási célzattal meg kell azokat küldeni a miniszterelnöknek, valamint az érintett régiók és tartományok részére. A szükségállapot kihirdetését követő harminc nap eltelte után kizárólag a Gazdasági és Pénzügyminisztériummal folytatott konzultációt követően adható ki polgári védelmi rendelkezés. ${ }^{61} \mathrm{~A}$ fentiekben már leírtak szerint a nemzeti szintû́ szükségállapot akkor szúnik meg, ha annak időtartama lejár, vagy ha azt a Minisztertanács határozatával megszünteti. A kódex kitér a rendes állapotba való visszatérés szabályaira is, rögzítve, hogy a szükségállapot lejárta előtt legalább harminc nappal rendelkezni kell az eltervezett, de meg nem valósított intézkedések végrehajtásáról. ${ }^{62}$

58 Polgári Védelmi Kódex 24. cikk.

59 Ordinanze di protezione civile.

60 Luciani, 2020, 123-125. o.

61 Polgári Védelmi Kódex 25. cikk.

62 Polgári Védelmi Kódex 25. cikk. 


\section{Az alapjogok korlátozására vonatkozó szabályok a különleges jogrend idején}

Az olasz különleges jogrendi szabályozás korábbiakban már taglalt hiányossága az alapjogok korlátozása kapcsán is tetten érhetô. Az alkotmány alapelvi része rögzíti, hogy az Olasz Köztársaság elismeri és biztosítja az ember sérthetetlen jogait, amelyek mint egyént vagy mint olyan társadalmi szervezet tagját illetik meg, amelyben személyisége kibontakozik, és megköveteli a politikai, gazdasági és társadalmi szolidaritásból fakadó megmásíthatatlan kötelezettségek teljesítését. ${ }^{63} \mathrm{Az}$ alapvető jogokat és kötelességeket pedig az állampolgárok jogairól és kötelességeiről szóló részben, négy - az egyén kapcsolatrendszere alapján kialakított - fejezetben tárgyalja. Így az ember személyi mivoltából eredő jogok és az állampolgársággal összefüggő rendelkezések a polgári kapcsolatokról, ${ }^{64}$ a család, a munka, a hivatás és az oktatás kérdésköre, az egészséghez való jog, illetve a környezetvédelem az etikai és társadalmi kapcsolatokról, ${ }^{65}$ a második generációs gazdasági és szociális jogok, a szakszervezetek alapítására vonatkozó rendelkezések, a sztrájkjog, a tulajdonhoz és a megtakarításhoz való jog a gazdasági kapcsolatokról, ${ }^{66}$ a nép politikai akaratképzésben való részvételét biztosító jogok pedig a politikai kapcsolatokról ${ }^{67}$ szóló fejezetben szerepelnek. ${ }^{68}$

Az alkotmányban nem kapott helyet egy általános - a hazai Alaptörvényben találhatóhoz hasonló - alapjog-korlátozási klauzula, és nyitott kérdés marad az is, hogy a kormány a hadiállapot során a parlament kamaráitól kapott kivételes felhatalmazás keretében mely jogokat korlátozhatja. ${ }^{69}$ Nincs tehát olyan rendelkezés, amely kimondaná, hogy alapvető jog kizárólag más alapvető jog érvényesülése érdekében, a szükségesség és arányosság tesztjének megfelelően korlátozható, illetve sem a különleges jogrend idején kivételesen korlátozható, sem pedig az érinthetetlen alapjogok nincsenek felsorolva.

Néhány esetben az egyes alapjogok kapcsán utal az alkotmány a korlátozás lehetőségére, így a polgári kapcsolatok körében rögzített személyes szabadság, a magánlakás és levéltitok sérthetetlensége, a szabad véleménynyilvánításhoz való jog és a szabad mozgáshoz való jog korlátozásáról, annak feltételeiről, módjáról és biztosítékairól törvényi úton lehet határozni. Ezek némelyikének - így a személyes szabadság, a levéltitok és a szabad véleménynyilvánításhoz való jog - korlátozása kizárólag az igazságügyi hatóságok indoklással ellátott határozata alapján lehetséges. ${ }^{70}$ Azonban csupán a szabad mozgáshoz, a tartózkodási hely szabad megválasztásához való jog, valamint a gyülekezési jog korlátozása vonatkozásában határozza

63 Alkotmány 2. cikk.

64 Rapporticivili.

65 Rapporti etico-sociali.

66 Rapportieconomici.

67 Rapportipolitici.

68 Pace, 2010, 2-3. o.

69 Zarcone, 2019.

70 Alkotmány 13-16. cikk. 
meg az alkotmány, hogy milyen másik alapvető jog érvényesülése érdekében kerülhet arra sor. Így a gyülekezési jog - a közterületen tartandó gyứlések esetén - közérdekből vagy más bizonyított okból, a szabad mozgáshoz való jog pedig - amely kapcsán az alkotmány külön ki is emeli a politikai alapú szúkítés tilalmát - biztonsági és egészségügyi okból is korlátozható. ${ }^{71}$ Utóbbi kapcsán érdemes megemlíteni, hogy az Olasz Köztársaságnak az egészség védelmére irányuló kötelezettsége egyrészt az egészség mint alapvető egyéni jog, másrészt pedig mint közösségi érdek védelmét jelenti, amely kettősséget az alkotmánybíróság is kifejtette, ${ }^{72}$ megalapozva ezáltal az egészséghez való jog teljes körú védelmét. Ezt a védelmet az egyén pszichofizikai integritásában, az egészségügyi kezelésekkel kapcsolatos álláspontjaiban, továbbá az egészséges környezethez való jogban bontotta ki. ${ }^{73}$

Egyedül a személyes szabadság vonatkozásában találunk rendkívüli szabályt. Ennek értelmében - törvényi szinten meghatározott - sürgős és rendkívüli esetekben a rendőri szervek ideiglenes intézkedéseket foganatosíthatnak. Azokról azonban 48 órán belül értesíteni kell az igazságügyi hatóságokat, és amennyiben azok nem hagyják jóvá az intézkedéseket újabb 48 órán belül, azokat visszavontnak, illetve semmisnek kell tekinteni. ${ }^{74}$

Ugyan az alapjogok különleges jogrend idején való korlátozásának olasz szabályozása hiányos, meg kell említeni, hogy az Olasz Köztársaság által egyaránt ratifikált Emberi Jogok Európai Egyezménye, valamint az Egyesült Nemzetek Szervezetének Polgári és Politikai Jogok Nemzetközi Egyezségokmánya rendelkezik rendkívüli szituációk idejére irányadó szabályozással, amelynek keretében meghatározzák azon kötelezettségeket, jogokat és tilalmakat, amelyek sérelmére háború vagy a nemzet létét fenyegető szükségállapot, illetve más rendkívüli állapot esetén sem kerülhet sor. ${ }^{75}$

\section{A koronavírus-járvány olaszországi kezelése}

Az olasz jogrendszer kapcsán nem beszélhetünk külön egészségügyi válsághelyzeti vagy egészségügyi vészhelyzeti kategóriáról, csupán a Polgári Védelmi Kódex által tipizált, adott esetben akár a szükségállapot elrendelésének alapjául szolgáló kockázatok ${ }^{76}$ körében találjuk meg - a szeizmikus, vulkáni, meteorológiai, kémiai, nukleáris, technológiai, ipari és környezeti mellett - az egészségügyi kockázatot. A mindig valamilyen más kockázat vagy esemény következményeként felmerülő egészségügyi kockázat valamennyi olyan kritikus szituációt felölel, amely hatással lehet az emberi egészségre. Egészségügyi válsághelyzetről

71 Alkotmány 16-17. cikk.

72 Alkotmánybíróság 1990/307. és 1990/455. számú döntése.

73 Egresi, 2013, 189-192. o.

74 Alkotmány 13. cikk (3).

75 Emberi Jogok Európai Egyezménye 15. cikk; Polgári és Politikai Jogok Nemzetközi Egyezségokmánya 4. cikk.

76 Rischi di protezione civile. 
a nemzeti egészségügyi szolgálat létrehozásáról szóló törvény ${ }^{77}$ sem rendelkezik, azonban felhatalmazza az egészségügyért felelős minisztert, hogy az ország egész területére vagy annak egy részére kiterjedő hatállyal sürgős jellegü rendeleteket bocsásson ki a higiéniai, a közegészségügyi és az állategészségügyi kérdésekben. Ugyanezen területek vonatkozásában hasonló rendeleteket bocsáthat ki a regionális kabinet elnöke, illetve a polgármester is, amelyek területi hatálya több településre vagy akár az egész régióra is kiterjedhet. ${ }^{78}$

Tekintettel arra, hogy a koronavírus Európában először Olaszországban jelent meg, illetve az Olasz Köztársaság egyike a járvány által leginkább érintett országoknak, kiemelten fontos a jogalkotó koronavírus-járvány következtében kialakult helyzetre adott reakciójával foglalkozni. A járványhelyzetre adott első olaszországi válaszként az egészségügyi miniszter 2020. január 25-i, a koronavírussal érintett országokból való beutazást korlátozó rendeletét ${ }^{79}$ jegyezhetjük fel. A Minisztertanács csak ezt követően, január 31-én hirdette ki határozatával ${ }^{80}$ a Polgári Védelmi Kódex szerinti nemzeti szintú szükségállapotot. ${ }^{81}$ Idôbeli hatályként a rendelkezés napjától számított 6 hónapot jelölt meg, amelyet annak lejártával előbb október 15-ig, ${ }^{82}$ majd pedig újabb határozatával 2021. január 31-ig hosszabbított meg. ${ }^{83}$ Így - mostani tudásunk alapján - elmondható, hogy a nemzeti szintú szükségállapot az Olasz Köztársaságban egy teljes évig hatályban marad.

A polgári védelmi szabályoknak megfelelően 2020 . február elején el is fogadták a szükséges beavatkozások összehangolásáról és a lakosság megsegítéséről szóló rendelkezést, azonban végül nem a polgári védelmi szabályok szolgáltak a koronavírus-járvány elleni harc eszközéül. A meghozott központi intézkedéseknek ugyanis a február végén elfogadott és március elején törvényerőre emelkedett, ${ }^{84}$ a Covid-19 vírus következtében jelentkező járványügyi szükségállapot kezelésére irányuló sürgős intézkedésekről szóló törvényerejû́ rendelet ${ }^{85}$ biztosított keretet, amelyet az azonos címú, jelenleg is hatályban lévő és törvényi szinten ugyancsak megerősített ${ }^{86}$ márciusi törvényerejú rendelet ${ }^{87}$ helyezett hatályon

77 Legge 23 dicembre 1978, n. 833: Istituzione del servizio sanitario nazionale (a továbbiakban: Eü. szolg. tv.).

78 Eü. szolg. tv. 32. cikk.

79 Ordinanza del Ministero della Salute 25 gennaio 2020: Misure profilattiche contro il nuovo Coronavirus.

80 Delibera del Consiglio dei Ministri 31 gennaio 2020 Dichiarazione dello stato di emergenza in conseguenza del rischio sanitario connesso all'insorgenza di patologie derivanti da agenti virali trasmissibili.

81 Luciani, 2020, 116-119. o.

82 Delibera del Consiglio dei Ministri 29 luglio 2020 Proroga dello stato di emergenza in conseguenza del rischio sanitario connesso all'insorgenza di patologie derivanti da agenti virali trasmissibili.

83 Delibera del Consiglio dei Ministri 7 ottobre 2020: Proroga dello stato di emergenza in conseguenza del rischio sanitario connesso allinsorgenza di patologie derivanti da agenti virali trasmissibili.

84 Legge 5 marzo 2020, n. 13: Conversione in legge, con modificazioni, del decreto-legge 23 febbraio 2020, n. 6 , recante misure urgenti in materia di contenimento e gestione dell'emergenza epidemiologica da COVID-19.

85 Decreto-Legge 23 febbraio 2020, n. 6: Misure urgenti in materia di contenimento e gestione dell'emergenza epidemiologica da COVID-19 (a továbbiakban: 2020/6. tvr.).

86 Legge 22 maggio 2020, n. 35: Conversione in legge, con modificazioni, del decreto-legge 25 marzo 2020, n. 19, recante misure urgenti per fronteggiare l'emergenza epidemiologica da COVID-19.

87 Decreto-Legge 25 marzo 2020, n. 19: Misure urgenti per fronteggiare l'emergenza epidemiologica da COVID-19 (a továbbiakban: 2020/19. tvr.). 
kívül. ${ }^{88}$ Ez alapján a koronavírus-járvány kezelése és leküzdése érdekében a miniszterelnök rendeletében a szükségesség és arányosság követelményeinek megfelelő sürgős intézkedéseket hozhat legfeljebb 30 napos - de a szükségállapot végéig meghosszabbítható - idôtartamra. A rendeletalkotás során azonban figyelembe kell vennie az egészségügyért felelős miniszter javaslatát, illetve köteles konzultációt folytatni a belügyminiszterrel, a védelmi miniszterrel, a gazdasági és pénzügyminiszterrel, valamint az érintett ügyekért felelős más miniszterekkel, továbbá ha az intézkedések az ország egész területére kiterjednek, az autonóm tartományok vezetőivel és a régiók konferenciájának elnökével, ha pedig az intézkedések csak meghatározott régiókra vonatkoznak, az érintett regionális kabinetek elnökeivel is. ${ }^{89}$

A járvány második hullámának kezelése ${ }^{90}$ során - a szükségállapot meghosszabbításával párhuzamosan - a sürgős intézkedésekről szóló törvényerejû rendeletet is több alkalommal módosították. A koronavírus-járvány leküzdésére irányuló további sürgős intézkedéseket ${ }^{91}$ és a járványügyi szükségállapot időbeli hatályának lejártához, ${ }^{92}$ valamint meghosszabbításához ${ }^{93}$ kapcsolódó rendelkezéseket rögzítő törvényerejú rendeletek egyaránt megváltoztatták kisebb-nagyobb mértékben a 2020/19. tvr. szövegét, ám a mai napig az határozza meg a koronavírus-járvány elleni küzdelmet. Ezen törvényerejú rendelet - ahogy már a 2020/6. tvr. is - felhatalmazást ad a miniszterelnöknek arra, hogy egyes alapvetô szabadságjogokat a szükségállapotra való tekintettel - a fentiekben leírtaknak megfelelően - rendeletével korlátozzon. ${ }^{94} \mathrm{Az}$ érintett alapjogokat pedig példálózó jellegú felsorolásban határozza meg.95 Ez alapján elrendelhetô a szabad mozgáshoz való jognak, így a lakó- és tartózkodási hely elhagyásának és az ország területére való szabad belépés jogának, illetve a gyülekezési jognak a korlátozása. Mindezeknek megfelelően a szükségállapot során több más európai államéhoz hasonló jellegú és terjedelmú korlátozásokat vezettek be a miniszterelnök rendeletei. Ezek korlátozták, illetve felfüggesztették - többek között - a nyilvános helyek, kulturális és sportesemények látogatását, a vallási szertartások megtartását, az oktatást, a vállalkozási, valamint üzleti tevékenység folytatását. ${ }^{96}$ Fontos megjegyezni, hogy nemcsak a koronavírus-járvány leküzdése által indokolt korlátozások, hanem a járványhelyzet következtében

88 Omizzolo-Sodano, 2020, 138. o.

89 2020/19. tvr. 1-2. cikk.

90 Allegretti, 2020, 1-8. 0.

91 Decreto-Legge 16 maggio 2020, n. 33: Ulteriori misure urgenti per fronteggiare l'emergenza epidemiologica da COVID-19.

92 Decreto-Legge 30 luglio 2020, n. 83: Misure urgenti connesse con la scadenza della dichiarazione di emergenza epidemiologica da COVID-19 deliberata il 31 gennaio 2020 e disciplina del rinnovo degli incarichi di direzione di organi del Sistema di informazione per la sicurezza della Repubblica.

93 Decreto-Legge 7 ottobre 2020, n. 125: Misure urgenti connesse con la proroga della dichiarazione dello stato di emergenza epidemiologica da COVID-19 e per la continuita' operativa del sistema di allerta COVID, nonche' per l'attuazione della direttiva (UE) 2020/739 del 3 giugno 2020.

94 Lucarelli, 2020, 573-577. 0.

95 Golia et al., 2020, 24. 0.

96 2020/19. tvr. 1. cikk. 
kialakuló egészségügyi és pénzügyi problémák megoldása érdekében hozott rendelkezések is törvényerejû rendeletekben öltöttek testet. Ez utóbbiak közül kiemelendő az úgynevezett Cura Italia-rendelet, ${ }^{97}$ amely egyrészt a munkavállalók, a családok és a vállalkozások gazdasági támogatására, másrészt pedig a nemzeti egészségügyi szolgálat megerősítésére vonatkozó rendelkezéseket tartalmaz. A rendelkezések végrehajtásának és összehangolásának garantálása érdekében pedig rendkívüli biztost neveztek ki.98

Érdekes megfigyelni az idő előrehaladtával, a koronavírus terjedésével és így a járványhelyzet súlyosbodásával párhuzamba hozható szemléletváltást, amely során az olasz kormány, úgy ítélve meg a koronavírus-járvány miatt fennálló helyzetet, mint ami megfelel az alkotmány 77. cikkében támasztott sürgősségi, szükségességi és rendkívüliségi követelményeknek, ${ }^{99}$ a polgári védelmi intézkedésről - a szükségállapot Polgári Védelmi Kódex szabályai szerinti többszöri meghosszabbítása mellett - a sürgősségi rendeleti kormányzásra tért át. ${ }^{100} \mathrm{Az}$ annak keretében kibocsátott törvényerejú rendeletek ráadásul a miniszterelnök hatáskörébe utalták a szükségállapot kezelése érdekében szükséges intézkedések meghozatalát, felhatalmazva ôt arra, hogy rendeletével - amely kapcsán kevéssé érvényesül a parlamenti kontroll funkciója alapjogokat korlátozzon. ${ }^{101}$ Mindez pedig komoly közjogi vitát generált.

\section{A különleges jogrend bevezetésével és a járványügyi szülkségállapot kihirdetésével kapcsolatos tapasztalatok, jogviták}

A hadiállapot - mint egyetlen klasszikus értelemben vett különleges jogrendi helyzet olaszországi elrendelésére az alkotmány 1948-as hatálybalépése óta nem került sor, ellenben a szükségállapotot a Polgári Védelmi Kódexben foglaltak szerint több alkalommal is bevezették. A Polgári Védelmi Osztály ${ }^{102}$ tájékoztatása ${ }^{103}$ alapján földrengés és vulkánkitörés miatt öt-öt, meteorológiai esemény és árvíz miatt hét, környezetszennyezés miatt pedig hat alkalommal hirdettek szükségállapotot a 21. század során az Olasz Köztársaságban. Két alkalommal egészségügyi okból kifolyólag is rendeltek el szükségállapotot az ezredfordulót követően, azonban a koronavírus-járvány miatti nemzeti szintú szükségállapotot megelőzően nem találunk olyan természeti eredetú vagy emberi tevékenységből származó eseményt, amely jelen járványhelyzethez hasonló hatással lett volna az állam kapcsolatrendszerére,

\footnotetext{
97 Decreto-Legge 17 marzo 2020, n. 18: Misure di potenziamento del Servizio sanitario nazionale e di sostegno economico per famiglie, lavoratori e imprese connesse all'emergenza epidemiologica da COVID-19.

98 Cura Italia-rendelet 122 . cikk.

99 Staiano, 2020, 532. 0.

100 Mobilio, 2020, 352-353. o.

101 Lorenzo, 2020.

102 Dipartimento della Protezione Civile.

103 Az elrendelt szükségállapotokról szóló tájékoztatás a Polgári Védelmi Osztály honlapján található. A honlap elérhető: www.protezionecivile.gov.it/ (Letöltve: 2020 . december 15.).
} 
illetve az olasz társadalom egészére. ${ }^{104} \mathrm{~A}$ koronavírus-járvány következtében kialakult példátlan helyzet és kezelése, illetve az annak során hozott intézkedések több okból is közjogi vita tárgyát képezik.

Elsősorban a sürgősségi rendeleti kormányzás alkotmányos modelltől eltérő megvalósítását ${ }^{105}$ kifogásolták. A szükségállapot kezelésére irányuló sürgős intézkedésekről szóló törvényerejŭ rendelet ugyanis a tényleges korlátozó rendelkezéseket a miniszterelnök hatáskörébe utalja. Azonban hiába ad felhatalmazást a Polgári Védelmi Kódex a kormányfőnek a polgári védelmi tevékenységek összehangolására szolgáló iránymutatások elfogadására, az alkotmány a sürgősségi rendeletalkotás meghatározó jogforrásaként nem a miniszterelnök rendeletét, hanem a törvényerejü rendeletet határozza meg. ${ }^{106}$ Jogosan vetődhet fel a kérdés, hogy miért nem közvetlenül törvényerejü rendeletekben korlátozza, illetve függeszti fel az egyes alapvetô jogokat a kormány, hanem - problematikusabb módon ${ }^{107}$ a miniszterelnök rendeleteivel. E felvetésre válaszul érdemes újra rögzíteni, hogy a miniszterelnök kizárólag a törvényerejû́ rendeletben meghatározott alapelvek és kritériumok megtartásával intézkedhet. Emellett többen azzal érvelnek, hogy a járvány gyors terjedése és a betegségben elhunytak magas száma azonnali reagálást igényel a fertőzések megfékezése, az egészségügyi szolgáltatások biztosítása, vagyis az egészséghez való jog mint közösségi érdek okán. ${ }^{108}$ Egy ilyen helyzetben pedig - amikor a parlament kamaráinak is nehézségei adódnak feladataik rendes ellátása kapcsán - a törvényerejú rendeletnél rugalmasabb jogforrási eszközre van szükség. A miniszterelnöki rendelet használatát tehát - amellett, hogy a polgári védelmi és az egészségügyi ágazati jogszabályokat elégtelennek ítélték meg a koronavírus-járvány okozta szükségállapot kezelésére - elsősorban a gyorsaság és a központosítás indokolja. ${ }^{109}$

Ugyanakkor az a kritika is felvetődik, hogy - köszönhetően e jogforrás használatának a parlament ellenőrző funkciója a szükségállapot során jelentős mértékben gyengült. ${ }^{110}$ Bár a törvényerejû́ rendelet hatálytalanná válik, amennyiben a két kamara nem alakítja azt át hatvan napon belül törvénnyé, a parlament ezen ellenőrző szerepe némileg kiüresedik azzal, hogy a 2020/19. tvr. egyrészt nem tartalmaz zárt felsorolást a miniszterelnök rendkívüli intézkedései vonatkozásában, másrészt pedig a járványhelyzet miatti körülmények és az idő szúkössége miatt nem kerül sor érdemi parlamenti vitára. Mindez a parlamenti kontrollfunkció kiüresedését, a hatalommegosztás elvének sérelmét eredményezi, ahol a kamarák feladata kimerül a kormány rendelkezéseinek elfogadásában, ezáltal pedig a szükségállapot

104 Bonetti, 2020, 689-692. o.

105 Mobilio, 2020, 354-357. o.

106 Lucarelli, 2020, 568-570. o.

107 Venanzoni, 2020, 490-503. 0.

108 Bonetti, 2020, 703-709. 0.

109 Mobilio, 2020, 369-374. o.

110 Venice Commission, 2020, V.A.18. 
kezelésének folyamatát - igazából korlátok nélkül - egyedül a kormány irányítja. ${ }^{111}$ Ez annak fényében is problémás, hogy a parlament múkködése a járványhelyzet idején is biztosítható. ${ }^{112}$ Egyrészt számos olyan intézkedést elfogadtak, amelynek köszönhetően a szükséges mértékben biztosított lehet a kamarák tagjainak biztonságos részvétele az üléseken, ${ }^{113}$ másrészt pedig a - több európai államban megvalósuló - parlamenti távmunka, távszavazás lehetősége is felmerült. ${ }^{114}$ Ez utóbbi kapcsán a képviselők egészséghez való joga, illetve a parlament múködésének folytonossága a két konkuráló érdek, amelyet közös nevezőre kell hozni. Ugyanakkor nem szabad megfeledkezni arról sem, hogy a parlament intézménye éppen abból nyeri relevanciáját, hogy tagjai összegyưlnek az ország különböző részeiből. Az alkotmány azon rendelkezését, amely a parlament és a kamarák határozatainak érvényességét a tagok többségének jelenlétéhez köti, ${ }^{115}$ hagyományosan megengedôen értelmezték, így az nem gördít leküzdhetetlen akadályt a parlamenti távmunka megvalósítása elé, arról maguk a kamarák dönthetnek, így ahhoz a képviselők együttmúködése lenne szükséges. ${ }^{116} \mathrm{~A}$ törvényerejű rendeleteket számos alkalommal úgy módosították, hogy ezzel a kormány mozgásterét szúkítették (így például rögzítették, hogy a miniszterelnök vagy egy általa kijelölt miniszter köteles az elfogadott korlátozó intézkedéseket a kamaráknak bemutatni). ${ }^{117}$ Ennek fényében túlzónak tûnnek a hatalommegosztás sérelmét kiáltó kritikák. ${ }^{118}$

Kérdések merültek fel a régiók - kormányzati szintủ jogforrásokat kiegészítő - rendeleteinek törvényessége kapcsán is, ugyanis a koronavírus-járvány elleni intézkedés során kibocsátott törvényerejû́ rendeletek nem szabályozták egyértelmúen az állami és regionális jogszabályok viszonyait, komoly problémát okozva ezzel. ${ }^{119} \mathrm{~A}$ nemzeti egészségügyi szolgálat létrehozásáról szóló törvény korábbiakban már hivatkozott szakasza és az ahhoz kapcsolódó alkotmánybírósági gyakorlat ${ }^{120}$ lehetőséget teremt arra, hogy a régiók közegészségügyi okból sürgős jellegú rendeleteket bocsássanak ki. A 2020/6. tvr. ezen rendelkezésre, valamint ugyanazt a felhatalmazást szintén rögzítő, az állami hatáskörök régiókra és helyi hatóságokra történő átruházásáról szóló törvényhozási rendelet ${ }^{121} 117$. szakaszára, valamint a helyi szervek szervezetének egységes szerkezetbe foglalt szabályait rögzítő törvényhozási rendelet $^{122} 50$. cikkére valóhivatkozással rögzítette, hogy miniszterelnöki rendelet meghozataláig

111 Lucarelli, 2020, 581-583. o.

112 Pignataro, 2020, 486-506. o.

113 Malaschini, 2020, 272-277. o.; Bonetti, 2020, 721-727. o.

114 Malaschini, 2020, 277-280. o.

115 Alkotmány 64. cikk (3) bekezdés.

116 Lupo, 2020, 123-133. o.

117 2020/19. tvr. 2. cikk.

118 Bonetti, 2020, 720-721. o.

119 Lásd bővebben: Mone, 2020.

120 Alkotmánybíróság 2003/33. és 2019/44. számú döntése.

121 Decreto Legislativo 31 marzo 1998, n. 112: Conferimento di funzioni e compiti amministrativi dello Stato alle regioni ed agli enti locali, in attuazione del capo I della legge 15 marzo 1997, n. 59.

122 Decreto Legislativo 18 agosto 2000, n. 267: Testo unico delle leggi sull'ordinamento degli enti locali. 
lehetőség van regionális rendeletek kibocsátására. ${ }^{123}$ Azonban nem rendelkezett kielégítően ennek korlátairól és derogációs tulajdonságáról, a régiók nehezen ellenőrizhető aktivitása pedig komoly feszültséget generált. ${ }^{124}$ Ezt orvosolandó a 2020/19. tvr. - a 2020/6. tvr. rendelkezéseit hatályon kívül helyezve - már a fenti jogszabályokra való hivatkozás nélkül úgy rendelkezik, hogy a régiók a hatáskörükbe tartozó tevékenységekkel összefüggésben korlátozó intézkedéseket hozhatnak, amennyiben területük egésze vagy egy része vonatkozásában az egészségügyi kockázat súlyosbodása azt indokolja. Hasonlóan a korábbi rendelkezéshez, erre a miniszterelnöki rendelet elfogadásáig van lehetőség, az állami szintú jogszabállyal a regionális jogszabály hatályát veszti. ${ }^{125}$ Ezen módosítások a régiók koronavírus-járvány kezelése érdekében hozott rendeleteinek pontosabb körülhatárolását eredményezték, azonban nem oldottak meg minden bizonytalanságot, és a későbbiekben is merültek fel konfliktusok az állami és regionális szintú intézkedések eltérése kapcsán. Példaként említhető Toszkána régió lakóhely elhagyásához kapcsolódó, Calabria régió vendéglátási tevékenységet érintő, illetve Szicília régió kiskorúak szabadban való aktív tevékenységét szabályozó, utóbb kifogásolt és vissza is vont rendelete. ${ }^{126}$

A koronavírus-járvány kezelésére irányuló állami és helyi szintû szabályozás összhangjának hiányára mutatott rá az a probléma is, amely a lakosság elszigetelését szolgáló intézkedésekhez kapcsolódó büntetőjogi szankciók vonatkozásában merült fel. A 2020/6. tvr. ugyanis rögzítette, hogy ezen intézkedések megsértése büntetőjogi felelősséget von maga után, és az olasz büntető törvénykönyv ${ }^{127}$ meghatározott szakaszai ${ }^{128}$ alapján szabadságvesztéssel is büntethető. Nem volt azonban világos, hogy mindez a helyi szintû hatóságok által kibocsátott intézkedések kapcsán is fennáll-e. Végül ezt az anomáliát is a 2020/19. tvr.-nek sikerült - a büntetőjogi szankciók eltörlésével - feloldania. ${ }^{29}$

A szükségállapot és a koronavírus-járvány kezelésére hozott intézkedések - számos alkotmányos jogot korlátozva - rávilágítottak arra a fentiekben már kifejtett problémára is, miszerint az Olasz Köztársaság alkotmánya nem rendelkezik kivételes helyzetben alkalmazható alapjog-korlátozási klauzulával. A rendelkezések által - a koronavírus jellegéből adódóan - leginkább érintett alapjogok korlátozásának alapjául szolgáló érdekeket viszont rögzíti az alkotmány, amely a szabad mozgáshoz való jog kapcsán egészségügyi okot, a gyülekezési jog kapcsán pedig közérdeket takar. Így is felmerülhet azonban az alapjog-korlátozások alkotmányellenességének kérdése, amelyet a jogtudomány képviselői arra hivatkozva utasítottak el, hogy az állam egészség védelmére irányuló kötelezettsége - amely kettős ter-

$1232020 / 6$. tvr. 3. cikk (2) bekezdés.

124 Lucarelli, 2020, 577-581. o.

125 2020/19. tvr. 3. cikk (1) bekezdés.

126 Mobilio, 2020, 359-365. o.

127 Regio decreto 19 ottobre 1930, n. 1398: Approvazione del testo definitivo del Codice Penale (a továbbiakban: Codice Penale).

128 Codice Penale 438., 452. és 650 . cikk.

129 Canestrini, 2020, 120-121. 0. 
mészetéből adódóan alapvető egyéni jogot és kollektív érdeket is jelent ${ }^{130}$ - valamennyi intézkedés alapja lehet. ${ }^{131}$

\section{5. Összegzés}

Az eddigiekben leírtak alapján megállapítható, hogy az olasz jogrendben nincs átfogó különleges jogrendi szabályozás. Az olasz alkotmánynak nincs önálló, e tárgykörbe tartozó rendelkezéseket összefoglaló fejezete. Egyedül a hadiállapot kategóriáját említi, rögzítve annak elrendelését és a kormány felhatalmazását, ám sem az elrendelés alapjául szolgáló helyzetet, sem pedig a kormány kivételes hatáskörét nem részletezi, és törvényi szinten sem találunk olyan jogszabályt, amely ezt az űrt hivatott betölteni. Ugyanakkor alkotmányos szinten is találunk olyan intézményeket, amelyek bár nem nevezhetők klasszikus értelemben vett különleges jogrendi kategóriáknak, ám magukon hordozzák annak bizonyos jegyeit. Így a sürgősségi rendeleti kormányzás és a központi hatáskörelvonás egyaránt a kormány jogosítványait szélesíti ki, előbbi vonatkozásában azzal, hogy rendkívüli és sürgős esetben saját felelősségére törvényerejû́ rendeletet bocsáthat ki, utóbbi során pedig azzal, hogy meghatározott feltételek bekövetkezése esetén - a szubszidiaritás, a tisztességes együttmüködés és az arányosság elvei szerint - a helyi szintű hatóságok helyett járjon el. Ezek ugyan kizárólag bizonyos feltételek esetén alkalmazhatók, és eltérnek az államszervezet rendes múködési rendjétől, azonban kivételességük és az alapul szolgáló helyzet rendkívülisége nem feltétlenül indokolja a különleges jogrendi kategóriát. Mindezek alapján megállapítható, hogy az olasz alkotmány nem biztosítja kivételes helyzetek idejére olyan erős felhatalmazás lehetőségét a végrehajtó hatalom számára, mint amilyennel több másik európai állam kapcsán találkozhatunk. A törvényi szinten, polgári védelmi kategóriaként szabályozott szükségállapot - illetőleg annak nemzeti szintű kategóriája - rendelkezik még különleges jogrendi jelleggel, leginkább az annak kezelése érdekében hozott polgári védelmi rendelkezések kapcsán. Azok ugyanis a szükségállapot elrendeléséről szóló határozatban foglalt kereteknek megfelelően és a jogrend, illetve az Európai Unió alapelveinek megtartásával eltérhetnek a hatályos jogszabályoktól.

Kijelenthető tehát, hogy az olasz különleges jogrendi szabályozás európai viszonylatban rendkívül szúkszavú. Ez az alulszabályozottság a magyarországi különleges jogrendi rendelkezések tükrében pedig különösen szembetűnő. Hiszen míg Magyarország Alaptörvénye hat szituációt rögzít, addig az olasz alkotmány csak egyetlen klasszikus különleges jogrendi helyzetet tartalmaz. Az olasz hadiállapot az Alaptörvény rendkívüli állapotával hozható párhuzamba. Ez utóbbi kapcsán is megjelenik a hadiállapot kifejezés mint a rendkívüli állapot

130 Azzariti, 2020.

131 Bonetti, 2020, 692-703. o.; Mobilio 2020, 365-369. o. 
kihirdetésének alapja. Az olasz hadiállapot és a rendkívüli állapot kategóriákban közös, hogy azok elrendelése a parlament hatáskörébe tartozik, illetve mindkettő kapcsán fontos szerepet kap a köztársasági elnök, hiszen az olasz szabályozás szerint sajátos kontrollfunkciót gyakorol a hadiállapot kihirdetésével, a magyar rendelkezések értelmében pedig az Országgyúlés akadályoztatása esetén ő maga rendelheti el a különleges jogrendet. Eltérés tapasztalható ugyanakkor a rendkívüli hatáskörrel felruházott szerv vonatkozásában. A hadiállapot során a kormány kapja meg a szükséges felhatalmazást, a rendkívüli állapot idejére azonban felállítanak egy önálló testületet, a Honvédelmi Tanácsot az egyes törvényhozói és végrehajtói hatáskörök gyakorlására. Fontos itt megjegyezni, hogy az Alaptörvény kilencedik módosítása ${ }^{132}$ komoly változtatásokat eszközöl a magyarországi különleges jogrendi szabályozás területén. Ennek keretében a különleges jogrendi esetkörök száma háromra csökken, és a rendkívüli helyzet kategóriája helyett az Alaptörvény is a hadiállapot terminusát használja háborús helyzet, háborús veszély és külső fegyveres támadás vonatkozásában. Ám nemcsak elnevezésben, hanem tartalmilag is közeledik egymáshoz a módosítással a két állam ezen különleges jogrendi kategóriája, ugyanis - a Honvédelmi Tanács intézményének megszüntetésével - a magyarországi hadiállapot idejére is a Kormányra ruházza át az Országgyưlés a jogokat. Kijelenthető azonban, hogy mind a hatályos, mind pedig a hatálybalépés előtt álló, háborús szituáció esetén kihirdetendő magyarországi különleges jogrendi esetkör lényegesen átfogóbban van szabályozva - alkotmányos szinten is -, mint az olasz hadiállapoti szituáció. Ugyan polgári védelmi kategóriáról beszélünk, de érdemes megjegyezni az olasz szükségállapot és a magyar veszélyhelyzet esetköreinek hasonlóságát, amely az elrendelésük alapjául szolgáló események, az azt elrendelő szerv, valamint a kezelésük során kibocsátott jogszabályok természete vonatkozásában áll fenn. De úffent hangsúlyozandó, hogy míg utóbbi alkotmányos szinten rögzített különleges jogrendi helyzet, addig előbbirốl a polgári védelem szabályait rögzítő törvénykönyv rendelkezik.

Az alapvetô jogok különleges jogrendi korlátozása vonatkozásában csak ismételni tudjuk önmagunkat: az olasz szabályozás rendkívül szúkszavú, és hiányzik a korlátozásoknak keretet adó - több más európai alkotmányban, így Magyarország Alaptörvényében is megtalálható - klauzula, amely megfelelő iránymutatást adna különleges jogrend vagy akár rendkívülinek nem minősülő szituációk idejére.

A koronavírus-járvány okozta rendkívüli helyzet is rávilágított az olasz jogrendszer ezen hiányosságaira. Ugyan a járványhelyzet olaszországi kezelését a magyarországi mellé állítva megállapíthatjuk, hogy az azonos nehézségekkel szembesülő államok járvány leküzdésére irányuló korlátozó intézkedései hasonlók, ugyanakkor az ezeknek keretet biztosító jogi szabályozás eltéró. ${ }^{133} \mathrm{Az}$ olasz jogrendszerben - a korábbiakban leírtak szerint - nincs

132 Magyarország Alaptörvényének kilencedik módosításáról szóló T/13647. számú törvényjavaslat. (A módosításról szóló törvényt a kézirat lezárásáig nem hirdették ki a Magyar Közlönyben.).

133 A koronavírus-járvány olasz és magyar kezelésének összehasonlításáról lásd bővebben: Hojnyák-Ungvári, 2020. 
a magyar veszélyhelyzethez hasonló, alkotmányos szinten rögzített, humánjárvány esetén elrendelhető különleges jogrendi szituáció. Így az Olasz Köztársaságban szükségállapotot hirdettek ki, amely polgári védelmi kategória mellett a különleges jogrendi elemeket magán hordozó sürgősségi rendeletalkotás eszköze biztosít alapot a szükséges intézkedések meghozatalához. Ezzel mind Magyarországon, mind pedig Olaszországban rendeleti kormányzás valósult, illetve valósul meg, amelynek felhatalmazottja kapcsán a tekintetben nincs eltérés, hogy veszélyhelyzetben és a sürgősségi rendeleti kormányzás során is a kormány hozhat törvényi erôvel bíró jogszabályokat, ám az Olasz Köztársaság vonatkozásában a gyakorlatban a miniszterelnök hozza meg - a törvényerejú rendeletek felhatalmazása alapján - a tényleges korlátozó intézkedéseket. Különbséget tapasztalhatunk az elrendelt helyzet időbeli hatálya kapcsán is, hiszen míg Olaszországban kizárólag határozott időtartamra hirdethetố ki a szükségállapot, addig Magyarországon 2020 tavaszán határozatlan időtartamra rendelték el a veszélyhelyzetet. Tekintettel arra, hogy a koronavírus-járvány okozta rendkívüli állapot leküzdése, az emberek élethez, illetve egészséghez való jogának garantálása azt megköveteli, mindkét állam élt az alapjog-korlátozás eszközével, és mivel - a járvány jellegéből adódóan leginkább az emberek izolálására, illetve interakcióik elkerülésére törekedtek, a korlátozások köre, intenzitása és formája közel azonos.

A koronavírus-járvány leküzdésére hozott intézkedések vonatkozásában elsősorban a sürgősségi rendeleti kormányzás nem megfelelő alkalmazása, az azzal biztosított túlzott mértékủ miniszterelnöki hatáskör és az alapjogok korlátozása vált komoly viták tárgyává. E tekintetben hasonlóság mutatkozik Magyarországhoz és több más európai országhoz, ahol szintén a különleges jogrend bevezetésének, a rendeleti kormányzás formájának, felhatalmazottjának, illetve az alapjogok szúkítésének alkotmányosságát kérdőjelezték meg.

A rendestôl eltérő, különleges állapot gyors és eredményes kezelése érdekében hozott, korábban kevéssé tapasztalt intézkedések rávilágítanak az olasz jogrendszer hosszú ideje meglévő, ám igazán csak most jelentkező hiányosságaira. Jelen szükségállapot hatására számos olasz szerző megfogalmazta azon véleményét, miszerint a járványhelyzet leküzdését követően - az alkotmányos elvek és a demokratikus rend szem előtt tartásával - drasztikus jogszabályi és intézményi reformok szükségesek, elsősorban a jogalkotási eljárás, a kontrollmechanizmusok, illetve az alapvető jogok korlátozásának garanciái vonatkozásában. ${ }^{134}$ 


\begin{tabular}{|c|c|c|c|c|}
\hline & Különleges & \multicolumn{3}{|c|}{ Különleges jogrendi jelleg } \\
\hline & Hadiállapot & $\begin{array}{l}\text { Sürgősségi } \\
\text { rendeleti } \\
\text { kormányzás }\end{array}$ & $\begin{array}{c}\text { Központi } \\
\text { hatáskörelvonás }\end{array}$ & $\begin{array}{l}\text { Nemzeti szintű } \\
\text { szülkségállapot }\end{array}$ \\
\hline $\begin{array}{l}\text { Szabályozás } \\
\text { szintje }\end{array}$ & \multicolumn{3}{|c|}{ Alkotmányos } & $\begin{array}{l}\text { Törvényi (Polgári } \\
\text { Védelmi Kódex) }\end{array}$ \\
\hline Alkalmazás alapja & $\begin{array}{l}\text { Nincs rögzítve } \\
\text { (védekező jellegú } \\
\text { háború) }\end{array}$ & $\begin{array}{l}\text { Rendkívüli és } \\
\text { sürgős esetben }\end{array}$ & $\begin{array}{l}\text { Nemzetközi } \\
\text { jogrend sérelme, } \\
\text { közbiztonság } \\
\text { súlyos veszélyez- } \\
\text { tetettsége }\end{array}$ & $\begin{array}{l}\text { Természeti } \\
\text { csapások, emberi } \\
\text { tevékenységgel } \\
\text { összefüggő } \\
\text { szerencsétlenségek }\end{array}$ \\
\hline Elrendelés & $\begin{array}{l}\text { A parlament } \\
\text { rendeli el, de } \\
\text { a köztársasági } \\
\text { elnök hirdeti ki. }\end{array}$ & \multicolumn{2}{|c|}{$\begin{array}{l}\text { A kormány dönt a feltételek fenn- } \\
\text { állása esetén. }\end{array}$} & $\begin{array}{l}\text { A miniszterelnök } \\
\text { vagy az érintett } \\
\text { régió javaslatára } \\
\text { a kormány rendeli } \\
\text { el. }\end{array}$ \\
\hline Felhatalmazott & \multicolumn{3}{|c|}{ Kormány } & $\begin{array}{l}\text { A polgári védelmi } \\
\text { parancsnok, } \\
\text { a polgári véde- } \\
\text { lemért felelős } \\
\text { miniszter, } \\
\text { a miniszterelnök }\end{array}$ \\
\hline Gyakorlati esetek & $\begin{array}{l}\text { Nem hirdették ki } \\
\text { ez idáig. }\end{array}$ & \multicolumn{2}{|c|}{$\begin{array}{l}\text { Többször is élt már ezen eszközökkel } \\
\text { a kormány. }\end{array}$} & $\begin{array}{l}\text { Lásd A különleges } \\
\text { jogrend bevezetésével } \\
\text { és a járványügyi } \\
\text { szükségállapot } \\
\text { kihirdetésével kap- } \\
\text { csolatos tapaszta- } \\
\text { latok, jogviták címú } \\
\text { alfejezetet. }\end{array}$ \\
\hline
\end{tabular}

18. táblázat

Az Olasz Köztársaság különleges jogrendi szabályainak összegzése Forrás: a szerző saját szerkesztése 


\section{Irodalomjegyzék}

Allegretti, U. (2020) 'Osservazioni sulla lotta al coronavirus all'inizio della "seconda fase”, Forum di Quaderni Costituzionali, 2020/3, 1-8. o.

Azzariti, G. (2020) I limiti costituzionali della situazione d'emergenza provocata dal Covid-19 [Online]. Elérhető: www.questionegiustizia.it/articolo/i-limiti-costituzionali-dellasituazione-d-emergenza-provocata-dal-Covid-19_27-03-2020.php (Letöltve: 2020. december 15.)

BonetTi, P. (2020) 'La Costituzione regge l'emergenza sanitaria: dalla pandemia del coronavirus spunti per attuarla diversamente', Osservatorio sulle Fonti, 13(2), 689-739. o.

Buscema, L. (2019) 'The State of Emergency and the (Inalienable) Firmness of the Values of Freedom of a Democratic Order: the Italian Approach', Rivista AIC, 2019/2, 211-243. o.

CANESTRINI, N. (2020) 'Covid-19 Italian Emergency Legislation and Infection of the Rule of Law', New Journal of European Criminal Law, 11(2), 116-122. o.

Celotto, A. (2002) 'Parlamento e poteri legislativi del Governo in Italia: 1' abuso del decreto d'urgenza (decreto-legge)', Derecho PUCP, 2002/55, 55-73. o.

DE Minico, G. (2016) Costituzione, emergenza e terrorismo. 1. kiadás. Nápoly: Jovene

De Vergottini, G. (2001) 'Profili costituzionali della gestione delle emergenze', Rassegna parlamentare: rivista mensile di studi costituzionali e di documentazione legislativa, 2001/2, 275-294. 0.

EgRESI, K. (2013) Az olasz alkotmány. 1. kiadás. Budapest: Gondolat Kiadó

Formuso, S. (2015) La decretazione d'urgenza in Italia. Pisa: Pisa University Press

Golia, A. Jr., Hering, L., Moser, C., Sparks, T. (2020) 'Constitutions and Contagion. European Constitutional Systems and the COVID-19 Pandemic', Max Planck Institute for Comparative Law and Internatial Law, Research Paper Series, 42/2020.

HoJnYÁk, D., Ungvári, Á. (2020) 'Az Európai Unió egyes tagállamainak koronavírusjárványra adott válasza, különös tekintettel a vizsgált államok által bevezetett különleges jogrendi szabályozásra', Miskolci Jogi Szemle, 15(1), 122-138. o.

LORENZO, L. (2020) DPCM e Costituzione - Un approfondimento per interrogarsi sugli strumenti giuridici utilizzati in emergenza coronavirus e sulla loro adeguatezza rispetto al dettato costituzionale [Online] Elérhető: www.altalex.com/documents/news/2020/05/11/dpcm-ecostituzione (Letöltve: 2020. december 15.)

LuCARelli, A. (2020) 'Costituzione, fonti del diritto ed emergenza sanitaria', Rivista AIC, 2020/2, 559-583. O.

LuCiAni, M. (2020) 'Il sistema delle fonti del diritto alla prova dell'emergenza', Rivista AIC, 2020/2, 109-141. 0.

Lupo, N. (2020) 'L'attività parlamentare in tempi di coronavirus', Forum di Quaderni Costituzionali, 2020/2, 121-142. 0 . 
Malaschini, A. (2020) 'Sulle concrete misure adottate dal Parlamento in occasione dell'emergenza Covid-19'. Forum di Quaderni Costituzionali, 2020/2, 267-283. o.

MoBILIO, G. (2020) 'La decretazione d'urgenza alla prova delle vere emergenze. L'epidemia da COVID-19 e i rapporti tra decreto-legge e altre fonti', Osservatorio sulle Fonti, 13(speciale), 351-376. o.

MONE, D. (2020) 'Il Covid- 19 in Italia: salute e altri diritti fondamentali fra potere di ordinanza statale e regionale', Diritto Pubblico Europeo Rassegna online, 2020/1.

Morrone, A. (2009) 'Le ordinanze di necessità e di urgenza, tra storia e diritto' in Aljs Vignudelli, A. (szerk.) Istituzioni e dinamiche del diritto. I confini mobili della separazione dei poteri. 1. kiadás. Milánó: Giuffrè

Nevola, R. (szerk.) (2017) La decretazione d'urgenza nella giurisprudenza costituzionale. Corte Costituzionale Servizio Studi

Omizzolo, M., Sodano, P. (2020) 'The Covid-19 Between State of Emergency and Exception in Italy and Its Consequences on Human Rights', European Journal of Social Sciences, 3(2), 135-145. o.

PACE, A. (2010) 'Dai diritti del cittadino ai diritti fondamentali dell'uomo', Rivista AIC, 2010/4, $1-22.0$.

Pignataro, M. (2020) 'Come preservare la continuità dell'attività parlamentare ai tempi del COVID-19? Alcune riflessioni sul lavoro "a distanza" e le vie percorribili a normativa vigente', Forum di Quaderni Costituzionali, 2020/1, 486-506. o.

Staiano, S. (2020) 'Né modello né sistema. La produzione del diritto al cospetto della pandemia', Rivista AIC, 2020/2, 531-557. o.

VenANZONI, A. (2020) 'Linnominabile attuale. L'emergenza Covid-19 tra diritti fondamentali e stato di eccezione', Forum di Quaderni Costituzionali, 2020/1, 490-503. o.

Venice Commission (2020) Interim Report on the Measures Taken in the EU Member States as a Result of the Covid-19 Crisis and Their Impact on Democracy, the Rule of Law and Fundamental Rights (Opinion No. 995/2020) [Online]. Elérhetô: www.venice.coe.int/webforms/documents/ default.aspx?pdffile $=$ CDL-AD(2020)018-e (Letöltve: 2020 . december 15.)

ZARCONE, C. (2019) Guerra e Costituzione [Online]. Elérhetô: www.altalex.com/documents/ news/2019/02/25/guerra-e-costituzione (Letöltve: 2020. december 15.) 


\title{
22. A prezidenciális jelleg hangsúlyossága a különleges jogrend romániai szabályozásában
}

\author{
SZENTPÁLI-GAVALLÉR PÁL
}

\section{A különleges jogrend alkotmányos és törvényi szintü szabályozása, esetkörei}

A román jogrendszerben az alkotmány ${ }^{1}$ (elfogadva 1991-ben, módosítva 2003-ban)² nem szentel önálló fejezetet a különleges jogrend kérdésének, hanem a Románia elnökéről szóló fejezet egyes szakaszai rendelkeznek az ilyen helyzetekről. A további különleges jogrendi szabályokat a törvényi és rendeleti szabályozás tartalmazza. Az utóbbi rendeleti szabályozás vonatkozásában a későbbiekben sajátos szabályozási megoldások is bemutatásra kerülnek, az idekapcsolódó alkotmánybírósági gyakorlat vázolásával.

1 Románia alkotmánya (Constituţia României) (a továbbiakban: alkotmány).

2 Ahogy Varga Attila is rámutat, a 2003-as sikeres alkotmánymódosítás, valamint a 2011-es és 2013-as sikertelen alkotmánymódosítási kísérletek során az alkotmány felülvizsgálatának alternatívájaként egyaránt felmerült (igaz, inkább csak elméleti vitaként) egy új alkotmány elfogadásának a lehetôsége, valamint szükségessége (Varga, 2019, 83. o.).

Dr. Szentpáli-Gavallér Pál

pal.szentpali-gavaller@mfi.gov.hu

kutató (Mádl Ferenc Összehasonlító Jogi Intézet)

PhD-hallgató (Miskolci Egyetem, Deák Ferenc Állam- és Jogtudományi Doktori Iskola)

Szentpáli-Gavallér, P. (2021) 'A prezidenciális jelleg hangsúlyossága a különleges jogrend romániai szabályozásában' in Nagy, Z., Horváth, A. (szerk.) A különleges jogrend és nemzeti szabályozási modelljei, 480-503. o. Budapest: Mádl Ferenc Összehasonlító Jogi Intézet.

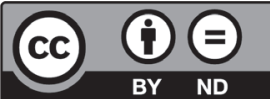


Az alkotmány a köztársasági elnökről szóló fejezetben részletezi az ostromállapotot és a sürgősségi állapotot mint kivételes intézkedéseket, valamint az alkotmány³ organikus törvény szabályozási körébe utalja egyfelől a részleges vagy teljes mozgósítás állapotának és a hadiállapot jogállásának a szabályozását mint az ország elleni fegyveres támadásra adott választ. Az ostromállapotot és a sürgősségi állapotot ugyanaz a sürgősségi kormányrendelet ${ }^{4}$ szabályozza, a mozgósítás és a hadiállapot szabályait pedig törvény ${ }^{5}$ rögzíti.

$\mathrm{Az}$ alkotmány és az annak alapján elfogadott legjelentősebb jogforrások ${ }^{6}$ tehát különbséget tesznek a következők között:

- az ostromállapot és a sürgósségi állapot mint a legmagasabb fokú veszélyhelyzettípusok, amelyek esetében Románia elnöke és a parlament rendelkezik alapvető hatáskörrel;

- a sürgősségi helyzet mint magas fokú veszélyhelyzet, amelynek esetében a kormány rendelkezik alapvető hatáskörrel; és

- a riadóállapot, amely alacsonyabb fokú veszélyhelyzetet feltételez, és amelyet szintén a kormánynak kell kezelnie.

Az ostromállapot (starea de asediu) olyan rendkívüli, politikai, katonai, gazdasági, szociális vagy más jellegú intézkedéseket jelöl, amelyeket egyes területi-közigazgatási egységekben vagy az ország egész területén az állam honvédelmi kapacitásainak súlyos, aktuális vagy elkerülhetetlen, a szuverenitást, a függetlenséget, az egységet és területi épséget fenyegető veszély elhárítása érdekében történő mozgósításra foganatosítanak.

A sürgősségi állapot ${ }^{7}$ (starea de urgență) olyan rendkívüli, politikai, gazdasági és közrendi jellegű intézkedéseket jelöl, amelyeket egyes területi-közigazgatási egységekben vagy az ország egész területén, a következő esetekben foganatosítanak:

- a nemzetbiztonságot vagy az alkotmányos demokráciát fenyegető súlyos, aktuális vagy elkerülhetetlen veszély esetén;

- olyan csapások elkerülhetetlensége vagy bekövetkezte esetén, amelyek szükségessé teszik ezek megelőzését, korlátozását vagy következményeinek elhárítását.

3 Alkotmány 73. cikk f-g. pont.

4 Az ostromállapotról, valamint a sürgősségi állapotról szóló 1999. évi 1. sürgősségi kormányrendelet (Ordonanța de urgență nr. 1/1999 privind regimul stării de asediu și regimul stării de urgență) (a továbbiakban: Ostromállapot r.).

5 A fegyveres erők részleges vagy teljes mozgósításának és a hadiállapot rendjéről szóló 2009. évi 355. törvény (Legea nr. 355/2009 privind regimul stării de mobilizare parțială sau totală a forțelor armate și al stării de război) (a továbbiakban: Fegyveres erők tv.).

6 A hivatkozott jogforrások a következők: sürgősségi kormányrendelet, 2004. évi 21. sürgősségi kormányrendelet a Sürgősségi Esetek Menedzsmentjének Nemzeti Rendszeréről; 2001. évi 88. rendelet a katasztrófavédelmi közösségi közszolgálatok alapításáról, szervezéséről és müködéséről; 2015. évi 203. törvény a honvédelem tervezéséről.

7 Vö.: Tanasescu, 2020, 191-192. o. 
Az ostromállapot és a sürgősségi állapot rendjének alapvetô szabályai szerint Románia elnöke elnöki rendelettel (dekrétum) az egész országban vagy egyes területi-közigazgatási egységekben rendelheti el az ostromállapotot vagy a sürgősségi állapotot. ${ }^{8} \mathrm{~A}$ dekrétumot a miniszterelnöknek ellen kell jegyeznie. A dekrétumot azonnal közzéteszik Románia hivatalos közlönyében. ${ }^{9}$ A dekrétum kihirdetését követő legfeljebb öt napon belül Románia elnöke kérelmezi a parlamenttől az intézkedések jóváhagyását. ${ }^{10} \mathrm{Az}$ alkotmány szerint ${ }^{11}$ ha a parlament nem tart ülésszakot, a parlament az ostromállapot vagy a sürgősségi állapot bevezetésétől számított legfeljebb 48 órán belül jog szerint összehívottnak számít, és a bejelentett állapotok egész időtartama alatt müködik. Az ostromállapot és a sürgősségi állapot idején is a parlament a végrehajtó hatalom ellensúlyaként jelenik meg, amely kontrollt gyakorol az államfó dekrétuma ${ }^{12}$ és annak végrehajtása felett is, és alapvető szerepet játszik az intézkedések és az azokat kiváltó okok közötti arányosság fenntartásában. Amennyiben a parlament nem hagyja jóvá az ostromállapotot vagy szükségállapotot, Románia elnöke azonnal visszavonja a dekrétumot, és az elrendelt intézkedések megszúnnek.

Ostromállapotot legfeljebb 60 napra, sürgősségi állapotot legfeljebb 30 napra lehet elrendelni. Parlamenti jóváhagyással az ostromállapot vagy a sürgősségi állapot ezen időkeretek tiszteletben tartásával meghosszabbítható, valamint térben kiterjeszthető vagy szúkíthetô. Ha az állapot lejárta előtt megszủnik a veszélyhelyzet, akkor dekrétummal és a parlament előzetes jóváhagyásával rendelhető el az állapot visszavonása. Ostromállapot vagy sürgősségi állapot elrendelése és fenntartása csak az ezeket kiváltó okok szerinti mértékben és a Románia által a nemzetközi jog szerint vállalt kötelezettségek tiszteletben tartásával lehetséges. ${ }^{13}$

Az ostromállapot vagy sürgősségi állapot megszúnését követő 60 napon belül Románia elnöke tájékoztatást nyújt a parlamentnek az adott állapot bevezetésének okairól, a foganatosított intézkedésekről és a hasonló helyzetek jövőbeni elkerülésének lehetőségeiről.

A sürgősségi helyzet (situația de urgență) olyan kivételes, nem katonai jellegú esemény, amely méreteinél és intenzitásánál fogva veszélyezteti a lakosság életét és egészségét, a környezetet, fontos anyagi és kulturális értékeket, és a hétköznapi viszonyok helyreállitása érdekében sürgős intézkedések, többletforrások és a bevont eszközök egységes irányítása szükséges.

A riadóállapot (starea de alertă) olyan megelőző és a lakosságot figyelmeztető akciótervek azonnali foganatosítását jelenti, amelyek célja a lakosság életét és egészségét, a környezetet,

8 Lásd a Covid-19 elnöki dekrétumot, amelynek alapját adja az a tény, hogy Romániában a rendszerváltást követően félprezidenciális kormányzati rendszer alakult ki. Erről bővebben lásd:Veress, 2006.

9 A dekrétum kötelező tartalmi elemei a következők: az ostromállapot vagy sürgősségi állapot elrendelésének oka, területe, időtartama, az azonnal foganatosítandó intézkedések, az alapjogok és kötelezettségek nevesítése, amelyek korlátozásra kerülnek, azok a katonai és polgári hatóságok kijelölése, amelyek a dekrétumot végrehajtják és ezek hatáskörei (ostromállapot esetén a központi szereplő a Honvédelmi Minisztérium, sürgősségi állapot idején a Belügyminisztérium), valamint más szükséges rendelkezések.

10 A Covid-19 elnöki dekrétumot a parlament a 2020/3. határozatával hagyta jóvá.

11 Alkotmány 93. cikk.

12 Országgyưlés Hivatala Képviselői Információs Szolgálat, 2016, 37. o.

13 A 2004. évi 453. törvény által bevezetett előírás (Ostromállapot r. 3.1. cikk). 
fontos anyagi és kulturális értékeket veszélyeztető tényezők megelőzése és ezek következményeinek elhárítása.

A mozgósítás vagy hadiállapot esetén a parlament folytatja tevékenységét ezen állapotok teljes idôtartama alatt, vagy ha nincsen ülésszak, akkor a kinyilvánításuktól számított 24 órán belül a jog erejénél fogva összehívottnak számít, ${ }^{14}$ a parlamentet nem lehet feloszlatni mozgósítási, hadiállapot, ostrom- vagy sürgősségi állapot idején, ${ }^{15}$ Románia elnökének mandátuma háború vagy katasztrófa esetén organikus törvénnyel meghosszabbítható. ${ }^{16} \mathrm{Az}$ alkotmány nem módosítható ostromállapot vagy a sürgősségi állapot időtartama alatt, sem pedig háború idején..$^{17}$

A különleges jogrendi esetkörök vonatkozásában fontos a lakosság nemzetvédelmi felkészítéséről szóló jogszabály, ${ }^{18}$ amely a lakosság védelemre való felkészítése, valamint az ország védelmének előkészítése esetén fennálló állampolgári jogok és kötelezettségek meghatározása mellett szabályozza a katonai szolgálatot is, ennek körében pedig rögzíti a katonai szolgálatra kivételes intézkedések idején vonatkozó szabályokat. Ugyancsak tartalmaz külön szabályokat ostromállapot, mozgósítás és háború idejére a katonai szolgálat kapcsán a kötelező katonai szolgálat felfüggesztéséről és az önkéntes katonai szolgálat bevezetéséről szóló törvény. ${ }^{19}$ Ezek tartalma a sorkatonai jogállásról szóló fejezetben kifejtésre kerül. A hadiállapot vonatkozásában jelentôs törvény a Legfelsőbb Honvédelmi Tanácsról szóló törvény, ${ }^{20}$ amely annak szervezete és múködése mellett rögzíti a hatóság kötelezettségeit, hatásköreit is. A különleges jogrendhez kapcsolódóan említésre érdemes a nemzetbiztonsági törvény, ${ }^{21}$ amely szerint az állampolgárok erkölcsi kötelessége a nemzetbiztonság megvalósulásához, ${ }^{22}$ vagyis a társadalmi, gazdasági, politikai stabilitás meglétéhez hozzájárulni. Ezt pedig a törvény szerint - sok más mellett - az állami szuverenitás elleni tevékenység, az ország elleni háború vagy polgárháború provokálása, az állami hatalom gyengítésére irányuló fegyveres cselekmény, valamint a terrorcselekmények fenyegetik. ${ }^{23} \mathrm{~A}$ nemzetbiztonsági szempontból szükséges intézkedések koordinációja pedig a Legfelsőbb Honvédelmi

14 Alkotmány 92. cikk.

15 Alkotmány 89. cikk.

16 Alkotmány 83. cikk.

17 Alkotmány 152. cikk.

18 A lakosság nemzetvédelmi felkészítéséről szóló 2006. évi 446. törvény (Legea nr. 446/2006 privind pregătirea populației pentru apărare).

19 A kötelező katonai szolgálat felfüggesztéséről és az önkéntes katonai szolgálat bevezetéséről szóló 2005 . évi 395. törvény (Legea nr. 395/2005 privind suspendarea pe timp de pace a serviciului militar obligatoriu și trecerea la serviciul militar pe bază de voluntariat).

$20 \mathrm{Az}$ ország Legfelsőbb Honvédelmi Tanácsának szervezetéről és mưködéséről szóló 2002. évi 415. törvény (Legea nr. 415/2002 privind organizarea și funcționarea consiliului suprem de apărare a țării).

21 A nemzetbiztonságról szóló 1991. évi 51. törvény (Legea nr. 51/1991 privind siguranța națională a româniei) 2. cikk (a továbbiakban: Nemzetbiztonsági tv.).

22 Fontos kiemelni a nemzetbiztonsági szempontrendszert arra tekintettel is, hogy több európai állam között Tálas Péter Románia vonatkozásában is helytállóan megállapítja, hogy „[...] a biztonság szubjektív megközelítése, a fenyegetettségpercepció jelentősen elszakadt és távolra került az objektív biztonságtól, a fenyegetettség tényleges mértékétől [...]”. (Tálas, 2016, 43. o.).

23 Nemzetbiztonsági tv. 3. cikk. 
Tanács (Consiliul Suprem de Apărare a Țării) feladata. ${ }^{24}$ Mindezeken túl a különleges jogrendi helyzetek vonatkozásában fontos jogszabályok azok a rendeletek, valamint határozatok, amelyek a kompetenciával rendelkező minisztériumok feladatait határozzák meg. Ezek általában az adott minisztérium szervezeti és múködési szabályait rögzítő jogszabályok.

A különleges jogrendre való felkészülés során a nem honvédelmi tárcák szerepével kapcsolatosan békeidőben megállapítható, hogy az alkotmány alapján a kormány ${ }^{25}$ a végrehajtó hatalom letéteményeseként a parlament által elfogadott kormányzási program szerint biztosítja az ország bel- és külpolitikájának megvalósítását, ellátja a közigazgatás általános vezetését. ${ }^{26}$ Továbbá - ahogyan azt a kormány és a minisztériumok szervezetéről és múködéséről szóló törvény rögzíti - biztosítja a gazdaság és társadalom kiegyensúlyozott müködését és a nemzeti érdekek előmozdítását. ${ }^{27} \mathrm{~A}$ kormányzási program keretében a kormány számos más feladata mellett államhatalmi funkciót gyakorol a közrendi és a nemzetbiztonsági szabályok biztosítása érdekében. ${ }^{28}$ Románia kormánya a miniszterelnökből, helyetteséből és 16 miniszterből áll. ${ }^{29} \mathrm{~A}$ minisztériumok közül - honvédelmi tárcaként - a Nemzetvédelmi Minisztérium felelős elsősorban különleges jogrendi helyzetekben, valamint az arra való felkészülés során az intézkedések koordinálásáért, azonban más tárcák is rendelkeznek kompetenciákkal a különleges jogrend kapcsán. Maga a kormány az erőforrással és infrastruktúrával rendelkezô irányítási és végrehajtási struktúrákat magában foglaló nemzeti mobilizációs rendszer ${ }^{30}$ irányításában múködik közre. ${ }^{31}$

A kormány kapcsán érdemes megemlíteni, hogy a miniszterelnök ellenjegyzése szükséges ahhoz, hogy az elnök kivételes intézkedést rendeljen el. A Nemzetvédelmi Minisztérium mellett a belügyi tárca rendelkezik a különleges jogrend kapcsán komolyabb feladatkörrel. A Belügyminisztérium alapvető feladatai körébe tartozik a terrorizmus, az illegális migráció, valamint a kiberbűnözés elleni harccal kapcsolatos szervezés és végrehajtás, továbbá szakigazgatási szervein keresztül biztosítja a válsághelyzetek civil megelőzési és kezelési képzésének fejlesztését. ${ }^{32}$ A Belügyminisztérium szervezetéről és múködéséről szóló sürgősségi kormányrendelet rögzíti, hogy feladatkörébe tartozik a polgári védelem és a válságkezelés, valamint

24 Nemzetbiztonsági tv. 6. cikk.

25 Romániai kormányzati honlapja: https:/gov.ro/ro/guvernul/cabinetul-de-ministri (Letöltve: 2020. november 16.).

26 Alkotmány 102. cikk.

27 A román kormány és minisztériumok szervezetéről és múködéséről szóló 2001 . évi 90. törvény (Legea nr. 90 din 26 martie 2001 privind organizarea și funcționarea Guvernului României și a ministerelor) (a továbbiakban: Szervezeti tv.) 1. cikk (2) bekezdés.

28 Szervezeti tv. 1. cikk (5) bekezdés.

29 Szervezeti tv. 3. cikk;22/2019. számú bizalmi kormányhatározat (Hotărârea nr. 22 din 4 noiembrie 2019 pentru acordarea încrederii Guvernului).

30 Fegyveres erők tv. 11. cikk.

31 Fegyveres erők tv. 12. cikk.

32 Románia Belügyminisztériumának honlapja: www.mai.gov.ro/despre-noi/atributiile-ministerului-afacerilorinterne/ (Letöltve: 2020. december 12.). 
a határvédelmi rendszer biztosítása.33 (A szakirodalom ugyanakkor azt is megjegyzi, hogy a válságkezelés terén a megyei szervek szintén meghatározó szerepet kapnak.) ${ }^{34}$ Emellett kidolgozza a rendőrség és a közbiztonsági erők békeidőben, sürgősségi helyzetben és háborús helyzetben alkalmazandó stratégiai előírásainak végrehajtását, valamint az államhatárral kapcsolatosan biztosítja a minisztériumok közti koordinációt. ${ }^{35} \mathrm{Az}$ ostromrendelet értelmében az alkotmányos rendet fenyegető veszély esetén elrendelt sürgősségi állapot idején foganatosított intézkedések koordinálása a Belügyminisztérium feladata. ${ }^{36} \mathrm{~A}$ sürgősségi állapot idején katonai rendelet (ordonanță militară) kibocsátására van feljogosítva a belügyminiszter, a helyettese, továbbá az általuk felhatalmazott tisztségviselők attól függően, hogy a rendkívüli állapot az ország egész területére vagy csak egyes közigazgatási egységeire terjed ki. ${ }^{37} \mathrm{~A}$ Belügyminisztérium alá rendelt Vészhelyzeti Főigazgatóság (Inspectoratul General pentru Situaţii de Urgenţă) feladata a különböző veszélyhelyzetek megelőzésére és kezelésére irányuló intézkedések megtétele. Múködése során többek között nyomon követi és értékeli a vészhelyzetek kiváltó okait, tájékoztatja a lakosságot, megelőzô oktatást biztosít számukra, valamint evakuálási intézkedést biztosít személyek és meghatározott áruk veszélyeztetettsége esetén.

A Külügyminisztérium szerepe az államok közötti békés kapcsolatok és együttmûködés fejlesztését célzó nemzetközi kezdeményezésekben való közremúködés, valamint Románia nemzeti érdekeinek nemzetközi színtéren való előmozdítása révén ${ }^{38}$ leginkább a különleges jogrendi esetkörök megelőzésében áll. Az Igazságügyi Minisztérium szervezetéről és múködéséről szóló rendelet a minisztériumi szintű állandó munkaszervezetek között ${ }^{39}$ rendelkezik a Vészhelyzetek Miniszteri Bizottságáról,40 amely miniszteri szintú felhatalmazott szervként válságkezelést támogató szerepet tölt be a válsághelyzetek megelőzése és kezelése során. Tevékenysége során válságkezelési szabályozást dolgoz ki, felméri a válsághelyzeteket, megfelelő intézkedéseket irányoz elő, a szükséges emberi, anyagi és pénzügyi források felhasználását felügyeli, valamint a Vészhelyzeti Főigazgatóságon keresztül informálja a Nemzeti Válságkezelési Bizottságot. ${ }^{41} \mathrm{~A}$ Gazdasági Minisztérium a müködéséről és szervezetéről szóló határozat alapján feladatai ellátása körében biztosítja a katasztrófaelhárítási és polgári védelmi intéz-

33 A Belügyminisztérium szervezetéről és mưködéséről szóló 2007. évi 30. sürgősségi kormányrendelet (Ordonanță de urgență nr. 30 din 25 aprilie 2007 privind organizarea și funcționarea Ministerului Afacerilor Interne) (a továbbiakban: BM kormányrendelet) 1. cikk.

34 Meltzer-Stefanescu-Ozunu, 2018, 2. o.

35 BM kormányrendelet 3. cikk b) pont 5. és 10. alpont.

36 Ostromállapot r. 18. cikk (1) bekezdés.

37 Ostromállapot r. 23. cikk 2. pont.

38 A Külügyminisztérium szervezetéról szóló 16/2017. számú határozat (Hotărârea nr. 16/2017 privind organizarea și funcționarea Ministerului Afacerilor Externe) 1. cikk.

39 Az Igazságügyi Minisztérium szervezetéről és múködéséről szóló rendelet (Regulament din 19 ianuarie 2011 de organizare și funcționare a Ministerului Justiției).

40 Vészhelyzetek Miniszteri Bizottsága (Comitetul ministerial pentru situații de urgență - Ministerial Committee for Emergency Situations).

41 Az Igazságügyi Minisztérium szervezetéról és müködéséről szóló rendelet (Regulament din 19 ianuarie 2011 de organizare și funcționare a Ministerului Justiției) 26-28. cikk. 
kedéseket, a nemzeti és uniós szintû kritikus infrastruktúra meghatározását, kijelölését és védelmét; gazdasági területen javaslatot tesz a Legfelsőbb Honvédelmi Tanácsnak; részt vesz minisztériumközi bizottságok munkájában a nemzetbiztonsággal, vészhelyzetek kezelésével, polgári védelemmel és a kritikus infrastruktúra védelmével kapcsolatos kérdések vonatkozásában. ${ }^{42}$ A Közlekedési és Infrastrukturális Minisztérium tevékenységi körének megfelelően ellátja a veszélyhelyzetek kezelését. ${ }^{43}$ A Regionális Fejlesztési Minisztérium közremúkködik központi és helyi szintû válságkezelési intézkedések kidolgozásában, valamint vészhelyzetek esetén biztosítja az operatív központ szervezését és múködését. ${ }^{44} \mathrm{Az}$ Egészségügyi Minisztériumot vezető miniszter pedig meghozza a járványok, valamint fertőző betegségek által előidézett vészhelyzetek megelőzése, valamint kezelése érdekében szükséges intézkedéseket. ${ }^{45}$

A veszélyhelyzetek alakulásától függően az elnök a parlament hozzájárulásával meghosszabbíthatja a rendkívüli intézkedés idôtartamát, valamint kiterjesztheti vagy korlátozhatja annak hatályát. Főszabály szerint az ostromállapot, valamint a sürgősségi állapot az elrendelésről vagy a meghosszabbításról szóló rendeletben meghatározott időpontban szúnik meg, azonban az elrendelésre okot adó helyzet idő előtti megszúnése esetén rendeletben megszüntethető a kivételes intézkedés. ${ }^{46}$ Ahogy azt már említettük, kivételes intézkedések során katonai rendeletek bocsáthatók ki, amelyek rendelkezéseinek megsértése polgári jogi, szabálysértési vagy büntetőjogi felelősséget von maga után. ${ }^{47} \mathrm{~A}$ katonai rendelet kibocsátására jogosultak meghatározása ostromállapot és sürgősségi állapot esetén is azon múlik, hogy az ország egész területére vagy csak meghatározott részére terjed-e ki. Az ország egész területére elrendelt ostromállapot esetén a honvédelmi miniszter vagy a vezérkari fönök, egyes körzeteknél pedig az érintett területi egységek parancsnokai jogosultak katonai rendelet kiadására. Sürgősségi állapot esetén pedig az ország egész területére elrendelt kivételes intézkedés kapcsán a belügyminiszter vagy helyettese, az egyes területekre elrendelt kivételes intézkedés kapcsán a megyei rendőrségi főfelügyelők, ha pedig a sürgősségi állapotot két vagy több megyére rendelték el, a helyettes által felhatalmazott egyéb tisztviselók jogosultak katonai rendelet kiadására. ${ }^{48}$ Azonban az ostromállapot és a sürgősségi állapot idején is csak szükség esetén, az elrendelés alapjául szolgáló helyzettel ará-

42 A Gazdasági Minisztérium múködéséről és szervezetéről szóló 27/2017. számú határozat (Hotărârea nr. 27/2017 privind organizarea și funcționarea ministerului economiei) 4. cikk.

43 A Közlekedési Minisztérium szervezetéről és müködéséről szóló 21/2015. számú határozat (Hotărârea nr. 21 din 14 ianuarie 2015 privind organizarea și funcționarea Ministerului Transporturilor) 2. cikk 43. pont.

44 A Regionális Fejlesztési és Közigazgatási Minisztérium szervezetéről és múködéséről szóló 51/2018. számú határozat (Hotărârea nr. 51 din 15 februarie 2018 privind organizarea și funcționarea Ministerului Dezvoltării Regionale și Administrației Publice) 5. cikk 59. és 98. pont.

$45 \mathrm{Az}$ egészségügyi reformról szóló 2006. évi 95. törvény (Legea nr. 95 din 14 aprilie 2006 privind reforma în domeniul sănătății) 25. cikk (2) bekezdés.

46 Ostromállapot r. 15-16. cikk.

47 Ostromállapot r. 27. cikk.

48 Ostromállapot r. 23. cikk. 
nyosan, az igazságügyi miniszter egyetértésével korlátozható az alapvető jogok és szabadságok gyakorlása. ${ }^{49}$

Ahogy arról már szó esett a korábbiakban, az alkotmányban egy másik, honvédelmi feladatokat megfogalmazó szakasz értelmében az ország elleni fegyveres támadás esetén Románia elnöke intézkedéseket foganatosíthat a támadás visszaverésére. Mindezeket pedig késedelem nélkül a parlament tudomására hozza. Abban az esetben, ha a parlament nem tart ülésszakot, az agresszió kirobbanásától számított 24 órán belül jogilag összehívottnak számít. Mozgósítás vagy hadiállapot esetén pedig a parlament folytatja tevékenységét ezen állapotok teljes időtartama alatt, vagy ha nincsen ülésszak, akkor a kinyilvánításuktól számított 24 órán belül jogilag összehívottnak kell tekinteni. ${ }^{50} \mathrm{~A}$ fegyveres erők mozgósításáról és a hadiállapotról önálló törvény rendelkezik. A mozgósítás a különféle politikai, gazdasági, társadalmi, közigazgatási, diplomáciai, jogi és katonai területeket érintő intézkedések békeidőben történő kidolgozását, előkészítését, valamint ezeknek az állam szuverenitását, integritását, demokratikus alapelveit támadó komoly fenyegetettség esetén való alkalmazását foglalja magában. ${ }^{51} \mathrm{~A}$ hadiállapot pedig azon rendkívüli intézkedések összessége, amelyeket az állam önvédelmi joga gyakorlása érdekében alkalmazhat, leginkább politikai, gazdasági, társadalmi, közigazgatási, diplomáciai, jogi és katonai területeken. ${ }^{52} \mathrm{~A}$ mozgósítás lehet részleges vagy teljes, attól függően, hogy az állam, valamint az apparátus egészét érinti-e..$^{53}$ Mind a mozgósítás, mind pedig a hadiállapot során az alapvető jogok kizárólag az alkotmánnyal összhangban korlátozhatók..$^{54}$ A mozgósítás, valamint a hadiállapot elrendelése az alkotmány rendelkezései alapján történik. Mindez az elnök és a parlament együttmúködését feltételezi, ugyanis Románia elnökének a mobilizálásra és háborús helyzetre vonatkozó rendeletét a parlament hagyja jóvá vagy utasítja el. ${ }^{55} \mathrm{~A}$ nemzeti mozgósítási rendszer - amely az irányítási és végrehajtási szervezeten túl magában foglalja a kapcsolódó infrastruktúrát és az erőforrásokat - irányítása a parlament, az elnök, a Legfelsőbb Honvédelmi Tanács, a kormány és más állami szervek feladatkörébe tartozik.

Megkerülhetetlen intézmény a Legfelsőbb Honvédelmi Tanács, amely autonóm közigazgatási hatóságként egységesen megszervezi és egybehangolja az ország védelmével és a nemzetbiztonsággal, a nemzetközi biztonság fenntartásában, a katonai szövetségeken belüli kollektív védelemben, valamint a béke fenntartásával vagy visszaállításával kapcsolatos kezdeményezésekben való részvétellel összefüggő tevékenységeket. ${ }^{56} \mathrm{~A}$ Legfelsőbb Honvédelmi Tanácsról szóló törvény alapján a Legfelsőbb Honvédelmi Tanács javaslatot tesz Románia

49 Ostromállapot r. 4. cikk.

50 Alkotmány 92 . cikk.

51 Fegyveres erók tv. 1. cikk.

52 Fegyveres erók tv. 2. cikk.

53 Fegyveres erők tv. 3. cikk.

54 Fegyveres erók tv. 4. cikk.

55 Fegyveres erők tv. 5-7. cikk.

56 Alkotmány 119. cikk. 
nemzetbiztonsági és katonai stratégiájával kapcsolatban, valamint elnöki kérésre javaslatot tesz és elemzést végez az ostromállapot és sürgősségi állapot elrendelése, a fegyveres erők mozgósítása, az országgal szembeni fegyveres támadás elleni fellépés, valamint hadiállapot kihirdetése kapcsán..$^{57}$

Az alkotmány rendelkezik a honvédelem terén lévő feladatokról, amely szerint Románia elnöke a fegyveres erôk parancsnoka, és ellátja a Legfelsőbb Honvédelmi Tanács elnökének tisztségét. ${ }^{58} \mathrm{~A}$ parlament előzetes jóváhagyásával kihirdetheti a fegyveres erők részleges vagy általános mozgósítását. Csakis rendkívüli esetekben az elnök döntését utólagosan kell jóváhagyásra a parlament elé terjeszteni a döntés meghozatalától számított legfeljebb öt napon belül. Az ország elleni fegyveres támadás esetén Románia elnöke intézkedéseket foganatosít a támadás visszaverésére, és ezeket késedelem nélkül a parlament tudomására hozza. Ha a parlament nem tart ülésszakot, akkor a jog erejénél fogva öszszehívottnak tekintendő az agresszió kirobbanásától számított 24 órán belül.59 Mozgósítás vagy hadiállapot esetén a parlament folytatja tevékenységét ezen állapotok teljes időtartama alatt, vagy ha nincsen ülésszak, akkor a kinyilvánításuktól számított 24 órán belül a jog szerint összehívottnak számít. A kivételes intézkedések vonatkozásában Románia elnökének jogosítványai elég hangsúlyosak, de a parlament ellenőrző szerepe elméletileg nem szúnik meg. A honvédelmi törvény szerint a honvédelmi kérdésekben az elnök dönt országgyúlési felhatalmazással. Háború idején a Legfelsőbb Honvédelmi Tanács hozza a döntéseket, tájékoztatási kötelezettséggel tartozik a parlamentnek, amelynek a hadiállapot bejelentése után legkésőbb 24 órával össze kell ülnie, és ez így is marad a háborús helyzet végéig (24 órás időhatár csak az alkotmányban szerepel). A hadsereg főparancsnoksága felel a mûveletekért, valamint a katonai akciók irányítója békeidőben és válsághelyzetekben (Válsághelyzetek Központja). Békében, válsághelyzetekben és háborúban a Nemzetvédelmi Minisztérium élén álló miniszter képviseli a minisztériumot a többi minisztériummal és kormányzati szervvel, illetve az egyéb közigazgatási hatóságokkal szemben, valamint az együttmúködést is koordinálja.

\section{Az alapjogok korlátozásával kapcsolatos kérdések}

A Románia alkotmányában található alapjog-korlátozási szabályoknak két szintje különíthető el. Az alkotmány tartalmazza az általános alapjog-korlátozási klauzulát, amely szerint egyes jogok vagy szabadságok gyakorlása kizárólag törvénnyel korlátozható, ha ezt

57 Az ország Legfelsőbb Honvédelmi Tanácsának szervezetéról és múködéséről szóló 2002. évi 415. törvény (Legea nr. 415/2002 privind organizarea și funcționarea consiliului suprem de apărare a țării) 4 . cikk.

58 Alkotmány 92. cikk.

59 Országgyưlés Hivatala Közgyưjteményi és Közművelődési Igazgatóság Képviselői Információs Szolgálat, 2016, 36-37. o. 
adott esetben a nemzetbiztonságnak, a közrendnek, a közegészségnek vagy a közerkölcsnek, az állampolgárok jogainak és szabadságjogainak a védelme, a büntetőljárás lefolytatása, valamely természeti csapás vagy rendkívül súlyos katasztrófa következményeinek megelőzése megköveteli. ${ }^{60}$ Továbbá elôírja, hogy ezt a korlátozást csak akkor lehet elrendelni, ha az szükséges. Az intézkedésnek arányosnak kell lennie a kiváltó helyzettel, és diszkriminációmentes módon, a jog vagy szabadság létének csorbítása nélkül kell a korlátozást alkalmazni.

Az általános alapjog-korlátozási klauzulából levezethető alkotmányjogi feltételrendszer összefoglalva a következő:

1. Az alapjog vagy alapszabadság korlátozásának kizárólagos eszköze a törvény. A román alkotmányos rend lehetôvé teszi a kormánynak, hogy törvényi szintú szabályozást alkosson meg azokban a rendkívüli esetekben, amelyeknek szabályozása nem tû́r késedelmet (úgynevezett sürgősségi kormányrendelet [ordonanţe de urgenţă]). A sürgősségi kormányrendelet a közzétételével hatályba lép, viszont utólag a parlamentnek jóvá kell hagynia. A parlament az ilyen rendeletet változtatás nélkül jóváhagyhatja, módosításokkal fogadhatja el vagy elutasíthatja. Kérdésként felmerül, hogy az alapjog vagy alapszabadság korlátozása sürgősségi kormányrendelettel megtörténhet-e. A kérdést a 2003. évi alkotmánymódosítás oldotta meg, ekkor került az alkotmányba ${ }^{61}$ az az elő́rás, amely szerint sürgősségi kormányrendeleteket nem lehet elfogadni az alkotmányos törvények területén, ezek nem érinthetik az állam alapvetố intézményeinek a jogállását, az alkotmányban előírt jogokat, szabadságokat és kötelezettségeket, a választási jogokat, és nem rendelhetnek el egyes javaknak a köztulajdonba való átvételérôl szóló kényszerintézkedéseket. Következésképpen az a sürgősségi kormányrendelet, amely az alkotmányban elốrt jogokat vagy szabadságokat (alapjogok vagy alapszabadságok) korlátozza, alkotmányellenes. Az alkotmánymódosítás előtt elfogadott törvényerejû́ rendeleti normákat is elismerték alapjog vagy alapszabadság korlátozására alkalmas eszköznek. ${ }^{62}$ Így kialakult a törvényerejû́ kormányrendeletek két csoportja:

- az alkotmánymódosítás után elfogadott kormányrendeletek esetén nem lehetséges az alapjog törvényerejû̉ kormányrendelet révén történő korlátozása;

— az alkotmánymódosítás előtt elfogadott, alapjogot vagy alapszabadságot korlátozó törvényerejû̉ kormányrendeletek viszont alkotmányos módon tartalmazhatnak alapjog- vagy alapszabadság-korlátozást. ${ }^{63}$

2. Az alapjog vagy alapszabadság korlátozásának indoka a nemzetbiztonságnak, a közrendnek, a közegészségnek vagy a közerkölcsnek, az állampolgárok jogainak és szabadságjogainak a védelme, a büntetőeljárás lefolytatása, valamely természeti csapás vagy valamely

60 Alkotmány 53. cikk.

61 Alkotmány 115. cikk.

62 A román alkotmánybíróság döntéseket (decizii) fogad el az alkotmányossági kérdések vizsgálata során, ezért az alkotmánybírósági döntések kifejezést röviden ABD-ként jelöljük (1994/75. ABD, 1994/139. ABD).

$632005 / 148$. ABD. 
rendkívül súlyos katasztrófa következményeinek megelőzése lehet. Idekapcsolódik, hogy két jogszabály alkotmányosságát megállapították, mert korlátozzák ugyan az információhoz való hozzáférést, de a korlátozásokat a nemzetbiztonság érdekében törvényben foganatosítják az alkotmány keretei között. ${ }^{64} \mathrm{~A}$ nemzetbiztonság fogalmának egyébként az alkotmánybíróság értelmezése szerint gazdasági tartalma is van: a román állam makrogazdasági és pénzügyi stabilitása nemzetbiztonsági kérdés. ${ }^{65}$

3. A korlátozás mértékét illetően pedig az alkotmány általános követelményként támasztja azt, hogy a korlátozás csak akkor alkotmányos, amennyiben megfelel a következő kritériumoknak:

- a demokratikus társadalomban a korlátozás szükséges (ide sorolta be az alkotmánybíróság gyakorlata, hogy a korlátozásnak szükségszerủen időlegesnek kell lennie); ${ }^{66}$

- a korlátozás arányos az azt kiváltó helyzettel;

- a korlátozást diszkriminációmentesen alkalmazzák;

- a korlátozás nem érintheti az alapjog vagy az alapszabadság létét, következésképpen csak az alapjog vagy alapszabadság gyakorlása korlátozható.

Az alkotmányban foglaltakból ${ }^{67}$ még egy kapcsolódó korlát következik: az alapjogok és alapszabadságok vagy ezek biztosítékai alkotmánymódosítással sem szüntethetők meg, következésképpen az alkotmánymódosító törvény is lehet alkotmányellenes, amennyiben alapjogokat vagy alapszabadságokat csorbítana. ${ }^{68}$

Az alkotmánybíróság gyakorlata pontosította, hogy a korlátozásnak ez a feltételrendszere csakis az alapjogokra és alapszabadságokra és nem bármilyen alanyi jogra vonatkozik. Így nem minősül alapjognak vagy alapszabadságnak például: bármilyen súlyú teher szállítása a közutakon; ${ }^{69}$ a fizetésképtelen adós tevékenysége:;0 valaki a szabadsága elött többlet távolléti díjat kapjon, ugyanis ebben az esetben külön törvény által alapított alanyi jogról és nem alapjogról van szó, ${ }^{71}$ ezzel szemben a fizetéshez való jog alapjog, a fizetések költségvetési törvénnyel való felfüggesztése, elhalasztása az alkotmány feltételrendszerének ${ }^{72}$ tiszteletben tartása nélkül alkotmányellenes; ${ }^{73}$ az éhségsztrájk nem alapjog, ezért korlátozható; ${ }^{74}$ a közös tulajdon szabályozásából fakadó korlátozások sem jelentenek alapjog-korlátozást. ${ }^{75}$

64 Alkotmány 53. cikk, 2006/766. ABD.

65 2006/855. ABD.

66 1994/75. ABD, 1994/139. ABD, 1992/6. ABD.

67 Alkotmány 152 . cikk.

68 Alkotmány 152 . cikk.

$692004 / 11$. ABD.

70 2001/223. ABD.

71 2005/214. ABD.

72 Alkotmány 53. cikk.

73 2005/148. ABD.

74 1999/13. ABD.

75 1999/237. ABD. 
Az alkotmányos alapjog-korlátozás másik szintje az egyes alapjogok és alapszabadságok nevesített korlátozása. Az alkotmány számos alapjog esetén kifejezetten utal a korlátozás lehetőségére.

Az előzőeken túl az alkotmány több alapjog esetén is kifejezetten utal arra, hogy annak gyakorlása, biztosítása a törvényben meghatározott keretek között vagy a törvény feltételei szerint lehetséges. Fontos leszögezni, hogy azok az esetek, amikor maga az alkotmány szövege további törvényi szabályozásban ismeri el azt a lehetőséget, hogy a jogalkotó határozza meg az alapjog vagy alapszabadság gyakorlásának a feltételeit, ${ }^{76}$ akkor nem kell vizsgálni az általános korlátozási klauzula által megállapított feltételrendszert, hiszen a klauzula általános normának minősül, amelyhez képest az egyes alapjogra vagy alapszabadságra vonatkozó előírások, ideértve a korlátozások lehetőségét is, előnyt élveznek. Nyilván fenn kell állnia az összhangnak az egyes alapjogra vagy alapszabadságra vonatkozó alkotmányos szabályok és a törvényes részletező, a jog gyakorlásának feltételeit és korlátait meghatározó törvényi szintű szabályozás között.

Az ostromállapot és a sürgősségi állapot idején az alapjog-korlátozásra közös szabályok vonatkoznak, amelyek szerint az ostromállapot és sürgósségi állapot idején tilos:

- az élethez való jog korlátozása, kivéve, amikor a haláleset a háborús jog tiszteletben tartásával foganatosított cselekmény következménye;

- a kínzás, valamint az embertelen vagy megalázó bánásmód;

- a nemzeti vagy nemzetközi jog szerint bűncselekménynek nem minősített tettért való elítélés;

— az igazságszolgáltatáshoz való szabad hozzáférés jogának korlátozása.

A normából egyértelműen következik, hogy ezek az alapjogok sem az ostromállapot, sem a sürgősségi állapot idején nem korlátozhatók. Ostromállapot és sürgősségi állapot idején tehát bizonyos alapjogok és alapszabadságok korlátozása lehetséges, a fent tárgyalt kivételek tiszteletben tartása mellett és az alkotmányban foglalt feltételek szerint. ${ }^{77}$ Fontos itt leszögezni, hogy a jogszabály eredeti szövege általánosan lehetővé tette az alapjog-kor-

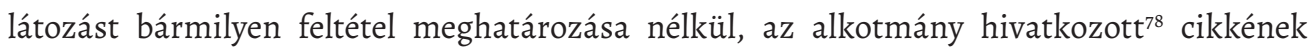

76 Például a táblázatban is bemutatott esetben az alkotmány 25. cikke szerint a belföldi és a külföldi mozgásszabadság garantált, de e jog gyakorlásának a feltételeit törvény állapítja meg; hasonlóképpen a közigazgatási bíráskodás esetében a hatóság által jogában vagy törvényes érdekében sértett személy bírósághoz való fordulásának a jogát törvény korlátozhatja. Így például a közigazgatási bíráskodásról szóló 2004. évi 554. törvény kivonja a bírósági kontroll alól a katonai aktusokat és a hatóságoknak a parlamenttel való kapcsolataik vonatkozásában kibocsátott aktusait (5. cikk).

77 Alkotmány 53. cikk.

78 Alkotmány 53. cikk. 
teljes figyelmen kívül hagyásával.79 Ostromállapot vagy sürgősségi állapot idején nem kell alkalmazni a közigazgatási döntéshozatal átláthatóságára és a társadalmi egyeztetésre vonatkozó szabályokat azon jogszabálytervezetek esetén, amelyek ezen állapotok bevezetésének a következményei. ${ }^{80}$

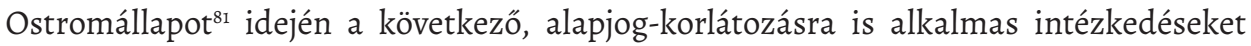
lehet foganatosítani:

- országhatár lezárása vagy az ellenőrzés intenzitásának növelése;

— katonai célú termékek előállításával foglalkozó vállalatok termelési tevékenységének fokozása;

- a katonai célú fuvarozás elsőbbségének biztosítása;

- javak elkobzása.

Sürgősségi állapot idején a következő, alapjog-korlátozásra is alkalmas intézkedéseket lehet foganatosítani:

- a védelmi célú fuvarozás elsőbbségének biztosítása;

— országhatár lezárása vagy az ellenőrzés intenzitásának növelése;

- javak elkobzása.

Sürgősségi állapot idején a hatóságok, közintézmények, vállalkozások és a lakosság köteles a vonatkozó jogszabályok alkalmazására és az elrendelt intézkedések tiszteletben tartására.

79 A vonatkozó jogszabályi szöveg eredeti változata: „Ostromállapot és sürgősségi állapot idején az elrendelésüket kiváltó okok súlyosságával arányosan, és kizárólag, amennyiben ez szükséges, az Alkotmányban elöírt alapjogok és szabadságok az igazságügyi miniszter beleegyezésével korlátozhatók." Ezt az alkotmánysértő állapotot a 2004. évi 453. törvény szüntette meg.

80 A 2020. évi 34. sürgősségi kormányrendelet által bevezetett elöírás.

$81 \mathrm{Az}$ Ostromállapot r. 20. cikke szerint a katonai és polgári hatóságok jogosultak: a lakosságnál található túzfegyverek és robbanóanyagok kötelező időszakos letétét elrendelni; a mozgásszabadságot korlátozni; ellenőrizni, razziákat foganatosítani; gyülekezési jogot korlátozni, tüntetéseket, felvonulásokat engedélyezni vagy megtiltani; az ostromállapottal vagy sürgősségi állapottal érintett helyszínekről bármely személyt, akinek a jelenléte nem indokolt, eltávolítani; az eltávolított vagy menekült személyeket nyilvántartani és irányítani; az ostromállapotra vagy sürgősségi állapotra vonatkozó információkat, a természeti katasztrófák kivételével, csak a katonai hatóságok engedélyével lehet nyilvánosságra hozni; az audiovizuális és a nyomtatott sajtó elsőbbséggel köteles a katonai hatóságok hirdetményeit közzétenni; ideiglenesen elrendelhetik üzemanyag-töltóállomások, vendéglátóipari létesítmények, egyesületi székhelyek vagy más nyilvános helyek bezárását; ideiglenesen elrendelhetik nyomtatott sajtótermékek terjesztésének tilalmát, vagy rádió-, valamint televíziós músorok sugárzását megtilthatják; különböző létesítmények katonai őrzését rendelhetik el; élelmiszer és más alapvetố áruk racionalizálására vonatkozó intézkedéseket foganatosíthatnak; katonai rendeleteket fogadhatnak el az ostromállapotot vagy szükségállapotot elrendelő dekrétum feltételei szerint; a közúti, vasúti, tengeri, folyami és légi közlekedést megtilthatják; tartalékos katonákat mozgósíthatnak, és elrendelhetik a munkaképes természetes személyek közérdekű munkavégzését. 


\begin{tabular}{|c|c|}
\hline & A korlátozó rendelkezés tartalma \\
\hline Élethez való jog & $\begin{array}{l}\text { A haláleset a háborús jog tiszteletben tartásával foganatosított cse- } \\
\text { lekmény következménye. }\end{array}$ \\
\hline \multirow{4}{*}{ Magántulajdon } & $\begin{array}{l}\text { A lakosságnál található fegyverek és robbanóanyagok kötelező idő- } \\
\text { szakos letéte. }\end{array}$ \\
\hline & $\begin{array}{l}\text { Élelmiszer és más alapvetô áruk racionalizálására vonatkozó intézke- } \\
\text { déseket foganatosíthatnak. }\end{array}$ \\
\hline & Javak elkobzása. \\
\hline & Különböző létesítmények katonai őrzését rendelhetik el. \\
\hline Kényszermunka tilalma & $\begin{array}{l}\text { Tartalékos katonákat mozgósíthatnak, és elrendelhetik a munkára } \\
\text { alkalmas természetes személyek közérdekú munkavégzését. }\end{array}$ \\
\hline \multirow{6}{*}{ Mozgásszabadság } & Személyek és jármúvek szabad mozgásának korlátozása. \\
\hline & $\begin{array}{l}\text { Az ostromállapottal vagy sürgősségi állapottal érintett helyszínekről } \\
\text { bármely személyt, akinek a jelenléte nem indokolt, el lehet távolítani. }\end{array}$ \\
\hline & Az eltávolított vagy menekült személyek nyilvántartása és irányítása. \\
\hline & $\begin{array}{l}\text { Ideiglenesen elrendelhetik üzemanyag-töltőállomások, vendéglátó- } \\
\text { ipari létesítmények, egyesületi székhelyek vagy más nyilvános helyek } \\
\text { lezárását. }\end{array}$ \\
\hline & A közúti, vasúti, tengeri, folyami és légi közlekedést megtilthatják. \\
\hline & Országhatár lezárása vagy az ellenőrzés intenzitásának növelése. \\
\hline \begin{tabular}{|c|} 
Lakóhely, tartózkodási hely \\
sérthetetlensége
\end{tabular} & Személyek és helyek ellenőrzése, razziák foganatosítása. \\
\hline Gyülekezési szabadság & $\begin{array}{l}\text { Gyülekezési jog korlátozása, tüntetések, felvonulások engedélyezése } \\
\text { vagy megtiltása. }\end{array}$ \\
\hline \multirow{3}{*}{$\begin{array}{l}\text { Kifejezés (szólás, vélemény- } \\
\text { nyilvánítás) szabadsága }\end{array}$} & $\begin{array}{l}\text { Az ostromállapotra vagy sürgósségi állapotra vonatkozó informá- } \\
\text { ciókat, a természeti katasztrófák kivételével, csak a katonai ható- } \\
\text { ságok engedélyével lehet nyilvánosságra hozni. }\end{array}$ \\
\hline & $\begin{array}{l}\text { Az audiovizuális és a nyomtatott sajtó elsőbbséggel köteles a katonai } \\
\text { hatóságok hirdetményeit közzétenni. }\end{array}$ \\
\hline & $\begin{array}{l}\text { Ideiglenesen elrendelhetik nyomtatott sajtótermékek terjeszté- } \\
\text { sének tilalmát, vagy rádió-, valamint televíziós músorok sugárzását } \\
\text { megtilthatják. }\end{array}$ \\
\hline Gazdasági szabadság & $\begin{array}{l}\text { Katonai célú termékek előállításával foglalkozó vállalatok termelési } \\
\text { tevékenységének fokozása. }\end{array}$ \\
\hline
\end{tabular}


A sürgősségi helyzetre és a riadóállapotra vonatkozó szabályozások ${ }^{82}$ nem tartalmaznak az alapjogok és alapszabadságok korlátozására vonatkozó rendelkezéseket, azonban a szabályozás elöírja, hogy a különleges jogrendi helyzetek kezelése kizárólag az alapjogok és alapszabadságok tiszteletben tartásával valósítható meg. Következésképpen, ha a veszélyhelyzet alapjog-korlátozást tesz szükségessé, akkor az ostromállapot vagy sürgősségi állapot kihirdetése szükséges, ezzel szemben a sürgősségi helyzet és a riadóállapot nem tesz lehetôvé alapjog-korlátozást. A szabályozás nem tér ki külön az egészségügyi veszélyhelyzetre, mert a román jogalkotó az egészségügyi veszélyhelyzet kezelésére a riadóállapot jogintézményét tartja megfelelőnek (lásd ezzel kapcsolatban a következő alfejezetet). Az állami egészségügyi intézményrendszer feladatai között szerepel a járványhelyzetek megelőzése és a járványügyi riadóállapot elrendelése és a járványok ellenőrzése, de a járványok által kiváltott sürgősségi helyzetekre vonatkozó intézkedéseket a törvény miniszteri rendelet szabályozási körébe utalja. ${ }^{83}$ Egyetlen törvényes rendelkezés van, amit még érdemes megemlíteni: az állami hatóságok járvány idején jóváhagyhatják nem engedélyezett gyógyszerek alkalmazását is. ${ }^{84}$

Alkotmányjogi szempontból érdekes, hogyan múködnek a gyakorlatban a fenti rendelkezések. Az Ostromállapot $r$. járványügyi veszélyhelyzet kezelésére nem alkalmas. Megalkotására az alkotmány elfogadásához képest megkésve került sor, és tartalmát a „bányászjárások" ${ }^{\prime 5}$ történelmi tapasztalata formálta. Ahogy korábban már említettük, az Ostromállapot r. kifejezett előírást tartalmaz arra vonatkozóan, hogy az alapjogok korlátozása az alkotmány ${ }^{86}$ szerint történhet, mégpedig úgy, hogy a korlátozás kizárólagos eszköze a törvény, vagyis a korlátozás kizárólagos parlamenti hatáskör. Ezt a megközelítést részben lazíthatja, hogy az Ostromállapot $r$. törvényerejú jogszabály, és ez a rendelet valóban tartalmazza bizonyos alapjogok korlátozásának a lehetőségét. Tehát a helyzet értelmezhető úgy, hogy a korlátozás törvényi szintje (elvi lehetősége) a törvényerejû kormányrendelet révén teljesül,

82 A Sürgősségi Esetek Menedzsmentjének Nemzeti Rendszeréről szóló 2004. évi 21. sürgősségi kormányrendelet (Ordonanța de urgență nr. 21 din 15 aprilie 2004 privind Sistemul Național de Management al Situațiilor de Urgență), valamint a katasztrófavédelmi közösségi közszolgálatok alapításáról, szervezéséről és múködéséről szóló 2001. évi 88. kormányrendelet (Ordonanța nr. 88 din 30 august 2001 privind înființarea, organizarea și funcționarea serviciilor publice comunitare pentru situații de urgență).

$83 \mathrm{Az}$ egészségügy reformjáról szóló 2006. évi 95. törvény (Legea nr. 95 din 14 aprilie 2006 privind reforma în domeniul sănătății) (a továbbiakban: Eü. reform tv.) 5-6. és 25. cikk.

84 Eü. reform tv. 703. cikk.

85 Romániában a rendszerváltás után a posztkommunista politikai hatalom az ellenzéki mozgalmakkal szemben vetette be a Zsil-völgyi bányászokat 1990-ben. Az 1977-es Zsil-völgyi, szociális követelésekre alapuló, de rendszerellenes potenciállal rendelkező bányászmozgalom után a kommunista titkosszolgálatok beépültek a helyi bányászati vezetők közé. Főleg ennek köszönhetően lehetett őket Bukarestbe hívni az ellenzéki mozgalmak szétverésére. 1999 januárjában és februárjában két bányászjárásra is sor került, amikor a bányászok szociális követeléseket fogalmaztak meg, valamint az 1990. évi bányászjárásban betöltött szerepéért börtönbüntetésre ítélt bányászvezér, Miron Cozma elítélése ellen tüntettek. A bányászok ellen karhatalmi erőket kellett bevetni, és a szabályozás erre a történelmi tapasztalatra épül.

86 Alkotmány 53. cikk. 
a dekrétum csak konkretizálja, a helyzetre szabja az e törvényi elöirások szerinti konkrét korlátozásokat. ${ }^{87}$

A Covid-19-világjárvány következtében elrendelt sürgősségi állapotról szóló 2020. évi 195. elnöki dekrétum ${ }^{88}$ (a továbbiakban: Covid-19 elnöki dekrétum) tételesen felsorolja a korlátozásra kerülő alapjogokat: a szabad mozgás jogát, a családi és a magánélet jogát, a lakhely sérthetetlenségét, az oktatáshoz való jogot, a gyülekezési szabadságot, a magántulajdonjogot, a sztrájkjogot és a gazdasági szabadságot korlátozza a dekrétum, azonban ezek között olyan jogok is szerepelnek (például az oktatáshoz való jog), amelynek korlátozására az Ostromállapot r. nem teremt jogalapot (elvi szinten sem szabályozza az oktatáshoz való jog korlátozásának a lehetőségét). A Velencei Bizottság megállapítása szerint a kormány intézkedésének minősül e dekrétum kiadása. ${ }^{89}$ A Covid-19 elnöki dekrétum viszont elrendeli, hogy a sürgősségi állapot idejére valamennyi oktatási intézmény szüneteltesse a tevékenységét.90 Az is kétségtelen, hogy az elnöki dekrétumot jóváhagyó 2020/3. parlamenti határozat nem törvény, és a dekrétumot sem emeli törvényi rangra, tehát Romániában aggályos az alkotmány ${ }^{91}$ alapján a dekrétum által bevezetett alapjog-korlátozások alkotmányossága, különösen azon alapjogok és alapszabadságok tekintetében, ahol a korlátozás lehetőségére nem utal a törvényi szintú szabályozás, azaz az Ostromállapot r. Ellentétes szakmai álláspontot is megfogalmaztak, amely szerint az államfó diszkrecionálisan korlátozhatja az alapjogokat és alapszabadságokat, köszönhetően az utólagos parlamenti kontrollnak, ${ }^{92}$ vagyis ezen álláspont szerint az ostromállapotot vagy sürgősségi állapotot elrendelő dekrétum utólagos parlamenti jóváhagyása teljesíti az alkotmány elvárásait.93 Az érvelés inkább az egész jogi felépítmény múködőképességének a biztosítását szolgálja, mert a szabályozás logikai egységének vizsgálata és az alkotmányos kritériumok következetes alkalmazása nem erre az értelmezési eredményre vezet. Sôt, az alapjogok és alapszabadságok korlátozásának legalsó szintje a katonai rendeletek köre (amelyeket a belügyminiszter bocsátott ki és a miniszter-

87 Itt válik fontossá az a probléma, amiről már volt szó: a 2003. évi alkotmánymódosítás megtiltotta, hogy alapjogot vagy alapszabadságot törvényerejû́ kormányrendelettel korlátozzanak, de a korábbi, így például az 1999-ben elfogadott korlátozások hatályosak maradtak.

88 Decret nr. 195 din 16 martie 2020 privind instituirea stării de urgență pe teritoriul României.

89 Venice Commission, 2020, 13. o.

90 A Covid-19 elnöki dekrétum 49. cikk.

91 Alkotmány 53. cikk.

92 Apostol Tofan, 2014, 148. o.

93 Alkotmány 53. cikk. 
elnök ellenjegyzett), és amelyek szintén fontos korlátozásokat vezettek be a Covid-19 elnöki dekrétum alapján. ${ }^{44}$

Következésképpen az ostromállapot és a sürgősségi állapot törvényi szintú szabályozása és a szabályok gyakorlati alkalmazása jogállami kritériumok alapján nem problémamentes, elsősorban azért, mert az Ostromállapot r.-be foglalt szabályozás pontatlan és elégtelen. Az Ostromállapot r.-ben világosan meg kellett volna szabni a korlátozható jogokat és a korlátozás maximális mértékét, külön az ostromállapot, külön a sürgősségi állapot esetére, hogy azt az elnöki dekrétum konkretizálhassa, tehát törvényi úton megállapított tartalmú különleges jogrendet rendelhessen el. A jelenlegi gyakorlat így jogállami mércék mentén aggályos, és nincs összhangban a hatályos alkotmány elvárásaival.

Szintén aggályos, mert az alapjogok és alapszabadságok korlátozását is tartalmazza, hogy a katonaság állományának jogállásáról, valamint a rendőrök jogállásáról szóló jogszabályokat sürgősségi kormányrendelettel módosították, e törvényerejú kormányrendelet $^{95}$ egyes előírásai ellentétesek az alkotmánnyal, ${ }^{96}$ mert alapjog-korlátozó jellegúek, és így csakis törvényi formában lehetett volna elfogadni ezeket, például a fizetett vagy fizetés nélküli szabadságok felfüggesztésének vagy kötelező elrendelésének joga a munka szociális védelmére vonatkozó alapjogba ütközik. ${ }^{97}$ Amíg például a szabadságról való visszahívás valóban indokolt lehet az ostromállapotban vagy a sürgősségi állapotban, ennek jogi alapját az alkotmány ${ }^{98}$ alapján akkor is törvénynek és nem sürgősségi kormányrendeletnek kellene biztosítania. A törvényerejû́ rendelet egyébként a szabályozás szükségességét pontosan azzal indokolta, hogy a vonatkozó törvények elégtelenek, és nem tartalmaznak rendelkezéseket az ostromállapot és a sürgősségi állapot esetére.

94 E korlátozások a következők: vendéglátóipari egységek bezárása (1. katonai rendelet); a zárt térben megvalósuló kulturális, tudományos, múvészeti, vallási, sport-, szórakoztató rendezvények betiltása (1. katonai rendelet); 100 fósnél nagyobb, nyílt térben megvalósuló események betiltása (1. katonai rendelet); spanyolországi és olaszországi repülójáratok felfüggesztése (1. katonai rendelet), majd a tilalom kiterjesztése más államokra (3. katonai rendelet, 5. katonai rendelet, 7. katonai rendelet), nemzetközi személyszállítás felfüggesztése (7. katonai rendelet); otthoni karantén elrendelése (1. katonai rendelet); fogorvosi szolgáltatások megtiltása a sürgősségi beavatkozások kivételével (2. katonai rendelet); üzletházak, plázák bezárása (2. katonai rendelet); határzár nem EU- vagy EGT-tagállamok állampolgárai vonatkozásában (2. katonai rendelet); keresztelőn, esküvőn vagy temetésen maximum nyolc személy vehet részt (2. katonai rendelet); kijárási korlátozás bevezetése (kivétel munkavégzés, alapvető szükségleti cikkek beszerzése, halaszthatatlan egészségügyi szükséglet, mezőgazdasági munkavégzés) (3. katonai rendelet); 65 év feletti személyek kijárási korlátozása 11-13 óra között (3. katonai rendelet); minden Románia területére lépő személy esetében karantén elrendelése (3. katonai rendelet); Suceava város és 8 község területének karantén alá vonása (6. katonai rendelet), majd Țăndărei város karantén alá vonása (7. katonai rendelet) stb.

95 2020. évi 36. sürgősségi kormányrendelet (Ordonanța de urgență nr. 36/2020 pentru modificarea și completarea unor acte normative, precum și pentru adoptarea unor măsuri pe timpul stării de urgență instituite prin Decretul nr. 195/2020 privind instituirea stării de urgență pe teritoriul României).

96 Alkotmány 53. és 115. cikk.

97 Alkotmány 41. cikk.

98 Alkotmány 53. és 115. cikk. 
Az ostromállapotra és a sürgősségi állapotra vonatkozó bírósági gyakorlattal kapcsolatosan a kézirat lezárásának időpontjáig megállapítható, hogy első fokon folyamatban levő eljárások vannak, például vitatják az 1. katonai rendeletben foglalt vallásos rendezvények betiltásának jogszerủségét.

De lege ferenda az Ostromállapot $r$. helyett a parlament által elfogadott, az alapjog-korlátozás kérdését világosan, teljesen, az alkotmányos elvárásokkal összhangban szabályozó törvényt kell alkotni, hasznosítva a járványhelyzet tapasztalatait.

\section{Egészségügyi vészhelyzet kezelése, koronavírus-járvány}

Az alkotmányban meghatározott, fentebb már tárgyalt esetkörökön túl említésre érdemes - az 1. alfejezetben már említett - sürgósségi helyzet (situaţia de urgenţă), amelyet a válságkezelési rendszerről szóló sürgősségi kormányrendelet úgy határoz meg, mint nem katonai jellegú rendkívüli eseményt, amely az emberi életet vagy egészséget, a környezetet, az anyagi javakat, kulturális értékeket veszélyezteti, és így a rendes állapot helyreállítása érdekében sürgős intézkedések meghozatala szükséges.

Egészségügyi válsághelyzet esetén Romániában háromszintú válságkezelési rendszer müködik: nemzeti, megyei, valamint helyi szinten. Mindhárom szinten megfelelő válságkezelési operatív központokat alakítottak ki, amelyek megosztják egymással az információkat, oda-vissza csatolásos formában egyeztetnek, segítik a döntéshozatalt annak előkészítésével, valamint együttmúködnek más szervekkel.

Nemzeti szinten ${ }^{99}$ múködő minisztériumközi testület, a Vészhelyzetek Országos Bizottsága (Comitetul Naţional Pentru Situații De Urgență) komplex feladatokat lát el a vészhelyzetek kezelése terén. A bizottság döntéshozó tagokból, szakértőkből és a minisztériumok által delegált szakemberekből áll. A bizottság a belügyminiszter közvetlen irányítása alatt múködik. ${ }^{100}$

A polgári védelmi törvény meghatározza ${ }^{101}$ a lakosság, a felszerelés, a kulturális értékek és a környezet védelme érdekében háború vagy katasztrófa esetén szükséges intézkedéseket, és elôírja a vészhelyzeti tervezést válság vagy háború esetére. Az alkotmányos alapjog-korlátozással kapcsolatban már szó esett arról, hogy annak másik szintje az egyes alapjogok és alapszabadságok nevesített korlátozása. Említésre érdemes, hogy az állandó lakhely és

99 Elérhető: https://ec.europa.eu/echo/files/civil_protection/vademecum/ro/2-ro-1.html\#lega (Letöltve: 2020. január 30.).

100 A bizottság összetétele a következő: elnöke a belügyminiszter, alelnöke a Belügyminisztérium egyik államtitkára, tagjai: mindegyik érintett minisztériumból egy államtitkár vagy a központi állami intézmények vezető képviselői, tanácsadók: mindegyik minisztériumból és a központi állami szervből egy vagy két szakértő vagy szakember.

101 A polgári védelemről szóló 2004. évi 481. törvény (Legea nr. 481 din 8 noiembrie 2004 privind protecția civilă). 
tartózkodási hely sérthetetlenségének szabályától a törvény eltérhet például járvány terjedésének megelőzése érdekében.

Ahogy arról már a különleges jogrend alkotmányos és törvényi szabályozását bemutató alfejezetben is szó esett, az Egészségügyi Minisztériumot vezető miniszter meghozza a járványok, valamint fertőző betegségek által előidézett vészhelyzetek megelőzése, illetve kezelése érdekében szükséges intézkedéseket. ${ }^{102}$

Általános járványügyi miniszteri rendelet nem született Romániában, csak a Covid-19járvány miatt fogadták el az egészségügyi miniszter 414/2020. rendeletét, ${ }^{103}$ amely a karanténra és a 297/2020. rendelettel történt módosítása után a koronavírus-tesztelésre vonatkozó szabályokat tartalmazza. A korábbi szabályokban foglaltakhoz képest e miniszteri rendeletek nem vezetnek be alapjogokat érintő új korlátozásokat, csak a korlátozások tartalmát részletezik orvosi szempontok szerint.

Ahogy arról már korábban szó esett, a Covid-19 elnöki dekrétum tételesen felsorolja a korlátozásra kerülő alapjogokat: a mozgásszabadság jogát, a magánélethez való jogot, a lakhely sérthetetlenségét, az oktatáshoz való jogot, a gyülekezési szabadságot, a magántulajdonjogot, a sztrájkjogot és a gazdasági szabadságot korlátozza a dekrétum (lásd az előző gondolati egységben foglaltakat). Azonban ezek között olyan jogok is szerepelnek (például az oktatáshoz való jog), amelyek korlátozására az Ostromállapot r. nem teremt jogalapot (elvi szinten sem szabályozza az oktatáshoz való jog korlátozásának a lehetőségét), ehhez képest a 2020/195. elnöki dekrétum elrendeli, hogy a sürgősségi állapot idejére valamennyi oktatási intézmény szüneteltesse a tevékenységét. ${ }^{104} \mathrm{Az}$ is kétségtelen, hogy az elnöki dekrétumot jóváhagyó 2020/3. parlamenti határozat nem törvény, és a dekrétumot sem emeli törvényi szintre, tehát Romániában az alkotmány ${ }^{105}$ alapján aggályos a dekrétum által bevezetett alapjog-korlátozások alkotmányossága, különösen azon alapjogok tekintetében, ahol a korlátozás lehetőségére nem utal a törvényi szintú szabályozás, azaz Ostromállapot r. Ellentétes szakmai álláspontot is megfogalmaztak, amely szerint az államfő diszkrecionálisan korlátozhatja az alapjogokat és alapszabadságokat, köszönhetően az utólagos parlamenti kontrollnak, ${ }^{106}$ vagyis ezen álláspont szerint az ostromállapotot vagy sürgősségi állapotot elrendelő dekrétum utólagos parlamenti jóváhagyása teljesíti az alkotmány már hivatkozott elvárásait (lásd ezzel kapcsolatosan az előző, alapjog-korlátozással kapcsolatos alfejezetet).

102 Eü. reform tv. 25. cikk (2) bekezdés.

103 A Covid-19-fertőzés által okozott nemzetközi közegészségügyi vészhelyzetben megbetegedettek számára karanténintézkedés bevezetéséről és a járvány következményeinek megelőzésére és korlátozására vonatkozó intézkedések megállapításáról szóló 414/2020. számú rendelet (Ordinul nr. 414/2020 privind instituirea măsurii de carantină pentru persoanele aflate în situația de urgență de sănătate publică internațională determinată de infecția cu COVID-19 și stabilirea unor măsuri în vederea prevenirii și limitării efectelor epidemiei).

104 A Covid-19 elnöki dekrétum 49. cikk.

105 Alkotmány 53. cikk.

106 Apostol Tofan, 2014, 148. o. 
Az elhúzódó járványhelyzetre vonatkozó intézkedések jogi kereteinek újragondolása a 2020. évi 55 . törvény ${ }^{107}$ révén történt meg, vagyis a jogalkotó általános szabályok helyett kifejezetten a koronavírus-járvánnyal kapcsolatban alkotott meg sajátos szabályokat. A sürgősségi állapot fenntartása helyett Romániában riadóállapot van a kézirat lezárásának pillanatában is, és a jogszabály ebben az időszakban is korlátoz bizonyos alapjogokat. A korlátozásoknak ideiglenes jellegúeknek kell lenniük, valamint a törvény a fokozatosság elvét írja elő a korlátozások foganatosítására, továbbá deklaratív jelleggel kimondja, hogy a korlátozások célja az élet és az egészség védelme. E törvény a riadóállapot fogalmát is megalkotta: a riadóállapot olyan rendkívüli kiterjedésú és intenzitású különleges helyzetre adott intézkedésrendszer, amely ideiglenes és a helyzet jelenlegi vagy jövőbeni súlyosságával arányos, és amely szükséges az életet, az egészséget, a környezetet, a fontos anyagi és kulturális értékeket vagy a tulajdont fenyegető veszélyek megelőzésére és elhárítására. A riadóállapotot helyi, megyei vagy országos szinten is el lehet rendelni a kormány hatáskörében, legfeljebb 30 napra, és újabb 30 napos időszakokra meghosszabbítható. ${ }^{108} \mathrm{~A}$ jogszabály lehetővé teszi riadóállapot alatt az ideiglenes kilakoltatást a fertőzött övezetekből; hatósági vagy otthoni karantén elrendelését; a gyülekezési jog korlátozását; kulturális, tudományos, vallási, sportrendezvények korlátozását vagy megtiltását; a mozgásszabadság korlátozását; adott területek lezárását; épületek, települések vagy térségek karantén alá helyezését; a közlekedési szolgáltatások korlátozását vagy megtiltását; határátkelők ideiglenes lezárását; intézmények vagy vállalkozások múködésének korlátozását vagy ideiglenes megtiltását; vendéglátóipari egységek múködésének korlátozását vagy megtiltását; bevásárlóközpontok tevékenységének felfüggesztését; kötelező maszkviselést; intézményekbe és vállalkozásokba történő belépésnél a kötelező járványügyi szứrés elrendelését (érintésmentes lázmérővel); a szabadságok megszakítása elrendelhető; munkavégzés ideje módosítható, hogy a munkakezdés időpontja egy-egy órás eltolódással kezdődjön a különféle munkavállalói csoportok számára; kiemelt gazdasági területeken a sztrájkjog gyakorlása ideiglenesen tiltható; online oktatás bevezethetó.

\section{4. Összegzés}

Ahogy arról már korábban is szó esett, a különleges jogrend román és a hazai hatályos szabályozása közötti lényegi eltérés az, hogy míg az előbbi négy szabályozási tárgykört (ostromállapot, sürgősségi állapot, mozgósítás és hadiállapot), addig ahhoz képest az utóbbi, magyar hatályos szabályozás hat tényállást (rendkívüli állapot, szükségállapot, veszély-

107 A Covid-19-járvány megelőzésére és az azok elleni küzdelemre irányuló egyes intézkedésekrôl szóló 2020. évi 55. törvény (Legea nr. 55 din 15 mai 2020 privind unele măsuri pentru prevenirea și combaterea efectelor pandemiei de COVID-19).

108 Lásd például a 2020/1065. kormányhatározatot (Hotărârea nr. 1.065 din 11 decembrie 2020 privind prelungirea stării de alertă pe teritoriul României începând cu data de 14 decembrie 2020, precum și stabilirea măsurilor care se aplică pe durata acesteia pentru prevenirea și combaterea efectelor pandemiei de COVID-19), amely 2020. december 14-től hosszabbítja meg a riadóállapotot 30 nappal. 
helyzet, váratlan támadás, megelőző védelmi helyzet, terrorveszélyhelyzet) állapít meg. A román ostrom- és sürgősségi állapotot érintő szabályozással párhuzamosan az Alaptörvényünk szerint a rendkívüli vagy szükségállapot kihirdetésére kerül sor. Lényegi eltérés azonban, hogy a román szabályozásban - speciális jelleggel - katonai rendelet és sürgősségi kormányrendelet megalkotására van lehetőség, míg a magyar szabályozás rendeletalkotásra ad lehetőséget. ${ }^{109}$

A román szabályozásban a parlamenti jóváhagyással kiadott elnöki döntés alapján kialakuló katonai tényállásokhoz, azaz a mozgósításhoz és a hadiállapothoz képest a magyar szabályozás szerint az Országgyúlés hadiállapot kinyilvánítása vagy idegen hatalom fegyveres támadásának közvetlen veszélye (háborús veszély) esetén kihirdeti a rendkívüli állapotot. A rendkívüli állapot idején a Honvédelmi Tanács gyakorolja az Országgyúlés által rá átruházott jogokat a köztársasági elnök jogai mellett, amelyhez társulnak a Kormány jogai. A Honvédelmi Tanács rendeletet alkothat, amely a rendkívüli állapot megszúnésével hatályát veszti, kivéve, ha az Országgyưlés a rendelet hatályát meghosszabbítja. A szükségállapot idején az Országgyúlés akadályoztatása esetén a köztársasági elnök dönt a Magyar Honvédség bevetéséről. Ebben az időszakban a rendkívüli intézkedéseket rendeleti úton a köztársasági elnök vezeti be. A rendeleti úton bevezetett rendkívüli intézkedések harminc napig maradnak hatályban, kivéve, ha hatályukat az Országgyưlés - akadályoztatása esetén az Országgyúlés honvédelmi ügyekkel foglalkozó bizottsága - meghosszabbítja. A köztársasági elnök rendelete a szükségállapot megszúnésével hatályát veszti. A magyar hatályos szabályozás szerint a különleges jogrend kihirdetéséhez az országgyưlési képviselők kétharmadának szavazata szükséges. Ha az Országgyűlés akadályoztatva van, a köztársasági elnök jogosult a hadiállapot kinyilvánítására, a rendkívüli állapot kihirdetésére és a Honvédelmi Tanács létrehozására, valamint a szükségállapot kihirdetésére. Rendkívüli állapot vagy szükségállapot idején az Országgyúlés nem mondhatja ki feloszlását, és nem oszlatható fel. A magyar és a román szabályozás összehasonlítása során mindegyik román tényállás esetén egyértelmúen látható az elnök markáns szerepe. Fontos itt ismételten arra is kitérni, hogy a Covid-19-járvány miatt a román szabályozás - speciális jelleggel - törvényi úton bevezette a riadóállapot fogalmát is. Ezzel kapcsolatban jelezni szükséges, hogy megfontolásra érdemes egy esetleges hasonló jogintézmény magyar jogrendszerbe illesztésének vizsgálata. A román Legfelsőbb Honvédelmi Tanácshoz hasonló szerv - a Honvédelmi Tanács - a hatályos magyar szabályozásban is létezik; az érdemi eltérést az jelenti, hogy a magyar Honvédelmi Tanács rendeletet alkothat; további különbség, hogy a román testület a különleges jogrend kihirdetését megelőzően is múködik. A magyar szabályozáshoz képest lényegi eltérést képez az a korábbiakban már jelzett tény, hogy Romániában az elnök szerepe kifejezetten hangsúlyos, erre nyújt - többek között - jó példát, hogy az ostromállapot és a sürgősségi állapot rendjének szabályai szerint Románia elnöke elnöki rendelettel (dekrétum) 
az egész országban vagy egyes területi-közigazgatási egységekben elrendelheti az ostromállapotot vagy a sürgősségi állapotot.

A román szabályozás lényegének bemutatását szolgálja a következő táblázat.

\begin{tabular}{|c|l|l|}
\hline & \multicolumn{1}{|c|}{ Ostromállapot, sürgősségi állapot } & \multicolumn{1}{|c|}{ Mozgósítás, hadiállapot } \\
\hline Szabályozás szintje & Alkotmányos, törvényi és rendeleti szint \\
\hline Elrendelési okok & $\begin{array}{l}\text { Az állam szuverenitását vagy } \\
\text { területi integritását; } \\
\text { a nemzetbiztonságot vagy az al- } \\
\text { kotmányos demokráciát fenyegető } \\
\text { súlyos, aktuális vagy elkerülhe- } \\
\text { tetlen veszély. }\end{array}$ & $\begin{array}{l}\text { Az ország elleni fegyveres } \\
\text { támás esetén. }\end{array}$ \\
\hline Elrendelés & Elnök (az országgyúléssel együttmúkködve) \\
\hline Felhatalmazott & Elnök & \multicolumn{2}{|l|}{} \\
\hline Gyakorlati esetek & $\begin{array}{l}\text { Sürgősségi állapot: egy alkalommal } \\
\text { (202o: Covid-19). }\end{array}$ & Nem rendelték el. \\
\hline $\begin{array}{l}\text { Különleges jogrendnek nem } \\
\text { minősülő rendkívüli helyzet }\end{array}$ & Sürgősségi helyzet, riadóállapot \\
\hline
\end{tabular}

\section{0. táblázat \\ Különleges jogrendek a román szabályozásban \\ Forrás: a szerzô sajátösszeállitása}

Magyarország Kormánya 2020. november elején az Országgyúlésnek benyújtotta a Magyarország Alaptörvényének kilencedik módosításáról szóló tervezetet, amelyet az Országgyưlés 2020. december 15. napján elfogadott, és a vonatkozó rendelkezések 2023-ban lépnek hatályba ${ }^{110}$ Ennek értelmében - a román jogintézményekhez képest - az Alaptörvény a kilencedik módosítását követően már csak három különleges jogrendi tényállást fog szabályozni: a hadiállapotot, a szükségállapotot és a veszélyhelyzetet. E módosítással - külföldi példák nyomán - a jogalkotó átláthatóbbán ${ }^{11}$ kívánja tenni a korábbi hat helyett három esetkörre módosuló különleges jogrendi tényállások rendszerét, amely a fegyveres védelmi és biztonsági tevékenységekben érintett szervezetekre vonatkozó szabályokkal egy korszerủbb, a változó biztonsági környezethez jobban alkalmazkodó és az elmúlt évek válságkezeléseinek tapasztalataira építő, hatékony rendszer kialakítására törekszik. A módosítás a korszerủsítés és a rendszerszintủ megújítás mellett számos ponton többletgaranciákat épít be

110 T/13647. számú tervezet: www.parlament.hu/irom41/13647/13647.pdf (Letöltve: 2020. december 15.). A módosítást még nem hirdették ki a Magyar Közlönyben.

111 Vö.: Till, 2017, 73-75. o. 
a védelmi és biztonsági funkciók ellátásának szervezeti, múködési és szabályozási keretei vonatkozásában is. A különleges jogrend intézményrendszerében - a módosítás eredményeként - a köztársasági elnök és a Honvédelmi Tanács nem kap szerepet, és ennek következményeként a Kormány szerepe megerősödik, amit jelez a különleges jogrendre vonatkozó közös szabályokban foglalt rendeletalkotási jogkör hangsúlyossá válása. A módosítás alapján a jövőbeli magyar és román szabályozás a tényállások száma és átláthatósága tekintetében hasonló lesz. A 2023-ban hatályba lépő magyar szabályozás és a román között egyértelmú eltérés az, hogy a román elnöki túlsúllyal szemben a magyar szabályozásban a Kormány kap meghatározó szerepet, annak markáns rendeletalkotási jogkörével. Jelezni kell azt is, hogy a 2023-as új szabályozás létrehozza a magyar szabályozásban is az elsődlegesen katonai tényállásként értelmezhető hadiállapotot, ami - ebből a szempontból - a magyar szabályozást közelíteni fogja a román szabályozáshoz.

A fentiekben már szó esett arról, hogy az egészségügy reformjáról szóló törvény nem szabályozza külön az egészségügyi veszélyhelyzetet, mert a román jogalkotó az egészségügyi veszélyhelyzet kezelésére a sürgősségi állapot jogintézményét tartja megfelelőnek. Az állami egészségügyi intézményrendszer feladatai között szerepel a járványhelyzetek megelőzése, a járványügyi riadóállapot elrendelése és a járványok ellenőrzése, de a járványok által kiváltott sürgősségi helyzetekre vonatkozó intézkedéseket a törvény miniszteri rendelet szabályozási körébe utalja. ${ }^{112}$ Egyetlen törvényes rendelkezés van, amelyet még érdemes megemlíteni: az állami hatóságok járvány idején jóváhagyhatják nem engedélyezett gyógyszerek alkalmazását is. ${ }^{113}$

Alkotmányjogi szempontból érdekes, hogyan múködnek a gyakorlatban a fenti rendelkezések. Az Ostromállapot r. járványügyi veszélyhelyzet kezelésére nem alkalmas, ezért is volt indokolt a külön jogszabály megalkotása, viszont ezen túlmenően egységes, pontos szabályozás kidolgozása a jövőben indokolt lenne.

A járvány alatt alkotmánybírósági döntések sora foglalkozott az alapjogok korlátozásának kérdésével, így az alkotmánybíróság több döntésével korrigálta a kormány sokszor elsietett, az alkotmányos rendbe nem integrált intézkedéseit. ${ }^{114} \mathrm{Az}$ alkotmánybíróság megállapította például, hogy a sürgősségi állapotban a kijárási tilalmat megszegőkre kirótt büntetéseket előiró jogszabály alkotmánysértő (mert alapjog-korlátozáshoz kapcsolódnak, ezért ezeket kizárólag törvényben és nem törvényerejü kormányrendeletben lehet elő́rni);;15 a sürgősségi kormányrendeletben vagy miniszteri rendeletben meghatározott karanténkötelezettség alkotmányellenes (az alapjog korlátozása törvényi szabályozást igényel); megállapította, hogy a riadóállapot kihirdetéséhez nem szükséges a parlament jóváhagyása, mert az egy alkotmánynál alacsonyabb szinten megalkotott jogintézmény, és a végrehajtó hatalmi

112 Eü. reform tv. 5-6. és 25. cikk.

113 Eü. reform tv. 5-6. és 25. cikk. 703. cikk.

114 Vö.: 2020/152. ABD, 2020/157. ABD, 2020/397. ABD, 2020/457. ABD, 2020/458. ABD, 2020/581. ABD.

115 Ez körülbelül 300000 kirótt szabálysértési bírság jogellenességét jelentette. 
ág élhet e jogkörrel az alkotmányos keretek között; kimondta, hogy alkotmánysértő a polgármesterek és tanácsosok (önkormányzati képviselők) mandátumát meghosszabbító sürgősségi kormányrendelet (mert ilyen hosszabbítást kizárólag törvény rendelhet el).

\section{Irodalomjegyzék}

Apostol Tofan, D. (2014) Drept administrativ, volumol I. 3. kiadás. Bukarest: C. H. Beck

Kelemen, R. (2020) 'Különleges jogrend az Európai Unió egyes tagállamainak alkotmányaiban' in Farkas, Á., Kelemen, R. (szerk.) (2020) Szkülla és Kharübdisz közöttTanulmányok a különleges jogrend elméleti és pragmatikus kérdéseiröl, valamint nemzetközi megoldásairól. 1. kiadás. Budapest: Magyar Katonai Jogi és Hadijogi Társaság

Meltzer, M., Stefanescu, L., Ozunu, A. (2018) 'Keep Them Engaged: Romanian County Inspectorates for Emergency Situations' Facebook Usage for Disaster Risk Communication and Beyond', Sustainability, 10(5), 1-24. o.

Országgyúlés Hivatala Képviselői Információs Szolgálat (2016) Kormányhatáskörök és parlamenti ellenôrzés rendkivüli állapot esetére az Európai Unió tagországaiban [Online]. Elérhető: https://tinyurl.hu/SsjG/ (Letöltve: 2020. január 14.)

Szabó, Cs., HoRváth, L. (2012) 'Magyarország Alaptörvényének és a Magyar Köztársaság Alkotmányának összevetése a különleges jogrend vonatkozásában', Hadmérnök, 7(2), 395404. o.

TÁLAs, P. (2016) 'A terrorveszélyhelyzet-diskurzus margójára', Nemzetés Biztonság, 9(1), 40-47. o.

TANASESCU, E. (2020) 'COVID-19 and constitutional law: Romania' in Serna de la Garza, J. M. (szerk.) Covid-19 and Constitutional Law. Covid-19 et droit constitutionnel. 1. kiadás. México: Universidad Nacional Autónoma de México

TilL, Sz. (2017) 'A különleges jogrendi kategóriarendszer egyszerűsítésének jövőbeli esélyei', Iustum Aequum Salutare, 13(4), 55-75. o.

VARGA, A. (2019) Román alkotmányjog. Budapest-Kolozsvár: Forum Iuris

Venice Commission (2020) Interim Report on the Measures Taken int he EU Member States as a Result of the Covid-19 Crisis and Their Impact on Democracy, the Rule of Law and Fundamental Rights (Opinion No. 995/2020) [Online]. Elérhető: www.venice.coe.int/webforms/documents/ default.aspx?pdffile=CDL-AD(2020)018-e (Letöltve: 2020 . december 15.)

Veress, E. (2006) 'Elnök és kormány viszonya Romániában: a félparlamentarizmus gyakorlata', Magyar Kisebbség, 10(1-2), 299-311. o. 


\title{
23. A kivételes állapot alkotmányos és törvényi szintû́ szabályozása Svédországban
}

\author{
UNGVÁRI ÁLMOS
}

\section{A különleges jogrend alkotmányos és törvényi szintű szabályozása}

Svédország alkotmánya ${ }^{1}$ - amelynek fejlődése európai és skandináv vonatkozásban is különleges - formáját tekintve közbülső helyet foglal el az írott, kontinentális (chartális) és az íratlan (történeti) angol alkotmány között. ${ }^{2} \mathrm{Az}$ ugyanis nem egy egységes dokumentum, hanem négy úgynevezett alaptörvény (grundlagar), a kormányzatról szóló törvény, ${ }^{3}$ a trónöröklés rendjét rögzítő öröklési törvény, ${ }^{4}$ a sajtó szabadságának garanciái mellett a közérdekű dokumentumok nyilvánosságát is szabályozó sajtószabadságról szóló törvény, ${ }^{5}$

I A svéd alkotmányos rendszer legfontosabb törvényeinek angol nyelvü, rövid magyarázattal ellátott gyüjtését lásd: Isberg, 2016.

2 Kiss, 1991, 168. o.

3 Regeringsformen-Kungörelse (1974:152) om beslutad ny regeringsform (a továbbiakban: Kormányzati tv.).

4 Successionsordning (1810:0926).

5 Tryckfrihetsförordning (1949:105) (a továbbiakban: Sajtószab.tv.).

Dr. Ungvári Álmos

almos.ungvari@mfi.gov.hu

kutató (Mádl Ferenc Összehasonlító Jogi Intézet)

PhD-hallgató (Pázmány Péter Katolikus Egyetem, Jog- és Államtudományi Doktori Iskola)

Ungvári, Á. (2021) 'A kivételes állapot alkotmányos és törvényi szintû szabályozása Svédországban' in Nagy, Z., Horváth, A. (szerk.) A különleges jogrend és nemzeti szabályozási modelljei, 504-529. o. Budapest: Mádl Ferenc Összehasonlító Jogi Intézet.

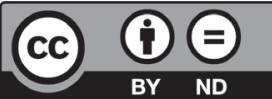


illetve a véleménynyilvánítás szabadságáról szóló törvény ${ }^{6}$ együttesen alkotja. ${ }^{7}$ Ugyan nem sorolják az alaptörvények közé, azonban a svéd alkotmányos rendszer fontos pillére a törvényhozás szervezetének és múködésének szabályait rögzítő, a parlamentről (Riksdag) szóló törvény ${ }^{8}$ is. Központi alaptörvényként a leginkább alkotmány jellegú, a hatalomgyakorlás alapjait, az alapvető jogokat, illetve az államszervezet felépítését és múködését rögzítő Kormányzati tv.-re szoktak hivatkozni. A különleges jogrend tárgyköre kapcsán is ez a jogszabály bír relevanciával.

A svéd jogi doktrína a kivételes állapotok három fajtáját különbözteti meg: a háborút (az állam elleni külső támadást), a rendkívüli körülményeket, valamint a (belső) szükségállapotot. ${ }^{9}$ Azonban különleges jogrendi helyzetként egyedül az elsőt rögzítették alkotmányos szinten, ugyanis a Kormányzati tv. önálló fejezetben rendelkezik a háború és háborús veszély kategóriáiról. Ugyanakkor - hasonlóan egyébként a norvég és a dán alkotmányhoz hallgat a békeidejú kivételes szituációkról, azok vonatkozásában nem tartalmaz különleges szabályokat. ${ }^{10} \mathrm{~A}$ svéd megközelítés szerint a háborúnak nem minősülő válsághelyzetek kezelése a rendes jogrend szerint - a jogállamiság alapelveinek megtartásával - történik, azaz a rendes jogrendi jogszabályok keretében kell biztosítani a kivételes állapotra való hatékony reakciót. ${ }^{11}$ Ezt az alkotmányos készültség (Författningsberedskap) kifejezéssel írják le, ${ }^{12}$ amelynek keretében számos törvényt és rendeletet alkottak a háborús helyzetre, a rendkívüli eseményekre való felkészülés, valamint azok kezelése érdekében. A kivételes állapoti kategóriák fenti hármasából tehát az első kettő törvényileg meghatározott, ám a - többek között - terrorcselekmény, szervezett bủnözés, komolyabb baleset, természeti katasztrófa, járvány vagy a kritikus infrastruktúra múködésének zavara következményeként jelentkező szükségállapoti helyzet sem alkotmányos, sem alacsonyabb jogszabályi szinten nincs rögzítve. És bár föszabály szerint ilyen és ehhez hasonló esetekben is a rendes jogi normák irányadók, hiszen nem minősülnek alkotmányos értelemben vett háborús szituációnak, mégis kialakult egyfajta - az alkotmányos elv szintjét még talán el nem érő - különleges jogrendi gyakorlat. Tekintettel arra, hogy ez a gyakorlat néhány, az 1970-es években bekövetkezett esemény hatására alakult ki, a békeidejủ szükségállapot alkotmányos szinten való rögzítése már a Kormányzati tv. elôkészítése során is vitát generált, és bár annak elfogadásával a különleges jogrendi hatalomgyakorlás egyedül háború idején vált legitimálhatóvá, a kérdés újra és újra felmerül. ${ }^{13}$ Ezt a problémát járta körül a válságra való felkészülésről szóló

6 Yttrandefrihetsgrundlag (1991:1469) (a továbbikban: Vélemény tv.).

7 Nergelius, 2019, 316. o.

8 Riksdagsordning (2014:801) (a továbbiakban: Parlamenti tv.).

9 Hirschfeldt, 2017, 194. o.

10 Cameron-Jonsson Cornell, 2020, 1175. o.; Dibb, 2020, 535. o.; Hirschfeldt, 2020, 1148. o.

11 Jonsson Cornell, 2020, 377. o.

12 Cameron-Jonsson Cornell, 2020, 1177. o.

13 Jonsson Cornell-Salminen, 2018, 227-228. o. 
alkotmányos szabályokat áttekintő 2008 -as állami jelentés, ${ }^{14}$ amelynek nyomán javaslat ${ }^{15} \mathrm{ké}^{-}$ szült a Kormányzati tv. háborús rendelkezéseinek kibővitésére, ám a 2011. január 1-jén hatályba lépő - a központi alaptörvény jelentős reformját hozó - módosítások ${ }^{16}$ érdemben nem változtatták meg a különleges jogrendi fejezetet.

\subsection{Háború és háborús veszély}

A Kormányzati tv. 15., Háború és háborús veszély ${ }^{17}$ címú fejezete döntően hatásköri szabályokat tartalmaz,18 ellenben a különleges jogrendi helyzeteket nem definiálja. Konszenzus alakult ki annak kapcsán, hogy a háború fogalmát nem lehet jogszabályban meghatározni, a különleges jogrend elrendeléséről a kormány dönt, egyedül az állam részben vagy egészben történő megszállása esetén érvényesülnek automatikusan a háborús szabályok. ${ }^{19}$ A Kormányzati tv. értelmében azonban a kormány csak parlamenti felhatalmazás alapján hirdetheti ki a hadiállapotot, ezalól kizárólag az államot érő fegyveres támadás képez kivételt. ${ }^{20}$

Ha a Svéd Királyság háborúba kerül vagy háborús veszélynek van kitéve, a kormány vagy a házelnök - akár Stockholmon kívül eső helyre - összehívja a parlamentet. Abban az esetben viszont, ha a körülmények azt indokolják, a parlament a házelnökből és ötven másik, a parlament által választott tagból állón ${ }^{21}$ Haditanácsnak (Krigsdelegationen) adja át a helyét. Az erről szóló rendelkezés a miniszterelnök és a Külügyi Tanácsadó Testület (Utrikesnämndens) együttmúködését igényli. Amennyiben ugyanis a királyság háborúban áll, a miniszterelnökkel való egyeztetést követően a Külügyi Tanácsadó Testület tagjai, ha pedig az állam háború közvetlen veszélyének van kitéve, a Külügyi Tanácsadó Testület tagjai és a miniszterelnök közösen döntenek a hatáskör-átruházásról. Utóbbi esetben a rendelkezés érvényességéhez a miniszterelnök és a Külügyi Tanácsadó Testület hat tagjának egyetértése szükséges. Kivételesen pedig - ha a háborús körülmények megakadályozzák a Külügyi Tanácsadó Testület összeülését - a kormány is határozhat erről. ${ }^{22}$ Amíg helyettesíti - az alaptörvény nem határoz meg határidőt az illetékességére vonatkozóan -, a Haditanács a parlament valamennyi

14 Krisberedskapen i grundlagen - Översyn och internationell utblick. Expertgruppsrapport, Grundlagsutredningens rapport XIII Stockholm, 2008 (a továbbiakban: SOU 2008:61.). Elérhetô: www.regeringen.se/49bb8d/ contentassets/od28bo2e5ee046a8b4549ac4eb9874af/krisberedskapen-i-grundlagen-sou-200861 (Letöltve: 2020. november 30.).

15 En reformerad grundlag. Betänkande av Grundlagsutredningen. Stockholm, 2008 (a továbbiakban: SOU 2008:125.). Elérhető: www.regeringen.se/rattsliga-dokument/statens-offentliga-utredningar/2008/12/sou2008125/ (Letöltve: 2020. november 30.).

16 A Kormányzati tv. reformjáról bővebben lásd: Nergelius, 2013, 372-379. o.

17 Krig och krigsfara.

18 Csink, 2017, 12. o.

19 SOU 2008:61. 28., 47-48. o.

20 Kormányzati tv. 15. fejezet 14. cikk.

21 Parlamenti tv. 13. fejezet 11. \$.

22 Kormányzati tv. 15. fejezet 1-2. cikk. 
hatáskörét gyakorolhatja, így törvényeket, sőt akár alaptörvényt is alkothat és módosíthat. Egyedül a parlamenti választásokkal kapcsolatos szabályok képeznek kivételt. Arról, hogy a parlament ismételten betöltheti-e hatáskörét - közös tárgyalás útján vagy külön-külön -, a Haditanács és a kormány jogosult dönteni. ${ }^{23} \mathrm{~A}$ Kormányzati tv. tehát megerősíti a törvényhozó hatalom pozícióját háború idején, a parlament kompetenciáinak a Haditanácsra való átruházásával pedig biztosítja, hogy minden körülmények között legyen egy olyan, az arányosság elvét tiszteletben tartó törvényhozó testület, amely méretéből adódóan a háborús szituáció során is megfelelően tud múködni, ugyanakkor biztosítja a kellô mértékú reprezentativitást is. ${ }^{24}$ Szintén a parlament jogkörét erősíti, hogy ha a háború vagy háborús veszély következtében a kormány nem képes ellátni feladatait, dönthet annak felállításáról, és meghatározhatja ügyrendjét. ${ }^{25} \mathrm{~A}$ parlament múködésének biztosítására szolgáló fontos garanciális szabály az is, hogy parlamenti választást háború idején kizárólag a parlament döntése alapján lehet tartani, ha pedig a Svéd Királyság háborús veszélynek van kitéve az általános választások tervezett idejében, azt elhalaszthatja, ám ehhez mindkét esetben a képviselők háromnegyedes többsége szükséges. A parlamenti választásról szóló döntést legalább évente felül kell vizsgálni, és azok megtartására a különleges jogrendi helyzet elmúltával a lehetố leghamarabb sort kell keríteni. ${ }^{26}$

A Kormányzati tv. arra az esetre is tartalmaz rendelkezéseket, amikor sem a parlament, sem pedig a Haditanács nem képes feladatait ellátni. Ilyenkor a királyság védelme és a háború befejezése érdekében - a szükséges mértékben - a kormány gyakorolja a törvényhozói hatáskört. Ez alapján a kormány rendeletével szabályozhat törvényi útra tartozó területeket. Emellett - az olyan felhatalmazási törvényeket megalapozandó, ${ }^{27}$ mint a kisajátítást és kártalanítást szabályozó ${ }^{28}$ vagy a meghatározott áruk háború idején való forgalmazásának korlátozásáról ${ }^{29}$ szóló törvény - azt is rögzíti, hogy a védelmi készültség szempontjából szükséges bármely más esetben törvény felhatalmazása alapján a kormány rendeleti úton dönthet valamely törvényi szintú, igénybevétellel kapcsolatos vagy más hasonló rendelkezés hatálybalépéséről vagy alkalmazásának megszüntetéséről. Ez utóbbi esetben a törvény körül kell hogy határolja a felhatalmazás alkalmazásának feltételeit. Fontos azonban, hogy a rendeleti kormányzás keretében a kormány nem hozhat, nem módosíthat és nem helyezhet hatályon kívül alaptörvényt, illetve a parlamentről és a parlamenti választásokról szóló törvényt. Érdemes kiemelni, hogy a kormány kivételes rendeletalkotási jogkörének alapjaként nemcsak a háborút és a háborús veszélyt nevesíti a Kormányzati tv., hanem az azok követ-

23 Kormányzati tv. 15. fejezet 3. cikk.

24 SOU 2008:61. 29. 0.

25 Kormányzati tv. 15. fejezet 4. cikk.

26 Kormányzati tv. 15. fejezet 11. cikk.

27 SOU 2008:61. 33. 0.

28 Förfogandelag (1978:262).

29 Ransoneringslag (1978:268). 
keztében elóállt rendkívüli körülményeket is. ${ }^{30} \mathrm{~A}$ rendkívüli jogalkotási felhatalmazáson túl a kormány - a parlament döntése nyomán - más hatóság hatáskörébe utalhatja a központi alaptörvény szerint egyébként rá tartozó feladatokat. ${ }^{31}$

Külön rendelkezéseket találhatunk a Svéd Királyság megszállása vonatkozásában. Az elfoglalt területekkel kapcsolatban sem a parlament, sem a kormány nem hozhat döntést, ott egyik szerv tagja sem gyakorolhat hatáskörébe és felelőssége alá tartozó feladatokat. Ezeken a területeken minden közhatalmi szerv köteles megtenni mindazt, ami a legjobban szolgálja a védelmet, az ellenállási mozgalmat, a polgári lakosság védelmét, illetve Svédország külpolitikai érdekeit. Azonban semmilyen körülmények között nem folytathat közhatalmi szerv olyan tevékenységet, amely ellentétes a nemzetközi joggal, vagy amely a megszálló erőket szolgálja. ${ }^{32}$

A Kormányzati tv. mellett több más jogszabály is rendelkezik a hadiállapot kezelésének kérdéséről. ${ }^{33}$ Ezek közül kiemelendő az ország háborúra való felkészülését szabályozó, a teljes védelemről és készültségről szóló törvény, ${ }^{34}$ amelynek értelmében a polgári és katonai dimenzióval egyaránt rendelkező védelmi tevékenység megerősitése érdekében a kormány dönthet a többfokozatú készültség indokolt szintjének bevezetéséről. Ez háború idején automatikusan a legmagasabb készültséget jelenti, míg háborús veszély esetén a kormány dönthet annak fokozatáról. A készültségről szóló határozat hatálya kiterjedhet kizárólag egyes országrészekre vagy tevékenységekre is..$^{35} \mathrm{~A}$ társadalom rendes múködésének biztosítása, sebezhetőségének csökkentése érdekében a felelős hatóságok teljes védelem megtervezésére ${ }^{36}$ és készültségi intézkedésekre ${ }^{37}$ vonatkozó kötelezettségét rendeletek rögzítik. Ezek értelmében a készültség esetén a szükséges előkészületi tevékenységek elvégzéséért felelős hatóságok - amelyek köre a rendelet mellékletében rögzítésre került - készenléti tervvel kell hogy rendelkezzenek, személyzetüket kötelesek felkészíteni, illetve a készültség során tevékenységüket elsősorban a teljes védelem szempontjából fontos feladatokra kell korlátozniuk..$^{38}$ Emellett az események alakulásáról, a tervezett és megvalósított intézkedésekről folyamatosan tájékoztatniuk kell a kormányt, a fegyveres erők vonatkozásában pedig dokumentációszolgáltatási kötelezettségük van. ${ }^{39}$ Ezenfelül rendeletben rögzítik a hatóságok

30 Kormányzati tv. 15. fejezet 5-6. cikk.

31 Kormányzati tv. 15. fejezet 8 . cikk.

32 Kormányzati tv. 15. fejezet 9. cikk.

33 Említésre érdemes: az óvóhelyekről szóló törvény [Lag (2006:545) om skyddsrum], valamint a katonai mozgósításról szóló törvény [Lag (1994:1809) om totalförsvarsplikt] is.

34 Lag (1992:1403) om totalförsvar och höjd beredskap (a továbbiakban: Védelmi tv.).

35 Védelmi tv. 1-4. \$.

36 Förordning (2015:1053) om totalförsvar och höjd beredskap (a továbbiakban:Védelmi r.).

37 Förordning (2015:1052) om krisberedskap och bevakningsansvariga myndigheters åtgärder vid höjd beredskap (a továbbiakban: Válság r.).

38 Válság r. 15-17. \$; Védelmi r. 4-6.\$.

39 Válság r. 18. \$; Védelmi r. 7-8. \$. 
kötelező együttmúködési területeit, ${ }^{40}$ a készültségrỏl szóló döntések kihirdetésének, ${ }^{41}$ valamint a fegyveres erók hadra hívásának szabályait ${ }^{42}$ is. A készültség során az önkormányzatok és régiók is kötelesek a mûveletek összehangolására és a rendelkezésre álló erőforrások felhasználásának biztosítására szolgáló rendkívüli intézkedéseket hozni, ${ }^{43}$ ezzel kapcsolatos feladataikat az önkormányzatok és régiók békeidőben bekövetkező rendkívüli eseményekkel kapcsolatos intézkedéseirôl szóló törvényben ${ }^{44}$ és annak rendeletében ${ }^{45}$ találjuk meg. A települések és régiók kötelesek megtenni a készültségi tevékenységekhez szükséges előkészítő intézkedéseket. Erről és a rendkívüli események alakulásáról folyamatosan tájékoztatniuk kell a megyei igazgatóságot és a hatáskörrel rendelkező kormányzati szervet. ${ }^{46} \mathrm{~A}$ készültség során a regionális igazgatóság felel a polgári védelem és az egészségügyi ellátás irányításáért, az olyan helyi szintû válságkezelési tevékenységek, mint például a szükséges áruk biztosítására irányuló intézkedések, illetve az árszabályozás az önkormányzat hatáskörébe tartoznak. ${ }^{47} \mathrm{~A}$ készültség megszüntetéséről - amennyiben az elrendelésére okot adó körülmények már nem állnak fenn - a kormány dönthet. ${ }^{48}$

Rendelet rögzíti azon törvények körét is, amelyek a készültség keretében háborús helyzetben automatikusan hatályba lépnek. ${ }^{49}$ Így háború vagy háborús veszély során - a fentiekben említett két felhatalmazási törvény mellett - alkalmazandóvá válik többek között a háborús körülmények közötti fizetési rendszerről, ${ }^{50}$ a hajók átruházásának tilalmáról,,$^{51}$ a vízenergia háborúban történő felhasználásáról,,$^{52}$ a háborús határơrizetről,,$^{53}$ a háborús kereskedelemről, ${ }^{54}$ a rendkívüli munkajogi szabályokról, ${ }^{55}$ a kötelező foglalkoztatásról, ${ }^{56} \mathrm{va}-$ lamint az árszabályozásról ${ }^{57}$ szóló törvény is. Megállapítható ez alapján, hogy a svéd jogrend az alkotmányos felkészültség elvének megfelelően - számos jogszabályt tartalmaz a háború és a háborús veszély kezelésére, azonban a Kormányzati tv. lehetőséget biztosít az ezektől

40 Válság r. 7. \$.

41 Védelmi r. 9-10. \$.

42 Védelmi r. 11. \$.

43 Védelmi tv. 7. \$.

44 Lag (2006:544) om kommuners och regioners åtgärder inför och vid extraordinära händelser i fredstid och höjd beredskap (a továbbiakban: Rendkívüli események tv.).

45 Förordning (2006:637) om kommuners och regioners åtgärder inför och vid extraordinära händelser i fredstid och höjd beredskap (a továbbiakban: Rendkívüli események r.).

46 Rendkívüli események tv. 3. fejezet 1. és 5. \$; Rendkívüli események r. 4. és 6-7. \$.

47 Rendkívüli események tv. 3. fejezet 3. \$.

48 Védelmi tv. 5. $\$$.

49 Védelmi r. 13. \$.

50 Lag (1957:684) om betalningsväsendet under krigsförhållanden.

51 Lag (1939:299) om förbud i vissa fall mot överlåtelse eller upplåtelse av fartyg m.m.

52 Lag (1962:627) om utnyttjande av vattenkraft vid krig.

53 Lag (1979:1088) om gränsövervakningen i krig m.m.

54 Krigshandelslag (1964:19).

55 Arbetsrättslig beredskapslag (1987:1262).

56 Lag (1994:2077) om arbetsförmedlingstvång.

57 Prisregleringslag (1989:978). 
való eltérésre. Ugyanakkor az alkotmányos szabályozás különleges jogrend idején is törekszik arra, hogy a kormány által gyakorolható rendeleti kormányzásra csak végső esetben kerüljön sor. Említésre érdemes, hogy míg a háborús helyzet kihirdetése és kezelése során a parlament és a kormány egyaránt fontos szerepet játszik, az államfő - szemben több más európai állam, így például Magyarország szabályozásával - nem rendelkezik különleges jogrendi hatáskörökkel. Igaz, a svéd király hatásköre rendes körülmények között is leginkább reprezentatív funkciókra korlátozódik. ${ }^{58}$

\subsection{Békeidejü kivételes szituációk}

Ismételten érdemes megjegyezni, hogy alkotmányos szinten egyedül a háború vonatkozásában beszélhetünk különleges jogrendi rendelkezésekről, a más típusú, békeidőben jelentkező válságokkal szemben nincs átfogó szabályozási keretrendszer. Ilyenkor - az alkotmányos készültség korábbiakban kifejtett elvének szellemében - az egyes rendes jogszabályok szakaszai szolgálnak a kivételes állapot kezelésének alapjául, azt azonban számos olyan elv is befolyásolja, amely nincsen expressis verbis jogszabályi szinten rögzítve. Ezek között említhetô a felelősségi elv, illetve a szubszidiaritás elve. Előbbi értelmében az egyes hatóságok kötelesek azon tevékenységeiket ellátni krízishelyzetben, amelyekért rendes körülmények között is felelősek. Utóbbi alapján pedig a társadalmi élet különböző zavarait ott kell kezelni, ahol bekövetkeztek, és azoknak, akiket érint. ${ }^{59}$

Ugyan a hadiállapotról szóló fejezete nem alkalmazható, azonban így is tartalmaz a Kormányzati tv. olyan rendelkezéseket, amelyek egy estleges - háborúhoz nem köthető - krízishelyzet elhárítása esetén is biztosítják a minél gyorsabb és hatékonyabb eljárás lehetôségét. Ezek elsősorban a parlament müködésének folyamatosságára és a kormány jogalkotási tevékenységére vonatkoznak. Előbbit biztosítják a parlament megválasztására és megalakulására vonatkozó szakaszok, illetve annak lehetősége, hogy ülésének biztonsága és szabadsága érdekében Stockholmtól eltérő helyre hívják össze a parlamentet. ${ }^{\circ}{ }^{\circ}$ Utóbbi kapcsán pedig rögzíti a Kormányzati tv., hogy a kormány egyrészt rendelkezik saját jogalkotó hatáskörrel, másrészt törvényi felhatalmazásra meghatározott ügyek vonatkozásában rendeletet bocsáthat ki, amelyet a parlament döntése alapján felülvizsgálat céljából köteles neki benyújtani. A felhatalmazással együtt a kormány megkaphatja a lehetőséget arra is, hogy az adott kérdésben a szabályok kiadásának jogát közigazgatási hatóságra vagy helyi önkormányzatra ruházza át. ${ }^{61}$

E helyütt érdemes megemlíteni a svéd közigazgatási modell - a koronavírus-járvány kapcsán is elötérbe kerülő - sajátosságát, miszerint a központi közigazgatás szervezetrend-

58 Ortwein, 2003, 408-410. o.

59 Ericson-Wilske, 2020, 1089-1090. o.

60 Kormányzati tv. 3. fejezet 10-11. cikk; 4. fejezet 1. cikk.

61 Kormányzati tv. 8. fejezet 3-8., 10. cikk. 
szerére nagyfokú decentralizáció jellemző, és a minisztériumok tevékenysége a szakpolitikák kidolgozásában merül ki, a közigazgatási feladatok jelentős részét pedig kormányzati ügynökségek látják el. ${ }^{62}$ Ezek ugyan a minisztériumoknak vagy a parlamentnek alárendelten múködnek, ám nagyfokú önállósággal bírnak, a központi kormányzat irányítási jogköre kizárólag abban nyilvánul meg, hogy meghatározza múködésük céljait, elveit, kinevezi a vezetőket, ellenőrzi az elért eredményeket, de egyedi ügyek elintézésére már nem utasíthatja azokat. ${ }^{63} \mathrm{~A}$ kormány tehát irányít, vezet, befolyásol és szabályoz, azonban szoros értelemben vett közigazgatási hatáskört nem gyakorol. ${ }^{64}$ Így a kormánynak kivételes állapot idején sincs joga a kormányzati ügynökségek irányítására, szerepe az általános intézkedésekre és a koordinálásra terjed ki, és így az ügynökségek végzik az operatív tevékenységet. ${ }^{65}$ A válságkezelési tevékenységek összehangolása, az egyes kormányhivatalok és kormányzati ügynökségek közötti információcsere biztosítása érdekében hozták létre az évente legalább két alkalommal ülésező Válságkezelő Testületet (Kansliet för krishantering), amelynek elnöke a belügyminiszter, tagjai pedig az országos rendőrfőkapitány, a Svéd Nemzetbiztonsági Szolgálat (Säkerhetspolisen) vezetője, a svéd fegyveres erők (Affärsverket svenska kraftnät) föparancsnoka, valamint a Svéd Polgári Készenléti Ügynökség, az Országos Egészségügyi és Népjóléti Testület, a Posta- és Távközlési Ügynökség és a Svéd Sugárbiztonsági Ügynökség képviselői.

Fontos kérdés, hogy - szemben a háborúéval - a békeidejú kivételes helyzet, illetve válság fogalma egyértelmúen körülhatárolható-e. A jogirodalomban és a jogalkotási munka során is vita alakult ki ennek meghatározásáról, amely során azt a normálistól eltérő, váratlanul bekövetkező, alapvetô és kiemelt fontosságú értékeket fenyegető, gyors és központosított reakciót igényló szituációként írták körül. ${ }^{66}$ Jogszabályi szinten ez a - fentiekben már említett - Rendkívüli események tv.-ben jelenik meg, amely rögzíti, hogy rendkívülinek a rendestől eltérô, társadalmi funkciók súlyos zavarával vagy annak kockázatával járó, sürgős intézkedést igénylő esemény számít. ${ }^{67} \mathrm{Az}$ önkormányzatok - amelyek vonatkozásában szintén tetten érhető a jelentős decentralizáció ${ }^{8}$ - és a régiók kötelesek az esetlegesen bekövetkező ilyen eseményekre és azok hatására vonatkozó elemző tevékenységet folytatni, felkészítő oktatást biztosítani és a különböző önkormányzati szervek együttmúködését előmozdítani, tervezési és felkészülési munkálataikat összehangolni. ${ }^{69}$ Emellett a településeken és a régiókban válságkezelő testületet (Krisledningsnämnd) kell felállítani a rendkívüli események kezelésére. A testület hivatalba lépésének lehetőségéről annak elnöke dönt. Sürgős esetekben,

62 Berkes, 2018, 57. o.

63 Denti, 2007.

64 Tamás, 2011, 561. o.; Kormányzati tv. 12. fejezet 2. cikk.

65 Jonsson Cornell-Salminen, 2018, 226-227. o.

66 SOU 2008:61. 62-64. o.

67 Rendkívüli események tv. 1. fejezet 4. \$.

68 Kormányzati tv. 14. fejezet 2. cikk.

69 Rendkívüli események tv. 2. fejezet 1. \$, 7-8. \$. 
amikor a testületi döntés jelentős késedelemmel járna, az elnök jogosult a testület nevében - annak mihamarabbi értesítésével - eljárni. Amennyiben a válságkezelő testület szükségesnek ítéli, az önkormányzat vagy a régió más testületeinek tevékenységét - a rendkívüli esemény jellegére és mértékére tekintettel - részben vagy egészben saját hatáskörébe vonhatja. Abban az esetben, ha a rendkívüli esemény már nem áll fenn, az önkormányzat, illetve a régió megszüntetheti a válságkezelő testület tevékenységét. ${ }^{70} \mathrm{~A}$ kormányzati hatóságok rendkívüli események vonatkozásában fennálló kötelezettségeit is rendelet rögzíti, mellékletben felsorolva azokat, amelyek kiemelt felelősséggel tartoznak, ennek keretében pedig - többek között - együttmúködnek a megyei igazgatóságokkal, más állami hatóságokkal, a régiókkal és az önkormányzatokkal, értékelik a nemzetközi kooperáció lehetőségét, valamint mérlegelik a kutatási és fejlesztési tevékenységek szükségességét. ${ }^{71} \mathrm{Az}$ ügynökségek saját maguk és a társadalom rendkívüli eseményekre való felkészítése érdekében folyamatosan vizsgálják, hogy saját hatáskörükön belül van-e olyan kockázat, amely müködésüket rendkívüli események idején veszélyeztetheti. Ennek során kiemelt figyelmet fordítanak a váratlanul felmerülő, a komoly fenyegetést jelentő, illetve sürgős döntéseket és együttmúködést igénylő helyzetekre, valamint a legszükségesebb társadalmi funkciók fenntarthatóságának kérdésére. ${ }^{72}$ Hasonlóan a régiókhoz és önkormányzatokhoz, tájékoztatási kötelezettségük van a kormány irányában az események alakulása, a rendelkezésre álló erőforrások, továbbá a tervezett és megvalósított intézkedések vonatkozásában. ${ }^{73}$

A békeidejû kivételes szituációk kapcsán relevanciával bír az elektromos készenléti törvény ${ }^{74}$ és a polgári védelmi törvény ${ }^{75}$ is. Előbbi a villamosenergia-ágazat rendkívüli eseményeihez kapcsolódó készenléti és válságkezelési intézkedéseket, utóbbi pedig az emberi élet és egészség biztosítására, valamint a vagyon és környezet védelmére irányuló rendelkezéseket rögzíti. ${ }^{76} \mathrm{~A}$ polgári védelmi törvény az önkormányzatok és az állam kötelezettsége mellett az egyének felelősségét is szabályozza, rögzítve azt, hogy aki emberek életét veszélyeztető, illetve az egészségre vagy a környezetre kockázatot jelentő eseményről tudomást szerez, lehetősége szerint köteles az érintett személyt vagy személyeket figyelmeztetni és szükség esetén segítséget hívni. ${ }^{77}$ Azon létesítmények tulajdonosa pedig, ahol az emberekre vagy a környezetre nézve súlyos károkat okozó balesetek veszélyével járó tevékenységet folytatnak, köteles egyfajta válsághelyzeti készültségről gondoskodni. ${ }^{78} \mathrm{Az}$ egyének ez irányú kötelezettségének betartásához az önkormányzat tanácsadás és tájékoztatás útján köteles

70 Rendkívüli események tv. 2. fejezet 2-6. \$.

71 Válság r. 10. \$.

72 Válság r. 8. \$.

73 Válság r. 13. \$.

74 Elberedskapslag (1997:288) (a továbbiakban: Elektromos készenléti tv.).

75 Lag (2003:778) om skydd mot olyckor (a továbbiakban: Pvtv.).

76 Elektromos készenléti tv. 1-4. \$; Pvtv. 1. fejezet 1. \$.

77 Pvtv. 2. fejezet 1. \$.

78 Pvtv. 2. fejezet 4. $\$$. 
segítséget nyújtani. Emellett az önkormányzat maga is köteles megelőző intézkedéseket hozni, amelyek vonatkozásában cselekvési programmal kell rendelkeznie. Abban fel kell tüntetni a megelőző tevékenység célját, az esetleges kockázatokat és az intézkedések szervezésének leírását. ${ }^{79} \mathrm{~A}$ válsághelyzet kezelését követően az önkormányzat köteles biztosítani az esemény okai, lefolyása és a végrehajtott múvelet észszerű tisztázása érdekében annak kivizsgálását. ${ }^{80} \mathrm{Az}$ önkormányzat rendkívüli helyzetek kezelésére irányuló feladatait annak egy vagy több bizottsága is elláthatja, de lehetőség van arra is, hogy azokat részben vagy egészben másik önkormányzat lássa el. ${ }^{81} \mathrm{~A}$ törvény az állam hegyi, légi, tengeri és környezetvédelmi, valamint radioaktív anyagok kibocsátásakor eljáró mentőszolgálat felállításával kapcsolatos kötelezettségéról rendelkezik, ${ }^{82}$ valamint rögzíti, hogy a kormány a polgári védelmi szempontok figyelembevételével további szabályokat adhat ki az élet, az egészség és a környezet védelmére vonatkozóan. A polgári védelem és a rendkívüli események kezelése kapcsán ki kell emelni a Svéd Polgári Készenléti Ügynökséget mint a társadalom válsághelyzetekre való felkészüléséért felelős kormányzati ügynökséget. Ennek feladata, hogy mindenfajta kivételes helyzet során ellássa a szektorokon átnyúló és kormányzati szintú koordinációs, a megelőzéssel és a felkészüléssel kapcsolatos feladatokat, valamint a válsághelyzet kezelésére megfelelő intézkedéseket hozzon. Ezen túlmenően különös figyelmet fordít a tájékoztatásra és a figyelemfelhívásra, ennek részeként tréningeket, továbbképzéseket is szervez köztestületeknek, szervezeteknek és magánszemélyeknek, valamint programot indítottak annak bemutatására, hogy a lakosság milyen, a mindennapjaikat érintő háborús vagy válsághelyzetben találhatja magát. Az erre való felkészülés támogatása érdekében pedig - a program keretében - minden háztartásba eljuttattak egy Ha krízis vagy háború jön ${ }^{83}$ címú kiadványt.

Annak ellenére, hogy a svéd szabályozás és a jogirodalom hangsúlyozza a rendes jogrend szerinti eljárást háborúhoz nem köthetô rendkívüli körülmények esetén, és - sok más állammal szemben - nem biztosítja ilyenkor különleges jogrendi szabályok útján a végrehajtó hatalom rendeleti kormányzásának lehetőségét, ${ }^{84}$ mégis kialakult egyfajta - a kormány és miniszterei intézkedéseit érintő - szükségállapoti gyakorlat. Az alkotmányos keretektől eltérő kivételes eljárás az 1970-es években bekövetkező három terrorcselekmény nyomán alakult

79 Pvtv. 3. fejezet 1-3. \$.

80 Pvtv. 3. fejezet 10. $\$$.

81 Pvtv. 3. fejezet 11-12. \$.

82 Pvtv. 4. fejezet.

83 Om krisen eller kriget kommer. Elérhető: www.dinsakerhet.se/siteassets/dinsakerhet.se/broschyren-omkrisen-eller-kriget-kommer/om-krisen-eller-kriget-kommer_a5_uppslag_msbi186.pdf (Letöltve: 2020. november 30.).

84 Jonsson Cornell-Salminen, 2018, 233-234. o. 
ki. ${ }^{85}$ Mindhárom esetben tehát az alkotmányos keretek betartását mellőzve, megfelelő jogi alap nélkül járt el a kormány, ám az Alkotmányjogi Bizottság - amely jogosult megvizsgálni, hogy a kormány és a miniszterek miként kezelik a kormányzati ügyeket, a meghozott döntések összhangban vannak-e az alkotmánnyal ${ }^{86}$ - felülvizsgálata során mindhárom esetben megállapította a szükséghelyzet fennállását, így igazoltnak látta a kormány fellépését. Az Alkotmányjogi Bizottság a Bulltofta-dráma kapcsán jelentésében úgy fogalmazott, hogy bár szigorúan véve a kormány egyértelmúen nem tartotta be az alkotmányos szabályrendszert, ám tekintettel a fenyegető helyzetre és az idő rövidségére, a kormány a szükségállapoti helyzetet helyesen mérte fel, így nem emelt kifogást az intézkedésekkel szemben. A Norrmalmstorg-ügy felülvizsgálata során - ahol a kormány eljárása mellett a rendőri vezetés is értékelésre került - az Alkotmányjogi Bizottság a Bulltofta-drámára visszautalva állapította meg a szükséghelyzetet. ${ }^{87}$ Az Alkotmányjogi Bizottság mindkét eset kapcsán és a Kormányzati tv. előkészítése során is javaslatot tett a kormány rendkívüli helyzetben való fellépésére vonatkozó különleges jogrendi szabályok alkotmányos szintű rögzítésére. Ennek fényében különösen érdekes, hogy máig nem került sor szükségállapoti kategória létrehozására. Ez leginkább azzal magyarázható, hogy míg háború idején egyértelmû, békeidejû́ szükségállapot során problémás a rendes, törvényeken alapuló jogrendtől való eltérés igazolhatósága. ${ }^{88}$

Mindezek alapján a szükségállapoti kategória jellegének meghatározása igen problémás, hiszen jogszabályi szinten nincs rögzítve, ugyanakkor létezése elfogadott. Nem egyértelmú, hogy alkotmányos elvnek minősül-e, vagy csak eseti kivételnek kell tekinteni. Ha alkotmányos elvként fogadjuk el, komoly problémákat vet fel például a kormányzati ügynökségek függetlensége és az eljáró tisztviselők büntetőjogi felelőssége kapcsán. ${ }^{89}$ Aggályos az is, hogy az eljárás során ugyanaz a hatóság - a kormány - határozza meg formalizált eljárás nélkül a szükségállapot fennállását, majd ő maga gyakorol kivételes hatalmat, mindezt pedig csak utólag (és inkább politikai jelleggel) vizsgálják felül. Illetve már az Alkotmányjogi Bizottság errôl szóló, kvázi precedenst teremtő döntései is régiek. ${ }^{\circ}$ És bár az elmúlt években - egészen

85 Az első, 1972-es Bulltofta-dráma során három jugoszláv állampolgárságú férfi eltérített egy belföldi repülőgépjáratot, az utasok életeért cserébe váltságdijat, illetve hét horvát nemzetiségú, Svédországban fogva tartott személy szabadon bocsátását követelték. A kormány a követeléseknek eleget téve Bulltoftába szállította, majd elengedte a megjelölt személyeket, illetve kifizette a kért váltságdíjat. Az 1973 augusztusában bekövetkezett Norrmalmstorg-ügyben a kormány újfent túllépte hatáskörét, amikor egy fegyveres rablás során túszokat ejtő terrorista követelésére odaszállították és beengedték a bankhelyiségbe a korábban elítélt Clark Olofssont. A harmadik eset pedig a Vörös Hadsereg Frakció hat tagjához köthető, akik 1975 áprilisában elfoglalták a stockholmi nyugatnémet nagykövetséget, ennek során megöltek két túszt, és felrobbantották a nagykövetség épületének egy részét. A terroristákat elfogták és kiutasították, ám egyikük - sebesülései miatt - kórházi kezelésre szorult, és csak ezt követően utasította ki ôt a kormány, amelyre a hatályos jogszabályok szerint az nem volt jogosult.

86 Kormányzati tv. 13. fejezet 1-2. cikk.

87 Jonsson Cornell-Salminen, 2018, 229-230. o.; Hirschfeldt, 2020, 1152-1153. o.; Ericson-Wilske, 2020, 1088. o.; SOU 2008:61. 81-83. o.

88 Hirschfeldt, 2020, 1152-1153. o.

89 Jonsson Cornell-Salminen, 2018, 231-233. o.

90 Jonsson Cornell-Salminen, 2018, 234-235. o. 
a koronavírus-járvány megjelenéséig - nem következett be komoly, alkotmányjogi relevanciával bíró békeidejû́ kivételes állapot, a különleges jogrendi szabályozás kibővitése újra és újra felmerül. Legutóbb 2008-ban tettek javaslatot a Kormányzati tv. háborús fejezetének kibővitésére, amellyel annak címe Háború, háborús veszély és veszélyhelyzetre (Krig, krigsfara och nödsituationer) módosult volna. A javaslat rögzítette volna, hogy olyan veszélyhelyzetek kezelése érdekében, amelyek az emberi életet, a környezetet, illetve a vagyont károsítják vagy veszélyeztetik, a kormány rendeletet bocsáthat ki. Amennyiben a késedelem komoly károkat okozna, olyan tárgyköröket is rendeleti úton szabályozhat, amelyek egyébként törvényi szintre tartoznak. A rendeleti kormányzásnak azonban komoly korlátait határozta meg a javaslat. Egyrészt az nem érintheti az alaptörvényeket, valamint a parlamentről szóló és a parlamenti választásokról szóló törvényeket sem, másrészt a rendeleteket a lehető leghamarabb a parlament elé kell terjeszteni, ugyanis azok tizenkét nappal kihirdetésüket követően hatályukat vesztik, így a rendelkezések továbbéléséről törvényben való megerősítésükkel a parlament dönthet..$^{91} \mathrm{~A}$ kormányt békeidőben rendeleti kormányzási hatáskörrel felruházó javaslatot végül azonban a komoly parlamenti kontrollfunkció ellenére sem fogadták el.

A békeidőben bekövetkező kivételes szituációk svédországi kezelése kapcsán tehát egyrészt az alkotmányos felkészültség elve, másrészt pedig a törvényileg nem szabályozott szükségállapot gyakorlata irányadó. Előbbi kapcsán leginkább a jogszabályi széttagoltság, illetve töredezettség, valamint az problematikus, hogy a parlamentnek nincs jelentős szerepe, a jogszabályok nem biztosítanak számára kiterjesztett felügyeleti jogkört. ${ }^{92}$ Utóbbi vonatkozásában pedig az állapítható meg, hogy - szabályozás hiányában - kizárólag stabil parlamenti bizalom és politikai konszenzus idején múködőképes. ${ }^{93}$

\section{Az alapjogok korlátozására vonatkozó szabályok különleges jogrend idején}

A sajátos szerkezetú svéd alkotmány két alaptörvénye, a sajtószabadságról szóló, illetve a véleménynyilvánítás szabadságáról szóló törvény értelemszerúen a címben megjelölt, illetve az azokhoz kapcsolódó alapjogokról rendelkezik, kitérve azok korlátozásának lehetőségére. Mindkettő rögzíti, hogy az abban foglalt jogosultságok kizárólag az alaptörvény rendelkezései alapján korlátozhatók. ${ }^{94} \mathrm{~A}$ sajtószabadságról szóló törvény meghatározza a sajtószabadság határait, így például lehetővé teszi bizonyos reklámok tilalmát, valamint az olyan személyes adatok, mint az etnikai hovatartozás, politikai vélemény, nemi identitás

91 SOU 2008:125. 1. rész 510. és 521. o.; Hirschfeldt, 2020, 1153-1155. o.

92 Cameron-Jonsson Cornell, 2020, 1178. o.; Jonsson Cornell, 2020, 380-381. o.

93 Jonsson Cornell-Salminen, 2018, 228-231. o.

94 Sajtószab. tv. 1. fejezet 7. \$; Vélemény. tv. 10. \$. 
vagy egészségi állapot közzétételét tiltó jogszabályok elfogadását.95 Az információszabadság részét képező nyilvános dokumentumokhoz való hozzáférés kizárólag törvény által és csak abban az esetben korlátozható, ha azt az állam biztonsága vagy nemzetközi kapcsolatai, a központi költségvetési politika, a monetáris politika vagy más közgazdasági érdek, a hatóságok felügyeleti tevékenysége, bứncselekmények megelőzése vagy felderítése, az egyének személyes vagy pénzügyi körülményeinek védelme, illetve az állat- és növényfajok megőrzése azt megköveteli. ${ }^{96} \mathrm{~A}$ véleménynyilvánítás szabadságáról szóló törvény azonban az egyes alapjogok korlátozása kapcsán a Kormányzati tv.-re utal. A Kormányzati tv. ugyanis 1974-es hatálybalépése óta önálló fejezetben szabályozza az alapvető jogok és szabadságok tárgykörét. A fejezet - az érintett alapjogoknál utalva a két másik alaptörvényre - rögzíti a véleménynyilvánításhoz való jog különböző megnyilvánulásait, a testi integritáshoz való jogot, a mozgásszabadságot, a jogbiztonságot, a diszkrimináció tilalmát, a szakszervezeti jogot, a tulajdonhoz való jogot, a szerzői jogot, a vállalkozás szabadságát, illetve az oktatáshoz és kutatáshoz való jogot.

A fejezet utolsó alfejezete az alapvető jogok és szabadságok korlátozásának lehetőségéről szól. Az alfejezet első szakasza rögzíti, hogy melyek azok a jogok és szabadságok, amelyeket ez egyáltalán érinthet. Ez alapján - kizárólag törvényi úton - korlátozható a véleménynyilvánítási, mozgás-, gyülekezési, egyesülési és információs szabadság, a testi integritáshoz, illetve a nyilvános bírósági eljáráshoz való jog. ${ }^{97} \mathrm{Az}$ alapjogok korlátozásának célja és kiterjedése vonatkozásában a Kormányzati tv. általános keretszabályként rögzíti, hogy arra csak egy demokratikus társadalomban elfogadható okból, a cél eléréséhez szükséges mértékben, azzal arányosan - a vélemény kialakításának szabadságát mint a demokrácia egyik alapintézményét nem veszélyeztetve - kerülhet sor. Nincs helye korlátozásnak pusztán politikai, vallási, kulturális vagy más hasonló okból..$^{8}$ Egyes alapvető jogok vonatkozásában konkrétan megjelöli azokat az értékeket, amelyek érvényre juttatása a szabadságok szúkítésének alapjául szolgálhat. İgy a véleménynyilvánítási és az információs szabadság a Svéd Királyság biztonsága, a nemzeti árukínálat, a közrend és közbiztonság, a magánszemély sérthetetlensége, a magánélet szentsége és a bưnüldözés eredményessége, valamint egyéb különösen fontos okból korlátozható. A véleménynyilvánítási szabadság vonatkozásában a kereskedelmi tevékenységet is megjelöli az alaptörvény. Fontos garanciális rendelkezés, hogy a korlátozások bevezetése során is különös figyelmet kell fordítani a véleménynyilvánítási és az információs szabadság politikai, vallási, szakmai, tudományos és kulturális ügyekben való lehető legszélesebb körủ érvényesülésére.99 A gyülekezési jog és a tüntetés szabadsága a közrend fenntartása, a lakosság gyülekezés vagy tüntetés alatti biztonsága, a királyság biztonsága,

95 Sajtószab.tv. 1. fejezet 11-14. \$.

96 Sajtószab.tv. 2. fejezet 1. \$.

97 Kormányzati tv. 2. fejezet 20. cikk.

98 Kormányzati tv. 2. fejezet 21. cikk.

99 Kormányzati tv. 2. fejezet 23. cikk. 
illetve a közlekedés érdekében, valamint járványveszély esetén, az egyesülési szabadság pedig kizárólag a lakosság valamely fajú, bőrszínú vagy etnikai származású csoportjára fenyegetést jelentő katonai vagy félkatonai jellegû szervezet vonatkozásában korlátozható. ${ }^{100}$

A Kormányzati tv. második fejezete átfogóan rögzíti az alapvető jogok és szabadságok, illetve azok korlátozásának kérdéskörét. Utóbbi kapcsán felmerülő kritika, hogy arra széles körben, minősített többséget sem igénylő törvények által nyílik lehetőség. ${ }^{101}$ Szúk keretek között ugyan, de a parlamenti képviselőknek lehetőségük van az alapjogok korlátozásának megakadályozására. Az alaptörvény rendelkezése értelmében tíz képviselő kérelmére az elkészített törvénytervezet, törvénymódosítási vagy hatályon kívül helyezési javaslat tárgyalását annak beterjesztésétől számított tizenkét hónapra el kell halasztani. Ilyenkor a parlament a kérdéses javaslatot a leadott szavazatok öthatodos többségével fogadhatja el. Nincs meg ez a lehetőségük a képviselőknek a törvények időbeli hatályát két évnél nem hosszabb időre meghosszabbító, valamint meghatározott tárgyköröket szabályozó javaslatok esetében. Utóbbiak körébe tartozik a közszolgálat vagy hivatalos feladat teljesítése során megismert, illetve a sajtószabadságról szóló törvény alapján titkosnak minősülő ügyek nyilvánosságra hozatalának tilalma, a házkutatás és ahhoz hasonló intézmények, valamint a büntetőjogi szabadságmegvonás. A halasztási eljárás alkalmazhatóságát az egyes javaslatok vonatkozásában a parlament nevében az Alkotmányjogi Bizottság vizsgálja. ${ }^{102}$

A Kormányzati tv. alapjogi fejezete nem tartalmaz különleges jogrend idején alkalmazandó, alapvető jogok korlátozására vonatkozó rendelkezéseket, és az alaptörvény hadiállapotról szóló része is csak egyetlen idevágó szakaszt tartalmaz. Ennek értelmében a korlátozó javaslatok tárgyalásának fentiekben kifejtett elhalasztására nincs lehetőség háború, illetve háborús veszély idején. ${ }^{103}$ Így az alapvető jogok korlátozása kapcsán a rendes jogszabályok (a Kormányzati tv. második fejezete) alkalmazandók kivételes körülmények során is. Kivételt képeznek ezalól a közrendről szóló törvény ${ }^{104}$ egyes rendelkezései. Az ugyanis kimondja, hogy abban az esetben, ha Svédország háborúban áll vagy háborús veszély fenyegeti, illetve ha az egy járvány megelőzése, valamint leküzdése érdekében szükséges, a kormány rendeletével megtilthatja nyilvános összejövetelek és rendezvények megtartását, illetve a járványhelyzet kezelése során felhatalmazást adhat a megyei igazgatóságoknak a gyülekezési jog korlátozása kapcsán. ${ }^{105} \mathrm{Az}$ ezen tilalom ellenére megtartott nyilvános összejöveteleket és rendezvényeket feloszlathatják, a szervezésben részt vevő személyeket pedig akár szabadságvesztéssel is sújthatják. ${ }^{106}$

100 Kormányzati tv. 2. fejezet 24. cikk.

101 Nergelius, 2019, 331. o.

102 Kormányzati tv. 2. fejezet 22. cikk.

103 Kormányzati tv. 15. fejezet 7. cikk.

104 Ordningslag (1993: 1617) (a továbbiakban: Közrendi tv.).

105 Közrendi tv. 15. \$.

106 Közrendi tv. 22. és 29. \$. 
Említésre érdemes továbbá, hogy a polgári védelemről szóló törvény is tartalmaz jogkorlátozó rendelkezéseket, elsősorban a tulajdonjog sérelme vonatkozásában. A polgári védelmi tevékenység során ugyanis - ha az az emberi élet, az egészség, a környezet, illetve a vagyon megóvása érdekében szükséges - a mentési tevékenység vezetője beavatkozhat mások tulajdonjogi viszonyaiba, kiüríthet területeket, felhasználhat vagy akár meg is semmisíthet ingatlanokat, azonban minden, mások jogát korlátozó döntéséről annak indokát megjelölve köteles írásban jelentést tenni. ${ }^{107}$

\section{A koronavírus-járvány svédországi kezelése}

Az egészségügyi válsághelyzetek kezelése kapcsán - a korábbiakban bemutatott törvények és rendeletek mellett - releváns jogszabály a betegségek terjedésének megakadályozására szolgáló intézkedéseket rögzítô, a fertőzések elleni védekezésról szóló törvény (a továbbiakban: Járványügyi tv. ${ }^{108}$ és az annak egyes részletszabályait tartalmazó rendelet. ${ }^{109}$ A törvény a fertőző betegségeken belül - amely kifejezés valamennyi, az emberi egészségre veszélyt jelentő, emberek között terjedő betegséget felölel - megkülönböztet általános és társadalomra veszélyes betegségeket. Előbbi kategóriába olyan fertőző betegségek tartoznak, amelyek hosszas megbetegedéssel, súlyos tünetekkel vagy akár életveszéllyel, illetve más komoly következményekkel járnak, és terjedésük a fertőzött személyekre irányuló intézkedések révén megakadályozható. Utóbbi kategóriába pedig azok a társadalmi funkciók súlyos zavarával vagy annak közvetlen kockázatával járó általános veszélyes betegségek tartoznak, amelyek rendkívüli intézkedéseket igényelnek. Az e két fogalom alá tartozó betegségeket a Járványügyi tv. mellékletében sorolja fel. ${ }^{110} \mathrm{~A}$ járványügyi tevékenység nemzeti szintű koordinációjáért a közegészségügyi kérdésekkel foglalkozó, a lakosság egészségügyi fenyegetésektől való megóvásáért munkálkodó kormányzati hatóság, a Közegészségügyi Ügynökség (Folkhälsomyndigheten) tartozik felelősséggel. ${ }^{111} \mathrm{~A}$ törvény rendelkezéseiből nem következő intézkedések biztosítása a régiók hatáskörébe tartozik. ${ }^{112} \mathrm{~A}$ Járványügyi tv. az esetek kivizsgálásáról szóló fejezetében rögzít bizonyos, a fertőzések elleni védekezést szolgáló rendkívüli intézkedéseket. Ennek értelmében ha egy Svédországba érkező személyről okkal feltételezhető, hogy a társadalomra veszélyes betegséggel fertőződött meg, a regionális szinten kinevezett járványügyi orvos ${ }^{113}$ döntésére ôt és a vele együtt utazókat ellenőrzésnek kell alávetni. Ugyancsak a járványügyi orvos a társadalomra veszélyes betegség elterjedésének

107 Pvtv. 6. fejezet 2. és 6. \$.

108 Smittskyddslag (2004:168) (a továbbiakban: Járványügyi tv.).

109 Smittskyddsförordning (2004:255).

110 Járványügyi tv. 1. fejezet 3.\$.

111 Járványügyi tv. 1. fejezet 7. $\$$.

112 Járványügyi tv. 1. fejezet 8. \$.

113 Járványügyi tv. 1. fejezet 9. \$. 
veszélye esetén az annak kitett személyt - meghatározott épület elhagyásának tilalmával járó - karanténba helyezheti. Abban az esetben viszont, ha a társadalomra veszélyes betegség egy meghatározott földrajzi területhez kapcsolódik, ott terjedt el, a szükséges intézkedéseket - az országba beérkező személyek egészségügyi ellenőrzését, a fertőzéssel érintett terület lezárását - a Közegészségügyi Ügynökség hozza meg. ${ }^{114} \mathrm{Az}$ általános veszélyes betegségek terjedése megelőzése érdekében - meghatározott tevékenységeket érintő - egyedi magatartási szabályokról dönthet a kezelőorvos. ${ }^{115} \mathrm{~A}$ járványhelyzetek kezelése kapcsán a Járványügyi tv. bizonyos kivételes jellegú hatáskörökkel ruházza fel a kormányt. Ez alapján - amennyiben a parlament nem dönt a Járványügyi tv. mellékleteinek módosításáról - a kormány dönthet az általános és a társadalomra veszélyes betegségekre vonatkozó rendelkezések alkalmazásáról, az erről szóló rendeletet azonban mihamarabb be kell nyújtani felülvizsgálatra a parlamentnek. A törvényben nem rögzített, a járványok elleni védekezéshez szükséges kiegészítő szabályok kibocsátására szintén a kormány - vagy az általa kijelölt hatóság - jogosult. Emellett a Járványügyi tv.-nek megfelelő különleges szabályokat hozhat a fertőzések elleni védekezésről háború, háborús veszély, az ezek következtében eloállt rendkívüli körülmények, valamint a fertőzések ellenőrzésének fenntartását megnehezítő, nemzeti szintú intézkedéseket igénylő békeidejû́ válságok esetén. ${ }^{116}$

A koronavírus-járvány okozta egészségügyi válsághelyzet svédországi kezelését alapjaiban határozták, illetve határozzák meg a Kormányzati tv. egyes rendelkezései, illetve azok hiánya. Utóbbi kapcsán szükséges visszautalnunk arra, hogy a Svéd Királyság vonatkozásában nem beszélhetünk alkotmányos szinten rögzített békeidejú különleges jogrendi szabályozásról, így - ellentétben több más európai állammal - Svédországban rendes jogrendi keretek között zajlik a járványhelyzet elleni küzdelem. ${ }^{117} \mathrm{~A}$ svéd fellépés sajátossága a Kormányzati tv. mozgásszabadságról és a közigazgatási hatóságok függetlenségéről szóló szakaszaiból fakad. Előbbi alapvető jog ugyan törvényben korlátozható, és helyi szinten vagy egyes személyeket érintő módon egészségügyi okból is szúkíthető, ám nincs jogszabályi alapja a szabad mozgáshoz való jog járványhelyzet által indokolt, nemzeti szintû korlátozásának. ${ }^{118} \mathrm{~A}$ közigazgatási hatóságok kormányzattól való - nemzetközi összevetésben egyedülállóo ${ }^{119}$ - függetlensége ${ }^{120}$ ugyancsak megköti a kormány kezét, ${ }^{121}$ az alapján ugyanis a koronavírus-járvány kezelését elsősorban a Közegészségügyi Ügynökség - jogilag kötelező erővel nem bíró - ajánlásai határozzák meg. A járványügyi szakemberek által meghozott - többek között a megfelelő távolság és a higiéniai előírások megtartására, az otthoni munkavég-

114 Járványügyi tv. 3. fejezet 8-10. \$.

115 Járványügyi tv. 4. fejezet 2 . $\$$.

116 Járványügyi tv. 9. fejezet 2-6. \$.

117 Venice Commission, 2020, IV.B.14.

118 Jonung, 2020, 2-3. o.

119 Nergelius, 2018, 300. o.

120 Hirschfeldt, 2020, 1163-1168. o.

121 Mikko, 2020, 7-8. o. 
zésre, a szükségesnek nem minősülő utazások elhalasztására, valamint a magukon a koronavírus tüneteit felfedező, illetve idős személyek otthonmaradására irányulón ${ }^{122}$ - rendelkezésekhez ugyan formálisan nincs kötve a kormány, ám a történeti hagyományok az ajánlások követését kívánják meg. ${ }^{123}$ Központi szinten a Közegészségügyi Ügynökség mellett a Svéd Polgári Készenléti Ügynökség és az Országos Egészségügyi és Népjóléti Testület munkáját kell megemlíteni. ${ }^{124}$ Előbbi a polgári védelmi tevékenységek koordinálásáért, utóbbi pedig - a hatáskörét rögzítő rendelet ${ }^{125}$ értelmében - az egészségügyi és szociális szolgáltatások tudományos és tapasztalaton alapuló elvégzéseeért, a válságra való felkészülést segítő tájékoztatásért, valamint a megfelelő szakértelem válsághelyzet idején való rendelkezésre állásáért ${ }^{126}$ felelős a koronavírus-járvány kezelése során is. A Közegészségügyi Ügynökség tevékenységét rögzítő jogszabály alapján ${ }^{127}$ - az állásfoglalások kibocsátásán túl - az ügynökség koordinálja és ellenőrzi az orvosi ellátásra való felkészültség megtervezését, figyelemmel kíséri és elemzi a fertőző betegségek kialakulását és a védekezés során tapasztaltakat, illetve tájékoztatást nyújt a Külügyminisztérium számára az utazási ajánlásokkal kapcsolatos döntések meghozatalához. ${ }^{128}$ Továbbá említésre érdemes, hogy a kormányzati szereplők közötti, a válságkezeléssel kapcsolatos információáramlás biztosítása érdekében a belügyminiszter - már a járványhelyzet korai szakaszában - összehívta a Válságkezelő Testület rendkívüli ülését.

A Közegészségügyi Ügynökség ajánlásai mellett jogszabályi szintú intézkedésekről is beszélhetünk, amelyek alapját elsősorban a Járványügyi tv. és a Közrendi tv. szolgáltatta. ${ }^{129}$ Elsőként a február 1-jén hatályba lépő, a Járványügyi tv. általános és társadalomra veszélyes betegségekre vonatkozó szabályainak koronavírus-járványra való alkalmazhatóságát kimondó rendeletet ${ }^{130}$ kell megemlíteni, amely alapján egyrészt a megbetegedett személyekkel szemben - a járvány megfékezése érdekében - bizonyos kényszerintézkedések alkalmazhatók, illetve a kormány felhatalmazást kapott a koronavírus elleni küzdelemhez szükséges kiegészító és különleges szabályok kiadására. ${ }^{131}$ Ennek megfelelően több, alapvető jogot is korlátozó rendeletet fogadott el a kormány. Kiemelendő ezek közül a nyilvános összejövetelek és rendezvények tilalmáról szóló, 2020. március 12-én hatályba lépő rendelet, ${ }^{132}$ amely ötszáz fő́ben maximalizálta a nyilvános összejöveteleken és rendezvényeken részt vevő

122 Bentzen, N. et al., 2020, 10. o.

123 Jonung, 2020, 5. o.

124 Ericson-Wilske, 2020, 1093.0.

125 Förordning (2015:284) med instruktion för Socialstyrelsen (a továbbiakban: OENT r.).

126 OENT r. 4 . \$1. pont; 8-9. \$.

127 Förordning (2013:1020) med instruktion för Folkhälsomyndigheten (a továbbiakban: KEÜ r.).

128 KEÜ r. $1-3$. $\$$.

129 Ludvigsson, 2020, 2464. 0.

130 Förordning (2020:20) om att bestämmelserna i smittskyddslagen (2004:168) om allmänfarliga och samhälls-

farliga sjukdomar ska tillämpas på infektion med 2019-nCoV.

131 Ericson-Wilske, 2020, 1080-1081. o.

132 Förordning (2020:114) om förbud mot att hålla allmänna sammankomster och offentliga tillställningar. 
személyek számát. A rendelet későbbi módosításainak köszönhetően ez a szám - meghatározott kivételekkel ${ }^{133}$ - ötven, ${ }^{134}$ majd pedig nyolc ${ }^{135}$ főre csökkent, illetve a megyei igazgatóság felhatalmazhatja az önkormányzatokat és a megyei közigazgatási testületeket, hogy helyi szintú jogszabályokat bocsássanak ki. Szemben a mozgásszabadsággal, a gyülekezési jog járványhelyzet idején való korlátozása alkotmányos és törvényi szinten egyaránt biztosított, köszönhetően a Kormányzati tv. és a Közrendi tv. - korábban bemutatott - rendelkezéseinek. A kormány az oktatási törvény ${ }^{136}$ felhatalmazása ${ }^{137}$ alapján rendeleti úton ${ }^{138}$ teremtette meg az iskolák járványhelyzet-kezelése érdekében történő bezárásának feltételeit, előkészítve - az egyes oktatási tevékenységek felfüggesztését lehetővé tévő - az iskolai tevékenységek békeidejű rendkívüli körülmények során történő ideiglenes megszüntetéséről szóló törvény ${ }^{139}$ elfogadását. A konkrét rendelkezések értelmében az iskolák a tizenhat éves kor alatti gyerekek esetében nyitva maradtak, az idősebb diákok és egyetemisták vonatkozásában pedig online térben folytatódott az oktatás. ${ }^{140}$ A szociális szolgáltatásokról szóló törvény ${ }^{141}$ rendelkezése ${ }^{142}$ nyomán rendeletével ${ }^{143}$ tiltotta meg a kormány az idősotthonok látogatását. Meghozott intézkedéseivel - közzétett stratégiája ${ }^{144}$ értelmében - a kormány célja a koronavírus terjedési ütemének csökkentése, az emberek életének, egészségének és munkahelyének védelme, valamint a társadalomra és az egészségügyre nehezedő nyomás enyhítése.

Az addigi felhatalmazást elégtelennek találva, a kormány gyorsabb és erőteljesebb fellépésének biztosítása érdekében ideiglenes hatállyal módosították a Járványügyi tv.-t. ${ }^{145}$ A három új szakasz elfogadásával egyidejúleg megszavazott különálló törvény ${ }^{146}$ rögzítette, hogy a módosítás 2020. július 1-jén hatályát veszti. Az új rendelkezések kiterjesztették

133 A hatályos szabályozás értelmében a temetéseken részt vevők száma legfeljebb húsz fő lehet, illetve lehetőség van maximum háromszáz személy részvételével zajló nyilvános összejövetelek és rendezvények megtartására, ha a résztvevők között legalább egyméteres távolság végig biztosított.

134 Förordning (2020:162) om ändring i förordningen (2020:114) om förbud mot att hålla allmänna sammankomster och offentliga tillställningar.

135 Förordning (2020:1000) om ändring i förordningen (2020:114) om förbud mot att hålla allmänna sammankomster och offentliga tillställningar.

136 Skollag (2010:800) (a továbbiakban: Oktatási tv.).

137 Oktatási tv. 29. fejezet 29. \$.

138 Förordning (2020:115) om utbildning på skolområdet och annan pedagogisk verksamhet vid spridning av viss smitta.

139 Lag (2020:148) om tillfällig stängning av verksamheter på skolområdet vid extraordinära händelser i fredstid 140 Ludvigsson, 2020, 2465-2467. o.

141 Socialtjänstlag (2001:453) (a továbbiakban: Szoc. tv.).

142 Szoc. tv. 16. fejezet 10. \$.

143 Förordning (2020:163) om tillfälligt förbud mot besök i särskilda boendeformer för äldre för att förhindra spridningen av sjukdomen Covid-19.

144 A svéd kormány koronavírus-járvány kezelésére irányuló stratégiája elérhető: www.regeringen.se/ regeringens-politik/regeringens-arbete-med-coronapandemin/strategi-med-anledning-av-det-nyacoronaviruset/ (Letöltve: 2020. december 15.).

145 Lag (2020:241) om ändring i smittskyddslagen (2004:168).

146 Lag (2020:242) om ändring i smittskyddslagen (2004:168). 
a kormány jogalkotó hatáskörét, rögzítve, hogy ha az a koronavírus-járvány kezelése érdekében szükséges és a parlament nem dönt, a kormány rendeletet alkothat az egyének kötelezettségei, illetve az egyének és a közösség viszonya vonatkozásában. Így ideiglenes intézkedéseket hozhat különösen a gyülekezés, illetve a gyógyszerek és különböző orvosi eszközök kereskedelmének korlátozásáról, a bevásárlóközpontok, szórakozó- és vendéglátóhelyek bezárásáról, valamint egyes jelentős infrastruktúrák múködésének leállításáról. ${ }^{147}$ Emellett rendeleteket bocsáthat ki a gyógyszerek és orvosi eszközök önkormányzatok és régiók közötti kereskedelmének és újraelosztásának összehangolása érdekében. ${ }^{148} \mathrm{~A}$ kormány tehát rendkívüli rendeletalkotási hatáskört kapott, amellyel együtt számos garanciális szabályt is törvénybe foglalt. A már említett ideiglenes hatály mellett rögzítették, hogy a kibocsátott rendeleteket haladéktalanul be kell nyújtani felülvizsgálatra a parlamenthez, amely azt törvénnyel módosíthatja vagy hatályon kívül helyezheti. ${ }^{149} \mathrm{~A}$ parlamenti kontrollfunkció gyakorlását segíti a frakcióvezetőknek a parlament múködésének folytonosságát biztosító döntése, amelynek értelmében - a haditanács intézményére emlékeztető módon - 2020 végéig a parlamenti döntéshozatalban csak 55 képviselő vesz részt. ${ }^{150} \mathrm{~A}$ kormány felhatalmazásának korlátját jelenti az is, hogy a rendeletek nem szúkíthetik azokat az alapvető jogokat és szabadságokat, amelyek a Kormányzati tv. alapján kizárólag törvényi szinten korlátozhatók. ${ }^{151} \mathrm{~A}$ kormány kivételes felhatalmazását rögzítő szakaszok hatályon kívül helyezésével egyidejûleg - a Járványügyi tv. újabb módosításával - a koronavírust felvették az általános és társadalomra veszélyes betegségek közé. ${ }^{152}$

Azzal, hogy a járványhelyzet az ajánlások és a meghozott intézkedések hatására sem mérséklődött, a svéd járványkezelésre is a szigorúbb rendelkezések, illetve a törvényi szintú szabályok váltak jellemzővé. Előbbire a gyülekezési jog egyre jelentősebb korlátozása, utóbbira pedig a vendéglátóhelyeket érintő járványügyi intézkedésekről szóló törvény ${ }^{153}$ szolgál például. E törvény értelmében a vendéglátóhelyek kötelesek müködésüket a koronavírus elleni védekezés jegyében átalakítani, az ezzel kapcsolatos előírások és tilalmak betartását pedig az önkormányzatok környezet- és egészségvédelmi bizottsága ellenőrzi. Decemberi módosítása ${ }^{154}$ következtében az eredetileg 2020. év végéig hatályos törvény egészen 2021 májusáig érvényben marad. Ugyancsak a szigorítások részeként értékelhető az alkoholtermékek forgalmazását este tíz és délelőtt tizenegy óra között megtiltó rendelet ${ }^{155}$ elfogadása.

147 Járványügyi tv. 6a. \$ (1) bekezdés.

148 Járványügyi tv. 6b. \$.

149 Járványügyi tv. 6c. \$.

150 Cameron-Jonsson Cornell, 2020, 1178. o.; Ericson-Wilske, 2020, 1094. o.

151 Jonsson Cornell, 2020, 379. o.

152 Lag (2020:430) om ändring i smittskyddslagen (2004:168).

153 Lag (2020:526) om tillfälliga smittskyddsåtgärder på serveringsställen.

154 Lag (2020:1192) om dels fortsatt giltighet av lagen (2020:526) om tillfälliga smittskyddsåtgärder på serveringsställen, dels ändring i samma lag.

155 Förordning (2020:956) om tillfälligt förbud mot servering av alkohol. 


\section{A különleges jogrend bevezetésével és a járványhelyzet kezelésével kapcsolatos tapasztalatok, jogviták}

A Svéd Királyságban az 1974-es kormányzatról szóló törvény hatálybalépése óta nem került sor sem háború, sem háborús veszély kihirdetésére, így sem a Haditanács, sem pedig a kormány nem gyakorolta még különleges jogrendi jogosultságait. A kormány központi alaptörvényben nem rögzített, alkotmányos kereteken túllépő szükségállapoti gyakorlat keretében történő kivételes hatalomgyakorlása azonban nem példa nélküli. A három - fentiekben bemutatott - precedens jellegú esemény mellett említésre érdemes az 1981-ben zátonyra futott U-137-es - atomfegyverekkel felszerelt - szovjet tengeralattjáró ügye, amelynek kezelését miniszterek egy csoportjára bízták, biztosítva ezzel az eset gyors és következetes megoldását. ${ }^{156}$

A közelmúlt jelentős, közjogi vitát is kiváltó válsághelyzeteként meg kell említeni a 2004 decemberében az Indiai-óceánon bekövetkezett szökőárt, amely ugyan területileg nem érintette Svédországot, de több mint ötszáz svéd állampolgár életét követelte, és ezreket kellett evakuálni. A kormány válságintézkedéseit komoly kritikával illették, leginkább annak késedelmes megindítása és az információáramlás elégtelensége vonatkozásában. A természeti katasztrófa kormányzati kezelésének értékelése céljából 2005 januárjában a kormány független bizottság felállításáról döntött. Utóbbi jelentése ${ }^{157}$ rámutatott, hogy az ehhez hasonló esetekben a kormánynak fel kell ismernie a kialakult helyzetből fakadó fenyegetéseket, a megfelelő intézkedéseket és a jogalkotás szükségességét, valamint gondoskodnia kell a válságkezelés finanszírozásáról és a kielégítő tájékoztatásról, illetve kapcsolatban kell állnia más államokkal az intézkedések összehangolása és a konfliktusok elkerülése érdekében. A bizottság jelentése a szervezeti struktúrát és a hatáskörmegosztást is kifogásolta a válságkezelési szabályozás kapcsán, hozzájárulva ezzel a Válságkezelési Hivatal - eredetileg Miniszterelnöki Hivatalon belüli - létrehozásához. ${ }^{158}$ E természeti katasztrófán kívül Svédország kapcsán nemigen találunk közjogi szempontból releváns válsághelyzetet.

A koronavírus-járvány kapcsán egyelőre nem beszélhetünk jelentős jogesetekről, ami annak fényében nem meglepő, hogy a Svéd Királyság válságkezelése - ellentétben sok más európai országgal - szabályozás helyett ajánlásokra és információkra támaszkodott. ${ }^{159}$ A svéd válságpolitikát elsősorban a korlátozó intézkedések - relatív - hiánya és a koronavírus-járvány következtében elhunytak magas száma miatt érte - jogilag talán kevésbé releváns - kritika. Azonban megemlíthetók az alapjogok korlátozása, a kormány kivételes rendeletalkotása, a korlátozásokat tartalmazó jogszabályok és ajánlások kihirdetése, valamint

156 SOU 2008:61. 83-84. 0.

157 Sverige och tsunamin - granskning och förslag. Expertrapporter från 2005 års katastrofkommission, Stockholm, 2005. Elérhető: www.regeringen.se/49bb3a/contentassets/8627d9339e414175bocef6b33eea2a64/ sverige-och-tsunamin---granskning-och-forslag-expertrapporter (Letöltve: 2020. december 15.).

158 SOU 2008:61. 77-78., 93. o.

159 Hirschfeldt, 2020, 1168-1169. o. 
a kormányzati ügynökségek függetlensége vonatkozásában felmerült problematikus és vitás kérdések.

Az alapvető jogok és szabadságok kormány általi korlátozására a központi alaptörvény rendkívül szúk lehetőséget ad, és mivel annak rendelkezései a koronavírus-járvány kezelése során is irányadók, nem beszélhetünk az alapjogok korlátozása kapcsán olyan vitáról, amely számos más államban tapasztalható. A kormány rendeletei - egyre szigorúbb szabályokat előírva - leginkább a gyülekezési jogot érintették. Ezek alkotmányos és törvényi megalapozottsága azonban nem képezi vita tárgyát, egyedül annak tartalmát érte kritika. A nyilvános események és összejövetelek korlátozása bár összhangban áll a hatályos jogi szabályozással, azonban járványügyi szempontból problematikusnak tekinthető, hogy a különböző kulturális és sporteseményekkel szemben a rendeleti korlátozás sem a tömegközlekedést, sem pedig a bevásárlóközpontokat nem érinti. Emiatt pedig felmerül a Közrendi tv. felülvizsgálata szükségességének kérdése. ${ }^{160}$

A kormány rendeletalkotási jogköre annak ideiglenes jellege, a parlament erős kontrollfunkciója, valamint a kizárólag törvényben korlátozható alapvető jogok érinthetetlensége miatt nem szolgált közjogi viták alapjául, azonban az ennek alapjául szolgáló, a Járványügyi tv. módosításáról szóló törvény elfogadása aggályokat vetett fel. A Törvényalkotási Tanács (Lagrådet) - amely a legfelsőbb bíróság és a legfelsőbb közigazgatási bíróság bíróiból, illetve volt bíróiból álló, a törvényalkotás során véleményező szerepet betöltő testület ${ }^{161}$ - sérelmezte a törvény nem megfelelő előkészítését, és az ennek során elvégzendő konzultációs tevékenység elmulasztását. A Kormányzati tv. nem tartalmaz részletes szabályokat a törvények elfogadása kapcsán, kizárólag ajánlások rendelkeznek az elókészítő munkához szükséges időtartamról, rögzítve, hogy föszabály szerint a konzultációs eljárás nem lehet három hónapnál rövidebb, ám sürgős esetekben kivételt lehet tenni. A Járványügyi tv. módosítása során a kormány a törvényjavaslatot csak korlátozott számú konzultációs testülethez juttatta el, mindössze 24 órás válaszidőt biztosítva számukra. A Törvényalkotási Tanács a rövid határidő mellett a nem megfelelő számú szervvel való egyeztetést is kifogásolta. ${ }^{162}$

Köszönhetően annak, hogy a koronavírus-járvány kezelése érdekében hozott rendeletek sokszor a kihirdetésük ${ }^{163}$ napján léptek hatályba, ám az sokszor késedelmes volt, a jogszabályok megismerhetőségének vitatottsága jogbiztonsági kérdéseket vetett fel. Hasonló probléma merült fel a Közegészségügyi Ügynökség nyomtatott és online formában is közzétett ajánlásai kapcsán is. Az ügynökség weboldalán közzétett ajánlásoknál több esetben hiányzott ugyanis a nyomtatásban való megjelenés dátuma, számos elốrásnál pedig a hatálybalépés utáni időpontot jelöltek meg. Az ehhez hasonló zavarok vezettek oda, hogy egy,

160 Ericson-Wilske, 2020, 1081-1082. o.

161 A Törvényalkotási Tanács szabályait önálló törvény rögzíti: Lag (2003:333) om Lagrådet.

162 Dibb, 2020, 535., 539-540. o.; Jonsson Cornell, 2020, 378-379. o.

163 A jogszabályok és egyéb rendelkezések kihirdetéséről szóló törvény [Lag (1976:633) om kungörande av lagar och andra författningar] értelmében a jogszabályok és egyéb rendelkezések kihirdetésére négy felület áll rendelkezésre, ám főszabályként azokat a Svéd Jogszabálygyưjiteményben (Svensk författningssamling) kell kihirdetni. 
a vendéglátóhelyeken való tartózkodást előíró ajánlást egyes éttermek annak érvényessége elôtt alkalmaztak, amelynek köszönhetően komoly anyagi kár érte őket. ${ }^{164}$

A járványhelyzet hatására megmutatkoztak a svéd közigazgatási modell árnyoldalai is. A kormányzati ügynökségek nagyfokú függetlenségének komoly történelmi előzménye és hagyománya van Svédországban, amely abban is megmutatkozik, hogy bár megvan hozzá a joga, a kormány nem utasítja el a Közegészségügyi Ügynökség ajánlásait. Felmerült ugyanakkor a politikai felelősség kérdése, amelyet ugyan elvileg a kormány visel, ám a gyakorlatban kevéssé valósul meg. ${ }^{165} \mathrm{~A}$ koronavírus-járvány okozta válsághelyzet kapcsán újra felmerült a békeidejû́ rendkívüli szituációk kezelésének alkotmányos szintû szabályozása. ${ }^{166}$

A kritikákra tekintettel a kormány a koronavírus-járvány kezelése érdekében hozott rendelkezések értékelésére - 2020. július 1-jével - bizottságot állított fel. Az úgynevezett Koronabizottság (Coronakommissionen) feladata - az erról szóló irányelv ${ }^{167}$ értelmében - a kormány, az érintett közigazgatási hatóságok, a régiók és az önkormányzatok által a vírus terjedésének korlátozása, valamint hatásának enyhítése érdekében bevezetett intézkedések vizsgálata, illetve nemzetközi összehasonlítás elvégzése. Végső jelentését 2022. február 28-ig kell elkészítenie a bizottságnak; ez idő alatt két másik, köztes jelentést köteles tenni: az elsőt 2020. november 30-ig, a másodikat pedig 2021. október 31-ig. Az első részjelentés ${ }^{168}$ közzétételére végül 2020. december 15-én került sor. A bizottság ebben a járványhelyzet alatti idősgondozásról számol be, a koronavírus idősek körében való nagyfokú terjedésének és az ahhoz kapcsolódó magas halálozási aránynak az okát az idősgondozással foglalkozó intézmények felkészületlenségére, rossz felszereltségére, valamint szerkezeti hibákra vezetve vissza, mindezekért a jelenlegi és korábbi kormányokat téve felelőssé. A bizottság szerint az idősek védelmére irányuló stratégia kudarcot vallott, a strukturális felkészültség hiánya pedig elsősorban a széttagolt szervezetrendszernek, a nem megfelelő jogszabályi keretnek, az orvosi eszközökhöz való hozzáférés akadályoztatottságának, az elkésett és sokszor nem megfelelő döntéshozatalnak, valamint a személyi állomány és a megfelelő munkakörülmények hiányának köszönhetô.

164 Dibb, 2020, 541-542. 0.

165 Ludvigsson, 2020, 2464-2465. o.; Ericson-Wilske, 2020, 1094-1096. 0.; Cameron-Jonsson Cornell, 2020, 1181-1182. 0 .

166 Ericson-Wilske, 2020, 1085. o.

167 Kommittédirektiv (2020:74) Utvärdering av åtgärderna för att hantera utbrottet av det virus som orsakar sjukdomen Covid-19. Elérhető: www.regeringen.se/49f46d/contentassets/593c32df14114d9c81eeba9c96e2 6e41/dir2020_74.pdf (Letöltve: 2020. december 15.).

168 Internationella erfarenheter av Covid-19 i äldreboenden. Underlagsrapport till SOU 2020:80 Äldreomsorgen under pandemin, Stockholm 2020. Elérhető: www.regeringen.se/4af363/contentassets/a8e708fff5e84279bf11ad bdof78fcc1/internationella-erfarenheter-av-Covid-19-i-aldreboenden_webb.pdf (Letöltve: 2020. december 15.). 


\section{5. Összegzés}

Az alkotmányos szintú svéd különleges jogrendi szabályozás kimerül a háború és a háborús veszély kategóriáinak rögzítésében. E helyzetekről ugyan külön fejezetben rendelkezik a Kormányzati tv., ám nem rögzíti azok definícióját. Nem határozza meg, hogy mikor, illetve meddig alkalmazhatók a kivételes jellegú szabályok, ebből következően a kormány döntésén múlik a hadiállapot fennállása, egyedül az ország megszállása képez kivételt, ilyenkor automatikusan a háborús szabályok alkalmazandók. A Kormányzati tv. különleges jogrendi fejezete elsősorban hatásköri rendelkezéseket tartalmaz. Figyelemre méltó, hogy háború, illetve a háborús veszély kihirdetésével egyidejüleg összehívják a parlamentet, és nem ruházzák fel kivételes rendeletalkotási hatáskörrel a kormányt, csak a legvégső esetben. Ehhez azonban szükséges az is, hogy a parlamentet egyfajta szúkített képviseleti szervként kivételesen helyettesítő Haditanács ne tudja feladatait ellátni. Alacsonyabb jogszabályi szinten a hadiállapotra való felkészülés szabályait rögzítő különböző törvények és rendeletek emelhetők ki, amelyek meghatározzák a felelős hatóságok, a régiók és az önkormányzatok feladatait. Rendelet sorolja fel azokat a jogszabályokat is, amelyek háború idején automatikusan alkalmazandók. Elmondható tehát, hogy bár háború és háborús veszély során lehetőség van a különleges jogrendi jogalkotásra, a svéd jogrend jogszabályai széles körben tartalmaznak ilyenkor alkalmazható normákat. Ez hatványozottan igaz a békeidejú kivételes szituációk kapcsán. Ezen utóbbiak vonatkozásában ugyanis nem találunk alkotmányos szintú különleges jogrendi helyzetet, azonban számos törvény és rendelet foglalkozik a rendestől eltérô, társadalmi funkciók súlyos zavarával vagy annak kockázatával járó, sürgős intézkedést igénylő események kezelésével. A svéd megközelités értelmében valamennyi, nem háborúhoz köthető válsághelyzet megoldása rendes jogrend szerint kell hogy történjen. Ennek köszönhető, hogy jogszabályok széles köre tartalmaz rendkívüli események idején alkalmazandó rendelkezéseket, ami a válságkezelési szabályozás széttagoltságához vezet. Inkább tekinthetố különleges jogrendi helyzetnek a sem alkotmányos, sem törvényi szinten nem rendezett szükségállapoti kategória, amely az 1970-es években egymás után rövid időn belül bekövetkezett három terrorcselekmény és annak kezelése hatására kialakult gyakorlat. Ennek során a kormány kivételes hatalomgyakorlására van lehetőség, amely - a jogszabály hiánya mellett - azért rendkívül problematikus, mert egyedül a kormány határozza meg a szükséghelyzet fennállását, majd gyakorol rendkívüli hatásköröket. Mindezt pedig csak utólag értékeli az Alkotmányjogi Bizottság. Bár a szükségállapoti gyakorlat alkotmányjogi helyzete nem egyértelmú, és az azt megalapozó jelentések is régiek, létezését tényként fogadja el a svéd alkotmányjog-tudomány.

A svéd mellé állítva megállapítható, hogy a magyarországi különleges jogrendi szabályozás jelentősen kiterjedtebb és átfogóbb. A legkézenfekvőbb különbség, hogy Magyarország Alaptörvénye a békeidejú szituációkra is kitérve hat - illetve az Alaptörvény kilencedik módosítása ${ }^{169}$

169 Magyarország Alaptörvényének kilencedik módosításáról szóló T/13647. számú törvényjavaslat. (A módosításról szóló törvényt a kézirat lezárásáig nem hirdették ki a Magyar Közlönyben.). 
értelmében 2023 júliusától három - különleges jogrendi szituációt nevesít, valamennyi vonatkozásában megadva az elrendelésük alapjául szolgáló feltételeket. A svéd háború és háborús veszély kategóriákkal a hatályos Alaptörvény rendkívüli állapoti, megelőző védelmi helyzeti és váratlan támadási kategóriái állíthatók párhuzamba. Utóbbi kettő esetében a Kormányt ruházzák fel rendkívüli hatáskörökkel, míg a svéd háború és háborús veszély idején csak végső esetben kerülhet sor a kormány rendeleti kormányzására. Különbséget jelent, hogy a két magyar szituációt behatárolt idôtartamra lehet kihirdetni, a svéd hadiállapot határideje kapcsán azonban nem találunk rendelkezést. A rendkívüli állapot a tekintetben mutat hasonlóságot, hogy annak elrendelésével szintén egy testületi szervet ruháznak fel rendeletalkotási jogkörrel, azonban a magyar Honvédelmi Tanács a svéd Haditanácsnál szúkebb körú, nem a parlament kvázi szúkebb ülését biztosító szerv. Különbséget jelent az is, hogy ellentétben a svéd királlyal, a magyar államfó jelentős hatáskörrel rendelkezik. Az Alaptörvény módosítása következtében a háborús szituációhoz kapcsolódó különleges jogrendi helyzetek egyetlen kategóriában öltenek testet. A hadiállapot elrendelésének alapjaként explicit módon megjelenik a háború és a háborús veszély fogalma az Alaptörvényben is, ugyanakkor a Honvédelmi Tanács megszüntetésével a Kormány lesz jogosult rendeletet alkotni.

Az alapvető jogok korlátozását a svéd Kormányzai tv. és Magyarország Alaptörvénye hasonlóan szabályozza. Mindkettő rögzíti a korlátozás lehetőségének alapvető feltételeit, kitérve annak elfogadható okára és mértékére, ezen túlmenően pedig további követelményeket támaszt az egyes alapjogok vonatkozásában. A Kormányzati tv. alapjogi fejezete azonban gyakorlatilag változatlanul érvényes háború és háborús szituáció esetén is, míg az Alaptörvény rögzíti a különleges jogrend esetén kivételesen korlátozható alapvető jogok körét. A svéd szabályozásban egyedül a gyülekezési jog képez kivételt, annak háborús szituációban való korlátozására a Közrendi tv. alapján kerülhet sor.

A koronavírus-járvány okozta válsághelyzet svédországi és magyarországi kezelése annak fényében jelentős eltérést mutat, hogy míg hazánkban veszélyhelyzetet rendeltek el, a Svéd Királyságban nem került sor különleges jogrendi helyzet kihirdetésére, azaz a rendes jogrendi szabályok érvényesülnek. A svéd válságkezelést alapvetően a Közegészségügyi Ügynökség ajánlásai határozzák meg, azonban törvényi felhatalmazás alapján ideiglenes jelleggel a svéd kormány is kivételes rendeletalkotási jogkört gyakorolhatott. Ezt azonban jelentősen szúkítette az erős parlamenti kontrollfunkció, valamint az alapvető jogok korlátozásának tilalma. Komoly különbséget jelent, hogy a svéd alkotmányos szabályozás értelmében a mozgásszabadság rendeleti úton való korlátozására nincs lehetőség, így szemben a magyarországi - és több más európai államban is bevezetett - korlátozásokkal, Svédországban nem rendeltek el kijárási tilalmat. Egyedül a gyülekezési jogot érintő szabályozás mutat hasonlóságot, az azt korlátozó rendelkezések mértéke hasonlít - a novemberi szigorítások következtében - leginkább a magyar rendelkezésekhez. 


\begin{tabular}{|c|c|c|c|}
\hline & $\begin{array}{c}\text { Háború és háborús } \\
\text { veszély }\end{array}$ & Rendkívüli események & Szülkségállapot \\
\hline Szabályozás szintje & Alkotmányos & Törvényi & $\begin{array}{l}\text { Nincs jogszabályi } \\
\text { szinten rögzítve }\end{array}$ \\
\hline Alkalmazás alapja & $\begin{array}{l}\text { A kormány } \\
\text { döntése, } \\
\text { megszállás }\end{array}$ & $\begin{array}{l}\text { A rendestől eltéró, tár- } \\
\text { sadalmi funkciók súlyos } \\
\text { zavarával vagy annak koc- } \\
\text { kázatával járó, sürgős intéz- } \\
\text { kedést igényló esemény }\end{array}$ & A kormány döntése \\
\hline Elrendelés & Kormány & \multirow{2}{*}{$\begin{array}{l}\text { Rendes jogrendi jog- } \\
\text { szabályok alkalmazása } \\
\text { (önkormányzatok, régiók, } \\
\text { ügynökségek) }\end{array}$} & \\
\hline Felhatalmazott & $\begin{array}{l}\text { Parlament, Hadi- } \\
\text { tanács, kormány }\end{array}$ & & Kormány \\
\hline Gyakorlati esetek & $\begin{array}{l}\text { Nem hirdették ki } \\
\text { ez idáig. }\end{array}$ & Többször sor került rá. & $\begin{array}{l}\text { Lásd a Békeidejü kivételes } \\
\text { szituációk címú részt. }\end{array}$ \\
\hline
\end{tabular}

21. táblázat

A Svéd Királyság különleges jogrendi szabályainak összegzése

Forrás: a szerzô saját összeállítása

\section{Irodalomjegyzék}

Bentzen, N., Boström, A., Del Monte, M., Odink, I., Prpic, M., Tuominen, M. (2020) States of Emergency in Response to the Coronavirus Crisis: Situation in Certain Member States III. [Online] Elérhető: www.europarl.europa.eu/RegData/etudes/BRIE/2020/651972/EPRS_ BRI(2020)651972_EN.pdf (Letöltve: 2020. december 15.)

BERKES, L. (2018) 'A központi közigazgatás modelljei. Svédország' in Gerencsér, B. Sz. (szerk.) Összehasonlitó és európai uniós közigazgatási jog. 3. kiadás. Budapest: Pázmány Press

Cameron, I., Jonsson Cornell, A. (2020) 'Fredstida kriser i en konstitutionell kontext en komparativ analys och en försiktig framåtblick för Sveriges del', Svensk Juristtidning, 2020/10, 1173-1190. o.

Csink, L. (2017) 'Mikor legyen a jogrend különleges?', Iustum Aequum Salutare, 13(4), 7-16. o.

DENTI, D. (2007) Administrative Law in Sweden and Italy: A Comparison [Online]. Elérhető: www. academia.edu/896258/Administrative_Law_in_Sweden_and_in_Italy_a_comparison (Letöltve: 2020. december 15.)

Dівв, J. (2020) 'Om beredning, kungörelse och ikraftträdande av författningar i kristid', Svensk Juristtidning, 2020/7, 534-545. o.

ERICSON, M., WILSKE, O. (2020) 'Covid-19 i Sverige - rättsliga perspektiv på krisberedskap och de åtgärder som vidtagits för att hantera pandemin', Svensk Juristtidning, 2020/10, 1080-1097. 0. 
Hansson, P., Persson, M. (2020) 'Sweden: COVID-19', European State Aid Law Quarterly, 19(1), 97-98. o.

HiRSCHFELDT, J. (2017) 'Mänskliga rättigheter och andra konstitutionella kärnvärden när krisen slår till' in Lind, A. S., Namli, E. (szerk.) Mänskliga rättigheter i det offentliga Sverige. 1. kiadás. Lund: Studentlitteratur

HiRSCHFELDT, J. (2020) 'Svensk krishantering i fredstid - de konstitutionella aspekterna och en framåtblick', Svensk Juristtidning, 2020/10, 1148-1171. o.

IsBERG, M. (szerk.) (2016) The Constitution of Sweden. The Fundamental Laws and the Riksdag Act. 1. kiadás. Stockholm: Sveriges Riksdag

JoNSSON CORNELL, A. (2020) 'Författningsberedskap i praktiken - en kommentar med anledning av lagen om ändring i smittskyddslagen', Svensk Juristtidning, 2020/5, 377-381. o.

Jonsson CoRnell, A., Salminen, J. (2018) 'Emergency Laws in Comparative Constitutional Law - The Case of Sweden and Finland', German Law Journal, 19(2), 219-250. o.

Jonung, L. (2020) Sweden's Constitution Decides Its Covid-19 Exceptionalism [Online]. Elérhetô: https://project.nek.lu.se/publications/workpap/papers/wp20_11.pdf (Letöltve: 2020. december 1.)

Kiss, B. (1991) 'A svéd alkotmányfejlődés fóbb elemei', Acta Universitatis Szegediensis: Acta Juridica et Politica, 1991/1, 167-179. o.

Ludvigsson, J. F. (2020) 'The First Eight Months of Sweden's COVID-19 Strategy and the Key Actions and Actors that Were Involved', Acta Paediatr, 109(12), 2459-2471. o.

Mikкo, M. (2020) 'COVID-19 Policy in Sweden: Disaster or Object of Admiration?', Diplomaatia, 2020/201, 7-8. o.

Nergelius, J. J. (2013) 'Constitutional Reform in Sweden: Some Important Remarks', Tijdschrift voor Constitutioneel Recht, 2013/4, 372-379. o.

NeRgELiUS, J. J. (2018) Svensk statsrätt. 1. kiadás. Lund: Studentlitteratur

Nergelius, J. J. (2019) 'The Constitution of Sweden and European Influences: The Changing Balance Between Democratic and Judicial Power' in Albi, A., Bardutzky, S. (szerk.) National Constitutions in European and Global Governance: Democracy, Rights, the Rule of Law. Hague: T. M. C. Asser Press

ORTWEIN, B. M. II. (2003) 'The Swedish Legal System: An Introduction', Indiana International \&Comparative Law Review, 13(2), 405-445. o.

TAMÁs, A. (2011) 'Svédország közigazgatása' in Szamel, K., Balázs, I., Gajduschek, Gy., Koi, Gy. (szerk.) Az Európai Unió tagállamainak közigazgatása. 1. kiadás. Budapest: CompLex

Venice Commission (2020) Interim Reporton the Measures Taken in the EU Member States as a Result of the Covid-19 Crisis and Their Impact on Democracy, the Rule of Law and Fundamental Rights (Opinion No. 995/2020) [Online]. Elérhető: www.venice.coe.int/webforms/documents/ default.aspx?pdffile=CDL-AD(2020)018-e (Letöltve: 2020. december 15.) 


\section{A különleges jogrendi esetkörök alkotmányos és törvényi szintū szabályozása Szlovákiában}

\section{SZINEK JÁNOS -SZINEK CSÜTÖRTÖKI HAJNALKA}

\section{A különleges jogrend alkotmányos és törvényi szintủ szabályozása}

Szlovákiában a különleges jogrendre vonatkozó általános szabályok a Szlovák Köztársaság Alkotmányában, ${ }^{1}$ míg a részletszabályok a háború, hadiállapot, rendkívüli állapot és veszélyhelyzet idején az állam biztonságáról szóló alkotmánytörvényben ${ }^{2}$ kerültek rögzítésre. Ez utóbbit akár a Szlovák Köztársaság „válságalkotmányának” is nevezhetnénk, hiszen meghatározó szerepet játszik az állam szuverenitásának védelmében. ${ }^{3}$ Svák az állam bizton-

I Ústavný zákon č. 460/1992 Zb., Ústava Slovenskej republiky (a továbbiakban: alkotmány).

2 Ústavný zákon č. 227/2002 Z. z., o bezpečnosti štátu v čase vojny, vojnového stavu, výnimočného stavu a núdzového stavu v znení neskorších predpisov (a továbbiakban: Állambiztonsági alk.tv.).

3 Škrobák, 2020.

Dr. Szinek János

janos.szinek@mfi.gov.hu

kutató (Mádl Ferenc Összehasonlító Jogi Intézet)

PhD-hallgató (Miskolci Egyetem, Deák Ferenc Állam- és Jogtudományi Doktori Iskola)

Dr. Szinek Csütörtöki Hajnalka

kutató (Mádl Ferenc Összehasonlító Jogi Intézet)

PhD-hallgató (Miskolci Egyetem, Deák Ferenc Állam- és Jogtudományi Doktori Iskola)

Szinek, J., Szinek Csütörtöki H. (2021) 'A különleges jogrendi esetkörök alkotmányos és törvényi szintû szabályozása Szlovákiában' in Nagy, Z., Horváth, A. (szerk.) A különleges jogrend és nemzeti szabályozási modelljei, 530-548. o. Budapest: Mádl Ferenc Összehasonlító Jogi Intézet.

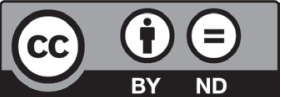


ságáról szóló alkotmánytörvényt az alkotmány háború vagy más rendkívüli helyzet idején alkalmazandó változatának nevezte. ${ }^{4}$

Míg az alkotmány meglehetősen szúkszavúan rendezi a különleges jogrenddel kapcsolatos kérdéskört, ${ }^{5}$ az állam biztonságáról szóló alkotmánytörvény a különleges jogrendi esetkörök taxatív felsorolását adja. Az alkotmánytörvényben egyenként meghatározták a különleges jogrend kihirdetésének feltételeit, a kihirdetés eljárási rendjét, az adott különleges jogrendi esetkör területi és időbeli hatályának, valamint az egyes alapvető jogok korlátozásának lehetőségét és az ezzel kapcsolatos kötelezettségeket. Az alkotmánytörvény továbbá szabályozza az egyes alkotmányos szervek múködésének sajátos rendjét is.

A szlovák jogrend kapcsán fontos kiemelni, hogy az alkotmányos rendszer nemcsak az alkotmányból, hanem az alkotmány mellett több alkotmánytörvényből (más néven: alkotmányos törvények vagy alkotmányerejü törvények) áll. Ezen oknál fogva a szlovák szakirodalom az ország alkotmányát polylegálisnak nevezi. ${ }^{6} \mathrm{Az}$ alkotmányos rend szerves részét alkotják tehát az egyéb alkotmánytörvények is, amelyeket az alkotmányban elöírt, az összes parlamenti képviselő háromötödös többségével (minősített többség) lehet elfogadni, illetve módosítani.7 Az alkotmány és az alkotmánytörvények viszonyának kérdésével a szlovák alkotmánybíróság is foglalkozott. Ennek kapcsán az alkotmánybíróság határozatában kimondta, hogy a jogrend legfelsőbb rétegét az alkotmány képezi; annak elfogadásához, módosításához és eltörléséhez több szavazat szükséges, mint az egyszerú törvények esetében. Formai szempontból a szlovák jogforrási hierarchia nem tesz különbséget az alkotmány és az alkotmánytörvények között. ${ }^{8}$ Az alkotmánytörvények tehát e szempontból kétségkívül ugyanolyan jogerővel bírnak, mint az alkotmány, és kizárólag az alkotmánytörvények képesek azt közvetlenül módosítani, illetve kiegészíteni. ${ }^{9}$

A fentiek alapján tehát megállapítható, hogy Szlovákiában a különleges jogrendre vonatkozó szabályok kizárólag alkotmányos szinten kerültek rögzítésre. A szlovák jogrendben

4 Svák-Cibul'ka-Klíma, 2013, 97. o.

$5 \mathrm{Az}$ alkotmány a különleges jogrend szabályozási követelményeire vonatkozóan mindössze két felhatalmazó rendelkezést tartalmaz. Az 51. cikk (2) bekezdése értelmében „háború, hadiállapot, rendkívüli állapot vagy veszélyhelyzet esetén az alapvető jogok és szabadságok korlátozásának feltételeit és mértékét, valamint a kötelességek mértékét alkotmánytörvény állapítja meg”. A 102. cikk (3) bekezdése pedig kimondja, hogy „a hadüzenetre, hadiállapotra, rendkívüli állapotra, veszélyhelyzetre, valamint a háború, hadiállapot és rendkívüli állapot idején a közhatalom gyakorlására vonatkozó részletszabályokat alkotmányos törvény állapítja meg”.

6 Giba et al., 2019, 76. o.

7 Alkotmány 84. cikk (4) bekezdés.

8 I. ÚS 39/93 sz. határozat.

9 Giba et al., 2019, 75. o. 
azonban megjelennek egyéb, hagyományos értelemben különleges jogrendi esetkörnek nem minősülő esetek is, amelyek viszont törvényi szinten szabályozottak. ${ }^{10}$

Az állam biztonságáról szóló alkotmánytörvénynek megfelelően a különleges jogrend nevesített esetkörei a következők: háború (vojna), hadiállapot (vojnovýstav), rendkívüli állapot (výnimočný stav), veszélyhelyzet (núdzovýstav). ${ }^{11}$

Egyes szlovák szakirodalmi meghatározások alapján a háború olyan állami intézkedések összessége, amelyek révén a szükséges mértékben az állami és önkormányzati szervek, a gazdasági egységek és a társadalmi szervezetek tevékenysége az egész államban irányítható és korlátozható. ${ }^{12} \mathrm{~A}$ háború - mint különleges jogrendi esetkör - kapcsán az Állambiztonsági alk.tv. rögzíti, hogy annak kinyilvánítása a köztársasági elnök hatáskörébe tartozik, aki arról a Szlovák Köztársaság Nemzeti Tanácsa (a továbbiakban: parlament) határozata alapján dönt. A kinyilvánítás feltételeként a szlovák szabályozás két konkrét esetet jelöl meg: ha a Szlovák Köztársaságot idegen hatalom támadja meg hadüzenet kinyilvánításával, vagy ha az idegen hatalom hadüzenet kinyilvánítása nélkül sértette meg annak biztonságát, valamint ha a Szlovák Köztársaság nemzetközi szerződéses kapcsolataiból eredő kötelezettségeket teljesítve kerül háborús konfliktusba másokkal. ${ }^{13} \mathrm{~A}$ jogszabály a háború kapcsán úgy rendelkezik, hogy azt csak és kizárólag az ország teljes területére vonatkozóan lehet kinyilvánítani. Az Állambiztonsági alk.tv. meghatározza a háború időtartamát is: a háború a kinyilvánítás napjától a béke megkötésének napjáig tartó időszak. ${ }^{14} \mathrm{E}$ különleges jogrendi esetkör fennállása esetén a szükséges mértékben és a szükséges időtartamra a Szlovák Köztársaság teljes területén vagy annak egy részén az alapjogok és szabadságok korlátozás alá eshetnek, az események menetétôl függően kötelezettségek szabhatók. A bevezethető kötelezettségek és a korlátozások maximális mértéke taxatív módon felsorolásra kerültek a jogszabályban.

Szlovákiában a hadiállapot kinyilvánítására a köztársasági elnök jogosult, aki a kormány javaslatára cselekedhet. A háborúhoz hasonlóan a hadiállapot kinyilvánításához is teljesülniük kell bizonyos feltételeknek. Az Állambiztonsági alk.tv.-ben ilyen feltételként jelenik meg a hadüzenettel kapcsolatos közvetlen veszély fennállása, illetve ha az országot hadüzenet nélkül idegen hatalom közvetlen támadása fenyegeti. ${ }^{15} \mathrm{~A}$ hadiállapot kinyilvánítá-

10 A különleges jogrendet érintő szlovák szabályozásban szembetűnő érdekességként jelenik meg, hogy az alkotmányos szintủ szabályozás esetében a jogalkotó a stav (állapot) megnevezést alkalmazza, míg a törvényi szintủ szabályozás a különleges jogrendi esetköröknek nem minősülő esetekre a situácia (helyzet) megnevezést használja, ezzel is elősegítve az esetek minősítését követő helyes jogalkalmazást.

11 Bár a núdzový stav kifejezés magyarra fordítva szükségállapotot jelent, de tartalmát tekintve inkább a magyar veszélyhelyzethez áll közelebb, ezért is találkozunk a magyar nyelvú szakirodalmakban a veszélyhelyzet megnevezéssel. Lásd például: Németh, 2016. E kategória a továbbiakban veszélyhelyzet elnevezéssel kerül rögzítésre.

12 Šimák, 2005, 37. o.

13 Állambiztonsági alk.tv. 2. cikk (1) bekezdés.

14 Állambiztonsági alk.tv. 2. cikk (5) bekezdés.

15 Állambiztonsági alk.tv. 3. cikk (1) bekezdés. 
sának tekintetében a köztársasági elnöknek mérlegelési jogköre van, hiszen a kormány javaslatát bármikor jogában áll elutasítani.

A hadiállapot hatálya az egész ország területére kiterjed. ${ }^{16} \mathrm{E}$ különleges jogrendi esetkör kapcsán az Állambiztonsági alk.tv. arról is rendelkezik, hogy szükséges mértékben és a szükséges időtartamra az alapjogok és szabadságok korlátozás alá eshetnek, valamint a Szlovák Köztársaság teljes területén vagy annak egy részén, az események menetétól függően kötelezettségek szabhatók. ${ }^{17} \mathrm{~A}$ bevezethető kötelezettségeket és a korlátozások maximális mértékét taxatív módon az alkotmánytörvény sorolja fel.

Rendkívüli állapotot a köztársasági elnök a kormány javaslata alapján hirdethet ki, de kizárólag abban az esetben, ha terrortámadás vagy utcai zavargások közvetlen veszélye áll fenn, illetve ha ezek az események már bekövetkeztek. Az „utcai zavargások” a jogszabályban megfogalmazottak alapján egy olyan kiterjedt magatartás, amely a közhatalmi szervekkel szemben alkalmazott erőszakos cselekményekkel, üzletek és raktárak kifosztásával vagy egyéb, tulajdonra irányuló erőszakos cselekménnyel vagy más, tömeges erőszakos jogellenes cselekmény elkövetésével párosul, amely súlyosan fenyegeti a közbiztonságot, és amennyiben a rend helyreállítása a hatóságok fellépése révén, illetve más jogi eszközök alkalmazásával hatástalannak bizonyul. ${ }^{18} \mathrm{~A}$ hadiállapothoz hasonlóan a köztársasági elnök a rendkívüli állapot kihirdetésének tekintetében is mérlegelési jogkörrel rendelkezik, hiszen jogosult a kormány javaslatának elvetésére is.

A háborútól és a hadiállapottól eltérően, a rendkívüli állapot esetében a területi hatály tekintetében eltérés figyelhetô meg. Míg az előző kettő különleges jogrendi esetkört az ország egész területére kell elrendelni, addig a rendkívüli állapot esetében területi szempontból a kihirdetés hatálya kizárólag az érintett területre korlátozódik. E különleges jogrendi esetkör időtartama legfeljebb 60 nap lehet. Abban az esetben, amennyiben olyan új körülmények merülnek fel, amelyek közvetlenül kapcsolódnak a rendkívüli állapot kihirdetésének kiváltó okaihoz, a rendkívüli állapot további 30 nappal meghosszabbítható. A kihirdetés és a meghosszabbítás során is érvényesülniük kell a szükségesség és arányosság kritériumainak. ${ }^{19}$

A különleges jogrendi esetkörök negyedik kategóriájaként az Állambiztonsági alk.tv. a veszélyhelyzetet jelöli meg, amelynek kihirdetésére a kormány jogosult. A fentiekben már elemzett három különleges jogrendi esetkörrel ellentétben ebben az esetben nem szükséges a köztársasági elnök vagy a parlament utólagos jóváhagyása. A veszélyhelyzet akkor rendelhetô el, ha emberi életet és egészséget veszélyeztetô esemény következik be - vagy annak a közvetlen veszélye áll fenn -, okozati összefüggésben járványok bekövetkeztével, a természeti vagy más jelentős épített környezeti érték, ingatlan vagyon sérelmével összefüggésben, amelyet természeti szerencsétlenség, katasztrófa, ipari, szállítási vagy egyéb múködési 
baleset idéz elö. ${ }^{20} \mathrm{~A}$ veszélyhelyzet kihirdetésének területi hatálya megegyezik a rendkívüli állapotnál bemutatott területi hatállyal: a veszélyhelyzet kihirdetésének területi hatálya is csak az érintett területre korlátozódik. E különleges jogrendi esetkört a szükséges mértékben és a szükséges időtartamra, de legfeljebb 90 napra lehet kihirdetni.

A rendkívüli állapotot és a veszélyhelyzetet megvizsgálva láthatjuk, hogy a legalapvetőbb különbség a helyzet jellegére vonatkozik, amelyre az adott alkotmányos rezsim reagál - rendkívüli állapot esetén a veszélyt az emberek vagy embercsoportok védett érdekekkel szembeni támadásai jelentik, míg a veszélyhelyzet során az alkotmányos rezsim egy vis maior jellegú veszélyre vagy egy olyan veszélyre reagál, amelyet nem valamely személy vagy személycsoport szándékos jogellenes magatartása okoz. A veszélyhelyzet tehát inkább egy objektív jellegủ biztonsági helyzet veszélyére reagál. A másik jelentős különbség abban áll, hogy míg a rendkívüli állapotot a köztársasági elnök a kormány javaslata alapján hirdetheti ki, veszélyhelyzet esetében a kormány egymaga dönthet, természetesen a fent említett feltételek teljesülése mellett. ${ }^{21} \mathrm{~A}$ rendkívüli állapot és a veszélyhelyzet esetében közös pontként jelenik meg, hogy kihirdetésük jogszerúségéről, illetve az ezzel összefüggő döntések jogszerűségéről az alkotmány értelmében az alkotmánybíróság hivatott dönteni. ${ }^{22}$

A négy különleges jogrendi esetkör vizsgálata után megállapítható, hogy az állam külső szuverenitásának védelmére alapvetôen a háború és hadiállapot esetköreit, ${ }^{23}$ míg az állampolgárok és az állam belső biztonságának védelmére a rendkívüli állapot és a veszélyhelyzet esetköreit rendeli alkalmazni.

Ezen a ponton szükségesnek tartjuk megjegyezni, hogy a szlovák szabályozásban a koronavírus-járvány okozta helyzetre reagálva várhatóan 2020 decemberében az Állambiztonsági alk.tv. módosítására kerül sor, ami jelentős változásokat hoz a különleges jogrendi esetkörök tekintetében. Jelen fejezetben a kézirat lezártáig hatályos szabályozást mutatjuk be.

\subsection{Az alkotmányos szervek bemutatása és a különleges jogrendi tényállásokra vonatkozó közös szabályok}

Ahogy azt már fentebb említettük, az Állambiztonsági alk.tv. részletesen szabályozza az egyes alkotmányos szervek múködésének sajátos rendjét. Ilyen alkotmányos szervnek tekinthető a kormány, a minisztériumok és a központi szervek, a járási hivatalok, az önkormányzatok, valamint a megyei önkormányzatok. Kulcsfontosságú szervként jelenik meg e tekintetben továbbá a Szlovák Köztársaság Parlamenti Tanácsa (a továbbiakban: Parlamenti Tanács) és a Szlovák Köztársaság Biztonsági Tanácsa (a továbbiakban: Biztonsági Tanács) is, amelyek múködését az alábbiakban mutatjuk be röviden.

20 Állambiztonsági alk.tv. 5. cikk (1) bekezdés.

21 Škrobák, 2020.

22 Kelemen, 2020, 219. o. Lásd még: alkotmány 129. cikk (6) bekezdés.

23 Burdová, 2011, 57. 0. 
A szóban forgó jogszabály alapján kerül létrehozásra a Parlamenti Tanács (Parlamentná rada Slovenskej republiky), amely háború, hadiállapot és rendkívüli állapot idején a parlament feladatait hivatott ellátni. Az ellátott feladatok körében azonban meghatározott kivételek is találhatók. ${ }^{24}$ Egy nagyon speciális és kivételes szervról van szó, amely az előbbiekben felsorolt különleges jogrendi esetkörök életbelépése esetén a parlament alkotmányos hatáskörét gyakorolja abban az esetben, ha a parlament tevékenysége valamilyen okból akadályoztatva van. ${ }^{25}$

Szintén az Állambiztonsági alk.tv. alapján jön létre a Biztonsági Tanács (Bezpečnostná rada Slovenskej republiky), amelynek eltérő feladatai vannak különleges jogrend idején és békeidőben. ${ }^{26}$ Háború, hadiállapot és rendkívüli állapot idején a kormány akadályoztatása esetén a Biztonsági Tanács látja el annak feladatait. Az ellátott feladatok körében azonban meghatározott kivételek is találhatók: ilyen például a kormány programjának kialakítása és végrehajtása, a bizalmi szavazás iránti kérelem, valamint a közkegyelem gyakorlása. A Biztonsági Tanács békeidejû́ múködésérôl szóló törvény ${ }^{27}$ részletesen meghatározza a Biztonsági Tanács feladatait, amelyek elsősorban a következôk: a szlovák biztonsági rendszer kialakítása, a nemzetközi biztonsági kötelezettségek teljesítése, valamint a biztonsági helyzet kiértékelésével kapcsolatos javaslatok előkészítése. A Biztonsági Tanács kapcsán kiemelendő, hogy a jogszabály annak struktúráját is meghatározza. Eszerint a Biztonsági Tanács alegységei a kerületi biztonsági tanácsok és a járási biztonsági tanácsok.

Az Állambiztonsági alk.tv. közös rendelkezései szerint a hadüzenetről és a béke megkötéséről, a hadiállapot, a rendkívüli állapot és a veszélyhelyzet kihirdetéséról és megszüntetéséről, valamint az alapvető jogok és szabadságok korlátozásáról és a kötelezettségek kiszabásáról, továbbá a Parlamenti Tanács, a Biztonsági Tanács, a kerületi biztonsági tanácsok és a járási biztonsági tanácsok állásfoglalásáról szóló határozatok haladéktalanul közzétételre kerülnek a szlovák nyomtatott sajtóban, a rádióban és a televízió közvetítésében, illetve kihirdetésre kerülnek a Szlovák Köztársaság Törvénytárában. ${ }^{28}$

Az alkotmánytörvény rendezi a háború, hadiállapot vagy rendkívüli állapot fennállása idején az esedékes választások kérdéskörét, az állammal szembeni kártalanítási jogosultság esetköreit, a különleges jogrendi időszakban a törvényes határidők számításának és az elévülésnek a kérdéseit, továbbá rendelkezik a folyamatban lévő bírósági, közigazgatási és végrehajtási eljárási kérdésekről is. ${ }^{29}$

24 A kivételek taxatív felsorolása kapcsán lásd: Állambiztonsági alk.tv. 7. cikk (2) bekezdés.

25 Giba et al., 2019, 74. o.

26 A Biztonsági Tanács békeidőben a kormány tanácsadó testületeként vesz részt a Szlovák Köztársaság biztonsági rendszerének kialakításában és múködtetésében, teljesíti a nemzetközi biztonsági kötelezettségeket, felméri a belföldi és a külföldi biztonsági helyzetét; előkészíti a kormány számára a Szlovák Köztársaság biztonságának fenntartására, a válsághelyzetek megelőzésére irányuló intézkedésekre, valamint a válsághelyzet megoldására irányuló javaslatokat.

27 Zákon č. 110/2004 Z. z., o fungovaní Bezpečnostnej rady Slovenskej republiky v čase mieru (a továbbiakban: Biztonsági Tanács tv.).

28 Zbierka Zákonov Slovenskej republiky (a Szlovák Köztársaság hivatalos lapja).

29 Állambiztonsági alk.tv. 11. cikk. 


\subsection{A válsághelyzet és a rendkívüli helyzet mint a különleges jogrendnek nem minősülő rendkívüli felhatalmazás esetkörei}

A klasszikus értelemben vett különleges jogrendi tényállások mellett a szlovák jogi szabályozásban megjelenik két további esetkör is, amelyek nem tartoznak a különleges jogrendi esetkörök közé. Ezek a válsághelyzet (krízová situácia) és a rendkívüli helyzet (mimoriadna situácia). A rendkívüli helyzet azonban nem összekeverendő a különleges jogrendi esetkörnek minősülő rendkívüli állapottal.

A válsághelyzet fogalmának tisztázása tekintetében a háború és hadiállapoton kívüli válsághelyzetek kezeléséről szóló törvény ${ }^{30}$ tekinthető irányadónak. A jogszabályban foglaltak alapján válsághelyzet alatt olyan állapotot értünk, amelynek során az állam biztonsága sérül vagy veszélybe kerül, és az arra felhatalmazott alkotmányos szervek meghatározott feltételek beállta esetén kihirdetik a rendkívüli állapot, a veszélyhelyzet vagy a rendkívüli helyzet esetkörök egyikét. ${ }^{31} \mathrm{~A}$ szóban forgó törvényben a válságkezelés igazgatási szervei is rögzítésre kerültek, amelyek a következők: a kormány, a Biztonsági Tanács, a minisztériumok és a központi szervek, a Szlovák Nemzeti Bank, a kerületi biztonsági tanács, a körzeti hivatal, a járási biztonsági tanács és az önkormányzatok. Amint ebből a felsorolásból is kitúnik, a válságkezelő szervek és az általunk fent rögzített alkotmányos szervek között enyhe átfedés figyelhető meg. Megjegyzendő továbbá, hogy e törvény alapján a kormány a válsághelyzetek kezelése céljából felállíthatja a Központi Válságstábot (Ústredný krízový štáb) is, amelynek elnöke a belügyminiszter. A Központi Válságstáb múködésével kapcsolatos részletszabályokat a testület alapszabálya tartalmazza, amelyet a kormány hagy jóvá. ${ }^{32}$

A lakosság polgári védelméról szóló törvény ${ }^{33}$ a rendkívüli helyzetet egy olyan veszélyeztetési időszakként vagy egy rendkívüli eseményt követő időszak eredményeként határozza meg, amely negatív hatással van az életre, az egészségre vagy a vagyonra..$^{34} \mathrm{~A}$ jogszabály a rendkívüli helyzetek fajtáit is meghatározza. Ilyen rendkívüli helyzetnek minősülnek az elemi csapások, a balesetek, a különféle katasztrófák, a közegészségügyi veszélyhelyzetek és a terrorista támadások. Rendkívüli helyzet során olyan intézkedések bevezetésére kerülhet sor, amelyek az élet, az egészség vagy a vagyon megmentésére, a fenyegetés kockázatainak csökkentésére vagy egyéb olyan tevékenységre irányulnak, amelyek a rendkívüli esemény terjedésének és következményeinek megakadályozását eredményezik. ${ }^{35}$

30 Zákon č. 387/2002 Z. z., o riadení štátu v krízových situáciách mimo času vojny a vojnového stavu (a továbbiakban: Válsághelyzet tv.).

31 Válsághelyzet tv. 2. \$a) pont.

32 A Központi Válságstáb alapszabálya a Szlovák Köztársaság Kormányhivatalának oldaláról szlovák nyelven tölthető le: https://tinyurl.com/vdee4xc (Letöltve: 2020. december 15.).

33 Zákon č. 42/1994 Z. z., o civilnej ochrane obyvatel'stva (a továbbiakban: Polgári védelmi tv.).

34 Polgári védelmi tv. 3. \$ (1) bekezdés.

35 Polgári védelmi tv. 3 . $\$(1)$ bekezdés. 
A Polgári védelmi tv. célja a rendkívüli események bekövetkezte kapcsán a polgárok életének, egészségének és vagyonának védelme a rendkívüli események következményeivel szemben, továbbá az állami szervek múködési rendjének, valamint a természetes és jogi személyek feladatainak és kötelezettségeinek meghatározása. ${ }^{36} \mathrm{~A}$ polgári védelmi feladatok ellátása terén a törvény szerint a kormánynak vannak kiemelt feladatai, míg a belügyminiszter előkészítő, koordinációs, végrehajtási és ellenőrzési feladatokkal van megbízva. A fentebb felsorolt polgári védelmi szereplők feladatainak meghatározása kapcsán a törvény rendelkezik az érintettek jogairól, a károsultak segélyezéséről és kártalanításáról, a védelmi épületek kijelöléséről, valamint részletesen meghatározza az egyes kötelezettségek megszegése esetén kiszabható közigazgatási jogi szankciók körét.

\subsection{A különleges jogrendre való felkészülést segitő békeidejü szabályok, valamint a válságkezelésre vonatkozó szabályok}

Míg a különleges jogrendi esetkörökre vonatkozó szabályok a szlovák szabályozásban kizárólag alkotmányos szinten jelennek meg, addig a különleges jogrendet megelőző, illetve az arra való felkészülést szolgáló békeidejú szabályok törvényi szinten kerültek rögzítésre.

A téma kapcsán kiemelt jelentőséggel bír a már fentebb említett Válsághelyzeti tv., a Polgári védelmi tv., valamint a Biztonsági Tanács tv. Tekintettel jelen munka terjedelmi korlátaira, és mivel az előző fejezetben már részben szóltunk az első két törvényről, e ponton nem kerül sor azok részletes ismertetésére, azonban az alábbiakban röviden szólunk a Biztonsági Tanács békeidejü múködésérôl szóló törvényi szabályozásról.

A szóban forgó törvény részletesen meghatározza a Biztonsági Tanács üléseinek rendjét, tisztségviselőinek (elnökének és alelnökének) jogállását és feladatait, a Biztonsági Tanács egyes szakbizottságait, feladatköreit és múködését. A különleges jogrendre történő felkészülés kapcsán egyrészről a Biztonsági Tanácsnak mint békeidejü tanácsadó szervnek vannak kiemelkedő feladatai, másrészről pedig minden állami és önkormányzati szerv egy általános felhatalmazással van kötelezve a különleges jogrendi esetekre való felkészülésre. ${ }^{37}$

A Biztonsági Tanács tv. részletesen meghatározza a Biztonsági Tanács feladatait a szlovák biztonsági rendszer kialakításával, a nemzetközi biztonsági kötelezettségek teljesítésével, a biztonsági helyzet kiértékelésével, valamint a javaslatok előkészítésével kapcsolatban. A Biztonsági Tanács békeidőben a kormány tanácsadó testületeként vesz részt a Szlovák Köztársaság biztonsági rendszerének kialakításában és múködtetésében, teljesíti a nemzetközi biztonsági kötelezettségeket, felméri az állam belföldi és külföldi biztonsági helyzetét. Ezenfelül előkészíti a kormány számára a Szlovák Köztársaság biztonságának fenntartására, a válsághelyzetek megelőzésére irányuló intézkedésekre, valamint a válság-

36 Píry, 2020.

37 Állambiztonsági alk.tv. 6. cikk (3) bekezdés. 
helyzet megoldására irányuló javaslatokat. ${ }^{38} \mathrm{~A}$ Biztonsági Tanács elnöke a miniszterelnök, alelnöke a Biztonsági Tanács által felhatalmazott miniszterelnök-helyettes; további tagjai a védelemért felelős és a belügyekért felelős miniszter, a pénzügyminiszter és a külügyminiszter. A Biztonsági Tanács további tagjait a miniszterelnök javaslatára 48 órán belül a köztársasági elnök nevezi ki és menti fel. ${ }^{39}$

A Biztonsági Tanács az egyes szakterületek tekintetében önálló bizottságokban múködik:

— Külügyi Bizottság;

- Védelmiterv-bizottság;

- Polgárivédelmiterv-bizottság;

- Hírszerzési Bizottság;

- Energiabiztonsági Bizottság;

- Kiberbiztonsági Bizottság.

A Biztonsági Tanács bizottságainak tagjai kapcsán megfigyelhető, hogy az egyes szakterületek tekintetében a tagság a teljes központi közigazgatást lefedi - így például a Külügyi Bizottság tagjai a Külügyminisztérium, a Védelmi Minisztérium, a Belügyminisztérium, a Gazdasági Minisztérium, a Pénzügyminisztérium, a Közlekedési és Építésügyi Minisztérium, a Szlovák Köztársaság Kormányhivatala, a Szlovák Köztársaság Állami Tartalékalapja, a Nemzetbiztonsági Hivatal, a Köztársasági Elnök Hivatala, a Hírszerzési Szolgálat, valamint a Szlovák Nemzeti Bank képviselői. Az egyes szerveknek számtalan koordinációs és végrehajtási feladata van a különleges jogrendi helyzetekre való felkészülésben.

\section{Az alapjogok korlátozására vonatkozó szabályok különleges jogrend idején}

Az alapvetô emberi jogokkal és szabadságokkal kapcsolatos általános rendelkezéseket az alkotmány ${ }^{40}$ deklarálja. Bár az alkotmány garanciákat fogalmaz meg az alapjogok tekintetében, azonban azok különleges jogrend esetén történő korlátozhatóságának kérdését nem rendezi.

Az alkotmányban általános garanciaként jelenik meg az egyén szabadsága, az egyén egyenlősége méltóságában és jogaiban, továbbá az alkotmány deklarálja, hogy az alapvető jogok és szabadságok megvonhatatlanok, elidegeníthetetlenek, elévülhetetlenek és meg-

38 Állambiztonsági alk.tv. 8. cikk (2) bekezdés.

39 Állambiztonsági alk.tv. 8. cikk (4) bekezdés.

40 Alkotmány II. fejezet (Alapvetőjogokés szabadságjogok) 12. cikk. 
szüntethetetlenek, ${ }^{41}$ az alkotmány továbbá garantálja az alapvető jogok és szabadságjogok egyetemlegességét.

A szlovák alkotmány csupán két felhatalmazó rendelkezést tartalmaz a különleges jogrendre vonatkozó részletszabályok megalkotására vonatkozóan. A felhatalmazás alanya tekintetében az alkotmány azonban nem közöl további információkat. ${ }^{42} \mathrm{~A}$ különleges jogrendi esetkörök tekintetében az alkotmányban meghatározott felhatalmazás alapján az Állambiztonsági alk.tv. taxatíve felsorolja a különleges jogrendi esetek kapcsán az alapjogok korlátozásának megengedett szintjét és a korlátozható alapjogok és kötelezettségek körét. A jogszabály struktúráját követve, a bevezető rendelkezések után minden egyes különleges jogrendi esetkörnél taxatíve meghatározásra kerülnek az egyes korlátozható alapjogok és kötelezettségek.

A négy különleges jogrendi esetkör kapcsán megállapítható, hogy míg háború és hadiállapot esetén az alapvető jogok és szabadságok gyakorlásának korlátozása és a kötelezettségek teljesítésének követelményei csak a szükséges mértékben és a szükséges időre határozhatók meg, amelyeket az ország egészén vagy egyes területein zajló eseményektől függően szükséges meghatározni, addig a rendkívüli állapot és a veszélyhelyzet esetén a szabályozás a fenyegetés súlyától függően teszi lehetővé az alapjog-korlátozást. Tekintettel jelen munka terjedelmi korlátaira, valamint arra, hogy Szlovákia modern kori története során kizárólag veszélyhelyzet kihirdetésére került sor, e ponton eltekintenénk az összes, különleges jogrendi esetkör ideje alatt korlátozható alapjogok részletes ismertetésétól, csupán a veszélyhelyzet kihirdetése kapcsán rögzítenénk az egyes korlátozható alapjogokat.

Veszélyhelyzet idején az állam a szükségesség és arányosság elveinek teljesülése mellett korlátozhat bizonyos alapvető emberi jogokat, azonban azok korlátozása kizárólag az alkotmánnyal összhangban lehetséges. ${ }^{43} \mathrm{Az}$ alapjogok különleges jogrend idején - jelen esetben veszélyhelyzet idején - való korlátozhatóságáról, annak feltételeiről és terjedelméről, illetve az ezzel járó állampolgári kötelezettségekről az Állambiztonsági alk.tv. rendelkezik. ${ }^{44} \mathrm{~A} \mathrm{jog-}$ szabályban ezek taxatív módon kerültek felsorolásra.

A veszélyhelyzet által érintett vagy a közvetlen fenyegetés alatt álló területre a korlátozó intézkedések számos fajtája rendelhető el, mint például: személyek evakuálása, kötelező munkavégzés elöírása, magánhelyiségek katonai célra történő felhasználása, a gépjármû́használat megtiltása, postai küldemények kézbesítésének korlátozása, a szabad mozgás korlátozása, valamint a gyülekezési jog, sztrájkjog és a véleménynyilvánítási jog korlátozása. ${ }^{45}$

Az alkotmánytörvény által megengedett alapjog-korlátozás lehetőségét a Covid-19 okozta járványhelyzet ideje alatt a szlovák kormány is kihasználta. ${ }^{46} \mathrm{Az}$ alapjog-korlátozás kapcsán

41 Alkotmány 12. cikk (1) bekezdés.

42 Kelemen, 2019, 29. o.

43 Alkotmány 13. cikk (2) bekezdés.

44 Alkotmány 51. cikk (2) bekezdés.

45 Lásd bővebben az Állambiztonsági alk.tv. 5. cikk (3) bekezdését.

$46 \mathrm{Az}$ aktuális alapjog-korlátozó intézkedések kapcsán lásd a kormány október 28-án kibocsátott, 693/2020. számú határozatát. 
azonban mindenképpen szükségesnek tartjuk néhány szóban megemlíteni a közegészség védelméről, támogatásáról és fejlesztéséről szóló törvényt is, ${ }^{47}$ amelynek értelmében a Szlovák Köztársaság Közegészségügyi Hivatala - mint a közegészségügy területén illetékes államigazgatási hatóság - saját hatáskörben jogosult bizonyos intézkedések bevezetésére. Erre a szlovák alkotmány ad felhatalmazást, hiszen annak szabályozásából kitûnik, hogy a kötelezettségek és a korlátozások bevezetésére törvény (jelen esetben a Közeü.tv.) alapján kerülhet sor. ${ }^{48}$

A Szlovák Köztársaság Közegészségügyi Hivatalának e hatáskörét azonban számos vita övezte. ${ }^{49}$ Tekintettel arra a példa nélküli helyzetre, amelybe az egész világ látszólag egyik napról a másikra került, az illetékes hatóságoknak e tekintetben nem volt kidolgozott eljárásrendje. Erre való reakcióként a szlovák parlament rövidített jogalkotási eljárás keretében a Közeü.tv. módosítását fogadta el, amelyet Zuzana Čaputová államfő haladéktalanul aláirt. A módosítás célja az volt, hogy orvosolják az ellentmondásokat a Szlovák Közegészségügyi Hivatal koronavírus-járványra reagáló óvintézkedéseivel összefüggésben. A törvény aláírásával párhuzamosan azonban a köztársasági elnök azt is bejelentette, hogy a törvény bizonyos rendelkezései kapcsán az alkotmánybírósághoz fordul, ugyanis véleménye szerint a törvény azon rendelkezései, amelyek kizárják az óvintézkedések által érintett személyek kártérítésre való jogosultságát, alkotmányellenesek. Az alkotmánybíróság Čaputová beadványát jóváhagyta, a vitatott jogszabályhelyek hatályát felfüggesztette, majd a beadvány szövegét elbírálásra teljes egészében továbbutalta..$^{50}$

\section{A különleges jogrend kihirdetésének gyakorlati esetei}

Az előző fejezetekben elemzett különleges jogrendi esetkörök közül Szlovákiában ez idáig nem került sor sem a háború, sem a hadiállapot, ${ }^{51}$ sem pedig a rendkívüli állapot kihirdetésére. A veszélyhelyzet kihirdetése kapcsán azonban találunk gyakorlati példákat, hiszen Szlovákia modern kori történelme során ez idáig háromszor ${ }^{52}$ került sor e különleges jog-

47 Zákon č. 355/2007 Z. z., o ochrane, podpore a rozvoji verejného zdravia a o zmene a doplnení niektorých zákonov (a továbbiakban: Közeü.tv.).

48 Közeü.tv. 48. \$ (4) bekezdés.

49 Ehhez kapcsolódóan lásd: Havelková, 2020, 15. 0.; Havelková, 2020; Dobrovičová, 2020.

$50 \mathrm{Az}$ alkotmánybíróság 51/2020. sz. sajtóközleménye. Elérhető: www.ustavnysud.sk/documents/10182/ 107844303/TS_51_2020/c96cbo26-932e-4f15-8043-391be7018367 (Letöltve: 2020. december 2.).

51 Az 1918-ban létrejött, majd 1993-ban Csehországra és Szlovákiára kettévált Csehszlovákia esetében egyetlen alkalommal, a második világháború során került sor formálisan a hadiállapot kihirdetésére. 1941-ben Edvard Beneš, az emigrációba vonult csehszlovák államelnök kijelentette, hogy Csehszlovákia hadban áll a náci Németországgal, valamint Magyarországgal, mivel e két ország megsértette a csehszlovák állam szuverenitását.

52 Szlovákia legelőször 2011-ben, a 421/2011. sz. kormányhatározattal hirdetett veszélyhelyzetet az egészségügyi ellátórendszer hiányossága miatt. A veszélyhelyzet kihirdetése elsősorban arra irányult, hogy biztosítsa a folyamatos egészségügyi ellátást az országban, és megtiltsa bizonyos munkavállalói körök számára a sztrájkjog gyakorlását. 
rendi esetkör kihirdetésére - ebből két alkalom a koronavírus-járványhoz, illetve a 2020-as évhez köthetô. ${ }^{53}$ Mivel Szlovákiában a SARS-CoV-2 vírus okozta világjárvány miatt kétszer (az első és a második hullám ideje alatt) került sor a veszélyhelyzet kihirdetésére, ezért szükségesnek látjuk annak időszakonként történő bemutatását.

$\mathrm{Az}$ új típusú koronavírus okozta járványhelyzet miatt ${ }^{54}$ 2020. március 16-i hatállyal a szlovák kormány veszélyhelyzet kihirdetése mellett döntött. ${ }^{55} \mathrm{~A}$ kihirdetett különleges jogrendi esetkör hatálya azonban csak az egészségügyi rendszerre terjedt ki. Ahogy az már az előző fejezetekben is rögzítésre került, az Állambiztonsági alk.tv. a kihirdetés lehetőségét egy olyan esemény bekövetkeztéhez kapcsolja, amely az emberi életet, egészséget vagy vagyont veszélyezteti, vagy annak közvetlen veszélye áll fenn. Az alkotmánytörvény értelmében ilyen eseménynek minősül különösen a pandémia (járványhelyzet), a természeti vagy épített környezeti érték, illetve ingatlan vagyon sérelmével összefüggő olyan események, amelyeket természeti szerencsétlenség, katasztrófa, ipari, szállítási vagy egyéb múkködési baleset idéz elö. ${ }^{56}$ A veszélyhelyzet fontos jellemzőjeként jelenik meg, hogy az alkotmánytörvény értelmében a veszélyhelyzet ideje alatt az alapvető jogok és szabadságok korlátozás alá eshetnek. Ezen általános meghatározást követően a törvényben taxatív módon felsorolásra kerülnek a korlátozható alapjogok és szabadságok. Az alkotmánytörvény tehát nem ex constitutione korlátozza az alapjogokat, hanem lényegében felhatalmazást ad az alapjogok alkotmánytörvény szerinti korlátozására. Ezenfelül mindenképpen szükséges rögzítenünk, hogy a veszélyhelyzet kihirdetéséről szóló határozat önmagában nem bír általános korlátozó hatással, nem jelenti az összes alapvetô jog és szabadság korlátozását. ${ }^{57} \mathrm{~A}$ szlovák kormány még a veszélyhelyzet elrendelése elôtt, március 12-én 6:00 órától az egész ország területére kiterjedô"58 rendkívüli helyzetet hirdetett ki. ${ }^{59}$ Ez utóbbi azonban - a veszélyhelyzettel ellentétben -, ahogy már említettük, nem minősül hagyományos értelemben vett különleges jogrendi esetkörnek.

Látható tehát, hogy a szlovák kormány a koronavírus-járványra reagálva első ízben az egész országra kiterjedő rendkívüli helyzetet vezetett be, majd pár nappal később döntött a különleges jogrend bevezetése mellett. A rendkívüli helyzet és a veszélyhelyzet kihirdetése formailag egyaránt kormányhatározattal (uznesenie vlády) történt. ${ }^{60}$

53 Ennek kapcsán lásd a Szlovák Köztársaság Egészségügyi Minisztériumának honlapját: www.health.gov.sk/ Clanok?vyhlasenie-nudzoveho-stavu-v-zdravotnickych-zariadeniach (Letöltve: 2020. december 14.).

54 Venice Commission, 2020, 39. pont.

55 114/2020. sz. kormányhatározat.

56 Állambiztonsági alk.tv. 5. \$(1) bekezdés.

57 Drgonec, 2012, 76. o.

58 A rendkívüli helyzet kihirdetésére a Polgári védelmi tv. értelmében a másodfokú közegészségügyi veszély fennállása miatt került sor. Szlovákiában a rendkívüli helyzet egy nappal az Egészségügyi Világszervezet főigazgatója által 2020. március 11-én kihirdetett Covid-19-világjárványt követően került kihirdetésre.

59 111/2020. sz. kormányhatározat. A kormány a Polgári védelmi tv. 8. \$-a alapján volt jogosult a rendkívüli helyzet elrendelésére.

60 Jančát-Kostolanská-Leichmann-Šlajs, 2020. 
Szlovákiában a koronavírus-járvány első hulláma idején ${ }^{61}$ a veszélyhelyzetet a lehetséges maximális időtartamra, azaz 90 napra hirdették ki.62 Bár a különleges jogrend június 13-án véget ért, ${ }^{63}$ és nem került sor annak meghosszabbítására sem, a rendkívüli helyzet szabályai március 12-tôl a kézirat lezártáig továbbra is hatályban maradtak az országban. A rendkívüli helyzet kihirdetésének maximális időkerete a Polgári védelmi tv.-ben nem került rögzítésre, ${ }^{64}$ és ez idáig a szlovák kormány sem kezdeményezte annak visszavonását.

A koronavírus-járvány második hullámának következtében a szlovák kormány szintén az első hullám ideje alatt kihirdetésre kerülő különleges jogrendi esetkör bevezetése mellett döntött. Erre október 1-tôl 45 napig tartó időtartammal került sor. ${ }^{65} \mathrm{~A}$ veszélyhelyzet ebben az esetben is a rendkívüli helyzet szabályaival párhuzamosan került bevezetésre. ${ }^{66}$ 2020 novemberében a koronavírus-járvány második hullámának felszálló ága volt megfigyelhetô, ezért a kormány november 11-én újabb 45 nappal kényszerült meghosszabbítani a veszélyhelyzetet.

A koronavírus-járvány következtében elrendelt veszélyhelyzetek kapcsán azonban kiemelendő, hogy míg a márciusi veszélyhelyzet kifejezetten az egészségügyet érintette, addig az októberi, illetve novemberi veszélyhelyzet esetén inkább egy általános veszélyhelyzetről beszélhetünk.

E fejezeten belül szükségesnek tartunk néhány szót szólni azokról a közjogi-politikai vitákról is, amelyek a veszélyhelyzet kihirdetésével összefüggésben keletkeztek. Jelen munkában konkrétan három esetet kívánunk részletesebben ismertetni.

2011-ben a szlovák kórházakban dolgozó orvosok több mint egyharmadának egyidejû felmondása megrengette a szlovák kormányt, ezért az a veszélyhelyzet elrendelése mellett döntött. A kormányhatározatban kihirdetett veszélyhelyzet arra irányult, hogy biztosítsa a folyamatos egészségügyi ellátást, és megtiltsa bizonyos munkavállalók sztrájkjogának ${ }^{67}$ gyakorlását. Az eset kapcsán több alkotmánybírósági határozat is született. ${ }^{68}$ Leszögezendő azonban, hogy nem a különleges jogrendi esetkör kihirdetésével kapcsolatban, hanem a kényszermunka tilalmával összefüggésben kerültek vizsgálat alá a konkrét ügyek, amelyek során a szlovák alkotmánybíróság nem állapított meg alkotmányellenességet. Veszélyhelyzet

61 A koronavírus-járvány kezelésére (az első hullám idején) elfogadott főbb intézkedéseket az Európai Parlament Kutatószolgálata (European Parliamentary Research Service) is összegyüjtötte. Elérhető: www.europarl. europa.eu/RegData/etudes/BRIE/2020/652002/EPRS_BRI(2020)652002_EN.pdf (Letöltve: 2020. december 14.).

62 Vö. az Állambiztonsági alk.tv. 5. \$ (2) bekezdésével.

63 366/2020. sz. kormányhatározat.

64 Ennek kapcsán lásd: Polgári védelmi tv. 3b. \$ (3) bekezdés.

65 A szlovák kormány döntése értelmében a 2020. szeptember 30-án kihirdetett különleges jogrend október 1-től lépett hatályba. Ebben az esetben a szlovák kormány nem élt az Állambiztonsági alk.tv. által biztosított 90 napos időtartammal, így csupán 45 napra rendelte azt el.

66 268/2020. sz. kormányhatározat.

67 Megemlítendő, hogy a jogalkotó kizárólag a rendkívüli állapot esetkörénél szabályozza, hogy az nem hirdethetô ki a sztrájkjog érvényesülésének a megakadályozására.

68 Ehhez kapcsolódóan lásd az alkotmánybíróság határozatait: IV. ÚS 84/2012, I. ÚS 85/2012, I. ÚS 21/2012. 
kihirdetésére ezután csak 2020 márciusában és októberében, a koronavírus-járvány világjárvánnyá válása kapcsán került sor.

2020 októberében Viera Kováčiková föügyészhelyettes egy indítványt nyújtott be a veszélyhelyzet kapcsán az alkotmánybírósághoz. Az előterjesztés a kormány által elfogadott határozat alkotmányosságával kapcsolatban született meg. Ezenfelül az ellenzéki képviselők egy csoportja is az alkotmánybírósághoz fordult a veszélyhelyzet kihirdetése kapcsán. Az alkotmánybíróság 10 napon belül, október 14-én döntött ${ }^{69}$ arról, hogy az október 1-jei hatállyal meghirdetett veszélyhelyzet összhangban van a szlovák alkotmánnyal, sőt, a veszélyhelyzet kihirdetése az alkotmány mellett az Állambiztonsági alk.tv.-t sem sérti. Az alkotmánybíróság úgy ítélte meg, hogy a veszélyhelyzet kihirdetése nem ütközik az alkotmányba, és az sem alkotmányellenes, hogy hatálya az egész ország területére vonatkozik. A fentieken kívül az alkotmánybíróság szerint a kormány a veszélyhelyzet kihirdetésének minden formális követelményét teljesítette. A Szlovák Köztársaság Hírügynökségének (TASR) tájékoztatása alapján Mária Kolíková igazságügyi miniszter a veszélyhelyzet meghosszabbításával összefüggésben támogatni fogja az Állambiztonsági alk.tv. esetleges módosítását annak érdekében, hogy a törvény összhangban legyen az aktuálisan kialakult helyzettel.70

Szintén 2020 októberében látott napvilágot az a hír is, amely alapján a Föügyészség szerint a Szlovák Közegészségügyi Hivatal törvényt sértett a koronavírus-járvány első hulláma idején kihirdetett veszélyhelyzet alatti óvintézkedések elrendelése tekintetében, ezért a Főügyészség ügyészi figyelmeztetést küldött a Közegészségügyi Hivatalnak. A törvénysértés elsősorban azzal függött össze, hogy a Közegészségügyi Hivatalnak a rendkívüli helyzet és a veszélyhelyzet kihirdetése után már nem volt megfelelő hatásköre az óvintézkedések elrendelésére, és az intézkedések jogi formája sem volt megfelelő. Az ügyészség azt javasolta a Közegészségügyi Hivatalnak, hogy késedelem nélkül hozza meg a szükséges intézkedéseket, hogy a jövőben elejét vegyék a hatályos jogszabályok megsértésének. A dokumentumból az is kiderül, hogy az ügyészség nem az intézkedéseket, hanem azok elfogadásának módját kifogásolta. ${ }^{71}$

\section{4. Összegzés}

Szlovákiában a különleges jogrendre vonatkozó szabályok kizárólag alkotmányos szinten, a Szlovák Köztársaság Alkotmányában, illetve az Állambiztonsági alk.tv.-ben szerepelnek. Míg az alkotmányban a különleges jogrendre vonatkozó általános szabályok ta-

69 Az alkotmánybíróság 47/2020. sz. sajtóközleménye.

70 A Szlovák Köztársaság Hírügynökségének sajtóhíre a következő linken érhetô el: www.tasr.sk/tasr-clanok/ TASR:20201110TBA03162 (Letöltve: 2020. november 10.).

71 A Szlovák Köztársaság Hírügynökségének sajtóhíre a következő linken érhető el: www.tasr.sk/tasr-clanok/ TASR:20201006TBB00246 (Letöltve: 2020. november 10.). 
lálhatók, addig az alkotmánytörvény az egyes különleges jogrendi esetkörökre vonatkozó részletszabályokat fogalmazza meg. A szlovák jogrendben továbbá megjelennek egyéb, hagyományos értelemben különleges jogrendi esetkörnek nem minősülő esetek is, amelyek törvényi szinten kerültek szabályozásra.

A szlovák szabályozás a különleges jogrendi esetkörök négy kategóriáját különbözteti meg: a háborút, a hadiállapotot, a rendkívüli állapotot és a veszélyhelyzetet. Ezenfelül azonban a klasszikus értelemben vett különleges jogrendi esetkörök mellett feltûnnek a rendkívüli helyzet és a válsághelyzet kategóriák is. Míg előbbit a Polgári védelmi tv. szabályozza, utóbbi a háború és hadiállapoton kívüli válsághelyzetek kezeléséről szóló törvényben került rögzítésre.

Háború kérdésében a köztársasági elnök a parlament határozata alapján hivatott dönteni. A hadiállapot és a rendkívüli állapot kihirdetése kapcsán szintén a köztársasági elnök kezében összpontosul a döntés joga, aki a kormány javaslatára mérlegelheti e különleges jogrendi esetkör kihirdetésének lehetőségét. Veszélyhelyzet esetén a kormány egymaga jogosult annak kihirdetésére. Amennyiben a háború, hadiállapot és rendkívüli állapot idején a parlament akadályoztatva van, az Állambiztonsági alk.tv. rendelkezik az úgynevezett Parlamenti Tanács létrehozásáról. A Parlamenti Tanács a parlament hatásköreit gyakorolja. Kivételt képeznek ezalól az Állambiztonsági alk.tv.-ben az alábbi, taxatíve felsorolt esetek. Ezek alapján a Parlamenti Tanács:

— nem határozhat az alkotmány, az egyes alkotmánytörvények, a választási törvény, a politikai pártokról szóló törvény és a népszavazásról szóló törvény módosításáról;

— nem jogosult nemzetközi szerződés kötelező hatályának elismerésére;

- nem indítványozhat népszavazást a köztársasági elnök felmentéséről, és nem határozhat népszavazás kiírásáról;

— nem kezdeményezhet vádemelést a köztársasági elnök ellen.

Szintén az Állambiztonsági alk.tv. alapján hozzák létre a Biztonsági Tanácsot, amely a kormány háború, hadiállapot és rendkívüli állapot idején való akadályoztatása esetén látja el annak legfőbb feladatait. A Biztonsági Tanács kapcsán kiemelendő, hogy annak eltérő feladatai vannak a különleges jogrend idején és békeidőben. Míg különleges jogrend idején az Állambiztonsági alk.tv. szabályozza a Biztonsági Tanács múködését, addig békeidőben a Biztonsági Tanács békeidejú múködéséről szóló törvény alapján szükséges eljárni.

Az alábbi táblázatban összefoglaltuk a szlovák különleges jogrendi szabályozással kapcsolatos legfontosabb tudnivalókat. 


\begin{tabular}{|c|c|c|c|c|}
\hline & Háború & Hadiállapot & $\begin{array}{l}\text { Rendkívüli } \\
\text { állapot }\end{array}$ & Veszélyhelyzet \\
\hline $\begin{array}{c}\text { Szabályozás } \\
\text { szintje }\end{array}$ & \multicolumn{4}{|c|}{ Alkotmányos (alkotmány és Állambiztonsági alk.tv.) } \\
\hline $\begin{array}{c}\text { Elrendelési } \\
\text { okok }\end{array}$ & $\begin{array}{l}\text { Idegen hatalom tá- } \\
\text { madása a hadüzenet } \\
\text { kinyilvánításával } \\
\text { vagy anélkül, } \\
\text { vagy } \\
\text { nemzetközi szerző- } \\
\text { désből eredő kötele- } \\
\text { zettségek teljesítése } \\
\text { során kerül az ország } \\
\text { háborús konflik- } \\
\text { tusba másokkal. }\end{array}$ & $\begin{array}{l}\text { Az országot a háború } \\
\text { közvetlen veszélye } \\
\text { fenyegeti, } \\
\text { vagy } \\
\text { az országot a háború } \\
\text { kinyilvánítása nélkül } \\
\text { idegen hatalom } \\
\text { közvetlen támadása } \\
\text { fenyegeti. }\end{array}$ & $\begin{array}{l}\text { Terrortámadás } \\
\text { vagy } \\
\text { utcai zavargások } \\
\text { vagy } \\
\text { a fentiek bekövet- } \\
\text { keztének köz- } \\
\text { vetlen veszélye áll } \\
\text { fenn. }\end{array}$ & $\begin{array}{l}\text { Az emberi életet } \\
\text { és egészséget } \\
\text { veszélyeztető } \\
\text { esemény } \\
\text { bekövetkezte } \\
\text { vagy } \\
\text { bekövetkez- } \\
\text { tének közvetlen } \\
\text { fenyegetése. }\end{array}$ \\
\hline Elrendelés & $\begin{array}{l}\text { A köztársasági elnök } \\
\text { a parlament hatá- } \\
\text { rozata alapján }\end{array}$ & $\begin{array}{l}\text { A köztársasági elnök } \\
\text { a kormány javaslatára }\end{array}$ & $\begin{array}{l}\text { A köztársasági } \\
\text { elnök a kormány } \\
\text { javaslatára }\end{array}$ & Kormány \\
\hline $\begin{array}{l}\text { Gyakorlati } \\
\text { esetek }\end{array}$ & \multicolumn{3}{|c|}{ Ez idáig egyszer sem került kihirdetésre. } & $\begin{array}{l}\text { Ezzel kapcso- } \\
\text { latban lásd A kü- } \\
\text { lönleges jogrend } \\
\text { kihirdetésének } \\
\text { gyakorlati esetei } \\
\text { címú részt. }\end{array}$ \\
\hline $\begin{array}{c}\text { Különleges } \\
\text { jogrendnek } \\
\text { nem } \\
\text { minősülő } \\
\text { esetek }\end{array}$ & \multicolumn{4}{|l|}{$\begin{array}{l}\text { Válsághelyzet } \\
\text { Rendkívüli helyzet }\end{array}$} \\
\hline
\end{tabular}

22. táblázat

A Szlovák Köztársaság különleges jogrendi szabályainak összegzése Forrás: a szerzők sajátösszeállítása

Az alapjogok korlátozása tekintetében megállapítható, hogy az alkotmány csupán bizonyos garanciákat fogalmaz meg az alapjogokkal kapcsolatban, azonban azok különleges 
jogrend idején történő korlátozhatóságát nem rendezi. A különleges jogrendre vonatkozóan az alkotmányban foglalt meghatározott felhatalmazás alapján az Állambiztonsági alk.tv. taxatíve felsorolja a különleges jogrendi esetkörök tekintetében az alapjogok korlátozásának megengedett szintjét és a korlátozható alapjogok és kötelezettségek körét.

A különleges jogrend gyakorlati esetei kapcsán rögzítendő, hogy a Szlovák Köztársaság modern kori történelme során kizárólag a veszélyhelyzet kihirdetésére került sor. E gyakorlati példák közül két alkalom a koronavírus-járványhoz, tehát a 2020-as évhez köthető. Amennyiben nem „csak” Szlovákia, hanem Csehszlovákia történelmét vizsgáljuk (tehát az 1918-1993 közötti időszakot), megfigyelhető, hogy ebben az időszakban egyetlen alkalommal, 1941-ben került sor a hadiállapot kihirdetésére.

Ami a magyar szabályozással való összehasonlítást illeti, megállapítható, hogy a különleges jogrendi esetkörök szabályozása mindkét országban alkotmányos szinten került rögzítésre. Különbség mutatkozik azonban az elrendelhető különleges jogrendi esetkörök számának tekintetében - ez Szlovákiában négy, míg Magyarországon hat kategóriát takar. Az Alaptörvény kilencedik módosítása értelmében azonban a különleges jogrendi esetkörök szúkítése és átfogó szabályozásának módosítása figyelhetô meg. Ez azt eredményezi, hogy a meglévő hat különleges jogrendi esetkör (rendkívüli állapot, szükségállapot, megelőző védelmi helyzet, terrorveszélyhelyzet, váratlan támadás, veszélyhelyzet) háromra csökken (hadiállapot, szükségállapot, veszélyhelyzet). Így a kilencedik módosítás révén létrejövő különleges jogrendi esetkörök több ponton is hasonlóságot mutatnak a jelenleg is hatályos szlovák különleges jogrendi szabályozással.

A szlovák szabályozás szerinti háború és hadiállapot kategóriái a magyar szabályozásban a kilencedik Alaptörvény-módosítás után összevontan hadiállapotként jelenik meg.

Az Alaptörvény-módosítás által bevezetett szükségállapottal nagymértékú hasonlóságot mutat a szlovák rendkívüli állapot. Míg a rendkívüli állapot Szlovákiában csak terrortámadás vagy utcai zavargások következtében vagy ezek bekövetkeztének közvetlen veszélye esetén hirdethető ki, addig a magyar szabályozásból ismert szükségállapot az alkotmányos rend megdöntésére, felforgatására vagy a hatalom kizárólagos megszerzésére irányuló cselekmény esetén, illetve az élet- és vagyonbiztonságot tömeges mértékben veszélyeztető jogellenes cselekmény esetén hirdethető ki. Mindkét esetkör tekintetében közös vonásként jelenik meg, hogy az elrendelésük oka mindig valamilyen más személyek által kiváltott jogellenes cselekményen alapszik.

A veszélyhelyzet mint különleges jogrendi esetkör a szlovák és a magyar szabályozásban egyaránt elrendelhető valamilyen életet és egészséget veszélyeztető esemény bekövetkezte vagy bekövetkeztének közvetlen fenyegetése miatt. A két esetkörben közös, hogy mindig valamilyen külső, előre nem látható esemény szolgáltat okot a különleges jogrendi esetkörök ezen típusának bevezetésére.

Szintén a két nemzeti szabályozás közös vonásaként jelenik meg, hogy a magyar Honvédelmi Tanácshoz hasonló, a rendkívüli állapotban az államfö, a parlament és a kormány 
szerepét is átvevő testületre találunk hasonló példát a szlovák jogi szabályozásban: Szlovákiában ilyen szerv a Parlamenti Tanács (a parlament akadályoztatása esetén) és a Biztonsági Tanács (a kormány akadályoztatása esetén). A kilencedik Alaptörvény-módosítás azonban a Honvédelmi Tanácsot megszünteti, feladatait a Kormány hatáskörébe utalja, ezzel is megerősítve a Kormány különleges jogrend idején betöltött szerepét.

Szintén közös vonásként jelenik meg, hogy a szlovák és a magyar szabályozás egyaránt alkotmányos szinten rendelkezik az alapjog-korlátozás legfontosabb szabályairól. A szlovák alkotmányhoz hasonlóan az Alaptörvényben is megtalálható az általános alapjog-korlátozási klauzula. Az alapjogok különleges jogrend esetén történő korlátozása tekintetében szintén hasonlóság mutatkozik, hiszen mindkét nemzeti szabályozásban megtalálható az alapjogok különleges jogrend esetén felmerülő korlátozhatósága. Különbséget láthatunk azonban az alapjog-korlátozás részletszabályai tekintetében - míg ezek Szlovákia esetében alkotmányos szinten, az Állambiztonsági alk.tv.-ben kerültek szabályozásra, addig Magyarországon e szabályozás tekintetében a törvényi szint az irányadó.

\section{Irodalomjegyzék}

BuRdová, L. (2011) 'Negatívní sociální jevy - možné zdroje ohrožení vnitřní bezpečnosti' in Suja, M. (szerk.) Zborník Metodológia a metodika analýzy zdrojov ohrozenia vnútornej bezpečnosti SR. 1. kiadás. Bratislava: Akadémia Policajného zboru v Bratislave

DoBRovičovÁ, G. (2020) Niekol'ko poznámok $k$ opatreniam Úradu verejného zdravotníctva Slovenskej republiky [Online]. Elérhető: https://comeniusblog.flaw.uniba.sk/2020/11/09/ niekolko-poznamok-k-opatreniam-uradu-verejneho-zdravotnictva-slovenskejrepubliky/ (Letöltve: 2020. december 13.)

DRGONEC, J. (2019) Ústava Slovenskej republiky. 2. kiadás. Bratislava: C. H. Beck

DRGONEC, J. (2012) 'Podmienky a právny účinok vyhlásenia núdzového stavu', Justičná revue, 64(1), 61-86. o.

FARKAS, Á., KelEMEN, R. (szerk.) (2020) Szkülla és Kharübdisz között-Tanulmányok a különleges jogrend elméleti és pragmatikus kérdéseiről, valamint nemzetközi megoldásairól. 1. kiadás. Budapest: Magyar Katonai Jogi és Hadijogi Társaság

GiBA, M. et al. (2019) Ústavné právo. 1. kiadás. Bratislava: Wolters Kluwer

Havelkové, M. (2020) 'Kompetencia nariad'ovat protipandemické opatrenia v čase trvania núdzového stavu a mimoriadnej situácie', COMENIUS časopis, 2020/2, 15-25. o.

Havelková, M. (2020) Metódy a formy činnosti verejnej správyv čase pandémie [Online]. Elérhetô: https://comeniusblog.flaw.uniba.sk/2020/04/25/metody-a-formy-cinnosti-verejnejspravy-v-case-pandemie-2-cast/ (Letöltve: 2020. december 1.)

JANČÁT, L., KostolansKÁ, E., LEICHMANN, J., ŠLAJS, J. (2020) 'Vyhlašování a soudní př̌eskum zvláštních stavů ve vybraných státech', Právní rozhledy, 27(13-14), 510-514. o. 
Kelemen, R. (2019) 'Az Alaptörvény szükségállapot-szabályozásának kritikai áttekintése az egyes európai uniós tagállamok alkotmányainak figyelembevételével - Különös tekintettel a visegrádi államok alkotmányaira' in Bartkó, R. (szerk.) A terrorizmus elleni küzdelem aktuális kérdései a XXI. században. 1. kiadás. Budapest: Gondolat Kiadó

MAJERČÁk, T. (2008) 'Ústavná koncepcia osobných práv a slobôd', Právny obzor, 91(1), 16-29. o. NÉMETH, L. (szerk.) (2016) Nemzetialkotmányokaz EU-ban. 1. kiadás. Budapest: Wolters Kluwer PíRY, M. (2020) Základné práva a povinnosti v čase pandémie, správne delikty a trestná činnost'. [Online]. Elérhető: www.epi.sk/odborny-clanok/zakladne-prava-a-povinnosti-v-casepandemie-spravne-delikty-a-trestna-cinnost.htm (Letöltve: 2020 . november 19.)

Svák, J., Cibul'Ka, L'., KlímA, K. (2013) Ústavné právo Slovenskej republiky (Všeobecná čast'). 4. kiadás. Žilina: Eurokódex a Paneurópska vysoká škola

ŠıмÁk, L. et al. (2005) Terminologický slovník krízového riadenia. 1. kiadás. Žilina: Fakulta špeciálneho inžinierstva Žilinskej Univerzity v Žiline

Šкroвák, J. (2020) Správne právo v časoch pandémie koronavírusu. Čast' prvá: Núdzový stav(?) [Online]. Elérhető: https://comeniusblog.flaw.uniba.sk/2020/03/15/spravne-pravo-vcasoch-pandemie-koronavirusu-cast-prva-nudzovy-stav/ (Letöltve: 2020. november 4.)

Venice Commission (2020) Interim Report on the Measures Taken in the EU Member States as a Result of the COVID-19 Crisis and Their Impact on Democracy, the Rule of Law and Fundamental Rights (Study No. 995/2020) [Online]. Elérhetô: www.venice.coe.int/webforms/ documents/?pdf=CDL-AD(2020)018-e (Letöltve: 2020 . december 15.) 


\section{Spanyolország, ahol a különleges jogrend valóban különleges}

NÉMETH ZOLTÁN

\section{A különleges jogrend alkotmányos és törvényi szintű szabályozása és a különleges jogrend esetkörei}

Spanyolország alkotmányának 116. cikke rögzíti a különleges jogrendre vonatkozó legáltalánosabb szabályokat. ${ }^{1}$ E szakasz megkülönböztet riadókészültséget (el estado de alarma), szükségállapotot (el estado de excepción) és rendkívüli állapotot/ostromállapotot (el estado de sitio). ${ }^{2}$

A rendkívüli állapoti típusú szabályozás egy hibrid típust takar Spanyolország esetében, hiszen magában foglalja a magyarországi szükségállapoti tényállásból azokat, amelyek az állam alkotmányos rendjére irányuló belső támadásokat fogja össze, így a nem nemzetközi fegyveres összeütközés típusait, azaz a polgárháborút, az ellenállási mozgalmat, a tömegfelkelést, valamint a felkelést. Emellett viszont külső erőszakos cselekményekre is reagál. Nyilvánvalóan ez a szabályozási mód egyfajta reakció a történelmi tapasztalatokra vagy épp az elszakadni vágyó, jelenleg autonómiát élvező közösségek esetleges szeparatista

1 Vidal Prado-Delgado Ramos, 2011, 247. o.

2 Spanyolország alkotmánya (Constitución Española) 116. cikk.

Németh Zoltán, LLM

zoltan.nemeth@mfi.gov.hu

kutató (Mádl Ferenc Összehasonlító Jogi Intézet)

Németh, Z. (2021) 'Spanyolország, ahol a különleges jogrend valóban különleges' in Nagy, Z., Horváth, A. (szerk.) A különleges jogrend és nemzeti szabályozási modelljei, 549-562. o. Budapest: Mádl Ferenc Összehasonlító Jogi Intézet.

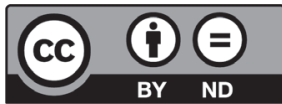


radikalizálódására, ami a katalánok vagy a baszkok kapcsán messze nem lehetetlen narratíva. Ebből adódóan szerencsésebb a tényállást ostromállapotnak nevezni. ${ }^{3}$

A spanyol alkotmányban még három elfogadott elôírás létezik különleges jogrendi esetekre, nevezetesen a 30. cikk (4) bekezdés, miszerint törvény útján szabályozandók az állampolgárok kötelességei súlyos veszélyhelyzet, katasztrófa vagy közveszély esetén. Az alkotmány 117. cikk (5) bekezdése pedig kimondja, hogy különleges jogrendi helyzet esetén a képviselőház nem oszlatható fel. A 169. cikk pedig rögzíti, hogy nem kezdeményezhető alkotmánymódosítás akkor, ha a 116. cikkben szabályozott különleges jogrendi helyzet van érvényben. ${ }^{4}$

Rendkívüli körülmények esetén előnyösebb olyan kivételes szabályozást biztosítani, amely az alacsonyabb rendú jog forrásait, amelyeket a végrehajtó hatalom korábban megalkotott, háttérbe szorítja azáltal, hogy alkotmányosan megvédi a törvényhozó hatalom hatásköreit a jogalkotás területén. ${ }^{5}$

A spanyol alkotmányjogászok közül Fernando Segadó megvédte a különleges jogrendi szabályozást, és kvázi körülmények halmazaként értelmezi és olyan helyzetek következményeként tekinti azokat, mint amelyek megzavarják a közhatalom normális múködését és fenyegetik az állam alapvetô intézményeit és elveit, és amelyek hatása az, hogy koncentrálni kell a kormányzati hatalmat. Azonban ha a kormány felhatalmazást kap diszkrecionális jogkörök alkalmazására kivételes körülmények között, vagy ha a hatáskörök diszkrecionális igénybevételéhez erre szükség van, akkor ez csak úgy múködtethető, ha biztosított annak folyamatos ellenőrzése. ${ }^{6}$

A spanyol alkotmány szabályozási rendszerével kapcsolatban fontos megemlíteni azt, hogy legfontosabb alapelve a különleges jogrendi szabályoknak az arányosság elve, amely nélkülözhetetlen a megfelelő jogszabályok megalkotása során.

Ostromállapot ${ }^{7}$ elrendelhető minden olyan esetben, amikor Spanyolország szuverenitását, függetlenségét, területi integritását vagy alkotmányos rendjét veszélyeztető erőszakos cselekmény leküzdése más eszközökkel nem valósítható meg.

Szükségállapoti típusú szabályozásból két tényállás található a spanyol alkotmányban: a riadókészültség és a szükségállapot.

A riadókészültség hasonlít a magyar veszélyhelyzetre, de emellett válsághelyzet típusú tényállásokat is tartalmaz. Riadókészültség akkor rendelhető el, ha az ország egész területén vagy annak egy részén az állam múködését súlyosan zavaró természeti vagy ipari

3 Kelemen, 2020, 222. o.

4 Lafuente Balle, 1989, 25. o.

5 Lafuente Balle, 1989, 26. o.

6 Lafuente Balle, 1989, 27. o.

7 1981/4. sz. törvény a szükségállapotról (Ley Orgánica 4/1981, de 1 de junio, de los estados de alarma, excepción y sitio) (a továbbiakban: Szükségállapoti tv.) 
katasztrófa, illetve egészségügyi válság alakult ki, vagy alapvető közszolgáltatások megbénultak, továbbá elsődleges szükségleti termékek kritikus hiánya alakult ki. ${ }^{8}$

Amikor a polgárok jogainak és szabadságainak szabad gyakorlása, a demokratikus intézmények normális múködése, a közösség számára elengedhetetlen közszolgáltatások vagy a közrend bármely más aspektusa annyira súlyosan megváltozik, hogy a rendes hatáskörök nem voltak elegendők annak helyreállításához és fenntartásához, a kormány az alkotmány 16. cikkének 3. szakaszával összhangban felhatalmazást kérhet a képviselőháztól a szükségállapot kimondásához. ${ }^{9}$

Jól látható módon ezzel a kettősséggel az alkotmányozó lehetôvé kívánta tenni, hogy a mindenkori kormányzat az állam múködését zavaró kisebb súlyú anomáliákat is hatékonyabban kezelje, hogy azok magasabb eszkalációs fokra ne juthassanak. ${ }^{10}$ Ezt erősíti az ország alkotmányában ${ }^{11}$ található felhatalmazás, valamint a kormánynak ${ }^{12}$ adott jogalkotási hatáskör is. Az alkotmány ugyanis lehetôvé teszi, hogy az abban foglalt alapjogi garanciákat felfüggesszék organikus törvénybe foglalt keretek között, amennyiben a vizsgálat tárgya fegyveres szervezettel vagy terrorista csoporttal kapcsolatos tevékenység. ${ }^{13}$

A 86. cikk pedig arra biztosít lehetőséget, hogy rendkívüli szükség és sürgősség esetén a kormány törvényerejú rendelet formájában ideiglenesen törvénypótló rendelkezéseket hozhat. Azzal a megszorítással, hogy tiltott tárgykört képez az állam alapvető intézményeire vonatkozó joganyag, az I. cím alatti alapvető jogok és kötelezettségek, autonóm közösségek rendszerére vonatkozó joganyag, valamint az általános választójog. Emellett a rendeletet a kihirdetést követő 30 napon belül a képviselőház elé kell terjeszteni, amely vagy helyben hagyja és ezzel a törvények sorába lépteti, vagy pedig hatályon kívül helyezi. ${ }^{14}$

A különleges jogrendi tényállások elrendelési szabályai tekintetében is megfigyelhető az a fokozatosság, ${ }^{15}$ amit a tényállási szinten a három különleges jogrendi kategória felépítése mutat. Ennek értelmében a riadókészültséget a kormány minisztertanácsi rendelet útján hirdeti ki. A rendeletben meg kell határozni a riadókészültség területi hatályát és időtartamát is, és az időbeli hatálya legfeljebb 15 nap lehet. Erről be kell számolni a képviselőháznak, amely szükség esetén felhatalmazást adhat a rendelet időbeli hatályának meghoszszabbítására. ${ }^{16} \mathrm{Ha}$ csak valamely autonóm közösség területére terjed ki, akkor annak elnöke is kezdeményezheti a kormánynál a riadókészültség bevezetését, a meghosszabbításról való döntés ebben az esetben is a képviselőház jogköre.

\footnotetext{
8 Szükségállapoti tv. 4 . cikk.

9 Szükségállapoti tv. 13. cikk (1) bekezdés.

10 Kelemen, 2020, 224. o.

11 Alkotmány 55. cikk.

12 Alkotmány 86. cikk.

13 Alkotmány 17-18. cikk.

14 Alkotmány 86. cikk.

15 Kelemen, 2020, 225. o.

16 Alkotmány 116. cikk (2) bekezdés.
} 
A szükségállapotot a kormány rendeletben hirdeti ki, azonban a rendeletet előzetesen jóvá kell hagynia a képviselőháznak. A kormány kérelemben fordul a képviselőházhoz, amelyben többek között meg kell határoznia az érintett alapjogok körét [amely kizárólag az 55. cikk (1) bekezdésére szorítkozhat], a bevezetni tervezett intézkedések körét, a szükségállapottal érintett földrajzi területet, valamint annak tervezett időtartamát, amely 30 napnál hosszabb nem lehet. Utóbbi 30 nap a képviselőháztól kapott felhatalmazás alapján ugyanennyi időre meghosszabbítható. ${ }^{17}$

Ostromállapotot a kormány kérelmére a képviselőház abszolút többséggel rendelhet el. Az elrendelő határozatban meg kell határozni az ostromállapot kereteit, területi és időbeli hatályát. ${ }^{18}$

Tehát a fokozatosság érzékelhetô az elrendelésre vonatkozó szabályozásban is, hiszen míg a válsághelyzeti típusú felhatalmazáshoz elég a kormány döntése, a szükségállapoti felhatalmazáshoz már tartalmában kell a képviselőház jóváhagyása, míg végül az ostromállapot kizárólag a képviselőház abszolút többségű döntése alapján rendelhető el.

Mindhárom különleges jogrendi tényállás esetében a felhatalmazott a kormány. Ez következik az alkotmány 97. cikk szerinti rendelkezéseiből, amelyek szerint a kormány irányítja a bel- és külpolitikát, a polgári és katonai közigazgatást, valamint az állam védelmét. Az alkotmány rögzíti továbbá, hogy árulás és az állam biztonságát veszélyeztető bưncselekmény esetén a kormány tagja felelősségre vonható, amely felelősségre vonás kapcsán a király kegyelmi joga nem érvényesíthető. ${ }^{19}$

A riadókészültség idején a rendelet által érintett terület közigazgatásának valamennyi polgári hatósága, az autonóm közösségek rendőri testületei és a helyi társaságok tagjai, továbbá a szolgálatban lévő egyéb tisztviselók és munkavállalók a kormány irányítása alatt álló illetékes hatóság utasításai szerint kötelesek a személyek, vagyontárgyak és az infrastruktúra biztonságához szükséges, rendkívüli szolgáltatások teljesítésére. Az érintett területi hatóságok kérhetik az állam közbiztonsági szerveinek a közremúködését. Ezen időszakokban korlátozható többek között a mozgás szabadsága, a fogyasztás egyes termékekre, de iparirányítási szabályok is kiadhatók. ${ }^{20}$

Szükségállapot idejére szintén a kormány a felhatalmazott, amely az organikus ${ }^{21}$ törvényben meghatározott módon alapjogokat is korlátozhat. ${ }^{22}$ Ezek alapján a kormány módosíthatja a fogva tartás, a házkutatás és a (postai, telefonos kommunikációs) megfigyelés szabályait, korlátozhatja a mozgás szabadságát és a sajtószabadságot, lefoglalhat kiadványokat, de ezek egyike sem eredményezhet eloozetes cenzúrát. Korlátozhatja továbbá a gyülekezési jogot, amelyhez társul a feloszlatás jogosítványa is, kivéve az alkotmány 6-7. cikke szerinti párt- és szakszervezeti gyûléseket. Betilthatja a kollektív munkaügyi kapcsolatok munkavál-

17 Alkotmány 116. cikk (3) bekezdés.

18 Alkotmány 116. cikk (4) bekezdés.

19 Alkotmány 97. és 102. cikk.

20 Szükségállapoti tv. 9-12. cikk.

21 Olyan jogi norma, amelynek az elfogadásához a spanyol alkotmány abszolút vagy minősített többséget ír elő, a benne szabályozott tárgykör fontossága miatt.

22 Kelemen, 2020, 227. o. 
lalói érdekérvényesítő eszközeit, rendelkezhet a fegyver, lőszer, robbanóanyag lefoglalásáról, bevezethet ipari korlátozásokat, felhatalmazást adhat objektumvédelemre. ${ }^{23}$

Ostromállapot idején szintén a kormány a felhatalmazott, amely mind a riadókészültség, mind a szükségállapot esetére meghatározott eszközökkel, intézkedésekkel élhet, továbbá az érintett területeken bevezetheti a katonai közigazgatást, amely koordinálja a szükséges intézkedéseket a hatóságok egyidejű tájékoztatása mellett. Ezeken felül a polgári hatóságok gyakorolnak minden olyan hatáskört, amelyet a kormány kifejezetten nem ruház a katonai szervekre, de a polgári hatóságokat a szükséges mértékben jelentéstételi kötelezettség terheli a katonai hatóságok irányában. Az érintett területen a képviselőház által meghatározott bưncselekmények körére bevezethetik a katonai igazságszolgáltatást is. ${ }^{24}$

Az operativitást segítő szabályok mellett a garanciák széles tárházát is felsorolja a spanyol alkotmány. A képviselőház különleges jogrend idején nem oszlatható fel, és bizonyos esetekben kötelezően össze kell hívni annak ülését. Ha feloszlatás vagy megbízatásának lejárta idején válik szükségessé valamely különleges jogrend elrendelése, akkor egy állandó küldöttséget kell múködtetni. A kormánynak pedig a riadókészültség idején kiadott rendeletéről tájékoztatnia kell a képviselőházat.

Az állam többi alkotmányos szervének müködése szintén nem szakítható meg, emellett a fentebb már érintett, kormányra vonatkozó felelősségi szabályok sem változtathatók meg. Rendkívüli bíróság nem hozható létre, és különleges jogrend idején nem kezdeményezhető az alkotmány módosítása sem. Az alkotmány ${ }^{25}$ pedig felsorolja azokat a jogokat, amelyeket szükségállapot vagy ostromállapot idején fel lehet függeszteni.

\section{Alapjog korlátozásával kapcsolatos kérdések}

A spanyol alkotmány az alapvetô jogok és kötelességek fejezetében szabályozza az állampolgárok alapvető jogait és ezek esetleges korlátozhatóságát, illetve külön kitér arra is, hogy különleges jogrendi helyzetben mely jogok gyakorlását lehet felfüggeszteni. Az alkotmányban szabályozott alapjogok egy része semmilyen körülmények között sem korlátozható, egyes alapjogok viszont korlátozhatók bizonyos körülmények fennállása esetén.

A nem korlátozható alapjogok:

— az élethez, testi és szellemi épséghez való jog (15. cikk);

- az embertelen, megalázó büntetés vagy bánásmód tilalma (15. cikk);

- a gondolati, lelkiismereti és vallásszabadság (16. cikk);

- az elítélés tilalma olyan bưncselekmény miatt, amely az elkövetés időpontjában nem minősült büncselekménynek (25. cikk). 
Az alapjogok másik csoportjába tartoznak azok, amelyek meghatározott esetekben korlátozhatók vagy törvénnyel, vagy bírói döntéssel.

\begin{tabular}{|l|l|}
\hline \multicolumn{1}{|c|}{ Alapjog } & \multicolumn{1}{|c|}{ Milyen esetben korlátozható? } \\
\hline $\begin{array}{l}\text { Szabadság és személyi biztonsághoz való jog } \\
\text { (17. cikk) }\end{array}$ & Törvénnyel korlátozható. \\
\hline $\begin{array}{l}\text { Becsülethez, családhoz, magánélethez és saját } \\
\text { képmáshoz való jog (18. cikk) }\end{array}$ & $\begin{array}{l}\text { Törvénnyel szabályozható az adatfelhasználás, } \\
\text { és tettenérés esetén is kivételt lehet tenni. }\end{array}$ \\
\hline $\begin{array}{l}\text { Lakóhely szabad megválasztása, szabad mozgás } \\
\text { az ország területén (19. cikk) }\end{array}$ & $\begin{array}{l}\text { Törvénnyel korlátozható, viszont politikai vagy } \\
\text { ideológiai okból nem. }\end{array}$ \\
\hline $\begin{array}{l}\text { Véleménynyilvánítás szabadsága, alkotás sza- } \\
\text { badsága, tanítás szabadsága, valós információ } \\
\text { közlése (20. cikk) }\end{array}$ & $\begin{array}{l}\text { Gyakorlásuk nem korlátozható, azonban korlátot } \\
\text { szab a becsület, a magánélet, a saját képmáshoz } \\
\text { való jog és az ifjúság és gyermekkor védelme. }\end{array}$ \\
\hline $\begin{array}{l}\text { A békés és fegyvertelen gyülekezési szabadság } \\
\text { (21. cikk) }\end{array}$ & Korlátja az előzetes bejelentési kötelezettség. \\
\hline $\begin{array}{l}\text { Egyesülési jog (22. cikk) } \\
\text { Választójog (23. cikk) }\end{array}$ & $\begin{array}{l}\text { Törvény szabályozza a létrehozásukat, és csak } \\
\text { bírói döntés kell a feloszlatáshoz vagy a tevé- } \\
\text { kenység felfüggesztéséhez. }\end{array}$ \\
\hline $\begin{array}{l}\text { Bírák és bíróságok általi védelem joga és a bíró- } \\
\text { sághoz fordulás joga (24. cikk) }\end{array}$ & Törvény szabályozza. \\
\hline Oktatáshoz való jog (27. cikk) szabályozza. \\
\hline Szakszervezethez csatlakozás joga és sztrájkjog
\end{tabular}

\section{3. táblázat}

Azalapjogok korlátozhatósága Spanyolországban

Forrás: a szerző saját szerkesztése

A fenti táblázatban bemutatott alapjogok és szabadságok köteleznek minden állami szervet, és csak törvény szabályozhatja ezen jogoknak és szabadságjogoknak a gyakorlását, de a törvénynek minden esetben kötelessége tiszteletben tartania azok lényegi tartalmát. ${ }^{26}$ 
Az egyes alapjogok korlátozhatóságán túl az alkotmány 55 . cikke ${ }^{27}$ szabályozza azokat az eseteket, amikor az egyes jogok felfüggeszthetők szükségállapot vagy ostromállapot esetén:

\begin{tabular}{|l|l|}
\hline \multicolumn{1}{|c|}{ Alapjog } & \multicolumn{1}{|c|}{$\begin{array}{c}\text { Mikor függeszthető fel az 55. cikk } \\
\text { alapján? }\end{array}$} \\
\hline Szabadság, személyi biztonság (17. cikk) & Szükségállapot és ostromállapot esetén. \\
\hline Magánlakás és magántitok védelme [18. cikk (2)-(3)] & Szükségállapot és ostromállapot esetén. \\
\hline $\begin{array}{l}\text { Szabad mozgás és lakóhely szabad megválasztása } \\
\text { (19. cikk) }\end{array}$ & Szükségállapot és ostromállapot esetén. \\
\hline $\begin{array}{l}\text { Szólásszabadság [20. cikk (a) - véleménynyilvánítás } \\
\text { szabadsága és (d) - valós információ szabad közlése] }\end{array}$ & Szükségállapot és ostromállapot esetén. \\
\hline Békés és fegyvertelen gyülekezési szabadság (21. cikk) & Szükségállapot és ostromállapot esetén. \\
\hline Sztrájkjog [28. cikk (2)] & Szükségállapot és ostromállapot esetén. \\
\hline $\begin{array}{l}\text { A kollektív munkaügyi vita esetén nyújtott szolgálta- } \\
\text { tások [37. cikk (2)] }\end{array}$ & Szükségállapot és ostromállapot esetén. \\
\hline
\end{tabular}

24. táblázat

Szükségállapot vagy ostromállapotesetén felfüggeszthető alapjogok Spanyolországban Forrás: a szerzősaját szerkesztése

Spanyolország történetében a 2020-as koronavírus-járvány mellett 2010-ben került bevezetésre különleges jogrend a légiforgalmi irányítás válsága miatt.

A szükségállapot kimondásának egyetlen esete 2010-ben történt, amikor munkaügyi viták alakultak ki az AENA (Spanyol Repülőtéri és Légnavigációs Társaság) és a polgári légiforgalmi irányítók között, akiket arra késztettek, hogy hagyják el munkahelyüket, ami gyakorlatilag a spanyol légtér bezárását okozta. Szembesülve ezzel a helyzettel a Szükségállapoti $t v{ }^{28}$ alapján a kormány kinyilvánította a szükségállapotot, tekintettel arra, hogy egy alapvető közszolgáltatás, a légi közlekedés megbénulása következett be. ${ }^{29}$

A fent említett királyi rendeletben a legrelevánsabb - és lényegében egyedüli - intézkedés a következő: „az AENA szolgálatában álló összes légiforgalmi irányító a szükségállapot érvényessége alatt a katonai személyzet felügyelete alá tartozik". Ennek ellenére 15 nap sem volt elegendő a helyzet megnyugtató kezelésére, ezért a szükségállapotot meghosszabbították.

27 Alkotmány 55. cikk.

28 Szükségállapoti tv. 4. cikk (b) pont.

29 Vidal Prado-Delgado Ramos, 2011, 247. 0. 


\section{Az egészségügyi vészhelyzet kezelése, koronavírus-járvány}

\subsection{A koronavírus-járvány első hulláma}

2010 óta szükségállapotot kizárólag a koronavírus miatt kellett bevezetni Spanyolországban. Több EU-tagállamhoz hasonlóan Spanyolországban is a kormány döntött a szükségállapot bevezetéséről. ${ }^{30} \mathrm{~A} 2020$. március 14-én kihirdetett királyi rendelettel a kormány az egész ország területére szükségállapotot hirdetett ki 15 napra, azaz 2020. március 29-ig, ${ }^{31}$ és ezt követően időszakonként újra és újra meghosszabbították. Erre azért volt szükség, hogy az állampolgárok egészségét és biztonságát védjék, és ezzel korlátozzák a járvány terjedését, illetve megerősítsék a közegészségügyi rendszert.

Érdemes megemlíteni, hogy a viszonylag rövid időre megadott felhatalmazás azzal a hátránnyal jár, hogy azt elég sứrú időközönként szükséges meghosszabbítani. A kormány 2020. március 14-én jóváhagyta, hogy a Covid-19által okozott egészségügyi vészhelyzettel szemben egész Spanyolország területén szükségállapotot hirdessenek, ezt később 2020. június 21. 00:00 óráig meghosszabbították, majd a kormány 2020. október 25-én jóváhagyta az ország egész területére érvényes szükségállapotot, amelynek időtartama 2020. november 9. 00:00 óráig szólt volna, azonban ezt 2021. május 9.00:00 óráig meghosszabbították.

A szükségállapot esetén az illetékes hatóság a kormány, azonban a különféle feladatok delegálásra kerültek egyes miniszterekhez, így a járványhelyzet kezelésében a honvédelmi miniszter, a belügyminiszter, a közlekedési miniszter és az egészségügyi miniszter játszott kulcsszerepet. Utóbbi olyannyira, hogy olyan esetekben, amikor egyik miniszter sem illetékes, az egészségügyi minisztert tették meg illetékes miniszternek. ${ }^{32}$

A jogszabály tartalmazta a személyek szabad mozgását jelentősen korlátozó intézkedéseket, miszerint a szükségállapot érvényességének ideje alatt a közutakon csak a következő tevékenységek végzése érdekében szabad közlekedni: élelmiszerek, gyógyszerek és alapvető szükségletek körébe tartozó termékek beszerzése; segítésnyújtás az egészségügyi központoknak, szolgáltatóknak és intézményeknek; munkába járás, üzleti tevékenység folytatása, visszatérés a szokásos tartózkodási helyre; idősek, kiskorúak, eltartottak, fogyatékossággal élő vagy különösen kiszolgáltatott helyzetú emberek segítése és gondozása; utazás pénzügyi és biztosítási szervezetekhez vis maior vagy szükséghelyzet miatt. ${ }^{33}$ Fontos rendelkezés még, hogy minden utazás során be kell tartani az egészségügyi hatóságok által kiadott ajánlásokat.

30 Venice Commission, 2020, 13. o.

31 463/2020. sz. királyi rendelet a Covid okozta válsághelyzet kezeléséről (Real Decreto 463/2020, de 14 de marzo, por el que se declara el estado de alarma para la gestión de la situación de crisis sanitaria ocasionada por el COVID-19) (a továbbiakban: a Covid okozta válsághelyzet kezeléséről szóló királyi rendelet).

32 A Covid okozta válsághelyzet kezeléséről szóló királyi rendelet.

33 A Covid okozta válsághelyzet kezeléséről szóló királyi rendelet 7. cikk. 
A jelenléti oktatást Magyarországhoz hasonlóan Spanyolországban is felfüggesztették, és ez vonatkozott az állami és a magánoktatási tevékenységekre egyaránt. A felfüggesztés ideje alatt az oktatási tevékenységeket lehetőség szerint online módokon keresztül tartották fenn. ${ }^{34}$

A kiskereskedelmi üzletek és létesítmények nyitva tartását is felfüggesztették, kivéve az élelmiszert, italt, alapvetô szükségleti cikkeket árusító üzleteket, a gyógyszerészeti, orvosi, optikai és ortopédiai szolgáltatást nyújtó üzleteket, fodrászatokat, újságárusokat, irodaszereket árusító üzleteket, benzinkutakat, dohányboltokat, állateledelboltokat és a mosodákat. Minden egyéb tevékenység vagy létesítmény, amely az illetékes hatóság véleménye szerint fertőzésveszélyt jelenthet, felfüggesztésre került. ${ }^{35} \mathrm{~A}$ múzeumok, levéltárak, könyvtárak, múemlékek bezártak. A sporteseményeket is csak zárt kapuk mögött lehetett megrendezni. A szállodai és éttermi tevékenységek szüneteltek a járvány első hullámában, és csak házhozszállítási szolgáltatásokat lehetett nyújtani. A fesztiválok, felvonulások szintén szüneteltek. $\mathrm{Az}$ istentiszteleteken, valamint a polgári és vallási szertartásokon (beleértve a temetéseket is) biztosítani kellett, hogy nagyobb tömeg ne alakuljon ki. Ezt oly módon kellett biztosítani, hogy garantálják, hogy a jelenlévők legalább egyméteres távolságban lehetnek egymástól. ${ }^{36}$

Hazánkhoz és az EU-tagállamokhoz hasonlóan a koronavírus-járvány első hulláma során Spanyolországban is komplex intézkedéscsomagot fogadtak el, amely a fent említetteken kívül tartalmazott még intézkedéseket a nemzeti egészségügyi rendszer egész ország területén történő megerősítésével kapcsolatban, a közegészség védelmével összefüggésben, a közúti, vasúti és légi közlekedéssel kapcsolatban, valamint az élelmiszer-ellátás biztonságának fenntartásával kapcsolatban is. Kiemelten foglalkozott a spanyol jogalkotó a kritikus infrastruktúrák védelmével, ${ }^{37}$ valamint a földgáz- és a villamosenergia-ellátás biztonságával is. Külön említést érdemel egy olyan intézkedés, amely a köz-, illetve magántulajdonban lévő médiával kapcsolatban előírta, hogy azok kötelesek hitelesen tájékoztatni, és kötelesek olyan üzeneteket, közleményeket közzétenni, amelyeket a felhatalmazott illetékes hatóságok, valamint a regionális és helyi közigazgatás szükségesnek tart ${ }^{38} \mathrm{~A}$ jogalkotó így kívánta biztosítani azt, hogy a lakosság lehetőség szerint a jelenlegi helyzetben is hiteles tájékoztatáshoz jusson.

Magyarországhoz nagyon hasonlóan Spanyolországban is felfüggesztésre kerültek az eljárási és adminisztratív határidők, még az elévülés határideje is. Ezek az intézkedések azt a célt szolgálták, hogy minél inkább csökkenteni lehessen a különféle ügyintézések számát és ezzel az emberek mozgását.

Spanyolország ugyan igyekezett a járványügyi intézkedéseket egységesen kezelni, de Magyarországgal ellentétben az egyes tartományok, autonóm közösségek is hoztak korlátozó intézkedéseket. A királyi rendeletben megerősítették az autonóm közösségek és a helyi kö-

34 A Covid okozta válsághelyzet kezeléséről szóló királyi rendelet 9. cikk.

35 A Covid okozta válsághelyzet kezeléséről szóló királyi rendelet 10. cikk.

36 A Covid okozta válsághelyzet kezeléséről szóló királyi rendelet 11. cikk.

37 8/2011., a kritikus infrastruktúrák védelméről szóló törvény (Ley 8/2011, de 28 de abril, por la que se estable-

cen medidas para la protección de las infraestructuras críticas).

38 A Covid okozta válsághelyzet kezeléséről szóló királyi rendelet 9., 11., 19. cikk. 
zösségek illetékes hatóságai által a koronavírus-járvány első hulláma alkalmával korábban elfogadott összes rendelkezést és intézkedést, amelyek továbbra is érvényben maradtak, feltéve, hogy kompatibilisek ezzel a rendelettel. ${ }^{39}$

A koronavírus-járvány első hullámának kvázi lezárásaként egy külön jogszabályban rendelkeztek az egyes intézkedések felfüggesztéséról 2020. június 4-én. ${ }^{40}$

A spanyol kormány intézkedéseit több éles kritika is érte, különösen amiatt, hogy az Európát is érintô második hullám egyik mutációja éppen Spanyolországban szedte áldozatait.

\subsection{A koronavírus-járvány második hulláma}

A járvány második hulláma már Spanyolországot is sokkal felkészültebben érte, mivel a tavaszi események során sok olyan tapasztalatot szereztek az egészségügyi hatóságok, amelyek segítségükre voltak a járvány hatékony kezelésében.

A 2020. október 25-i királyi rendelettel ${ }^{41}$ ismét szükségállapotot hirdetett a kormány a fertőzések terjedésének visszaszorítására, tekintettel a diagnosztizált esetek számának emelkedő tendenciájára és az egészségügyi nyomásra. E királyi rendelet révén különféle intézkedéseket hoztak a vírus terjedésével szemben. Először is megállapították az emberek éjszakai szabad mozgásának korlátozását annak érdekében, hogy a lehető legnagyobb mértékben elkerüljék a fertőzés terjedését ebben az időszakban. A rendelet bevezetésének indokolása ${ }^{42}$ szerint a kockázatos találkozások jó része éjszaka fordult elő az autonóm közösségek tájékoztatása szerint, ami jelentősen csökkenti az egyéb végrehajtott ellenőrzési intézkedések hatékonyságát. Emiatt az éjszakai mobilitás korlátozása arányos intézkedésnek minősül, amelynek pozitív hatása lehet a járvány terjedésére.

Hasonlóképpen lehetőség van az autonóm közösségek és városok autonómiastatútummal rendelkező területeinek az emberek be- és kilépésének korlátozására, bizonyos kivételekkel. Ezenkívül megteremtették annak lehetőségét, hogy korlátozzák az embercsoportok köz- és magántereken való csoportosulását, így a társadalmi mobilitás is visszaszorul.

A koronavírus második hulláma Spanyolországban is elindított egy intenzív második jogalkotási hullámot, amelynek eredménye számos királyi rendelet kihirdetése lett azzal a céllal, hogy egyrészt fékezzék az elszabadult járvány terjedését, másrészt pedig mérsékeljék a járvány okozta gazdasági károkat. Ilyen fontos jogszabály többek között a vállalkozások fizetőképes-

39 A Covid okozta válsághelyzet kezeléséről szóló királyi rendelet 11. cikk záró rendelkezés.

40 A Jogi és Közbiztonsági Főigazgatóság 2020. június 4-i utasítása a Covid-19 egészségügyi válsága által elfogadott intézkedések feloldásáról (Instrucción de 4 de junio de 2020, de la Dirección General de Seguridad Jurídica y Fe Pública, sobre levantamiento de medidas adoptadas por la crisis sanitaria del COVID-19).

41 956/2020. királyi rendelet a 926/2020. királyi rendelet kiterjesztéséről (Real Decreto 956/2020, de 3 de noviembre, por el que se prorroga el estado de alarma declarado por el Real Decreto 926/2020, de 25 de octubre, por el que se declara el estado de alarma para contener la propagación de infecciones causadas por el SARS-CoV-2.).

42 956/2020. királyi rendelet a 926/2020. királyi rendelet kiterjesztéséről. 
ségének biztosításáról${ }^{43}$ és az energiaágazat támogatásáról, valamint az egyes adoü̈gyi intézkedésekról, amelyeket november 17-én léptettek hatályba; a november 3-i királyi törvényerejứ ${ }^{44}$ rendelet, amely sürgős intézkedéseket fogadott el a szociális szektor állami szintű támogatásával kapcsolatban; a november 3-i királyi törvényerejú rendelet, amely jóváhagyta a munkanélküliek védelmét és a kulturális ágazat támogatását célzó kiegészítő szociális intézkedéseket; ${ }^{45}$ a szeptember 29-i királyi törvényerejû́ rendelet a Covid-19 által okozott egészségügyi válság kezelésére irányuló sürgős intézkedésekről a közigazgatásban alkalmazható távmunka és a nemzeti egészségügyi rendszer emberi erőforrásaival kapcsolatban; ${ }^{46}$ a szeptember $29-\mathrm{i}^{47}$ királyi törvényerejû́ rendelet, amely sürgős intézkedéseket fogadott el a nem egyetemi szintû oktatás területén; a szeptember $29-\mathrm{i}^{48}$ királyi rendelet, amely szabályozza az idegenforgalmi ágazat különböző szervezeteinek az Ipari, Kereskedelmi és Idegenforgalmi Minisztérium által a 2020-as költségvetési év során nyújtott közvetlen támogatását, a gazdaság újraélesztését; végül a foglalkoztatást támogató sürgős intézkedésekről szóló, július 3-i9 királyi törvényerejû rendelet. A felsorolt jogszabályokon kívül hazánkhoz hasonlóan a spanyol kormány is számos más területen hozott intézkedéseket: a Covid-19-alap létrehozása; a foglalkoztatás támogatása; a halászat segítése; kereskedelem, kultúra, utazás az ország területére.

\section{A különleges jogrend és a járványügyi vészhelyzet kihirdetésével kapcsolatos tapasztalatok, jogviták}

A spanyolországi Covid-19-re vonatkozó szabályozásról folytatott viták hasonló aggályokat tükröznek, mint más országokban. A közvélemény és a politikai pártok elsősorban

43 34/2020. királyi rendelet a vállalkozások fizetôképességének és az energiaágazat támogatásának sürgős intézkedéseiről (Real Decreto-ley 34/2020, de 17 de noviembre, de medidas urgentes de apoyo a la solvencia empresarial y al sector energético, y en materia tributaria).

44 33/2020. királyi rendelet a szociális szektor állami szintú támogatásával kapcsolatos sürgós intézkedésekről (Real Decreto-ley 33/2020, de 3 de noviembre, por el que se adoptan medidas urgentes de apoyo a entidades del Tercer Sector de Acción Social de ámbito estatal).

45 32/2020. királyi rendelet a munkanélküliek védelméról és a kulturális ágazat megsegítéséról (Real Decreto-ley $32 / 2020$, de 3 de noviembre, por el que se aprueban medidas sociales complementarias para la protección por desempleo y de apoyo al sector cultural).

46 29/2020. királyi rendelet a közigazgatási távmunkáról és az egészségügy humánerőforrásáról (Real Decreto-ley 29/2020, de 29 de septiembre, de medidas urgentes en materia de teletrabajo en las Administraciones Públicas y de recursos humanos en el Sistema Nacional de Salud para hacer frente a la crisis sanitaria ocasionada por la COVID-19).

47 31/2020. királyi rendelet a nem egyetemi oktatással kapcsolatos sürgős intézkedésekról (Real Decreto-ley 31/2020, de 29 de septiembre, por el que se adoptan medidas urgentes en el ámbito de la educación no universitaria).

48 866/2020. királyi rendelet az idegenforgalmi ágazatnak nyújtott támogatásokról (Real Decreto 866/2020, de 29 de septiembre, por el que se regula la concesión directa de subvenciones a diversos organismos y entidades del sector turístico por el Ministerio de Industria, Comercio y Turismo, durante el ejercicio presupuestario 2020.).

49 25/2020. királyi rendelet a gazdaság és a foglalkoztatás újraindításáról (Real Decreto-ley 25/2020, de 3 de julio, de medidas urgentes para apoyar la reactivación económica y el empleo). 
abban nem értenek egyet, hogy a közintézmények időben vagy későn reagáltak-e, valamint a válság kezelésében alkalmazott intézkedésekről és a használt jogi eszközökrőll.

Egyes spanyol alkotmányjogászok megvédték a különleges jogrendi szabályozást. Az ő értelmezésük szerint a különleges jogrend olyan helyzetek következménye, amelyek megzavarják a közhatalom normális múködését, fenyegetik az állam alapvető intézményeit és elveit, és amelyek hatása az, hogy koncentrálni kell a kormányzati hatalmat. Azonban ha a kormány felhatalmazást kap diszkrecionális jogkörök alkalmazására kivételes körülmények között, vagy ha a hatáskörök diszkrecionális igénybevételéhez erre szükség van, akkor ez csak úgy múködtethető, ha biztosított annak folyamatos ellenőrzése. ${ }^{50}$

A koronavírus-járvány miatt hozott intézkedések ellen négy régió (La Rioja, Katalónia, Extremadura és Murcia) emelt kifogást, mivel azok a mozgásszabadság alapvető jogának nyilvánvaló sérelmét jelentették állampolgáraik részére. Mindezek a régiók éltek az egészségügyi és sürgősségi jogi rendelkezésekben biztosított jogaikkal és kifogásolták a korlátozó intézkedéseket. Ezen a ponton a központi kormányzat deklarálta álláspontját, miszerint a mozgásszabadság korlátozása Spanyolország egész területére kiterjed, és néhány kivételtől eltekintve a tevékenységek korlátozása is országos hatókörủ (a kivételek: egészségügyi és szociális munkások; élelmiszerboltok és élelmiszer-eloállítás; ipar, építőipar, banki szolgáltatások; média; energia-, víz- és áramellátás).51

Hasonlóképpen jogi vita történt a központi kormányzat és egyes régiók (Katalónia, Murcia) között, amelyek szigorúbb karanténintézkedéseket szorgalmaztak, amelyek magukban foglalják az építkezés leállítását, és minden olyan ipari tevékenységet, amely nem kapcsolódik alapvető szükségletekhez. Eleinte a kormány teljesen elutasította ezen kiegészítő óvintézkedések egy részét, vagy csak nagyon lokalizált szigorú korlátozásokat hagyott jóvá, végül egészen váratlanul a kormány a március 29-i 10/2020. számú királyi törvényerejû́ rendelettel bejelentette döntését, hogy szüntessék be a „nem lényeges” gazdasági tevékenységeket. Ez az intézkedés releváns jogi kérdéseket vet fel a szükségállapot által a kormányra ruházott kivételes hatáskörök határaival, kiterjedésével és azok parlamenti ellenőrzésével kapcsolatban. ${ }^{52}$

Az autonóm rendszer hatályon kívül helyezése esetén lehetséges, hogy a kormány olyan intézkedéseket hozhat, amelyek közvetlenül érintik az autonóm közösségeket. Mindazonáltal minden autonóm közösség megőrzi azokat a hatásköröket, amelyek a jogszabály erejénél fogva megilletik óket. ${ }^{53}$

A spanyol törvények szerint a szükségállapot lehetővé teszi a kormány számára, hogy korlátozza a mozgás szabadságát, míg a riadókészültség lehetôvé teszi ennek és más alapvető jogoknak a felfüggesztését a közrend súlyos zavara esetén. ${ }^{54} \mathrm{~A}$ korlátozás és a felfüggesztés megkülönböztetése meglehetősen releváns, mivel az előbbi állam általi deklarálásának jogi követelményei kevésbé szigorúak, mint az utóbbi esetében. A riadókészültség kijelentése par-

50 Lafuente Balle, 1989, 27. o.

51 Nogueira López-Doménech Pascal, 2020.

52 Nogueira López-Doménech Pascal, 2020.

53 Lecumberri Beascoa, 2020.

54 Szükségállapoti tv. 11. cikk. 
lamenti utólagos ellenőrzés alatt áll, míg a szükségállapot kinyilvánításához a parlament elözetes engedélye szükséges.

Egyes tudósok azzal érveltek, hogy a Covid-19-válság kezelésére kivetett karanténok ennek az alkotmányos jognak a felfüggesztését vonják maguk után, ezért rendkívüli állapotra lenne inkább szükség. A mozgás szabadságának korlátozása helyett a már ismertetett királyi rendelet ${ }^{55}$ ideiglenesen megfosztja a teljes lakosságot ettől a jogtól.

Az egyik kortárs vita a spanyol alkotmányjogászok körében az, hogy a szükségállapotot biztosító jogi keret elegendő alkotmányos alapot nyújt-e a kormány által elfogadott intézkedésekhez - különösen, hogy a korlátozott kivételekkel történő erőteljes zárolás összeegyeztethető-e az alkotmánynak a mozgás szabadságára vonatkozó garanciájával. Egyesek ezzel szemben azzal érvelnek, hogy a különleges jogrend egy másik típusát kellett volna kihirdetni. ${ }^{56}$

Az átláthatóság, a jogbiztonság és a koordináció három kulcsfontosságú fogalom, amelyekre figyelmet kell fordítani a Covid-19-válság alatt és a jövőbeni válságok során.

\section{5. Összegzés}

A rendkívüli állapot típusú szabályozás egy hibrid típust takar Spanyolország esetében, hiszen magába foglalja a magyarországi szükségállapoti tényállásból azokat, amelyek az állam alkotmányos rendjére irányuló belső támadásokat fogják össze. Ez a szabályozási mód egyfajta reakció a történelmi tapasztalatokra vagy épp az elszakadni vágyó, jelenleg autonómiát élvező közösségek esetleges szeparatista radikalizálódására, ami a katalánok vagy a baszkok kapcsán messze nem lehetetlen narratíva. Ebből adódóan szerencsésebb a tényállást ostromállapotnak nevezni.

A riadókészültség hasonlít a magyar veszélyhelyzetre, de emellett válsághelyzet típusú tényállásokat is tartalmaz.

Mindhárom különleges jogrendi tényállás esetében a felhatalmazott a kormány. Ez következik az alkotmány 97. cikk szerinti rendelkezéseiből, amelyek szerint a kormány irányítja a bel- és külpolitikát, a polgári és katonai közigazgatástés azállam védelmét. Az alkotmány rögzíti továbbá, hogy az árulás és az állam biztonságát veszélyeztető bủncselekmény esetén a kormány tagja felelősségre vonható, amely felelősségre vonás kapcsán a király kegyelmi joga nem érvényesíthető.

A koronavírus-járvány kezelésével kapcsolatban is érdemes összehasonlítással élni, amikor bizonyos intézkedéseket vizsgálunk. Magyarországhoz nagyon hasonlóan Spanyolországban is felfüggesztésre kerültek az eljárási és adminisztratív határidők, valamint még az elévülés határideje is. Ezek az intézkedések azt a célt szolgálták, hogy minél inkább csökkenteni lehessen a különféle ügyintézések számát és ezzel az emberek mozgását.

Spanyolország ugyan igyekezett a járványügyi intézkedéseket egységesen kezelni, de Magyarországgal ellentétben az egyes tartományok, autonóm közösségek is hoztak korlátozó in-

55 A Covid okozta válsághelyzet kezeléséről szóló királyi rendelet. 56 De la Sierra, 2020. 
tézkedéseket. A 436/2020. királyi rendeletben megerősítették az autonóm közösségek és a helyi közösségek illetékes hatóságai által a koronavírus-járvány első hulláma alkalmával korábban elfogadott összes rendelkezést és intézkedést, amelyek továbbra is érvényben maradtak, feltéve, hogy kompatibilisek ezzel a rendelettel. Magyarországon ezzel szemben nem volt szükség az egyes tartományokra figyelemmel lenni, így egy sokkal gyorsabb és hatékonyabb jogalkotási tevékenység ment végbe, köszönhetően a centralizált állami berendezkedésnek. A spanyol kormányt számos kritika érte amiatt, hogy későn, nem a megfelelő időben hozta meg a szükséges intézkedéseket. Európa-szerte látható tendencia, hogy a járványhelyzetben hozott kormányzati intézkedéseket erős politikai és ideológiai kritikák kísérik, azonban ebben a rendkívüli helyzetben célszerủ kizárólag a szakmai szintú vitákra, véleményekre szorítkozni.

\section{Irodalomjegyzék}

De La Sierra, S. (2020) Old Norms and New Challenges in Spain's Response to COVID-19 [Online]. Elérhetó: www.theregreview.org/2020/05/20/de-la-sierra-old-norms-newchallenges-spain-response-Covid-19/ (Letöltve: 2020. december 15.)

KELEMEN, R. (2020) 'Különlegesjogrend az Európai Unió egyestagállamainakalkotmányaiban' in Farkas, Á., Kelemen, R. (szerk.) Szkülla és Kharübdisz között - Tanulmányok a különleges jogrend elméleti és pragmatikus kérdéseiröl, valamint nemzetközi megoldásairól. 1. kiadás. Budapest: Magyar Katonai Jogi és Hadijogi Társaság

LAfuente BALle, J. M. (1989) 'Los estados de alarma, excepción y sitio (I)', Revista de Derecho Político, 1989/30, 23-54. o.

LeCUMBerRi BeAscoA, G. (2020) El Derecho de excepción, una perspectiva de Derecho comparado [Online]. Elérhető: www.europarl.europa.eu/RegData/etudes/IDAN/2020/649366/EPRS_ IDA(2020)649366_ES.pdf (Letöltve: 2020. december 13.)

LEón Alonso, M. (2016) 'Sentencia del Tribunal Constitucional 83/2016, de 28 de abril de 2016. Control jurisdiccional exclusivo del Tribunal Constitucional de los actos gubernamentales y parlamentarios de declaración, autorización y prórroga de los estados de alarma', Ars Iuris Salmanticensis, 4(2), 234-237. o.

Nogueira López, A., Doménech Pascal, G. (2020) Fighting COVID 19-Legal Powers and Risks: Spain [Online]. Elérhető: https://verfassungsblog.de/fighting-Covid-19-legal-powers-andrisks-spain/ (Letöltve: 2020. december 15.)

Pérez Royo, J., Carrasco Durán, M. (2018) Curso de Derecho Constitucional. 16. kiadás. Madrid: Marcial Pons

Venice Commission (2020) Interim Report on the Measures Taken int he EU Member States as a Result of the Covid-19 Crisis and Their Impact on Democracy, the Rule of Law and Fundamental Rights (Opinion No. 995/2020) [Online]. Elérhető: www.venice.coe.int/webforms/documents/ default.aspx?pdffile=CDL-AD(2020)018-e (Letöltve: 2020 . december 15.)

Vidal Prado, C., Delgado Ramos, D. (2011) 'Algunas consideraciones sobre la declaración del estado de alarma y su prórroga', Revista Española de Derecho Constitucional, 31(92), 243-265. o. 


\title{
26. Ahol a különleges jogrend egyáltalán nem is különleges: az amerikai modell
}

\author{
BÉRES NÓRA \\ 1. A különleges jogrend \\ alkotmányos és törvényi szintü szabályozása, esetkörei
}

\author{
Hasonlóan néhány európai alkotmányhoz, az Egyesült Államok alkotmánya lényegében \\ egyáltalán nem tartalmaz rendelkezéseket a különleges jogrendre nézve. ${ }^{1}$ Ahogyan azt
}

I Noha az amerikai alkotmány az európai szabályozási logikával összecsengő különleges jogrendi esetköröket nem sorakoztat fel, az I. cikk 8. \$-a a Kongresszus hatáskörei között említi az USA közös védelmét, a hadüzenet küldését, valamint a milícia szervezetére, fegyverzetére és fegyelmére vonatkozó rendelkezések kibocsátását, valamint a milícia Egyesült Államok szolgálatában álló részének irányítását, fenntartva az egyes államok jogát a tisztek kinevezésére és a milícia kiképzésének irányítására a Kongresszus által megállapított fegyelmi renddel összhangban. Továbbá az I. cikk 10. \$-a azt is kimondja, hogy a tagállamok a Kongresszus hozzájárulása nélkül nem folytathatnak háborút, kivéve a tényleges megtámadtatás esetét vagy olyan fenyegető veszélyt, amely nem teszi lehetôvé a késlekedést. E rendelkezések tartalmi szempontból a magyar terminológia szerinti hadiállapottal rokoníthatók - amely kifejezés egyébként sem itt, sem máshol nem szerepel az amerikai alkotmányban. Utóbbi kihirdetése a Kongresszus feladata. A II. cikk 2. \$-a akként folytatja, hogy „az elnök az Egyesült Államok szárazföldi haderejének és hajóhadának és az egyes államok milíciájának fóparancsnoka, amikor az utóbbiakat az Egyesült Államok tényleges szolgálatában alkalmazzák". Tehát míg a hadiállapottal analóg helyzet kinyilvánítása a Kongresszus kizárólagos hatáskörébe tartozik, a haderő tényleges vezetése az elnököt, a végrehajtó hatalmi ág fejét - és egyben államfőt - illeti meg. Az 1791-ben elfogadott Második és a Harmadik Alkotmánykiegészítések szintén a hadiállapottal analóg helyzethez tartozó rendelkezéseket tartalmaznak azzal, hogy utóbbit expressis verbis továbbra sem nevezik így. A Második Alkotmánykiegészítés szerint: „Mivel egy jól szervezett milícia szükséges a szabad állam biztonsága szempontjából, nem lehet a népnek a fegyverek birtoklásához és viseléséhez való jogát csorbítani.” A Harmadik Alkotmánykiegészítés pedig megállapítja, hogy „béke idején katonát csak a ház tulajdonosának hozzájárulásával lehet beszállásolni; háború idején is a beszállásolás a törvényben megállapított módon történik" (Farkas-Kelemen, 2020, 260. o.).

Dr. Béres Nóra, PhD, LLM

nora.beres@mfi.gov.hu

kutató (Mádl Ferenc Összehasonlító Jogi Intézet)

tanársegéd (Miskolci Egyetem Állam- és Jogtudományi Kar, Európai és Nemzetközi Jogi Intézet)

Béres, N. (2021) 'Ahol a különleges jogrend egyáltalán nem is különleges: az amerikai modell' in Nagy, Z., Horváth, A. (szerk.) A különleges jogrend és nemzeti szabályozási modelljei, 563-591. o. Budapest: Mádl Ferenc Öszszehasonlító Jogi Intézet.

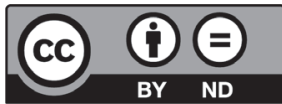

https://doi.org/10.47079/2021.nzha.kulon.4_26 
majd a későbbiek során láthatjuk, az amerikai szabályozás a különleges jogrend fogalmát az európai terminológia szerinti értelemben nem - pontosabban másképp - ismeri, ám jelen fejezet a szemléletes összehasonlító vizsgálat szempontjából kiterjesztő értelmezéssel a különleges jogrend kifejezést az amerikai megoldásokra is alkalmazza. Az Egyesült Államok szabályozása - szemben a kontinentális európai országok többségében alkalmazott úgynevezett dichotóm modellekkel ${ }^{2}$ - a monista modellt testesíti meg a különleges jogrend szabályozását, pontosabban „szabályozatlanságát” illetően. Ez alapján nem tehető egyértelmú különbség a kivételes állapot és a nem kivételes állapot között: a szabályozás különleges jogrendi jellegét az mutatja a rendes jogrendhez képest, hogy a kivételes állapotra adott válaszok rendkívüliek, a rendes jogrendi garanciákon túlnőnek. Az így hozott intézkedésekre jellemző, hogy azok sokszor ad hoc természetûek, és előzetesen nem szabályozott rendkívüli válaszok formájában jelennek meg. A monista modellre is igaz, hogy van intézkedésre jogosult (akár egyszemélyi) szerv, ${ }^{4}$ ebből adódóan pedig egyfajta hatalomkoncentráció figyelhető meg, ugyanakkor a bíróságok - különösen a Legfelsőbb Bíróság - a fékek és ellensúlyok elvét szem előtt tartva kulcsfontosságú szerephez jutnak: a bírói felülvizsgálat demokratikussági szempontból különösen felértékelődik, mert a kormányzati intézkedések esetleges „vadhajtásait" a bírósági kontrollmechanizmusnak kell „lemetszenie”. 5

A dichotóm modell és a monista modell melletti, illetve elleni érvek a részletesség és a normativitás együttes, ám mégis kizárólagos követelményei mentén vázolhatók fel, amit Csink Lóránd úgy jellemez, hogy „a különleges jogrend jogállami paradoxona”. ${ }^{6}$ Ez alapján a részletesség követelménye a dichotóm modell melletti érvként említhető, amelyet úgy lehetne összefoglalni, hogy mivel különleges jogrend idején egyértelmúen közhatalom gyakorlására kerül sor, és a közhatalom gyakorlásának jogi keretek közöttisége pedig alapvető jogállamisági követelmény - amely az államnak egyszersmind alkotmányos és nemzetközi jogi kötelezettsége ${ }^{7}$-, és mivel a jogállamiság elvéből az is következik, hogy az önkényes mérlegelés lehetőségét vissza kell szorítani, a különleges jogrendi szabályokat alkotmányos szinten kell rögzíteni akkor, ha a részletességnek eleget kívánunk tenni. Ezzel szemben a normativitás követelménye inkább a monista modell melletti érvkészletet gyarapítja. Tudniillik az is jogállamisági követelmény, hogy a jogi normák mindenkire, tehát a közhatalom gyakorlóira is vonatkozzanak, és ezeket az általános magatartási szabályokat - még ha nem is alkotmányos, de törvényi szinten - előzetesen állapítsák meg, mert csak így biztosítható a kiszámíthatóság, és várható el a normakövetés. Ám mivel a kivételes állapotot rendszerint

2 Elfogadva Mészáros Gábor álláspontját, a dichotómia itt azt jelenti, hogy bár a különleges jogrend és a rendes jogrend párhuzamosan érvényesülhet, az egyes konkrét intézkedések és jogintézmények szintjén azonban csak az egyik vagy másik ölthet testet. Mészáros, 2016, 37. o.

3 Mészáros, 2016, 37. o.

4 Mint ahogyan azt majd később láthatjuk, ezt a szerepet az Egyesült Államok esetén az elnök tölti be.

5 Mészáros, 2017, 100. 0.

6 Csink, 2017, 12-14. o.

7 Varga Zs., 2015, 11. o. 
előre nem látható társadalmi vagy természeti jelenségek idézik elő, ${ }^{8}$ valamennyi lehetséges forgatókönyv előzetes lefedése lehetetlen, tehát a különleges jogrend részletes és normatív szabályozásának kritériumai egyidejüleg nem teljesíthetôk.

Az 1787-ben elfogadott amerikai alkotmány szövege húen tükrözi az alkotmányozó atyák azon törekvését, hogy egyik hatalmi ág se kerüljön túlsúlyba a többihez képest. Ennek ellenére természetesen az Egyesült Államok szabályozása is elismeri annak szükségességét a hatékony válságkezelés és a jog reakcióképessége szempontjából, hogy veszélyhelyzetben (emergency) az intézkedésre jogosult, azaz az elnök kiterjesztett hatásköröket és nagyobb cselekvési szabadságot élvezhessen a békeidőben megszokottakhoz képest. A veszélyhelyzetben gyakorolható elnöki hatáskörök skálája kifejezetten széles, amelyek közül témánk szempontjából azok a különleges törvényi felhatalmazások (special statutory authorities) a legfontosabbak, amelyeket az elnök a saját maga vagy a Kongresszus által kihirdetett országos veszélyhelyzet (national emergency) esetén gyakorolhat.

A New York University kutatóintézete, a Brennan Center for Justice 2019. októberben publikált kutatása 123 olyan, törvényben szabályozott hatáskört különböztet meg, amelyet az amerikai elnök az általa kihirdetett országos veszélyhelyzetben gyakorolhat, továbbá ezen elnöki hatáskörök további 13 hatáskörrel bővülnek ki abban az esetben, ha az országos veszélyhelyzetet a Kongresszus rendelte el. Egyszerú matematikai számítással tehát arra juthatunk, hogy az elnököt 136 (!) féle különleges törvényi felhatalmazás illetheti meg akkor, amikor országos veszélyhelyzet kihirdetésére kerül sor. ${ }^{9}$

Jelen fejezet a különleges állapotokat szabályozó, valamint a különleges elnöki hatásköröket tartalmazó törvények közül csak a legfontosabbakkal foglalkozik részletesen, kiemelt figyelmet fordítva a közegészségi veszélyhelyzetre és a koronavírus-járványra. Ezek az alábbiak:

1944. évi törvény a közegészségügyi szolgáltatásokról; ${ }^{10}$

— 1976. évi törvény az országos veszélyhelyzetről:;1

- 1988. évi törvény a katasztrófavédelemről és a veszélyhelyzetben való segítségnyújtásról ${ }^{12}$ (az úgynevezett Stafford-törvény); ;13

— az Egyesült Államok Kódexe ${ }^{14} 22$. cím: Külkapcsolatok:15

8 Csink, 2017, 8. o.

9 Brennan Center, 2019.

10 Public Health Service Act [42 U.S.C. \$247d].

11 National Emergencies Act [50 U.S.C. \$\$1601 et seq.]

12 Robert T. Stafford Disaster Relief and Emergency Assistance Act [42 U.S.C. \$\$ 5121 et seq.].

$13 \mathrm{Az}$ angol terminológia a törvényre "Stafford Act”-ként hivatkozik, tisztelegve a néhai Robert T. Stafford egykori republikánus politikus és vermonti szenátor előtt, akit a jogszabály atyjának tekintenek, így mi is ezt a rövidítést használjuk.

14 Az Egyesült Államok Kódexe [10 U.S.C. \$ 2808] általános és állandó, szövetségi szintû törvénygyüjtemény, amely tárgyak szerint tartalmazza az egyes címeket, és a képviselőház törvényi felülvizsgálati tanácsának irodája adja ki. Elérhető: www.govinfo.gov/help/uscode (Letöltve: 2020. december 10.).

15 U. S. Code [22 U.S.C. $\$ 2318$ (a)(1)]. 
— 2002. évi törvény a belbiztonságról:16

— 2006. évi törvény a Katrina hurrikán utáni veszélyhelyzet-kezelési reformról. ${ }^{17}$

Az alábbiakban az egyes törvények elfogadásuk időrendi sorrendje és nem a rájuk történt hivatkozások gyakorisága szerint kerülnek bemutatásra azzal, hogy ismételten hangsúlyozni kell: számos más jogszabályban és jogterületen ${ }^{18}$ is vannak még a témánkhoz szervesen kapcsolódó föderális szintû szabályok, mindazonáltal a teljesség igényével való bemutatásra törekvés jelen munka korlátai között lehetetlen vállalkozás volna.

\subsection{A közegészségügyi szolgáltatásokról szóló 1944. évi törvényés a közegészségi veszélyhelyzet}

A közegészségügyi szolgáltatásokról szóló 1944. évi törvény ${ }^{19}$ alapján az Egyesült Államok egészségügyért felelős minisztere (Secretary for Health and Human Services) közegészségi veszélyhelyzetet (public health emergency) rendelhet el. A közegészségi veszélyhelyzetre okot adó társadalmi és természeti jelenségek a gyakorlatban nagyon változatosak lehetnek, azaz nemcsak betegségek tartozhatnak ide, hanem például a közegészséget sértő vagy veszélyeztetô természeti katasztrófák is.

Ha csak 2020-at nézzük, az egészségügyért felelős miniszter 12 alkalommal hirdetett ki közegészségi veszélyhelyzetet e törvény alapján az egész Egyesült Államok vagy meghatározott tagállam(ok) területére nézve. Januárban a Puerto Rico-i földrengés, az opioidkrízis $^{20}$ és a koronavírus-járvány miatt rendelte el országos szinten. Áprilisban és júliusban az opioid-krízis és a koronavírus-járvány miatti közegészségi veszélyhelyzetet országos

16 Homeland Security Act [6 U.S.C. \$1 101].

17 Post Katrina Emergency Management Reform Act [6 U.S.C. \$ 601].

18 Ilyenek például a közegészségügy, az ingatlanok kisajátítása, a honvédelem, a kormánytisztviselők (kiterjesztően értelmezve, idesorolva a rendőröket, a hivatásos katonákat, a parti őrség tagjait stb.) foglalkoztatásának feltételei, a magántulajdon lefoglalása, a büntetőeljárás és a fogva tartás, a nemzetközi kapcsolatok (Brennan Center, 2019, 3-43. o.).

19 1944. évi közegészségügyi szolgáltatásokról szóló törvény 319. cikk (a) bekezdés: „Ha az egészségügyért felelős miniszter a népegészségügyi tisztviselőkkel folytatott egyeztetést követően úgy látja, hogy (1) egy betegség vagy orvosi rendellenesség, illetve (2) egy fertőző betegség jelentős elterjedése, biológiai terrortámadás vagy egyéb ok miatt közegészségi veszélyhelyzet áll fenn, akkor e közegészségi veszélyhelyzetre reagálva megfelelő intézkedéseket hozhat, beleértve támogatások odaítélését, költségtérítések kifizetését, szerződések megkötését és olyan vizsgálatok lefolytatását, amely utóbbiak a betegség vagy orvosi rendellenesség okát, kezelését vagy megelőzését szolgálják.".

20 2019-ben közel 50 ezer ember halálát okozta opioid-túladagolás az Egyesült Államokban. E fájdalomcsillapítókkal való visszaélés mintegy 78,5 milliárd dollár értékủ gazdasági terhet rótt az ország költségvetésére, beleértve az egyészségügyi költségeket, a kiesett munkaerőt, a kábítószerfüggők kezelését és a büntető igazságszolgáltatás költségeit. A jelenség mögött a gyógyszergyártók gazdasági haszonszerzési célja állt, amely arra ösztönözte őket, hogy ne hozzák nyilvánosságra az opioid okozta függőség valódi fokát. National Institute on Drug Abuse, elérhető: www.drugabuse.gov/drug-topics/opioids/opioid-overdose-crisis (Letöltve: 2020 . december 15.). 
szinten meghosszabbította. 2020 augusztusában a kaliforniai erdőtüzek és a Laura hurrikán miatt hirdetett ki a miniszter közegészségi veszélyhelyzetet, előbbi miatt Kalifornia államban, utóbbi miatt Louisiana államban és Texas államban. Szeptemberben szintén erdőtüzek miatt Oregon államban hirdette ki, illetve októberben ismételten meghosszabbította az egészségügyért felelős miniszter a közegészségi veszélyhelyzetet az egész Egyesült Államokban az opioid-krízis és a koronavírus-járvány miatt.

A közegészségi veszélyhelyzet a veszélyhelyzet fennállásáig vagy 90 napig tarthat, ám ezt az időtartamot az egészségügyért felelős miniszter meghosszabbíthatja (a fenti adatokból is kitűnik, hogy a megújítás hozzávetőlegesen háromhavonta történik). A közegészségi veszélyhelyzet elrendeléséról a Kongresszust 48 órán belül értesíteni kell, továbbá tájékoztatni kell az érintett szerveket, beleértve a Belügyminisztériumot, az Igazságügyi Minisztériumot és a Szövetségi Nyomozó Irodát (FBI). ${ }^{21}$

A közegészségi veszélyhelyzet elrendelésének gyakorisága a korábbi években is hasonlóan magas volt, illetve jelenleg is számos közegészségi veszélyhelyzet van párhuzamosan hatályban, ezekből adódóan pedig arra következtethetünk, hogy egy, a gyakorlatban rendszeresen alkalmazott jogintézményről van szó, amely Magyarország Alaptörvényének különleges jogrendi koncepciójával, ${ }^{22}$ annak ultima ratio jellegével nehezen állítható párhuzamba. ${ }^{23}$

\subsection{Az Egyesült Államok Kódexe: külkapcsolatok és az előre nem látható veszélyhelyzet}

Az Egyesült Államok Kódexe ${ }^{24}$ alapján, amelyet 1961-ben fogadtak el, az elnök elrendelheti a Védelmi Minisztérium (Department of Defense) előirányzatainak lehívását, állományának bevetését, szolgáltatásainak igénybevételét, valamint hadtudományi oktatást és katonai kiképzést más államnak vagy nemzetközi szervezetnek történő katonai, gazdasági, békefenntartói, terrorizmus elleni és proliferáció elleni segítségnyújtás céljából azzal, hogy ennek éves összege a 100 millió amerikai dollárt nem haladhatja meg.

E jogszabályhely az elrendelés lehetséges okaként az előre nem látható veszélyhelyzetet (unforeseen emergency) jelöli meg, ám annak fogalmát nem bontja ki. Továbbá ugyanezen cikk rendelkezik arról, hogy e szabályozás csupán szubszidiárius jellegú, azaz csak akkor lehet rá hivatkozni, ha a fegyverexport ellenőrzéséről szóló törvényben ${ }^{25}$ használt veszélyhelyzet-fogalom feltételei nem teljesülnek. Az Egyesült Államok Kódexének e helyütt tárgyalt rendelkezése értelmében 1988 és 2017 között 57 alkalommal hirdettek ki előre nem látható

21 U. S. Department of Health and Human Services (2020) Public Health Emergency Declarations: www.phe. gov/emergency/news/healthactions/phe/Pages/default.aspx (Letöltve: 2020. december 9.).

22 Till, 2018, 1. o.

23 Legfeljebb az egészségügyről szóló 1997. évi CLIV. törvény szerinti egészségügyi válsághelyzet vagy a katasztrófavédelemről és a hozzá kapcsolódó egyes törvények módosításáról szóló 2011. évi CXXVIII. törvény szerinti katasztrófaveszély nyújthat releváns összehasonlítási alapot.

24 Az Egyesült Államok Kódexe 22. cím 32. fejezet II. alfejezet II. rész (a) bekezdés (1) pont.

25 Arms Export Control Act [22 USC \$\$ 2751 et seq.]. 
veszélyhelyzetet. Például 2014-ben az USA e törvénye alapján támogatta Franciaország Malival, Csáddal és Nigerrel szembeni terrorizmus elleni tevékenységét. ${ }^{26}$

\subsection{Az országos veszélyhelyzetről szóló 1976. évi törvény és az országos veszélyhelyzet}

Az amerikai elnök országos veszélyhelyzetet (national emergency) az 1976. évi, az országos veszélyhelyzetről szóló törvény ${ }^{27}$ alapján ${ }^{28}$ hirdethet ki, ${ }^{29}$ amire rendkívül széles diszkrecionális jogköre nyílik, hiszen a törvényben - amely egyébként meglehetősen rövid - még arra nézve sem találhatunk korlátozó rendelkezéseket, hogy milyen típusú társadalmi vagy természeti jelenségek idézhetnek elő veszélyhelyzetet. Ugyanakkor az országos veszélyhelyzet kihirdetésekor az elnöknek annak törvényi jogalapját is megjelölve előre meg kell határoznia, hogy a veszélyhelyzet alatt mely hatásköreit fogja gyakorolni, és a Kongresszusnak minden hatodik hónapban be kell számolnia a veszélyhelyzettel kapcsolatos kiadásokról.

Bár e törvény értelmében az országos veszélyhelyzet legkésőbb egy év után ipso iure megszû́nik,,$^{30}$ az elnöknek jogában áll ezt az időtartamot meghosszabbítani, és ez utóbbi - gyakorlatilg rutinszerúen - elő is fordul. Noha az országos veszélyhelyzetről szóló törvény felhatalmazza a Kongresszust, hogy az elnök által kihirdetett országos veszélyhelyzetnek véget

26 Brennan Center, 2019.

27 A törvény elfogadásának időpontja beszédes: a vietnámi háború és a Watergate-ügy után elengedhetetlennek tûnt, hogy az elnök és a Kongresszus szerepkörét határozottabb törvényi kontúrokkal vonják meg. Constitutional Daily, The Debate Over Emergency Powers and the Border Wall, elérhető: https://constitutioncenter. org/blog/the-debate-over-emergency-powers-and-the-border-wall (Letöltve: 2020 . december 12.).

28 1976. évi országos veszélyhelyzetről szóló törvény 201. cikk (a) bekezdés: „A Kongresszus azon törvényei értelmében, amelyek engedélyezik bármely különleges vagy rendkívüli hatalom gyakorlását országos veszélyhelyzet kihirdetése esetén, az elnök jogosult országos veszélyhelyzet kihirdetésére. Az ilyen kiáltványt haladéktalanul továbbítják a Kongresszusnak, és közzéteszik a Szövetségi Nyilvántartásban.”.

$29 \mathrm{Az}$ országos veszélyhelyzet kihirdetése pro forma végrehajtási utasítással (executive order) vagy kiáltványnyal (proclamation) történik. A végrehajtási utasítások nem jogszabályok, címzettjük a törvényhozás, tehát a Kongresszusnak kell végrehajtani őket. A végrehajtási utasításokat a Kongresszusnak nem kell jóváhagynia, és nem is tudja egyszerúen hatályon kívül helyezni őket. A Kongresszus azonban elfogadhat olyan jogszabályokat, amelyek megnehezítik vagy akár ellehetetlenítik az utasítás végrehajtását, például a költségvetési finanszírozás megvonásával. Csak a mindenkori hivatalban lévő elnök dönthet egy végrehajtási utasítás hatályon kívül helyezéséról úgy, hogy kiad egy erre vonatkozó másik végrehajtási utasítást. A végrehajtási utasításokkal szemben a kiáltványok valódi jogszabályok, de valódi kötőerôvel csak attól fogva rendelkeznek, ha a Kongresszus jóváhagyta őket. Lásd az American Bar honlapját: www.americanbar.org/groups/ public_education/publications/teaching-legal-docs/what-is-an-executive-order-/ (Letöltve: 2020. december 9.), valamint a Deccan Herald honlapját: www.deccanherald.com/international/explainer-what-does-apresidential-proclamation-mean-852924.html (Letöltve: 2020 . december 9.).

30 1976. évi országos veszélyhelyzetről szóló törvény 202. cikk (d) bekezdés: „Az elnök által e törvény alapján kihirdetett és korábban másként meg nem szüntetett országos veszélyhelyzet kihirdetésének évfordulóján szűnik meg, ha az elnök az egyes évfordulót megelőző 90 napos időszakon belül nem teszi közzé a Szövetségi Nyilvántartásban azt, és nem értesíti a Kongresszust arról, hogy az országos veszélyhelyzet az évforduló után is fennmarad.". 
vessen, ${ }^{31}$ erre az elmúlt 40 évben mindössze egyszer volt példa. (Erról részletesebben lásd a 4. pontot.)

A törvény 1978-ban történt hatálybalépése óta összesen 69 alkalommal hirdettek ki országos veszélyhelyzetet az Egyesült Államokban, ebből pedig 40 (!) jelenleg is hatályban van; ${ }^{32}$ így például a legelső, Jimmy Carter által kihirdetett országos veszélyhelyzet, amely az iráni kormány tulajdonszerzését korlátozza (legutoljára 2020. november 12-én újították meg), ${ }^{33}$ vagy például több mint 26 éve van hatályban a tömegpusztító fegyverek proliferációja miatt Bill Clinton által elrendelt országos veszélyhelyzet (legutóbb szintén 2020. november 12-én újították meg). ${ }^{34}$ Úgyszintén a 2001. szeptember 11-i terrortámadások után George W. Bush által bevezetett országos veszélyhelyzetet sem helyezték még hatályon kívül (utoljára 2020. szeptember 10-én hosszabbították meg). ${ }^{35} \mathrm{~A}$ koronavírus-járvány miatti, jelenleg is hatályos országos veszélyhelyzetet 2020. március 13-án hirdette ki Donald Trump. Az országos veszélyhelyzet közegészségi okokból történő elrendelése az előző kormányzati ciklus gyakorlatát figyelembe véve sem példátlan: Barack Obama a HiN1-influenzajárvány idején is országos veszélyhelyzetet hirdetett ki 2009ben $^{36}$ (amely egyébként az elrendelés első évfordulóján - megújítás hiányában - a törvény erejénél fogva megszúnt).

\subsection{A Stafford-törvény és a veszélyhelyzet, az elemi katasztrófa, valamint a veszélyhelyzeti készültség}

A Szövetségi Veszélyhelyzet-kezelési Ügynökség (Federal Emergency Management Agency) a központi szintû válságkezelés első számú letéteményese, amelyre a törvényi szintủ szabályokat a Stafford-törvény állapítja meg. A Stafford-törvény hatálybalépésével a szövetségi szintû́ válságkezelés normatív kereteit felállító 1974. évi katasztrófavédelmi törvényt ${ }^{37}$ váltotta fel. Már elöljáróban érdemes rögzíteni, hogy e törvény tárgyi hatálya a külső támadásokat, a nukleáris baleseteket, valamint a kémiai, biológiai vagy radioaktív incidenseket nem öleli fel.

31 Erre a Kongresszusnak úgynevezett közös rendelettel nyílik lehetősége, amelyet a képviselőház és a szenátus együttesen hoznak meg. [1976. évi országos veszélyhelyzetről szóló törvény 202. cikk (a) bekezdés (1) pont: „Az elnök által e törvény alapján kihirdetett országos veszélyhelyzet megszủnik, ha a veszélyhelyzetet közös rendelettel megszüntetik."].

32 Brennan Center, 2020.

33 Blocking Iranian Government Property, E.O. 12170, November 14, 1979, 85 FR 72895.

34 Proliferation of Weapons of Mass Destruction, E.O. 12938, November 14, 1994, 85 FR 72897.

35 Declaration of National Emergency by Reason of Certain Terrorist Attacks, Proc. 7463, September 14, 2001, 85 FR 56467.

36 Declaration of a National Emergency with Respect to the 2009 H1Ni Influenza Pandemic, Proc. 8443 , October 23, 2009, 74 Fed. Reg. 55439-55440.

37 Disaster Relief Act, Kahn-Barondess, 2008, 913. o. 
A különleges jogrendi kategóriák tekintetében a Stafford-törvény háromféle klasszifikációt határoz meg, így elsőként a veszélyhelyzet (emergency) fogalmát rögzíti. ${ }^{38} \mathrm{~A}$ normaszöveget olvasva kitûnik, hogy a veszélyhelyzet fennállásának megállapítása az elnök mérlegelési jogkörébe tartozik, továbbá, hogy kihirdetésére csak taxatíve meghatározott célból (az emberi élet megóvása, a tulajdon, a közegészség és a közbiztonság védelme, valamint katasztrófahelyzet okozta fenyegetés csökkentése vagy elhárítása) kerülhet sor, és hogy a szövetségi szintú támogatás a tagállami és helyi önkormányzati intézkedésekhez képest szubszidiárius jellegú.

Ezt követően a törvény az elemi katasztrófa (major disaster) definícióját határozza meg. ${ }^{39}$ A rendelkezés tartalma a veszélyhelyzetet definiáló bekezdésben foglaltakhoz hasonlít abban, hogy az elemi katasztrófa bekövetkeztének megállapítása szintén az elnök mérlegelési jogkörébe tartozik, és a kihirdetésre itt is csak meghatározott célokból kerülhet sor (a károk, veszteségek, nehézségek és szenvedések enyhítése), valamint a szövetségi szintú támogatás a tagállami, helyi önkormányzati és katasztrófavédelmi szervek intézkedéseihez képest ismét szubszidiárius jellegú, ellenben normatív többletként jelentkezik, hogy e rendelkezés a kihirdetésre okot adó eseteket taxatíve felsorolja (hurrikán, tornádó, vihar, dagály, hullámverés, szökőár, cunami, földrengés, vulkánkitörés, földcsuszamlás, sárcsuszamlás, hóvihar, szárazság, tűzvész, árvíz vagy robbanás). Mind a természeti csapások, mind az emberi tevékenység által okozott elemi katasztrófák (például emberi szándékosságból vagy gondatlanságból okozott erdőtüzek) e rendelkezés tárgyi hatálya alá tartoznak.

Azon túl, hogy mind a veszélyhelyzet, mind az elemi katasztrófa fennállásának kihirdetése az elnök hatáskörébe tartozik, a Stafford-törvény további cikkei ${ }^{40}$ alapján látható, hogy az elemi katasztrófa és a veszélyhelyzet fennállása tekintetében az elnök figyelmének felhívása és a különleges jogrendre vonatkozó kérelem előterjesztése az érintett tagállam kormányzójának hatáskörébe tartozik.

Mint ahogyan azt fentebb már említettük, a veszélyhelyzeti készültséggel a Staffordtörvény a VI. cím alatt foglalkozik. A szabályozás érdekessége, hogy míg a veszélyhelyzet és az elemi katasztrófa fogalmát az amerikai jogalkotó már a törvény elején, az I. cím alatt

38 Stafford-törvény 102. cikk (1) bekezdés: „E törvény értelmében veszélyhelyzet alatt valamennyi olyan helyzetet vagy esetet érteni kell, amelynek kapcsán az elnök úgy határoz, hogy az emberi élet megóvása, a tulajdon, a közegészség és a közbiztonság védelme, valamint katasztrófahelyzet okozta fenyegetés csökkentése vagy elhárítása érdekében szövetségi szintủ támogatás nyújtása szükséges az Egyesült Államok bármely pontján a tagállamok és helyi önkormányzatok kapacitásának megerősítéséhez.".

39 Stafford-törvény 102. cikk (2) bekezdés: „E törvény értelmében »elemi katasztrófa« alatt valamennyi olyan komoly és súlyos kárt okozó természeti katasztrófát - így hurrikánt, tornádót, vihart, dagályt, hullámverést, szökőárat, cunamit, földrengést, vulkánkitörést, fölcsuszamlást, sárcsuszamlást, hóvihart vagy szárazságot - és - tekintet nélkül keletkezésük okára - valamennyi tủzvészt, árvizet vagy robbanást érteni kell, amelynek kapcsán az elnök úgy határoz, hogy a károk, veszteségek, nehézségek és szenvedések enyhítése érdekében az e törvény szerinti elemi katasztrófák során nyújtandó támogatás nyújtása szükséges az Egyesült Államok bármely pontján a tagállamok, helyi önkormányzatok és katasztrófavédelmi szervek rendelkezésre álló kapacitásának és forrásainak megerősítéséhez.".

40 Stafford-törvény 401 . cikk a) pont és 501 . cikk a) pont. 
meghatározza, addig a veszélyhelyzeti készültség (emergency preparedness) kategóriája csak később ${ }^{41}$ túnik fel először, aminek célja, hogy a szövetségi kormányzat és a tagállamok együttesen viseljék a felelősséget az életet és tulajdont fenyegető veszélyekre való felkészülés során. A törvény meghatározza a veszély (hazard), ${ }^{42}$ illetve a természeti katasztrófa ${ }^{43}$ fogalmát is. E cím harmadik lényegi fogalommeghatározása a veszélyhelyzeti készültség definíciója, amely alatt minden olyan tevékenység és intézkedés értendő, amely a veszélyre való felkészülés során vagy a veszély kiváltotta hatások visszaszorítása, valamint a civil lakosságnak biztosítandó közszolgáltatások és polgári létesítmények helyreállítása érdekében szükséges. A Stafford-törvény értelmében a veszélyhelyzeti készültséget nem az elnök, hanem a Kongresszus állapítja meg, amelyet mind megelőző jelleggel, mind a veszély fennállása alatt és után is kihirdethet.

1953 és 2014 között évente (!) átlagosan 35,5 elemi katasztrófát hirdettek ki az elnökök a Stafford-törvény és elődje, a katasztrófavédelemről szóló 1954. évi törvény alapján, illetve 1974 és 2014 között évente átlagosan kilencszer hirdettek ki veszélyhelyzetet a Staffordtörvény 102. cikk (1) bekezdése szerint. ${ }^{44}$

\subsection{A 2002. évi belbiztonsági törvényés az elemi katasztrófa, valamint a terrorhelyzet}

Reagálva a 2001. szeptember 11-i New York-i és a Pentagont érő terrortámadásokra, az Egyesült Államok Kongresszusa új belbiztonsági törvényt fogadott el, ${ }^{45}$ amellyel az addig a végrehajtó hatalmi ághoz tartozó számos feladat- és hatáskört egy új központi kormányzati végrehajtó szervre, a Belbiztonsági Minisztériumra (Department of Homeland Security) ruháztak át. A Belbiztonsági Minisztérium alá tartozik többek között a Szövetségi Veszélyhelyzet-kezelési Ügynökség, az Egyesült Államok Vám- és Pénzügyőrsége (US Customs Service), Állat- és Növényegészségügyi Ellenőrző Szerve (Animal and Plant Health Inspection Service), valamint Bevándorlási és Állampolgársági Hivatala (Immigration and Naturalization Service). ${ }^{46}$ A Belbiztonsági Minisztérium elsődleges feladata a terrortámadások elhárítása, illetve utóhatásainak csökkentése.

41 Stafford-törvény 601. cikk.

42 Stafford-törvény 602. cikk a) (1) bekezdés: „Veszély alatt az olyan veszélyhelyzetet és katasztrófát kell érteni, amely (A) természeti csapásból, illetve (B) balesetből vagy emberi tényezőből ered.".

43 Stafford-törvény 602. cikk a) (2) bekezdés: „Természeti katasztrófa alatt valamennyi, az Egyesült Államok bármely pontján előforduló hurrikánt, tornádót, vihart, árvizet, dagályt, hullámverést, szökőárat, cunamit, földrengést, vulkánkitörést, fölcsuszamlást, sárcsuszamlást, hóvihart, szárazságot, tűzvészt és egyéb katasztrófát kell érteni, amely a polgári lakosság tulajdonában anyagi kárt vagy személyében testi sérülést okoz vagy okozhat.".

44 Brennan Center, 2019.

45 Továbbá ekkor fogadták el az úgynevezett patriótatörvényt is: Uniting and Strengthening America by Providing Appropriate Tools Required to Intercept and Obstruct Terrorism Act (USA Patriot Act) [Public L. No. 107-56-OCT. 26, 2001].

46 U. S. Department of Homeland Security: History: Who Became Part of the Department? Elérhető: www.dhs.gov/ xabout/history/editorial_0133.shtm (Letöltve: 2020 . december 1.). 
A különleges jogrendi kategóriák tekintetében a 2002. évi belbiztonsági törvény viszszautal ${ }^{47}$ a Stafford-törvényre, ${ }^{48}$ átvéve az elemi katasztrófa fogalmát. Azonban új törvényi terminológiát teremt, amikor kimondja a terrorhelyzet (terrorism) fogalmát. ${ }^{49} \mathrm{~A}$ belbiztonsági törvénnyel továbbá felállították a belbiztonsági miniszteri tisztséget (Secretary of Homeland Security), akinek egy 2003 februárjában elfogadott elnöki rendelet ${ }^{50}$ elsődleges feladatául az elemi katasztrófák során a szövetségi szintú fellépés koordinálását jelölte meg (beleértve a nukleáris baleseteket és terrortámadásokat is).

\subsection{A 2006. évi Katrina hurrikán utáni veszélyhelyzet-kezelési reformról szóló törvény és a katasztrofális esetek}

E törvény elfogadásával az Egyesült Államok Kongresszusa a Katrina hurrikán okozta kihívásokra igyekezett hatásos választ adni. Mint ahogyan azt a jogszabály elnevezése is mutatja, tulajdonképpen egy reformtörvényről van szó, amely mind a Stafford-törvényt, mind a belbiztonsági törvényt módosította, és felállította az Egyesült Államok Veszélyhelyzet-kezelési Hatóságát (Emergency Management Authority).

A 2006. évi Katrina hurrikán utáni veszélyhelyzet-kezelési reformról szóló törvény elemi katasztrófák esetén kiterjeszti az elnök hatáskörét az előzetes evakuálás elrendelésére és a kormányzati segítségnyújtás előzetes kérelem nélküli folyósítására, valamint széles körben felülvizsgálja a válságkezelési rendelkezéseket azzal, hogy a Szövetségi Veszélyhelyzet-kezelési Ügynökséget továbbra is a Belbiztonsági Minisztérium szervezetrendszerébe tagolja. A törvény bevezeti a katasztrofális eset (catastrophic incident) fogalmát, ezzel is tovább bővítve a különleges jogrend jellegú kategóriák halmazát.

47 2002. évi belbiztonsági törvény 2. cikk (11) bekezdés.

48 Stafford-törvény 102. cikk (2) bekezdés.

49 2002. évi belbiztonsági törvény 11. cikk (15) bekezdés: „Terrorizmus alatt minden olyan tevékenységet érteni kell, ami (A) olyan cselekményt jelent, amely (i) veszélyes az emberi életre, vagy potenciálisan rombolhatja a létfontosságú infrastruktúrát vagy a kulcsfontosságú erőforrásokat; és (ii) megsérti az Egyesült Államok vagy bármely állam vagy az Egyesült Államok bármely más alegységének büntető törvényeit; és (B) úgy tủnik, hogy (i) célja a polgári lakosság megfélemlítése vagy kényszerítése; (ii) a kormány politikájának megfélemlítéssel vagy kényszerrel történő befolyásolása; vagy (iii) a kormány magatartásának tömegpusztítással, merénylettel vagy emberrablással történő befolyásolása.".

50 Homeland Security Presidential Directive-5, February 28, 2003, Subject: Management of Domestic Incidents. Elérhető: www.dhs.gov/sites/default/files/publications/Homeland\%20Security\%20Presidential\%20 Directive\%205.pdf (Letöltve: 2019. december 7.). 


\section{Az alapjogok korlátozására vonatkozó szabályok különleges jogrend idején}

Az Amerikai Egyesült Államok emberi jogokhoz füződő viszonya meglehetősen sajátos. E viszonyról sokat elárul, ha gyorsan számba vesszük azokat a legfontosabbnak mondható egyetemes és regionális emberi jogi instrumentumokat, amelyeknek az USA nem részes állama: a Gazdasági, Szociális és Kulturális Jogok Nemzetközi Egyezségokmányának (1966), a nőkkel szembeni megkülönböztetés minden formájának felszámolásáról szóló egyezménynek (1979), a Gyermekjogi Egyezménynek (1989), a migráns munkavállalók és családtagjaik jogainak védelméről szóló nemzetközi egyezménynek (1990), a Nemzetközi Büntetőbíróság Római Statútumának (1998), a fogyatékossággal élő személyek jogairól szóló egyezménynek (2006), az erőszakos körülmények között eltűnt személyek védelméről szóló nemzetközi egyezménynek (2006), ${ }^{51}$ valamint az Emberi Jogok Amerikai Egyezményének (1969). (Utóbbitól való távolmaradásának okát például az Egyesült Államok policyjelleggel azzal indokolta, hogy belső jogvédelmi rendszere sokkal hatékonyabb, mint a regionális kontrollmechanizmus.) $)^{52}$ A legfontosabb emberi jogi nemzetközi szerződések közül tehát az USA csupán a Polgári és Politikai Jogok Nemzetközi Egyezségokmányát (1966, a továbbiakban: Egyezségokmány vagy PPJNE) ratifikálta, igaz, azt is csak a PPJNE megszületése után 26 évvel, 1992-ben..$^{53}$ Mivel azonban a PPJNE megsértése miatt egyéni panasszal csak azon államok ellen lehet élni az Emberi Jogok Bizottsága előtt, amelyek ratifikálták az Egyezségokmány Első Fakultatív Jegyzőkönyvét (1966), azt mondhatjuk, hogy az emberi jogok, illetve alkotmányos alapjogok legmagasabb kontrollmechanizmusa egyéni ügyekben - számba véve a nemzetközi fórumok joghatóságának fenti okok miatti hiányát - az Egyesült államok Legfelsőbb Bírósága. Továbbá az amerikai szabályozás rendhagyó jellegéből adódik az a sajátos körülmény, hogy a különleges jogrend idején történő alapjog-korlátozásról egyetlen törvény sem rendelkezik részletesen, így ez is azt indokolja, hogy e témában mindenképpen a Legfelsőbb Bíróság joggyakorlatát kell alapul venni. A soron következő jogesetek tehát a következő szempontrendszer szerint kerülnek bemutatásra: egyrészt érintjük a Legfelsőbb Bíróság járványkezeléshez kapcsolódó ügyeit, másrészt pedig olyan ügyeket tárgyalunk, amelyek a hadiállapothoz kapcsolódnak.

Ami a járványkezelés kérdését illeti, a Legfelsőbb Bíróság első idekapcsolódó esete a Compaigne Francaise de Navigation a Vapeur v. Louisiana Board of Health ügy ${ }^{54}$ volt 1902-ben,

51 The Advocates for Human Rights, Human Rights \& the U. S. How Has the United States Handled Human Rights Issues in the Past \& Today? Elérhető: www.theadvocatesforhumanrights.org/human_rights_and_the_united_ states (Letöltve: 2020. december 20.).

52 Raisz, 2010, 289. o.

53 United Nations Treaty Collection. Elérhető:https://treaties.un.org/pages/ViewDetails.aspx?src=TREATY\&mtdsg_ no=IV-4\&chapter=4\&clang=_en (Letöltve: 2020 . december 22.).

54 U. S. Supreme Court, Compaigne Francaise de Navigation a Vapeur v. Louisiana Board of Health, 186 U.S. 380 (1902). 
amelyben megállapítást nyert, hogy nem ütközik a Tizennegyedik Alkotmánykiegészítésbe az a louisianai jogszabály, amely járványhelyzetben elrendeli a kötelező karantént. Az eset tényállása szerint 1898-ban a Britannia gőzös először Palermóból Marseille-be, majd onnan New Orleansba hajózott. Mielőtt úti célját elérte volna, a hajó legénysége és 408 utasa - akik túlnyomó többségben olasz bevándorlók voltak - járványügyi ellenőrzésen esett át egy, a Mississippi folyón található állami karanténállomáson, ahol mindenkit egészségesnek nyilvánítottak. Ennek ellenére két nappal később a hatóságok nem engedték a gőzöst a szárazföldön kikötni, mivel New Orleans egészségügyi hatósága a várost vesztegzár alá helyezte. Az intézkedés célja az volt, hogy megfékezzék a sárgalázat és annak Európából történő, ismétlődő behurcolását. A Compaigne Francaise de Navigation a Vapeur hajótársaság, vagyis az ügy felperese ellenben többek között azzal érvelt, hogy az intézkedés valódi célja a bevándorlók partra szállásának megakadályozása volt, és az intézkedés a hajótársaság tisztességes eljáráshoz való jogát, illetve az alkotmány kereskedelmi klauzuláját ${ }^{55}$ is sérti. Az ügyben a Legfelsőbb Bíróság kimondta, hogy a tagállamok hatáskörében áll a karantén elrendelése közegészségi okokból addig, amíg a Kongresszus ezzel ellentétes tartalmú jogszabályt nem hoz, ebből levezetve pedig a bíróság a felperes által benyújtott fellebbezést elutasította.

Az amerikai Legfelsőbb Bíróság járványkezeléshez kapcsolódó második és egyben talán a legfontosabb, mérföldkőnek számító döntése minden bizonnyal a Jacobson v. Massachusetts ügy ${ }^{56} 1905$-ből, amelyben az alkotmányvédő fórum kimondta, hogy a tagállamok hatáskörében áll kötelező védőoltásokról szóló jogszabályokat alkotni és karantént elrendelni, továbbá hogy az egyén szabadsága nem abszolút, és hogy ezért adott esetben alá kell vetnie magát a tagállami hatóságok intézkedéseinek. Az ügy tényállása szempontjából releváns, hogy akkoriban Massachusetts egyike volt annak a 11 tagállamnak, amelyekben a helyi önkormányzatok kötelezően rendelhették el közegészségi és közbiztonsági okokból védőoltások beadatását. Így történt 1902-ben is Cambridge-ben, amikor kitört a himlőjárvány. Az ügy felperese Henning Jacobson svéd származású lelkész volt, aki korábban, gyermekként szülőhazájában már kapott himlő elleni vakcinát, az oltás beadása után azonban súlyos mellékhatások jelentkeztek nála. Mivel utóbbira való hajlamot örökletesnek vélte, mind a saját, mind a gyermeke számára megtagadta a himlő elleni védőoltás beadatását, ami miatt eljárás alá vonták, és pénzbírságot szabtak ki vele szemben. Jacobson szerint ezzel az állam megsértette a szabadságát, valamint „észszerútlen, önkényes és elnyomó” bánásmódot alkalmazott vele szemben. Érvelését a Legfelsőbb Bíróság nem fogadta el, és 7:2 arányban kimondta, hogy Massachusetts szabályozása a Tizennegyedik Alkotmánykiegészítést nem sérti. A bíróság hangsúlyozta, hogy a társadalmi együttélés természetes velejárója, hogy az egyén érdeke és a köz érdeke olykor ütközik, és előfordulnak olyan súlyos veszéllyel fenyegető helyzetek, amikor az egyén szabadságát a köz érdekében korlátozásoknak kell alávetni. Továbbá a dön- 
tésben azt is kimondták, hogy a kötelező védőoltás elrendelése nem önkényes és elnyomó akkor, ha a közbiztonság észszerú érdeke úgy kívánja meg. A Legfelsőbb Bíróság elutasította a felperes arra irányuló érvelését, hogy egyes orvosi közösségek szintén ellenzik a vakcina beadatását, mivel szerintük az egyéb súlyos megbetegedéseket okoz; döntését a bírói fórum azzal indokolta, hogy az orvostudományi elméletek közötti választás nem a bíróságok, hanem a törvényhozó feladata.

Az ügy számos utóhatást váltott ki. Egyrészt a döntés megszületése után három évvel létrejött az Amerikai Oltásellenes Liga (Anti-Vaccination League of America), ${ }^{57}$ másrészt a döntés a Legfelsőbb Bíróság esetjogában precedensértékûvé vált, amit később többször is megerősítettek. Így például a Zucht v. King ügyben ${ }^{58} 1922$-ben, ahol a Legfelsőbb Bíróság kimondta, hogy az iskola járványügyi okokból megtagadhatja az olyan tanuló felvételét, aki egy kötelező védőoltást nem kapott meg. Mi több, a Jacobson v. Massachusetts ügy 2020-ban is visszaköszönt az egyik louisianai fellebbviteli bíróságon (United States Court of Appeals for the Fifth Circuit), ahol megállapítást nyert, hogy jogszerú az a texasi korlátozó rendelkezés, amely az abortuszokat, mint nem életmentô orvosi beavatkozásokat, elhalasztja a koronavírus-járvány terjedésének lassítása érdekében. ${ }^{59}$

A bemutatott jogesetek második csoportja a hadiállapot köré csoportosítható. A Legfelsőbb Bíróság e kérdéssel elsőként még az amerikai polgárháborúhoz kapcsolódóan, az Ex parte Milligan ügyben ${ }^{60}$ foglalkozott. A bíróság ítéletében megállapította, hogy a civilek felelősségre vonása katonai törvényszékek előtt alkotmányellenes mindaddig, amíg rendes bíróságok müködnek. Az ügy névadóját, Lambdin Milligant és társait kormány elleni összeesküvéssel, a Konföderáció támogatásával és lázítással vádolták, majd hármukat katonai törvényszék eloott akasztás általi halálra ítélték. Milligan védője a habeas corpus jogának megsértésére hivatkozott, majd az ügy a Legfelsőbb Bíróság elé került. Utóbbi kimondta, hogy a vádlottnak civilként joga van ahhoz, hogy bûncselekmény elkövetésének vádja miatt rendes bíróság előtt vonják felelősségre, mivel az alkotmány biztosítja az észszerütlen házkutatás és lefoglalás elleni védelmet, valamint megköveteli az alapos gyanúval alátámasztott letartóztatást és indokolt esetekben tárgyalás lefolytatását esküdtszék elôtt. A bíróság nyomatékosan hangsúlyozta, hogy a katonai büntetőjog csak katonai mûveletekre alkalmazható és csak akkor, ha már a rendes bíróságok nem funkcionálnak. A Legfelsőbb Bíróság többségi véleménye abban is állást foglalt, hogy a habeas corpus felfüggesztésével az állampolgárokat legfeljebb fogva tartani lehet, azonban büntetőeljárás alá vonni vagy kivégezni őket nem.

57 The History of Vaccines, The Anti-Vaccination Society of America: Correspondence. Elérhető: www. historyofvaccines.org/content/blog/anti-vaccination-society-america-correspondence (Letöltve: 2020. december 10.).

58 U. S. Supreme Court, Zucht v. King, 260 U.S. 174.

59 U. S. Court of Appeals for the Fifth Circuit, No. 17-50060, Appeal from the U. S. District Court for the Western District of Texas, USDC No. 1:17-CV-690.

60 U. S. Supreme Court, Ex parte Milligan, 71 U. S. (4 Wall.) 2 (1866). 
Rendkívül vitatott esetei az amerikai Legfelsőbb Bíróságnak a Hirabayashi-ügy6 és a Korematsu-ügy, ${ }^{62}$ amelyeket későbbi döntéseiben felül is bírált az alkotmányvédő fórum. Mindkét eset a Pearl Harbor lebombázása utáni időkből való, amikor különösen erôteljessé vált a japánokkal szembeni idegengyúlölet az amerikai közvéleményben. A Hirabayashi-ügy előzménye volt, hogy miután az Egyesült Államok belépett a második világháborúba, Franklin $D$. Roosevelt elnök felhatalmazta a katonai parancsnokokat, hogy az általuk igazgatott katonai területekről bárkit kitiltsanak, ennek következtében pedig a parancsnokok a nyugati parton élő japán származású lakosokat (akkor is, ha egyébként amerikai állampolgárok voltak) kijárási tilalom és korlátozó intézkedések alá helyezték, végül pedig internálótáborokba küldték. Az ügy felperesét, Gordon Hirabayashit a kijárási tilalom megsértése miatt vonták felelősségre, aki ügyét a Legfelsőbb Bíróságig vitte. Utóbbi a felperes fellebbezését elutasítva kimondta, hogy egy kisebbségi nemzetiségi csoport tagjaival szembeni kijárási korlátozás elrendelése nem ütközik az alkotmányba akkor, ha az állam háborúban áll azon országgal, ahonnan ennek a nemzetiségi csoportnak a felmenői származnak.

A döntést csak még inkább beárnyékolta a bíróság egy évvel később, a Korematsu-ügyben meghozott, szintén mérföldkőnek számító ítélete. Az eset fókuszában ugyanaz a tényállás és probléma állt: Fred Korematsu 23 éves japán származású amerikai állampolgár megtagadta a kijelölt katonai terület elhagyását, arra hivatkozva, hogy az az Ötödik Alkotmánykiegészítésbe ütközik. A Legfelsőbb Bíróság döntésében akként érvel, hogy az Egyesült Államok kémkedéssel szembeni védelme mint közérdek áll ellentétben a japán származású amerikai állampolgár egyéni érdekével, és hogy mivel a kitiltást nem a felperes származása, hanem katonai szükségszerủség indokolta, így az nem ütközik az amerikai alkotmányba; a hadiállapot fennállása alatti effajta jogkorlátozás tehát nem alkotmányellenes. A Legfelsőbb Bíróság egyébként e döntését 2018-ban a Trump v. Hawaii ügyben ${ }^{63}$ (amelynek homlokterében az elnök azon végrehajtási utasítása állt, amely bizonyos, főképp muszlim vallású nemzetiségek számára megtiltotta a beutazást az országba akkor is, ha érvényes vízummal és úti okmánnyal rendelkeznek) hatályon kívül helyezte.

\section{A koronavírus-járvány miatt bevezetett különleges jogrend az Egyesült Államokban és a járványkezelésre adott szövetségi, tagállami és helyi szintứ válaszok}

A Covid-19-járvánnyal kapcsolatban először okvetlenül meg kell jegyezni, hogy a legfrissebb, 2020. december 15-i adatok alapján az Egyesült Államok jelenleg a világ legfertőzöttebb országa: 2020. január 21. óta több mint 17,5 millió beteget regisztráltak, és több mint 315 ezer 
ember hunyt el a betegségben. ${ }^{64} \mathrm{Az}$ ország újonnan megválasztott, 2021. januárban hivatalba lépő elnöke, Joe Biden a koronavírus elleni küzdelmet a legnagyobb kihívásnak nevezte, amivel az Egyesült Államoknak meg kell küzdenie a második világháború óta. Biden kampányának egyik visszatérő eleme volt a járvány minél hatékonyabb és átfogóbb kezelésének ígérete, amelynek keretében hangsúlyozta, hogy a Trump-adminisztráció által bevezetett intézkedéseket nem tartja elegendőnek. ${ }^{65}$ Ebből adódóan várható, hogy a jövő év elején beiktatandó elnök új politikai irányvonalat képvisel majd a járványkezelést illetően, ${ }^{66}$ mindazonáltal jelen elemzés csupán az eddig bevezetett intézkedéseket, az eddigi prioritásokat vizsgálja meg.

A koronavírus-járvány miatt az Egyesült Államokban először 2020. január 31-én hirdetett közegészségi veszélyhelyzetet az egészségügyért felelős miniszter az 1944. évi közegészségügyi ellátásokról szóló törvény ${ }^{67}$ alapján (amelyet azóta többször megújítottak). Ezt követően pedig, 2020. március 13-án az amerikai elnök kihirdette az országos veszélyhelyzetet is, részben a fenti törvényi rendelkezés, részben pedig az 1976. évi országos veszélyhelyzetrôl szóló törvény ${ }^{68}$ értelmében, amely országos veszélyhelyzet e sorok írásakor szintén hatályban van még. Azt mondhatjuk tehát, hogy a föderális szintú járványkezelés két alappillére az Egyesült Államokban a közegészségi veszélyhelyzet és az országos veszélyhelyzet párhuzamos kihirdetése volt.

Ugyanakkor az ország közigazgatási berendezkedéséből adódóan nemcsak e két, a szövetségi törvényhozástól származó különleges jogrendi kategória van egymással párhuzamosan hatályban, hanem mind a tagállamok, mind a helyi önkormányzatok jogosultak származékos jogalkotási hatáskörben - mintegy „vertikálisan” - különleges jogrendet kihirdetni és a válságkezeléssel kapcsolatosan szükséges jogszabályokat meghozni. Így a járványkezelés és ezzel összefüggésben a különleges jogrend szabályozása is erősen decentralizált az országban.

A válságkezelés az Egyesült Államokban általában véve helyi szintrôl indul, amelyet az illetékes tagállam kormányának támogatása, illetve súlyosabb veszélyhelyzetek esetén a szövetségi kormány támogatása egészíthet ki. ${ }^{69}$ Ellenben, a könnyebb megértés reményében, a járványkezelést e helyütt nem e logika szerint mutatjuk be, hanem a jogalkotási hatáskörök származásának iránya szerint haladunk: így a szövetségi alkotmányos és törvényi szintû rendelkezéseket vizsgáljuk meg először, majd pedig a tagállamok és a helyi önkormányzatok koronavírus-járványra adott válaszait vesszük sorra.

64 Centers for Disease Control and Prevention, United States COVID-19 Cases and Deaths by State. Elérhető: https://Covid.cdc.gov/Covid-data-tracker/\#cases_casesper100k (Letöltve: 2020. december 15.).

65 A két elnökjelölt legutolsó, 2020. október 23-i vitája is a választási kampány véghajrájában javarészt a járványkezelési kérdések körül forgott. Elérhető: www.youtube.com/watch?v=yGPfKkjDIts (Letöltve: 2020. december 2.).

66 Lásd bővebben: Biden-Harris, The Biden Plan to Combat Coronavirus (COVID-19) and Prepare for Future Global Health Threats. Elérhetô: https://joebiden.com/Covid-plan/ (Letöltve: 2020. december 15.).

67 1944. évi közegészségügyi szolgáltatásokról szóló törvény 319. cikk (a) bekezdés.

68 1976. évi országos veszélyhelyzetről szóló törvény 201. cikk (a) bekezdés.

69 Lindsay-Webster, 2020. 
A szövetségi törvényhozás koronavírus-járványra adott válaszait illetően az Egyesült Államok alkotmánya kimondja, hogy a Kongresszus kizárólagos adókivetési hatáskört élvez az ország közös védelmének és általános jólétének biztosítása érdekében. ${ }^{70}$ Noha a katasztrófák elhárítása és a közegészségi veszélyhelyzetek kezelése szintén a Kongresszus hatáskörébe tartozik az olyan krízishelyzetekben, mint amilyen a koronavírus-járvány is, számos kongresszusi hatáskört átruházhatnak az elnökre azzal, hogy továbbra is a törvényhozás irányítja a szövetségi államok pénzügyi segélyeinek adminisztrációját és elosztását. ${ }^{71} \mathrm{Az}$ amerikai alkotmány továbbá főszabályként előírja, hogy a Pénzügyminisztérium csak akkor fordíthat közpénzt egy adott célra, hogyha azt előzetesen a Kongresszus előirányzatként jóváhagyta. ${ }^{72}$

Az Egyesült Államok költségvetése ${ }^{73}$ háromféle előirányzatot különböztet meg: szokásos előirányzatok (regular appropriations), folytatólagos ráfordítások (continuing resolutions) és kiegészítő előirányzatok (supplemental appropriations). Az olyan sürgősségi kiadások, mint a katasztrófák elhárításának és a közegészségi veszélyhelyzetek kezelésének finanszírozása, azaz az országos veszélyhelyzet miatt megállapított kiadások a kiegészítő előirányzatok kategóriájába tartoznak, és általában véve mentesülnek az egyéb, a fent említetten túli költségvetési korlátozások alól. ${ }^{74}$

A koronavírus-járvány kitörése óta a Kongresszus több olyan törvényt is elfogadott, amely a tagállamok, helyi önkormányzatok, vállalkozások és magánszemélyek járványkezelési költségeinek vagy a járvány miatt felmerült egyéb kiadásainak finanszírozását támogatja. Ezek a támogatások egyrészt a közegészségügyi ellátórendszer többletkiadásainak (például tesztelési infrastruktúra kialakítása és fenntartása) fedezését, másrészt a gazdaság élénkítését célozzák meg. A kifejezetten a koronavírus-járvánnyal összefüggésben elfogadott legfontosabb szövetségi törvények:

— a koronavírus miatti készültségről és kiegészítő előirányzatokról szóló törvény; ${ }^{75}$

— „a családok az elsők" törvény; ${ }^{76}$

— a koronavírus-segélyről, járványkezelésről és gazdaságvédelemről szóló törvény,77 valamint

— a fizetések védelméről és az egészségügyi ellátás színvonalának növeléséről szóló törvény. ${ }^{78}$

70 U. S. Const. art. I, \$ 8, cl. 1.

71 Elsea, J. K. et al., 2020.

72 U. S. Const. art. I, \$9, cl. 7.

$73 \mathrm{Az}$ Egyesült Államok éves költségvetésének tervezetét az elnök készíti elő. Ezután a Kongresszus megtárgyalja a tervezetet, majd ezt alapul véve válaszként elkészíti a sajátját, amelyet visszaküld az elnöknek. A költségvetésre vonatkozó legfontosabb törvényi szabályokról lásd: Congressional Budget and Impoundment Control Act of 1974 (CBA) [2 U.S.C. \$\$ 601-688]; Balanced Budget and Emergency Deficit Control Act of 1985 (BBEDCA) [2 U.S.C. \$\$900-922].

74 Saturno-Heniff-Lynch, 2016.

75 Coronavirus Preparedness and Response Supplemental Appropriations Act [Pub. L. No. 116-123].

76 Families First Coronavirus Response Act (FFCRA) [Pub. L. No. 116-127].

77 Coronavirus Aid, Relief, and Economic Security Act (CARES Act) [Pub. L. No. 116-136].

78 Paycheck Protection Program and Health Care Enhancement Act [Pub. L. No. 116-139]. 
A törvények által bevezetett legfontosabb járványkezelési intézkedések az alábbiak szerint foglalhatók össze.

A 2020. március 5-én elfogadott, a koronavírus miatti készültségről és kiegészítő előirányzatokról szóló törvény 8,3 milliárd amerikai dollárt irányzott elő a járvány elleni küzdelem elsődleges lépéseire, így tesztelésre, védőoltással kapcsolatos kutatásokra, orvosi eszközök beszerzésére, továbbá az Egyesült Államok külképviseleteinek védelmére, esetleges evakuálására. Ezt követően, a 2020. március 18-án elfogadott „a családok az elsők” törvény elsősorban különböző szociális juttatásokról rendelkezik, így például fizetett betegszabadságról, adójóváírásról, Covid-19-tesztelésről, étkezési segélyezésről stb. A Kongresszus Költségvetési Irodája szerint csak ez a törvény 2030-ig mintegy 192 milliárd amerikai dollárral fogja megnövelni a költségvetési hiányt, amelyből a koronavírushoz kapcsolódó fizetett szabadságok és adójóváírások hozzávetőlegesen 105 milliárd dollárt tesznek majd ki. ${ }^{79}$ A 2020. március 27-én elfogadott, a koronavírus-segélyről, járványkezelésről és gazdaságvédelemről szóló törvény átfogó intézkedéscsomagot vezetett be a gazdaság, a közegészségügy, a tagállamok, a helyi önkormányzatok, a vállalkozások és a magánszemélyek megsegítése érdekében, és mintegy 2 billió (!) amerikai dollárt irányzott elő a Covid-19 elleni komplex küzdelemre. E törvény lehetôvé teszi, hogy a tagállamok meghatározott célokra fordítsák a szövetségi kormányzattól kapott pénzügyi támogatást, valamint kiegészítő munkanélküli segélyben részesíti a járvány miatt elrendelt kijárási korlátozás, karantén és munkahelybezárások miatt a „munkából kieső” munkavállalókat. Végül a 2020. április 23-án elfogadott, a fizetések védelméről és az egészségügyi ellátás színvonalának növelésérôl szóló törvény létrehozott egy pénzalapot a kisvállalkozások megsegítésére, és újabb közegészségügyi támogatásról rendelkezett; a törvény a március 27-én elfogadott átfogó intézkedéscsomaghoz képest további 484 milliárd amerikai dollárt irányzott elő a Covid-19 elleni védekezésre. (Érdekességként megjegyzendő, hogy e törvény a koronavírustesztek finanszírozását már önálló előirányzatként kezeli.)

A Kongresszuson túl a szövetségi végrehajtás is átfogóan reagált a Covid-19 által előidézett krízisre. A szövetségi minisztériumok (federal executive agencies) különös hatáskörú központi közigazgatási szervek, amelyek származékos jogalkotási hatáskörrel rendelkeznek. Utóbbi a Kongresszustól származik, amelyet a törvényhozó szerv a szövetségi közigazgatási eljárási törvény ${ }^{80}$ alapján ruházhat át a szövetségi minisztériumokra. ${ }^{81}$

A szövetségi minisztériumok rendes jogalkotási eljárása főszabály szerint kétféle lehet: formális és informális. Formális jogalkotásról akkor beszélünk, amikor a Kongresszus utasítja a szövetségi minisztériumot, hogy alkosson rendelet (statute) formájában új jogszabályt. Magát a jogalkotást egy úgynevezett közigazgatási bíró (administrative law judge) előtt tartott nyilvános vita előzi meg, ahol az érdekeltek előadhatják a jogszabályjavaslattal kapcsolatos

79 Swagel, 2020.

80 Administrative Procedure Act (APA) [5 U.S.C. $\$ \$ 500-596]$.

81 Price, 2020. 
észrevételeiket. ${ }^{82}$ Ennél azonban sokkal gyakoribb a szövetségi minisztériumokon belüli informális jogalkotás, amikor a minisztérium egy korábbi, általa meghozott rendeletet módosít vagy egészít ki. ${ }^{{ }^{3}}$ Ebben az esetben az érdekelteknek a formális jogalkotáshoz képest rövidebb idő áll rendelkezésükre, hogy előadják a jogszabályjavaslattal kapcsolatos ellenérveiket.

A formális és informális jogalkotási eljárások alól léteznek kivételek. Az egyik az, amikor a szövetségi minisztériumok sürgősségi jogszabályt (emergency rule) fogadnak el. Erre akkor adódik lehetőségük, amikor a rendes jogalkotási eljárás követése a közérdekkel ellentétben áll (például azért, mert sok időt vesz igénybe). ${ }^{84}$ A Covid-19 elleni fellépés keretében a szövetségi minisztériumok számos ilyen sürgősségi jogszabályt hoztak.

A rendes jogalkotási eljárások alóli egyéb kivételek a kongresszusi felülvizsgálati törvényben ${ }^{85}$ lelhetők fel. Utóbbi kimondja, hogy a szövetségi minisztériumoknak valamennyi újonnan elfogadott rendeletet meg kell küldeniük a Kongresszusnak, amelynek képviselőháza és szenátusa együttesen hozott közös rendelettel megsemmisítheti a szövetségi minisztériumok által elfogadott rendeleteket. Mindazonáltal ha e közös rendelet ellen az elnök vétót emel, a minisztériumi jogszabály hatályba léphet. A kongresszusi felülvizsgálati törvényben meghatározott másik kivétel az, hogy ha az egészséget vagy a biztonságot közvetlen veszély fenyegeti, akkor az elnök végrehajtási utasítással a minisztériumi rendeletet azonnal hatályba léptetheti. ${ }^{86} \mathrm{Mi}$ több, az elnök végrehajtási utasítással közvetlenül is elrendelheti, hogy a szövetségi minisztériumok egy jogszabályt vagy egy egyedi jogi aktust meghozzanak azzal, hogy a szövetségi közigazgatási eljárási törvény rendelkezéseit ilyen esetekben is be kell tartani. Noha az elnök végrehajtási utasítása alapján meghozott minisztériumi jogszabályok felülvizsgálatára a bíróságok jogosultak, a bírói gyakorlat meglehetôsen megengedő e téren: a szövetségi minisztériumoknak elég csupán az „észszerűség” fennállását bizonyítaniuk az általuk meghozott jogszabály jogszerüségének alátámasztásához. ${ }^{87}$

A szövetségi minisztériumok koronavírus-járványra adott válaszai közül érdemes számba vennünk néhányat. Így például a „családok az elsők” törvény felhatalmazta a Szövetségi Munkaügyi Minisztériumot, hogy a törvény által kiterjesztett fizetett munkavállalói távollét jó gyakorlatának részletszabályait kidolgozza. ${ }^{88}$ Vagy például a koronavírus-segélyről, járványkezelésről és gazdaságvédelemről szóló törvény feljogosította az Oktatási Minisztériumot, hogy döntsön a föiskolai és egyetemi hallgatók járvánnyal kapcsolatos nehézségei leküzdéséhez nyújtandó segélyekről. Úgyszintén, a fizetések védelmérôl és

82 Administrative Procedure Act $\$ \$ 556-557$.

83 Administrative Procedure Act $\$ 553$.

84 Administrative Procedure Act $\$ 553(\mathrm{~b})(\mathrm{B})$.

85 Congressional Review Act (CRA) [5 U.S.C. \$\$ 801-808].

86 Congressional Review Act $\$ 801(\mathrm{c})(2), \$ 801(\mathrm{c})(2)(\mathrm{A})$.

87 Brannon, 2018.

88 Families First Coronavirus Response Act $\$ 5111 ; 85$ Fed. Reg. 19,326 (Apr. 6, 2020). Elérhető: https://perma.cc/ FF93-MUZV (Letöltve: 2020. december 19.); corrected by 85 Fed. Reg. 20,156 (Apr. 10, 2020). Elérhető: https:// perma.cc/Z7TJ-7WFR (Letöltve: 2020. december 19.). 
az egészségügyi ellátás színvonalának növeléséről szóló törvény a Kisvállalkozások Hivatalát bízta meg, hogy utóbbi rendelkezzen az arra jogosult kisvállalkozásoknak járó közvetlen kifizetések folyósításáról. ${ }^{89}$

Az Egyesült Államok közigazgatási berendezkedéséből és a járványkezelésre vonatkozó szabályozás decentralizált jellegéből adódóan e helyütt a tagállami és helyi szintű szabályozást sem hagyhatjuk figyelmen kívül. A Tizedik Alkotmánykiegészítés ${ }^{\circ}$ az egyes hatáskörök szövetségi kormányzat, tagállamok és polgárok közötti megosztásáról rendelkezik. Eszerint ha az alkotmány egy hatáskört nem utal a szövetségi kormányzathoz, és annak a hatáskörnek a gyakorlását nem is tiltja meg a tagállamok számára, akkor az a hatáskör a tagállamokat illeti meg; ha pedig a tagállamok ezzel a hatáskörrel nem élnek, akkor a kérdés a polgárokra van bízva. A bíróságok a gyakorlatban a Tizedik Alkotmánykiegészítést úgy értelmezik, hogy a rendőrségi hatáskörök a tagállamokhoz tartoznak, így a közegészségi veszélyhelyzet okán elrendelt intézkedések elrendelése és betartatása is. ${ }^{91}$

Ezzel összhangban a legtöbb tagállamban saját végrehajtási intézkedések vannak hatályban, amelyeket a tagállamok a szövetségi közigazgatási eljárási törvénnyel összhangban, saját közigazgatási eljárási törvényeik ${ }^{22}$ alapján dolgoznak ki. A közigazgatási eljárási törvényekben felsorolt hatáskörök mellett a tagállami alkotmányok is számos hatáskört utalnak a kormányzókhoz, akik e felhatalmazásukat a polgárok katasztrófáktól és veszélyhelyzetektől való megóvása érdekében gyakorolhatják. Ekképpen a karantén vagy kijárási korlátozás elrendelése a kormányzók hatáskörébe tartozik, a végrehajtás foganatosítása pedig a tagállami egészségügyi hatóságok feladata.

E sorok írásakor az Egyesült Államok valamennyi, azaz mind az 50 tagállamában különleges jogrend van hatályban, amelyek elnevezése terminológiai sokféleségről árulkodik.93 Ami az alaki jogforrást illeti, a tagállami kormányzók rendszerint végrehajtási utasításokban hirdetik ki a különleges jogrendet. Utóbbira példaként hozható Ohio, ahol a kormányzó

89 Price, 2020.

90 U. S. Const. amend. X.

91 Galva-Atchison-Levey, 2005.

92 Például Washington State Administrative Procedure Act, Wash. Rev. Code $\$ 34.05$ (1988); Massachusetts State Administrative Procedure, Mass. Gen. Laws ch. 30A, \$\$ 1-25 (1954).

9328 tagállamban, például Alabamában, Dél-Karolinában, Kaliforniában, Hawaiin vagy Utahban veszélyhelyzeti állapot (state of emergency), 11 tagállamban, például Alaszkában, Arizonában, Louisianában vagy Új-Mexikóban közegészségi veszélyhelyzet (public health emergency), míg a legfertőzöttebb tagállamokban katasztrófahelyzet (disaster, disaster emergency vagy state of disaster emergency) van hatályban. Vannak tagállamok, amelyek egyedi különleges jogrendi terminológiát alkalmaznak. Így például Arkansasben veszélyhelyzetet (emergency), Maine-ben polgári veszélyhelyzetet (state of civil emergency), Minnesotában pedig békeidős veszélyhelyzetet (peacetime emergency) hirdettek ki. National Governors Association, Status of State COVID-19 Emergency Orders. Elérhető: www.nga.org/state-Covid-19-emergency-orders/ (Letöltve: 2020. december 15.). 
2020. márciusban veszélyhelyzeti állapotot hirdetett ki, ${ }^{94}$ és ennek megfelelóen a tagállam egészségügyi hatósága kijárási korlátozást vezetett be. ${ }^{95}$

Továbbá a tagállami különleges jogrend idôbeli hatályát tekintve azt mondhatjuk, hogy az általában az országos veszélyhelyzet fennállásához igazodik. Erre jó példa Montana kormányzójának végrehajtási utasítása, amely úgy rendelkezik, hogy a veszélyhelyzeti állapot a tagállamban addig tart, amíg az elnök a járványhelyzet miatti országos veszélyhelyzetet vissza nem vonja. ${ }^{96}$ Azonban a különleges jogrend határozott idejû́ elrendelésére is találunk példát: New York állam szabályozása szerint a katasztrófahelyzet 2021. április 21-ig marad hatályban. (Utóbbi egyébként megújítható.).7

Végül a helyi önkormányzatok járványkezelési intézkedéseiról kell még szólnunk. Az Egyesült Államokban a helyi önkormányzatok (local governments) megyékből (counties) és önkormányzatokból (municipalities) állnak. A megyékhez további kerületek (boroughs, parishes), az önkormányzatokhoz pedig városok (cities, towns) és települések (villages) tartoznak. A helyi önkormányzatok jogalkotási hatásköre a tagállamoktól ered, és e származékos jogalkotási hatáskörüket nem léphetik túl.98

Jóllehet a Tizedik Alkotmánykiegészítés rendelkezik a szövetségi állam és a tagállamok közötti hatáskörmegosztásról, a tagállamok és a helyi önkormányzatok közötti hatáskörmegosztásról egyáltalán nem szól, így újfent a Legfelsőbb Bíróság joggyakorlata mutathat irányt nekünk e kérdésben. Utóbbi a Hunter v. City of Pittsburgh ügyben ${ }^{99}$ megállapította, hogy „a helyi önkormányzatok a tagállamok alsóbb szintú politikai szervezeti egységei, olyan kiszolgáló szervek, amelyek a tagállam által rájuk ruházott kormányzati hatáskörök gyakorlására hivatottak [...] A helyi önkormányzatok számának, jellegének, múködésük időtartamának, valamint területi illetékességüknek a meghatározása a tagállamok abszolút diszkrecionális jogkörébe tartozik." A Legfelsőbb Bíróság ezen tételt később a Trenton v. New Jersey ügyben ${ }^{100}$ is fenntartotta, és kimondta, hogy „,kifejezett tagállami alkotmányos rendelkezés hiányában a helyi önkormányzatoknak nincsen olyan beleértett jogalkotási hatásköre, amely a tagállam által ráruházott kifejezett hatásköröket túllépi. A helyi önkormányzat csupán a tagállam egyik szervezeti egysége, és ha a tagállam úgy látja, akkor a helyi önkormányzat valamely hatáskörét visszatarthatja, visszavonhatja, vagy új hatáskört állapíthat meg számára. Legyen bármily' nagy vagy éppen kicsi a [helyi önkormányzat] cselekvési szabadsága, a tagállam teremtménye marad, amely a szuverén akarata által ráruházott ha-

94 Ohio Exec. Order No. 2020-01D (Mar. 9, 2020).

95 Director's Stay Safe Ohio Order, Ohio Dep't of Health (Apr. 30, 2020); Director's Order, Ohio Dep't of Health (July 7, 2020).

96 Mont. Exec. Order No. 2-2020 (Mar. 12, 2020); Mont. Exec. Order No. 3-2020 (Mar. 13, 2020).

97 N. Y. Exec. Order No. 202.60 (Sept. 4, 2020).

98 State \& Local Government, The White House. Elérhető: https://perma.cc/BLD9-C5DY (Letöltve: 2020. december 1.).

99 Hunter v. City of Pittsburgh, 207 U. S. 161, 178 (1907).

100 City of Trenton v. New Jersey, 262 U. S. 182, 187 (1923). 
tásköröket és privilégiumokat gyakorolja, illetve bírja.” A Legfelsőbb Bíróság precedensei alapján általánosságban elmondhatjuk, hogy a helyi kormányzatok csak a kifejezetten rájuk ruházott hatásköröket gyakorolhatják akkor, ha e hatásköröket szükségszerú és tisztességes hatáskör-átruházással delegálták rájuk, és amely hatáskörök a helyi kormányzat létezése szempontjából alapvetőnek bizonyulnak.

Ilyen, a járványkezelés szempontjából fontos helyi hatáskör az adókivetés, azon belül is az általános forgalmi adó kérdése. A New York State Association által közzétett kutatás ${ }^{101}$ becslései szerint csak New York államban 1,8 milliárd dolláros bevételkiesés várható 2020-ban a Covid-19 miatt visszaesett forgalom miatt. A helyi kormányzatok bevételkieséseinek kompenzációjára a korábban ismertetett szövetségi törvényeken túl még egy további, a képviselőház által előterjesztett törvényjavaslatot ${ }^{102}$ fontos megemlíteni, amelyet jelenleg éppen tárgyal a Kongresszus. E törvényjavaslat szerint további 179 milliárd dollárral támogatná a központi költségvetés a helyi önkormányzatokat. Egy másik, járványkezeléssel szervesen összefonódó helyi hatáskör az oktatás, pontosabban a távoktatás elrendelése. Miután utóbbi Philadelphiában bevezetésre került, a helyi iskolakörzetben az önkormányzat minden olyan tanulónak laptopot és ingyenes internet-hozzáférést biztosított, akiknek otthon addig nem volt (e költségek hozzávetőlegesen meghaladták a 11 millió amerikai dollárt). ${ }^{103}$ Harmadikként e helyütt a maszkviselés szabályozását emelnénk ki, amely szintén helyi önkormányzati hatáskört képez. A maszkviselés betartatása a városi rendőrkapitányságok és a sheriffek feladata. ${ }^{104}$ Végezetül érdekességként megemlítendő, hogy az Egyesült Államokban a helyi önkormányzatok múködésének egyik sajátossága a képviselö-testületek üléseinek nyilvánossága, így azokon bárki részt vehet. Utóbbi biztosítása a Covid-19-járvány idején ismételten újfajta kihívást keltett életre, amelynek megoldásaként a képviselő-testületek üléseit is áttették a virtuális térbe. ${ }^{105}$

\section{A különleges jogrend kihirdetésével kapcsolatos jogviták}

A különleges jogrend kihirdetésével kapcsolatos jogviták kapcsán elmondható, hogy a közegészségi veszélyhelyzet kapcsán számottevő precedensekről nem lehet beszámolni.

101 Marren-Acquario, 2020.

102 Heroes Act, H.R. 925, 116th Cong. (House engrossed amendment, Oct. 1, 2020).

103 School Year 2020-2021: Advancing Education Safely. School District of Philadelphia. Elérhető: https://perma.cc/ HYF6-QB5M; Chromebooks. School District of Philadelphia. Elérhető: https://perma.cc/KF6Q-TH67; Internet Access Options for Families. School District of Philadelphia. Elérhető: https://perma.cc/FA57-A89V; Press Release. School District of Philadelphia, School District Will Use \$11 Million to Help Bridge the Digital Divide Among Students. Elérhető: https://perma.cc/J93L-DJD5 (Letöltve: 2020. december 15.).

104 Price, 2020.

105 Lásd erről bővebben például az észak-karolinai Asheville vagy az arizonai Surprise szabályozását: Asheville, N. C., Mun. Code pt. 1, art. II, $\$ 9$ (1985); McDaniel, 2020; Ord. No. 2020-12, City of Surprise, Arizona (Mar. 17, 2020); Ariz. Rev. Stat. \$38-431.01(A). 
(Az persze más kérdés, mint ahogyan már fentebb is utaltunk rá, hogy a 2020. évi választási kampány során a két elnökjelölt heves politikai vitákba bocsátkozott e kérdésben.) Mindazonáltal a közelmúlt eseményei egy szemléletes példával szolgálnak számunkra - még ha nem is a koronavírus-járvánnyal kapcsolatban -, ez pedig az Egyesült Államok déli határán épülő fal ügye.

Először is a vita jogi hátterét szükséges röviden felvillantani. Mint ahogyan láttuk, a korábban bemutatott országos veszélyhelyzetről szóló törvény kimondja, hogy amennyiben az elnök országos veszélyhelyzetet hirdet ki, a képviselőháznak minden hatodik hónapban felül kell vizsgálnia a veszélyhelyzet jogszerűségét, ha pedig az arra okot adó körülmények már nem állnak fenn, akkor kezdeményeznie kell a szenátusnál, hogy a veszélyhelyzetet együttes rendelettel szüntessék meg. Utóbbi rendelkezés a törvény elfogadása, azaz 1976 óta egészen a közelmúltig Csipkerózsika-álomban szendergett, amikor is Donald Trump országos veszélyhelyzetet hirdetett $\mathrm{ki}^{106}$ a déli országhatáron tervezett falépítéshez szükséges költségvetési finanszírozás biztosítása céljából, miután azt a Kongresszus, mint szokásos költségvetési előirányzatot (összege 5,7 milliárd amerikai dollár), korábban már kifejezetten elutasított. ${ }^{107}$ (A költségvetés elfogadásáról lásd bővebben a 3. pontot.) Ugyanakkor a Kongresszus által hozott országos veszélyhelyzetet megszüntető rendelet ellen Trump vétóval élt, így e veszélyhelyzet még jelenleg is hatályban van. ${ }^{108}$

Az eset élesen rámutat a szabályozás gyenge pontjaira. Egyrészt arra, hogy a veszélyhelyzet fogalmának tisztázatlansága és az intézkedésre jogosultnak juttatott rendkívül széles diszkrecionális jogkör zöld utat enged az elnöknek a törvény különböző politikai célokra történő felhasználására. Másrészt arra, hogy az elnöki vétó (és természetesen a korlátlan alkalommal való megújítás lehetoosége) gyakorlatilag lehetôvé teszi, hogy az elnök határozatlan időre rendelhesse el a veszélyhelyzetet. Harmadrészt az a probléma is megmutatkozik, hogy az elnök ezáltal szokásos költségvetési irányzatot vonhat el a Védelmi Minisztériumtól, ugyancsak politikai célokra. Az esetet valószínúsíthetően annak megosztó politikai karaktere és a közeledô választások miatt ellentétes szakirodalmi visszhangok kísérték. Így például Mark Tushnet, a Harvard Egyetem jogi karának professzora szerint az országos veszélyhelyzet alatt elköltött kiegészítő előirányzatok felhasználása tekintetében az elnöknek olyan széles mérlegelési jogköre van, hogy pozíciója még ebben a helyzetben is de iure sziklaszilárd lábakon áll. ${ }^{109}$

106 Declaring a National Emergency Concerning the Southern Border of the United States, Proc. 9844, February 15, 2019, 84 FR 4949-4950.

107 Halchin, 2020, 19. o.

108 Lásd bővebben: The Atlantic: The Alarming Scope of the President's Emergency Powers. Elérhető: www.theatlantic. com/magazine/archive/2019/01/presidential-emergency-powers/576418/ (Letöltve: 2020. december 15.).

109 NBC News, Fact Check: What's a 'National Emergency', Can Trump Declare One to Get His Wall? Elérhető: www.nbcnews.com/politics/donald-trump/fact-check-what-s-national-emergency-can-trump-declareone-n954966 (Letöltve: 2020. december 15.). 
Az eset egy másik érdekes aspektusa a magántulajdon kisajátításának kérdése - tudniillik a falépítési projektben megjelölt területek kétharmad része magánkézben van -, ugyanis a Legfelsőbb Bíróság korábban a Youngstown Sheet \&Tube Co. v. Sawyer ügyben ${ }^{110}$ megakadályozta, hogy Harry Truman elnök magántulajdonban lévő acélmúveket sajátítson ki veszélyhelyzetre hivatkozva. A bíróság érvelése szerint az acélmúvek kisajátításának feltétele, hogy a Kongresszus megszavazza ellentételezésként a kárpótlást mint rendes előirányzatot, a törvényhozó ezen hatáskörét pedig az elnök még veszélyhelyzet idején sem gyakorolhatja. Az eset tükrében érdekes elgondolkodni azon, hogyan döntene a Legfelsőbb Bíróság, ha jelen ügyben kellene állást foglalnia...

\section{5. Összegzés}

A modern alkotmányokkal és Magyarország Alaptörvényével ellentétben az Amerikai Egyesült Államok 1787-ben elfogadott alkotmánya és annak 27 alkotmánykiegészítése egyáltalán nem tartalmaz rendelkezéseket a különleges jogrendre nézve, amelynek példája szemléletesen illusztrálja, hogy a különleges állapotok alkotmányos szintú szabályozása nem szükségképpeni elvárás az alkotmányozóval szemben. Az USA-ban alkalmazott szabályozási megoldás dogmatikai értelemben az úgynevezett monista megközelítést követi, ami egyrészt azt eredményezi, hogy a különleges jogrendre vonatkozó szabályok az egyes jogszabályokban sporadikusan lelhetók fel, másrészt pedig azt, hogy a válaszreakciók tárháza majdnem végtelen, azaz az intézkedésre jogosult szerv, aki főszabály szerint az elnök, diszkrecionális jogköre rendkívül széles. Így tehát azt mondhatjuk, hogy míg hazánk az európai országokhoz hasonlóan a dichotóm modell mellett kötelezte el magát, az Egyesült Államok szabályozása teljesen más szabályozási logikát követ.

A magyar szabályozással szintén ellentétes megközelítést tükröz, hogy az amerikai alkotmány nem tekinthető kiindulópontnak a különleges jogrendet illetően, a vonatkozó törvényi rendelkezések taxatív számbavétele pedig gyakorlatilag lehetetlen vállalkozás - vagy legalábbis egy tematikus fókuszú könyvfejezet által kínált terjedelmi lehetôségeken messze túlmutató. Mindazonáltal jelentőségét tekintve valamennyi jogszabály közül kiemelkedik az 1976-ban elfogadott országos veszélyhelyzetről szóló törvény, amely - mint azt az Egyesült Államok déli határán épülő fal ügyében is láthattuk - lényegében véve biankó csekket ad az elnök kezébe a veszélyhelyzet elrendelését illetően. A veszélyhelyzet fogalmát a jogszabályban homály övezi, a szakirodalomban is csupán szótári, nem pedig jogalkotói vagy bírói értelmezéssel találkozhatunk. Ez utóbbi szintén idegen megoldás a magyar jogalkotó szemszögéből nézve, tekintve, hogy az Alaptörvény a különleges jogrend eseteit részletesen definiálja. Az országos veszélyhelyzetről szóló törvény 1979-es hatálybalépése óta összesen

110 U. S. Supreme Court, Youngstown Sheet \& Tube Co. v. Sawyer, 343 U.S. 579 (1952). 
69 alkalommal hirdettek ki az Egyesült Államokban országos veszélyhelyzetet, és ebből 40 (!) mind a mai napig hatályban van. És az országos veszélyhelyzetről szóló törvény csak egy a sok közül. A legfontosabbak közé sorolhatók továbbá az 1944. évi törvény a közegészségügyi szolgáltatásokról, az 1988. évi törvény a katasztrófavédelemről és a veszélyhelyzetben való segítségnyújtásról (az úgynevezett Stafford-törvény); az Egyesült Államok Kódexe; a 2002. évi törvény a belbiztonságról; valamint a 2006. évi törvény a Katrina hurrikán utáni veszélyhelyzet-kezelési reformról. Ezek a szövetségi törvények újabb különleges jogrendi esetköröket alkotnak, a gazdagítva a fogalmi diverzitást.

Valamennyi, a különleges állapotra vonatkozó törvényi szabályozást számba véve azt mondhatjuk, hogy az Egyesült Államok elnöke 136 (!) különféle jogkört gyakorolhat különleges jogrend idején, és akkor még nem beszéltünk azokról a hatáskörökről, amelyeket a Kongresszus, a szövetségi minisztériumok, a tagállami kormányok és a helyi önkormányzatok gyakorolhatnak különleges helyzetekben. Utóbbi sokfélesége értelemszerúen a hatalmas földrajzi kiterjedésú és népességú ország közigazgatási berendezkedésével is szoros összefüggésben áll, aminek eredménye, hogy nemcsak különféle szövetségi törvények lehetnek - akár ugyanazon tényállás alapján - egyszerre hatályban, hanem hogy vertikálisan is számos jogszabály vonatkozik az egyes tagállami és helyi szintú kérdésekre. Ez hazánkat tekintve ugyancsak elképzelhetetlennek tûnik, mivel a magyar közigazgatás centralizált jellegú.

Az amerikai és a magyar szabályozás közötti újabb elvi különbség, hogy az Egyesült Államokban a különleges jogrend meghosszabbítása egyáltalán nem számít „különlegesnek”. Ha csak az országos veszélyhelyzetrôl szóló törvényt vesszük ismét szemügyre, láthatjuk például, hogy az elsőként, 1979-ben Carter elnök által kihirdetett országos veszélyhelyzetet azóta is minden évben (!) megújították, számos más veszélyhelyzethez, például a 2001. szeptember 11-i terrortámadásokhoz kapcsolódóan kihirdetett veszélyhelyzethez hasonlóan.

Megállapíthatjuk tehát, hogy az amerikai modell mind a szabályozás koncepciója, decentralizációja, sokszínúsége, mind az ultima ratio jelleg hiánya, mind pedig az elrendelés határozatlan időtartama miatt teljesen eltér a magyar jogalkotó által alkalmazott keretektól.

Ami a koronavírus-járványt illeti, nem meglepő, hogy mivel az Egyesült Államok több mint 17 millió regisztrált fertőzöttel (2020. decemberi adat) a világ legfertőzöttebb országa, valamint mivel az országban 2020 novemberében elnökválasztást tartottak, a járványkezelés politikailag rendkívül szenzitív kérdést képez. Minthogy 2021. januárban a demokrata Joe Biden személyében (aki a leköszönő elnök, Donald Trump járványkezelési stratégiáját kampánya alatt végig hevesen bírálta) hivatalba fog lépni az ország 46. elnöke, a koronavírus miatt hozott intézkedések tekintetében is új irányvonalak várhatók. Mindazonáltal azt mondhatjuk, hogy a járványra válaszul adott eddigi erőfeszítéseket sem szabad alábecsülni.

A Covid-19 miatt az Egyesült Államokban először 2020. január 31-én hirdetett közegészségi veszélyhelyzetet az egészségügyért felelős miniszter az 1944. évi közegészségügyi ellátásokról szóló törvény alapján (amelyet azóta többször megújítottak). Ezt követően pedig, 2020. március 13-án az amerikai elnök bevezette az országos veszélyhelyzetet is, részben 
a fenti törvényi rendelkezés, részben pedig az 1976. évi országos veszélyhelyzetről szóló törvény értelmében, amely országos veszélyhelyzet e sorok írásakor szintén hatályban van még. Azt mondhatjuk tehát, hogy a föderális szintû̉ járványkezelés két alappillére az Egyesült Államokban a közegészségi veszélyhelyzet és az országos veszélyhelyzet párhuzamos kihirdetése volt.

A koronavírus-járvány a Kongresszust azonnali krízismenedzsmentre sarkallta, amelynek keretében elfogadták a koronavírus miatti készültségről és kiegészítő előirányzatokról szóló törvényt, „a családok az elsők” törvényt, a koronavírus-segélyről, járványkezelésről és gazdaságvédelemről szóló törvényt, valamint a fizetések védelméról és az egészségügyi ellátás színvonalának növeléséről szóló törvényt. A szövetségi törvényekről általában véve azt állapíthatjuk meg, hogy kettős célt szolgálnak: egyrészt az egészségügyi ellátórendszer felvértezését, másrészt a gazdaság élénkítését, a szociális ellátások kiterjesztését. Ezen törvények közül is kiemelkedik a koronavírus-segélyről, járványkezelésről és gazdaságvédelemről szóló törvény, amely átfogó intézkedéscsomagot vezetett be a gazdaság, a közegészségügy, a tagállamok, a helyi önkormányzatok, a vállalkozások és a magánszemélyek megsegítése érdekében, és mintegy 2 billió (!) amerikai dollárt irányzott elő a Covid-19 elleni komplex küzdelemre, amelynek keretében a járvány kezelésében a szövetségi minisztériumok, a tagállami kormányok és a helyi önkormányzatok is aktívan és összehangoltan részt vesznek. A járvány terjedésének lassításával kapcsolatos korlátozó intézkedések (például kijárási korlátozások, karantén, maszkviselés, távoktatás stb.) elrendeléséről általánosságban megállapítható, hogy rájuk nézve nem találhatunk rendelkezéseket a szövetségi szintú törvényekben, mivel azok teljes mértékben a tagállamok, illetve származékos jelleggel a helyi önkormányzatok hatáskörébe tartoznak. E helyütt megjegyzendő, hogy az amerikai szabályozás decentralizált jellege a magyar szabályozás erőteljesen centralizált jellegével újfent ellentétes képet mutat.

Végezetül fontos az alapjogok korlátozását illetően is néhány szót szólni, amely kérdésben az Egyesült Államok Legfelsőbb Bíróságának joggyakorlata kínál iránymutatást számunkra. (A magyar és az amerikai szabályozás közötti újabb eklatáns eltérésként hozható fel, hogy az amerikai alkotmány a magyar Alaptörvénnyel ellentétben nem rendelkezik a különleges jogrend idején történő alapjog-korlátozás szabályairól.) A releváns jogesetek halmazát két részhalmazra bonthatjuk, amelyek közül az egyik kifejezetten a járványkezeléshez, a másik pedig a hadiállapothoz kapcsolódik. És bár a hadiállapothoz fưzőőo jogkorlátozásra vonatkozó legfontosabb, úgynevezett Korematsu-tételét a bíróság 2018-ban, a Trump v. Hawaii ügyben hatályon kívül helyezte, a bírói fórum járványkezeléssel kapcsolatban tett 19. század eleji (!) megállapításai még ma is érvényesek. A Legfelsőbb Bíróság mérföldkőnek számító ítéleteiben kimondta, hogy a tagállamoknak hatáskörében áll a karantén elrendelése közegészségügyi okokból addig, amíg a Kongresszus ezzel ellentétes tartalmú jogszabályt nem hoz (Compaigne Francaise de Navigation a Vapeur v. Louisiana Board of Health ügy); továbbá kimondta, hogy a társadalmi együttélés természetes velejárója, hogy az egyén érdeke és 
a köz érdeke olykor ütközik, és előfordulnak olyan súlyos veszéllyel fenyegető helyzetek, amikor az egyén szabadságát a köz érdekében korlátozásoknak kell alávetni, valamint hogy a kötelező védőoltás elrendelése nem önkényes és elnyomó akkor, ha a közbiztonság észszerú érdeke úgy kívánja meg (Jacobson v. Massachusetts ügy); és végül, hogy az iskola járványügyi okokból megtagadhatja az olyan tanuló felvételét, aki egy kötelező védőoltást nem kapott meg (Zucht v. King ügy). A Legfelsőbb Bíróság utóbbi három megállapítása tehát jelen sorok írásakor is hatályban van; aktualitásukat mi sem mutatja jobban, hogy a Jacobson $v$. Massachusetts ügyre az egyik louisianai fellebbviteli bíróság 2020. áprilisban, a koronavírussal kapcsolatban elrendelt korlátozó intézkedések kapcsán is hivatkozott.

\begin{tabular}{|c|c|c|c|c|c|c|}
\hline 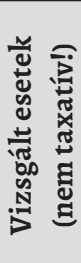 & 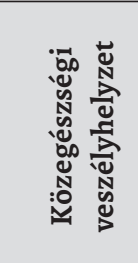 & 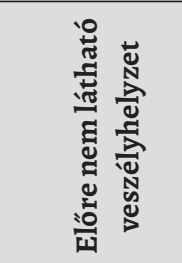 & 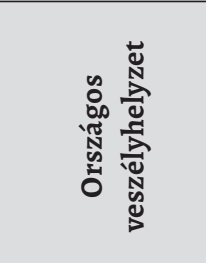 & 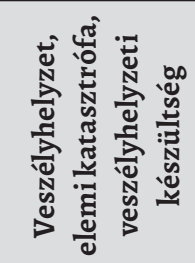 & 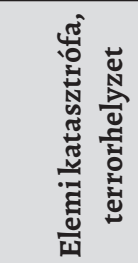 & 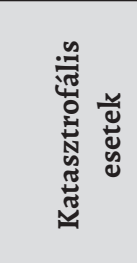 \\
\hline 卖. & \multicolumn{6}{|c|}{ Törvényi } \\
\hline 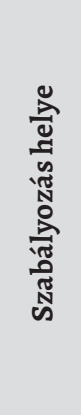 & $\begin{array}{l}\text { 1944. évi } \\
\text { közegész- } \\
\text { ségügyi } \\
\text { szolgálta- } \\
\text { tásokról } \\
\text { szóló } \\
\text { törvény }\end{array}$ & $\begin{array}{l}\text { Az Egyesült } \\
\text { Államok } \\
\text { Kódexe (1961) }\end{array}$ & $\begin{array}{l}\text { 1976. évi } \\
\text { országos ve- } \\
\text { szélyhelyzetről } \\
\text { szóló törvény }\end{array}$ & $\begin{array}{l}\text { 1988. évi } \\
\text { törvény } \\
\text { a katasztrófa- } \\
\text { védelemről és } \\
\text { a veszélyhely- } \\
\text { zetben való } \\
\text { segítségnyúj- } \\
\text { tásról }\end{array}$ & $\begin{array}{l}\text { 2002. évi } \\
\text { belbiz- } \\
\text { tonsági } \\
\text { törvény }\end{array}$ & $\begin{array}{l}\text { 2006. évi } \\
\text { Katrina } \\
\text { hurrikán } \\
\text { utáni } \\
\text { veszély- } \\
\text { helyzet- } \\
\text { kezelési } \\
\text { reformról } \\
\text { szóló } \\
\text { törvény }\end{array}$ \\
\hline
\end{tabular}




\begin{tabular}{|c|c|c|c|c|c|c|}
\hline 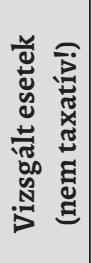 & 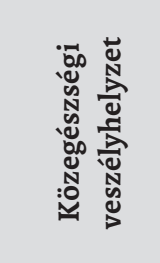 &  & 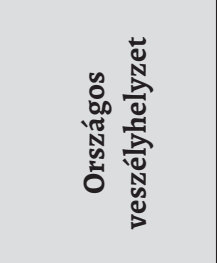 & 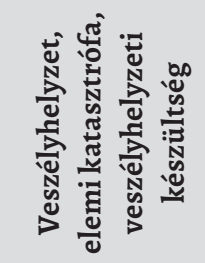 & 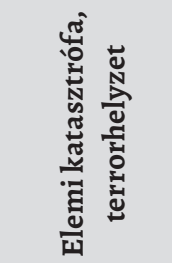 & 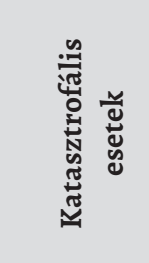 \\
\hline 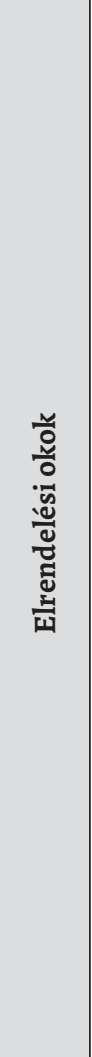 & $\begin{array}{l}\text { Változatos } \\
\text { okok, } \\
\text { nemcsak } \\
\text { betegségek, } \\
\text { hanem } \\
\text { például } \\
\text { a köz- } \\
\text { egészséget } \\
\text { sértő vagy } \\
\text { veszé- } \\
\text { lyeztető } \\
\text { természeti } \\
\text { kataszt- } \\
\text { rófák is } \\
\text { idetartoz- } \\
\text { hatnak. }\end{array}$ & $\begin{array}{l}\text { Az elrendelés } \\
\text { lehetséges oka } \\
\text { az előre nem } \\
\text { látható ve- } \\
\text { szélyhelyzet, } \\
\text { ám annak } \\
\text { fogalmát } \\
\text { a törvény } \\
\text { nem bontja } \\
\text { ki (szubszidi- } \\
\text { árius jellegú } \\
\text { szabályozás, } \\
\text { azaz csak } \\
\text { akkor lehet rá } \\
\text { hivatkozni, } \\
\text { ha a fegy- } \\
\text { verexport } \\
\text { ellenőrzé- } \\
\text { séról szóló } \\
\text { törvényben } \\
\text { használt } \\
\text { veszélyhely- } \\
\text { zet-fogalom } \\
\text { feltételei nem } \\
\text { teljesülnek). }\end{array}$ & $\begin{array}{l}\text { Rendkívül } \\
\text { széles diszkre- } \\
\text { cionális jogkör, } \\
\text { még arra sem } \\
\text { találhatunk } \\
\text { korlátozó ren- } \\
\text { delkezéseket, } \\
\text { hogy milyen } \\
\text { típusú társa- } \\
\text { dalmi vagy } \\
\text { természeti } \\
\text { jelenségek } \\
\text { idézhetnek elő } \\
\text { veszélyhely- } \\
\text { zetet. }\end{array}$ & $\begin{array}{l}\text { Az emberi élet } \\
\text { megóvása, } \\
\text { a tulajdon, } \\
\text { a közegészség } \\
\text { és a köz- } \\
\text { biztonság } \\
\text { védelme, } \\
\text { valamint } \\
\text { katasztrófa- } \\
\text { helyzet okozta } \\
\text { fenyegetés } \\
\text { csökkentése } \\
\text { vagy } \\
\text { elhárítása. }\end{array}$ & $\begin{array}{l}\text { Terrortá- } \\
\text { madások és } \\
\text { nukleáris } \\
\text { balesetek. }\end{array}$ & $\begin{array}{l}\text { Elemi ka- } \\
\text { tasztrófák }\end{array}$ \\
\hline 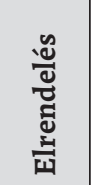 & $\begin{array}{l}\text { Egész- } \\
\text { ségügyért } \\
\text { felelős } \\
\text { miniszter }\end{array}$ & Elnök & & & $\begin{array}{l}\text { Belbiz- } \\
\text { tonsági } \\
\text { miniszter }\end{array}$ & Elnök \\
\hline
\end{tabular}




\begin{tabular}{|c|c|c|c|c|c|c|}
\hline 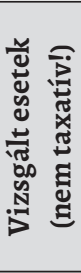 & 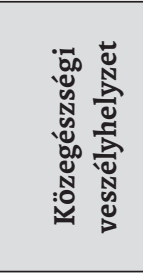 & 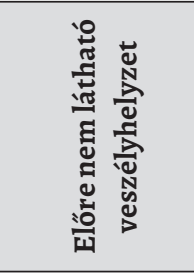 & 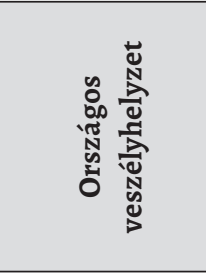 & 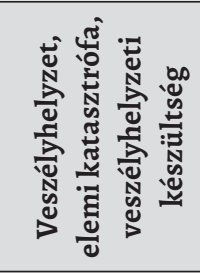 & 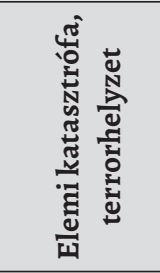 & 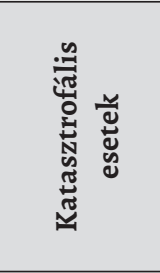 \\
\hline 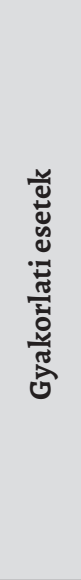 & $\begin{array}{l}\text { Csak } \\
2020 \text {-ban } \\
12 \text { alka- } \\
\text { lommal } \\
\text { hirdették } \\
\text { ki. }\end{array}$ & $\begin{array}{l}1988 \text { és } 2017 \\
\text { között } 57 \text { al- } \\
\text { kalommal hir- } \\
\text { dettek ki előre } \\
\text { nem látható } \\
\text { veszélyhely- } \\
\text { zetet. }\end{array}$ & $\begin{array}{l}\text { 1978-ban } \\
\text { történt hatály- } \\
\text { balépése óta } \\
\text { összesen } 69 \\
\text { alkalommal } \\
\text { hirdettek ki } \\
\text { országos ve- } \\
\text { szélyhelyzetet } \\
\text { az Egyesült } \\
\text { Államokban, } \\
\text { ebből pedig } \\
40 \text { (!) jelenleg } \\
\text { is hatályban } \\
\text { van. }\end{array}$ & $\begin{array}{l}1953 \text { és } \\
2014 \text { között } \\
\text { évente (!) } \\
\text { átlagosan } \\
\text { 35,5 elemi } \\
\text { katasztrófát } \\
\text { hirdettek ki. }\end{array}$ & $\begin{array}{l}\text { A kutatás } \\
\text { során } \\
\text { konkrét } \\
\text { példát nem } \\
\text { tártunk fel. }\end{array}$ & $\begin{array}{l}\text { A kutatás } \\
\text { során } \\
\text { konkrét } \\
\text { példát nem } \\
\text { tártunk } \\
\text { fel. }\end{array}$ \\
\hline
\end{tabular}

25. táblázat

Az Egyesült Államok különleges jogrendi szabályainak összegzése

Forrás: a szerző saját szerkesztése

\section{Irodalomjegyzék}

Brennan Center (2019) A Guide to Emergency Powers and Their Use [Online]. Elérhető: www. brennancenter.org/our-work/research-reports/guide-emergency-powers-and-their-use (Letöltve: 2020. december 6.)

Brennan Center (2020) Declared National Emergencies Under the National Emergencies Act [Online]. Elérhető: www.brennancenter.org/sites/default/files/2020-12/Declared\%20 Emergencies\%20under\%20NEA120820.pdf (Letöltve: 2020 . december 9.)

Brannon, V. C. (2018) Can a PresidentAmend Regulations by Executive Order? Cong. Res. Serv., LSB10172 (July, 18, 2018) [Online]. Elérhető: https://perma.cc/KFY7-ACMW (Letöltve: 2020. december 15.) Csink, L. (2017) 'Mikor legyen a jogrend különleges?', Iustum Aequum Salutare, 13(4), 7-16. o. ElSEA, J. K. et al. (2020) Emergency Authorities under the National Emergencies Act, Stafford Act, and Public Health Service Act. 1-2. Cong. Res. Serv., R46379 (updated July 14, 2020) [Online]. Elérhető: https://perma.cc/XLU5-55UN (Letöltve: 2020. december 7.)

FARKAS, Á., KELEMEN, R. (szerk.) (2020) Szkülla és Kharübdisz között. Tanulmányok a különleges jogrend elméleti és pragmatikus kérdéseiröl, valamint nemzetközi megoldásairól. Budapest: Magyar Katonai Jogi és Hadijogi Társaság 
Galva, J. E., Atchison, C., Levey, S. (2005) Public Health Strategy and the Police Powers of the State. 120 Pub. Health Rep. 20, 21-22 (Supp. 1, 2005) [Online]. Elérhető: https://perma.cc/ H68H-5NKG (Letöltve: 2020 . december 11.)

Halchin, L. E. (2020) National Emergency Powers. Washington: Congressional Research Service, 1-25. o.

Kahn, L. H., BARondess, J. A. (2008) 'Preparing for Disasters: Response Matrices in the USA and the UK', Journal of Urban Health, 85(6), 910-922. 0.

Killian, J. H. (1994) The Constitution of the United States of America [Online]. Elérhető: www. senate.gov/civics/resources/pdf/US_Constitution-Senate_Publication_103-21.pdf (Letöltve: 2020. december 1.)

Lindsay, B., WebsteR, E. (2020) Congressional Primer on Responding to and Recovering from Major Disasters and Emergencies 1-2. Cong. Res. Serv., R41981. (updated June 3, 2020) [Online]. Elérhető: https://perma.cc/EDH5-ATYE (Letöltve: 2020. december 7.)

Marren, J. F., ACQuario, S. J. (2020) Lost Revenue and State Aid Cuts: Coronavirus Economic Impact on Counties 3. New York State Association of Counties (May 2020) [Online]. Elérhetô: https://perma.cc/EPN7-YZ8Z (Letöltve: 2020. december 15.)

MCDaniel, P. (2020) Asheville City Council Meeting to Be Held Following CDC, State and Local Guidelines. City of Asheville (Mar. 21, 2020) [Online]. Elérhető: https://perma.cc/H4WZ-J664 (Letöltve: 2020. december 15.)

MÉszÁros, G. (2016) 'A „szabályozatlan” kivételes állapot amerikai modellje: tévút vagy követendő példa?' Fundamentum, 2016/2-4, 37-55. o.

MÉszÁros, G. (2017) Különleges helyzetek és beavatkozási lehetôségek az alkotmányos demokráciákban (PhD-értekezés). Debrecen: Debreceni Egyetem Marton Géza Állam- és Jogtudományi Doktori Iskola

PRICE, A. (2020) Federal, State and Local Government Responses to COVID-19. Library of Congress (November 2020) [Online]. Elérhetô: www.loc.gov/law/help/Covid-19-responses/us.php\#_ ftn95 (Letöltve: 2020. december 15.)

RaISZ, A. (2010) 'Az emberi jogok amerikaközi védelme', Publicationes Universitatis Miskolcinensis Sectio Juridica et Politica, 28(1), 281-295. o.

Saturno, J. V., Heniff JR., B., LYNCH, M. S. (2016) The Congressional Appropriations Process: An Introduction 19. Cong. Res. Serv., R42388 (updated Nov. 30, 2016) [Online]. Elérhető: https:// perma.cc/2K5A-JNPT (Letöltve: 2020. december 19.)

SwAGEL, P. L. (2020) Congressional Budget Office, Preliminary Estimate of the Effects of H.R. 6201, 1-2 (Apr. 2, 2020) [Online]. Elérhető: https://perma.cc/6XNU-5GAV (Letöltve: 2020. december 10.)

Till, Sz. (2019): 'Különleges jogrend' in Jakab, A., Fekete, B. (szerk.) Internetes Jogtudományi Enciklopédia [Online]. Elérhető: http:/lijoten.hu/szocikk/kulonleges-jogrend (Letöltve: 2020. december 11.)

Тóтн, Z. J. (2017) 'Az Egyesült Államok alkotmányának kartális és történeti jellege’, Polgári Szemle, 13(4-6), 219-233. o.

VARGA Zs., A. (2015) Eszménybőlbálvány? A joguralom dogmatikája. 1. kiadás. Budapest: Századvég 


\title{
27. A korlátlan államhatalom sajátos korlátja: a különleges jogrend Kínában ${ }^{1}$
}

\author{
DORNFELD LÁSZLÓ
}

\section{A különleges jogrend alkotmányos és törvényi szintú szabályozása és esetkörei}

Kína ma hatályos, 1982-es alkotmánya ${ }^{2}$ meglehetősen szúkszavúan foglalkozik a különleges jogrend kérdésével, azt nem tölti ki részletes tartalommal. Az Országos Népi Gyúlés (az ország törvényhozása) évente mindössze két hétig ülésezik plenárisan, ${ }^{3}$ egyéb időszakokban annak Állandó Bizottsága gyakorolja feladat- és hatásköreit. Tagjai egy elnök, alelnökök, a fốtitkár, valamint a törvényhozás bizonyos képviselői (míg a plenáris ülésen 2980,

I A fejezetben a kínai szavak és nevek átírása a pinyin kínai fonetikus ábécével történik. Kivételt képeznek a már rögzült alakok (például Peking, Mao Ce-tung), amelyek ismert formájukban kerülnek feltüntetésre.

2 A Kínai Népköztársaság alkotmányát (中华人民共和国宪法, Zhonghua Renmin Gongheguo Xianfa) 1982ben fogadták el. Ez a negyedik alkotmány az ország történelmében a sztálinista mintájú 1952-es, majd a „négyek bandája” nevével fémjelzett 1975-ös és a rövid ideig hatályban lévő 1978-as alkotmányok után. Az alkotmány ugyan az 1977-es szovjet alkotmányt követi, ám a Teng Hsziao-ping nevével fémjelzett reformidőszak során került elfogadásra, így például olyan rendelkezéseket tartalmaz, mint az alkotmány primátusa, valamint a Kínai Kommunista Párt alkotmányos keretek között meghatározott tevékenysége. Az így létrejött sajátos modellt egyesek „egypárti alkotmányosságként” definiálják (Shigong, 2014; Spitzer, 2020, 284. 0.).

3 Alkotmány 61. cikk.

Dr. Dornfeld László

laszlo.dornfeld@mfi.gov.hu

kutató (Mádl Ferenc Összehasonlító Jogi Intézet)

Dornfeld, L. (2021) 'A korlátlan államhatalom sajátos korlátja: a különleges jogrend Kínában' in Nagy, Z., Horváth, A. (szerk.) A különleges jogrend és nemzeti szabályozási modelljei, 592-608. o. Budapest: Mádl Ferenc Öszszehasonlító Jogi Intézet.

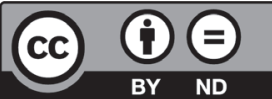


addig az Állandó Bizottság munkájában 175 képviselő vesz részt). Az Állandó Bizottság hatásköreivel foglalkozó részben az alkotmány ennek a szervnek a hatáskörébe utalja a hadiállapot, ${ }^{4}$ illetôleg a szükségállapot ${ }^{5}$ bevezetésének lehetôségét. ${ }^{6} \mathrm{~A}$ különleges jogrend bevezetésérôl szóló döntés alapján az államelnök hirdeti ki azt. ${ }^{7}$ Ezalól kivételt jelentenek a központi kormányzat igazgatása alatt álló tartományok, autonóm területek és városok, amelyek esetén az Államtanács (vagyis a központi kormány) dönt a szükségállapot bevezetéséról. ${ }^{8}$

Fontos megjegyezni, hogy Hongkong és Makaó saját speciális jogrenddel rendelkezik, amelynek részeként saját alaptörvényük van, eltérő jogrendszerrel és közigazgatással rendelkeznek, és ezeken a területeken a különleges jogrend bevezetésével kapcsolatos szabályok is eltérőek. A hongkongi alaptörvény ${ }^{9}$ rendelkezése a törvényhozás Állandó Bizottsága számára teremt lehetőséget a hadiállapot elrendelésére, illetve a szükségállapot bevezetésére olyan zứrzavar miatt, amely veszélyezteti a nemzeti egységet vagy biztonságot, és amely nem áll a régió kormányának ellenőrzése alatt. ${ }^{10} \mathrm{~A}$ makaói alaptörvény ${ }^{11}$ gyakorlatilag szóról szóra ugyanezt a rendelkezést tartalmazza. ${ }^{12}$

Ezeket a rendelkezéseket különböző törvények töltik meg tényleges tartalommal. Kiemelendő ezek közül a veszélyhelyzeti intézkedési törvény, ${ }^{13}$ az ostromállapotról szóló törvény, ${ }^{14}$ valamint a honvédelmi törvény. ${ }^{15}$

4 Az Alkotmány a zhanzheng zhuangtai kifejezést használja, hivatalos angol fordításban state of war.

5 Az Alkotmány a jinji zhuangtai kifejezést használja, hivatalos angol fordításban state of emergency.

6 Alkotmány 67. cikk 19-20. pont.

7 Alkotmány 80. cikk.

8 Alkotmány 89. cikk 16. pont.

9 A Kínai Népköztársaság hongkongi különleges közigazgatási régiójának alaptörvényét (中华人民共和国香 港特别行政区基本法, Zhonghua Renmin Gongheguo Xianggang Tebie Xingzhengqu Jibenfa) 1990-ben fogadták el, és 1997-ben, a terület Nagy-Britanniától történő visszatérését követően lépett hatályba.

10 Hongkongi alaptörvény 18. szakasz.

11 A Kínai Népköztársaság makaói különleges közigazgatási régiójának alaptörvényét (中华人民共和国澳门特 别行政区基本法, Zhonghua Renmin Gongheguo Aomen Tebiexingzhengqu Jibenfa) 1993-ban fogadták el, és a terület Portugáliától történő 1999-es visszatérését követően lépett hatályba.

12 Makaói alaptörvény 18 . cikk.

13 A törvényhozás Állandó Bizottsága által 2007. augusztus 30-án elfogadott, az államelnök 69. sz. határozatában kiadott veszélyhelyi intézkedési törvény (中华人民共和国突发事件应对法, Zhonghua Renmin Gongheguo Yingdui Fa) (a továbbiakban: Veszélyhelyzeti tv.).

14 A törvényhozás Állandó Bizottsága által 1996. március 1-jén elfogadott, az államelnök 61. sz. határozatában kiadott ostromállapotról szóló törvény (中华人民共和国戒严法, Zhonghua Renmin Gongheguo Jieyan Fa) (a továbbiakban: Ostromállapot tv.).

15 A törvényhozás Állandó Bizottsága által 1997. március 14-én elfogadott, az államelnök 84. sz. határozatában kiadott honvédelmi törvény (中华人民共和国国防法, Zhonghua Renmin Gongheguo Guofang Fa) (a továbbiakban: Honvédelmi tv.). 
A szükségállapot vonatkozásában az Ostromállapot tv. ${ }^{16}$ és a Veszélyhelyzeti tv. tartalmaz rendelkezéseket. Hivatalosan mindkét törvény hatályban van, ${ }^{17}$ annak ellenére, hogy más-más terminológiát használnak, illetőleg a bevezetés kapcsán ellentétes szabályokat tartalmaznak. A szükségállapot a korábbi helyzetek elégtelen kezelése miatt került bevezetésre a kínai jogrendszerben az ostromállapot felváltására, ami egyúttal a katonai helyett a civil válságkezelés felé tolta el a különleges helyzetek kezelését. ${ }^{18} \mathrm{Az}$ új törvényt pontosan az Ostromállapot tv. 2003-as SARS-járvány során tapasztalható elégtelenségei miatt fogadták el, amely során egyértelmúvé vált, hogy az Ostromállapot tv. rendelkezései nehezen alkalmazhatók nem tradicionális fenyegetések (például terrorizmus, fertőző betegségek) esetén. ${ }^{19}$ Ugyanakkor külföldi kommentátorok a korábbi szabályozás egyfajta „kiterjesztéseként” értelmezik az új szabályozást. ${ }^{20}$ Ezen jogi bizonytalanságok alapján mindkét törvény szabályozása bemutatásra kerül.

Az Ostromállapot tv. alkalmazására akkor nyílik lehetőség, ha olyan rendkívüli helyzet következik be, mint társadalmi zúrzavar, lázadás vagy súlyos zavargások, amelyek súlyosan veszélyeztetik a nemzet egységét és biztonságát vagy a közbiztonságot, és amelyek mellett a közrend nem tartható fenn, és az emberek életének és vagyonának biztonsága rendkívüli intézkedések meghozatala nélkül biztosított. ${ }^{21} \mathrm{~A}$ bevezetéssel kapcsolatban a törvény megismétli az alkotmány rendelkezéseit, hozzátéve, hogy az Államtanács által bevezetett szükségállapot esetén a miniszterelnök hirdeti ki azt. ${ }^{22} \mathrm{~A}$ szükségállapot idején alkalmazható eszközök kapcsán a törvény meglehetősen általánosan fogalmaz: az érintett területen az állam e törvénynek megfelelően különleges szabályokat és előirásokat határozhat meg az állampolgárok jogainak és szabadságának gyakorlására vonatkozóan, ${ }^{23}$ valamint az érintett terület kormányzata meghozza a közrend mielőbbi normalizálásához, az emberek életének és vagyonának biztonságához, valamint a napi szükségleteik ellátásához szükséges intézkedéseket. ${ }^{24}$ Ezen túlmenően a törvény a természetes és jogi személyek számára kötelezettségként határozza meg, hogy szigorúan be kell tartaniuk ezeket a rendelkezéseket, és aktívan segíteniük kell a szerveket a közrend normalizálásában. ${ }^{25} \mathrm{~A}$ különleges jogrendi szabályok biz-

16 A törvény az ostromállapot (jieyan, Delisle fordításában state of siege) kifejezést használja, amely a 2004-es alkotmányreform előtt az alkotmányban is szerepelt. Ugyan tervben volt egy szükségállapoti törvény elfogadása is, erre végül mégsem került sor (Delisle, 2010, 405-406. o.).

$17 \mathrm{Az}$ ILO oldalán szereplő országjelentés is ezt erősíti meg. Elérhető: www.ilo.org/dyn/irlex/en/ f?p=14100:1100:0::NO::P1100_ISO_CODE3,P1100_SUBCODE_CODE,P1100_YEAR:CHN,,2015 (Letöltve: 2020. december 15.).

18 Jianfu, 2004.

19 Deloise, 2010, 420. o.

20 Elérhető: www.loc.gov/law/help/health-emergencies/china.php (Letöltve: 2020. december 15.).

21 Ostromállapot tv. 2. szakasz.

22 Ostromállapot tv. 3. szakasz.

23 Ostromállapot tv. 4. szakasz.

24 Ostromállapot tv. 5. szakasz.

25 Ostromállapot tv. 6. szakasz. 
tosítását a Népi Rendőrség, illetőleg a Népi Fegyveres Rendőrség biztosítja, az Államtanács pedig javasolhatja a Népi Felszabadító Hadsereg bevetését. ${ }^{26}$

A szükségállapot megszervezésének a feladata az Államtanácsé, ha az országosan vagy a közvetlenül a központi kormány igazgatása alatt álló tartomány, autonóm terület vagy város területén kerül bevezetésre. Utóbbi esetben a tartományi közigazgatás feladata a tényleges tevékenységek megszervezése, ám indokolt esetben az Államtanács átveheti ezt a feladatot. ${ }^{27}$ Fel kell állítani egy speciális szervet, amely összehangolja az érintett egységek által a szükségállapoti feladatok ellátása érdekében tett intézkedéseket, és egységes terveket és intézkedéseket dolgoz ki a különleges jogrend érvényesítésére. A szükségállapoti feladatok ellátásában részt vevő katonai egységek katonai parancsnokság alatt maradnak. ${ }^{28}$

A szükségállapot kapcsán a másik fontos jogszabály a Veszélyhelyzeti tv., amely elsősorban a szükségállapot alatti szinteket szabályozza. Ezen törvény alapján ha egy különösen súlyos veszélyhelyzet történik, amely komoly veszélyt jelent az emberek életére vagy vagyonbiztonságára, a nemzetbiztonságra, a közbiztonságra, a környezetbiztonságra vagy a társadalmi rendre, és annak súlyos társadalmi kárát nem lehet megszüntetni vagy hatékonyan enyhíteni az e törvényben található enyhébb eszközök által, úgy a szükségállapot bevezetésének van helye. ${ }^{29} \mathrm{~A}$ két törvény egyaránt hatályban van mind a mai napig, mert bár az alkotmányos reform megváltoztatta a jogintézmény nevét, az Ostromállapot tv.-t nem helyezte hatályon kívül, azok rendelkezései pedig nem ellentétesek egymással.

A hadiállapot vonatkozásában a Honvédelmi tv. rendelkezéseit kell alkalmazni. A törvény a külső agresszió elleni felkészülés és fellépés, a fegyveres felforgatás meghiúsítása, az állam szuverenitásának, egységének, területi integritásának és biztonságának védelme érdekében folytatott katonai tevékenységek során alkalmazandó. ${ }^{30} \mathrm{~A}$ törvény 8 . fejezete tárgyalja a hadiállapotra vonatkozó szabályozást. Az állam az alkotmány értelmében hadiállapotot hirdet, különféle intézkedéseket fogad el az emberi, anyagi és pénzügyi erőforrások összpontosítására, és valamennyi állampolgárt vezet az ország védelme és az agresszió elleni ellenállás során. ${ }^{31}$ Itt a normatív részletszabályok egyáltalán nem kerülnek kifejtésre, ${ }^{32}$ ahogy az is érdekessége a jogszabálynak, hogy az államot egész egységként kezeli, míg az alkotmány kifejezetten a törvényhozás Állandó Bizottsága kezébe adja a hatalmat a hadiállapot kihirdetésére.

26 Ostromállapot tv. 8. szakasz.

27 Ostromállapot tv. 9. szakasz.

28 Ostromállapot tv. 10. szakasz.

29 Szükségállapoti törvény 69. szakasz.

30 Honvédelmi tv. 2. szakasz.

31 Honvédelmi tv. 44. szakasz.

32 Spitzer, 2020, 288. o. 


\subsection{A különleges jogrendre való felkészülést segító békeidejü szabályok és a kapcsolódó szervezetrendszer}

A különleges jogrendre való felkészülés szabályait elsősorban a Veszélyhelyzeti tv. tartalmazza. Ez azonban csak egy komponense a 2003-as SARS-járvány után életre hívott Állami Katasztrófavédelmi Rendszernek, amely négy pillérből áll (a kínai államigazgatásban népszerú szlogenek közül ez az „egy terv, három alrendszer” megnevezést kapta). Ebből az első, a „terv” megnevezés a Katasztrófaelhárítási Általános Állami Tervre vonatkozik, amelyet még 2003-ban hívtak életre. Emellett létezik 28 a különböző veszélyhelyzeti tervekből, amelyek eltérő kihívásokra (például természeti katasztrófák, balesetek, társadalmi zavarok) válaszolnak, illetve 160 szektorspecifikus veszélyhelyzeti terv, amelyek így együtt egy részletes tervezési rendszert alkotnak. ${ }^{33}$ Mindezek mellett különböző szinteken is tervek kerülnek kidolgozásra, 2015-ig mintegy 1,3 millió veszélyhelyzeti terv született meg. ${ }^{34}$

A második pillér a szervezeti rendszer, ahol az Államtanács szerepe a legjelentősebb, amely mind békeidőben, mind rendkívüli helyzetben az államszervezet csúcsán áll. A veszélyhelyzetek felmérése és kezelése érdekében speciális állandó irodákat hoztak létre helyi, illetve központi szinten is. A harmadik pillér két elv beépítése: az események szintekbe sorolása, illetve az információmegosztás. Végül a negyedik pillért a jogi szabályozás jelenti. ${ }^{35}$

A már említett Veszélyhelyzeti tv. tartalmazza a tervek készítésével és tartalmával kapcsolatos szabályokat, ${ }^{36}$ a potenciális veszélyforrások monitorozásának kötelezettségét, ${ }^{37}$ biztonságirányítási rendszer létrehozását és ellenőrzését írja elő, ${ }^{38}$ a veszélyes létesítményekért, illetve a tömegközeledésért vagy más, sok ember által használt közterületért felelős jogi személyek számára is előír vizsgálati, illetve elókészületi kötelezettségeket, ${ }^{39}$ a mentőcsapatok képzését, kijelölését és gyakorlatait határozza meg,40 illetve egyéb, a különböző rendszerek kialakításával és múködtetésével kapcsolatos kötelezettségeket is szab, valamint oktatási és ismeretterjesztő kampányokról is rendelkezik. ${ }^{41}$ Külön fejezet rendelkezik arról, hogy milyen módon kell az illetékes szerveknek figyelniük a potenciális veszélyeket, és a már meglévő veszélyhelyzeti terveket hogyan kell aktiválni és gyakorlatba ültetni veszélyhelyzet esetén. ${ }^{42}$

Ugyan elméletben ez a rendszer megfelelően felépítettnek tûnik, a gyakorlat azt mutatja, hogy számos problémától szenved. Például sem a vonatkozó törvény, sem az általános terv nem tartalmaz iránymutatásokat arra nézve, hogy a veszélyhelyzeti terveket miként kell

$33 \mathrm{Lu}-\mathrm{Xue}, 2016,415$. 0.

34 Shen et al., 2015, 271. 0.

$35 \mathrm{Lu}$-Xue, 2016, 418-419. o.

36 Veszélyhelyzeti tv. 17-18. szakasz.

37 Veszélyhelyzeti tv. 20. szakasz.

38 Veszélyhelyzeti tv. 22. szakasz.

39 Veszélyhelyzeti tv. 23-24. szakasz.

40 Veszélyhelyzeti tv. 25-28. szakasz.

41 Veszélyhelyzeti tv. 30-36. szakasz.

42 Veszélyhelyzeti tv. 37-62. szakasz. 
összeállítani, csakis a tartalmukat határozza meg. Az alacsonyabb szintú terveket gyakran a magasabb szint által kidolgozottról másolják le. Habár számszerúleg rengeteg különböző terv van, ezek között számos megegyező tartalmú létezik. A helyzetet tovább rontja, hogy a tervek készítői gyakran nem veszik elég komolyan ezt a kötelezettséget, a komolyabbnak itélt feladatokra koncentrálva inkább. ${ }^{43} \mathrm{~A}$ tervezési rendszer nagy hiányossága még az is, hogy csak a készítés pillanatában felismert veszély esetén alkalmazható, váratlan helyzetekben nem, márpedig a felkészülés alapját ez adja. ${ }^{44}$

\subsection{A válságkezelésre vonatkozó szabályok}

A válságkezelés szabályozását a veszélyhelyzeti intézkedési törvény tartalmazza, amely meghatározza a szükségállapotot el nem érő szintek kezelését. A jogszabály erre a veszélyhelyzet $^{45}$ kifejezést alkalmazza, és olyan természeti és emberi katasztrófára, közegészségügyi eseményre vagy társadalmi biztonsági eseményre vonatkozik, amely véletlenül következett be, súlyos társadalmi kárt okozott vagy okozhat, és veszélyhelyzeti intézkedések elfogadására van szükség a kezelésük során. A törvény az esetkörök négy szintjét határozza meg csökkenő súlyossági sorrendben: különösen komoly, komoly, jelentős, rendes. ${ }^{46} \mathrm{~A}$ másodiktól a negyedik szintû veszélyhelyzetekkel kapcsolatos intézkedések szintjét a törvény a lehető legalacsonyabban határozza meg, az érintett megye kormányzatánál. Amennyiben kettő vagy több megye érintett a veszélyhelyzet által, úgy az eggyel magasabb, prefektúrai szint a felelős a szükséges intézkedések megtételéért. A megyei kormányzatnak azonnal intézkedéseket kell tennie a veszélyhelyzet felmérése és kezelése érdekében, vagy amennyiben úgy ítéli meg, hogy az ebből eredő károk kezelése meghaladja az erőforrásait, úgy azonnal tájékoztatnia kell a magasabb közigazgatási szintet erről. ${ }^{47} \mathrm{Az}$ első, különösen komoly kategóriába tartozó veszélyhelyzet esetén a miniszterelnök vezetésével az Államtanács feladata a helyzet elemzése, az arra adott válasz kidolgozása és végrehajtása. Minden megyei vagy azon felüli szintú helyi kormányzat közösen létrehoz egy veszélyhelyzet-elhárítási parancsnokságot, amely az adott kormányzatok elnökeiből, a kapcsolódó részlegek vezetőiből, valamint a Népi Felszabadító Hadsereg, illetve a Népi Fegyveres Rendőrség helyi parancsnokából áll azzal a céllal, hogy egységesen vezesse és koordinálja a veszélyhelyzet elhárítását minden szinten..$^{48}$

A veszélyhelyzetet kezelő kormányzati szint által hozott döntéseket a megfelelő időben nyilvánosságra kell hozni a lakosság számára. ${ }^{49} \mathrm{~A}$ válaszlépéseknek szükségesnek és ará-

43 Tong-Zhang, 2020, 148. o.

44 Tong-Zhang, 2020, 149-150. o.

45 A törvény a tufa shijian kifejezést használja, amely angol fordításban emergency incident formában jelenik meg.

46 Veszélyhelyzeti intézkedési törvény 3. szakasz.

47 Veszélyhelyzeti intézkedési törvény 7. szakasz.

48 Veszélyhelyzeti intézkedési törvény 8. szakasz.

49 Veszélyhelyzeti tv. 10. szakasz. 
nyosnak kell lenniük az adott veszélyhelyzet által okozott társadalmi kár jellegének és mértékének megfelelően, és amennyiben több eszköz is rendelkezésre áll, azt kell alkalmazni, amely jobban biztosítja az emberek jogainak és érdekeinek védelmét. ${ }^{50}$

Az egyes veszélyhelyzetek kezelésével a törvény külön fejezete foglalkozik. Ennek rendelkezései alapján a veszélyhelyzet bekövetkeztét követôen haladéktalanul megszervezi az illetékes részlegeket, beveti a vészhelyzeti mentőcsapatokat, és intézkedéseket hoz. ${ }^{51} \mathrm{~A}$ lehetséges intézkedések körét a törvény részletesen meghatározza, természeti és emberi katasztrófa, illetve közegészségügyi esemény esetén például ilyenek a mentés és evakuáció megszervezése, a veszélyesnek ítélt területek kijelölése és elzárása; a sérült közművek helyreállítása; mentési, higiéniai, karanténintézkedések végrehajtása; bizonyos eszközök és létesítmények használatának tiltása vagy korlátozása, bizonyos tevékenységek korlátozása vagy megtiltása; állampolgárok mentési műveletekben való részvételének megszervezése, a speciális tudással rendelkezők számára munkakötelezettség előirása; az élelem, az ivóvíz, az üzemanyagok és más alapvető életszükségletek biztosítása; szigorúbb büntetések bizonyos cselekmények (például árfelhajtás, fosztogatás, védekezés eredményességének veszélyeztetése) esetén. ${ }^{52}$

Amennyiben a társadalmi biztonságot fenyegető esemény következik be, úgy a törvény egészen más eszközöket biztosít, mint például az erőszakos tevékenységben érintett felek erővel történő szétválasztása, épületek, szállító jármûvek, felszerelések, létesítmények és üzemanyagok, gáz-, energia- és vízellátás ellenőrzése, közlekedési utak és helyek lezárása, a helyszínen tartózkodó személyek személyazonosságának igazolása és az érintett nyilvános helyeken végzett tevékenység korlátozása, ideiglenes kordonok felhúzása bizonyos fontos közintézmények körül, illetve egyéb törvényi, határozati és államtanácsi rendelkezések. ${ }^{53}$

Amit fontos még megemlíteni a válságkezelés kapcsán, hogy a veszélyhelyzeti intézkedés képezi az alapját, ám egyéb veszélyhelyzeti jogszabályok is alkothatók specifikus problémák kezelése vonatkozásában. A törvény 2007-es elfogadásától 2015-ig több mint 60 ilyen jogszabály született. ${ }^{54}$ Ilyen a közegészségügyi veszélyhelyzetek sürgős kezeléséról szóló rendelet, ${ }^{55}$ amely a "közegészségügyi veszélyhelyzeteket” úgy határozza meg, mint fertőző betegségek vagy ismeretlen betegségek által okozott jelentős járványhelyzet, étellel és a munkahelyi mérgezéssel kapcsolatos súlyos események, valamint egyéb olyan súlyos közegészségügyi események, amelyek váratlanul következnek be, és súlyos kárt okoznak a társadalom közegészségében. ${ }^{56} \mathrm{~A}$ jogszabály rendelkezései az Államtanács, illetve a helyi, alacsonyabb szintű kormányzati szervek számára biztosítanak felhatalmazást arra, hogy

50 Veszélyhelyzeti tv. 11. szakasz.

51 Veszélyhelyzeti tv. 48. szakasz.

52 Veszélyhelyzeti tv. 49. szakasz.

53 Veszélyhelyzeti tv. 50. szakasz.

54 Shen et al., 2015, 271. o.

55 Az Államtanács által 2003. május 9-én kihirdetett 376. sz. rendelet (Tufa Gonggong Weisheng Shijian Yingji

Tiaoli) a közegészségügyi veszélyhelyzetek sürgős kezeléséről.

56 A közegészségügyi veszélyhelyzetek sürgős kezeléséről szóló rendelet 2. szakasza. 
fellépjen az ilyen veszélyhelyzetek esetén. A fertőző betegségekkel kapcsolatosan több más törvény, illetve rendelet is született..$^{57} \mathrm{Ez}$ az egyik legnagyobb veszélyforrás ma Kínában, különösen az ország elmaradottabb, vidéki régióiban - az ország lakosságának mintegy 60\%-a él ezeken a területeken mint mezőgazdasági munkás, és az elégtelen egészségügyi ellátórendszer miatt különösen kitett a fertőző betegségeknek és járványoknak. ${ }^{58}$

\section{Az alapjogok korlátozására vonatkozó szabályok különleges jogrend idején}

A kínai alkotmány külön fejezetben sorolja fel az állampolgárok jogait és kötelezettségeit. Meglehetősen kevés védelmet élveznek ugyanakkor ezek a jogok, és maga az alkotmány is tartalmaz egy olyan klauzulát, amely kimondja az államérdek elsőbbségét: az állampolgárok csak annyiban gyakorolhatják jogaikat, amennyiben ezzel nem sértik az állam vagy a közösség érdekeit, más állampolgárok jogait. ${ }^{59} \mathrm{Ez}$ azt jelenti, hogy az állam rendes múködése során különleges felhatalmazás nélkül is igen széles lehetőség nyílik az állam számára az alapjogok korlátozására. ${ }^{60}$

Mindezek fényében igen meglepő, hogy a különleges jogrendi szabályozásban komoly aggodalomként jelentek meg a hatáskörükön túlterjedő állami szereplők. Mind az Ostromállapot tv., mind a Veszélyhelyzeti tv. előírják, hogy a kivételes intézkedéseket csak meghatározott feltételekre kell korlátozni, és arányosnak kell lenniük a veszéllyel. ${ }^{61} \mathrm{~A}$ kettô közül az Ostromállapot tv. sokkal komolyabb jogkorlátozó intézkedéseket tartalmaz, például lehetôvé teszi az utcai gyülekezés, demonstráció betiltását, a sztrájktilalmat, a sajtóembargót, a hírközlés, a postai szolgáltatások és a távközlés feletti ellenőrzést, az országba történő belépés és az abból történő kilépés ellenőrzését, valamint bármilyen egyéb tevékenység betiltását. ${ }^{62}$ Lehetőség nyílik továbbá a forgalom ellenőrzésére, a kijárási tilalom bevezetésére, a fegyverek és más veszélyes eszközök ellenőrzésére, a lakóingatlanok, ingóságok ideiglenes használatba vételére. ${ }^{63} \mathrm{~A}$ törvény jelentős és széles jogköröket biztosít a szükségállapotban érintett rendőröknek, fegyveres rendőröknek és katonáknak, például ellenőrzéseket, kutatásokat és igazoltatásokat folytathatnak, bizonyos esetekben azonnal őrizetbe vehetnek embereket, és tevékenységük során akár lőfegyvert is használhatnak. ${ }^{64}$

57 Ezeket bővebben lásd: www.loc.gov/law/help/health-emergencies/china.php (Letöltve: 2020. december 15.).

$58 \mathrm{Hu}-\mathrm{Chen}-\mathrm{Kuai}, 2018$.

59 Alkotmány 51. cikk.

60 Deloise, 2010, 405. o.

61 Veszélyhelyzeti tv. 11. szakasz, valamint Ostromállapot tv. 7. szakasz.

62 Ostromállapot tv. 13. szakasz.

63 Ostromállapot tv. 14-17. szakasz.

64 Ostromállapot tv. 21-30. szakasz. 
A jóval enyhébb esetek kezelésére megalkotott Veszélyhelyzeti tv. szúkebb körben biztosít lehetőséget az alapjogok korlátozására. A törvény lehetővé teszi a magánszemélyek és a jogi személyek ingatlanjainak ideiglenes használatbavételét a helyi kormányzati szervek által. ${ }^{65} \mathrm{~A}$ hatóságoknak lehetőségük van a veszélyes területek lezárására, a forgalom korlátozására, bizonyos létesítmények használatának a korlátozására vagy tiltására, valamint a lakosság bevonására a kárelhárításba. ${ }^{66}$

Az alapjogok korlátozásának megfelelő ellenőrzése hangsúlyos szempont volt a vonatkozó jogszabályok elfogadása során is. A szükségállapot jogrendszerbe történő bevezetése kapcsán érvként merült fel az, hogy az új rendelkezés alapján történő felhatalmazás védi az állampolgárok jogait is. ${ }^{67} \mathrm{~A}$ Veszélyhelyzeti tv. elfogadása során törölték azt a rendelkezést a törvény szövegéből, amely bírsággal fenyegette a tömegkommunikációs csatornákat abban az esetben, ha azok hatósági engedély nélkül tesznek közzé információkat, vagy hamis információkat közvetítenek. ${ }^{68}$

\section{A koronavírus-járványra adott állami reakció}

A kínai Vuhan városa mint a Covid-19-járvány kiindulópontja került be a hírekbe. Szemben a 2003-as SARS-járvánnyal, ezt nem sikerült a kínai hatóságoknak időben megfékezniük, és 2020 márciusában a WHO világjárvánnyá nyilvánította azt.

Kínában nem került bevezetésre szükségállapot, ugyanakkor a Veszélyhelyzeti tv. szerinti legmagasabb, egyes szintű (különösen komoly) veszélyhelyzet került elrendelésre, amely alapján a tartományok meghozhattak olyan intézkedéseket, mint városok és utak lezárása. A járványokra a nyugati országoknál alapvetően jobban felkészült kínai jogrendszerben számos jogszabály tartalmaz olyan rendes intézkedéseket is, amelyek a különleges jogrend nélkül is igénybe vehetôk. Például felhatalmazást adtak a karanténszabályok bevezetésére, a fertőzöttek és külföldről érkezők megfigyelésére, a járvánnyal összefüggésben egészségügyi igazolások kiállítására. Az intézkedések részeként betiltották a vadhús fogyasztását, ugyanis feltehetően ezen az úton jutott be a denevérekben található koronavírus az emberi szervezetbe, eloidézve a járványt. ${ }^{69} \mathrm{Az}$ intézkedések részeként 76 napos lezárás alá vonták Vuhan városát, ahol a tömegközeledést is felfüggesztették. Később egész Hubei tartományra kiterjesztették ezt a lezárást. Az intézkedések mellett nagy szerepe volt az effektív járványkezelésben annak is, hogy a lakosság igen nagy számban tartotta be az előírásokat, például a maszkviselésre vagy a távolságtartásra vonatkozóan. Ebben minden bizonnyal nagy szerepe volt a SARS-járványról élő emlékeknek is. ${ }^{70}$

65 Veszélyhelyzeti tv. 12. szakasz.

66 Veszélyhelyzeti tv. 49. szakasz.

67 Deloise, 2009, 351. 0.

68 Tong-Zhang, 2020, 35. o.

69 Zhengfa-Wanqiang, 2020.

70 Burki, 2020, 1240. o. 
A kormányzat számos olyan rendelkezést hozott, amelyek a vírus terjedésének lassítását szolgálták. Így például támogatták az otthon maradás politikáját, betiltották a tömeges öszszejöveteleket, lemondták vagy elhalasztották a nagy nyilvános rendezvényeket, és bezárták az iskolákat, egyetemeket, kormányhivatalokat, könyvtárakat, múzeumokat és gyárakat. Ezzel együtt megpróbálták korlátozni a belföldi utazásokat is.$^{71}$ Problémát okozott, hogy a járvány terjedése idején ünnepelték a kínai újévet, amikor a világ számos részén, illetve az országban távolabb élố kínaiak hazautaznak a családjaikhoz. Mivel sokan csak egy hetet töltenek családjaikkal - amely rövidebb, mint a fertőzés és a tünetek megjelenése közötti leghosszabb ismert lappangási időszak -, a hatóságok az ünnepek meghosszabbításával próbálta elejét venni a korai hazautazásoknak. A védekezés során nemcsak a betegeket, de a tünetmentes fertőzötteket és enyhe tüneteket mutatókat is elkülönítették szükségkórházakban, amelyeket például stadionokból és konferenciaközpontokból alakítottak ki. ${ }^{72}$

2020 tavaszán már enyhíteni lehetett a bevezetett korlátozásokon, ám a vírus nem túnt el teljes egészében az országból ezután sem. ${ }^{73} \mathrm{Az}$ intézkedések eredményeként 2020 júniusára mindössze csak a fôvárosba, Pekingbe, illetve Liaoning és Xinjiang tartományokba jutott el a fertózés. Ebben a hónapban egy fővárosi nagykereskedelmi piacról indult el újra a járvány terjedése, ismét lezárásokat eredményezve Pekingben. ${ }^{74}$

Több probléma is adódott azonban a kínai védekezéssel. Először is, hogy a korai védekezés során a titkolózás és a szervek lassú reagálása miatt csak 2020. január végén került nyilvánosságra az a tény, hogy a vírus emberról emberre is képes terjedni, holott az erről szóló információk már decemberben is rendelkezésre álltak. Ebben a veszélyhelyzeti szabályozás következetlensége is szerepet játszott: míg a Veszélyhelyzeti tv. és a közegészségügyi veszélyhelyzetekre vonatkozó állami terv szerint minden helyi, illetve a központi kormányzatok megfelelő szervei is közzétehetnek figyelmeztetéseket, addig a fertőző betegségek megelőzéséről szóló törvény szerint az Államtanács közegészségügyért felelős szerve és a tartományi kormányzat tehet közzé korai figyelmeztetést. Ráadásul utóbbi törvény rendelkezéseit nem is lehet alkalmazni ismeretlen eredetû́ betegség esetén, amíg az Államtanács azt jóvá nem hagyja, jelentős időveszteséget okozva ezzel. Végül a Veszélyhelyzeti tv.-ből hiányzik az átfogó felső szintú tervezés. A veszélyhelyzeti terv elindításáért felelős szerv megjelölése következetlen. A törvény felhatalmazza a megyei szint feletti helyi kormányokat, hogy kezdeményezzék a veszélyhelyzeti tervek alkalmazását, de a fertőző betegségek megelőzéséről szóló törvény előirja, hogy a megyei szint feletti kormányok csak akkor alkalmazhatják a veszélyhelyzeti tervet, ha az Államtanács vagy a tartományi közegészségügyi osztálya ehhez hozzájárult. ${ }^{75}$

71 Tangcharoensathien et al., 2021.

72 Chen et al., 2020, 765. o.

73 Tangcharoensathien et al., 2021.

74 Elérhető: www.bbc.com/news/av/world-asia-china-54034809 (Letöltve: 2020 . december 15.).

75 Zhengfa-Wanqiang, 2020. 


\section{A különleges jogrend a gyakorlatban, viták és kihívások}

A Kínai Népköztársaság 1949-es kikiáltása után totalitárius jegyeket magán viselő államként a hadsereg számos alkalommal vett részt a válságok kezelésében, ám ennek vonatkozásában nem léteztek külön normatív szabályok vagy jogi alap. ${ }^{76}$ Különleges jogrendről ezért csak a Mao Ce-tung halála után elfogadott 1982-es alkotmány szerint lehetett beszélni, ${ }^{77}$ amikor a Teng Hsziao-ping fémjelezte reformidőszak megindult. A különleges jogrend legelső alkalmazására az 1989-es Tienanmen téri diáklázadás, illetve az ezzel egy időben zajló tibeti szektariánus konfliktus során került sor. Április 27-én a demokráciát követelő diákok a Tienanmen térre vonultak, majd tárgyalásokba kezdtek a kormánnyal. Ahogy az események elhúzódtak, a megállapodáspárti kormánytagok háttérbe szorultak a Li Peng miniszterelnök vezette keményvonalasok ellenében. Május 20-ára az ő javaslatára Pekingben kihirdették az ostromállapotot. Ezzel nagyjából egy időben zajlottak a tibeti buddhista lakosság zavargásai is, amelyekre válaszul március 7-én szintén bevezetésre került az ostromállapot, amely csak a terület fôvárosát, Lhászát érintette. Pekingben betiltották a gyülekezéseket, és a Népi Felszabadító Hadsereg több tízezer katonáját vezényelték ki a Tienanmen térre, hivatalosan az ostromállapoti szabályok betartatása érdekében, ám a valóságban ez súlyos vérengzéshez vezetett, amikor a katonák és a diákok összecsaptak. Tibetben Hu Jintao helyi párttitkár, későbbi államelnök hozta meg a megfelelő döntéseket, és figyelmeztette a zavargások résztvevőit a törvény megsértésének súlyos következményeire. ${ }^{78}$

Különösen a pekingi Tienanmen téri események komoly nemzetközi és hazai kritikákat váltottak ki. A kínai vezetés komoly erőt fordított rá, hogy az ostromállapot bevezetésének jogosságát igazolja a közvélemény és a kritikusok eloottt, a különleges jogrend alkalmazásának alkotmányos kereteire történő hivatkozással. A kritikák ugyanakkor rákényszerítették a kormányzatot, hogy részletesebb szabályozást dolgozzon ki, így erősebb jogi alapot adva a különleges jogrendi intézkedéseknek. Ez lett az 1996-os Ostromállapot tv. ${ }^{79} \mathrm{~A}$ kínai különleges jogrendi rendszert a 2003-as SARS-járvány tette próbára, amely Dél-Kínából indult el. A központi kormányzat különféle különleges felhatalmazásokkal hozott rendkívüli rendeleteket, ugyanakkor ostromállapot hivatalosan nem került bevezetésre. Szigorú büntetőjogi szankciókat hoztak például a vírus tudatos terjesztése és a rémhírterjesztés kapcsán. Ugyan az intézkedések jogszerüsége és jogi megalapozottsága ebben az esetben aligha vonható

76 Így például az ország létrehozását követően annak stabilizálásában - a megfelelő civil szervek hiányában -, illetve a kulturális forradalomban az államszervek szétforgácsolódását követően. 1976-ban a Tienanmen téri demonstráció feloszlatásakor is mindenféle jogi háttér nélkül (Deloise, 2009, 348. o.).

77 Fontos megemlíteni, hogy a kommunista államot megelőzően múködő Kínai Köztársaság (a mai Tajvan) ismerte és alkalmazta ezt az eszközt: 1948 és 1987 között folyamatosan szükségállapot volt Tajvanon. Elérhető: www.lowyinstitute.org/the-interpreter/end-martial-law-important-anniversary-taiwan (Letöltve: 2020. december 15.).

78 Deloise, 2009, 348-349. o.

79 Deloise, 2009, 350. o. 
kétségbe, azok ad hoc mivolta komoly kritikákat eredményezett. 2004-ben a tapasztalatok alapján az ostromállapotot felváltotta a szükségállapot az alkotmányban. ${ }^{80}$

Az új jogintézményt a 2007-ben elfogadott Veszélyhelyzeti tv. töltötte ki tartalommal. Eredetileg a szükségállapoti törvény megalkotására születtek javaslatok, de ennek képviselői alulmaradtak, mivel a veszélyhelyzetek sokkal gyakoribb problémát jelentettek a ritkán bekövetkező nagyobb válsághelyzeteknél, és a törvény sokkal mérsékeltebb, a normális múkködéstől jóval kevésbé eltérő eszközöket igényelt. ${ }^{81}$ Ennek a törvénynek a gyakorlati alkalmazása meglehetôsen nagy, mintegy évi 80 ezer társadalmi biztonságot veszélyeztető esemény (feltehetôen tüntetések és tiltakozások) történik az országban évente. A válságkezelés alsóbb jogi szintekre történő delegálása abból a szempontból is tudatos volt, hogy a különleges jogrend ugyan egyértelmú jogi helyzetet teremt ezek kezelésére, de általánossá válása komoly problémákhoz vezethet. ${ }^{82}$ Bizonyos esetekben politikai okokból nem került bevezetésre a különleges jogrend, habár eszközeit - igaz veszélyhelyzetként - alkalmazták, így például 2008-ban, a pekingi olimpia évében, amikor földrengés történt Szecsuan tartományban, és zavargásokra került sor Tibet és Xinjiang tartományokban. ${ }^{83}$ A Népi Fegyveres Rendőrségről szóló törvény ezt követően módosításra került, az Ostromállapot tv.-ben foglaltakhoz hasonló felhatalmazást adva a testületnek a zavargások kezelésére. ${ }^{84}$

A törvények bírósági felülvizsgálata nem ismert Kínában. Az Országos Népi Gyúlés egyik bizottsága jogosult normakontrollra, ám ezalól az Országos Népi Gyűlés, illetve annak Állandó Bizottsága által hozott jogszabályok kivételt képeznek. A gyakorlatban az Államtanács által hozott közigazgatási határozatokat és rendeleteket is mindig az alkotmánnyal összhangban állónak tekintik. Ugyan az illetékes törvényhozási bizottságnak megvan a lehetősége, hogy az alsóbb szintư közigazgatási szervek által hozott határozatokat alkotmányellenesnek nyilvánítsa, a gyakorlatban még sosem élt ezzel a jogával. ${ }^{85}$ Mindezek mellett a bíróságok végrehajtó hatalom felett gyakorolt kontrollja a kínai politikai rendszerben erősen megkérdőjelezhető. ${ }^{86}$

\section{5. Összegzés}

Az alábbi táblázat tartalmazza a kínai különleges jogrendi esetkörökkel kapcsolatos legfontosabb szabályozásokat.

80 Deloise, 2009, 350-352. o.

81 Deloise, 2009, 352. 0.

82 Deloise, 2009, 354-355. o.

83 Deloise, 2009, 355-356. o.

84 Deloise, 2009, 355-356. o.

85 Elérhető: https://npcobserver.com/2018/01/19/recording-review-an-introduction-to-constitutional-reviewwith-chinese-characteristics/ (Letöltve: 2020. december 15.).

86 Deloise, 2009, 343. o. 


\begin{tabular}{|c|c|c|}
\hline & Szülkségállapot & Védelmi állapot \\
\hline Szabályozás szintje & \multicolumn{2}{|c|}{$\begin{array}{l}\text { Alkotmányos, törvényi } \\
\text { (Veszélyhelyzeti tv., Ostromállapot tv., Honvédelmi törvény) }\end{array}$} \\
\hline Elrendelési okok & $\begin{array}{l}\text { Különösen súlyos veszélyhelyzet, amely } \\
\text { komoly veszélyt jelent az emberek életére } \\
\text { vagy vagyonbiztonságára, a nemzetbizton- } \\
\text { ságra, a közbiztonságra, a környezetbizton- } \\
\text { ságra vagy a társadalmi rendre } \\
\text { (a hongkongi és makaói alaptörvényekben } \\
\text { olyan zûrzavar, amely a nemzeti egységet } \\
\text { vagy biztonságot veszélyezteti, és a helyi } \\
\text { kormányzat nem tudja azt megfékezni). }\end{array}$ & $\begin{array}{l}\text { Külső fegyveres támadás } \\
\text { az ország ellen, } \\
\text { nemzetközi közös védelmi } \\
\text { kötelezettségnek való } \\
\text { megfelelés. }\end{array}$ \\
\hline Elrendelés & \multicolumn{2}{|c|}{$\begin{array}{l}\text { Az Országos Népi Gyűlés Állandó Bizottsága dönt a bevezetésről, az ál- } \\
\text { lamelnök hirdeti ki. } \\
\text { A szükségállapotot a közvetlenül a központi kormány igazgatása alá tartozó } \\
\text { területeken az Államtanács vezeti be. }\end{array}$} \\
\hline Felhatalmazott & \multicolumn{2}{|c|}{ Az Államtanács (központi kormány), tartományi és helyi szervek. } \\
\hline Gyakorlati esetek & \multicolumn{2}{|l|}{$\begin{array}{l}1989 \text { - Tienanmen téri és tibeti események; } \\
2003 \text { - SARS-járvány; } \\
2008 \text { - tibeti és xinjiangi zavargások }\end{array}$} \\
\hline $\begin{array}{l}\text { Különleges jog- } \\
\text { rendnek nem mi- } \\
\text { nősülő rendkívüli } \\
\text { helyzet }\end{array}$ & \multicolumn{2}{|l|}{ Veszélyhelyzet } \\
\hline
\end{tabular}

26. táblázat

Kina különleges jogrendi szabályozásának összefoglalása

Forrás: a szerző saját összeállitása

A Kínai Népköztársaság jogrendszerében a különleges jogrend intézménye meglehetősen új, csak a Mao Ce-tung halála utáni reformidőszakban került be az 1982-ben elfogadott alkotmányba. Előtte, különösen az 1949-es alapításkor és az 1970-es években, a kulturális forradalom idején az állam egyfajta állandó, nem hivatalos különleges jogrendben múködött, ahol a mindennapi ügyekben nagy szerep jutott a hadseregnek. ${ }^{87} \mathrm{~A}$ különleges jogrend - annak ellenére, hogy az állam mind a mai napig a rendes jogalkotás keretében is jelentős 
hatalmat gyakorol korlátozott felügyelet mellett - mégis felértékelödött, és többször a jogalkotás fókuszába került. Ennek többféle magyarázata és oka van, ezek közül kiemelendő, hogy az 1980-as évek óta tartó reform egyik fontos pillére a jogi reform, és bár Kína az elmúlt időszakban az átlagnál rosszabb, az alsó harmadban lévő helyezést ért el jogállamisági vizsgálatokon, folyamatosan javít a helyezésén. ${ }^{88} \mathrm{~A}$ különleges jogrend hatalomkoncentráló természete is hasznos eszközzé teszi azt, és eszközül szolgálhat a Kínai Kommunista Párt által meghatározott értékek védelméhez. Mindezek mellett a különleges jogrend bizonyos hatalomlimitáló aspektusai a liberalizációt támogatók számára is szimpatikus eszközzé teszik azt. ${ }^{89}$ Mindezek ellenére a különleges jogrend jelenléte a kínai jogrendszerben továbbra is paradoxon, tekintve, hogy ennek alkalmazása nélkül, a rendes müködés keretei között is szinte korlátlan hatalommal bír a kormányzat a felmerülő rendkívüli helyzetek kezelésére.90

A kínai jogrendben az alkotmány kétféle különleges jogrendi eszközt határoz meg: a szükségállapotot, illetve a hadiállapotot. Mindkettő csak röviden, a bevezetésre jogosult szerv kapcsán kerül említésre az alkotmányban. A bevezetésról mindkét esetnél a törvényhozás, az Országos Népi Gyúlés Állandó Bizottsága dönt, és az államelnök hirdeti azt ki. A közvetlenül a központi kormány, az Államtanács irányítása alá tartozó területeken maga az Államtanács dönthet a szükségállapot alkalmazásáról. Az ország két speciális igazgatású területe, Hongkong és Makaó esetén az Országos Népi Gyúlés Állandó Bizottsága dönt a szükségállapot bevezetéséről, amennyiben a helyi kormányzat képtelennek bizonyul a súlyos zavar kezelésére. A hadiállapotot külső fegyveres támadás, illetve nemzetközi közös védelmi kötelezettségnek való megfelelés esetén lehet elrendelni, a Honvédelmi tv.-ben foglalt részletszabályai meglehetősen általánosak.

A szükségállapot szabályait két törvény, az Ostromállapot tv., illetve a veszélyhelyzeti intézkedésekről szóló törvény tartalmazza. Ez jóval kidolgozottabb jogintézmény, elrendelésére olyan különösen súlyos veszélyhelyzet esetén kerülhet sor, amely komoly veszélyt jelent az emberek életére vagy vagyonbiztonságára, a nemzetbiztonságra, a közbiztonságra, a környezetbiztonságra vagy a társadalmi rendre. Az Ostromállapot tv. tartalmazza a szükségállapotra vonatkozó szabályokat, amelyek jóval szigorúbbak, míg a veszélyhelyzeti intézkedési törvény elsősorban az ennél enyhébb veszélyhelyzetekre vonatkozóan szabályoz. A veszélyhelyzet ugyan nem különleges jogrend, mégis különleges felhatalmazást ad. A rendszerben egy erős fokozatosság figyelhető meg: a súlyosságában négy fokozatra osztott veszélyhelyzet legkomolyabb, különösen súlyos fokozata esetén van lehetőség szükségállapotot bevezetni. A felhatalmazás megoszlik az Államtanács, illetve a helyi kormányzati szervek között, amiben az a felismerés rejlik, hogy utóbbiak eredményesebben tudják kezelni a helyi problémákat.

88 Elérhető: https://worldjusticeproject.org/rule-of-law-index/country/2020/China/ (Letöltve: 2020. december 15.).

89 Deloise, 2009, 344-345. o.

90 Deloise, 2010, 407. 0. 
A kínai jogrendszer múködéséből kifolyólag az állam számára nem okoz különösebb problémát az alapjogok korlátozása a rendes múködés során, az alkotmány deklaráltan az egyéni jogok gyakorlása elé helyezi az államérdeket. Ennek ellenére érdekes módon a különleges jogrend esetén a jogalkotó kimondottan igyekezett az állami beavatkozás mértékét csökkenteni, a vonatkozó törvények például tartalmazzák a szükségesség-arányosság kritériumait az intézkedések meghozatala kapcsán, illetve garanciákat a jogok korlátozása kapcsán. Ezt a törvények liberalizációpárti kommentátorai igyekeznek úgy magyarázni, mint az államhatalom korlátozásának csírái a későbbi kínai jogfejlődésben.

A különleges jogrend gyakorlati alkalmazása kapcsán meglehetősen rossz tapasztalatok vannak a nemzetközi közösség emlékezetében. Az 1989-es Tienanmen téri események, illetve ezzel egy időben a tibeti zavargások elfojtása ostromállapot bevezetésével történt, amelyet ekkoriban még a hadsereg elsődlegessége jellemzett. A tapasztalatok alapján elfogadott Ostromállapot tv. próbálta korlátozni ezt, és biztosabb jogi alapot adni a későbbi intézkedéseknek. A 2003-as SARS-járvány kezelése újra komoly kritikákra adott okot, ami az alkotmány reformjához, a szükségállapot megteremtéséhez, illetve a többszintú veszélyhelyzeti válságkezelés kialakításához vezetett. Itt már jelentős megközelítésbeli eltérés mutatkozott, a hadsereg szerepét mérsékelték, és elsősorban a civil közigazgatás kezébe adtak eszközöket. Köszönhetően a SARS-járvány tapasztalatainak, illetve annak, hogy az ország járványügyi szabályozása meglehetősen kidolgozott - a fejletlenebb vidéki területeken gyakrabban előforduló járványok okán -, az ország az átlagnál eredményesebben tudta kezelni a koronavírus-járványt. Rámutatott azonban a krízis a szabályozás következetlenségeire, a tervezési rendszer - amely a veszélyhelyzet és így a különleges jogrend alapja - hibáira.

A kínai és a magyar szabályozás összehasonlítása nagyon nehéz feladat, hiszen a két ország rendes múködése is jelentősen eltér egymástól. Elmondható, hogy a különleges jogrendi esetkörök száma jóval alacsonyabb Kínában a jelenlegi magyar szabályozásnál. Az Alaptörvény kilencedik módosítása alapján eloálló szisztémában az eszközök száma azonos lesz (a kínai kvázi különleges jogrend veszélyhelyzetet is ideszámítva), és a típusuk is, ám a múködési elvük eltérő. Míg idehaza a szükségállapot csak az alkotmányos rend megváltoztatásának kísérletét és a tömeges erőszakos cselekményeket foglalja magában, addig a kínai szabályozásban a szükségállapot egyúttal a magyar rendszer szerinti veszélyhelyzetet is magában foglalja. Ott a megosztás logikája az, hogy a legsúlyosabb veszélyhelyzetek esetén alkalmazható különleges jogrend, egyébként csak az enyhébb veszélyhelyzeti eszközök vehetôk igénybe. A kínai veszélyhelyzetbe következésképp a természeti és emberi katasztrófák, balesetek, fertőző betegségek mellett a társadalmi rend ellen irányuló kisebb súlyú és intenzitású cselekmények is beletartoznak.

Az elrendelés kapcsán mind idehaza, mind Kínában nagy jelentőség jut a törvényhozásnak, a szükségállapotot és a hadiállapotot ez a szerv rendelheti el. A veszélyhelyzet elrendelésére Kínában a helyi (megyei, prefektúrai, tartományi) kormányzat, illetve a legsúlyosabb esetekben a központi kormány jogosult. A kínai rendszerben így - az ország 
területének méretéből adódóan - jóval nagyobb szerep jut a helyi kormányzati szerveknek a rendkívüli események kezelésében.

Egyéb aspektusaiban a szabályozás a jogrendszer komoly eltérőségei, illetve a politikai berendezkedés különbözősége miatt nem hasonlítható össze érdemben. Összességében elmondható, hogy Kínában nagy hangsúlyt helyezett az elmúlt évtizedekben az állam arra, hogy ezeket a szabályokat minél alaposabban kidolgozza, főlleg a veszélyhelyzetek tömegességére való tekintettel. A rendszer a koronavírus-járvány kapcsán bizonyította múködőképességét, ám számos hiba is feltárásra került, különösen a korai védekezés kapcsán.

\section{Irodalomjegyzék}

BURKI, T. (2020) 'China's Successful Control of COVID-19', The Lancet Infectious Diseases, 20(11), 1240-1241. O.

Chen, S., YAng, J., Yang, W., WANG, C., Bärnighausen, T. (2020) 'COVID-19 Control in China during Mass Population Movements at New Year', The Lancet, 395(10226), 764-766. o.

DelisLE, J. (2009) 'States of Exception in an Exceptional State: Emergency Powers Law in China' in Ramraj, V. V., Thiruvengadam, A. K. (szerk.) Emergency Powers in Asia. Exploring the Limits of Legality. 1. kiadás. Cambridge: Cambridge University Press

Delisle, J. (2010) 'Security First? Patterns and Lessons from China's Use of Law To Address National Security Threats', Journal of National Security Law \& Policy, (4)2, 397-436. o.

Hu, J., CHEN, C., KuAI, T. (2018) 'Improvement of Emergency Management Mechanism of Public Health Crisis in Rural China: A Review Article', Iran Journal of Public Health, 47(2), 156-165. o.

JIANFU, H. (2004) The Revision of the Constitution in the PRC. A Great Leap forward or a Symbolic Gesture? [Online]. Elérhető: https://journals.openedition.org/chinaperspectives/2922 (Letöltve: 2020. december 15.)

Lu, X., XuE, L. (2016) 'Managing the Unexpected: Sense-making in the Chinese Emergency Management System', Public Administration, 94(2), 414-429. o.

Shen, W., JiAng, L., ZANG, M., MA, Y., JiAnG, G., HE, X. (2015) 'Practical Experiences and Lessons of Medical Response to Major Disasters in China', Hong Kong Journal of Emergency Medicine, 22(5), 270-280. o.

Shigong, J. (2014) 'Chinese-Style Constitutionalism: On Backer's Chinese Party-State Constitutionalism', Modern China, 40(2), 133-167. o.

SPItzer, J. (2020) 'Különleges jogrendi szabályozás a kínai, a japán, a dél-koreai és a szingapúri jogrendszer sajátosságai között’ in Farkas, Á., Kelemen, R. (szerk.) Szkülla és Kharübdisz között - Tanulmányok a különleges jogrend elméleti és pragmatikus kérdéseiról, valamint nemzetközi megoldásairól. 1. kiadás. Budapest: Magyar Katonai Jogi és Hadijogi Társaság 
Tangcharoensathien, V., Bassett, M. T., Meng, Q., Mills, A. (2021) Are Overwhelmed Health Systems an Inevitable Consequence of Covid-19? Experiences from China, Thailand, and New York State [Online]. Elérhető: www.bmj.com/content/372/bmj.n83 (Letöltve: 2020. december 15.) ToNG, X., ZHANG, H. (2020) China's Emergency Management. 1. kiadás. Szingapúr: Springer Zhengfa, Z., WANQIANG, W. (2020) 'Amendment of China's Biotechnology Laws in Relation to the Prevention and Containment of the COVID-19 Pandemic', Biotechnology Law Report, (39)6, 458-467. o. 


\section{KONKLÚZIÓK}




\section{8. Összegzés - A koronavírus-járvány kezelésének tapasztalatai a vizsgált államokban}

\section{HOJNYÁK DÁVID - UNGVÁRI ÁLMOS}

A világ országainak koronavírus-járvány okozta egészségügyi válsághelyzetre adott válaszát egymás mellé állítva - különböző vizsgálódási szempontok alapján, illetve más-más államok szabályozását elemezve - a hazai ${ }^{1}$ és külföldi² szakirodalom egyaránt vizsgálja, de az Európai Unió tagállamainak járványkezelésével ${ }^{3}$ is foglalkozott már a jogirodalom.

Jelen fejezetben a könyváltal tárgyalt országok szabályozását foglaljuk össze. Rögzítjük, hogy mely országokban rendeltek el különleges jogrendi állapotot, illetve azt - a nemzeti jogszabályok adta kereteknek megfelelően - milyen időbeli hatállyal hirdették ki. Emellett elemzésre kerül,

1 Lásd például: Hojnyák-Ungvári, 2020, 122-138. o.; Hegedős-Karácsony-Monostori, 2020, 28-42. o.; Hojnyák-Ungvári, 2021.

2 Lásd például: Cameron-Jonsson Cornell, 2020, 1173-1190. o.; Golia-Hering-Moser-Sparks, 2020; Desmet, 2020, 79-88. o.; Guasti, 2020, 47-60. o.

3 Binder et al., 2020; Atanassov et al., 2020; Bentzen et al., 2020; Alexandre et al., 2020. Külön kiemelendő a Velencei Bizottság által kibocsátott jelentés, amely alkotmányjogi szempontból vizsgálja és értékeli az európai uniós tagállamok járványkezelési szabályozását a koronavírus-járvánnyal összefüggésben (Venice Commission, 2020).

Dr. Hojnyák Dávid

david.hojnyak@mfi.gov.hu

kutató (Mádl Ferenc Összehasonlító Jogi Intézet)

PhD-hallgató (Miskolci Egyetem, Deák Ferenc Állam- és Jogtudományi Doktori Iskola)

Dr. Ungvári Álmos

kutató (Mádl Ferenc Összehasonlító Jogi Intézet)

PhD-hallgató (Pázmány Péter Katolikus Egyetem, Jog- és Államtudományi Doktori Iskola)

Hojnyák, D., Ungvári Á. (2021) 'Összegzés - A koronavírus-járvány kezelésének tapasztalatai a vizsgált államokban' in Nagy, Z., Horváth, A. (szerk.) A különleges jogrend és nemzeti szabályozási modelljei, 610-623. o. Budapest: Mádl Ferenc Összehasonlító Jogi Intézet.

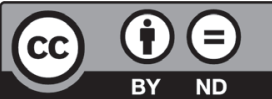


hogy a vizsgált országokban a gyors és hatékony válságintézkedések érdekében mely állami szereplők felhatalmazásával és milyen formában valósul meg a rendeleti kormányzás, illetve hogy annak vonatkozásában milyen mértékben és formában tudják ellenőrző funkciójukat ellátni az egyes államok törvényhozó szervei. Továbbá az alapjogok korlátozásának kérdésével is foglalkozik a fejezet, valamint utalás történik azokra a közjogi-politikai jellegű vitákra is, amelyek nemzeti szinten jelentkeztek a foganatosított kormányzati intézkedések nyomán. A fejezetben a vizsgált államok intézkedéseinek egymás melle állításával és elemzésével lehetőség nyílik a koronavírus-járvány kezelése érdekében alkalmazott nemzeti járványkezelési megoldások összehasonlítására, valamint ennek eredményeként különböző szabályozási modellek kialakítására.

\section{Különleges jogrend bevezetése a koronavírus-járvány kezelése érdekében}

A vizsgált államok koronavírus-járvány kezelésének jogszabályi keretei közti különbség leglátványosabban a különleges jogrendi állapot elrendelése, illetve annak hiánya vonatkozásában mutatkozik meg. A vizsgált országok alig fele alkalmazta a különleges jogrend eszközét, ráadásul - ahogyan arra jelen könyv korábbi fejezetei rámutatnak - annak nincsen általános sztenderdje, szabályozása számos ponton eltér. Így érdemes egyrészt egymás mellé állítani az államok által bevezetett különleges jogrendi szituációkat, másrészt pedig megvizsgálni azt, hogy azon országok esetében, ahol a koronavírus-járvány kezelése rendes jogrendi keretek között zajlott, mely ágazati jogszabályok kerültek alkalmazásra.

Magyarországhoz hasonlóan Csehországban, Szlovákiában, az Egyesült Királyságban, Finnországban, Lettországban, Romániában és Spanyolországban egyaránt különleges jogrendet vezettek be. Azonban hiába képezte a különleges jogrend bevezetésének alapját ugyanaz a humánjárvány, az elrendelt kategóriák, illetve azok elnevezése nem azonos. Így például Magyarország mellett Szlovákia és Lettország is veszélyhelyzetet hirdetett, Csehország és Finnország szükségállapotot vezetett be, Spanyolországban pedig riadókészültséget rendeltek el. A járványhelyzetre válaszul Románia sürgősségi állapotot rendelt el, ám még a tavasz végén - a koronavírus-járvány leküzdésének sajátos szabályait rögzítő törvényben - új alapokra helyezte a válságkezelés jogszabályi kereteit. A sürgősségi állapot fenntartása helyett riadóállapotot léptettek életbe, amely egy ideiglenes, többek között az életet és az egészséget fenyegető veszélyek megelőzésére és elhárítására irányuló, a különleges helyzet jelenlegi és jövőbeli súlyosságával arányos rendkívüli intézkedésrendszer. Ezektől eltérő megoldást alkalmazott az Egyesült Királyság, ahol törvényi úton hirdettek ki egy újfajta, speciálisan a koronavírus-járvány kezelésére megalkotott - a járvány kezelésének megkönnyítését és terjedésének lassítását, az állami szervek múködésének biztosítását és a gazdaság múködőképességének megőrzését célzó - kivételes jogrendi állapotot. 
A törvény időbeli hatálya meghatározott időre, fôszabály szerint két évre szól, ám annak fél évvel történő meghosszabbítására és lerövidítésére is lehetőség van.

Ez utóbbi vonatkozásában is jelentősen eltér a többi állam által bevezetett különleges jogrendi állapottól az Egyesült Királyság járványkezelése. A többi vizsgált ország ugyanis rövidebb határidôt jelölt meg, és azt hosszabbította meg, ha továbbra is szükségesnek találta a kivételes állapot fenntartását. Ennek oka elsősorban az, hogy a demokratikus kontroll érvényesítése és a hatalmi ágak egyensúlyának megőrzése érdekében szükséges a különleges jogrend időszakos felülvizsgálata. Emiatt a legtöbb vizsgált állam alkotmányos, illetve törvényi szabályozása nem is ad lehetőséget az elrendeltnél lényegesen hosszabb időbeli hatály meghatározására. Számos országban pedig - így például Csehországban, Szlovákiában, Lettországban, illetve Romániában - a jogszabályi keretek által biztosított leghosszabb határidőre vezettek be különleges jogrendet. A Cseh Köztársaság kormánya harminc napra rendelte el a szükségállapotot, amelyet időről időre felülvizsgáltak, és több alkalommal is meghosszabbítottak. Ugyanígy harmincnapos határidőket határozott meg Románia is a sürgősségi állapot, illetve a riadóállapot vonatkozásában. A spanyol járványkezelés során a kétféle megoldást sajátosan ötvözték, ugyanis első alkalommal mindössze tizenöt napra vezettek be különleges jogrendet, ám azt több alkalommal is meghosszabbították, a kézirat lezárásának időpontjában hatályban lévő rendelkezés szerint pedig a riadókészültség időbeli hatálya Spanyolországban egészen 2021 májusáig tart. Szlovákiában és Lettországban - a járványhelyzet enyhülésére és súlyosbodására reagálva - nem volt folyamatosan hatályban a különleges jogrendi helyzet. A szlovák kormány tavasszal kilencven napra rendelte el a veszélyhelyzetet, ám nem hosszabbította meg, hanem rövid rendes jogrendi időszakot követően a járvány második hullámának kezelése érdekében újból kihirdette azt, immáron negyvenöt napra. (Később pedig - szintén negyvenöt nappal egy alkalommal meg is hosszabbította.) Hasonlóan járt el Lettország is, amely tavasszal két hónapra rendelt el különleges jogrendi állapotot, amelyet még egy alkalommal, szúk egy hónappal ugyan meghosszabbított, ám júniustól egészen novemberig a lett válságkezelés is rendes jogrendi keretek között zajlott. Novemberben azonban újabb veszélyhelyzet kihirdetésére került sor, valamivel több mint kéthónapos időtartamra. Az elrendelt különleges jogrendi helyzetek időbeli hatályát vizsgálva ki kell emelni, hogy Magyarország határozatlan időre vezette be a különleges jogrendi állapotot, amelyhez hasonló megoldást egyedül Kína esetében tapasztalhatunk. Magyarország Alaptörvényének rendelkezése értelmében ugyanis a veszélyhelyzetet elrendelő Kormány jogosult azt megszüntetni, abban az esetben, ha a kihirdetésének feltételei már nem állnak fenn. Ennek megfelelően a járványhelyzet enyhülésével a márciusban bevezetett veszélyhelyzetet Magyarország Kormánya - az Országgyűlés felhívására - nyár elején megszüntette. Hasonlóan azonban Szlovákia és Lettország járványkezeléséhez, a járvány második hullámának hatására novemberben újra különleges jogrend lépett életbe hazánkban is. A különleges jogrendi szituációk elrendelése kapcsán megállapítható, hogy a vizsgált államok - talán egymástól nem teljesen függetlenül - közel egy időben (Magyarországon március 11-én, Csehországban és Lettországban március 12-én, Spanyolországban március 14-én, Finnor- 
szágban, Romániában és Szlovákiában március 16-án, az Egyesült Királyságban pedig március 25-én) vezették be a különleges jogrendi állapotot. Említésre érdemes továbbá, hogy valamennyi vizsgált ország hozott korábban is a koronavírus-járvány kezelésére irányuló intézkedéseket.

Alapvetően megállapítható, hogy ezen államok rendkívül hasonlóan reagáltak az egészségügyi válsághelyzetre, azt szinte azonos keretek között kezelték. A szlovák kormány által márciusban kihirdetett veszélyhelyzet említhető kivételként, azt ugyanis nem általános hatállyal, hanem kizárólag az egészségügyi rendszerre kiterjedően vezették be. A koronavírus-járvány második hulláma idején azonban már Szlovákiában is az egész országra kiterjedt a különleges jogrend hatálya. Ugyancsak valamennyi állam vonatkozásában kijelenthető, hogy korábban nemigen tapasztalt közjogi helyzetet teremtett a különleges jogrend elrendelése, így például Csehországban és Finnországban sem került sor korábban a szükségállapot bevezetésére.

A koronavírus-járványt rendes jogrendi kereteknek megfelelően kezelő államokat egyrészt aszerint csoportosíthatjuk, hogy mely ágazati jogszabályokat hívták segítségül a járványhelyzet leküzdésére, másrészt pedig az alapján oszthatjuk fel ôket, hogy korábban is meglévő vagy a koronavírus-járványra válaszul létrehozott jogintézményeket alkalmaztak. A vizsgált államok közül a legtöbb - így Ausztria, Franciaország, Hollandia, Lengyelország, Németország, Dánia, Norvégia, és Svédország is - a járványügyi, illetve közegészségügyi jogszabályok alapján járt el. Észtország, Litvánia és Olaszország járványkezelése pedig a polgári védelmi, valamint a válságkezelésről szóló jogszabályokra támaszkodott. Az előbbi csoportba tartozó államok sok esetben azonban a koronavírus-járvány leküzdéséhez elégtelennek ítélték meg a jogszabályi kereteket, ezért módosításokat eszközöltek a járvány-, illetve közegészségügyi törvényeiken. Azok mértéke ugyan eltéréseket mutat, de Ausztriában, Németországban, Lengyelországban, Dániában, Norvégiában és Svédországban is elsősorban a különböző korlátozó intézkedések meghozatalának jogalapját biztosítja, valamint növeli a központi kormányzat és az egészségügyi hatóságok hatáskörét. Ezek a módosítások több állam esetében is ideiglenesek, kizárólag meghatározott ideig maradnak hatályban. Így például a dán járványügyi törvény módosítása 2021 márciusában veszti hatályát, Svédországban pedig a módosított rendelkezések csak 2020 nyaráig voltak hatályban. Említésre érdemes Hollandia példája, ahol eleinte mindenfajta módosítás nélkül kizárólag a közegészségügyi törvény rendelkezéseire alapozták az intézkedéseket, ám később - a különleges jogrendi állapot elrendelését hiányoló, a demokratikus kontroll meglétét, valamint az alapjogok korlátozásának alkotmányosságát megkérdőjelező - kritikák hatására mégis módosították a jogszabályt. Kiemelendő továbbá a franciaországi járványkezelés, ahol a szükségállapotnak egy új formáját rögzítették a közegészségügyi törvénykönyvben. Az egészségügyi szükségállapot olyan egészségügyi katasztrófa esetén alkalmazható, amely jellegénél és súlyosságánál fogva veszélyezteti a lakosság egészségét. Ez a jogintézmény azonban ideiglenesen lett a kódexbe bevezetve, az legkésőbb 2021. április 1-ig tartható fenn. Az egészségügyi szükségállapotot 2020. március 24-tôl két hónapos időtartamra hirdették ki az ország egész terü- 
letére, később pedig több alkalommal meghosszabbították. Franciaországban tehát egy különleges jogrendi állapotnak ugyan nem minősülő, mégis kivételesnek titulálható, ráadásul újonnan, a koronavírus-járványra válaszul megalkotott helyzetet vezettek be. Hasonlóan járt el - a jogintézmény újdonságától eltekintve - Lengyelország is, ahol az egészségügyért felelős miniszter rendeletével előbb járványveszélyt, később pedig járványállapotot hirdetett. A polgári védelmi jogszabályok alapján eljáró államok vonatkozásában szintén elmondható, hogy bár nem került sor különleges jogrend bevezetésére, de rendkívüli jelleggel bíró válságkezelési intézkedéseket foganatosítottak. Így például Észtországban - a kifejezetten különleges jogrend elrendelését nem igénylő válsághelyzetek egységes kezelése érdekében megalkotott - veszélyhelyzeti törvény alapján veszélyhelyzetet hirdettek ki, amely egyszeri meghosszabbítással valamivel több mint két hónapig volt hatályban, később pedig a sokkal enyhébb válsághelyzeti állapot kategóriája került bevezetésére. Az Olasz Köztársaságban pedig a Polgári Védelmi Kódexben szabályozott nemzeti szintú szükségállapotot hirdettek ki, időbeli hatályként a rendelkezés napjától számított hat hónapot megjelölve. Azt azonban két alkalommal is meghosszabbították, így - a kézirat lezárásakor hatályban lévő jogszabályok alapján - elmondható, hogy a szükségállapot Olaszországban egy teljes évig hatályban marad.

A koronavírus-járvány kezelésének jogi kereteit nyilvánvalóan determinálta az államok különleges jogrendi szabályozása. A járványhelyzet során a rendes jogrendi keretek szerint eljáró államok között találunk olyat, ahol fel sem merülhetett a különleges jogrend elrendelése, hiszen nem is találunk békeidejû különleges jogrendi szituációt, kizárólag háborús rendelkezést (például Olaszország, Svédország). Vannak államok, ahol bár a hadiállapoton kívül más különleges jogrendi kategóriák is rögzítésre kerültek, ám a koronavírus-járvány nem illeszkedik azok tényállásába (például Észtország, Franciaország). Illetőleg vannak olyan államok is, ahol hiába beszélhetünk elrendelhető különleges jogrendi helyzetről, annak kihirdetésére - komoly közjogi vitákat kiváltva - mégsem került sor (például Hollandia, Lengyelország).

Érdemes megemlíteni, hogy a különleges és rendes jogrendi szabályok kombinációjára is találunk példát. Szlovákiában a kormány még a veszélyhelyzet elrendelése elött az egész országra kiterjedó hatállyal rendkívüli helyzetet hirdetett, amely jogintézmény nem minősül hagyományos értelemben vett különleges jogrendi esetkörnek, részletszabályait pedig a polgári védelmi, illetve a közegészségügyi törvények tartalmazzák. Ellentétben a különleges jogrendi állapottal, a rendkívüli helyzet Szlovákiában megszakítás nélkül hatályban volt. Magyarországon pedig a veszélyhelyzet nyári megszüntetésével egyidejúleg, az egyes intézkedések és korlátozások fenntartásának indokoltsága miatt járványügyi készültséget hirdettek ki, amelynek egyes rendelkezései a veszélyhelyzet újbóli bevezetését követően is hatályban maradtak.

Habár jelen könyv részletesen foglalkozik az Egyesült Államok és Kína különleges jogrendi szabályozásával, valamint a koronavírus-járvány kezelésével, azok kevéssé hasonlít- 
hatók az eddig tárgyalt államok megoldásaihoz. Az Egyesült államok egészségügyért felelős minisztere már január végén közegészségi veszélyhelyzetet hirdetett, 2020. március 13-án pedig az elnök kihirdette az országos veszélyhelyzetet is. Tehát különleges jogrendi helyzetet vezettek be a járványhelyzet kezelése érdekében, ám az USA különleges jogrendi modellje a szabályozás koncepciója és decentralizációja, az ultima ratio jelleg hiánya, valamint az elrendelés határozatlan időtartama miatt jelentősen eltér a hazai - és a legtöbb európai - különleges jogrendi keretektől. Ezzel szemben Kínában szükségállapot helyett a különleges jogrendi szituációnak nem minősülő - a kifejezetten az alacsonyabb szintú válsághelyzetek kezelése érdekében elfogadott, veszélyhelyzeti intézkedésekről szóló törvényben rögzített veszélyhelyzet kategóriáját vezették be. A négyfokozatú kategóriarendszer legsúlyosabbnak minősülő első szintjét, az úgynevezett különösen komoly veszélyhelyzetet rendelték el határozatlan idôtartamra, időbeli korlát nélkül, azonban idővel enyhítették az intézkedéseket. Emellett megállapítható, hogy a kínai jogrendszer - köszönhetően annak, hogy számos jogszabálya tartalmaz járványkezelést segítő kivételes intézkedést - fel van készülve egy esetleges járványhelyzet bekövetkezésére.

\section{A koronavírus-járvány kezelése érdekében megvalósuló rendeleti kormányzás, és a parlament kontrollfunkciója}

A koronavírus-járvány terjedésének megakadályozása és az egészségügyi válsághelyzet leküzdése tehát valamennyi államtól gyors és hatékony reakciót követelt meg, amit a vizsgált államok leginkább a kormányzat hatáskörének kibővítésével, illetve mozgásterének megnövelésével láttak megvalósíthatónak. A különleges jogrendi állapotot elrendeló államok vonatkozásában - tekintve, hogy az általánostól eltérő szabályok intézményesítésével a jogalkotó célja a hatalommegosztás rendjének átalakítása, illetve meghatározott szervek számára többletjogosítványok biztosítása ${ }^{4}$ - ez a rendeleti kormányzás eszközének alkalmazásával valósul meg. Így Csehországban, Magyarországon, Romániában, Szlovákiában, Finnországban, Lettországban, valamint Spanyolországban a különleges jogrendi szituáció kihirdetésével egyidejúleg felhatalmazták a kormányt, hogy rendeleti úton alkossa meg a szükséges intézkedéseket. Az Egyesült Királyságnak a koronavírus-járvány kezelése érdekében megalkotott törvénye is a rendeleti kormányzás kereteit kívánta megteremteni. A kormány jogalkotói hatáskörrel való felruházása kapcsán az jelent komolyabb különbséget, hogy egyes országokban - a kormány mint kollektív testület mellett - meghatározott miniszterek kiemelt szerepet kapnak a járványkezelés során. Csehországban és Romániában az egészségügyért felelős miniszter, Spanyolországban pedig - az egészségügyi miniszter mellett -

4 Csink, 2017, 13-14. o. 
a honvédelmi, a belügyi, illetve a közlekedési tárca vezetője alanya - a szükséges rendkívüli intézkedések kibocsátása révén - a rendeleti kormányzásnak.

A különleges jogrendet be nem vezető államok vonatkozásában is megfigyelhető, hogy a kormánynak vagy valamely tagjának kivételes jogköröket biztosítottak a hatékony járványkezelés érdekében. Ez a polgári védelmi jogszabályok alapján eljáró államok vonatkozásában különösen igaz. Észtországban a járványkezelést például a kormány által kijelölt miniszter irányítja, aki jogosult a járványkezelés érdekében szükséges utasítások kibocsátására. Olaszországban - bár a szükségállapot során is van lehetőség az intézkedések speciális rendelkezésekkel való összehangolására - a járványhelyzet kezelésének végül mégsem a polgári védelmi szabályok, hanem a sürgősségi rendeleti kormányzás intézményének megfelelően kibocsátott törvényerejû̉ rendeletek adtak keretet, amelyek értelmében a koronavírus-járvány kezelése és leküzdése érdekében a miniszterelnök rendeletében - az egészségügyért felelős miniszter javaslata alapján - sürgős intézkedéseket bocsáthat ki.

A járvány-, illetve közegészségügyi törvényeket alkalmazó államok kivétel nélkül kisebb-nagyobb módosításokat eszközöltek a vonatkozó jogszabályaikon. Ausztriában és Dániában is a törvények célzott módosítása teremtett jogalapot a kormány kivételes rendelkezéseinek kibocsátásához. Németországban a módosítások hatására - a szövetségi államok hatásköreinek sérelme nélkül - a Szövetségi Egészségügyi Minisztérium kap felhatalmazást valamennyi, a járványhelyzet szempontjából releváns intézkedés meghozatalára. Lengyelországban a korábban is meglévő járványveszély és járványállapot kategóriáit módosították úgy, hogy azok vonatkozásában rendeletalkotási jogkörrel ruházták fel a Minisztertanácsot. Ugyan a svéd járványkezelést alapvetően a Közegészségügyi Ügynökség ajánlásai határozzák meg, azonban a gyorsabb fellépés biztosítása érdekében - ideiglenes hatállyal - kiterjesztették a kormány jogalkotó hatáskörét, rögzítve, hogy ha az a koronavírus-járvány kezelése érdekében szükséges, és nem várható a parlament jogalkotása, a kormány rendeletet alkothat. A Franciaországban újonnan létrehozott és be is vezetett egészségügyi szükségállapot során - az egészségügyért felelős miniszter javaslata alapján - a miniszterelnök jogosult rendeletével meghozni a koronavírus-járvány leküzdéséhez szükséges rendelkezéseket. Hollandia járványkezelése a tekintetben tér el a többi vizsgált államétól, hogy ott eleinte a közegészségügyi törvény mindenfajta módosítása nélkül az egészségügyi miniszter irányította a koronavírus-járvány elleni védekezést, amivel egyidejủleg - a biztonsági körzetekról szóló törvény alapján - a biztonsági körzetek vezetői kaptak felhatalmazást arra, hogy - az egészségügyi miniszter iránymutatása mellett - átvegyék a védekezés megszervezésével kapcsolatos, a polgármestereket megillető hatáskörök gyakorlását. Később azonban - a járványkezelést ért kritikák hatására - módosították a közegészségügyi törvényt, amely alapján miniszteri rendeletekben rögzítik a járványkezeléshez szükséges intézkedéseket. Norvégiában már a kormány rendkívüli felhatalmazását biztosító törvényjavaslat elfogadása előtt kritikát fogalmaztak meg az előkészítő munka elégtelensége és a megfelelő demokratikus kontroll hiánya kapcsán, így végül az elfogadott törvényszöveg szűkebb felhatalmazást biztosított a kormánynak, amely mellett a király is jelentős hatásköröket gyakorolhat. 
Tekintettel arra, hogy a koronavírus-járvány okozta válsághelyzet leküzdése érdekében a végrehajtó hatalom törvényhozói jogosítványokat kapott, érdemes áttekinteni, hogy a hatalmi ágak egyensúlyának biztosítása érdekében miként érvényesül a parlamenti kontrollfunkció. A különleges jogrendet bevezető államok esetében a garanciális szabályok több típusát különböztethetjük meg. Csehország és Lettország esetében a különleges jogrendi állapot fennállásához elengedhetetlen a parlament támogatása. Előbbi esetében a parlament alsóháza, a képviselőház utólagosan megsemmisítheti a kormány különleges jogrend bevezetésére irányuló döntését, az elrendelt szükségállapot meghosszabbításához pedig - amely a koronavírus-járvány kezelése kapcsán meg is valósult - szükség van a képviselőház előzetes jóváhagyására. Ezen túlmenően a parlament a kihirdetett szükségállapotot a meghatározott idôtartam lejártát megelőzően bármikor megszüntetheti. Más államok vonatkozásában - így például Finnországban és Magyarországon - a különleges jogrend során kibocsátott rendeletek megerősítésében valósul meg a törvényhozó hatalom ellenőrző szerepe. A magyar különleges jogrendi szabályozás értelmében a kormányrendeletek hatályának meghosszabbításához szükséges a parlamenti támogatás, a koronavírus-járvány kezelése során pedig ennek érdekében az Országgyúlés törvényben rögzítette azt, hogy a meghozott rendeletek csak a veszélyhelyzet megszû́nésével veszítik el hatályukat. Az Egyesült Királyságban a különleges jogrendet bevezetó törvény vitája során a kormány ígéretet tett arra, hogy beszámol a parlamentnek a meghozott intézkedésekről, így lehetőség nyílik a kivételes rendelkezések megvitatására. Bár nem minősül klasszikus különleges jogrendi kategóriának, itt érdemes megemlíteni az Olasz Köztársaságban a járványhelyzet során alkalmazott sürgősségi rendeleti kormányzás vonatkozásában érvényesülő parlamenti kontrollt. A törvényerejú rendeleteket ugyanis késedelem nélkül be kell nyújtani a parlamentnek, amely azokat hatvan napon belül törvénnyé alakíthatja, vagy hatályon kívül helyezheti. Komoly vitákat váltott ki, hogy a koronavírus-járvány kezelése érdekében kibocsátott törvényerejú rendeletek a miniszterelnök hatáskörébe utalták a kivételes intézkedések meghozatalát, ezáltal pedig a parlament ellenőrzési jogköre kevésbé érvényesült.

Azon államok vonatkozásában, ahol rendes jogrendi keretek között reagáltak az egészségügyi válsághelyzetre, kevésbé releváns kérdés a parlament ellenőrző funkciójának érvényesülése. Ezekben az országokban a kivételes jogosítványok és intézkedések törvényi rendelkezésen alapulnak, egyes államok kapcsán azonban így is rögzítettek bizonyos többletgaranciákat. Franciaországban és Lengyelországban ezt a kormány tájékoztatási kötelezettsége jelenti. Előbbi államban a kormány köteles valamennyi, az egészségügyi szükségállapottal kapcsolatos intézkedéséről haladéktalanul tájékoztatni a parlament mindkét házát, utóbbiban pedig havonta tesz jelentést a Minisztertanács a szenátusnak és a képviselőháznak. A svédországi szabályozás ennél erősebb kontrollfunkciót biztosít a parlamentnek. A svéd kormány által kibocsátott rendeleteket ugyanis haladéktalanul be kell nyújtani felülvizsgálatra a parlamentnek, amely azt törvénnyel módosíthatja, vagy akár hatályon kívül is helyezheti. Hasonló szerepe van a holland parlamentnek, ahol a törvényhozás egy héten belül dönt a kormány rendeletének megerősítéséről, amely szabálytól csak sürgető körülmény fennállta esetén lehet eltérni, a parlament azonban ez 
esetben is kontrollt gyakorol a megalkotott rendeletek felett. E szabályok rögzítésére viszont csak a demokratikus kontroll hiányát megfogalmazó kritikák hatására került sor.

Az európai járványkezelési modellekhez kevésbé illeszkedő megoldások közül az Egyesült Államokban szövetségi törvények határozzák meg a korlátozó rendelkezéseket, illetve segélyintézkedéseket, a kínai veszélyhelyzeti szabályozás pedig a helyi szintû́ kormányzatot bízza meg - a veszélyhelyzeti tervben foglaltaknak megfelelő - veszélyhelyzet felmérésére és kezelésére irányuló intézkedések meghozatalával.

A vizsgált államok járványkezelési megoldásainak összevetéséből kitűnik, hogy annak során - függetlenül attól, hogy az különleges jogrendi vagy rendes jogrendi keretek között valósult meg - a kormányt vagy annak meghatározott tagjait ruházták fel kivételes hatáskörrel, amely elsősorban különböző korlátozó rendelkezések kibocsátásában öltött testet.

\section{A koronavírus-járvány kezelése során bevezetett alapjog-korlátozás, valamint a járványkezeléssel összefüggésben felmerült közjogi-politikai viták}

Míg az alapvető jogok békeidőben történő korlátozása alkotmányjogi szempontból aggályosnak tekinthető, addig az állam normál müködését veszélyeztető állapotban - így jelen esetben a koronavírus-járvány következtében elóálló egészségügyi válsághelyzetben - a hatékony járványkezelés érdekében az alapjogok korlátozhatók vagy akár fel is függeszthetők, így azok szükségszerúen csorbát szenvednek. Függetlenül attól, hogy az e munka által elemzett országok a koronavírus-járvánnyal szembeni védekezés érdekében bevezettek-e különleges jogrendet, avagy ennek mellôzésével rendes jogrendi keretek között igyekeztek kezelni a járványhelyzetet, megállapítható, hogy mindegyik vizsgált országban sor került az alapjogok bizonyos szintû́ korlátozására a járványkezelésre felhatalmazott állami szervek vagy személyek által.

Az alapjogokat korlátozó rendkívüli intézkedések vonatkozásában elsőként azt szükséges rögzíteni, hogy mely alkotmányos érték védelme vagy alapvető jog érvényesülése érdekében került sor más alapjogok korlátozására. A koronavírus-járvány jellegéből is adódik, hogy az emberi élet és egészség védelme tette szükségessé az alapjogok rég nem látott, jelentős mértékú korlátozását világszerte. Az alapjogok korlátozásának alkotmányosságához ugyanakkor nemcsak az alkalmassági teszt, hanem az arányossági és szükségességi teszt elvégzése is szükséges. Ez alapján alapvető jogot korlátozni - a legitim cél megjelölésén túl - csak a feltétlenül szükséges mértékben, az elérni kívánt céllal arányosan, és az alapvető jog lényeges tartalmának tiszteletben tartásával lehet. Az alapjogok korlátozásának további, tartalmi korlátjaként jelentkezik az abszolút jogok korlátozásának tilalma. Habár az alapjogok korlátozására irányuló rendkívüli intézkedések a vizsgált országokban számos esetben közjogi-politikai vitákat generáltak, azok jogszerűsége többségében megfelelt az alapjogok korlátozásának alkotmányosságához 
füződő nemzeti és nemzetközi sztenderdeknek egyaránt. Az elemzett országok sorában kivételként egyedül Kína említhetô, ahol az alapvető jogok korlátozása nem a demokratikus és jogállami elveknek feleltethetô meg, így ott az alapjogok meglehetősen csekély védelmet élveznek. Ez okból kifolyólag Kínában a koronavírus-járvány kezelése érdekében bevezetett intézkedések vonatkozásában az alapjog-korlátozás fentebb ismertetett szabályai kevéssé érvényesülnek.

Az emberi élet és egészség, azaz a közegészség védelme mint legitim cél érdekében bevezetett korlátozó intézkedések az alapjogok széles körét érintették. Jelen munka terjedelmi korlátait meghaladná az egyes országok által bevezetett korlátozó intézkedések taxatív jellegú felsorolása, ezért e ponton csupán azokra az alapjogokra kívánunk utalni, amelyek az elemzett országok szinte mindegyikében korlátozásra kerültek a járványkezelés során. Ezen alapjogok a következők:

— a személyes szabadsághoz való jog;

- a mozgásszabadság és a tartózkodási hely szabad megválasztásának joga;

- gyülekezési jog;

— a vállalkozáshoz, illetve az üzleti tevékenység végzéséhez füződő jog;

- az oktatáshoz való jog.

Habár a korlátozó intézkedések az emberek alapvető jogait egyenlő mértékben és általánosan érintették, ugyanakkor azok hatással voltak egyes társadalmi csoportok külön jogaira is. E körön belül megemlítendők különösen az idősek, valamint a tanköteles korú gyermekek, hiszen e két társadalmi csoport vonatkozásában több ország is speciális, ugyanakkor egymáshoz hasonló szabályokat léptetett életbe (például az idősek vásárlási idősávjának bevezetése vagy a digitális távoktatásra történő átállás az oktatásban stb.).

Ami az alapjogok korlátozásának mértékét illeti, megállapítható, hogy a vizsgált államok által elrendelt korlátozások intenzitása között számottevő különbség nem fedezhető fel, egy kivételtől eltekintve. E kivételt Svédország jelenti, amely egy különutas válságkezelési stratégiát alkalmazott, amit számos kritika ért annak unortodox jellege miatt. Svédországban - a vizsgált országokkal ellentétben - az alapjogok korlátozására csak nagyon szúk körben került sor. A széles körú alapjog-korlátozás elmaradásának hátterében az állt, hogy a svéd járványkezelési modell az alapvető jogok korlátozása helyett az állampolgároknak szóló, jogilag nem kötelező erejú ajánlások kibocsátásában látta a járvány hatékony kezelésének módját.

A vizsgált államok szabályozásában további hasonlóság figyelhető meg a tekintetben, hogy az alapjog-korlátozó intézkedések bevezetésére és hatályon kívül helyezésére, valamint azok szigorítására és enyhítésére hozzávetőlegesen egy időben került sor. Az első korlátozó intézkedések elrendelésére a legtöbb vizsgált államban a koronavírus-járvány megjelenésének időpontjában, 2020 márciusában került sor, míg azok enyhítése vagy eltörlése május-júniusban történt meg. A korlátozások ismételt bevezetésére vagy szigorítására pedig a koronavírus-járvány második hullámával egy időben, tehát október-november hónapokban került sor. Ezek a megállapítások ugyanakkor csak a vizsgált európai országokra vonatkoznak, hiszen az Egyesült Államokban, 
de különösen Kínában, a koronavírus megjelenésének helyén a járvány lefolyása, ezáltal pedig a korlátozó intézkedések bevezetése és visszavonása más idősíkon mozgott.

Érdemes röviden említést tenni azokról a szabályozási sajátosságokról, amelyek a vizsgált országok államszerkezetéből adódnak. Habár az államszerkezet alapvetően kétféle, föderatív vagy unitárius lehet, azonban egyes szakirodalmak a kettő közötti átmenetként nevesítik a regionális berendezkedésú államokat is, mint harmadik kategóriát. ${ }^{5}$ Ezzel összefüggésben, a vizsgált országok vonatkozásában azt látjuk, hogy a föderatív berendezkedésû (Ausztria, Németország, Egyesült Államok), valamint a regionális berendezkedésú (Egyesült Királyság, Olaszország, Spanyolország) országokban a járványkezeléssel összefüggő döntések meghozatala és végrehajtása megoszlik a központi/szövetségi kormányzat, valamint a tagállamok/tartományok/régiók között. Mindez az alapjogok korlátozása kapcsán azért bír jelentőséggel, mert azt látjuk, hogy e nem unitárius berendezkedésû államokban a járványkezelés során meghozott központi kormányzati alapjog-korlátozó intézkedések mellett a bizonyos szintû autonómiát élvező területi egységek is kibocsátanak olyan intézkedéseket, amelyek adott esetben alapjogokat korlátoznak. Az ilyen típusú korlátozó intézkedések természetesen nem lehetnek ellentétesek a központi kormányzat által elrendelt korlátozásokkal, és azok a gyakorlatban általában kiegészítik, illetve szigorítják a központilag meghozott intézkedéseket - mindez pedig nem ritkán konfliktust generál a központi kormányzattal.

Az egészségügyi válsághelyzet kezelésével összefüggésben - függetlenül attól, hogy bevezetésre került-e különleges jogrend, vagy sem - élénk és intenzív közjogi, valamint politikai viták alakultak ki a vizsgálat alá vont államok szinte mindegyikében. E ponton fontosnak tartjuk rögzíteni, hogy e viták sok esetben csak látszólag szólnak a rendkívüli felhatalmazással kapcsolatos jogi kérdésekről, azok a gyakorlatban sokszor tisztán csak politikai természetúek. Jelen munkának nem célja, hogy taxatív felsorolást adjon a járványügyi veszélyhelyzet kapcsán kibontakozó viták tárgyáról, e ponton csupán utalni kívánunk azokra a jogilag releváns témakörökre, amelyek a vizsgált országokban jelentős közjogi-politikai viták alapját képezték, amelyek a következők:

- a különleges jogrend bevezetésének indokolatlansága, avagy a bevezetés hiánya;

- a különleges jogrend időtartamával, valamint annak meghosszabbításával kapcsolatos kérdések;

— az alapjogok aránytalan és szükségtelen mértékú korlátozása;

- a rendkívüli felhatalmazással bíró személy vagy szerv túlzott hatalma, valamint alkotmányellenes és a jogállamiság kritériumait sértő intézkedései;

— a törvényhozó szervek korlátozott mozgástere;

- a nem unitárius államok vonatkozásában a központi kormányzat és az autonómiát élvező területi egységek közötti hatásköri viták a korlátozó intézkedések kapcsán.

5 Trócsányi-Schanda, 2014, 39-41. 0. 
A járványkezelés során megalkotott rendkívüli intézkedések legitimációja feletti elméleti viták hamar gyakorlati formát öltöttek, mégpedig a bírósági út igénybevétele által. Ha eltekintünk azoktól a vitáktól, amelyeket tisztán politikai célok és érdekek vezéreltek, és kizárólag a jogilag releváns ügyekre fókuszálunk, akkor azt látjuk, hogy számos országban, ahol különleges jogrend került bevezetésre, bár a törvényhozó hatalom mozgástere és kontrollfunkciója jelentôsen leszúkkült, de ezzel párhuzamosan a nemzeti alkotmánybíróságok, legfelsőbb bíróságok, rendes és közigazgatási bíróságok, sőt az ombudsmanok szerepe és felelőssége megnőtt a korlátozó intézkedések ellenőrzése tekintetében. Számos vizsgált országban (például Ausztriában, Csehországban, Franciaországban, Romániában stb.) a bíróságok korrigálták, adott esetben pedig meg is semmisítették a rendeleti kormányzás felhatalmazottja által megalkotott rendkívüli intézkedéseket. De találunk olyan példát is, ahol bírósági út igénybevétele nélkül, szimplán a társadalmi nyomás és a politikai ellenzék kritikája következtében került sor a járványkezelési stratégia módosítására. Erre jó példa Hollandia, ahol e viták hatására a kormány benyújtott egy törvénymódosítási javaslatot, amelynek célja az volt, hogy a demokratikus kontroll és a jogállamiság kritériumainak megfelelő jogszabályi keretet teremtsen a járvány második hulláma elleni védekezés során meghozandó intézkedésekhez.

\section{4. Összegzés}

A vizsgálat alá vont országok szabályozásának áttekintését követően megállapíthatjuk, hogy a koronavírus-járvány miatt azonos kihívásokkal szembesülő államok rendkívül hasonló intézkedéseket alkalmaztak a járvány leküzdése érdekében, azonban azok jogszabályi keretei számos ponton eltérést mutatnak.

A vizsgált országokat egyrészt az alapján csoportosíthatjuk, hogy a járvány elleni védekezés érdekében különleges jogrend bevezetésére sor került-e, avagy sem az adott országban. Előbbi kategóriába tartozik Magyarország, Csehország, Szlovákia, az Egyesült Államok, az Egyesült Királyság, Finnország, Lettország, Románia és Spanyolország. Ennek megfelelően a többi vizsgált államban rendes jogrendi keretek között valósult meg a járványhelyzet kezelése. Az utóbbi kategóriába tartozó országokat ugyanakkor tovább csoportosíthatjuk aszerint, hogy milyen típusú ágazati jogszabály(ok) alapján valósult meg a járvánnyal szembeni védekezés. Egyes országok a járványügyi és közegészségügyi törvényeik (Ausztria, Franciaország, Hollandia, Lengyelország, Németország, Dánia, Norvégia, Svédország), míg más országok a polgári védelmi, valamint válságkezelési törvényeik alapján (Észtország, Kína, Litvánia, Olaszország) szabályozták a járvánnyal szembeni védekezés jogi kereteit. A járvány elleni védekezés érdekében elrendelt különleges jogrendi esetkörök, illetve a különleges jogrendnek nem minősülő rendkívüli szituációk időbeli hatálya pedig rendkívül változatos képet mutat a vizsgált országok szabályozásában. 
A gyors és hatékony védekezés érdekében a különleges jogrendet elrendelő országokban egyúttal rendeleti kormányzás bevezetésére került sor, amelynek általános felhatalmazottja a vizsgált országok esetében a kormány. Ugyanakkor egyes, különleges jogrendet bevezető országok (Csehország, Egyesült Királyság, Románia, Spanyolország) esetében azt látjuk, hogy a kormány mellett egyes miniszterek (általában az egészségügyért felelős miniszter) is kiemelt szerepet kapnak a járványkezelés során, azáltal, hogy felhatalmazással rendelkeznek a szükséges rendkívüli intézkedések kibocsátására. A kormányzat mozgásterének növelése ugyanakkor nem csak a különleges jogrendet bevezető országokban figyelhető meg. Az egészségügyi válsághelyzetet rendes jogrendi keretek között kezelő országokban is megfigyelhető az a tendencia, hogy a kormánynak vagy valamely tagjának kivételes jogköröket biztosítottak a hatékony járványkezelés érdekében.

A különleges jogrendet - és ezáltal rendeleti kormányzást - bevezető országokban a végrehajtó hatalom hatáskörének kibővítése számos esetben a törvényhozó hatalom kontrollfunkciójának bizonyos mértékú korlátozását eredményezte. Mindez azonban egyik vizsgált állam vonatkozásában sem eredményezte a nemzeti parlamentek ellenőrző tevékenységének teljes kiiktatását. Azokban az országokban, ahol rendes jogrendi keretek között reagáltak a koronavírus-járványra, kevésbé releváns kérdés a törvényhozó szervek ellenőrző funkciójának érvényesülése, hiszen ezekben az országokban a kivételes jogosítványok és intézkedések törvényi rendelkezésen alapulnak, sốt egyes államokban többletgaranciát kaptak a nemzeti parlamentek a kormányzati válságintézkedések ellenőrzése terén. (Franciaországban és Lengyelországban a kormánynak a parlament irányába fennálló tájékoztatási kötelezettsége, míg Hollandiában és Svédországban a parlament válságintézkedéseket megerősítő jogosítványa által.)

A koronavírus-járvány okozta egészségügyi válsághelyzet leküzdése érdekében a vizsgált államok mindegyike élt az alapjog-korlátozás lehetőségével. Az emberi élet és egészség, vagyis a közegészség védelme érdekében bevezetett korlátozó intézkedések az alapjogok széles körét érintették. A járvány jellegéből adódik, hogy a rendkívüli helyzet megfelelő kezelése érdekében különösen a személyes szabadsághoz való jog, a mozgásszabadság és a tartózkodási hely szabad megválasztásának joga, a gyülekezési jog, a vállalkozás szabadsága, valamint az oktatáshoz való jog került korlátozásra. Az elemzett országok által korlátozott szabadságjogok köre, korlátozásuk intenzitása és formája közel azonos, függetlenül attól, hogy különleges jogrendi szituációt vezettek-e be, vagy sem. Megállapítható továbbá az is, hogy az egészségügyi válsághelyzet kezelésével összefüggésben a vizsgált országok szinte mindegyikében komoly közjogi-politikai viták alakultak ki.

\section{Irodalomjegyzék}

Alexandre, Z., Del Monte, M., Eckert, G., Kotanidis, S., LANGova, V., Rakovska, V. (2020) States of Emergency in Response to the Coronavirus Crisis: Situation in Certain Member States IV. [Online]. Elérhető: www.europarl.europa.eu/RegData/etudes/BRIE/2020/652002/EPRS_ BRI(2020)652002_EN.pdf (Letöltve: 2020. december 15.) 
Atanassov, N., Dalli, H., Dumbrava, C., Eckert, G., Jurviste, U., Radjenovic, A., Voronova, S. (2020) States of Emergency in Response to the Coronavirus Crisis: Situation in Certain Member States II. [Online]. Elérhető: www.europarl.europa.eu/RegData/etudes/ BRIE/2020/651914/EPRS_BRI(2020)651914_EN.pdf(Letöltve: 2020. december 15.)

Bentzen, N., Boström, A., Del Monte, M., Odink, I., Prpic, M., Tuominen, M. (2020) States of Emergency in Response to the Coronavirus Crisis: Situation in Certain Member States III. [Online]. Elérhető: www.europarl.europa.eu/RegData/etudes/BRIE/2020/651972/EPRS_ BRI(2020)651972_EN.pdf(Letöltve: 2020. december 15.)

Binder, K., Crego, M. D., Eckert, G., Kotanidis, S., Manko R., Del Monte, M. (2020) States of Emergency in Response to the Coronavirus Crisis: Situation in Certain Member States. [Online]. Elérhető: www.europarl.europa.eu/RegData/etudes/BRIE/2020/649408/EPRS_ BRI(2020)649408_EN.pdf (Letöltve: 2020. december 15.)

CAmeron, I., Jonsson Cornell, A. (2020) 'Fredstida kriser i en konstitutionell kontext en komparativ analys och en försiktig framåtblick för Sveriges del', Svensk Juristtidning, 2020/10, 1173-1190. o.

Csink, L. (2017) 'Mikor legyen a jogrend különleges?', Iustum Aequum Salutare, 13(4), 7-16. o.

Desmet, C. A. (2020): "The Legal Concept of "State of Emergency": A Comparison Between Romania and Other European Countries', Acta Universitatis Danubius Juridica, 16 (1), 79-88. o.

Golia, A. Jr., Hering, L., Moser, C., Sparks, T. (2020) 'Constitutions and Contagion. European Constitutional Systems and the COVID-19 Pandemic', Max Planck Institute for Comparative Law and Internatial Law, Research Paper Series, 42/2020

Guasti, P. (2020) 'The Impact of the COVID-19 Pandemic in Central and Eastern Europe. The Rise of Autocracy and Democratic Resilience', Democratic Theory, 7(2), 47-60. o.

Hegedős, S., KarÁcsony, A., Monostori, M. (2020) 'Alkotmányosság és járványveszély', Jogelméleti Szemle, 2020/4, 28-42. 0.

HoJNYÁk, D., UngVÁRI, Á. (2020) 'Az Európai Unió egyes tagállamainak koronavírusjárványra adott válasza, különös tekintettel a vizsgált államok által bevezetett különleges jogrendi szabályozásra', Miskolci Jogi Szemle, 15(1), 122-138. o.

HoJnYÁk, D., UngVÁRI, Á. (2021) 'A Visegrádi Együttműlködés országainak koronavírusjárványra adott válasza', Iustum Aequum Salutare, (17)1, 305-323. o.

TRócsáNYI, L., SCHANDA, B. (2014) Bevezetés az alkotmányjogba-AzAlaptörvényés Magyarország alkotmányos intézményei. Budapest: HVG-ORAC

Venice Commission (2020) Interim Report on the Measures Taken in the EU Member States as a Result of the Covid-19 Crisis and Their Impact on Democracy, the Rule of Law and Fundamental Rights (Opinion No. 995/2020) [Online]. Elérhető: www.venice.coe.int/webforms/documents/ default.aspx?pdffile=CDL-AD(2020)018-e (Letöltve: 2020 . december 15.) 


\section{9. Összegzés - A különleges jogrend az alkotmányokban}

\section{HORVÁTH ATTILA}

Bjørnskov és Voigt egy közelmúltbeli tanulmánya szerint 2013-ban nem kevesebb mint 171 ország alkotmányában voltak megtalálhatók valamilyen különleges jogrendi rendelkezések. ${ }^{1}$ A szerzők egy másik írásukban pedig arra mutattak rá, hogy 1985 és 2014 között 137 ország - tehát a szuverén államok mintegy kétharmada - vezetett be valamilyen típusú rendkívüli állapotot. ${ }^{2}$ Bár a jelen kötetben vizsgált államok lényegesen eltérő megoszlást mutatnak a fenti szempontokból, az kétségtelen, hogy a rendkívüli helyzetek talán nem is annyira rendkívüliek, a kivételes állapotok nem teljesen kivételesek, és amit könyvünkben különleges jogrendnek neveztünk, az nem is okvetlenül minősül különlegesnek. A kötet zárófejezetében arra keressük a választ, hogy hazánk és 20 külföldi ország vizsgálatát követően milyen hasonlóságok és eltérések rajzolódnak ki a különleges jogrendi szabályozásban.

Mielőtt rátérünk a következtetésekre, szükségesnek tartunk néhány megállapítást tenni a terminológiai problémákkal és a „különleges jogrend” kifejezéssel kapcsolatban. Bár jelen kiadvány a címében is tartalmazza ezt a kifejezést, az 5. fejezetben utaltunk rá, hogy ez a fogalom még a hazai jogi terminológiában is alig egy évtizedes múltra tekint vissza; a közbeszédben (és

1 Bjørnskov-Voigt, 2018a, 105. o.

2 Bjørnskov-Voigt, 2018b, 110. o.

Dr. Horváth Attila, PhD

attila.horvath@mfi.gov.hu

vezető kutató (Mádl Ferenc Összehasonlító Jogi Intézet)

adjunktus (Nemzeti Közszolgálati Egyetem Államtudományi és Nemzetközi Tanulmányok Kar, Alkotmányjogi és Összehasonlító Közjogi Tanszék)

Horváth, A. (2021) 'Összegzés - A különleges jogrend az alkotmányokban' in Nagy, Z., Horváth, A. (szerk.) A különleges jogrend és nemzeti szabályozási modelljei, 624-643. o. Budapest: Mádl Ferenc Összehasonlító Jogi Intézet.

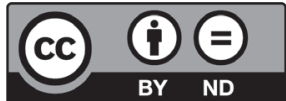


részben a szakmai közegben) való meghonosodását pedig erôteljesen gátolja, hogy a rendkívüli jogrend kifejezés - vélhetően közérthetősége miatt - egyre inkább teret nyer. Amennyiben a különleges jogrend angol megfelelőjére, a special legal orderre keresünk rá az interneten, egyértelmúvé válik, hogy ez a kifejezés egyáltalán nem minősül bevett terminológiának, hiszen lényegében valamennyi találat Magyarországhoz kötődik. Ebből a szempontból akár önkényesnek is tû́nhet ennek a kevésbé bevett fogalomnak a használata, és kritikai éllel szóvá tehető, hogy egy hazai fogalmat vetítünk ki külföldi államokra. Csakhogy a kötet megírása során deklaráltan a magyar szabályozás volt a kiindulópontunk, és így elsősorban arra vállalkoztunk, hogy a hazai különleges jogrend külföldi megfelelőjét keressük - annak elnevezésétől és alkotmányos státuszától függetlenül. Ennek megfelelően a különleges jogrend kifejezést ebben a kötetben a hazai szabályozástól elszakítva, mintegy összefoglaló értelemben használtuk, és ezt annak tudatában tettük, hogy a fogalom az egyes országokban nagyban eltérő jelentéstartammal bír, és számos esetben nem is abban a formában értelmezhető, ahogyan azt a magyar Alaptörvény teszi. ${ }^{3}$

Ami a további terminológiai problémákat illeti, közismert, hogy a jogi nyelvezet szigorúan kötött, az egyes fogalmak, kifejezések meghatározott jelentéssel bírnak, és nem cserélhetők fel egymással. Ennek az elvnek azonban nem volt könnyú megfelelni egy olyan kötetben, amely 18 különböző nyelven íródott alkotmányokat és jogszabályokat vizsgált, hiszen az egyes idegen nyelvú kifejezések magyarra fordítása (esetenként az angol nyelv közbeiktatásával) több esetben sem volt problémamentes, és a magyar kifejezések nem mindig alkalmasak egy-egy különleges jogrendi tényállás eredeti értelmének visszaadására. ${ }^{4}$ A külföldi szabályozás értelmezése és a magyar szabályozással való összevetése során ügyelni kellett arra, hogy számos esetben a hazai szabályozásban is ismert tényállást (különösen például a szükségállapotot) más országok más kifejezéssel használják. ${ }^{5}$

A következőkben három szempont alapján végezzük el a kötetünkben vizsgált államok összevetését. Először az alkotmányos szabályozás mélységét tárjuk fel, majd az alkotmányban szabályozott különleges jogrendi tényállások számát vetjük össze. Ezt követôen pedig azt vázoljuk fel, hogy a gyakorlatban mennyiben kerültek „élesítésre” ezek a különleges jogrendi tényállások. A fejezet zárásaként megvizsgáljuk, hogy a magyar Alaptörvény különleges jogrendi része miként értékelhető a külföldi szabályozások tükrében.

3 Ezzel kapcsolatban röviden ki kell térni a kivételes állapoti rendszerek monista és dichotóm (más elnevezéssel: dualista) modellekre való felosztására (Ferejohn-Pasquino, 2004, 223-226. o.; Mészáros, 2016, 196197. o.). Eszerint a monista megközelítés azt vallja, hogy a felmerülő válságok és rendkívüli helyzetek is a normál jogrend keretében kezelendők, míg a dichotóm álláspont úgy érvel, hogy a kivételes állapotok kivételes jogi szabályozást, azaz egy alternatív jogrendet igényelnek. Az arra okot adó körülmények esetén a hatalom - Ferejohn és Pasquino kifejezésével élve - „átkapcsol” a különleges jogrendre (Ferejohn-Pasquino, 2004, 221. o.).

4 Vö.: Csink, 2017, 10. o.

5 Egyes hazai munkák a fordítási és megfeleltetési problémákat úgy hidalták át, hogy a tükörfordításban hadiállapotként vagy háborús állapotként értelmezhetô kifejezéseket rendkívüli állapotként fordították - valószínúleg abból a megfontolásból, hogy a megkönnyítsék a magyar szabályozással való összevethetőséget (Kelemen, 2020, 210-211. o.). 


\section{Az alkotmányos szabályozás mélysége}

A kivételes állapotok alkotmányi-jogi szabályozását vizsgáló írások gyakran utalnak arra, hogy az alkotmányok jelentősen különböznek egymástól abból a szempontból, hogy milyen mélységben, milyen terjedelemben, milyen részletességgel foglalkoznak a különleges jogrendi állapotokkal. ${ }^{6}$ A divergencia okainak tárgyalása meghaladná az összegzés kereteit, azonban az biztosan kijelenthetô, hogy a történelmi tapasztalatok, valamint az alkotmány születésének idôpontjai és körülményei meghatározók - vagy ahogyan Kelemen Roland fogalmaz, a 20. század történelmi hagyományainak lenyomatai is kirajzolódnak az egyes alkotmányokon. ${ }^{7}$

A különleges jogrendhez való viszonyulások már eleve abból a szempontból is divergálnak, hogy egyáltalán van-e a helye ilyen jellegú rendelkezéseknek az alkotmányban. Scheppele szerint alapvetően kétféle álláspont létezik az államot érő fenyegetések kezelésével kapcsolatban: a a szerző által törvényesnek nevezett alapállás (legalist) értelmében az államnak minden körülmények között a jogi keretek között kell maradnia - még akkor is, ha ezekben a rendkívüli helyzetekben az állam mozgástere eltér a normál időszaktól.9 A törvényen kívüliséget valló álláspont (extralegalist) ezzel szemben úgy érvel, hogy súlyos válsághelyzetek esetén az államnak lehetősége van jogon kívüli eszközöket is igénybe venni, ugyanis észszerûtlen (jogi) keretek közé szorítani az államot éppen akkor, amikor egy, a létét fenyegetô kihívással áll szemben. ${ }^{10}$ Sőt - mutat rá a szerző - a kivételes helyzetek kezelésének jogi szabályozására irányuló próbálkozás eleve sérti magát a jogrend integritását is. ${ }^{11}$ Noha a kötetben bemutatott országokban - némileg az Egyesült Államok kivételével - alapvetően az első álláspont a domináns, ${ }^{12}$ a konkrét nemzeti szabályozás ettől még jelentős különbségeket mutat.

A 7. ábrán a vizsgált alkotmányokat ${ }^{13}$ két szempont szerint helyeztük el egy pontdiagramon. Az egyik szempont a különleges jogrendi jellegú rendelkezések (karakterben

6 Lásd például Gross, 2004, 6-8. o.; Scheppele, 2008, 166. o.; Khakee, 2009, 11-12. 0.

7 Kelemen, 2020, 211. o.

8 Scheppele, 2008, 165-166. o. Vö.: Venice Commission, 2020, II.D.22. (A bizottság a constitutional és az extra-constitutional kifejezéseket használja.).

9 Az Alaptörvény által bevezetett különleges jogrend kifejezés pontosan ezt a megközelítést tükrözi vissza, hiszen ebben az esetben is egy jogrendről - ráadásul alkotmányban szabályozott jogrendről - van szó, még ha az „különleges” is.

10 A kivételes állapotok jogi szabályozásával (szabályozhatóságával) szemben bizalmatlan államok közül elsősorban - a jelen kötetben nem érintett - Svájcot kell kiemelni (Khakee, 2009, 19-20. o.). Mindez azonban nem jelenti azt, hogy a svájci alkotmányban ne lennének szükségállapoti rendelkezések.

11 A különböző álláspontokra lásd még a kötet 1. fejezetét, valamint: Khakee, 2009, 6-7. o.

12 Vö.: Khakee, 2009, 21-24. o. A szerző Norvégiával és Franciaországgal kapcsolatban is arra mutat rá, hogy a jogi szabályozás ugyan mindkét államban viszonylag részletes, viszont Norvégiában a szükségszerüség doktrínája, Franciaországban pedig a rendkívüli elnöki jogkör teremtheti meg a lehetőséget egy olyan hatalomra, amelynek a határai rendkívül tágak.

13 Kartális alkotmány hiányában az ábrán nem tüntettük fel az Egyesült Királyságot. 
számított) terjedelme, ${ }^{14}$ a másik pedig az alkotmányban nevesített különleges jogrendi tényállások száma. ${ }^{15} \mathrm{Az}$ így elóállt pontdiagramból egyrészt plasztikusan kirajzolódik a vizsgált alkotmányok heterogenitása, másrészt az ábra támpontot ad az országok csoportosításához. ${ }^{16}$

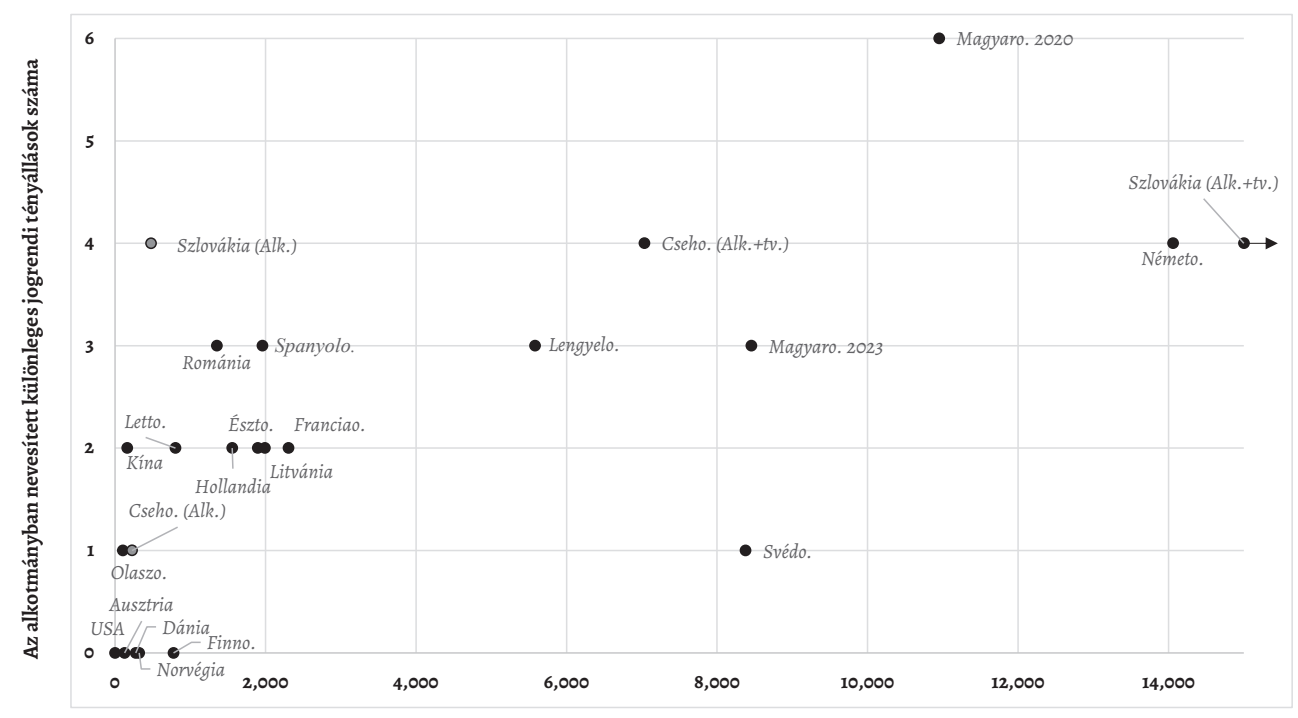

A különleges jogrendi jellegû̉ rendelkezések terjedelme (karakter)

7. ábra

A különleges jogrendi szabályozás paraméterei a vizsgált alkotmányokban

Forrás: a szerző saját összeállitása a nemzeti alkotmányok alapján

Az első jól elkülöníthető kategóriába Ausztria, Dánia, az Egyesült Államok, Finnország, Norvégia, valamint Olaszország és Kína sorolható. A hét országban közös, hogy az alkotmányuk egészen minimális teret szentel a különleges jogrendnek, és így csak nyomokban találunk ilyen jellegú rendelkezéseket. Az Egyesült Államok alkotmányában ugyan előfordul néhányszor a háború ${ }^{17}$ (war), a közvetlen veszély ${ }^{18}$ (imminent danger) és a közveszély ${ }^{19}$ (public danger) kifejezés, azonban nem különleges jogrendi kontextusban, így ez esetben nulla karakterrel vettük figye-

14 A terjedelem vizsgálatánál - a magyar Alaptörvény kivételével - az alkotmányok angol nyelvû szövegéből azokat a rendelkezéseket vettük alapul, amelyek kimondottan a különleges jogrendről szólnak. Ha az adott alkotmányba beiktatásra került egy vagy több különleges jogrendi „blokk”, akkor ezeket vettük figyelembe, de ilyenkor nem számítottuk be az alkotmány egyéb kapcsolódó rendelkezéseit (például ha valamely különleges jogrend csak meg lett említve valamely közhatalmi szerv jogkörei között).

15 Az ezzel kapcsolatos megfontolásokról lásd az összegzés következő pontját.

16 A különleges jogrendi rendelkezések terjedelmének hasonló vizsgálatára lásd: Khakee, 2009, 11. 0.

17 I. cikk 10. bekezdés, III. cikk 3. bekezdés, Ötödik Alkotmánykiegészítés.

18 I. cikk 10. bekezdés.

19 Ötödik Alkotmánykiegészítés. 
lembe az alkotmányt. ${ }^{20} \mathrm{Az}$ osztrák alkotmány egyedül a hadüzenetet (Kriegserklärung) említi, ${ }^{21}$ a dán pedig a sürgősségi helyzetre (scerdeles påtræengende tilfæelde) tesz egy rövid utalást, ${ }^{22}$ míg a finn alkotmányban a különleges körülmények ${ }^{23}$ (poikkeusolojen) és a háború ${ }^{24}$ (sota) is említésre kerül. A norvég alkotmányban a király hatásköreivel kapcsolatban található egy rövid rendelkezés a háborúval (krig) kapcsolatban, ${ }^{25}$ illetve van egy utalás a rendkívüli körülményekre ${ }^{26}$ (overordentlige omstendigheter - példaként az ellenséges megszállást és a fertőző betegségeket említve). Hangsúlyozandó, hogy egyik alkotmány sem írja körül ezeket a helyzeteket, így erre a négy államra úgy tekintünk, mint ahol az alkotmány szintjén egyáltalán nincs különleges jogrendi helyzet definiálva. Az olasz alkotmány annyiban mutat némi eltérést, hogy nem pusztán háborúról/hadüzenetról tesz említést, hanem a hadiállapot (stato di guerra) kifejezést használja. ${ }^{27}$ Ez utóbbinak álláspontunk szerint hangsúlyosabb az „állapotjellege”, így Olaszország esetén - szemben a másik három állammal - úgy találtuk, hogy azonosítható egy különleges jogrend (a hadiállapot). ${ }^{28}$ Hasonló a helyzet Kínában is: az alkotmány ugyan itt is kifejezetten nevesíti a hadiállapotot ${ }^{29}$ (zhanzheng zhuangtai) és a szükségállapotot ${ }^{30}$ (jinji zhuangtai), azonban nem tölti meg tartalommal ezeket. Összességében mind az öt alkotmányról elmondható, hogy lényegében semmilyen konkrétumot (különösen definíciót, hatásköri szabályokat) nem tartalmaz a különleges jogrend vonatkozásában.

A második kategóriába hét állam, Észtország, Franciaország, Hollandia, Lettország, Litvánia, Románia és Spanyolország sorolható. Itt a közös pontot egyrészt az jelenti, hogy mindegyik alkotmányban azonosítható két vagy három jól definiált különleges jogrendi helyzet; másrészt pedig itt már nem pusztán említésre kerülnek ezek a tényállások, hanem a szabályozás is bővebb. Utóbbi elsősorban a hatásköri szabályokat, valamint az egyes helyzetek pontosabb definiálását jelenti.

A harmadik csoportot Magyarország, Lengyelország, Németország és Svédország képezi. Ezekben az államokban az alkotmány egy meglehetősen részletes és komplex szabályozást tartalmaz, amely - különösen Magyarország, Lengyelország és Svédország esetén - jól elkülönül az alkotmány többi rendelkezésétől..$^{31} \mathrm{~A}$ magyar Alaptörvény és a lengyel alkotmány külön részt, illetve fejezetet szentel a különleges jogrendnek. Svédországban az alkotmány részét képező kormányzati törvény szintén külön fejezetben (15. fejezet) tárgyalja a háborút

20 Vö.: Ferejohn-Pasquino, 2004, 214. o.

21 38. cikk, 40. cikk (2) bekezdés.

22 23. cikk.

23 23. és 128. szakasz.

24 93. szakasz.

25 26. cikk.

26 68. cikk.

27 78. cikk.

28 Vö.: Gross, 2004, 8. o.

29 67. cikk 18. pont.

30 67. cikk 20. pont.

31 A magyar Alaptörvény a jelenleg hatályos és a 2023. július 1-től hatályos szövegváltozatával is szerepel az ábrán. 
és a háborús veszélyt. Valamennyi szabályozásról elmondható, hogy tisztázza a különleges jogrendi tényállásokat (bár Svédországban ez csak egy tényállást jelent) és tartalmazza a hatásköri szabályokat, amiből viszonylag jól kirajzolódik, hogy ezekben a helyzetekben mely szerveknek milyen kompetenciája van.

A kötetben vizsgált országok közül sajátos Csehország és Szlovákia szabályozása. Amint a két országfejezetben kiemeltük, mindkét országról elmondható, hogy az alkotmányos rendszer nem pusztán az alkotmányból áll, hanem ezenfelül az alkotmánytörvények is alkotmányos szintú szabályozásnak tekinthetôk. Mindez némileg megnehezíti a két ország besorolását a fenti kategóriákba, ugyanis az alkotmányos szabályozás mélységének megítélése attól függ, hogy kizárólag az alkotmányt vesszük alapul, vagy pedig az alkotmánytörvényeket is vizsgáljuk. ${ }^{32} \mathrm{Az}$ előbbi esetben arra a következtetésre juthatunk, hogy mindkét alkotmány - különösen a cseh - elnagyoltan tárgyalja (pontosabban inkább csak megemlíti) a különleges jogrendet. ${ }^{33} \mathrm{~A}$ szlovák alkotmányban mind a négy különleges jogrendi tényállás nevesítve van, viszont Csehország esetén csak a hadiállapot kerül említésre. Ezek alapján a két ország - főként Csehország - inkább a fentebb tárgyalt első kategóriába lenne sorolható. Amennyiben az állambiztonsági tárgyú alkotmánytörvényeket is elemzés alá vonjuk, megváltozik a kép, hiszen ezen jogszabályokban mindkét állam komplex módon és kimerítően szabályozza a különleges jogrendet, és így a harmadik csoport országaival mutat hasonlóságot. ${ }^{34}$ (Megjegyzendő, hogy a szlovák alkotmánytörvény terjedelme közel 35 ezer karakter, ${ }^{35}$ vagyis a vizsgált országok közül itt találtuk meg a legrészletesebb alkotmányos szintû szabályozást.)

Az alkotmányos szabályozás mélységével kapcsolatban azt is érdemes megvizsgálni, hogy a különleges jogrendi rendelkezések hol és hogyan helyezkednek el az alkotmányban. Itt megint csak a hazai szabályozás lehet a kiindulópont, ugyanis az Alaptörvény egyértelmúen lehatárolja a különleges jogrendi rendelkezéseket, mintegy külön blokkot képezve. (Ez ugyanakkor nem jelenti azt, hogy csak ebben a részben találunk különleges jogrendi szabályokat.) A vizsgált országokban nem ez a „blokkosított” megoldás az általános, azaz a különleges jogrendi szabályok jobbára szétszórtan (például az egyes közhatalmi szervek hatásköreibe ágyazva) találhatók meg az egyes alkotmányokban.

A magyar szabályozáshoz legközelebb a lengyel alkotmány esik, amely egy külön fejezetben (XI. fejezet), rendkívüli állapotok (stany nadzwyczajne) cím alatt foglalja össze - viszonylag részletesen - a három különleges jogrendre vonatkozó szabályokat. Hasonló megoldással él

32 Ebből az okból mindkét országot kétszer is feltüntettük az ábrán: a szürke pont csak az alkotmány szabályozási terjedelme alapján került megállapításra, a feketénél pedig figyelembe vettük az alkotmánytörvényeket is.

33 Vö.: Gross, 2004, 6. o.; Khakee, 2009, 11. o. A szerzők a cseh alkotmányt is azon alkotmányok között említik, amelyek csak említés szintjén utalnak a különleges jogrendre.

34 Vö.: Kelemen, 2020, 209. o. A szerző leszögezi, hogy a tanulmányában az alkotmánytörvényt a cseh alkotmánybíróság álláspontjának megfelelően az alkotmány összetevőjének tekinti.

$35 \mathrm{Az}$ ábrán a Szlovákia mellett látható nyíl arra utal, hogy az országot jelképező pont pozíciója nem pontos, azonban áttekinthetőségi okokból a vízszintes tengely skálájának maximumát nem emeltük 35 ezerre. 
a spanyol alkotmány is, ahol - a parlament és a kormány viszonyát taglaló V. részben - szintén egy blokkban találjuk a különleges jogrendi rendelkezéseket, bár itt külön fejezetről nem, csak külön cikkről ${ }^{36}$ beszélhetünk. Az észt ${ }^{37}$ és a litván ${ }^{38}$ alkotmány egyaránt a nemzetvédelemról szóló fejezetbe ágyazva, egy blokkban tárgyalja a különleges jogrendet. A román alkotmány az elnökról szóló fejezet egyik cikkében ${ }^{39}$ foglalkozik a kivételes állapotokkal.

A szétszórt szabályozási módot követi a német alaptörvény és a francia alkotmány is. Az előbbi ugyan egy külön fejezetet (Xa. fejezet) szentel a különleges jogrendnek, azonban ebben csak a védelmi helyzet (Verteidigungsfall) kerül szabályozásra; a másik három tényállással az alaptörvény máshol, három különböző fejezetben foglalkozik: a katasztrófahelyzetet ${ }^{40}$ a szövetségi és a tartományi szint kapcsolatát tárgyaló II. fejezet, a szükséghelyzetet ${ }^{41}$ a szövetségi és tartományi hatáskörök megosztásáról szóló VII. fejezet, a belső vészhelyzetet ${ }^{42}$ pedig a szövetségi végrehajtásról szóló VIII. fejezet szabályozza. Franciaországban a két különleges jogrend közül a rendkívüli elnöki jogkör értelemszerúen a köztársasági elnökről szóló II. fejezetben található, ${ }^{43}$ míg az ostromállapot a parlament és a kormány viszonyát tárgyaló $V$. fejezetben lett elhelyezve. ${ }^{44}$ Ez utóbbi megoldáshoz áll közel a lett alkotmány is: a hadiállapotról ${ }^{45}$ az elnökről szóló III. fejezetben, míg a rendkívüli állapotról ${ }^{46}$ a kormányról szóló IV. fejezetben olvashatunk. (Azokban az alkotmányokban, ahol csak egy különleges jogrend kerül szabályozásra - mint például Svédországban - ez a vizsgálati szempont nem értelmezhető). Talán nem túlzás azt állítani, hogy az előbbiek mintegy visszatükrözik a különleges jogrend alkotmányon belüli „rangját”, hiszen markáns különbségeket látunk abból a szempontból is, hogy az alkotmányozó milyen szintú szerkezeti egységet szentelt a különleges jogrendnek. Ez alapján a magyar Alaptörvény a leginkább kiemelkedő, ugyanis a különleges jogrendi rendelkezések külön részben - tehát az Alaptörvényen belüli legmagasabb szintû szerkezeti egységben - találhatók. Amint fentebb utaltunk rá, a lengyel és a svéd alkotmány is egy külön fejezetben tárgyalja ezeket a helyzeteket (bár a svéd csak egyet), valamint a német alaptörvény is hasonló megoldással él. A többi alkotmányban a különleges jogrendnek már „csak” néhány szakasz vagy bekezdés jut.

Az alkotmányos szabályozás mélységének elemzését azzal a megjegyzéssel kell lezárni, hogy ez a vizsgálati szempont értelemszerúen nem tért ki az alkotmány alatti (lényegében a törvényi) szintre. Önmagában abból a tényből, hogy egy állam az alkotmányában szúk teret szentel a különleges jogrendnek, egyáltalán nem következik az, hogy a jogi szabályozás elna-

36 116. cikk.

$37 \mathrm{X}$. fejezet 128-131. \$.

38 XIII. fejezet 142-145. cikk.

39 93. cikk.

40 35. cikk.

41 80a. cikk.

42 91. cikk.

43 16. cikk.

44 36. cikk.

45 43-44. cikk.

46 62. cikk. 
gyolt és nem kielégítő. Jó példa erre Finnország, ahol az alkotmányban éppen csak említésre kerülnek a különleges körülmények és a háború, azonban törvényi szinten átfogóan szabályozásra kerülnek a kivételes állapotok. Az Egyesült Királyságban hasonló a helyzet (természetesen azzal az eltéréssel, hogy alkotmányos szabályozásról nem beszélhetünk), ugyanis a részletesen is elemzett Civil Contingencies Act átfogó szabályozást biztosít.

\section{A különleges jogrendi tényállások száma}

A különleges jogrendek összevetésénél a másik kézenfekvő vizsgálati szempont a tényállások száma. Az Alaptörvény - kissé sarkosan fogalmazva - „elkényezteti” a kutatót, hiszen - legalábbis formailag - egy kimondottan egyértelmú, áttekinthető kategóriarendszert tartalmaz. Az egyes különleges jogrendi tényállásokat nemcsak normál jogrendi állapottól, hanem egymástól is világosan lehatárolja. A vizsgált alkotmányok többsége távolról sem alkalmaz olyan világos kategorizálást, mint az Alaptörvény, így a különleges jogrendi tényállások számának összevetése csak látszólag egyszerủ feladat. Hazánkban egyszerủen csak össze kell számolni az Alaptörvény kapcsolódó részében az alcímek számát, és világos képet kapunk a különleges jogrendi tényállások számáról. ${ }^{47} \mathrm{~A}$ kutatásunk tárgyát képező 20 külföldi állam vizsgálata két szempontból is tartogatott nehézséget. Egyrészt az egyes alkotmányokban azonosítani kellett a különleges jogrendi tényállásokat, csakhogy számos esetben ez sem volt magától értetődő, ugyanis nem minden alkotmány ad világos fogódzót arra, hogy mit tekint különleges jogrendnek. A kutatónak ebben az esetben alapvetően két lehetősége van: vagy egzakt, kellően inkluzív definíciót kell adnia a különleges jogrendre, és az ehhez illő tényállásokat kell vizsgálnia, ${ }^{48}$ vagy pedig egy meglévő szabályozást vesz alapul, és ennek analógiájára azonosítja az egyes tényállásokat. Magunk ezen utóbbi módszert választottuk,

$47 \mathrm{Az}$ Alaptörvény kilencedik módosítása még ennél is egyértelmúbb helyzetet teremt azzal, hogy a 2023. július 1-től hatályos 48. cikk úgy fogalmaz: „Különleges jogrend a hadiállapot, a szükségállapot és a veszélyhelyzet.”.

48 Ezt a kiindulópontot követi Bjørnskov és Voigt az alkotmányok szükségállapoti rendelkezéseinek összevetésére irányuló munkájában (Bjørnskov-Voigt, 2018a). A szerzők a szükségállapoti alkotmányt (emergency constitution) a következőképp definiálják: „az alkotmányba ágyazott formális jogi rendelkezések rendszere, amely meghatározza, hogy ki és milyen körülmények esetén vezethet be szükségállapotot, kinek kell ezt jóváhagynia, melyik közhatalmi szereplő milyen olyan különleges hatáskörrel rendelkezik, amellyel rendes körülmények között nem" (103. o.). Gross hasonló módon jár el a komparatív jellegú írásában, kifejezetten leszögezve, hogy - néhány kivétellel - csak az alkotmányban található rendelkezéseket vizsgálja (Gross, 2004, 5. o.). Érdemes még felidézni a Velencei Bizottság definícióját is: a testület szerint a szükségállapot (state of emergency) egy olyan - ideiglenes - helyzet, amely során a végrehajtó hatalmat kivételes hatáskörökkel ruházzák fel és kivételes szabályok kerülnek alkalmazásra annak érdekében, hogy az állam felülkerekedjen egy rendkívüli, az országra alapvető veszélyt jelentő állapoton (Venice Commission, 2020, II.A.5.). A Comparative Constitutions Project a kérdőívében a szükségállapot (state of emergency) alkotmányban való megjelenésének vizsgálatához a következő instrukciót adja: „State of emergency includes other exceptional states, such as siege, martial law and defense." (Elkins-Ginsburg-Meltin, 2016, 51. o.) A szerzők ehhez hozzáteszik, hogy az előbbi helyzetek nem explicit említését is figyelembe veszik. 
és - amint fentebb utaltunk rá - elsősorban azokat a tényállásokat kerestük, amelyek hasonlítanak az Alaptörvény kategóriáira. Az azonosított kivételes állapotok nagy része megfeleltethetô az Alaptörvény valamelyik tényállásának, azonban akadtak határesetek is. Így például az olasz alkotmányban egyedül a hadiállapot az, amely egyértelmúen megfeleltethető az általános különleges jogrendi kategóriáknak. Ezenkívül viszont az alkotmány említést tesz a sürgősségi rendeleti kormányzásról is, ${ }^{49}$ amely túlzottan homályos kategóriának tûnik ahhoz, hogy besorolható lenne valamelyik „bevett” különleges jogrendi tényállásba. Az alkotmány értelmében a kormány rendkívüli és sürgős esetben (in casi straordinari di necessità e di urgenza) a saját felelősségére törvényerejű rendeletet bocsáthat ki - a rendkívüli és sürgős esetek azonban nincsenek közelebbről körülírva. Hasonló a helyzet a központi hatáskörelvonással, amelyről szintén említést tesz az alkotmány, lehetővé téve, hogy a kormány a helyi hatóságok helyett járjon el (többek között például akkor, ha a közbiztonság súlyosan veszélyben van)..50 Ezen jogintézmény kivételes jellege is nyilvánvaló, azonban sui generis különleges jogrendi kategóriaként aligha értelmezhetô. Egyes esetekben a szorosan összefonódó, lényegében együttesen szabályozott kivételes állapotok szétválaszthatósága sem egyértelmú. Erre szolgálhat példaként a svéd alkotmány részét képező kormányzati törvény, amelynek 15. fejezete a Háború és háborús veszély (Krig och krigsfara) címet viseli. Két külön tényállásról van-e szó (ahogyan például a magyar Alaptörvény is szétválasztja egymástól a rendkívüli állapotot és a megelőző védelmi helyzetet), vagy a két állapot nem választható szét? A kérdés megválaszolásához a fejezet alapos tanulmányozása sem visz közelebb, ugyanis a jogalkotó többnyire együttesen kezeli ezt a két helyzetet, azaz a rendelkezések többsége egyszerre szól a háborúról és a háborús veszélyről. Ugyanakkor olyan szabályokat is találunk, amelyek csak az egyik vagy másik állapotra irányadók. Ennek fényében mi egy különleges jogrendi kategóriaként tekintünk a két helyzetre, azonban az az érvelés is elfogadható, hogy voltaképpen két különböző tényállásról van szó, hiszen a háború és a háborús veszély végső soron kizárják egymást. A román alkotmány a mozgósítást és a hadiállapotot kezeli együttesen, ${ }^{51}$ így itt is értelmezés kérdése, hogy két külön különleges jogrendről beszélünk-e. ${ }^{52}$

A másik probléma abból fakad, hogy - mivel nem elégedtünk meg pusztán az alkotmányok vizsgálatával - a törvényi szintet is vizsgáltuk. Ez viszont felveti azt a kérdést, hogy tekinthető különleges jogrendnek az, ami nem az alkotmány szintjén van szabályozva..$^{53}$ Magyar szemmel egyértelmúnek túnik, hogy a normál jogrendi múködéstől való eltérés eseteit, feltételeit és korlátait alkotmányos szinten kell szabályozni, és az a különleges jogrend, amit az alkotmány annak minősít. (Ugyanakkor hazánkban is találunk példát

49 77. cikk.

50 120. cikk.

51 92. cikk.

52 Az elhatárolási nehézségeket illusztrálandó érdemes megjegyezni, hogy az egyik komparatív munka rendkívüli állapot néven összevonja ezt a két kategóriát (Kelemen, 2020, 211. o.).

53 Így például Bjørnskov és Voigt a korábban hivatkozott munkájukban világossá teszik, hogy kizárólag az egyes alkotmányok szövege képezi a vizsgálatuk tárgyát (Bjørnskov-Voigt, 2018a, 103. o.). 
az olyan - kvázi különleges jogrendnek ${ }^{54}$ is nevezhető - helyzetekre, amelyek a különleges jogrend szintjét nem érik el, de karakterüket tekintve hasonlítanak arra. ${ }^{55}$ ) A vizsgált államok közül több olyan is akadt, ahol törvényi - tehát az alkotmány alatti - szinten határoztak meg olyan helyzetet, amely de facto akár különleges jogrendi állapotként is értékelhető, vagy legalábbis jellegében hasonló. Erre látványos példát jelent az olaszországi szükségállapot (stato di emergenza), amely egy klasszikus különleges jogrendi tényállásnak tekinthető, azonban az alkotmány - talán meglepő módon - még csak nem is utal rá, és teljes egészében törvényi szinten kerül szabályozásra. Hasonló a helyzet Franciaországban, ahol szintén a szükségállapot (état d’urgence) az a helyzet, amelyik nem alkotmányos rangú, hanem csak törvényi szabályozásban található meg. Finnország kapcsán fentebb arra mutattunk rá, hogy az alkotmányban csak említés szintjén jelennek meg a háború és a különleges körülmények. Törvényi szinten viszont már konkretizálja a jogalkotó ezeket a helyzeteket - ennek megfelelően beszélhetünk védelmi állapotról (puolustustila) és szükségállapotról (poikkeusolojen). Hollandiában az alkotmányban szabályozott két különleges jogrendet, a hadiállapotot ${ }^{56}$ (oorlogstoestand) és a szükségállapotot ${ }^{57}$ (uitzonderingstoestand) további kettő, törvényben szabályozott helyzet, a katasztrófahelyzet (ramp) és a krízishelyzet (crisis) egészíti ki. Az észt megoldás hasonló képet mutat: az alkotmány csak a hadiállapot ${ }^{58}$ (sõjaseisukord) és a szükségállapot (erakorraline seisukord) ${ }^{59}$ szabályait tartalmazza, a válsághelyzetról (hädaolukord) és a veszélyhelyzetről (eriolukord) viszont csak törvényi szinten rendelkezik. A lett alkotmány szintén ugyanezt a két különleges jogrendi kategóriát, a hadiállapotot ${ }^{60}$ (kara stāvokl,a) és a szükségállapotot ${ }^{61}$ (iznēmuma stāvokli) egy harmadikkal, a veszélyhelyzettel (ārkārtējās sitūa cijas) egészíti ki törvényi szinten. Romániában az alkotmányban nevesített három különleges jogrend (hadiállapot ${ }^{62}$ [starea de război], ostromállapot ${ }^{63}$ [starea de asediu], sürgősségi állapot ${ }^{64}$ [starea de urgență]) mellett törvényi szinten szabályozásra kerül a sürgősségi helyzet (situația de urgență) és a riadóállapot (starea de alertă). Svédországban még komplexebb a helyzet, ugyanis alkotmányos szinten csak a háború és a háborús veszély (krig och krigsfara) jelenik

54 A fogalom értelmezésére lásd: Kelemen, 2019, 13-15. o.

55 Ilyen például a tömeges bevándorlás okozta válsághelyzet, amelyet a jogalkotó 2015-ben iktatott be a menedékjogról szóló 2007. évi LXXX. törvénybe (80/A. \$ skk.). A jogalkotói lépés kritikájára lásd: Mészáros, 2015. A szerző kvázi kivételes állapotnak nevezi a tömeges bevándorlás okozta válsághelyzetet (110-111. o.). Szente viszont ezt egyenesen egy hetedik különleges jogrendnek tekinti (Szente, 2020,125 . o.). Till szerint: „A „tömeges bevándorlás okozta válsághelyzet kezelése« fogalmának bevezetése 2015 őszén ugyanakkor elsődlegesen az alkotmányozó kétharmad hiányából eredő szabályozási technikaként értelmezendő [...]." (Till, 2016, 10. o.).

56 96. cikk.

57 103. cikk.

58 128. cikk.

59 129-130. cikk.

60 43-44. cikk.

61 62. cikk.

62 65. cikk (2) bekezdés d) pont.

63 93. cikk (1) bekezdés.

64 93. cikk (1) bekezdés. 
meg, amelyekhez hozzáadódik két további kivételes állapot, a törvényben szabályozott rendkívüli körülmények (extraordinära händelser), valamint az inkább csak jogelméleti kategóriaként létező (belső) szükségállapot, vagyis alkotmányos készültség (författningsberedskap).

A fentiek alapján tehát kijelenthető, hogy már önmagában a különleges jogrendi tényállások (kategóriák) azonosítása is alapos megfontolást igénylő, a kutatói értelmezésnek tág teret hagyó feladat, hiszen állást kell foglalni abban, hogy

- az alkotmányban milyen részletességûnek kell lennie a szabályozásnak ahhoz, hogy a különleges jogrendi tényállás azonosítható legyen;

— az egymással szorosan összefonódó különleges jogrendi tényállások szétválaszthatók-e;

— kizárólag az alkotmányt vizsgáljuk, vagy a kapcsolódó törvényeket is elemzés alá vonjuk.

Amennyiben a 7. ábrán országonként feltüntetett különleges jogrendi tényállások számát összevetjük más komparatív munkákkal, ${ }^{65}$ az esetleges eltérések okára a fentiek szolgálnak magyarázatul.

Az alkotmányban szabályozott különleges jogrendi tényállások száma alapján Gross megkülönbözteti az egyetlen tényállást intézményesítő, a duális struktúrájú - tehát a kivételes állapotok két fajtáját szabályozó - és a többszintű (kettőnél több tényállást tartalmazó) különleges jogrendi szabályozást, és arra is rámutat, hogy a második kategóriába tartozó alkotmányok többsége egy hadiállapot/háborús állapot jellegú és egy belső veszélyekre reagáló, szükségállapot jellegú különleges jogrendet alakított ki ${ }^{66} \mathrm{Az}$ általunk vizsgált államok is besorolhatók ezen csoportokba, azonban a kategóriák összevetését nagyban nehezíti, hogy ugyanazon vagy hasonló elnevezés alatt az egyes alkotmányok más-más helyzeteket, kiváltó okokat értenek. (İgy például a természeti katasztrófák Magyarországon veszélyhelyzet, Csehországban szükségállapot kihirdetését teszik lehetôvé; de az előző fejezetből az is kitûnik, hogy a Covid-19-re is különböző nevű különleges jogrendi kategóriák bevezetésével reagáltak az egyes országok.) Az viszont egyértelmúen kirajzolódott, hogy a vizsgált alkotmányok egy része a természeti (esetenként ipari) katasztrófák kezelését leválasztja az általános szükségállapoti kategóriáról, és külön tényállásban szabályozza alkotmányos (Magyarország, Csehország, Lengyelország, Németország, Szlovákia) vagy törvényi szinten (Észtország, Hollandia, Kína, Lettország, Olaszország). Az alkotmányokban azonosított különleges jogrendi tényállások közül egyértelmúen a franciaországi rendkívüli elnöki jogkör az, amelynek legkevésbé van megfelelője más országban. Az Alaptörvény által nevesített terrorveszélyhelyzet szintén egyedinek tekinthető abban az értelemben, hogy egyetlen másik

65 Például Khakee, 2009, 32. o.; Kelemen, 2020, 210-211. o.

66 Gross, 2004, 9-17. o. 
alkotmány sem nevesít hasonló kategóriát ${ }^{67}$ (ami természetesen nem jelenti azt, hogy a terrorveszély vagy -támadás kívül esne a különleges jogrendek körén - így például az Egyesült Államokban a 2001-es, Franciaországban pedig a 2015-ös terrortámadások alapozták meg a szükségállapot kihirdetését). ${ }^{68}$

\section{Különleges jogrend a gyakorlatban}

Akár a különleges jogrend, akár a rendkívüli állapot, akár a kivételes állapot kifejezést tekintjük, mindegyik azt sugallja, hogy a valóságban ezek a helyzetek ritkán fordulnak elő. A képet alaposan árnyalja, hogy egy közelmúltbeli kutatás szerint 1985 és 2014 között 137 ország - tehát a szuverén államok mintegy kétharmada - vezetett be valamilyen típusú rendkívüli állapotot ${ }^{69}$ - ebből a szempontból tehát nem is annyira kivételes jelenségekről van szó. Ami az általunk vizsgált 21 államot illeti, a helyzet közel sem ennyire drámai. A következő táblázat összefoglalja, hogy a vizsgált államokban a jelenlegi alkotmány hatálybalépése óta mikor milyen - az alkotmányban szabályozott - különleges jogrendet, illetve különleges jogrendnek nem minősülő helyzetet vezettek be.

\begin{tabular}{|c|c|c|}
\hline & $\begin{array}{l}\text { Alkotmányban nevesített } \\
\text { különleges jogrendek }\end{array}$ & $\begin{array}{l}\text { Nem alkotmányi szintû́ } \\
\text { kivételes helyzetek }\end{array}$ \\
\hline Ausztria & $\mathrm{X}$ & - \\
\hline \multirow{4}{*}{ Csehország } & Hadiállapot: - & \multirow{4}{*}{$\begin{array}{l}\text { Veszélyhelyzet: } 13 \text { alkalommal (főként } \\
\text { természeti katasztrófák, valamint afrikai } \\
\text { sertéspestis, veszélyes hulladék illegális } \\
\text { lerakása) }\end{array}$} \\
\hline & $\begin{array}{l}\text { Szükségállapot } 6 \text { alkalommal: } \\
\text { 2002: árvíz; } \\
\text { 2006: árvíz; } \\
\text { 2007: hurrikán; } \\
\text { 2013: árvíz; } \\
\text { 2020: Covid-19; } \\
\text { 2020: Covid-19 }\end{array}$ & \\
\hline & Közvetlen veszélyhelyzet: - & \\
\hline & Államot fenyegetô állapot: - & \\
\hline Dánia & $\mathrm{X}$ & n. a. \\
\hline
\end{tabular}

67 Vö.: Ságvári, 2016. A szerző számos európai ország alkotmányának vizsgálatát követően arra a következtetésre jutott, hogy „a különleges jogrend kifejezetten terrorizmusra szabása nem európai gyakorlat”.

68 Gross és Ní Aoláin a terrorizmus és a jog összefüggéseit a 2001. szeptember 11-i terrortámadások következményeinek tükrében vizsgáló kötete arra a következtetésre jutott, hogy az államok többsége a szükségállapoti jogalkotáson keresztül reagált a terrorizmusra (Gross-Ní Aoláin, 2006, 420-421. o.).

69 Bjørnskov-Voigt, 2018b, 110. o. 


\begin{tabular}{|c|c|c|}
\hline & $\begin{array}{l}\text { Alkotmányban nevesített } \\
\text { különleges jogrendek }\end{array}$ & $\begin{array}{l}\text { Nem alkotmányi szintű } \\
\text { kivételes helyzetek }\end{array}$ \\
\hline Egyesült Államok & $\mathrm{X}$ & $\begin{array}{l}\text { Országos veszélyhelyzet: } 69 \text { alkalommal } \\
\text { (természeti katasztrófák, 09/11, Covid-19) }\end{array}$ \\
\hline Egyesült Királyság & $\mathrm{X}$ & n. a. \\
\hline \multirow{2}{*}{ Észtország } & Hadiállapot:- & \multirow{2}{*}{$\begin{array}{l}\text { Veszélyhelyzet } 1 \text { alkalommal } \\
\text { (2020: Covid-19) }\end{array}$} \\
\hline & Szükségállapot: — & \\
\hline Finnország & $\mathrm{X}$ & $\begin{array}{l}\text { Szükségállapot } 1 \text { alkalommal } \\
\text { (2020: Covid-19) }\end{array}$ \\
\hline \multirow{2}{*}{ Franciaország } & Ostromállapot: - & \multirow{2}{*}{$\begin{array}{l}\text { Szükségállapot } 8 \text { alkalommal: } \\
\text { 1955, 1958, 1961: algériai háború; } \\
\text { 1985, 1986, 1987: tengeren túli területi } \\
\text { zavargások; } \\
\text { 2005: külvárosi zavargások; } \\
\text { 2015: terrortámadások } \\
\text { Egészségügyi szükségállapot: 1 alka- } \\
\text { lommal (2020: Covid-19) }\end{array}$} \\
\hline & $\begin{array}{l}\text { Rendkívüli elnöki jogkör: } 1 \text { alka- } \\
\text { lommal (1961: algériai háború) }\end{array}$ & \\
\hline \multirow{2}{*}{ Hollandia } & Hadiállapot: - & \multirow{2}{*}{$\begin{array}{l}\text { Katasztrófahelyzet és krízishelyzet: } \\
\text { számos alkalommal (2000 és } 2012 \text { között } \\
13 \text { alkalommal, nagyrészt helyi szinten) }\end{array}$} \\
\hline & Szükségállapot:- & \\
\hline \multirow{2}{*}{ Kína } & Védelmi állapot: - & \multirow{2}{*}{$\begin{array}{l}\text { Egész országra kiterjedő veszélyhelyzet: } \\
1 \text { alkalommal (2020: Covid-19) }\end{array}$} \\
\hline & Szükségállapot: - & \\
\hline \multirow{3}{*}{ Lengyelország } & Hadiállapot:- & \multirow[t]{3}{*}{ n. a. } \\
\hline & Szükségállapot:- & \\
\hline & Veszélyhelyzet: - & \\
\hline \multirow{2}{*}{ Lettország } & Hadiállapot:- & \multirow{2}{*}{$\begin{array}{l}\text { Veszélyhelyzet: } 3 \text { alkalommal } \\
\text { 2011: energiaellátási zavarok } \\
\text { 2020: Covid-19 } \\
\text { 2020: Covid-19 }\end{array}$} \\
\hline & Szükségállapot: — & \\
\hline \multirow[b]{2}{*}{ Litvánia } & Hadiállapot:- & \multirow[t]{2}{*}{ n. a. } \\
\hline & $\begin{array}{l}\text { Szükségállapot } 2 \text { alkalommal: } \\
\text { 2014: afrikai sertéspestis; } \\
\text { 2018: szárazság }\end{array}$ & \\
\hline
\end{tabular}




\begin{tabular}{|c|c|c|}
\hline & $\begin{array}{l}\text { Alkotmányban nevesített } \\
\text { különleges jogrendek }\end{array}$ & $\begin{array}{l}\text { Nem alkotmányi szintủ } \\
\text { kivételes helyzetek }\end{array}$ \\
\hline \multirow{6}{*}{ Magyarország } & Rendkívüli állapot:- & \multirow{6}{*}{$\begin{array}{l}\text { Tömeges bevándorlás okozta vál- } \\
\text { sághelyzet: } 1 \text { alkalommal (2016 óta } \\
\text { folyamatosan) }\end{array}$} \\
\hline & Szükségállapot:- & \\
\hline & Megelőző védelmi helyzet: — & \\
\hline & Váratlan támadás:- & \\
\hline & $\begin{array}{l}\text { Veszélyhelyzet: } 18 \text { alkalommal } \\
\text { (árvíz, belvíz, ipari katasztrófa, } \\
\text { Covid-19) }\end{array}$ & \\
\hline & Terrorveszély-helyzet:- & \\
\hline \multirow{4}{*}{ Németország } & Védelmi helyzet: - & \multirow[t]{4}{*}{$\begin{array}{l}\text { Országos járványhelyzet: } 1 \text { alkalommal } \\
\text { (2020: Covid-19) }\end{array}$} \\
\hline & Szükségállapot: - & \\
\hline & Belső vészhelyzet: - & \\
\hline & $\begin{array}{l}\text { Katasztrófahelyzet: } 1 \text { alkalommal } \\
\text { (2020: tartományi szinten } \\
\text { Covid-19) }\end{array}$ & \\
\hline Norvégia & $\mathrm{X}$ & n. a. \\
\hline Olaszország & Hadiállapot:- & $\begin{array}{l}\text { Szükségállapot: } 2000 \text { után } 26 \text { alka- } \\
\text { lommal (természeti katasztrófák, kör- } \\
\text { nyezetszennyezés, Covid-19) }\end{array}$ \\
\hline \multirow{3}{*}{ Románia } & Hadiállapot:- & \multirow[t]{3}{*}{ n. a. } \\
\hline & Ostromállapot:- & \\
\hline & $\begin{array}{l}\text { Sürgősségi állapot: } 1 \text { alkalommal } \\
\text { (2020: Covid-19) }\end{array}$ & \\
\hline \multirow[b]{3}{*}{ Spanyolország } & Ostromállapot: - & \multirow[t]{3}{*}{ n. a. } \\
\hline & Szükségállapot: - & \\
\hline & $\begin{array}{l}\text { Riadókészültség } 4 \text { alkalommal: } \\
\text { 2010: légiirányítók sztrájkja; } \\
\text { 2020: Covid-19; } \\
\text { 2020: Covid-19; } \\
\text { 2020: Covid-19 }\end{array}$ & \\
\hline Svédország & Hadiállapot: - & n.a. \\
\hline
\end{tabular}




\begin{tabular}{|l|l|l|}
\hline & \multicolumn{1}{|c|}{$\begin{array}{c}\text { Alkotmányban nevesített } \\
\text { különleges jogrendek }\end{array}$} & \multicolumn{1}{c|}{$\begin{array}{c}\text { Nem alkotmányi szintü } \\
\text { kivételes helyzetek }\end{array}$} \\
\hline \multirow{5}{*}{ Szlovákia } & Háború: - & $\begin{array}{l}\text { Rendkívüli helyzet: 1 alkalommal } \\
\text { (2020: Covid-19) }\end{array}$ \\
\cline { 2 - 2 } & Hadiállapot - & \\
\cline { 2 - 3 } & Rendkívüli állapot: - & \\
\cline { 2 - 3 } & $\begin{array}{l}\text { Veszélyhelyzet 3 alkalommal: } \\
\text { 2011: egészségügyi ellátórendszer } \\
\text { hiányossága (regionálisan); } \\
\text { 2020: Covid-19; } \\
\text { 2020: Covid-19 }\end{array}$ & \\
\hline
\end{tabular}

\section{7. táblázat \\ A különleges jogrendek gyakorlati esetei Forrás: a szerző saját összeállítása \\ Megjegyzések a táblázathoz: \\ $X=$ az alkotmány nem tartalmaz különleges jogrendi kategóriákat \\ - = a jelenlegi alkotmány hatálybalépése óta még nem volt bevezetve}

Amint a táblázatból kiolvasható, a 20 alkotmányban nevesített összesen 41 különleges jogrendi állapot mintegy $80 \%$-a - ismét hangsúlyozzuk: a jelenlegi alkotmányok hatálya alatt - még soha nem került kihirdetésre, és mindössze nyolc olyan országot találtunk, amelyik élt azzal a lehetőséggel, hogy az alkotmányában (illetve Csehország és Szlovákia esetén az alkotmánytörvényben) nevesített helyzetet vezetett be. (Az alkotmányos szabályozás alatti rendkívüli helyzetek viszont jóval gyakrabban fordultak elő.) A táblázat egyben arra is rávilágít, hogy a különböző országok különbözőképp kezelik a hasonló jellegủ válsághelyzeteket. Mindez leginkább a Covid-19-en keresztül látható, hiszen - amint az előző fejezetben láttuk - a járvány eltérő szintú és elnevezésú helyzet bevezetését eredményezte.

Ami a kiváltó okokat illeti, egyértelmúen a természeti csapások (a járványt is ideértve) dominálnak. Európában fegyveres-katonai körülmények a táblázatban feltüntetett államok közül csak Franciaországban alapoztak meg rendkívüli intézkedéseket. Az állam tág értelemben vett múködési zavarai csak Spanyolországban (légiirányítók 2010-es sztrájkja), valamint Szlovákiában (az egészségügyi ellátórendszer zavarai 2011-ben) vezettek el alkotmányos szinten szabályozott különleges jogrend kihirdetéséhez. (Lettországban az energiaellátási zavarok miatt 2011-ben szintén veszélyhelyzetet vezettek be, azonban ez nem minősül alkotmányban definiált különleges jogrendnek.)

Ferejohn és Pasquino két lehetséges okát látja annak, hogy a fejlett demokráciák miért hirdetnek ritkán különleges jogrendet. Egyrészt eleve ritkák az olyan rendkívüli helyzetek, amikor szükség lenne erre a lépésre; ráadásul - a negatív történelmi tapasztalatok miatt az állami vezetők részéről gyakran van egyfajta idegenkedés vagy óvatosság a kivételes ál- 
lapot bevezetésével kapcsolatban. Másrészt a technikai-technológiai fejlődésnek köszönhetôen az államok már olyan válsághelyzeteket is tudnak a normál jogrendi múködés keretei között kezelni, amelyek egy évszázada még rendkívüli helyzet hirdetésével jártak volna. ${ }^{70}$ A 2004-es írásuk szerint napjainkban gyakran még azok az államok is vonakodnak bevezetni a különleges jogrendet, amelyeknek erre alkotmány adta lehetőségük lenne; ehelyett a felmerülő válságot az adott helyzethez igazított jogi szabályozás keretében igyekeznek kezelni. ${ }^{71} \mathrm{~A}$ szerzők szerint az alkotmányban intézményesített különleges jogrendektől való idegenkedésnél az sem elhanyagolható tényező, hogy a mindenkori politikai vezetés a népszerűségi szempontokra is figyelemmel van, azonban egy jogkorlátozó különleges jogrend árthat a kormányzók népszerűségének. ${ }^{72}$ Sőt - teszik hozzá -, egy rendkívüli állapot bevezetése mindig felveti a gyanút, hogy ez a lépés voltaképpen a kormányzó erők önös érdekét szolgálja - és ez a gyanú politikai kockázatot is hordoz magában. ${ }^{73}$

Bár Ferejohn és Pasquino előbbi teóriája kissé képlékenynek túnik, az kétségtelen, hogy meglátásaik több általunk vizsgált országban is visszaköszönnek, ugyanis az országfejezetekben nem egy helyen utaltunk arra, hogy többször merült fel valamely különleges jogrend bevezetése, mint ahányszor végül ténylegesen is kihirdetésre került. Így például a Lengyelországról szóló fejezetben azt láttuk, hogy bár a Covid-19 megalapozta a veszélyhelyzet kihirdetését, a kormány politikai szempontok miatt elvetette ezt a megoldást. Bár más megfontolásból, de a holland vezetés szintén megkerülte a különleges jogrend bevezetését. Az Észtországgal foglalkozó tanulmány pedig arra mutatott rá, hogy az elmúlt évtizedekben többször is felmerült a szükségállapot „aktiválása”, de végül erre egyszer sem került sor.

\section{A magyar különleges jogrend a külföldi megoldások tükrében}

Amint az összegzés elején említettük, jelen kötet megírásakor a magyar szabályozás képezte a kiindulópontot, így zárásként azt foglaljuk össze, hogy a vizsgált külföldi jogi szabályozások tükrében hogyan is értékelhető az alaptörvény. (Az összevetést megalapozandó, egy érdekesség: Bjørnskov és Voigt a fentebb már hivatkozott, nem kevesebb mint 351 - részben természetesen már nem hatályos - alkotmányt vizsgáló kutatásukban elvégzett klaszter-

70 Ferejohn-Pasquino, 2004, 215-216. o. Megjegyzendő ugyanakkor, hogy Bjørnskov és Voigt közelmúltbeli empirikus kutatása arra a következtetésre jutott, hogy a demokráciák hajlamosabbak szükségállapotot hirdetni, mint az autokráciák (Bjørnskov-Voigt, 2018b, 122. o.).

71 Ferejohn-Pasquino, 2004, 234. o.

72 A teljes képhez hozzátartozik, hogy a szerzők a tanulmányukban gyakran utaltak a nemzetközi terrorizmusra mint globális veszélyre, vagyis a vizionált jogkorlátozásokról elsősorban a terrorizmus kontextusában írtak.

73 Ferejohn-Pasquino, 2004, 235. o. 
analízis során arra jutottak, hogy a német, a magyar és a montenegrói alkotmány "lóg ki” leginkább az elemzés tárgyát képező alkotmányok közül. $)^{74}$

1. Elsőként magára a „különleges jogrend” kifejezésre kell kitérnünk. A különleges jogrend kifejezés ugyanis azt implikálja, hogy meghatározott körülmények esetén nemcsak kihirdetésre kerül egy bizonyos - többnyire alkotmányos szinten nevesített - állapot/helyzet, hanem egyúttal az állam mûködésében (a közhatalmi jogosítványok elosztásában, az intézkedések körében stb.) is alapvető változás következik be. ${ }^{75} \mathrm{Ez}$ az elnevezés egyben azt is világossá teszi, hogy a hazai szabályozás egyértelmúen a fentebb „legalistának” nevezett modellt követi, hiszen az állam a kivételes állapotokat jogilag szabályozott keretek között kívánja kezelni. Vajon használ-e más ország is ilyen átfogó, az egyes konkrét tényállásokon túlmutató, az állam és a jog mûködésének megváltozására utaló kifejezést az alkotmányában? Amint említettük, a lengyel alkotmány is külön fejezetben szabályozza ezeket a rendelkezéseket, azonban a fejezet címe (Rendkívüli állapotok [Stany nadzwyczajne]) is inkább a tényállások összefoglaló elnevezésére utal, és így formailag nem feleltethető meg a különleges jogrend elnevezésnek. ${ }^{76}$

2. Amint fentebb utaltunk rá, az Alaptörvény különleges jogrendi blokkja több szempontból is kivételesnek tekinthető. Egyrészt nem találtunk még egy olyan alkotmányt, amelyik ilyen látványosan elkülönítené ezen rendelkezéseket a normál jogrendi működéstől. Beszédes tény, hogy az Alaptörvény - a Nemzeti Hitvallást, valamint a Záró és vegyes rendelkezéseket leszámítva - négy részből áll, és ebből egy egész rész a különleges jogrendnek van szentelve. Ebből arra következtethetünk, hogy az alkotmányozó a különleges jogrendet egyenrangúan kezelte az alapjogi és az államszervezeti résszel. Mindez egyben azt is jelenti, hogy az Alaptörvényben meglehetősen tisztán érvényesül az „alkotmány az alkotmányban” koncepció, amit az angol szakirodalomban gyakran emergency constitution kifejezéssel illetnek. ${ }^{77}$ Másrészt figyelmet érdemel a különleges jogrendi rész terjedelme is. A 7. ábra alapján megállapítható, hogy a vizsgált alkotmányok közül abszolút értelemben nem az Alaptörvény tudhatja magának a legterjedelmesebb különleges jogrendi részt (ebből a szempontból a német alaptörvény megelőzi [valamint a szlovák alkotmány is, azonban ott már egy különálló jogszabályról beszélünk]), azonban amennyiben a relatív terjedelmet vizsgáljuk, messze kiemelkedik az Alaptörvény, ugyanis az eredeti, hatálybalépéskori szövegének közel 12\%-a a különleges jogrenddel foglalkozott ${ }^{78}$ (Németország esetén kevesebb mint 8\% ez az arány). Anélkül,

74 Bjørnskov-Voigt, 2018a, 117-118. o.

$75 \mathrm{Az}$, hogy egy „élesített” különleges jogrend milyen mélységû́ változásokat hoz, természetesen nagyban függ a kihirdetésre okot adó körülmények jellegétől. Például az árvíz miatt néhány napra kihirdetett veszélyhelyzettől nagyban különbözik a 2020-2021-es Covid-19-veszélyhelyzet. Egy szükségállapot vagy egy rendkívüli állapot pedig még alapvetőbb változásokat hozhat - de ez maradjon meg inkább elméleti spekulációnak.

76 Megjegyzendő, hogy a lett veszélyhelyzeti törvény - többek között a 4. cikk (1) bekezdésében és a 11 . cikk

(1) bekezdésében - használja a īpašs tiesiskais režims kifejezést, ami tükörfordításban speciális jogi rezsimet jelent (vagyis kimondottan közel esik a különleges jogrend terminológiához), azonban ezt nem olyan átfogóan teszi, mint a magyar Alaptörvény.

77 Lásd például: Bjørnskov-Voigt, 2018a, 103. o.; Ackerman, 2004.

78 2020-ban - a kilencedik Alaptörvény-módosítás előtt - már valamivel kisebb ez a szám. 
hogy túlzott jelentőséget tulajdonítanánk ezeknek a formai szempontoknak, fontosnak tartjuk, hogy rávilágítsunk ezekre is, hiszen kevés alkotmány fordít ilyen kiemelt figyelmet a különleges jogrendnek.

3. Az Alaptörvény további markáns, a vizsgált alkotmányoktól élesen elütő sajátossága a különleges jogrendi tényállások száma. Az eredetileg öt kategória később hatra bővült, ami messze nemcsak a vizsgált országokat tekintve a legtöbb, hanem - tudomásunk szerint valamennyi alkotmányt figyelembe véve is ez a legmagasabb szám. Amint az 5. fejezetben utaltunk rá, a szakértők inkább kritikusan viszonyultak ehhez a tagolt szabályozáshoz, jobbára túlszabályozottságot emlegetve. A különleges jogrendi helyzetek „ideális” számát illetően - amint arra az 5. fejezet összegzésében is rámutattunk - természetesen nincs egy egységes álláspont; az egyik megközelítés szerint a minél cizelláltabb szabályozás a kormányzati túlreagálás megelőzésének egy fontos eszköze lehet:;9 más megközelítés szerint viszont a sok és egymást részben átfedő kategória indokoltan bonyolulttá teszi a szabályozást, és elhúzódó közjogi-politikai vitákat generálhat. ${ }^{80}$ Alexander Hamilton már közel negyed évezreddel ezelőtt úgy fogalmazott, hogy „a nemzetek biztonságát veszélyeztető körülmények száma végtelen, és emiatt nem lenne bölcs dolog alkotmányos korlátok közé szorítani a veszély ellen védekező hatalmat". ${ }^{81}$ Annyiban talán ma is egyetérthetünk Hamiltonnal, hogy parttalan vállalkozásnak túnik minden egyes újabb potenciális fenyegetésre újabb és újabb különleges jogrendi kategóriát kreálni - márpedig az utóbbi 30 év alkotmánymódosításai pontosan ebbe az irányba mutattak Magyarországon. Azt is láttuk, hogy ebből a szempontból fontos fordulatot jelent az Alaptörvény kilencedik módosítása, amely a jelenlegi hat különleges jogrendi tényállást három, a korábbinál inkluzívabb kategóriába vonja össze, és ezzel sokkal inkább illeszkedni fog a két-három tényállást intézményesítő alkotmányok közé.

4. A hazai különleges jogrendi szabályozás tartalmi oldalára rátérve leszögezhető, hogy a tényállások nagy száma alaposan megnehezíti a többi állammal való összevetést, hiszen az Alaptörvényben nevesített hat kategória jelentősen eltér egymástól. Ami a hatáskörök elosztását illeti, a magyar szabályozás összességében egy kiegyensúlyozott, de bonyolult rendszert alakított ki. Különleges jogrend esetén az Országgyuulés - köztársasági elnök Kormány triász egyike sem kerül túlsúlyba, ugyanis a különböző különleges jogrendi esetek különböző jogosítványokat adnak ezeknek a szereplóknek. Amint azonban a 5. fejezetben rámutattunk, a kilencedik Alaptörvény-módosítás megváltoztatja ezt a felállást, és valamennyi különleges jogrendi tényállásnál deklaráltan a Kormányt teszi a döntéshozatali centrummá, jelentősen növelve ezzel a szerepét és egyben a felelősségét is. ${ }^{82}$

79 Vö.: Jakab, 2009, 635. o.; Till, 2017, 73. o.

80 Vö.: Drinóczi-Bien-Kacala, 2020, 191. o.

81 A The Federalist 23. esszéjét idézi: Gross, 2004, 8-9. o. Hamilton írása elérhető: https://guides.loc.gov/ federalist-papers/text-21-30\#s-lg-box-wrapper-25493336 (Letöltve: 2020. december 15.).

82 Bjørnskov és Voigt kutatása szerint az utóbbi évtizedekben a szükségállapoti szabályozás terén a végrehajtó hatalom tendenciózus megerősödése figyelhető meg (Bjørnskov-Voigt, 2018a, 125. o.). Ennyiben tehát a kilencedik Alaptörvény-módosítás is illeszkedik ebbe a trendbe. 


\section{Irodalomjegyzék}

Ackerman, B. (2004) 'The Emergency Constitution', Yale Law Journal, 113(5), 1029-1091. o.

BJøRnskov, C., VoIgT, S. (2018a) 'The Architecture of Emergency Constitutions', International Journal of Constitutional Law, 16(1), 101-127. o.

BJøRnskov, C., Voigt, S. (2018b) 'Why Do Governments Call a State of Emergency? On the Determinants of Using Emergency Constitutions', European Journal of Political Economy, 54, 110-123. 0 .

Csink, L. (2017) 'Mikor legyen a jogrend különleges?', Iustum Aequum Salutare, 13(4), 7-16. o.

Drinóczi, T., BIEN-KacAlA, A. (2020) 'COVID-19 in Hungary and Poland: Extraordinary Situation and Illiberal Constitutionalism', The Theory and Practice of Legislation, 8(1-2), 171-192. 0 .

Elikins, Z., Ginsburg, T., Meltin, J. (2016) The Comparative Constitutions Project: A CrossNational Historical Dataset of Written Constitutions (Survey Instrument) [Online]. Elérheto: www.comparativeconstitutionsproject.org/files/surveyinstrument.pdf (Letöltve: 2020. december 15.)

Ferejohn, J., Pasquino, P. (2004) 'The Law of the Exception: A Typology of Emergency Powers', International Journal of Constitutional Law, 2(2), 210-239. o.

Gross, O. (2004) 'Providing for the Unexpected: Constitutional Emergency Provisions', Israel Yearbook of Human Rights, 33, 1-31.

Gross, O., Ní AoláIn, F. (2006) Law in Times of Crisis: Emergency Powers in Theory and Practice. 1. kiadás. Cambridge: Cambridge University Press

JАКАB, A. (2009) 'Az Országgyưlés akadályoztatása különleges állapotokban' in Jakab, A. (szerk.) Az Alkotmány kommentárja I. 1. kiadás. Budapest: Századvég

KELEMEN, R. (2019) 'Az Alaptörvény szükségállapot-szabályozásának kritikai áttekintése az egyes európai uniós tagállamok alkotmányainak figyelembevételével' in Bartkó, R. (szerk.) A terrorizmus elleni küzdelem aktuális kérdései a XXI. században. 1. kiadás. Budapest: Gondolat Kiadó

KELEMEN, R. (2020) 'Különlegesjogrend az Európai Unió egyes tagállamainakalkotmányaiban' in Farkas, Á., Kelemen, R. (szerk.) Szkülla és Kharübdisz között-Tanulmányok a különleges jogrend elméleti és pragmatikus kérdéseiről, valamint nemzetközi megoldásairól. 1. kiadás. Budapest: Magyar Katonai Jogi és Hadijogi Társaság

KHAKeE, A. (2009) Securing Democracy? A Comparative Analysis of Emergency Powers in Europe (Geneva Centre for the Democratic Control of Armed Forces Policy Paper - No. 30) [Online]. Elérhető: www.files.ethz.ch/isn/99550/PP30_Anna_Khakee_Emergency_Powers.pdf (Letöltve: 2020. december 15.)

MÉszÁros, G. (2015) 'Egy „menekültcsomag” veszélyei. Mit is jelent valójában a tömeges bevándorlás okozta válsághelyzet?', Fundamentum, 19(2-3), 107-119. o. 
MÉszÁros, G. (2016) 'Különleges helyzetek és a joguralom határai: A kivételes állapot az alkotmányos demokráciákban', Jog-Állam-Politika, 8(4), 185-200. o.

SÁGVÁRI, Á. (2016) Különleges jogrenddel a terror ellen - kitekintés az európai gyakorlatra [Online]. Elérhetô: https://jog.tk.hu/blog/2016/o2/kulonleges-jogrenddel-a-terror-ellen (Letöltve: 2020. november 10.)

SCHEPPELE, K. L. (2008) 'Legal and Extralegal Emergencies' in Whittington, K., Kelemen, R. D., Caldeira, G. A. (szerk.) The Oxford Handbook of Law and Politics. 1. kiadás. Oxford - New York: Oxford University Press

SZENTE, Z. (2020) 'A 2020. március 11-én kihirdetett veszélyhelyzet alkotmányossági problémái', Állam-és Jogtudomány, 61(3), 115-139. o.

TilL, Sz. (2016) 'Alkotmányos változatok migránsokra és terrorra', Katonai Jogi és Hadijogi Szemle, 4(1-2), 7-63. o.

TiLL, Sz. (2017) 'A különleges jogrendi kategóriarendszer egyszerúsítésének jövőbeli esélyei', Iustum Aequum Salutare, 13(4), 55-75. o.

Venice Commission (2020) Respect for Democracy, Human Rights and the Rule of Law during States of Emergency: Reflections (Study No. 987/2020) [Online]. Elérhető: https://rm.coe.int/ respect-for-democracy-hu-man-rights-and-rule-of-law-during-states-of-e/16809e82co (Letöltve: 2020. december 15.) 


\section{A sorozatban eddig megjelent múvek:}

1. Veress Emőd: A szindikátusi szerződés

2. Domaniczky Endre: Határterületeken

3. Szilágyi János Ede, Hrecska-Kovács Renáta (szerk.):

A sztrájkjog összehasonlitó jogi elemzése egyes európai államokban 


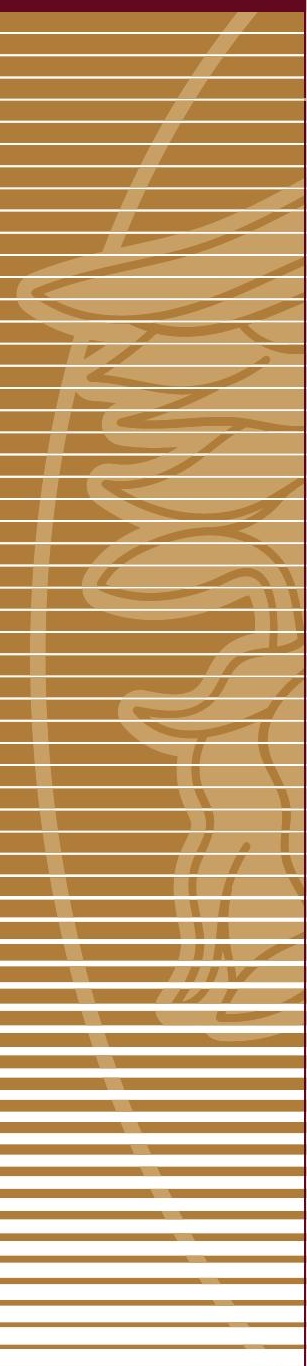

